Editor: Editorial de la Universidad de Granada

D.L.: Gr. 869 - 2007

ISBN: 978-84-338-4307-4 


\section{ÍNDICE}

ANÁLISIS Y EVALUACIÓN

I. INTRODUCCIÓN. HISTORIA Y CARÁCTER DE LA INSTITUCIÓN

Yolanda Torrubia Fernández

I.1. EL MUSEO Y SU LOCALIZACIÓN. Emplazamiento y contexto urbano.

I.2. ORIGEN E HISTORIA DEL MUSEO

1.3. TEMÁTICA

I.4. LA COLECCIÓN.

a) Origen, temática, titularidad y gestión.

b) Investigación y Conservación

1.5. EL INMUEBLE.

Breve caracterización formal e histórica. 
I.6. TITULARIDAD. RÉGIMEN JURÍDICO. MODELO DE GESTIÓN.

I.7. GESTIÓN ECONÓMICA Y DE RECURSOS HUMANOS

II. COLECCIONES

Ismael Andrés Torralba

David Ruiz García

II.1. DEFINICIÓN

24

II.2. INCREMENTO DE LAS COLECCIONES 58

II.3. DOCUMENTACIÓN

$\begin{array}{ll}\text { II.4. INVESTIGACIÓN } & 97\end{array}$

II.5. CONSERVACIÓN 103

II.6. EVALUACIÓN DE LAS PRINCIPALES CARENCIAS Y PRIORIDADES 111 
$\begin{array}{lr}\text { III. ARQUITECTURA } & 122\end{array}$

Yolanda Torrubia Fernández

III.1. SEDE DEL MUSEO ARQUEOLÓGICO DE SEVILLA 124

III.2. ESTADO DE CONSERVACIÓN DE LA ARQUITECTURA 139

III.3. Régimen de protección del edificio 172

III.4. Relación con el entorno 173

III.5. Espacios 179

III.5.1. Área pública sin colecciones $\quad 179$

III.5.2. ÁREA PÚBLICA CON COLECCIONES 184

III.5.3. ÁREA INTERNA CON COLECCIONES 188

III.5.4. ÁREA INTERNA SIN COLECCIONES $\quad 199$

III.6. ACCESOS Y CIRCULACIONES 203

TABLA DE SUPERFICIES

PLANOS DE DISTRIBUCIÓN DE ESPACIOS Y DE ACCESOS Y CIRCULACIONES 222

III.7. PLANES DE EMERGENCIA Y EVACUACIÓN 225

III.8. INSTALACIONES 226

III.9. CONCLUSIONES GENERALES 228 
IV. EXPOSICIÓN

María Dolores García Pérez

Sebastián Podadera Fernández

IV.1. DISCURSO EXPOSITIVO

IV.2. COLECCIONES QUE CONDICIONAN LA EXPOSICIÓN

IV.3. CONDICIONES DEL MONTAJE ACTUAL

IV.4. FUNCIONAMIENTO Y ACCESIBILIDAD

IV.5. PLANTA SÓTANO...

IV.6. PRIMERA PLANTA

V. DIFUSIÓN Y COMUNICACIÓN

\section{Rafael Díaz Alonso}

Josefa Cano García

V.1. DEFINICIÓN DE PÚBLICO

V.2. SERVICIOS

V.3. ATENCIÓN AL PÚBLICO

V.4. OTROS ESPACIOS PÚBLICOS

V.5. PROGRAMACIÓN DE ACTIVIDADES

V.6. ACTIVIDADES

393

V.7. COMUNICACIÓN 
VI. SEGURIDAD

Patricia Monzo Losada

VI.1. SISTEMAS DE SEGURIDAD

420

VI.2. PERSONAL DE SEGURIDAD

423

VI.3. CONCLUSIÓN

425

VII. RECURSOS HUMANOS

426

Patricia Monzo Losada

VII.1. ANÁLISIS Y EVALUACIÓN: RECURSOS HUMANOS

427

VII.2. CONCLUSIÓN

440 
VII. RECURSOS ECONÓMICOS

Patricia Monzo Losada

VIII.1. ANÁLISIS Y EVALUACIÓN: RECURSOS ECONÓMICOS

442

VIII.2. CONCLUSIÓN

IX. CONCLUSIÓN GENERAL. ANÁLISIS Y EVALUACIÓN

IX.1. CONCLUSIONES DE LA PRIMERA FASE.

LÍNEAS DE ACTUACIÓN DE LOS PROGRAMAS

452

IX.2. LA MISIÓN

454

IX.3. OBJETIVOS GENERALES 
PROGRAMAS

I. PROGRAMA INSTITUCIONAL 455

Yolanda Torrubia Fernández

I.1. EL MUSEO Y SU LOCALIZACIÓN. 456

I.2. TEMÁTICA Y OBJETIVOS DEL MUSEO

I.3. TITULARIDAD. RÉGIMEN JURÍDICO. 458

I.4. COLECCIONES. 461

I.5. RELACIONES INTERNACIONALES 462

I.6. GESTIÓN ECONÓMICA Y RECURSOS HUMANOS 462 
II. PROGRAMA DE COLECCIONES

Ismael Andrés Torralba

David Ruiz García

II.1. PROGRAMA DE INCREMENTO

464

II.2. PROGRAMA DE DOCUMENTACIÓN

493

II.3. BIBLIOTECA

530

II.4. PROGRAMA DE INVESTIGACIÓN.

534

II.5. PROGRAMA DE CONSERVACIÓN

538

II.6. RESTAURACIÓN.

III. PROGRAMA DE ARQUITECTURA

Yolanda Torrubia Fernández

III.1. CONSIDERACIONES PREVIAS

594

III.2. TIPO DE ACTUACIÓN PROPUESTA 
III.3. NECESIDADES DE INTERVENCIÓN EN EL EDIFICIO

DEL PABELLÓN RENACENTISTA ${ }^{1}$

III.4. RELACIÓN DE ESPACIOS ${ }^{2}$

PLANOS DEL EDIFICIO DEL PABELLÓN RENACENTISTA CON

LA NUEVA DISTRIBUCIÓN DE ESPACIOS

PLANOS DEL NUEVO EDIFCIO CON LA NUEVA DISTRIBUCIÓN DE ESPACIOS

III.4.1. ÁREA PÚBLICA SIN COLECCIONES

SEGÚN CONVENGA, PUES EL MUSEO DISPONDRÁ DE APARATOS PARA TAL FIN. III.4.2. ÁREA PÚBLICA CON COLECCIONES

III.4.3. ÁREA INTERNA CON COLECCIONES

III.4.4. ÁREA INTERNA SIN COLECCIONES

650

TABLAS DE SUPERFICIES

657

III.5. ACCESOS Y CIRCULACIONES

661

III.6. PLANES DE EMERGENCIA Y EVACUACIÓN

678

III.7. INSTALACIONES

679

III.8. CONCLUSIONES 
IV. PROGRAMA EXPOSITIVO

María Dolores García Pérez

Sebastián Podadera Fernández

IV.1. INTRODUCCIÓN TEÓRICA

683

IV.2. CARACTERÍSTICAS TÉCNICAS

IV.3. PASEO ARQUEOLÓGICO

IV.4. CUADRO DEL DISCURSO MUSEOLÓGICO

PLANOS DEL DISCURSO $\quad 719$

$\begin{array}{ll}\text { V. PROGRAMA DE DIFUSIÓN } & 721\end{array}$

Rafael Díaz Alonso

V.1. LA DIFUSIÓN EN UN MUSEO ARQUEOLÓGICO

$\begin{array}{ll}\text { V.2. ÁREA DE DIFUSIÓN } & 728\end{array}$

$\begin{array}{ll}\text { V.3. SERVICIOS } & 777\end{array}$

$\begin{array}{ll}\text { V.4. PROYECTO PARA LOS SERVICIOS } & 779\end{array}$

V.5. EL USUARIO DEL MUSEO 
VI. PROGRAMA DE COMUNICACIÓN

Josefa Cano García

VI.1. BREVE INTRODUCCIÓN AL CONCEPTO DE CORPORATE

VI.2.EL CORPORATE EN INSTITUCIONES CULTURALES.

PARTICULARIDADES Y SITUACIÓN ACTUAL

829

VI.3. PROYECTOS

831

VI.4. LA DIRECCIÓN DE LA COMUNICACIÓN

841

VI.5. FUNCIONES DE LA COMUNICACIÓN

842

VI.6. NORMAS GENERALES DE COMUNICACIÓN

846

VI.7. MANUAL DE LA GESTIÓN DE LA IMAGEN CORPORATIVA

849

VI.8. DIMENSIÓN FUNCIONAL

851

VI.9. PROTOCOLO DE RELACIONES CON LA PRENSA

851

VI.10. MAPA DE PÚBLICOS

855

VI.11. PLAN ANUAL DE COMUNICACIÓN 2007

858

VI.12. DIRECTRICES PARA LA ELABORACIÓN DEL PAC 2007

864

VI.13. PROBLEMAS DE IDENTIDAD CORPORATIVA

876 
VII. SEGURIDAD

Yolanda Torrubia Fernández

Patricia Monzo Losada

VII.1. PROTECCIÓN CONTRA INCENDIOS

879

VII.2.PROTECCIÓN CONTRA ACTOS ANTISOCIALES

881

VII.3. PROTECCIÓN CONTRA ACCIDENTES

884

PLANOS

885

VIII. PROGRAMA DE RECURSOS HUMANOS

891

Patricia Monzo Losada

VIII.1.CONSIDERACIONES GENERALES

892

VIII.2. RELACIÓN DE PUESTOS DE TRABAJO

892

VIII.3. ORGANIGRAMA FUNCIONAL

903

VIII.4. PREVISIÓN DE UN PLAN DE PREVENCIÓN DE RIESGOS LABORALES 
IX. PROGRAMA ECONÓMICO

Patricia Monzo Losada

IX.1. CONSIDERACIONES GENERALES

913

IX.2. PLANIFICACIÓN ESTRATÉGICA

916

IX.3. ANÁLISIS DE COSTES

926

BIBLIOGRAFÍA

AGRADECIMIENTOS 


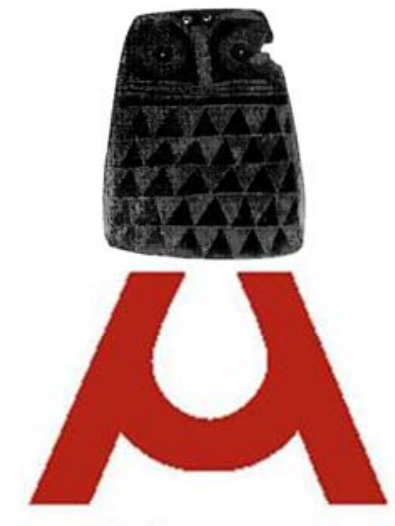

Museo Arqueológico de Sevilla

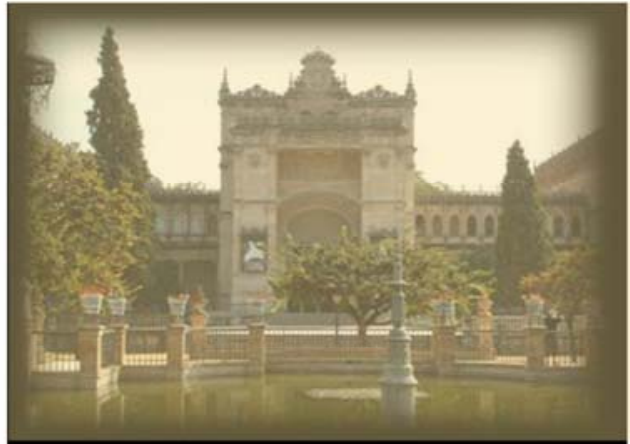

\section{INTRODUCCIÓN}

HISTORIA Y CARÁCTER

DE LA INSTITUCIÓN

Yolanda Torrubia Fernández 


\section{1. EL MUSEO Y SU LOCALIZACIÓN}

\section{Emplazamiento y Contexto urbano}

EI Museo Arqueológico de Sevilla se encuentra ubicado en el Parque de Maria Luisa, en la denominada Plaza de América, cuyo acceso principal se sitúa en la Avenida de la Palmera, más concretamente en el Paseo de las Delicias y sus otros dos accesos por la Avenida de la Borbolla y la Avenida de Eritaña.

No se encuentra dentro del casco histórico de la ciudad, pero sí en una zona céntrica, conocida por los sevillanos y por los turistas como es el Parque de Maria Luisa. Esta zona forma parte del proyecto para la Exposición iberoamericana de 1929, momento en el que se urbanizó y configuró el entorno del museo, además de construirse el edificio que hoy ocupa el mismo. Por tanto, el museo se encuentra rodeado por un parque, en el que destacan por su importancia la Plaza de España, conocida por todos y fruto también de esa Exposición, y la Plaza de América, en la que se ubica nuestro museo. Enfrente del Museo Arqueológico se sitúa el Museo de Artes y Costumbres Populares, obra de la misma época y el mismo arquitecto, Aníbal González. Son dos edificios no construidos para un uso museístico, sino para pabellones de la Exposición Iberoamericana, pero que finalmente configuran el espacio de dos de los museos fundamentales de la ciudad.

De todo esto podemos deducir que no es una zona de la ciudad de atracción turística fundamental, pues ésta se concentra en torno al Alcázar y la Catedral, sino que entorno a ella se concentran jardines y zonas residenciales, pero suele aparecer en los mapas del centro de Sevilla, así que puede considerarse dentro de la zona más conocida de la ciudad.

En el siguiente plano de la ciudad se ubican los principales monumentos de la misma, incluido el Museo Arqueológico. 


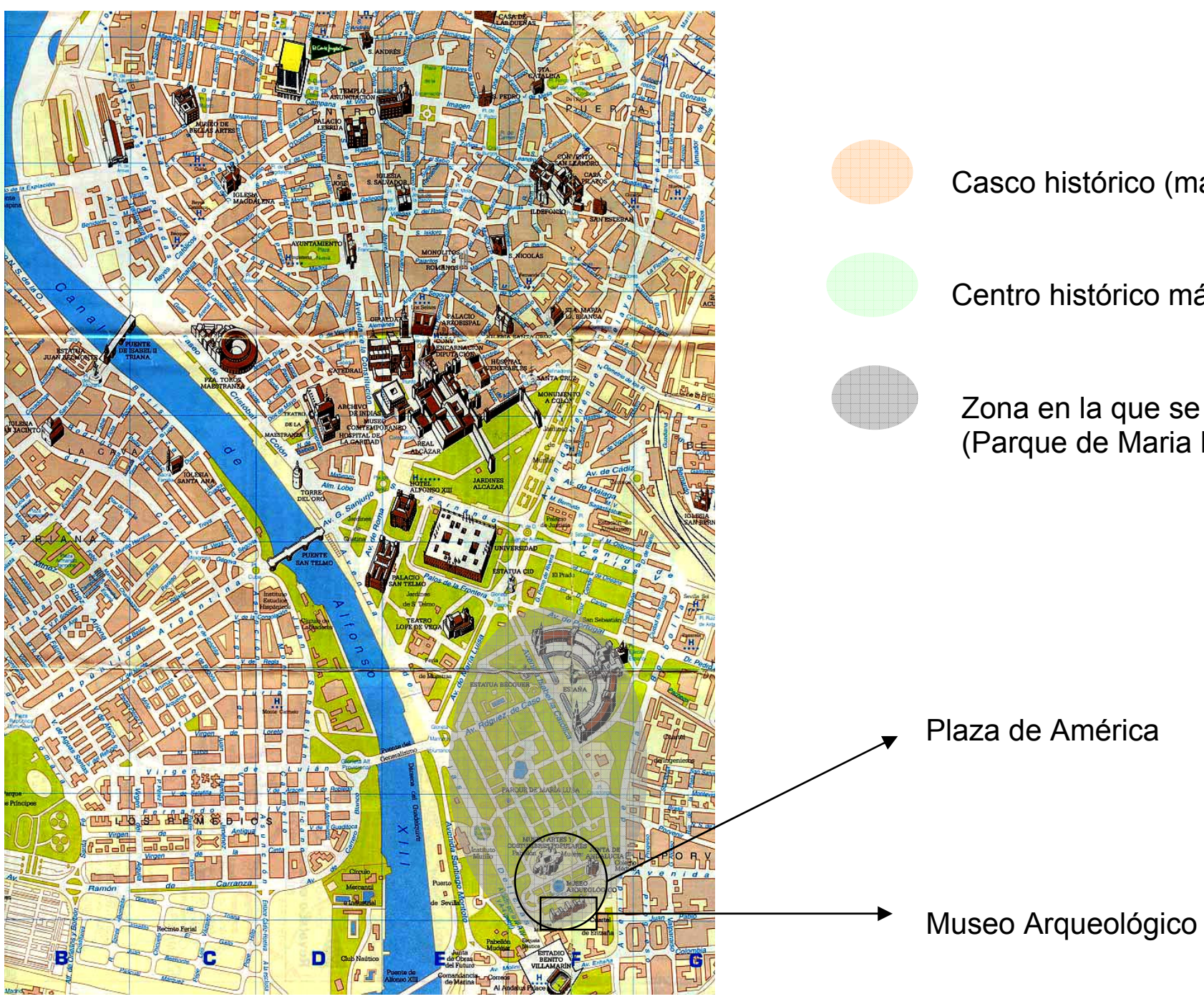


Las siguientes vistas aéreas muestran la situación del edificio en a ciudad.

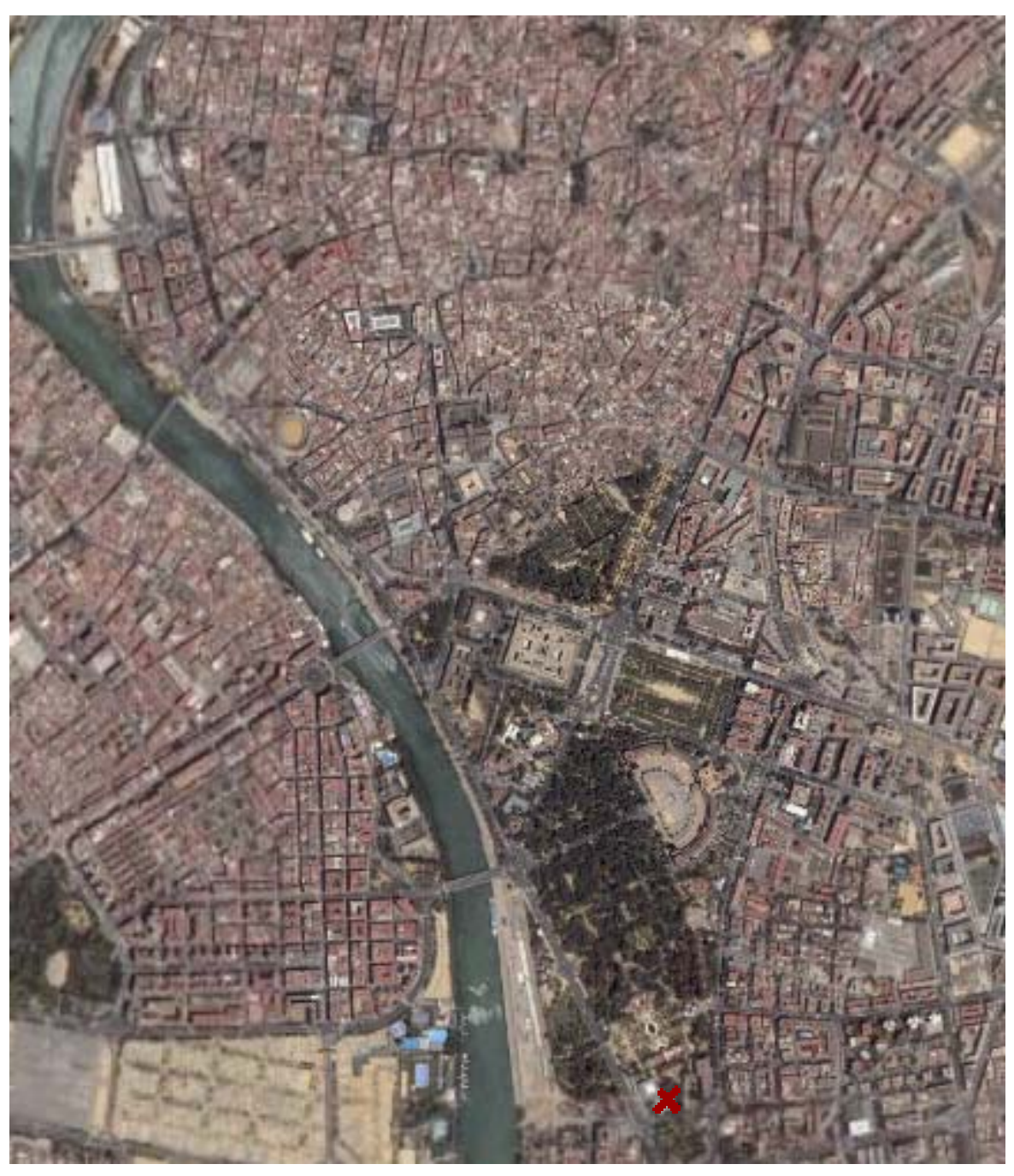

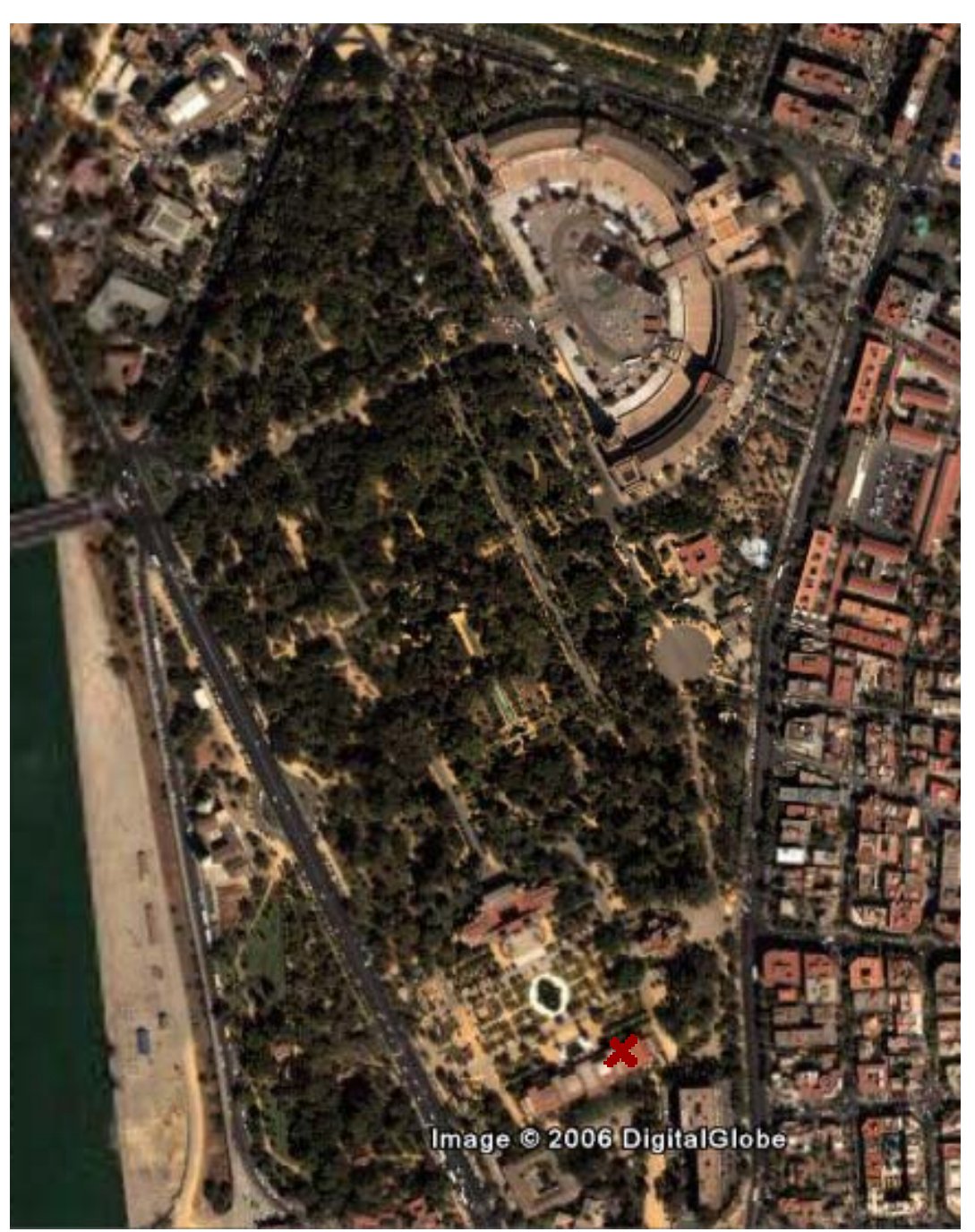


${ }_{20} \boldsymbol{M}$

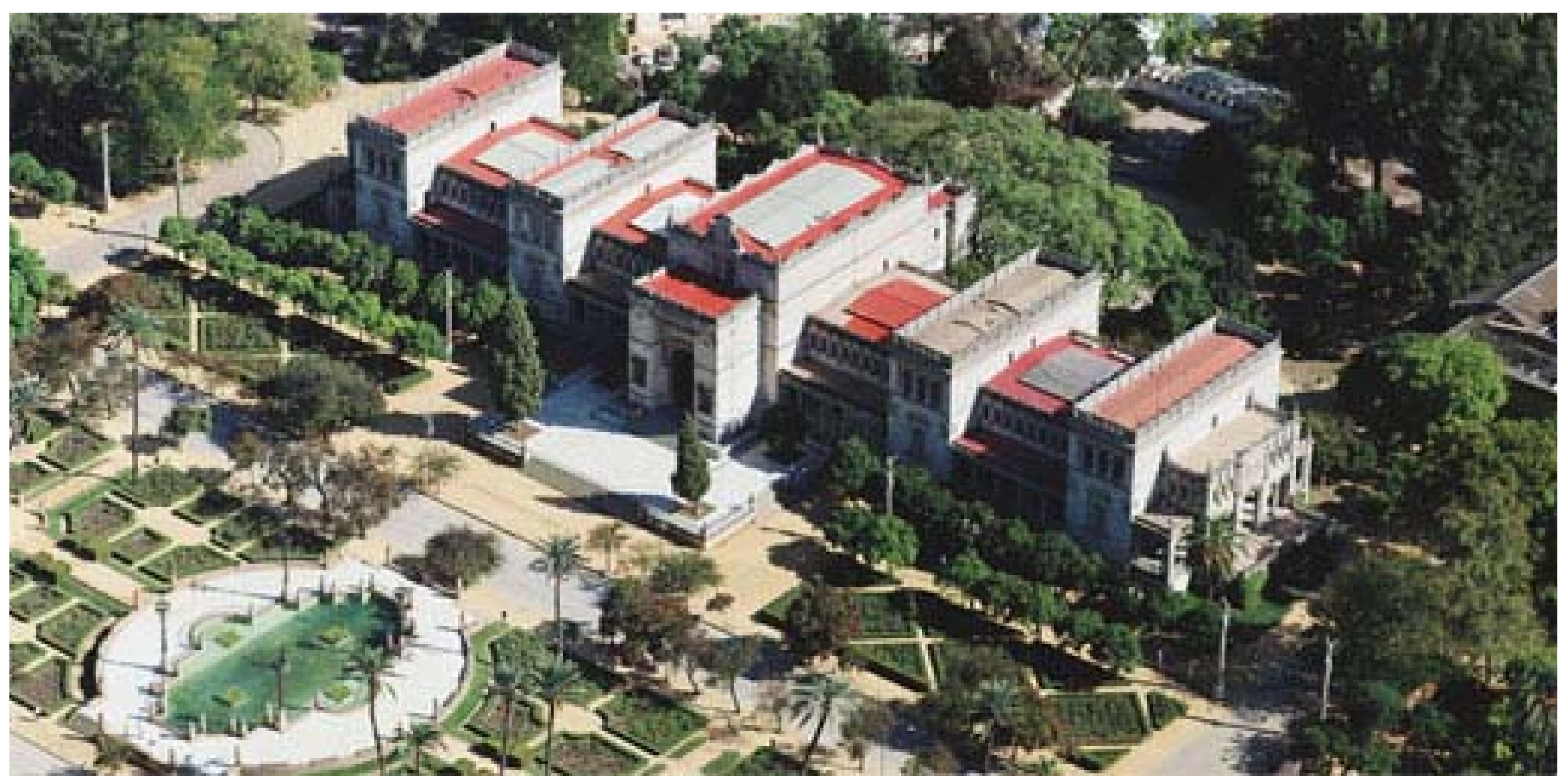




\section{I.2. ORIGEN E HISTORIA DEL MUSEO}

El origen del Museo Arqueológico de Sevilla se relaciona, como el de la mayoría de los museos españoles, con los procesos desamortizadores que comenzaron en la primera mitad del siglo XIX. Tras varios decretos en los que se suprimían las órdenes religiosas y se confiscaban los bienes de las mismas, la Real Orden 19 junio 1835 pone los archivos, bibliotecas y objetos de arte a cargo de una Junta que los recoja, examine e inventaríe. Por la Ley de 22 de julio de 1837 se nacionalizan los bienes del clero secular y la Iglesia y en su artículo 25 destina a los museos las obras de arte. La Real Orden de 13 de junio de 1844 crea las Comisiones Provinciales de Monumentos, quedando bajo su cargo los museos provinciales. La Ley de Instrucción Pública de 9 de septiembre de 1857, conocida como Ley Moyano, ordena la creación de bibliotecas, archivos y museos donde aún no hubiera; pero la creación oficial del Museo Arqueológico de Sevilla se produce mediante el Real Decreto de 20 de marzo de 1867, por el que se crean el Museo Arqueológico Nacional y los museos arqueológicos provinciales.

En la ciudad de Sevilla existían colecciones arqueológicas desde el siglo XVI y ya en el siglo XIX se producen excavaciones en Itálica y otros puntos de la provincia. Algunas de estas colecciones darán lugar en 1892 a la Colección Municipal, con la compra de estas piezas por parte del Ayuntamiento. Muchas de estas piezas fueron instaladas como Museo Arqueológico Provincial en el Convento de los Capuchinos, cuya colección fue aumentando progresivamente gracias a las donaciones y a las excavaciones que se realizaban. A partir de 1840 el Museo Arqueológico se une al de Bellas Artes, instalándose ambos en el Convento de la Merced, pero por Real Orden de 21 de noviembre de 1879 se crea oficialmente el Museo de Antigüedades de Sevilla, con lo que tenemos dos museos diferentes, con dirección y personal diferentes, pero en una misma sede. Esta 
situación se prolongó hasta los años 40 del siglo $X X$, cuando en 1941 el Ayuntamiento de Sevilla cede, de forma ilimitada pero condicionada al uso museístico, al Ministerio de Educación Nacional el Pabellón de Bellas Artes o del Renacimiento de la Exposición Iberoamericana de 1929 para la instalación del Museo Arqueológico Provincial, cediendo además en depósito la Colección Municipal. El museo abrirá sus puertas al público en mayo de 1946.

\section{I.3. TEMÁTICA}

El Museo Arqueológico de Sevilla se ha ido gestionando lentamente a lo largo del tiempo. Tras la desamortización, la evolución de sus colecciones, donaciones y excavaciones llegan a transmitir al visitante un mensaje particular y significativo del coleccionismo arqueológico hallado en el Bajo Valle del Guadalquivir.

La exhibición de este compendio de hallazgos arqueológicos ha creado un discurso museográfico que patenta la singularidad de la institución y la concreción de sus piezas en el panorama museístico de la Península Ibérica.

El contenido de este museo se encuentra en el fenómeno del coleccionismo privado que se produjo en Sevilla desde el XVII hasta el siglo XIX, lo que propició la formación de importantes colecciones de antigüedades. Parte de esta 
colección se ha instalado en distintas estancias sevillanas hasta la creación oficial del Museo de Antigüedades de Sevilla abriéndose al público en mayo de 1946, sede actual del museo.

La temática está sujeta al contenido de estas colecciones destacando los yacimientos encontrados de los primeros testimonios de la presencia humana en este territorio durante el Paleolítico. La cultura de nuestros antepasados y los pueblos colonizados en Andalucía antes de la invasión de los romanos, son mostrados con la interesante colección de fósiles e instrumento del Paleolítico y del Neolítico, así como los poblados calcolíticos de Valencina de la Concepción, sus ajuares megalíticos y restos cerámicos.

A continuación, dicha temática se encuentra vertebrada por la aparición de la cultura tartética, con el Tesoro del Carambolo, que documenta una etapa histórica aún por investigar por la ausencia de rigor científico en algunas lagunas. Este hecho otorga al Museo Arqueológico de Sevilla una gran significación y una particularidad que manifiesta la importancia de su muestra comparándola con el resto de museos arqueológicos de España.

Otra de las colecciones que da notoriedad a este museo es el descubrimiento de la ciudad romana de Itálica situada en la planta principal. Sus orígenes se remontan al año 206 a.C. tras ganar la batalla a los cartagineses. Este poblado romano convivió con la cultura turdetana que pronto se impregnó de la influencia romana. La colección de estas piezas, en su mayoría esculturas, evidencian la monumentalidad y la riqueza de su cultura, junto con el incalculable valor histórico que ha sido objeto de estudio por parte de destacados especialistas nacionales e internacionales. Destacan en su conjunto el legado epigráfico en piedra o bronce junto con los restos de retratos, esculturas y mosaicos con decoraciones geométricas o figuradas. 
Por último, debemos mencionar los hallazgos de la antigüedad tardía con la aparición de restos arqueológicos paleocristianos y con sus primeras manifestaciones en nuestro territorio entorno al siglo III. Resaltan piezas como los sarcófagos, elementos sustentantes arquitectónicos y ajuares funerarios.

Y por último una leve representación de la presencia islámica con la exhibición de piezas que revelan la destreza manual de sus creadores. Básicamente se exponen vasijas y azulejos.

\section{I.4. LA COLECCIÓN}

\section{a) Origen, temática, titularidad y gestión.}

Como ya se ha dicho, la génesis de la colección del Museo, al igual que en el resto de museos provinciales, es resultado de las desamortizaciones, a las que se unirán antiguas colecciones como la reunida por Francisco de Bruna y las procedentes de las primeras excavaciones oficiales realizadas en Itálica a mediados del siglo XIX. A mediados del siglo $\mathrm{XX}$ la colección aumenta gracias a los depósitos realizados por la Diputación y el Ayuntamiento. A todo ello, habría que sumarle las piezas procedentes de intervenciones desarrolladas en la capital y en su provincia, junto a objetos procedentes de hallazgos casuales, donaciones y compras efectuadas por la institución.

Atendiendo a la naturaleza de sus colecciones y su temática y siguiendo el "sistema de clasificación de 
museos" que actualmente utiliza el ICOM, , el Museo Arqueológico de Sevilla se puede agrupar dentro de las instituciones museísticas de arqueología y antigüedades, ya que el $99 \%$ de su colección pertenece a la disciplina arqueológica, mientras que el $1 \%$ restante está constituida por objetos de arte industrial o de artes aplicadas a la industria, denominadas "artes decorativas".

La colección posee una continuidad cronológica que abarca, sin interrupción, desde la Prehistoria hasta prácticamente nuestros días, procediendo en su mayor parte de las distintas intervenciones arqueológicascientíficas desarrolladas en la propia capital hispalense y en su provincia; no obstante, existen piezas de origen diverso, como de distintas provincias del territorio español (principalmente del sur de la península lbérica) y de fuera de nuestras fronteras (Líbano, Italia, Sudán e Iberoamérica).
Existen en la colección piezas de diversa titularidad: estatal, autonómica, municipal y privada, siendo el total de obras que integran la colección de 400.000 (compuesta tanto por lotes como por piezas individuales), ubicadas la mayoría en el almacén.

En el apartado dedicado a Análisis de las Colecciones se detallará cómo el número de piezas ingresadas durante 2.004 y 2.005 es de 60.000 .

La gestión diaria de las colecciones es llevada a cabo por el personal facultativo del museo, redactándose por el Área de Conservación e Investigación tres libros de registro ${ }^{3}$ :

- De la colección estable del Museo.

- De depósitos pertenecientes a la Administración del Estado y a sus Organismos Autónomos.

\footnotetext{
${ }^{3}$ Siguiendo lo establecido en el Artículo 10 del Real Decreto 620/1987, de 10 de abril, por el que se aprueba el Reglamento de Museos de titularidad estatal y del Sistema Español de Museos.
} 
- De otros depósitos.

Para el inventario y catalogación de las piezas, los catalogadores utilizan la aplicación DOMUS, implantada en el museo desde 2.003, cuando se inicia la catalogación de los fondos museográficos de la exposición permanente. Aún no se ha iniciado la catalogación en DOMUS de los fondos documentales y bibliográficos.

Además de la ficha de catálogo, se llevan a cabo informes de conservación y restauración:

- De las piezas que forman parte de los fondos del Museo.

- Para las solicitudes de préstamos.
Asimismo, se redactan documentos para el control de "movimientos" y se facilita a investigadores externos la consulta de todos los catálogos.

Con respecto a le gestión del museo en general, así como de la biblioteca, el Área Administrativa utiliza el sistema operativo Windows, mientras la biblioteca se sirve del programa ABSYS.

Tratando los fondos bibliográficos como parte de la colección del museo, destacar que el número total de volúmenes de que dispone, tanto de monografías como de publicaciones periódicas, es de 21.588, acordes con la temática de la institución: Arqueología, Museología, Historia Antigua y Arte. Se profundizará en el Análisis de Colecciones en el crecimiento de la biblioteca, con lo que sólo destacaremos aquí que durante los años 2.004 y 2.005 han sido dados de alta 586 volúmenes y que el grado de informatización es de 3.400 volúmenes, mientras que todos están catalogados manualmente. 


\section{b) Investigación y Conservación}

En cuanto al del papel y alcance científico de la institución en investigación, destacar que, en lo que respecta a colecciones, el museo ocupa un lugar privilegiado a nivel nacional dentro de la disciplina arqueológica. Durante los dos últimos años, la mayoría de las actividades realizadas (congresos, conferencias, cursos, etc.) han girado, principalmente, en torno al periodo romano y a la convivencia de las tres culturas en la época medieval.

Recientemente se ha publicado una versión actualizada del catálogo por el antiguo director del museo y además se ha vuelto a publicar la revista de la Asociación de Amigos del museo, con tres nuevos números hasta la fecha.

Es de destacar la magnitud de la actividad científica que gira entorno al museo y que quedará lo suficientemente analizada en el Análisis de las Colecciones. Sólo aportar como dato que durante el periodo 2004-2005 se ha atendido un total de 208 peticiones por parte de investigadores externos. Es por esto también que en el Programa Arquitectónico se hará hincapié en conseguir un espacio adecuado para atender a los investigadores, que pueden aportar al museo gran cantidad de datos sobre su colección.

Al analizar el estado de conservación de las colecciones, más detallado en la sección del Análisis dedicada a tal fin, se pueden clasificar las piezas según su estado de conservación en:

- Bueno. En torno a un $70 \%$

- Regular. Alrededor de un $20-25 \%$

- Malo. Un 5-10\% aproximadamente.

Son unos resultados bastante positivos, teniendo en cuenta que a excepción de la sala de epigrafía jurídica, no existe un programa de recogida y control de las condiciones climáticas. Además, las fuentes de luz, naturales y 
artificiales, se entremezclan a lo largo del recorrido expositivo, sin un adecuado control lumínico.

Aunque en ocasiones se han realizado campañas para el control de plagas por empresas externas y se realiza una limpieza general con periodicidad semanal, seguramente por la falta de estanqueidad, se localizan pequeños insectos inertes en el interior de las vitrinas. El Parque de María Luisa donde se sitúa el museo, funciona como pulmón y filtro para la contaminación atmosférica, por lo que no se han detectado sustancias nocivas en el interior.

\section{I.5. EL INMUEBLE}

\section{Breve caracterización formal e histórica.}

El Museo Arqueológico de Sevilla está ubicado en lo que fue el Pabellón de Bellas Artes de la Exposición Universal de 1929. El concurso celebrado a partir de 1911 para la elaboración del proyecto general de emplazamiento y distribución de la misma fue ganado por el arquitecto Aníbal González. Los tres pabellones principales de la exposición se ubicaron en el Huerto de la Mariana, hoy Plaza de América: el Pabellón de Industrias, en estilo neomudéjar plateresco (hoy Museo de Artes y Costumbres Populares), el Pabellón de Bellas Artes, en estilo neorrenacimiento plateresco (hoy Museo Arqueológico) y el Pabellón de la Casa Real en estilo neogótico isabelino (hoy dependencias municipales).

El edificio del Pabellón de Bellas Artes se encuadra dentro del llamado Regionalismo Arquitectónico, movimiento en el que los arquitectos buscan una arquitectura nueva y 
auténtica pero sacándola de las raíces propias de la región. Así, se analizan los períodos históricos de la arquitectura desarrollada en cada lugar a lo largo de los siglos, cosa que ya había hecho el Historicismo en el siglo XIX, pero esta vez con un giro conceptual. No se trata de buscar en los estilos del pasado para cubrir las necesidades constructivas, sino de partir de los estilos históricos para lograr a través de su análisis un "orden arquitectónico regional" y así llegar a una "arquitectura nacional", resultado de la yuxtaposición de las arquitecturas regionales. Es un movimiento que no pretende tipificar los estilos históricos sino extraer de ellos las enseñanzas para hacer algo nuevo, aunque firmemente enraizado en la tradición, lo que muchas veces enmascaró esa novedad.

Aníbal González vive en Madrid la reacción contra el Neoclasicismo y la búsqueda de alternativas al eclecticismo. Se vive en toda Europa un deseo de cambio en los primeros años del siglo $X X$ que se manifiesta de forma diferente en cada lugar. Es el momento del Art Nouveau belga, el Jungendstil alemán, el Secesionismo vienés, el Modernismo catalán, el Floreale italiano, la Escuela de Glasgow escocesa, etc. Cuando González llega a Sevilla era un arquitecto modernista, pero no es una ciudad adecuada para el desarrollo de tal estilo. La arquitectura sevillana se articula plenamente dentro del panorama español nacionalista, reproduciendo todos los estilos en búsqueda de un "estillo sevillano". Este estilo arquitectónico sevillano surge de la conjunción de unos elementos estilísticos históricos y unos elementos constructivos originales, es decir, los diversos estilos históricos, fundamentalmente el mudejarismo y el clasicismo, pasados por el tamiz de las técnicas y artesanías constructivas locales y de la capacidad del arquitecto.

Aníbal González y Álvarez Osorio nació en Sevilla el 10 de junio de 1876. Finalizó sus estudios en la Escuela Superior de Arquitectura de Madrid en 1902, donde recibió una formación de línea académica. Posteriormente se instala en Sevilla, donde desarrollaría la mayoría de sus proyectos 
que abarcan obras de todo tipo. No obstante, desde 1910, en que se efectúa el concurso de proyectos, hasta 1929, en que tiene lugar la muerte de González, se dedica casi exclusivamente a la Exposición Iberoamericana. Sus primeras obras, en los años del primer decenio del siglo, pueden encuadrarse dentro del Modernismo, pero a partir de 1906 inicia una evolución que lo hará desembocar en el historicismo nacionalista. Es clave el concurso para la Exposición Iberoamericana ya citado, que en septiembre de 1911 se falla a su favor con un proyecto que retoma los estilos históricos de la arquitectura española. No obstante su estilo se verá cada vez más sometido a su dominio de la técnica y a su maestría compositiva, que poco a poco van imponiendo un claro sello personal a su producción, que se manifiesta claramente en la Palaza de América en sus tres pabellones.

El Pabellón de Bellas Artes, hoy Museo Arqueológico, fue concebido por Aníbal González como lugar de exposición similar a un museo. Su construcción se llevó a cabo entre
1912 y 1919 en estilo neorrenacentista plateresco, con un cerramiento de ladrillo revestido con piedra artificial y sobre un basamento de piedra. Se estructura en un bloque longitudinal, con una planta rectangular atravesada por nueve cuerpos, siendo el central una gran sala elíptica a cada lado de la cual se distribuyen cuatro salas que configuran la planta simétrica del edificio.

Para la decoración escultórica se convocó un concurso internacional, resuelto en 1913 a favor de Lorenzo Coullaut Valera, asociado a Manuel Delgado Brackembury. Se realizan ocho esculturas para las hornacinas exteriores, que representan desde la izquierda de la fachada principal, la Historia (Delgado), la Pintura (Coullaut), la Escultura (Delgado), la Arqueología (Delgado); y en fachada posterior la literatura (Coullaut), la Arquitectura (Delgado), la Música y la Cerámica (Coullaut). Además se les encargan también cuatro "putti" con escudos para rematar las esquinas del palacio, así como cuatro grandes grupos alegóricos para las hornacinas interiores de la sala elíptica, 
que luego se colocaron en la glorieta de Covadonga y representan el Arte (Coullaut), la Ciencia (Delgado), el Trabajo (Delgado) y el Genio (Coullaut).

Pasada la exposición, el edificio quedó sin utilidad hasta la Guerra Civil, cuando sirvió durante un tiempo como hospital al servicio de los soldados italianos llegados a España para intervenir en la contienda.

Después de la Guerra, el 31 de diciembre de 1941, siendo Alcalde de Sevilla D. Manuel Ibarra y Lasso de la Vega, el Ayuntamiento cede el edificio al entonces Ministerio de Educación Nacional con el fin de instalar el Museo Arqueológico Provincial, cediéndose también en depósito la Colección Arqueológica Municipal. En marzo de 1942, el inspector general de museos, D. Joaquín María de Navascués, toma posesión del inmueble en nombre del Ministerio, comenzando poco después las obras de adecuación para museo.
El proyecto de instalación del museo se debe a la colaboración de D. José María de Navascués, el director del museo D. Juan Lafita y el arquitecto D. Félix Hernández Giménez, que dirige estas primeras obras, tras las que quedan abiertas al público las ocho primeras salas (hoy las XI a XX) ordenadas de forma cronológica, además de los despachos de dirección, oficinas y biblioteca. El 25 de mayo de 1946 se inauguran las ocho salas ya comentadas, del ala occidental, incluido el gran salón central, abriendo el museo al público el 29 de mayo de 1946.

En las décadas posteriores hasta llegar a la configuración actual del museo, se suceden obras de acondicionamiento, mantenimiento y la apertura progresiva de más salas hasta configurar las 27 que hoy se visitan. Estas intervenciones serán detalladas en la sección dedicada a la Arquitectura del museo. 


\section{I.6. TITULARIDAD.}

\section{RÉGIMEN JURÍDICO.} MODELO DE GESTIÓN

El Museo Arqueológico de Sevilla es un museo de titularidad estatal gestionado por la Junta de Andalucía.

No obstante, el edificio procedente de la Exposición Iberoamericana de 1929 es de propiedad municipal, pero fue cedido por el Ayuntamiento de Sevilla al entonces Ministerio de Educación Nacional por acuerdo de 31 de diciembre de 1941 para la instalación del Museo Arqueológico. Así, actualmente el Ministerio de Cultura ostenta la titularidad del edificio y las colecciones adscritas al mismo, quedando pues sometido al Real Decreto 620/1987, de 10 de abril, por el que se aprueba el Reglamento de los Museos de Titularidad Estatal y del Sistema Español de Museos. No obstante, el artículo 5, apartado 2, de este reglamento establece:
Artículo 5. Régimen aplicable a los Museos de titularidad estatal.

2. Sin perjuicio de lo dispuesto en el párrafo anterior, la Administración del Estado puede establecer convenios con las Comunidades Autónomas para la gestión de Museos de titularidad estatal, que no alterarán su adscripción ministerial.

En virtud de lo dispuesto en este artículo y en el Real Decreto 864/1984, de 29 de febrero, sobre el traspaso de funciones y servicios del Estado a la Comunidad Autónoma de Andalucía en materia de Cultura, el Estado transfiere la gestión de los museos de titularidad estatal a la Junta de Andalucía mediante convenio, recogido en la Resolución de 27 de mayo de 1994, de la Dirección General de Bienes Culturales, por la que se da publicidad a los Convenios entre el Ministerio de Cultura y Consejería de Cultura y Medio Ambiente, sobre Gestión de Archivos y Museos de titularidad estatal y sobre Gestión de Bibliotecas de 
titularidad estatal. (BOJA 90 de 16 de junio de 1994). En este convenio se especifica que el Estado mantendrá la titularidad que le corresponde sobre los edificios y colecciones, siendo los ingresos de fondos que no sean de titularidad estatal en concepto de depósito. Asimismo detalla todos los procesos de autorizaciones a los que el museo queda sometido por parte del Estado (salida de fondos, restauraciones, etc.). Así, las intervenciones que pretendan hacerse en el edificio deberán ejecutarse por parte del Ministerio o con su consentimiento, así como las restauraciones de las piezas adscritas al museo.

Las consideraciones sobre los fondos se recogen en la estipulación segunda:

\section{Segunda. Fondos.}

2.1 El Estado mantendrá las titularidades que en la actualidad le corresponden sobre los fondos museísticos y archivísticos, que se conservan en los Museos y Archivos objeto de este Convenio y sobre aquellos otros que depositen a partir de la entrada en vigor del presente Convenio, cuya gestión se efectuará por la Comunidad Autónoma.

2.2 Los ingresos de fondos que se efectúen en los Museos y Archivos objeto de este Convenio no modificarán el régimen de su titularidad dominical, sin perjuicio de su gestión por la Comunidad Autónoma.

2.3 Los ingresos de fondos que no sean de titularidad estatal,(...), se realizarán siempre en concepto de depósito, previa autorización de la Consejería de Cultura y Medio Ambiente de la Junta de Andalucía.

2.4 La Junta de Andalucía podrá realizar los depósitos que tenga por convenientes en calidad de propietaria o de mandatario de un tercero.

2.5 La Administración General del Estado, sólo responderá de los fondos ingresados que haya autorizado expresamente.

$$
\begin{array}{lll}
2.6 & \ldots & \\
2.7 & \ldots & \\
2.8 & \text { La Junta de Andalucía, en el ejercicio de la }
\end{array}
$$
gestión museística o archivística de los fondos que ingresen en 
los Museos y Archivos objeto de este Convenio, responderá frente al Estado en las mismas condiciones que el depositario.

$2.9 \quad$...

2.10 La salida de fondos de titularidad estatal de los Archivos y Museos objeto de este Convenio, salvo por razones de servicio establecidas reglamentariamente, necesitará autorización del órgano competente de la Administración General del Estado. Las solicitudes, formalizadas conforme a la Orden que dicte al efecto el Ministerio de Cultura deberán efectuarse con una antelación mínima de dos meses a la fecha prevista, y la autorización se entenderá concedida si la Administración General del Estado no la emitiese en el plazo de un mes a contar desde la recepción de la solicitud. En el caso de depósitos se respetarán las condiciones de los mismos.

La salida temporal de fondos fuera del territorio español continuará rigiéndose por el art. 31 de la Ley 16/1985, de 25 de junio, del Patrimonio Histórico Español y por los artículos 52 y ss. de RD 111/1986, de 10 de enero, de desarrollo parcial de la misma.

2.11 Las intervenciones de conservación y restauración de fondos de titularidad estatal conservados en los Archivos y
Museos objeto de este Convenio, requerirán autorización de la Junta de Andalucía, así como el consentimiento de la Administración General del Estado, que se entenderá otorgado si no se hubiese emitido expresamente en el plazo de un mes desde la recepción de la correspondiente solicitud.

2.12 Cualquier convenio sobre reproducción total o parcial de fondos de titularidad estatal, conservados en los Archivos o Museos a que se refiere este Convenio, deberá ser autorizado por el Ministerio de Cultura. Asimismo, dicho Ministerio deberá comunicar previamente a la Administración gestora los convenios que suscriba para la reproducción de estos fondos.

2.13 La Comunidad Autónoma garantizará el cumplimiento de las normas estatales que regulen el acceso a la consulta en los Archivos y Museos objeto de este Convenio.

El edificio e instalaciones se recogen en la estipulación cuarta: 


\section{Cuarta. Edificios e instalaciones}

4.1 El Estado conserva la titularidad de los edificios e instalaciones de los Archivos y Museos objeto de este Convenio.

4.2 Las inversiones que se realicen en los edificios de los referidos Archivos y Museos, y que no supongan la mera conservación de los mismos serán programadas por el Ministerio de Cultura, por propia iniciativa o a propuesta de la Comunidad Autónoma y siempre previa consulta con los órganos competentes de esta última.

Dichas inversiones se realizarán con cargo a las partidas que se habiliten al efecto en los Presupuestos Generales del Estado o, subsidiariamente, en los de la Comunidad Autónoma.

4.3 En todo caso, la contratación y ejecución de las mismas se llevará a cabo con arreglo a lo previsto en la legislación de Contrato de Estado.

4.4 Los gastos de mantenimiento y conservación de los edificios e instalaciones de los Archivos y Museos objeto de este Convenio, incluidos los que se deriven de las nuevas inversiones, serán atendidos por la Junta de Andalucía con cargo a sus Presupuestos.
4.5 Los edificios e instalaciones de los Archivos y Museos de ambas Administraciones se dedicarán a funciones archivísticas y museística, así como de difusión cultural siempre que no perjudiquen el normal desarrollo de las anteriores.

Así se determina que el Estado conservará la titularidad de los edificios y colecciones objeto de este convenio, uno de ellos el Museo Arqueológico de Sevilla, y correrá con los gastos de inversión, mientras la Junta de Andalucía asume la gestión del mismo y los gastos de mantenimiento. Cualquier restauración o movimiento de piezas, así como cualquier intervención en el edificio, deberá ser autorizado por el Ministerio de Cultura. Además se aclara que la Junta de Andalucía podrá ingresar piezas de su propiedad en el museo en concepto de depósito, y dado que los objetos arqueológicos hallados en la Comunidad Autónoma pertenecen a la Junta de Andalucía, es abundante la cantidad de piezas que ésta deposita en el museo. 
Además de la titularidad y gestión del museo, es importante destacar el nivel de protección que tienen el edificio y sus colecciones, ya que éste determina el procedimiento a seguir en caso de intervenciones o restauraciones. El Museo Arqueológico de Sevilla, como ya hemos dicho, es un museo de titularidad estatal sometido al Real Decreto 620/1987, de 10 de abril, por el que se aprueba el Reglamento de los Museos de Titularidad Estatal y del Sistema Español de Museos. Dicho Reglamento establece en su artículo 5 la protección que se le da a los inmuebles destinados a albergar museos de titularidad estatal y a sus colecciones:

Artículo 5. Régimen aplicable a los Museos de titularidad estatal.

1. Los Museos de titularidad estatal se regirán por las disposiciones de la Ley 16/1985, de 26 de junio, del Patrimonio Histórico Español, y normas de desarrollo que resulten de aplicación y por las contenidas en este título.

2. ...
3. En aplicación del artículo 60.1 de la Ley 16/1985, quedan sometidos al régimen de protección establecido para los bienes de interés cultural, los inmuebles destinados a la instalación de Museos de titularidad estatal y los bienes muebles integrantes del Patrimonio Histórico Español custodiados en aquellos.

Así, tanto el edificio como las colecciones del museo quedan sometidos al régimen que la Ley 16/1985, de 25 de junio, del Patrimonio Histórico Español establece para los Bienes de Interés Cultural. 


\section{I.7. GESTIÓN ECONÓMICA Y DE RECURSOS HUMANOS}

En lo referente a la gestión económica, el museo no cuenta con un presupuesto propio que pueda gestionar libremente sino que se trata de partidas presupuestarias anuales repartidas en diferentes capítulos provenientes del presupuesto de la Junta de Andalucía, como se verá en el apartado de Análisis Económico.

Con respecto al organigrama de personal, el museo cuenta con una organización funcional plana, con escasa jerarquía entre los puestos lo que, acompañado por el sistema de gestión económica, hace que la planificación y la gestión de los recursos sean difíciles de llevar a cabo.

El personal y sus funciones, mayoritariamente funcionario $y$ laboral, será analizado y posteriormente revisado en el Programa de Recursos Humanos, con la posibilidad de externalizar algunos puestos con el fin de mejorar problemas que se verán en el Análisis, entre otros, los derivados del sistema de turnos de la seguridad que han hecho que el museo se vea desprovisto en ocasiones de personal para la seguridad nocturna. 
${ }^{38} \boldsymbol{Q}$
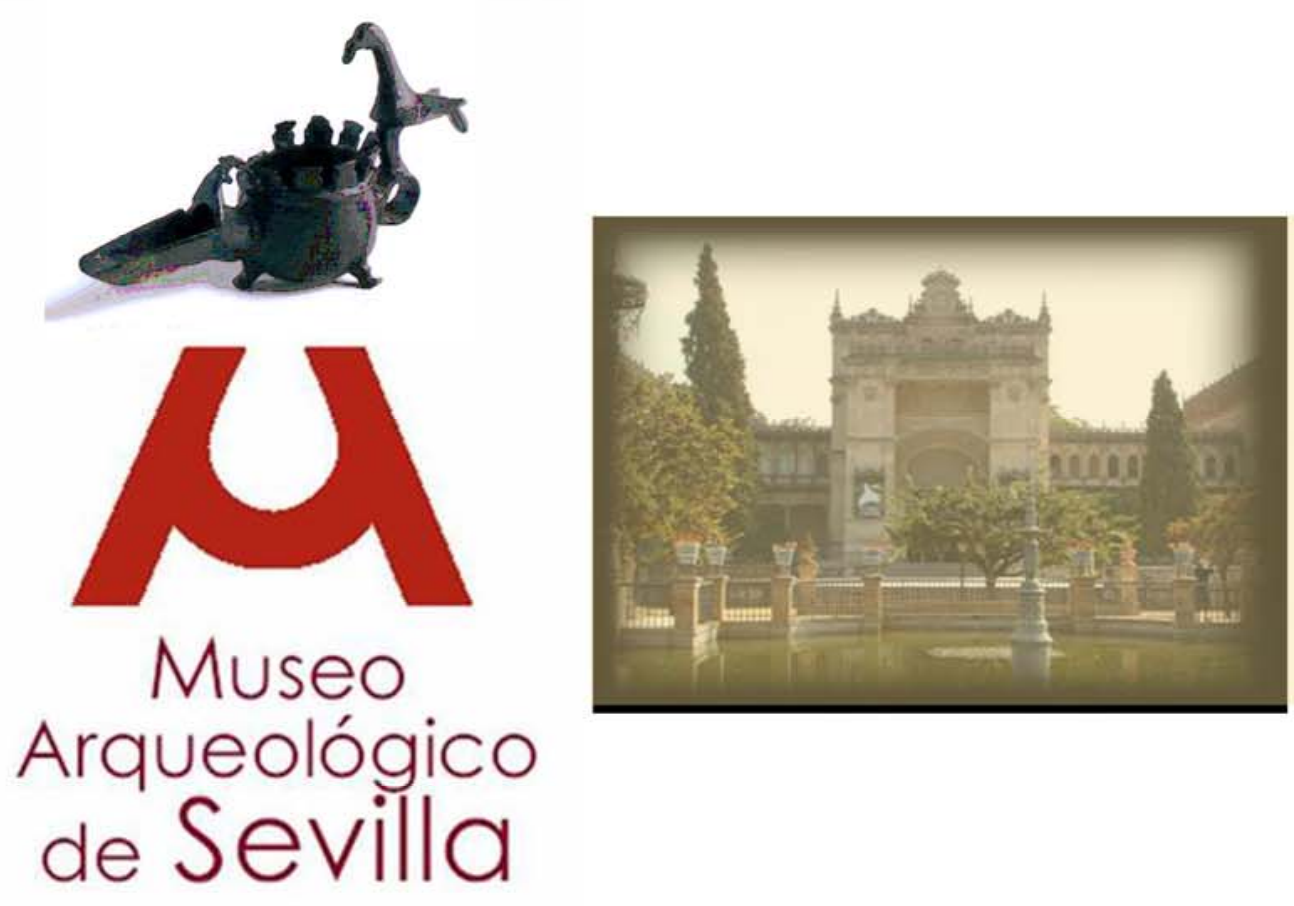

COLECCIONES

Ismael Andrés Torralba

David Ruiz García 


\section{II.1. DEFINICIÓN}

\section{II.1.1. Origen e historia de las colecciones}

El origen del coleccionismo en la capital hispalense data del siglo XVI, iniciado por nobles como D. Fabrique Enríquez y su hijo D. Per Afán de Rivera, quienes adornaron su Casa de Pilatos con antigüedades procedentes de la propia Italia.

El coleccionismo en Sevilla hunde sus raíces en el amor por lo bello, curioso, raro y antiguo, así como por mostrar la categoría social del propio coleccionista, de esta forma, surgen numerosas casas y palacios que, sobre todo a principios del siglo $\mathrm{XX}$, intentan imitar la mansión de mayor solera sevillana, la Casa-Palacio de los Duques de Medinaceli. Nacen pues, casas "escaparates" como la de D. Eduardo Ibarra o la de D. ${ }^{a}$ Regla Manjón, Condesa de Lebrija.
La primera colección del Museo Arqueológico de Sevilla, es el resultado de las distintas desamortizaciones producidas a lo largo del siglo XIX. Esta primera colección, también se nutriría de las excavaciones realizadas en la Colonia Aelia Augusta Italica.

Gran parte de los objetos procedentes de la cercana Itálica, se irán ingresando en la colección del Museo (formada por antiguas colecciones como la constituida por el Marques de Lora de Estepa en el siglo XVII), cuya primera sede se encontraba en el Alcázar del rey D. Pedro. Esta colección fue reunida por D. Francisco de Bruna a finales del siglo XVIII, posteriormente se fueron agregando numerosas piezas procedentes de excavaciones oficiales realizadas por D. Ivo de la Cortina entre 1.839 y 1.842, y por D. Demetrio de los Ríos a partir de 1.862 .

Para la adquisición de objetos procedentes de las desamortizaciones, excavaciones ilegales o patrocinadas por el propio Estado, así como la recogida de todo objeto 
arqueológico en manos de particulares, jugarán un papel primordial la Junta de Museos, creada en 1.835, y posteriormente la Comisión de Monumentos Históricos y Artísticos de la Provincia de Sevilla, a partir de 1.844.

En 1.945, la colección aumentaría gracias al depósito realizado por la Diputación Provincial de Sevilla y por el propio Ayuntamiento, cuya colección perteneció al propio D. Francisco Mateos Gago.

A todo ello, habría que sumarle la enorme cantidad de piezas procedentes de las distintas intervenciones arqueológicas desarrolladas en la propia capital y en su provincia, junto a los objetos procedentes de hallazgos casuales, donaciones y compras efectuadas por la propia institución. Todo ello ha dado lugar que hoy en día, el Museo albergue unas 400.000 piezas, ya sea en depósito o propiedad.
Aunque la colección permanente del Museo abarca desde los inicios de la humanidad hasta prácticamente nuestros días, son varias las colecciones que destacan por su importancia, entre las que se pueden distinguir las siguientes:

\section{Colección perteneciente a las primeras edades del metal}

Es la relativa a las primeras edades del metal, periodo al que corresponde el conocimiento de los metales y de su transformación. Sociedades procedentes de núcleos tan importantes como Valencina de la Concepción, Carmona o Utrera, proporcionarán piezas de gran relevancia que, hoy día, aportan un fuerte carácter al Museo dentro de las sala de Prehistoria. Dentro de esta colección, destacan el conjunto de ídolos realizados en diversas materias primas pertenecientes a la Edad del Cobre, cuyo periodo histórico 
transcurre desde el 3.000 al 2.000 a.C. Entre las piezas más importantes, se pueden destacar las siguientes:

Ídolo placa oculado (número de registro: RE 25.837): realizado en pizarra, fue hallado en el Tholos del Cerro de la Cabeza, en el término municipal de Valencina de la Concepción. Posee una altura de $21 \mathrm{~cm}$. y corresponde a la cultura o sociedad calcolítica.

Vasija decorada con motivos geométricos pintados (número de registro: ROD 7.004): fue hallado en Los Algarbes, Cádiz. Esta cerámica fabricada a mano, posee una altura máxima de $21,5 \mathrm{~cm}$. y pertenece a la cultura o sociedad calcolítica.

\section{Cuenco con decoración impresa (número de registro: $\mathrm{RE}$} 25.996): cerámica a mano hallada en Écija. Posee un diámetro de $14,3 \mathrm{~cm}$. y pertenece a la cultura o sociedad campaniforme.
Puñal (número de registro: RE 25.998): hallado en la finca de Torrevuelo (Carmona), está realizado en bronce y pertenece a la cultura o sociedad campaniforme.

Molde para hacer hachas planas (número de registro: ROD 8.584): fue hallado en Utrera. Realizado en piedra, con una longitud de 21,5 cm.. Pertenece a la Edad del Bronce.

Espada tipo "Monte sa idda" (número de registro: RE 1.982/109): procede de Alcalá del Río. Realizado en bronce, posee una longitud de $78 \mathrm{~cm}$.. Pertenece al Bronce Final.

Hacha plana (número de registro: $\mathrm{RE}$ 1.984/497): está realizada en bronce y procede del término municipal de Estepa. Sus dimensiones son $26 \times 12 \mathrm{~cm}$. y pertenece a la Edad del Bronce.

Ídolo cilíndrico oculado (número de registro: RE 6.615): realizado en mármol, fue localizado en la localidad 
sevillana de Morón de la Frontera. Posee una altura de $17,8 \mathrm{~cm}$. y un diámetro de $8,8 \mathrm{~cm}$. Pertenece a la cultura o sociedad calcolítica.

Lámina decorada con ojos soles (número de registro: RE 1.988/126): hallada en el Tholos de "Las Canteras", término municipal de Alcalá de Guadaira. Realizada en oro, posee un longitud de 4,6 cm. y un peso de 1,32 gr.. Pertenece a la cultura o sociedad calcolítica.

Lámina de oro decorada (número de registro: RE 11.879): procede del Dolmen de Matarrubia, Valencina de la Concepción. Realizada en oro, su longitud es de $2 \mathrm{~cm}$. y pesa $0,5 \mathrm{gr}$.. Pertenece a la cultura o sociedad calcolítica.

\section{Fragmento decorado (número de registro: RE 1.996/7):} lámina de oro hallada en Valencina de la Concepción. Posee una altura de $2,5 \mathrm{~cm}$., una anchura de $3,8 \mathrm{~cm}$. y un peso de 0,88 grs.. Pertenece a la cultura o sociedad calcolítica.
Fragmentos menudísimos de lámina lisa (número de registro: $\operatorname{RE} 11.723, \operatorname{RE} 11.850$ a 11.854): fragmentos de láminas de oro hallados en Matarrubilla, término municipal de Valencina de la Concepción. Poseen un peso de 4,40 gr. y pertenecen a la cultura o sociedad calcolítica.

Empuñadura esférica con decoración reticulada (número de registro: ROD 7.028): hallada en los Algarbes, Cádiz. Está realizada en oro con una longitud de $6 \mathrm{~cm}$. y un peso de 5,8 gr.. Pertenece a la cultura o sociedad calcolítica.

Cuenco decorado a peine (número de registro: RE 13.204): cerámica hecha a mano y hallada en Écija. Posee un diámetro de $15,5 \mathrm{~cm}$. y pertenece a la cultura o sociedad campaniforme.

Cinco puntas de flecha unidas con cinta de oro (número de registro: Cinta RE 1.983/285. Puntas RE 1.983/286 A 290): halladas en Villaverde del Río, están realizadas en oro y bronce. La cinta mide $24 \times 0,5 \mathrm{~cm}$. y pesa $4,55 \mathrm{gr}$., mientras 
que las puntas de flecha miden entre 6 y $10 \mathrm{~cm}$. Pertenecen a la cultura o sociedad campaniforme.

Espiral de extremos engrosados (número de registro: RE 11.134): procede del Cerro de Montorcaz, en Villanueva del Río y Minas. Realizada en oro, posee un diámetro interior de $4 \mathrm{~cm}$. y un peso de $146 \mathrm{gr}$.. Pertenece al Bronce Final.

Fragmento de torques (número de registro: $\mathrm{RE} \mathrm{7.272)}$ ): hallada en el Cortijo de "El Acebuchal", Lora del Río. Realizada en oro, posee una longitud de $4,7 \mathrm{~cm}$. y un peso de 51,98 gr.. Pertenece al Bronce Final.

Tutuli (número de registro: $\mathrm{RE}$ 6.614): procede de El Castañuelo, Huelva. Realizada en oro, tiene una altura de $0,9 \mathrm{~cm}$. y un peso de 1,5 gr.. Pertenece al Bronce Final.

\section{Colección de piezas orientalizantes}

Con respecto al periodo orientalizante, el Museo Arqueológico de Sevilla conserva una rica y variada colección de piezas pertenecientes a esta cultura, resultado del contacto de los pueblos indígenas con los distintos colonizadores procedentes del Mediterráneo. Entre ellas, destacan el conjunto de piezas procedentes de "El Carambolo", joyas de titularidad municipal que representan bastante bien la fama de opulencia que tuvo Tartessos.

Dentro del marco peninsular, la colección de piezas orientalizantes y tartéssicas del Museo es una de las más importantes del país, compartiendo piezas de excepcional valor con otros museos gestionados por la Junta de Andalucía, como es el caso del Museo de Cádiz. Entre ellas, se pueden destacar las siguientes piezas: 
Astarte (número de registro: RO 11.136): procedente de "EI Carambolo", está realizada en bronce. Posee una altura de $16,5 \mathrm{~cm}$. y pertenece a la cultura o sociedad orientalizante.

Dos arracadas de bronce chapadas en oro (número de registro: $\operatorname{ROD} 101$ y $R O D$ 102): procedentes de la necrópolis de "El Acebuhal", Carmona. Están realizadas en oro y bronce, con un diámetro máximo de $6,5 \mathrm{~cm}$. Pertenecen a la cultura o sociedad tartéssica.

Broche de cinturón con botones de oro (número de registro: ROD 87): hallado en la necrópolis de "EI Acebuchal", Carmona. Fabricado en bronce y oro, posee un peso de 67 gr.. Pertenece a la cultura o sociedad tartéssica.

Tesoro de "El Carambolo" (número de registro: ROD 5.486 a 5.505): consta de 21 piezas halladas en "El Carambolo", Camas. Realizado totalmente en oro, posee un peso total de 2.950 gr.. Compuesto 16 placas de cinturón, dos pectorales, un collar y varios sellos. Pertenece a la cultura o sociedad tartéssica.

Colgante con crecientes y cabezas bifrontes. Tesoro de Ébora (número de registro: RE 9.056): hallado en el Cortijo de Ébora, Cádiz. Fabricado en oro, posee una longitud de $1,9 \mathrm{~cm}$., un diámetro de $1,5 \mathrm{~cm}$. y un peso de $2,75 \mathrm{gr}$.. Pertenece a la cultura o sociedad tartéssica.

Fíbula de tipo "Acebuchal" (número de registro: ROD 87): procede de la necrópolis de "El Acebuchal", Carmona. Fabricado en plata, posee una longitud de $14 \mathrm{~cm}$. y un peso de 99 gr.. Pertenece a la cultura o sociedad tartéssica.

Ungüentario (número de registro: ROD 104): procede de la necrópolis de "El Acebuchal", Carmona. Está realizado en alabastro y posee una altura de $8 \mathrm{~cm}$. Pertenece a la cultura o sociedad orientalizante. 
Urna cineraria. Vaso tipo "Chardón" (número de registro: ROD 8.728): hallado en Setefilla, Lora del Río. Está realizada a mano con una altura de $30 \mathrm{~cm}$. y un diámetro en la boca de $22 \mathrm{~cm}$. Pertenece a la cultura o sociedad tartéssica.

Ánfora (número de registro: RE 14.549): procede de "EI Carambolo", Camas. Cerámica hecha a torno de $65 \mathrm{~cm}$. de altura. Pertenece a la cultura o sociedad orientalizante.

Lucerna de barniz rojo (número de registro: ROD 6.661): hallada en Huelva, posee una longitud de $12 \mathrm{~cm}$. Pertenece a la cultura o sociedad orientalizante.

\section{Bandeja con decoración vegetal y figura (número de} registro: ROD 9.037): procede de "El Gandul", Alcalá de Guadaira. Realizado en bronce, su longitud es de 42,7 cm. y su anchura $28,8 \mathrm{~cm}$.. Pertenece a la cultura o sociedad orientalizante.
Melkart-Hércules (número de registro: ROD 30): de procedencia desconocida, está realizado en bronce con una altura de $14,3 \mathrm{~cm}$. y una anchura de $9 \mathrm{~cm}$.. Pertenece a la cultura o sociedad orientalizante.

Astarte "Bronce Carriazo" (número de registro: ROD 6.902): comprado en un mercadillo de antigüedades. Está realizado en bronce y posee una longitud de $15 \mathrm{~cm}$.. Pertenece a la cultura o sociedad orientalizante.

\section{Colección de piezas de origen turdetano}

Pueblo heredero de la cultura tartéssica, ha legado piezas únicas procedentes de las distintas necrópolis halladas en la provincia, así como los innumerables exvotos recogidos de los distintos santuarios de Andalucía, sobre todo en su parte oriental.

Dentro de la colección, uno de los conjuntos de mayor relevancia es el llamado "Tesoro de Mairena", compuesto por las siguientes piezas: 
Tesoro de Mairena (número de registro: RE 1.981/537 a 1.981/547): consta de diez piezas realizadas en oro y plata, con un peso total de 649,2 gr.. Está formado por dos brazaletes de $39 \mathrm{~cm}$. de longitud, una diadema, un cinturón de 36,7 cm. de longitud, una fíbula tipo "La Tene" de 6,2 $\mathrm{cm}$. de longitud, una pulsera de $4,1 \mathrm{~cm}$. de diámetro, un anillo con águila de $1,8 \mathrm{~cm}$. de diámetro, una bulla de 0,18 $\mathrm{cm}$., un colgante de $0,16 \mathrm{~cm}$. y tres vasijas realizadas en plata con alturas que oscilan los 9,4 y los $13 \mathrm{~cm}$..

Entre otras piezas, se pueden destacar un pendiente con signo de Tanit (número de registro: ROD 9.518), un exvoto con dos ojos realizado en plata (número de registro: $\mathrm{RE}$ $1.982 / 97)$, una copa con palomas adosadas realizada a torno (número de registro: RE 1.981/614) y dos cuencos procedentes del Castillo de las Guardas (número de registro: RE $1.980 / 5$ y $R E 1.980 / 6)$.

\section{Colección de esculturas procedentes de Itálica}

Ocupan un marco cronológico desde comienzos de la época imperial hasta el siglo III inclusive, todas ellas con un gran carácter colosal e idealista, propias del poder imperial (hay que tener en cuenta que los emperadores Trajano y Adriano fueron naturales de esta colonia).

La presencia de artistas extranjeros y el interés del propio emperador Adriano por enriquecerla, dio lugar a las mejores creaciones del momento dentro del marco peninsular.

El Museo Arqueológico de Sevilla conserva un gran número de ellas, entre las que podríamos destacar las siguientes:

Torso masculino colosal: posiblemente hallado en el Foro durante las excavaciones desarrolladas en Itálica durante 1.839. Posee una altura máxima de 1,49 m. y está 
realizado en mármol blanco. Copia basada en los modelos de Policleto, posiblemente representaba un miembro de la familia imperial en época de Tiberio.

Estatua heroica colosal de Trajano: hallada en 1.788 con una altura máxima de 2,20 m.. Realizada en mármol de Paros, representa un desnudo heroico del emperador Trajano, y sus rasgos clasicistas son propios de la tradición policlética. Su estilo es propio de un taller asiático y ha sido fechada en el siglo II d.C. (época adrianea).

Estatua heroica colosal acéfala: hallada en la zona de "Los Palacios" en 1.788 y realizada en mármol Afyon o Paros blanco. Su altura máxima es de $2 \mathrm{~m}$.. Según A. García Bellido, representa al emperador Adriano. Le faltan la cabeza, el brazo derecho, la mano izquierda y parte de las piernas. Ha sido fechada en el siglo II d.C..

Piernas de estatua colosal en traje militar: hallada en 1.780 en "Los Palacios". Realizada en mármol blanco y tiene una altura de 1,15 m. Posiblemente estaba provista de grebas metálica, por su grandiosidad, representaría una apoteosis. Se encuentra fechada en el siglo II d.C..

Mano con rayo: realizada en mármol blanco escultórico Pi1 de Carrara, posee una longitud máxima de 0,32 m. Posiblemente representa la mano del dios Júpiter y ha sido fechada en el siglo II d.C., dentro del marco adrianeo.

Cabeza colosal de Augusto: realizada en mármol Pentélico, mide $0,73 \mathrm{~m}$.. Le faltan piezas del cráneo y de la nariz. Representa al emperador Augusto en una aptitud de confianza y serenidad. Se encuentra dentro del marco tiberiano o claudio.

Cabeza colosal con corona cívica: realizada en mármol de Almadén de la Plata o Fuenteherido, mide 0,62 m.. Posiblemente representa a Galba o Vespasiano y quizás proceda de un taller local. Ha sido fechada en época flavia. 
Busto de Adriano: con una altura máxima de 0,82 m., está realizada en mármol Pentélico. Obra de gran calidad y perfección, es una copia de finales de época adrianea.

Busto de anciano: fue hallado en 1.895 en "Las Alcantarillas". Realizado en mármol de Almadén de la Plata o Fuenteheridos. La altura máxima es de 0,54 m. En un principio se conservaba en la Casa de la Condesa de Lebrija hasta que fue trasladada al Museo. Ha sido fechada a finales de época trajanea.

Hermes Dionysóphoros: casi la totalidad de la pieza fue hallada en 1.788 en "Los Palacios" y la pierna derecha en 1.901. Realizada en mármol de Paros, mide $2,03 \mathrm{~m}$. de altura. Parcialmente conservada, en un primer momento sostenía el dios Dionisos niño. Pertenece a época adrianea.

Torso de Meleagro: hallado en 1.781 en la zona de "Los Palacios", posee una altura máxima de 0,95 m.. Está realizado en mármol blanco y por sus destalles estilísticos ha sido identificado como Meleagro. Se encuentra fechado en época adrianea.

Afrodita Anadyomene: hallada en 1.940 en una domus, está realizada en mármol de Paros. Posee una altura máxima de $2,25 \mathrm{~m}$. y se encuentra parcialmente conservada. Su magnífica talla es propia de época adrianea y formaba parte del culto imperial a la diosa Venus.

Estatua de Artemisa: procede del teatro y fue descubierta en el año 1.900. Realizada en mármol de Paros, posee una altura máxima de 2,38 m.. Su estado de conservación es óptimo y su labra es excelente. Ha sido fechada en época adrianea.

Cabeza de Alejandro: está realizada en mármol de Paros, con una altura de $0,37 \mathrm{~m}$. Ha sido identificado como Alejandro y pertenece al II d.C. 
Cabeza de Tyche: hallada en el pueblo de Santiponce, posee una altura máxima de 0,62 m.. Está realizada en mármol blanco, posiblemente de Fuenteheridos. La majestuosa cabeza está coronada por una diadema y una torre. Pertenece a época adrianea.

Ara (Número Inventario 125): procedente de las excavaciones realizadas en el teatro en 1.972 por J.M. Luzón. Está realizada en mármol de Carrara y posee una altura de 0,99 m.. Tiene representada escenas dionisiacas con ménades y sátiros. Ha sido fechada a mediados del siglo I a.C..

Ara (Número Inventario 124): hallada en 1.971 durante las excavaciones del teatro. Realizado en mármol blanco de Carrara, posee una altura máxima de 0,99 m.. Tiene representado una tympanistria, un sátiro, una chimairophonos y una médane. Pertenece a época augustea.
Ara (Número Inventario 126): hallada en 1.971 en la orchestra del teatro, conserva parte del cilindro. Posee una altura máxima de 0,99 $\mathrm{m}$. y está realizada en mármol de Carrara. Sus relieves representan tres médanes y un sátiro. Pertenece a época augustea.

\section{Colección de bronces jurídicos:}

El Museo conserva, en una de las salas de Arqueología Romana, una magnifica colección de bronces jurídicos, documentos que juegan un papel esencial dentro de la Epigrafía Jurídica, denominada por el profesor Alföldy como: "aquella parte de la epigrafía romana que se refiere al derecho romano según su definición, es decir, a las reglas obligatorias de la vida pública y privada en el mundo romano, teniendo en cuenta también, evidentemente, las fuentes de estas reglas, por un lado, y las consecuencias del mantenimiento de las reglas dichas, es decir, el orden socio-político del Imperio romano, por otro". 
Dichos bronces, juegan un importantísimo papel para el conocimiento del derecho romano, y sólo son comparables con los conservados en el Museo Arqueológico Nacional y los encontrados en la propia Italia.

El Museo Arqueológico de Sevilla conserva los siguientes bronces jurídicos:

Lex Flavia Irnitana: está compuesta por seis tablas de bronce de $58 \times 91 \mathrm{~cm}$. y procede del municipio Flavio Irnitano. Fue hallada en 1.981 y hoy día se encuentran depositadas en el Museo. Presentan varios orificios, por lo que estuvieron colocadas sobre un muro. Las tablas que se conservan son la III, V, VII, VIII, IX y X, y originariamente estaría compuesta por 10. Corresponden a una ley flavia municipal de la época de Domiciano.

Lex Flavia Villonensis: fragmento de forma irregular de $11 \times 8 \mathrm{~cm}$. y hallado en el municipio sevillano de El Rubio.
Perteneció a la ley fundacional del municipio Villonense del que se conservan cinco fragmentos.

Diploma militare ex Baetica: fragmento de forma casi rectangular de $8 \times 5 \mathrm{~cm}$.. Ha sido datado en una fecha anterior al año 90 d.C.

Tabula Siarensis: dos fragmentos de tabla que presentan forma irregular. Fueron hallados en 1.982 en el término municipal de Utrera. Contienen varias disposiciones relativas a los honores tributados a Germánico con motivo de su fallecimiento en Antioquia.

Epistula Titi ad Muniguenses: tabla rectangular de 20,8×30 cm.. Hallada en el foro de Munigua por el Instituto Arqueológico Alemán en 1.958. Se trata de una epístula en la que el emperador Tito comunica su apelación a los cuatorviros y decuriones de Munigua en el 79 d.C., manteniendo la condena del municipio al pago de 50.000 sestercios a Servilius Pollio. 
Fragmento italicense de epístula: fragmento en bronce de $16 \times 21 \mathrm{~cm}$.. Hallado en 1.868 junto al anfiteatro de Itálica. Pertenece a la Colección Municipal y se encuentra depositado en el Museo.

Tabula de hospitalidad de Munigua: tabla rectangular decorada con un frontón coronado por palmetas. Sus dimensiones son $37,4 \times 27 \mathrm{~cm}$.. Fue hallada por el Instituto Arqueológico Alemán en Munigua en 1.958. Representa un pacto de hospitalidad entre un quaestor pro praetore y la ciudad de Munigua. Cronológicamente ha sido situada en el año 5 o 6 d.C. por D'Ors, en época de Augusto o Tiberio por Alföldy y antes del año 40 d.C. según Grünhagen.

En el año 2.000, el Museo recibió un nuevo bronce jurídico procedente del término municipal de Osuna, localidad en la que se hallaron las tablas de la lex coloniae Genetivae luliae alrededor de 1.870, y que posteriormente fueron llevadas al Museo Arqueológico Nacional.
Esta nueva tabla, que contiene desde los capítulos XIII al $\mathrm{XX}$, complementa a las conservadas en Madrid, y evidencia la fundación de las colonias romanas mediante el control militar.

\section{Colección de mosaicos procedentes de Itálica}

El Museo Arqueológico de Sevilla comparte con la Casa de la Condesa de Lebrija, una rica colección de mosaicos procedentes de la Colonia Aelia Augusta Italica.

Como sucede en muchos otros lugares, una gran parte de los mosaicos de Itálica no cuentan con datos cronológicos derivados de la excavación, por lo que muchos de ellos han sido fechados en función de los posibles edificios que los albergaban.

Los mosaicos procedentes de la nova urbs, permiten fecharlos gracias a que la urbanización se produce en 
época posterior a Adriano (117 a 138 d.C.) y comienza su declive a partir del siglo III d.C. Por tanto, ocupan un periodo comprendido desde la segunda mitad del siglo II y parte del III d.C.

En Itálica se impuso la moda del mosaico blanco y negro, pero con la tendencia a ponerle alguna nota de color en el centro (tendencia que aceptó la Bética), así como el empleo de cuadros pequeños, de una o dos figuras, acompañados de grandes conjuntos ornamentales.

\section{De todos ellos, se pueden destacar los siguientes:}

Mosaico con Busto de Baco (número de inventario: 786): fue donado por el Ayuntamiento de Sevilla al Museo en 1.944 y sus dimensiones son 2,96x2,70 m.. El tamaño de las teselas oscilan de 0,5 a $1 \mathrm{~cm}$. en el busto de dios Baco. Está compuesto por los siguientes colores: blanco de canto de río, negro azulado, rojo vinoso de Halconera y amarillo de canto de río. El busto del dios Baco está compuesto por azules, verdes y naranja, todos ellos en vidrio. Ha sido fechado en la segunda mitad del siglo II d.C.

Mosaico con Bustos Báquicos (número de inventario: 1.053): fue donado por el Ayuntamiento de Sevilla al Museo en 1.944 y sus dimensiones son 5,30x5,12 m.. Las teselas poseen un grosor de $0,5 \mathrm{~cm}$. en las carnaciones de las figuras y $1 \mathrm{~cm}$. en el resto. Los colores que han sido empleados para su elaboración son los siguientes: blanco, negro azulado, rojo y ocre de caliza alternados con vidrios en azul Prusia, azul claro y verdes claros. Se encuentra fechado desde la segunda mitad del siglo II a principios del siglo III d.C.

Mosaico de Hylas: hallado en Itálica durante las campañas desarrolladas en 1.927 y 1928, por el Conde de Aguiar. Se encuentra depositado en el Museo y sus dimensiones son $1,12 \times 1,12 \mathrm{~m}$. Las teselas poseen entre 5 y 7 milímetros con un predomino de los colores oscuros, combinados con azules, verdes y blancos. Narra el rapto de Hylas, basado 
en un pasaje de la Argonáutica y muy bien ajustado a los versos de Apolonio de Rodas. Ha sido fechado a principios del siglo III d.C.

Mosaico de Perissoterus: fue hallado en 1.896 y posteriormente depositado en el Museo. Sus dimensiones son $0,64 \times 0,54$ y sus teselas oscilan aproximadamente 1 $\mathrm{cm}$. Predominan el color Siena tostado, y su cenefa superior es rojo vinoso. Los vidrios son de color verde y amarillo. Se encuentra fechado a finales del siglo II y principios del III d.C.

Fuente de los Tritones: hallado entre 1.891 y 1.892 e ingresado en el Museo por la Comisión Provincial de Monumentos en 1.894. Sus dimensiones son 3,80x3,80 m. y en cada uno de sus ángulos hay un chaflán convexo y un nicho en el centro de cada lado. Todo el perímetro del cuadrado se encuentra enmarcado por una cinta doblada y en el centro aparecen representados cuatro tritones. Posee una gran riqueza de colorido y ha sido fechado a principios del siglo III d.C.

Fragmentos con rostros y medallones florales: fueron comprados por el Museo Arqueológico de Sevilla los días 12 y 16 de julio de 1.909. Han sido fechados a finales del siglo II d.C.

Mosaico de Conchas Marinas: hallado en una fecha anterior a noviembre de 1.895 y donado ese mismo año al Museo. Sus dimensiones son $23 \times 20 \mathrm{~cm}$. Para su realización se emplearon conchas marinas de diversas especies. Se encuentra fechada a comienzos del siglo III d.C. aproximadamente.

Fragmentos con figuras: fue depositada en 1.911 en el Museo por D. R. Amador de los Ríos. Tiene representados la imagen de un flautista que podría tratarse de una tritonesa que porta a Anfítrite o Venus. 
Fragmento con Pajarito: sus dimensiones son 25x22 cm. y sus teselas oscilan entre lo 4 y $5 \mathrm{~mm}$.. Presenta un pajarito posándose o levantando el vuelo en una rama. Predominan el blanco, negro, plomizo, ocre oscuro, rojizo y el rosa vivo. Posiblemente perteneció a un mosaico funerario y ha sido fechado en el siglo IV d.C.

Mosaico sepulcral de Antonia Vetia: hallado en 1.903 durantes las excavaciones dirigidas por D. M. Fernández López. Sus dimensiones son 0,90x0,62 m. y fue depositado en el Museo por la Comisión de Monumentos. Las teselas miden $1 \mathrm{~cm}$. aproximadamente y se han usado los colores blanco, verde, azul y rojo en sus distintas tonalidades. Tiene representado una figura femenina sentada en un sillón de respaldo rojo vivo y sostiene en sus manos una muñeca. A uno y otro lado de la figura se han representado dos candelabros con cirios. Presenta una placa con el nombre de la difunta y, en la mitad inferior, tiene representado un cordero y un pajarito. Ha sido fechada en el siglo IV d.C.
Mosaico sepulcral de Maria Severa (número de registro: 3.536): depositado en el Museo por la Comisión de Monumentos en 1.904. Sus dimensiones son 1,18x0,60 m. y se encontraba sobre una pintura mural, también conservado en el Museo. Las teselas miden $1 \mathrm{~cm}$. por término medio y presenta una inscripción, dos pájaros y varias flores.

Mosaico de Opus Sectile: hallado alrededor del año 1.904. Está compuesto por piezas perfectamente cortadas que forman motivos a base de rombos y círculos. Ha sido fechado a finales del siglo II y primera mitad del siglo IV d.C. por su semejanza al aparecido en la Domus del Amor y Psique en Ostia. Parte de él se encuentra conservado en la Casa de la Condesa de Lebrija.

Opus Sectile: fue hallado en la Casa de la Exedra en 1.924 y posteriormente depositado en el Museo. La unidad temática mide $30 \mathrm{~cm}$. en cuadrado y se emplearon los colores negro, gris oscuro, blanco y amarillo. 
Esta colección de mosaicos procedentes de Itálica, guardan una estrecha relación con los mosaicos que se encuentra en la Casa de doña Regla Manjón (la Casa de la Condesa de Lebrija), de la que el propio D. R. Amador de los Ríos dejó el siguiente testimonio: "verdadero Museo de legítimo renombre en Sevilla, el cual es visitado con fruición por los extranjeros, pues dicha señora tiene siempre franca para todo el mundo la puerta de su casa". Dicha casa, conserva extraordinarios mosaicos como son "Los Amores de Zeus", el "Mosaico de Medusa" o los "Bustos de mosaico de Planetas" entre otros.

El Museo Arqueológico de Sevilla, también conserva otros mosaicos procedentes de la provincia, como es el caso del "Juicio de Paris" aparecido en el término municipal de Casariche.

\section{Colección de piezas procedentes de la cultura islámica}

Compuesta por numerosos elementos arquitectónicos como fustes, capiteles o paneles de distintas tipologías, así como un extensa colección de brocales de pozos con diversas inscripciones de carácter cúfico, azulejos realizados con la técnica de la cuerda seca, vasijas o grandes tinajas, son una pequeña muestra de la islamización de toda Andalucía.

\section{II.1.2. Titularidad de la colecciones}

El Museo Arqueológico de Sevilla, como institución museística de titularidad Estatal y gestionada por la Consejería de Cultura de la Junta de Andalucía, alberga un conjunto de colecciones que presentan la siguiente titularidad: 
Titularidad Estatal: conjunto de bienes culturales muebles asignados 0 depositados en el Museo Arqueológico de Sevilla pertenecientes a la Administración General del Estado.

El titular del Museo Arqueológico, en este caso el Estado, asigna un conjunto de piezas para que formen parte de la colección estable del centro. Su marco legal se encuentra en el artículo 6 del Reglamento de Museos que concretamente establece que las colecciones estatales de fondos museísticos están constituidas por los bienes del Patrimonio Histórico Español pertenecientes a la Administración del Estado y a sus Organismos Autónomos asignados a los Museos de titularidad Estatal (artículo 6.1) y que los bienes asignados a un Museo de Titularidad Estatal pasan a integrar la colección estable del mismo, sin perjuicio de que puedan ser depositados en otros museos, así como en instituciones no museísticas para el cumplimiento de otros fines culturales $o$ de alta representación del Estado. En ningún caso estos depósitos alterarán dicha asignación (artículo 6.2).

También se realiza el depósito de bienes culturales muebles pertenecientes a la Administración General del Estado y a sus Organismos Autónomos.

\section{Titularidad Autonómica, Junta de Andalucía:}

Conjunto de bienes culturales muebles pertenecientes a la Junta de Andalucía que ésta ha decido ingresar en el Museo Arqueológico de Sevilla. De todos ellos merece destacarse por su importancia cuantitativa los que se producen casi a diario procedentes de las intervenciones arqueológicas realizadas en Sevilla y su provincia. Debe tenerse en cuenta dos cuestiones: en primer lugar que desde la asunción plena de competencias por parte de la Junta de Andalucía en materia arqueológica, operada por el Real Decreto 864/1.984, de 29 de febrero, las piezas arqueológicas que se descubran en Andalucía, sea 
consecuencia de un hallazgo fortuito o a consecuencia de una actividad arqueológica son de titularidad autonómica (a partir de la entrada en vigor de la Ley 16/1.985, de Patrimonio Histórico Español dichos bienes culturales son de dominio público con todas las consecuencias derivadas de esta circunstancia -entre ellas- la imprescriptibilidad del dominio por lo que en cualquier tiempo pueden recuperarse de quien las tuviere) y en segundo lugar, que el vigente Reglamento de Actividades arqueológicas (aprobado por el Decreto 168/2003 de 17 de junio) establece que con carácter previo a la determinación por parte del Director General de Bienes Culturales sobre el museo donde deben depositarse las piezas arqueológicas que aparezcan como consecuencia de una actividad arqueológica, lo que debe hacer al resolver sobre la autorización de dicha actividad, debe pedir informe a la actual Dirección General de Museos. Es una realidad bien conocida que, las numerosas actividades arqueológicas que se realizan en nuestra provincia están generando un enorme volumen de restos arqueológicos que en el Museo Arqueológico de Sevilla está planteando serios problemas de almacenamiento y de carga de trabajo técnico que deberá ser resuelto en los distintos programas.

\section{Titularidad Municipal, Ayuntamiento de Sevilla:}

Compuesta por la Colección Municipal, adquirida en 1.892, y por un gran número de piezas procedentes de la provincia de Sevilla (Santiponce, Camas,...). Está compuesta por unas 11.700 piezas. Forman parte de un depósito perteneciente a un tercero, con carácter voluntario.

\section{Titularidad Privada:}

Compuesta por depósitos pertene-cientes a terceros. Proceden de particulares o instituciones de titularidad no Estatal ni Autonómica.

De carácter voluntario: Supuesto General. Previsto en el artículo 94 de la Ley de Patrimonio Histórico de Andalucía 
según el cual la Consejería de Cultura podrá aceptar el depósito voluntario de bienes muebles integrantes del Patrimonio Histórico Andaluz en las condiciones que convenga con sus titulares. Según el artículo 14 del Reglamento de Creación de Museos y de Gestión de Fondos Museísticos, el correspondiente contrato se formalizará en un documento normalizado que será aprobado por Orden del Consejero de Cultura. Según el artículo 5.28 del ROA en relación con el artículo 2.2 del D. 333/96, es competencia del Director General de Museos la aceptación de los depósitos voluntarios.

Motivado en el facilitar el acceso a los investigadores. El artículo 22.5 del Reglamento de Protección del Patrimonio Histórico Andaluz, contempla el supuesto de que los titulares de bienes inscritos en el Catálogo a los que se imponga el acceso a investigadores pueden optar por depositarlos en un centro de carácter público durante el tiempo necesario para su estudio.
Depósitos forzosos: Se pueden citar los siguientes:

- Artículo 45.4 de la Ley de Patrimonio Histórico de Andalucía. El incumplimiento de las obligaciones que impone en la Ley a los titulares de derechos sobre bienes inscritos en el Catálogo podrá llevar aparejada la designación de depósito forzoso del bien en un Centro de carácter público hasta tanto no se garantice la conservación de los bienes afectados. La competencia, según el artículo 5.29 ROA es del Director General de Bienes Culturales. En el mismo sentido que el artículo 45.4 de la Ley de Patrimonio Histórico de Andalucía, el artículo 36.3 de la Ley de Patrimonio Histórico Español respecto a los bienes muebles declarados BIC o Inventariados.

- Artículo 13.2 de la Ley de Patrimonio Histórico Español. Respecto a los bienes muebles declarados de interés cultural se podrá acordar como obligación sustitutoria al deber de visita pública, el depósito del bien en un lugar que reúna las condiciones de seguridad $y$ exhibición durante un periodo máximo de cinco meses 
cada dos años. El órgano competente es el Director General de Bienes Culturales (artículo 5.29 ROA).

- Artículo 11 de la Ley de Museos. La Consejería de Cultura podrá ordenar el depósito de los bienes culturales de extraordinario interés existentes en un museo, en el que determine, cuando existan excepcionales motivos de urgencia, conservación, seguridad o accesibilidad y hasta que desaparezcan las causas que originaron dicho traslado.

- Artículo 12 de la Ley de Museos. La Consejería de Cultura igualmente podrá disponer el depósito de los fondos de un museo en otro, motivado en las deficiencias de la instalación o el incumplimiento de la normativa existente por parte de los responsables que pongan en peligro la conservación, seguridad o accesibilidad de los fondos.
- Artículo 13 de la Ley de Museos. En caso de disolución o clausura de un museo, todos sus fondos serán depositados en otro museo acorde con la naturaleza de los bienes expuestos y conforme al principio de proximidad territorial reintegrándose completamente al museo de origen en caso de nueva creación o reapertura del mismo.

- Artículo 17 de la Ley de Museos. Aquellos objetos de interés museográfico para Andalucía cuya importancia sea notoria y que estuvieren por cualquier circunstancia en peligro de destrucción, pérdida o deterioro, podrán ser, constituidos en depósito en el museo correspondiente. Al cesar dichas circunstancias procederá la devolución de los depositados. 


\section{II.1.3. Características y tipología en porcentaje aproximado}

\section{Arqueología}

El 99 \% de la colección del Museo Arqueológico de Sevilla pertenece a la disciplina arqueológica.

La Arqueología, bien como actividad práctica, bien como ciencia, estudia las antiguas civilizaciones a partir de los monumentos y demás testimonios ágrafos. Es por ello que, es la fuente principal y el valedor más riguroso a la hora de recolectar, valorar e interpretar los objetos propiamente arqueológicos, especialmente los procedentes de las intervenciones y prospecciones arqueológicas. Por tanto, es subsidiaria de la historia, y encuentra en la museología y la museografía la ciencia y la técnica indispensables para configurar adecuadamente sus hallazgos en el Museo.
Con especiales connotaciones de valor histórico y documental, las piezas arqueológicas las define su ciencia como artísticas, por lo que entran con pleno derecho las instituciones que las atienden en la tipología general de los museos de arte, hasta el punto de ocupar muchos de los arqueológicos un lugar especial y preeminente entre todos los de esta tipología (según queda reflejado en la Clasificación de museos que actualmente utiliza el ICOM).

Serían los años los que se encargarán de añadir mucha flexibilidad a los conceptos de pura arqueología, despojándola de buena cantidad de seco cientifismo y añadiendo a su dominio la maravilla de las artes suntuarias. Acentuando esa duplicidad de nortes es como se ha llegado a obtener el óptimo semblante de los museos arqueológicos...

Esta opinión de Gaya Nuño referida a los museos arqueológicos de España es válida para resaltar la categoría de este tipo de museos entre los de arte, y a la vez la extraordinaria atracción que ejercen sobre el público. 


\section{Artes decorativas}

El $1 \%$ de la colección del Museo Arqueológico de Sevilla está constituida por objetos de arte industrial o de artes aplicadas a la industria, llamadas "artes decorativas".

El conjunto de objetos que forman parte de esta colección, poseen un efecto ornamental o de adorno. Muestran riqueza y perfección técnica en su realización, y al igual que las colecciones arqueológicas, las piezas que constituyen este tipo de "artes menores" formaron parte de los distintos gabinetes de antigüedades, por lo que es bastante habitual que los museos de arqueología alberguen piezas de este tipo, como es el caso del Museo Arqueológico Nacional.

\section{II.1.4. Número de piezas que integran la colección}

El Museo Arqueológico de Sevilla, al igual que el resto de museos arqueológicos, posee cierta dificultad para conocer el número exacto de piezas que integra su colección, debido a la imposibilidad de registrar un volumen tan inmenso de materiales procedentes de las excavaciones arqueológicas. Este número cada vez se hace más complicado, pues no solo se trata ya de lotes de fragmentos de cerámica amorfos y seleccionados, sino también de las muestras de tierra, carbones, fauna, etc..., que cada vez con más frecuencia ingresan en el almacén.

Los datos que a continuación se ofrecen, resultan de la consulta de los libros de registro, en el que se han considerado los lotes como piezas individualizadas, si bien el número de piezas que integran la colección es aproximadamente de $\mathbf{4 0 0 . 0 0 0 ~ ( l o t e s ~ y ~ p i e z a s ~ i n d i v i d u a l e s ) , ~}$ y en el mes de diciembre del 2.005, el número de registros inventariados en el Sistema Integrado de Documentación y Gestión Museográfica DOMUS versión 2.6 es de $\mathbf{3 8 . 4 2 9}$. Se incluyen las cifras referentes a la colección estable, con un arco cronológico desde el 12 de marzo de 1880 hasta el 8 de noviembre de 2005, y a la colección en depósito de otras instituciones, tanto públicas como privadas. 
En el caso de esta "segunda colección", su desarrollo temporal es menor al de la colección estable. Comienza en el 10 de marzo de 1943 y finaliza en la misma fecha que la anterior, el 8 de noviembre de 2005.

\section{Colección estable}

La colección estable del Museo la forman un total de 39.105 piezas.

La colección estable de esta institución museística está constituida por los bienes del Patrimonio Histórico Español pertenecientes a la Administración del Estado y a sus Organismos Autónomos asignados a dicho Museo de titularidad Estatal, según queda contemplado en el artículo 6.1 del Reglamento de los Museos de Titularidad Estatal y del Sistema Español de Museos (aprobado por el Real Decreto 620/1.987, de 14 de abril). Los bienes asignados al Museo Arqueológico de Sevilla pasan a integrar la colección estable del mismo, sin perjuicio de que puedan ser depositados en otros museos, así como en instalaciones no museísticas para el cumplimiento de otros fines culturales o de alta representación del Estado. En ningún caso estos depósitos alterarán dicha asignación ( según el artículo 6.2 de dicho Reglamento).

\section{Colección en depósito de otras instituciones (públicas o privadas) y particulares}

La colección en depósito de otras instituciones forman un total de 9.623 piezas.

El Museo Arqueológico de Sevilla tiene admitido conforme a su capacidad de custodia y con la prioridad que a continuación se señala, el depósito de las siguientes categorías de bienes culturales: 
- Bienes pertenecientes a la Administración del Estado o a sus Organismos Autónomos estén o no asignados a otros Museos de titularidad estatal.

- Bienes declarados de interés cultural o incluidos en el Inventario General de Bienes Muebles o procedentes de excavaciones $y$ hallazgos arqueológicos que acuerde ingresar la Administración competente para hacer efectivo el cumplimiento de los dispuesto en los artículos 13.2, 36.3, 42.2 y 44.2 de la Ley 16/1985, del Patrimonio Histórico Español.

- Bienes pertenecientes a la Comunidad Autónoma de Andalucía que ésta ha decidido ingresar.

- Bienes pertenecientes a terceros que la Junta de Andalucía acuerda recibir mediante contrato de depósito.

\section{II.1.5. Ubicación de colecciones (en número)}

En atención a este criterio, se pueden definir tres áreas de ubicación de las piezas. En primer lugar estarían las piezas expuestas, situadas en las Salas de Prehistoria,
Arqueología Romana y Arqueología Medieval, consideradas como las

verdaderas piezas museables. En segundo lugar las piezas almacenadas en las salas de reserva, en este caso, situadas a lo largo de 31 salas en el sótano del edificio desde 1980. Por último, las piezas en depósito en otras instituciones, ya sean depósitos de bienes culturales pertenecientes a la Administración General del Estado, o bien, de la Junta de Andalucía, todas ellas adscritas al Museo Arqueológico de Sevilla.

\section{Expuestas}

El número de piezas expuestas en las Salas de Prehistoria forman un total de $\mathbf{7 3 0}$ piezas.

La colección expuesta en estas salas ocupa un periodo histórico desde la hominización del Valle del Guadalquivir hasta la cultura o sociedad turdetana. 
El número de piezas expuestas en las Salas de Arqueología Romana y Arqueología Medieval forman un total de 2.028 piezas.

La colección expuesta en estas salas ocupa un periodo histórico desde la cultura o sociedad iberorromana hasta la llegada de la Edad Moderna.

\section{En reserva}

El número de piezas almacenadas en las salas de reserva forman un total de $\mathbf{3 9 6 . 8 8 6}$ piezas.

Se encuentran reunidas en el almacén por orden de procedencia ocupando el siguiente orden:

- Sala 1: Cádiz, África, Huelva, Badajoz, Sevilla, Málaga, Gaseoducto Carmona-Écija, Salteras, Gerena, Guillena, Gaseoducto Alcalá de Guadaira, La Campana y "Colección Lara".
- Sala 2: Sevilla, Carmona y Universidad Laboral.

- Sala 3: Sevilla (Puerta Jerez).

· Sala 4: "Colección Municipal”, Carteia, Cádiz, El Coronil, Los Algarbes (Cádiz), Benaocaz, Baelo Claudia, Carteia, Chipiona, Villamartín, Los Barrios, Jerez, Algeciras, San Roque, Medina Sidonia, San José del Valle, Algodonales, Zahara de la Sierra, Ébora, Sanlúcar, provincia de Málaga, Badajoz, Roma, Córdoba, Talavera de la Reina, Ubrique, Almentralejo, Sarepta (Líbano), Sudán, América, Alhama de Granada, Ronda, Madrid, Numancia, Monesterio, Santander, Almería, Manzanares, Cuenca, México, Sahara, Niebla, Riotinto, Paterna del Campo, Matalascañas, Moguer, Corteganilla, Aracena, Burgos, Puebla de Guzmán, Jabugo, Tejada, Montemolín, Almodóvar del Río, El Sotillo, Posadas, Encinarejo del Medio, Palma del Río, Benamejí, Medina Azahara y "Colección Lara”. 
- Sala 5: Alcolea del Río, Alcalá del Río, Alcalá de Guadaira, Alanís de la Sierra, Almadén de la Planta, Aznalcóllar, El Arahal, Brenes, La Algaba, Alanís, Aznalcázar y Universidad Laboral.

- Sala 6: Castilleja de Guzmán, El Carambolo, Coria del Río, Constantina, Camas, Cabezas de San Juan, Castillo de las Guardas, Los Corrales, Casariche, Cantillana, Cazalla de la Sierra y de Carrión de los Céspedes.

- Sala 7: "Colección Peláez", Carmona, El Alcaudete, Sevilla, Itálica, Casariche, Lora de Estepa, Cantillana, Castilblanco de los Arroyos, Utrera y Santiponce.

- Sala 8: Orippo y Dos Hermanas.

- Sala 9: Gerena, Gilena, Huévar, Sevilla, Fuentes de Andalucía, Espartinas, Estepa, Guillena, Guadajoz, Guadalcanal, Gines, La Campana y Écija.
- Sala 10: Herrera, Gilena, Sevilla y Gerena.

- Sala 11: Lora del Río, Osuna, La Luisiana, Olivares, Lebrija y Lora de Estepa.

- Sala 12: Montemolín, Montellano, Mairena del Alcor, El Madroño, Marchena, Marinaleda, Los Molares, Morón de la Frontera y Montemolín.

- Sala 13: Peñaflor, Pedrera, Paradas, Olivares y Osuna.

- Sala 14: San José de la Rinconada, La Puebla de Cazalla, Brenes, La Roda de Andalucía, Sanlúcar, El Saucejo, San Juan de Aznalfarache, Salteras, La Puebla del Río y Puebla de los Infantes.

- Sala 15: Itálica y Écija.

Sala 16: Itálica. 
Sala 17: Sevilla y Utrera.

Sala 18: Utrera, Valencina de la Concepción, Villaverde

del Río, Umbrete, Tomares, Tocina, Villafranca-Los Palacios, Sevilla y Mulva.

Sala 19: Mulva.

Sala 20 y 26b: Gilena, Sevilla, Peñaflor, Casariche, Cazalla de la Sierra, Osuna, Pruna, Villafranca-Los Palacios, Carmona, Constantina, Aznalcóllar, Santiponce, Sevilla y Valencian de la Concepción.

Sala 21: Itálica.

Sala 22: Herrera, Carmona, Sevilla e Itálica.

Sala 23: Sevilla y piezas de variada procedencia.

Sala 24: Marchena y Sevilla.
- Sala 25a: Sevilla y San Juan de Aznalfarache.

Sala 25b: Sevilla.

Sala 26b: Sevilla.

Sala 27: Sevilla.

Sala 28: Villaverde del Río, Sevilla, Lora del Río, Valencina de la Concepción, Gilena y Écija.

- Sala 29: Sevilla.

- Sala 31: Sevilla.

- Sala 32: Sevilla y Guadalcanal. 


\section{En depósito en otras instituciones}

El número de piezas en depósito en otras instituciones forman un total de 356 piezas.

Un gran número de estos fondos, son propiedad de la Junta de Andalucía que han salido de la institución museística como consecuencia de la autorización de depósitos en museos inscritos en el Registro de Museos de Andalucía. De todas formas, las piezas en depósito en otras instituciones, ya sean depósitos de bienes culturales pertenecientes a la Administración General del Estado, o bien, de la Junta de Andalucía, continúan estando adscritas al Museo Arqueológico de Sevilla.

\section{II.1.6. Volumen de piezas almacenadas en las salas de reserva (en metros cúbicos)}

El volumen aproximado de piezas almacenadas en las salas de reserva ocupan un total de $\mathbf{3 5 2 , 7 3}$ metros cúbicos. Los fondos se encuentran repartidos, por orden de procedencia, en los sótanos de la institución a lo largo de 31 salas. Cada sala se encuentra dividida por diferentes bloques de estanterías de dos cuerpos con 6 baldas cada uno, si bien, existen un número elevado de piezas y cajas que se encuentran depositadas en el suelo debido a la falta de espacio.

En líneas generales, la mayoría de los fondos se

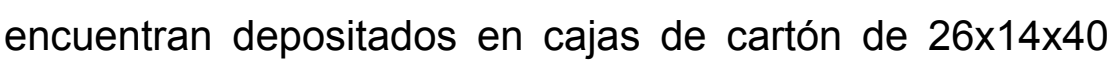
cm., aunque los depósitos realizados en los últimos 10

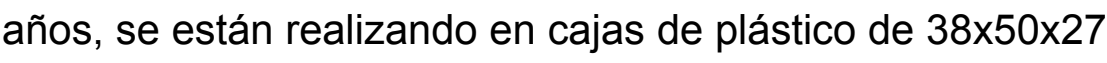
$\mathrm{cm}$., lo que supone una mejora en la conservación de la colección. 
Las cajas de menor tamaño suelen contener un máximo de 4 bolsas de plástico, mientras que las cajas de mayor tamaño suelen contener 8 bolsas. Algunos de los contenedores poseen piezas que ocupan, en mayor o menor medida, el total del volumen de la caja, normalmente suelen ser piezas completas o semicompletas.

El volumen de piezas conservado en cada sala es el siguiente:

Sala 1: 1,06 metros cúbicos. 73 cajas de cartón de $26 \times 14 \times 40 \mathrm{~cm}$. almacenadas en dos estanterías de dos cuerpos cada una.

Sala 2: 0,29 metros cúbicos. 6 cajas de cartón de $26 \times 14 \times 40 \mathrm{~cm}$. depositadas en el suelo junto a un brocal de pozo.
Sala 3: 1,92 metros cúbicos. 5 cajas de madera de $52 \times 52 \times 124 \mathrm{~cm}$. depositadas en el suelo junto a dos ánforas.

Sala 4: 7,71 metros cúbicos. 492 cajas de cartón de $26 \times 14 \times 40 \mathrm{~cm}$. almacenadas en 10 estanterías de dos cuerpos cada una; 19 cajas de cartón de $26 \times 14 \times 40$ cm., 9 epígrafes y 4 grandes recipientes árabes depositados en el suelo.

Sala 5: 4,91 metros cúbicos. 279 cajas de cartón de $26 \times 14 \times 40 \mathrm{~cm}$. almacenadas en 5 estanterías de dos cuerpos cada una; 56 cajas de cartón de $26 \times 14 \times 40$ cm., 1 basa, 2 fragmentos arquitectónicos, 1 ánfora Dressel, 1 capitel, 1 relieve, 3 torsos de esculturas, 1 columna y 1 gran vasija depositados en el suelo.

Sala 6: 3,18 metros cúbicos. 219 cajas de cartón de $26 \times 14 \times 40 \mathrm{~cm}$. almacenadas en 3 estanterías de dos cuerpos cada una. 
Sala 7: 5,78 metros cúbicos. 397 cajas de cartón de $26 \times 14 \times 40 \mathrm{~cm}$. almacenadas en 7 estanterías de dos cuerpos cada una y en 4 estanterías que constan de un solo cuerpo.

Sala 8: 9,89 metros cúbicos. 123 cajas de cartón de $26 \times 14 \times 40 \mathrm{~cm}$. almacenadas en 3 estanterías de dos cuerpos cada una y 80 cajas de plástico de $41 \times 61 \times 26 \mathrm{~cm}$. almacenadas en 2 estanterías de dos cuerpos cada una; 11 cajas de cartón de 41×61×26cm., 6 ánforas completas, 1 ánfora fragmentada, 1 escudo, 1 capitel, 1 sarcófago de mármol y 2 fragmentos de madera con decoración depositados en el suelo.

Sala 9: 17,50 metros cúbicos. 220 cajas de plástico de $41 \times 61 \times 26 \mathrm{~cm}$. almacenadas en 19 estanterías de un solo cuerpo, exceptuando la estantería n. 2 que consta de dos cuerpos; 18 cajas de 41×61×26 cm., 20 fragmentos de mosaicos, 3 epígrafes, 6 elementos arquitectónicos, 1 epígrafe, 4 botijas y 2 recipientes árabes depositados en el suelo.

Sala 10: 2,12 metros cúbicos. 54 cajas de cartón de $26 \times 14 \times 40 \mathrm{~cm}$. almacenadas en 2 estanterías de dos cuerpos cada una; 30 cajas de cartón de $26 \times 14 \times 40$ cm., 1 cabeza femenina, 1 brocal de pozo, 1 columna y 7 botijos depositados en el suelo.

Sala 11: 6,57 metros cúbicos. 246 cajas de cartón de $26 \times 14 \times 40 \mathrm{~cm}$. almacenadas en 5 estanterías de dos

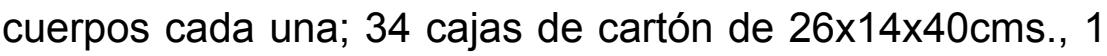
vaso Chardón, 1 lápida y 25 fragmentos arquitectónicos depositados en el suelo.

Sala 12: 7,40 metros cúbicos. 277 cajas de cartón de $26 \times 14 \times 40 \mathrm{~cm}$. almacenadas en 5 estanterías de dos cuerpos cada una; 88 cajas de cartón de $26 \times 14 \times 40$ cm., 2 epígrafes, 2 fragmentos de mosaicos, 1 escudo, 1 pila 
bautismal, 1 pilón, 3 grandes bloques de piedra y 1 capitel depositados en el suelo.

Sala 13: 4,01 metros cúbicos. 223 cajas de cartón de $26 \times 14 \times 40 \mathrm{~cm}$. almacenadas en 4 estanterías de dos cuerpos cada una; 30 cajas de cartón de $26 \times 14 \times 40$ cm., 1 fragmento arquitectónico, 1 epígrafe, 1 urna de incineración y 1 piedra de molino depositados en el suelo.

Sala 14: 6,52 metros cúbicos. 154 cajas de cartón de $26 \times 14 \times 40 \mathrm{~cm}$. almacenadas en 3 estanterías de dos cuerpos cada una y 95 cajas de cartón de $26 \times 14 \times 40$ almacenadas en 6 estanterías de un solo cuerpo. 12 fragmentos arquitectónicos depositados en el suelo.

Sala 15: 14,19 metros cúbicos. 22 cajas de cartón de $26 \times 14 \times 40 \mathrm{~cm}$. almacenadas de 3 estanterías de 1 solo cuerpo; 1 epígrafe procedente de Écija, 70 fragmentos arquitectónicos y escultóricos, y 7 trozos de mosaicos depositados en el suelo

Sala 16: 17,11 metros cúbicos. 1.050 cajas de cartón de $26 \times 14 \times 40 \mathrm{~cm}$. almacenadas en 22 estanterías de un solo cuerpo; 5 cajas de cartón de $26 \times 14 \times 40$ cm., 1 gran tinaja, 33 fragmentos arquitectónicos y escultóricos, y 1 epígrafe depositados en el suelo.

Sala 17: 15,59 metros cúbicos. 535 cajas de cartón de 26x14x40 cms. almacenadas en 13 estanterías de dos cuerpos cada una y 459 cajas de cartón de 26×14×40 cm. almacenadas en 20 estanterías de un solo cuerpo; 50 cajas de cartón de 26x14×40 cm., 1 brocal de pozo, 2 botijos, 1 capitel árabe y 2 fragmentos arquitectónicos depositados en el suelo.

Sala 18: 23,86 metros cúbicos. 348 cajas de cartón de $26 \times 14 \times 40 \mathrm{~cm}$. almacenadas en 6 estanterías de dos cuerpos cada una y 416 cajas de cartón de $26 \times 14 \times 40 \mathrm{~cm}$. 
almacenadas en 24 estanterías de un solo cuerpo; 23 cajas de 26x14x40 cm., 2 vasijas medianas, 5 grandes vasijas, 1 escultura y 1 ánfora mudéjar depositados en el suelo.

Sala 19: 14,23 metros cúbicos. 3.456 cajas de cartón de $11 \times 8 \times 18 \mathrm{~cm}$. almacenadas en 21 estanterías de un solo cuerpo y 482 cajas de cartón de $26 \times 14 \times 40 \mathrm{~cm}$. almacenadas en 6 estanterías de dos cuerpos cada una; 50 cajas de plástico de $39 \times 29 \times 27$, una losa de mármol, 10 fragmentos arquitectónicos y 1 vasija depositadas en el suelo.

Sala 20 y 26b: 10,81 metros cúbicos. 72 cajas de plástico de 47x27x36 cm., 13 cajas de cartón de 35x37x50cm., 16 cajas de plástico de $60 \times 40 \times 27 \mathrm{~cm}$., 21 cajas de plástico $39 \times 29 \times 27$ cm., 27 fragmentos arquitectónicos, 2 recipientes cerámicos, 3 fragmentos de mosaicos y 1 epigrafía depositados en el suelo.
Sala 21: 7,90 metros cúbicos. 15 sarcófagos de plomo, 37 fragmentos arquitectónicos y 1 torso romano depositados en el suelo.

Sala 22, 22a y 22b: 5,97 metros cúbicos. 70 cajas de

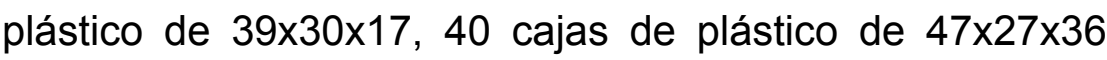
cm., 2 sarcófagos de plomo, 18 fragmentos arquitectónicos, 21 fragmentos de mosaicos depositados en el suelo.

Sala 23: 3,95 metros cúbicos. 60 cajas de cartón de

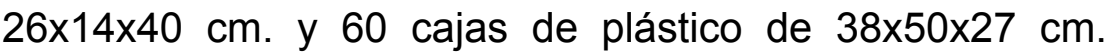
depositados en el suelo.

Sala 24: 13,40 metros cúbicos. 90 cajas de cartón de

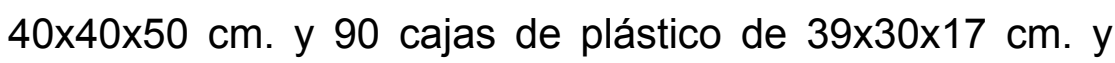
250 trozos de mosaicos depositados en el suelo.

Sala 25a: 13,01 metros cúbicos. 188 cajas de plástico de $38 \times 50 \times 27$ cm., 2 grandes recipientes cerámicos, 1 
recipiente cerámico de mediano tamaño y 3 fragmentos arquitectónicos depositados en el suelo.

Sala 25b: 4,24 metros cúbicos. 53 cajas de cartón de $40 \times 40 \times 50 \mathrm{~cm}$. depositadas en el suelo.

Sala 26a: 8,14 metros cúbicos. 112 cajas de plástico de $38 \times 50 \times 27 \mathrm{~cm} ., 1$ escultura sedente y 20 fragmentos arquitectónicos depositados en el suelo.

Sala 27: 6,93 metros cúbicos. 33 cajas de plástico de

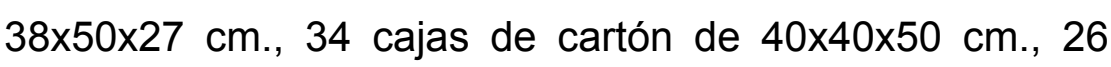
fragmentos arquitectónicos, 1 pedestal epigráfico y 16 tégulas depositados en el suelo.

Sala 28: 13,43 metros cúbicos. 254 cajas de plástico de $38 \times 50 \times 27 \mathrm{~cm}$. y 4 cajas de cartón de $40 \times 40 \times 50 \mathrm{~cm}$. depositadas en el suelo.
Sala 29: 15,39 metros cúbicos. 300 cajas de plástico de $38 \times 50 \times 27 \mathrm{~cm}$. depositadas en el suelo.

Sala 31: 76,87 metros cúbicos. 38 cajas de plástico de $38 \times 50 \times 27 \mathrm{~cm}$., 1 lote de tégulas y ladrillos depositados en el suelo.

Sala 32: 8,73 metros cúbicos. 189 cajas de plástico de $39 \times 30 \times 17 \mathrm{~cm}$. y 97 cajas de plástico de $38 \times 50 \times 27 \mathrm{~cm}$. depositadas en el suelo.

Las salas 30 y 33 , albergan distintos materiales de mantenimiento necesarios para el pleno funcionamiento de la institución museística, es lo que podría denominarse como "espacios de material logístico".

No debemos olvidar que muchas de las salas albergan elementos arquitectónicos desprendidos y posteriormente depositados en el almacén, por lo que ocupan diversos espacios de forma temporal. Entre los distintos elementos 
arquitectónicos se pueden identificar varias gárgolas, pináculos y diversos motivos neorrenacentistas del edificio diseñado por Aníbal González.

\section{II.2. INCREMENTO DE LAS} COLECCIONES

\section{II.2.1. Criterios de incremento de colecciones}

Existe una normativa de carácter autonómico que se encarga de diseñar unas directrices para la elaboración de memorias de investigación y registro de piezas arqueológicas resultado de excavaciones. Se trata del decreto 168/2.003 de 17 de junio por el que se aprueba el reglamento de actividades arqueológicas. En su artículo número 38 , "inventario detallado de los materiales encontrados", apartado segundo se explica que el inventario deberá especificar "al menos" la composición por materias primas de los bienes culturales recuperados en la actividad, e identificarlos por unidades de estratificación o contextos. Igualmente deberán figurar los números de registro así como la referencia a la signatura de los embalajes en que se han guardado. A pesar de esto resulta una gran disparidad formal y de contenido en la presentación de resultado por parte de los arqueólogos, siendo así que algunos de ellos numeran las bolsas en las cuales han incluido numerosos fragmentos, dejando estos como parte de un todo sin siglar y otros, en cambio llegan al detalle de recoger en los inventarios la numeración de dichas piezas.

De todo esto, deducir que el número real, absoluto, de piezas manipuladas en el Museo es realmente difícil de calcular. Las cifras ofrecidas en este trabajo serán, por tanto, una aproximación bastante real y sin embargo absolutamente necesaria para la elaboración de programas de almacenamiento, conservación preventiva o restauración. 


\section{II.2.2. Incremento de las colecciones en los dos últimos años:}

Al tratarse de un museo arqueológico, los ingresos que se producen son en su gran mayoría fragmentarios, es decir, no se trata de piezas completas, sino de alguna de sus partes. Esto lleva a los conservadores a plantear un discurso no basado en la reunión de materiales, lo cual facilitaría las tareas de control de temperatura, humedad, iluminación o acceso de público, sino en torno a alguna idea como la caza en un periodo determinado, por ejemplo. En el caso de las colecciones, la matriz en torno a la cual se reúnen es su titularidad, y por tanto, la colección que ha crecido en mayor medida durante los dos últimos años, ha sido la de los depósitos efectuados por la Junta de Andalucía, siendo el modo de ingreso más habitual el originado por las diversas excavaciones, dando como resultado los depósitos, aunque también hay un cierto número de ingresos por incautaciones de materiales por la Guardia Civil o por compras del propio Museo de piezas de singular relevancia para completar alguna laguna en el discurso expositivo.

El número de piezas ingresadas en los dos últimos años son las siguientes:

\section{Número de piezas ingresadas en el 2.004}

- Procedentes de Sevilla capital...................12.406 piezas.

- Procedentes de la provincia de Sevilla.......15.875 piezas.

Número de piezas ingresadas en el 2.005

- Procedentes de Sevilla capital..................16.367 piezas.

- Procedentes de la provincia de Sevilla..........9.603 piezas.

A título sólo indicativo, reseñar que en los libros de registros, además de la suma obtenida, habría que añadir: varias piezas de hierro, 2 bolsas de escoria, 51 bolsas de material óseo, 1 bolsa de material lítico, 79 cajas de 
material variado, 1 bolsa de estuco y otras 20 bolsas sin especificar. Todo esto permite atisbar la enorme dificultad para plantear programas de almacenamiento adecuados a las necesidades reales de crecimiento de las colecciones.

Del total obtenido podríamos deducir que en torno a unas 60.000 piezas aproximadamente, uniendo criterios en el siglado y eliminando errores, sería un número más o menos adecuado para elaborar las previsiones de crecimiento de las colecciones, siempre con mucha precaución, para los dos próximos años.

\section{II.2.3. Incremento de las colecciones en los dos últimos años (metros cúbicos):}

El volumen de piezas ingresadas en los años 2.004 y 2.005 ocupan, aproximadamente, un total de 227,98 metros cúbicos. Todas las piezas proceden de Sevilla capital y su provincia, y en su mayoría, se encuentran almacenadas en cajas de plástico de $48 \times 80 \times 60$ que albergan un total de 8 bolsas de plástico, mientras que un escaso número de cajas de 24×40×30 albergan un máximo de 4 bolsas.

Se encuentran almacenadas en las distintas salas de reservas del almacén, principalmente en las salas 28 y 29 , junto al muelle de descarga situado en la parte posterior del Museo.

El volumen de piezas ingresadas en el 2.004 es el siguiente:

Provincia de Sevilla: 14,51 metros cúbicos. Está constituido por un total de 63 cajas plástico de 48x80x60 cm.

Sevilla capital: 39,97 metros cúbicos. Está constituido por un total de 173 cajas de plástico de $48 \times 80 \times 60 \mathrm{~cm}$. y 4 cajas de plástico de 24×40×30 cm.. Además, habría que añadir 1 tinaja, 1 tinaja almohade, 1 tégula, 2 inscripciones, 1 lápida anepigráfica y 2 inscripciones funerarias. 
El volumen de piezas ingresadas en el 2.005 es el siguiente:

Provincia de Sevilla: 85,70 metros cúbicos. Está constituido por un total de 370 cajas de plástico de $48 \times 80 \times 60 \mathrm{~cm}$. y 16 cajas de plástico de $24 \times 40 \times 30 \mathrm{~cm}$. . Además, habría que añadir 1 jarro de bronce de estilo orientalizante, 1 brasero/aguamanil, 10 ánforas, 1 jarro, 1 brasero y 2 estelas.

Sevilla capital: 87,78 metros cúbicos. Está constituido por un total de 381 cajas de plástico de 48x80x60 cm.. Además, habría que añadir 1 capitel, 6 cántaros de principios del siglo XVIII y 1 placa anepigráfica de mármol.

Como se puede apreciar, el volumen de piezas ingresadas en el 2.004 y el 2.005 derivan, en su mayoría, de los depósitos de bienes culturales muebles pertenecientes a la Comunidad Autónoma de Andalucía que gestiona el Museo, procedentes de hallazgos, prospecciones y excavaciones arqueológicas llevadas a cabo en Sevilla y su provincia.

El gran volumen de piezas ingresadas es debido a dos causas: por un lado, las excavaciones arqueológicas de grandes superficies en la propia capital hispalense, es el caso de San Juan de Acre, la Encarnación o las propias obras del Metro. Por otro lado, a las prospecciones y excavaciones arqueológicas que se están llevando a cabo en las distintas obras del AVE, tanto las ejecutadas por la Junta de Andalucía en el tramo Sevilla-Bobadilla, como las realizadas por el Ministerio de Fomento en el tramo Córdoba-Bobadilla. A todo ello habría que sumar el enorme yacimiento surgido en la Plaza de España o "Salón" de Écija, que ha derivado al depósito de un enorme cantidad de material arqueológico. 


\section{II.3. DOCUMENTACIÓN}

\section{II.3.1. Evolución de los sistemas documentales de colecciones.}

Como antecedente, el Reglamento para el Régimen de Museos Arqueológicos del Estado, ordenaba, a partir de 1.901, la redacción de tres repertorios: el inventario general, el catálogo sistemático, el catálogo monográfico, el registro de entrada de objetos por compra o donaciones y el registro de objetos en depósito. Aunque no se llegaron a redactar unas instrucciones precisas de catalogación.

Con la publicación, en 1.947, de las Instrucciones para la redacción de fichas de inventario y de catálogo sistemático, se recogieron con todo detalle cómo debían confeccionarse todos los sistemas catalogación de fondos.
Los sistemas documentales de las colecciones de Museo Arqueológico de Sevilla mantienen, actualmente, la normativa recogida en el vigente Reglamento de los Museos de Titularidad Estatal y del Sistema Español de Museos.

\section{a) Tipos de libros de registro}

Encargados del tratamiento administrativo de los fondos, tiene por objeto la inscripción de los datos relativos a la identificación básica de los bienes que la integran, y constituye el principal instrumento jurídico-administrativo que acredita y protege los bienes del Patrimonio Histórico Español y Andaluz custodiados en el Museo Arqueológico de Sevilla.

No sólo suministran información, son una ayuda indispensable para el conocimiento de la historia de las colecciones del Museo; en caso de robo y reclamaciones son auténticos documentos probatorios con valor legal. Por 
este valor documental, están sujetos a los requisitos que para estos instrumentos marca la normativa de procedimiento administrativo.

En un principio, las Instrucciones para la redacción de fichas de inventario y de catálogo sistemático ordenaba, al Museo Arqueológico de Sevilla, a la redacción de:

\section{Registro de entrada de objetos en propiedad}

Se efectúa en un libro de 250 páginas y consigna el mismo día de entrada de los objetos en el Museo los siguientes datos: fecha de ingreso, número de entrada, número de inventario general, descripción del objeto, dimensiones, conservación, procedencia, forma de adquisición, número de expediente y observaciones.

\section{Registro de entrada de objetos en depósito}

Se realiza en un libro con las mismas características que el anterior. Se debe cumplimentar el mismo día del ingreso y recogerá los siguientes datos: fecha del depósito, número del depósito, número del inventario general, descripción del objeto, dimensiones, conservación, procedencia, propietario o depositante, número de expediente $y$ observaciones.

Actualmente, en el Museo Arqueológico de Sevilla, tal y como se establece el Reglamento de Museos en su artículo 10.1, se llevan de forma independiente tres Libros de Registro de Fondos Museográficos:

\section{De la colección estable del Museo}

En el que se inscriben los fondos que la integran por orden de entrada. 
De depósitos pertenecientes a la Administración del

Estado y a sus Organismos Autónomos

En el que se inscriben los de esa titularidad por dicho concepto en el Museo por orden de entrada.

\section{$\underline{\text { De otros depósitos }}$}

En el que se inscriben, por orden de entrada, los fondos de cualquier otra titularidad que ingresan en el Museo.

No se inscriben en los Libros de Registros los bienes culturales que ingresan en el Museo por la celebración de exposiciones temporales, aunque si se realiza un control administrativo de la recepción y de la salida de los mismos.

Según el artículo 11 del Reglamento, todos los fondos que por cualquier concepto ingresan en el Museo Arqueológico de Sevilla son:
- Inscritos en el Registro correspondiente conforme a lo dispuesto en el artículo anterior, por orden cronológico de su ingreso, haciendo constar los datos que permitan su perfecta identificación y, en su caso, el número del expediente relativo al depósito. En este Registro se anotan las incidencias administrativas de los bienes.

- Marcados con su número de inscripción en dichos Registros mediante la impresión de aquél por el procedimiento más adecuado a la naturaleza de los fondos.

Por su parte, la Disposición Transitoria Segunda del Reglamento establece el plazo de un año de la entrada en vigor del Reglamento (hasta el 14 de mayo de 1988) para proceder a la adaptación de las inscripciones de los fondos anteriormente indicado, respetándose en el orden de inscripción el que tuviesen en los Registros procedentes del Museo. Además, indica que todo depósito de bienes propiedad estatal que no esté acreditado documentalmente, pasará a formar parte de la colección estable como asignado. 
Tal como señala el Reglamento de Museos en su artículo 10.2, no se inscriben en los Libros de Registro de depósitos los bienes que ingresen en el Museo para la celebración de exposiciones temporales, sin perjuicio del debido control administrativo de la recepción y de la salida de los mismos.

Tampoco se registran los depósitos temporales por ofertas de venta o donación, pendientes de resolución.

\section{b) Tipos de fichas de inventario}

El inventario se encarga del tratamiento técnico-científico de los fondos. Cumpliendo con el actual Reglamento de Museos, el Museo Arqueológico de Sevilla elabora un Inventario, que tiene como finalidad identificar pormenorizadamente los fondos asignados al Museo y los depositados en éste, con referencia a la significación científica o artística de los mismos, y conocer su ubicación topográfica. Este Inventario se lleva por orden cronológico de entrada de los bienes culturales muebles en el Museo (artículo 12.1 del Reglamento de Museos).

Hasta la implantación del sistema informático DOMUS en junio del 2.003, en el Museo Arqueológico de Sevilla se han elaborado los siguientes tipos de inventarios:

\section{Ficha de Inventario Navascués}

Modelo de ficha de elaboración manual que sigue las instrucciones de J.M ${ }^{a}$. Navascués (Inspector General de Museos Arqueológicos), conforme al método ensayado por él mismo durante su dirección del Museo de Córdoba. Sus instrucciones fueron publicadas a partir del año 1.942, y posteriormente se publicaron las Instrucciones para la redacción de fichas de inventario y de catálogo sistemático en 1.947. Se volvió a reeditar a principios de los años 80 por la ANABAD, lo que nos da una idea de la importancia que ha tenido en la documentación de los museos de toda España. 
Consiste en un criterio único para la redacción del Inventario General con una normalización de la ficha. Tiene por finalidad identificar un objeto y conocer los fondos del Museo Arqueológico de Sevilla. En él, cada objeto tiene una cédula de cartulina blanca de $18 \times 24 \mathrm{~cm}$. y si dos o más objetos forman unidad deben estar en la misma ficha. Esta cédula consta el nombre del museo, es decir, Museo Arqueológico de Sevilla, el número de inventario, las fotografías (anverso y reverso o general y detalle, según las necesidades) de las cuales se realizan contactos de 24x36 mm., designación del objeto (en lenguaje coloquial seguido del término técnico entre paréntesis), materia, dimensiones, peso, estado de conservación, observaciones y datos complementarios. Se dan instrucciones precisas sobre fotografías, nomenclatura, tipos de observaciones pertinentes, etc.... Ha estado vigente en el Museo Arqueológico de Sevilla hasta la implantación de la aplicación informática ODISEUS.

\section{Ficha ODISEUS}

Implantada 1.993 mediante programa informático por la Consejería de Cultura de la Junta de Andalucía. Fue experimentado en el Museo de Artes y Costumbres Populares de Sevilla por J. Rivero y A. Limón.

Se encuentra integrado en el sistema de Información del Patrimonio Histórico de Andalucía junto a otras bases de datos del patrimonio autonómico. Uno de sus activos principales es el tesauro de términos específicos, producto de la reflexión a partir de la experiencia del Instituto Andaluz de Patrimonio Histórico, creado en 1.989.

\section{Ficha DOMUS versión 3.0}

El sistema informático DOMUS lleva implantado en el Museo Arqueológico de Sevilla desde junio del 2.003. Actualmente, la versión 3.0 permite el control sistemático de la colección estable por medio de bases de datos 
documentales y relacionales de gran versatilidad sobre una lista terminológica normalizada de las diversas áreas científicas, técnicas y administrativa.

En este momento, el Museo está utilizando el módulo Catalogación de Fondos Museográficos para realizar el inventario, mediante la utilización de una ficha común para todos los fondos.

\section{c) Tipos de fichas de catálogo}

Al igual que el Inventario, el Catálogo se encarga del tratamiento técnico-científico de los fondos. Tiene como finalidad documentar y estudiar los fondos asignados al Museo y los depositados en el mismo en relación con su marco artístico, histórico, arqueológico, científico o técnico.

El Catálogo contiene los datos sobre el estado de conservación, tratamientos, biografía, bibliografía y demás incidencias análogas relativas a la pieza.
Las normas técnicas para su elaboración, al igual que en el Inventario, vienen reflejadas en el artículo 13 del Reglamento de los Museos de Titularidad Estatal y del Sistema Español de Museos, y fijadas por el Ministerio de Cultura.

Hasta la implantación del sistema informático DOMUS en junio del 2.003, en el Museo Arqueológico de Sevilla se han elaborado los siguientes tipos de catálogos:

\section{Fichas de Catálogo Navascués}

Modelos de fichas cuya redacción fueron llevadas a cabo por J.Ma . Navascués y publicadas, en 1.947, en las Instrucciones para la redacción de fichas de inventario y de catálogo sistemático. El Reglamento para el Régimen de Museos Arqueológicos del Estado, ordenaba desde 1.901, los siguientes catálogos: 


\section{Catálogo sistemático}

Tiene por finalidad dar a conocer los objetos del Museo Arqueológico en relación con el cuadro artístico, arqueológico o histórico que convenga a las necesidades docentes y científicas del Museo. Las cédulas son de las mismas características que las del inventario general y también se dan instrucciones acerca de la casuística que pueda presentarse. Esta cédula comporta los siguientes datos: nombre del museo (Museo Arqueológico de Sevilla), edad, cultura, sección, serie, datos generales de identificación del objeto, escuela, publicaciones en las que se encuentra descrito o reproducido (con indicación de páginas y láminas), y finalmente una descripción muy minuciosa que ocupa todo el reverso donde se da cuenta de la técnica y se razona la clasificación del objeto.

\section{Catálogo monográfico}

Sirve para reunir todos los antecedentes, noticias, trabajo, estudios y observaciones a que hayan dado lugar cada uno de los objetos del Museo Arqueológico de Sevilla. Se contiene en carpetas de $35 \times 24 \mathrm{~cm}$. para que una vez dobladas queden del tamaño de las cédulas del inventario general y el catálogo sistemático. Estas carpetas contienen los datos recogidos en el catálogo sistemático y además apéndices para notas, observaciones de limpieza, observaciones de conservación y observaciones de restauración..

\section{Ficha ODISEUS}

Sistema informático implantado por la Consejería de Cultura de la Junta de Andalucía en los museos andaluces desde 1.993. Está integrado en el sistema de Información del Patrimonio Histórico de Andalucía junto a otras bases de datos de patrimonio autonómico. Una de sus 
características principales es el tesauro de términos específicos.

\section{Ficha DOMUS versión 3.0}

La versión 3.0 lleva implantada en el Museo Arqueológico de Sevilla desde junio del 2.006. Permite el control sistemático de la colección estable por medio de bases de datos documentales y relacionales de gran versatilidad sobre un tesauro de término específicos.

Actualmente, el Museo está utilizando el módulo Catalogación de Fondos Museográficos para realizar el catálogo, mediante la utilización de una ficha común para todos sus fondos.

\section{d) Documentación de conservación y restauración}

Para la correcta conservación y restauración de los bienes culturales muebles que se albergan en el Museo, además de la correspondiente ficha de catálogo (DOMUS versión 3.0) que recoge todos los datos sobre el estado de conservación, tratamientos, biografía, bibliografía y demás incidencias relativas a la pieza; se llevan a cabo dos informes de conservación y restauración:

\section{De las piezas que forman parte de los fondos del Museo}

Consiste en un informe del Laboratorio/Taller de Restauración en el que se reflejan una serie de datos, tales como: la identificación del objeto, en el que especifica el número de registro de restauración, el número de inventario, la fecha de entrada, la fecha de salida, la fecha de comienzo, la fecha final, el departamento, la procedencia, las medidas, el peso, el objeto, la materia o materias, la técnica de fabricación y la descripción. La documentación y analítica, que refleja el número de 
negativos, los negativos de restauración, las diapositivas, los análisis y radiografías, y por último, la bibliografía. El estado de conservación, con las restauraciones anteriores y el estado de conservación actual. El motivo de la intervención, con el grado de urgencia, si es una revisión rutinaria, si va a ser solicitado para una exposición temporal o si el motivo de la intervención es a causa de un accidente. Por último, la restauración del bien cultural mueble, en el que se especifica el tratamiento realizado, las observaciones, las condiciones espaciales de conservación que necesita, el restaurador o restauradores que han intervenido, la fecha del informe y el operador.

Uno de los grandes problemas que presentan las piezas procedentes de las excavaciones arqueológicas, es la activación de las sales solubles debido a los cambios bruscos de humedad relativa, de temperatura y de luz. Por ello, es frecuente que se lleven a cabo informes con los procesos de desalación, en el que se especifican el tipo de pieza, su número de inventario, la fecha de comienzo de desalación y la fecha de finalización. Todo ello con sus correspondientes observaciones.

\section{Solicitudes para préstamos de colecciones}

Se tratan de una serie de informes de conservación necesarios para el préstamo temporal de las colecciones del Museo. Consisten en tres fichas: ficha de conservación, ficha de conservación abreviada e informe previo de conservación.

\section{Ficha de conservación}

Presenta el título de la exposición y su número interno. A continuación aparecen los datos del prestatario, del objeto prestado (especificando el número de inventario), los datos previos del estado de conservación (aspectos puntuales, restauraciones, ...), del transporte, su contexto expositivo, toda la documentación gráfica necesaria, y por último, las referencias necesarias para el montaje de la pieza (fecha 
de apertura, empresas, informe de conservación, observaciones generales y personas que han examinado el bien cultural mueble).

\section{Ficha de conservación abreviada}

Refleja el título de la exposición, la sede, fechas de inauguración y clausura, el prestatario, un informe de conservación, el número interno de la pieza, su número de caja, la fecha de llegada y salida con los correspondientes responsables, y por último, la documentación gráfica necesaria.

\section{- Informe previo de conservación}

En el que figura el título de la exposición, la sede, fechas de inauguración y clausura, el prestatario, la pieza, su número interno, el estado de conservación (datos del formulario de préstamo), un informe previo al embalaje, los responsables que han examinado la pieza y la documentación gráfica.

Tanto en las actas de entrega con en las de devolución, figuran el estado de conservación de las piezas que han sido prestadas para las exposiciones temporales. Todo ello es acompañado de un pliego de observaciones y condiciones sobre el transporte, embalaje y manipulación de los bienes culturales muebles que participan en las exposiciones.

Toda la documentación referente a la conservación y restauración, no sólo ayuda a prolongar la vida de la pieza arqueológica para su correcta exhibición en el Museo, sino que ayudan al estudio científico del objeto, respondiendo a diversas preguntas como su datación, cronología, atribución y origen geográfico. 


\section{e) Documentación gráfica de las colecciones}

Existe una documentación gráfica referida a los objetos contenidos en el Museo Arqueológico de Sevilla, es el denominado Archivo Fotográfico, compuesto por fotografías de negativo de $35 \mathrm{~mm}$. en blanco y negro (las denominadas "formato sello"), por contactos y otro de negativos. Con la implantación del sistema DOMUS en junio del 2.003, dejaron de utilizarse las fotografías de negativo y se empleó el sistema de fotografía digital JPEG, que permite una óptima resolución y ayuda al traslado de la documentación gráfica en los distintos sistemas informáticos.

\section{f) Otros instrumentos documentales (topográficos, control de movimientos de fondos...)}

Otros documentos utilizados en el Museo, son los referentes a los "movimientos", es decir, cualquier desplazamiento que suponga un cambio de la ubicación de la pieza.

La decisión de los "movimientos" es competencia del Área de Conservación e Investigación, por lo que requieren un tratamiento documental para asegurar su localización física en cualquier circunstancia, y justificar por qué ha cambiado de sitio.

En el Museo Arqueológico de Sevilla, se utilizan los siguientes instrumentos documentales:

Documentos topográficos de las salas de reserva del almacén

Se utilizan para la localización de las piezas situadas en las salas de reserva del almacén. Corresponden a los movimientos internos, ya que se realizan en el interior del propio Museo, y al tratarse de un cambio de ubicación a largo plazo, llevan implícitos un cambio en su signatura 
topográfica dentro del catálogo. No requieren de tramitaciones administrativas, por lo que su control lo establece el propio conservador del Museo.

En los documentos topográficos del almacén, se reflejan el número de sala, el número de estantería, el número de balda, la cantidad de cajas que contiene la balda, y por último, la procedencia.

Para facilitar el trabajo, el Área de Conservación e Investigación del Museo Arqueológico de Sevilla utiliza un plano de los sótanos del edificio en el que se reflejan la ubicación de los interruptores, la localización de las estanterías, las piezas que se encuentran en el suelo, los lugares donde se han producido acumulaciones de cajas, la localización de fragmentos arquitectónicos y escultóricos por acumulación, los brocales de pozo y vasijas grandes, y finalmente, los mosaicos.

\section{Documentos topográficos de la exposición permanente}

Documentos empleados para la localización de las piezas situadas en las salas de exposición permanente, es decir, en las Salas de Prehistoria, Arqueología Romana y Arqueología Medieval. Corresponden a movimientos internos a largo plazo, por lo que llevan implícito un cambio en la signatura topográfica, al igual que el topográfico de las salas de reserva del almacén. Su control lo establece el conservador del Museo.

Documentos de entrada de bienes culturales muebles en el Laboratorio/Taller de Restauración

Estos documentos son empleados para localizar las piezas que entran en el Laboratorio/Taller de Restauración. Corresponden a movimientos internos a corto plazo, por lo que no necesitan cambiar de signatura topográfica. No requieren tramitaciones administrativas, de manera que su control lo establece el propio Museo. 
Documentos para el préstamo de bienes culturales $\underline{\text { muebles del Museo para exposiciones temporales }}$

Se utilizan ante la salida de los bienes culturales muebles de la institución museística. Corresponden a movimientos externos a corto plazo, es decir, durante la permanencia de la pieza en la exposición temporal.

Para la salida de piezas arqueológicas para exposiciones temporales, el interesado presenta la correspondiente solicitud de préstamo. El Área de Conservación e Investigación del Museo estudia la calidad de la exposición, así como el estado de conservación de la pieza, elaborando un informe para la Dirección.

La Dirección evalúa la conveniencia o no del préstamo, enviando un comunicado a la institución en caso de la no aprobación.

En el caso de que se apruebe, se elabora un expediente donde se valora la pieza, se detallan todos los datos y se adjuntan los documentos a rellenar por la institución, y se envía para que ésta lo devuelva firmado. Este expediente genera tres copias, una para la institución, otra para la Delegación Provincial de Cultura y otra para el Museo Arqueológico de Sevilla.

En el caso que la obra salga fuera del territorio nacional, antes de que la Consejería de Cultura de la Junta de Andalucía emita la autorización para que se efectúe el préstamo, la pieza ha de pasar por la Junta de Exportación y Valoración de Obras de Arte que procede a evaluar el préstamo autorizándolo o no.

Cuando la Consejería de Cultura de la Junta de Andalucía autoriza el préstamo es cuando la pieza sale y se genera un acta de préstamo con tres copias, una para el centro, otra para la institución y otra para el Ministerio.

Cuando finaliza el préstamo, se genera una acta de devolución, una vez que el centro ha recibido la obra. 
El Museo Arqueológico de Sevilla, registra todos los movimientos en el Libro de Registro, o en el expediente de la pieza.

En el artículo 16 del Reglamento de Creación de Museos y de Fondos Museísticos se establecen las condiciones generales del préstamo para exposiciones temporales de obligada aceptación y cumplimiento por el prestatario:

- Uso exclusivo para la finalidad solicitada y autorizada. Todo cambio de lugar y custodia precisa el consentimiento expreso del Director General de Instituciones del Patrimonio Histórico.

- Reintegración al Museo Arqueológico de Sevilla dentro del plazo estipulado. Cualquier solicitud de prórroga debe plantearse por escrito con un mes de antelación a la expiración del préstamo, siendo un otorgamiento discrecional.
- Los gastos derivados del préstamo son de cuenta del prestatario.

· Suscripción de póliza de seguro "clavo a clavo" por el importe que especifique el Museo Arqueológico de Sevilla. Los documentos acreditativos de su suscripción deben estar en poder del Museo Arqueológico de Sevilla con una antelación mínima de 7 días.

- El prestatario se hace responsable de la conservación de los bienes debiendo adoptar las máximas precauciones. No pueden, sin consentimiento previo y escrito de la Junta de Andalucía, realizarse ninguna restauración, limpieza o reparación. Tampoco pueden extraerse ni separarse los elementos complementarios accesorios.

- El embalaje y transporte, por personal y empresas especializadas aprobados y supervisados por la Dirección del Museo Arqueológico de Sevilla, debiendo emitir informe 
sobre las operaciones de transporte y embalaje, tanto a la entrega como a la devolución. Debe comunicarse con una semana de antelación el día de recogida de los bienes culturales muebles una vez autorizado.

- Se autoriza la fotografía y reproducción de los bienes culturales muebles prestados para el catálogo y publicidad durante el plazo de préstamo. Otro uso de la reproducción debe ser autorizada por el Director General de Instituciones del Patrimonio Histórico.

- Deben entregarse 10 ejemplares del Catálogo de la Exposición y de demás publicaciones relacionadas con la misma.

De todas estas operaciones quedará su reflejo documental en el expediente de préstamo y se anotará en la ficha de catálogo de cada uno de los bienes la relación de préstamos de que fueron objeto.
También son movimientos externos a corto plazo, el traslado de piezas arqueológicas del Museo para tratamientos de restauración en el Instituto Andaluz de Patrimonio Histórico (IAPH) o para las reproducciones.

Documentos para el depósito de bienes culturales $\underline{\text { muebles en otras instituciones }}$

Son documentos utilizados para movimientos externos a largo plazo, es decir, para el depósito de bienes culturales muebles en otros museos, organismos o instituciones, motivados por razones culturales o de alta representación.

Predominan los depósitos realizados en los museos inscritos en el Registro de Museos de Andalucía (RAM), mediante la solicitud de constitución de depósito por la institución solicitante.

El Área de Conservación e Investigación del Museo, evalúa la conveniencia de efectuar el depósito y emite un informe 
opinando sobre la constitución del mismo, ya sea favorable o desfavorable. Dicho informe se envía a la institución solicitante.

Internamente, si se considera adecuado la constitución del depósito, se elabora un documento para la tramitación de la autorización que se envía a la Delegación Provincial de Cultura, ya sea la pieza propiedad de la Junta de Andalucía o del Ministerio.

Una vez tramitada la autorización para la constitución del depósito, el Museo Arqueológico de Sevilla procede al envío de la pieza, que una vez entregada a la institución, se genera el acta de entrega que es firmada por la Dirección del centro y por la institución. Se realizan tres copias: para el Museo, para la Delegación Provincial de Cultura y para la Institución.

El Museo anota el movimiento de fondos en el Libro de Registro correspondiente.
Por último, se encuentran los movimientos por baja, que tienen carácter documental y tiene su reflejo en el Registro de Ingreso, Inventario y Catálogo de fondos del Museo Arqueológico de Sevilla. La baja es justificada por la destrucción, desaparición, reintegración (producen baja los fragmentos de una pieza arqueológica ya inventariados si éstos permiten posteriormente la reconstrucción del bien cultural mueble), ordenación de fondos o permuta.

\section{II.3.2. Colecciones documentales. Archivos:}

Además de los documentos ya comentados, el Museo Arqueológico de Sevilla contiene otros tipos de documentos que pueden localizarse en las distintas áreas de la institución museística. Son los referentes a las correspondencias de antiguos directores, viejas fotografías, archivos de la historia de la institución, catálogos antiguos, ... que forman parte de la propia historia del Museo. 
Muchos de esos documentos, son necesarios para el estudio y la comprensión de la colección, así como de la propia institución museística. Poseen especial importancia los referentes al Archivo Fotográfico, compuestas por fotografías de negativo de $35 \mathrm{~mm}$. en blanco y negro (las denominadas "formato sello" de las fichas Navascués), imprescindibles para el estudio de los fondos que se encuentran custodiados en el Museo.

\section{a) Número, características y tipologías} (Administrativos o documentales, fotográficos, sonoros, audiovisuales...)

Dentro de la colección documental, se pueden distinguir los siguientes tipos de archivos:
Fichas del inventario general, del catálogo sistemático, del catálogo monográfico y de los registros de entrada de objetos en propiedad y en depósito

Corresponden a las denominadas "Fichas Navascués". Consisten en unos modelos de fichas cuya redacción fue efectuada por J.Ma . Navascués (Inspector General de Museos Arqueológicos), y publicadas en 1.947 en las Instrucciones para la redacción de fichas de inventario y de catálogo sistemático.

- El inventario general está compuesto por cédulas de cartulina blanca de $18 \times 24 \mathrm{~cm}$. con el nombre del museo, el número de inventario, las fotografías (anverso y reverso o general y detalle), con contactos de 24×36 mm., designación del objeto, materia, dimensiones, peso, estado de conservación, observaciones y los datos complementarios. 
- El catálogo sistemático, de cédulas de cartulina blanca de $18 \times 24 \mathrm{~cm}$. que constan del nombre del museo, edad, cultura, sección, serie, datos generales de identificación del objeto, escuela, publicaciones en las que se encuentra descrito o reproducido (con indicación de páginas y láminas) y una descripción minuciosa en el reverso.

- El catálogo monográfico, contenido en carpetas de 35 x $24 \mathrm{~cm}$. que contienen los datos recogidos en el catálogo sistemático, apéndices y observaciones de limpieza, conservación y restauración.

- Los libros de registro de entrada de objetos en propiedad, que constan de 250 páginas. Contienen los siguientes datos: fecha de ingreso, número de entrada, número de inventario general, descripción del objeto, dimensiones, conservación, procedencia, forma de adquisición, número de expediente y observaciones.
- Los libros de registro de entrada de objetos en depósito, que constan de 250 páginas en el que figuran: fecha del depósito, número de depósito, número del inventario general, descripción del objeto, dimensiones, conservación, procedencia, propietario o depositante, número de expediente y observaciones.

Archivos de adquisición de piezas, compras y donaciones

Consisten en una serie de documentos (facturas, recibos, certificados de autenticidad, ...) que acreditan la pertenencia del bien cultural mueble al Museo Arqueológico de Sevilla y ayudan a mejorar el conocimiento de la historia del objeto.

El Museo adquiere colecciones para la posterioridad, por lo que cualquier tipo de cesión (ya sea por donación, 
préstamo, venta o destrucción) va acompañada de una información exhaustiva y objetiva.

Dentro de este tipo de documentos asociados al ingreso, podemos destacar: los permisos de excavación, las actas de depósito y las actas de entrega, las diligencias judiciales por expolio o exportación ilícita, las actas de dación y las actas de donación.

\section{Archivo administrativo}

Contiene toda la documentación relacionada con la gestión administrativa del Museo (modelo 046 para la reproducción de una pieza de la colección, correspondencias,...), gestión del personal, gestión del presupuesto, gestión del edificio, gestión de los visitantes(libros de sugerencias y reclamaciones)...

\section{Otros Archivos}

El Museo Arqueológico de Sevilla contiene otros tipos de documentos relacionados con la propia historia de la institución o de la colección estable, tales como las actas de correspondencia de los antiguos directores del Museo, los antiguos catálogos procedentes del Convento de la Merced (Museo Provincial de Bellas Artes), el archivo fotográfico (fotografía de $35 \mathrm{~mm}$. "formato sello", contactos, negativos, diapositivas y videos), el archivo monetario, el archivo de metales y el seudo-archivo antropológico.

\section{b) Crecimiento}

En la actualidad, el Museo Arqueológico de Sevilla no conoce el grado de crecimiento del archivo administrativo, considerado como una de las secciones en continuo crecimiento. 
El archivo fotográfico, de los denominados "formato sello", ha dejado de crecer desde 1.987 una vez que se dejaron de utilizar las fichas de inventario general Navascués. Sí han crecido las fotografías digitales en formato JPEG utilizadas en el sistema informático DOMUS versión 3.0, obteniéndose un total de 5.482 imágenes. El sistema informático ODISEUS, también ha dejado de crecer, y toda su información ha sido trasladada al nuevo sistema informático implantado en el 2.003.

Los documentos relacionados con los ingresos, tales como los permisos de excavación, las actas de depósito, las actas de entrega, las diligencias judiciales por expolio o exportación ilícita, las actas de dación y las actas de donación, son informes que crecen a diario.

El número de depósitos en los 2.004 y 2.005, según queda reflejado en la carpeta de actas de depósito, es de 86 , de los cuales, 52 corresponden a Sevilla y 34 a la provincia.
Estos datos, permiten hacer un balance del grado de crecimiento.

Actualmente han dejado de crecer las fichas del inventario general, las fichas del catálogo sistemático, las fichas del catálogo monográfico y las fichas del sistema informático ODISEUS.

\section{c) Grado de inventario, catalogación e informatización}

En el actual sistema informático de gestión museográfica, DOMUS versión 3.0 , no se ha iniciado el inventario y la catalogación de los fondos documentales del Museo, por tanto, supone un $0 \%$ del total. 


\section{d) Condiciones de conservación y almacenaje}

Todos los fondos documentales se encuentran depositados en los distintos archivadores metálicos, situados en el Área de Conservación e Investigación y en el Área Administrativa del Museo. Los fondos bibliográficos, se encuentran repartidos a lo largo de 497 metros lineales de estanterías en el interior de la biblioteca del Museo.

\section{e) Acceso de investigadores. Servicios prestados}

El Museo Arqueológico de Sevilla permite el acceso a los investigadores, según queda contemplado en el artículo 23 del Reglamento de los Museos de Titularidad Estatal y del Sistema Español de Museos, por lo que se les facilita la contemplación y estudio de los fondos que no estén expuestos al público, así como la consulta de todos los catálogos sin menoscabo del normal funcionamiento de los servicios del Museo.
Esta facilidad de acceso es compatible con la previa necesidad de contar con el permiso de investigación cuando sea necesario, como es el caso del estudio y documentación gráfica de los materiales depositados en la institución, previsto en el artículo 52 de la Ley de Patrimonio Histórico de Andalucía y desarrollado en el Reglamento de Actividades Arqueológicas cuya competencia corresponde al Director General de Bienes Culturales, que tiene con carácter general la competencia sobre el régimen de autorizaciones en materia de investigación sobre el Patrimonio Histórico según el artículo 1.1 del Decreto 333/1996, de 9 de julio.

También se facilita la reproducción de los objetos del Museo Arqueológico de Sevilla (artículo 24 del Reglamento) por cualquier procedimiento, para facilitar la investigación y la difusión cultural, preservar la debida conservación de las obras y no inferir en la actividad normal del Museo. 


\section{II.3.3. Existencia de una programación en las tareas documentales del museo. Descripción de los procesos prioritarios.}

Según queda establecido en el Capítulo VI del Reglamento de los Museos de Titularidad Estatal y del Sistema Español de Museos, la Dirección tiene asignado toda la labor de dirección y coordinación de los trabajos de tratamiento administrativo y técnico de los fondos.

El Área de Conservación e Investigación, que se encuentra bajo la Dirección del Museo, se encarga de la identificación, control científico, preservación y tratamiento de los fondos, así como el seguimiento de la acción cultural del mismo. Por ello, elabora los instrumentos de descripción precisos para el análisis científico de los fondos; realiza el examen técnico y analítico correspondiente a los programas de preservación, rehabilitación y restauración pertinentes; elabora y ejecuta programas de investigación en el ámbito de la Arqueología; y redacta las publicaciones científicas y divulgativas.

Con respecto al Área de Administración, se encarga de las funciones relativas al tratamiento administrativo de los fondos del Museo, su seguridad y la gestión económicoadministrativa y del régimen interior de la institución.

Existe una programación de trabajo sobre DOMUS, con la catalogación de la colección permanente del Museo, y bajo la dirección de la Directora de la institución museística.

También, se están reorganizando los expedientes administrativos y de las exposiciones temporales, así como el control del sistema de registro llevado a cabo por el conservador del Museo. 


\section{II.3.4. Informatización de la documentación y gestión museística:}

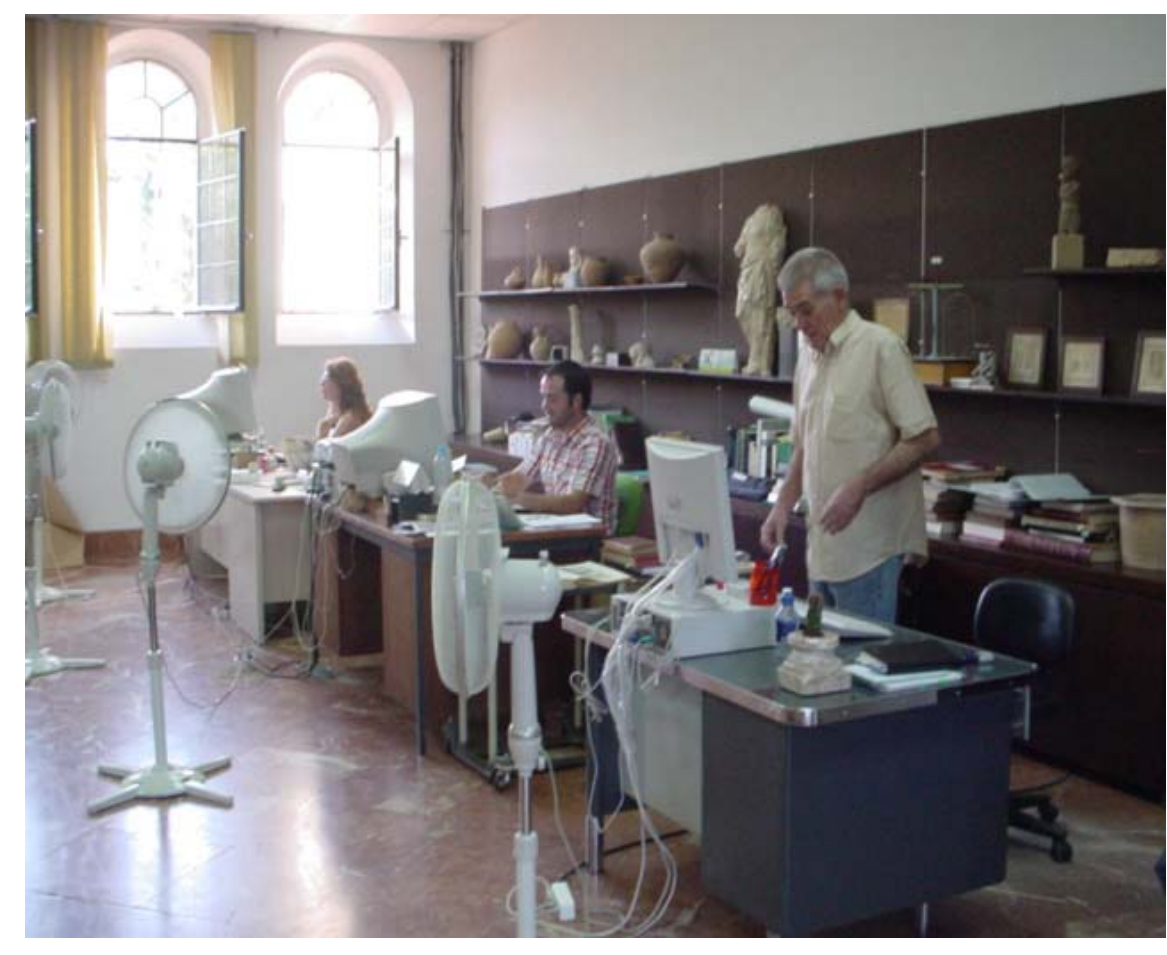

Área de Conservación e Investigación (M.A.S.)
El análisis del estado de la gestión documental de los museos españoles llevó, a partir de 1.993, a comprobar la existencia de variedad de criterios en el tratamiento documental. Esta situación dio lugar al inicio de un estudio para la normalización de la gestión de los museos.

En 1.993, en Andalucía se recoge el programa ODISEUS, integrado en el sistema de Información del Patrimonio Histórico de Andalucía junto a otras bases de datos del patrimonio autonómico. Uno de sus activos principales es el tesauro de términos específicos, producto de la reflexión a partir de la experiencia del Instituto Andaluz de Patrimonio Histórico (IAPH), creado en 1.989.

En 1.996 sale a concurso y se adjudica un Proyecto de Normalización Documental: elementos para una aplicación informática en la gestión museográfica, aparecido en 
1.996, dirigido por Andrés Carretero y por Marina Chinchilla, que ha derivado en la aplicación informática DOMUS versión 1.0 que se empezó a implantar en algunos museos desde 2.001 y que busca el control sistemático de los fondos museográficos, documentales, bibliográficos y administrativos, por medio de bases de datos documentales y relacionales de gran versatilidad sobre una lista terminológica normalizada de las diversas áreas científicas, técnicas y administrativas (Normalización Documental de Museos: elementos para una aplicación informática de gestión museográfica, Madrid: Ministerio de Educación-Dirección General de Bellas Artes y Bienes Culturales, 1.996).

En el Museo Arqueológico de Sevilla, el programa informático DOMUS sustituye a la anterior aplicación informática (ODISEUS) en el mes de junio del 2.003, iniciándose la catalogación de los fondos museográficos de la exposición permanente y una pequeña parte de los bienes culturales muebles almacenados en las salas de reserva del almacén. Aún no se ha iniciado la catalogación, en DOMUS versión 3.0, de los fondos documentales y bibliográficos de la institución.

\section{a) Informatización de los instrumentos documentales}

En la Ley de Patrimonio Histórico Español, en su Reglamento sobre Museos de Titularidad Estatal, define en el artículo 13, lo siguiente en cuanto a sistematización de datos:

1. El Ministerio de Cultura dictará normas técnicas para la elaboración del Inventario y el Catálogo, así como en las estadísticas sobre presentados de servicios.

2. Dichas normas técnicas regularán el contenido, la recogida, tratamiento y remisión por los Museos de estas informaciones para su integración por el Ministerio de Cultura en la base de datos correspondiente a Museos de titularidad Estatal. 
3. El Ministerio de Cultura prestará la colaboración y asistencia técnica a los Ministerios y a los órganos competentes de la Comunidades Autónomas para el cumplimiento de Is dispuesto en este artículo.

Cumpliendo con la legislación vigente, el Museo Arqueológico de Sevilla tiene implantado la aplicación informática DOMUS versión 3.0, para la catalogación de los fondos museográficos y los fondos documentales del Museo.

La sección administrativa del Museo, utiliza los programas Word 2.000 y Excell para las labores propias de su función, tales como las correspondencias, documentos contables, estadísticas, cartas, certificados, oficios, ..., mientras que en la Biblioteca, el programa informático bibliográfico de catalogación y gestión utilizado es el ABSYS por Daratz.

También se realiza la gestión de la página web desde la propia Consejería de Cultura, con una gran relación de datos relativos al Museo: horarios de apertura, dirección, temática, precios públicos, $\ldots$.

\section{b) Programas informáticos}

En la actualidad, el Museo Arqueológico de Sevilla está utilizando el sistema DOMUS versión 3.0 para la catalogación de los fondos museográficos del Museo desde el mes de junio del 2.006. Anteriormente se ha estado utilizando el Sistema Integrado de Documentación y Gestión Museográfica DOMUS versión 2.6.

La sección administrativa del Museo emplea los programas Word 2.000 y Excell para la elaboración de cartas, estadísticas, contabilidad,...

La Biblioteca de la institución se sirve del programa informático ABSYS para la catalogación y gestión de los fondos bibliográficos del Museo. 
c) Número de imágenes digitalizadas. Formatos. Conjunto de colecciones a los que corresponden.

El número de imágenes digitalizadas, hasta el mes de diciembre de 2.005, es de 5.482. Se está utilizando un sistema de fotografía digital en formato JPEG, que permite una óptima resolución y ayuda al traslado de la documentación gráfica en los distintos sistemas informáticos, incluido el Sistema Integrado de Documentación y Gestión Museográfica DOMUS.

Corresponden a la mayor parte los fondos que se encuentran expuestos en las salas de exposición permanente (Salas de Prehistoria, Arqueología Romana y Arqueología Medieval), y a un escaso número de bienes culturales muebles depositados en las salas de reserva del almacén.

\section{Il.3.5. Porcentaje de fondos museográficos y documentales inventariados y catalogados:}

En el Museo Arqueológico de Sevilla, el programa informático DOMUS sustituye a la anterior aplicación informática (ODISEUS) en el mes de junio del 2.003, iniciándose la catalogación de los fondos museográficos de la exposición permanente y una pequeña parte de los bienes culturales muebles depositados en las salas de reserva del almacén.

Toda la información de los fondos museográficos reflejada en el inventario general, el catálogo sistemático y el monográfico, ha sido volcada al Sistema Integrado de Catalogación y Gestión Museográfica DOMUS versión 3.0.. También, toda la información del sistema ODISEUS ha migrado al nuevo sistema informático.

Actualmente, el porcentaje de fondos museográficos inventariados y catalogados pertenecientes a la colección 
permanente del Museo es de un $10 \%$. En el actual sistema informático, no se ha iniciado el inventario y la catalogación de los fondos documentales, bibliográficos y administrativos, por tanto, supone un $0 \%$ del total.

\section{II.3.6. Porcentaje de fondos museográficos y documentales fotografiados y digitalizados.}

El porcentaje de fondos museográficos digitalizados es de un $4 \%$. Corresponden a bienes culturales muebles expuestos en las salas de exposición permanente y a un escaso número de piezas almacenadas en las salas de reserva.

Los fondos documentales no han sido fotografiados ni digitalizados, ya que aún no se ha iniciado la catalogación de dichos fondos en DOMUS versión 3.0.

\section{II.3.7. El sistema de documentación y gestión museográfica DOMUS:}

DOMUS es un Sistema Integrado de Documentación y Gestión Museográfica desarrollado por el Ministerio de Cultura (Subdirección General de Museos Estatales y Subdirección General de Tratamiento de la información).

Se trata de una aplicación informática para la documentación y gestión de los fondos museográficos y documentales de los museos, que nace a partir del informe Normalización Documental de Museos (publicado por el Ministerio de Cultura en 1.996), en el que se recogían el análisis funcional y los requerimientos necesarios para la construcción de un sistema informatizado de documentación y gestión museística.

DOMUS integra en una única herramienta los procesos de gestión de información necesarios en la actividad diaria del museo, referidos a: documentación de colecciones, según un modelo normalizado de estructuras de información; 
gestión de colecciones; y gestión administrativa propia del

Museo como institución.

En la actualidad, la versión DOMUS que se encuentra implantada en el Museo Arqueológico de Sevilla es la 3.0.

\section{a) Implantación de DOMUS en el museo}

En el Museo Arqueológico de Sevilla, el programa informático DOMUS sustituye a la anterior aplicación informática (ODISEUS) en el mes de junio del 2.003, iniciándose la catalogación de los fondos museográficos de la exposición permanente y una pequeña parte de los bienes culturales muebles almacenados en las salas de reserva del Museo.

En el mes de junio del 2.006 se ha implantado la versión 3.0, que ha sustituido la anterior versión 2.6.

\section{b) Módulos que se están utilizando}

Actualmente, el Sistema Integrado de Documentación y Gestión Museográfica está siendo utilizado en el Área de Conservación e Investigación del Museo Arqueológico de Sevilla por dos documentalistas, que están utilizando los siguientes módulos:

- Fondos Museográficos: este módulo se utiliza para introducir información acerca de los fondos custodiados en el Museo Arqueológico de Sevilla. Permite realizar la tradicional documentación en dos niveles, Inventario y Catálogo, resuelta con la existencia de campos de obligada cumplimentación, como ficha común para todos los fondos.

- Documentación Gráfica: se utiliza para gestionar y controlar las reproducciones gráficas de los fondos del Museo, así como para llevar un control más detallado de las restauraciones que pueden realizarse en los distintos fondos. Puede ser de gran utilidad para prestar servicios de cara al público, investigadores, instituciones externas, publicaciones... 
- Consultas: permite buscar y visualizar los documentos almacenados en la Base de Datos.

- Conservación: se usa para guardar constancia exhaustiva de los múltiples tratamientos de conservación que sufren los fondos a lo largo de su vida museística, ya que éstos afectan a la vida de las piezas y pueden condicionar futuras actuaciones sobre ellas. También permite descubrir con el detalle necesario las actuaciones de conservación realizados en los fondos Museográficos.

\section{c) Porcentaje de fondos museográficos y fondos documentales inventariados en DOMUS}

El porcentaje de fondos museográficos inventariados en DOMUS versión 3.0 hasta el mes de junio de 2.006 es del $10 \%$ de la colección permanente del Museo. Como dato indicativo, en el mes de diciembre del 2.005, el número de registros inventariados en el Sistema Integrado de Documentación y Gestión Museográfica era de 38.429.
Aún no se ha iniciado el inventario y la catalogación en DOMUS de los fondos documentales del Museo, por lo tanto se considera un $0 \%$ del total de la serie.

\section{d) Número de imágenes digitales en DOMUS}

El número de imágenes digitalizadas en DOMUS es de 5.482. Esta cantidad ha sido tomada en el mes de diciembre del 2.005, y pertenece a los fondos museográficos del Museo. Se ha utilizado la fotografía digital en formato JPEG, que permite agilizar la gestión y el control de las reproducciones gráficas de la colección permanente de la institución.

\section{e) Áreas del museo que trabajan en DOMUS}

Actualmente, el Área de Conservación e Investigación se encarga de la gestión y la catalogación de los fondos museográficos del Museo, utilizando los módulos de Fondos Museográficos, Documentación Gráfica, 
Conservación y Consultas (explicados en el apartado de "Módulos que se están utilizando").

\section{f) Programación de trabajo sobre DOMUS, si existe}

El Área de Conservación e Investigación, trabaja con el sistema informático DOMUS versión 3.0, y es coordinada por el conservador del Museo, quien es responsable ante la Dirección de la institución museística (encargada de dirigir y coordinar el funcionamiento del Museo) del tratamiento técnico-científico de los fondos.

En la actualidad, existen dos catalogadores, que están encargados del inventario y catalogación de los fondos museográficos que alberga el Museo.

\section{II.3.8. Biblioteca}

Los datos referentes a la Biblioteca, son el resultado de la consulta de los informes realizados por el Instituto Nacional de Estadística (INE) durante el año 2.004 (a los que se les han añadidos los datos referentes al 2.005). Esta operación, que se realiza cada dos años, tiene como objetivo el proporcionar toda la información relativa al equipamiento, recursos humanos y financiación de las bibliotecas, necesarias para satisfacer los requerimientos informáticos de las Administraciones Públicas españolas y de la UNESCO.

EI INE realiza esta estadística al amparo de la Ley de la Función Estadística Pública de 9 de Mayo de 1.989. 


\section{a) Número actual de volúmenes (monografías y publicaciones periódicas)}

El número total de volúmenes, tanto de monografías como de publicaciones periódicas, a 23 de noviembre del 2.005 es de 21.588. A todos estos volúmenes abría que incluir 35 documentos sonoros, 45 documentos audiovisuales y 30 documentos electrónicos.

La biblioteca no contiene manuscritos, microformas, documentos cartográficos, documentos de música impresa, ni documentos gráficos.

Es necesario hacer referencia al conjunto de libros antiguos anteriores a 1.901, compuestos por un total de 235 volúmenes.

\section{b) Especialización temática}

Según el Instituto Nacional de Estadística, la biblioteca del Museo Arqueológico de Sevilla es una biblioteca especializada de archivos y museos, cuya titularidad pertenece a la Administración General del Estado.

Contiene un gran número de volúmenes acordes con la temática de la institución museística que lo alberga, es decir, Arqueología, Museología, Historia Antigua y Arte, aunque también recibe un número elevado de publicaciones que han sido editadas por la Empresa Pública de Gestión de Programas Culturales de la Junta de Andalucía.

\section{c) Crecimiento}

El número de monografías que han sido dadas de alta, desde el 1 de enero del 2.004 hasta el 31 de diciembre del 2.004 , es de 176 volúmenes. 
El número de monografías dadas de alta, desde el 1 de enero del 2.005 hasta el 23 de noviembre del 2.005, es de 262 volúmenes.

El número de publicaciones periódicas dadas de alta, desde el 1 de enero del 2.005 hasta el 23 de noviembre del 2.005 , es de 148 volúmenes.

No se tiene constancia del crecimiento de las publicaciones periódicas durante el año 2.004. Por tanto, el número de volúmenes dados de alta durante los años 2.004 y 2.005 es de 586.

\section{d) Grado de catalogación e informatización}

Hasta el 23 de noviembre del 2.005, el grado de informatización es de 3.400 volúmenes, en el que se ha utilizado el sistema informático ABSYS para la gestión y catalogación de los fondos bibliográficos del Museo; mientras que el grado de catalogación de forma manual es de 21.588 volúmenes, por lo que se encuentra totalmente catalogada.

\section{e) Condiciones de almacenaje y conservación}

La biblioteca del Museo Arqueológico de Sevilla posee una superficie total de 165 metros cuadrados, cantidad que coincide con la superficie útil de uso. La longitud de los estantes ocupados por la colección de fondos de la biblioteca posee 497 metros lineales de libre acceso.

Todos los volúmenes, tanto monografías como publicaciones periódicas, se encuentran ordenados en las estanterías por registro de entrada.

\section{f) Servicios prestados}

La biblioteca del Museo Arqueológico de Sevilla posee una colección de fondos documentales especializados, organizados para facilitar la adquisición, conservación, 
comunicación y presentación con fines de estudio, educación y deleite de los testimonios materiales que guarda el Museo y apoyar las actividades propias del mismo.

La forma de acceso a la biblioteca es libre, con un promedio de 20 a 40 horas semanales de apertura al público (horario de 9:00 horas a 14 horas de lunes a viernes). Posee un total de 36 puestos de consultas, con un ordenador que tiene acceso a internet y una impresora, ambos de uso público y para la gestión interna.

La biblioteca carece de su propia página web, por lo que su catálogo no es accesible a través de internet. Además, no realiza préstamos domiciliarios.

El número de monografías y publicaciones periódicas disponibles, a 23 de noviembre de 2.005, para préstamos interbibliotecarios es de 243 volúmenes.

Durante el año 2.004 ha sido visitada por 190 investigadores, posee 705 usuarios inscritos, todos ellos adultos, y actualmente, no existe ninguna persona especializada encargada de la biblioteca.

\section{g) Programa informático bibliográfico de catalogación y gestión utilizado}

Actualmente, el programa informático utilizado para la catalogación y gestión de la biblioteca es ABSYS por Daratz.

\section{II.3.9. Difusión de la documentación:}

Según establece el artículo 23 el Reglamento de los Museos de Titularidad Estatal y del Sistema Español de museos, los Museos deben facilitar a los investigadores la contemplación y el estudio de los fondos que no estén expuestos al público, así como la consulta de todos los catálogos sin menoscabo del normal funcionamiento de los servicios.

Esta facilidad de acceso es compatible con la previa necesidad de contar con el permiso de investigación 
cuando sea necesario, como es el caso del estudio y documentación gráfica de los materiales depositados en los museos, previsto en el artículo 52 de la Ley de Patrimonio Histórico Andaluz y desarrollado en el Reglamento de Actividades Arqueológicas cuya competencia es del Director General de Bienes Culturales, que tiene con carácter general la competencia sobre el régimen de autorizaciones en materia de investigación sobre el Patrimonio Histórico según el artículo 1.1 del Decreto 333/1996, de 9 de julio.

También es compatible con el cobro a los investigadores de los precios públicos que se prevén en la Orden de Precios Públicos de la Consejería de Cultura de 5 de junio de 1.989 , donde no se prevé ninguna exención.

\section{a) Acceso de los investigadores a la documentación de las colecciones (manual e informatizada)}

El Museo Arqueológico de Sevilla facilita el acceso a los investigadores con la previa necesidad de contar con el correspondiente permiso de investigación.

Básicamente, la consulta de la documentación de la colección se realiza de forma manual a través de sus archivos, que contienen información documental, escrita y gráfica, relativa a los fondos museográficos y al Museo como institución. También se facilita la búsqueda y visualización de los documentos almacenados en la Base de Datos del Sistema Integrado de Documentación y Gestión Museográfica DOMUS versión 3.0.

Tiene previsto permitir el acceso a DOMUS vía internet para la consulta de los fondos museográficos y 
documentales de la institución, únicamente para fines de estudio e investigación.

Con respecto a la Biblioteca, se facilita el acceso a los usuarios externos. Es el caso de otros museos, docentes, estudiantes, investigadores y público en general.

\section{b) Acceso público a la documentación de las colecciones: catálogos publicados, catálogos online (Internet)}

Además de la biblioteca, que presta servicios a los diferentes usuarios externos, como es el público en general, el Museo Arqueológico de Sevilla tiene publicado tres catálogos $(1.969,1980$ y 2.006) que constituyen una guía útil para conocer la historia de la institución y la colección de bienes culturales muebles que forman parte de sus fondos.
Recientemente dispone de una nueva página web que contiene información general sobre el Museo, con temas de actualidad, como es la exposición temporal sobre Munigua; la historia de la institución; y las colecciones que alberga, mostrando las obras más significativas y los fondos museísticos que contiene (entre otros datos de gran interés). Próximamente, pondrá a disposición toda la información contenida en la aplicación informática DOMUS versión 3.0, con el catálogo e imágenes digitales de las colecciones del Museo a través de la página web www.juntadeandalucia.es/cultura/museoarqueologicosevilla , facilitando el acceso de la ciudadanía al patrimonio histórico andaluz.

Además, dispone de su propia correo electrónico disponible para cualquier consulta:

www.museoarqueologicosevilla.ccul@juntadeandalucia.es 


\section{II.4. INVESTIGACIÓN}

\section{II.4.1. Valoración del papel y alcance científico de} la institución en el panorama investigador nacional e internacional.

En la bibliografía consultada se produce un acuerdo a cerca de la necesidad básica del desarrollo de la investigación dentro de las actividades cotidianas del museo ${ }^{4}$. Desde un doble espacio. Investigación científica, dentro del ámbito de las colecciones por un lado, e investigación museológica y museográfica, qué queremos contar con esas colecciones y cómo, por otro.

Dentro del Plan de Calidad de los museos andaluces EI tesoro de la cultura tartésica, llamado del Carambolo, junto con las colecciones procedentes de las numerosas

\footnotetext{
${ }^{4}$ Solo a modo de ejemplo citaremos: CABRERA BONET, P. La investigación en los museo", Política científica, no 134, nov. 1992, pp. 11-16.
}

excavaciones de la ciudad de Itálica, sus hitos principales, colocan a los fondos del Museo arqueológico de Sevilla entre los principales no sólo de sus museos hermanos de la Comunidad andaluza sino del país e incluso de los estados de nuestro entorno cultural.

\section{II.4.2. Estado de la investigación de la colección del museo. Criterios y prioridades.}

Gran parte del material que se recibe de las campaña arqueológicas es recibido y colocado en los almacenes sin que realmente se estudie ni se conozca con exactitud en qué ha consistido el ingreso o depósito.

\section{II.4.3. Adecuación del personal técnico del museo} a la especialidad de las colecciones.

En cuanto a conservación, museología en general y arqueología medieval 


\section{II.4.4. Proyectos de investigación nacionales e} internacionales en los dos últimos años.

La falta de programas de colaboración a nivel institucional no hace posible el desarrollo de proyectos de investigación en los que los profesionales del museo hayan colaborado

\section{II.4.5. Relación con los departamentos universitarios y otros organismos de investigación.}

Actualmente no se han establecido relaciones de carácter institucional entre el Museo Arqueológico de Sevilla y las universidades de su distrito

\section{II.4.6. Organización de congresos, coloquios,} mesas redondas, cursos en los dos últimos años.
Habitualmente la política seguida en el museo en lo relativo a organización de actividades de participación ciudadana, consiste en la cesión de instalaciones a otras instituciones las cuales se encargan de la elección de la temática.

\section{Para el 2004 la programación fue como sigue:}

Abre el año Febrero con la inauguración de la exposición "Itálica virtual" el 24, siendo clausurada el 24 de Abril.

Mayo trajo un intenso periodo de actividades.

Las exposiciones fueron:

- "Paisaje, agua, ciudad" desde el 31 hasta el 15 de Junio.

- El día 22 se inauguró una nueva sala dentro de la exposición permanente, la correspondiente al ejército.

- "Palabras para una vida" con una duración del 28 del 5 al 15 del mes siguiente. 


\section{II.4.7. Otras actividades:}

Para el día de los museos se organizaron "Talleres de cerámica y mosaico con niños y jóvenes con Síndrome de Down. El 21 se repitió la actividad aunque en esta ocasión trabajando con adultos. En este mismo día se realiza otra actividad para las personas deficientes, "ver y sentir el museo con personas con Síndrome de Down".

Termina el mes impartiendo la conferencia "la música en el museo arqueológico de Sevilla. Objetos de la antigüedad relacionados con la música y la danza" durante los días 19 y 20 de mayo.

Desde el 18 al 21 de Octubre se realizó un "curso de egiptología" con la mediación de la asociación andaluza de egiptología.

Noviembre será un mes para las religiones de la antigüedad. El centro de profesores de Sevilla junto a la
Universidad Pablo de Olavide y durante los días 2, 4, 9, 11, $16,18,23$ y 25 impartirán un curso titulado "Historia de las religiones: judaísmo, cristianismo y Islam". Le seguirá, el día 26, una conferencia organizada por la Asociación de amigos del museo arqueológico de Sevilla, la cual versó sobre "La primera arquitectura religiosa cristiana, siglos III al V".

Y finaliza el año con la conferencia organizada por la asociación de amigos del museo el día 7 que se tituló "Ladrillos estampados tardoantiguos de Baetica".

Durante el 2005 estos han sido los actos desarrollados en las instalaciones del museo.

En Enero fueron impartidas dos conferencias, ambas durante el día 27.La primera de ellas llevaba por título: " Las esferas de piedra precolombinas de Costa Rica: contexto arqueológico e investigaciones recientes" y la segunda "Numismática Omeya andaluza". En esta ocasión 
fue la Asociación de amigos del Museo Arqueológico de Sevilla la encargada de la organización.

El mes de Mayo con la celebración del día internacional de los museos el 18 presentó las siguiente actividades:

- Presentación al público de materiales procedentes de las últimas excavaciones en la necrópolis de época tartésica de la Cruz del negro de Carmona en las salas de prehistoria.

- Visitas guiadas por alumnos de la asignatura de museología de la Facultad de Bellas Artes de la Universidad de Sevilla.

- Concierto en la Sala XIX a cargo de la orquesta del "Colegio Alemán Alberto Durero".

- En la sala XX concierto a cargo de la orquesta del Conservatorio de música Manuel de Falla, de Sevilla.
- Actuación de un grupo de danza de Coria del Río interpretando danzas árabes.

- Y una degustación de productos ingleses, árabes e italianos.

Pasamos al mes de Octubre durante el cual tiene lugar la inauguración el día 22 de la exposición "Artifex, ingeniería romana en España" con una duración hasta el día 8 de enero de 2006. La muestra, que ha itinerando por otros museos antes de llegar a Sevilla, explica mediante dibujos y maquetas los sistemas de construcción de las canalizaciones de agua.

Durante el mes de Diciembre se desarrolla la campaña de navidad en los museos titulada "Sevilla en el nacimiento de Jesús" con una duración desde el 7 hasta el día 23 de diciembre. 


\section{II.4.8. Memorias y publicaciones: catálogos, monografías, revistas}

Durante 2004 se vuelve a publicar la Revista de la Asociación de Amigos del Museo. Hasta la fecha se ha venido editando de una forma irregular.

El primero de los números aparece en el mes de Mayo.

El segundo en 2004 en el mes de Diciembre.

El tercero y último hasta la fecha corresponde en contenido al año 2005 aunque su edición es de fecha 12 de Junio de 2006.

También se produce la edición de una versión actualizada del catálogo del museo, en el año 2006. Su autor ha sido el antiguo director

\section{II.4.9. Atención al número de investigadores} nacionales, dos últimos años, por departamento.

La consulta a las estadísticas recogidas por la Junta de Andalucía sobre las actividades del museo arqueológico ha arrojado el siguiente computo de investigadores atendidos durante los dos últimos años:

\begin{tabular}{|c|c|c|}
\hline \multicolumn{3}{|c|}{2004} \\
\hline Investigadores & $\begin{array}{c}\text { Rodajes y } \\
\text { fotografías }\end{array}$ \\
\hline Enero & 2 & 2 \\
\hline Febrero & 6 & 5 \\
\hline Marzo & 10 & 5 \\
\hline Abril & 13 & 1 \\
\hline Mayo & 11 & 3 \\
\hline Junio & 8 & 4 \\
\hline
\end{tabular}




\begin{tabular}{|c|c|c|}
\hline Julio & 1 & 1 \\
\hline Agosto & 10 & 2 \\
\hline Septiembre & 3 & 3 \\
\hline Octubre & 10 & 2 \\
\hline Noviembre & 12 & 3 \\
\hline Diciembre & 3 & 1 \\
\hline \multicolumn{3}{|c|}{2005} \\
\hline & Investigadores & $\begin{array}{l}\text { Rodajes y } \\
\text { fotografías }\end{array}$ \\
\hline Enero & 6 & 3 \\
\hline Febrero & 11 & 3 \\
\hline Marzo & 12 & 0 \\
\hline Abril & 13 & 0 \\
\hline Mayo & 9 & 2 \\
\hline Junio & 11 & 2 \\
\hline
\end{tabular}

\begin{tabular}{|c|c|c|}
\hline Julio & 9 & 2 \\
\hline Agosto & 5 & 1 \\
\hline Septiembre & 10 & 4 \\
\hline Octubre & 13 & \\
\hline Noviembre & 12 & $\begin{array}{c}\text { No figuran } \\
\text { los datos }\end{array}$ \\
\hline Diciembre & 6 & \\
\hline
\end{tabular}




\section{II.5. CONSERVACIÓN}

\section{II.5.1. Criterios generales en materia de conservación preventiva y restauración.}

\section{Concepto de conservación preventiva}

En la mayoría de casos, con algunas excepciones como los museos de ciencia y técnica, el Parque de las Ciencias de Granada, o algunos centros de arte contemporáneo, el fin primordial de los museos en torno al que giran todos los otros es la consecución de la mayor durabilidad de las piezas que atesoran. Vestigios de las culturas que nos han precedido y que consideramos obligado transmitir en las mejores condiciones posibles a nuestros descendientes.

En el periodo de inicio de la disciplina el concepto de conservación preventiva se identificaba con el estudio del medio ambiente en los museos. O lo que es igual, se trataba de controlar los parámetros que conforman el clima del interior del museo. Actualmente se están teniendo en cuenta todos aquellos factores que tomen parte en la degradación de los objetos.

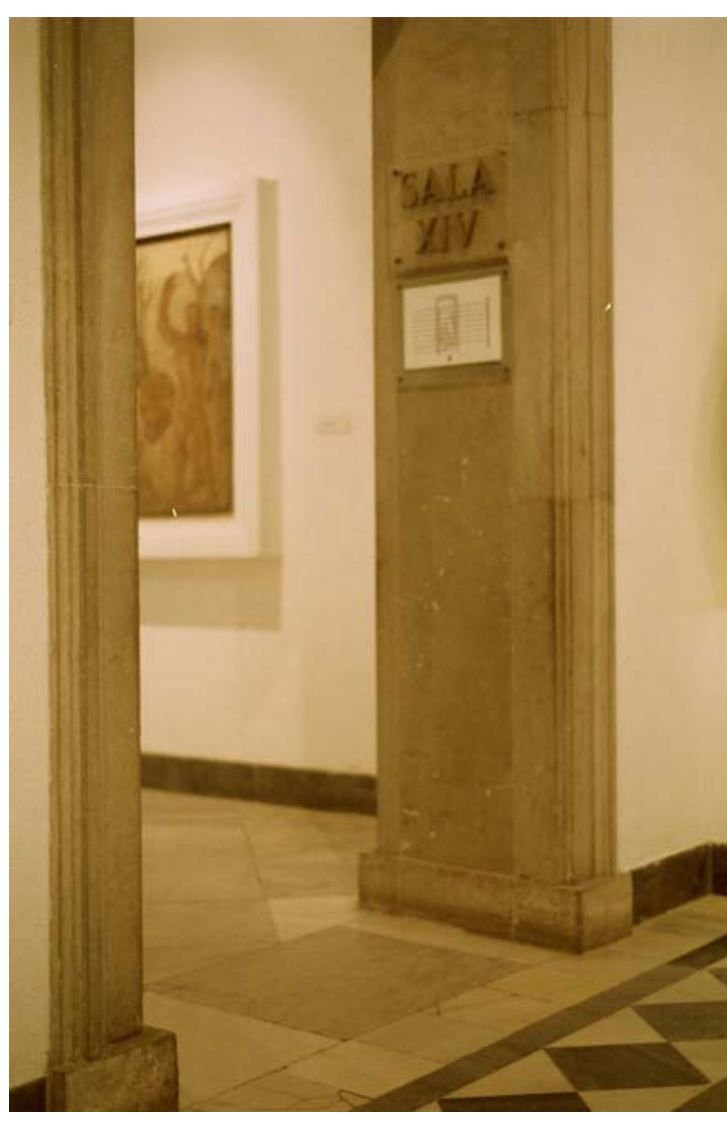

Entrada a sala con cartel informativo en la zona de tránsito 
Esta apertura de miras se concreta en los siguientes aspectos. En lugar de pensar en las piezas individualmente se pasa a pensar en la globalidad de las colecciones. El estudio de las salas como compartimentos estancos ha sido sustituido por el análisis del edificio completo a pesar de que se continúe con la idea de la creación de pequeñas zonas climáticas. De trabajo individual a proyecto en equipo. De planificación a corto plazo se cambia por un trabajo a un plazo mayor.

De creer que el disfrute público era uno de los principales problemas para la conservación se ha cambiado a intentar explicar al público la fragilidad de las piezas de los museos. Y por consiguiente el objetivo de la conservación, antes prioritario exclusivamente, ha sido alcanzado por el de la comunicación y difusión de los contenidos del museo.

En el caso de que algún desperfecto ya se haya llegado a ocasionar todavía se puede producir una intervención, en este caso de una mayor agresividad, pero necesaria para durabilidad de la pieza. Nos referimos a la restauración. Sólo llegaremos a este estadio en caso de una rotura del material en cualquier grado que éste pueda producirse. Por tanto, como principio general se trata de reparar la quiebra y consolidar el material para evitar la progresión de la misma.

En cuanto a su aspecto final la pieza debe mostrar claramente la diferencia entre las zonas originales sin ninguna clase de tratamiento y las reparadas, de modo que si en un futuro se descubriese un modo más adecuado de proceder en la restauración pudiera ser eliminada la anterior sin daño para la pieza.

El protocolo seguido en las restauraciones marca que los conservadores deciden cual es la prioridad en el envío a restauración según el grado de avería, pero en las intervenciones el ritmo viene marcado en la realidad por los restauradores. 


\section{II.5.2. Condiciones de conservación específicas según la naturaleza de las colecciones.}

Los materiales en este museo en cuanto a su material constitutivo se pueden agrupar en las siguiente tipologías:

- Materiales orgánicos: Hueso, marfil, madera y otros.

- Materiales inorgánicos: Piedra, cerámica, vidrio y metales.

Como se ha observado no existe control sobre las condiciones climáticas generales por lo que tampoco se han establecido programas de conservación preventiva adecuados a las especificidades materiales de las colecciones. No obstante, hay dos almacenes específicos, muy pequeños para las necesidades del museo. Uno de ellos dedicado a metales situado en el salón de actos y el otro en el área de restauración. Éste se dedica a acoger las piezas intervenidas

\section{II.5.3. Conservación preventiva.}

En general no existe un plan de climatización para el museo. Este consiste solamente en el empleo de estufas y ventiladores, pero no se produce una recogida de datos sistemática para el adecuado control de las condiciones ambientales en que ese encuentran las colecciones.

En alguna sala sí que hay algún aparato de registro, imprescindible en una institución de este tipo. Sin embargo, el acúmulo de los datos no va aparejado con su posterior tratamiento, no existiendo ningún histórico de esta clase de información.

En consulta a los restauradores en plantilla del museo los porcentajes facilitados en cuando al estado de conservación de las colecciones han sido los siguientes: 
- Bueno. Significa que se considera a estas piezas estabilizadas por lo que no necesitan ninguna clase de intervención . En torno a un 70 \% de la colección.

- Regular. Esto significa que requiere una mínima intervención. Alrededor de un $20-25 \%$ de la colección.

- Malo (requiere una intervención integral y/ o urgente). No existe un número de piezas significativo con necesidades urgentes de intervención ya que las revisiones por parte de los restauradores hacen posible un estado de conservación suficiente para evitar entrar en esta fase de intervención aguda.

La colección viene mostrando una gran estabilidad en su comportamiento frente a la degradación, habiendo conseguido un alto grado de aclimatación a su medio ambiente en la zona del semisótano. Allí la temperatura y humedad están estabilizadas.
Los datos de control de humedad relativa y temperatura de las zonas contenedoras de bienes culturales, como ya se dijo, no quedan registrados en el museo, por lo que resulta imposible saber si las condiciones actuales sean las óptimas para las piezas.

La única sala en la que sí existe un control es la de epigrafía jurídica donde encontramos un termohigrógrafo. Junto con esta sala en las zonas de reserva dedicadas a los metales, se producen deshumectaciones cuando los conservadores y restauradores lo estiman necesario. Por propia experiencia los conservadores han llegado a la conclusión de que en el exterior se dan unas condiciones de clima muy similares a las de la planta baja y sin embargo son muy diferentes a las de la planta superior y a las de los sótanos de las reservas.

Cuando el calor aumenta de forma sensible para los visitantes y personal del museo el procedimiento de 
regulación consiste en desactivar los humidificadores que se encuentren encendidos.

Una gran parte de las entregas de las excavaciones de los arqueólogos no han sido abiertas a partir del año 1984.

En las salas, los vigilantes emplean calefactores para ellos, lo cual aumenta la temperatura sin ningún tipo de control por el departamento de conservación. A pesar del constante paso de vigilantes hemos detectado en algunas piezas restos de grafito. En concreto en algunas de las Tablas que recogen las leyes municipales de época romana, mostrando a la luz la insuficiencia de las catenarias como elemento disuasorio para los visitantes.

La iluminación no tiene controles de intensidad aunque este no suponga un gran problema debido a que la mayoría de las piezas de este museo no poseen una sensibilidad especial hacia este factor de la conservación preventiva. En general, la mayoría de puntos de iluminación utilizan fuentes de neón. Para la conservación de materiales arqueológicos no constituye inconveniente alguno pues afectaría por ejemplo al desgaste en caso de empleo como decoración de tintas, pero las usadas aquí no muestran gran sensibilidad en los exámenes efectuados por los restauradores.

La excepción a esta elección de fuentes de iluminación se encuentra en las vitrinas del tesoro en las cuales se ha optado por una iluminación con fuente dicroica. Esta lámpara aporta una temperatura de color de unos 3100 grados kelvin, un índice de reproducción del color en torno a 100 , el valor máximo, esto es, reproduce los colores con una gran fidelidad, permitiendo una bueno observación al visitante y una conservación aceptable para el Bien Cultural, pues no se busca un efecto de teatralidad. También hay lugares donde la iluminación procedente del exterior se aprecia. Entre ellas, la sala oval de los emperadores, la sala de los toros iberoturdetanos o la sala 
del Niobida. Iluminación permitida sin ninguna clase de matización o protección.

Todo esto en lo referido a colecciones expuestas.

En lo tocante a colecciones acumuladas en las zonas de reserva:

- Condiciones de temperatura y humedad, algo peores, pues al estar el almacén situado en un nivel por debajo del ras de tierra y no poseer ninguna clase de aislante del exterior en sus salidas de seguridad, con ventanas sin cristales, llegan a producirse entradas de agua de escorrentía de lluvia durante la primavera, cuando las lluvias caen con una fuerza mayor en la ciudad, arrastrando la arena de la plaza que circunda el museo y convirtiéndola en barro. La iluminación al igual que en la zona de exposición: paredes y vitrinas, ha sido diseñada eligiendo neones, persiguiendo una iluminación general y suficiente de las salas, a las cuales el visitante no puede acceder; se busca simplemente dar facilidades al equipo de trabaja-dores del museo en sus tareas.

En esta parte del museo quizás se haya conseguido una organización del espacio más adecuada a la conservación frente a un mayor peso del discurso expositivo en las salas de exposición. Se han usado estanterías estables aunque en número hayan devenido insuficientes por la gran cantidad de entrada de piezas, poniendo en riesgo la conservación de todas ellas. Existe incluso un plano bien detallado de las salas que componen esta zona del museo, con su numeración, llegando hasta la 24 , de igual modo a las salas de exposición.

Pasando a la contaminación decir que las vitrinas en las salas de exposición en varias ocasiones en que se han visitado, han estado cubiertas de polvo ${ }^{5}$. Tampoco el encaje de los vidrios que las componen es perfecto, pues

\footnotetext{
$\overline{{ }^{5} \text { Nos referimos a la Sala } 1 \text {, vitrina } 1 .}$
} 
hemos detectado en el interior de ellas pequeños insectos muertos. Con anterioridad se han llevado a cabo campañas de fumigación de salas por empresas externas al museo para la eliminación de insectos. El insecticida empleado fue paradiclorobenceno, alcanfor. Aunque la limpieza se efectúa con una periodicidad semanal el resultado a ojos de un visitante no es muy efectivo. La mayoría de insectos que se han encontrado, han sido mosquitos, arañas pequeñas, moscas y cucarachas, aunque estas últimas sólo en una ocasión.

Por tanto uno de los problemas más acuciantes para las piezas es la falta de unas vitrinas más modernas, construidas con materiales más adecuados y sobre todo con unos sistemas de junturas y cierres perfectos que las conviertan en totalmente estancas.

En cuanto a la contaminación atmosférica, no se han detectado en los análisis de piezas muestras que vengan a manifestar unos índices problemáticos de contaminación exterior penetrando en el interior y afectando a las colecciones.

La acústica en cambio si representa un problema, no tanto ya en función de la degradación de materiales, sino más bien para el completo disfrute de la visita. En el exterior del museo, un parque, se realizan servicios de limpieza, sin duda necesarios, pero molestos al penetrar sus ruidos a las salas de exposición.

Por último las medidas directas tomadas por el personal a favor de la conservación preventiva en lo referente a manipulación, transporte y embalaje de las colecciones son las que siguen:

- El personal va a realizar la manipulación de piezas siempre provisto de guantes para evitar el contacto del sudor de las manos con los materiales. Esto conseguirá por un lado eliminar un porcentaje de probabilidades de caída de las piezas por resbalarse por el sudor. Por otro 
que al entrar en contacto el sudor de las manos de los manipuladores con las piezas pudiera causar alguna reacción con algún material propiciando entonces la puesta en marcha de mecanismos de estropeo de las piezas.

- Se tendrá un gran cuidado en el momento de la elección de la zona por la cual se va a manipular la pieza, prestando atención para escoger aquel lugar que no presente puntos de unión frágiles con el cuerpo principal.

- El transporte se realiza en fases: En primer lugar se vacían un par de vitrinas. Su contenido se traslada, en carritos especialmente destinados al transporte de piezas, en un almacén también destinado únicamente a este fin, por la tanto vacío de cualquier uso. Allí las envuelven y colocan para su almacenamiento. $Y$ para colocarlas del mismo modo al que previamente habían estado, se habían fotografiado.
- Si se trata de un caso de préstamo a otro museo, las transportan hasta el lugar de embalaje los miembros del personal del museo y se encargan de la preparación para el viaje los que vienen por ella.

\section{II.5.4. Restauración}

Al igual que ocurre en cualquier otro museo de contenido arqueológico los materiales más necesitados de intervención restauradora van a ser los cristales y los metales.

El procedimiento a seguir durante los trabajos de restauración se compone de los siguientes pasos:

En primer lugar, y tras comprobar la estabilidad del material se somete a la pieza a una limpieza a fondo. En caso de necesidad y de que la pieza aguante, también se procurará una desalación. A continuación se procede a una estabilización mayor, seguida de una reconstrucción en 
caso de encontrarse en estado fragmentario. $\mathrm{Y}$ por último

si existiesen lagunas materiales se procedería a su reintegración.

Como un ejemplo del orden de prioridades que se ha venido desarrollando, ofrecemos una muestra de las piezas intervenidas, durante el año 2004.

*cerámica: $39 \quad$ unidades.

*vidrio: 1 unidad.

*metal: 19 unidades.

*piedra: 6 unidades.

*material variado procedente de excavaciones: 20 unidades

TOTAL DE PIEZAS INTERVENIDAS: 85 unidades.

\section{II.6. EVALUACIÓN DE LAS PRINCIPALES CARENCIAS Y PRIORIDADES.}

Una vez analizados cada uno de los apartados relativos a las colecciones del Museo, se han llegado a las siguientes conclusiones:

La colección de piezas procedentes de Itálica, ha acompañado a la institución desde sus orígenes. El gusto por la antigüedad clásica ha estado presente en la ciudad desde el siglo XVI, por tanto, se puede decir que la colección de piezas procedentes de la ciudad natal de Trajano y Adriano, constituyen la verdadera alma de la institución.

Otra serie de piezas de extraordinaria importancia son las pertenecientes al periodo orientalizante. Aunque esta colección es bastante significativa, no es tan numerosa como la de origen romano. Tampoco ha acompañado a la historia de la institución museística desde sus orígenes, 
por lo tanto, posee un cierto carácter secundario, pero no menos importante.

En lo que se refiere a las características y tipología de la colección, prácticamente en su totalidad pertenece a la disciplina arqueológica, con un mínimo porcentaje de fondos pertenecientes a las artes decorativas. Esta particularidad, no origina que el Museo Arqueológico de Sevilla sea un institución museística de carácter mixto.

En cuanto a la titularidad de las colecciones, el Museo Arqueológico de Sevilla, como museo de titularidad Estatal y gestionado por la Junta de Andalucía, alberga bienes culturales muebles pertenecientes a la Administración General del Estado y a sus Organismos Autónomos, a la Junta de Andalucía, al Ayuntamiento de Sevilla, así como de titularidad privada procedentes de particulares 0 instituciones de titularidad no Estatal ni Autonómica.
En lo que se refiere al número de piezas que integran la colección, la institución museística posee dificultad para conocer el número exacto de piezas que la integran, debido a la imposibilidad de registrar un volumen tan inmenso de materiales procedentes de las excavaciones arqueológicas. Todo ello produce un hacinamiento de piezas en el almacén, unas veces colocadas en cajas de cartón sobre las diversas baldas de las estanterías, y otras veces colocadas en el suelo, con todo el problema que conlleva desde el punto de vista de la conservación.

Con respecto a la ubicación de las colecciones, el 0,7 \% de los fondos museográficos se encuentra expuestos en la exposición permanente del Museo. Los fondos almacenados en las salas de reservas del almacén, constituyen el $99 \%$ de la colección, todas ellas depositadas a lo largo de 31 salas y situadas en distintas estanterías o en el propio suelo colocadas por orden de procedencia. Por consiguiente, este espacio, que ocupa el $25 \%$ del edificio, debe tener un especial tratamiento en los 
futuros programas. El número total de piezas que se encuentran depositadas en otros museos es de 356, supone el 0,3\% de los fondos museográficos, es decir, una mínima parte de la colección, aunque bastante relevante si se compara con los fondos expuestos en la salas de exposición permanente. De todas formas, suponen un alivio ante los problemas de almacenamiento y conservación que posiblemente tendrían en el Museo, y favorecen la difusión de los fondos asignados o adscritos a la institución.

\section{El volumen aproximado de piezas almacenadas en las} salas de reserva ocupan un total de 352 metros cúbicos, una cifra bastante significativa que permite dar una idea aproximada de los espacios ocupados en las 31 salas situadas en el sótano. Además, permite dar una visión global del espacio ocupado para el futuro proyecto arquitectónico. La mayoría de las salas, se encuentran ocupadas por distintos módulos de estanterías. Prácticamente, la totalidad de las estanterías están ocupadas por distintos tipos de cajas, si bien, hay un gran número de ellas depositas de forma agrupada en el suelo, sobre todo a partir de la sala 20 . Se han contabilizado 11 tipos de cajas, variedad que es debida a los distintos modelos que han sido utilizados a lo largo de los años, si bien, en los últimos 10 años se están utilizando cajas de plástico. Estas últimas mejoran el estado de conservación de las piezas y facilitan su manipulación.

Una de las deficiencias que se ha observado, es la acumulación de fragmentos arquitectónicos, epigrafías, esculturas, urnas, sarcófagos,..., que se encuentran depositados en el suelo, con todos los problemas de conservación que ello conlleva. Dichas piezas de mediano y gran formato, ocupan la totalidad de las salas, dificultando la libre circulación por éstas.

Se ha calculado el incremento de las colecciones en los dos últimos años. La mayoría de las piezas que ingresan en el Museo son fragmentos (amorfos, bordes o bases). 
Por lo que se refiere al número de ingresos, la colección que más ha crecido es la de los depósitos efectuados por la Junta de Andalucía.

El número de piezas ingresadas en el 2.004 y el 2.005 (procedentes de Sevilla y su provincia) es, aproximadamente, de unas 60.000. Esta cantidad permite elaborar, con cierta cautela, el grado de crecimiento de la colección en los dos próximos años. Tales piezas, ocupan un total de 228 metros cúbicos.

Las diferentes cajas se van depositando en las distintas salas del almacén, por orden de procedencia, si bien, existe una gran acumulación de cajas procedentes de la capital, que se están depositando en el suelo a lo largo de las salas 28 y 29 , debido a que se encuentran junto al muelle de descarga.

En lo referente a la documentación, en el Museo Arqueológico de Sevilla ha habido una evolución en los sistemas documentales de las colecciones. Desde la publicación de las Instrucciones para la redacción de fichas de inventario y de catálogo sistemático, el Museo ha llevado la redacción manual del inventario general, del catálogo sistemático, del catálogo monográfico, el registro de entrada de objetos por compra o donaciones y el registro de objetos en depósito. A partir de 1.993, la Consejería de Cultura de la Junta de Andalucía implantó el sistema informático ODISEUS. Finalmente, en junio del 2.003, se implanta el Sistema Integrado de Documentación y Gestión Museográfica DOMUS. El nuevo sistema informático ha ido renovándose en sus distintas versiones hasta la implantación de la versión 3.0 en junio de 2.006 .

En lo que se refiere a los libros de registros, el Área de Conservación e Investigación ha llevado a cabo la redacción de los libros de entrada de objetos en propiedad, de entrada de objetos en depósito, de la colección estable del Museo, de depósitos pertenecientes a la Administración del Estado y de sus Organismos Autónomos y de otros 
depósitos. Actualmente, el conservador del Museo continúa con la redacción de los tres últimos Libros de Registro, facilitando el tratamiento administrativo de los fondos.

En cuanto a las fichas de inventario, el Área de Conservación e Investigación ha utilizado de forma progresiva la ficha de Inventario Navascués, el sistema ODISEUS, y finalmente, la aplicación DOMUS.

Con respecto a las fichas de catálogo, el Museo ha estado utilizando las fichas de Catálogo Navascués (sistemático y monográfico), ODISEUS, y DOMUS respectivamente.

Como método de documentar todo lo referente a la conservación y restauración de los fondos, actualmente la aplicación DOMUS versión 3.0 recoge todos los datos relativos al estado de conservación y los tratamientos de restauración efectuados en la pieza. El Laboratorio/Taller de Restauración redacta informes sobre los tratamientos efectuados, las observaciones, las condiciones de conservación necesarias,.... También se realizan informes de conservación para el préstamo de fondos, como en el caso de las exposiciones temporales, por los que se realizan fichas de conservación, fichas de conservación abreviadas e informes previos de conservación. Se ha de tener en cuenta que toda la documentación referente a la conservación y restauración de los fondos, ayudan a conocer el historial de la pieza arqueológica. Permiten conocer el tratamiento necesario para corregir cualquier patología y ayudan a responder preguntas como la datación, cronología, atribución u origen geográfico del objeto.

Para la documentación gráfica de las colecciones, en el Área de Conservación e Investigación se alberga el Archivo Fotográfico. Con la implantación del sistema DOMUS se comenzó a utilizar la fotografía digital en formato JPEG, facilitando el almacenaje de la información gráfica y permitiendo el traslado de imágenes a los distintos 
sistemas informáticos, lo que supone una mejora en las condiciones de conservación y almacenaje de dicha documentación gráfica.

Otros tipos de instrumentos documentales utilizados, son los referentes a cualquier desplazamiento que suponga un cambio en la ubicación de la pieza. El Museo utiliza el topográfico del almacén y el topográfico de la exposición permanente. También se utilizan documentos relativos a la entrada de piezas en el Laboratorio/Taller de Restauración, documentos para el préstamo de bienes culturales para exposiciones temporales, y los relativos al depósito de piezas en otras instituciones. Todos estos documentos, junto a los Libros de Registro, permiten localizar, en cualquier momento, el lugar de ubicación de una determinada pieza, por lo que son imprescindibles para el pleno funcionamiento del Museo.

En cuanto a los tipos de archivos, se pueden distinguir entre los referentes a la adquisición de piezas, compras y donaciones que acreditan la pertenencia de la pieza a la institución (facturas, recibos, certificados,...); el archivo administrativo, que se encuentra en el Área Administrativa del Museo y contiene datos sobre la gestión administrativa del mismo, como personal, presupuesto, libros de sugerencias y reclamaciones,...); y otros tipos de archivos que hoy día forman parte de la historia de la institución o de la colección estable, compuesto por la correspondencia de los antiguos directores/as, el archivo fotográfico, el archivo monetario, el archivo de metales y el seudo-archivo antropológico.

Actualmente, el archivo administrativo se encuentra en continuo crecimiento, pero no se conoce el grado del mismo. El archivo fotográfico, con fotografías "formato sello", ha dejado de crecer desde que se implantaron los sistemas informáticos de catalogación de fondos. Ha tenido un gran crecimiento las fotografías digitales en formato JPEG. El sistema informático ODISEUS dejó de utilizarse una vez implantado la aplicación DOMUS. También han 
dejado de crecer las fichas del inventario general, las fichas del catálogo sistemático y las fichas del catálogo monográfico. Los documentos relativos a los ingresos están en continuo crecimiento, por ejemplo, se han contabilizado el número de actas de deposito durante 2.004 y 2.005 , contabilizándose un total de 86 , de las cuales, 52 corresponden a Sevilla y 34 a su provincia.

Aún no se ha iniciado la catalogación de los fondos documentales, bibliográficos y administrativos en la aplicación DOMUS versión 3.0, por lo que será preciso un aumento temporal del personal del Área de Conservación e Investigación hasta tener finalizado una buena parte de la catalogación de dichos fondos.

En cuanto a las condiciones de conservación y almacenaje de los fondos documentales y administrativos, todos ellos se encuentran depositados en el interior de archivadores metálicos tanto en el Área de Conservación e Investigación, como en el Área Administrativa del Museo.
El acceso de los investigadores a los fondos documentales se encuentra regulado por el artículo 23 del Reglamento, por lo que el personal del Museo facilita la consulta de todos los catálogos. Para el control del dicho acceso, el interesado debe contar con el debido permiso de investigación.

Actualmente, se está realizando la catalogación de los fondos museográficos por dos catalogadores, coordinados por el conservador y bajo la Dirección General del Museo. Desde la llegada de la nueva directora, se ha iniciado la reorganización de los expedientes administrativos y de las exposiciones temporales, lo que supone una mejora en la programación de tareas de la institución. Gracias a la reorganización de dichos expedientes, se podrá volcar toda la información al sistema informático DOMUS versión 3.0 e iniciar la catalogación de los fondos documentales del Museo. 


\section{Para la informatización de la documentación y gestión}

museística, en junio de 2.003 se implantó la aplicación informática DOMUS. Toda la información contenida en el sistema informático anterior (ODISEUS), ha sido trasladada a DOMUS versión 3.0. El Área Administrativa, utiliza los programas Word 2.000 y Excell para almacenar la correspondencia, para redactar cartas y certificados, para los oficios,..., mientras que en la biblioteca, el sistema utilizado es ABSYS por Daratz, que resulta muy efectivo para la catalogación y gestión de los fondos bibliográficos.

En el mes de diciembre del 2.005, se anotó el número de imágenes digitalizadas en formato JPEG, alcanzándose un total de 5.842. Todas las imágenes corresponden a un gran número de los fondos expuestos en las distintas salas de la exposición permanente y a un pequeño número de piezas que se encuentran depositadas en las salas de reserva del almacén. Como se puede observar, sería necesario incrementar el número de imágenes digitalizadas de los fondos museográficos, lo que ayudaría a una mejor identificación de las piezas para cualquier tipo de consulta y para conocer el verdadero estado de conservación de la mismas.

Actualmente, en DOMUS versión 3.0 se han inventariado y catalogado el $10 \%$ de los fondos museográficos, pero aún no se ha iniciado el inventario de los fondos documentales, bibliográficos y administrativos en dicha aplicación, por lo que una vez organizados dichos expedientes, deberían iniciarse la catalogación de dichos fondos, bien en un cambio de la programación de tareas, o bien, ampliando el personal del Área de Conservación e Investigación de forma temporal.

La aplicación DOMUS sólo está siendo utilizado por los catalogadores, los cuales, están utilizando los siguientes módulos: Fondos Museográficos, Documentación Gráfica, Consultas y Conservación. Como se puede apreciar, el número de módulos utilizados por los catalogadores es mínimo debido a la gran cantidad de fondos museográficos 
que deben ser inventariados y catalogados, por lo que no disponen del tiempo suficiente para iniciar la catalogación de los fondos documentales, así como de los administrativos y bibliográficos.

En lo que se refiere a la biblioteca, el número total de volúmenes es de 21.588, tanto de monografías como de publicaciones periódicas. A esta cantidad, habría que incluir 30 documentos sonoros, 45 documentos audiovisuales y 30 electrónicos. Además, la institución contienen 235 volúmenes anteriores a 1.901, lo que muestra la importancia de dicha área.

La superficie de la biblioteca es suficiente para albergar tal cantidad de volúmenes, e incluso existe espacio suficiente para el ritmo de crecimiento de sus fondos (586 volúmenes en 2.004 y 2.005).

Es necesario hacer una reflexión sobre los fondos anteriores a 1.901 que se encuentran depositados en el despacho del antiguo director, por lo que se impide, en cierta medida, la posibilidad de consultar dichos fondos.

No existen aparatos de reproducción, como lectores/ reproductores de microformas, lectores/ reproductores de imagen, lectores/ reproductores de sonido, ni fotocopiadoras. Ello impide al usuario la consulta de los documentos sonoros, audiovisuales y electrónicos.

Los fondos están especializados en Arqueología, Museología, Historia Antigua y Arte, por lo que pueden ser de gran utilidad para investigadores y universitarios, especialmente a los relacionados con estas disciplinas. Pero los datos referentes a su uso revelan la escasa visita por parte de las personas ajenas a la institución. Tiene inscrito 705 usuarios, todos ellos adultos, por lo que sería necesario hacer un buen Programa de Difusión que aumente el número de investigadores, universitarios y jóvenes estudiantes. 
Presta un buen servicio con acceso a Internet, posee 36 puestos de consultas y con un promedio de 20 a 40 horas semanales de apertura al público, pero no dispone de la consulta de su catálogo para los usuarios remotos, por lo que sería necesario publicarlo en la página web de la institución.

Todos sus fondos bibliográficos se encuentran catalogados de forma manual, y sólo el $6,3 \%$ se encuentran informatizados en el sistema ABSYS, por lo que sería necesario aumentar el grado de informatización de los fondos mediante una nueva programación de tareas.

En lo referente a la difusión de la documentación, el Área de Conservación e Investigación facilita a los investigadores el acceso a la documentación básicamente de forma manual, aunque también se facilita la búsqueda y visualización de los documentos almacenados en la Base de Datos de la aplicación DOMUS.
La biblioteca permite el acceso a los distintos usuarios externos, como es el caso de otros museos, docentes o estudiantes; pero no realiza ningún tipo de préstamo, lo que minimiza la oferta de servicios ofrecidos por dicha área.

El Museo tiene publicado tres catálogos, que junto a los datos publicados en su nueva página web, permiten conocer, de forma abreviada, la historia de la institución y de las colecciones que alberga.

Una de las principales carencias de este museo es la falta de un programa de conservación preventiva. Es urgentísima la elaboración de un sistema de recogida e interpretación de datos climáticos ${ }^{6}$. Habrá que tener presente la necesidad de preparar ex novo los programas de control climático, con pretensión de futuro, al no existir puntos de referencia.

\footnotetext{
${ }^{6}$ Buena muestra de esta necesidad es la Victoria Alada en estado de
} descomposición por alguna de sus zonas. 
Una gran cantidad de piezas de las salas de exposición se encuentra bien al alcance de posibles visitantes despistados 0 incluso malintencionados: obras muy cercanas al visitante, elementos disuasorios insuficientes e incluso falta de alarmas en caso de proximidad del visitante a las piezas.

La evacuación de las piezas en caso de catástrofe se tiene que realizar actualmente por la zona de los almacenes, pues tienen dos salidas, una hacia la calle y otra hacia la planta sótano. El piso de los almacenes no es adecuado para esta evacuación pues esta zona del museo nunca se pensó en su concepción original como almacén.

La evacuación de personas se haría por las mismas salas de la exposición permanente, resultando peligrosa tanto para los propios visitantes, como para las colecciones, ya que los sistemas de iluminación no están adaptados a situaciones de emergencia.
El resultado de la experiencia museística para el visitante puede llegar a ser incómodo, debido a la suma de varios factores como la entrada del ruido externo, por el frío y hasta por la inaccesibilidad para público discapacitado de una de las vitrinas estrella del discurso: la del Tesoro del Carambolo.

Visualmente se construye el discurso mediante unos materiales anticuados, primando el criterio acumulativo, propio de exposiciones del siglo XIX. 

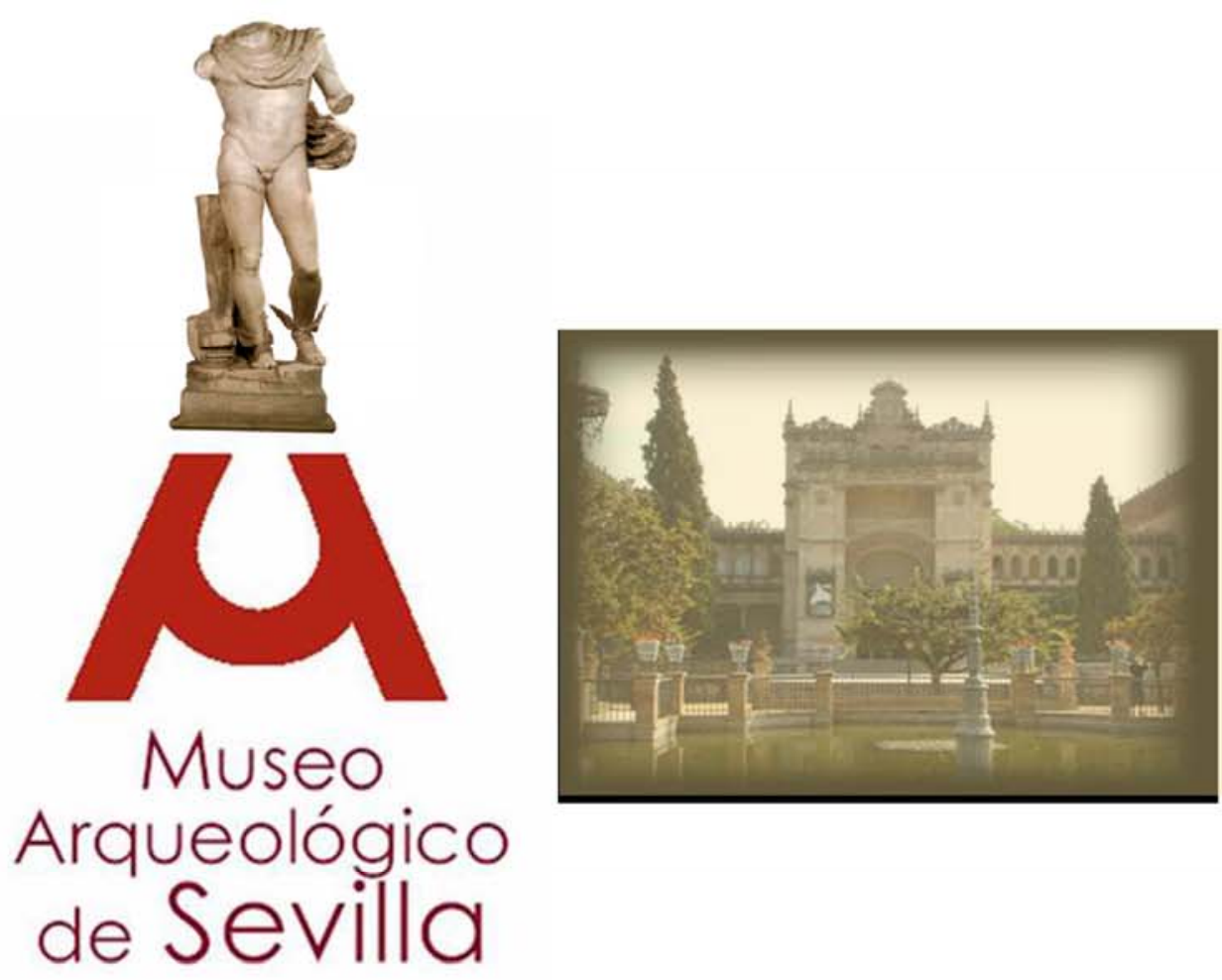

\section{ARQUITECTURA}

Yolanda Torrubia Fernández 
ANÁLISIS Y EVALUACIÓN DE LA ARQUITECTURA DEL MUSEO

ARQUEOLÓGICO DE SEVILLA.

PRINCIPALES CARENCIAS Y PRIORIDADES.

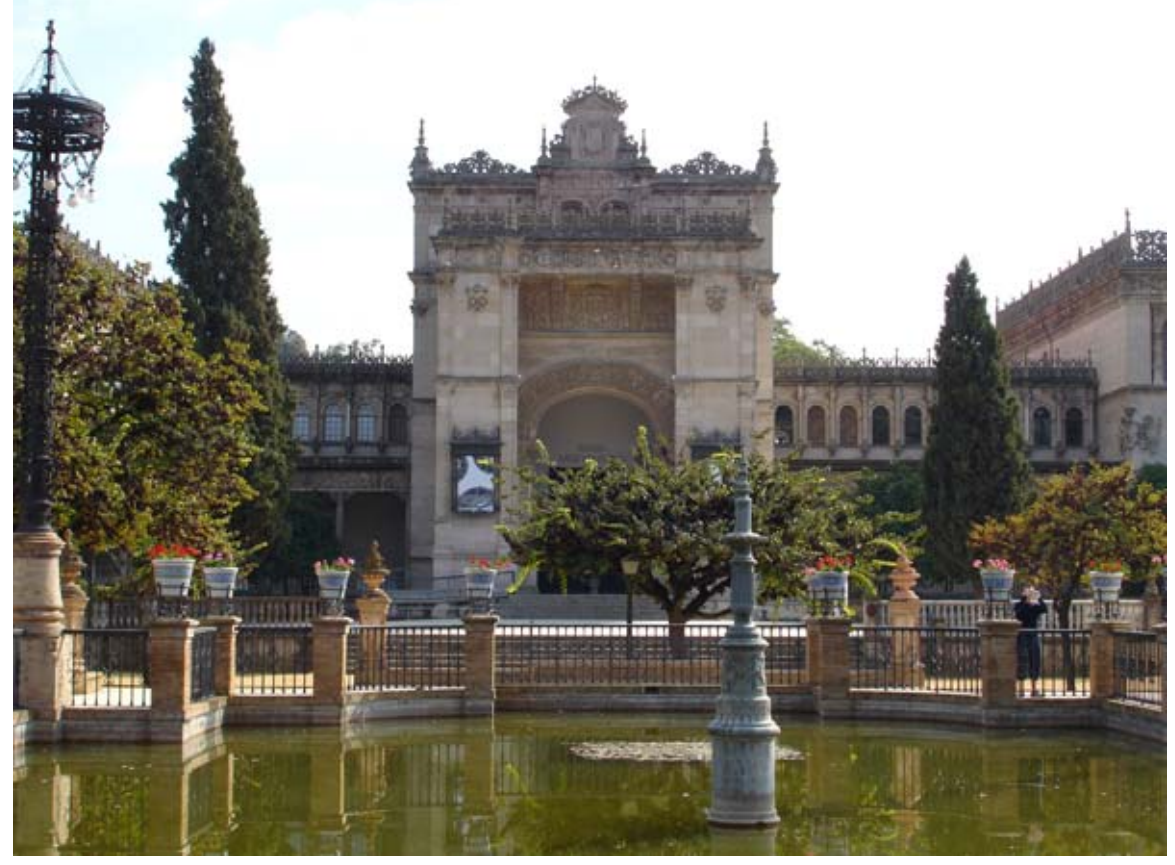




\section{III.1. SEDE DEL MUSEO ARQUEOLÓGICO}

\section{DE SEVILLA}

\section{III.1.1. EMPLAZAMIENTO}

El Museo Arqueológico de Sevilla se encuentra ubicado en el Parque de Maria Luisa, en la denominada Plaza de América, cuyo acceso principal se sitúa en la Avenida de la Palmera, más concretamente en el Paseo de las Delicias y sus otros dos accesos por la Avenida de la Borbolla y la Avenida de Eritaña.

Las siguientes vistas aéreas muestran la situación del edificio en a ciudad.

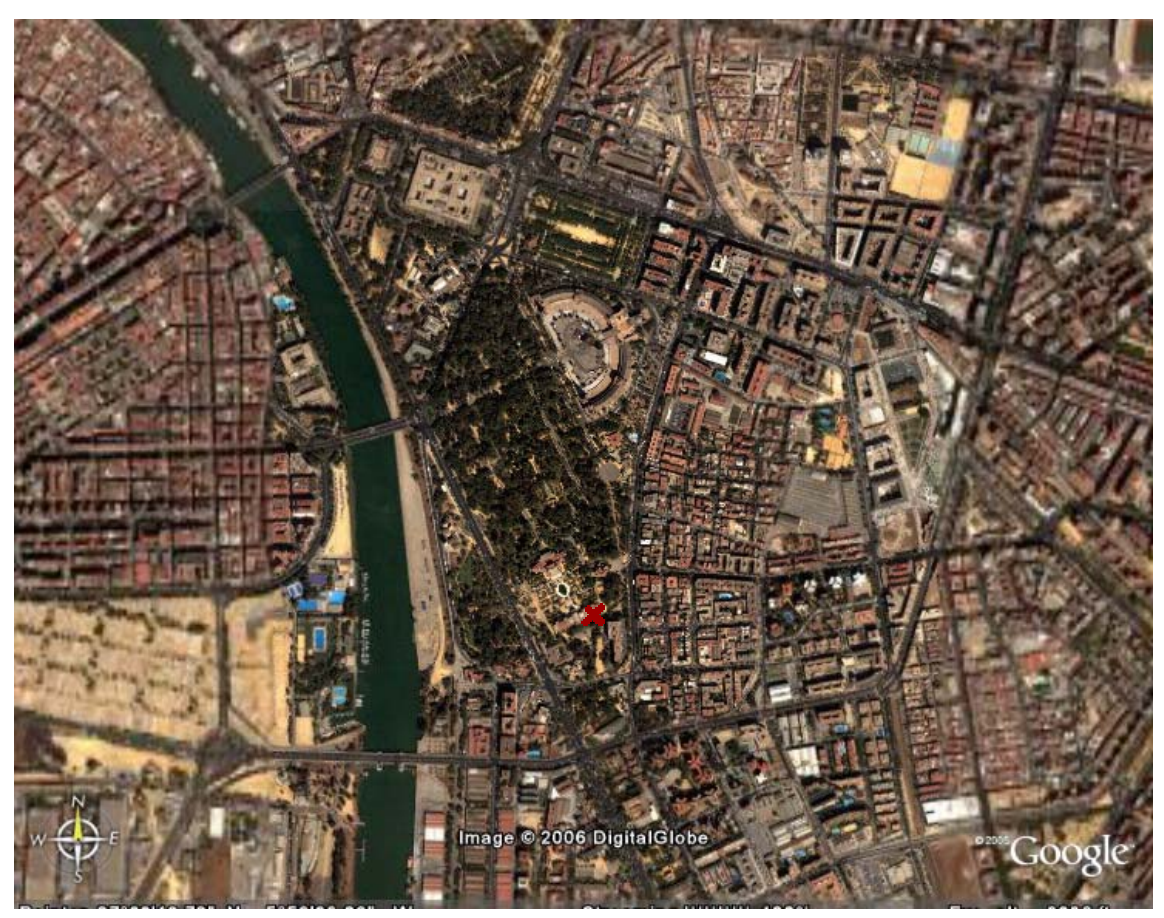


${ }_{140} \boldsymbol{M}$

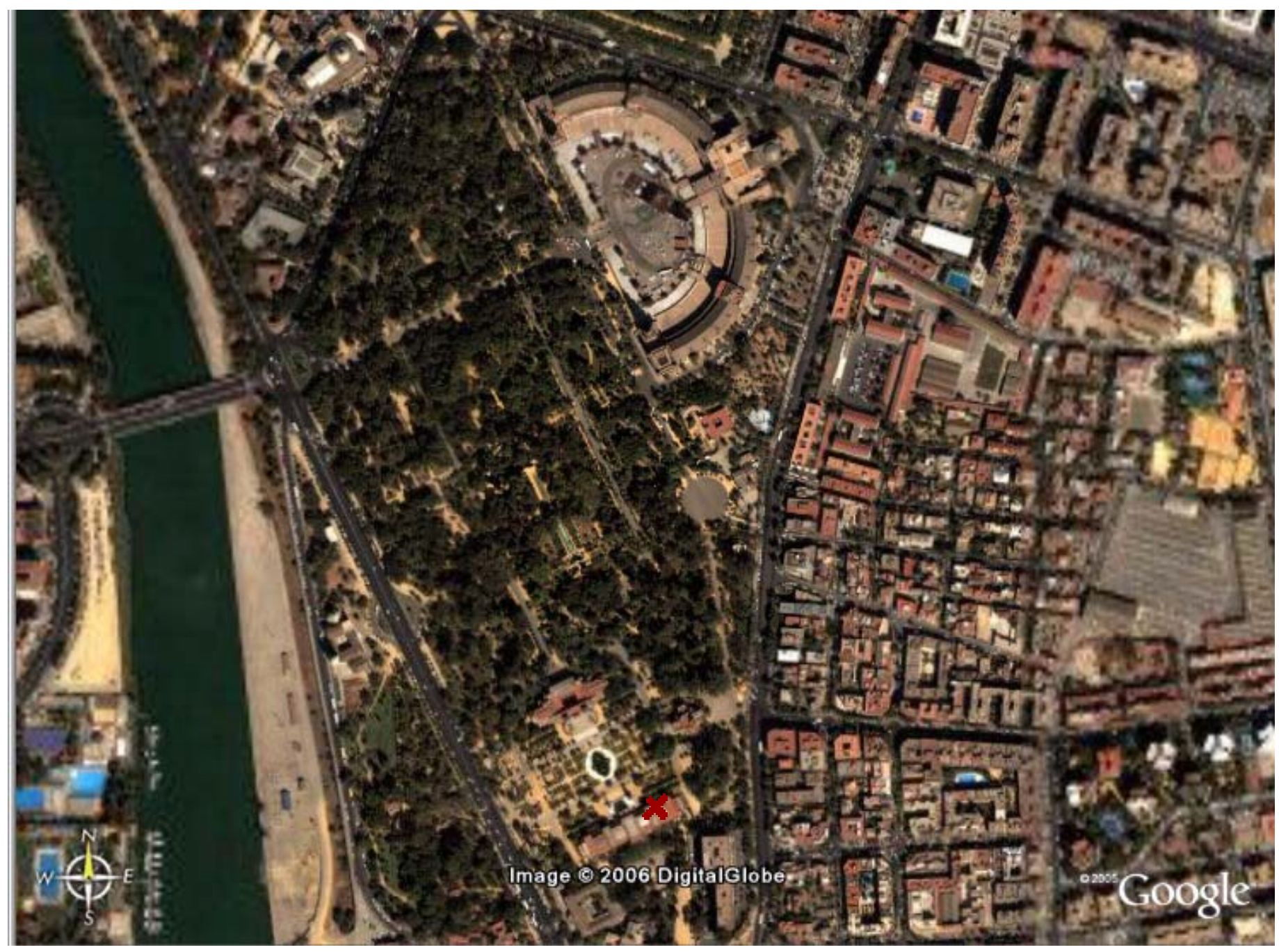



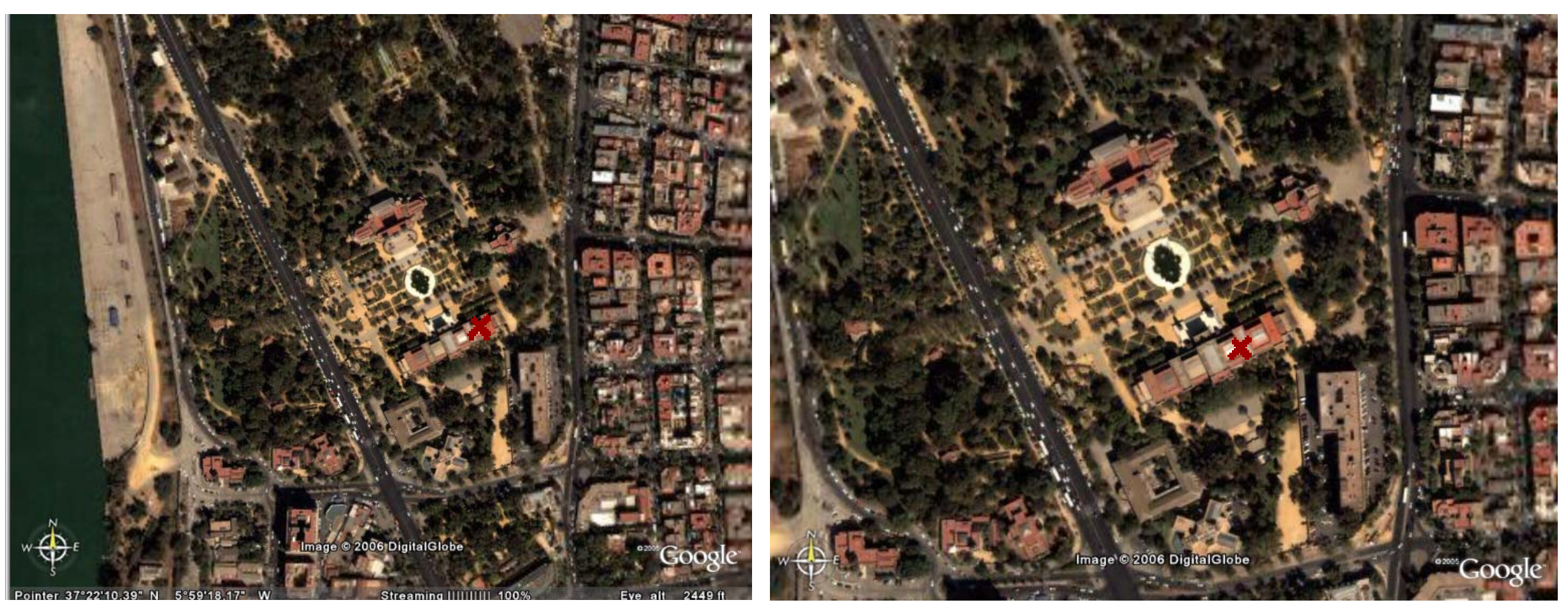
${ }_{142} \boldsymbol{M}$

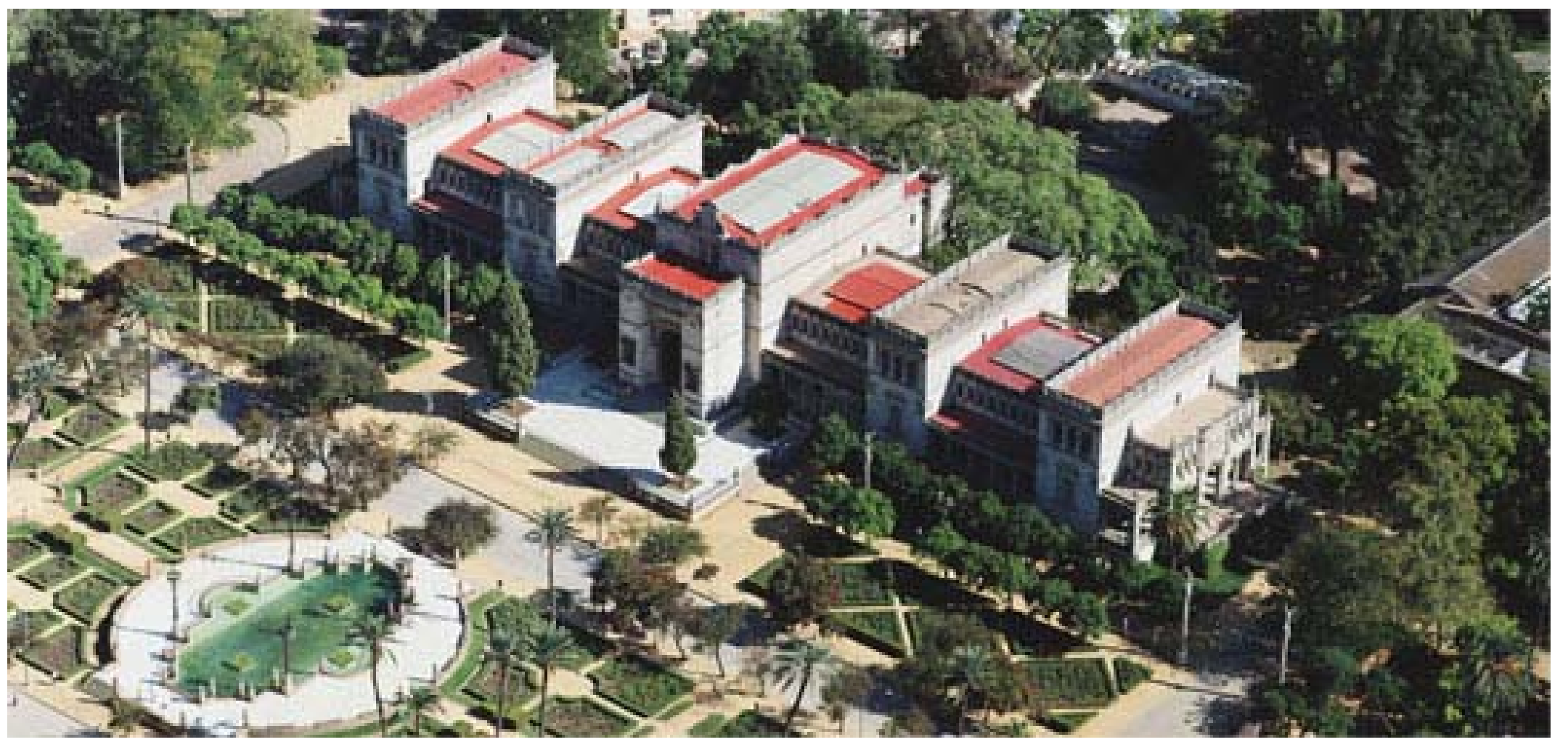




\section{III.1.2. HISTORIA DEL EDIFICIO}

O El palacio de bellas artes de la exposición iberoamericana de 1929

\section{a) La Exposición iberoamericana de 1929}

El Museo Arqueológico de Sevilla está ubicado en lo que fue el Pabellón de Bellas Artes de la Exposición Universal de 1929. Para su construcción fue convocado un concurso de proyectos para cuya resolución, la Comisión Gestora de la Exposición acordó en octubre de 1910 la designación de un Comité Ejecutivo que estaría integrado por diez vocales, cinco en representación de las corporaciones municipal y provincial (tres concejales y dos diputados provinciales) y cinco por las fuerzas vivas de la ciudad, es decir, el comercio, la industria, las bellas artes y la banca. Este primer Comité quedó constituido de la siguiente forma: por el Ayuntamiento, Antonio Halcón y Vinent, alcalde; Federico de Amores (Conde de Urbina) y José Galán
Rodríguez, concejales; por la Diputación Provincial, Manuel Hoyuela Gómez y José Benjumea y Zayas; por las fuerzas vivas, Fernando Barón y Martínez- Agulló (Conde de Colombí), José Gestoso y Pérez, Nicolás Luca de Tena, Pedro Fernández Palacios y Gonzalo Bilbao Martínez. Por Real Orden de 26 de junio de 1911 se dio personalidad jurídica a este Comité Ejecutivo. En este mismo año viene a Sevilla el arquitecto provincial de Valencia, Vicente Rodríguez, que había trabajado en la Exposición Regional de Valencia de 1909, que interviene activamente aconsejando al Comité sobre el emplazamiento de la exposición y los pabellones que deberían formarla. De esta colaboración saldrá el primer plano de la exposición, que será el plano piloto para los participantes en el concurso de anteproyectos.

El 5 de abril de 1911 se aprueban las 23 bases del "concurso de anteproyectos de emplazamiento general" de la Exposición Iberoamericana, al que podían acceder los arquitectos que ejercieran su profesión en España. El 
espacio dentro de cuyos limites se ubicaría la exposición comprendía los jardines de San Telmo, el Parque de Maria Luisa, el Huerto de Mariana y un sector del Prado de San Sebastián. Se da libertad a los concursantes para la disposición de los edificios, siempre respetando el arbolado existente, así como para el estilo de los mismos. La exposición se articularía en tres partes, una de arte general e histórica, otra industrial y otra recreativa, con los siguientes edificios fundamentales: Industrias y Manufacturas, Agricultura, Maquinaria, Mineria, Guerra y Marina, Fomento, Bellas Artes, Casa Real, Actos y Fiestas y Gran Casino. Además debían señalarse los lugares adecuados para la construcción de edificios auxiliares y pabellones americanos. De todos edificios, dos serían permanentes y se dedicarían a Exposición de Bellas Artes y Exposición de industrias diversas. El plazo de presentación se extendió hasta septiembre del mismo año.
Cuando se cerró el plazo se habían presentado tres proyectos, el de Aníbal González, el de Fermín Alamo y uno anónimo que fue descalificado.

El proyecto de Anibal Gonzalez era el más completo, dividiendo la Exposición en cinco partes:

$1^{\text {a }}$ Exposición Nacional de Artes, Industrias y Ciencias. Con los pabellones provisionales y permanentes propuestos en las bases.

$2^{\mathrm{a}}$ Exposición de Estados americanos. Se construirían pabellones para las naciones que no pudieran edificar el suyo.

$3^{\mathrm{a}} \quad$ Instalaciones de las regiones españolas.

$4^{\mathrm{a}} \quad$ Sevilla histórica y tradicional. Ofrece una visión ideal de Sevilla en el siglo XVI, con sus edificios, usos y costumbres.

$5^{\mathrm{a}} \quad$ Parque de atracciones. Con una gran pista o "Stadium" para los espectáculos deportivos. 


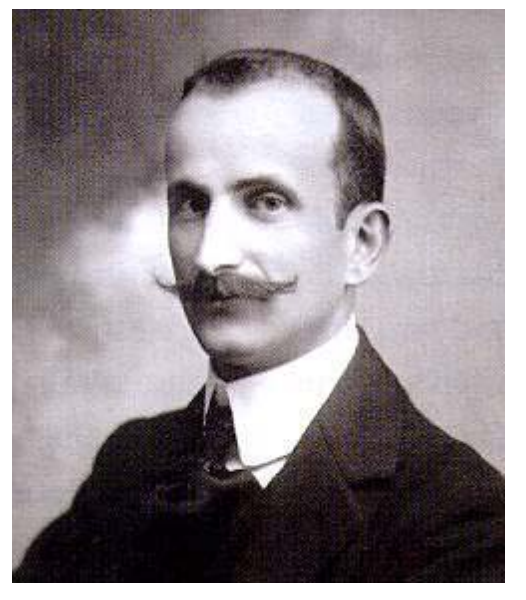

De los pabellones proyectados por Gonzalez solo tres llegaron a construirse, los dos permanentes del llamado Huerto de la Mariana ( actual Plaza de América ) - el de Industrias (en estilo neomudéjar plateresco, hoy Museo de Artes y Costumbres Populares) y el de Bellas Artes (en estilo neorrenacimiento plateresco, hoy Museo Arqueológico)- más el de la Casa Real, en la misma plaza, que se pensó provisional pero luego se hizo de construcción sólida (en estilo neogótico isabelino).
El Comité se reunió para juzgar los proyectos el 9 de septiembre de 1911, pero se decidió hacer una consulta a la Real Academia de Bellas Artes de Sevilla, la cual, para que elaborara el dictamen nombró una ponencia integrada, entre otros, por los arquitectos Francisco Aurelio Álvares y Mariano Gonzalez Rojas, por los pintores José García Ramos y Virgilio Mattoni de la Fuente, que emitió el dictamen definitivo el 25 de septiembre, a favor del trabajo de Anibal González, aconsejando algunas modificaciones. Al día siguiente el Comité Ejecutivo de la Exposición concedía el premio a Aníbal González y Alvarez-Ossorio.

En sus inicios, la Exposición fue planteada desde el punto de vista económico, es decir, con la intención de mostrar las aptitudes de la ciudad de Sevilla para el desarrollo económico e industrial. Pero en 1912 esa visión va cambiando y se empieza a pensar en una Exposición artística y que sirva de atracción turística. Por otro lado, en 1912 se veía que no podría inagurarse en 1914 como estaba previsto, planteándose la fecha de inauguración el 1 
de enero de 1916, pero el estallido de la Primera Guerra Mundial daría lugar al retraso de la Exposición.

En mayo de 1912 Aníbal González expone ante el Comité, que había ido cambiando de integrantes con el paso de los años, el primer proyecto de emplazamiento de la Exposición Iberoamericana, segundo planteamiento después del anteproyecto presentado al concurso. La disposición rodea el Parque, recientemente reformado por J.C.N. Forestier, colocando el Stadium continuación de la gran plaza de entrada y el Pabellón Real en el Huerto de la Mariana, que pasaría a ser la "Plaza de Honor" con los pabellones permanentes de Industrias y Bellas Artes en sentido perpendicular al Paseo de las Delicias, y como fondo el Pabellón Real. A partir de aquí se piensa en tres núcleos fundamentales en la Exposición: Plaza de España, Plaza de América y Sector Sur. Nos centraremos en la Plaza de América, por ser el actual emplazamiento del edificio que nos ocupa.
La idea del conjunto de la Plaza de América, corazón de la Exposición Iberoamericana, estaba ya afianzada en marzo de 1912, cuando se publica el proyecto definitivo del Pabellón de Bellas Artes, pero queda definida en el proyecto de emplazamiento ya comentado, presentado al Comité el 25 de mayo del mismo año. Anibal plantea una planta rectangular, con los pabellones de Bellas Artes e Industrias situados frente a frente, uno en cada lado mayor del rectángulo y separados por una distancia de cian metros; el Pabellón Real cierra en conjunto en uno de los lados menores, y en el otro se situa el Monumento a Cervantes. Se urbaniza la plaza con un rectángulo central ajardinado situando en medio una terraza con un estanque y fuentes, ornamentados con hierro forjado.

La Plaza reunía los símbolos de la Exposición Iberoamericana, ya que en ella se encontraban los pabellones que representaban los dos temas principales de la misma: Industrias y Artes Decorativas y Bellas Artes. Además, el de Bellas Artes representa el "estilo español", 
la arquitectura nacional en neorrenacimiento y el de Industrias personifica el "estilo sevillano", la arquitectura regionalista en neomudéjar; ambos están bajo la tutela de la Corona, el Pabellón Real, proyectado en el "estilo de los Reyes Católicos", símbolo de la unidad de los reinos de España. El Monumento a la lengua castellana, simbolizada en Miguel de Cervantes, aludía a las naciones americanas, pues es el idioma es uno de los lazos que unen España con la mayoría de estas naciones. El Comité denominó a este espacio Plaza de América.

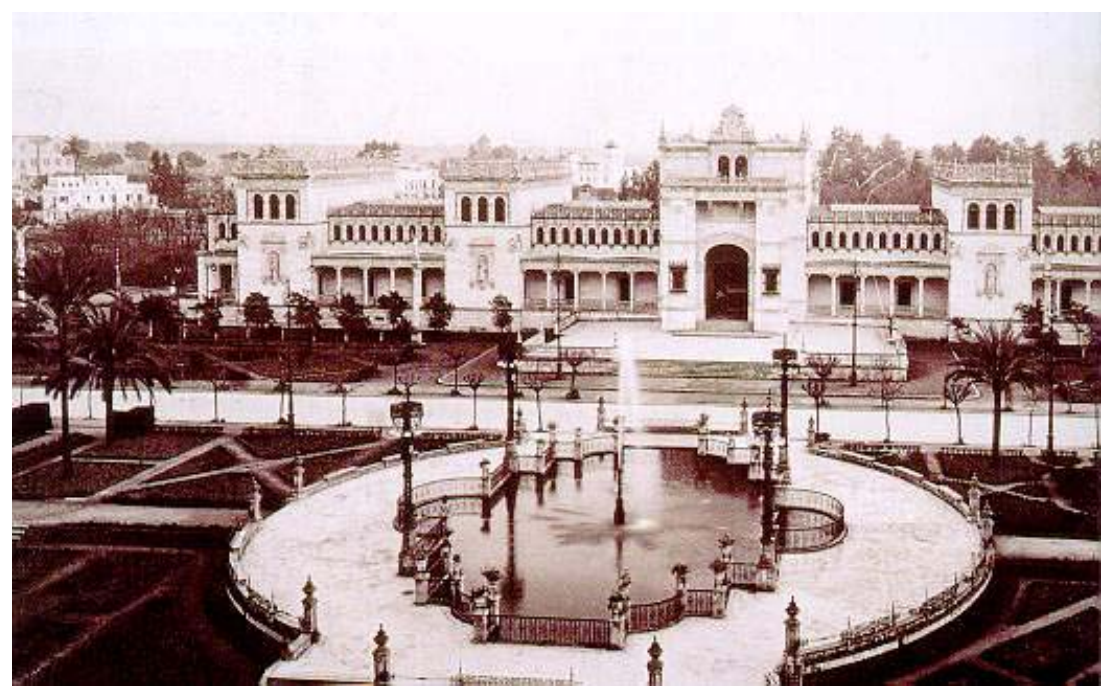

\section{b) La construcción del Pabellón de Bellas Artes}

Concebido por Anibal Gonzalez como lugar de exposición similar a un museo, su construcción se llevó a cabo entre 1912 y 1919. En estilo neorrenacentista plateresco, el edificio se construyó con un cerramiento de ladrillo revestido con piedra artificial y sobre un basamento de piedra. Se estructura en un bloque longitudinal, con una planta rectangular de $117 \times 25,50$ metros (sin contar los salientes anterior y posterior ni las terrazas laterales) atravesada por nueve cuerpos. El cuerpo central es una gran sala elíptica de 23,20 metros en su eje mayor y 14 metros en el menor y a cada lado de ésta se distribuyen cuatro salas, que configuran la planta simétrica del edificio. Así, a cada lado de la elipse se dispone en primer lugar una sala casi cuadrangular de 15 × 14,70 metros; a ésta le sigue otra rectangular de 12 × 6,90 metros y de nuevo otro cuerpo casi cuadrangular como el anterior $y$ otro rectangular. Cuenta con una superficie total de 3143,8 $\mathrm{m}^{2}$. Pensado para facilitar la circulación y la exposición, el 
arquitecto proyecta numerosas salas y dispone luz cenital y lateral alta en las salas cuadrangulares, pensadas para exponer esculturas y relieves y luz cenital en la rectangulares, pensadas para pinturas y dibujos; todo ello con paramentos lisos de color neutro, preferentemente grises. Una planta de sótanos fue proyectada para aislar de la humedad la zona de exposición y para canalizar los sevicios de agua, electricidad, alcantarillado, etc.

Para la decoración escultórica se convocó un concurso internacional, resuelto en 1913 a favor de Lorenzo Coullaut Valera, asociado a Manuel Delgado Brackembury. Se realizan ocho esculturas para las hornacinas exteriores, que representan desde la izquierda de la fachada principal, la Historia (Delgado), la Pintura (Coullaut), la Escultura (Delgado), la Arqueología (Delgado); y en fachada posterior la literatura (Coullaut), la Arquitectura (Delgado), la Música y la Cerámica (Coullaut). Además se les encargan también cuatro "putti" con escudos para rematar las esquinas del palacio, así como cuatro grandes grupos alegóricos para las hornacinas interiores de la sala elíptica, que luego se colocaron en la glorieta de Covadonga y representan el Arte (Coullaut), la Ciencia (Delgado), el Trabajo (Delgado) y el Genio (Coullaut).

La construcción sufrió importantes retrasos por problemas económicos y por problemas entre Anibal Gonzalez y los contratistas, hijos de Miguel Fernández Palacios, lo que provocó la dimisión de José Gómez Millán como arquitecto de la empresa y el Comité adjudica la construcción a Antonio Granados Olier. En 1917 se inagura la Plaza de América y el edificio aún no estaba terminado.

\section{- La instalación del museo arqueológico de Sevilla en el pabellón de bellas artes.}

Pasada la exposición, el edificio quedó sin utilidad hasta la Guerra Civil, cuando sirvió durante un tiempo como hospital al servicio de los soldados italianos llegados a España para intervenir en la contienda. 
Después de la Guerra, el 31 de diciembre de 1941, siendo Alcalde de Sevilla D. Manuel Ibarra y Lasso de la Vega, el Ayuntamiento por acuerdo municipal, se cede el edificio al entonces Ministerio de Educación Nacional con el fin de instalar el Museo Arqueológico Provincial, cediéndose también en depósito la Colección Arqueológica Municipal. En marzo de 1942, el inspector general de museos, D. Joaquín María de Navascués, toma posesión del inmueble en nombre del Ministerio, comenzando poco después las obras de adecuación para museo. No obstante, el edificio había sido concebido con una finalidad similar, como Pabellón de Bellas Artes, con lo que ya contaba con amplios espacios bien iluminados con luz natural.

El proyecto de instalación del museo se debe a la colaboración de D. José María de Navascués, el director del museo D. Juan Lafita y el arquitecto D. Félix Hernández Giménez, que dirige estas primeras obras, tras las que quedan abiertas al público las ocho primeras salas (hoy las XI a XX) ordenadas de forma cronológica, además de los despachos de dirección, oficinas y biblioteca. Al museo se accede en este momento por la puerta lateral occidental que se encontraba junto a la puerta del salón ovalado, que quedaría cerrada y la salida se efectuaría por la puerta lateral oriental. El museo abre al público el 29 de mayo de 1946 y en este mismo año comienzan las obras de consolidación del edificio y la sustitución de techos y artesonados por bóvedas, así como la colocación de viguetas en el sótano en los lugares donde se colocarían objetos pesados. En 1945 terminan las obras de acondicionamiento y se pasa a la decoración de las salas y la instalación de las piezas. El 25 de mayo de 1946 se inauguran las ocho salas ya comentadas, del ala occidental, incluido el gran salón central.

Años más tarde, se considera la necesidad de ampliar el número de salas abiertas al público, influyendo la aparición en 1958 del Tesoro del Carambolo y su inmediata adquisición por el Ayuntamiento para evitar su traslado al Museo Arqueológico Nacional. Este descubrimiento 
potenció la investigación arqueológica en el Bajo Valle del Guadalquivir y con ello la definición de la cultura tartéssica en Andalucía, con lo que se necesitó espacio en el museo para presentarla al público. Con este fin se habilitó el vestíbulo de la entrada posterior del edificio, inaugurado en 1968 por en Ministro de Educación y Ciencia D. Manuel Lora Tamayo y el director general de Bellas Artes D. Gratiniano Nieto Gallo. Ya en 1962-63 se habían llevado a cabo obras de mantenimiento y reparación de las cubiertas, consolidándose los techos del ala oriental. Las obras continuaron bajo la dirección de D. Aurelio Gómez de Terreros y D. Rafael Manzano, habilitándose todo el ala oriental del edificio (hoy salas XXI a XXVII) y realizando la entreplanta al reducirse la altura de algunos ámbitos, sin perder la luz cenital. Además se construyen en la parte alta dependencias para almacenes, que hoy son salas de exposiciones temporales, todo ello inaugurado en 1970 por el director general de Bellas Artes D. Florentino Pérez Embid.
En 1972 y 1973 continúan las obras con el arquitecto D. José Galnares Sagastizábal. Se elimina las vidrieras de entrada de luz central de algunas salas por problemas de humedades derivados de los atascos en los bajantes como consecuencia de las palomas de la Plaza de América, con lo que se gana en el ala occidental del edificio la entreplanta, a la que se trasladan los espacios de dirección, secretaría, oficinas, salón de actos y biblioteca. Además se habilitan en la planta sótano del ala oeste, diez nuevas salas abiertas al público, en las que se instalará el Tesoro del Carambolo en una sala con importantes medidas de seguridad, que sirve de eje a esta zona, en la que se ubican las salas de Prehistoria y Protohistoria (hoy salas I a X). Con ellas, el museo alcanza las 27 salas abiertas actualmente, inauguradas el 4 de marzo de 1973 por D. Florentino Pérez Embid, director general de Bellas Artes.

Años más tarde y directamente por la dirección del museo, se habilitan los sótanos para almacenes. Para ello se 
retiran los escombros amontonados, se iguala y rebaja el terrizo, se construyen arquetas para control de los bajantes, se echa un piso de cemento, se encalan las paredes, se dota de instalación eléctrica y se colocan estanterías metálicas, comenzándose el traslado de piezas desde diferentes zonas del edificio.

Durante 1980 y 1981 se realizan nuevas obras en el edificio, que afectan sobre todo a las cubiertas. Se había intentado en todo momento respetar la luz central que inicialmente había tenido el edificio, pero ésta creaba diversos inconvenientes, como las goteras y la dificultad para controlar la temperatura en las salas, demasiado elevada durante los meses de verano y demasiado bajas durante el invierno. Bajo la dirección del arquitecto D. Manuel Lafarga, se sustituyeron los antiguos lucernarios por una estructura de fábrica. Asimismo, se construyó una entreplanta en la biblioteca que dobló su capacidad, unos talleres de restauración bien iluminados y ventilados en la planta alta, un laboratorio fotográfico y un montacargas que comunicara los talleres y los servicios del museo con los nuevos almacenes.

En 1985 se encarga de nuevo a D. Manuel Lafarga el último proyecto realizado hasta ahora en el museo; se trata de la construcción de la rampa de acceso al edificio para minusválidos, doble y a cada lado de la puerta principal, y la renovación de la solería de la terraza delante de la puerta. Asimismo se construyen en el sótano aseos nuevos para el público en el sótano, pues hasta entonces el museo sólo contaba con un pequeño aseo a la entrada del edificio de dimensiones muy reducidas. 


\section{III.1.3. TITULARIDAD DEL EDIFICIO}

Nos encontramos ante un museo de titularidad estatal gestionado por la Junta de Andalucía, como son los museos provinciales de la Comunidad Autónoma.

No obstante, en este caso, el edificio procedente de la Exposición Iberoamericana de 1929 es de propiedad municipal, pero fue cedido por el Ayuntamiento de Sevilla al entonces Ministerio de Educación Nacional por acuerdo de 31 de diciembre de 1941 para la instalación del Museo Arqueológico. Así, actualmente el Ministerio de Cultura ostenta la titularidad del edificio y de gran parte de sus colecciones, quedando pues sometido al Real Decreto 620/1987, de 10 de abril, por el que se aprueba el Reglamento de los Museos de Titularidad Estatal y del Sistema Español de Museos. No obstante, el artículo 5, apartado 2 de este reglamento establece:
Artículo 5. Régimen aplicable a los Museos de titularidad estatal.

2. Sin perjuicio de lo dispuesto en el párrafo anterior, la Administración del Estado puede establecer convenios con las Comunidades Autónomas para la gestión de Museos de titularidad estatal, que no alterarán su adscripción ministerial. En virtud de lo dispuesto en este artículo y en el Real Decreto 864/1984, de 29 de febrero, sobre el traspaso de funciones y servicios del Estado a la Comunidad Autónoma de Andalucía en materia de Cultura, el Estado transfiere la gestión de los museos de titularidad estatal a la Junta de Andalucía mediante convenio recogido en la Resolución de 27 de mayo de 1994, de la Dirección General de Bienes Culturales, por la que se da publicidad a los Convenios entre el Ministerio de Cultura y Consejería de Cultura y Medio Ambiente, sobre Gestión de Archivos y Museos de titularidad estatal y sobre Gestión de Bibliotecas de titularidad estatal. (BOJA 90 de 16 de junio de 1994). En este convenio se especifica que el Estado mantendrá la 
titularidad que le corresponde sobre los edificios y colecciones, siendo los ingresos de fondos que no sean de titularidad estatal en concepto de depósito. Asimismo detalla todos los procesos de autorizaciones a los que el museo queda sometido por parte del Estado (salida de fondos, restauraciones, etc.). Así, las intervenciones que pretendan hacerse en el edificio deberán ejecutarse por parte del Ministerio o con su consentimiento.

El edificio e instalaciones se recogen en la estipulación cuarta:

\section{Cuarta. Edificios e instalaciones}

4.1 El Estado conserva la titularidad de los edificios e instalaciones de los Archivos y Museos objeto de este Convenio. 4.2 Las inversiones que se realicen en los edificios de los referidos Archivos y Museos, y que no supongan la mera conservación de los mismos serán programadas por el Ministerio de Cultura, por propia iniciativa o a propuesta de la Comunidad
Autónoma y siempre previa consulta con los órganos competentes de esta última.

Dichas inversiones se realizarán con cargo a las partidas que se habiliten al efecto en los Presupuestos Generales del Estado o, subsidiariamente, en los de la Comunidad Autónoma. 4.3 En todo caso, la contratación y ejecución de las mismas se llevará a cabo con arreglo a lo previsto en la legislación de Contrato de Estado.

4.4 Los gastos de mantenimiento y conservación de los edificios e instalaciones de los Archivos y Museos objeto de este Convenio, incluidos los que se deriven de las nuevas inversiones, serán atendidos por la Junta de Andalucía con cargo a sus Presupuestos.

4.5 Los edificios e instalaciones de los Archivos y Museos de ambas Administraciones se dedicarán a funciones archivísticas y museística, así como de difusión cultural siempre que no perjudiquen el normal desarrollo de las anteriores. 
Así se determina que el Estado conservará la titularidad de los edificios y correrá con los gastos de inversión, mientras la Junta de Andalucía asume la gestión del mismo y los gastos de mantenimiento.

\section{III.2. ESTADO DE CONSERVACIÓN DE LA ARQUITECTURA}

Desde la construcción del edificio como Palacio de Bellas Artes de la exposición Iberoamericana, éste ha sufrido numerosas intervenciones; la mayoría de éstas con el fin de ir acondicionándolo a su uso museístico y otras para el mantenimiento del mismo. No obstante, es destacable el escaso mantenimiento que el edificio ha tenido y la falta de estudios sistemáticos del estado de la arquitectura, lo que ha provocado que actualmente el inmueble sufra numerosas patologías, que serán analizadas a continuación, para cuya reparación hará falta una intervención integral muy costosa y que podría obligar al cierre del edificio durante un tiempo. 


\section{III.2.1. INTERVENCIONES REALIZADAS}

La primera intervención importante será a partir de la cesión del edificio por el Ayuntamiento al Ministerio de Educación Nacional para la instalación del Museo en 1941. Tras ésta quedan abiertas las primeras ocho salas del museo en 1946. El proyecto de instalación del museo se debe a la colaboración de $\mathrm{D}$. José María de Navascués, el director del museo D. Juan Lafita y el arquitecto D. Félix Hernández Giménez.

El mismo año de su apertura comienzan las obras de consolidación del edificio y la sustitución de techos y artesonados por bóvedas, así como la colocación de viguetas en el sótano en los lugares donde se colocarían objetos pesados. En 1945 terminan las obras de acondicionamiento y se pasa a la decoración de las salas y la instalación de las piezas.
Con la aparición en 1958 del Tesoro del Carambolo se habilitó el vestíbulo de la entrada posterior del edificio para su presentación, inaugurado en 1968.

En 1962-63 se habían llevado a cabo obras de mantenimiento y reparación de las cubiertas, consolidándose los techos del ala oriental. Las obras continuaron bajo la dirección de D. Aurelio Gómez de Terreros y D. Rafael Manzano, habilitándose todo el ala oriental del edificio y realizando la entreplanta al reducirse la altura de algunos ámbitos, sin perder la luz cenital. Además se construyen en la parte alta dependencias para almacenes, que hoy son salas de exposiciones temporales, todo ello inaugurado en 1970 por el director general de Bellas Artes D. Florentino Pérez Embid.

En 1972 y 1973 continúan las obras con el arquitecto D. José Galnares Sagastizábal. Se elimina las vidrieras de entrada de luz central de algunas salas por problemas de humedades derivados de los atascos en los bajantes como 
consecuencia de las palomas de la Plaza de América, con

lo que se gana en el ala occidental del edificio la entreplanta, a la que se trasladan los espacios de dirección, secretaría, oficinas, salón de actos y biblioteca. Además se habilitan en la planta sótano del ala oeste, diez nuevas salas abiertas al público. Con ellas, el museo alcanza las 27 salas abiertas actualmente, inauguradas el 4 de marzo de 1973 por D. Florentino Pérez Embid, director general de Bellas Artes.

Años más tarde y directamente por la dirección del museo, se habilitan los sótanos para almacenes. Para ello se retiran los escombros amontonados, se iguala y rebaja el terrizo, se construyen arquetas para control de los bajantes, se echa un piso de cemento, se encalan las paredes, se dota de instalación eléctrica y se colocan estanterías metálicas, comenzándose el traslado de piezas desde diferentes zonas del edificio.
Durante 1980 y 1981 se realizan nuevas obras en el edificio, que afectan sobre todo a las cubiertas. Se había intentado en todo momento respetar la luz central que inicialmente había tenido el edificio, pero ésta creaba diversos inconvenientes, como las goteras y la dificultad para controlar la temperatura en las salas, demasiado elevada durante los meses de verano y demasiado bajas durante el invierno. Bajo la dirección del arquitecto D. Manuel Lafarga, se sustituyeron los antiguos lucernarios por una estructura de fábrica. Asimismo, se construyó una entreplanta en la biblioteca que dobló su capacidad, unos talleres de restauración bien iluminados y ventilados, un laboratorio fotográfico y un montacargas que comunicara los talleres y los servicios del museo con los nuevos almacenes.

En 1985 se encarga de nuevo a D. Manuel Lafarga el último proyecto realizado hasta ahora en el museo; se trata de la construcción de la rampa de acceso al edificio para minusválidos, doble y a cada lado de la puerta principal, y 
la renovación de la solería de la terraza delante de la puerta. Asimismo se construyen en el sótano aseos nuevos para el público en el sótano, pues hasta entonces el museo sólo contaba con un pequeño aseo a la entrada del edificio de dimensiones muy reducidas.

\section{III.2.2. ESTADO ACTUAL DE LA ARQUITECTURA PATOLOGÍAS DEL EDIFICIO?.}

\section{A) PATOLOGÍAS GENERALES}

\section{a) Cimentación}

\section{- Composición:}

Sobre el terreno en el que está construido el edificio hay que decir que los estratos en esta zona se componen de arcillas limosas de consistencia blanda en la parte más superficial y gravas arenosas de gran resistencia a continuación. El nivel freático de la zona es de 6,9 metros, como en el resto de la ciudad, pero se ha encontrado agua en un nivel superior a éste, posiblemente por la rotura de alcantarillado, saneamiento, etc. ${ }^{7}$ El estudio de las patologías del edificio ha sido facilitado en gran parte por el realizado
en marzo de 2001 para el proyecto fin de carrera de la Escuela Universitaria de
Arquitectura técnica de Sevilla, coordinado por D. José Antonio Solís Burgos, El museo
arqueológico de Sevilla. Estudio de Rehabilitación y Plan de Evacuación. Agradecemos su colaboración. 
La cimentación del edificio es similar a la de los otros de la zona, como el Museo de Artes y Costumbres Populares, obra del mismo arquitecto. Se trata de zanjas corridas bajo muros de carga. Éstas se componen de argamasa con cal, cantos rocosos y restos cerámicos. La zona perimetral tiene un basamento de granito que recorre todo el perímetro y sobre él se encuentran los muros de carga estructurales de $60 \mathrm{~cm}$. de espesor. En una de las reformas del edificio se bajó la cota interior del sótano para poder utilizarlo como almacenes o salas de exposiciones y en la zona de exposición se realizó una solera de hormigón de $10-15 \mathrm{~cm}$. Alrededor de todo el perímetro se realizó un borde de hormigón de un metro aproximadamente desde la cota 0 del terreno hasta el inicio de la cimentación para evitar que se infiltrases las aguas superiores al nivel freático.

\section{- Lesiones:}

El principal problema del edificio es que la cimentación se apoya en un estrato colapsable y expansivo, lo que produce un asiento desigual en los cimientos provocando la aparición de grietas en la estructura del edificio. Así, aparece una gran fisura que atraviesa al edificio longitudinalmente, que se ve claramente en los almacenes del sótano y que llega hasta la última planta a través del muro de carga pasando por el óvalo.

Se ha llevado a cabo durante unos años un estudio de la evolución de las grietas mediante testigos y se ha llegado a la conclusión de que el edificio no corre peligro y de que la grieta ha parado en su aumento.

La terraza exterior este presenta un asiento en sus esquinas dando lugar al desplome de las pilastras 
extremas, así como la rotura de la balaustrada y la aparición de fisuras.

Los arcos de la fachada tienen fisurada la clave desde el trasdós hasta el intradós, lo que podría deberse a los citados asientos en la cimentación.

\section{b) Estructura}

- Composición:

Se trata de muros de carga de ladrillo cogidos con mortero, forjados con viguetas metálicas y también, en la cubierta de algunas zonas como el óvalo, cerchas de perfiles metálicos.

$\rightarrow$ De los muros de carga:

El cerramiento del edificio se hace con muros de ladrillo macizo sujetos con mortero de cemento. De éstos, hay muros que llegan hasta le entreplanta y sobre los que descansan las terrazas del porche, algunas de las cuales han sido cegadas, y muros que suben hasta las torteas 0 las cubiertas.

En la base de estos muros de ladrillo encontramos un basamento de piedra granítica de sillares de aproximadamente $1 \times 1,5$ metros apoyado en zapatas corridas y escalonadas, que servirían de aislante a la fábrica de ladrillo para evitar humedades por capilaridad. Este basamento se encuentra en algunos puntos exfoliado.

Toda la fachada se encuentra revestida con placas de mortero que figuran ser de piedra, lo que ayuda a dar al exterior del edificio un aspecto renacentista. 
$\rightarrow$ De los forjados:

Se componen básicamente de viguetas de acero laminado, ladrillo macizo sobre las viguetas, doble rosca de ladrillo macizo, mortero de agarre y baldosa cerámica. Se cierra el forjado con bóvedas de una rosca de ladrillo hueco sencillo, formándose una cámara de aire entre la bóveda y el doble tablero de ladrillo macizo. Para rematar el techo interior de las terrazas o porches se coloca un artesonado de madera y yeso pintado. Esta estructura es la que más aparece, siendo la que vemos en planta baja.

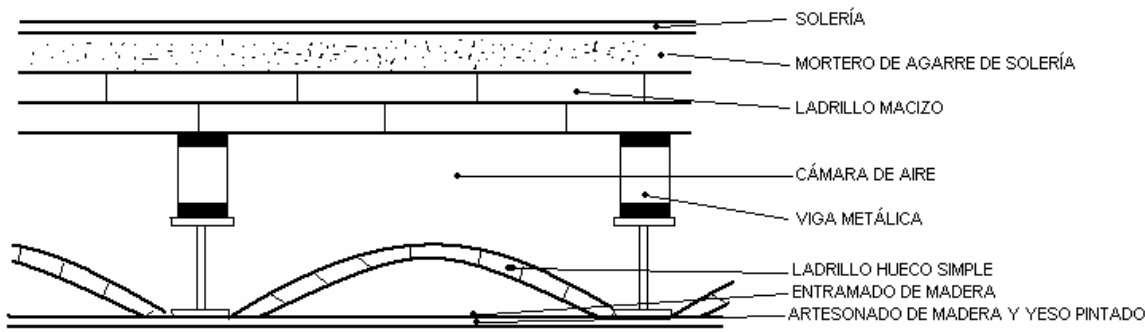

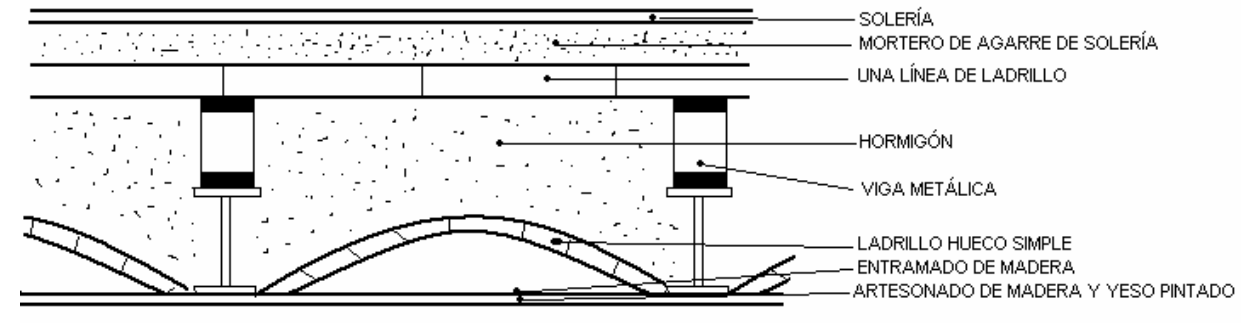

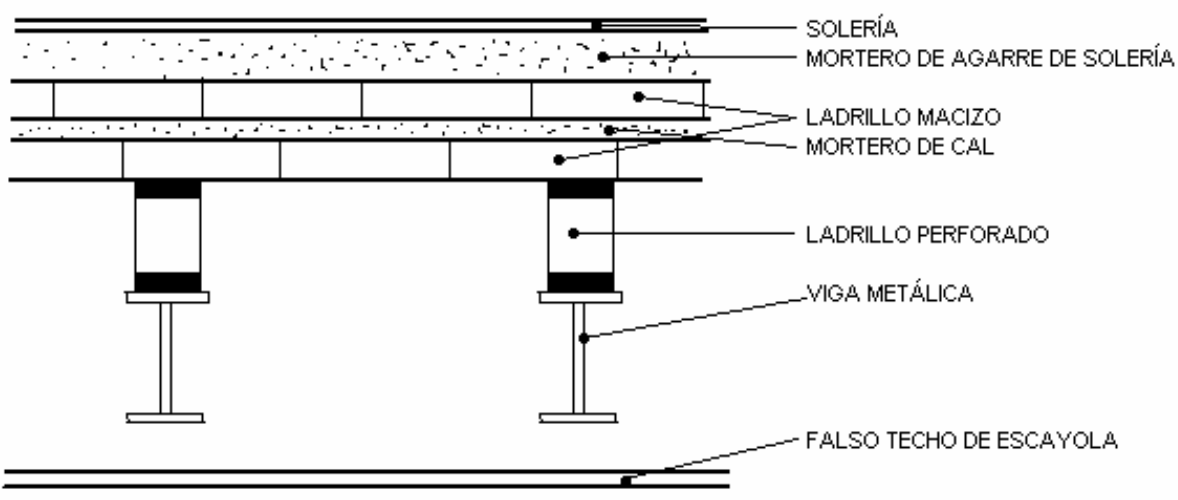


Otra variante que aparece es la de rellenar los senos con hormigón calizo y en vez de llevar un doble tablero de ladrillo macizo es de ladrillo sencillo.

En las zonas interiores, la bóveda de ladrillo hueco sencillo es sustituida por un falso techo.

Desde que en 1919 se terminan las obras del edificio como Pabellón de Bellas Artes hasta la actualidad, ha habido modificaciones en las estructuras del mismo.

Cuando pasa a ser museo se hacen las primeras remodelaciones para solucionar la carga que provocan sobre el forjado de la planta baja algunas piezas de gran tamaño. Para ello se construyen en el sótano, en la parte de almacenes, y debajo de cada escultura de gran formato, unas pilastras de ladrillo que transmiten directamente las cargas al terreno, pilastras que son zunchadas con vigas metálicas.
Además, se construye la entreplanta con sus propios pilares con perfiles metálicos, disponiéndose una nueva cimentación para solucionar las cargas de la nueva estructura.

También en el sótano, en la zona de exposición, se hace un vaciado del muro para dar mayor diafanidad a la sala creando una estructura de perfiles metálicos de pilares y vigas que contará con una cimentación propia.

Se plantean problemas de iluminación en la planta baja, con lo que en la entreplanta se practican en cada sala unos espacios por donde filtrar la luz. Pero estas ventanas por su disposición son difíciles de limpiar y reparar, con lo que habría que contar con una estructura que permita la instalación de andamios para el mantenimiento, pero que siga dejando pasar la luz. 


\section{- Patologías de la estructura:}

Principalmente aparecen fallos de filtración en las cubiertas y fallos en la cimentación, cuya corrección detendría en gran parte en avance de las patologías.

$\rightarrow$ Patologías de los muros:

Aparece en varios lugares una distorsión o diferencia de asientos entre dos puntos, que puede producir la rotura del cimiento.

Se han producido desplomes en los pináculos y las balaustradas de las terrazas laterales, sobre todo de la oeste. Esto se debe principalmente a un hundimiento del terreno de la zona, que también provoca fisuras en las fachadas.

Hay una fisura vertical que parte en dos el edificio en toda su longitud pasando por el óvalo y que está ligada a la cimentación. Aparecen además fisuras menores en diferentes puntos, así como en fachadas, incluso en las claves de algunos arcos. 


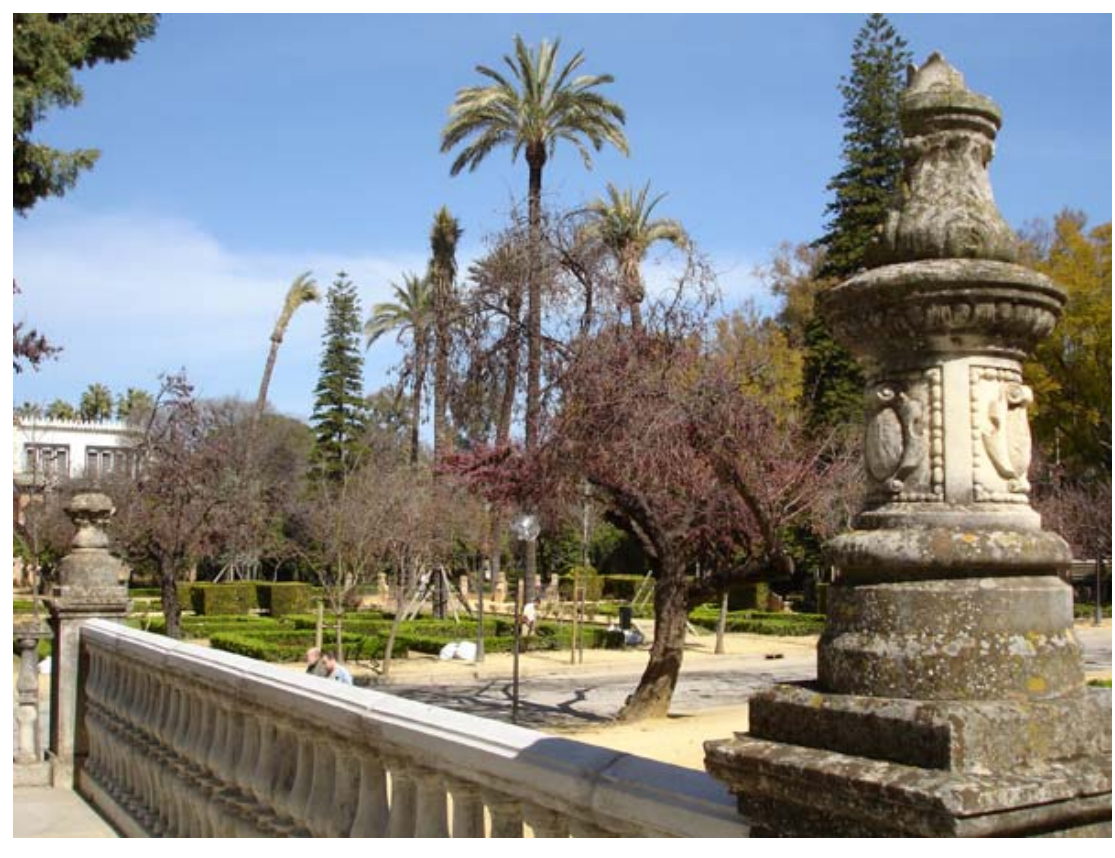

Falta del remate en terraza norte

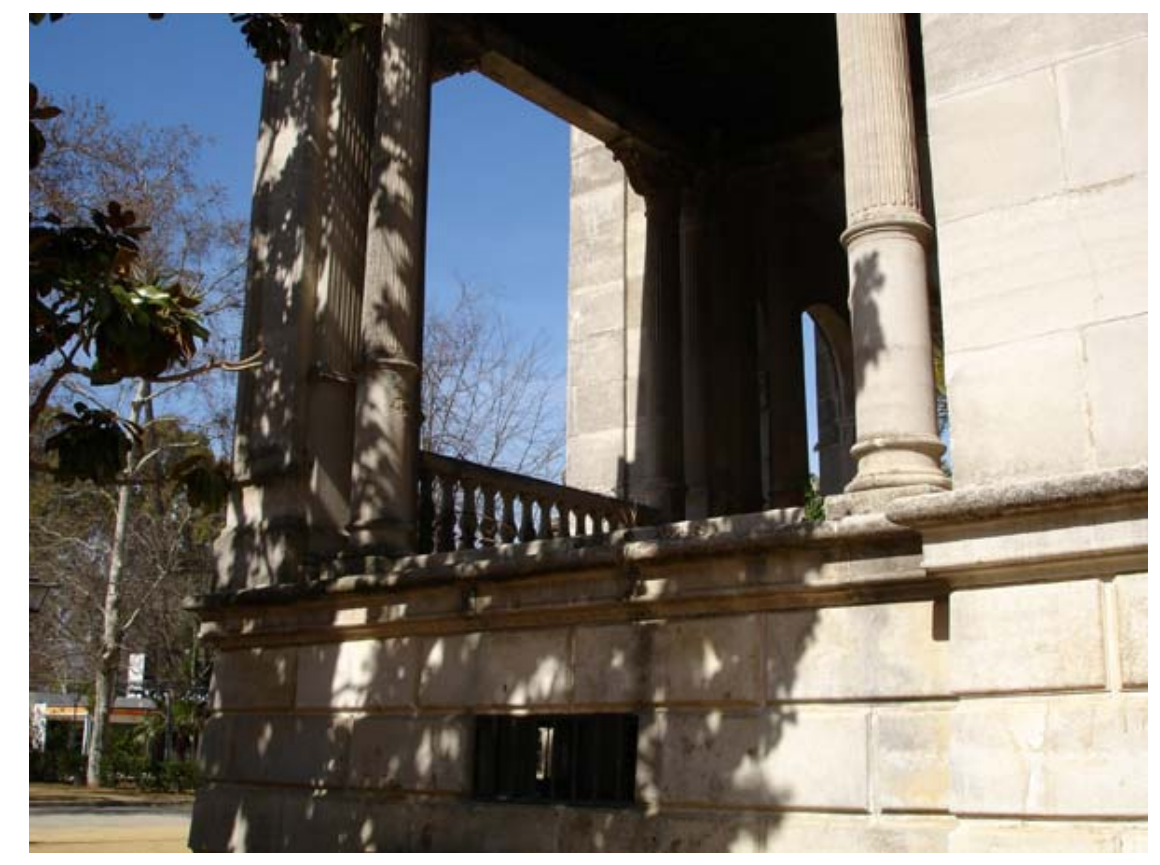

Ausencia de la balaustrada en terraza oeste 

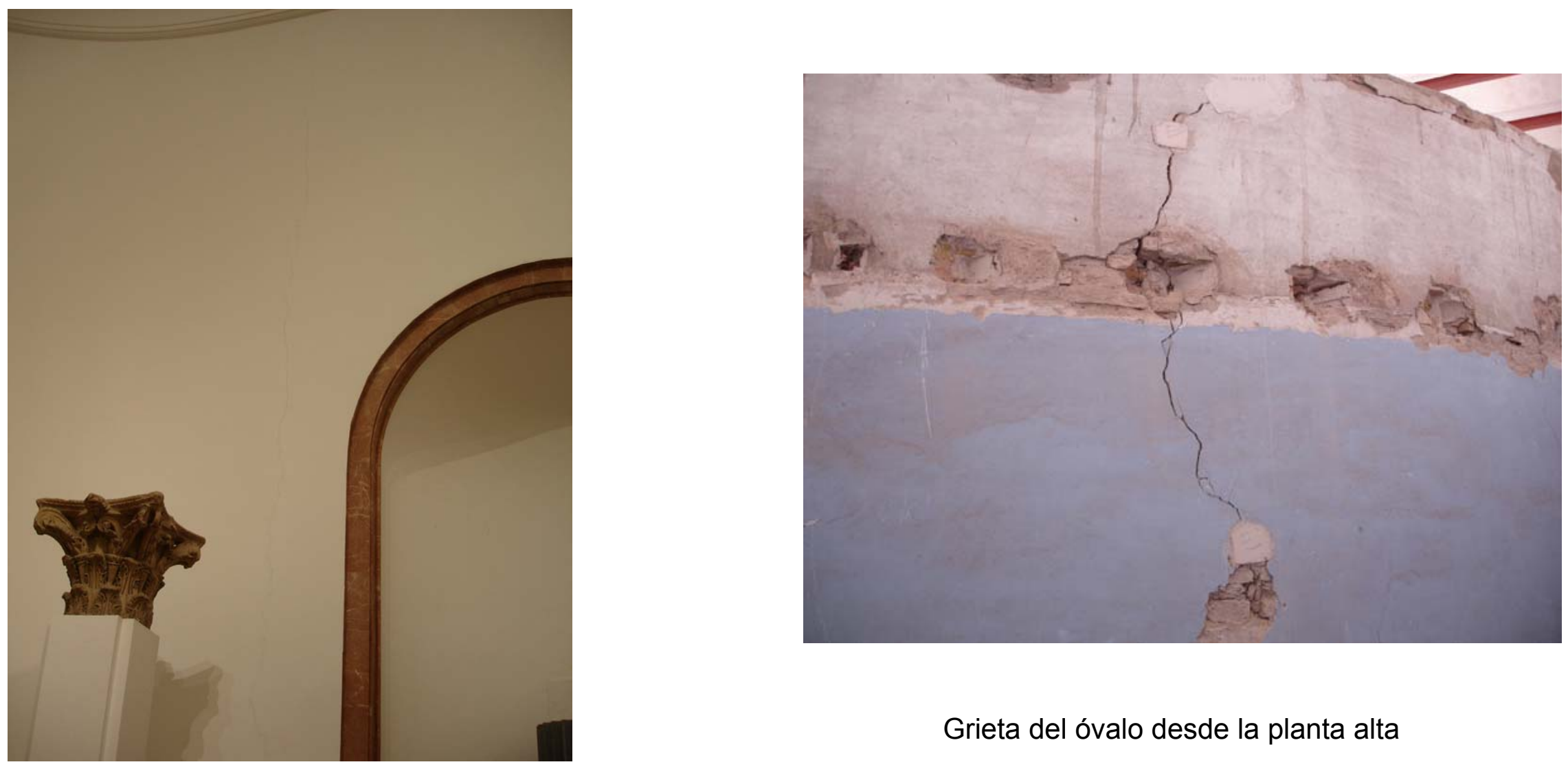

Grieta del óvalo desde la planta alta

Grieta del óvalo desde la sala 
El ladrillo tiene diversas patologías provocadas por el deterioro o alteraciones en el material debido al paso del tiempo. Algunas son de tipo físico como las fisuras provocadas por diversas causas como la expansión y contracción por variaciones de temperatura y humedad o por la congelación, descongelación y evaporación de agua. Otras son de tipo químico como el apagado de la cal de la arcilla, la corrosión de metales en contacto con el ladrillo, los ataques de sulfatos, el ataque alcalino por el cemento, la cristalización de sales que da lugar a eflorescencias, etc.

Por otra parte, se producen patologías propias del sistema constructivo, como desequilibrios y movimientos por la inestabilidad del muro debido en alguna medida a los factores de resistencia de los materiales, lo que provoca deformaciones, fisuraciones y desplomes. $\rightarrow$ Patologías de forjados y cerchas:

Las cubiertas no están suficientemente impermeabilizadas, con lo que se producen filtraciones que oxidan las cerchas y las viguetas de los forjados, además de graves daños en los artesonados de las terrazas.

Algunas cubiertas han sido reparadas, sustituyendo las viguetas, que en algunos casos presentaban un grave estado de corrosión.

\section{c) La acción del agua: humedades}

El agua es el agente más destructor de un edificio, tanto por su acción disgregadora, como porque transporta elementos nocivos (cloruros, sales de cloruros, oxígeno...) a los materiales de construcción, sobre todo si son antiguos.

Se puede presentar en estado líquido, sólido o gaseoso y desde diferentes frentes, como el suelo (capilaridad), las 
cubiertas y fachadas (filtraciones) o desde el interior (rotura de bajantes, saneamiento). El estado líquido es el que más lesiones produce (capilaridad, infiltraciones, eflorescencias...), pero también al solidificarse con la bajada de la temperatura aumenta de volumen y rompe los materiales y al evaporarse al subir la temperatura produce condensaciones.

La humedad provoca el aumento de la permeabilidad, la pérdida y disgregación de los materiales aglutinantes, la pérdida de la capacidad mecánica, la disminución del aislamiento térmico, la aparición de eflorescencias, etc. y además favorece el ataque de microorganismos y hongos.

\section{- Humedades que afectan al edificio:}

Humedad de origen freático: si la cimentación queda dentro de la zona de oscilación del nivel freático, con lluvia intensa las aguas subterráneas naturales aparecen por las partes bajas de los muros, creando manchas de gran extensión que pueden llegar a cubrir todo el paramento.

Humedad del terreno por rotura de la red de abastecimiento o redes sanitarias: si hay una rotura en las proximidades o en el interior del edificio aparecen manchas en algunas zonas del muro, no en su totalidad y suelen tener forma mas o menos circular.

Eflorescencias y critoeflorescencias: todos los materiales tienen sales solubles que se disuelven con el agua, pero cuando ésta se evapora se forman cristales que al calentarse se convierten en polvo en la superficie del material, apareciendo manchas blanquecinas. Las eflorescencias cristalizan en el exterior del material produciendo manchas y las eflorescencias cristalizan en el interior del material produciendo roturas. 
Humedad de capilaridad procedente del terreno: el agua entra por los poros de los materiales de construcción, creándose un zócalo de humedad de altura uniforme.

Humedad provocada por el agua de lluvia: puede producirse la absorción por capilaridad a través de los muros o filtrarse por las grietas o fisuras, lo que provocaría manchas circulares por anillos. También puede afectar la salpicadura constante del agua de lluvia en la parte baja de los paramentos exteriores, ya que pueden penetrar provocando manchas en forma de zócalo.

Humedad de condensación: se suele producir por la condensación del aire húmedo en el interior, normalmente provocado por personas o máquinas, que cuando entra en contacto con una superficie fría (temperatura de rocío) se condensa produciendo manchas de diferentes formas e incluso puede aparecer moho.
Humedad de obra o construcción: originada en el proceso constructivo por el agua contenida en algunos materiales o por la absorción de agua por la estructura en el caso de precipitaciones antes de colocar los cerramientos. Tiene manifestaciones diversas.

\section{- Afección a los diferentes elementos constructivos:}

Cubierta: en diferentes lugares (sobre todo a través de juntas de dilatación, juntas de cubierta, anclajes...) se ha infiltrado el agua creando patologías variadas, dados los diferentes tipos de cubiertas que posee el edificio, pero fundamentalmente goteras y manchas.

Fachada: se ha producido la penetración, infiltración y absorción de agua por los cerramientos del edificio a través de huecos, fisuras y poros, produciendo la entrada de agua y manchas. 
Sótanos: penetra el agua del subsuelo por los muros y la solera del sótano, que es proclive por su situación a la aparición de humedades de todo tipo. Se producen infiltraciones con entrada de agua, eflorescencias de sales, hinchamientos, despegues de revestimientos y hongos.

Soleras: básicamente aparece humedad por capilaridad por falta de impermeabilización y humedades accidentales por fallos en el saneamiento.

Muros: también aparecen humedades de todo tipo.

\section{B) PATOLOGÍAS DE INTERIORES}

\section{a) Instalación eléctrica}

La instalación eléctrica del edificio se ha quedado obsoleta, por un lado por la aparición de equipos nuevos que realizan mejor las funciones necesarias, y por otro por la elevación de los costes de operación debido al mayor consumo y a las frecuentes averías, dado el envejecimiento de la instalación.

El Reglamento electrotécnico para baja tensión (REBT) aprobado por Decreto 2413/1973, de 20 de septiembre, introduce cambios tan importantes que hace inútil cualquier intento de aprovechamiento de las instalaciones anteriores a 1973, que deberán rehabilitarse en su totalidad. Además, este REBT fue derogado por el Real Decreto 842/2002, de 2 de agosto, con lo que habrá que revisar si las 
instalaciones posteriores a 1973 están de acuerdo a este nuevo reglamento.

Las instalaciones posteriores a 1973 pero que tengan una antigüedad de más de 10-15 años también deberían ser renovadas en su totalidad aunque sean reglamentarias, ya que el envejecimiento y obsolescencia de materiales y equipos las incapacita para desarrollar sus funciones. Aquellas que tengan menos de 10-15 años podrán aprovecharse dependiendo de su estado.

Hay que tener en cuenta que en este edificio el mantenimiento de la instalación eléctrica ha sido mínimo, por lo que es imprescindible la inspección de todos los elementos de la instalación, desde la recopilación de la documentación eléctrica existente, pasando por la revisión ocular de equipos y materiales hasta la medición de las magnitudes eléctricas que reglamentariamente deban mantener determinados valores de seguridad.

Así, deberán analizarse:
- los cuadros eléctricos

- los paramentos eléctricos

- la instalación de puesta a tierra

- los mecanismos eléctricos

\section{b) Instalaciones de fontanería y saneamiento}

Es este uno de los elementos que más sufre en el edificio, pues suelen producirse roturas o fisuras que requieren un mantenimiento continuado. Además, si el edificio es de nueva construcción los materiales serán homogéneos, pero si el edificio es antiguo como el caso que nos ocupa, habrá gran cantidad de materiales que se habrán envejecido, oxidado, fisurado, etc. y a los que se les habrá dado diferentes soluciones.

\section{- Composición:}

El saneamiento del edificio está resuelto con bajantes de fundición, fibrocemento y P.V.C. que recogen las aguas 
hacia el interior, tanto las de lluvia desde las cubiertas como las de las diferentes fuentes de agua del edificio.

\section{- Patologías:}

Lo más destacable es que no se sabe hacia dónde discurren las aguas cuando han salido del edificio, pues la salida a la red de alcantarillado del parque no se sabe donde está, y esto puede producir que haya una rotura en la conexión y se esté filtrando agua al terreno.

Por otro lado, se produce la entrada en la red de saneamiento de aves muertas, plumas, hojas, etc. ya que las cazoletas no tiene rejillas, con lo que se producen atascos y desagües lentos. Hay además bajantes de fundición en los que se producen pérdidas debido a la corrosión que presentan, por lo que algunos se han sustituido por P.V.C. También pueden producirse roturas porque algunos bajantes están sujetos a las paredes de manera rígida, lo que no permite el movimiento que se produce por la caída del agua.

\section{C) PATOLOGÍAS DE EXTERIORES}

\section{a) Fachadas}

\section{- Cerrajería}

El edificio cuenta con elementos de hierro en la cancela de acceso a la puerta principal y en las rejas de las ventanas de los módulos centrales de los alzados principal y posterior, siendo éstas las que han sufrido una mayor oxidación, llegando incluso al desprendimiento de algunos elementos.

La conservación de la cerrajería es importante, ya que su oxidación y corrosión por la acción del agua y el viento puede afectar a otros materiales a los que suele anclarse. Por tanto, habrá que hacer un estudio profundo del estado en el que se encuentra, del tipo de corrosión que sufre y establecer un diagnóstico. 


\section{- Carpintería}

En el edificio encontramos un tipo de ventanas altas y estrechas que dan luz diurna al interior.

Debemos diferenciar entre la carpintería de madera y la carpintería metálica. Dentro de la carpintería de madera, la del interior del edificio no presenta patologías importantes, pero sí la del exterior, donde además, el sistema abatible de las ventanas hace que se produzcan infiltraciones de agua y tiene poca resistencia al viento. La carpintería metálica solo la vemos en el exterior y el problema principal es causa de su situación ante las inclemencias del tiempo.

La carpintería de madera del exterior está en su mayoría expuesta a riesgos de humedad y de oscilaciones de la misma, lo que puede llevar al ataque de xilófagos, hongos, termitas y a pudriciones. Además, los cambios de temperatura provocan la dilatación y contracción de la madera, lo que origina fendas en la misma, que además de lo que supone de rotura del material, también facilita el ataque de hongos e insectos. En las puertas de acceso al edificio por las terraza de la fachada principal en planta baja se observa la rotura y desencuadre de las puertas de acceso.

La carpintería metálica fija se ve afectada por infiltraciones de agua en la junta de unión de la ventana con el paramento, lo que provoca la corrosión del acero. La carpintería metálica abatible es en esencia una construcción desacertada, pues el alfeizar de la ventana tiene pendiente hacia el interior, con lo que, aunque se encuentre en la parte interior, cualquier infiltración o entrada de agua se deslizará rápidamente hacia el interior.

Habrá que hacer un estudio detallado de la carpintería para determinar los tratamientos más adecuado. 


\section{- Artesonados:}

En este apartado analizaremos las patologías de la madera de los elementos constructivos del techo, es decir, de la carpintería de armar o decorativa. Como carpintería de armar solo encontramos el artesonado situado en el porche de acceso al museo. Los demás son falsos techos decorativos de madera, que se encuentran repartidos por salas y terrazas; no obstante, algunos de los existentes en el antiguo pabellón de Bellas Artes han sido eliminados. Todos los artesonados son de madera de pino según la información proporcionada. Aunque más que artesonados, como ya hemos aclarado anteriormente, lo que predomina en el edificio son revestidos de madera en el techo, nombraremos como artesonado todas las superficies de madera que cubren los techos, ya que de todas formas, las patologías son las mismas, las de la madera.

La madera es un material vivo y vulnerable, que se ve afectado tanto por agentes externos como por aquellos intrínsecos como fendas, abolladuras, nudos... Además, la madera reaccionará si el diseño no está bien hecho o si el tratamiento recibido no es el adecuado, por lo que habrá que tener en cuenta la especie de madera elegida, el tratamiento de protección que ha recibido, los factores de construcción de la propia obra, etc.

Uno de los agentes destructores de la madera más habituales son los insectos xilófagos, que en este edificio no se han encontrado en los artesonados, aunque por la situación de estos y por su policromía han podido pasar inadvertidos. Como elementos de referencia se han observado elementos de madera cercanos como bancos y puertas y tampoco se ha detectado la presencia de estos insectos.

Otro agente que sí aparece en todos los artesonados son los hongos. Aparece la patología conocida como madera pasmada, que en su estado inicial presenta un color pardorojizo que se va extendiendo y cuando se encuentra 
avanzada se observan unas vetas negras que son los límites de la zona de vegetación de los hongos. También se observa la presencia de hongos en la aparición de masas blancuzcas algodonadas con una exudación que cae en gotas. Habrá que estudiar profundamente el estado del artesonado, pues los hongos tienen una gran potencia destructora.

Observamos también pérdidas de materia debidas a un mal montaje, separación de fibras, desprendimientos, alabeos de los elementos debidos a esfuerzos, etc.

Las patologías detectadas en los artesonados se basan en una inspección ocular, por lo que para reafirmarlas habrá que realizar análisis microbiológicos en cada artesonado.

Antes de pasar a la eliminación de estos agentes, la primera medida y la más importante es la corrección de los defectos destructivos que han favorecido su proliferación.
Posteriormente se saneará la madera y se aplicará el tratamiento adecuado.

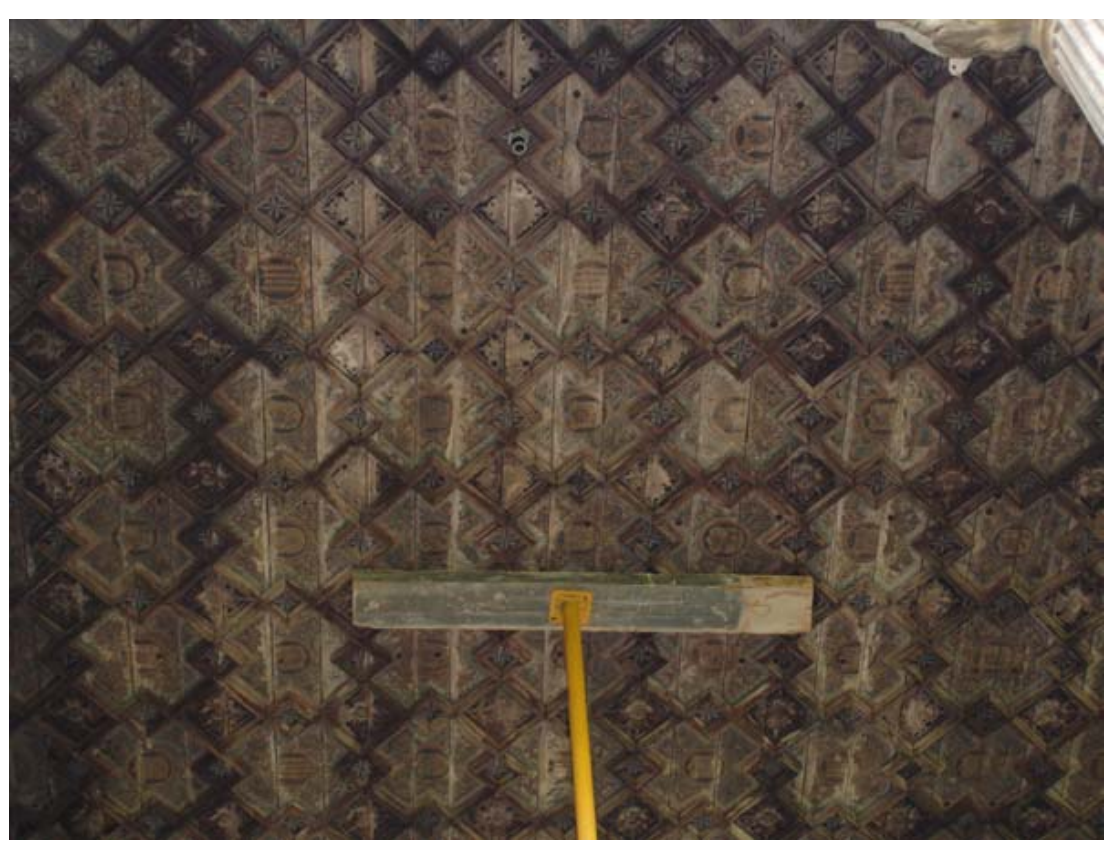

Detalle de los daños en los artesonados de las terrazas 


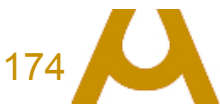

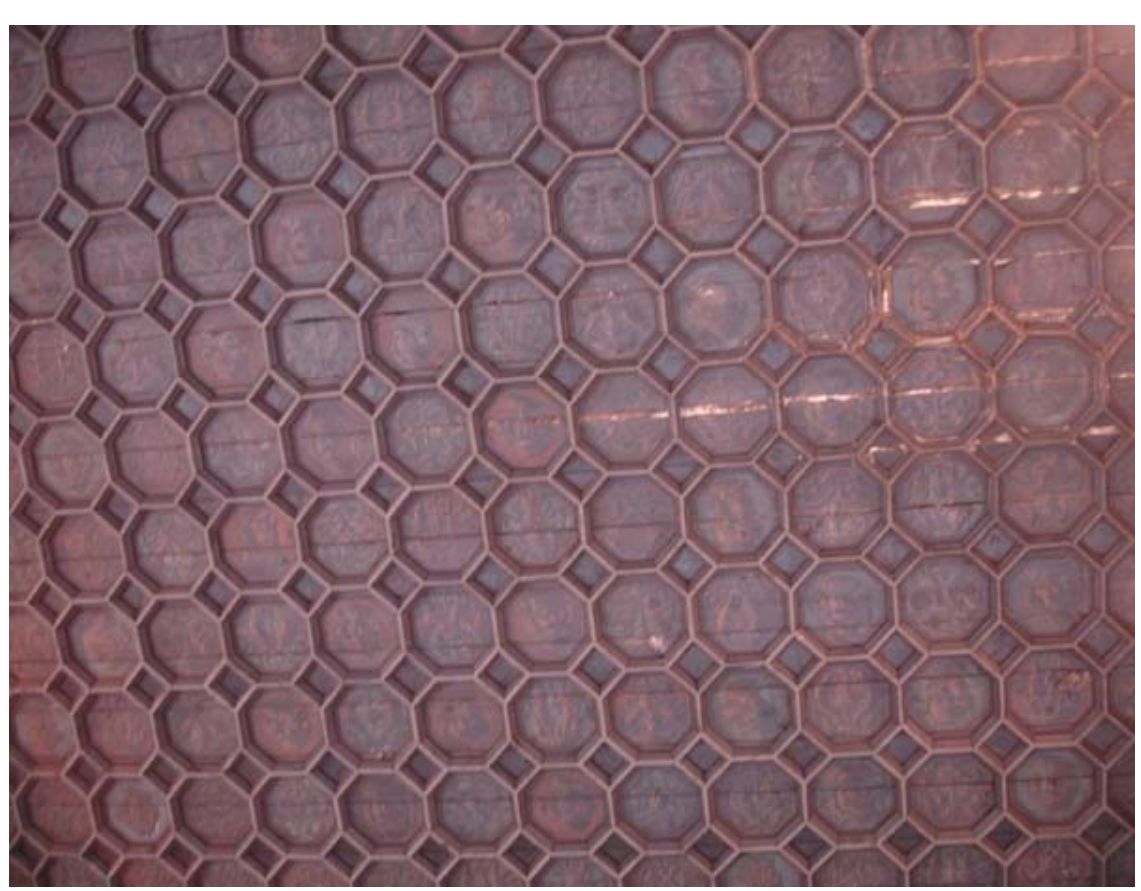

Artesonado de una de las terrazas laterales

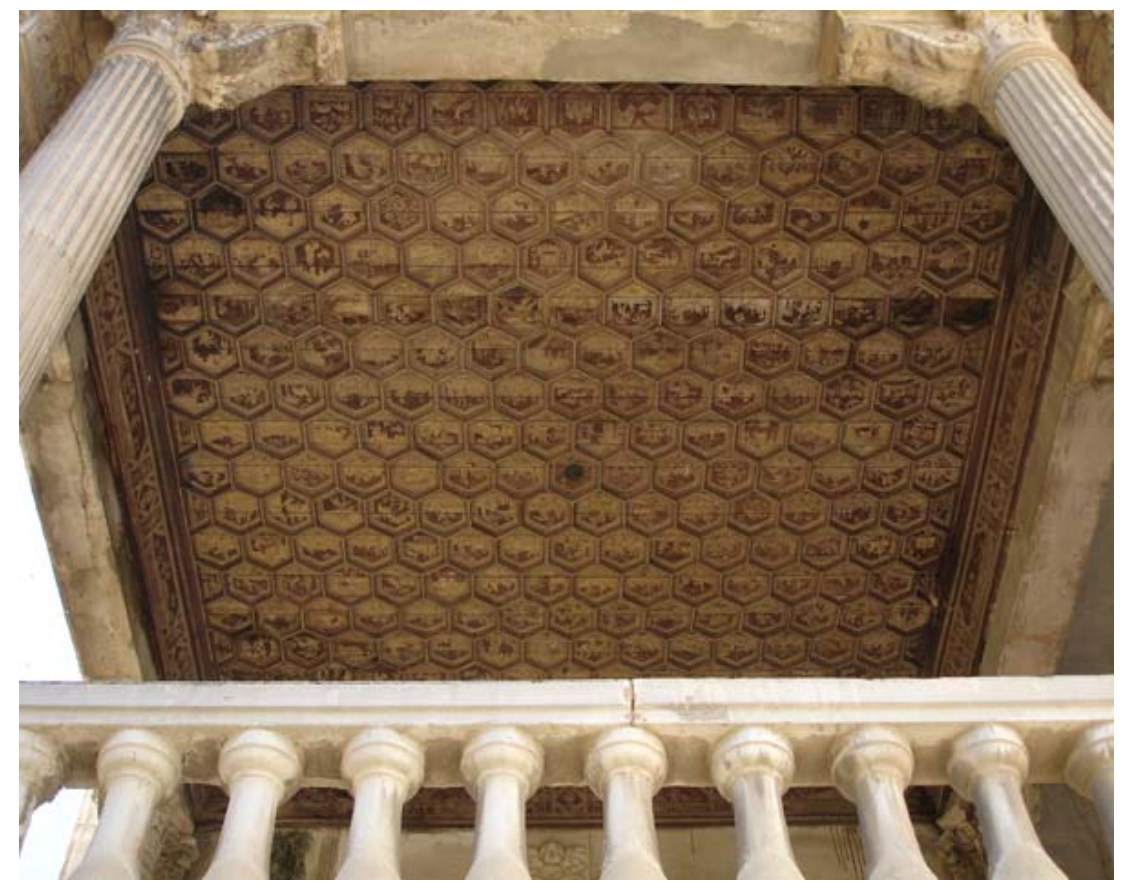

Artesonado de una de las terrazas 


\section{- Hormigón arquitectónico}

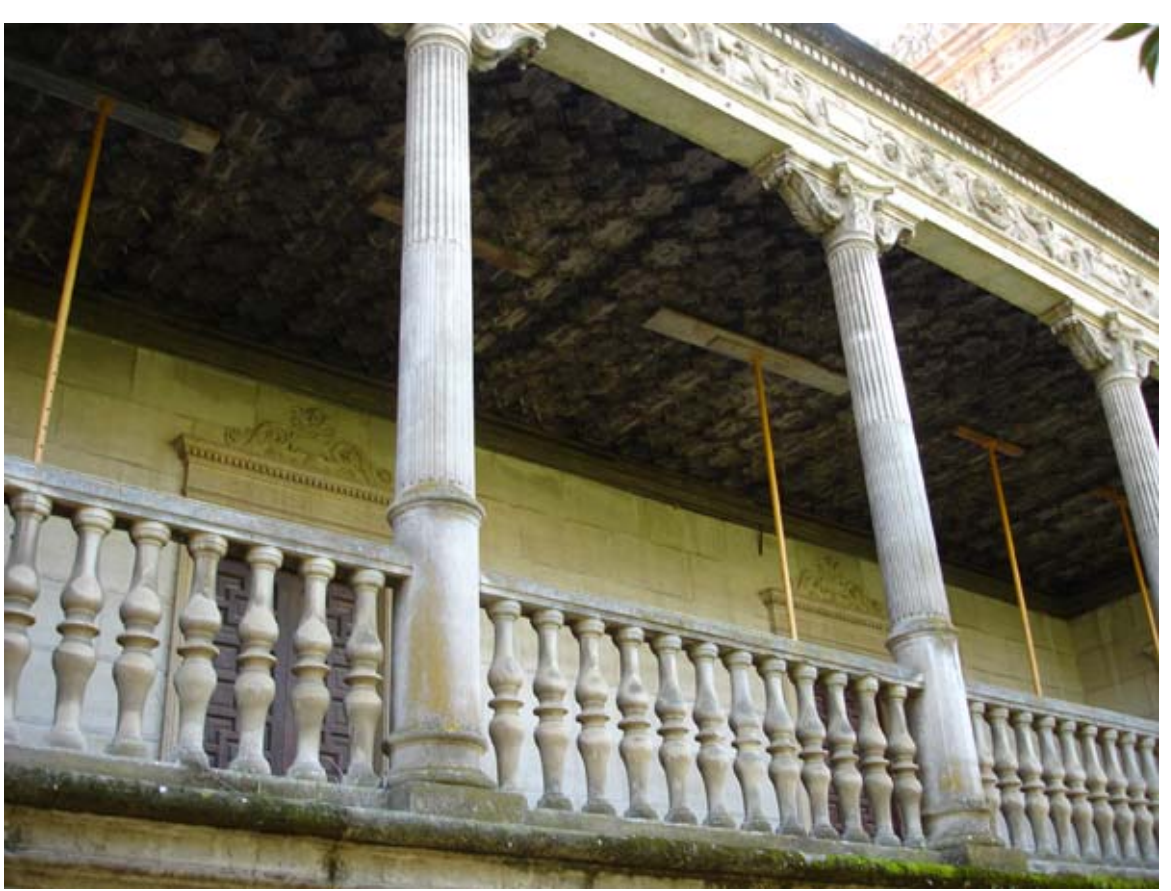

Terraza apuntalada por peligro de desprendimientos en el artesonado
Hasta finales del siglo XIX se emplearon para la confección de morteros las cales calcáreas y algo las cales hidráulicas, así como, en determinados casos, el yeso y la tierra arcillosa. Desde 1898 el cemento Pórtland y otros cementos han sustituido a las cales, que hoy se emplean muy poco como conglomerante.

En el caso que nos ocupa, se usa el mortero de cemento no sólo para la unión de la fábrica sino también como revestimiento y ornamentación. Todo el edificio se encuentra revestido con placas de hormigón arquitectónico de aproximadamente $97 \times 57 \mathrm{~cm}$. Además se disponen motivos decorativos (escudos, leones, bustos...) y una crestería de remate en todo el perímetro. 
- Fenómenos físicos:

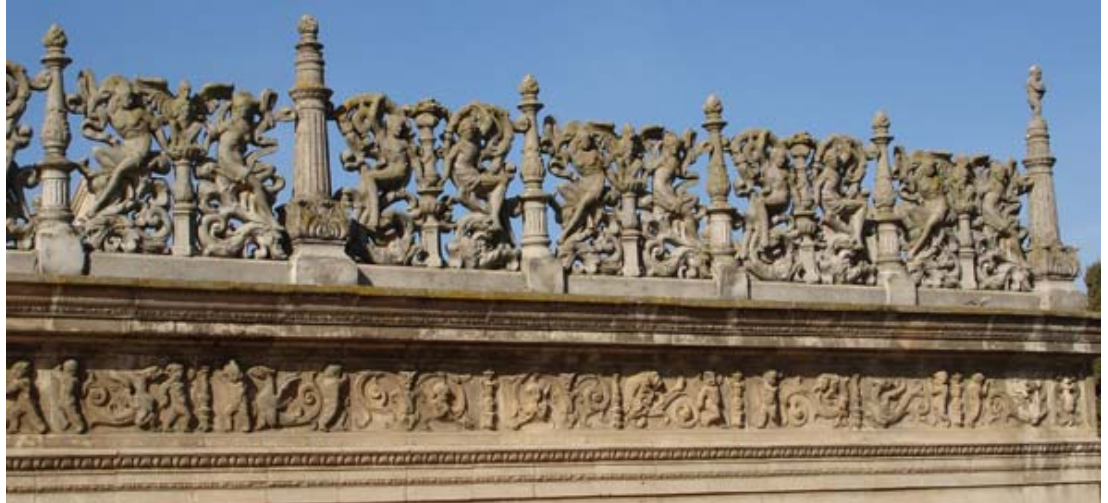

El hormigón en todo el edificio se encuentra muy dañado debido, por un lado, a la mala dosificación y un inadecuado armado en la construcción y por otro, a la desprotección frente a los agentes atmosféricos que con el paso del tiempo acaban por envejecer el material.

Patologías del hormigón arquitectónico:

Las principales patologías de la fachada según el agente causante de las mismas son:
○

\section{Cambios}

de

temperatura.

Provocan

variaciones de tensión entre la superficie y el interior, produciéndose fisuras en la superficie. Las heladas provocan contracciones y dilataciones del material y facilitan la entrada de sales y ácidos que provocan reacciones químicas.

O

$$
\text { Viento y lluvia. }
$$

Tienen acción abrasiva sobre los paramentos.

La armadura interna de la crestería en contacto con la humedad y la lluvia se ha oxidado provocando el desprendimiento de mortero. Esto genera una cadena que hace que los daños en la crestería no dejen de avanzar, ya que una pequeña fisura provoca la entrada de agua y la consiguiente oxidación de la armadura interna, que se 
desprende del mortero provocando que la fisura se abra más.

○

Asientos estructurales. Producen fisuras que facilitan la entrada de otros agentes agresores. Los movimientos que se producen en la base suelen afectar sobre todo a las juntas, que son las zonas más débiles.

- Desagües defectuosos, filtraciones de agua en juntas de bajantes, etc. Provocan manchas de humedades en las fachadas.

- Superficies con inadecuada evacuación de aguas, como ocurre en varios puntos de las cubiertas.

- Uniones metálicas poco protegidas, que provocan manchas de oxidación en el revestimiento.

- $\quad$ Fenómenos químicos:
Ácido carbónico y sales como el carbonato cálcico, que llegan a las fachadas a través del agua de la lluvia, provocando eflorescencias blanquecinas.

Ácido sulfúrico proveniente de la
contaminación ambiental, que es el mayor agente
destructor.

- $\quad$ Fenómenos biológicos:

- Sustancias orgánicas que al descomponerse provocan reacciones químicas que perjudican al mortero. Por ejemplo la suciedad de las palomas (guano), que debe eliminarse con anterioridad a la limpieza general de los paramentos.

Así, se hace necesaria la intervención para la reparación de este material. 


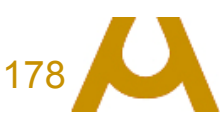

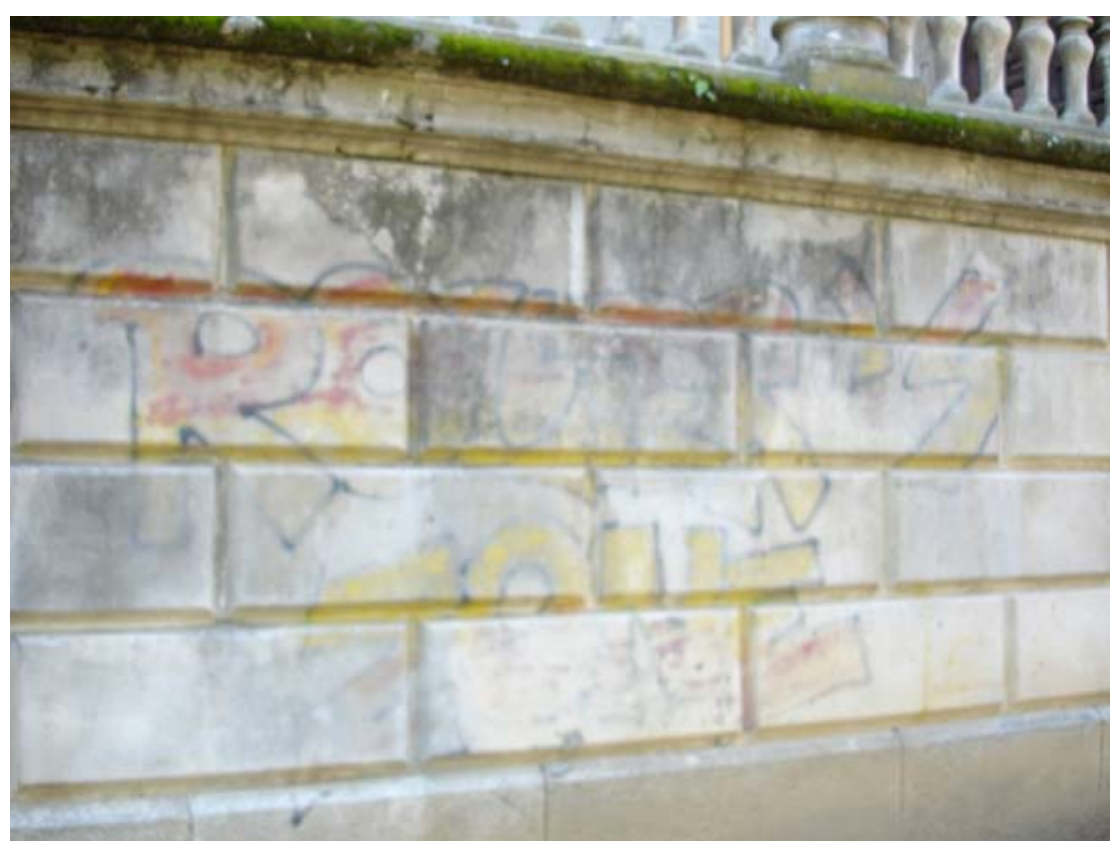

Suciedad de diferentes tipos en fachada

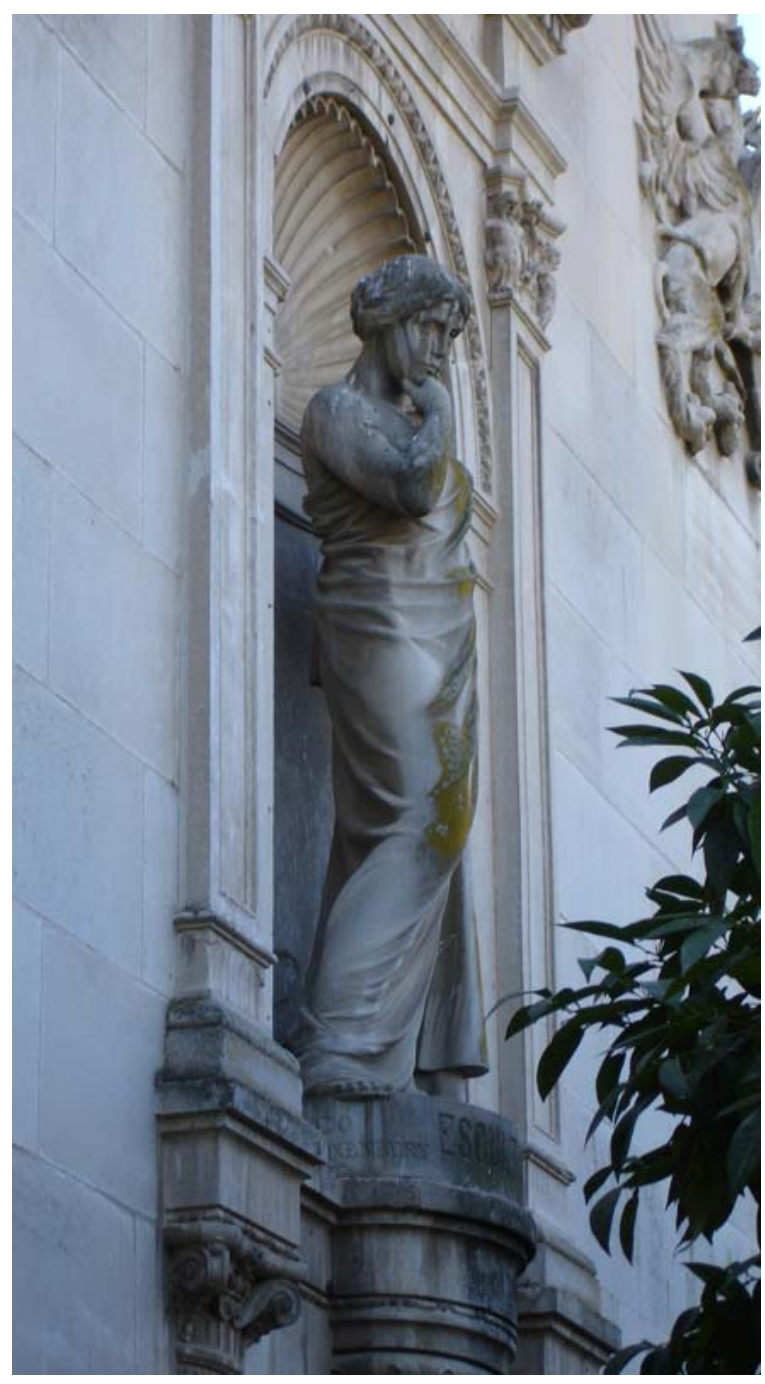




\section{- Estudio biológico:}

Los materiales inorgánicos también pueden sufrir biodeterioro. Son colonizados fundamentalmente por organismos autótrofos, aunque también puedan aparecer heterótrofos. Además, los materiales inorgánicos pueden tener sustancias organizas más sensibles al ataque biológico. Es importante tener en cuenta los factores ambientales, pues un material que generalmente no sufra ataques puede ser colonizado en condiciones extremas. Los estucos, morteros, revoques, frescos y productos cerámicos utilizados en arquitectura son generalmente atacados por los mismos organismos que la piedra. Normalmente presentan una porosidad más elevada que puede favorecer la aparición de microflora por retener más agua.

Destacaremos los principales agentes dañinos:
Bacterias y actinomicetos. Atacan a la piedra con métodos químicos provocando alteraciones como una costra negra, pulverización o exfoliación.

- Hongos. Aparecen con humedad y temperatura elevadas $\mathrm{y}$, aunque no suelen aparecer en la piedra, los residuos orgánicos que la piedra puede tener permiten su crecimiento. Producen ácidos orgánicos disolviendo piedras calcáreas, minerales silicáticos, minerales con hierro y magnesio y fosfatos.

- Cianobacterias y algas. En la piedra puede haber algunas microscópicas. Condicionan su aparición la intensidad luminosa, la humedad, la temperatura y el ph. Deterioran los materiales pétreos a través de sus procesos respiratorios, reteniendo agua y liberando ácidos.

- $\quad$ Líquenes. Sobreviven en diferentes concentraciones de agua. Ejercen una presión física mediante 
contracciones y expansiones produciendo fragmentación del sustrato.

- Plantas, musgos. Crecen en las cornisas donde se acumulan restos orgánicos si hay condiciones favorables, es decir, suficiente agua, adecuada iluminación y buena porosidad que favorezca la retención de agua y la penetración de las raíces. Dan problemas químicos y mecánicos. Por un lado, las raíces ejercen presión. Éstas tienden a crecer en zonas de menor resistencia como el mortero, pero también en zonas más compactas cuando ha disminuido su cohesión por otros factores como el hielo o la lluvia. Por otro lado, producen ácido carbónico por los procesos respiratorios y varían los parámetros microclimáticos aumentando la humedad por estancamiento de agua.

- $\quad$ Animales. El mayor problema de este edificio son las palomas cuyos excrementos contienen ácidos que reaccionan con la piedra produciendo efectos corrosivos y creando problemas de naturaleza estética e higiénica.
El 26 de enero de 2001 se recogieron muestras para su análisis $^{8}$ y dieron como resultado la existencia de cianobacterias, líquenes, musgo y plantas. Sería conveniente realizar un nuevo estudio detallado para determinar en qué medida los elementos anteriormente analizados están afectando a las fachadas del edificio con el fin de encontrar los métodos más adecuados de limpieza y prevención.

\footnotetext{
${ }^{8}$ Muestras tomadas con motivo de la elaboración del proyecto de fin de carrera ya citado.
} 


\section{b) Cubiertas}

El edificio presenta distintas alturas distribuidas simétricamente a partir del eje transversal situado en la dirección norte-sur del edificio. Presenta azoteas no transitables y algunos huecos con material traslúcido para permitir le entrada de luz natural.

\section{Componentes de las cubiertas:}

\section{- $\quad$ Base estructural.}

En los módulos de menor altura y en los porches está formada por planos completos (forjados) sin pendiente, horizontales, separados entre sí $73 \mathrm{~cm}$. y entre dicha viguería bovedillas rebajadas formadas con rosca de ladrillo hueco sencillo.

En otros cuatro módulos laterales de mayor altura, la base se conforma con cerchas metálicas sin inclinación.

En el módulo central encontramos como base la formación de cerchas metálicas dispuestas de tal forma que permiten la conformación de cubiertas a dos aguas mediante pares y tirante.
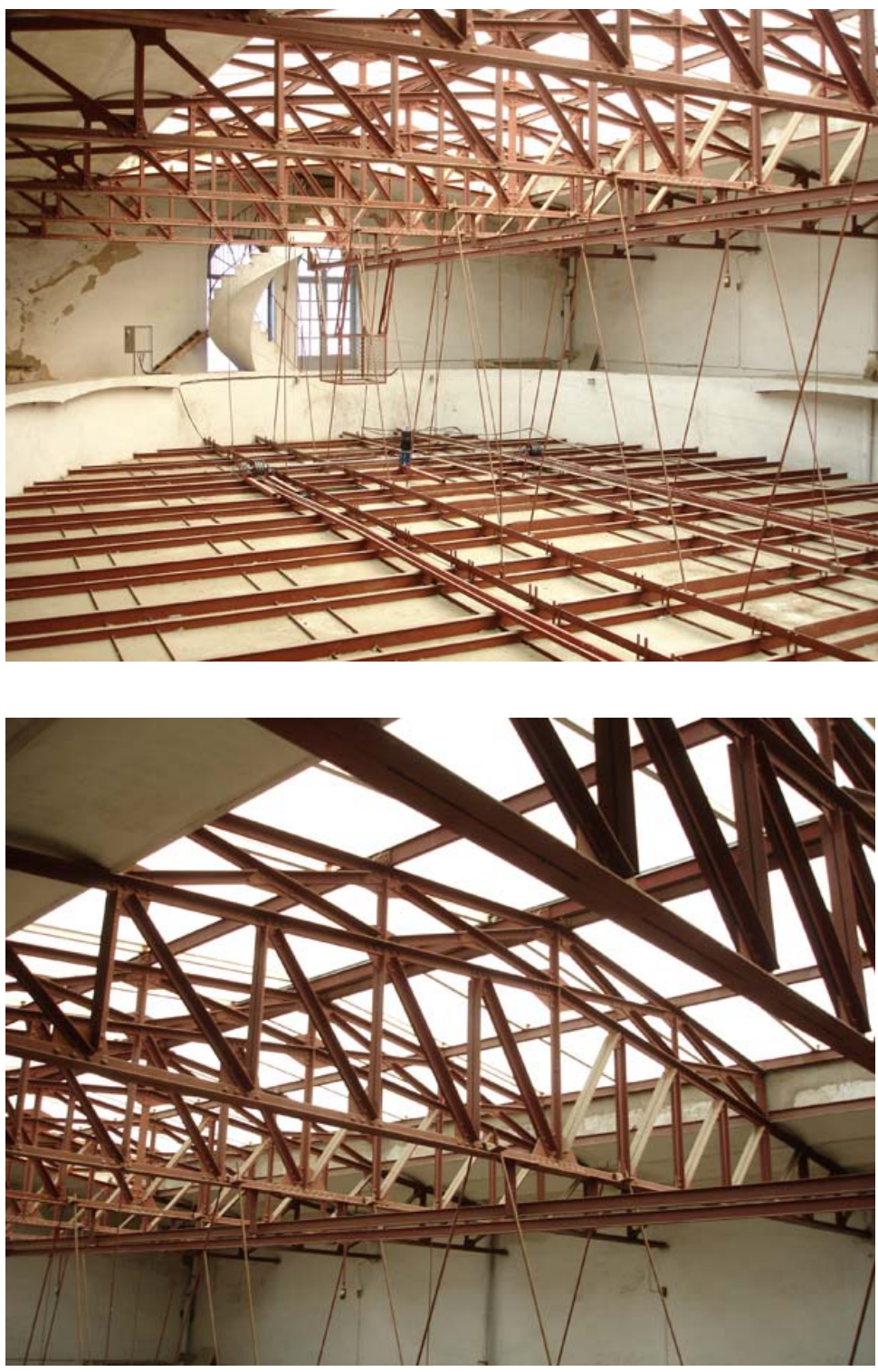

Estructura de la cubierta del óvalo (módulo central) 
- Soporte de la cobertura.

Para la base estructural sin inclinación el soporte lo constituyen planos continuos formados por una doble rosca de ladrillo macizo. Estos planos están separados de la base estructural mediante tabicas interpuestas de ladrillo macizo sobre la viguería, lográndose de esta manera la pendiente necesaria y la cámara ventilada que tienen estas cubiertas. Así, la solución constructiva se realizó mediante dos hojas.

Para el caso de la base de cerchas metálicas el soporte de la cobertura presenta igualmente una doble rosca de ladrillo macizo recibida con mortero de agarre, formando un sólido con el conjunto de la viguería, rellenando las hoquedades formadas por la curvatura de la tabiquería abovedada entrevigas. Así, no hay cámara ventilada y la formación de pendiente la proporciona la ligera inclinación de los tirantes de la cercha metálica.
ESQUEMA DE LA CUBIERTA

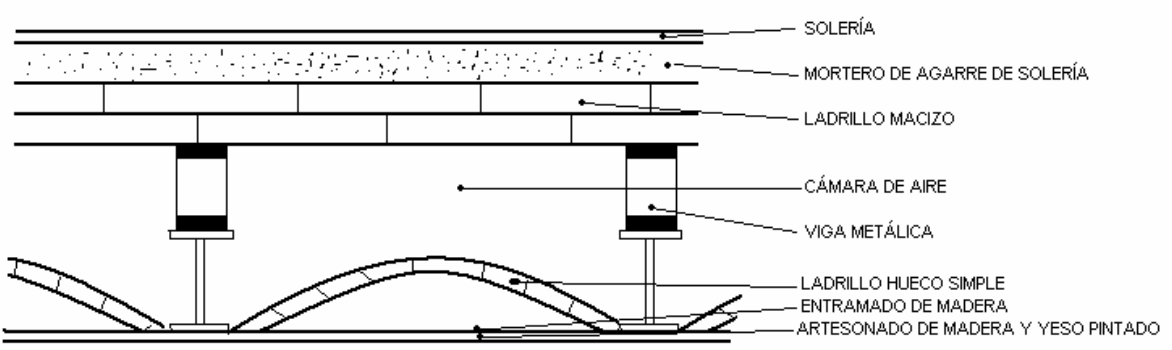

- La cobertura.

Se constituye de un plano continuo cerámico de $14 \times 28 \mathrm{~cm}$ adherido al soporte mediante mortero de agarre.

El módulo central del edificio, donde se sitúa el óvalo, tiene una combinación de azotea y cubierta a dos aguas que se levanta a partir de la solería compuesta en principio por perfilería metálica y planchas de vidrio. Posteriormente, en algunas cubiertas, dicha estructura fue retirada por problemas de filtraciones debido a la oxidación de la 
perfilería y a la falta de estanqueidad, sustituyéndose por perfilería de aluminio y planchas de policarbonato que siguen permitiendo la entrada de luz y proporcionan una perfecta estanqueidad. Esta solución se adoptó en las cuatro salas que se sitúan simétricamente dos a dos a ambos lados del ovalo, alternadas con módulos de mayor altura posibilitando una iluminación natural indirecta.

El acceso a las cubiertas se realiza a través de puertas metálicas de reducidas dimensiones $(50 \times 100 \mathrm{~cm})$ y en las techumbres más elevadas a través de una escalera empotrada en el paramento interior del módulo que da paso a la cubierta por una trampilla. Actualmente por seguridad dicho acceso no se utiliza y se accede desde la cubierta anexa inferior con escaleras portátiles.

Escalera y puerta de acceso a cubiertas desde la planta alta (almacén de antropología)

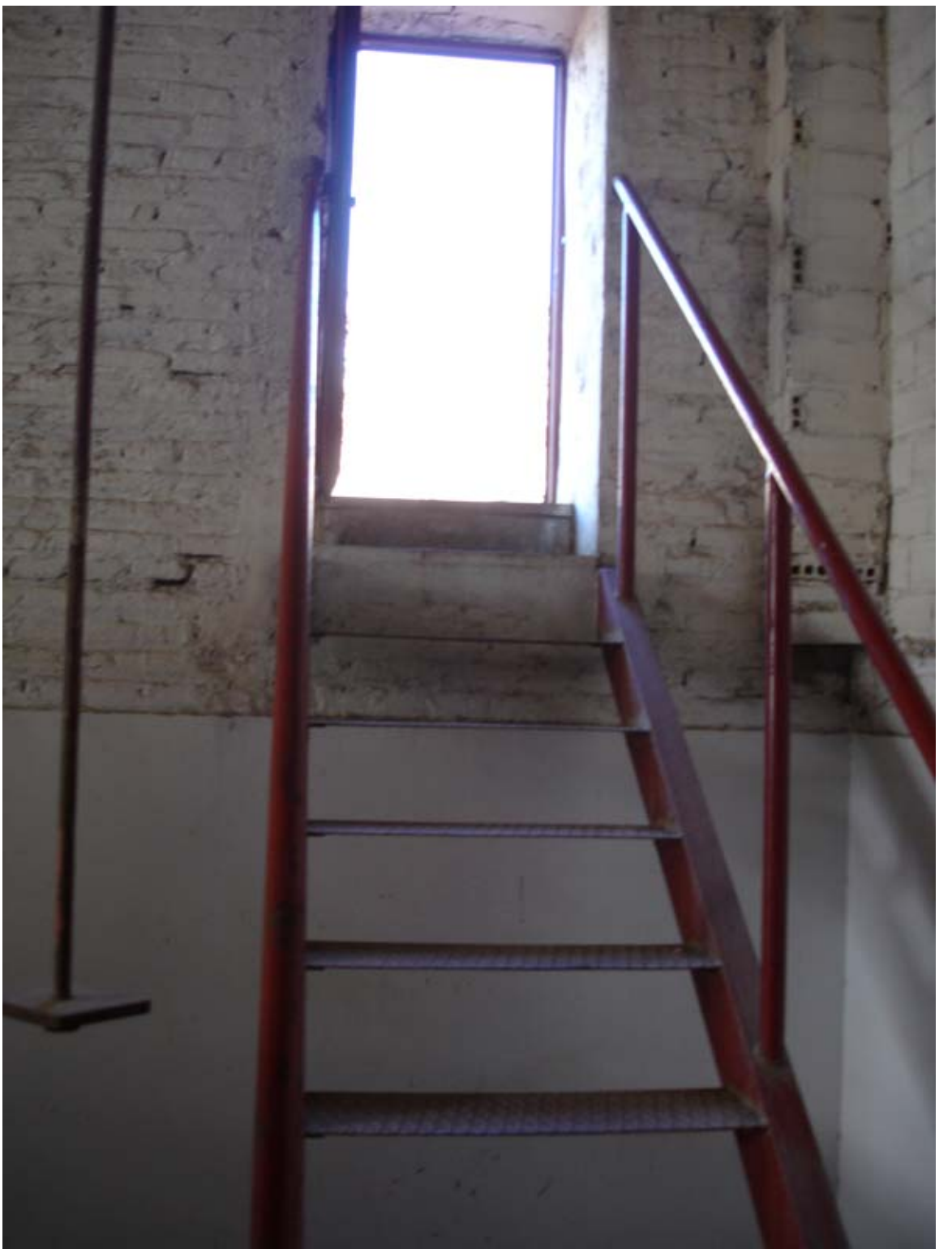


Las patologías más relevantes de las cubiertas y sus causas son:

- Las variaciones de temperatura noche-día, veranoinvierno producen movimientos que rompen los paños y provocan empujes laterales sobre los bordes. Esto combinado con el agua de lluvia produce alteraciones en los elementos metálicos.

- En aquellas cubiertas de policarbonato, al sustituirlas por las anteriores de vidrio se elevó el plano de la cobertura con un nuevo solado cerámico como material de agarre que dio lugar a un canal mal resuelto por el que entra agua debajo del nuevo solado de la cubierta, creándose una zona de humedades. Todos los planos de cobertura cerámicos fueron impermeabilizados posteriormente mediante una armadura de velos de poliéster y pintura de imprimación superficial.

- $\quad$ El daño más grave es el deterioro progresivo de la base estructural de la cubierta con la corrosión de las viguetas metálicas que merma sus propiedades mecánicas.

- La presencia masiva de palomas que provocan frecuentes taponamientos de los bajantes por la acumulación de plumas y palomas muertas ha hecho que se produzcan a veces retenciones de agua en las cubiertas transmitiendo humedades a los paramentos. Además, la nueva impermeabilización ya comentada no permite la limpieza de las cubiertas para retirar los restos de palomas y excrementos, ya que exige una fricción agresiva que podría dañar las láminas de poliéster. Por eso se dispuso una red de tuberías flexibles a lo largo de toda la cubierta para retirar la suciedad mediante riego a presión, produciendo la masiva filtración de agua en el interior del edificio.

Atendiendo a la normativa vigente de obligado cumplimiento, las cubiertas de los edificios deben cumplir las siguientes condiciones: 
- $\quad$ Ser estanca, es decir, proporcionar impermeabilidad al edificio.

- Poseer un cierto grado de aislamiento térmico (Norma Básica NBC-CT-79. Condiciones térmicas en los edificios).

- Disponer de un grado de aislamiento acústico en los espacios habitados (Norma Básica NBE-CA-82. Condiciones acústicas de los edificios).

- Cumplir las prescripciones sobre protección contra incendios que determinan que el material de techar será incombustible (Norma Básica NBE-CPI-96. Condiciones de protección contra incendios).

- Tener resistencia mecánica suficiente frente a la acciones estáticas, dinámicas, térmicas, eólicas, etc. que incidan sobre la misma, así como a los movimientos de sus capas. Además deberá permitir realizar las labores de conservación de su superficie.

- $\quad$ El material de techar será no heladizo y resistente al medio contaminante al que se encuentre sometido. 
${ }_{186} \boldsymbol{M}$

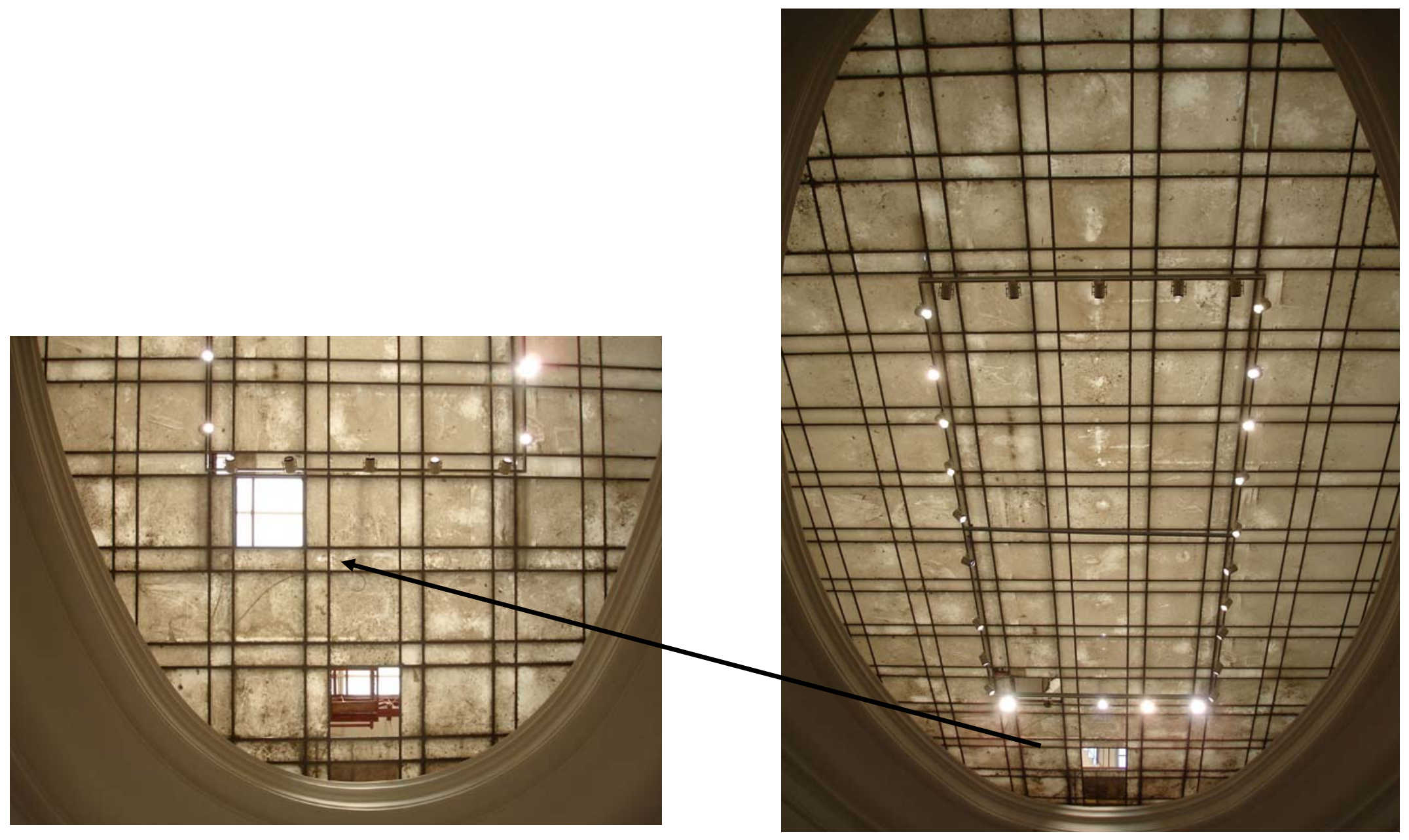

Deterioro del techo de la sala oval 


\section{III.3. RÉGIMEN DE PROTECCIÓN DEL EDIFICIO}

El Museo Arqueológico de Sevilla, como ya hemos dicho, es un museo de titularidad estatal, por lo que queda sometido al Real Decreto 620/1987, de 10 de abril, por el que se aprueba el Reglamento de los Museos de Titularidad Estatal y del Sistema Español de Museos. Dicho Reglamento establece en su artículo 5 la protección que se le da a los inmuebles destinados a albergar museos de titularidad estatal y a sus colecciones:

Artículo 5. Régimen aplicable a los Museos de titularidad estatal.

1. Los Museos de titularidad estatal se regirán por las disposiciones de la Ley 16/1985, de 26 de junio, del Patrimonio Histórico Español, y normas de desarrollo que resulten de aplicación y por las contenidas en este título.
2. Sin perjuicio de lo dispuesto en el párrafo anterior, la Administración del Estado puede establecer convenios con las Comunidades Autónomas para la gestión de Museos de titularidad estatal, que no alterarán su adscripción ministerial.

3. En aplicación del artículo 60.1 de la Ley 16/1985, quedan sometidos al régimen de protección establecido para los bienes de interés cultural, los inmuebles destinados a la instalación de Museos de titularidad estatal y los bienes muebles integrantes del Patrimonio Histórico Español custodiados en aquellos.

4. El Ministerio de Cultura ejercerá las funciones protectoras previstas en la citada Ley 16/1985 cuando se trate de Museos gestionados por la Administración del Estado o que formen parte del Patrimonio Nacional y promoverá la comunicación y coordinación entre todos los Museos de titularidad estatal en los términos establecidos en el artículo 61.3 de la misma.

Así, el edificio que nos ocupa queda sometido al régimen que la Ley 16/1985, de 25 de junio, del Patrimonio Histórico Español establece para los Bienes de Interés Cultural. 


\section{III.4. RELACIÓN CON EL ENTORNO}

El Palacio de Bellas Artes está íntimamente relacionado con su entorno, tanto con la Plaza de América desde su concepción, como más tarde con el Parque de María Luisa $y$, a través de los años, con la ciudad de Sevilla.

La Plaza de América se puede considerar como una de las creaciones de Aníbal González delimitables como actuación cerrada, ya que presenta un orden intrínseco interno.

El proyecto de la Plaza es posterior al de los pabellones de Bellas Artes y de Industria y Artes Decorativas, que ya éstos se encontraban en construcción cuando en 1913 se aprobó su proyecto. No obstante, son estos dos pabellones los que configuran, junto con el Palacio Real (posteriormente declarado permanente), la morfología de la plaza. Estos tres pabellones fueron diseñados por Aníbal González en tres estilos artísticos diferentes: el Palacio de Industria y Artes Decorativas en mudéjar, el Palacio Real en gótico y el Palacio de Bellas Artes en renacentista.

En 1893, la Infanta Doña María Luisa Fernanda de Borbón, duquesa viuda de Montpensier, había cedido a la ciudad la mitad de los suntuosos jardines de San Telmo, desde el arrecife y paseos que se hicieron de la glorieta de San Diego en la esquina de la Fábrica de Tabacos al paseo de la orilla del río, hasta el antiguo huerto de Mariana donde hoy se ubica la Plaza de América.

En 1913 comenzarán las obras para la remodelación de los jardines y su incorporación a la Exposición Iberoamericana, encargadas al ingeniero francés J.C.N Forestier.

El Palacio de Bellas Artes y el de Industrias y Artes Decorativas se sitúan transversalmente a uno de los ejes principales del trazado realizado por J.C.N. Forestier para 
el Parque de María Luisa. A ambos edificios se circunscribe una plaza rectangular con los vértices redondeados, cuyo eje principal se superpone al citado eje del parque, terminando su trazado en un ábside semicircular que se dispone en el extremo opuesto al parque, enfrentado con la fachada posterior del Palacio de Bellas Artes. La anchura de esta plaza rectangular responde a la longitud del mayor de los edificios, el Palacio de Bellas Artes, por lo que el de Industria y Artes Decorativas se engloba dentro de unos parterres que permiten definir la circulación que se genera perimetral a la mencionada plaza. El Palacio Real se sitúa en uno de los extremos del eje ortogonal al mencionado, y se circunscribe en otra plaza rectangular con los lados menores semicirculares, cuya anchura esté en la misma relación con el edificio que la plaza anteriormente tratada con el de Bellas Artes.

La plaza sufre posteriormente modificaciones que el Comité de Ejecución de la Exposición introduciría en todos los proyectos de Aníbal González. Una de las más claras modificaciones, además de añadir en 1914 el estanque central, fue la anexión de la plaza al parque de María Luisa en octubre de 1915. Con modificaciones realizadas por J.C.N. Forestier, se destruye formalmente el borde del trazado colindante con el parque y se dividen los grandes arriates que engloban al Palacio de Industria y Artes Decorativas, con lo que se transforma sustancialmente la claridad compositiva del sector norte de la Plaza.

Aún no respondiendo a la idea original de Aníbal González, tanto la Plaza de América, como el Palacio de Bellas Artes, suponen hoy en día un valor importantísimo del Patrimonio cultural e histórico sevillano.

Desde el punto de vista de los usos de la plaza, éstos afectan directamente al museo. Así, el uso turístico de la misma repercute en el museo de diferentes formas; por ejemplo, el turismo masivo o de grupo, es decir, de autobuses que suelen llegar a primera hora de la mañana 
para visitar la Plaza de América no suele traer visitantes al museo; el turismo individual o en familia sí suele visitar el museo, pero faltan servicios entorno al mismo que ofrecer al público, ya que los dos bares existentes en la plaza no son de muy buena calidad. El uso de la plaza por parte de los ciudadanos de Sevilla a veces trae visitantes al museo, pero otras veces las familias simplemente pasean por el parque.

Con respecto a otros elementos del entorno que afectan al edificio hay que citar la existencia de palomas y murciélagos, estos últimos especie protegida, que repercuten negativamente en la conservación de la arquitectura. Asimismo, la cercanía del río aumenta la humedad y los problemas en la red de saneamiento del parque no tienen en cuenta el deterioro que supone para nuestro edificio. 
Plano de la Plaza de América y distribución de los edificios que la configuran

Pabellón Real/ Pabellón gótico,

Pabellón de Industria y Artes Decorativas/ Pabellón Mudéjar, hoy Museo de Artes y Costumbres Populares

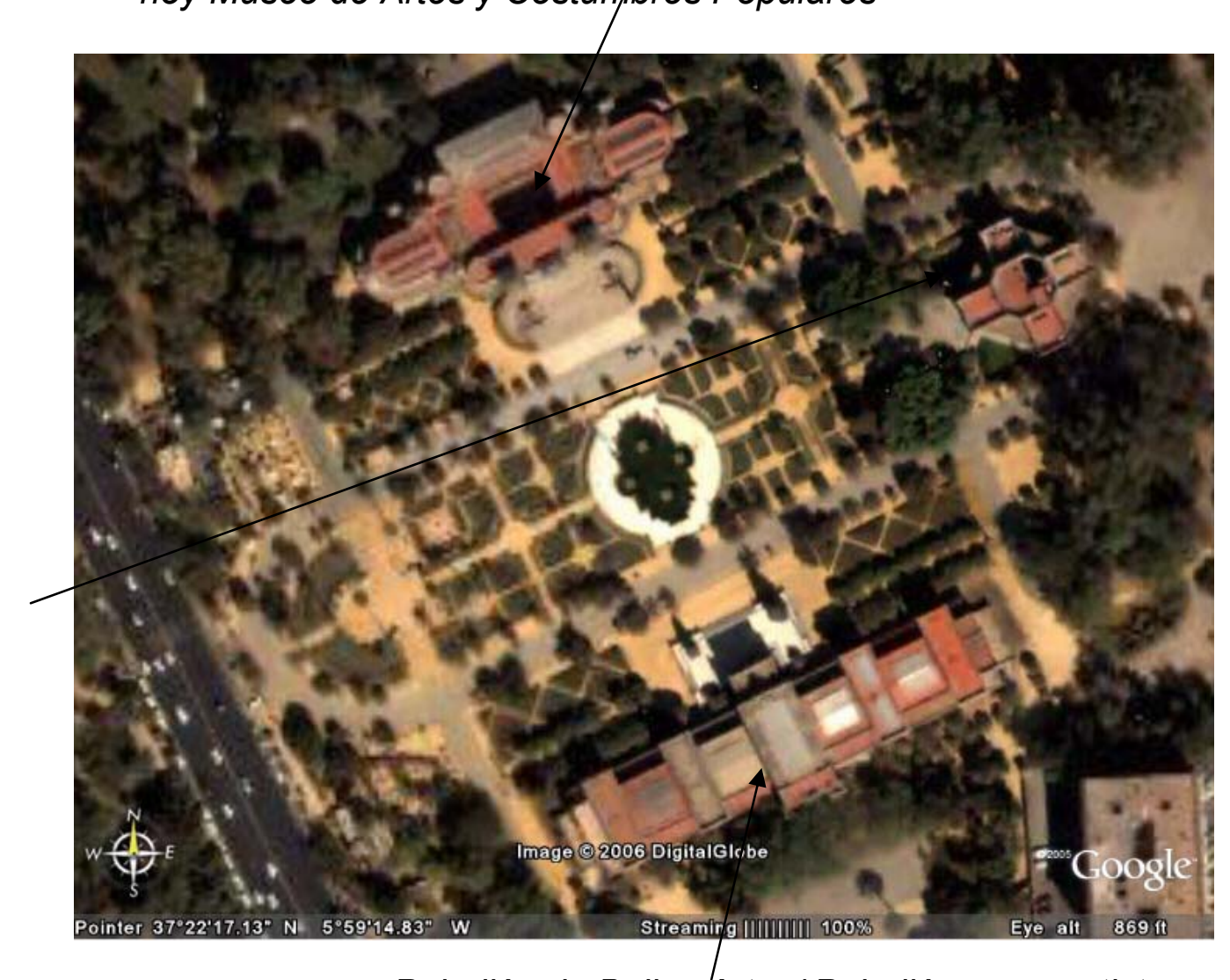

Pabellón de Bellas Artes/ Pabellón renacentista, hoy Museo Arqueológico 


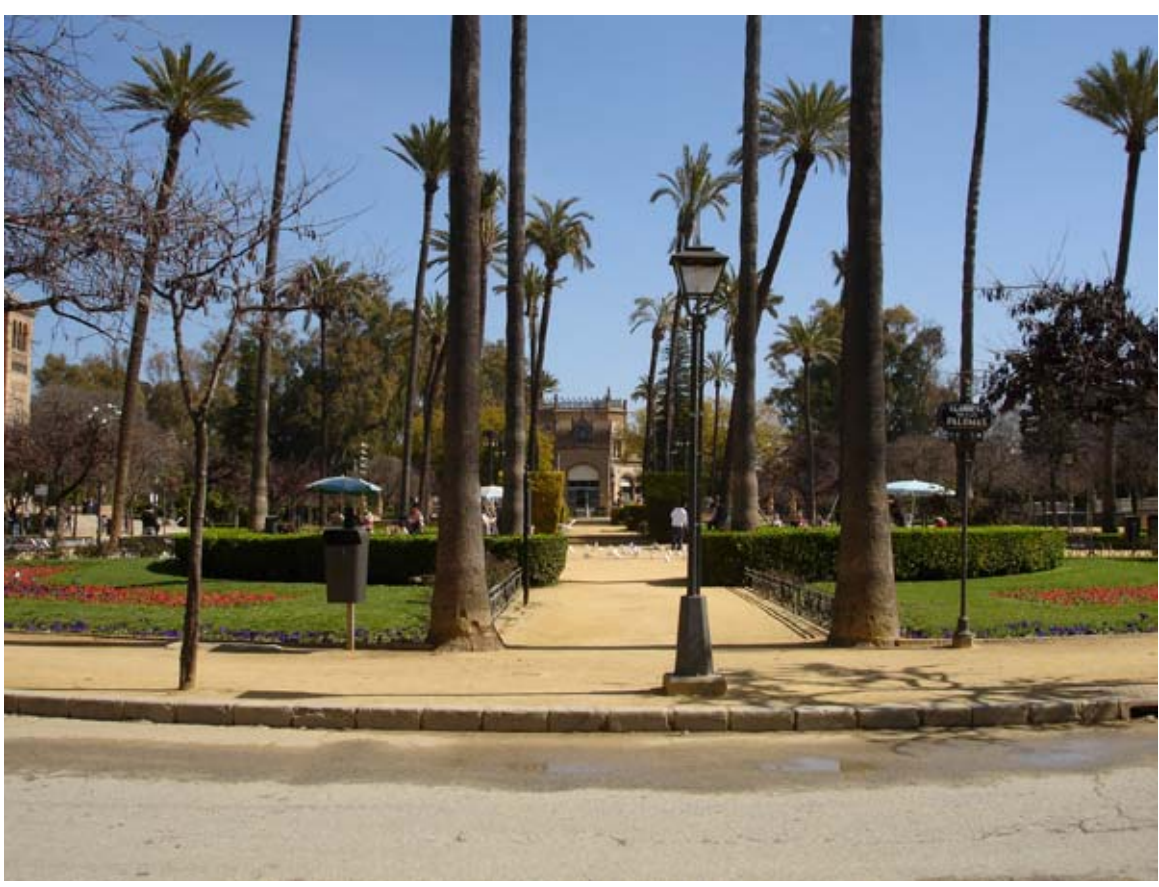

Plaza de América con Pabellón Real al fondo

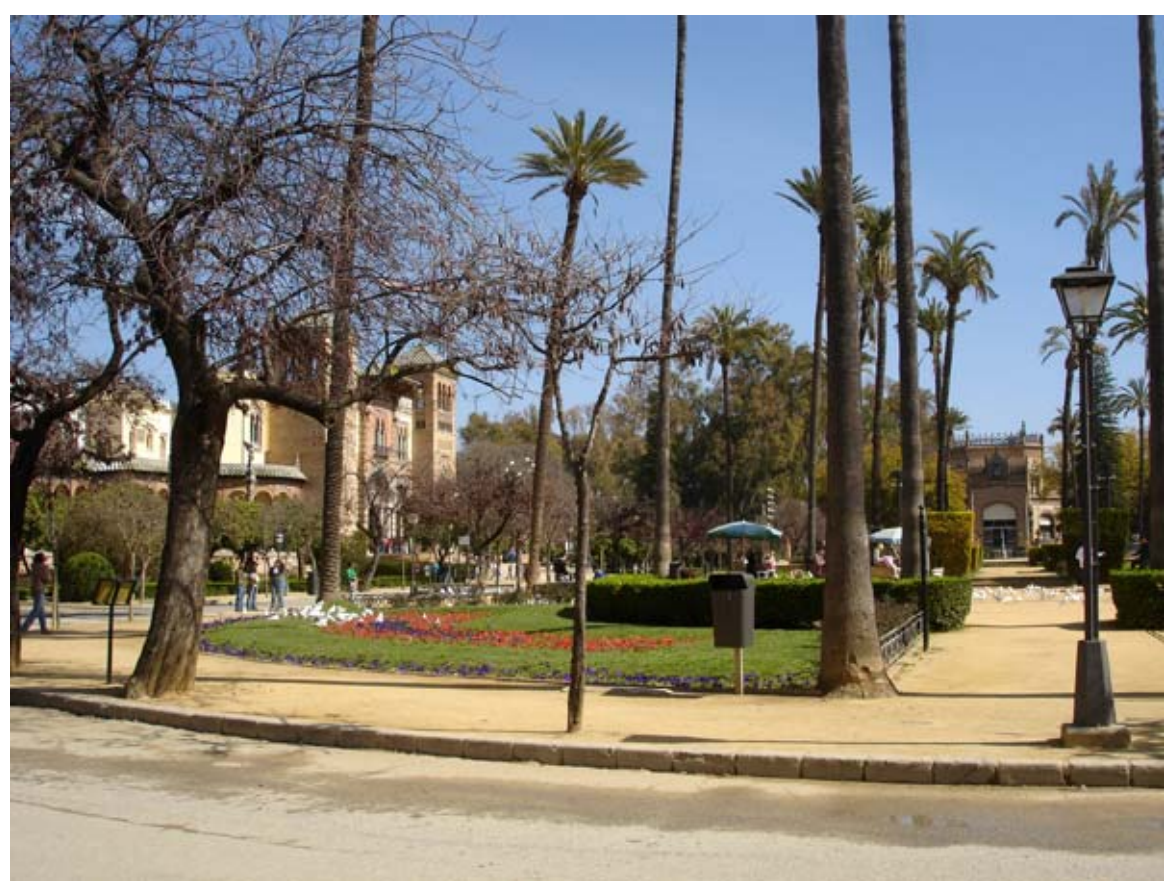

Plaza de América con Museo de Artes y Costumbres Populares y Pabellón Real 


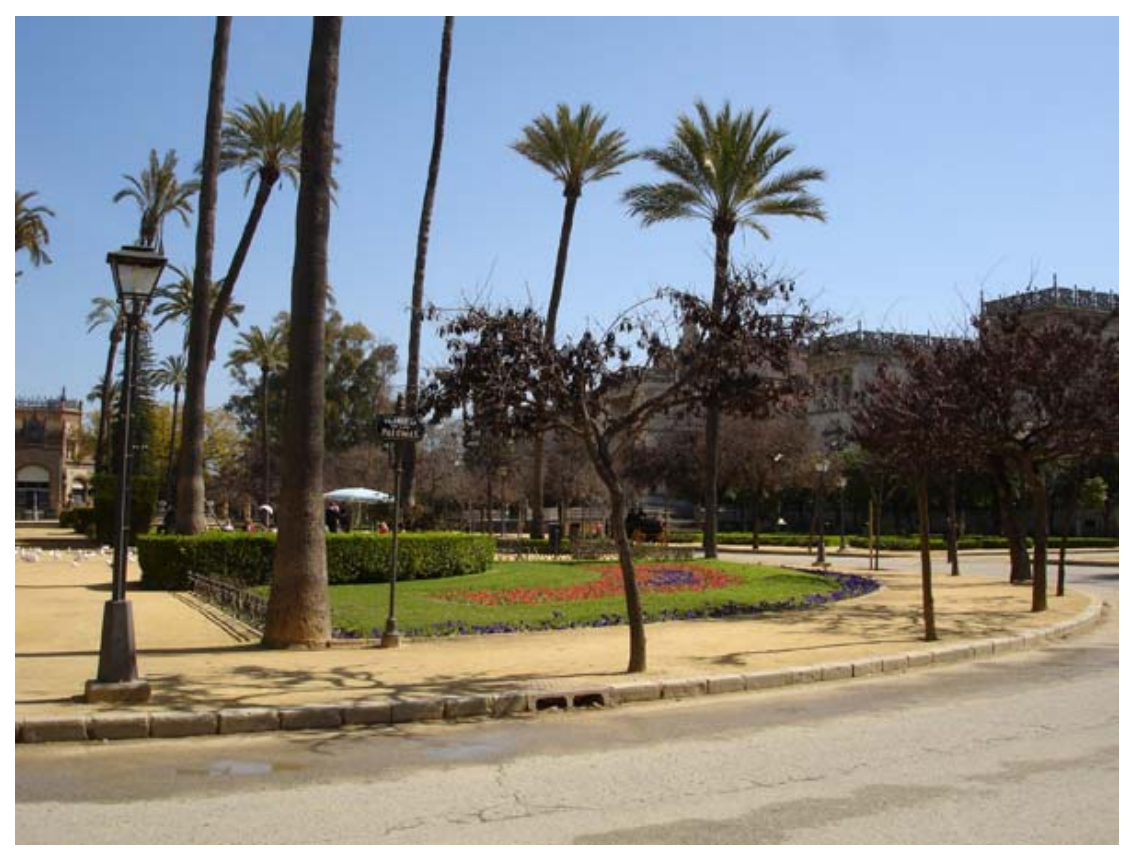

Plaza de América con Museo Arqueológico y Pabellón Real

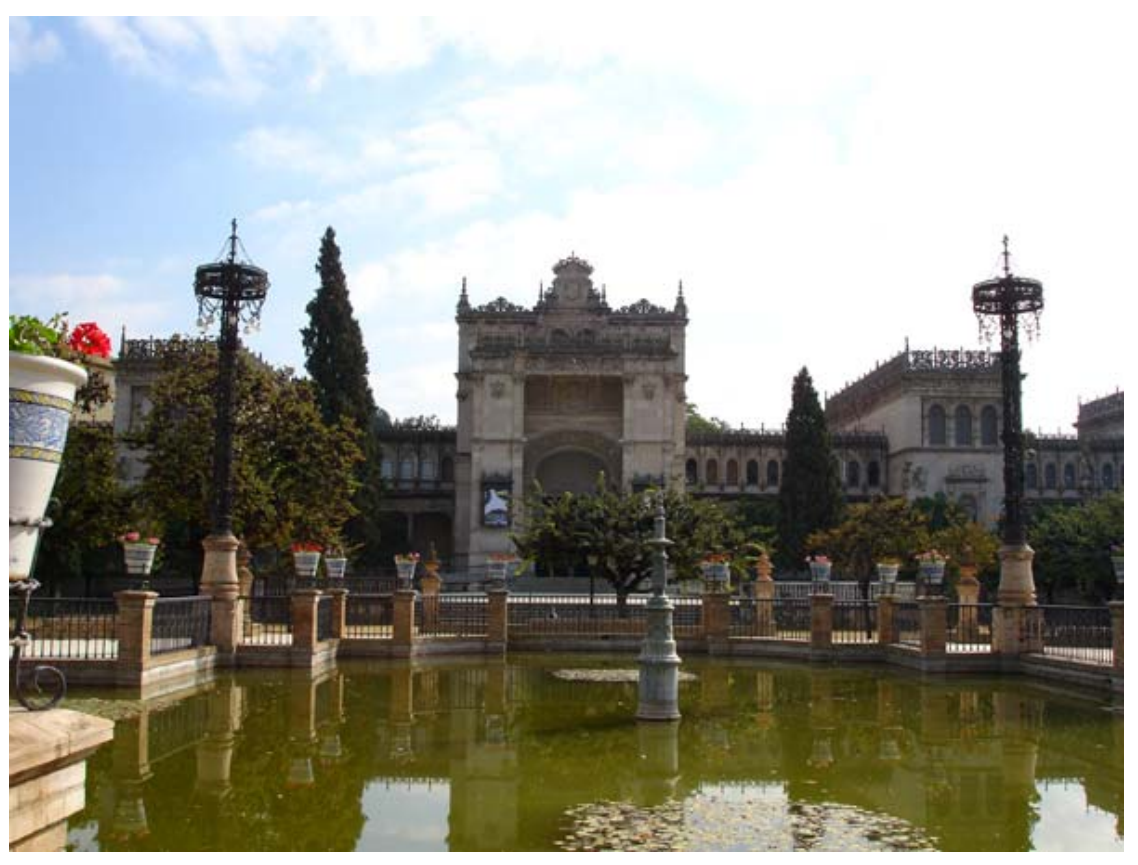

Museo Arqueológico 


\section{III.5. ESPACIOS}

A continuación se analizan los espacios del museo desde el punto de vista de su superficie, distribución de los mismos en el museo y equipamientos.

\section{III.5.1 ÁREA PÚBLICA SIN COLECCIONES}

\section{a) Área de acogida}

El vestíbulo es el único espacio de acogida que tiene el museo. Para llegar a él se accede por la escalera principal de la fachada del edificio, por la que se llega a la puerta principal del mismo. Ésta da paso a un pequeño espacio de tránsito desde el que se accede a mano derecha a una terraza techada pero descubierta por el lateral. Desde ésta se entra al vestíbulo. En él se sitúa un mostrador que es el punto de información donde se recogen los folletos, sirviendo también de taquilla. También encontramos una máquina de café y una vitrina con libros a la venta.
Este espacio es inadecuado e insuficiente como recepción, pues además de no resultar demasiado acogedor, no es lo suficientemente grande como para atender a los grupos. Así, cuando llega un grupo visitante debe reunirse en el exterior del vestíbulo, en la terraza que le antecede, como ya hemos dicho techada pero expuesta a las inclemencias del tiempo puesto que está abierta en todo su frente.

No existen guardarropa ni consigna.

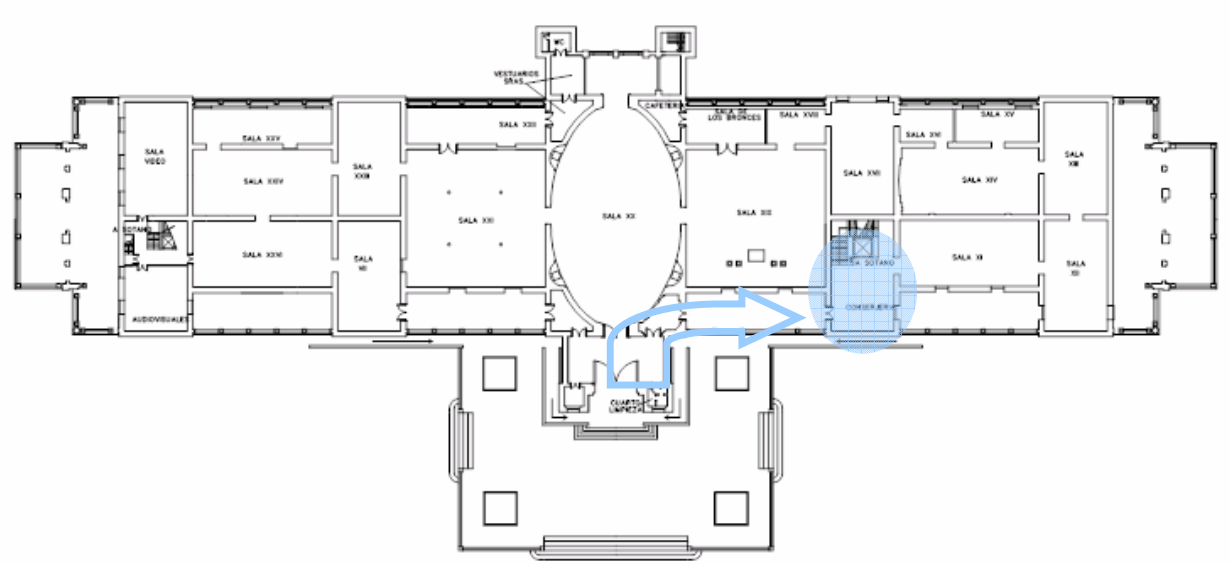

Planta Baja 


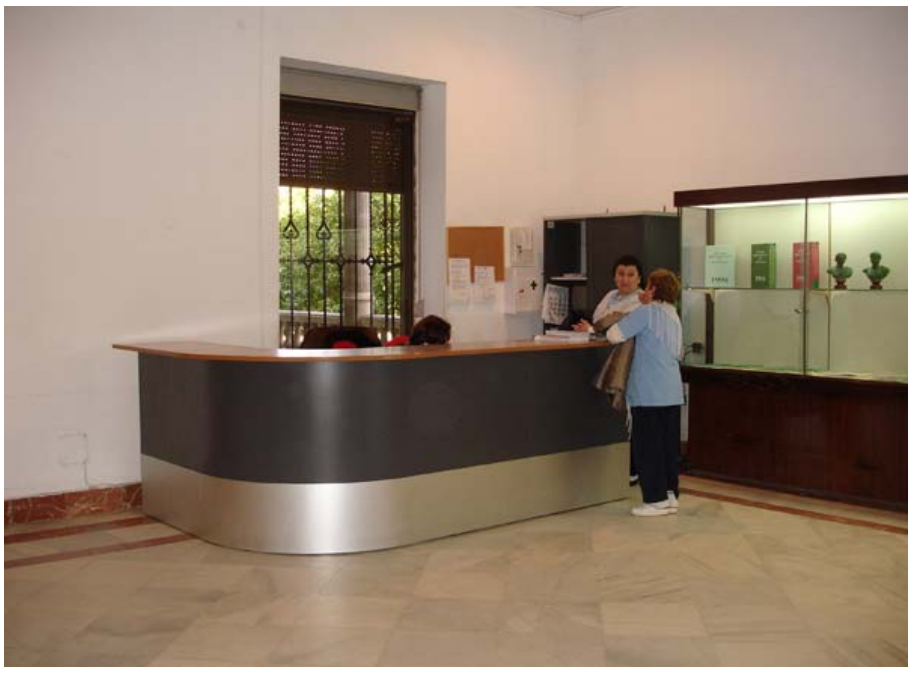

Vestíbulo. Mostrador de información

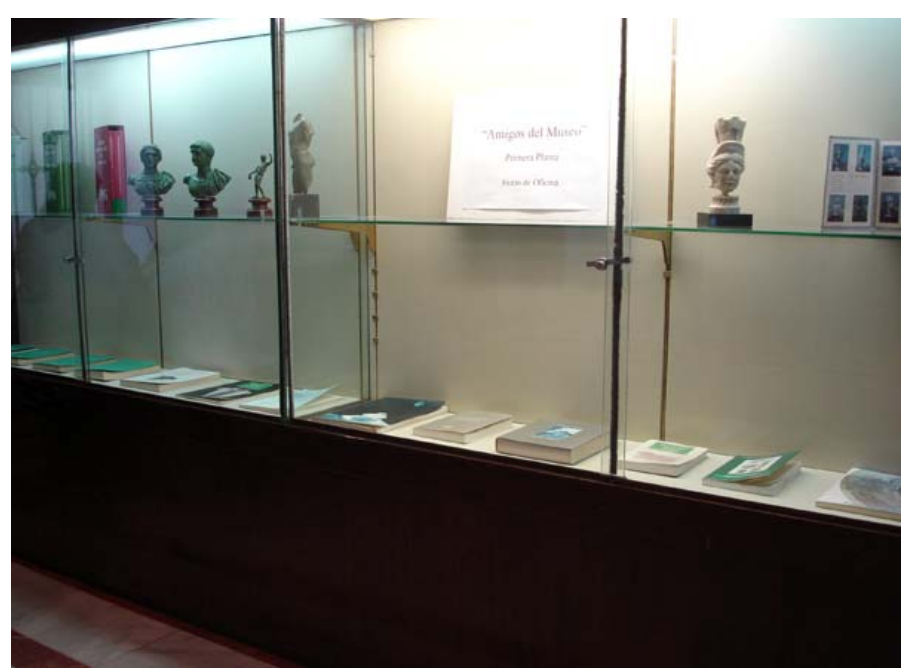

Vestíbulo. Vitrina de libros a la venta

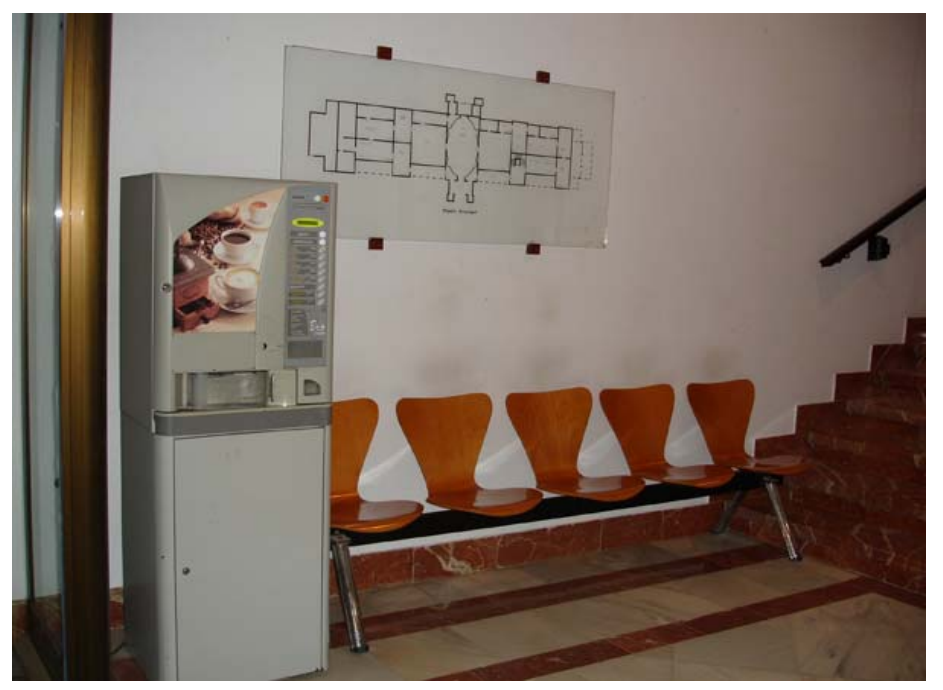

Vestíbulo. Asientos y máquina de café

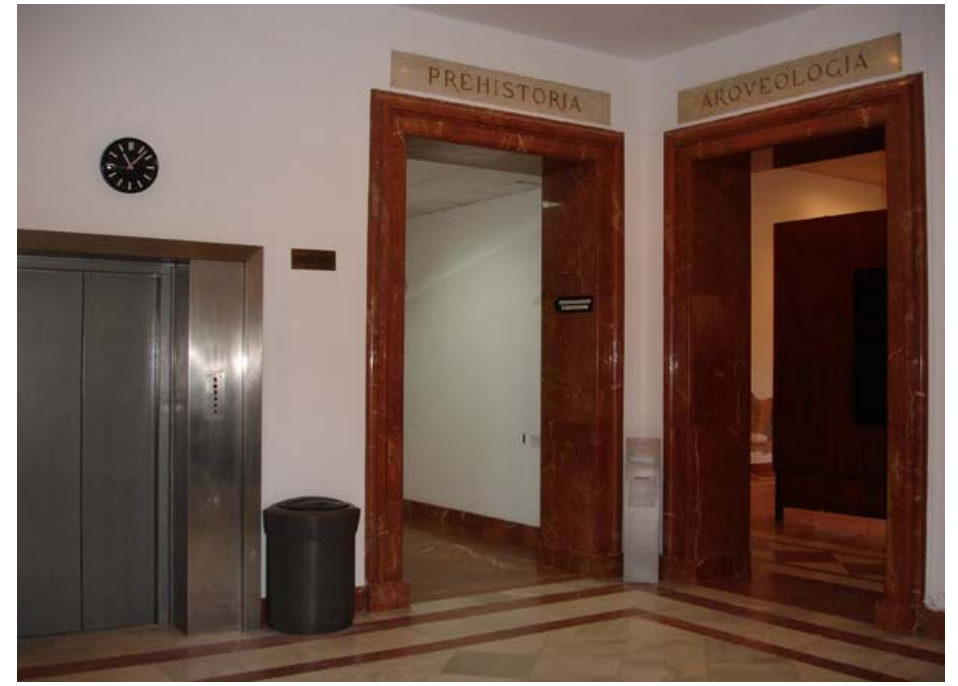

Vestíbulo. Acceso a zona expositiva 


\section{b) Servicios}

Los servicios del museo son también insuficientes. No dispone de tienda, salvo la pequeña vitrina ya citada en el vestíbulo, ni de cafetería o restaurante, salvo la máquina de café también nombrada. Tampoco tiene guardería, teléfono público o cajero automático.

Los aseos del público se sitúan en el sótano, pero no hay aseos ni en la planta baja ni en la superior, con lo que desde las salas de exposiciones de la planta baja o desde la biblioteca o las salas de exposiciones temporales de la primera planta hay que bajar al sótano para llegar a los aseos, lo que resulta una incomodidad para visitantes e

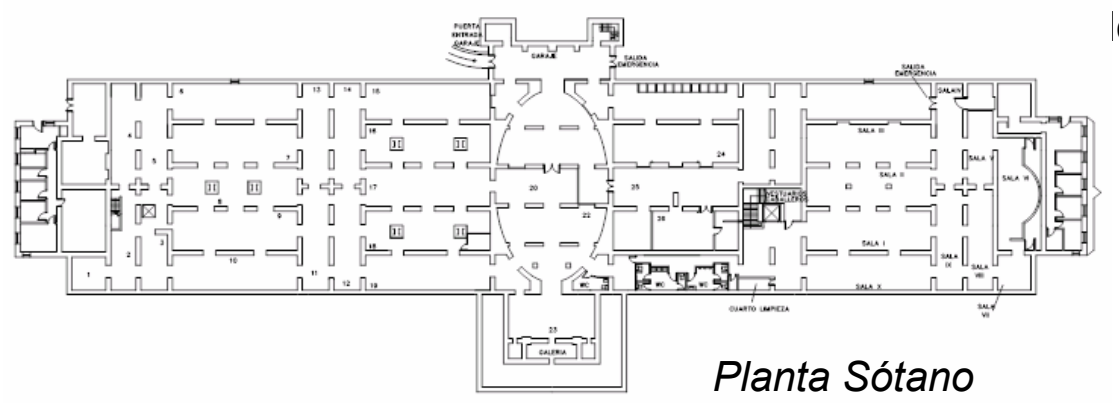

\section{c) Salas para actividades}

El salón de actos se sitúa en la primera planta, teniendo la ventaja de que para llegar a él no hay que atravesar ninguna zona expositiva, con lo que pueden realizarse actividades teniendo las salas cerradas al público. No es demasiado grande pero suficiente para los actos, conferencias o seminarios que pueden darse en el museo. En ocasiones se ha utilizado para la instalación de exposiciones temporales por ser un espacio adyacente a las salas dedicadas a este fin.

Carece el museo de una sala específica para audiovisuales, que alguna vez se han instalado en las salas de exposiciones temporales o en el salón de actos.

Tampoco dispone de talleres didácticos o un lugar para hacer actividades con grupos, que tendrían que hacerse en el salón de actos o en las propias salas.

La asociación de amigos del museo ocupa una sala anexa a la biblioteca, que en su momento fue sala de investigadores, con lo que actualmente no se dispone de una sala específica para atender a los investigadores. 

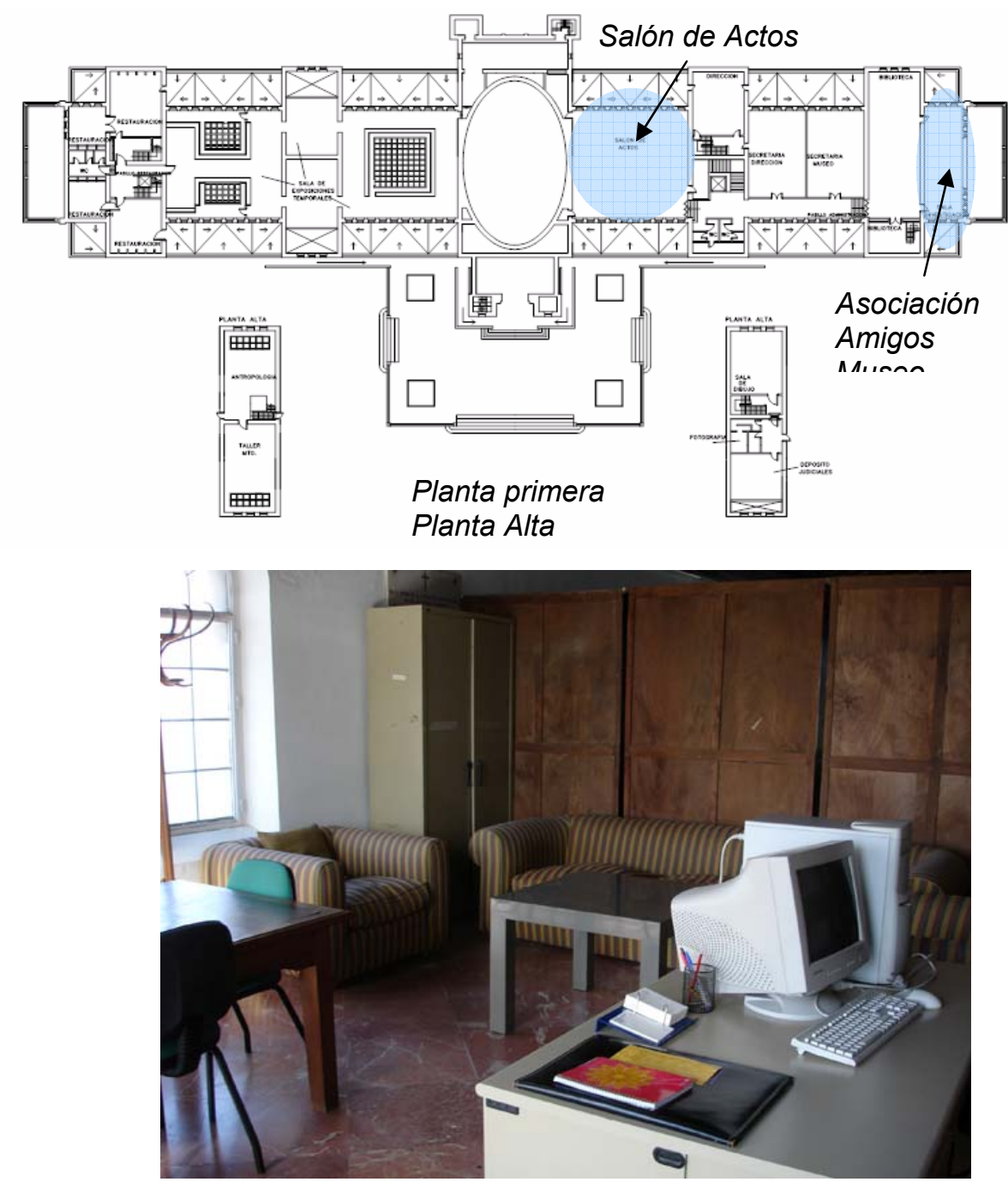

Sala anexa a la biblioteca, hoy en parte ocupada por la Asociación de Amigos del Museo

\section{d) Biblioteca}

Como espacio es suficiente para sus fines, pues es una biblioteca especializada en arqueología que no tiene demasiados usuarios. Dispone de mesas con lámparas para trabajar y enchufes alrededor de las mismas para ordenadores $\mathrm{u}$ otros sistemas. Tiene un despacho anexo para bibliotecarios. Es de destacar que no disponga de climatización, ni de frío ni de calor, sufriéndose bastante las inclemencias del tiempo.

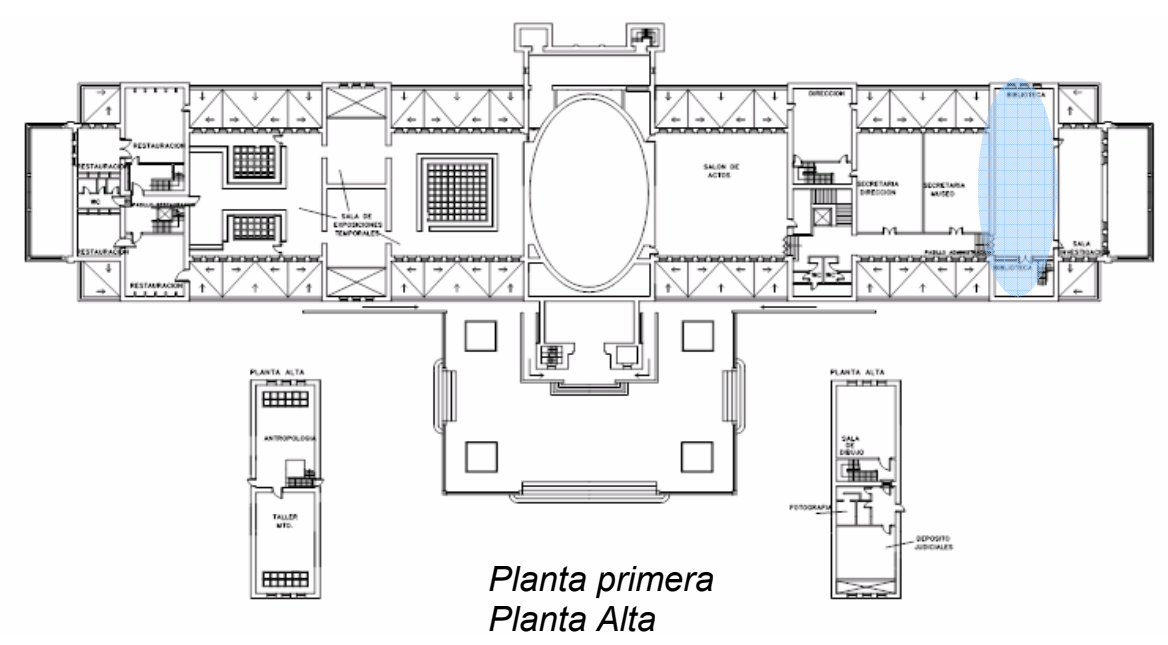




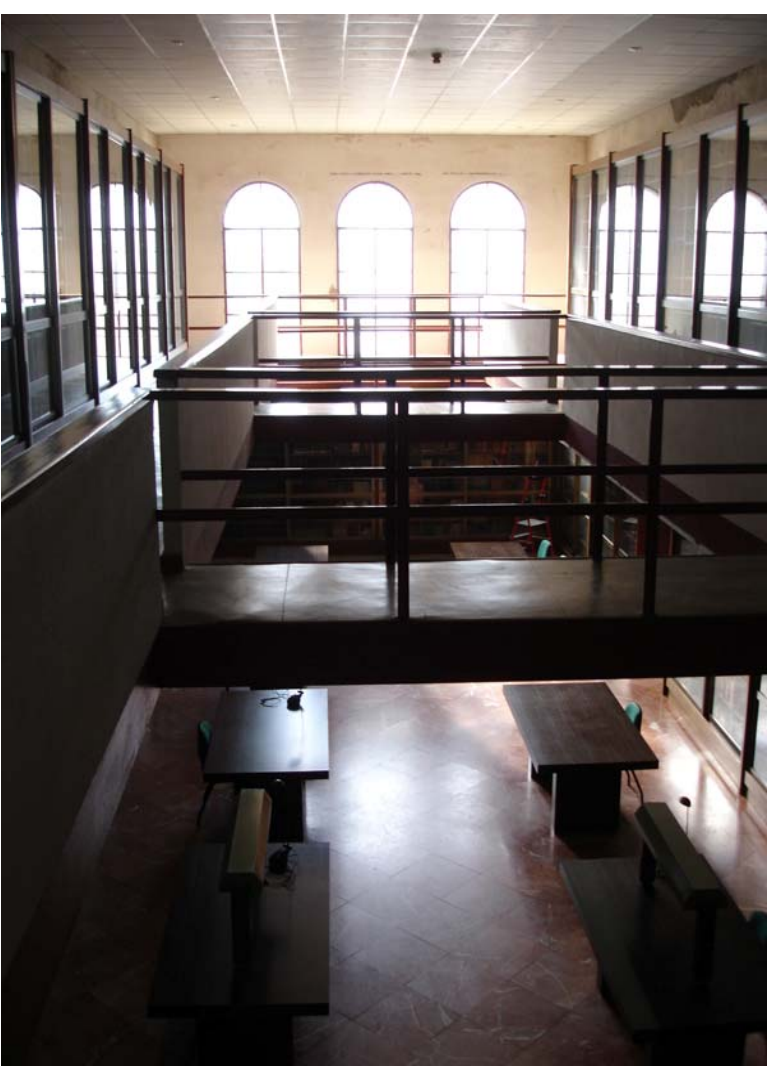

Biblioteca

\section{e) Archivos documentales}

No existen como tales, ordenados para la consulta, sino que se encuentran en el despacho de conservadores y otros espacios del museo, con instalaciones y mobiliario obsoletos.

\section{f) Otros espacios}

No existen zonas de descanso en todo el recorrido de la exposición permanente. La única zona sin colecciones está en el tránsito de la planta baja al sótano y viceversa, para lo que hay que pasar por el vestíbulo.

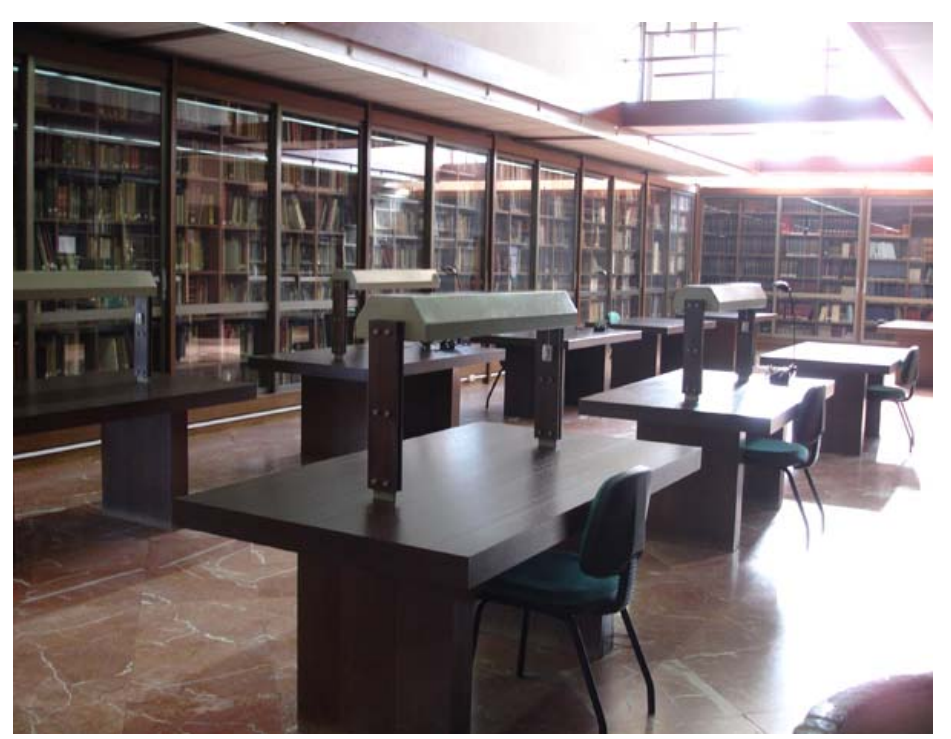




\section{III.5.2. ÁREA PÚBLICA CON COLECCIONES}

\section{a) Salas de exposición permanente}

En la tabla de superficies se muestran los metros cuadrados de exposición permanente que tiene actualmente el museo. Sus deficiencias serán analizadas en el apartado de museografia.

Desde el punto de vista arquitectónico destacar la intervención en las terrazas de la parte trasera del edificio para incorporarlas a la exposición permanente. Son cuatro terrazas traseras, cada una de ellas cerrada con un muro por detrás de las columnas abriendo en algunos ventanas en las que se tamiza la luz a través de celosías y cegados totalmente otros. Así, las salas XV y XVI se corresponden con una de las terrazas, dividida en dos salas, conservando aún la sala XV el artesonado de la misma. Las salas XVIII y XIXbis eran otra terraza, también dividida en dos salas, conservándose el artesonado sólo en la sala
XIXbis. La sala XXII se corresponde con otra terraza sin división y con el artesonado completo y en la sala XXV se sitúa la cuarta terraza cegada.

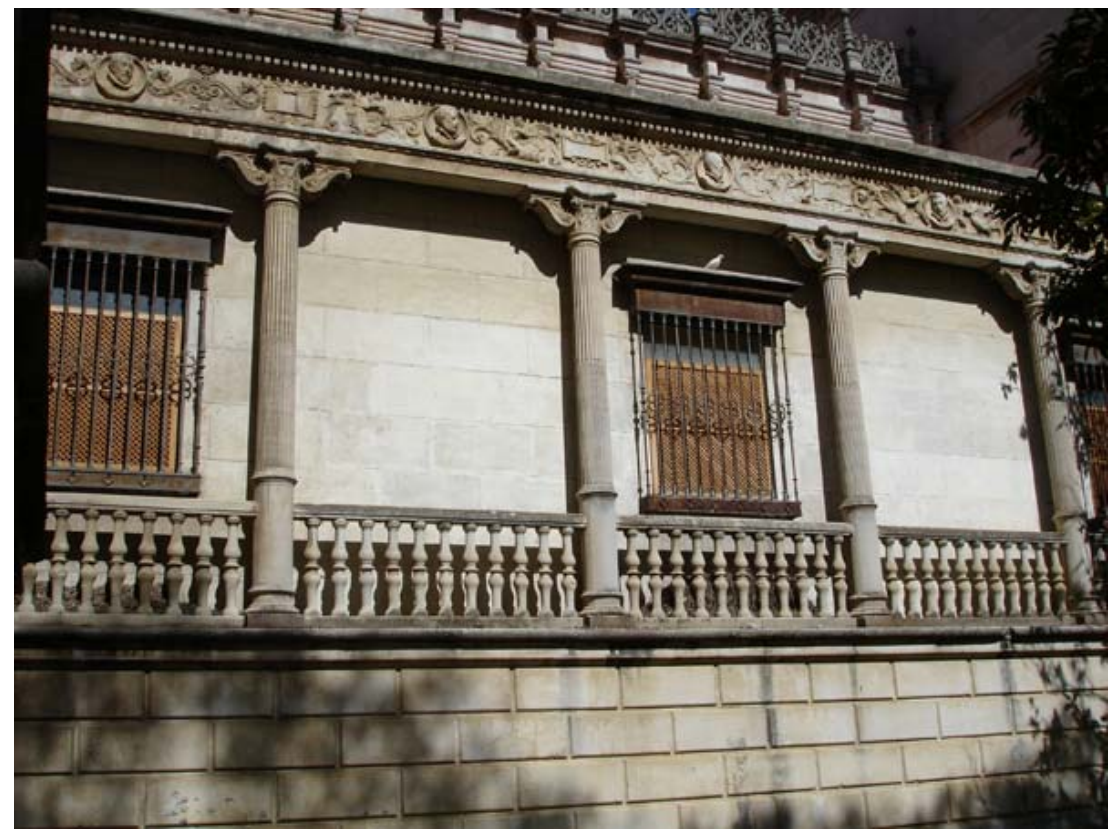

Terraza cegada para incorporarla a la exposición permanente 


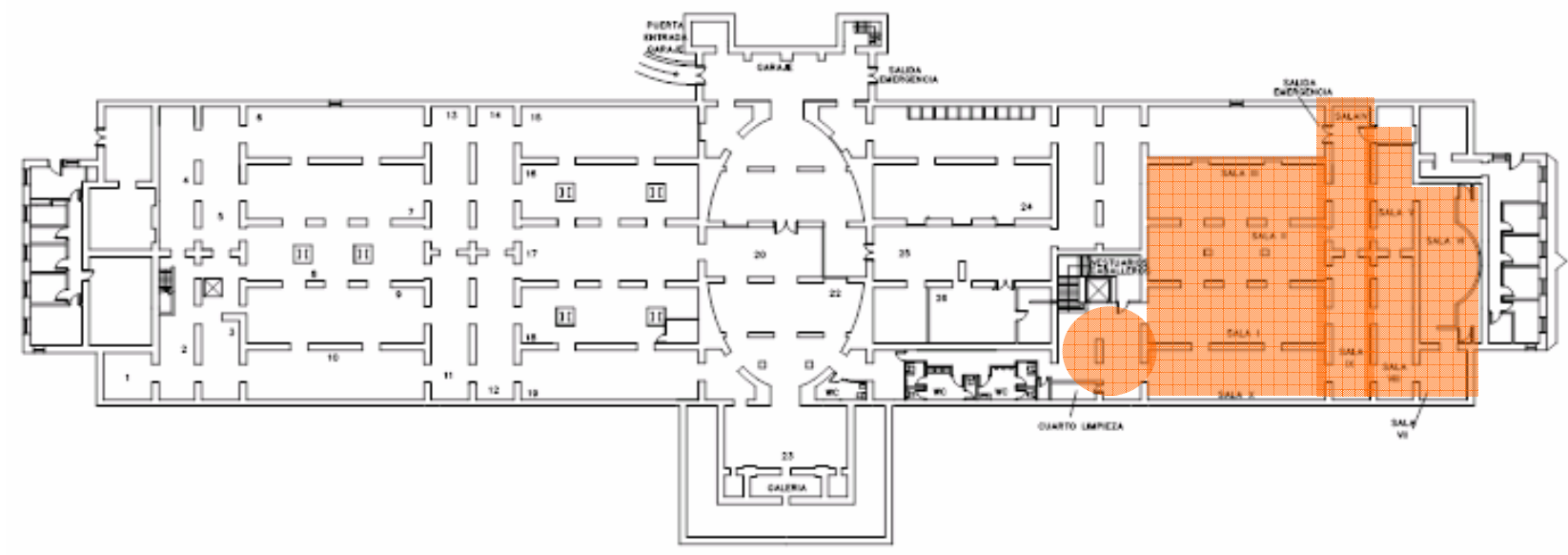

\section{Planta Sótano}

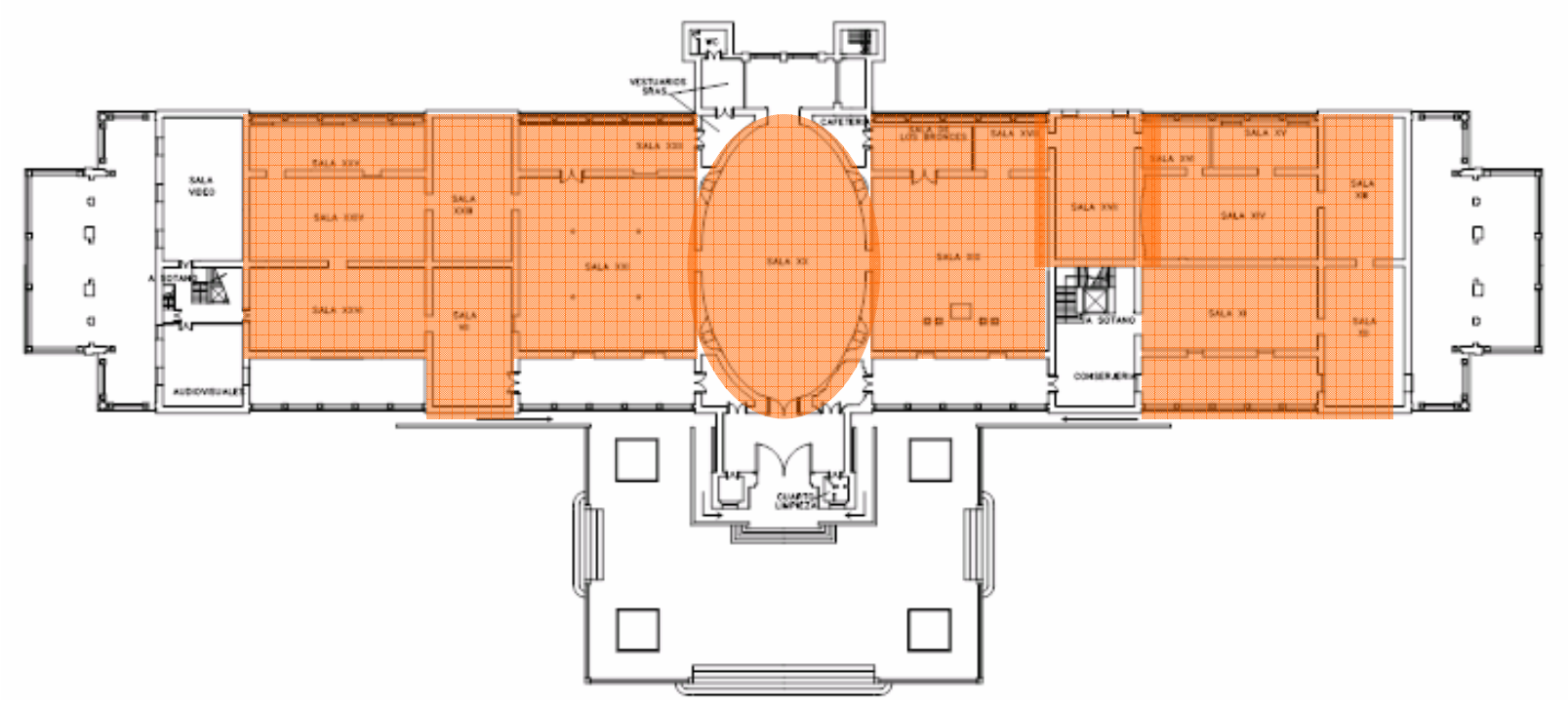

Planta Baja 


\section{b) Salas para exposiciones temporales}

Las salas para exposiciones temporales se sitúan en la primera planta, a continuación del salón de actos, que en ocasiones ha sido también utilizado para ampliar la zona de exposición. En teoría son cuatro salas; la primera de ellas (a) es una sala casi cuadrada en cuyo centro se disponen vitrinas alrededor del lucernario que la ilumina, con lo que tenemos cuatro pasillos en torno a las vitrinas, las cuales están ya anticuadas para los conceptos actuales de exposición. A continuación hay otras dos salas de medianas dimensiones (se detallan en la tabla de superficies como b y c). Y después de estas, en dirección a la zona de restauración hay otra sala (d) con vitrinas antiguas instaladas para exposición alrededor de los dos lucernarios de la sala, al igual que en la primera.

El espacio es insuficiente para una exposición temporal de mediana envergadura, lo que ha hecho que, como ya se ha dicho, en ocasiones haya que ampliar el espacio utilizando el salón de actos. Pero además, para la utilización de todo este espacio citado habría que acondicionar toda la zona, pues salvo la sala primera, el resto del espacio está inutilizado por el almacenaje anárquico de objetos arqueológicos. Por tanto, en la tabla de superficies se recoge toda esta zona de la planta alta que va desde el óvalo hasta el pasillo de restauración como área para exposiciones temporales, pero hay que aclarar que para que pueda servir a este uso habría que intervenir sobre ésta, con lo que actualmente la mayoría de exposiciones temporales no utilizan toda la zona, sino solamente las salas a y b.

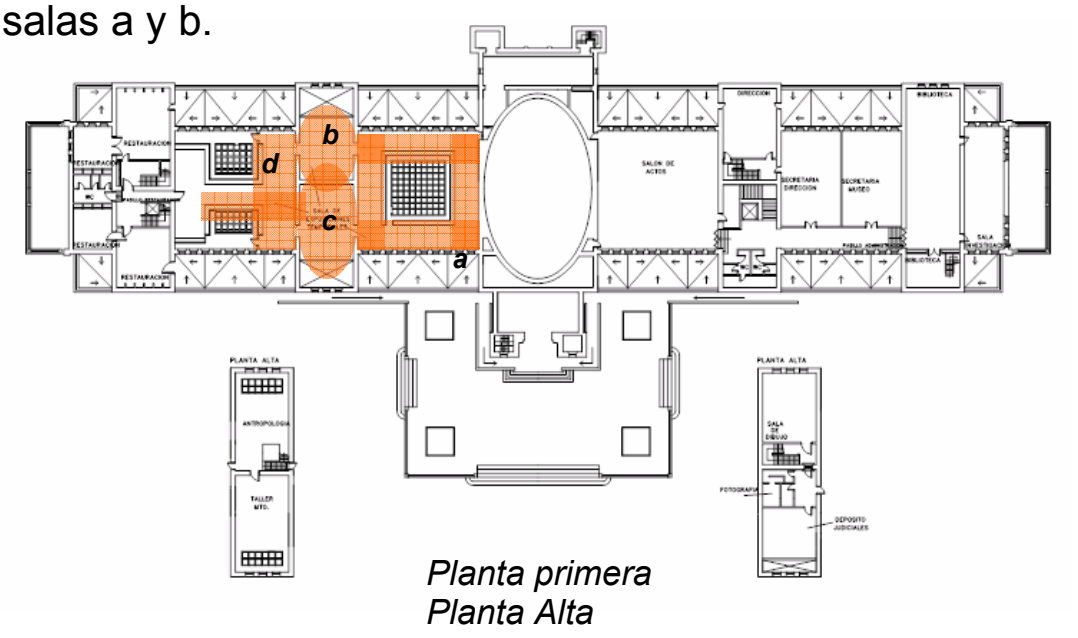




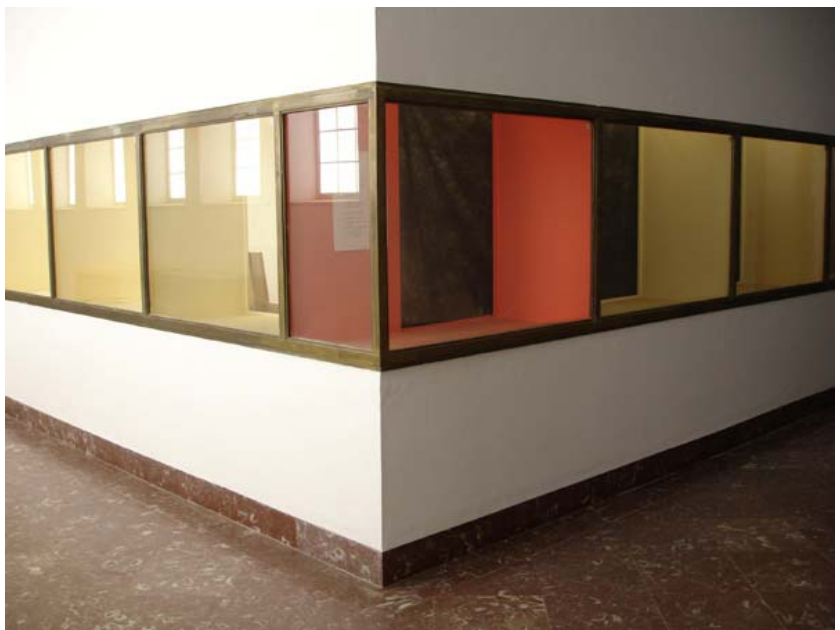

Sala para exposiciones temporales a

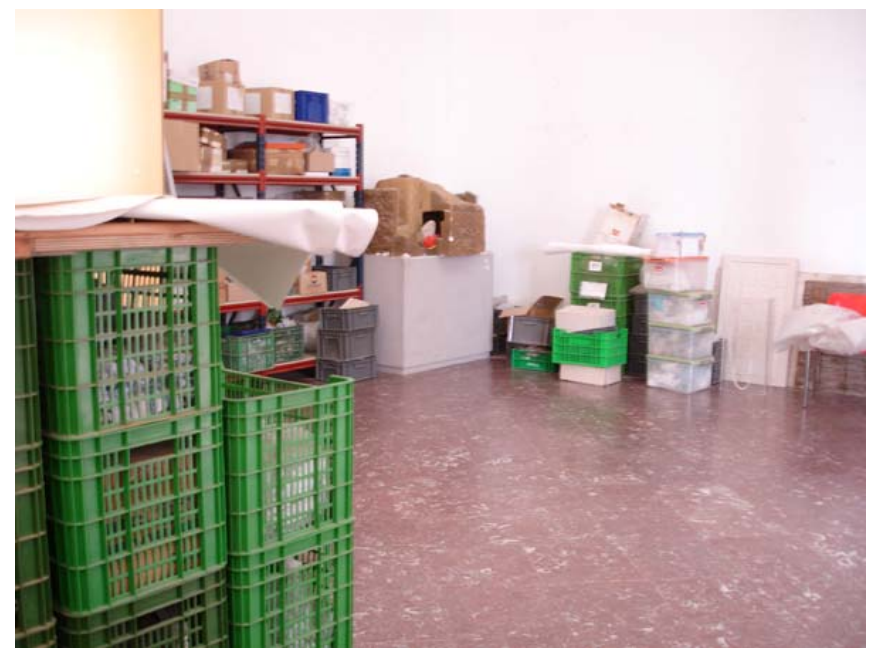

Sala para exposiciones temporales $b$

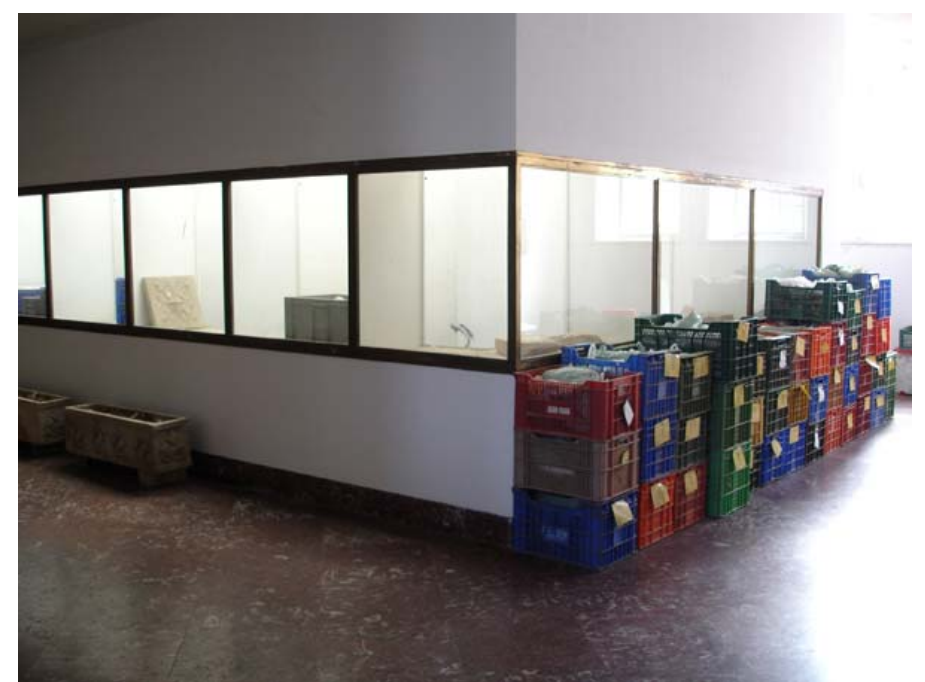

Sala para exposiciones temporales $d$ 


\section{c) Sala de Investigadores}

No existe como tal de manera específica, sino que los investigadores son atendidos en el despacho de conservadores o en otras zonas como el almacén o áreas próximas a la biblioteca. Es imprescindible disponer de un espacio acondicionado y equipado para la investigación, pues la sala de conservadores es incluso insuficiente para el personal del museo, con lo que es totalmente inadecuada para su uso por los investigadores. Tampoco el almacén ni la biblioteca son adecuados.

Existe ya el pensamiento desde la dirección del museo de dedicar la antigua sala de investigación de nuevo a este fin, pues hoy está ocupada en parte por la asociación de amigos del museo, además de utilizarse para reuniones y algunos cursos que se organizan en el museo.

\section{III.5.3. ÁREA INTERNA CON COLECCIONES}

\section{a) Área de recepción de colecciones}

No existe como tal, sino que las obras entran por el almacén del sótano directamente desde la calle a una zona denominada muelle de descarga, pero sin una sala acondicionada para su recepción y además normalmente colapsada de cajas y material arqueológico. Desde el almacén pueden llegar con el montacargas a las salas de exposición o a los talleres de restauración. Esto es así si las piezas son de pequeño o mediano formato porque si son de gran volumen o peso solo entran por el almacén si van a permanecer el él, mientras que si van a ir a los talleres de restauración o a las salas de exposición suelen acceder al museo por el óvalo, ya que el montacargas solo puede soportar pesos de $400 \mathrm{Kg}$. o inferiores y su plataforma solo tiene aproximadamente un metro de lado. Además, el pasillo que llega a los talleres de restauración, así como las puertas, son demasiado pequeñas para 
permitir el paso de piezas voluminosas. Esto es una falta bastante grave, puesto que solo pueden entrar y salir obras por el óvalo en horarios en que el museo está cerrado, con lo que debería disponerse un área diferenciada para la recepción de colecciones y un sistema que permitiera que todas las obras llegaran perfectamente desde ella a todas las zonas del museo.

Tampoco dispone al museo de almacén de tránsito, área de embalaje, almacén de embalajes, despacho de registro, sala de cuarentena o cámara de fumigación. Sólo puede decirse que en la planta baja, en el extremo oriental del

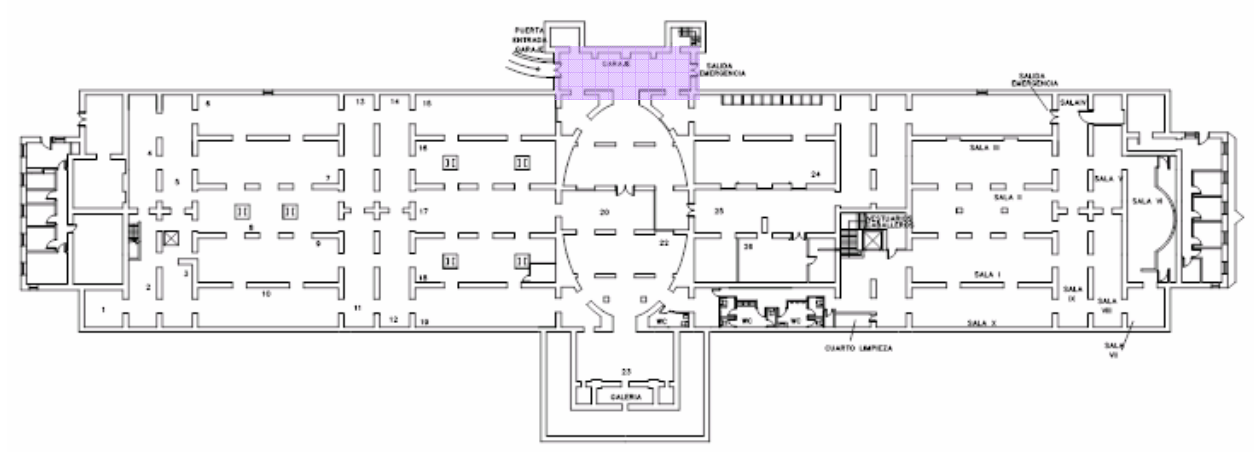

Planta Sótano

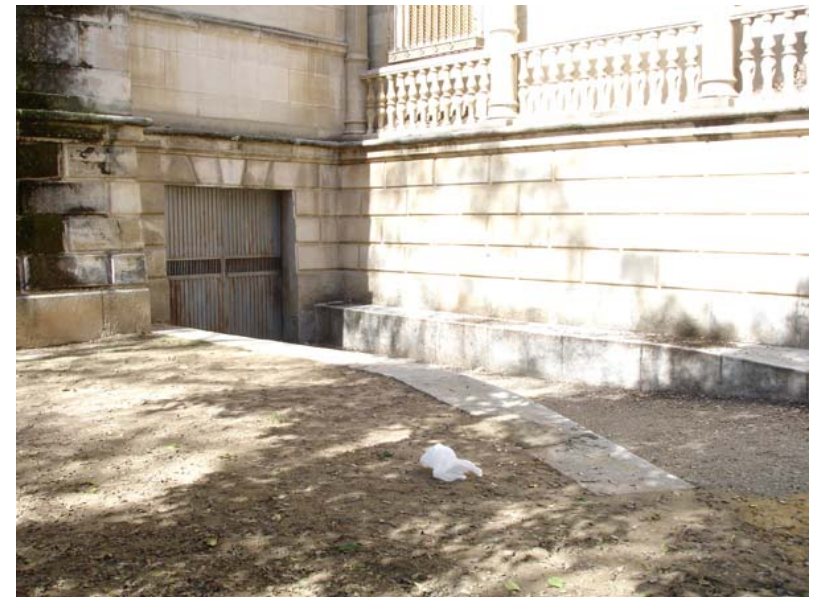

Acceso al muelle de descarga desde el exterior

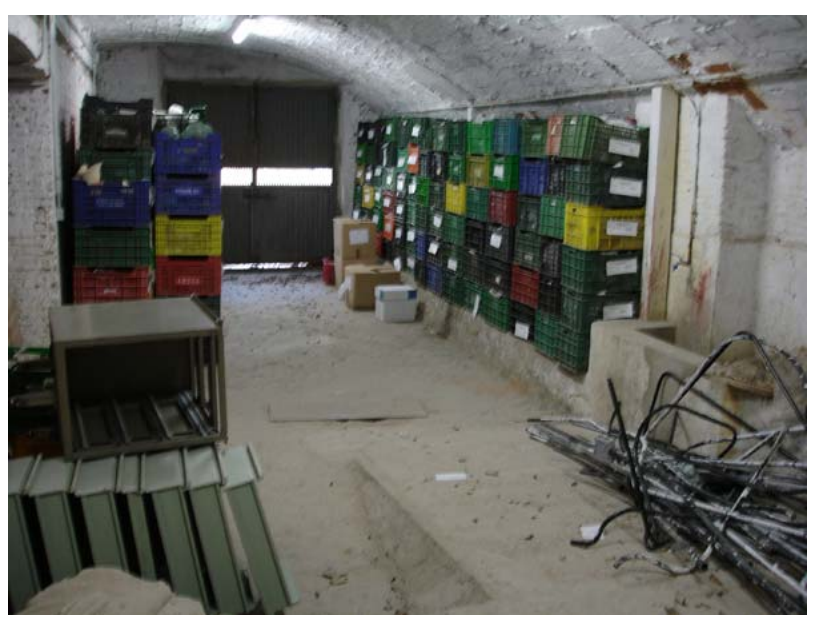

Muelle de descarga/ Área de recepción de colecciones 


\section{b) Conservación}

\section{- Talleres de restauración}

Los talleres fueron instalados a principios de los 80 con la intervención del arquitecto D. Manuel Lafarga en la primera planta del museo, en el ala oriental del edificio.

Son dos salas, una dedicada a piedra y otra a metales y cerámica, separadas por un pasillo de tránsito por el que pasa todo el personal de mantenimiento y limpieza, e incluso pueden llegar personas ajenas al museo, ya que desde la biblioteca hasta esta zona no ha ningún impedimento de paso y desde la entrada del museo hasta la biblioteca tampoco. Esto obliga a los restauradores a mantener siempre las puertas de los talleres cerradas cuando ellos no están dentro. Además, los talleres se sitúan muy lejos de la zona de investigación, están apartados del resto del museo, con lo que es difícil la comunicación.
Desde este pasillo de tránsito, por una puerta a la derecha se accede al taller de restauración de metales y cerámica y por otra a la izquierda al de piedra. A la entrada del taller de restauración de metales y cerámica hay un espacio para documentación fotográfica, bastante pequeño y por poca luz, así como un armario en el que se almacenan piezas. También dentro del taller de restauración de piedra se dispone un pequeño almacén climatizado con un deshumidificador (el único climatizado de todo el museo junto con el de metales, que se sitúa en el salón de actos) en el que se depositan las obras recién restauradas, que nunca vuelven al almacén del sótano, dadas las malas condiciones del mismo (se indica su situación en el plano porque forman parte de la zona de restauración, pero su superficie se considera dentro de la de los almacenes).

En cuanto al equipamiento para intervenciones de restauración es aceptable pero mejorable. Se dispone de campanas de vacío, microscopio, placas de calentamiento, hornos de secado y baños térmicos. Tienen una balanza 
para pesos pequeños, actualmente estropeada, por lo que se ha pedido otra, pero no para pesos grandes. Los restauradores estiman que son necesarias estas dos balanzas, un agitador mecánico para mover las mezclas que ya ha sido solicitado, un baño térmico de arena para volver a dar forma a las planchas deformadas, una instalación de desmineralización de agua, así como lámparas de luz día que ya han sido solicitadas.

Por otra parte, la iluminación y la ventilación de los talleres son muy buenas, aunque la ventilación se efectúa de manera natural y sería conveniente disponer de un sistema de regeneración de aire. Es adecuada la ubicación de los mismos, pues al estar en la primera planta no pueden producirse inundaciones y permite la entrada de luz natural. No obstante, acusan la falta de climatización y otras deficiencias como la ausencia de armarios para guardar los botes de productos abiertos, ya que tienen un armario para productos químicos sin utilizar, pero los que están ya abiertos se reparten por las mesas del taller, cuando deberían ubicarse en armarios específicos con sistema de regeneración de aire que minimice la toxicidad en el almacén. Es también dificultosa la entrada de una grúa para restaurar un objeto de mediano tamaño dada la situación del fregadero en medio del taller de metales y el pequeño tamaño de las puertas de acceso a ambos talleres y por tanto imposible la entrada de uno de gran tamaño, que deben ser restaurados en sala o en el almacén, con lo que en los talleres solo se abordan piezas de pequeño y mediano formato. Las restauraciones más habituales del taller son las de los fondos expositivos, orientadas a una conservación preventiva y la de las piezas procedentes de excavaciones que llegan al museo. Como ya se ha dicho anteriormente, las piezas restauradas van a la salas de exposiciones, a exposiciones temporales o al pequeño almacén climatizado situado dentro del taller de piedra, sin volver al almacén del sótano, ya que según los restauradores la intervención habría sido en balde si las piezas se instalan después en las condiciones que este presenta. 
La instalación eléctrica es deficiente, pues no aguanta el funcionamiento de determinados aparatos como extractores fuertes. Por otra parte, no hay suficientes enchufes.

En general, falta mobiliario de administración y documentación para una organización de laboratorio más actualizada.

Así, la conclusión de los restauradores es que los talleres mantienen su funcionamiento con unos equipamientos decentes pero insuficientes y que están anticuados, siendo necesaria una renovación del equipamiento técnico y un replanteamiento y redistribución de los talleres para que puedan cumplir adecuadamente sus funciones.

Respecto a la normativa de seguridad e higiene en el trabajo, no se han hecho estudios pero no se cumplen la mayoría de las premisas, como el almacenamiento de productos químicos abiertos en armarios. 
Taller de restauración de metales y cerámica

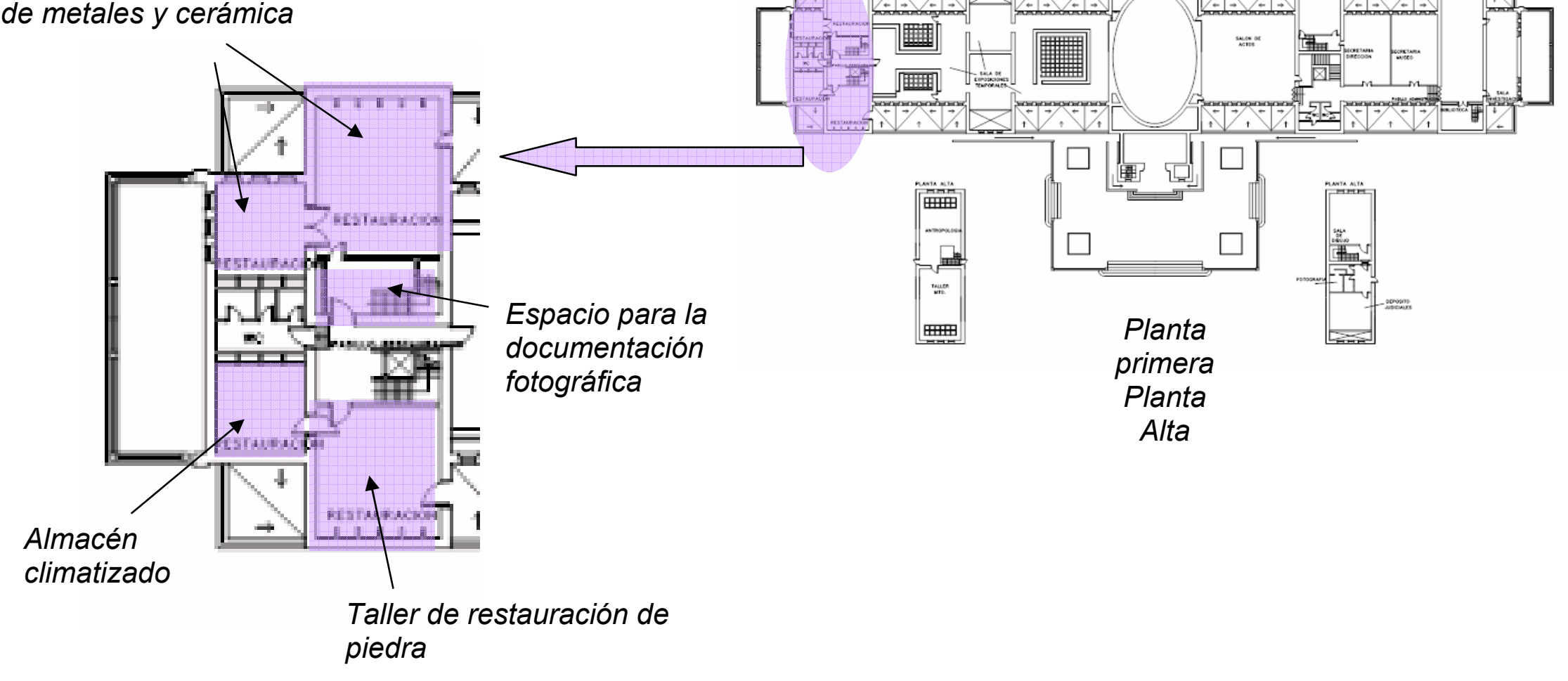




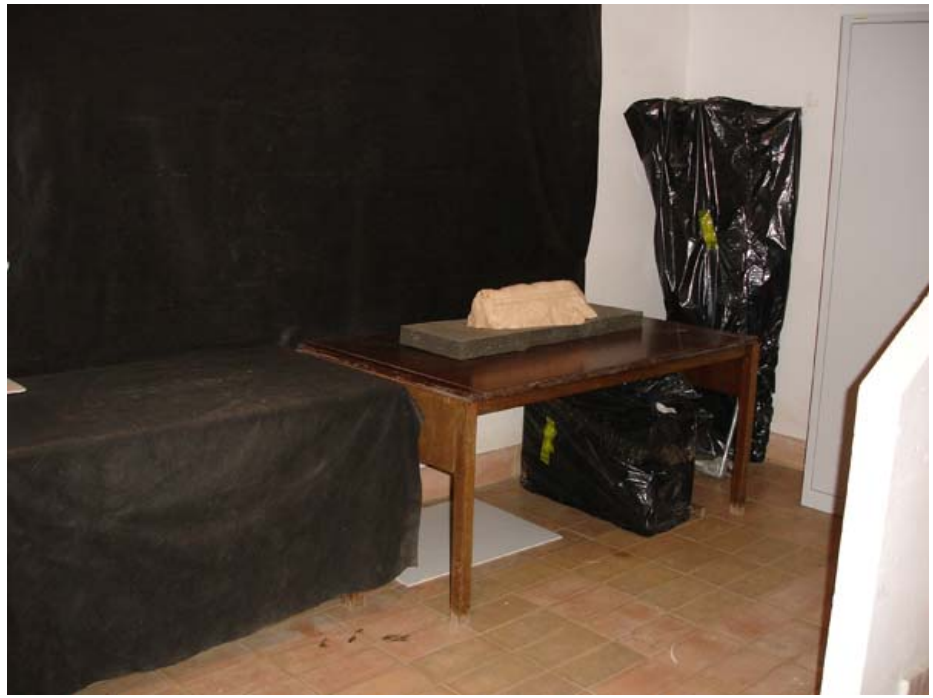

Espacio para la documentación fotográfica

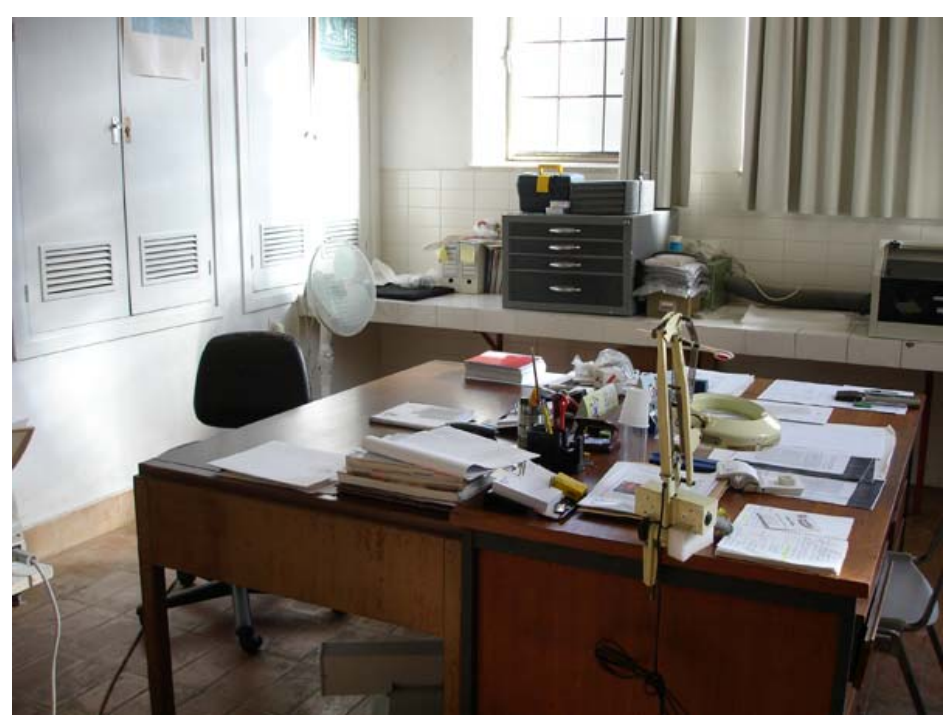

Taller de restauración de metales y cerámica. Zona de despacho y almacenamiento de productos

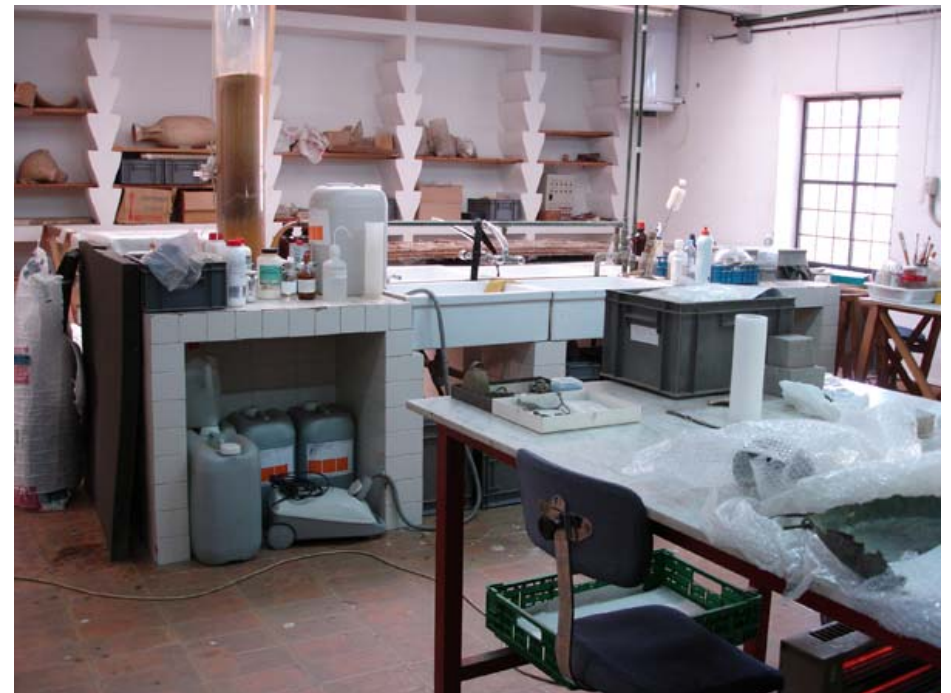

Taller de restauración de metales y cerámica. Zona de trabajo

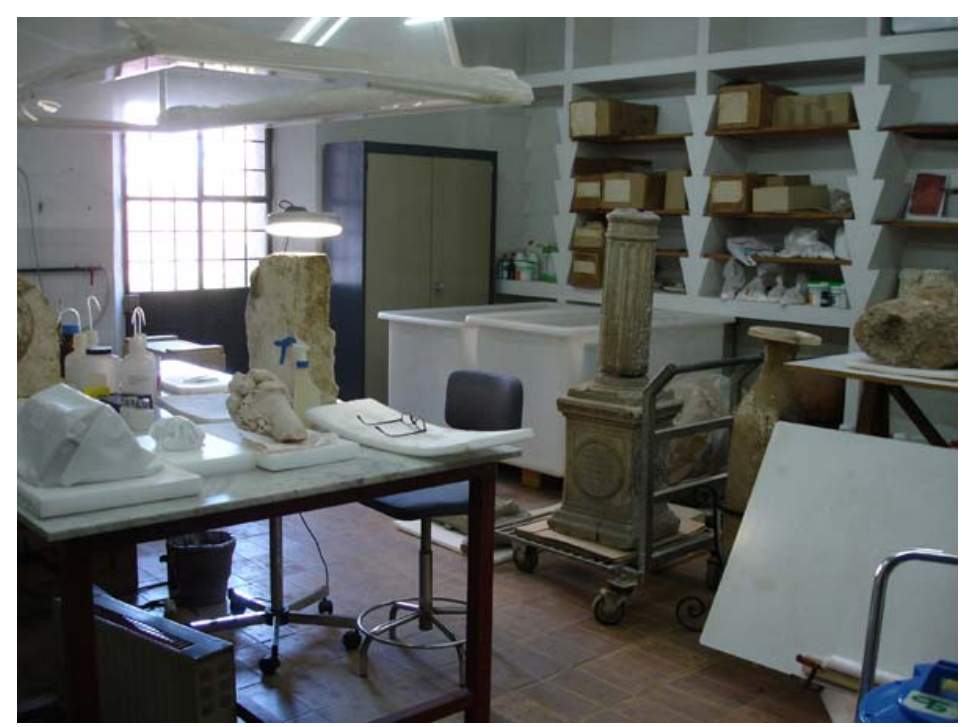

Taller de restauración de piedra 
- Cámaras de fumigación, barnizado, climatización...

El museo carece de estas instalaciones.

\section{c) Almacenes}

La mayor parte de las salas de reserva o almacenes se sitúan en el sótano, habilitados a tal fin a finales de los años 70 por la dirección del museo. Por ello, cuando en lo sucesivo nos refiramos al almacén en general estaremos hablando de éste.

En la tabla de superficies se especifica la de las zonas de almacén, pues no es sólo uno sino varios los almacenes del museo, ya que, como se ha dicho anteriormente, hay dos pequeños almacenes en el museo, que disponen de un deshumidificador; a uno de ellos se accede desde el taller de restauración de piedra puesto que está situado en su interior, y se dedica al almacenaje de objetos ya intervenidos y al otro se accede desde el salón de actos y se dedica sólo al almacenaje de metales, que necesitan un control absoluto de la humedad para evitar la oxidación.

Por otra parte, hay varios armarios repartidos por el museo que contienen material arqueológico y son difíciles de cuantificar, por ejemplo el situado a la entrada del taller de restauración de metales o el que contiene la colección de numismática en el despacho de los conservadores.

En la planta alta también hay almacenes. Por lado, en la situada sobre la zona de restauración existe un almacén de antropología en el que se conservan sobre todo restos óseos procedentes de tumbas, y por otro, en la situada sobre la dirección hay un almacén en principio dedicado a depósitos judiciales pero en el que hoy se almacenan objetos arqueológicos de todo tipo.

Hay que destacar además que por diferentes partes del museo se disponen cajas de material arqueológico o directamente piezas, como en la zona de exposiciones 
temporales, lo que hoy hace que sea imposible utilizarla para tal fin.

Este hecho de la disgregación del almacén dificulta la labor conservadora, investigadora, catalogadora y el propio orden del mismo. No sabemos si esto se ha producido por la falta de espacio en el almacén del sótano, pero es verdad que en general el espacio de almacén es insuficiente. Suele ocurrir en los museos arqueológicos, donde ingresan diariamente cantidad de piezas procedentes de excavaciones, frecuentemente sin ninguna purga previa, es decir, fragmentos que en ocasiones ni siquiera sirven a los investigadores pero que la legislación obliga al museo a conservar.

Los criterios de ordenación de los almacenes serán detallados en el apartado de colecciones, así como la evolución del crecimiento de las colecciones en reserva y el porcentaje de ocupación de la superficie de las salas de reserva. No obstante podemos decir aquí que la ocupación está al 100\%, es decir, el almacén ya se encuentra al límite de su capacidad. También se analizará en el apartado de colecciones el mobiliario utilizado para depositar las piezas, pero podemos decir que la mayoría de ellas se ubican en estanterías. Con respecto a los medios mecánicos para el movimiento o manipulación de los bienes, el museo cuenta con una grúa pluma para bajos tonelajes y una transpaleta o transpallet. 


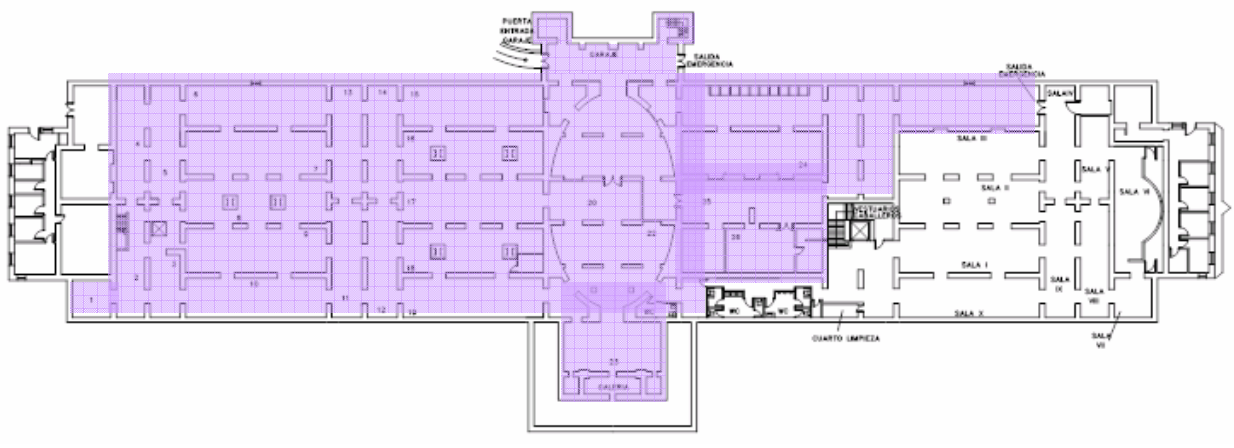

Planta Sótano

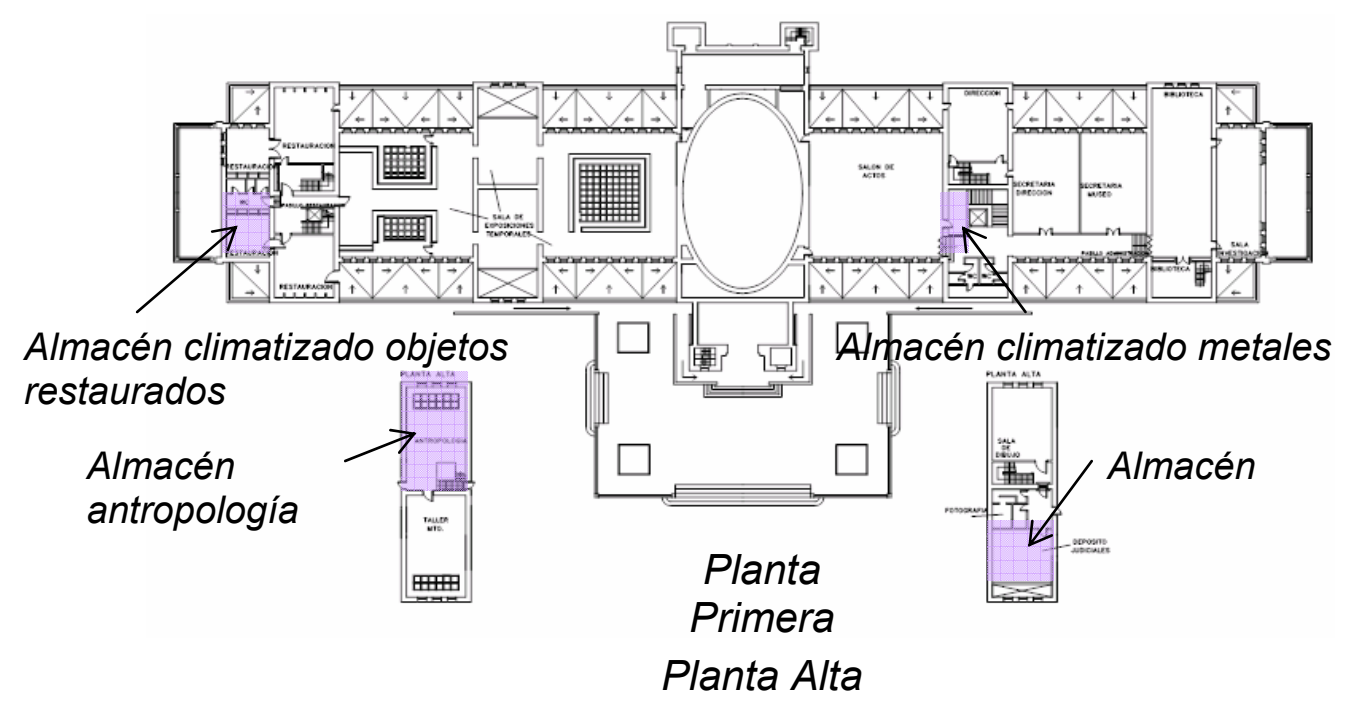

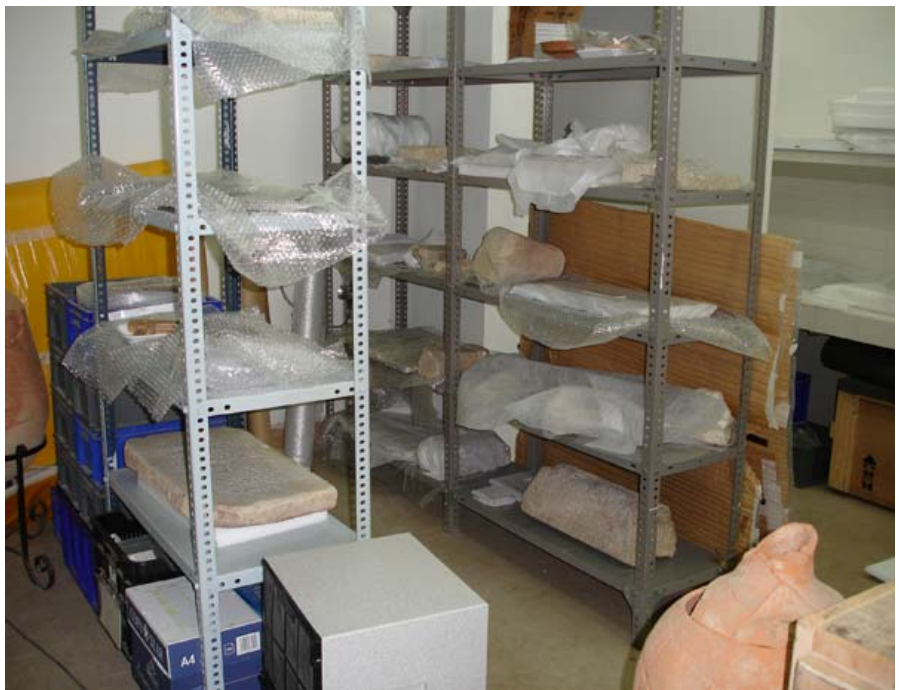

Almacén climatizado para objetos restaurados

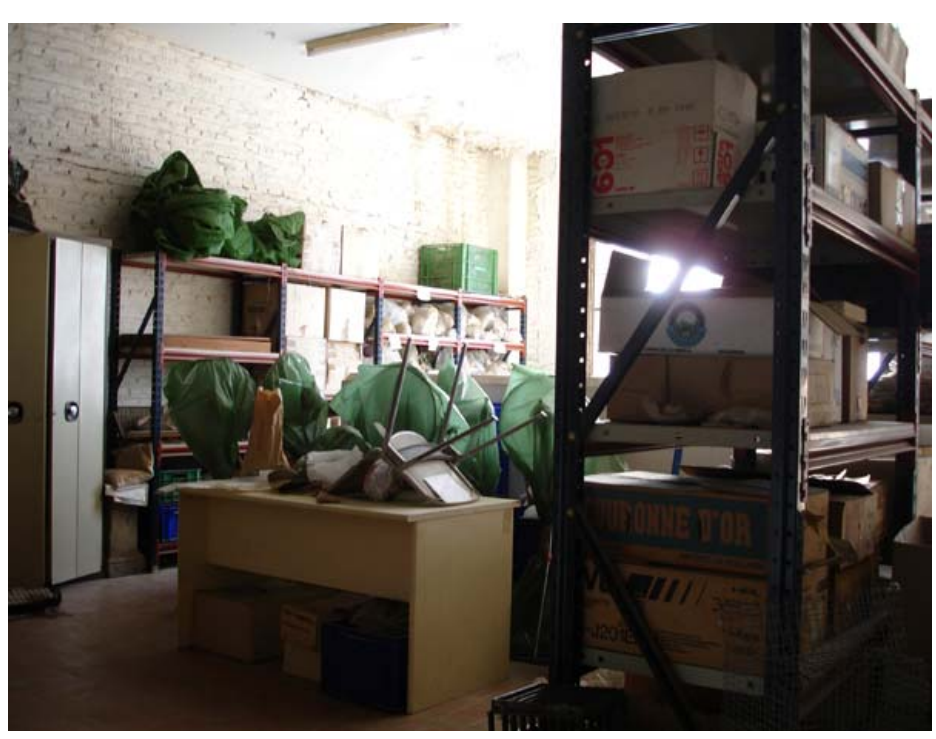

Almacén de antropología 


\section{d) Archivos documentales}

No hay un lugar diferenciado para la ubicación de los mismos, sino que se reparten por el despacho de conservadores y la biblioteca, disponiéndose de un planero para los documentos y un armario para la filmoteca. No se pueden diferenciar por tanto espacios para fonoteca, filmoteca, archivos fotográficos, archivos administrativos, archivos históricos, salas de consulta, etc.

\section{e) Área de fotografía}

No existe como tal. Solo hay un espacio para la documentación fotográfica a la entrada al taller de metales y cerámica que sólo es utilizada por los restauradores para la documentación de intervenciones, por lo que se contempla en la tabla de superficies dentro de la zona de restauración. El resto de la documentación fotográfica se realiza en la sala de conservadores si son piezas pequeñas o en sala si son piezas de movilidad dificultosa.
El museo cuenta con una sala en la planta alta situada sobre la dirección en la que antiguamente había un taller fotográfico, pero ahora está en desuso y sólo se utiliza la cámara digital. 


\section{III.5.4. ÁREA INTERNA SIN COLECCIONES}

\section{a) Dirección y administración}

Se considera en este apartado el despacho de dirección situado en la primera planta y la secretaría de dirección en la que se lleva la administración del museo, que es la sala que lo antecede.

Son solo estos dos espacios los que deben asumir estas funciones, incluidas salas de reuniones si es necesario. También se utiliza para sala de reuniones la antigua sala de investigación anexa a la biblioteca.

\section{b) Departamentos técnicos}

El museo cuenta con un despacho para conservadores en la primera planta, contiguo al de dirección, que comparten tres de los conservadores del museo y dos catalogadores actualmente contratados para informatizar la colección en el programa Domus. Por tanto, aunque pertenezca al área interna sin colecciones, en ocasiones sí las hay, bien por el trabajo de los conservadores, bien por trabajos de documentación interna o incluso por atenderse aquí a veces a los investigadores. Además, en este espacio se conserva, como ya se ha dicho, la colección de numismática.

Además de este despacho existe otro en la planta alta, justo encima del despacho de dirección, ocupado por un conservador.

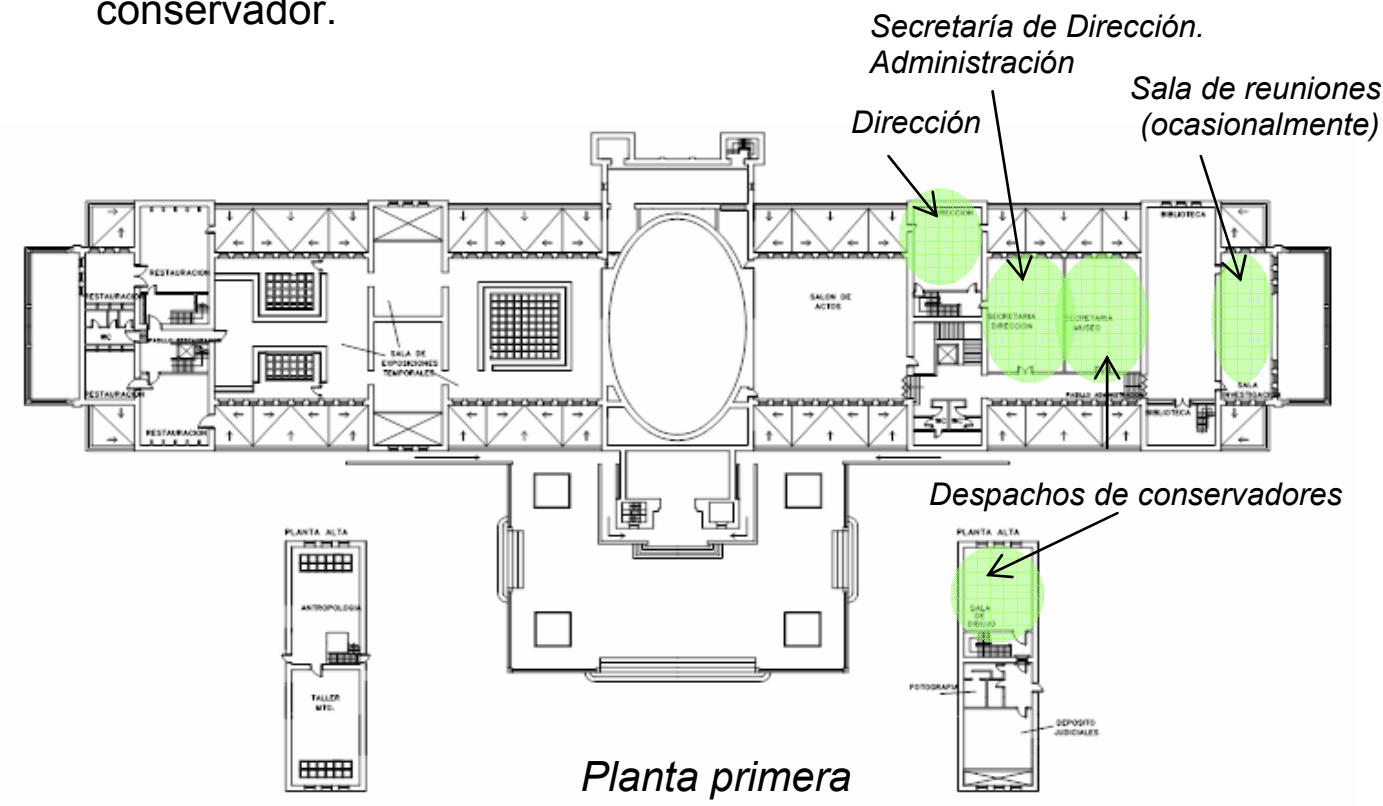

Planta alta 


\section{c) Vigilancia y seguridad}

No existe consola de seguridad ni circuito cerrado ed televisión. Los vestuarios de los vigilantes se sitúan en la planta sótano, al lado del ascensor. No hay zonas de descanso ni aseos independientes.

\section{d) Mantenimiento y limpieza}

El museo no tiene zonas separadas para el mantenimiento, sino que éstas se reparten por salas diferentes. No cuenta con cuarto de calderas, cuarto eléctrico, cuarto de fontanería ni central informática. Hay un cuarto de limpieza a la entrada del museo, en el espacio de acceso desde la calle, y otro en el sótano, en el espacio de acceso desde el ascensor. Existen dos espacios para el almacén de objetos o herramientas de mantenimiento, uno de ellos situado en el sótano, en el espacio de acceso desde el ascensor, es decir, anexo al cuarto de limpieza antes citado, y otro en la planta alta sobre la zona de restauración.

\section{e) Almacenes de enseres de exposiciones temporales}

No existe como tal en el museo, se disponen en el almacén del sótano o en otros espacios sin uso del museo en los que se acumulan objetos de todo tipo.

\section{f) Otros espacios}

Existen ocho terrazas en la planta primera, cuatro en el frente y cuatro en la parte trasera del museo, a las que se acceden por escaleras internas y que no son accesibles para el público. Éstas se corresponden en planta baja con otras, de las cuales, las cuatro de la parte trasera han sido cegadas para aprovecharse como salas de exposición permanente y de las cuatro de la fachada principal del edificio, dos sirven de acceso y salida del museo respectivamente y las otras dos no son accesibles al 
216

público y además están apuntaladas para evitar desprendimientos del artesonado.

Existen dos aseos para el personal del museo, uno en la zona de despachos y otro al lado de la zona de los talleres de restauración. 

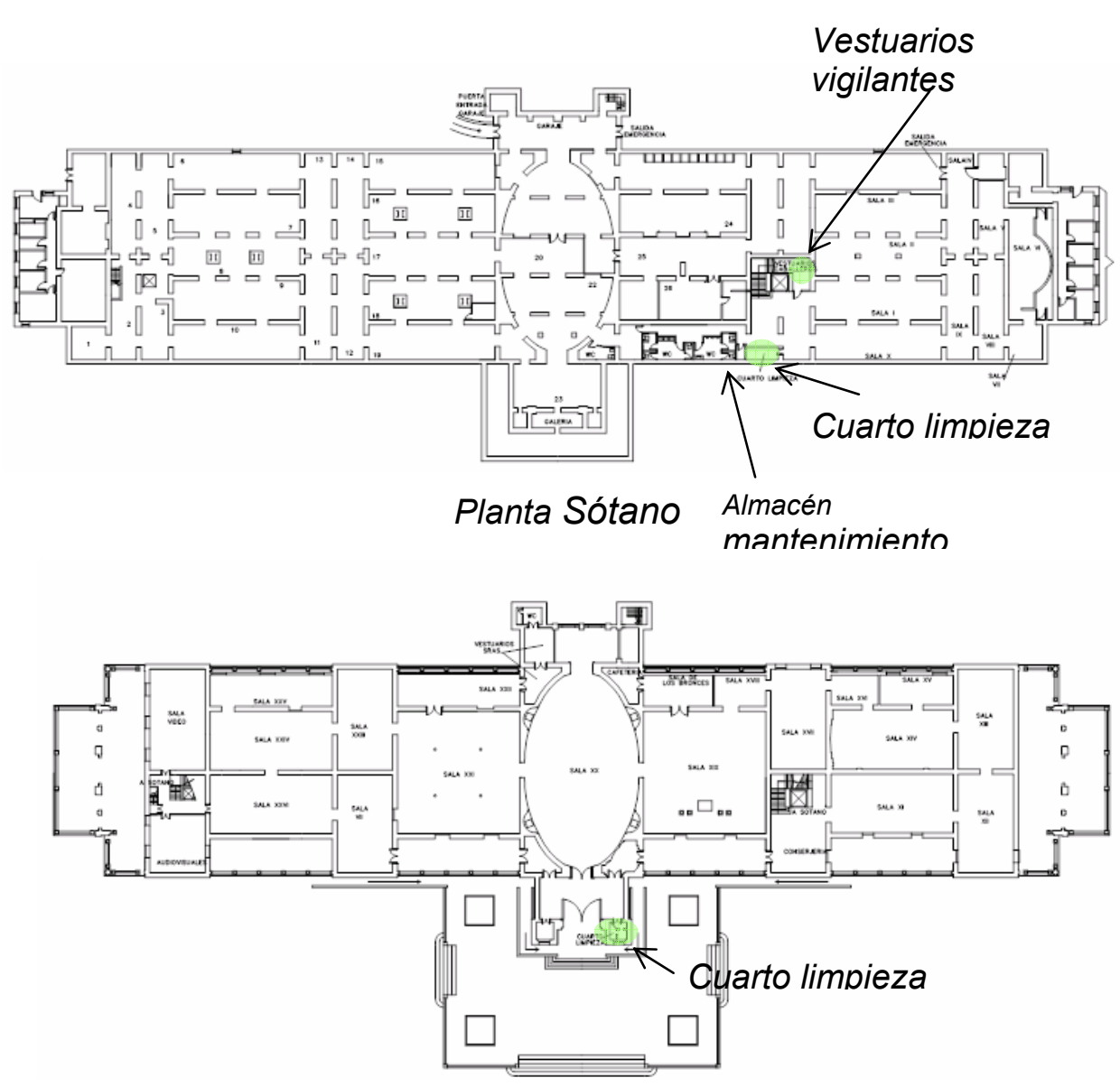

Planta Baja

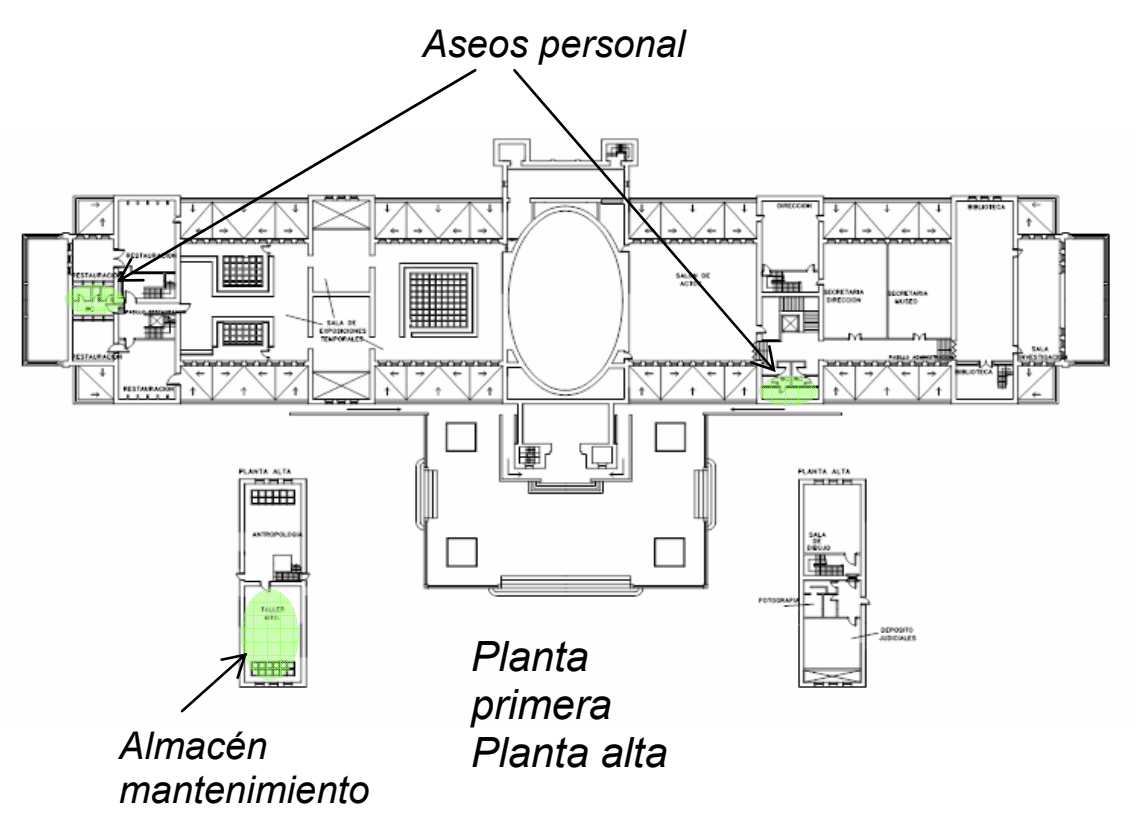




\section{III.6. ACCESOS Y CIRCULACIONES}

\section{III.6.1. Superficies y características de los accesos y las vías de circulación}

Las superficies de los accesos al museo y las vías de circulación, tanto de personas como de las obras, se detallan en la tabla de superficies y se han comentado en el apartado anterior dedicado a la descripción de los espacios.

Destacar aquí que sólo existe un acceso para las personas, ya sean personal de museo o público visitante, situado en la fachada principal del edificio. Se accede mediante las escaleras o rampas de este frente, por las que se llega a la puerta principal. Tras atravesarla, se pasa por un espacio de tránsito ya comentado desde el que se llega a la terraza que, a modo de pasillo, conduce al vestíbulo de recepción del museo. A partir de aquí, el público podrá acceder a las zonas de exposición permanente, bien en la misma planta baja o bien descendiendo hasta el sótano, o subir a la planta primera para ir a la biblioteca o a la zona de exposiciones temporales si las hubiera. El personal del museo subirá hasta la planta primera que es donde se sitúa la zona de administración y conservación.

La entrada de obras suele hacerse por el almacén del sótano, pudiendo llegar el medio de transporte utilizado desde la calle hasta la puerta del mismo, situada en la parte trasera del edificio, detrás del óvalo. No obstante, ya se ha citado anteriormente que desde el almacén, por el montacargas, sólo pueden transportarse obras de dimensiones o peso medianos (menor o igual a $400 \mathrm{Kg}$. y no muy voluminosas) para llevarlas a las salas o a los talleres de restauración, por lo que en ocasiones las obras más pesadas o de mayor volumen acceden al museo por el óvalo y desde allí deben salvar todas las escaleras que se encuentren en su camino. 
Las principales vías de circulación del edificio son, de manera horizontal, en las plantas baja y sótano las mismas salas, pues no existen pasillos de tránsito ni zonas de descanso en el área expositiva. Sólo pueden considerarse vías de circulación en la planta baja, la entrada al edificio y las dos terrazas de acceso y de salida del edificio; la primera de ellas utilizada por todas las personas que acceden al museo (visitantes, personal...) y la de salida utilizada sobre todo por los visitantes, pues se sitúa al final del recorrido expositivo, después de la última sala, que es la XXVII. En la planta primera en el ala oeste del edificio sí hay un pasillo en el que se disponen la secretaría de dirección o administración y la dirección, el despacho de los conservadores y la biblioteca, así como el salón de actos en el extremo opuesto a la biblioteca. Al otro lado del óvalo, en el ala este, se sitúan las salas dedicadas a exposiciones temporales y los talleres de restauración, a los que se llega por un pasillo demasiado estrecho para el paso de determinadas obras. Para llegar a este ala desde la opuesta, en la planta primera se rodea el óvalo por un pasillo recientemente arreglado para instalar una rampa que salvara los escalones. Sirven de circulación, a continuación de este pasillo, las salas dedicadas a exposiciones temporales cuando no hay ninguna instalada, pues a veces son atravesadas por el personal de mantenimiento o los restauradores para llegar del ala oeste al este y viceversa, utilizando también para este paso el salón de actos. Por tanto, aunque no se recogen estas salas de exposiciones temporales ni el salón de actos como vías de circulación porque estos espacios están destinados a otros fines, son muchas veces utilizados como zona de paso.

De manera vertical, el museo cuenta con varias escaleras, un ascensor y un montacargas:

De abajo a arriba, desde el sótano parten tres escaleras. Una se sitúa anexa al ascensor y sube hasta la zona de administración de la planta primera pasando por el vestíbulo de acceso al museo en la planta baja; es la más utilizada para la circulación de personas y la única que puede utilizar el público. Otra está situada en el ala 
opuesta del edificio, anexa al montacargas, y aunque también comunica con la planta primera, no es seguida como la anterior, sino que se parte en otra escalera en la planta primera. Ésta sube hasta la zona de restauración de la planta primera pasando por un espacio contiguo a la sala XXVI del museo y es utilizada sólo por el personal del museo. La tercera escalera que parte del sótano está situada en la parte trasera del edificio, detrás del óvalo, en la zona de entrada de colecciones, y sube por una de las torres hasta la planta alta, sin pasar por la planta baja ni la planta primera. Actualmente no se utiliza, pues llega a una zona que actualmente era la vivienda de la restauradora del museo y después se utilizó con almacén pero ahora está prohibido el acceso porque según el estudio de unos arquitectos el suelo padece aluminosis y no soporta peso.

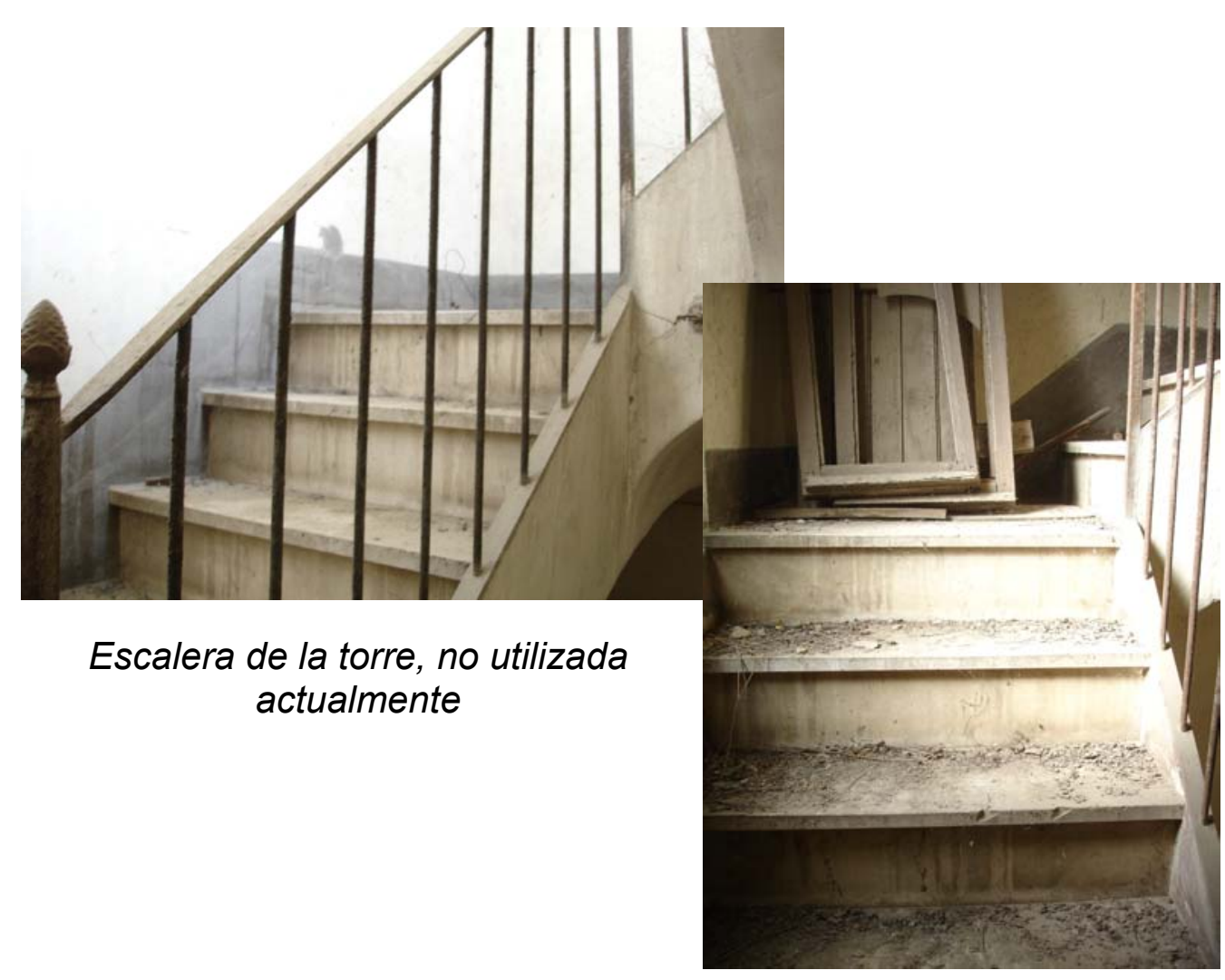


Para acceder desde la planta primera a la planta alta, que solo ocupa los dos cuerpos más altos del edificio, situándose uno de ellos sobre la zona de restauración y el otro sobre el despacho de dirección, hay sendas escaleras que parten de esta planta primera y solo cubren este tramo desde la primera a la alta. Estas sólo son utilizadas por el personal del museo, pues el público no accede a estas zonas.

El ascensor se sitúa anexo a las primeras escaleras que se han citado, las que pasan por el vestíbulo de acceso al museo y son utilizadas por personal y público visitante.

El montacargas se sitúa anexo a otras escaleras, las que llegan hasta la zona de restauración, en el ala oriental del edificio.

\section{III.6.2 Descripción y análisis de los accesos y circulaciones verticales y horizontales de:}

\section{a) Bienes Culturales (obras)}

Como ya se ha dicho, la entrada de piezas suele realizarse por una puerta del sótano que da directamente al exterior, desde la que las obras entran directamente en el almacén y desde éste pueden llevarse por el montacargas a las plantas baja y primera y después a cualquier lugar del museo. No existe área específica de recepción de colecciones ni sala de acondicionamiento o climatización para las piezas.

El montacargas de que dispone el museo para la circulación vertical de las piezas soporta el peso de 400 $\mathrm{Kg}$. como máximo y tiene una plataforma de aproximadamente 1 metro de lado $\left(1 \mathrm{~m}^{2}\right)$, por lo que tiene esta limitación que hace que la circulación de obras no sea satisfactoria. Cuando las obras pesan más de los $400 \mathrm{Kg}$. que permite el montacargas o son demasiado voluminosas para entrar el él y quieren llevarse a la zona de 
restauración o de exposiciones temporales de la planta primera o a la de exposición permanente de la planta baja, ingresan en el museo por la planta baja, por el óvalo. No obstante, si van a quedarse en planta baja no tienen que salvar escaleras, pero si tienen que subir a planta primera y no pueden subir en el montacargas la única solución es salvar escaleras. Además, desde el montacargas hasta la zona de administración tendrían que salvar las escaleras del salón de actos.

Entrada habitual de piezas y circulación hasta el montacargas

Muelle descarga. Entrada piezas.

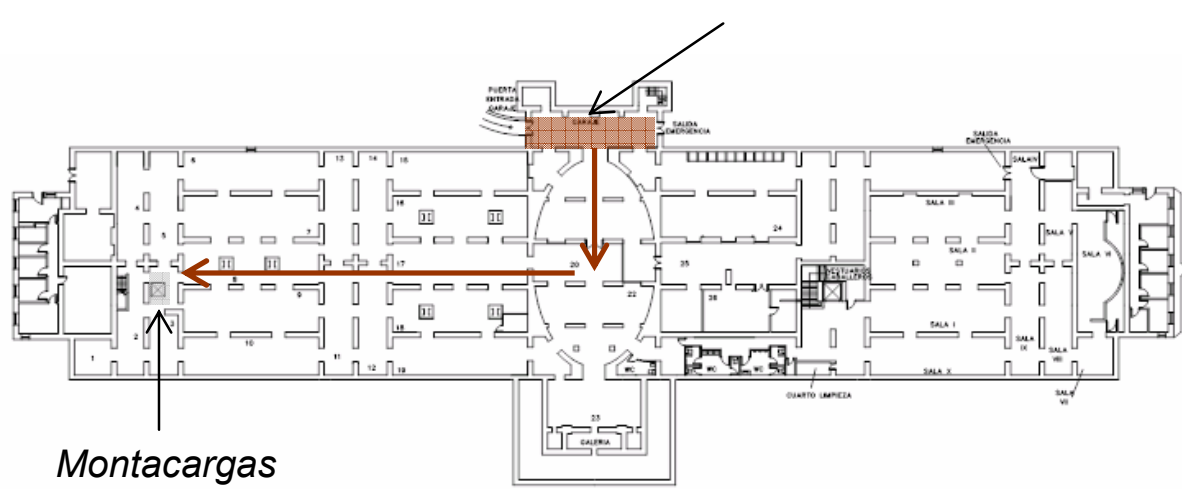

Planta Sótano

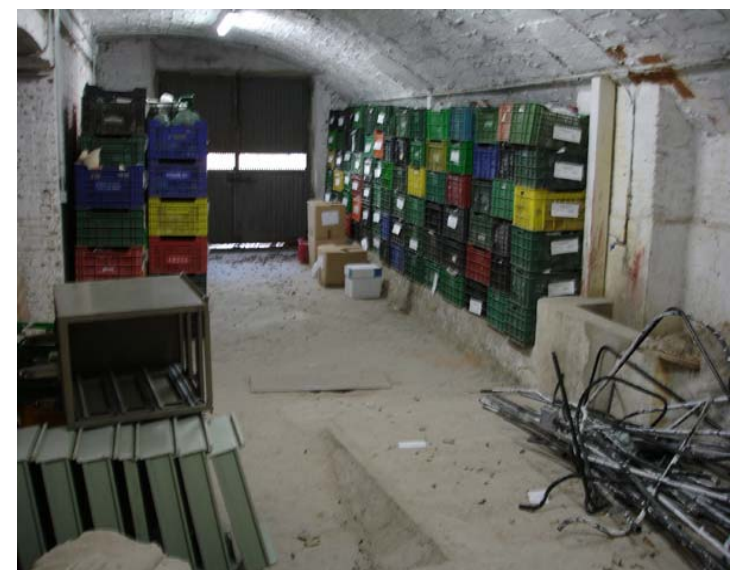

Muelle de descarga/ Área de recepción de colecciones
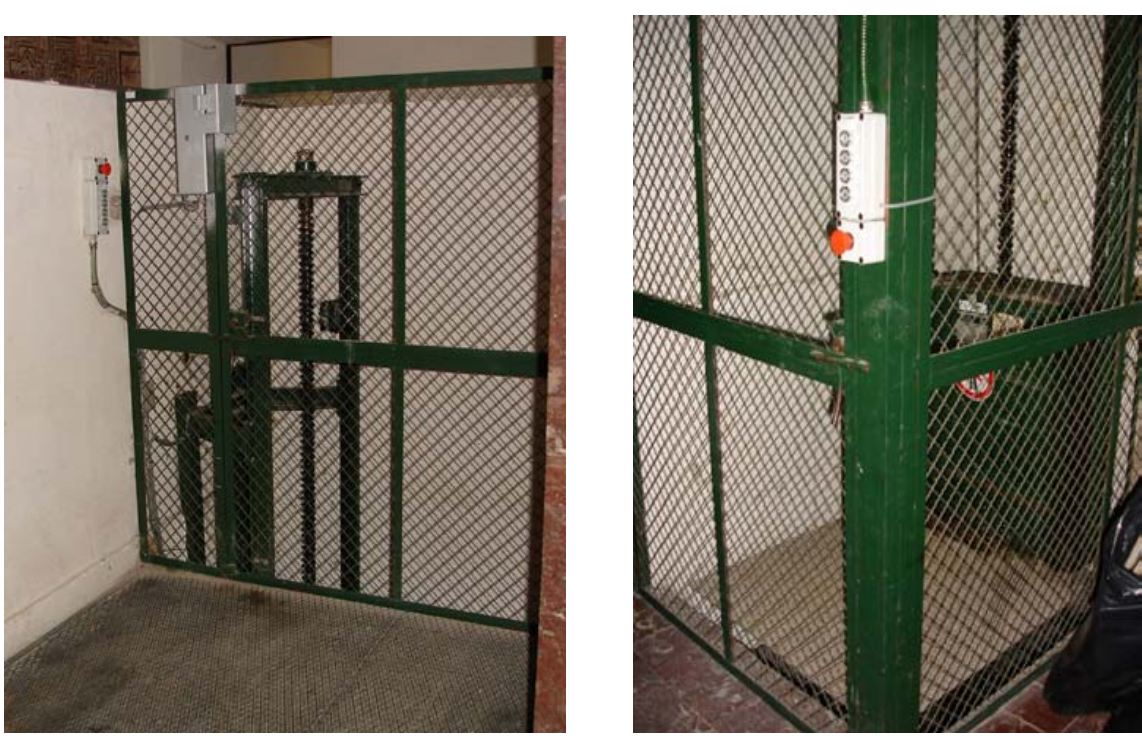

Montacargas 
A partir de aquí, algunos de los movimientos más frecuentes de piezas en el museo y sus facilidades o dificultades son los siguientes:

- Área de recepción (almacén normalmente) $\rightarrow$ desembalaje (en el mismo almacén) $\rightarrow$ registro (en almacén o en sala) $\rightarrow$ montacargas $\rightarrow$ sala de exposiciones temporales.

Es el movimiento de las piezas que ingresan en el museo para participar en exposiciones temporales.

Para llegar desde el montacargas hasta las salas de exposiciones temporales no hay que salvar escalones.

- Área de recepción (almacén normalmente) $\rightarrow$ desembalaje (en el mismo almacén) $\rightarrow$ registro (en almacén o en talleres) $\rightarrow$ talleres de restauración.

Es el recorrido que suelen tener las piezas que llegan al museo procedentes de excavaciones, donaciones, etc. si van a pasar a las salas de exposición permanente o es necesaria la intervención.

Puede hacerse sin problemas por el montacargas siempre que, como ya hemos dicho, la pieza no supere los parámetros permitidos por éste.

- $\quad$ Área de recepción del almacén $\rightarrow$ desembalaje (en el mismo almacén) $\rightarrow$ almacén.

Es lo habitual en la gran cantidad de piezas procedentes de excavaciones arqueológicas que van a permanecer en el almacén en principio, sin restaurarse ni exponerse.

- $\quad$ Exposición permanente $\rightarrow$ almacenes (y viceversa).

Es el recorrido de piezas que cambian de la exposición permanente, aunque es más frecuente de la exposición permanente al almacén directamente porque a la inversa, es decir, cuando una obra del almacén va a exponerse, suele restaurarse primero. 
Por el montacargas no hay que salvar escaleras. El problema está si la pieza es demasiado grande o pesada para el montacargas lo que implicaría tener que transportarla a peso por las escaleras. Hay que decir que las obras de gran tamaño de la exposición permanente no suelen moverse.

- Almacenes $\rightarrow$ taller de restauración $\rightarrow$ exposición permanente.

Cuando una obra va a exponerse suele restaurarse antes, con lo que llega a las salas de exposición desde los talleres de restauración.

Por el montacargas este movimiento es seguro, con lo que piezas que no puedan transportarse en él no suelen moverse ni del almacén ni de la sala de exposición permanente si se encuentran en ésta y suelen intervenirse in situ si es necesario.

A la inversa, es decir, desde la exposición permanente a los almacenes del sótano no se produce, pues si una obra es intervenida puede después volver a su lugar en la exposición, salir para una exposición temporal o ir al almacén climatizado del taller de restauración de piedra, no al del sótano.

- $\quad$ Almacenes $\rightarrow$ taller de restauración $\rightarrow$ almacén climatizado de la zona de restauración.

Como ya hemos dicho anteriormente, cuando una obra es intervenida, ya sea de los almacenes o de las salas de exposición, si va a ir a almacén se deposita en el almacén climatizado, pues el del sótano no reúne las condiciones necesarias para que la intervención haya servido.

El movimiento es similar al anterior, puesto que el almacén climatizado se sitúa en el interior del taller de piedra, no hay impedimentos para el transporte.

- $\quad$ Almacenes $\rightarrow$ sala de investigación/ documentación (y viceversa). 
Actualmente a los investigadores se les atiende en el mismo almacén, en la sala de conservadores o en la biblioteca o áreas próximas a la misma. Para transportar una obra desde el almacén hasta esta zona, desde el montacargas hay que salvar un pequeño tramo de escaleras hasta la zona de administración y dos hasta la biblioteca.

Podemos citar en este apartado el movimiento de obras para su documentación o catalogación, puesto que actualmente esta tarea se realiza en la sala de conservadores. No existe espacio específico para la documentación fotográfica, por lo que ésta suele hacerse en este mismo lugar o bien en los talleres de restauración.

- Almacenes/ Exposición permanente $\rightarrow$ taller de restauración $\rightarrow$ salida

Es el movimiento habitual cuando una obra sale del museo para ser prestada para una exposición temporal externa.
Del almacén al taller de restauración ya ha sido comentado el recorrido, mientras que del taller de restauración la obra suelen salir del museo por la puerta del sótano por la que acceden normalmente.

De la exposición permanente al taller de restauración también pueden transportarse piezas por el montacargas. Aquellas que son de difícil manipulación por su gran peso o volumen no suelen moverse y por lo tanto no son prestadas para exposiciones temporales.

Es de destacar dentro de este apartado que sería necesario acondicionar el museo para permitir la manipulación y el transporte de las obras de manera fácil y segura, por lo que habría que salvar los escalones que hay entre la zona de restauración y la de administración, así como instalar un montacargas que permita mover todas las piezas del museo. 
Por otra parte, no existe sectorización alguna en el museo, es decir, todos los espacios están comunicados, con lo que haría falta establecer un protocolo de acceso a determinados espacios en los que suele haber piezas como son los talleres de restauración.

\section{b) Público visitante}

El público visitante accede al museo por las escaleras o la rampa de la fachada principal del edificio y llega a un área de tránsito desde la que se accede a la derecha a una terraza techada pero descubierta en su lateral que sirve de pasillo y llega hasta el vestíbulo de entrada al museo. No existe zona diferenciada para el acceso individual, de grupos o usuarios de la biblioteca o salas de investigación, como tampoco para el personal del museo.

A partir del vestíbulo detallaremos los movimientos que suelen hacer los visitantes del museo.
Si el visitante sólo tiene intención de acceder a la biblioteca debe subir a la planta primera por el ascensor o la escalera que parten del vestíbulo y tomar el pasillo a la izquierda para salvar un tramo de escaleras de acceso a la biblioteca. Por tanto, la biblioteca no es accesible a personas con movilidad reducida (es la única zona del museo que no lo es).

Si el visitante quiere acceder al salón de actos tendrá que subir también a la planta primera por el ascensor o la escalera que parten del vestíbulo y tomar a la derecha para salvar el tramo de escalera que accede al salón de actos. Este tramo sí es salvable por una plataforma elevadora para silla de ruedas. El mismo recorrido tendrá que hacer para llegar a la zona de exposiciones temporales, atravesando el salón de actos y tomando el pasillo que rodea el óvalo.

El recorrido más habitual que hace el público es el de la exposición permanente, que será detallado en el apartado 
de museografia. La circulación por la zona de exposición permanente está determinada de forma cronológica, aunque el recorrido puede hacerse libremente, es decir, se puede visitar antes la planta baja que el sótano, pero el recorrido que marca el museo es el siguiente: desde el vestíbulo se baja al sótano por la escalera (indicada bajo el rótulo "Prehistoria") o el ascensor y se llega a un espacio bajo el vestíbulo que sirve de distribuidor y desde el que se inicia la visita a mano izquierda, con el recorrido desde la sala I hasta la $X$, que vuelve a salir al mismo espacio; desde aquí se sube de nuevo a la planta baja, al vestíbulo de entrada.

Desde él se accede a la segunda zona expositiva bajo el título "Arqueología", cuyo recorrido también está determinado para pasar por todas las salas de esta planta, desde la XI hasta la XX, que es el óvalo, por el que se pasa al ala este del edificio, y desde ésta a la XXVII, en la que termina la visita; la salida del museo se realiza desde esta sala XXVII, que da acceso a la terraza situada en simetría con la de acceso y de las mismas características, por la que se sale de nuevo al espacio por el que se entró en el museo y de éste a la calle.

Así, la entrada y la salida se realizan por el mismo espacio, de pequeñas dimensiones. 


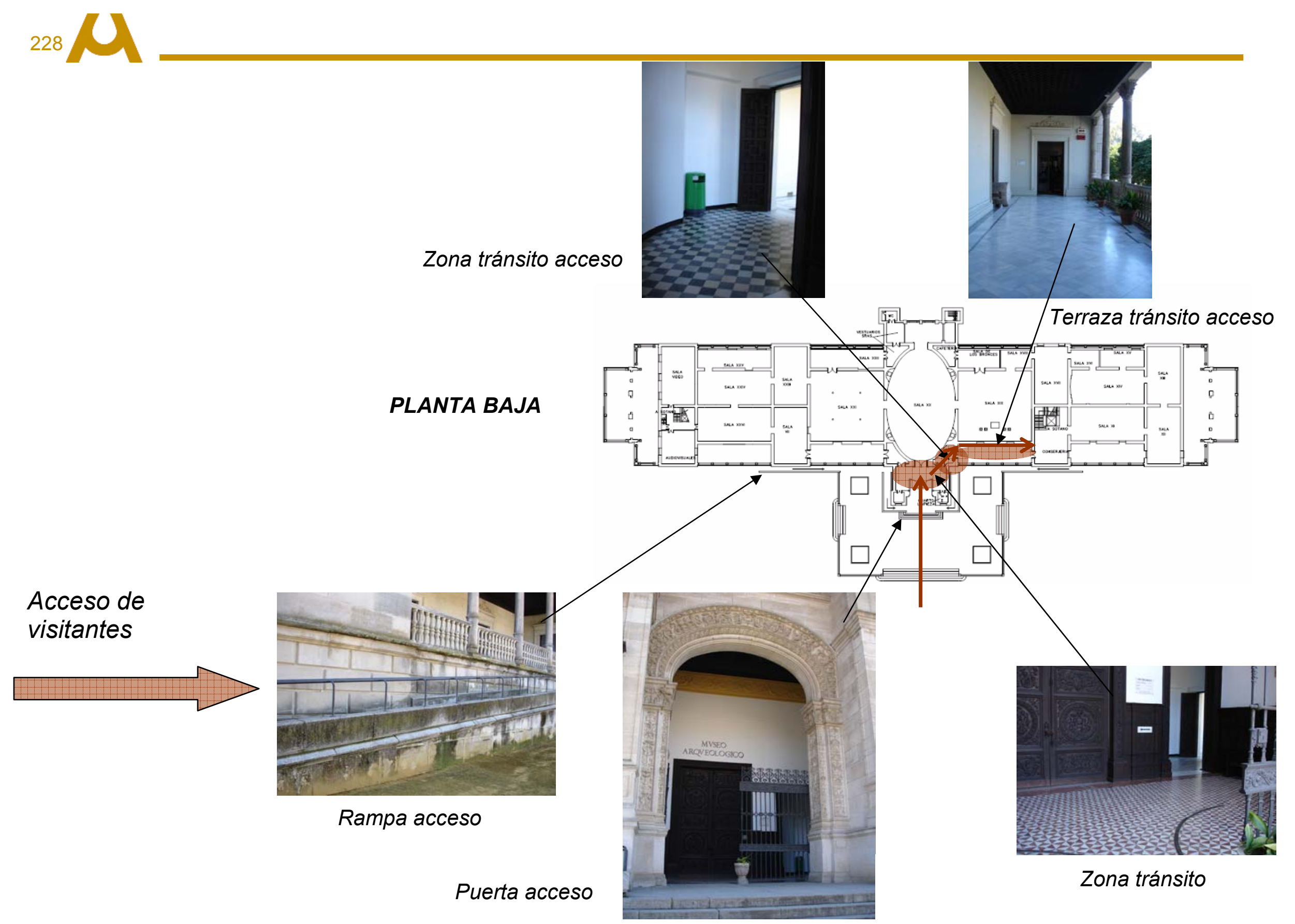


Pasillo por detrás del óvalo, que comunica el salón de actos con la zona de exposiciones temporales

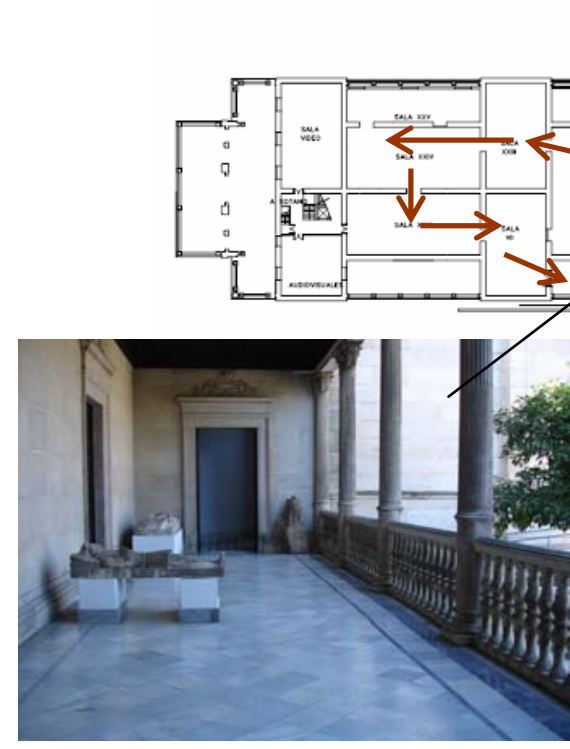

Terraza salida

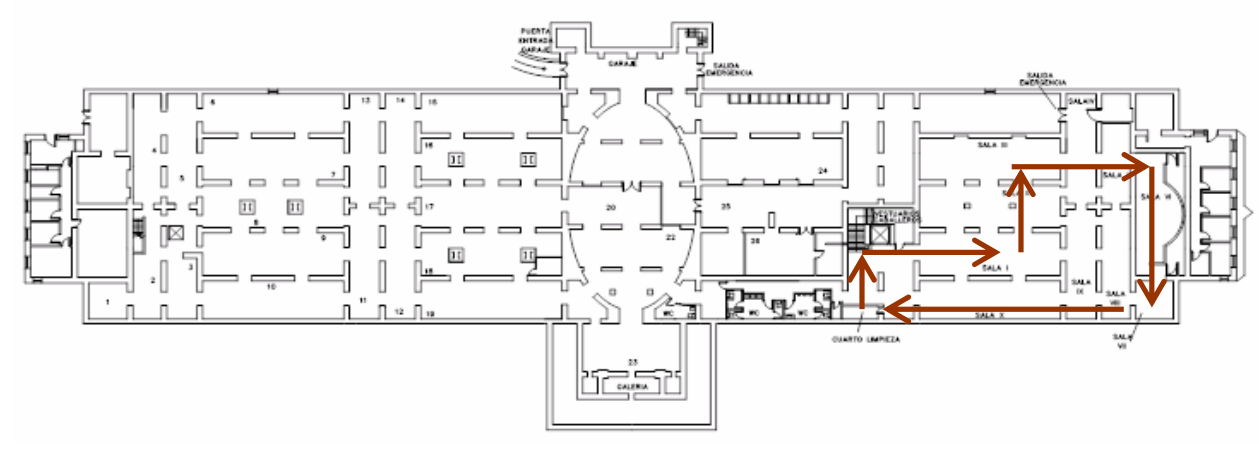

Planta

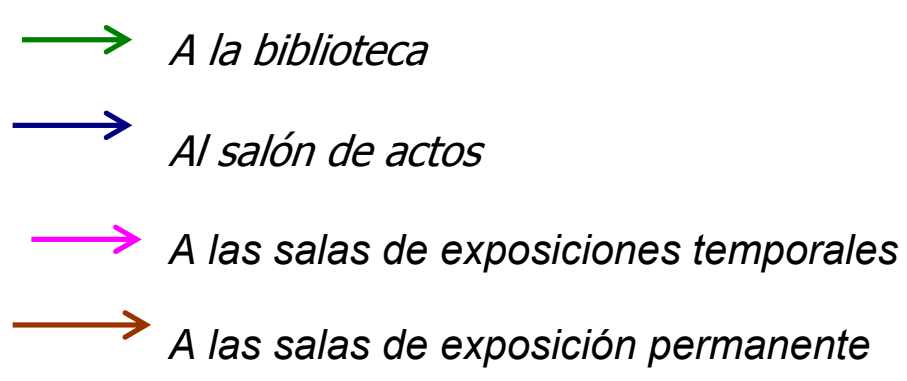




\section{c) Personal del museo}

Como ya se ha dicho, el personal del museo accede al mismo por el mismo lugar que el público visitante (Ver acceso de visitantes). Desde el vestíbulo, el personal suele dirigirse a su puesto de trabajo:

El personal técnico del museo, así como el de dirección y administración, está ubicado en la planta primera, en el ala occidental del edificio, a la que acceden por las escaleras o el ascensor del vestíbulo, salvo los restauradores, que deben cruzar hasta el ala oriental. Desde aquí, pueden moverse a los almacenes del sótano por el ascensor o escaleras. Una de las entradas almacén del sótano se sitúa en la zona expositiva, en la sala IV y a la otra se llega directamente por las escaleras que vienen desde la planta baja en la zona oriental, al lado del montacargas. Destacar que los talleres de restauración se encuentran apartados del resto del personal, en el otro extremo del museo.

El personal de vigilancia tiene su vestuario en el sótano, al lado del ascensor, y desde aquí se dirige a salas.
El personal de atención al público se sitúa solamente en el vestíbulo de entrada y son una persona o dos.

El personal de mantenimiento y limpieza se mueve libremente por todo el museo.
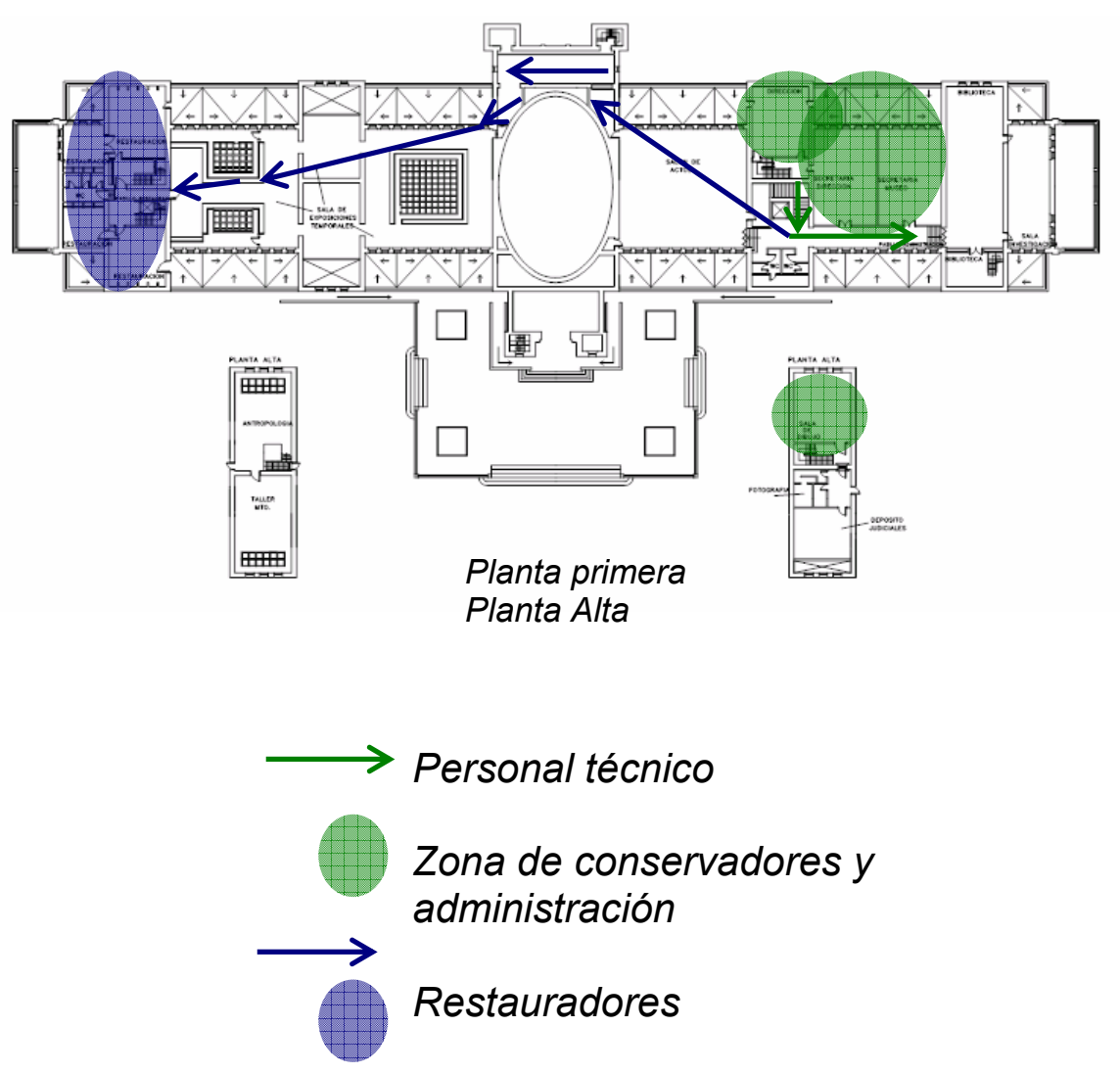

Zona de restauración 


\section{d) Proveedores, servicios y mantenimiento externo}

Todas las mercancías suelen entrar por el almacén, por la zona de descarga, que se ha denominado área de recepción de colecciones porque también sirve a este fin, pero es en realidad el muelle de descarga de cualquier mercancía que llega al museo.

Cualquier persona que entre en el museo lo hace por el acceso ya comentado.

Desde estos puntos de acceso también utilizan el ascensor para subir a las plantas superiores.

Es importante destacar que la zona de administración puede independizarse de la de exposición, es decir, no hace falta pasar por la exposición para llegar a la zona del personal técnico del museo y viceversa. No obstante, la zona de exposición no está separada del vestíbulo de acceso por puertas que puedan cerrarse, con lo que los trabajadores del museo siempre tienen acceso a las salas estando el museo cerrado.

Tampoco hay que pasar por la zona de exposición permanente para acceder a la de exposiciones temporales o al salón de actos y viceversa.

Así, podrían independizarse algunas zonas según el horario de funcionamiento del museo. 


\section{TABLA DE}

SUPERFICIES

\begin{tabular}{|c|c|c|c|}
\hline \multirow{7}{*}{$\begin{array}{l}0 \\
0 \\
0 \\
0 \\
0 \\
0 \\
0\end{array}$} & \multirow{7}{*}{ 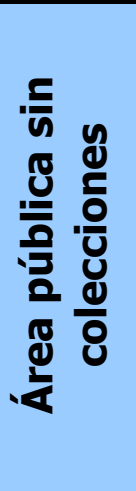 } & $\begin{array}{l}\text { a) Área de acogida } \\
\text { Vestíbulo }\end{array}$ & $\begin{array}{l}39,55 \\
39,55\end{array}$ \\
\hline & & b) Servicios & 27,93 \\
\hline & & Aseos para el público & 27,93 \\
\hline & & $\begin{array}{l}\text { c) Salas para actividades } \\
\text { Salón de Actos }\end{array}$ & $\begin{array}{r}\mathbf{2 8 8 , 2 6} \\
237,44\end{array}$ \\
\hline & & Antigua Sala de Investigación, hoy varios usos (Asociación de Amigos del Museo, reuniones, cursos) & 50,82 \\
\hline & & $\begin{array}{l}\text { d) Biblioteca } \\
\text { Sala de lectura } \\
\text { Despacho bibliotecario/a }\end{array}$ & $\begin{array}{c}\mathbf{1 6 9 , 4 2} \\
140,75 \\
28,67\end{array}$ \\
\hline & & Total & 525,16 \\
\hline
\end{tabular}




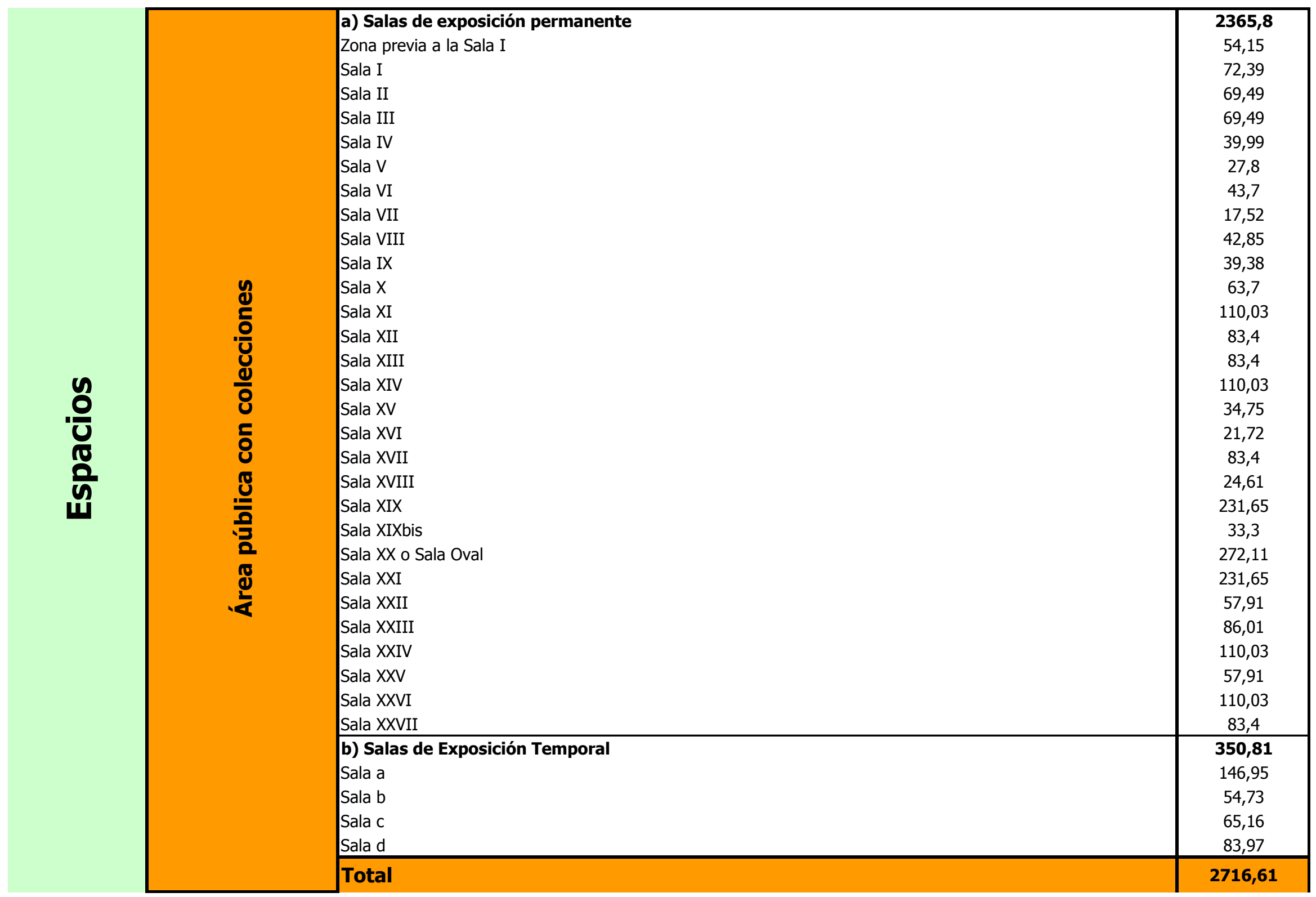




\begin{tabular}{|c|c|c|c|}
\hline \multirow{30}{*}{$\begin{array}{l}\text { y } \\
0 \\
0 \\
0 \\
0 \\
0\end{array}$} & \multirow{12}{*}{ 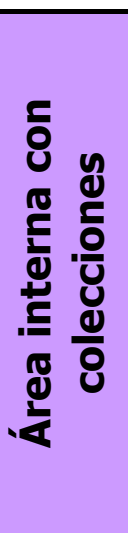 } & a) Área de recepción de colecciones (muelle de descarga) & 58,93 \\
\hline & & b) Conservación (Talleres de Restauración) & 156,1 \\
\hline & & Taller de restauración de metales y cerámica & 88,9 \\
\hline & & Zona de documentación fotográfica & 15,07 \\
\hline & & Taller de restauración de piedra & 52,13 \\
\hline & & c) Almacenes & 1913,98 \\
\hline & & Almacén del sótano & 1749,6 \\
\hline & & Almacén de piezas restauradas & 24,5 \\
\hline & & Almacén de metales & 12,14 \\
\hline & & Almacén de antropología & 83,43 \\
\hline & & Antiguo almacén de depósitos judiciales, hoy almacén & 44,31 \\
\hline & & Total & 2129,01 \\
\hline & & a) Dirección y Administración & 152,6 \\
\hline & & Despacho de dirección & 59,95 \\
\hline & & Secretaría de dirección y administración & 92,65 \\
\hline & E & b) Despartamentos técnicos & 152,6 \\
\hline & 음 & Despacho de conservadores de la primera planta & 92,65 \\
\hline & Ư & Despacho de conservadores de la planta alta & 59,95 \\
\hline & $\underline{\underline{\omega}}$ & c) Vigilancia y Seguridad & 11,57 \\
\hline & 8 & Vestuarios del personal de seguridad & 11,57 \\
\hline & 들 & d) Mantenimiento y Limpieza & 96,6 \\
\hline & $\pi$ & Almacén de productos de limpieza de la planta baja & 5,21 \\
\hline & c & Almacén de productos de limpieza del sótano & 5,79 \\
\hline & $\frac{1}{d}$ & Almacén de mantenimiento del sótano & 2,17 \\
\hline & $\underline{\underline{E}}$ & Almacén de mantenimiento de la planta alta & 83,43 \\
\hline & & e) Otros espacios & 59,37 \\
\hline & a) & Almacén de objetos de restauración para la limpieza de vitrinas & 9,26 \\
\hline & & Aseos del personal del museo de la zona de administración & 31,28 \\
\hline & & Aseos del personal del museo de la zona de restauración & 18,83 \\
\hline & & Total & 472,74 \\
\hline
\end{tabular}




\begin{tabular}{|c|c|c|c|}
\hline \multirow{5}{*}{$\begin{array}{l}0 \\
0 \\
0 \\
0 \\
0\end{array}$} & \multirow[t]{2}{*}{ 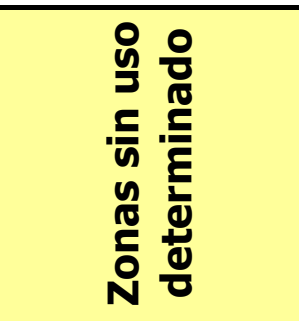 } & $\begin{array}{l}\text { Dos espacios tras la sala VI del sótano } \\
\text { Antigua sala de vídeo en el extremo oriental del edificio en planta baja } \\
\text { Antigua sala de audiovisuales en el extremo oriental del edificio en planta baja } \\
\text { Espacio detrás del óvalo en planta baja } \\
\text { Antigua casa de la restauradora detras el óvalo en planta alta } \\
\text { Antigua sala de fotografía junto al despacho de conservadores de planta alta }\end{array}$ & $\begin{array}{l}13,01 \\
86,01 \\
49,52 \\
95,84 \\
94,84 \\
12,74 \\
\end{array}$ \\
\hline & & Total & 351,96 \\
\hline & \multirow[t]{2}{*}{ 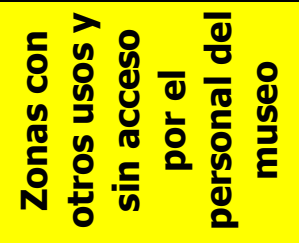 } & $\begin{array}{l}\text { Espacio en el extremo occidental del edificio con acceso exterior, no comunicado con el museo (Uso por Lipasam) } \\
\text { Espacio en el extremo oriental del edificio con acceso exterior, no comunicado con el museo } \\
>\text { Transformador de Sevillana para el abastecimiento eléctrico del parque } \\
>\text { Club Unesco }\end{array}$ & $\begin{array}{c}\mathbf{9 3 , 0 9} \\
\mathbf{1 6 5 , 4 8} \\
55,45 \\
110,03\end{array}$ \\
\hline & & Total & 258,57 \\
\hline & & Total & 6454,05 \\
\hline
\end{tabular}

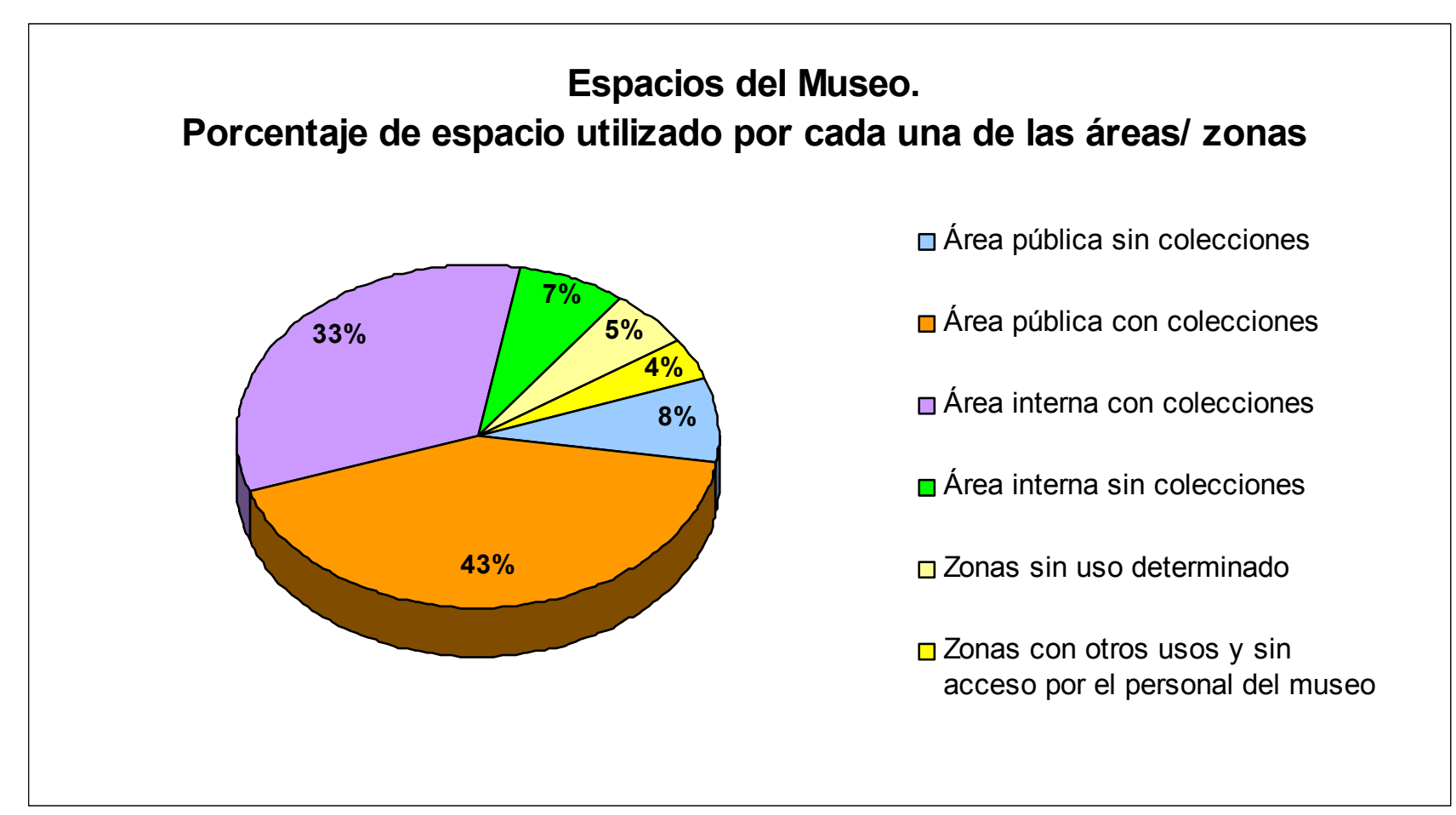




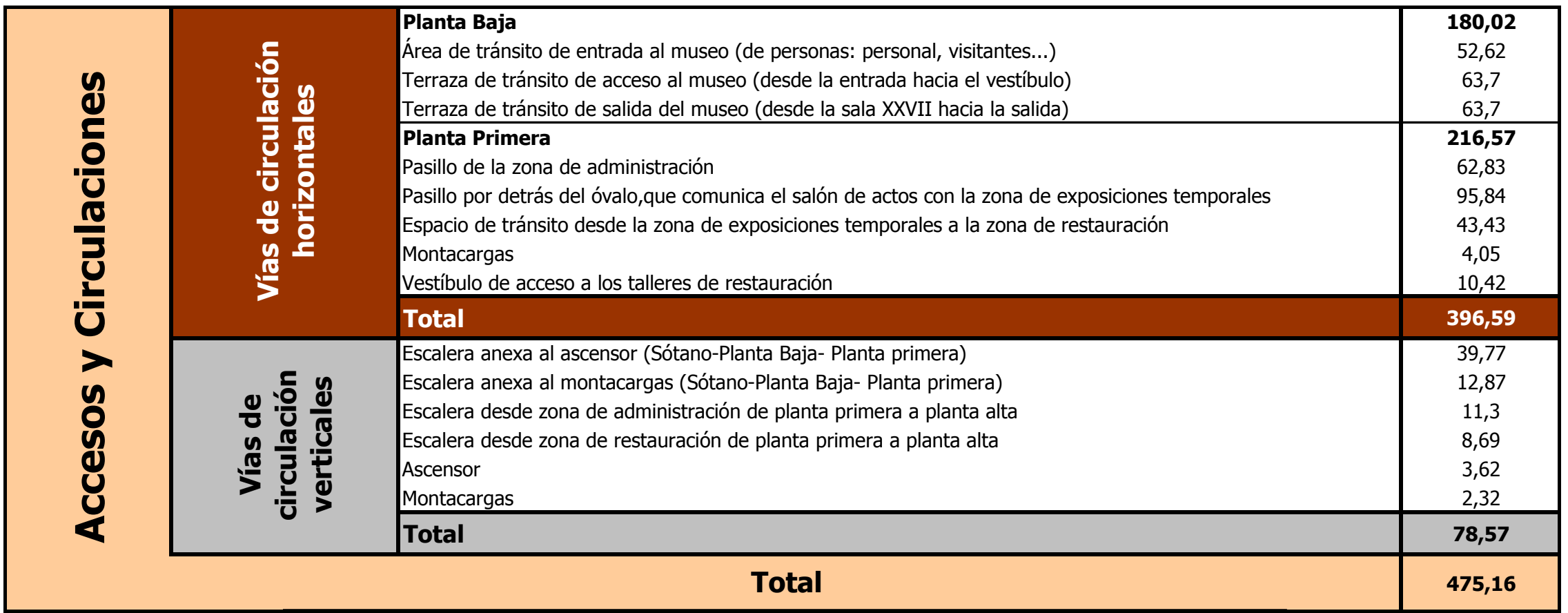

\section{Espacios del Museo.}

Porcentaje utilizado por cada una de las áreas/zonas, incluyendo accesos y vías de circulación

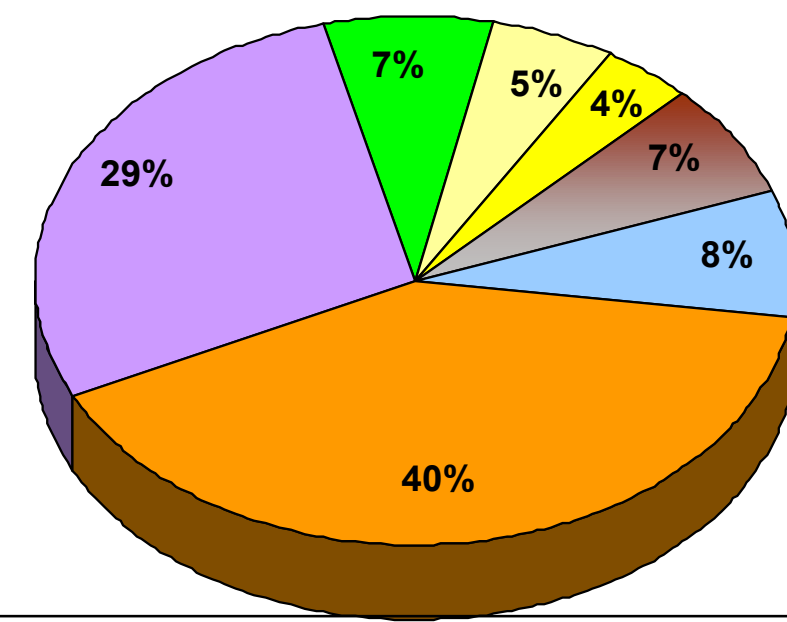

$\square$ Área pública sin colecciones

$\square$ Área pública con colecciones

$\square$ Área interna con colecciones

$\square$ Área interna sin colecciones

$\square$ Zonas sin uso determinado

$\square$ Zonas con otros usos y sin acceso por el personal del museo

$\square$ Accesos y Circulaciones 


\section{PLANOS DE DISTRIBUCIÓN DE ESPACIOS Y DE ACCESOS Y CIRCULACIONES}

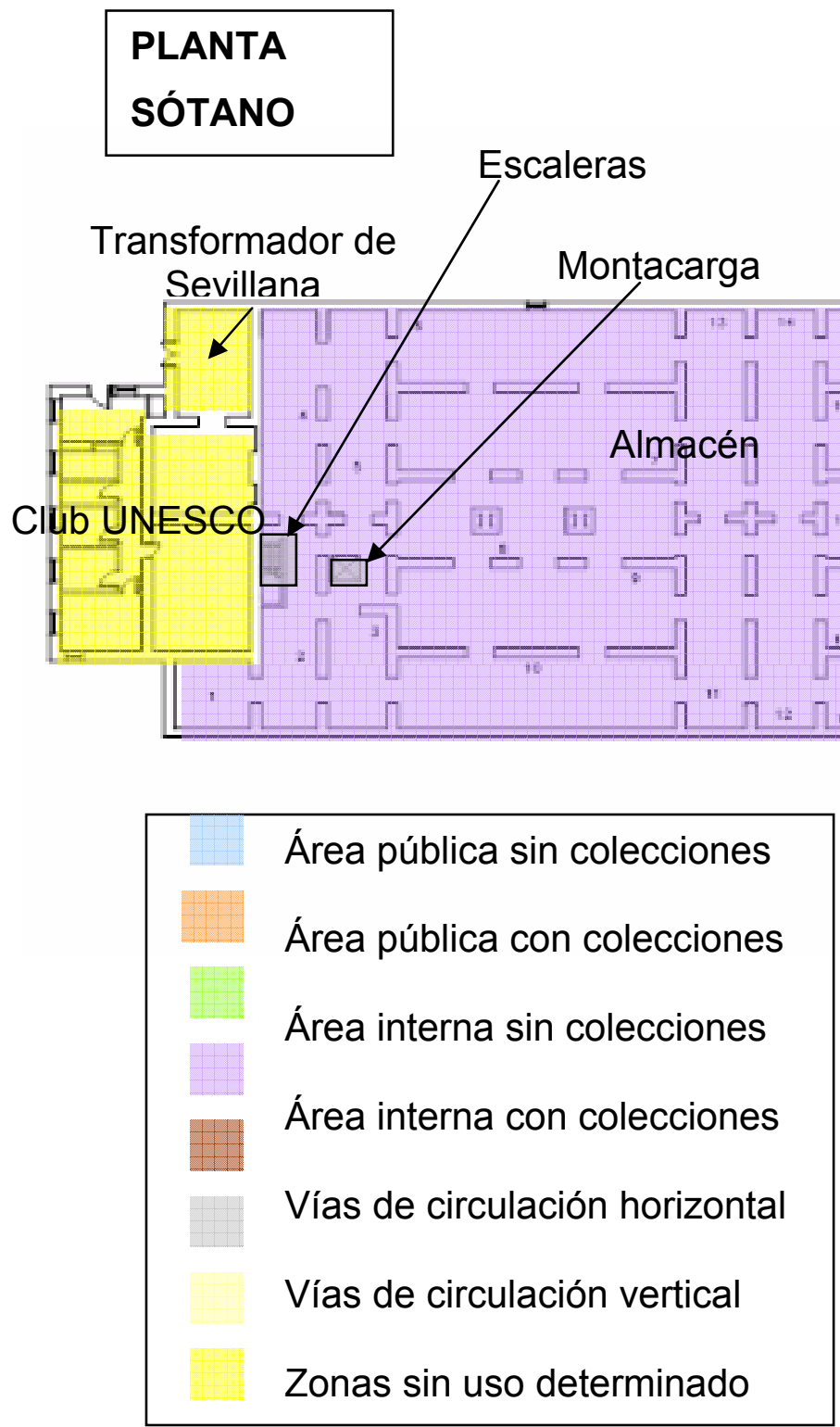

Área de recepción de colecciones (muelle de caraa $v$ descaraa) Vestuario de vigilantes

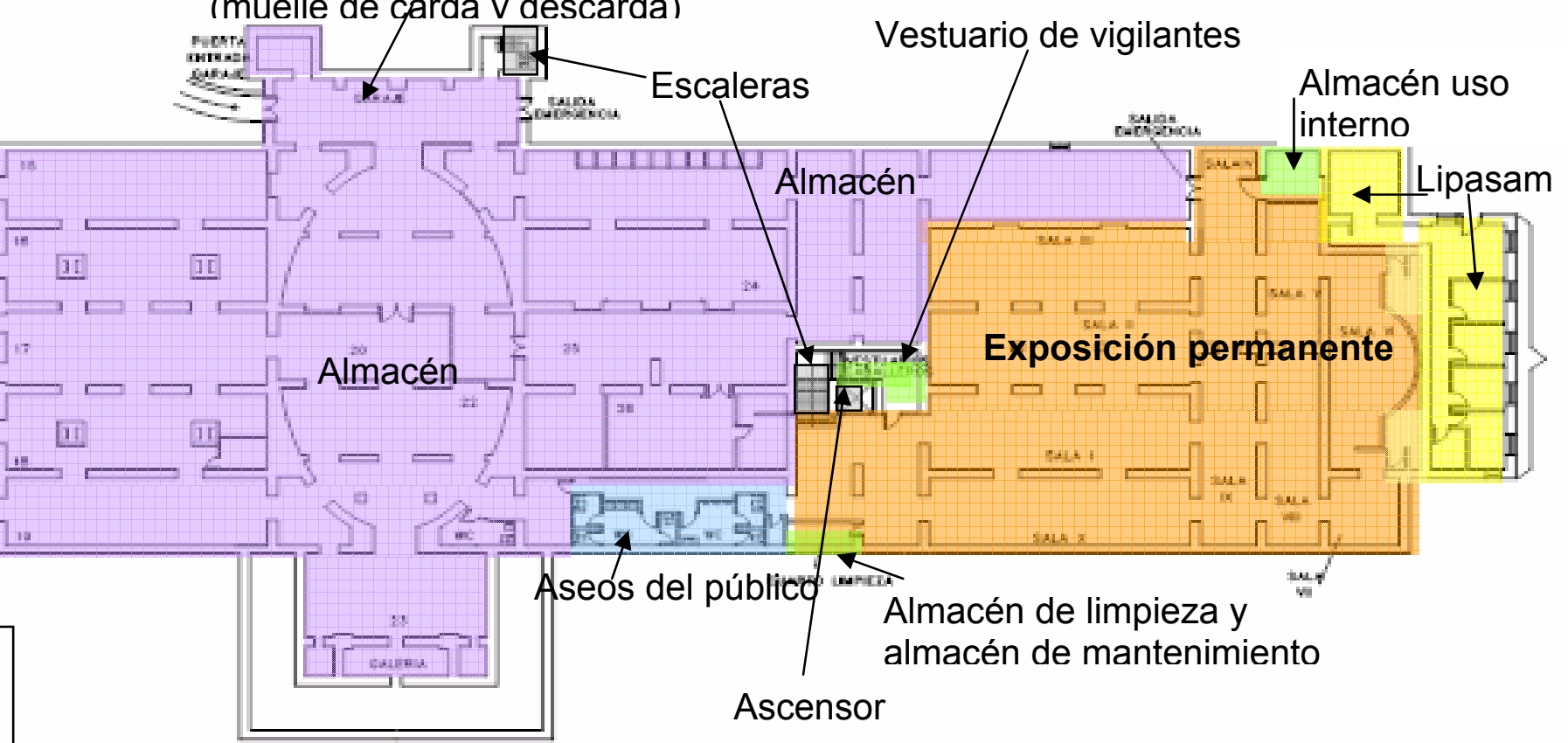




\section{PLANTA BAJA}

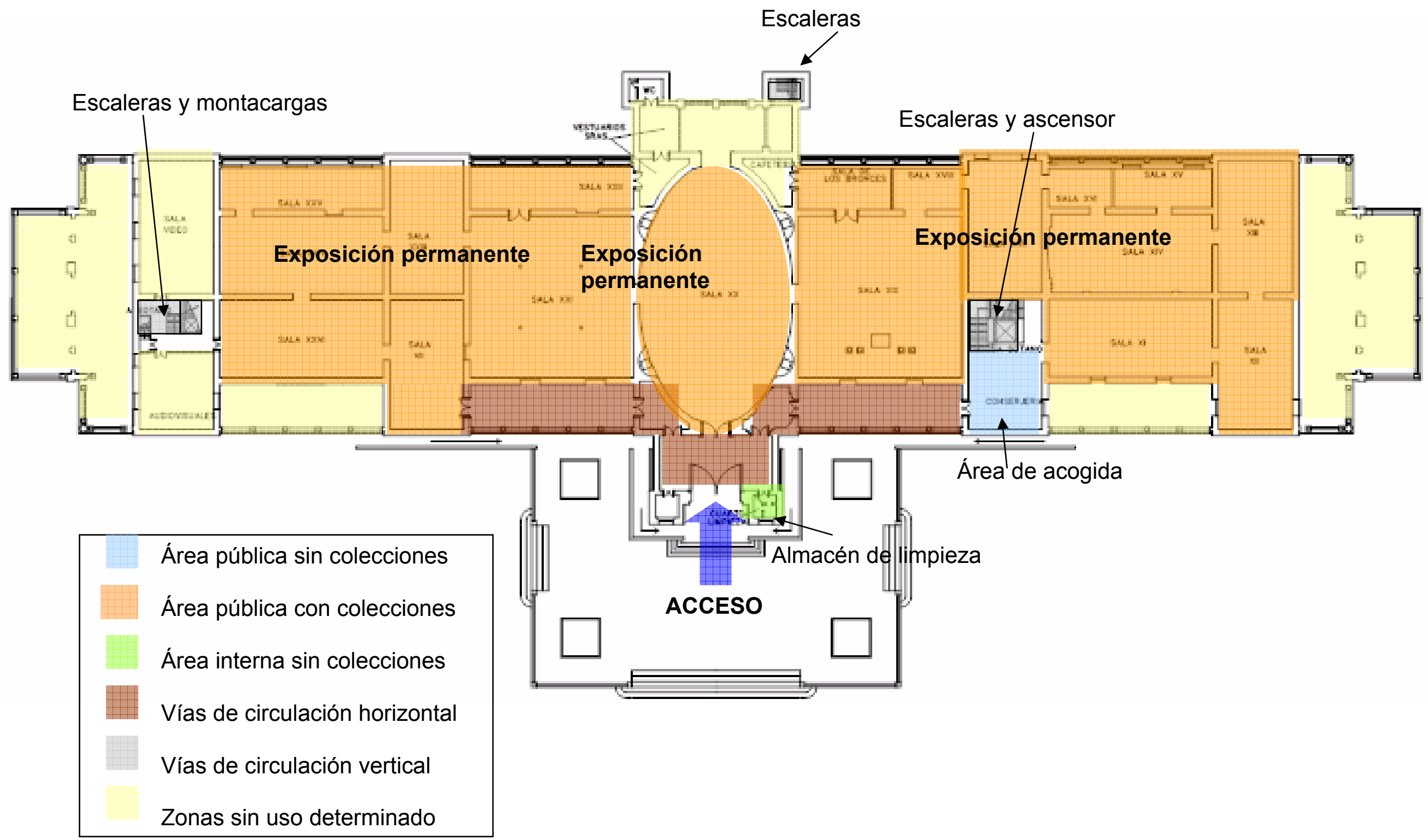




\section{PLANTA PRIMERA Y PLANTA ALTA}

Aseos de personal

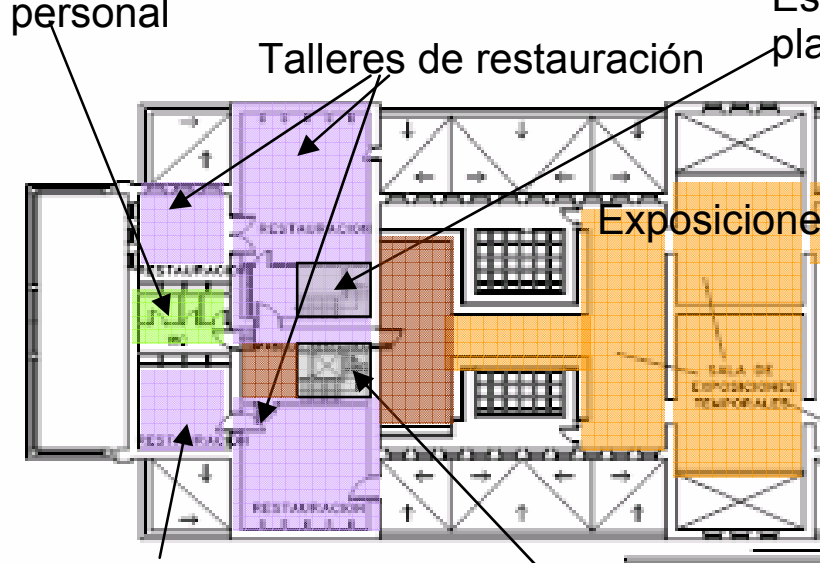

Almacén climatizado para objetos restaurados

Escaleras y montacargas Almacén antropología Escaleras Almacén de mantenimiento +9. Escaleras a planta alta

Escaleras y ascensor
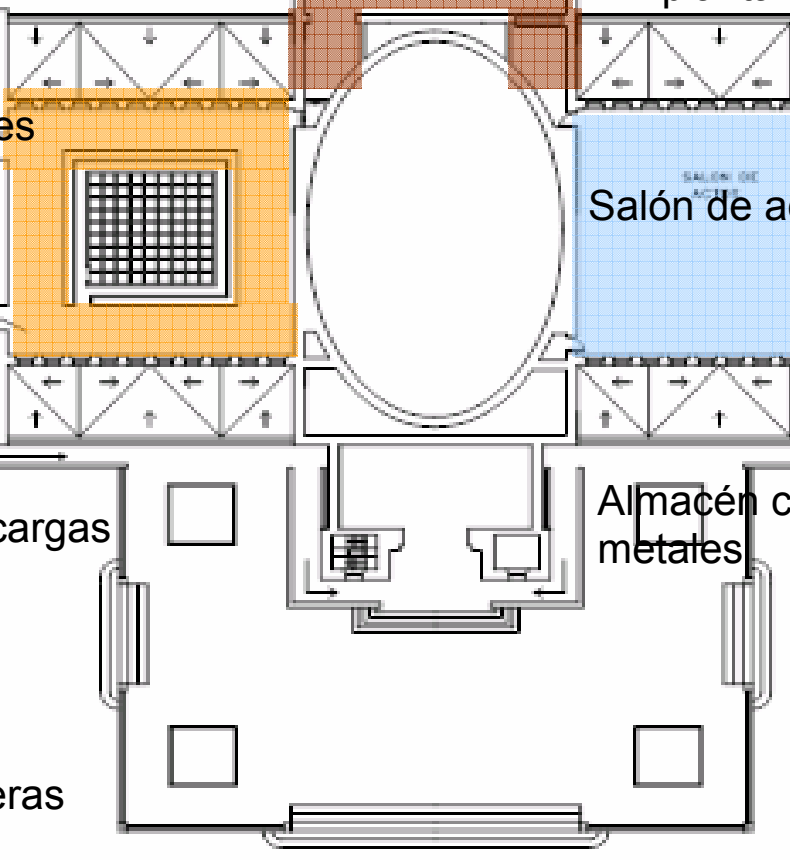

Área pública sin colecciones

Área pública con colecciones

Área interna sin colecciones

Área interna con colecciones

Vías de circulación horizontal

Vías de circulación vertical planta altal Salón de actos

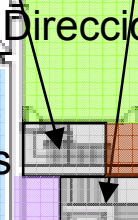

Asociación de

Amigos del Museo/ Sala de reuniones (ocasionalmente) Administración
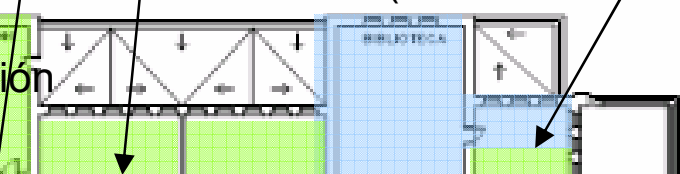


\section{III.7. PLANES DE EMERGENCIA $Y$ EVACUACIÓN}

No existe un plan de emergencia elaborado para el museo, ni tampoco la salida de emergencia cumple la normativa. La única salida de emergencia del edificio está situada en el sótano, en la sala IV, y da al almacén, desde el que el recorrido hasta la salida al exterior se hace en línea recta, salvo al final que hay que girar a la izquierda. Está señalizada en la puerta de la sala IV como "Salida de Emergencia", pero el recorrido por el almacén hasta la otra puerta no está indicado, ni tampoco tiene ninguna indicación la puerta de salida al exterior. Además, esta vía de evacuación en ocasiones se encuentra obstaculizada por cajas de material arqueológico que se van acumulando por todos los rincones del almacén.

Es por tanto imprescindible la elaboración de un plan de emergencia y evacuación con un protocolo de actuación definido, así como la ubicación y señalización de salidas de emergencia desde las plantas baja y primera que cumplan la normativa vigente, sobre todo del número de metros máximos que debe haber hasta la salida más cercana.

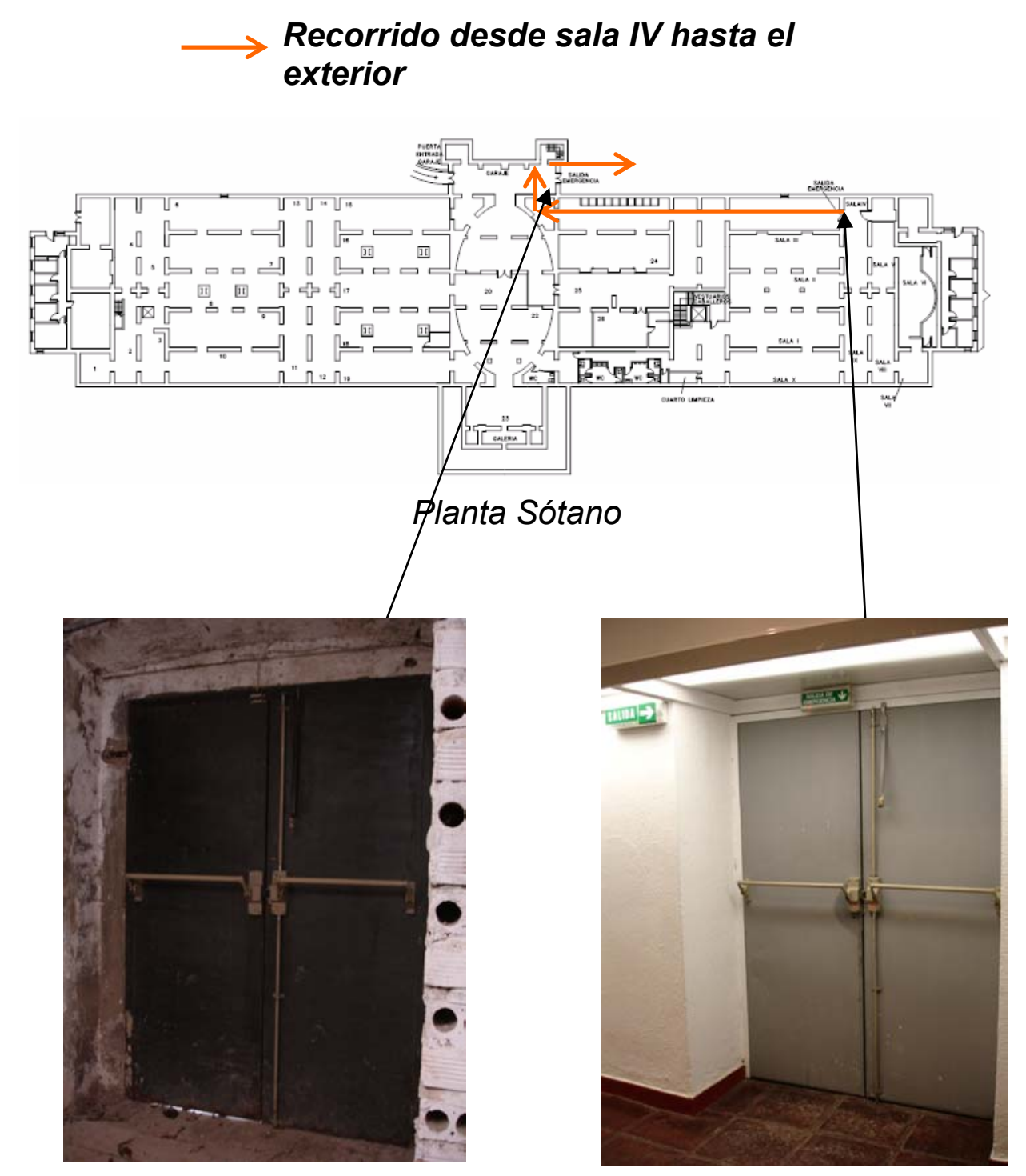




\section{III.8. INSTALACIONES}

\section{III.8.1. Condiciones ambientales}

\section{- Sistemas de ventilación del museo:}

La ventilación del museo se hace de forma natural a través de ventanas y puertas. No existen sistemas de ventilación forzados.

\section{- Sistemas de climatización:}

El museo no cuenta con sistemas de climatización general, ni para las personas ni para las obras expuestas. Tampoco está climatizada la mayor parte de los almacenes, sólo dos almacenes pequeños para piezas concretas.

En el almacén situado en el interior del taller de restauración de piedra se dispone un deshumidificador para mantener controlada la humedad de las piezas que allí se guardan, que son las intervenidas en los talleres de restauración.

El almacén al que se accede desde el salón de actos está acolchado y tiene un deshumidificador para controlar la humedad de los metales que allí se almacenan.

Por otra parte, en algunas zonas utilizadas por el personal del museo existen consolas independientes para la climatización con salida a las terrazas.

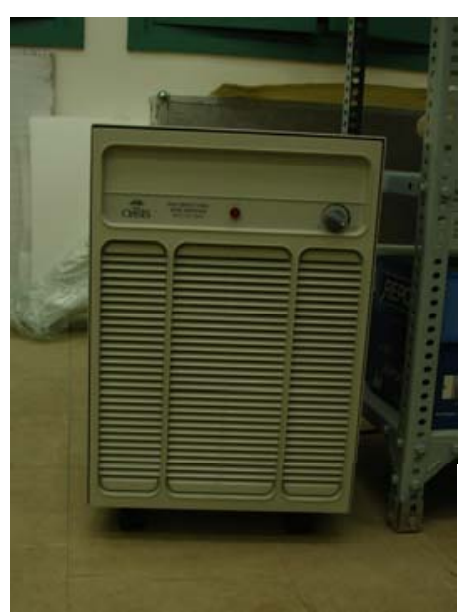

Deshumidificador del almacén donde se almacenan las piezas restauradas 
- $\quad$ Sistemas de medición de polución ambiental:

No existen en el museo.

\section{- Control ambiental en contenedores expositivos} (vitrinas). Serán analizadas en el apartado de museografia.

\section{III.8.2. Electricidad}

El sistema eléctrico ya fue analizado en el apartado de Patologías del edificio.

\section{III.8.3. Fontanería}

La instalación de fontanería y saneamiento ya fue analizada en el apartado de Patologías del edificio.

\section{III.8.4. Voz y datos}

Existe línea telefónica y red informática en el museo, pero la red interna solo cubre la primera planta, que es la de administración. Destacar que hay cables visibles por algunas partes del museo, aunque ya se han tomado algunas medidas para ocultarlos en algunos puntos. 


\section{III.9. CONCLUSIONES GENERALES}

A través del análisis que se ha realizado se dan una serie de datos sobre las deficiencias que el museo tiene desde el punto de vista arquitectónico, ya sea desde la visión propiamente estructural, como desde la funcional.

\section{ESTADO DE CONSERVACIÓN DE LA ARQUITECTURA}

La mayoría de las obras o intervenciones que ha tenido el edificio desde su construcción como Palacio de Bellas Artes de la exposición Iberoamericana han tenido como fin su acondicionamiento al uso museístico $y$, aunque sí ha habido obras de mantenimiento, el estudio realizado revela la deficiencia del mismo, así como la falta de estudios sistemáticos del estado de la arquitectura, lo que ha provocado que actualmente el inmueble sufra numerosas patologías ya analizadas cuya gravedad en algunos casos podría provocar para su reparación el cierre del edificio durante un tiempo.

Sobre las patologías generales del edificio podemos decir que tras un estudio de la evolución de las grietas, provocadas en su mayoría por patologías en la cimentación, se ha llegado a la conclusión de que el edificio no corre peligro. No obstante, habría que seguir haciendo estudios sistemáticos por si aparecieran más grietas y así determinar la gravedad de las mismas.

En cuanto a la estructura del edificio, se producen en general patologías propias del sistema constructivo, como desequilibrios y movimientos por la inestabilidad del muro debido en alguna medida a los factores de resistencia de los materiales, lo que provoca deformaciones, fisuraciones y desplomes.

Creemos que lo más acertado sería corregir en primer lugar los orígenes de las patologías de la cimentación y las 
cubiertas y posteriormente las de los muros, mediante el relleno de fisuras y la sujeción de los muros que lo necesiten.

Dedicamos un apartado especial a la acción del agua, ya que es uno de los problemas fundamentales de la arquitectura del museo. Desde el punto de vista de la estructura y cimentación, es importante que se controlen las fugas de las conducciones de aguas, ya que la humectación y la posterior desecación son muy dañinas para los materiales. Aparecen también fallos de filtración en las cubiertas, que no están lo suficientemente impermeabilizadas y provocan la oxidación de las cerchas y las viguetas de los forjados, además de graves daños en los artesonados de las terrazas. En resumen, la humedad de diferentes procedencias es un problema grave en el edificio, pues afecta a la cimentación, la estructura, las cubiertas, la fachada, los muros de todas las plantas, etc. Por tanto, es uno de los primeros problemas a resolver en caso de una intervención en el edificio.
En cuanto a patologías más concretas, la instalación eléctrica del edificio ha quedado obsoleta, por un lado por la aparición de equipos nuevos que realizan mejor las funciones necesarias, y por otro por la elevación de los costes de operación debido al mayor consumo y a las frecuentes averías, dado el envejecimiento de la instalación. El Reglamento electrotécnico para baja tensión (REBT) aprobado por Decreto 2413/1973, de 20 de septiembre, introduce cambios tan importantes que hace inútil cualquier intento de aprovechamiento de las instalaciones anteriores a 1973, que deberán rehabilitarse en su totalidad. Además, este REBT fue derogado por el Real Decreto 842/2002, de 2 de agosto, con lo que habrá que revisar si las instalaciones posteriores a 1973 están de acuerdo a este nuevo reglamento. Las instalaciones posteriores a 1973 pero que tengan una antigüedad de más de 10-15 años también deberían ser renovadas en su totalidad aunque sean reglamentarias, ya que el envejecimiento y obsolescencia de materiales y equipos las incapacita para desarrollar sus funciones. Aquellas que 
tengan menos de 10-15 años podrán aprovecharse dependiendo de su estado. Dado el escaso mantenimiento de la instalación eléctrica, es imprescindible la inspección de todos los elementos de la instalación.

Las instalaciones de fontanería y saneamiento requieren un mantenimiento continuado, pues suelen producirse frecuentemente roturas o fisuras en las mismas. Además, al ser un edificio antiguo, las reparaciones y sustituciones de materiales no habrán sido homogéneas, así como tampoco su resistencia o durabilidad. Por tanto, se hace imprescindible no sólo la sustitución de los bajantes que estén en mal estado, sino también la revisión de ambas redes para tener controlado su recorrido y así detectar los daños que vayan sufriendo, bien por roturas que puedan producir filtraciones de agua, bien por atascos provocados por la entrada de aves, plumas, hojas, etc. en la red de saneamiento. Destacar que el mal estado de la red de alcantarillado del parque incide negativamente en el museo provocando inundaciones con relativa frecuencia en el almacén y las salas de prehistoria cuando hay lluvias intensas.

Es importante el cuidado de las fachadas del edificio, de cuyo análisis pueden sacarse las siguientes conclusiones. Es importante solucionar la oxidación de la cerrajería; hacer un estudio detallado del estado y las patologías que afectan a la madera, incluidos los artesonados, para seleccionar el tratamiento adecuado; realizar una limpieza en profundidad del hormigón, así como reparar los desprendimientos y las humedades del mismo; por último habrá que hacer un estudio biológico para detallar los agentes de biodeterioro que afectan al edificio y aplicar el tratamiento adecuado de limpieza y prevención. 
ANÁLISIS Y EVALUACIÓN DE LOS ESPACIOS. PROBLEMAS Y NECESIDADES

Dentro del Área pública sin colecciones destacar que el principal problema de la misma es el Área de acogida. La recepción es insuficiente tanto en espacio como en dotación incluso para los visitantes individuales, pues ya que es la primera impresión que da el museo a sus usuarios, debería estar más cuidada. Pero para los grupos es incluso problemático, ya que éstos no tienen espacio en esta área, con lo que el grupo debe reunirse en el exterior del vestíbulo, en la terraza que le antecede, techada pero abierta en todo su frente. Por otra parte, no existen servicios complementarios para los visitantes, como guardarropa, consigna, tienda (salvo una pequeña vitrina en el vestíbulo), cafetería o restaurante, guardería, teléfono público o cajero automático. Es destacable también que los únicos aseos del público se sitúan en el sótano, con lo que no hay aseos ni en la planta baja ni en la superior.
La única sala para actividades de que dispone el museo es el salón de actos, de tamaño razonable para las actividades que suelen llevarse a cabo; por tanto, no hay salas acondicionadas para la realización de actividades didácticas con grupos, colegios, niños ni público en general, con lo que no es frecuente que se hagan.

La biblioteca, especializada en arqueología, es uno de los espacios mejor conseguidos del museo. Su tamaño es adecuado, pues no tiene demasiados usuarios, y las instalaciones también. Sí se podría destacar la falta de climatización, lo que hace incómoda a veces la estancia en la misma. Sería importante hacer una labor de difusión de esta biblioteca, pues es un lugar de trabajo excelente para investigadores, estudiantes o profesionales de la arqueología no suficientemente conocido.

Resulta imprescindible la ordenación del fondo documental del museo en un archivo adecuado para la consulta. 
En definitiva, el hecho de que el Área pública sin colecciones, donde se engloban todos los servicios y espacios de atención al público, represente tan sólo el $8 \%$ del espacio total del museo nos muestra la distribución anticuada del mismo y es uno de los problemas fundamentales a solucionar.

Dentro del Área pública con colecciones es importante el análisis de los espacios dedicados a la exposición permanente que, no obstante, serán analizados en profundidad en el apartado de museografia. Desde el punto de vista de la distribución de espacios en el museo, esta zona ocupa el $35 \%$ del total aproximadamente, lo que demuestra una distribución del museo antigua y no acorde con las nuevas directrices de la museología que, sin restar su importancia a la exposición, defienden un mayor espacio en el museo para actividades didácticas, servicios para el público o exposiciones temporales. Además, no existen zonas de descanso en todo el recorrido de la exposición permanente, siendo la única zona sin colecciones la situada en el tránsito de la planta baja al sótano y viceversa, para lo que hay que pasar por el vestíbulo.

Las exposiciones temporales disponen actualmente de un espacio insuficiente para su montaje en el museo, considerándose imprescindible su ampliación, la cual deberá ir acompañada de la modernización de estos espacios y del acondicionamiento de los mismos, pues el almacenamiento anárquico de objetos arqueológicos hace imposible su uso.

Dentro de este mismo área, que debería ser acondicionada para que la convivencia del público y las colecciones sea satisfactoria, están también las salas de investigadores. No obstante, el museo no cuenta con una sala específica para atenderlos, sino que los investigadores son atendidos en el despacho de conservadores o en otras zonas como el almacén 0 áreas próximas a la biblioteca. Es 
imprescindible por tanto dotar al museo de un espacio acondicionado y equipado para la investigación, lo que ya está en la mente de la dirección del museo, que pretende próximamente dedicar de nuevo a este fin la antigua sala de investigación, hoy ocupada en parte por la asociación de amigos del museo además de utilizarse para reuniones y algunos cursos.

En el Área interna con colecciones, el lugar al que llegan las piezas o muelle de descarga no puede llamarse área de recepción de colecciones como tal, pues es simplemente el espacio por el que entran las piezas al museo pero no está acondicionado climática ni funcionalmente, además de estar colapsado de material arqueológico. Tampoco dispone al museo de almacén de tránsito, área de embalaje, almacén de embalajes, despacho de registro, sala de cuarentena o cámara de fumigación. Pero la falta más grave en este área es el hecho de que el montacargas, que conecta el sótano con las plantas baja y primera es de pequeño tamaño ( un metro por cada lado aproximadamente) y sólo soporta el peso de piezas de hasta $400 \mathrm{Kg}$. con lo que piezas que sobrepasen ese formato o peso deben ser llevadas por las escaleras, lo que resulta impracticable, o introducidas por la planta baja pero es imposible que lleguen a la primera sin salvar escaleras. Esto nos parece un problema muy importante a solventar.

Los talleres de restauración son dos, uno dedicado a cerámica y metales y el otro a piedra. El equipamiento para intervenciones de que disponen es aceptable, aunque mejorable, pero tiene otros problemas más importantes. Por un lado, se sitúan en una zona de tránsito de personal de mantenimiento, con lo que las puertas deben estar siempre cerradas si los restauradores salen; sería interesante separar esta zona de restauración, junto con la de administración, del resto del museo, con un acceso al que sólo esté autorizado el personal técnico. Por otra parte, el pasillo de acceso a los talleres es demasiado estrecho para permitir el paso de obras de gran formato, que deben 
restaurarse en sala, y dificultoso para obras de mediano tamaño, así como también en los propios talleres es complicada la entrada de las mismas. Esto condiciona el que solo sean intervenidas piezas de pequeño o mediano formato. Además de estos problemas de resolución prioritaria, los restauradores acusan la falta de climatización de los talleres, la falta de mobiliario, la instalación eléctrica deficiente de que disponen, etc. y en general, piden una renovación y modernización de los mismos.

La mayor parte de los almacenes se sitúan en el sótano, ocupando casi el $25 \%$ del espacio del museo, siendo el total de almacenes del museo un $28 \%$ aproximadamente. En general, la disgregación del almacén dificulta la labor conservadora, investigadora, catalogadora y el propio orden del mismo. No sabemos si esto se ha producido por la falta de espacio en el almacén del sótano, pero es verdad que en general el espacio de reserva es insuficiente y difícil la resolución de este problema si sólo contamos con este edificio. Sólo dos pequeños almacenes están climatizados a través de un deshumidificador; el dedicado al almacén de metales, anexo al salón de actos, y el destinado a albergar objetos ya restaurados, en el interior del taller de restauración de piedra. Es decir, los objetos restaurados no vuelven al almacén principal del sótano, dada su falta de climatización y, sobre todo, de limpieza, ordenación y cuidado.

Es también importante destacar la falta y la necesidad de un espacio para la documentación fotográfica, pues aunque los restauradores disponen de un pequeño espacio para ello a la entrada del taller de metales y cerámica, el resto se realiza en la sala de conservadores si son piezas pequeñas o en sala si son piezas de movilidad dificultosa. El museo cuenta con una sala en la planta alta situada sobre la dirección en la que antiguamente había un taller fotográfico, pero ahora está en desuso y sólo se utiliza la cámara digital. Sería importante habilitar éste u otro 
espacio para la ubicación de todo el material necesario para esta labor documental.

Dentro del Área interna sin colecciones el problema fundamental es la falta de espacio en algunas zonas, pero no se consideran tan graves, puesto que es posible la reordenación de los mismos. El despacho para conservadores en la primera planta, contiguo al de dirección, es compartido por dos de los conservadores del museo y los documentalistas actualmente contratados para informatizar la colección en el programa Domus. Por tanto, aunque pertenezca al área interna sin colecciones, en ocasiones sí las hay, bien por el trabajo de los conservadores, bien por trabajos de documentación interna o incluso por atenderse aquí a veces a los investigadores. Además de este despacho existe otro en la planta alta, justo encima del despacho de dirección, ocupado por un conservador, con lo que podrían reorganizarse para dar más utilidad a este último despacho.
Por otra parte, el museo debería contar con zonas diferenciadas para Vigilancia y Seguridad y para Limpieza y Mantenimiento, pues éstas se encuentran repartidas por el museo.

Aparte de todos los espacios en uso por parte del museo que ya se han analizado, hay que tener en cuenta que hay algunas zonas del edificio que están en desuso por diferentes causas, bien por sufrir daños estructurales, bien por el difícil acceso o bien por la acumulación anárquica de objetos arqueológicos que se observa por todo el edificio. Estos espacios podrían aprovecharse, pues suponen más de $350 \mathrm{~m}^{2}$. Además de estos, unos $260 \mathrm{~m}^{2}$ de espacio, en los extremos oriental y occidental del edificio, son ocupados por instituciones o empresas ajenas al museo, como Lipasam, el Club UNESCO o Sevillana. Ya que, como hemos dicho, en el edificio no sobra espacio y el museo necesita bastante más, estas zonas deberían ser aprovechadas para la ampliación y el uso por parte del mismo. 
En resumen, se hace necesaria una redistribución de espacios e incluso la ampliación del museo, que ya se tratará en el apartado de programas, si queremos un museo moderno y adecuado a las nuevas tendencias de la museología, con mayor atención al público, a su bienestar y a mejorar su comprensión de las piezas, así como en general, su experiencia en el museo. No obstante, esto debe conseguirse sin que suponga un detrimento en el cuidado de las colecciones, cuya conservación y mantenimiento son labores fundamentales del museo, ya que sin un adecuado tratamiento de las piezas es imposible su difusión. Sería importante independizar las zonas de trabajo del personal del museo de las zonas de exposición, tanto temporal como permanente, uniendo a todos los trabajadores en una misma zona del museo.
ANÁLISIS Y EVALUACIÓN DE ACCESOS Y VÍAS DE CIRCULACIÓN. PROBLEMAS Y NECESIDADES.

Los accesos y vías de circulación, tanto verticales como horizontales, y tanto de personas como de obras, ocupan sólo el $7 \%$ del espacio total del museo y además, en su mayoría, estas zonas de tránsito ni siquiera están bien acondicionadas para tal fin.

Sólo existe un acceso para las personas, ya sean personal de museo o público visitante, situado en la fachada principal del edificio. $Y$ ésta es también la única salida del edificio de uso normal, pues existe otra de emergencia a la que se accede desde el sótano. Es imprescindible contar con un mayor número de accesos y salidas en el edificio.

La entrada de obras suele hacerse por el almacén del sótano, pudiendo llegar el medio de transporte utilizado desde la calle hasta la puerta del mismo. El problema está, 
como ya se ha citado anteriormente, que desde el almacén, por el montacargas, sólo pueden transportarse obras de dimensiones o peso medianos (menor o igual a $400 \mathrm{Kg}$. y no muy voluminosas) para llevarlas a las salas o a los talleres de restauración, por lo que en ocasiones las obras más pesadas o de mayor volumen acceden al museo por el óvalo y desde allí deben salvar todas las escaleras que se encuentren en su camino. Estos son problemas importantes a solventar, pues deben independizarse las zonas de acceso de obras de las de personas, siendo el óvalo un lugar de exposición y acceso de visitantes no adecuado para la recepción de piezas. Además no es aceptable que una pieza deba salvar escaleras para llegar a cualquier parte el museo.

Las principales vías de circulación del edificio son, de manera horizontal, en las plantas baja y sótano las mismas salas, pues no existen pasillos de tránsito ni zonas de descanso en el área expositiva. En la planta primera en el ala oeste del edificio sí hay un pasillo en el que se disponen la secretaría de dirección o administración y la dirección, el despacho de los conservadores y la biblioteca, así como el salón de actos en el extremo opuesto a la biblioteca. Al otro lado del óvalo, en el ala este, se sitúan las salas dedicadas a exposiciones temporales y los talleres de restauración, a los que se llega por un pasillo demasiado estrecho para el paso de determinadas obras. Para llegar a este ala desde la opuesta en la planta primera, hay que atravesar el salón de actos, rodear el óvalo por un pasillo y pasar por las salas dedicadas a exposiciones temporales. Por tanto, aunque las salas de exposiciones temporales y el salón de actos no deberían utilizarse como vías de circulación son muchas veces empleados como zona de paso. Esto debería resolverse uniendo las zonas de administración y restauración, pues el personal del museo no debería tener que atravesar zonas de uso público para estar en contacto y la situación actual hace que los restauradores estén aislados del resto del personal. 
Las vías de circulación vertical son varias escaleras, un ascensor y un montacargas. Ya se han comentado los problemas del montacargas. Todo el edificio es accesible para personas con movilidad reducida salvo la biblioteca, para la que hay que salvar escaleras, lo que debe ser inmediatamente solucionado.

Analizados los recorridos más frecuentes a seguir por las piezas del museo podemos concluir que hay que solventar algunos problemas como el acceso de las obras, que debería ser más digno, los problemas de peso y espacio del montacargas, así como escaleras como las del salón de actos para llevar obras del montacargas a la zona de administración en la planta primera. Es importante destacar que no existe sectorización alguna en el museo, es decir, todos los espacios están comunicados, con lo que haría falta establecer un protocolo de acceso a determinados espacios en los que suele haber piezas como son los talleres de restauración.
No existe un PLAN DE EMERGENCIA elaborado para el museo, ni tampoco la salida de emergencia cumple la normativa, ya que sólo existe una, señalizada en las salas de exposición del sótano, pero para llegar al exterior hay que atravesar el almacén en el que no existe ninguna indicación. Además, esta vía de evacuación en ocasiones se encuentra obstaculizada por cajas de material arqueológico que se van acumulando por todos los rincones del almacén. Es por tanto imprescindible la elaboración de un plan de emergencia y evacuación con un protocolo de actuación definido, así como la ubicación y señalización de salidas de emergencia desde las plantas baja y primera que cumplan la normativa vigente. 


\section{ANÁLISIS $Y$ EVALUACIÓN DE LAS} INSTALACIONES. PROBLEMAS Y NECESIDADES.

Ya se ha hablado de los problemas de instalaciones como la eléctrica o la de fontanería, con lo que en este apartado nos referimos a los problemas de las instalaciones relacionadas con la conservación de las piezas o el bienestar de los visitantes.

El museo no cuenta con sistema de climatización, con lo que las piezas se conservan tanto en almacén como en sala a temperatura ambiente, con los problemas que esto supone, sobre todo por la alta humedad de los almacenes del sótano. Ya se han citado los dos únicos pequeños almacenes que cuentan con un deshumidificador (metales y piezas restauradas) pero es insignificante la cantidad de piezas que éstos guardan en comparación con la gran cantidad de obras que no están climatizadas. Además, los visitantes del museo sufren las inclemencias del tiempo, teniendo que soportar las temperaturas extremas del invierno y el verano en Sevilla.
Tampoco cuenta el museo con sistemas de medición de los parámetros tenidos en cuenta para la conservación preventiva, ni en sala, ni en almacenes, ni en vitrinas: iluminación, humedad, temperatura, polución ambiental, etc.

\section{CONCLUSIÓN}

El resultado final del análisis arquitectónico, de espacios, accesos, circulaciones e instalaciones, hace pensar en la necesidad de abordar la reorganización, remodelación y modernización del museo desde un punto de vista integral. Es decir, para conseguir solventar todas las patologías y necesidades que se han analizado será necesaria una intervención en la que se incluyan todos los aspectos del museo. Ésta, que se planteará en los programas, será necesaria ejecutarla por fases bien estructuradas tanto en el tiempo como económicamente o bien mediante una gran inversión y con el cierre temporal del museo. 

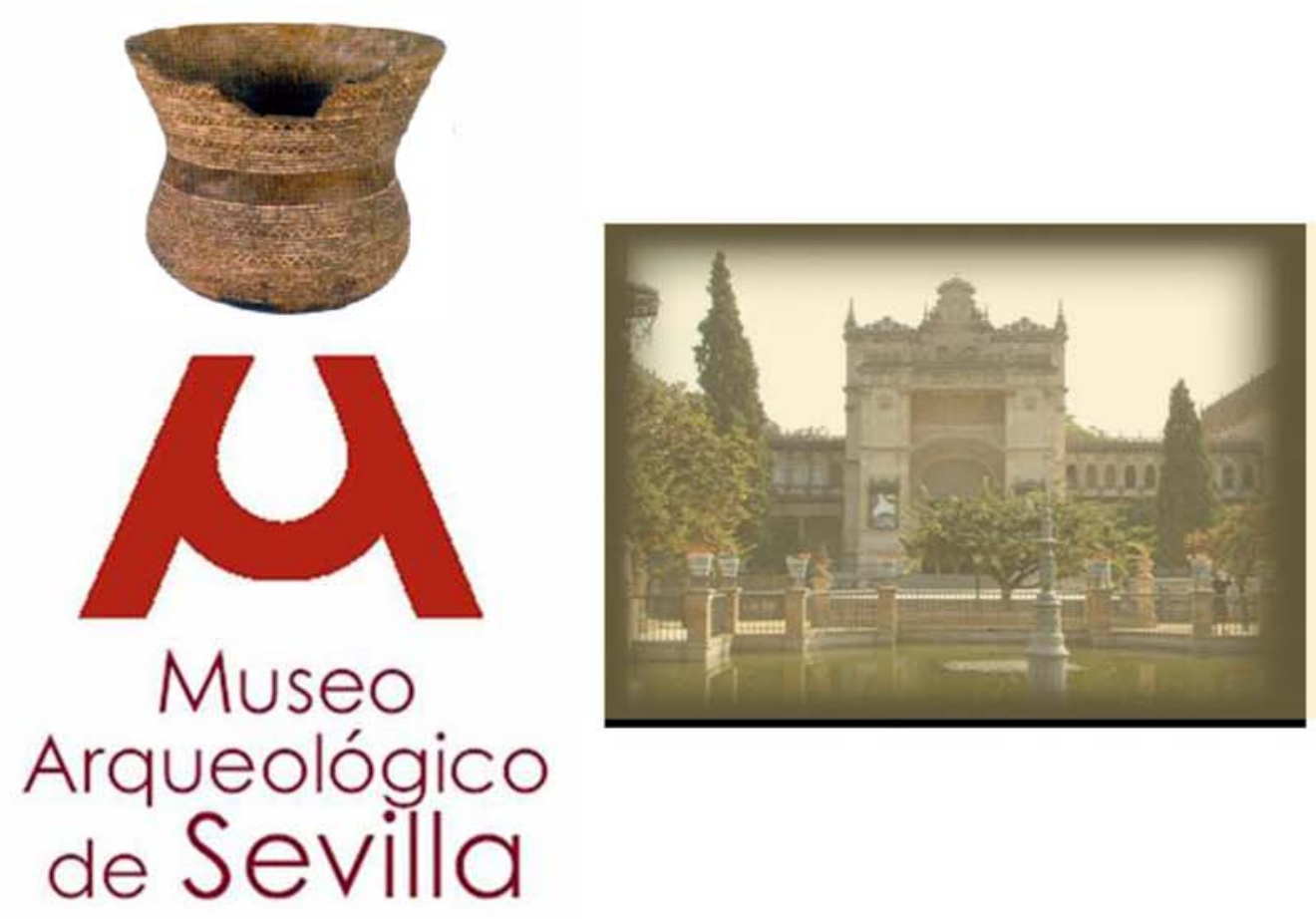

\section{EXPOSICIÓN}

María Dolores García Pérez

Sebastián Podadera Fernández 


\section{IV.1. DISCURSO EXPOSITIVO}

\section{IV.1.1. Contenidos generales, principales temas y mensaje a transmitir.}

Atendiendo a la diversidad de las colecciones particulares de notable interés y a las excavaciones arqueológicas realizadas en la provincia sevillana, nos encontramos con una exposición permanente donde se debe distinguir un discurso expositivo con un orden cronológico cultural, fijado a grandes rasgos a través de sus yacimientos y piezas más representativas.

En general el Museo alberga una muestra que hace patente la Historia de nuestros antepasados marcando la delimitación geográfica en la provincia de Sevilla. La diversidad de piezas expuestas nos transmite un mensaje sobre la cultura a la que pertenecieron, el modo de vida, la evolución del hombre, centrándose en la cultura romana y avanzando hasta el medievo. En definitiva, el Museo expone nuestra Historia a través de los yacimientos arqueológicos más significativos de la provincia, otorgándole un mayor protagonismo a la ciudad de Itálica por la relevancia que poseen sus piezas y su contextualización en nuestra ciudad.

\section{IV.1.2. Estructuración de las distintas áreas temáticas o partes del discurso según los espacios.}

A grosso modo, los contenidos de este discurso expositivo se pueden clasificar en tres grandes bloques, estructurado según el espacio y los temas:

\section{Bloque I: Salas de Prehistoria.}

Analizando el primer bloque, encontramos distintos temas que tratan esta disciplina desde el inicio de la vida en el 
Valle del Guadalquivir en las edades comprendidas desde el Paleolítico hasta la segunda Edad del Hierro, dando un destacado protagonismo espacial y expositivo a la transcendental cultura tartésica y turdetana con sus joyas y ajuares orientalizantes.

\section{Bloque II: Salas de Arqueología Romana.}

El segundo bloque trata de las salas de arqueología romana encontrándose en la planta principal. Este bloque contiene distintos temas en su discurso expositivo, sobre todo en su inicio puesto que comienza con una mezcla de elementos tridimensionales, típicamente indígenas de la cultura tartésica haciendo un puente hasta los puramente romanos.

A continuación, el discurso expositivo se fundamenta en un tema principal, Itálica. La mayoría de las piezas pertenecen a las excavaciones realizadas en la antigua ciudad de Itálica, patria del emperador Trajano. Las salas albergan principalmente esculturas de vitrinas dispersas por las salas que exponen materiales agrupados por temas monográficos tales como:

- El trabajo y el ocio.

- Ajuar de la casa romana.

- Cerámica romana.

- Religión.

- Comercio, monedas, ejército.

- $\quad$ Adorno femenino.

Por todas las salas se han distribuido numerosos retratos romanos de personajes anónimos y representaciones de Dioses y héroes. Formando parte de los pavimentos y pared encontramos mosaicos de diferentes yacimientos, destacando los de Itálica. Hemos de señalar la presencia de una sala de contenido jurídico con piezas epigráficas en bronce.

\section{Bloque III: Salas de Arqueología Medieval.}


En este tercer bloque el discurso se centra en los hallazgos paleocristianos, visigodos, árabes, mudéjares y góticorenacentistas. Fundamentalmente encontramos piezas que tratan temas relacionados con el comercio, artes suntuarias, arquitectura y decoración.

\section{IV.1.3. Estructuración de las distintas áreas temáticas 0 partes del discurso según los espacios.}

Este discurso se encuentra fragmentado en distintas salas:

Sala I-IV: Paleolítico - Edad del Bronce Final.

Sala V- IX: Colonizaciones.

Sala X: Cultura turdetana.
Sala $X$ (sótano) y sala $X I\left(1^{\text {a }}\right.$ plta $)$ pertenecen al mismo discurso museográfico, distinto material expositivo y discordancia de espacios.

Sala XI: Cultura iberorromana.

Sala XII- XXV: Periodo romano.

Sala XXVI: Antigüedad tardía.

Sala XXVII: Edad Media y Moderna.

\section{IV.1.4. Criterios expositivos y los niveles de comunicación.}

Desde el año 1.973 el criterio expositivo del discurso museográfico no ha variado sustancialmente, salvo en puntuales ocasiones en las que ha habido modificaciones por necesidades especiales en la exposición o por aprovechamiento de materiales de otras muestras.

Hemos de diferenciar dos criterios bien definidos y observables a simple vista, entre las salas que ocupan la planta baja y el resto del museo. Así, mientras las vitrinas que observamos en la planta sótano son permanentes y 
realizadas en obra, simulando hornacinas y cerradas con dos láminas de cristal a modo de escaparate, el resto de las vitrinas son exentas y realizadas en madera (DM o aglomerado), más actuales pero no más efectivas. De las primeras, también hay que comentar su interior, ya que el hecho de estar acabadas en tacto rugoso hace más difícil la estabilidad de las piezas, cosa que se acentúa aún más cuando colocamos un soporte para las mismas en metacrilato o cristal. A colación del comentario de estos soportes, hemos de decir que creemos que son materiales bastante precarios para la presentación de las piezas y en ocasiones los encontramos en posiciones un tanto forzadas. También comentar el sistema iluminativo que se usa, el cual está regido, salvo el la sala del Carambolo, por barras fluorescentes de luz blanca tamizadas por un difusor de polietileno, el cual es necesario retirar gradualmente para ser limpiado de los posible pequeños insectos que se queden en su superficie.
Algo que nos llama la atención son las pequeñas urnas olfativas que nos encontramos en las salas de prehistoria, elementos que son muy interesantes para hacer el discurso algo más instructivo y dogmático para el visitante, pero aun así tienen que atender a un mantenimiento necesario para que cumplan su función totalmente. Quizás sería interesante presentarlas en un formato más atractivo y llamativo para contextualizarselo al visitante.

En cuanto a las peanas, hemos de acentuar y diferenciar entre sus funciones, sustentante y estética. En cuanto a la primera, hemos de decir que por el peso de las piezas que soportan es lícito que estén realizadas en cemento, pero en cuanto a la segunda, no es nada admirable que ese material sea irreversible y que están pintados en blanco, cosa que afecta a la propia pieza en los bordes que tienen contacto con la peana; otro inconveniente de esta situación es que las obras se encuentran totalmente ancladas y, por tanto, la solicitud de su salida del museo, se hace más complicada. En conclusión, decir que sería necesario 
encontrar otro tipo de soportes para estas piezas, los cuales nos permitan observarlas sin esa masa blanca de cemento y, lo que consideramos más importante, facilitar su posible préstamo para exposiciones temporales, una de las tareas más importantes para el museo en cuanto a su difusión.

Los niveles de comunicación que encontramos en el museo quizás sean demasiado académicos, técnicos y monótonos, cosa que complica al espectador el entendimiento del propio discurso. Vemos necesario que el primer nivel lo establezca el propio objeto ya que disponiendo de una buena base, atractiva y utilitaria, el espectador va a ser más propenso a observar la pieza, pasar a niveles de comunicación más avanzados y sacar sus propias conclusiones. En el caso que nos ocupa los niveles más avanzados van en la línea de una cartela explicativa en la que se nos data la procedencia y algunas notas sobre su utilidad. Nombrando también las cartelas explicativas que nos encontramos al comienzo de cada sala.

\section{IV.2. COLECCIONES QUE CONDICIONAN} LA EXPOSICIÓN.

En las salas de prehistoria hay que destacar las necrópolis megalíticas por la presencia de la evolución del hombre en una de las vitrinas y por el tamaño de las estelas conservadas. Por otro lado tenemos los ajuares, donde el que más llama la atención por el material y su importancia es el del Tesoro del Carambolo, una de las piezas más emblemáticas del museo y que más conoce el público. También condicionaría la exposición la presencia de importantes colecciones cerámicas, entre las que destaca la cerámica de la cultura campaniforme puesto que explicaría la evolución de este tipo de prácticas en la culturaprehistórica. Pero de esta zona la colección más amplia aunque menos estudiada sería la de la Cultura Tartésica y Turdetana, lo que le da una importancia en potencia a su presencia. 
En cuanto a las salas dedicadas a Roma Itálica centra la exposición y condiciona todo el museo, destacando las importantísimas esculturas halladas en esta magnifica ciudad romana, tales son Diana, Isis, Venus, Cibeles, Retratos de Adriano y Trajano, Aras Báquicas o los grandes Mosaicos. No hay que dejar de nombrar las pocas piezas que van desde la época paleocristiana a la mudéjar donde vemos piezas que contextualizarían estos espacios de tiempo en la exposición permanente del museo, y donde destacamos las piezas mudéjares del final de la exposición que nos hablan de un tipo de piezas de arqueología diferente a la anteriormente vista y de un periodo no demasiado documentado en Sevilla.

\section{IV.3. CONDICIONES DEL MONTAJE}

\section{ACTUAL.}

\section{IV.3.1. Remodelaciones museográficas y sus fechas}

- 1.942: Primera adaptación del edificio a Museo aprovechando el Pabellón de Bellas Artes diseñado por Aníbal González en 1.929.

Responsables:

D. Joaquín $M^{a}$ de Navascués, Director General de Bellas Artes.

D. Juan Lafita, Director General de Museos.

D. Félix Hernández, arquitecto.

- 1.943: Colocación de viguetas y bóvedas en el sótano. Mismos responsables.

- 1.944: Mismos responsables.

Cubierta de la Sala del mercurio realizada en cristales termolux y lucernarios laterales altos.

Sala de la Venus.

Gran salón de Itálica.

Salón Ovalado.

- 1.945: Dirección, biblioteca, sala de lectura y salón de conferencias. Mismos responsables.

- 1.946: se inaugura con las siguientes salas:

SALA I. Antigüedades Prerromanas. 
SALA II. Arte Hispánico prerromano de la provincia.

SALA III. Antigüedades romanas de la provincia.

SALA IV. Escultura romana de Itálica.

SALA V. Escultura griega de Itálica.

SALA VI. Escultura grecorromana de Itálica.

SALA VII. Escultura romana italescense y epigrafía.

SALA VIII. Escultura romana imperial.

- 1.962: Consolidación de las cubiertas.

Responsable: Sr. Balbatín, arquitecto.

- 1.967: Construcción de la SALA IX, donde se ubicará el Tesoro del Carambolo.

- 1.970: Terminación de las siguientes cinco salas.

Responsable: D. Florentino Pérez Embid, Director General de Bellas Artes.

Con las siguientes unidades:

SALA X. Antigüedades romanas no italescenses.

SALA XI. Arte Paleocristiano.

SALA XII. Arte Visigodo.

SALA XIII. Arte Árabe.

SALA XIV. Arte Hispanomusulmán.
- 1.973: Reinstalación de las salas con la distribución actual, habilitación de las salas del sótano y creación de la tercera planta para Dirección, Biblioteca, etc....

Responsables:

D. Florentino Pérez Embid, Director General de Bellas Artes.

Sr. Calmares Sagastizábal, Arquitecto.

Nueva distribución:

SALA I. Paleolítico y Neolítico.

SALA II. Edad de Cobre: los poblados.

SALA III. Edad del Cobre: las necrópolis. Cultura campaniforme. Edad del Bronce.

SALA IV. Edad del Bronce Final.

SALA V. Las Colonizaciones. El Carambolo.

SALA VI. Orfebrería Prehistórica y Tartésica.

SALA VII. Orfebrería Turdetana y Toréutica orientalizante.

SALA VIII. Colonizaciones. Primera Edad del Hierro.

SALA IX. Colonizaciones. Mundo funerario.

SALA X. Segunda Edad del Hierro. Cultura Turdetana.

SALA XI. Cultura Iberoromana. 
SALA XII. Cultura Romana I.

SALA XIII. Cultura Romana II.

SALA XIV. Mercurio.

SALA XV. Cerámica Romana.

SALA XVI. Estelas Votivas de Itálica.

SALA XVII. Venus.

SALA XVIII. Retratos romanos.

SALA XIX. Diana.

SALA XX. Trajano.

SALA XXI. Epigrafía romana.

SALA XXII. El ejército romano.

SALA XXIII. Restos del Templo de Carteia. Comercio y Monedas.

SALA XXIV. Munigua.

SALA XXV. Mundo funerario romano.

SALA XXVI. Antigüedad tardía.

SALA XXVII. Edad Media y Moderna.

\section{IV.3.2. Estado de conservación y mantenimiento}

No ha sido nuestra intención durante este documento de análisis criticar o atacar todos los 'recursos museográficos', como ha podido parecer, y esto es demostrable en tanto en cuanto hemos de señalar en este apartado que el mantenimiento de la mayoría de los sistemas expositivos, a simple vista, deja bastante que desear, son bastante obsoletos $y$, aunque podríamos considerarlos aceptables, puesto que sabemos que el museo cuenta con unos medios muy deficientes y que personal intenta hacer lo que puede mediante una labor de limpieza y mantenimiento, hay elementos que deben ser modificados y que nadie presta atención por encontrarse en un estado de obsolescencia absoluto.

Así que, en conclusión, hay que decir que el estado de conservación de las piezas y el mantenimiento de los sistemas expositivos es aceptable pero que el museo pide a gritos una actualización de recursos y de discurso. 


\section{IV.3.3. Posibilidades de reutilización de los} elementos museográficos.

En este sentido sí pensamos que debemos ser tajantes y decir que no hay ninguna posibilidad de reutilización y que lo que necesita el museo es una renovación revolucionaria, la cual pasaría por la desinstalación total de la museografía que nos ofrece hoy y la reinstalación de una museografía moderna, acorde con las demandas del público hacia los museos y por supuesto que cuente con las nuevas tecnologías en cuanto a conservación preventiva e instalaciones museográficas y recurso de comunicación.

\section{IV.4. FUNCIONAMIENTO}

\section{ACCESIBILIDAD}

\section{IV.4.1. Salas cerradas (motivo y fechas).}

En la actualidad no hay ninguna sala cerrada pero si sabemos que por los problemas ya comentados de humedades y desagües del sótano, en ocasiones de lluvias acentuadas, se han tenido que cerrar las salas del Tesoro del Carambolo y las que la rodean, es decir, IV, V, VI y VII. Ha habido días en que ha sido necesario cerrar toda la planta sótano por estar anegada con un palmo de agua.

\section{IV.4.2. Adaptación en recorrido y/o contenido para personas discapacitadas.}

Con respecto a esto, hay que señalar que a pesar de la mala señalización del acceso para discapacitados físicos, el museo cuenta con toda la tecnología necesaria para que cualquier persona pueda acceder a cada rincón del museo, incluso al área administrativa, exceptuando la biblioteca en la que encontramos una barrera de escaleras a las que todavía no se les ha dado solución.

Con respecto a esto, hay que señalar que durante nuestro periodo de análisis y evaluación del museo, y por compañerismo, la sensibilidad hacia esta situación ha sido más acentuada y que en alguna ocasión hemos tenido 
algunas barreras de acceso por encontrarse en remodelación el ascensor, o bien, el impedimento de no funcionar la rampa de acceso a la sala de exposiciones temporales.

\section{IV.4.3. Evaluación de la exposición: análisis interno del museo.}

Para comenzar a realizar un análisis de los contenidos y principales temas que abarca la actual exposición permanente del Museo Arqueológico de Sevilla, hay que salir al exterior y observar desde esta situación los primeros problemas del edificio derivados de su ubicación. Aunque no son demasiados, si habría que señalar seis aspectos condicionantes, pero que pueden tener solución relativamente solventable:

- Humedades, por encontrarse rodeado del Parque de Maria Luisa, por lo que Aníbal González proyectó el edificio con una cámara aislante en el semisótano, hoy deficiente almacén del museo.
- Poca posibilidad de crecimiento por la ubicación señalada y por la poca presencia de edificios adquiribles para su deseable ampliación.

- Posicionamiento axial del 'gran salón ovalado', lo que no fue tenido en cuenta cuando Navascués, Lafita y Felix Hernández plantearon la primera instalación, ya que en 1.942 el concepto de monumentalidad no era el mismo que en la actualidad. Ahora la mejor manera de dar la importancia que se merece a este espacio es colocando la entrada al museo desde éste, cosa que trataremos más adelante.

- Problema derivado del anterior es la imposibilidad de dar al discurso expositivo una linealidad o un tratamiento por bloques, bien diferenciados.

- Tratamiento de la rampa de acceso a discapacitados, quizás desde el exterior parece estar escondida y debería 
tener un tratamiento más específico y más señalizado. Todo visitante al museo es igual de importante.

- Necesidad de que el museo se proyecte hacia ese exterior

magnífico que atesora, bien mediante la reproducción y colocación en los jardines de las piezas más emblemáticas, bien mediante la apertura y uso de las magnificas loggias que se proyectan al exterior donde se podrían colocar desde la cafetería a tiendas o lugares de descanso para el visitante.

Una vez comentados los problemas que pueden ser observados en el exterior, vamos a ir recorriendo el museo desde su entrada y comentando todos los problemas que puede plantear su instalación actual y por lo que se ha planteado la redacción de este Plan Museológico. Para empezar y consecuencia también de lo comentado, al principio, el primer problema que se plantea es la instalación de la entrada en lateral, lo cual se vio como solución a esa linealidad del discurso y que hoy resulta algo obsoleto. Esta situación no contribuye a la sensación de expectación que se le debe crear al público desde que entra en el museo (y si es posible desde el exterior mucho mejor) porque en los tiempos que corren la importancia se ha trasladado del objeto al sujeto, así, es el espectador al que se le debe cuidar (lo cual no significa que la pieza se olvide). Por esto y como comentaremos en los correspondientes programas de este documento, la entrada creemos que debería ser directa al gran salón ovalado, el cual actuaría de receptor, informador y distribuidor del visitante, protagonista por el deseo de que los museos sean más visitados.

La colocación de la entrada en lateral provoca también que la recepción al museo también haya quedado anticuada y que la falta de espacio sea un problema para la colocación de taquillas, guardarropa, etc.... La recepción actual, a nuestro juicio, es otro elemento que desprestigia totalmente 
al museo porque manifiesta esa falta de espacio porque es evidente que se aprovecha el pequeño rellano del ascensor para colocar unas sillas, una librería con tres o cuatro publicaciones y un pequeño mostrador donde la atención al visitante es deficiente. Además este rellano hace de distribuidor y aunque encontramos un directorio, en un principio el espectador no sabe donde se ubica, donde comienza la visita o donde puede o no acceder, es decir, que parte corresponde a administración, y por tanto a elementos internos, y cual pertenece al espacio abierto donde debe desarrollar su visita.

\section{IV.5. PLANTA SÓTANO...}

Una vez aclarado donde comenzar a visitar, lo primero que nos encontramos es que debemos descender al semisótano, bien por escaleras, bien mediante el ascensor reservado al personal o a discapacitados. Esta idea de ir a un sótano a visitar un museo, puede resultar extraño a ciertos visitantes y más si no se intenta hacer amena esa bajada. En la mente de todos esta la imagen de esos laboratorios sombríos de los investigadores y no es esa la visión que debe tener el espectador si no que éste debe esperarse más bien una aventura emocionante y atractiva para que no parezca si quiera que está descendiendo.

Una vez descendida la escalera nos encontramos un intento de "sala de recepción explicativa" de lo que se va a ver en esta planta, dedicada a la Prehistoria. Decimos intento porque los elementos usados son más bien piezas de museo, por su antigüedad, que museografía explicativa, aunque hemos de decir que ya con la entrada de la nueva directra se han retirado esos elementos. Si ya desde que accedemos tenemos la sensación de haber retrocedido en el tiempo unos treinta o cuarenta años, el remate de esta sala es que nos entramos el acceso a los servicios. Destacar de esta entrada, una vitrina muy interesante en la que se nos explica la enfermedad de los restos humanos encontrados en arqueología, vitrina que quizás deberíamos 
encontrar insertada en un contexto de explicaciones acerca de la arqueología con dioramas, maquetas, retroiluminaciones, etc....

Así, estamos hablando de un edificio y una museografía totalmente obsoleta desde prácticamente que entramos, lo cual no quiere decir que a la misma vez el inmueble no tenga unas posibilidades de musealización moderna espectaculares.

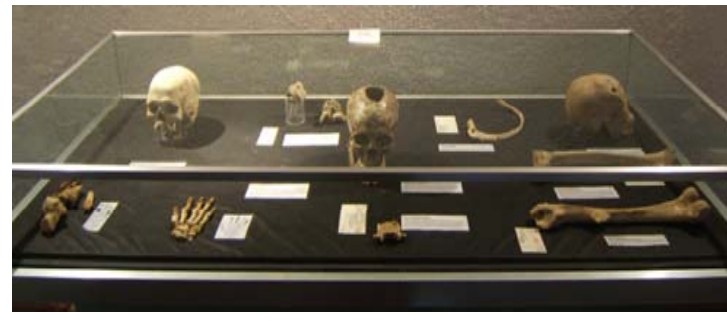

Es de interés comentar, que en la actualidad al espectador no se interesa, ni se sorprende por la cantidad de objetos, sino más bien por su calidad. Estas afirmaciones hacen que nos sea fácil argumentar, antes de comentar detenidamente, cómo de importante es que nos olvidemos de la museografía de este sótano, de vitrinas demasiado cargadas de objetos, demasiado parecidas en cuanto a contenido y disposición, lo que lleva a la confusión, con una luz demasiado fría y aséptica, cosa a la que contribuyen las vitrinas de cristal, más propias de un laboratorio de investigación que de un lugar de puesta en valor de culturas, costumbres, curiosidades, etc....

Introduciéndonos ya en las unidades temáticas de cada sala, la primera a comentar es la Sala I, en la cual, se nos pretende mostrar una especie de resumen de cómo surgió

la

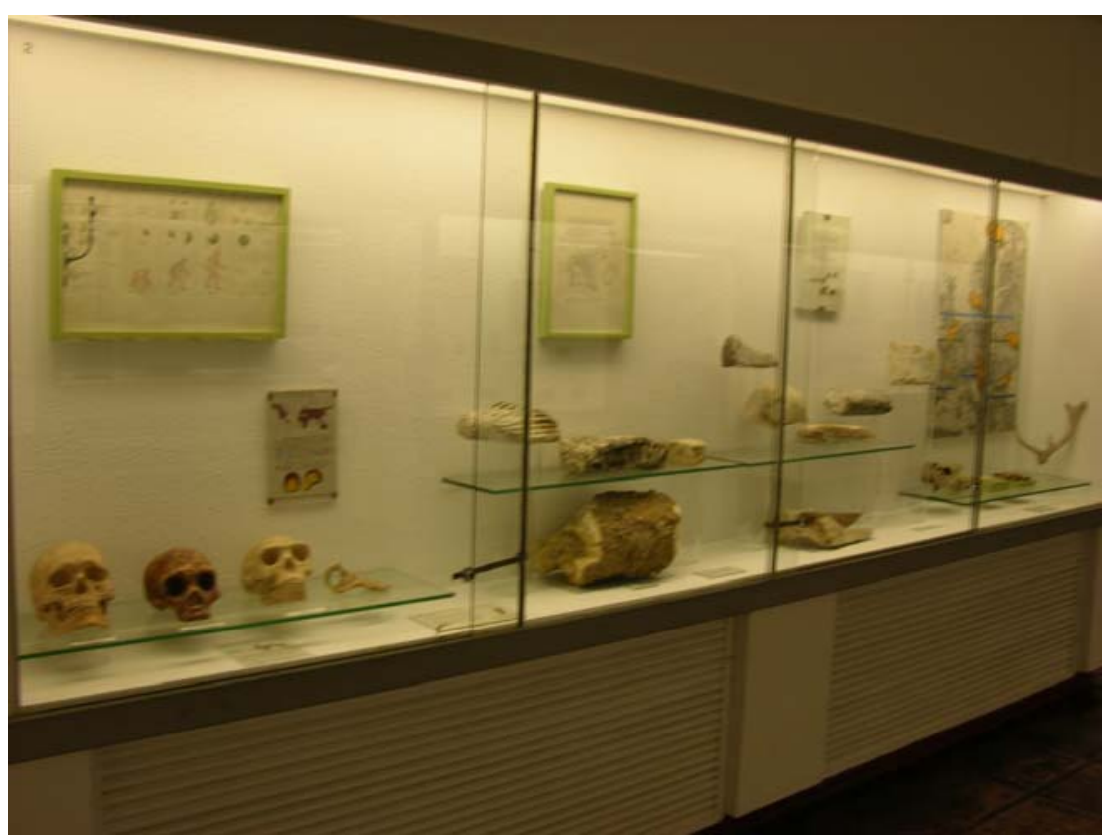


vida en el valle del Guadalquivir e imagen que se puede llevar un experto o nosotros mismos por estudiar el museo, pero que el visitante llano es difícil que se lleve porque el caos expositivo interior resulta tal que es probable que el visitante se limite a la observación o visualización de los objetos mas curiosos, sin intentar dar una explicación a los mismos, consecuencia de los cual es que la función didáctica del museo quede eliminada. No es lícito, en la etapa museística que atravesamos, dar explicaciones sobre temas tan importantes como es el surgimiento de la vida en el valle del Guadalquivir, a través de simples A4 escritos con la ya obsoleta máquina de escribir y dibujos tan ínfimos, anticuados y poco explicativos como los que observamos a lo largo de las vitrinas de esta sala. No es forma esta de que un niño tenga el interés suficiente como para pararse a entender lo que se expone. También hay que decir que se plantean dibujos de una actualidad mayor, con un contenido aceptable, pero que por su presentación y por la situación en la que están se convierten en meros oasis en un desierto de desinformación.
Museográficamente también es de recibo criticar la superposición de cristales, piezas y cilindros de metacrilato que hacen que la compartimentación que se le pretende dar a las vitrinas provoque más confusión y una malísima percepción de las piezas que se sitúan debajo de las vitrinas de cristal, autenticas marginadas del discurso. Todas estas cosas contribuyen a la sensación ya

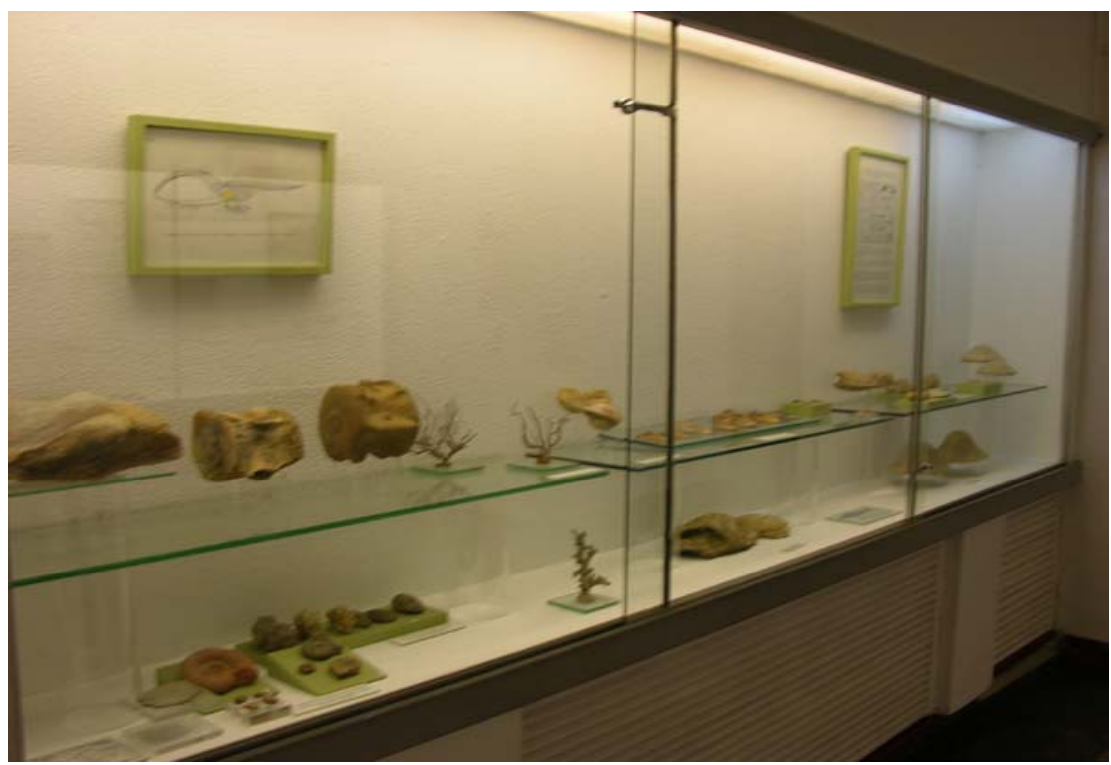

comentada de un aséptico almacén de investigador donde 
las obras estarían colocadas en el orden dentro de su desorden.

El orden cronológico y lineal del discurso expositivo se hace manifiesto desde la primera vitrina, única virtud que podría tener la disposición actual si no fuera porque en alguna ocasión también, observamos saltos expositivos entre textos explicativos y piezas que se exponen. El comienzo de este orden lineal lo percibimos en el deseo de explicar el mundo marino en la prehistoria, así el problema se centra no en el contenido sino en las formas de exposición, en realidad las piezas que se nos muestran son representativas del mundo marino, pero en ningún lugar se le da explicación al espectador de que son fósiles encontrados en plena tierra firme(tal como la conocemos hoy en día) pero que fueron seres vivos que nadaron donde hoy encontramos tierra y que Andalucía estuvo sumergida en las aguas del mar antes de producirse las diferentes evoluciones de los continentes que nos llevaron a emerger y colocarnos donde hoy nos encontramos. Son muy interesantes los dos textos explicativos que nos encontramos en el interior de esta vitrina, pero volvemos a observar la ya comentada obsolescencia en cuanto a formas. De comentar es también, a la acumulación de algunas piezas, lo que nos da la sensación de repetición y la colocación de cartelas más grandes que las piezas, lo cual no es criticable ya que deben leerse, pero si es posible colocarlas en otras posiciones que no hagan que la comparación por tamaño reste importancia a la pieza. La siguiente vitrina es un buen ejemplo de la necesidad de actualización del museo ya que se nos presenta un gráfico sobre la evolución del hombre en un esquema bastante escueto y que no corresponde con los tres cráneos que se exponen en la parte inferior. A nuestro juicio, este tratamiento de informaciones, en las que se pretende situarlo en un contexto amplio en el tiempo es importante para poder entender la evolución humana y todo lo que rodea esa evolución, debería realizarse con una rigurosidad mayor, en un espacio más amplio y donde se diferencien entre las especies de homínidos que 
evolucionaron en nuestro territorio y las que accedieron al mismo habiendo evolucionado en otros continentes; por todo esto creemos que esta información será clave en nuestra propuesta expositiva y deberá tener un tratamiento e importancia básica para el entendimiento del resto del discurso.

Además las explicaciones que se dan alrededor de temas tan importantes como la aparición del australopithecus o la presencia del hombre en el mundo prehistórico se sitúan en pequeños rincones y con demasiados obstáculos, lo cual provocará que el visitante no preste atención, a no ser que tenga un interés especial, cosa que no ocurre en demasiadas ocasiones.

Ya en la vitrina 3 se nos vuelve a introducir otro cráneo para explicar los primeros asentamientos en el valle del Guadalquivir, cosa que debería haber quedado cerrada en la anterior porque en la vitrina que nos ocupa se van a centrar los temas en explicarnos objetos de la vida cotidiana y sería conveniente que se mostrara al visitante una cierta unidad temática. En esta misma vitrina es interesante observar cómo han introducido elementos algo más actuales como es la explicación de cómo se sacaban las puntas de flecha en un cartón pluma, mientras estas se amontonan en la zona inferior de una manera inconcebible para un museo moderno.

Otra muestra de la poca unidad temática que respeta el museo se prueba en que el tema de los útiles de la vida cotidiana es continuado en la vitrina 5 , con lo cual hay un salto, quizás por aprovechamiento del espacio, que no contribuye al buen entendimiento de la evolución que se nos quiere mostrar desde que el hombre comenzó a tallar esos útiles hasta que comienza a pulirlos, es decir, del proceso de evolución desde el Paleolítico al Neolítico; cosa que no ocurrió en dos días sino que tuvo un perfeccionamiento en el tiempo bastante dilatado. Así, estas dos vitrinas deberían haberse planteado juntas para posibilitar al visitante la comparación de los trabajos y que 
cada uno pueda hacerse una imagen del porqué, cómo y cuándo de estas primeras experiencias de la vida del ser humano en la tierra. Volvemos a insistir en que está bien conseguido el contenido de los dos textos y dibujos explicativos pero que deja mucho que desear en cuanto a presentación, tratamiento, colores, en definitiva, atractivo; y no se ha de pensar en que no hemos tenido en cuenta la falta de presupuesto para este tipo de errores pero es que es criticable también esa falta de presupuesto.

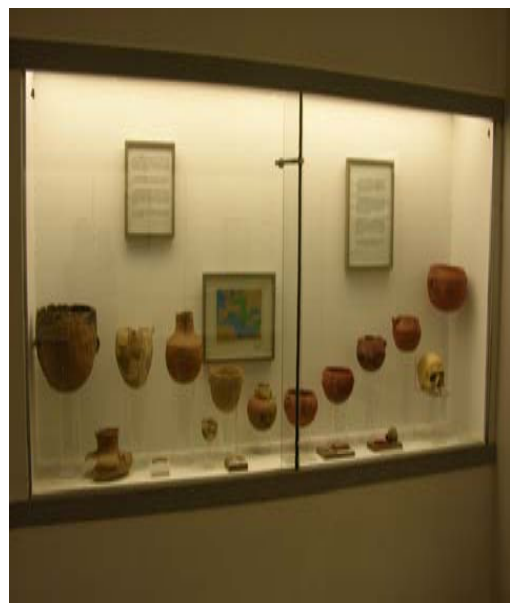

Da la impresión a medida que avanzamos de una cierta presteza en explicar esta primera parte de la historia que se muestra en el museo, lo cual puede tener dos lecturas, o bien que no se le da tanta importancia a la colección de prehistoria como a la de arqueología romana, con lo cual es resultado de la falta de investigación, o bien que la falta de sitio.

Comentamos ahora esta situación porque sorprende que en la vitrina 4 se colocan textos que nos hablan sobre las formas de vida en el Neolítico, la aparición de la agricultura y la ganadería, etc.... y no se exponga nada representativo

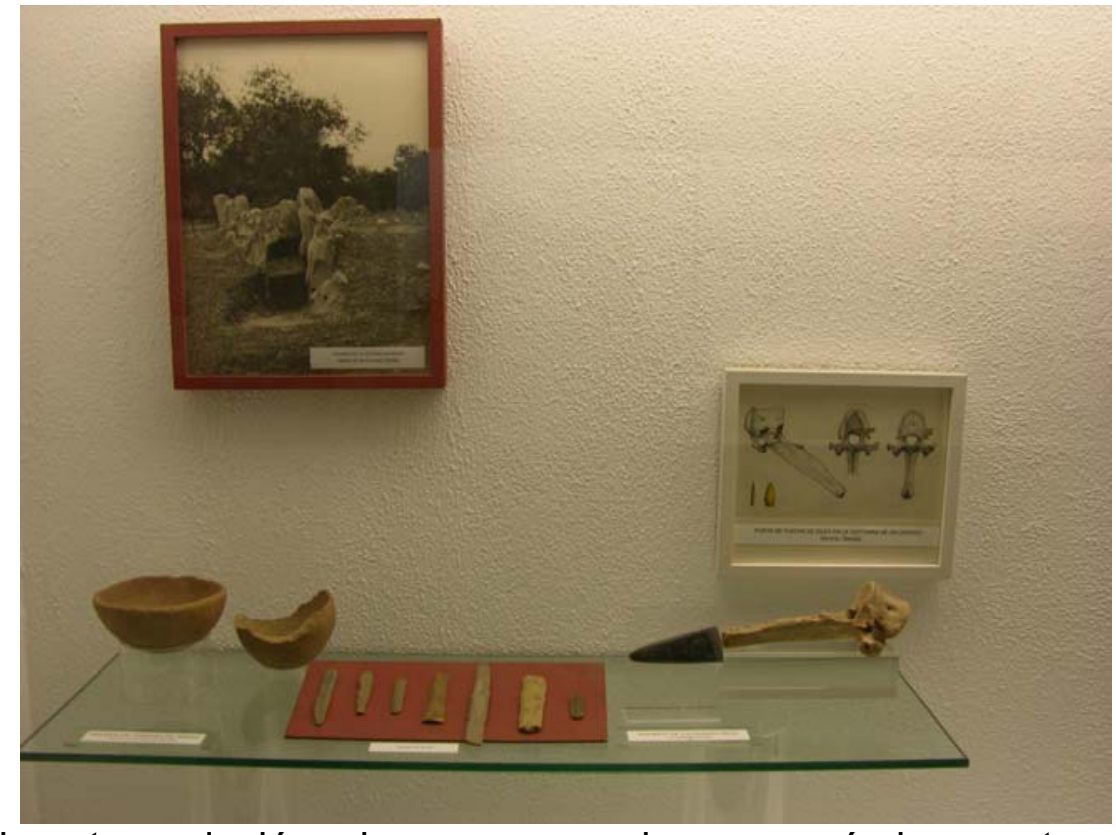

de esta evolución, si no que se coloquen cerámicas y otro 
cráneo que hace que el trabajo explicativo del texto sea nulo por no encontrar el visitante una praxis de las situaciones que se nos narran en los textos. Además el tema de la cerámica va a ser recurrente en esta misma sala y las posteriores para explicarnos la cerámica de almagra y la cultura campaniforme, otros tres aspectos que podrían constituirse en otra unidad temática.

Entre las vitrinas 5 y 6 nos encontramos un elemento que nos va a acompañar durante toda la visita a esta planta llamada de prehistoria y que a nuestro juicio es una buena idea pero que se encuentra en un estado de dejadez y dispersión que hace que su posible función lúdico-didáctica se anule. Nos referimos a las diferentes urnas en las que se les da a oler al visitante los ambientes que se podrían crear en cada época o en cada momento de la historia. Creemos que estos elementos funcionarian mucho mejor constituyendo una nueva unidad temática que proporcione a su Vez un atractivo diferente al espectador.
Quizás sea en la vitrina 6 donde se nos muestre la pieza más interesante de esta sala, un ídolo-placa, que se nos explicará en salas venideras, lo que significa un error importante porque ya que se nos muestra lo preceptivo es que se nos explique; y el cual tiene un tratamiento dentro de la vitrina demasiado igualitario a las demás piezas y donde el espectador solo puede sacar en conclusión que se nos está introduciendo en la cultura religiosa y mística de la gente del Neolítico, cuando se trata de una pieza de la Edad del Cobre.

Ya en la última vitrina se nos amplía un poco los tipos de enterramiento que conocemos y que se practicaban en el Neolítico. Se utilizan fotos, esquemas y dibujos que vuelven a no tener demasiada relación con los elementos que se exponen en la zona inferior, así, nos encontramos toda una serie de puntas de flecha y una vértebra de un animal perforada por una de esas puntas de flecha, es decir, que mientras en los textos se nos habla del culto a la muerte, las piezas nos dan a entender que se nos habla de 
la caza y los ritos que comportaba esta actividad, los cuales eran totalmente diferentes a los de inhumación. Aprovechando esta mención a la caza, hay que decir que este apartado es considerado muy importante por cualquier estudioso y que no se muestra ni aquí en esta especie de sala introductoria, ni va a tener un tratamiento más específico en ninguna de las demás salas.

Otro elemento a comentar para terminar con esta sala son las diferentes fotografías que se nos introducen en los fondos de las diferentes vitrinas, repetidas en toda la sección de prehistoria, y las cuales presentan un estado demasiado anticuado, demasiado pequeñas, poco explicativas y que podrían estar formando parte más del archivo fotográfico del propio museo más que de la exposición permanente del mismo. Además vemos necesario también que si la antigüedad de las fotos es tan manifiesta se deberían acompañar con otras que sean representativas de cómo están los yacimientos en la actualidad o información de cómo podemos visitarlos, detalles que harían que el interés del visitante fuese decreciendo.

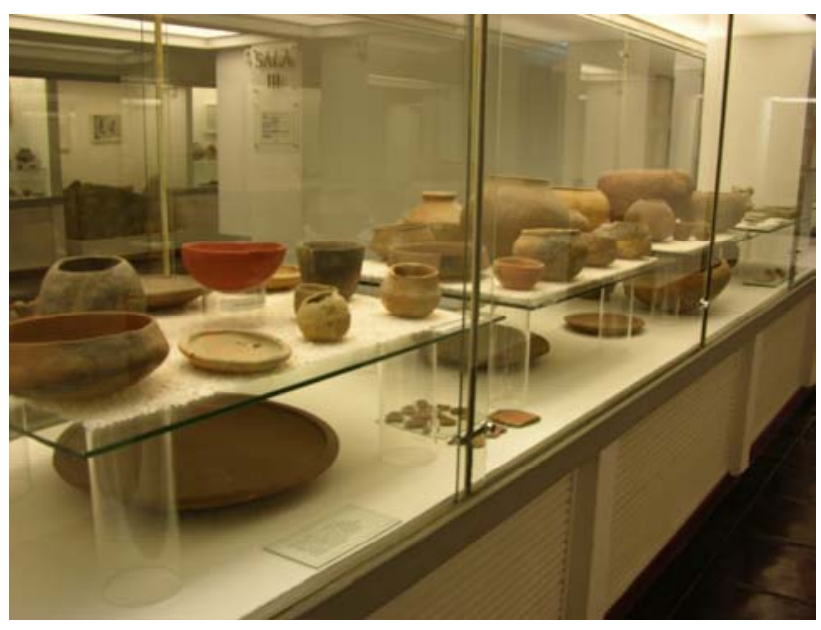

En conclusión, decir que vemos cómo en la sala I se han liquidado más de 80.000 años de prehistoria

y que lo siguiente que se nos explica es la Edad de los Metales, en la Sala II, dedicada en concreto al III Milenio o Edad del Cobre. Esta nueva introducción a un nuevo periodo histórico esta protagonizada por un yacimiento específico, importante para el museo en el momento de su descubrimiento, pero cuya razón de ser ha dejado de existir si lo comparamos con los yacimientos que se nos mostrarán en la siguiente sala. Además el uso de este 
monográfico puede hacer que se provoque una confusión al espectador por la posibilidad de que no le quede claro ese proceso evolutivo que se pretende explicar según el discurso lineal que se observa generalmente en esta planta sótano. Así, comentar también que si vemos necesaria la unidad temática, juzgamos igualmente de importante que el criterio del discurso museológico sea igual de unificado. Esto es otro obstáculo al observador que probablemente haga que éste se canse y se dedique más a una visita contemplativa y no didáctica.

Centrándonos ya en los objetos que se nos exponen y dejando un poco de lado este juicio inicial, hay que decir que observamos una cierta mejoría con respecto a la exposición de la sala anterior, quizás por ser monográfica y tener más claro qué se quiere exponer; lo que denota que se le da una importancia premeditada a este yacimiento. Se nos presenta una gran vitrina central compartimentada en tres grandes apartados: ídolos, cerámica y útiles; encontrados

en

el yacimiento

de Valencina de la

Concepción.

Los textos que acompañan a estos objetos en el interior de la vitrina, nos hablan sobre la actividad agrícola que se desarrollo en esta zona próxima a Santiponce, pero encontramos un gran fallo en el mapa y es la introducción del nombre de Itálica, una ciudad romana, y por tanto de otro momento de la historia, que puede confundir al

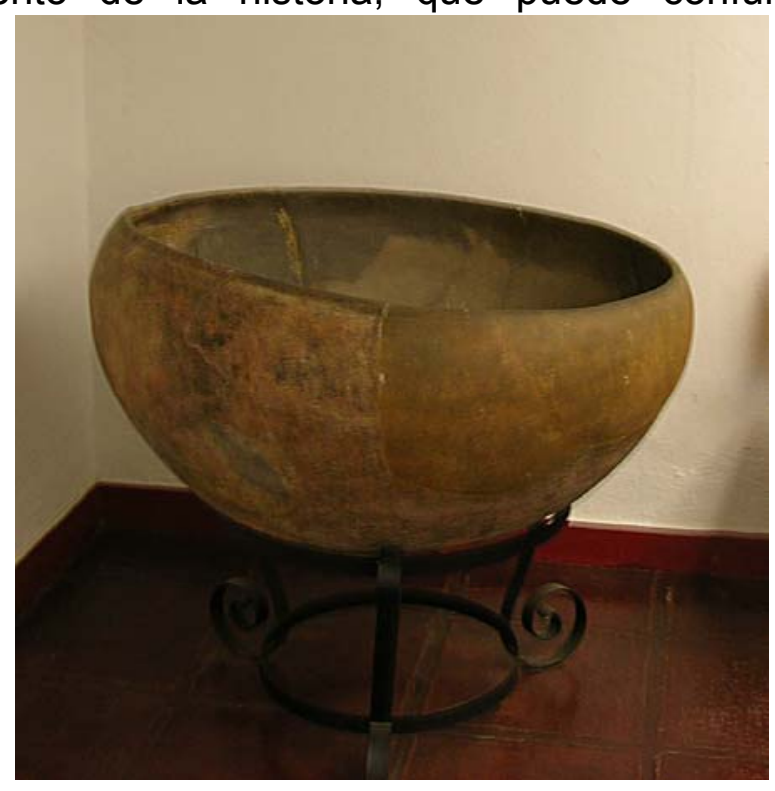


espectador. Museográficamente la sala tiene varias cosas a comentar, así, lo primero que encontramos al entrar es una vasija de provisiones con fotos del proceso de excavación y la localización exacta de su hallazgo, son fotos algo más actuales pero que vuelven a dejar mucho que desear en cuanto a presentación y atractivo. La vasija la encontramos sin protección, cerca de un banco donde puede sentarse el visitante y la tiene al alcance de su mano y sobre un soporte no demasiado apropiado para un objeto de más de 5.000 años de antigüedad. Quizás podría ser más interesante usar esta vasija junto a otras que nos encontraremos más adelante para realizar una especie de recreación del espacio donde se encontró y del uso que tenía.

Ya dentro de la vitrina lo primero que hay que señalar es la presencia de objetos de diverso material, lo cual puede que no sea peligroso en cuanto a conservación preventiva, pero si se debe tener en cuenta por si pudiera existir la posibilidad de que alguna cerámica recoja o desprenda humedad, si los metales existentes son del mismo material o si el tratamiento de los mismos está perfectamente realizado y la evolución que ha podido tener los años en que ha estado en esta vitrina.

Otro problema que se observa es el ya comentado en vitrinas anteriores y que se acentúa en ésta, y es la aglomeración de piezas, lo que provoca un desprestigio de las mismas y una superposición de piezas que hace que las que se sitúan debajo de las baldas de cristal no tengan iluminación ni se puedan observar en condiciones normales.

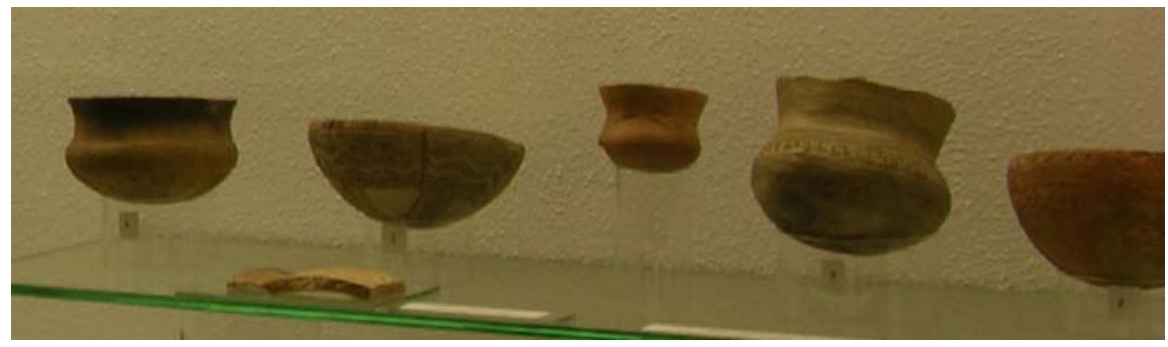


Como algo positivo a comentar, es el intento de ambientación que se le intenta dar a las piezas que se colocan encima de las baldas de cristal, lo que puede resultar algo burdo pero que comparado con lo ya observado hace que las piezas que se colocan bajo el signo de esta museografía estén un poquito mejor puestas en valor.

Dejando ya atrás el monográfico de la sala II, nos adentramos en la Sala III, donde volvemos al caos de sistemas explicativos y expositivos, el cual podemos decir que es aún mas acentuado del ya comentado anteriormente. Esto es debido a que el deseo de tratar el mundo funerario y diferentes ajuares del III y II Milenio o Edad del Cobre y del Bronce provoca que se amontonen los diferentes sistemas expositivos usados y no permitan una lectura clara de la razón de ser de esta sala que se verá continuada por las estelas de la sala IV. Se nos introducen, como tema principal de la sala, maquetas, fotos y pequeños 'dioramas' sobre los tipos de enterramiento y se nos vuelva a hablar de otro tipo diferente de cerámicas, las ya usadas en el II Milenio y que han sido denominadas como cultura campaniforme; esto puede quedar bien científicamente puesto que se coloca cronológicamente la aparición de los diferentes tipos de cerámicas pero no podemos pretender que el espectador encuentre un nexo de unión con las diferentes salas y sea capaz de realizar una reconstrucción mental de los parecidos y diferencias

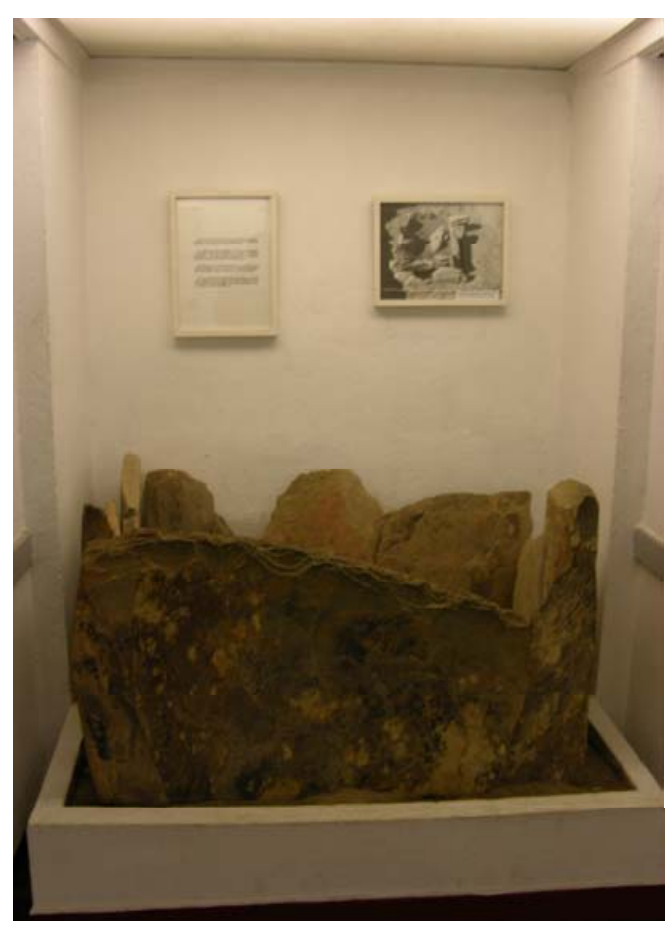


entre las cerámicas ya observadas y las que se nos presentan aquí, a lo más que el visitante interesado en este tema pueda ir de una sala a otra observando esto pero, a nuestro juicio, no sería la forma ideal de visita al museo porque alargaría el tiempo de estancia en el mismo y por tanto provocaría una falta de atención mucho más rápida en el visitante.

Centrándonos ya en las unidades que dividen la sala, es decir, en las vitrinas, hemos de comenzar por comentar las dos primeras (9 y 10) en donde se nos hace alusión monográficamente a dos enterramientos encontrados en la provincia de Sevilla, mientras la vitrina once es otro monográfico pero ya dedicado a un ajuar encontrado en Tarifa, con lo cual también se nos plantea una ruptura territorial sin explicarse que se nos unen territorios por razones de unificación geográfica en épocas pasadas. Continua con los ajuares en la vitrina 12 y al final, que podría entenderse por el principio si se visitara a izquierdas la sala, se coloca en la misma vitrina la cerámica campaniforme.

Como curiosidad comentar que es en el inicio de esta sala donde observamos por primera vez la colocación de textos en diferentes idiomas, algo que veremos pocas veces más y que no contribuye al buen entendimiento de la exposición por parte del publico extranjero, lo cual puede resultar un desprestigio para el propio museo, el cual, por sus colecciones, podría ser uno de los más importantes del ámbito nacional.

En cuanto a la museografía se vuelven a cometer fallos anteriormente señalados como la colocación amontonada de piezas, la colocación de objetos debajo de otras baldas de cristal, la mezcla de materiales y a poca unificación temática. Además esto último nos lleva a poder observar textos explicativos de piezas que encontramos en un lugar totalmente opuesto en sala, caso es el de la explicación del diorama del enterramiento en cista. Con el cual se comete un error aún mayor y es su falta de protección hacia el 
visitante, el cual está incluso tentado a utilizarlo simplemente como papelera como ya hemos comentado con la vasija de provisiones de la sala II y la propia que encontramos en esta sala. Otra vuelta atrás en el tiempo y en la unificación de temas la supone la introducción entre la vitrina 9 y 10 de unos núcleos de silex que perfectamente podrían haber sido colocados en la sala I, a pesar de pertenecer a hallazgos de la Edad del Cobre; comentar también con respecto a estos el mapa que los acompaña, una muestra más de la obsolescencia de los elementos explicativos.

También es problema de estas características la colocación de toda una serie de ídolos -placa, representativos como no del mundo funerario, pero que se nos colocan aquí como aparecidos en el III Milenio mientras ya en la sala I se nos estaba mostrando uno de estos sin explicación ni ubicación cronológica, aunque si puede suponer el espectador que pertenecerían a la Edad del Cobre puesto que las piezas que lo rodean y la cronología de la sala nos llevaría a esta conclusión, a la cual no podemos pedir al visitante que llegue.

Con todos estos problemas comentados hay que llegar a la conclusión de que este caos expositivo nos lleva a un contrariedad aún mayor y es la pérdida de la función pedagógica que debe tener cualquier museo, según definición del ICOM, y que ya no es una dificultad que afecte al espectador sino que también se está provocando que el museo salga del circulo de instituciones al que debería pertenecer, flaco favor en cuanto a su conocimiento, difusión, status investigador, conocimiento del mismo, etc....

La siguiente sala, es decir la Sala IV, que podría ser denominada 'de las estelas', por la clara presencia de éstas y por la unificación temática, que tiene relación a su vez con el mundo funerario anteriormente observado, pertenece ya a la Edad del Bronce Final. Comenzando por el texto de introducción que nos encontramos en el dintel de entrada, puede resultar demasiado escueto para la 
importancia que tuvieron estas enormes piedras en la cultura religiosa de los hombres del Bronce, y el cual tampoco encuentra seguimiento o complemento en el resto de textos que acompañan a las diferentes estelas que nos encontramos dispersadas en la sala.

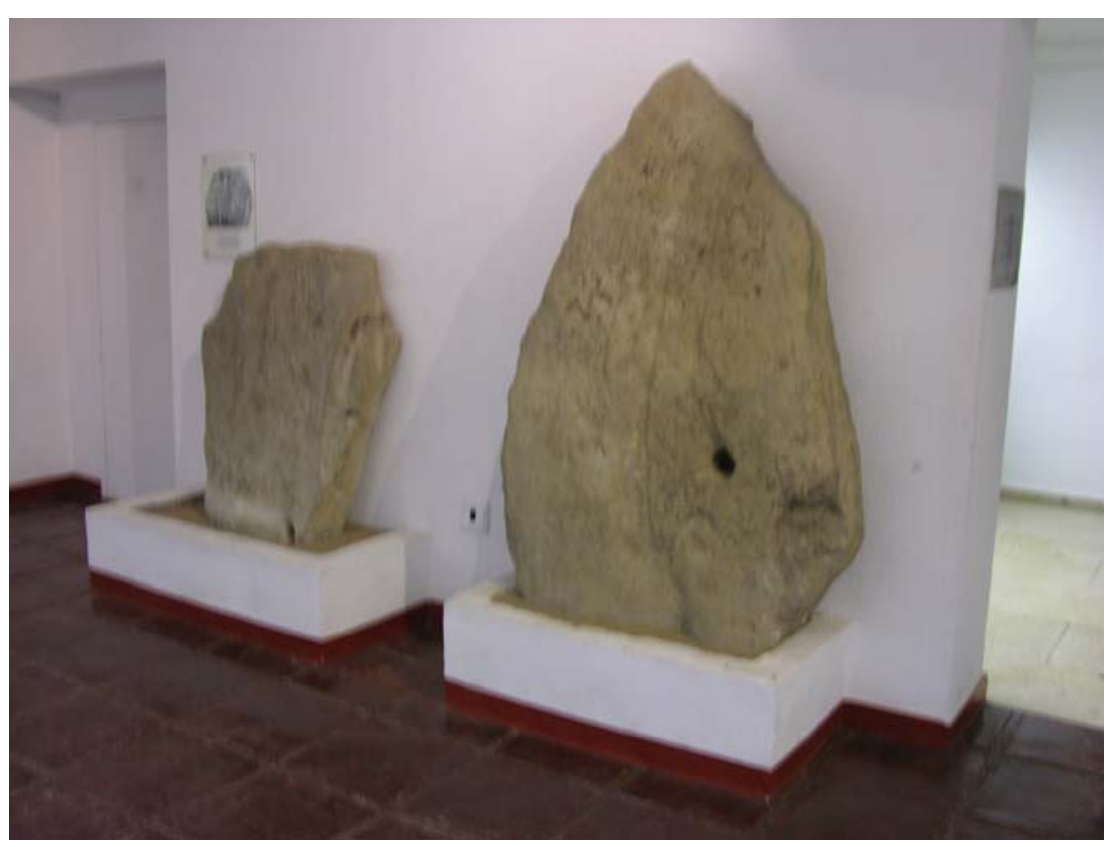

No queremos ser reiterativos o causar una sensación de animadversión hacia el museo, pero es que en esta sala se nos vuelve a cometer el error de introducir una vitrina con temas tan variados y de poca relación con lo funerario como son las hachas y moldes de fundición, armas y un jarrón que pertenece a otra sala pero que es observado por el visitante, que si no está medianamente atento puede creer que pertenece a este mismo periodo de la historia y no al tartésico como es en realidad. Además dentro de la vitrina se nos cuela un texto en el que se nos habla de los tipos de enterramiento del Bronce Final, una nueva mención a la falta de unidad temática. En conclusión un caos expositivo difícil no ya por el visitante no especializado sino también por el investigador, profesor o museólogo.

De analizar es también el sistema expositivo usado para estas grandes estelas, el cual presenta un estado de conservación malo y el cual es manifiestamente equivocado, por varias razones: 
-Falta de información textual y obsolescencia de la información gráfica.

-Mala iluminación.

-Suciedad y por tanto mala conservación.

-Uso del hormigón como material de soporte, lo que a su vez provoca:

- Presencia de restos de pintura blanca en los filos que tienen contacto con la pieza así como en zonas superiores puntuales.

- $\quad$ Anulación de la posibilidad de que esta pieza pueda ser expuesta en otro lugar, restaurada (tendría que hacerse in situ, lo que comportaría el cierre de parte de esta sala) o simplemente cambiada de sitio.

- Desprestigio de la puesta en valor de la pieza y por tanto de la importancia de un objeto de más de 4.000 años de antigüedad.
En las vitrinas volvemos a poder comentar fallos como la querencia hacia la cantidad más que a la calidad, la mezcla de materiales o el poco uso del discurso explicativo.

Una curiosidad que presenta también esta sala es la ubicación de la salida de emergencia en el fondo de la estancia, lo cual presenta problemas, no ya museográficos pero si de funcionalidad de la misma, que son:

-Situación algo laberíntica tanto al exterior como en el interior, ya que una vez traspasada la puerta lo que nos encontramos son los almacenes del museo, enorme estancia que no es precisamente un buen ejemplo de almacén.

-Problema derivado de la humedad del parque y el sistema de desagüe, lo cual ha provocado en más de una ocasión que se haya tenido que cerrar las salas más cercanas a esta salida por encontrarse inundadas, cosa que tampoco contribuye a una buena conservación preventiva. 


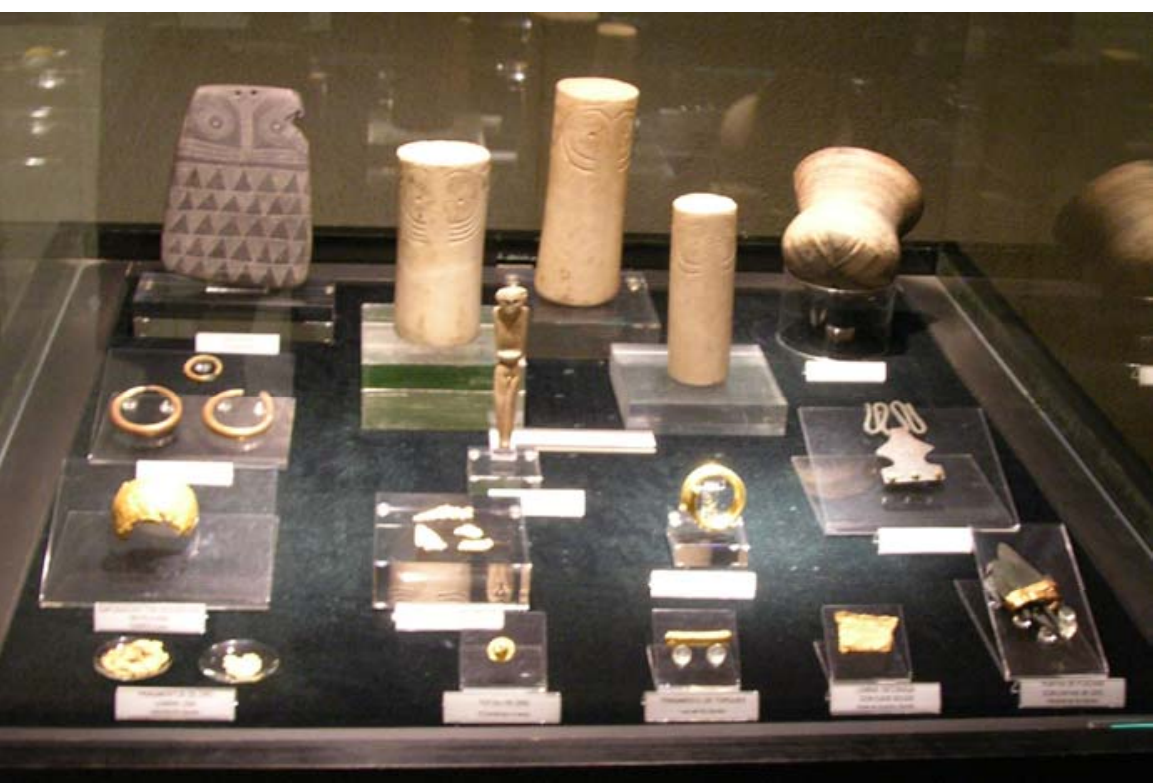

Pasando ya a comentar la siguiente sala, Sala V, ésta se nos plantea, a nuestro juicio, como un espacio introductorio al "sancta santorum" de la sección de prehistoria, el Tesoro del Carambolo que comentaremos más adelante. Así, en esta sala se nos presentan dos vitrinas y en cada una de ellas cerámicas halladas en sendas excavaciones, una sin relación aparente con la mencionada sala VI, salvo por el aspecto religioso o simbólico, encontradas en Marchena y otra en la que se nos muestran las cerámicas halladas en el Carambolo, una de las excavaciones más importantes realizadas en la provincia de Sevilla, más concretamente en Camas. Estos elementos pertenecen ya al periodo tartésico, lo que significa un nuevo salto en el tiempo que no tiene porque ser entendido por cualquier visitante y que por tanto nos lleva a romper el sentido cronológico que debería llevar el espectador en su visión general.

No es difícil darse cuenta del cambio notable de museografía que se utiliza para darnos paso a la muestra de orfebrería perteneciente a periodos que van desde la Edad del Cobre hasta Tartesos, pero si es muy complicado que el visitante observe esa recopilación en el tiempo y no piense que siguiendo el hilo cronológico mostrado en las salas anteriores englobe todos las piezas mostradas en esta sala dentro de un mismo periodo. 
Museográficamente los rasgos de modernidad en esta sala están algo más presentes, aunque también se podría pensar que es una sala demasiado parecida a una joyería más que a un museo. Las técnicas expositivas cambian y se produce una drástica polarización de la luz y el color, es decir, de los paños de pared blancos e iluminación blanca generalizada, se pasa a paños de pared negros e iluminación puntual. Este cambio es producto del tratamiento de las piezas, realizadas en materiales nobles, que demandan un cambio tanto en lo referente a museografía como en lo referente a seguridad. Las vitrinas están mejor trabajadas, aunque tampoco resulten las ideales, y la ambientación de la sala con paredes de piedra y los escalones que nos llevan a esa especie de altar donde se centraliza el "Tesoro del Carambolo", contribuyen a que el visitante de mucha más importancia a esta sala que al resto. Quizás esta sala contribuya más a ese deseo de atractivo que se pretende que tenga el museo y a ese deseo de hacer una puesta en valor del objeto que lo haga único y por tanto más atractivo. Algo que es paradójico con estas alabanzas hechas es que mientras en los textos se nos habla de Tartesos, los objetos presentados en el interior de las vitrinas son de periodos históricos muy variados, con lo cual volvemos a la confusión que reina en el discurso del museo.

Hay que comentar que en el interior de las vitrinas se produce un hecho contradictorio con la conservación preventiva y es la colocación de materiales de diferente tipo, lo cual puede provocar el deterioro de las piezas y que no contribuye a la unidad visual de los mismos. En contrapartida a esta situación hay que alabar la ordenación de la disposición de las piezas, el uso de un material tan acertado como es el metacrilato para colocar las piezas y la puesta en valor de los mismos, que se emborrona con el uso del terciopelo, un material que almacena muchísimo polvo y que puede provocar la degradación de las piezas. Interesante resulta también la culminación de la sala con la hornacina que alberga la pieza más importante de esta sala, la diosa Astarté del Carambolo frente a la vitrina 
cuadrada que alberga el resto del tesoro y donde si hay una unificación matérica, el oro. Es una buena solución para la finalidad de la puesta en valor el hecho de colocar este tesoro en alto y el uso de la hornacina.

A pesar de las alabanzas realizadas a esta sala en concreto, no es factible que se nos presente un cambio de criterio en la muestra de obras de arte por el material que se emplee, es decir, el criterio expositivo debería ir en la línea de poner en valor todas las piezas expuestas en el hilo de la museografía mostrada, la cual hace que las piezas parezcan únicas, como tesoros, que en realidad lo son y es como provocan la admiración del espectador.

Además la presencia de esta especie de "isla en medio del desierto", provoca que el espectador tenga unas expectativas futuras que no se van a cumplir porque en cuanto salimos de esta sala VI, volvemos al mismo sistema expositivo comentado en las salas de la I a la V, así, el resto de la visita va a discurrir por el mismo caos, obsolescencia, hacinamiento y toda esa serie de características museográficas que distingue esta planta sótano.

La pequeñísima y atestada Sala VII, nos aproxima al periodo orientalizante que tendrá sus máximas representaciones en la cultura turdetana y toréutica, con restos de tesoros que son a su vez restos de la museografía de la sala VI. Representativa de estos restos museográficos es la vitrina cuadrada y negra que se nos introduce casi con calzador en esta sala y donde la mezcla de materiales vuelve a ser preocupante.

Pasando ya a la vitrina 19, vuelta a la museografía de luz blanca y aséptica, nos presenta toda una mezcla de materiales que englobamos en el periodo orientalizante y de los cuales no se nos da ninguna explicación textual salvo por las pequeñas cartelas que acompañan a las obras. Debemos tomarnos esta sala, por tanto, como introductoria o de tránsito hacia las siguientes salas, donde 
se hará un tratamiento más amplio de la producción de cerámicas en este periodo orientalizante. Quizás por esta razón nos encontremos un vaso de cerámico de un yacimiento de Riotinto, que tendrá un tratamiento más amplio en salas venideras, y el cual lo encontramos de nuevo desprotegido como las vasijas de valencina $y$ apoyado en esos rudimentarios soportes de maceteros.

Así llegamos a la Sala VIII, enteramente dedicada a la producción cerámica tartésica, tan importante en la sociedad de la época y donde se mezclan las formas fenicias e indígenas, cosa que no se nos explica con detenimiento y por lo cual el espectador no va a entender que son representativas de las colonizaciones producidas en Andalucía en los siglos VII, VI y V a.C. Dedica las dos vitrinas(20 y 21)que nos encontramos a los yacimientos de Riotinto y Setefilla, dos excavaciones muy importantes para la colección del museo y de ahí su tratamiento más específico pero no más didáctico o explicativo.
A pesar de que el hacinamiento no es tan acusado, si se observa una vuelta a los métodos expositivos anteriores de superposición de piezas, colocación de fotografías explicativas demasiado antiguas y deseo de cantidad más que de calidad. Algo que sería muy interesante en este tipo de salas es el hecho de poder explicar al visitante cómo estas vasijas no se encuentran intactas, sino que las mismas llevan un proceso muy lento de reconstrucción que podría resultar bastante atractivo al visitante. Algo que se viene repitiendo en toda la sección y que no hemos comentado hasta ahora es el hecho de la poca unificación en cuanto a cartelas, gráficos, etc...., pareciendo en muchas ocasiones como si se hubiesen ido aprovechando los elementos explicativos de un proceso evolutivo en el tiempo de mejora de estos elementos, bien por consideración del personal interno del museo, como por la salida de piezas a otras exposiciones y su vuelta con una cartela de la exposición en la que pudo participar. 


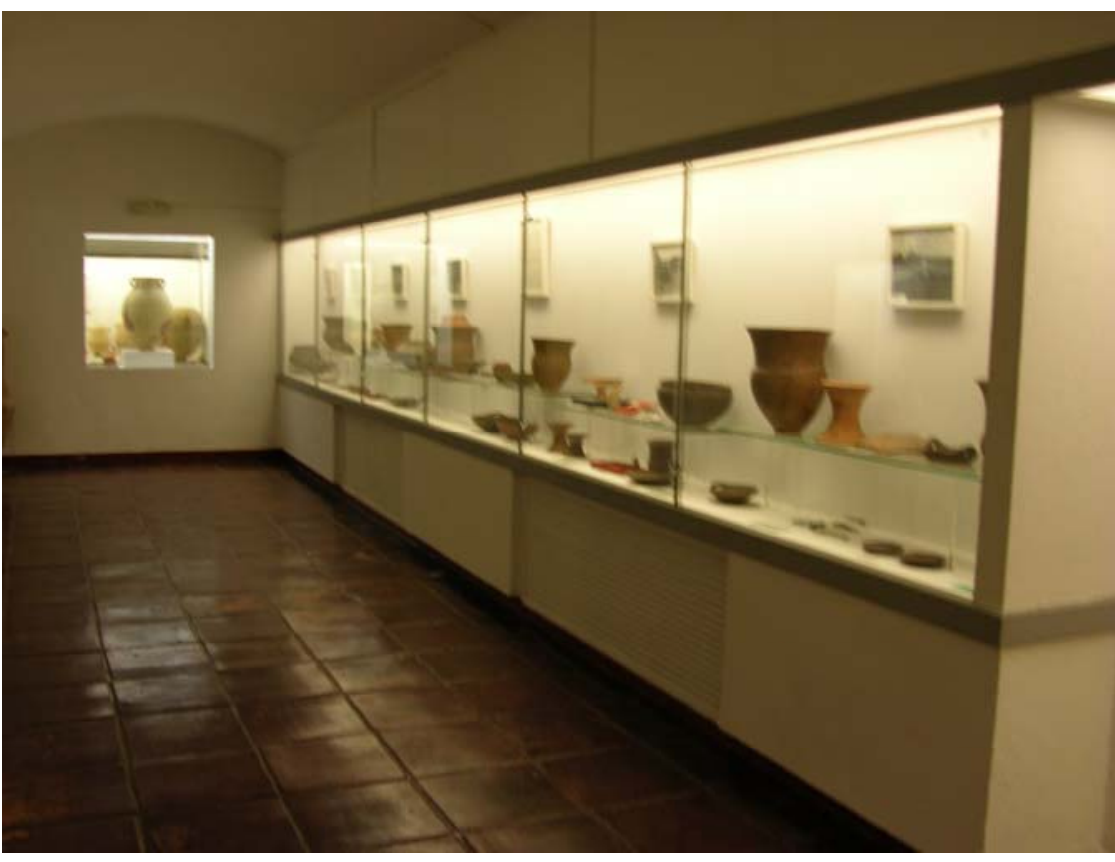

Una buena definición para la siguiente sala, Sala IX, sería la atemporalidad, observada desde el punto de vista del espectador, porque mientras en el cartel de entrada se nos habla del I Milenio a.C., las colonizaciones que se produjeron en el valle del Guadalquivir en esta época son más concretamente pertenecientes a los siglos $\mathrm{V}$ y VI a.C., donde Tartesos está muy presente y donde los parecidos con el pueblo griego pueden llevar al espectador a una confusión mayúscula, ya que es éste del que más información puede atesorar el visitante no especializado.

Aparece en esta sala el nombre de un estudioso de finales del siglo XIX y principios del XX, Jorge Bonsor, un personaje que hizo la excavación de los objetos que se nos muestran en la vitrina 24 en Los Alcores y que se le da una importancia que no se le ha dado a ningún estudioso que excavara ningún otro de los yacimientos mostrados en el museo. Así, esta vitrina parece más bien un homenaje a este personaje con lo que el criterio expositivo vuelve a atomizarse aún más. $Y$ no estamos diciendo que sea contraproducente mostrar respeto por estudiosos tan importantes como este pero si que sería factible la colocación de este homenaje en un contexto diferenciado del discurso cronológico y lineal que se pretende dar a la exposición, así, propondríamos hacer este homenaje hablando de que fue pionero en el desarrollo de la arqueología en Sevilla, que masca junto a otros, el inicio de 
la investigación arquológica moderna y sistemática, por lo que estos estudios alcanzaron gran importancia en la Sevilla de los siglos XIX y principalmente principios del XX.

Otro elemento de confusión presente en otras salas y que comentamos ahora es la presencia de restos expositivos de las salas II y IV en el fondo de esta sala IX, ya que el sistema de exposición laberíntico que presenta esta planta nos lleva a poder observar diferentes salas desde una misma, cosa que contribuye a la sensación de caos y de agobio que puede hacerse presente en el visitante a estas alturas de exposición permanente... y acabamos de empezar visitar el museo.

El remate de la obsolescencia $y$ de todos los fallos comentados en este análisis es la Sala $\mathbf{X}$, donde se quiere hacer un último esfuerzo por acoplar todo lo acontecido entre la Segunda Edad del Hierro y el periodo romano o prerromano, realizándonos además un acertado resumen de todo lo visto anteriormente en la vitrina 27 , cosa que pude llevar al espectador a realizar una lectura simplista consistente en pensar que cómo si en una vitrina se nos puede mostrar millones de años de historia de la Humanidad, se le castiga con una visita caótica y laberíntica a toda una planta donde los objetos que observamos están tratados con la misma importancia que en esta última vitrina. Así, es preceptivo mostrar un equilibrio entre esta buena unificación que se nos presenta en este resumen de la vitrina 27 y la lectura simplista que hemos narrado.

Hemos de comentar también como el periodo ibérico, considerado tan importante en Andalucía debería tener un tratamiento más allá de esta última vitrina 26 , con unidades temáticas tan importantes como pueden ser los exvotos que se exponen en bronce o la escultura del carnero tan representativa de este pueblo surgido en los siglos II y III a.C. y que estuvo presente en la Península hasta el asentamiento romano con la aparición de ciudades como Cartagonova, Itálica, Emerita-Augusta, etc.... 


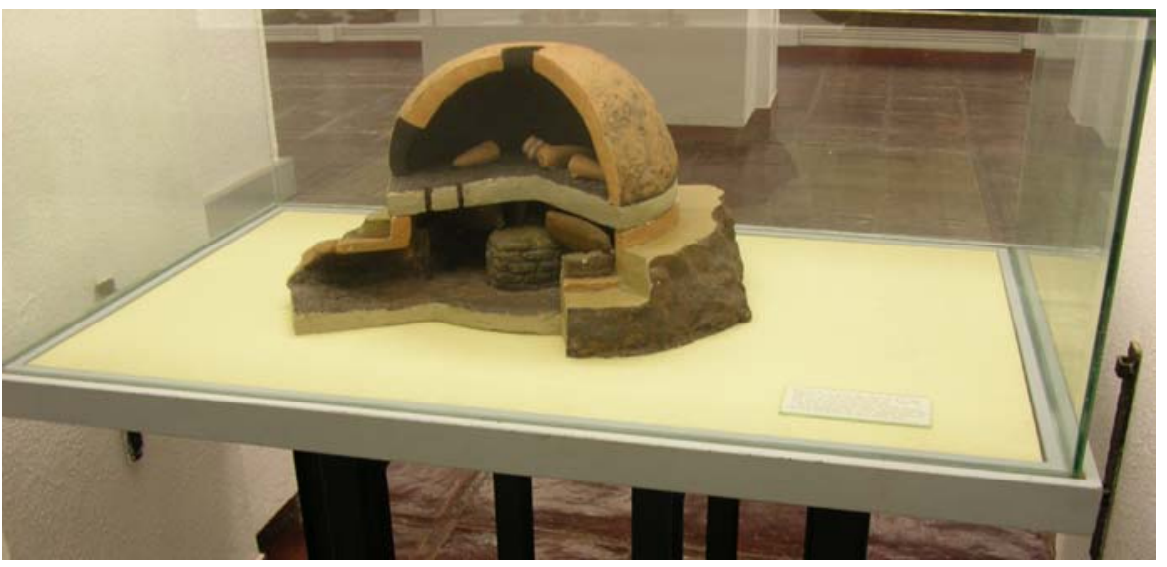

\section{IV.6. PLANTA PRIMERA...}

Hay una clara diferencia con respecto a las Salas de Prehistoria, no ya por el discurso museográfico, sino por el aspecto cualitativo y temático que poseen estas salas. Principalmente, hay una menor agudeza en la evolución cronológica pero una mayor incidencia en lo estético, reservando una gran monumentalidad a las piezas de mayor calidad artística. A lo largo de las salas, se distribuyen una serie de vitrinas que recogen temas monográficos, los cuales, contextualizan de alguna manera el mundo romano en Andalucía.

El análisis y evaluación de estas salas está determinado por el criterio expositivo, pues las piezas son más pesadas, voluminosas y tridimensionales, por ser en su mayoría esculturas. Las piezas más pequeñas se adosan a la pared o bien se recogen en una vitrina transmitiendo un mensaje, enlazando su contenido con la sala.

Comenzamos entrando por la Sala $\mathbf{X I}$, donde nos recibe un panel, a modo de presentación, que en su frente tiene colgado un relieve de una fuente para ser adosado a un muro. Es de mármol rojo y representa el símbolo de Roma, una loba amamantando a Rómulo y Remo, fundadores de la nueva potencia del Mediterráneo, sorprendidos por el pastor Fáustulo.

Es la primera pieza que nos encontramos en esta segunda parte del discurso museográfico y ya es confusa para el espectador profano, ya que como decimos es un símbolo 
de Roma pero lo que vamos a ver a continuación no es plenamente romano, por lo menos en esta primera gran sala. Se considera una obra relevante de la colección de piezas romana y la cual podría identificar el $80 \%$ de los

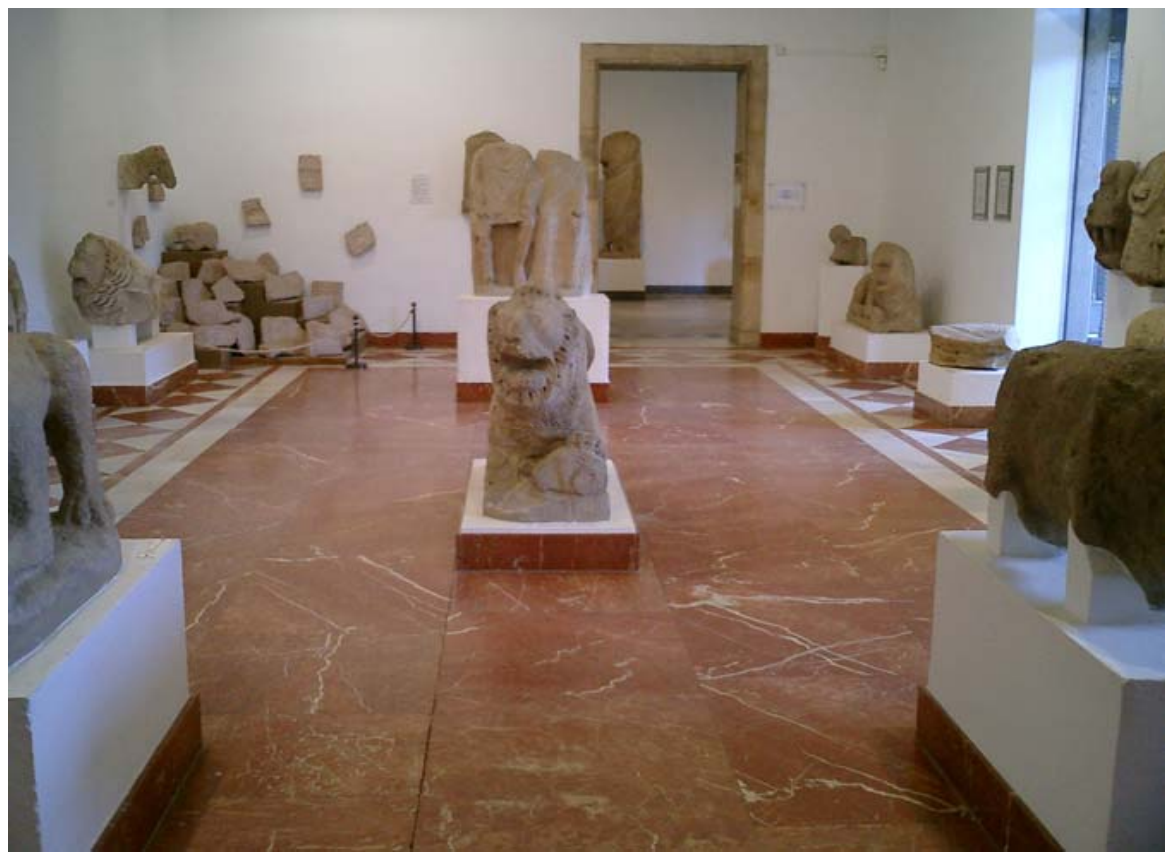

visitantes, con lo cual tendrían la sensación de que Roma comienza en esta sala, nada más lejos de la realidad.
Al margen derecho, observamos un panel explicativo de la cronología que van a acontecer en las sucesivas salas, bastante somero tanto en su contenido como en su tamaño, y poco llamativo tanto en color como en el tamaño de las letras.

A continuación, el interior de la sala alberga una gran diversidad de elementos indígenas, creando así un 'intento' de hilo conductor del discurso entre las salas de Prehistoria y las del mundo romano. Son elementos de transición que crean una mezcolanza entre piezas con un estilo quizás demasiado ecléctico y cuyo posible hilo conductor o intención sea recoger piezas que aúnen todas las características estilísticas propias de la cultura romana.

Encontramos piezas de distintas procedencias, elementos arquitectónicos sustentantes, como columnas y capiteles, colocados en la entrada de la sala, junto con piezas pertenecientes a monumentos funerarios, tanto adosados como de bulto redondo. Destacar la colocación de las 
piezas en su montaje porque hacen que el espectador pueda imaginarse cómo estarían colocadas en la realidad, aunque discursivamente quizás no sería ese su lugar.

Así, destacamos una gran selección de animales en piedra, dispersos por toda la sala. Son en su mayoría leones con marcados rasgos faciales que muestran su agresividad en algunos casos, y en otros, llama la atención de la postura escogida por el escultor. Principalmente están datados entre los siglos III y II a. C. y sus orígenes están distribuidos básicamente en Andalucía Occidental.

Una de las piezas singulares de esta sala es un toro ibérico de Alcalá del Río y del Siglo I a. C. junto con los caballos iberos ubicados en un ángulo izquierdo. Este último animal era muy reconocido en la cultura ibera, por ello, se le dedicó un santuario en Pinos Puente (Granada), donde se encontraron un centenar de relieves, encuadrados cronológicamente entre los siglos $\mathrm{V}$ o IV a. C. y de época romana. Museográficamente, están expuestos de forma acumulativa y sin ningún criterio de conservación preventiva, en cualquier caso, entre todas estas piezas destaca el prótomo enjaezado, por ser mucho más realista y por tener marcados rasgos ibéricos. $Y$ aunque el discurso de la planta superior es más fácil de seguir, estamos congestionando la sala y creando de nuevo la duda en el espectador, ya que cualquier persona podría encuadrar en el mismo periodo histórico la cultura romana e ibérica.

Para acabar con la iconografía zoomórfica de la cultura ibérica, nos encontramos con un relieve de una cierva en movimiento, procedente de Osuna.

Otro ejemplo del eclecticismo marcado de esta sala de transición son los elementos de carácter funerario, estelas con textos epigráficos, una colocada en la entrada de la sala y otra adosada a la pared a modo de friso, o la representación humana plasmada en piezas para ser colocadas en monumentos funerarios, como por ejemplo, el matrimonio sedente localizado en la necrópolis de Orippo (Dos Hermanas, Sevilla), que adquiere un alto 
grado de reconocimiento por la calidad artística de la pieza.

De nuevo nombrar a colación de lo comentado cómo las piezas pierden valor como 'tesoros', al ser colocadas acumulativamente, la gente puede deducir que al haber tantas no deben ser tan importantes porque estamos acostumbrados a valorar lo único e irrepetible y desde el punto de vista de la comunicación perjudica la captación y atención de la mirada del espectador. Esto nos lleva a hacer una reflexión; no sería mejor colocar las piezas más singulares con una museografía singular y que el público las tome como los "tesoros" que son. Estas piezas, en general, son un claro reflejo de la manifestación artística de la ecléctica cultura indígena que sufre el Periodo de Romanización, término que definiría perfectamente la sala y que aclararía al espectador temática y cronológicamente.

Los criterios museográficos elegidos para esta sala son bastante precarios. Empezando por que algunas figuras zoomórficas están alzadas con material de obra a modo de pedestal, un material difícilmente reversible y que plantea problemas de mantenimiento claramente visibles en su pintura, ya que para mantenerlos en ese blanco debe ser retocado cada cierto tiempo y si no se encarga esta labor a manos especializadas ocurre lo que vemos en los bordes de algunas esculturas y es que están pintados y deteriorados.

Mientras, las piezas adosadas en la pared con escuadras de hierro, algunas pintadas también en blanco, no respetan ninguna norma de seguridad y están provocando un daño físico a las obras difícilmente recuperable. A favor de esta instalación lo único que se puede decir es que sea muy probable que la intención en los años setenta fuese la mejor y es comprensible que los medios no fuesen los mismos que en la actualidad, argumento que apoya mucho más nuestra tesis de la necesidad de una reforma a todos los niveles de este gran museo. Para finalizar con esta primera sala de la planta superior decir que los elementos explicativos son de diversas características, como un mapa topográfico que contextualiza la cultura ibérica, y texto 
explicativo de la romanización de la misma. Los cuales tienen una intención algo más renovadora que los encontrados en el sótano pero en los que se vuelve a pecar en materiales que al espectador no le llaman la atención.

El recorrido establecido por la sala es un tanto tortuoso, limitado por la dispersión de piezas sobre pedestales que entorpecen el hilo visual del discurso, y además, las limitaciones de acceso de un discapacitado físico hacen que se complique su visita.

Cada sala está numerada con números romanos colocados sobre un metacrilato atornillado a la pared, acompañado en su parte inferior, por otro metacrilato del mismo formato que contiene un texto explicativo escueto y de letra desapercibida que contextualiza el contenido de las salas en varios idiomas, español, ingles y francés. Las cartelas están colocadas sobre la pared cerca de la pieza aportando datos de la misma sólo en español. La antigüedad de estos sistemas señaléticos es manifiesta.

Y por último, no podemos olvidarnos de la iluminación de estas salas, donde nos encontramos piezas más grandes, cosa que hace que juegue un papel importantísimo la incidencia de la luz sobre la pieza, el ángulo desde donde se ilumine y el no entorpecimiento de la luz natural a la artificial y viceversa. Todas estas características o puntos de referencia harán que la pieza resulte singular, se pueda observar el valor de la talla de las mismas y la expresividad, e incluso crear una barrera visual con el espectador que provoque un respeto y una mayor seguridad. Pero estas características no se cumplen aquí, están buscadas y ambicionadas pero la antigüedad de las instalaciones y algún fallo de atenuación de la luz artificial imposibilitan su adquisición. Un fallo primordial y fácilmente subsanable es el hecho de evitar la mezcla de luz natural y artificial, el material nos permite unos niveles de luxes altos con lo cual no estaría de más el intento de iluminación 
natural, pero en nuestra opinión es mucho más llamativo o de puesta en valor que la luz se haga con un foco directo desde el techo que enaltezca la pieza. En cualquier caso se haría totalmente necesario el uso de uno solo de los sistemas iluminativos, es decir, o bien tamizar la luz natural o bien incidir integramente con luz artificial.

Hasta ahora no observamos la presencia de termohigrógrafos medianamente modernos, de todas formas el museo carece de sistema de climatización, por tanto el control de temperatura y humedad es difícil de mantener en una ciudad un tanto seca, con una ubicación del museo más bien húmeda, y con unas temperaturas puntas en algunas temporadas del año que hacen que el museo sea el más frío o el más caliente de Andalucía.

Si accedemos a la Sala XII, titulada Cultura Romana I, donde se puede observar una gran variedad de piezas de muy diversas formas expuestas, y con una mayor calidad artística romana. Hay mosaicos, esculturas, bustos y pequeños objetos reunidos en dos vitrinas. Comenzaremos analizando la entrada a la sala que está flanqueada por dos mosaicos en forma de tondo, y adosados a la pared, que representan dos estaciones del año, a la derecha, el Otoño y a la izquierda, la Primavera, humanizados en dos figuras femeninas. Provienen de Dos Hermanas y están datados entorno al Siglo II-III a. C. El sistema expositivo de estas piezas vuelve a ser anticuado y por tanto, a estás alturas de la investigación museográfica erróneos. Sería mejor, que la sujeción de estas obras fuese realizada de manera más técnica y no con molduras de escayola que hacen que parezcan adornos de un hogar y no piezas singulares y destacables propias de ser expuestas en un gran museo. Delante de ambos encontramos dos pequeños pilares que elevan dos retratos de diferente procedencia, a la derecha, el busto de Ariadna, de la localidad de Espera y fechado en el Siglo II a. C. y a la izquierda, un retrato anónimo de Carmona del Siglo II-III a. C. Tanto estos bustos como los tondos antes nombrados, vuelven a presentar los problemas de material y pintura 
plástica, comentados con los plintos usados en la sala $\mathrm{XI}$, el mantenimiento de esos sistemas sustentantes provoca un deterioro a las piezas y es poco recomendable para su conservación.

El margen derecho de la sala está presidido por un torso monumental, desnudo, sedente y parece estar divinizado por la toga que cuelga desde su hombro. Fue hallado en Badajoz (Mérida), y se le atribuye al emperador Claudio.

Esta escultura está flanqueada por dos vitrinas que exponen un contenido monográfico sobre temas relacionados con la cultura romana. En este caso, la primera vitrina que vamos a analizar, trata sobre el trabajo especializado y el ocio. Su exposición nos muestra una gran variedad de objetos que requieren una preparación profesional para su uso, puesto que son útiles para practicar la medicina, tales como pinzas, bisturís, y pequeños cuencos de bronce para mezclar ungüentos y hacer pomadas.
También encontramos piezas para practicar la escritura como el codex, en el centro de la vitrina, acompañado del stilus para escribir. La mujer también tiene su lugar aquí con la aparición de las labores de costura, hilado y tejido, un pequeño telar nos sirve de ejemplo, junto con pesas y fusayoras. El trabajo del hombre, queda reflejado en la caza y pesca, con la fabricación de pequeños anzuelos. $Y$ por último, el ocio queda patente con la presentación de la máscara femenina, perteneciente a una tumba hallada en Utrera. Este tipo de vitrinas van a ir a apareciendo a lo largo del discurso, más o menos con un hilo conductor que es mostrar las diferentes facetas de la vida romana, pero que como unidades temáticas pueden llegar a confundir al espectador y llevarlo al eclecticismo del que peca este discurso.

Para poner un ejemplo usaremos esta primera vitrina, así, si estamos colocando piezas que se utilizaban para trabajar, unas manejadas por el hombre y otras por la mujer, sería conveniente que se cumplieran una serie de 
premisas, es decir, primero colocar las piezas más singulares y anular la acumulación. $Y$ segundo, que las facetas de la vida pudiesen presentarse como una unidad temática con un tratamiento mayor y más exclusivo de una sala.

La otra vitrina está dedicada al trabajo manual presentando útiles y herramientas del trabajo de campo, la cocina o la mina, propio de los trabajos realizados por los esclavos.

Museográficamente estas vitrinas corresponden a una etapa posterior a las usadas en la planta sótano, y presentan algunas virtudes que no tienen las otras, una mejor presencia, una presentación de las piezas algo más dispersas, pero siguen el criterio acumulativo, junto con la posibilidad de observar las piezas desde diferentes puntos de vista; aunque estéticamente y en cuanto a conservación preventiva el problema viene de usar un material de soporte como es la esterilla que acumula mucho polvo, no es neutro y que resulta un tanto anticuado y poco atractivo.
Una vez descritos los contenidos de cada vitrina, nos centraremos ahora en las piezas que completan la sala. A ambos lados de la sala, delante de cada vitrina, hay dos piezas de importante calidad artística. A la izquierda, Niobe, procedente de Italia (Siglo $\mathrm{V}$ a.C), y donada por el Dugue de Medinaceli. Es una figura humana, divinizada y sin rostro, reposando sobre su brazo derecho. Esta postura nos llega a asegurar que perteneció a un frontón de algún templo.

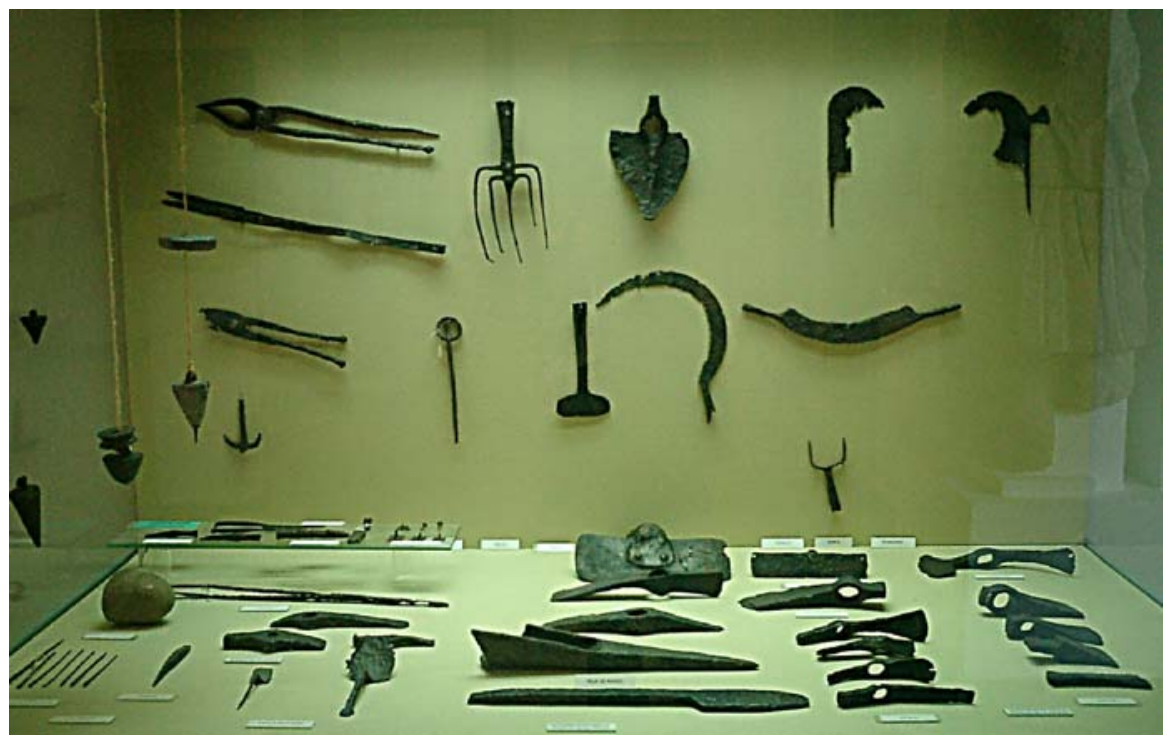


Frente a esta escultura, está una pequeña pieza tosca que escenifica al héroe Atlas portando el globo terráqueo, hallado en la antigua Cumbaria (Las Cabezas de San Juan, Sevilla), datado en el año 48 a. C.

Y por último, el torso de la amazona de Carmona. Sus tejidos y ropajes transmiten al espectador la monumentalidad de la figura, suponiendo que debía ser una de las esculturas que formaran parte de un coloso para ennoblecer la entrada a la ciudad.

La otra mitad de la sala está completada con piezas significativas como el Ara, del Siglo I a. C, localizado en Trigueros (Huelva). Y quedan dos esculturas de bastante importancia como el togado de llipa, con la cabeza de un novillo a sus pies, vestido con los ropajes propios de los senadores, de ahí su nombre como sacerdote sacrificador, descubierto en Alcalá del Río (Siglo I-Il a. C.) y el Apolo Citaredo, deslumbrante pieza por el perfeccionamiento artístico en el tratamiento de sus ropajes.
Por último, analizaremos el flanco izquierdo de la sala antes de acceder a la siguiente. Aparecen dos mosaicos a cada lado de la puerta de acceso, acompañados de dos retratos anónimos de caballeros romanos de la época julioclaudia. Los mosaicos un gran interés puesto que presentan escenas del circo romano, las carreras y juegos. Ambos localizados en Paradas (Sevilla) y datados entorno al III - IV a. C.

En general, el análisis museográfico de esta sala, presenta las mismas patologías que la anterior. Las piezas escultóricas de bastante peso, elevadas sobre unos plintos fabricados de cemento y lacados con pintura plástica. Las vitrinas poseen unas características técnicas muy específicas propia de los años 80 . Son vitrinas exentas adosadas a la pared, de perfil de acero, pintado y revestido de aluminio anodinado. El respaldo y la base, son de tablero aglomerado, tapizado en esterilla, materiales demasiado anticuados y que no responden a las técnicas avanzadas que se pueden conseguir en la actualidad. Los vidrios de luna incolora, con los laterales fijos y el frontal de 
corredera, con casaca y rodamiento metálicos sobre guía metálica con cerradura oculta. Y la iluminación, en la parte superior, mediante tubos fluorescentes de baja emisión, con celosía difusora de retícula metálica. Este tipo de vitrinas complican el control de la humedad y temperatura de los objetos que encontramos en el interior, muchos de ellos de materiales variados, una situacion que podría provocar a medio plazo el deterioro de los mismos.

En cuanto al itinerario de la sala, es un tanto tortuoso, ya que no sigue un discurso homogéneo en su contenido. La iluminación, combina luz artificial y cenital, de ahí que volvamos a encontrarnos los problemas comentados anteriormente, donde no es predominante ni un tipo de luz ni el otro, cosa que es importante para la puesta en valor de las piezas. Las cartelas y los textos explicativos siguen la misma tónica que la sala anterior, al igual que echamos en falta los sistemas de control de humedad relativa y temperatura.
La Sala XIII es la continuación de la anterior en cuanto a título se refiere, Cultura Romana II. Básicamente llama la atención la monumentalidad de esculturas colosales que se alberga esta sala. En primer lugar, a la derecha se puede observar un tercio inferior de una figura de grandes dimensiones. Se atribuye a un emperador divinizado con un traje militar, encuadrado en la época adriana, alrededor del 117- 138 d. C. descubierto en las excavaciones de 1780 en Itálica.

Llama la atención la grandiosidad del mosaico de opus tessellatum situado en la pared, teniendo su origen en la localidad de Écija (Sevilla), con fecha de Siglo III a. C. Representa al dios Baco triunfante sobre un carro tirado por tigres, que lleva dos figuras de difícil interpretación. Frente a este mosaico, aparece un togado de menor importancia, pero también proveniente de Itálica, con probabilidad de pertenecer a un uso funerario. Mención aparte e ineludible son los problemas museográficos y de discurso que pueden llegar a plantear los mosaicos, puesto 
que son grandes piezas en la mayoría de los casos y, si los colocas en el suelo quitas espacio expositivo a la sala, mientras que si los colocas en la pared puedes confundir al espectador sobre su colocación real en las villas romanas. A nuestro juicio es interesante la colocación de los mismos en la pared porque nos dan la posibilidad de obtener un espacio muy necesario en este museo que atesora una colección bastante amplia, pero siempre dejando alguno de ellos colocado en el suelo a modo de ejemplo y con un apoyo explicativo que deje claro cómo se insertaban en los pavimentos de la casa romana, qué significado tenían y la importancia que llegaron a alcanzar.

Otra pieza de especial interés, es la figura femenina recostada, probablemente una divinidad fluvial, labrada en mármol que serviría como fuente por la postura elegida y el conducto del agua. Delante de ésta, un pavimento hallado en Itálica y realizado con la técnica del opus sectile, generando figuras geométricas de especial interés artístico.
Comentar a estas alturas cómo vemos que la colección y el discurso van centrando la importancia de las piezas en el gran yacimiento que es Itálica pero que todavía no nos encontramos en las salas específicamente señaladas en el plano guía del edificio como salas de Itálica, así, creamos otro motivo de desinformación al público que puede englobar todas las piezas que encontramos en la planta superior en el yacimiento sevillano, mientras hay piezas que vienen incluso desde fuera de la capital andaluza. Nuestra propuesta sería una diferenciación clara y distante de salas dedicadas a Itálica y salas dedicadas a otros yacimientos, dentro de un gran apartado que sería Roma en la Península lbérica.

Al fondo de la sala, descubrimos una escultura colosal, es una estatua masculina y togada, extraída de las excavaciones anteriormente citadas en Itálica. A ambos lados, dos vitrinas con iguales características que la sala anterior, pero en su contenido difiere las piezas expuestas, puesto que nos transmiten el tema del ajuar doméstico, 
confrontando utensilios de la alta nobleza frente a los más vulgares de la cultura romana. Observable es la insistencia del discurso museológico a acumular piezas dentro de las vitrinas, y en muchas ocasiones repetidas, tan reiterativos como podemos resultar nosotros en el hecho de recalcar este problema fácilmente subsanable. Además este acopio exacerbado ha llevado a los responsables del mismo a considerar las salas como unidades expositivas iguales a las vitrinas, en el sentido de que se colocan muchas más piezas de las necesarias para explicar o dar a conocer las colecciones del museo.

En cuanto a las demás piezas que completan la sala, debemos decir que prima la exaltación de la figura masculina en dos torsos colosales enfrentados $y$ descubiertos entorno a mediados del siglo II d. C. en Itálica, sin olvidarnos de un tercero en el flanco izquierdo de la puerta de acceso a esta sala, tambien perneciente al mismo lugar. Sin embargo, hay que mencionar la colocación de un capitel corintio inconexo, aunque por haberse descubierto en el mismo yacimiento puede tener cabida su posición.

En cuanto a los criterios museográficos, se mantiene la misma pauta que en las salas anteriores. 


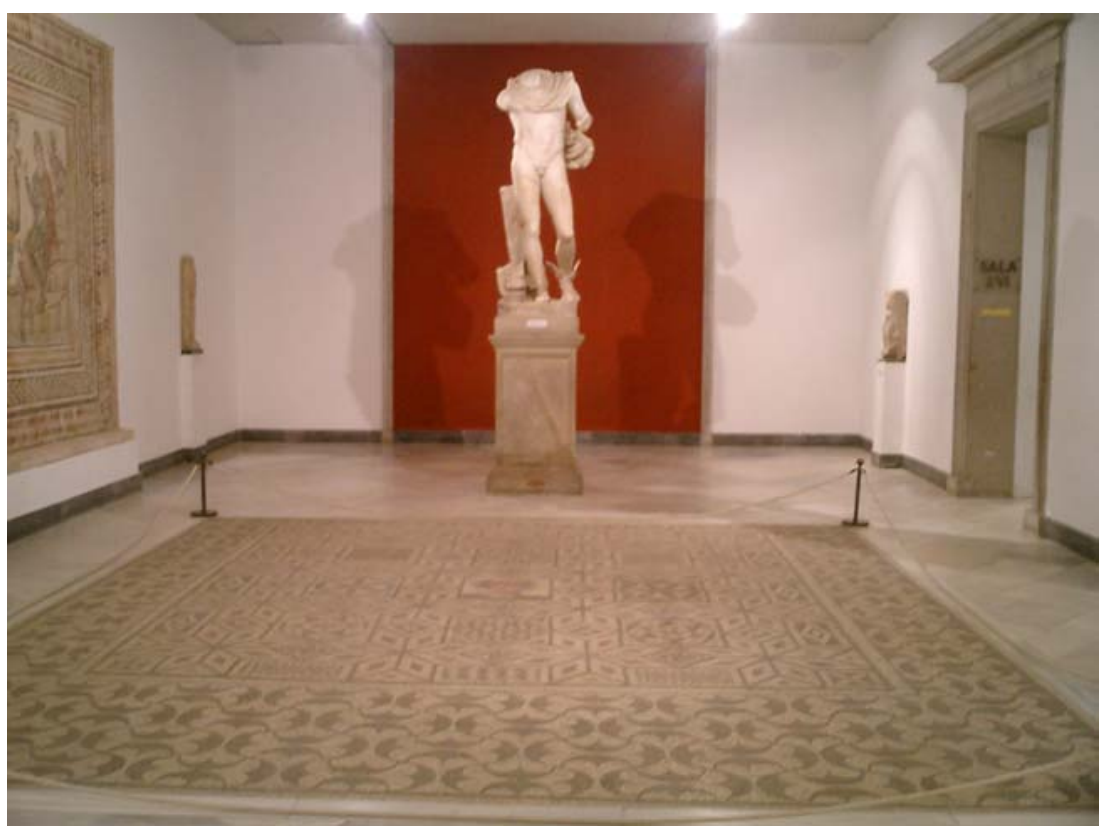

La Sala XIV, cobija en su interior puro aire de Itálica, por encontrarse en ella una de las piezas claves de la colección del Museo. Nos deslumbra el esplendor artístico de esta sala por encontrarnos en ella una cantidad considerable de magníficas obras, no ya por su calidad sino también por su relevancia en el discurso museográfico. Está dedicada a la divinidad de Mercurio, mensajero de Zeus. Esta pieza es de notable interés por considerarla como una de las esculturas más bella de la época clásica descubierta en la Península. Su perfección está influenciada de la cultura griega, bien proporcionado, fabricado en mármol blanco de Paros, lleva a

la reflexión, en cuanto a su postura, puesto que se supone que en su brazo derecho portaría al joven Baco y en la otra mano, sujetaría el símbolo de la paz, la vara lisa enmarcada por dos culebras. Los brazos han desaparecido, en cambio, se llegó a reconstruir una de sus piernas, siguiendo las pautas de la proporción del cuerpo, y modelada por el escultor Sánchez $\mathrm{Cid}^{9}$. Está elevado sobre un pedestal dedicaddo a un sacerdote de Augusto, descubierto en la ya citada localidad de Dos Hermanas. Se hace mención a este detalle, por el aprovechamiento de dichas piezas de elevado peso para ennoblecer obras de considerable prestigio y porque técnicamente puede

\footnotetext{
9 Itálica e el museo arqueológico de Sevilla. AA.VV. 1995. Catálogo De exposición. Artículo: Itálica en el Museo Arqueológico de la Plaza de América. Fernando Fernández Gómez. Pág. 31.
} 
parecer una solución lógica pero en cuanto a entendimiento del discurso puede llevar al espectador a pensar que las dos piezas pertenecen al mismo conjunto, que fueron encontradas juntas o que así era como se situaban las esculturas en la antiguedad. Al mismo tiempo, el criterio museográfico de colocar una cortina de color rojo como fondo de la figura, enfatizado con iluminación artificial de modo puntual, hace que su visión nos sirva de deleite y por tanto es de aprovar este tipo de soluciones para apoyar la museografía de estas obras tan importantes.

Otra de las piezas destacables de esta sala, es el torso de Diana, también fabricado en mármol blanco de la isla griega de Paros y datada a mediados del siglo II d. C. Fue descubierta en la excavación de Itálica en 1788. Esta pieza está mutilada de extremidades, pero esta falta está salvada por la metodología de elevarla sobre un plinto que equilibre sus desniveles.

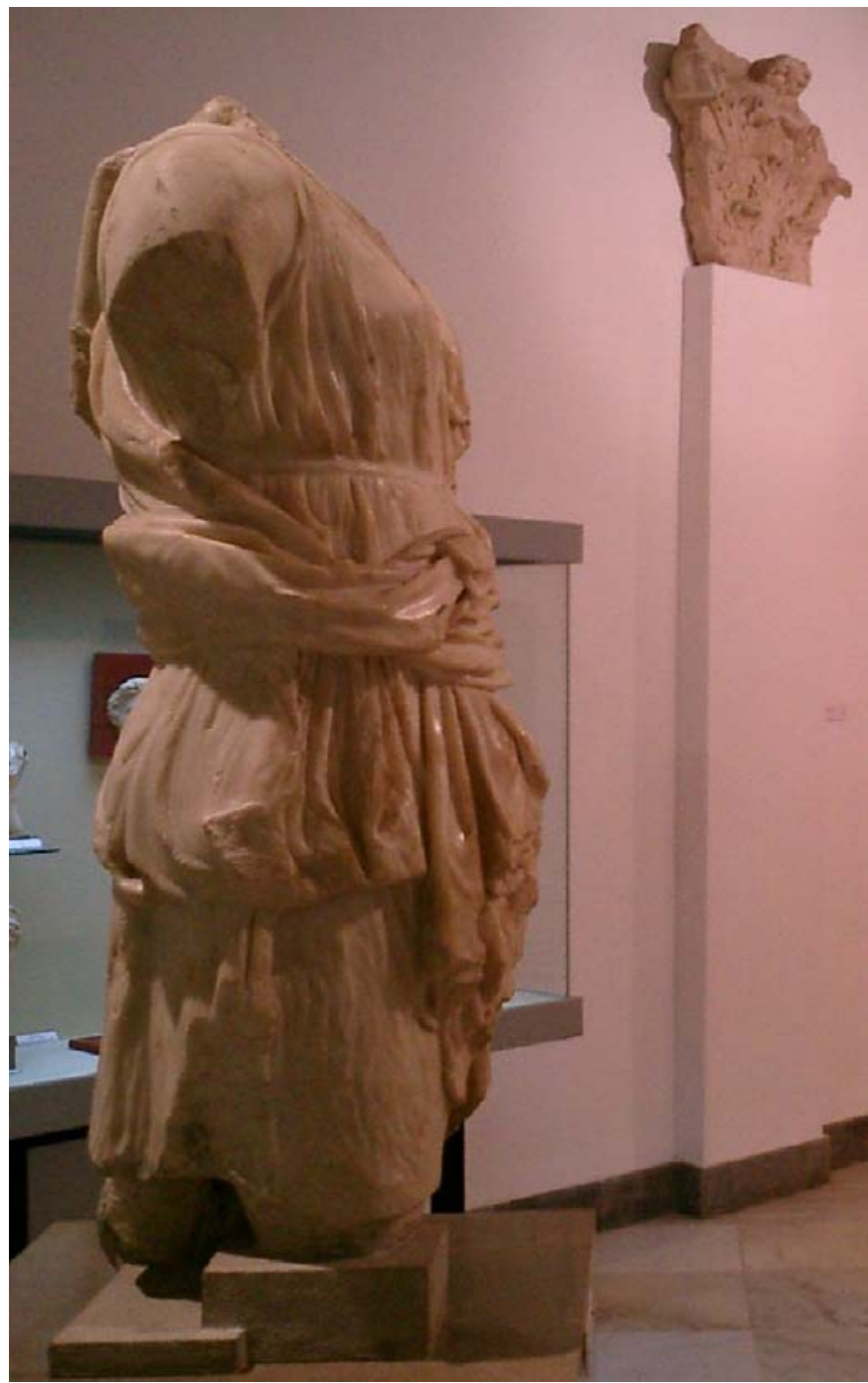


Otro grupo notorio en la sala son los mosaicos. El que llama más la atención es el pavimento policromo del centro, con el busto del Dios Baco en su centro, rodeado de cenefas con formas simétricas, también descubierto en Itálica y fechado en el siglo I - II d. C. Un pequeño problema que plantea este mosaico, comentado anteriormente, es que ocupa casi toda el área de la sala y deja muy poco espacio de tránsito al espectador que puede tener la tentación de atajar en cualquier momento sobre esta magnífica obra. A pesar de ello, creemos que su ubicación en el suelo ayuda a la comprensión de su localización espacial en la realidad de la casa romana, se pensará en su reubicación en un espacio más amplio en el futuro.

Adosados a la pared, encontramos el mosaico del episodio del Juicio de Paris, aparecido en Casariche, y encuadrado cronológicamente en el siglo IV d. C. Frente a este, encontramos un pequeño fragmento del mosaico de Perissotervus, nombrado así puesto que posee la firma de su autor. Al otro flanco de la puerta que da acceso a la sala $\mathrm{XV}$, el mosaico del rapto de Hylax, de principios del siglo II a. C. donde aparece en un relato de la mitología romana recogiendo agua de una fuente siendo observado por Hércules para capturarlo.

Al fondo de la sala y a los lados de la escultura de Mercurio, encontramos dos relieves. A la izquierda, una figura femenina de Itálica, del siglo II d. C. y a la derecha, una ménsula de un arco del triunfo, con un relieve de la Diosa Victoria halada, de mediados del siglo II d. C. procedente de Itálica también.

Sólo queda analizar las dos vitrinas monográficas que están a la izquierda de la entrada, una está dedicada al arte popular

romano, realizadas a molde. Destacan las antefijas, elementos utilizados para embellecer las cubiertas de edificios. También, se agrupan piezas de cerámica de color rojizo, del cual destaca el discutible disco que representa una figura posiblemente sobre un carro. Llama la atención 
el criterio acumulativo escogido para la exhibición de esta vitrina.

La otra vitrina destaca por su dispersión, con piezas como la mano de Zeus con el haz de rayos, y pequeños retratos que pueden representar divinidades junto con pequeños relieves de figuras.

Museográficamente esta sala estéticamente está homogénea, la ubicación de los mosaicos y el lugar tan prestigioso de la escultura de Mercurio, nos da la sensación de amplitud. Sin embargo, queda un poco descontextualizados tanto las vitrinas como el acceso a las siguientes salas (XV-XVI). Las vitrinas poseen las mismas características que las anteriores, y añadir la intrusión de textos explicativos sobre las manifestaciones artísticas haciendo alusión más bien a la fabricación de ingeniería que a la expuesta en las vitrinas. Un problema importante que volvemos a encontrar es la mezcla de procedencias de las piezas, si se supone que en esta sala comienza el discurso a centrarse en Itálica, los textos explicativos hablan de Itálica, es negativo el hecho de colocar piezas de otros yacimientos en medio de la vorágine italescense, el espectador a estas alturas de confusión es probable que deje de leer cualquier mención explicativa que se encuentre. En cuanto a la iluminación, destacamos la intencionalidad de puntualizar algunas piezas importantes para realzar su belleza. Los criterios de seguridad están salvados con pequeñas catenarias, mientras que otras piezas quedan al descubierto y su seguridad está casi anulada.

La Sala XV está dedicada a la Cerámica Romana, aunque está es de dimensiones reducidas y está presidida por el busto más elogiado de la exposición por su realismo, con una gran fuerza expresiva y por su forma de resolver la volumetría del cabello en bucles, su semblante juvenil y serio, posiblemente ha servido de modelo para muchos artistas. Es Alejandro Magno idealizado, descubierto en las excavaciones de Itálica en el siglo II d. C., expuesto sobre 
una columna y detrás de la figura, un estor rojizo, de igual modo que en la escultura de Mercurio, su finalidad es otorgar a la pieza un lugar ennoblecedor. Criticable es sin embargo la colocación, de nuevo, de la imagen sobre una columna que probablemente sea de la misma época, es una manera absurda de desprestigiar el elemento arquitectónico frente al artístico.

La sala está completada con tres vitrinas, adosadas a la pared, y dedicadas a la cerámica romana. A la derecha de la entrada, la cerámica común romana, frente a esta, la vitrina dedicada a la cerámica romana con paredes finas y por último, y más importante, una vitrina ocupada por la Terra Sigilata. Se puede observar una gran cantidad y variedad de útiles terrosos pertenecientes a la cultura romana. Toda la cerámica es de interés por la localización de diversos alfares en la Bética.

Aunque la sala está designada para la cerámica, la ubicación del interesante busto no armoniza con la compañía de las vitrinas. La única diferencia de las vitrinas con respecto a las

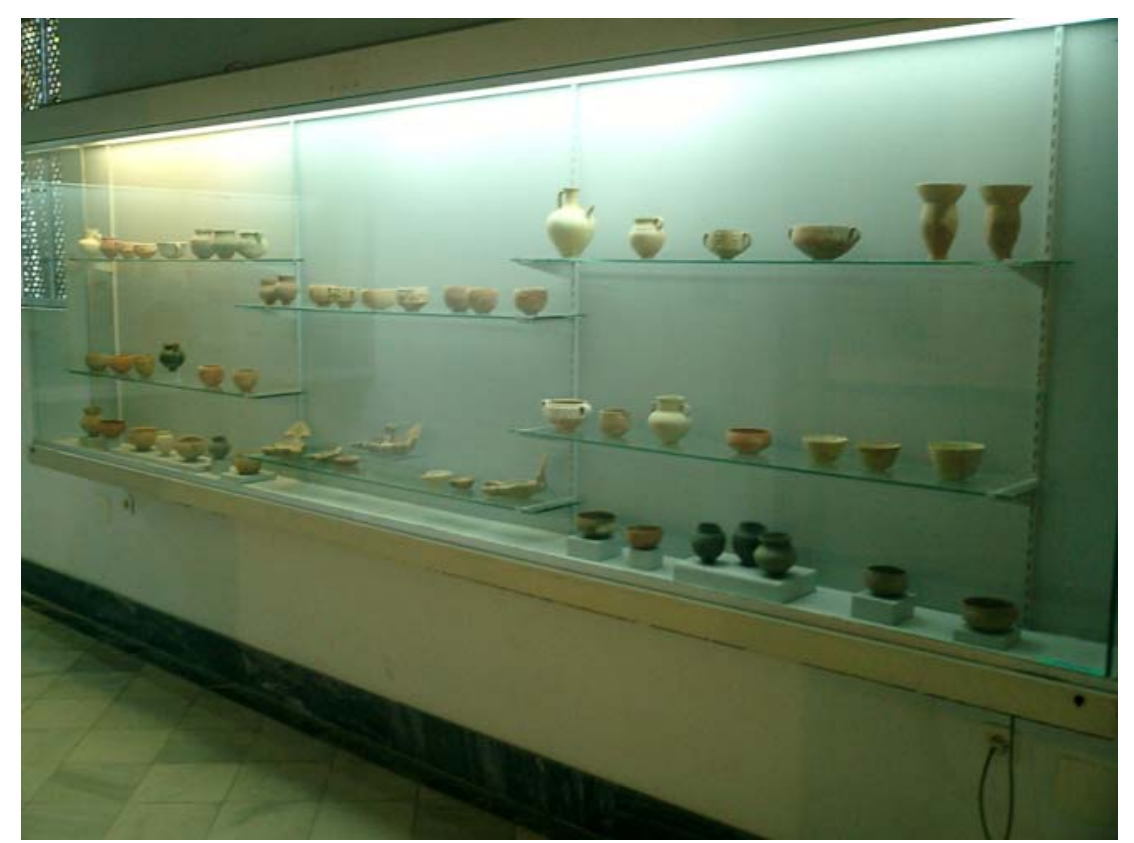

anteriores es que éstas son adosadas a la pared, pero comparten las mismas características técnicas. La descongestión acumulativa de las piezas de cerámica, esta solventada por la compartimentación en vitrinas de cristal dispersas por el panel trasero. Hay que tomar en cuenta la 
aparición de luz natural, remediada con unas celosías que rebajan la radiación cenital, aunque es inevitable su reflejo en los cristales de las vitrinas. También encontramos iluminación puntual dirigida hacia el busto.

La Sala XVI está dedicada a la exposición de diversos elementos religiosos tanto en sus manifestaciones oficiales como domésticas, así, la sala es denominada Estelas Votivas. Básicamente aparece la representación de unas siluetas de las huellas de unos pies que aluden a divinidades femeninas de origen oriental. Es por ello, que se colocaban estas estelas empotradas en el suelo con una finalidad simbólica. La más destacada es la encontrada en el anfiteatro de Itálica dedicada a la diosa Isis. En la entrada está ubicada una vitrina exenta, que expone piezas de culto y la religión doméstica, destacando pequeñas piezas como una figura de un togado, propia de un sacerdote sacrificador por la vestimenta que lleva. Más abajo en el suelo de la vitrina aparecen una serie de lucernas, o aras votivas, decorados con las figuras de distintas divinidades, aludiendo al tema monográfico de la vitrina.

Siguiendo con el análisis de la sala, podemos citar la inclusión de la técnica fotográfica plasmando el anfiteatro romano de Itálica en dos imágenes, una en blanco y negro, con una fotografía aérea, y la otra es la misma imagen a color pero en un formato apaisado. Esta última, está colocada encima de de una especie de vitrina con una pequeñas hornacinas que portan las citadas estelas. Es interesante señalar que es este tipo de museografía explicativa la que da razón de ser a las piezas que componen esta sala, ya que es de esta forma como el espectador puede llegar a concluir la importancia que tienen determinados yacimientos como el de Itálica en el estudio de la cultura romana. Incluso al lado podemos apreciar un texto informativo que cita textualmente "Juegos en el anfiteatro", donde se explica el significado de estas estelas. Quizás sea esta la sala más acorde con el ideal museográfico predominante en la actualidad. 
Frente a todo esto, se ha colocado un mosaico adosado a la pared donde se especifica en su cartela opus tessellatum descubierto en la Cuesta del Rosario en Sevilla y se cita en su cartela, que pertenece al Ayuntamiento sevillano. Representa dos figuras zoomórficas rodeadas de cenefas con formas geométricas. Para no caer en la redundancia señalar que los restos del discurso repetitivo, acumulativo y anticuado siguen estando presentes, a pesar de que se nota que a lo largo de los años ha habido intención de ir mejorando esta situación; cosa que no ha hecho más que empeorar los medios porque se mezclan sistemas de señalización, cartelas, materiales, etc...

En el ángulo, se puede apreciar un recipiente que sirve para contener un ambiente oloroso de pero se echa de menos una mención que se refiera a ese olor o de una explicación de la presencia de esta pieza en la sala.
Se debe hacer mención a la especialidad de la sala, puesto

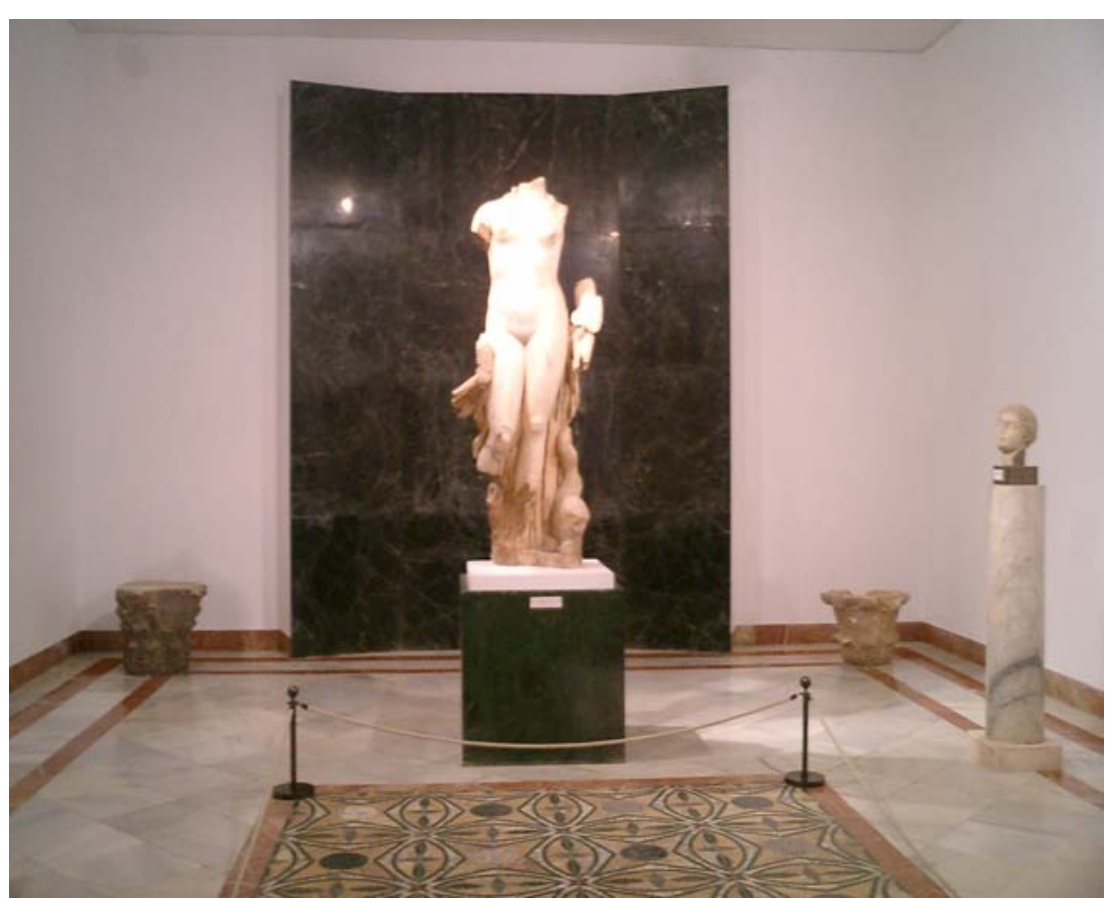

que es muy reducida y se ha recurrido a exponer aprovechando el mayor espacio posible colocando las piezas de forma vertical, exceptuando la volumetría de la vitrina en la entrada. La iluminación es artificial. $Y$ sus vitrinas son de iguales características que la anterior. 
La Sala XVII alberga otro de los puntos más interesantes de visitar en la exposición permanente, en la zona de cultura romana. La sala está titulada, Venus y como su nombre indica, aparece otra de las piezas más relevantes de la colección permanente del Museo. Es un cuerpo femenino con un alto nivel artístico. Está mutilada en los brazos y cabeza, pero este hecho no nos deja indiferentes ante la actitud de movimiento de la figura por la posición de sus piernas. Parece estar saliendo del mar, siguiendo su episodio mitológico. Además, podemos apreciar un delfín a sus pies y una hoja de una planta acuática. Hay que mencionar que al ser una pieza de interés se vuelve a recurrir a optar por un fondo para ennoblecer la pieza. Es una placa marmórea de color oscuro, fabricada entorno a los años 70, que ayuda a resaltar la palidez de la diosa. Fue encontrada en Itálica y se fecha en el año 117 d. C. A ambos lados de la divinidad se han colocado dos capiteles en el suelo con finalidad estética y quizás buscando una ambientación a las piezas que es más fácil de encontrar a través de otros medios antes que con el uso de elementos de excavación.

Delante de la diosa, está un pavimento del tipo opus sectilice, que utiliza losas de mármol para su fabricación, también localizado en Itálica (siglo II d. C).

Acompañando a Venus, encontramos tres torsos desnudos con unas proporciones anatómicas propias del gusto romano. Servían como manifestaciones de culto imperial datadas en la primera mitad del siglo I d. C. A la derecha de Venus, está el torso atribuido al Dios Mercurio, de época Adrianea y descubierto en las excavaciones de Itálica de 1839-40, en el área del foro. A la izquierda de la diosa, otro torso está asignado al héroe griego Maleagro, también de la misma época que el anterior. Y por último, frente a la Diosa el impresionante torso de un atleta, ejecutado en mármol blanco de Paros y perteneciente a la misma época que los anteriores. Esta pieza destaca por la insinuación de poseer los brazos alzados hacia arriba atándose la cinta en el pelo. 
Por último, citar dos bustos colocados a la izquierda de la diosa, solo que su procedencia es distinta a las anteriores. Uno de estos, fue hallado en Itálica y la otra fue un hallazgo fortuito en 1990 por parte de M. Romero Liria quien donó esta pieza al museo.

En cuanto a la descripción museográfica, debemos hacer notar la presencia de unos carteles informativos con fondos negros $y$ letras blancas que aluden al contenido de la sala tratando sobre

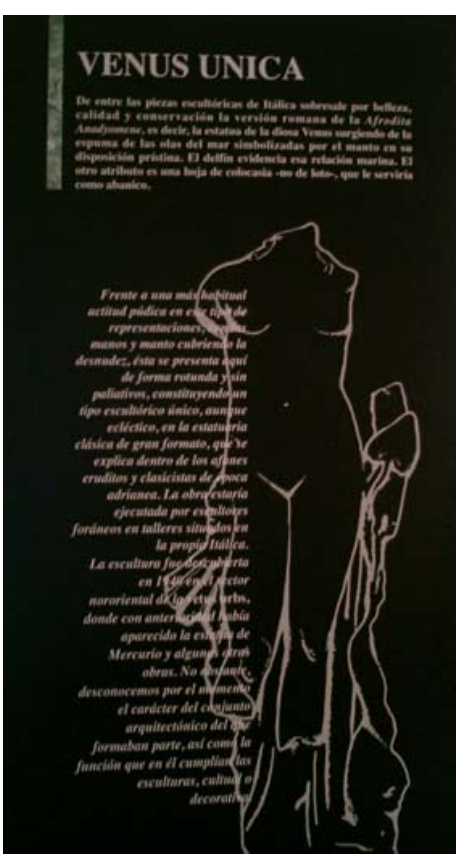

"Venus única" y "Dioses y héroes. Un ideal de belleza". Las peanas poseen la misma finalidad que las anteriores, sólo que en este caso se ha aprovechado el mismo material marmóreo utilizado en el fondo y en la propia peana de la diosa, para seguir un mismo criterio estético para la sala. Decir que volvemos a encontrar intenciones más modernas en estas salas donde la importancia de la colección que albergan lleva a que tengan un tratamiento quizás más cuidado. El hecho de llamar a la sala como hemos mencionado y la distribución de la variedad de escultura dan algo más de monumentalidad e importancia al museo, sólo hay que imaginar si esto ocurriera en todo el museo, el cual tiene toda una colección envidiable para poder conseguirlo.

La iluminación es natural y artificial, tal y como se ha comentado anteriormente. La circulación por esta sala es circular para poder visualizar a la pieza maestra por detrás, aunque los visitantes no lo perciben así.

La Sala XVIII trata la sociedad romana a través del retrato, una manifestación cultural de sobra conocida por la historia del arte. No sólo los emperadores son el objeto de los retratos; hombres del pueblo o de la nobleza, damas y matronas han sido representadas en mármol dejándonos 
constancia de la honda identificación que sentían con las modas. Alrededor de la sala, encontramos togados y en la vitrina encontramos una explicación sobre la distinción de las clases romanas unidas por el símbolo de la libertad.

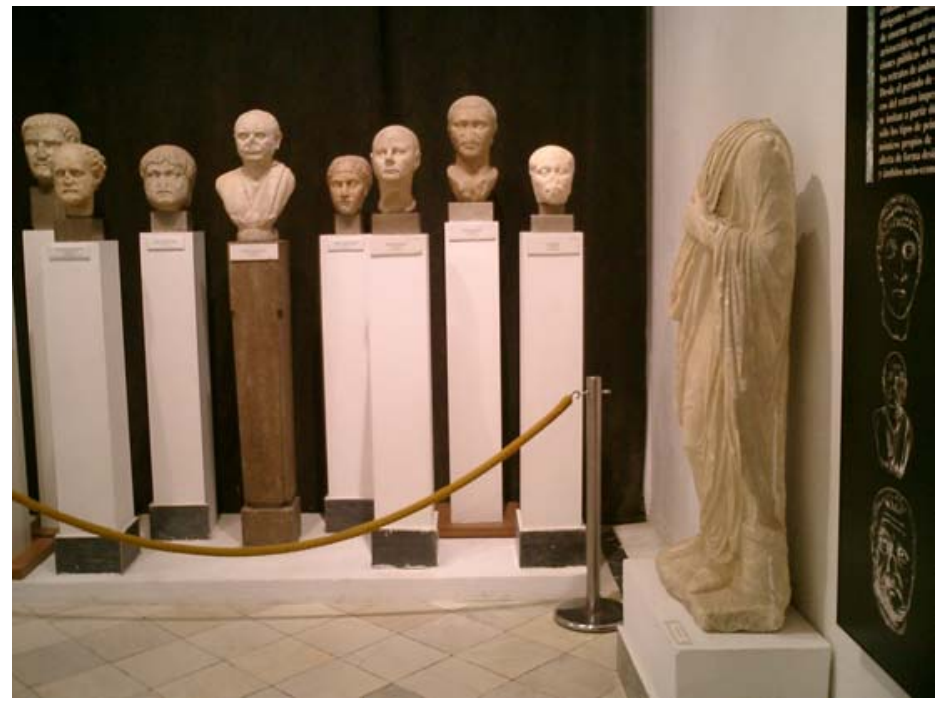

Museográficamente es una sala demasiado pequeña para la importancia que debe tener en el espectador el entendimiento de la lucha de clases, de la existencia de esclavos, etc. Además es una de las salas donde se hace más preocupante, y a la vez visible, el hecho de que el museo está falto de medios, está caduco y necesita una limpieza y redistribución urgentes; solamente hay que observar el aprovechamiento de carteles de otras exposiciones, el papel melinex tintado en negro que se aprovecha como fondo expositivo o la falta de mantenimiento de las peanas que soportan los retratos.

Llegamos a un punto estratégico del museo por encontrarse una de las obras maestras más destacada de la colección permanente. No ya sólo por su contenido, sino también por la amplitud del espacio. Esta Sala es la número $\mathbf{X I X}$, titulada de la Diana, pues es destacable la presencia de la diosa al acceder a la misma ya que centra todo el discurso de la misma.

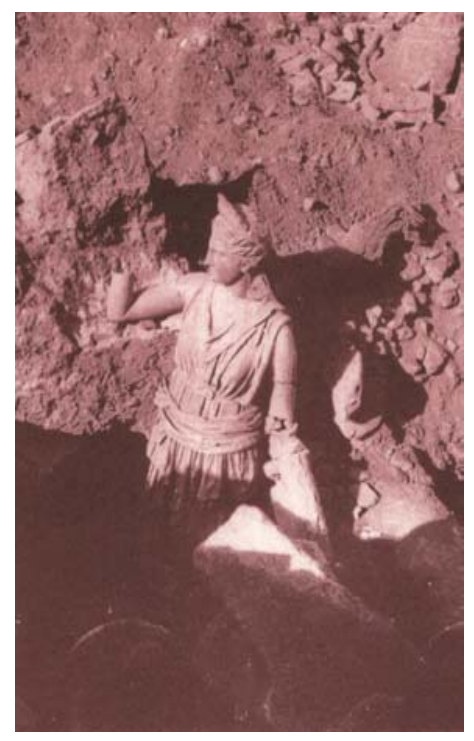
deleitarla, tanto por su belleza como por la fuerza y magnitud que con sus atributos transmite. Su hallazgo fue en 1901, junto 
con la aparición de cuatro columnas corintias asiáticas datadas en el siglo II a. C. Gracias a la documentación recopilada, tenemos constancia que esta sala ha sufrido muchas remodelaciones en su discurso museográfico. Anteriormente, la escultura magnificada de la divinidad estaba enmarcada por las cuatro columnas, ya mencionadas, rematadas en capiteles corintios que habían aparecido junto a ella, pero no como las vemos hoy dispuestas en línea, como si fuera la columnata de un templo, sino en las esquinas del cuadrado de un impluvium, que dejaba pasar la luz y en cuyo centro se abría una fuente similar a la de la sala XXI, pretendiendo sugerir la disposición del patio interior de una casa romana. ${ }^{10}$

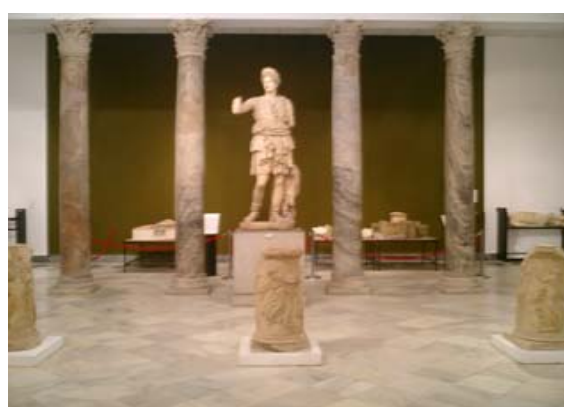

La amplitud de la sala nos ofrece una gran diversidad de piezas de un gran interés, junto con temas recurrentes en el discurso. Es por esa amplitud a la que nos referimos por lo que la sala pretende ser Ilenada, en apariencia, sin importar qué se coloca o que hilo debe mostrarse en la misma. Cosa que tampoco es necesaria porque según está mostrando la museología en la actualidad, no se busca la cantidad sino la calidad, así, en esta caso quizás la disposición de la Diana flanqueada por las columnas y las explicaciones que encontramos en los paneles y las maquetas del fondo hubiesen sido suficientes para esta sala; aún así hemos de señalar que todas estas modificaciones serán estudiadas y tratadas posteriormente en los programas de exposición de la segunda fase de esta Plan Museológico. 
Analizando ya la sala, a la izquierda de la entrada se aprecia una agrupación de elementos constructivos con inscripciones epigráficas, de diversa procedencia, como los dos primeros que se encontraron en el Traianeum, templo consagrado al emperador Trajano en Itálica. En sus inscripciones observamos dedicatorias bien a divinidades, o bien a personajes ilustres de la sociedad romana en Itálica. Todas estas piezas están sobre pequeños pedestales y algunos fragmentos de inscripciones están adosados en la pared. Comentar de nuevo ese esfuerzo por conseguir una museografía cada vez más cuidada y el aumento de paneles explicativos para las piezas.

En ambos ángulos del fondo, hay unos dibujos realizados por el arquitecto Alfonso Jiménez que aportan la idea de la magnitud de la obra de ingeniería del teatro romano de Itálica. Son magníficas explicaciones para hacer que el espectador sea consciente del volumen e importancia que tuvo la ciudad de Itálica como centro de acción del emperador Trajano.
A los lados, hay unas figuras femeninas, Ninfas dormidas recostadas, dormidas con un manto sobre las piernas. Por su posición y por la oquedad que tienen, se insinúa que estaban colocadas en una fuente ante la 'escena' del teatro, y ambas están datadas entorno 193 a 235 d. C. Llama la atención la creatividad en la manera de exponer ambas piezas, puesto que se ha colocado un espejo inclinado en la parte inferior para poder observar la parte posterior de la pieza. Quizás sería interesante, apoyándonos en los datos de situación mencionados, que su posición fuese diferente, acaso evocando una fuente en el centro de alguna de las salas y explicando como el agua también fue muy importante en la cultura romana.

A continuación, hay una catenaria de $50 \mathrm{~cm}$ de alto, que acota un espacio dedicado a dos maquetas, una la maqueta de lo que sería el Traianeum de Itálica y otra el bastión púnico y romano. 
Frente a Diana, están tres aras cilíndricas que formaban parte de la orquesta del teatro de Itálica. Son circulares con una decoración báquica en bajorrelieve y encontradas en la excavación de 1970. No pretendemos en ningún momento juzgar como fachosa esta sala por su distribución de piezas pero es de recibo pensar que tal como se pinta, y si no fuese por las maquetas que nos lo dejan algo más claro, el espectador profano puede pensar que la distribución del frontón de columnas, así como las estelas y la centralidad de la Diana podrían ser sus posiciones originales en la ciudad italescense.

Delante de estas tres piezas, está el busto de la Diosa Fortuna de época adrianea, y del mismo origen que anteriores. Los investigadores aún están barajando la posibilidad de que quizás sea la Diosa Cibeles. Sin embargo, no podemos descartar su relevancia por estar coronada con una torre almenada, como atributo por ser protectora de la ciudad.
A ambos lados, están sobre columnas, dos piezas. Una es la cabeza de una estatua de un sátiro junto con el cuerpo de una figurita de piedra. Y por último, sobre este grupo de piezas, en la parte superior de la puerta de acceso a la sala XIX b, está colocada una cornisa de un edificio, decorado con triglifos y metopas, supuestamente siguiendo las mismas pautas estéticas que el friso, hecho de nuevo criticable porque la pieza pasa prácticamente desapercibida para el espectador ya que en cualquier momento puede creer que esa cornisa puede formar parte del edificio del museo y no una pieza arqueológica. No estamos nada de acuerdo en el aprovechamiento de piezas para ser colocadas evocando sus posiciones originales en un edificio actual, sino que sería mucho más normal que se creara una ambientación tal como la que observamos tras la diosa Isis, aunque en esta tampoco se usan elementos de la misma excavación sino que se reaprovechan y se unen aleatoriamente. No vemos bien la teatralidad por la teatralidad sino que debemos pensar en disposiciones mucho más rigurosas científicamente pero 
que al espectador les resulten igual de atractivas, un ejemplo de ello podría ser la disposición de columnas, capiteles, puertas, etc... en el Museo de la Alhambra en Granada.

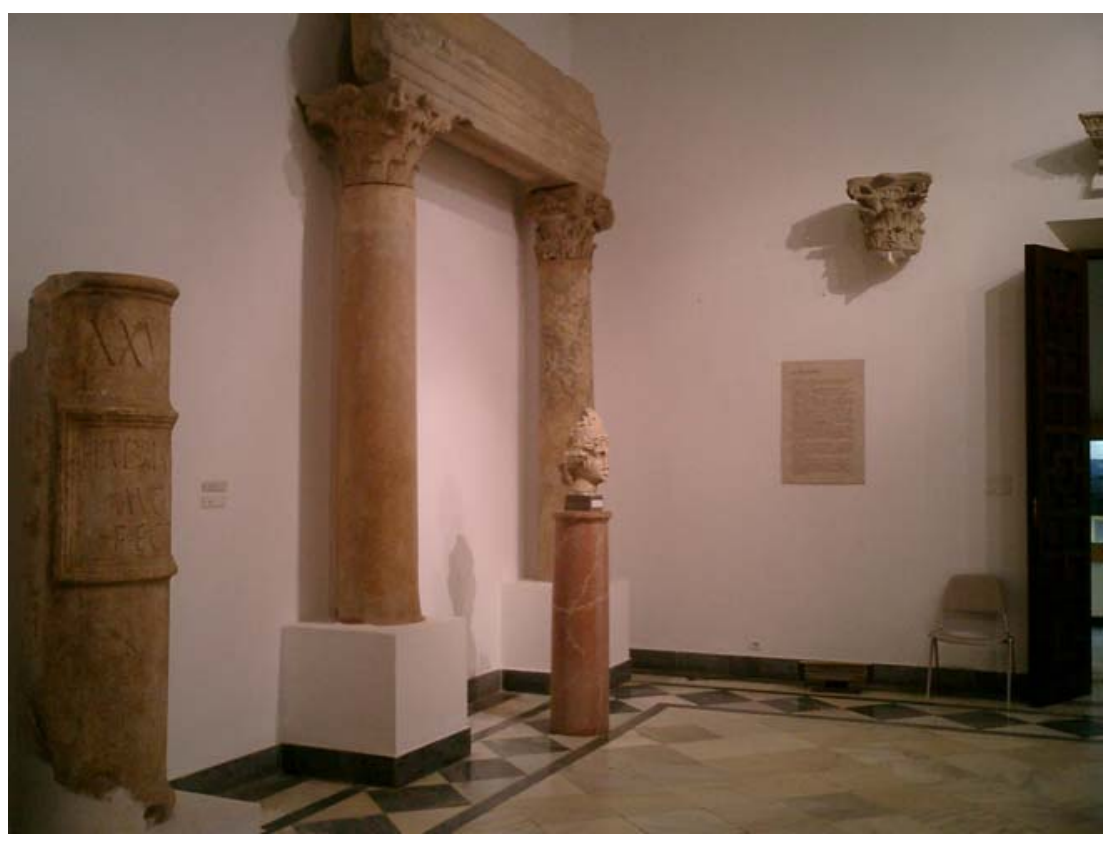

Otro gran conjunto arquitectónico es colocado en el ángulo derecho de la entrada. Es la reproducción de una construcción arquitectónica de dos columnas corintias soportando un friso corrido, encuadrando una figura bastante llamativa, es el busto de la Diosa Isis, representando la fidelidad conyugal y el amor materno. Este culto a divinidades de oriente era muy común en la cultura romana, admitían el culto a estas divinidades de otras culturas. Esta diosa fue descubierta en Alcalá del Río, Sevilla a diferencia de la reproducción arquitectónica que fueron descubiertas junto con el hallazgo de la Diosa Diana.

Cerca de esta agrupación, hay un texto explicativo que trata sobre la religión en la cultura romana. Posiblemente, sea un texto reaprovechado de otra exposición para profundizar en este tema que quizá tenemos mejor explicado en la guía del museo, pero que es necesario también que se explique al espectador profano que 
necesita una guía visual para ubicar la cultura romana tal y como es realmente y sin tener que leer un solo libro.

El último grupo que nos queda por analizar es el dedicado al Dios Baco. Un torso masculino con una túnica atada en la cadera, puede ser un emperador o un familiar heroizado, de la época de Claudio. Esta figura nos vincula al texto que está junto a ella, pues analiza la escena del Dios Baco sobre el teatro romano. Otra deidad muy importante en la cultura romana y que incluso podría tener un tratamiento monográfico y una ambientación mucho más cuidada que la que observamos.

Las últimas piezas que quedan por analizar, están colocadas flanqueando la puerta de acceso a la Sala XXX, son dos millarios de la calzada, que anuncia la distancia entre las ciudades de Sevilla y Mérida. De nuevo volvemos a repetirnos en señalar que no es bueno colocar piezas simplemente por el hecho de que el espectador las vea, estas piezas pueden dar un juego buenísimo para que el público pueda entender los sistemas de medidas romanos, cómo se creaba una ciudad, el trazado que se utilizaba, etc... conceptos que por otra parte hemos heredado y es bueno que todo el mundo pueda saberlo, conocerlo y compararlo.

Ya sabemos que la decisión tomada para ubicar todas estas piezas en esta sala no es arbitraria, sino que ha tenido un proceso museográfico que viene determinado por la pesadez de las piezas y la concordancia, no en todos los casos, que pudieran tener unas con otras.

Es una sala que ha sido transformada en el techo, puesto que se edificó una segunda planta y ocultó la luz natural que entraba por el lucernario rectangular que cubría la techumbre de la misma. Al ser modificado, se ha optado por la iluminación artificial y uniforme, algo que contribuye a crear un espacio unitario y dejar de dar una importancia a las piezas puntualmente, lo cual lleva al apoyo de la critica que realizábamos anteriormente, el espectador entiende 
este espacio como un todo que ha salido de la ciudad de Itálica tal y como se vería en la realidad.

La ubicación de algunas cartelas, separadas de las obras a las que hacen referencia, dificultan el contexto del discurso y los textos explicativos hacen alusión a temas concretos relacionados con el contenido de la sala.

El recorrido de la sala es circular, aunque se desvía a causa de haber colocado la Sala XIX B. Es reciente la ubicación de esta sala dedicada a los Bronces Jurídicos Romanos. Nos informa sobre la cantidad de documentos tanto históricos como jurídicos realizados en la Bética romana. Estos textos pertenecen en su mayoría al senadoconsulto, de los cuales, se ejecutaban una gran cantidad de copias para difundir la noticia que fuese relevante para el pueblo romano.

La conservación de estas piezas es necesaria para mantener su integridad puesto que al ser un material deleznable puede deformarse con facilidad. Los bronces están expuestos en unas vitrinas más actuales. La inclinación de los cristales nos ayuda a una mejor visión de las mismas, iluminadas en su interior. Están dispuestas en tres vitrinas a lo largo de los muros, aprovechando al máximo el poco espacio que permite la sala. Las técnicas museográficas empleadas en las vitrinas de los bronces son relativamente modernas, aunque si hemos observado como su mantenimiento es discutible y como los medidores de temperatura y humedad son deficitarios. Pero en este caso todas estas faltas son fácilmente reemplazables y juzgamos la solución de pegar las piezas a soportes de plástico neutro (podría ser polietileno) que permiten que las piezas sean observadas perfectamente.

Una vez visitada la sala pasamos a la monumental Sala $\mathbf{X X}$, titulada Trajano. En sí, es valiosa por la forma ovalada de sus paredes, por el lucernario en su techumbre y por la disposición de piezas de alto grado de calidad, que hace decir que es la sala más prestigiosa de todas las demás por ello es también conocida como Sala Imperial. 
Haciendo un recorrido visual, en general, encontramos bustos, esculturas casi completas, togados, desnudos y elementos constructivos como columnas acompañadas de capiteles de distintos estilos artísticos. Al mismo tiempo, observamos un mosaico dedicado al Dios Baco, y además, es

muy significativa esta porque obliga al visitante a realizar el recorrido de la sala de forma circular.

La disposición de las piezas están muy dispersas, algunas colocadas de forma acumulativa y aunque no se entorpece la visión de las mismas, si se puede observar como un deseo de ocupar espacio porque el museo se nos está acabando y hay que seguir exponiendo objetos. Hay que tener mucho cuidado con esto porque lo único que se está consiguiendo es que el museo resulte espesísimo, en algunos casos aburrido por la repetitividad y poco entendible al público.
Principalmente se expone la confrontación de los emperadores Trajano y Adriano en un lado de la sala oval y en otro. La escultura de Trajano heroizado parece presidir la sala, pues su monumentalidad abruma al visitante. Es una pieza original de Itálica y está considerada como una de las 


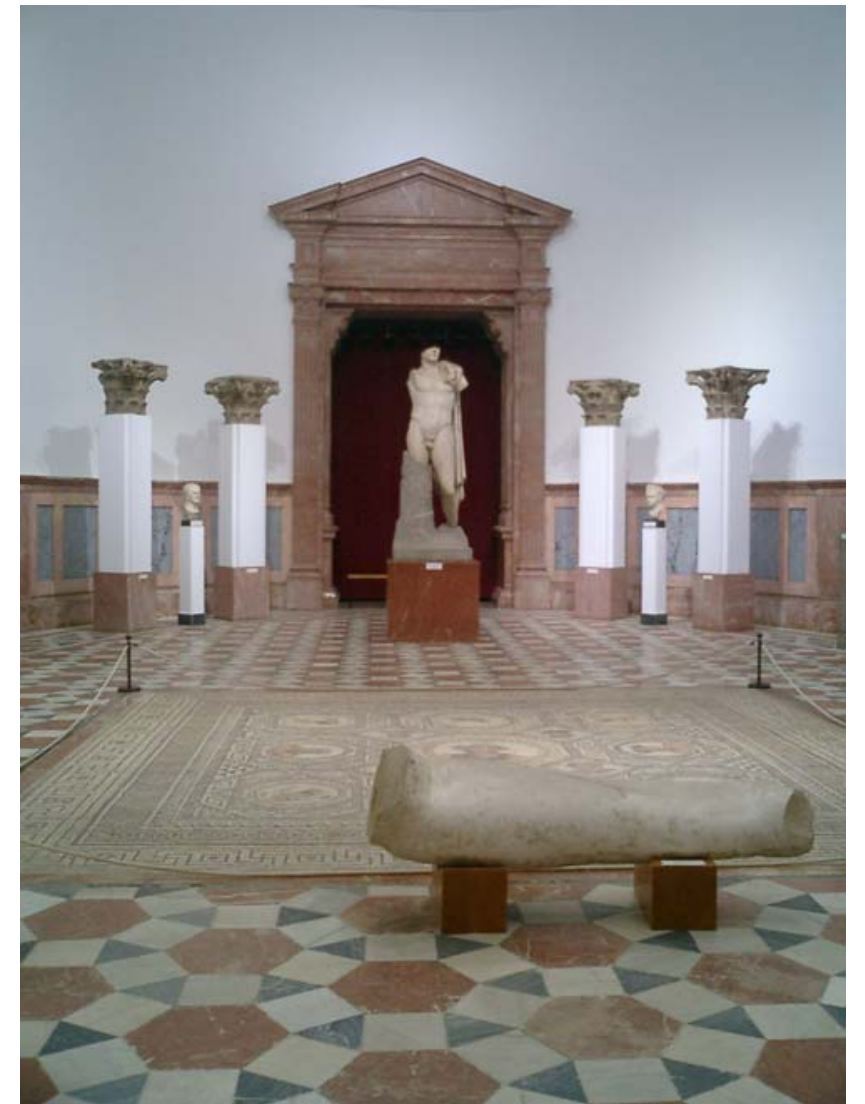

figuras anatómicas mejor realizada de toda la Bética. Adriano está retratado en un busto típico romano, procedente de Itálica, usando la técnica del trepano y sobre su coraza se observa relieve de medusa en el pecho, se representa

también parte de la toga, esto simboliza el poder del emperador.

Delante de él, un antebrazo colosal del 117- 138 d. C. Es una pieza encontrada en Itálica y por sus dimensiones tuvo que pertenecer a una escultura colosal presidiendo un edificio o la misma ciudad. A lo largo de la sala, encontramos retratos no identificados, pero que serían personajes relevantes dentro de la sociedad romana. En las cuatro hornacinas dispuestas en la sala encontramos la cabeza Colosal de Augusto, fechado entorno a 20- 40 d. C., un retrato de Galba, aunque aún sigue la investigación de su identificación como Octavia, mujer de Marco Antonio. 


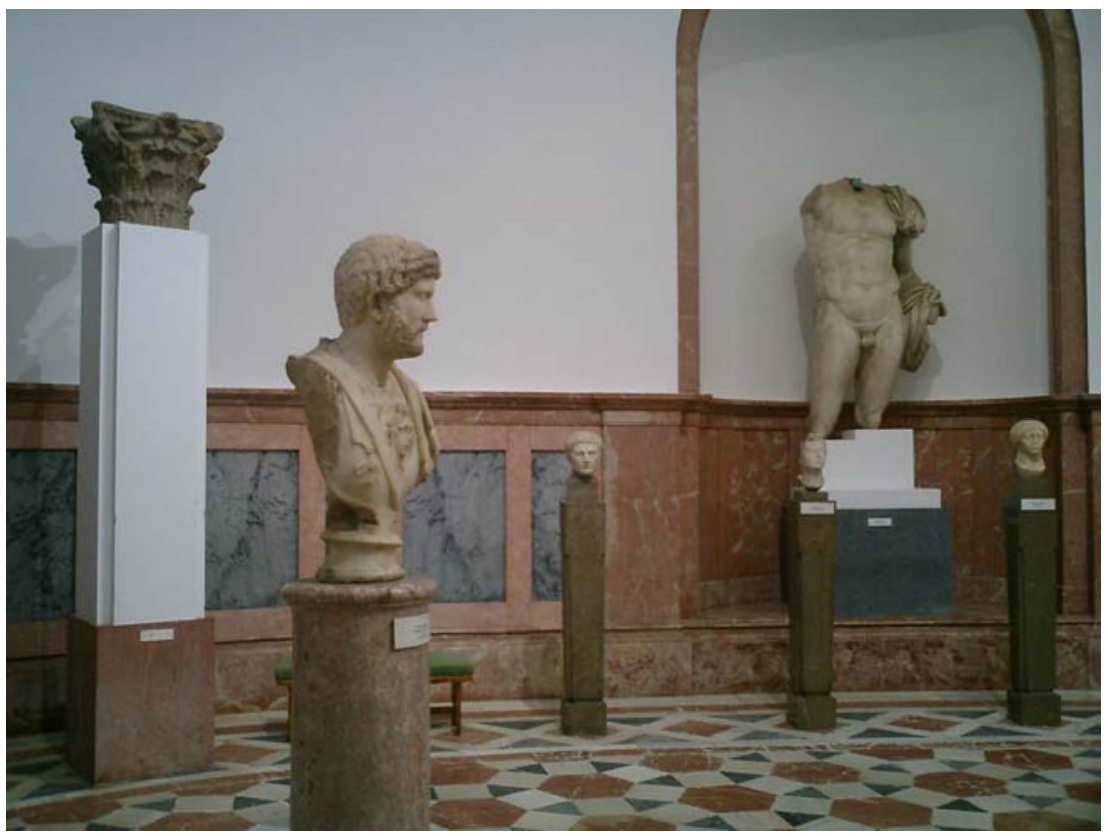

En la siguiente hornacina encontramos el torso de Adriano heroizado, de Itálica, enfrente Marco Aurelio joven, encuadrado cronológicamente en 140- 145 d. C. Destacar la monumentalidad de esta sala y su disposición centralizando el museo por lo que en nuestra opinión hace que, como hemos resaltado al principio de este discurso, la vemos como la que realmente tendría que ocuparse en labores de acogida y distribución de visitantes, con lo que las esculturas situadas aquí se reubicarían en espacios apropiados a su monumentalidad, teniendo en cuenta, por supuesto, el peso y las características técnicas necesarias. Los recursos pedagógicos utilizados en esta sala intentan contextualizar las piezas históricamente, pero distrae al espectador su contenido, pues no pertenece al discurso de esta sala. Volvemos a mencionar la incansable reutilización de materiales ajenos a esta exposición permanente.

A pesar del protagonismo del hallazgo italicense en toda la primera planta del museo, a partir de ahora los incrementos de las salas de exposición realizados entre los añor 1970 y 1073, mantienen un criterio diferente de los del montaje original, fundamentalmente tipológico, como la epigrafía que veremos en la sala $\mathbf{X X I}$ donde se concentra la Epigrafía Romana en piedra. Su esencia está protagonizada por piezas ya reconocidas en salas previamente visitadas. Sin embargo, se ha optado por dar un lugar en el discurso a estas obras que nos aportan una 
documentación sumamente importante puesto que es testimonio escrito de esta cultura.

Estas obras están distribuidas por la sala de una forma caótica al mismo tiempo que simétrica. A lo largo del muro se presentan lápidas funerarias de distintos tamaños y formatos, plegarias de consagración a los Dioses. Otros epígrafes son religiosos como el dedicado a la diosa Isis, otros tratan levemente de política y también, están documentadas las inscripciones conmemorativas de hechos importantes.

En el centro, el mosaico de los Tritones de Itálica, colocado originariamente en la sala XIX junto a Diana. Es un mosaico policromo, incompleto aunque con una profunda investigación desarrollada por Demetrio de los Ríos, excavado a mediados del siglo XIX.

Frente a la entrada, se encuentra una argamasa fabricada con fragmentos de material cerámico y una de cal dando lugar a una capa de gran resistencia y solidez denominada opus signinum que sirvió de pavimento, dedicado al dios Apolo.

La sala en general es amplia pero la vuelta a los métodos de aglomeración, de iluminación dispersa y pocas explicaciones audiovisuales hacen que el valor de la misma y de sus piezas esté cada vez mas deficitario a nivel de expectación o atención del espectador. Siguiendo con el nuevo criterio expositivo se analiza el tema del Ejército romano que se halla en la Sala XXII. En ella podemos apreciar todo lo relacionado con el mundo bélico. Principalmente existe la confrontación de dos piezas significativas de la sala. A la derecha, un busto del Dios de la guerra, Marte, procedente de Carmona (Siglo II d. C), donde se puede apreciar una destreza artística de alto nivel. Sobre la cabeza porta el casco que estaría adornado con complementos de bronce que no han llegado hasta nosotros. El fondo de la imagen esta resuelto con un panel de 


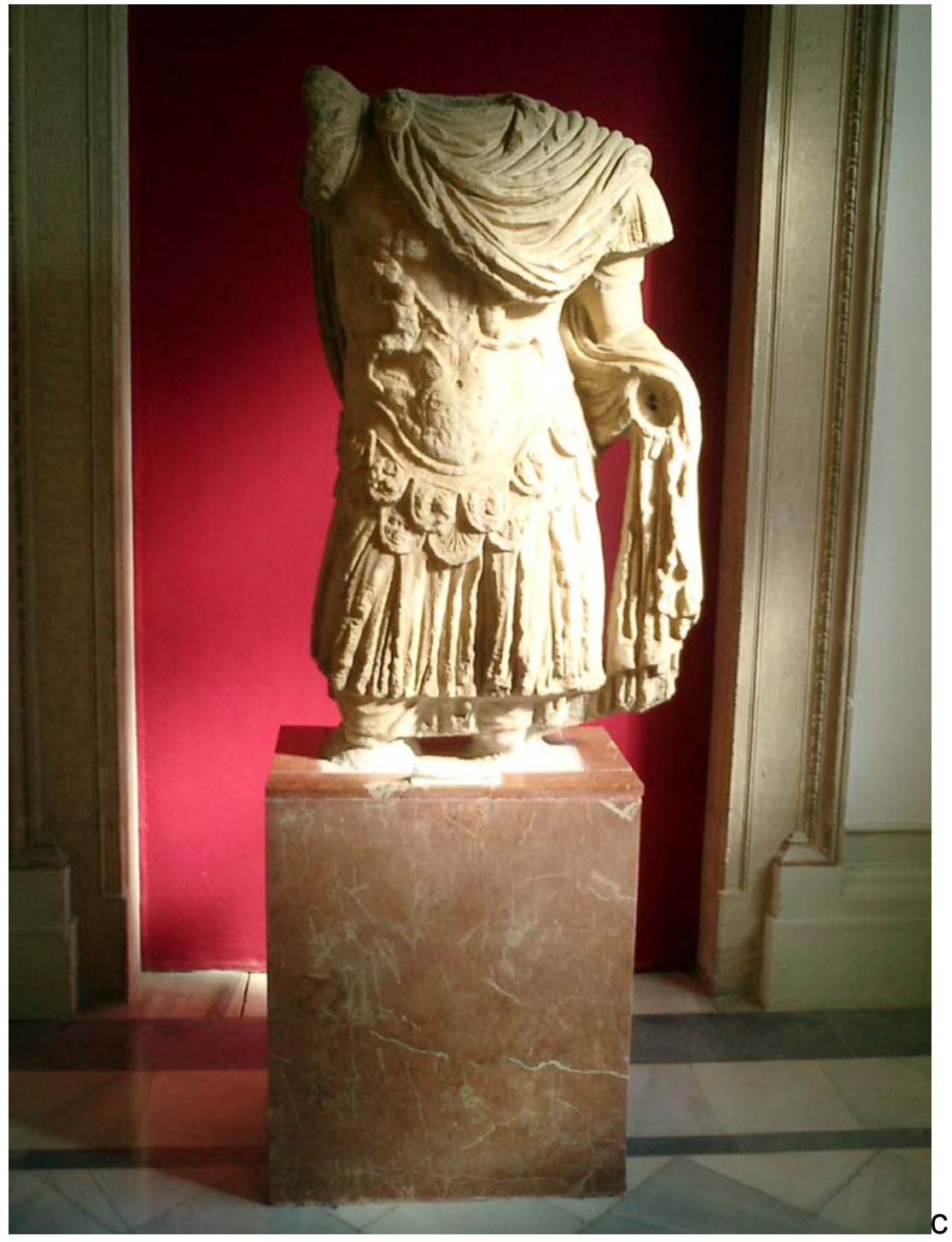

olccolor rojo, del mismo modo que en ocasiones anteriores como ocurría con el busto de Alejandro Magno. El busto está apoyado sobre un plinto cuadrangular, atendiendo a la misma unidad estética que se ha seguido.

Frente a éste, el denominado torso thoracato de un emperador, teniendo su origen en Itálica. Es un torso acorazado, decorado con unos relieves con alto grado de detalle con diversos motivos de la mitología. Al igual que Marte, el fondo también tiene un cortinaje del mismo color, y la pieza está elevada sobre un plinto de mármol.

Esta sala presenta novedades museográficas en cuanto a soportes expositivos. A la derecha de la entrada, hay tres pequeños plintos de unos $10 \mathrm{~cm}$. que soportan unas lápidas epigráficas aludiendo a temas bélicos. Este espacio está protegido por una pequeña catenaria.

A

continuación, una reconstrucción arquitectónica con una techumbre para mostrar labor de ingeniería de los ejércitos 
romanos usando ladrillos y tejas marcando el sello de la legión para dejar constancia de su autoría.

Al lado hay una vitrina adosada a la pared, la cual, parece ser de distinto fabricante que las anteriores. Soportado sobre una estructura de aglomerado lacado, descansa la vitrina con perfilería metálica. La iluminación es de tubos fluorescentes de baja emisión, con metacrilato traslúcido para emitir una luz difusora. En su interior, se encuentran varias herramientas, glandes, balas de plomo, puntas de proyectiles, lucernas con paisajes bélicos, vasija de bronce, sartén para la impedimenta militar y, destaca la figura de Marte niño bronce, de pie, procedente de Écija.

Frente a esta, hay una vitrina de mesa que contiene placas de bronce que certifica la inclusión de los indígenas al servicio militar otorgándoles unos beneficios documentados en estos diplomas, también dispersos los clavos de hierro y bronce, tuberías de plomo, quicios de puertas de bronce como manifestación de la actividad edilicia del ejército romano.

La sala tiene tres ventanas, sólo la del centro, está cubierta por un cortinaje rojo, aplicación museográfica para proteger la vitrina de mesa que está frente a ella. El tratamiento museográfico de estas ventanas es demasiado arcaico y es evidente que deberíamos tener en mente una solución para este tipo de problemas que plantea el museo constantemente.

Delante de la puerta de acceso, se aprecia una pieza en mediorelieve, con la representación de dos soldados de época republicana, enfrentados como enemigos, con indumentaria bélica. Fueron hallados en Estepa.

Por último, una vitrina hermética incrustada en la pared sobre un pedestal de mármol, muestra la pierna de un jinete de bronce junto con una cola dorada de un caballo, tal y como nos muestra un dibujo, pertenecería a una figura 
ecuestre. Bajo ésta una vasija de bronce, como testimonio de los expolios bélicos.

Esta sala tiene dos puertas de acceso en los dos extremos. Ambas están cegadas e inhabilitadas cubiertas con el fondo rojo. Por este motivo, la circulación de la sala debe ser circular, estos problemas se irán subsanando en el futuro debido a la nueva propuesta de distribución que se hará en los programas.

Las fórmulas museográficas empleadas en la sala dificultan la lectura del discurso. Por un lado, el contenido está fragmentado en varios grupos expositivos sin mantener una narración continua unos con otros y por otro lado, el apoyo de los textos explicativos es bastante obsoleto, pues tratan temas relacionados con las piezas expuestas siendo demasiado científicos añadiendo que la densidad de estas lecturas deja mucho que desear en un A4. Por otro lado, estos paneles están enmarcados con un cristal delante impidiendo una visión uniforme a causa de los reflejos ocasionados por las ventanas. Es criticable como en estas salas la mezcla de sistemas de iluminación hace que tengamos la sensación de que algunos de los focos son ya piezas del propio museo.

Tal y como comentábamos anteriormente, el criterio expositivo de la siguiente sala que vamos a tratar pertenece a un montaje topográfico exponiendo los restos del templo de Carteia están situados en la Sala XXIII, asentamiento púnico del siglo IV a. C. Llama la atención la monumentalidad de los elementos estructurales y decorativos del edificio. La colección de esta sala atiende a las actividades del comercio en el mundo romano. Prueba de ello, son los utensilios necesarios para el comercio, como la romana, la balanza, ganchos, pesas, contrapesos, todo ello reunido en una vitrina junto con los posibles adornos de figurillas que se colocaban en los carros para posibilitar el transporte terrestre de las mercancías. Aunque por otro lado, también se manifiesta el comercio marítimo 
con la presencia de ánforas para contener productos líquidos.

La dispersión de todos estos elementos se encuentran diferenciados por zonas. En primer lugar, en el ángulo derecho, observamos un plinto que eleva la mesa de capacidades junto a unos cuerpos arquitectónicos sustentantes. Al lado, los protomos de toro acompañados por dos figuras, Esculapio y una figura infantil con un perro, ambas sobre un plinto marmóreo. Al lado, la monumentalidad de la arquitectura de San Roque.

Siguiendo el recorrido de la sala, una vitrina exenta adosada a la pared con la variedad de utensilios y figurillas antes mencionadas, acompañadas de un mapa topográfico del comercio de la Península Ibérica a su lado.

Dicha circulación queda fragmentada por la ubicación de una vitrina exenta, que muestra las monedas de trueque que se usaba en distintas lugares como pueden ser la numismática árabe o la imperial localizada en una silueta topográfica dibujada en un metacrilato transparente, soportando en unos pequeños óculos las monedas para poder observarlas en el anverso y reverso. Decir respecto a esta vitrina que es algo difícil de entender para el espectador, su antigüedad es evidente y señalar que quizás no sería necesaria la colocación de toda esa cantidad de monedas porque a nivel investigador si puede ser interesante conocer hasta el último tipo de moneda que se acuñó, pero para el espectador simplemente es bueno que sepan que en esa época se acuñaban monedas, es decir, los métodos explicativos podrían ser diferentes a esa especie de pantalla acumulativa. 


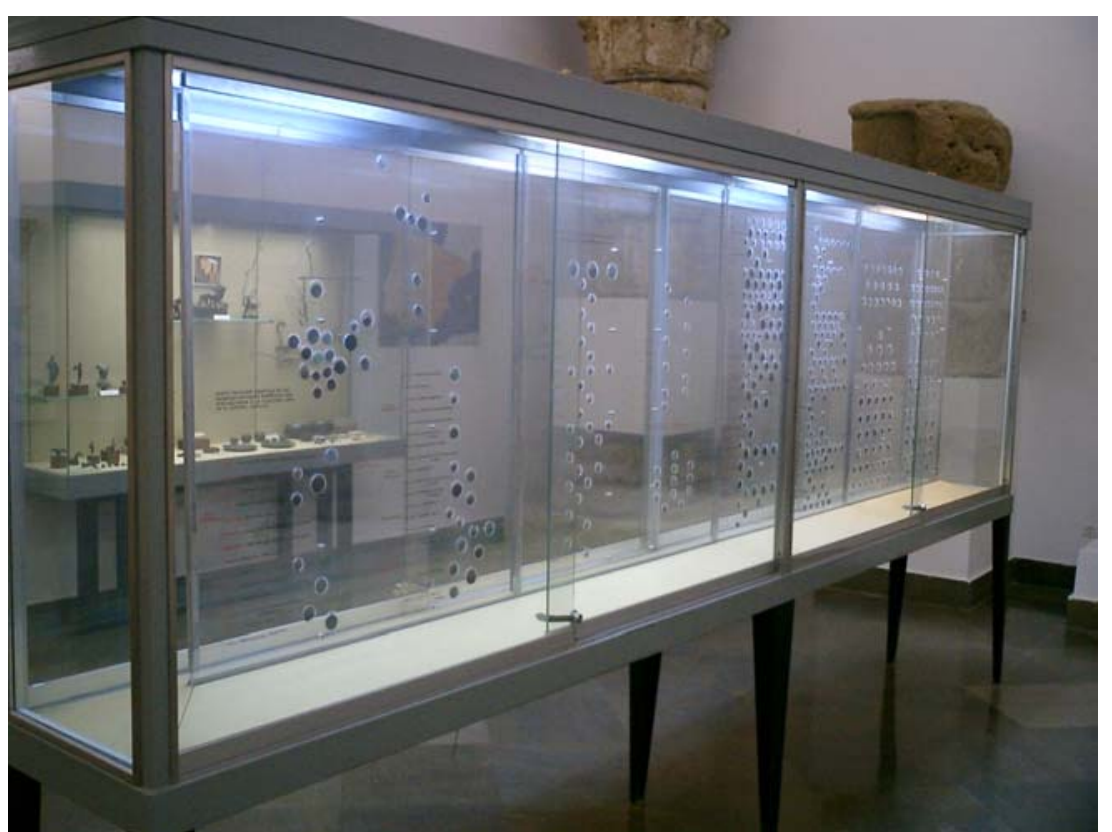

El otro lado de la sala queda protagonizado por la presencia de la Diosa Fortuna, como protectora de la ciudad y la actividad del comercio. Se puede apreciar todavía restos de su policromía, descubierta en el casco histórico de Sevilla. Tras ella, un mosaico romano de Alcolea del Río, Sevilla, de figuras geométricas.
Entre el mosaico y la escultura, una serie de ánforas y otra más voluminosa colocada en el suelo muestran la diversidad de formas de estos contenedores. Ancladas en la pared podemos ver las primeras, distintos formatos y tamaños quenos devuelven al criterio acumulativo museográficamente hablando, aunque en esta ocasión los sistemas expositivos están mejor resueltos técnicamente.

La iluminación de la sala está determinada por la generada desde el ángulo superior, bañando las piezas con una luz tenue. Las vitrinas exentas luz artificial siguiendo el modelo de las anteriores vistas en otras salas.

La cartelería en este caso es más clara que en casos previos. Solo que el criterio expositivo de presentar la numismática en ese tipo de vitrina, hace que el visitante quede un poco desconcertado por la visión posterior de otras piezas, además, si a esto añadimos las incidencias de los reflejos causados por las luces, imposibilita su observación. 
La siguiente sala es la número $\mathbf{X X I V}$, dedicada a al yacimiento de "Mulva", la antigua Munigua, sigue el criterio expositivo topográfico. Lo que más llama la atención de esta sala es la presencia de una maqueta dentro de una vitrina de mesa con la reproducción de la ciudad de Munigua. Además, le acompaña una vista parcial de la excavación en una fotografía aérea en blanco y negro a su izquierda sobre la pared.

A ambos lados de la entrada, hay unos monolitos de cuestionada conservación, con unas inscripciones honoríficas.

A la

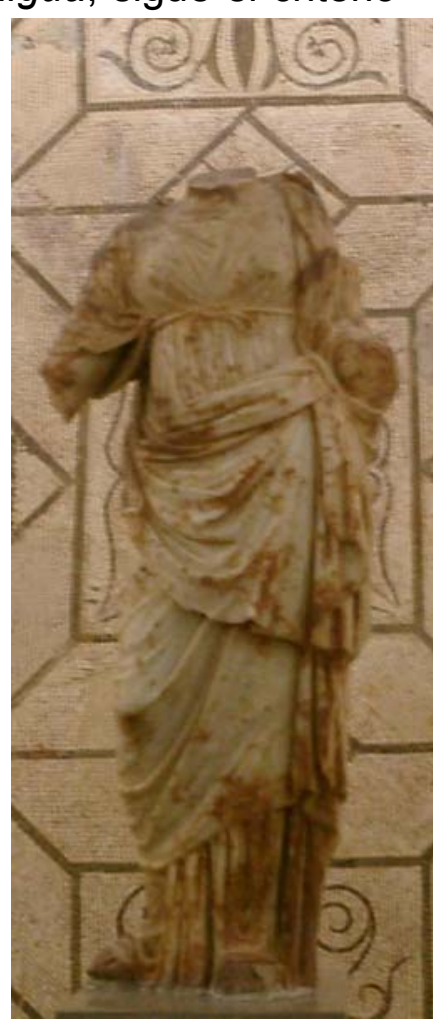
derecha una vitrina que contiene vasos de vidrio, joyas $y$ ajuares funerarios procedentes de las tumbas.

A continuación, una pequeña maqueta de la Edícula, del IIIII d. C. flanqueada por columnas corintias procedentes del yacimiento. Un sarcófago junto con una reja encima, junto con una vitrina que profundiza en el tema monográfico del ajuar funerario nos ayuda a comprender este aspecto en el ámbito social.

Al lado una escultura femenina que representa una ninfa, nos lleva a la coquetería del ajuar personal, concentrado en otra vitrina, toda clase de utensilios para la higiene femenina.

El recorrido de la sala nos muestra elementos arquitectónicos sustentantes, junto con inscripciones honoríficas.

Un aspecto relevante en la sala es una división de la misma provocada por la situación de un panel en el centro, que divide una parte y otra, obligando al visitante a realizar un recorrido circular. A un lado y al otro del panel están colocadas dos esculturas destacables. La Ninfa Hispania y, al otro lado, una Venus de Itálica del II d. C. 


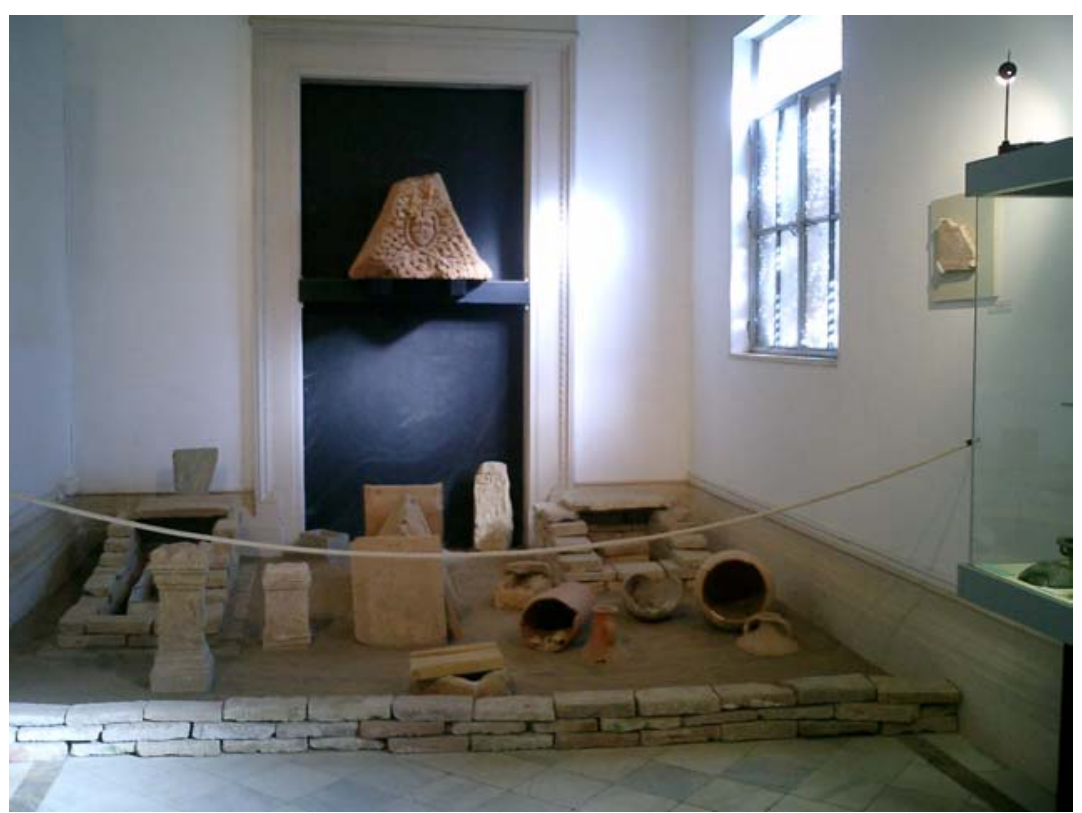

Principalmente debemos atender a la carencia de recursos expositivos que nos ayuden a contextualizar este lugar con una idea más clara. Las herramientas empleadas en esta sala son bastantes obsoletas, pues las fotografías en blanco y negro no sitúan el yacimiento con claridad, incluso la maqueta de la reconstrucción es otro elemento reaprovechado de otras exposiciones temporales.

La última sala dedicada a la cultura romana la encontramos en la XXV, haciendo un compendio sus ritos funerarios. Es una sala monográfica sobre este tema. Así pues, observamos distintas ceremonias representadas en sarcófagos columbarios

$\mathrm{y}$ monumentos funerarios levantados sobre lugares de incineración, los cupae.

En primer lugar, atenderemos la inhumación como ritual de enterramiento, el cual consistía en envolver al cuerpo del difunto en sábanas de lino y posteriormente introducirlo en sarcófagos de plomo o piedra como el que encontramos en la entrada de la sala decorado con escenas campestres o 
de cacería. Debajo de éste, una urna cineraria para albergar las cenizas del difunto, decorada con las puertas del infierno. Todo ello, viene desarrollado en un panel explicativo sobre estos rituales de enterramiento con un vocabulario muy científico. A continuación, la reproducción en aglomerado, de dos columbarios, conjunto de nichos donde se colocaban las urnas cinerarias o loculi. En medio, dos imágenes a color de la Tumba del Elefante de la necrópolis de Carmona, y en su centro una escultura de Attis, personaje mitológico protector de muertos y símbolo de la eternidad, colocados de una forma discordante en el discurso museográfico. Para contextualizar mejor este tema se debería recurrir a otros recursos expositivos más recurrentes y atractivos para el visitante. Entre las ventanas, adosadas a la pared sobre un panel, estelas funerarias que nos aportan datos sobre estos cultos.

El ritual funerario exigía la premisa de acompañar al difunto con todo su ajuar, de ahí, la vitrina monográfica de este tema con la exhibición de vasos de cerámica, bronce y vidrio, procedentes de la tumba de Orippo, Dos Hermanas, con una representación del yacimiento expuesta de una forma bastante sobria y escueta.

Al margen izquierdo de la sala, se ha recreado el monumento funerario descubierto en Alcolea del Río, con un frontón triangular representando a la Gorgona, con materiales originales hallados en la necrópolis.

En el centro de la sala se disponen dos unidades, una la cupae, receptáculo con una estructura semicircular levantado sobre el lugar de incineración junto con el ajuar del difunto. $Y$ la otra unidad, es una vitrina exenta con un ánfora como lugar de enterramiento de niños o bebes. 


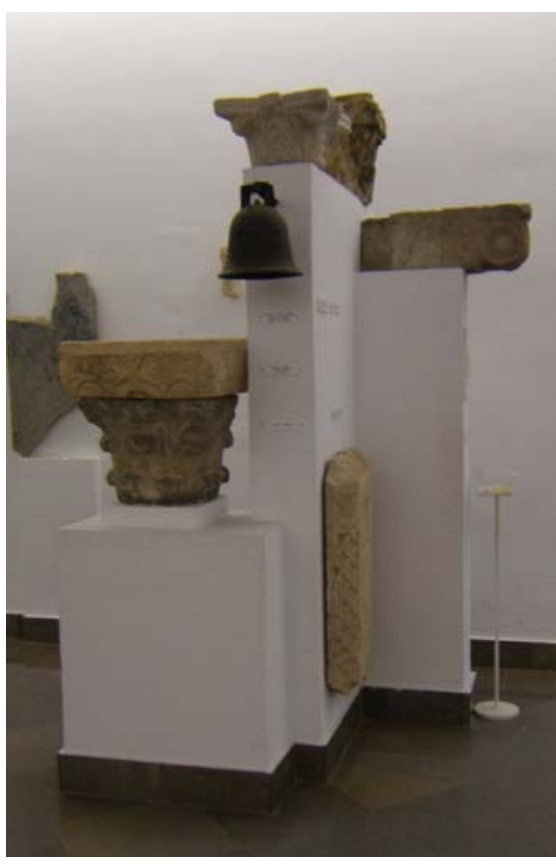

Esta sala también tiene las mismas características técnicas que las anteriores, sólo la excepción de un flexo alógeno sobre la parte superior de la vitrina, puntualizando la iluminación de la recreación. Las cartelas contienen un lenguaje demasiado científico para el visitante.

Las siguientes salas que vamos a analizar mantienen en común el razonamiento expositivo basándose en los hechos históricos que sucedieron en nuestra provincia. En Hispania, el Cristianismo se difundió con gran rapidez a finales del siglo II. La región de la Bética y, en general, la costa mediterránea (las áreas más romanizadas) parece que fueron la primeras en abrazar la nueva religión. Prueba de ello es que queda reflejado en el discurso museológico, en la sala XXVI, denominada "Antigüedad tardía".

Entrando en ella, encontramos el ángulo derecho con la exposición de fragmentos de sarcófagos paleocristianos como manifestación del ritual funerario de la inhumación. Éstos, están decorados con elementos iconográficos paganos, aunque pueden tener una interpretación cristiana. Dichos fragmentos están empotrados en la pared o bien con ganchos metálicos similares a las alcayatas. A continuación, sobre un plinto de obra lacada, apoya un sarcófago de principios del siglo IV, teniendo su origen quizás en Roma. Sobre él, una selección de ladrillos trabajados a molde, con motivos decorativos variados, en su mayoría con crismones. Al lado, otro sarcófago interesante por su material, es de plomo decorado con bandas de roleos, grecas y trenzados. En su parte inferior, elementos arquitectónicos sustentantes, como el cancel y capiteles visigodos del siglo VI, están dispuestos sobre 
unas sujeciones metálicas que ponen la pieza en suspensión, junto con otro capitel de igual características, delante de éstos, sobre un plinto. Con relación al carácter funerario de esta cultura, se señala la aparición de mosaicos para cubrir las sepulturas, también llamadas laudas sepulcrales. Encontramos dos ejemplos de interés, como son los de la niña Antonia Vetia y el de María Severa. Ambos con una buena destreza artística, tanto en calidad como en los motivos decorativos. Frente a ellos, sobre un plinto, una pila de abluciones de mármol con peces afrontado a una cruz como decoración.

Como documento epigráfico de la historiografía paleocristiana, encontramos la inscripción funeraria que formaba parte de la cubierta de la sepultura de un niño, adosado a la pared usando el mismo método de ganchos anteriormente explicados.

En medio de la sala hay un pie de metal simulando una columna y sobre el cual se coloca un cimacio visigodo

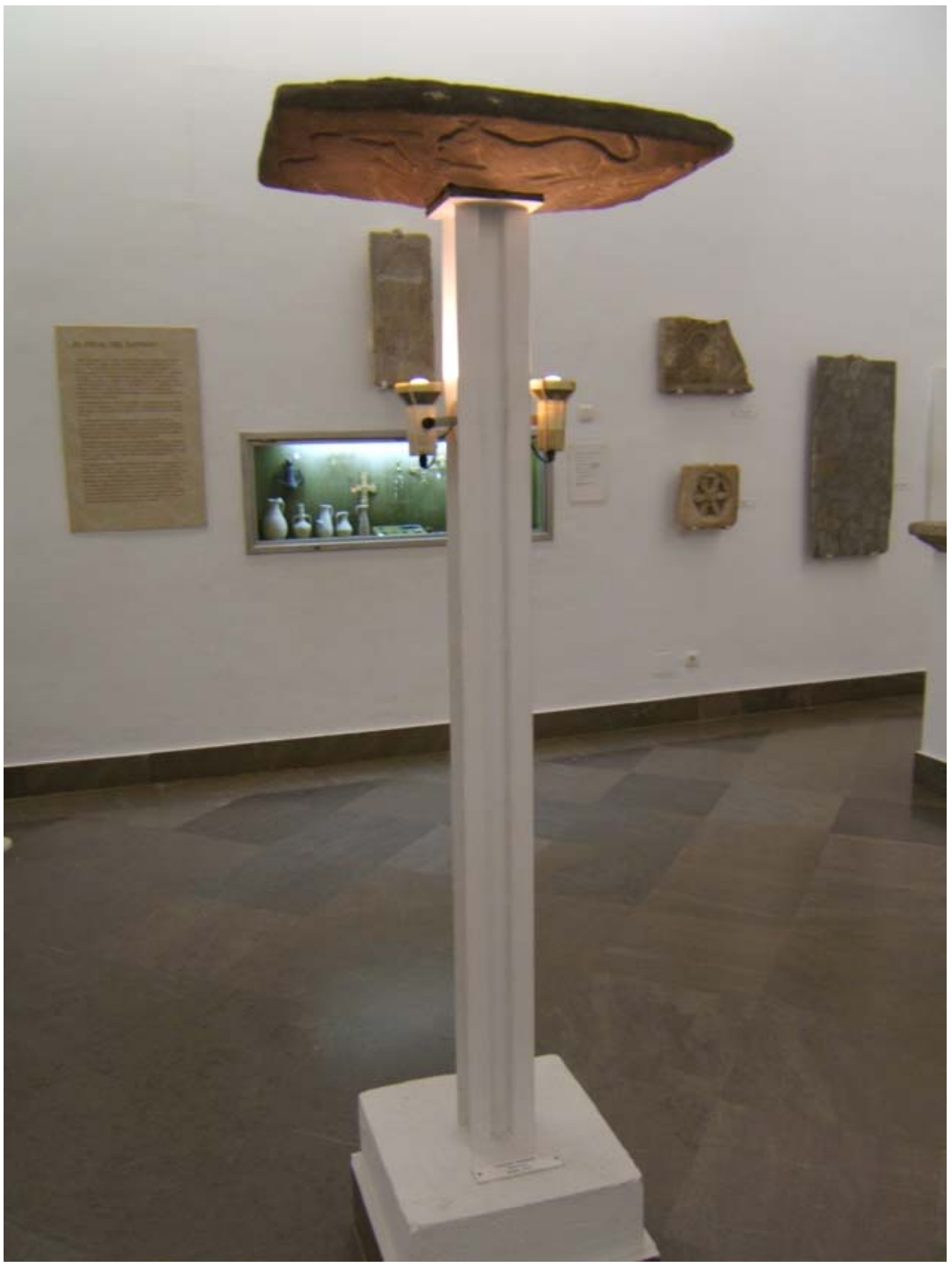


iluminado mediante dos pequeños y antiguos focos que proyectan su luz de abajo hacia arriba.

Nos llama la atención la aplicación museográfica de la vitrina que citamos a continuación. Empotrada en la pared, con forma rectangular, a modo de hornacina podemos observar las piezas expuestas sobre unos paneles revestidos en tela de pana verde. En su interior encontramos expuesto una copia del Tesoro de Torredonjimeno, de marcado bizantinismo con técnica del repujado calado, con incrustaciones de piedras preciosas.

Sobre esta vitrina una inscripción paleocristiana junto con un cartel explicativo de la caída del imperio romano, nos preludia la implantación de la cultura visigoda reflejada en la arquitectura y su decoración ornamental. Así pues, la solución museográfica para la presentación de estas piezas es una estructura de hormigón en la que se disponen éstas asemejando su colocación en la realidad.
Nos referimos a capiteles visigodos, una campana visigoda o una lauda sepulcral.

Otro tema monográfico está ubicado en la vitrina adosa a la pared que contiene el ajuar funerario de Mulva y Sevilla, destacables por las inscripciones del anagrama de Cristo, sobre terra sigilata, situado en los extremos. En su centro, cuatro cruces latinas con incrustaciones de piedras preciosas, junto con diversos anillos y sellos visigodos.

La técnica del releve la apreciamos en la exhibición de la figuración de unos pavos en un fragmento adosado a la pared, datados en el siglo VI-VII. Y a continuación, antes de acceder a la siguiente sala, observamos unas piezas muy originales, como son un ancla bizantina descubierta en la Plaza Nueva de Sevilla, o una cruz patada de mármol blanco con vetas grises, proveniente de Almendralejo. El recurso expositivo es igual al ya mencionado al estar adosadas a la pared. 
Por último, otra vitrina empotrada que contiene objetos de artes menores, con la presencia de unos bronces para los atalajes de caballos, un disco calado decorado con el crismón o anagrama de Cristo y un anillo de bronce con chatón rectangular con el símbolo del crismón de nuevo. Pero lo más interesante es un plato de vidrio decorado con una escena del Nuevo Testamento.

La última sala de nuestro discurso museográfico, es la sala

XXVII, y nos muestra

piezas del medievo y la edad moderna con la presencia de los musulmanes en territorio visigodo para fundar AlAndalus, generando una influencia cultural que quedará reflejado en distintas manifestaciones artísticas. Así pues,

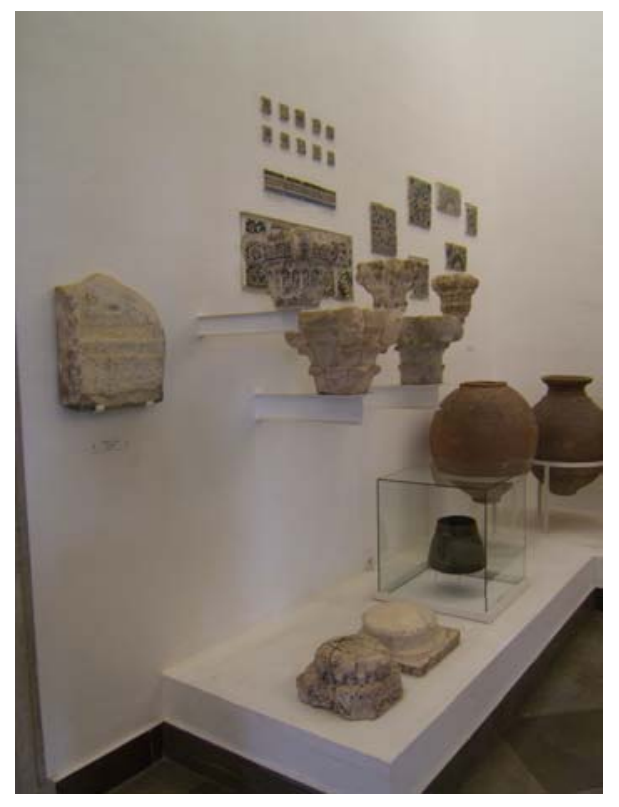

comienza la sala con la exposición de un plinto corrido en todo el testero izquierdo, elevando las piezas a una altura considerable para su visión. Sobre él, basas y capiteles mudéjares, con la decoración de hojas de acanto hasta tener su evolución en la técnica del ataurique.

El recurso utilizado en este caso para exponerlos es sobre unas sujeciones metálicas para colocarlos en suspensión. Abajo, dos fustes con inscripciones de caracteres cúficos con frases del Corán. En la parte superior de estas piezas, están empotrados en la pared una selección de azulejos a la cuerda seca, con motivos geométricos característicos del mundo árabe, que gracias a las influencias de las actividades comerciales, perfeccionaron la manufactura de estos azulejos, han llegado a nosotros hasta la actualidad. Esta destreza manual para las artes menores quedan patentes en las ánforas y tinajas mudéjares de los siglos XIV- XV apoyados sobre unos soportes de metal. 
Añadir que esta cultura, tan carismática por su religión y costumbres, nos manifiestan la habilidad de tallar la piedra como podemos observar en la pila exenta y rectangular de época califal. Su decoración es original puesto que los motivos ornamentales tienen relación con el uso de la pieza, contenedor de agua.

Una cenefa con decoración zoomórfica, patos, peces y galápagos, sobre unas flores acuáticas. Debajo de ella, otra pila con la técnica del vidriado en verde de época almohade. Detrás de estas dos piezas, se ennoblece el lugar con la recreación de un arco lobulado cegado con un cortinaje rojizo y flanqueado por dos capiteles. Esta composición nos recrea en la decoración ornamental de esta cultura para sus edificios.

Siguiendo con la línea del discurso museográfico, aparecen tres brocales del siglo XIII-XVI, decorados con motivos decorativos seriados, junto con inscripciones epigráficas cúficas con contenidos del Corán, al igual que las lápidas de la parte superior. Sin embargo, un brocal está situado en el centro de la sala para darle un lugar más prestigioso, ya que la pieza requiere su interés. Es un brocal de pozo octogonal con molduras trenzadas y epigrafía cúfica. Esta

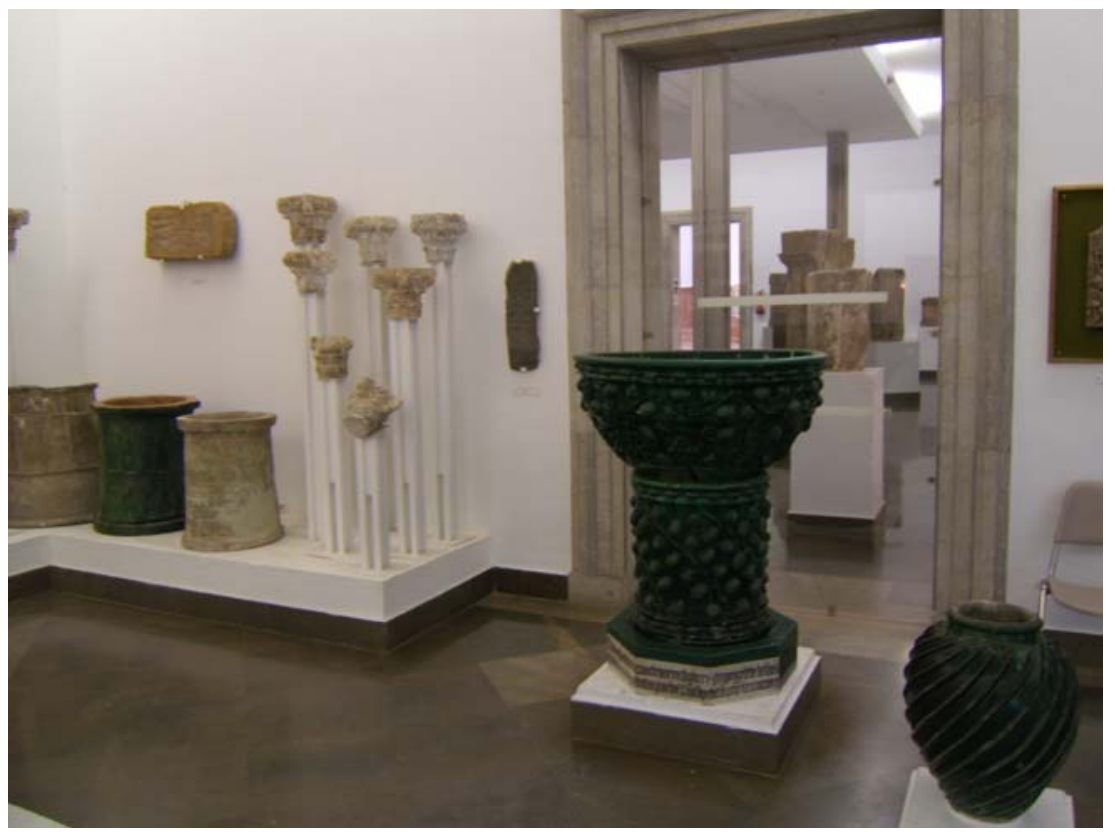

pieza al igual que las anteriormente citadas, no poseen ningún elemento que apoye la seguridad de la pieza, están al acceso de cualquier visitante para poder tocarlas. 


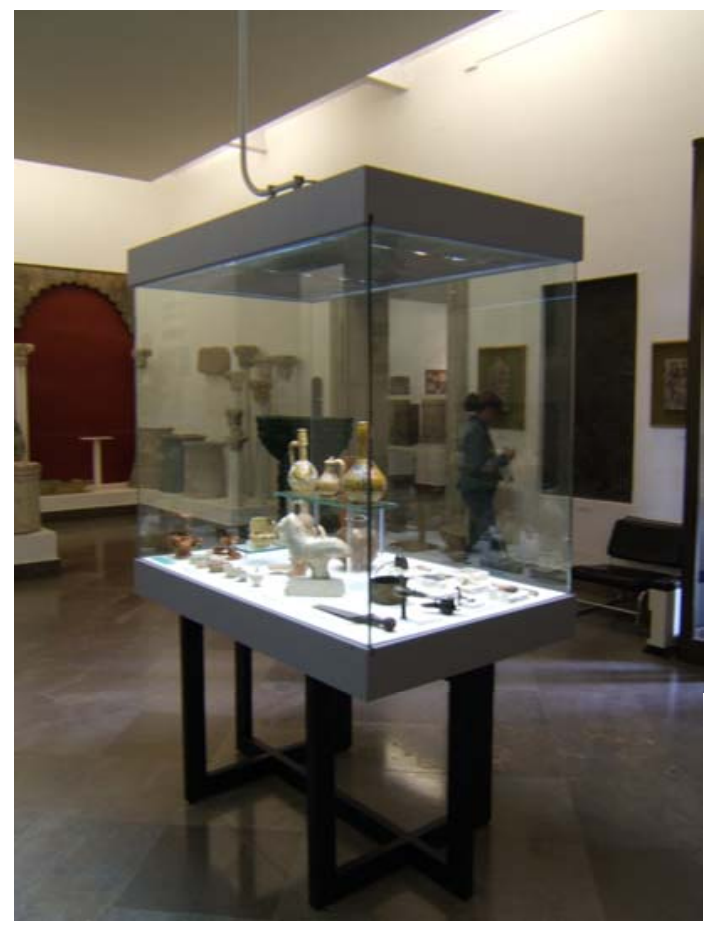

Lo mismo ocurre con una pila bautismal con la técnica del vidriado en verde, procedente del Hospital de San Lázaro de Sevilla. Es una pieza que destaca por su tamaño y por la espectacular decoración con roleos vegetales y flores estilizadas de influencia gótica, mezclada con la decoración mudéjar.

En el centro de la sala, al margen derecho, hay dos vitrinas. Una exenta, que contiene las artes menores árabes, hebréas y mudéjares. Principalmente, contiene cerámica descubierta en los Baños de la Reina Mora, con candiles, jarros, etc pertenecientes a época taifa y almohade. También se expone la figura del león califal, descubierto en Sevilla, junto a la producción de piezas en bronce como los candiles, junto con recipientes contenedores de aceite, y objetos varios como una flauta almohade, junto con una espada de hierro, amuletos, numismática, una diversidad de objetos que nos muestran la fusión de las culturas. El método museográfico destacable en la vitrina es la colocación de una tela de color claro, que ayuda a magnificar con claridad la belleza de las piezas que contiene. Además, se opta por jugar con las alturas proporcionadas por unos metacrilatos limpios y transparentes que ayudan al mismo fin. La otra vitrina 
presenta pequeñas vasijas de época medieval mostrando todas sus alternativas formales utilizadas en la época.

Destacar unos relieves de alabastro de estilo gótico ingles de los siglos XIV- XV, colocados cerca de la salida. Representan la Piedad y la Resurrección de Jesucristo, pertenecientes a las dependencias del Ayuntamiento, junto con una lauda de bronce que cubría el sepulcro de la esposa de Don Francisco Fernández. 

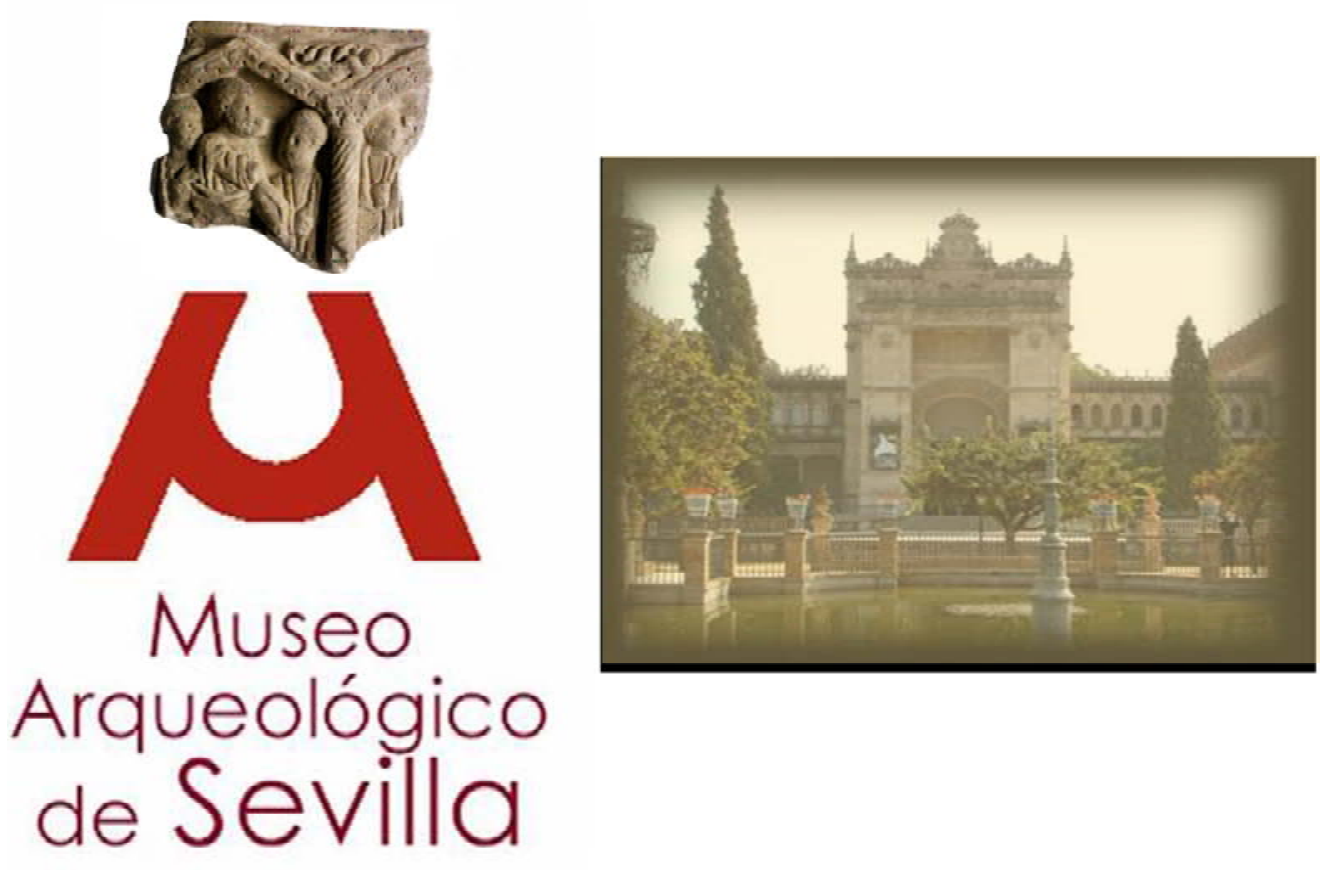

Arqueológico

de Sevilla

\section{DIFUSIÓN $y$ COMUNICACIÓN}

Rafael Díaz Alonso Josefa Cano García 


\section{V.1. DEFINICIÓN DE PÚBLICO}

La misión educativa y comunicativa de los museos se está equiparando con las funciones más asentadas como la investigación o conservación de las colecciones. Para llevar a acabo esta misión, los museos deben investigar y conocer sus públicos para poder contar con un punto de partida y les ayude a fijar objetivos claros, realistas y alcanzables de una manera científica y sistemática.

Las cosas no son lo que parecen ser, de ahí el sentido y utilidad del estudio y evaluación de público, aunque muchas veces la falta de recursos y requerimiento del personal para tareas más urgente se abandone o nos se lleve un seguimiento continuo.

El sentido claro de la dedicación de los museos a los visitantes se ha desarrollado poco en España a pesar de su riqueza patrimonial y museística, aunque en los últimos años ha cambiando por el creciente interés en la utilidad de estudios para conocer el publico del museo.

Entre las aportaciones futuras para los museo del siglo $\mathrm{XXI}$ debe destacar ${ }^{11}$ :

-Realizar análisis del publico para determinar quien visita y no visita el museo, con el propósito de extender los servicios del museo a su público.

-Evaluar la efectividad de las exposiciones y programas en un proceso de evaluación en desarrollo que fomente la revisión y experimentación para mejorar la experiencia educativa del visitante.

-Establecer estructuras de toma de decisiones para la elaboración de exposiciones y programas que impliquen

\footnotetext{
${ }^{11}$ Aportado por la Asociación Americana de Museos(AMM) en su documento Excellence and Equity: Education and ther Public Dimention of Museums(1992)
} 
una intervención formal entre el personal entendido en la materia, los intereses y necesidades del público y los estilos de percepción y procesamiento de la información de los visitantes. Usando métodos disponibles en la actualidad.

\section{V.1.1. Estudios generales y específicos}

A continuación presentamos análisis de visitantes del Museo Arqueológico de Sevilla, realizado a partir de os datos facilitados por el museo, teniendo en cuenta que la información se recopilo entre finales de 2005 y principios de 2006.

Se ha utilizado a partir de la estadística creada con los datos obtenidos de la venta de entrada por el personal de taquilla, los cuales rellena una grafica tratada posteriormente por los técnicos.
El dato principal que tenemos de los visitantes del Museo Arqueológico es el registro de numero de visitantes, para el año fue de 2003: 54.286 y para el 2004: 54.331.

Los diferentes tratamientos de la información nos permite presentar unas consideraciones manadas en forma de estudios estadísticos.

Comencemos con la evolución de las visitas entre 1990 y 2005:

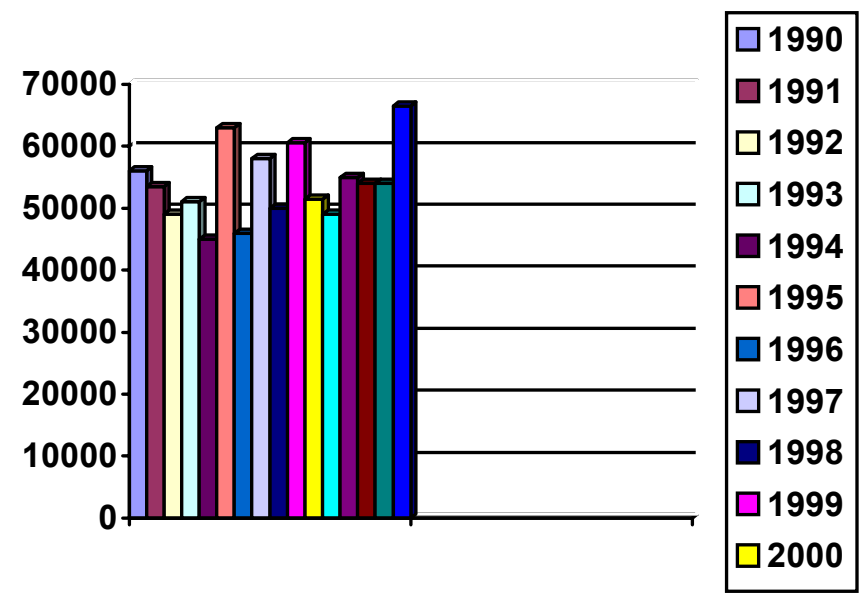


Nos permite ver que el volumen de vistas se mueve entre los 50000 y 60000 , superándose solo en los años 1995, 1999 y 2005. La superación de este ultimo año se debe a la celebración de una exposición que atrajo la vista de abundante publico.

Viendo la gráfica anual de la distribución de las visitas mañana y tarde ${ }^{12}$,

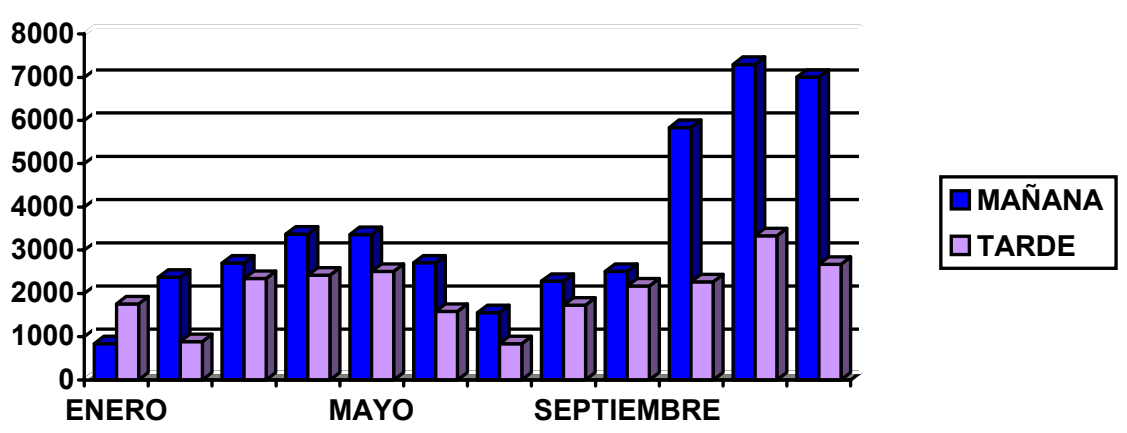

podemos ver como el volumen de vistas es mayor por la mañanas, siendo la diferencia muy marcada en los últimos

\footnotetext{
${ }^{12}$ Datos del año 2005
}

meses del año ,muy relacionada seguramente con el flujo de visitantes en grupo como podemos ver en la siguiente gráfica.

Grafica anual de distribución de visitantes en grupo individual $^{13}$ :

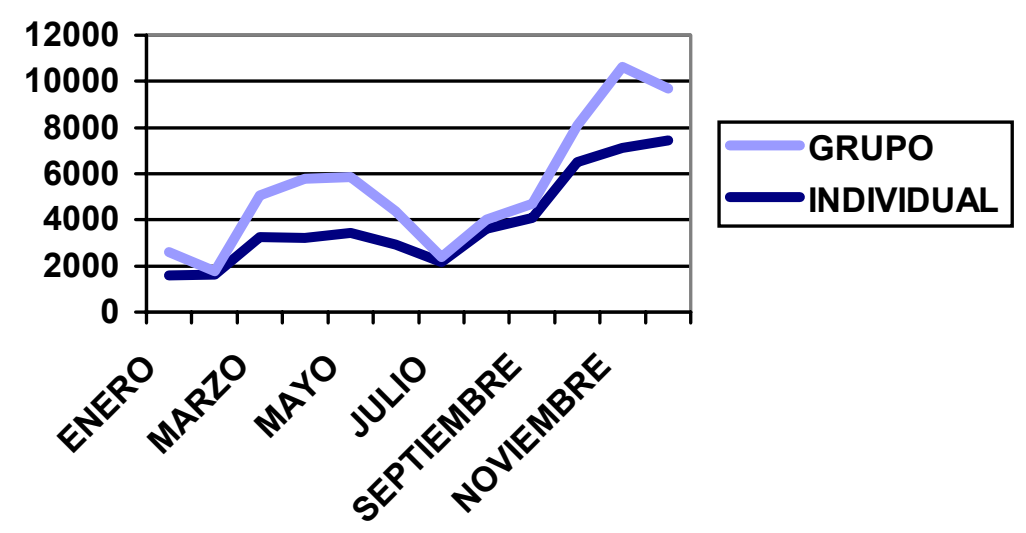

aumento de vistas en grupo destaca en primavera y en los últimos meses del año, coincidiendo con la temporada alta turística de la ciudad y el primer trimestre del curso escolar.

${ }^{13}$ Datos del año 2005 
En los meses de veranos se igualan los visitantes en grupos e individuales.

A continuación presentamos la gráfica de la evolución anual de los visitantes nacionales y no nacionales ${ }^{14}$.

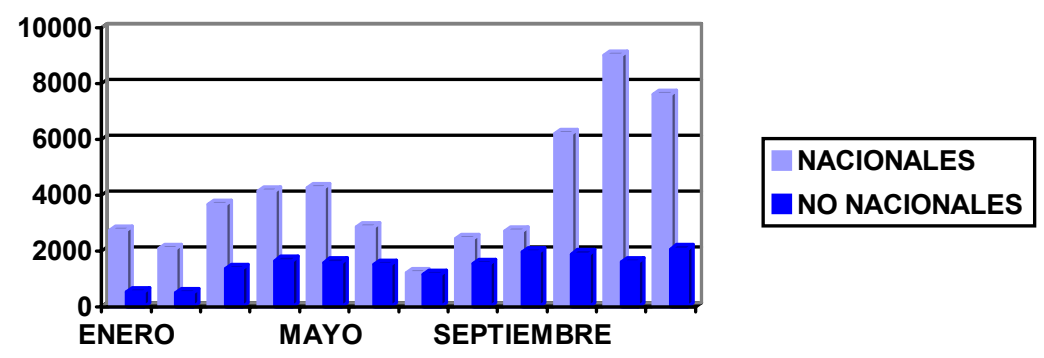

Los visitantes nacionales siempre superan a los no nacionales, siendo mayor la diferencia en los meses de Enero y Febrero, que coincidiría con el aumento de visitas de grupos escolares. Además, podemos ver un aumento de las visitas de no nacionales coincidiendo con la temporada alta turística de Sevilla. En julio se equiparan ambos grupos. El aumento de las visitas en los últimos meses coincide con la celebración de la exposición "Artifex"

La próxima gráfica nos presenta el porcentaje de los diferentes tipos de grupo que visitan el museo:

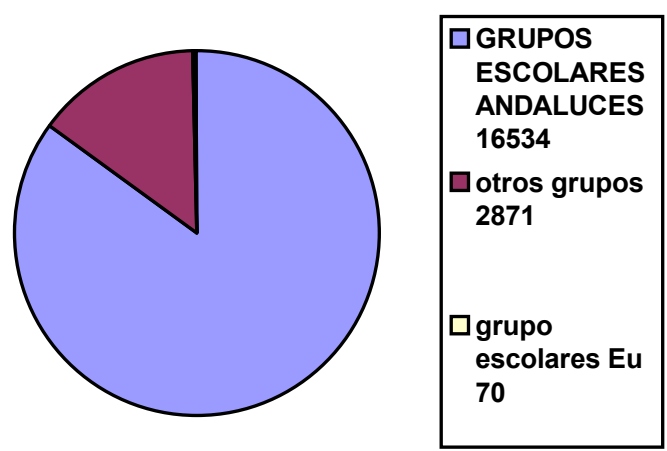

\footnotetext{
${ }^{14}$ Datos del año 2005
} 
En él destaca abrumadoramente que la mayoría de los grupos son escolares andaluces.

\section{a) Datos generales:}

Además de las estadísticas del público que visita el museo es necesario conocer las características y valores de la población en la que se ubica el museo. Parte del puede ser un público potencial, conociéndolo podemos implementar sus intereses a cerca del museo y conseguir atraerlo con la programación de actividades etc.

Presentamos los principales datos:

La población total de la ciudad es de 704.154 habitantes, siendo el porcentaje de menores de 20 años: $20,29 \%$ y el porcentaje de mayores de 65: 15,59\%.
El número de extranjeros es de: 20.722 , siendo la principal procedencia de los residentes de América del sur. Que suponen dentro del total de extranjeros $40,72 \%$.

En cuanto a servicios, en la ciudad existen 197 centros de enseñanza básica y 139 Centros de enseñanza secundaria, suponiendo un potencial de 336 centro de enseñanza población

Referente a la economía de la población destacamos que la renta familiar disponible está entre los 9.300 y 10.200 euros.

Principales datos:

La población activa alcanza las 308.647 personas, siendo 238.160 la población ocupada y 70.487 la población parada, por lo que la tasa de empleo es de un $41,7 \%$ y un $22,8 \%$ de la tasa de Paro. 
Por ultimo indicamos que la sección de actividad predominante es la "Sección G" que corresponde al comercio, reparación de vehículos de motor, motocicletas y ciclomotores y artículos personales y de uso doméstico, etc.

El museo cuenta con una población próxima abundante, cuenta con la ventaja de ser junto al Museo de Artes y Costumbres populares los únicos museos abiertos de la zona sur de la ciudad. La Zona sur cuenta con diferentes tipologías de población en sus barrios, por lo que el museo tiene la posibilidad de convertirse en un verdadero centro cultural en relación con su territorio.

Se ubica en una ciudad en la que se están produciendo cambios demográficos, con el aumento del sector de residentes emigrantes especialmente americanos, dedicada al sector servicio, aumento de la población mayor de 65 años etc.
Esta nueva conformación social debe de ser atendida con la cobertura de sus necesidades integración y bienestar.

\section{Indicadores turísticos}

Otros datos a tener en cuenta para la planificación del museo son los datos turísticos, ya que existe un amplio numero de visitantes no locales.

Veamos la procedencia de los visitantes a la ciudad.

\begin{tabular}{ll}
\hline procedencia & Numero de visitantes \\
\hline Andalucía & 438962 \\
Madrid & 424387 \\
Cataluña & 135311 \\
Resto de España & 377068 \\
UE & 622264 \\
Otros & 428814 \\
\hline
\end{tabular}




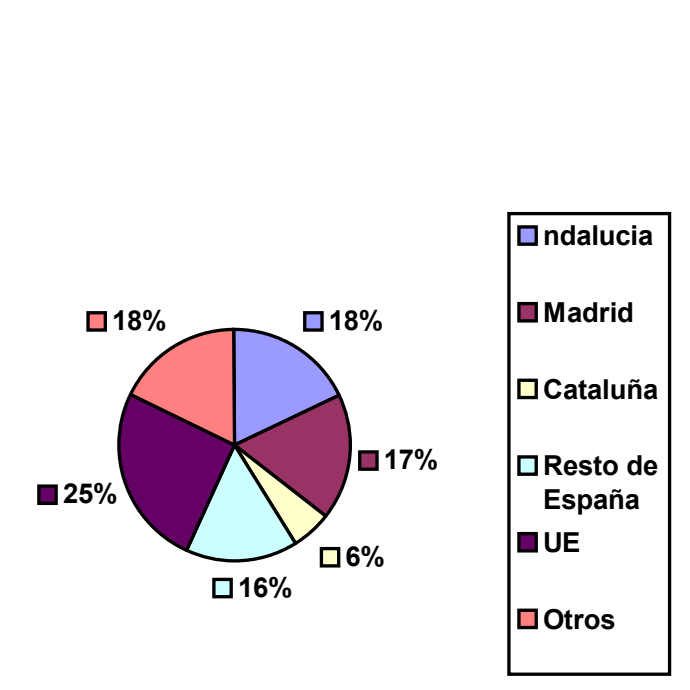

El mayor numero de visitantes son de la UE seguidos de andaluces y madrileños que son muy similares en valores.

En cuanto a la Composición por edad de los visitantes a la ciudad:

\begin{tabular}{ll}
\hline Edad & Porcentaje \\
\hline Menores de 18 años & $2^{\prime} 98 \%$ \\
De 18 a 25 & $26{ }^{\prime} 5 \%$ \\
De 26 a 34 & $29^{\prime} 17 \%$ \\
De 35 a 44 & $20^{\prime} 66 \%$ \\
De 45 a 54 & $10^{\prime} 75 \%$ \\
De 55 a 65 & $6^{\prime} 52 \%$ \\
De 65 y más & $3^{\prime} 44 \%$ \\
\hline
\end{tabular}

Los visitantes entre 18 y 25 suponen más de un cuarto del total de visitantes, y el $55 \%$ \% esta entre los 18 y 35 , son visitantes jóvenes.

La Distribución porcentual de número de veces visitada la ciudad es: 


\begin{tabular}{cc}
\hline $\begin{array}{c}\text { Número de } \\
\text { Vistas }\end{array}$ & Porcentaje \\
\hline $\begin{array}{c}\text { Primera vez } \\
\text { Una o dos } \\
\text { veces }\end{array}$ & $33^{\prime} 8 \%$ \\
De tres a & $33 \%$ \\
cinco veces & \\
Mas de seis & $20{ }^{\prime} 5 \%$ \\
veces & $12^{\prime} 8 \%$ \\
\hline
\end{tabular}

A la hora de elegir las visitas que se desean realizar en la estancia en la ciudad la temporalidad de la estancia es importante ,por lo debemos de conocer la estancia media:

\begin{tabular}{cccc}
\hline & España & UE & Resto del mundo \\
\hline $\begin{array}{c}\text { Estancia } \\
\text { media }\end{array}$ & 3'19 días & 4'49 días & 6'76 días \\
\hline
\end{tabular}

Podemos observar como los españoles deciden quedarse menos tiempo que el resto de visitantes, hay que tener en cuenta la posibilidades de andaluces y madrileños de hacer visitas cortas de un fin de semana.

Otro elemento importante a la hora de organizar la estancia es conocer el motivo principal del viaje

\begin{tabular}{cccc}
\hline Vacaciones & Otros & Negocios & Congreso \\
\hline $\mathbf{5 1} \mathbf{1} \%$ & $\mathbf{3 2} \mathbf{5} \%$ & $\mathbf{8} \mathbf{6} \%$ & $\mathbf{7}^{\prime} \mathbf{8} \%$ \\
\hline
\end{tabular}

Poco más de la mitad de los visitantes vienen a la ciudad por motivos vacacionales y turísticos, que es el motivo en el cual se visita más lugares de la ciudad. 
En el momento de diseñar la comunicación del museo, sus exposiciones y actividades es necesario conocer la fuente de información principal para viajar a Sevilla:

\begin{tabular}{cc}
\hline Fuente & Porcentaje \\
\hline Folletos Turísticos & $14 \%$ \\
Publicidad y reportaje e radio y prensa & $10 \%$ \\
Agencias de viajes & 12 ' $8 \%$ \\
Catalogo Tours Operartors & 10 '9\% \\
Guias turísticas & 12 '6\% \\
Internet & $10^{\prime} 1 \%$ \\
Amigos y familiares & 14 '8 \\
Experiencia vista anteriores & 14 '8
\end{tabular}

Respecto a la competencia con los lugares visitables en la ciudad vamos a ver el número de Visitas de lugares de interés turístico.

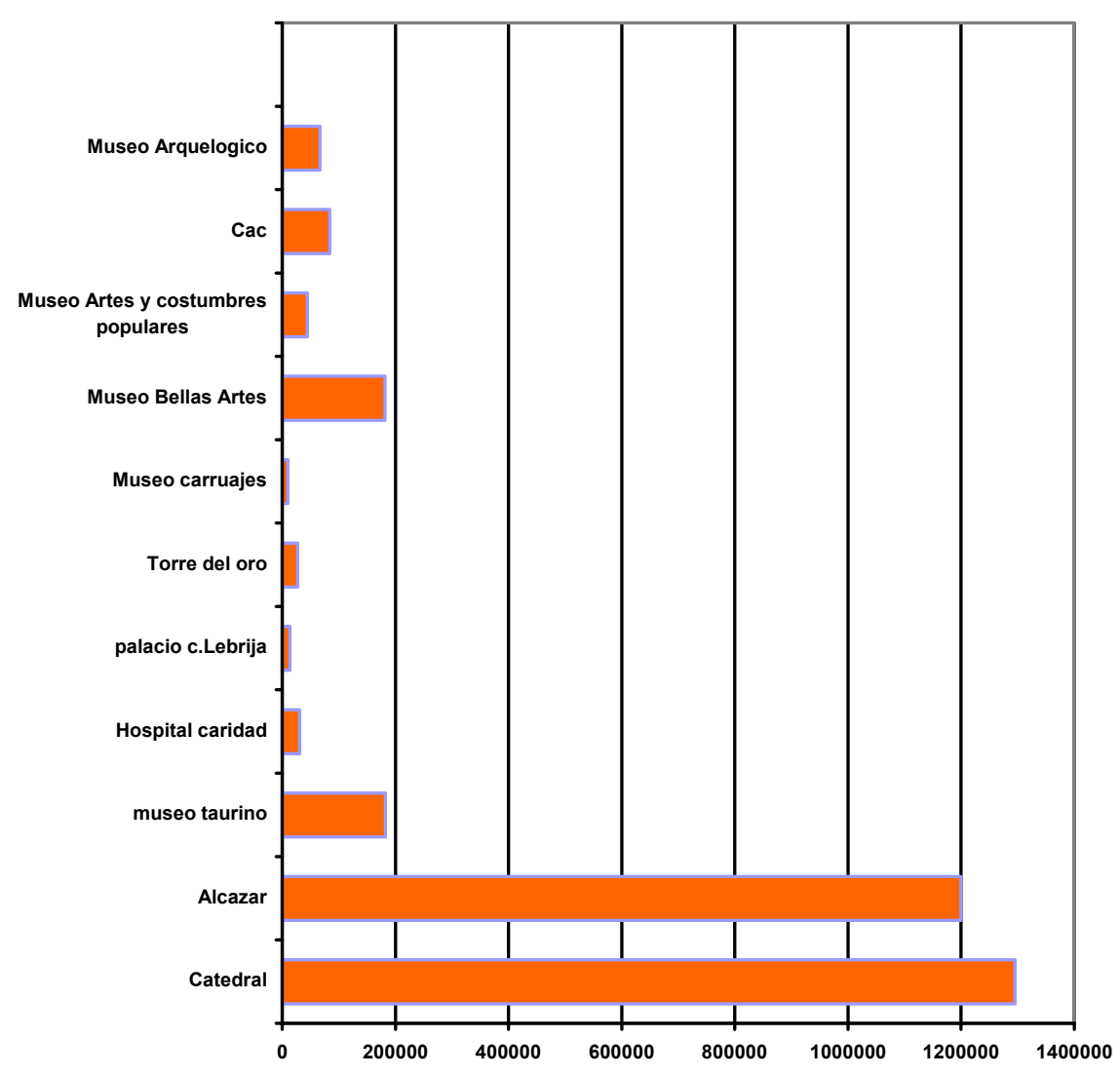

El número de visitas a la Catedral y al Alcázar supera absolutamente al resto de los lugares de interés, seguidos 
a distancia por el Museo Taurino y el Museo de Bellas Artes; el Museo Arqueológico, el CAC y el Museo de Arte Y Costumbres populares serían el tercer grupo.

\section{b) Primeros datos para estudios de público}

A pesar de los datos presentados para el análisis de los visitantes y la falta de un estudio de publico detallado, amplio y continuo hemos visto la necesidad de realizar un estudio de publico, que aportasen datos complementarios a los anteriormente expuestos y que sirviesen, además, para el diseño de proyectos y programas. Sin animo de ser exhaustivos y a modo de obtención de algunos datos orientativos se diseño el estudio de publico para que después de un análisis y evaluación de los resultados se puedan implicar a las futuras propuestas
El objetivo general de este estudio de publico es conocer algunos datos orientativos sobre los visitantes, para la adecuación de la exposición, actividades y servicios en un futuro.

Para futuros proyectos del museo tendrá que implementación realizar un amplio desarrollo de éste.

Las técnicas metodológicas. Desde un principio de pretendió trabajar tanto con técnicas cualitativas como cuantitativas. No se ha establecido muestras concretas, pero se ha intentado la obtención de resultados de diferentes topologías según variables relevantes: edad, sexo, vista individual, en pareja, grupo, familias, visitante asiduo a museos, estudiantes, jubilados, los las variables principales; teniendo la posibilidad de ampliar las variables según se fueran viendo los datos obtenidos.

Dos tipos de técnicas de recogida de datos hemos utilizado: 
-Estudios de observación del comportamiento de los visitantes mientras realizaban la visita a la exposición. Estos han llevado mucho tiempo, pero es muy muy rica en información. La técnica ha consistido en la observación directa por miembros del grupo de trabajo. Por cada visitante se dibujó recorrido y su sentido, se calculó el tiempo pertinente durante la vista, es decir tiempo dedicado, hora de entrada en el museo y salida, hora de entrada y salida de cada sala.

Para ello se realizo un esquema de cada una de las sala con la localización de los displays, vitrinas y piezas expuestas.

-Entrevistas previas y posteriores a los visitantes.

La entrevista previa esta centrada fundamentalmente en las disposiciones y expectativas que los visitantes traen a la exposición. La entrevista posterior está más centrada en aspectos de impacto de los contenidos expositivos, piezas, servicios, así como evaluación de las expectativas previa.

Se ha realizado, a otro grupo la entrevista posterior y un a tercer grupo de personas se le ha hecho las dos entrevistas(estas ultimas con la oportunidad de realizarlas en ingles y francés)

La técnica de la entrevista se ha utilizado por la obtención de datos más rápidamente, mas abundancia de información y por su economía.

Requirió un conocimiento previo de los elementos y situación del museo.

Otras entrevista se ha realizado a una muestra de población en el entorno del museo (Parque Maria Luisa $Y$ avenida Felipe II).

Los participantes a los que se le ha aplicado la técnica de entrevista y observación han sido visitantes seleccionados durante un domingo por la mañana, y entresemana mañana y tarde. 
Además se ha realizado dos grupos de discusión y además de entrevistas a abiertas personal de museo.

En el primero se utilizo un guión semiestructurado para discutir sobre diferentes aspectos de la institución. En la selección de participantes no se ha pretendido ser muy estricto según requiere la técnica, ya que se ha realizado a modo de experimento. Se plantearon dos grupos de discusión de personas ajenas a la institución, ya que para la realización de todo el proyecto se ha podido obtener abundante información del personal técnico viéndose innecesaria por el momento. El primer grupo fueron estudiantes de museología residentes en la provincia de Sevilla que conocen el museo y estudiantes de museología que sólo han visitado una o ninguna vez el museo. El otro grupo ha sido formado por profesores de primaria $y$ secundaria, unos relacionados por la enseñanza de materias relacionadas al museo (Historia, Patrimonio, Arte,) y otros del resto de materias no asociadas directamente(Ingles y Física)
El análisis de los tiempos dedicados, ha consistido en la realización de mapas de uso, y además la aplicación de serie de medidas independientes, que con análisis en conjunto aportan puntos de vista complementarios.

Medidas extraídas se aplican sobre las salas y unidades expositivas (display, vitrina, pieza):

-La accesibilidad ("passing") se operativiza en el tanto por ciento de visitantes que pasan por delante de un display, vitrina o pieza.

-Atractividad ("attracting power") que se operativiza con el numero de visitantes que paran delante de cada display pieza o vitrina.

-La atrapabilidad ("holding power") que se operatiza por el tiempo en segundos que los visitantes dedican a cada display. 
Una selección representativa de los resultados lo podemos ver en el apartado "La comunicación y difusión en la exposición"

\section{La utilización del espacio expositivo: recorridos.}

En este estudio se obtiene datos de la direccionalidad, el sentido y los espacios atravesados durante la visita

Las cuestiones planteadas para la entrevista previa son:

¿Cómo conoció la existencia del museo?

¿Por qué ha venido al museo?

¿Conoce que hay en el museo?

Si ya lo ha visitado, ¿Por qué regresa?

¿Existe alguna relación entre usted y el contenido del museo?

¿Qué le gustaría encontrar?

¿Visita otros museos?

¿Conoce otros museos de arqueología?
Comenzando con la solicitud de algunos datos del perfil, se centra fundamentalmente en recoger expectativas sobre el museo, también en rastrear los motivos de la visita.

La mayoría de los visitantes entrevistados suelen visitar museo o exposiciones, ocupando la cultura parte de su tiempo de ocio.

El visitante local suele haber visitado ya el museo alguna vez hace mucho tiempo, además conoce los elementos tradicionales del museo.

Los turistas a la ciudad unen su vista al Parque con la visita al Museo, siguiendo las guías que hablan de la interesante e importante colección de obras de arte y arqueológicas. También hemos encontrado estudiantes de Historia, Arte, Arqueología, etc.

Diferentes medios ligados al turismo, guías de la ciudad son fuente de difusión del museo. Los mupis informativos del Parque es un medio informativo de la existencia del museo para el turista que no tiene muy diseñado su vista a 
la ciudad o para localizarlo el que si tiene diseñada su visita

Los motivos de la vistas son muy variados, por interés turístico, por estar en la zona o por interés en el tema.

Finalmente en cuanto a las expectativas de encontrar tesoros de itálica, el tesoro del carambolo y restos antiguos de la ciudad principalmente. Los que no tenían planteada la vista de antemano tenían previsiones del contenido muy dispar: obras relacionada con el descubrimiento de América, restos arqueológicos egipcios, etc.

En el estudio de impacto se ha preguntado por:

Lo que más les gustó: de las piezas, salas, cantidad, Información del objeto y otros

Lo que menos le gusto: de las piezas, salas, cantidad, Información del objeto y otros.

También sobre Instalaciones, personal, etc.

Si consideran el contenido interesante.

Qué les hubiese gustado encontrar.
Y finalmente la oportunidad de dar alguna sugerencia.

La opinión del publico sobre el museo y el impacto de los contenidos es muy desequilibrada. Por un lado para los visitantes asiduos a museo le parece magnifica la colección pero tienen mala impresión de las condiciones, la luz, la calidad, la información, el acondicionamiento y abandono de instalaciones.

El interés de los visitantes por las piezas frecuentemente se debe a su riqueza grandiosidad, belleza o resonancias evocadoras. El tesoro del carambolo, la sala elíptica, los mosaicos, las esculturas de Itálica y el edificio, es lo mas atractivo para la mayoría de visitantes poca gente hace referencia a las salas de la planta sotano, como si fuese un anexo al verdadero museo que se la planta 1.

Hemos notado que los contenidos de las áreas son desconocidos para el visitantes, no distinguiendo entre temática, montaje y pieza. 
Entre las mejoras sugeridas esta la modernización del museo en el montaje(mas información de las piezas, etc.), así como de servicio: tienda, bar para descansar.

Para la entrevista del publico potencial planteamos las siguientes preguntas:

¿Qué visita cuando va a una ciudad?

¿Conoce museo arqueológico?

¿Conoce el museo arqueológico?

¿Qué recuerda de él?

¿Qué no le gustó?

¿Algo que le gusto?

La mayoría de entrevistados acertaban con la ubicación en la Plaza de América, conocían la institución de visitarlo con el colegio o instituto. Recordando los mosaicos, estatuas y salas con cuencos. La pieza más conocida era el tesoro de Carambolo.
Utilización de la técnica de "focus group". Constituye una técnica cualitativa en la que se dialoga con un grupo reducido de participantes conducido por un moderador. $A$ modo de experimentos se crearon dos grupos informales a los que se le plantaban una serie de tópicos recogidos en un guión previo:

-La imagen del museo.

-Qué necesita el museo arqueológico.

-Comparación con otros museos de arqueología.

-Contenidos que debería tener en cuenta en una remodelación.

-Piezas imprescindibles.

-Montajes y actividades sugeridas.

-Otras sugerencias.

Los principales resultados son:

La imagen es percibida como una institución anclada, poco atractivo, lo que atrae es el entorno y las piezas y sala elíptica. 
Tiene poca presencia en la vida de la ciudad aunque existe reconocimiento de la colección como importante.

Prima la modernización de las instalaciones, para llevarlo al siglo XXI. Sugiriendo que en una remodelación se tendría que abarcar la temática de la arqueología como trabajo y la problemática del patrimonio.

Otros contenidos sugeridos están relacionados con la vida cotidiana, interpretación de las culturas, usos de las piezas, explicación de la escultura mitológica, etc.

Además de la aplicación de otras técnicas expositivas que ayuden a interpretar la colección(como en el Museo arqueológico de Alicante) también se sugieren las audioguías para que el público obtenga más información según las necesidades e intereses particulares

La adecuación del museo para una visita cómoda tan bien es un elemento señalado

La ubicación del museo en la Plaza América se percibe como una característica potencial para la posibilidad de crear proyecto cultural atractivo y activo en la ciudad a modo de barrio de los museos.

\section{El cuestionario personal del museo consiste en:}

¿Cómo cree que se entera la gente de la existencia del museo?

¿Por qué cree que la gente viene a verlo?

¿Qué cree que esperan ver?

¿Qué cree que llama mas la atención al visitante?

¿Qué es lo q mas le gusta?

¿Qué es lo que menos le gusta al visitante?

¿Qué mejorarías?

¿Qué le gustaría ver en el museo?

¿Cómo se comporta el visitante?

El personal que tiene trato directo con el publico nos ha aporta importante información acerca de diferentes aspectos de los visitantes.

El primer que nos ha dolido aportar es la distinción de dos tipo de visitantes: "los de paseo" y "los que hacen la vista mas detenidamente". 
Respecto ala necesidades del publico, el Tesoro del Carambolo, la Astarté, y la escultura de Trajano son las piezas que más solicita información. Además los mosaicos son unas de las piezas que más percibe el personal que valora público. El personal atiende preguntas acerca de la procedencia de algunos objetos, si son piezas originales, etc. Además la falta de información interpretativa de los objetos provoca cuestiones en los visitantes como el porqué de la presencia de la escultura de Alejandro Magno en las salas de roma.

En general al publico le gusta la vista del museo por la colección, siendo negativa la impresión acerca de la instalaciones mucho frío en invierno y calor en verano, a lo que se le añade la alta humedad del entorno, estas condiciones ha provocado lipotimias en algunos visitantes.

El personal entrevistado ve necesidad de las audioguías porque los visitantes hacen una visita más ajustadas a sus intereses y soluciona muchas preguntas que surgen a lo largo de la visita.

Referente a las quejas de los visitantes el publico no entendía(hasta el cambio de dirección) la prohibición de no poder realizar fotografías en el interior del museo.

Los visitantes más asiduos a museos y viajeros echan en falta una cafetería y tienda del museo.

Finalmente queremos hacer notar que el personal se siente poco apoyado en su trabajo, lo que los desmotiva.

Otro medio de recolección de información para este proyecto ha sido la conversación informal con una arqueóloga y docente universitario relacionado con la arqueología en la ciudad.

\section{-Vistas en museos arqueológicos}

Presentamos comparación con otros museos arqueológicos o provinciales de la comunidad Autónoma. 
Museo de

$$
\text { Huelva }
$$

aMuseo

Arqueologico

de Granada

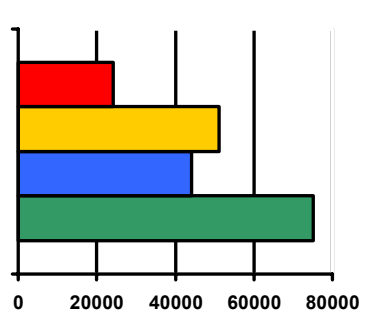

口Museo

Arquelogico

y Etnologico

Cordoba

Museo de

Cadiz

\section{-Estadísticas de ámbito estatal relacionado con la vista}

\section{a museos y tiempo libre ${ }^{15}$}

Vamos analizar que tendencias se siguen en nuestro ámbito estatal a falta de estadística de un ámbito más concreto.

Total de visitas a museos españoles:
43.026.073

\author{
Total de visitantes de museos Arqueológicos \\ 4.931 .007 \\ Total de visitantes de museos de Bellas Artes \\ 10.010 .518 \\ Total de visitantes de museos de Arte Contemporáneo \\ 4.525 .404
}

Los museos de Bellas Artes son los más visitados, lo que nos orienta sobre los intereses del publico a la hora de elegir las colecciones que visita, ¿Debe de potencia la presencia de obras artísticas el museo arqueológico discriminado el valor arqueológico?

Porcentaje de visita a un museo en el año:

\footnotetext{
${ }^{15}$ datos del Instituto Nacional de Estadística
} 


\begin{tabular}{clllll}
\hline $\mathbf{N}^{0}$ de visitas & $+\mathbf{3}$ veces & $\mathbf{=} \mathbf{2 - 3}$ & $\mathbf{1}$ vez & \multicolumn{1}{c}{$\mathbf{1}$ vez } & nunca \\
\hline$\%$ & $77^{\prime} 2$ & $77^{\prime} 7$ & $6{ }^{\prime} 5$ & $13^{\prime} 4$ & $65^{\prime} 1$ \\
\hline
\end{tabular}

Podemos ver que más de la mitad de la población no visita museos

Tiempo de la última visita:

\begin{tabular}{|c|c|c|c|c|c|}
\hline $\mathrm{N}^{0}$ de visitas & +3 veces & $=2-3$ & $1 \mathrm{vez}$ & - $1 \mathrm{vez}$ & nunca \\
\hline$\%$ & $7 ’ 2$ & $7 ’ 7$ & $6 ’ 5$ & $13^{\prime} 4$ & $65 ’ 1$ \\
\hline
\end{tabular}

Tipología de museo visitada en el ultimo trimestre:

\begin{tabular}{lll}
\hline & Que han visitado & Que prefieren ver \\
\hline Museo de arte & $52 \%$ & $57 \%$ \\
M. arqueológico & $16{ }^{\prime} 6 \%$ & $29 \%$ \\
\hline
\end{tabular}

Acompañamiento en la visita del museo:

\begin{tabular}{llllll}
\hline $\begin{array}{l}\text { Acompañami } \\
\text { ento }\end{array}$ & solo & $\begin{array}{l}\text { En } \\
\text { pareja }\end{array}$ & $\begin{array}{l}\text { amigo } \\
\text { s }\end{array}$ & $\begin{array}{l}\text { famil otros } \\
\text { ia }\end{array}$ & \\
\hline porcentaje & $12^{\prime} 3$ & $30^{\prime} 4$ & $33^{\prime} 2$ & $25^{\prime} 3$ & $2^{\prime} 8$ \\
\hline
\end{tabular}

La vista en pareja y grupos de amigos es la forma de visita más usual en los museos españoles, seguidos de la vista en familia. Dato muy importante a la hora de la planificación de actividades.

Principales dedicación en ocio:

\begin{tabular}{ll}
\hline Dedicación & porcentaje \\
\hline Tv, videojuegos & $58 \%$ \\
Descansar & $38 \%$ \\
Relaciones sociales & $38 \%$ \\
\hline
\end{tabular}




\begin{tabular}{lr}
\hline Familia & $35 \%$ \\
Leer, música & $34 \%$ \\
Excursiones, medioambiente & $28 \%$ \\
Espectáculos & $19 \%$ \\
Deporte & $14 \%$ \\
aumento de conocimientos & $8 \%$ \\
\hline
\end{tabular}

La tecnología del ocio como TV o videojuegos supone la mayor dedicación en el tiempo de ocio, pero la relaciones familiares y sociales suponen un alto porcentaje en la dedicación en el tiempo libre.

Porcentaje que dedica su tiempo de Ocio a la vista de exposiciones y actividades culturales:

\begin{tabular}{lll}
\hline sexo & femenino & masculino \\
\hline porcentaje & $5^{\prime} 4$ & $3^{\prime} 9$ \\
\hline
\end{tabular}

Las vistas de mujeres a exposiciones, museos $y$ actividades culturales es mayor que la de los hombres, esto nos hace cuestionarnos sobre la atención de intereses de este sector, dentro de disciplina la arqueología en la que aun perviven elementos discriminatorios.

Motivo de visita a un museo en el ultimo trimestre del año:

\begin{tabular}{ll}
\hline motivo & Porcentaje \\
\hline Exposición temporal & $30 \%$ \\
Gusta los museos & $12{ }^{\prime} 7 \%$ \\
Cultural & 11 '3\% \\
Estar en la zona & $8{ }^{\prime} \%$ \\
Visita a otro país & $6{ }^{\prime} 6 \%$ \\
Educación formal & $6{ }^{\prime} 2 \%$ \\
Paseo con hijos & $66^{\prime} 1 \%$ \\
Recomendación & $5{ }^{\prime} 7 \%$ \\
Ocio & $4{ }^{\prime} 6 \%$ \\
\hline
\end{tabular}


Las exposiciones temporales se revelan como el principal motivo para decidir la vista a un museo. Dato que se confirma en el aumento de vistas al Museo Arqueológico con motivo de exposiciones como "Artifex" e "Itálica virtual". Los que nos lleva a tener en cuenta la búsqueda de calidad, la búsqueda temas que interese al público, unos tratamientos adecuados y fundamentalmente la publicidad como elemento indispensable.

\section{c) El registro de visitantes}

El registro se realiza de forma manual por los "taquilleros de la entrada "que van anotando los datos de venta de entrada en una grafica.

Estas gráficas son mensuales, pero no es precisa ya que no hay distinción entre la venta de entradas y los visitantes reales, debido a confusiones como en el caso de visitante individuales extranjeros que deberían de pagar la entrada pero por poseer algún tipo de gratuidad (estudiantes, etc) se anota en las grafica como visitantes en grupo. Así podemos ver que hay situaciones que no están contempladas. Faltado, además, una regulación adecuada que acuerde diferentes exenciones y descuentos en el museo, contando solamente con la Orden del 5 de junio de 1989. ${ }^{16}$

\section{V.1.2. Gestión de visitas}

La visita se puede realizar directamente cuando llega el visitante, no hay ningún tipo problema para conseguir entradas.

En la gestión para la entrada de los grupos se tiene que rellenar un impreso con diferentes campos que el personal de taquilla remite al personal técnico ocupado de los visitantes. Esta establecido que pueden entrar grupos

\footnotetext{
${ }^{16}$ Orden de la Consejería de Cultura, de 5 de junio de 1989,por la que se fijan los precios que han de regir en los museos, archivos, conjuntos arqueológico y monumentales para visita de publico y reproducciones graficas (Boja número 52 de 4 de julio)
} 
cada 30 minutos en grupos de no más de 25 personas.

En el mismo mostrador de recepción se solicita la entrada y si está ocupado el hueco con otro grupo se señala el hueco disponible.

La gestión de las visitas de grupos con antelación ${ }^{17}$ se puede realizar por medio de la pagina web del museo, teléfono o personalmente. Además en taquilla se rellena un parte con los grupos

- Visita de grupo

A continuación presentamos las estadísticas de la visita en grupo $^{18}$ :

\footnotetext{
${ }_{18}^{17}$ Para noviembre de 2005.

${ }^{18}$ Curso 2003-2004
} 


\section{) Guías ${ }^{19}$ :}

Los únicos guías con los que cuenta la institución son los guías voluntarios.

El museo ofrece a los grupos que gestionan la visita con antelación la forma, previa petición, de ponerse en contacto con los guías voluntarios. Todos los guías son jubilados

El numero que participaron en 2005 fueron 3, atendiendo 44 vistas que suponen unas 1185 personas, de los cuales 26 eran colegios, 7 asociaciones de mayores y 4 talleres de distrito entre otros.

\section{b) Visitantes de la exposición permanente}

Ya hemos conocido los principales datos de los visitantes al museo en el apartado anterior de los estudios de publico.
En relación con los flujos, destaca el aumento de las visitas en primavera y otoño, frente al descenso para primeros meses del año y Agosto.

La realización de exposiciones temporales hace subir el numero de visitantes nacionales mientras que la de no nacionales continua su dinámica.

Las mañanas son las horas en la que se registran mayor numero de visitantes debido en gran parte a los grupos de educación formal. Por último, destacaremos que las visitas individuales y en las de grupo se equilibran para los meses de julio y agosto

Hasta el momento de ahora nos ha sido imposible calcular el numero de visitas en la hora punta. Dicha hora punta se puede ubicar a las 11 horas por las mañanas y las 17'30 por las tardes, siempre en invierno.

\footnotetext{
${ }^{19}$ Datos del año 2005
} 
c) La topología del visitante y grupos podemos sintetizarla en:

-La procedencia abundante de visitantes de formación formal; turistas de la ciudad que unen la visita de la plaza España, Parque y Museo en una Jornada; visitantes locales que están de paso por el Parque.

-Edad(sin datos por el momento)

-Por tipo de visita, podemos diferenciar dos tipos de visitantes: los que hacen una visita no detenida a modo de paseo y los visitantes que exploran mas profundamente el museo.

La visita de paseo esta relacionada con la localización del Museo dentro del Parque de Maria Luisa, se concentran los domingos y días festivos; y son grupos familiares que realizan un recorrido sin determinar, deteniéndose solo en algunos elementos significativos.

En el otro gran grupo abunda la visita en pareja tanto visitantes locales como turistas
Los grupos educativos hacen un recorrido integro del museo pero solo se detiene en elementos determinados.

Las salas u obras que atraen mas al publico son los mosaicos, el Tesoro del Carambolo, vitrinas, esculturas (especialmente las esculturas de tamaño considerable); la sala elíptica es atractiva para el visitante pero no permanece todo el tiempo que se podría espera. El área que más visitantes concentra es el comprendido entre la sala XIV hasta la sala XX y más adelante la sala XXV.

\section{Las salas u obras que menos numero de publico atrae} son: las salas de prehistoria, la Sala XV, Sala XIXb y XXVI.

La sala final(XXVII) es donde las personas que venían en grupo se vuelven ajuntar o se detienen más tiempo por ser la ultima sala.

\section{d) Recorrido integro del museo}


El recorrido se suele hacer integro debido al diseño: Se comienza en la planta baja donde hay que recorrer todo el sentido laberíntico.

Para recorrer la planta principal hay que hacer el recorrido unidireccional comenzando por la entrada y finalizando en la salida, no existe la oportunidad de acortar el camino la planta. Además, por ser la mas más atractiva y por la falta de planos de situación, el visitante recorre toda la planta. Algunos visitantes muestran ya cansancio al llegar a la sala elíptica y hace el recorrido más rápido buscando la salida, casi nunca buscan la entrada para salir del museo.

- Permanencia media el visitante 30-45 minutos para la vista de la planta 0 y sobre los 15 minutos para la visita de la planta -1 .

El tiempo estimado en recorrer las salas para el visitante de paseo ronda los 15-20 minutos, según nuestros cálculos.

\section{e) Visitantes de la exposición ${ }^{20}$}

El numero de visitas computadas en las exposiciones son:

\section{4}

Itálica virtual: 9619.

Palabras de una vida: sin computo

Ostia Antica: 2-4grupos de 20 visitantes por mañana y 20 visitantes por la tarde aproximación

2005

El Museo Puente entre Culturas 275

Los resultados en el aumento de visitantes al museo en el 2005 es la exposición

Artifex con 13068 vistas. Mas detenidamente especificaremos que las visitas por las mañanas individuales fueron 6810,por la tarde 3260,la de grupos por la mañana de 2242 y finalmente por las tardes 757 .

\section{f) Usuarios de talleres y otras actividades ${ }^{21}$}

\footnotetext{
${ }^{20}$ año 2004 y 2005
} 
A continuación presentamos el listado de actividades con su numero de asistentes:

Presentación del Boletín Amigos del Museo: 20.

Apertura de la sala del Ejercito: 20.

Concierto Día del museo: 150.

Conferencia Egiptolo: 120 en cada una de las tres conferencia.

Conferencia Baetica Paleocristiana": 50.

Conferencia "Ladrillo estampillado": 50.

Seminario de introducción a la antropología física: 10 alumnos.

Conferencia"numismática Omeya al-Andalus": 50.

Conferencia "Las esferas de piedra Precolombina de Costa Rica": sin computo.

Visita guiada para el dia del Museo vinieron grupos escolares los cuales ya habían concertado vista con guía.

21 año 2004
La afluencia a las actividades depende mucho de quien las organice y la publicidad que realicen los organizadores.

Además algunas actividades se concentran en fechas muy determinadas(Día de los museos por ejemplo)

\section{g) Usuarios del salón de actos}

Escaso afluencia por el escaso uso del salón. La asistencia principal corresponde a la celebración de conferencias, 8 actividades en el salón de actos en el espacio de 365 días del año 2004.Siendo una media de 50 que en total suma 290 en todo un año ${ }^{22}$.Puesto que las conferencias se programan por las tardes el uso de este espacio es nulo por las mañana.

\footnotetext{
${ }^{22}$ Habría que añadir los asistentes a la conferencia "Las esferas de piedra Precolombina de Costa Rica" que no tiene computo de visitantes.
} 
Hay que añadir que este espacio también se utiliza como sala de exposiciones temporales, junto a los espacios contiguos del ala este.

\section{h) Usuarios de la biblioteca}

El perfil de los usuarios responde fundamentalmente ala cobertura de las necesidades del personal técnico del museo, investigadores, y alguna presencia excepcional de estudiantes. Es llamativo por tanto la infrautilización de la biblioteca.

Además, hay que indicar que existe una problemática a la hora del computo en los usuarios de la biblioteca, ya que el personal en la mayoría de las veces no rellena la ficha de solicitud de fondos, por lo que el cómputos de estas fichas no corresponde con la el numero de usuarios ni fondos consultados.

Según los datos disponibles para 2003 se contabilizaron 332 consultas bibliográficas y se hicieron 6 nuevos carnet, datos que se registra en los informes anuales y demás documentos pero que como hemos dicho no corresponde con la realidad.

\section{i) Usuarios de la sala de investigación y archivo ${ }^{23}$}

El Perfil principal de investigadores lo podemos ver en el origen de éstos en el año 2005,proceden de la Universidad de Sevilla del Departamento de Prehistoria, Departamento de arqueología y Departamento de Derecho Romano; Universidad de Zaragoza, UNED, Instituto arqueológico alemán, Universidades de Madrid, Universidad de Córdoba, Universidad de Lisboa, Museo Arqueológico de Lisboa, Museo de América, Museo Arqueológico Nacional, Universidad de Trevelis, Universidad de Beirut, Universidad de la Sapienza, Universidad de Regio-Calabria alguna universidad inglesa. Algunas investigaciones están

\footnotetext{
${ }^{23}$ Datos facilitados del año 2005
} 
relacionadas con proyectos internacionales, existiendo algún caso de consulta para agencia de viajes o etc.

Las Consultas podemos agruparlas en diferentes grupos, así nos encontramos solicitud de información sobre Yacimientos concretos: Plaza de la Encarnación, Carteia, Orippo, hueso de los Molares, Peñaflor, Montemolín, Arahal, Valencina, Mulva, Marchena; muchas de estas consultas están relacionadas con las investigaciones dedicadas al conocimiento de los bienes patrimoniales de localidades y su difusión en la población local.

Otro grupo de consultas las podemos agrupas por solicita información de piezas según materiales: Restos antropológicos, fondos férreos romanos, ánforas romanas, etc.

El último grupo lo conforman solicitudes acerca de técnicas, tipos de objetos, épocas: Epigrafía en general, romana y romana jurídica, numismática, mosaicos, época romana, Edad del Cobre, arqueología americana, Huesos de la edad del Bronce, inscripciones griegas, etc a parte de esta agrupaciones también hay que citar investigaciones de temas concretos como la realizada para la Exposición de "Artifex", o investigación relacionada con museología.

La mayoría están enfocadas para proyectos de investigación, tesis, tesinas, investigaciones interuniversitarias, y exposiciones.

El número de investigadores para el 2003 fue de 139 y para el 2004 unos 81.

El horario para la investigación esta dispuesto por las mañanas.

La estancia suele tener la duración de dos días para investigadores que vienen de fuera de la ciudad o zonas lejanas, mientras que los investigadores que tienen más 
fácil la visita al museo pueden hacerla en algunos casos en un tiempo mas dilatado.

j) Usuarios de otros servicios: cafetería, tienda, restaurante...

El museo cuenta con maquinas expendedoras de refrescos, helados y café, su consumo se debe fundamentalmente a las condiciones climáticas que sufre el museo en los meses calurosos.

Los usuarios no consume por encontrar un espacio atractivo para descansar y tomar una consumición caliente o fría, las máquinas de productos fríos están en un pasillo y la de bebidas calientes en el hall de Recepción sin lugar propio.

Los visitantes no cuentan con espacio para la adquisición de productos relacionados con el museo. En el espacio de recepción se localiza una vitrina expositiva en la que hace años se mostraban publicaciones a la venta, actualmente podemos encontramos un catalogo de reproducciones asequibles fuera del museo.

Principales carencias

-Existencia de un publico potencial no atendido

-Moderada interacción con la población cercana

-Falta de llevar una estadística de visitantes continuamente y diseño adecuado de los modos de obtener los datos.

-Diseño de computo de visitantes a exposiciones temporales unido a la evaluación de exposiciones.

-No hay un buen funcionamiento de la biblioteca. 


\section{Prioridades}

-Posibilidad de aumentar el numero de visitantes, para aumentar el rendimiento social de la institución.

-atracción de otros grupos sociales.

-Realización de un estudio de publico para su uso en la adecuación de la exposición alas necesidades del publico.

-Diseño de control de usuarios/ visitantes.

-Mejorar la atención y uso de la biblioteca.

-Atender correctamente las necesidades del publico en cuestión de servicios.

\section{V.2. SERVICIOS}

No existe en la actualidad Carta de servicios

En el marco de la Segunda Modernización, el 23 de julio de 2002 se aprobó por Acuerdo del Consejo de Gobierno el Plan Director de la Organización para La Calidad de los Servicios. La evolución de la sociedad andaluza y las transformaciones obligan a un proceso de adaptación en la que se parte de la concepción de la Administración como un conjunto de órganos e instituciones prestatarios de servicios requeridos por la sociedad en su conjunto,

Supone a su vez un impulso para que las organizaciones públicas se adecuen al logro de resultados de acuerdo con los objetivos previamente definidos y sustituyan, en consecuencia, la tradicional visión del «administrado» por la del «ciudadano-cliente», que asume una posición activa y participativa frente a la propia organización como árbitro final de la calidad de los servicios prestados. 
Esta estrategia descansa en tres pilares:

-La elaboración de Cartas de Servicios.

-La Autoevaluación de las unidades y servicios administrativos.

-Los Premios a la Calidad de los servicios públicos de la Junta de Andalucía

Así la Administración General de la Junta de Andalucía y sus Organismos Autónomos persiguen el Modelo EFQM de Excelencia, en su versión para el Sector Público y las Organizaciones del Voluntariado

El Modelo EFQM de Excelencia es un marco de trabajo noprescriptivo basado en nueve criterios, que puede utilizarse para evaluar el progreso de una organización hacia la Excelencia. Se fundamenta en la premisa "Los resultados excelentes en el Rendimiento general de una Organización, en sus Clientes, Personas y en la Sociedad en la que actúa, se logran mediante un Liderazgo que dirija e impulse la Política y Estrategia, que se hará realidad a través de las Personas, las Alianzas y Recursos, y los Procesos".

Como hemos visto en la actualidad el museo no cuenta con una carta de servicios redactada y accesible a los usuarios. La creación de esta carta de calidad debería de presentar los servicios en cuanto a: La colección, la exposición permanente y temporal, los espacios, los contenidos, la función de la biblioteca y otros servicios, la accesibilidad a investigadores, la acción educativa-cultural, servicios para descanso(bancos, maquinas expendedoras)web, publicaciones(relacionadas), accesibilidad, Además de los compromisos de calidad, indicadores de calidad, derechos de usuarios, sugerencias y reclamaciones y finalmente la responsabilidad de la carta de servicios. Al no haber carta de servicio, por tanto, tampoco no hay folleto informativo de la carta de servicios. 
Añadimos e este apartado que no existe encuestas a usuarios para evaluar el grado de satisfacción de los servicios prestados y su percepción de la oferta y calidad de los mismos. La única comunicación, en este asunto, entre el publico y la Institución es a través de las reclamaciones en el Libro de reclamaciones y sugerencias y las solicitudes a personal de vigilancia o taquilla.

La única Prioridad en este apartado es la Definición y diseño de La carta de Servicios del Museo Arqueológico de Sevilla.

\section{V.2.1. Accesibilidad}

\section{a) Indicadores urbanos}

No hay ninguna indicación en la entrada de la población, ni en las vías principales de la ciudad, tampoco en los medios de transporte, ni en los puntos de información urbana. Tan solo en la entrada de la plaza de América justamente al lado de la valla del parque, dispuesta por el Ayuntamiento de la ciudad dentro de su plan señalético de monumentos de la Ciudad. Hay una carencia absoluta de los medios de difusión.

\section{b) Aparcamiento para turismo y autobuses}

Los medios de transporte no pueden acceder a la plaza de América donde se ubica el Museo. Los visitantes que lleguen a la zona tienen las avenidas mas cercanas para aparcar.

Podemos contabilizar en el entorno mas cercano 190 plazas(ver plano de localización de aparcamientos)

Para aparcamientos de motos encontramos un espacio disponible de 6 metros en la Avenida de la Borbolla. 
No se localiza ningún espacio para el aparcamiento de autobuses por lo que tienen que parar momentáneamente para dejar a los grupos cerca de la plaza. Pero existe la practica habitual de utilizar los espacios que hay justo delante de las puertas de acceso por la avenida de las Delicias o Avenida de la Borbolla frente a Calle Felipe II. Permaneciendo ahí con el chofer vigilando o buscando aparcamiento en otro emplazamiento con se solía hacer en la calle posterior del pabellón de Argentina.

Para usuarios minusválidos existe acondicionado y señalizado un espacio para dos plazas de aparcamientos frente al Pabellón de Brasil aunque es usual verla ocupada por automóviles de personas no autorizadas.
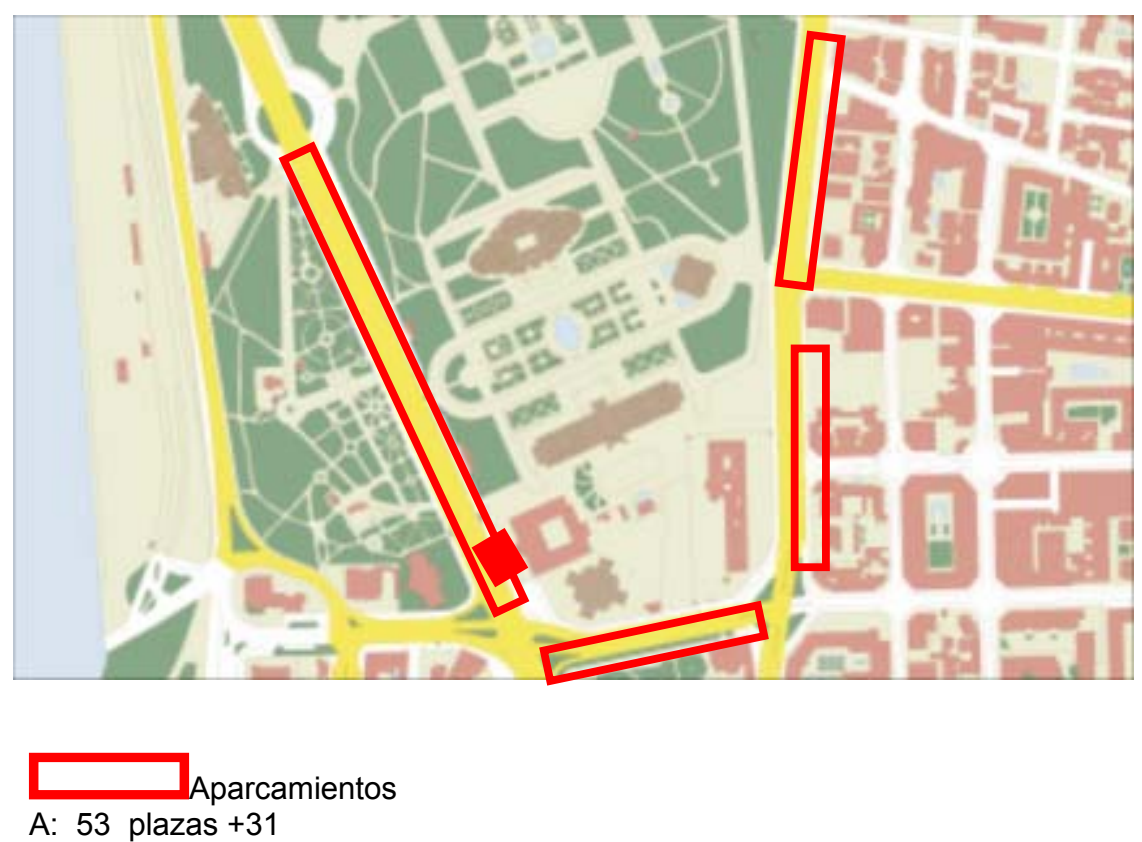

B: $15+22$ plazas

C: 27 plazas

D:23+18 plazas

elemento ya que nos encontramos con paradas de autobús próximas a las puertas de acceso a la Plaza América, en la avenida de la Borbolla y las Delicias: 

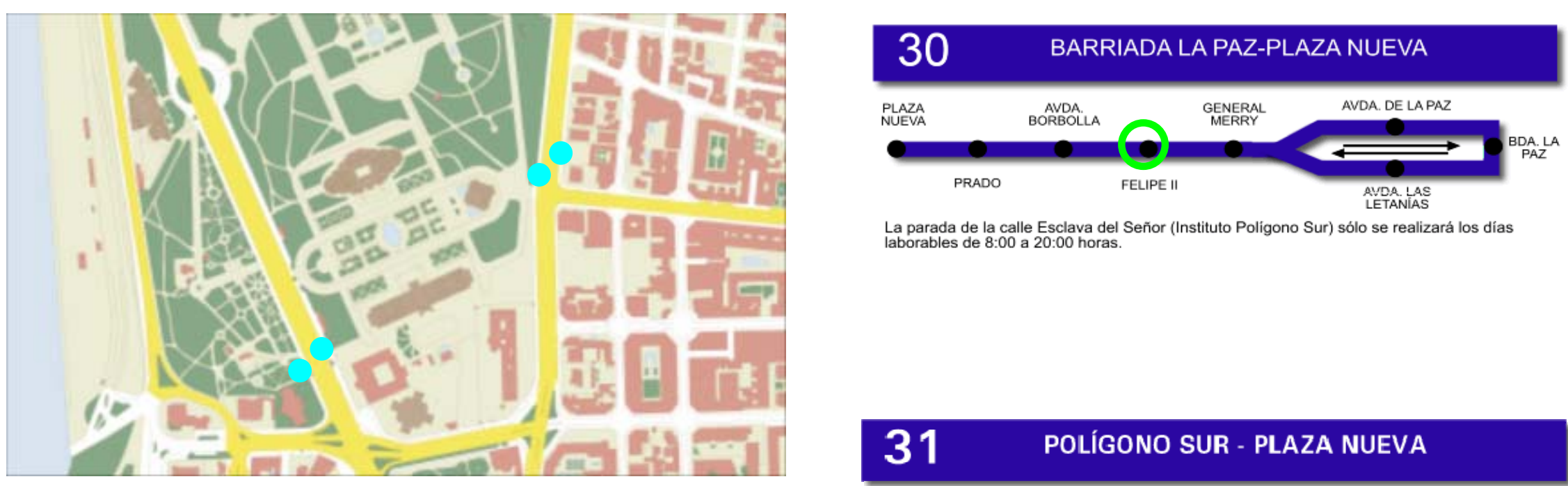

La parada de la calle Esclava del Señor (Instituto Poligono Sur) sólo se realizará los días
laborables de 8:00 a 20:00 horas.

Parada de bus

\section{POLÍGONO SUR - PLAZA NUEVA}

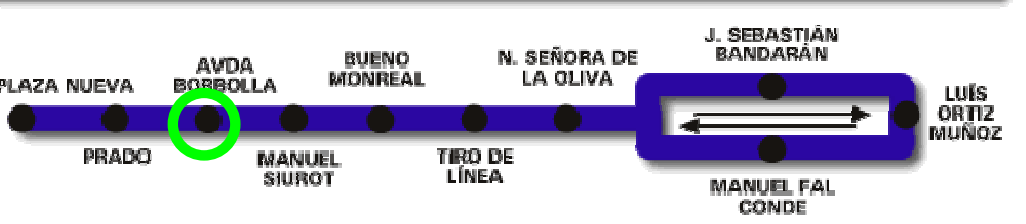

\section{Líneas:}

-radiales sur 


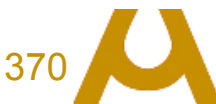

\section{PEDRO SALVADOR-PLAZA NUEVA}

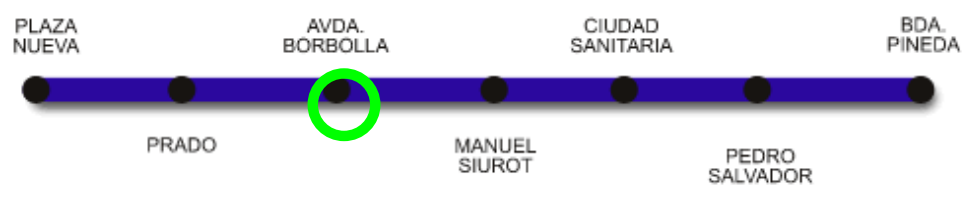

1 POLIGGONO NORTE-PASARELA-C. SANITARIA

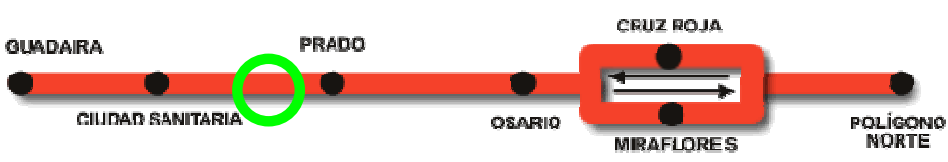

\section{LOS BERMEJALES-PLAZA NUEVA}

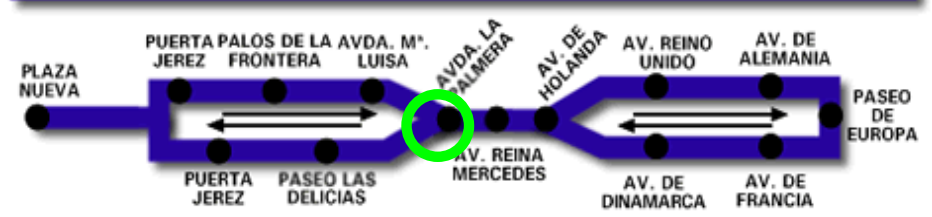

6 G.S. LÁZARO-LOS REMEDIOS-R.MERCEDES-C.SANITARIA

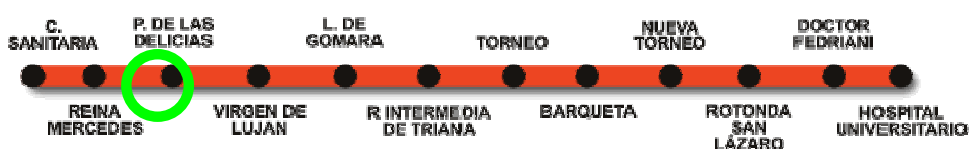

\section{UNIVERSIDAD P. OLAVIDE- PRADO}

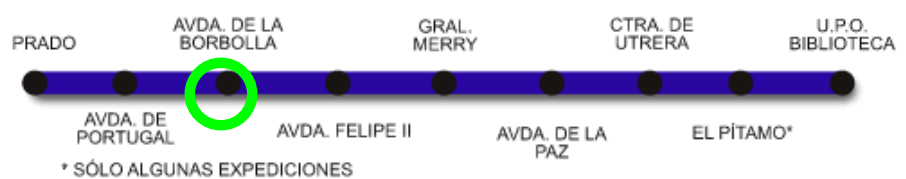

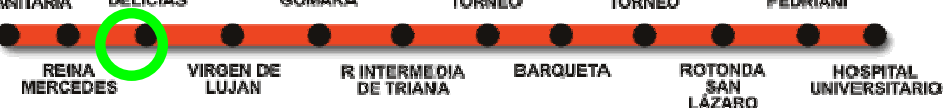

-transversales 
Supone una comunicación en una sola línea, sin transbordar, a :

Norte: Triana, Torneo, Plaza Nueva

Sur: Helipolis, Bami, Ciudad Sanitaria la Estrella, Pedro Salvador, Polígono sur

Este: Los remedios

Oeste : Felipe II, Avenida de la Paz, Avenida General Merry Polígono sur, La oliva

Vemos que el sistema de autobuses conecta con barrios de muy diversas topologías. Además las comunicaciones integra al museo dentro con una conexión directa con facultades y universidades de Sevilla y la Pablo de Olavide.

La implantación y aumento de los carriles bici ubican al Museo Arqueológico en un nudo, conectándolo con el resto de vias de la ciudad.
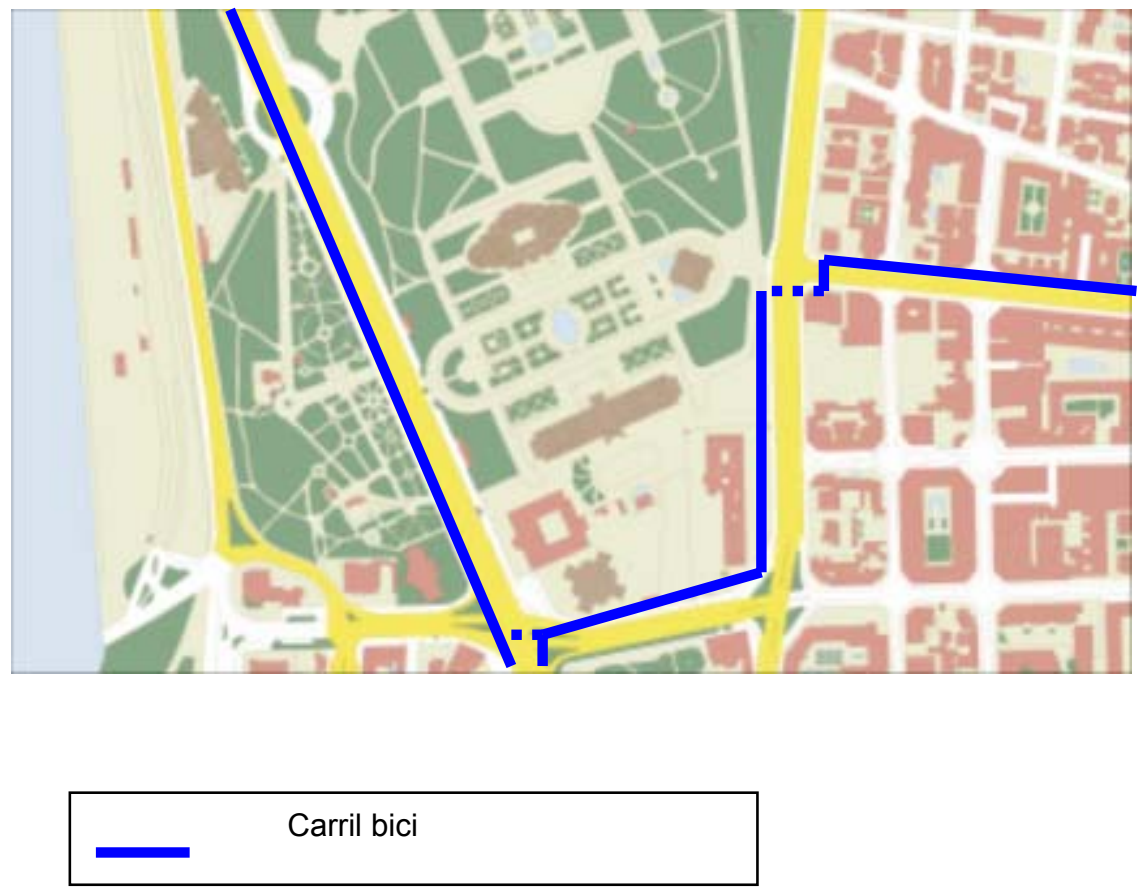

\section{V.2.2. Señalética}

a) Señalización externa

Casi siempre todas las ciudades contratan señalizaciones a empresas que tienen varios tipos y soportes estándar, 
sistemas prefabricados. Y Sevilla ha elegido uno de estos. Aunque como ya hemos apuntado anteriormente tan solo en la entrada de la plaza de América justamente al lado de la valla del parque se encuentra un solo hito que nos indica la plaza y el museo arqueológico.

Todavía en el año 2006 no se ha planteado cómo ajustar el diálogo entre el patrimonio y la señalética externa, con el deseo de reforzar la misión de acogimiento a un público visitante que, tras un viaje en avión, tren, autobús o coche descubre la ciudad sin comprenderla.

Sevilla forma parte de una aventura arquitectónica, urbana y humana a través del tiempo. La historia se divide en diferentes períodos, y cada uno tiene su protagonista. Personajes relevante, anécdotas y curiosidades que nos ayudan a comprender qué sucedió en los siglos precedentes. Un fragmento urbano sobre la que hay construidos infinidad de edificios emblemáticos.
Pero: ¿Cómo llegar a esos sitios?; ¿Cómo identificar el patrimonio?; ¿Estoy delante de un bien de interés cultural?; ¿Qué es lo que estoy viendo?...

El proyecto de señalética debe perseguir, por tanto, orientar e informar a estudiantes y visitantes de un sitio complejo en el que se alternan edificio y espacios verdes, y todo ello con la obligación de proporcionar un fuerte carácter artístico aportando contemporaneidad al conjunto.

La señalización exterior en carretera y entradas urbanas es totalmente ausente por lo que no existe posibilidad de orientación y ubicación, además de su sentido de llamada de atención y descubrimiento.

La orientación del museo sentido predominante en las zonas cercanas al museo se resuelve con dos tipos de orientación: por un lado la ya indicada señalética aportada por la gerencia de urbanismo recientemente. $\mathrm{Y}$ por otro lado los MUPIs del propio Parque de Maria Luisa. 
La señalización de identificación actualmente presenta una superposición de diferentes épocas. Por un lado nos encontramos la señal que sigue los modelos de la señalética de la exposición ibero-Americana, localizada en la acera del museo.

Mas cerca del Museo junto a la balaustrada de la explanada existe un indicador del museo con fotografía y explicación del edificio, instalado por el Ayuntamiento dentro de la propia señalética del Parque.

Lapida en la fachada actualmente se encuentra muy bajo y de mala visión por estar tapado por el acceso de rampas. Encima de él aparece el indicador mas reciente de la administración autonómica.

Ya en el en porche, pero visible desde fuera, nos encontramos sobre la puerta de acceso ala sala elíptica la rotulación en capitales mayúsculos e historicistas.

Se nos presenta por un lado un panorama falto de indicaciones exteriores, pero a la hora de identificar el edificio la superposición de diferentes señalética es reiterativa.

\section{Prioridades:}

Un proyecto, que trataría de intervenir sobre el contenido para que se convierta en un elemento clave de la identidad visual.

Concibiendo soporte señaléticos que se integren en este paisaje urbano de excepción. Reflexionando detenidamente acerca de todos los elementos: los materiales, el tamaño, los volúmenes, los colores y el número en los que se compondrián.

\section{Creando:}

Las señales de dirección: 
Las principales y de mayor tamaño indicarían el acceso al edificio desde calles adyacentes, áreas de estacionamiento y paradas de transportes públicos. Las señales de menor importancia direccionales indicarán los accesos concretos al edificio o el tránsito alrededor del mismo.

Las señales de identificación:

Se ocuparían de significar la existencia de este edificio en el entorno en el que se ubica, acompañadas de un rótulo del símbolo del museo. A nivel general, bastaría con una señal que indicara el nombre o función de la empresa a señalizar, pero en ciertas construcciones con un carácter más histórico, puede incluirse un indicativo con la fecha de construcción o algún otro dato significativo (B.I.C. arquitecto). A este tipo de señales, le acompañarían también unas informaciones complementarias sobre la identificación de accesos, entradas o parte principal del edificio, con menores dimensiones y de carácter secundario.

\section{Señales exteriores de instrucción:}

Se referirá a aspectos que regulen el tráfico, entrada, estacionamiento, horarios de apertura y condiciones especiales de acceso restringido.

\section{b) Señalización interna}

Las cartelas, planos y carteles del museo no nos descubren el objeto y tampoco nos lo presenta del modo más contextualizado y didáctico posible porque hay diversidad de cartelas dentro de las vitrinas. Están las de fondo verde que nos indican en general de que época se tratan, después están las de fondo blanco donde se intenta identificar la pieza, que no todas las piezas tienen cartelas. Y luego están los planos, mapas dentro de las vitrinas que no nos ayudan a situarnos, ni a comprender mejor lo que hay expuesto, no tiene una estructura clara. Junto con los 
carteles de fondo negro, que se ven que son de una exposición temporal que se celebró hace ya tiempo y se han incorporado en la exposición.

Antes de realizar un diseño de señalización interna hay que homologar el diseño aprobado como norma básica de aplicación universal.

Señales referidas al entorno arquitectónico:

-Los directorios generales

-Las señales de dirección

-Las señales de identificación

-Las señales de instrucción

Los directorios generales
Suelen ubicarse en los puntos más visibles en el acceso al edificio, en la entrada de modo que sean la primera información que reciba el usuario, y así pueda conducir su visita. Cuando el edificio consta de varias plantas conviene situar un directorio de planta única en los accesos a cada nivel bien junto al ascensor o bien junto a las escaleras.

Las señales de dirección:

Se presentan a lo largo de toda la planta del edificio, su finalidad principal es indicar y confirmar el recorrido a seguir por el usuario. Podemos encontrar estas señales a lo largo de corredores y puntos en los que se puedan tomar distintas alternativas. Así en el porche de entrada nos encontramos con una escueta flecha que nos indica la entrada.

También localizamos en el museo paneles de ubicación en metacrilato y gráficos en negro: uno en el sala de recepción y otro en el espacio de distribución de la planta sótano, se encuentran en malas condiciones, pero fundamentalmente 
destaca por su mala ubicación, siempre a la espalda de la dirección del visitantes.

Las señales de identificación:

En el museo sólo existe este tipo de señales que se integran en tres:

La primera indica el número de sala con números romanos y en una tipografía metálica pegada al metacrilato. La senguda situada más abajo, donde se encuentra un pequeño texto introductorio de la sala en español impreso en un papel A4 impreso en una impresora de chorro de tinta, dentro del metacrilato y la tercera situada enfrente de estas dos de metacrilato con el texto en tres idiomas: Inglés, Francés y Alemán.

Tienen la finalidad de tranquilizar al usuario al confirmar que finalmente ha localizado el motivo de búsqueda. Todos los destinos finales deben ser señalizados. Desde los

principales a los secundarios. Las señales más importantes nombrarán el número de sala y la época. Las de menores identificación se refieren a los llamados destinos particulares dentro del museo, así como algunos elementos añadidos de interés como pueden ser los aseos, extintores... La identificación también llegaría a la personalización, identificando los miembros del museo.

Las señales de instrucción:

Se referirán a horarios y referencias a aquellas prohibiciones o condiciones especiales que hay que respetar dentro del edificio (no fumar, no comer, guardar silencio, no usar cámaras de fotos, reservar acceso restringido a ciertas áreas...)

\section{Conclusión:}


Las señales de información, se situarán puntualmente en las zonas de interés para detallar la información, por lo tanto pueden repartirse por toda la superficie. Podemos decir lo mismo de las imperativas intercaladas como recordatorio en cualquier punto de ambiente. Las señales de instrucción, irán situadas junto a equipos de seguridad, apertura de puertas... Las imperativas, según la normativa, se ubicarán en itinerarios de salida de emergencia y donde estipulen las normas ya que es un Bien de Interés Cultural.

La colocación de las señales debe situarse de modo que pueda verse y ser leída a la distancia suficiente para tomar cualquier decisión que sea necesaria. Esto significa que deben colocarse, a ser posible, para ser visualizadas de frente por el usuario y su altura debe ser tal que se encuentre dentro del ángulo visual de un observador de altura media.

Al tratarse de un sistema, es lógico que señales del mismo tipo se encuentren expuestas del mismo modo, con la misma forma, en situación y altura similares. La finalidad es doble:

Por una parte se evita una competencia entre señales y por otra el usuario busca la señal siguiente del recorrido en una situación similar a la que ya conoce y le ayuda a seguir el sistema señalético con mayor facilidad.

\section{V.2.3. Instalaciones adecuadas para visitas de Discapacitado}

La solución a la circulación de sillas de ruedas esta parcialmente solucionado con la presencia de rampas de ascenso. Aunque aun hay ciertos puntos de inaccesibilidad como en la sala VI, que además de imposibilitar la vista a la sala entera también el recorrido del resto de la vista de la planta sotano ya que no hay alternativa para evitar la frontera arquitectónica.

El ascensor permite el acceso ala planta sótano y primera planta. 


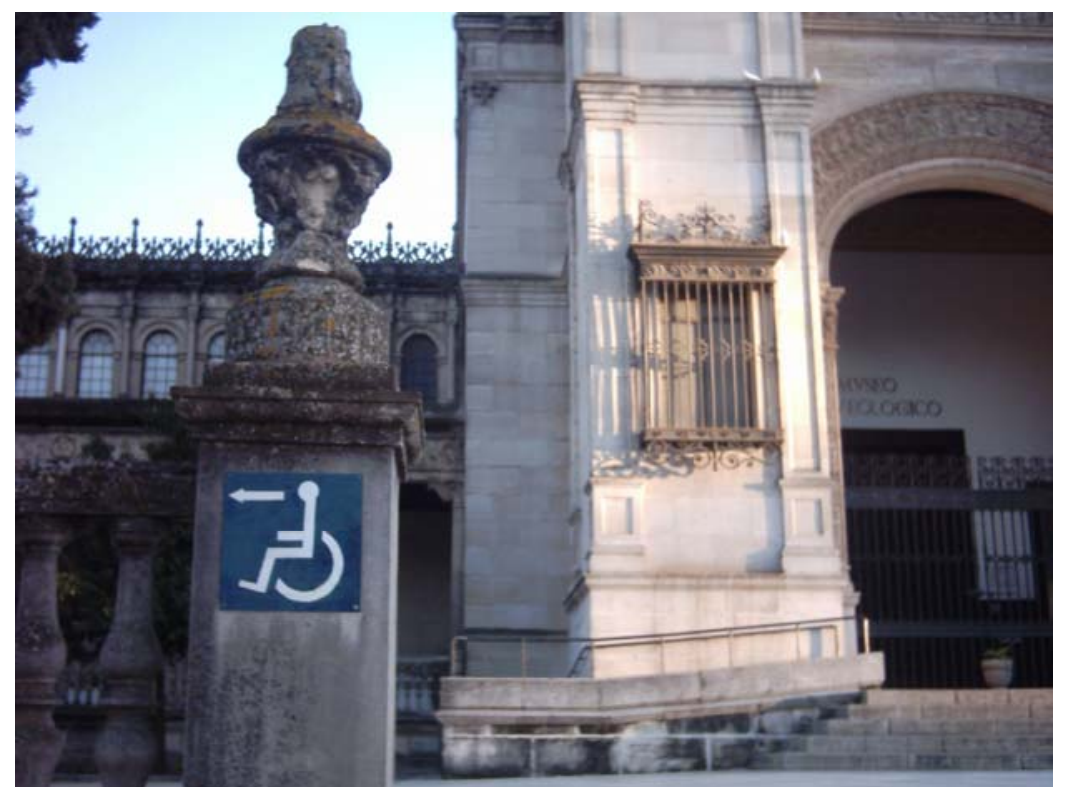

El movimiento en la planta primera en el pasillo de administración existe la imposibilitad de acceder a la biblioteca, a la actual sala de investigadores y a la sala de los amigos del museo, además de los baños del área de restauración.
Por ultimo, pero no menos importante, es la inadaptación del montaje expositivo para la vista en sillas de ruedas: la alturas de los pedestales, sus cartelas, anchura del espacio de algunas salas(Sala XXV),etc

\section{V.2.4. Instalaciones y equipamientos adecuados para la visita de niños}

Es llamativa por su ausencia de servicios en un museo que se ubica en un contexto especial como puede ser dentro de un parque, el cual cuenta con unos servicios limitados. 


\section{V.3. ATENCIÓN AL PÚBLICO}

El horario del museo es:

\section{Martes: 15:00h a 20:00h}

De Miércoles a Sábados: 09:00h a 20:00h

Domingos: 09:00 a 14:00h

Lunes: Cerrado

Pero existe una problemática con los días festivos. Durante los últimos años ha ocurrido que el museo ha estado cerrado en puentes o días festivos en los cuales ha habido mucho visitante en la ciudad. Esto ha provocado que la Consejería de Cultura de la Junta de Andalucía cerrara un acuerdo con los sindicatos sobre el calendario laboral de museos y conjuntos arqueológicos para el año de 2006 por el que se incrementan los días festivos de apertura al público y se pasando de cinco a diez días festivos. Además la apertura de dos lunes vísperas de festivos que corresponderán al 27 de febrero y al 14 de agosto. El nuevo calendario laboral posibilitará que el público disfrute de los museos y conjuntos arqueológicos los siguientes días no laborables: 2 de enero (lunes, por año nuevo), 28 de febrero (martes, Día de Andalucía),13 de abril (jueves, santo),14 de abril (viernes santo), 15 de agosto (martes, fiesta nacional), 12 de octubre (jueves, Fiesta Nacional), 6 de diciembre (miércoles, Día de la Constitución), 8 de diciembre (viernes, Día de la Inmaculada).A estos ocho días festivos se le suman otras dos festividades locales que aplicarán cada una de las capitales de provincias andaluzas.

Esta atención a la demanda ciudadana sitúa a Andalucía a la vanguardia de otras comunidades españolas que hasta ahora mantienen las pinacotecas cerradas la mayoría de los festivos.

\section{V.3.1. Recepción}

Recepción tras pasar el porche de entrada y cruzas una galería, se llega al espacio de distribución. Desde aquí se tiene el acceso área interna del museo, a las salas de 
exposiciones y salón de actos, con la posibilidad de usar el ascensor

Existe un mostrador de entrada para todos aquellos que accede al museo(personal, visitante, servicios, etc.). Junto a éste hay una vitrina expositora sin uso optimo en la actualidad.

Hay un plano de situación ubicado en un espacio inservible a demás de no encontrase cuadrado con el espacio ni resolver necesidades. Falta de una adecuada y correcta(¡salas de Arqueología y salas de Prehistoriai )señalización de los espacios. Además encontramos bancos y maquina expendedora de café

Hasta el día 13 de marzo existió en este espacio el panel de información interna del museo el cual ya se ha reubicado en el pasillo de administración.
No supone un espacio acogedor, No hace sentirse cómodo física y psicológicamente. El visitante debe de decidir si vista la sala de Arqueología o Prehistoria

No hay elemento que atraiga al visitante, anunciando sus contenidos, ni de actividades, ni servicios disponibles. Aunque el visitante que llega a este espacio decide visitarlo, no se constituye como un lugar atractivo que determinante para la decisión de visita al museo.

$\mathrm{Ni}$ el espacio ni la actitud del personal motiva la visita, siendo reflejo coherente de la propia institución.

Esta falta de acogida se prolonga en el espacio y tiempo de la vista del museo.

no existe una atmósfera en el que visitante se sienta importante, sintiéndose una casi ausencia de afectividad. Es un reflejo de que la sociedad, actualmente, no es el centro para la actividad del museo, no se ofrece unos servicios del museo al servicio del publico.

Pocos elementos para la confortabilidad. Aunque es un espacio diseñado para acogida, amplio y decisibo lugar de 
distribución, es insuficientes para comodidades de acogidas de un publico actual

El publico que visita museo cada vez viaja mas conoce las instalaciones de otros museo, además de vivir en un mundo en el que la competencia hace la especial atención del publico. Además no existe en recepción información de precios de entrada.

No existen taquillas para los usuarios del museo, ni para visitantes de las salas de exposición ni investigadores. A pesar de las numerosas vistas de grupos de escolares, turistas con mochilas o investigadores que llegar con material de trabajo. Además No hay servicio de guardarropa.

Concluiremos diciendo que el espacio es actualmente adecuado para sus necesidades pero no su planteamiento.
El mostrador de recepción es el único lugar de información al público, resultando muy deficiente pues existe confusión con su función taquilla y recepción.

No existes MUPIs u otro soporte de atención al público sobre instalaciones contenidos servicios etc.

La información disponible el folleto entregado en la entrada y hoja. Además esta en proceso de impresión de una guía del museo.

Las vistas guiadas están disponible para visitas organizadas previa cita, a cargo de guías voluntarios No existe una atención al publico en varios idiomas, No hay audio guía

La atención telefónica esta llevada por recepción.

\section{V.3.2. Puntos de información:}


Los Aseos públicos están limpios. No cuentan con servicio de cambiador para bebes. Los aseos solo para visitantes están disponibles en la planta baja, lo cual para la extensión del museo puede llegar a ser insuficiente para algunos usuarios. Además hay una casi nula señalización.

Actualmente no existe ningún servicio de tienda. Hay en recepción una vitrina expositora en la que hace algún tiempo se vendía publicaciones. Actualmente carece de una función salvo alguna información o la exposición de un catalogo reproducciones de piezas del museo, que no se venden en el museo.

No hay existencia de cafetería o restauración solo la presencia de máquinas expendedoras refrescos, helados y café. En este asunto hay que tener en cuenta la cercanía de los bares "Bilindo", "Alfonso" y "Abilio "en la planificación de los servicios de cafetería dentro del museo.
Las máquinas expendedoras son gestionadas por el Club UNESCO. No se ha querido averiguar el régimen de que tiene esta gestión, para evitar malos entendidos.

\section{Otros servicios}

No hay teléfono publico las cabinas más cercanas están en la Avenida de las delicias o en bares"Bilindo" (ver plano de los servicios del entorno). Respecto a cajeros automáticos, el más cercano se localiza en la Avenida Felipe II(ver plano de los servicios del entorno)

\section{V.3.3. Reproducciones y fotografías}

Para la reproducciones y fotografías se sigue el REAL DECRETO 620/1987, DE 14 DE ABRIL, POR EL QUE SE APRUEBA EL REGLAMENTO DE LOS MUSEOS DE TITULARIDAD ESTATAL Y DEL SISTEMA ESPAÑOL DE MUSEOS. En el capitulo VIII"Otros servicios culturales de los museos de Titularidad Estatal", artículo 24 "Copias y reproducciones"dice: "Los Ministerios respecto a los Museos que tienen adscritos o el órgano competente de las 
Comunidades Autónomas, cuando se trate de Museos gestionados por éstas en virtud del correspondiente convenio, establecerán las condiciones para autorizar la reproducción de los objetos del Museo por cualquier procedimiento, basándose en los principios de facilitar la investigación y la difusión cultural, salvaguardar los derechos de propiedad intelectual de los autores, preservar la debida conservación de la obra y no interferir en la actividad normal del Museo".

Tras la petición de reproducción a dirección del museo, el informe favorable de éste pasa a delegación provincial de cultura tras lo cual se lleva a pago de las tasas a Consejería de Hacienda.

El permiso de reproducción puede eximir de tasa, motivando por interés general u otros u otra índole, previa autorización de la dirección del museo y autorización de Delegación de cultura.
Los precios públicos de la junta de Andalucía son los siguientes ${ }^{24}$ :

\footnotetext{
${ }^{24}$ Orden de la Consejería de Cultura, de 5 de junio de 1989,por la que se fijan los precios que han de regir en los museos, archivos, conjuntos arqueológico y monumentales para visita de publico y reproducciones graficas (Boja número 52 de 4 de julio).
} 


\begin{tabular}{|c|c|c|}
\hline & $\begin{array}{l}\text { Fotografía de fondos } \\
2.000 \text { pts unidad }\end{array}$ & $\begin{array}{l}\text { Fotografía de fondos } \\
12,020242 \text { euros unidad }\end{array}$ \\
\hline $\begin{array}{l}\text { PRECIO DE } \quad \text { LAS } \\
\text { REPRODUCCIONES }\end{array}$ & $\begin{array}{l}\text { Reproducción en publicación } \\
\mathbf{5 . 0 0 0} \text { pts unidad }\end{array}$ & $\begin{array}{l}\text { Reproducción en publicación } \\
30,050605 \text { euros unidad }\end{array}$ \\
\hline $\begin{array}{l}\text { GRÁFICAS EN MUSEOS Y } \\
\text { CONJUNTOS } \\
\text { ARQUEOLÓGICOS } \\
\text { MONUMENTALES }\end{array}$ & \begin{tabular}{ll||}
$\begin{array}{ll}\text { Reproducción para } & \text { postales o } \\
\text { soporte } & \text { publicitario } \\
10.000 \text { pts unidad } & \end{array}$
\end{tabular} & $\begin{array}{l}\text { Reproducción para postales } \\
\text { soporter publicitario } \\
\mathbf{6 0 , 1 0 1 2 1 0} \text { euros unidad }\end{array}$ \\
\hline $\begin{array}{l}\text { Orden de la Consejería de } \\
\text { Cultura de } 5 \text { de junio de } 1989 \\
\text { (BOJA } 52 \text { de } 4 \text { de julio de } \\
\text { 1989) }\end{array}$ & $\begin{array}{l}\text { Filmación diapositivas y vídeo } \\
15.000 \text { pts } \\
\text { Reproducción de películas y } \\
\text { vídeos con fines comerciales } \\
40.000 \text { pts }\end{array}$ & $\begin{array}{l}\text { Filmación diapositivas y vídeo } \\
90,15 \text { euros } \\
\text { Reproducción de películas y } \\
\text { vídeos con fines comerciales } \\
240,40 \text { euros }\end{array}$ \\
\hline
\end{tabular}




\section{V.3.4. Alquiler de espacios}

No existe el alquiler de espacios, en algún caso se ha dado el caso de ceder el salón de actos a cambio de alguna colaboración.

\section{Carencias y prioridades respecto la accesibilidad.}

-El espacio de recepción actualmente adecuado para sus necesidades pero no su planteamiento(no es atractivo, es poco confortable, falta información de los contenido de la exposición y los servicios, etc)

-Falta de plan señalético externo e interno.

-Falta lugar para el adecuado aparcamiento de autobuses en el entorno de la Plaza América.
-Adecuación de la exposición para minusválidos, especialmente la sala donde se ubica el tesoro del Carambolo

\section{V.3.5. El servicio de la página web}

La pagina web del museo de ubica dentro del Portal de los museos y conjuntos arqueológicos y monumentales de Andalucía El Portal consta de 21 páginas web: 16 museos, 4 conjuntos arqueológicos y 1 conjunto monumental, una para cada centro.

Están pensados como un instrumento de difusión de las instituciones que, gracias a la Red, transcendiendo del marco geográfico ,actúa como medio de comunicación con el público y facilitando la preparación de la visita a todos los niveles, tanto individual como en grupo.

La arquitectura de contenidos de la pagina web se dividen en seis secciones: 
-INFORMACION GENERAL: La información necesaria para contactar con la institución o desplazarse físicamente a ella, el nombre de la directora, la dirección postal y electrónica, los teléfonos, horarios junto con los días festivos que el museo permanecerá cerrado y abierto, el precio de la entrada y los pasos a seguir cuando son visitas en grupo.

\section{Existen unas subdivisiones llamadas ACCESO,} SERVICIOS GENERALES y ACTUALIDAD

En el primero el visitante puede consultar el transporte público que le lleva al museo y los aparcamientos más cercanos, junto con una fotografía aérea del edificio.

Respecto a los SERVICIOS GENERALES se ha introducido una pequeña información de la biblioteca, el archivo y el taller de conservación-restauración.
Y en ACTUALIDAD no hay ninguna información por lo que da una imagen negativa al museo. La web esta pensada como un instrumento de difusión de la institución que gracias a la Red, trasciende el marco geográfico inmediato de la misma, difunde su patrimonio a todo el mundo, actúa como medio de contacto e intercambio con el público, genera información en ambos sentidos, desde el público al museo y viceversa y facilita a todos los niveles la preparación de la visita, para que privarle a éste de información.

-HISTORIA: En esta sección se pueden consultar los antecedentes de la institución y los acontecimiento que dieron lugar a su nacimiento.

-COLECCIONES: esta sección empieza con una contextualización de las piezas que, en muchos casos, están relacionadas con la historia y explica las circunstancias que la llevaron hasta el museo. 
Los sub-apartados OBRAS SINGULARES, PROPUESTA DE RECORRIDO y CONSERVACIÓN Y RESTAURACIÓN responden a las diversas actividades relacionadas con la gestión de una colección museográfica.

En OBRAS SINGULARES se pueden contemplar las fotografías de diversas piezas arqueológicas, cada una con su ficha divulgativa y una lupa de aproximación que permite ver las piezas en detalle.

En la PROPUESTA DE RECORRIDO se pone a disposición del visitante una propuesta de recorrido comentada por las colecciones que sirve de guía a la visita.

En CONSERVACIÓN Y RESTAURACIÓN se muestran los procesos de que se llevan a cabo tanto del edificio como de las propias piezas mediante una serie de imágenes del antes, el durante y el después de cada intervención.
-Tampoco existe ninguna sección específica donde se contemple las investigaciones que se llevan a cabo en la actualidad.

\section{La difusión de la web:}

La web es un instrumento de difusión pensado para poner dichas instituciones al servicio de los ciudadanos. Facilitando el acceso a nuestro patrimonio y, además, permite asumir las expectativas que exigen la actualidad de la información que se maneja. Ofrece una herramienta que permite al usuario tener una información ágil y actualizada del museo.

Dentro de la Difusión se orienta y facilita a los docentes la preparación de la visita de los grupos de escolares a través de un espacio denominado PROGRAMAS EDUCATIVOS, pensado como plataforma de contacto e intercambio de materiales, tales como documentos, recorridos alternativos, 
juegos, actividades. En este apartado se encuentra el servicio para la cita previa a través de Internet para grupos y grupos escolares. Mediante un formulario con diferentes campos y su envío al museo. Se ha notado la falta campos como observaciones y procedencia del centro, para que permita hace una estadística de lugares de procedencia.

Existen un buscador de texto libre para facilitar la localización rápida de cualquier tema o palabra. Una sección NOVEDADES, permite situar en la primera página, en un espacio destacado, cualquier noticia o información, recogida o no en otra sección.

Este museo por ahora no tiene una visita virtual; un recorrido por los espacios expositivos a través de una herramienta de desarrollo multimedia: la fotografía panorámica de $360^{\circ}$. Lo que significa que además de abarcar $360^{\circ}$ alrededro del eje horizontal, cubren $360^{\circ}$ alrededor de la vertical, permitiendo recorrer la imagen de izquierda a derecha y de arriba hacia abajo, que produce una sensación global envolvente, como si estuviéramos allí.

En un sitio web contemporáneo podemos encontrar muchos elementos que favorecen a una buena estética y composición al tiempo que perjudican una correcta visión por parte de todos, o la inmensa mayoría de los usuarios.

Son muchas las veces en las que encontramos lugares en la red donde la imagen impide ver lo que realmente damos como contenido informativo (y todo es información en la web, sea lo que sea lo que presentamos). En ellos vemos como se prefiere obviar las necesidades en función de tener una imagen barroca, recargada, llena de efectos o, por el contrario, con un diseño demasiado chillout. y, sobre todo, muchas veces, completamente inútil.

\section{La ley:}

A partir del 31 de diciembre de 2005 todos los sitios web relacionados con España que estén participados de un solo 
céntimo de dinero público han de estar adaptados a criterios de accesibilidad de discapacitados visuales.

Para lograrlo y darle un apoyo legal, el Congreso de los Diputados aprobó el tres de julio de 2002 la ley de Servicios de la sociedad de la información y de comercio electrónico. En ella se reflejan los datos, necesidades y multas si no se cumplíeran estos requisitos. Está publicada en la dirección:

http://www.congreso.es/public-Oficiales/L7/CONG/BOCG/A /A. 068-13.PD17

Por otra parte también podemos verla publicada en http://www.sidar.org/recur/ direc/.

Desde aquí también podemos acceder hacia legislaciones y normativas a seguir en otros estados.

Son muchas las instituciones del Estado que han acelerado en los últimos meses su conversión a esta necesidad. El miedo a que se repita el caso de Italia, donde directamente su Gobierno central cerró webs institucionales y oficiales no normalizadas.
Pero es el pavor al cierre lo que realmente nos ha de mover. Es por ello por lo que la ONCE y el SIDAR han facilitado, y sigue haciéndolo, ayuda a quienes necesiten convertir, o rediseñar una web ya existente, a las nuevas exigencias.

\section{Igualar}

Porque la propuesta de la ley no es simplemente realizar una versión para discapacitados visuales. Va mucho más allá. Lo que pretende es que ningún tipo de usuario se sienta discriminado ante una imagen visual distinta a la que puedan ver otros. Ello ha supuesto un nivel de exigencia a la hora de realizar adaptaciones donde la interfaz gráfica de usuario fuera, al menos, casi totalmente igual a la original.

También, esta exigencia, supone una adaptación mayor ya que la proliferación de navegadores y la constante aparición de nuevas versiones, están creando muchos 
problemas que, a los diseñadores, como es mi caso, nos está pidiendo un servicio constante a este tipo de planteamientos que, por fin, han hecho sacrificar aquellos sitios web donde predominaba más un "mira qué bonita la tengo" que un "mira qué podemos hacer juntos con ella".

\section{Carencias:}

-Uno de los objetivos futuros será adjuntar un mapa, que ubique al museo con la ciudad, para facilitarle el acceso a los visitantes que desconocen la ciudad.

-Falta otro apartado donde se detalle LAS NUEVAS ADQUISIONES, aunque es muy difícil que en un museo arqueológico se adquieran nuevas piezas creemos necesario este epígrafe para tener informado al público de los nuevas piezas descubiertas en las excavaciones que se llevan a cabo, que solo un sector muy reducido de la población está enterada de las excavaciones que se llevan a cabo a lo largo del año en su ciudad y provincia.
-Falta información respecto a los espacios singulares, zonas de interés histórico o monumental, rincones, servicios como la tienda, la sala de conferencias o proyecciones y vistas aéreas.

-falta un aliciente para la visita al museo ya que la pagina se concibe como una traslado del museo a formato web, sin aprovechar los recursos que ofrece una pagina web. Apartado con contenido para niños, secciones en la que se presente otras propuestas de vista del museo, etc

\section{V.3.6. EI servicio del gabinete pedagógico}

Dentro del organigrama de la delegación provincial de Sevilla de la Consejería de Cultura se encuentra el Gabinete Pedagógico de Bellas Artes. 
El desarrollo en España, como en otros países, de la dimensión pública del museo comenzó por la atención a la población infantil, especialmente en grupos escolares. La imposibilidad de atender a todo el público obliga a escoger y en la elección influyen la consideración de que los niños están en una mejor disponibilidad de aprender, por lo que el esfuerzo será $\mathrm{m}\{$ as rentable, y por otra parte, que resulta más fácil reunirlos y llevarlos al museo.

Dentro del museo el Gabinete Pedagógico de Bellas Artes se encarga de potenciar la utilización del Museo como un recurso didáctico de aplicación directa en los distintos ciclos de enseñanza no universitarios.

Como instrumento fundamental se crean las carpetas didácticos de distintos museos, formadas por un cuadernillo para el profesor y otro para el alumno.

Disponibles en el museo, instituciones educativas o en el propio gabinete, actualmente de puede acceder más cómodamente descargándolos desde la pagina web del museo. Editado por la Consejería de Cultura y La Consejería de Educación y Ciencia.

\section{El cuaderno del profesor}

Es un documento suficiente como para facilitar la programación de la visita al museo sin necesidad de la vista previa del profesor. Bastante información acerca del museo, arqueología, piezas, descripciones mitológicas, de los materiales de la piezas, etc

Presenta llustraciones de piezas salas vitrinas piezas reconstrucciones gráficos aunque están en b/n.

Se propone realizar la visita adecuándolo a los contenidos del curso, y que la visita no se haga de todo el museo.

Creemos que propone una actitud algo pasiva del profesor, faltando en la propuesta didáctica una actitud motivadora y atractiva por parte del responsable del grupo. 
No presenta un plano del museo donde localizar las salas ni los espacios disponibles o recursos pero esta actualizado excepto en que la versión disponible aparece que la sala XXII esta cerrada al público.

\section{El cuaderno del alumno}

Disponible solo para alumnos de 12 a 16 años.

Planteada a partir de una traslación del guión expositivo del museo.

Los contenidos son: introducción a qué es un museo, relato a modo de viñetas para explicar la arqueología, fichas de actividades y vocabulario.

Presenta abundantes gráficos y reconstrucciones

La actividad principal es rellenar las fichas, , rellenar preguntas a modo de examen, resolver preguntas que debe resolver fijándose en vitrinas, razonado los contenidos, etc.

\section{V.4. OTROS ESPACIOS PÚBLICOS}

Un estudio de los servicios del entorno es importante tener en cuanta a la hora de planificación del museo.

\section{Servicios disponibles en el entorno}

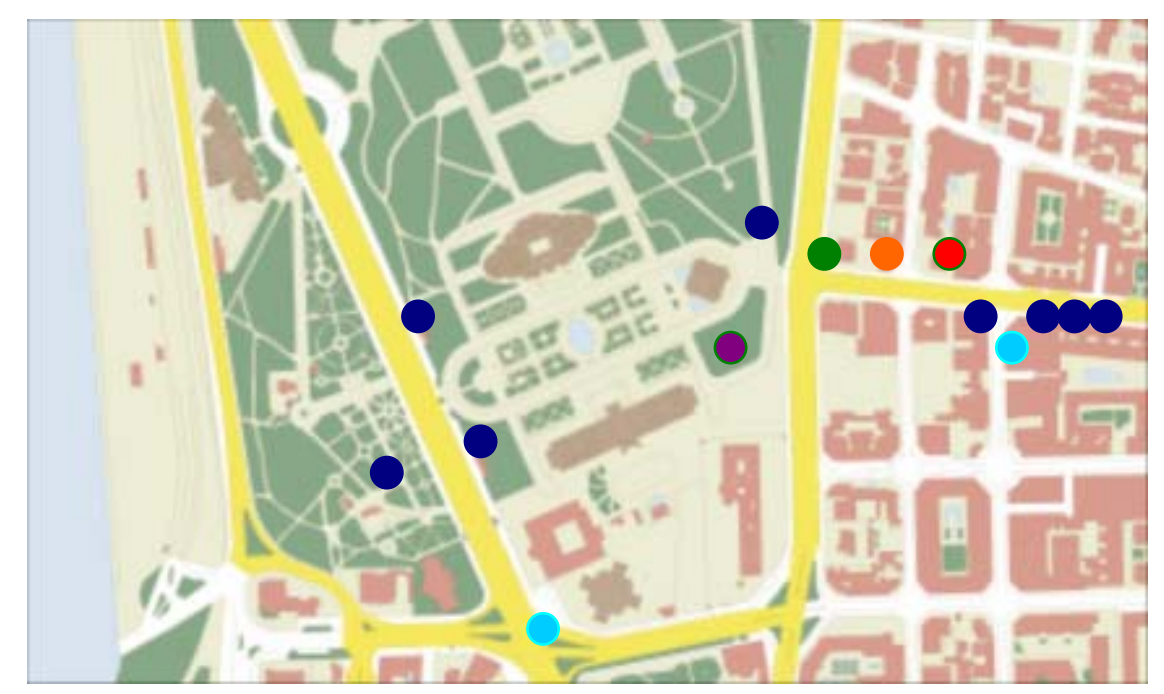




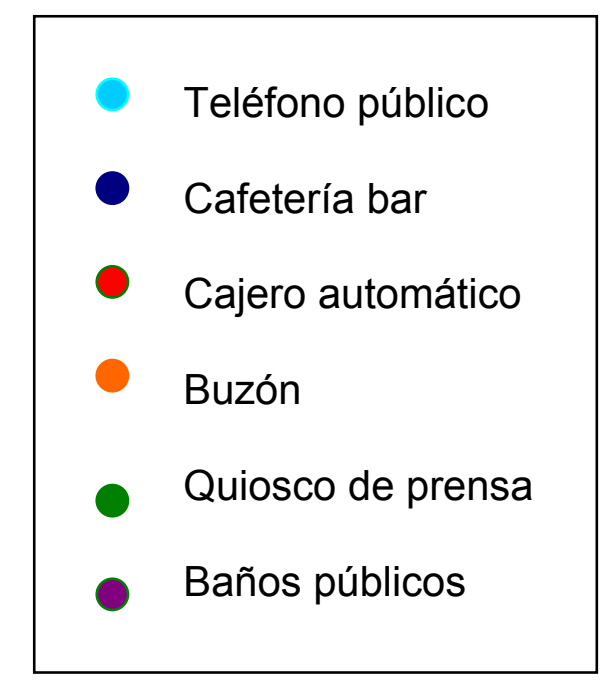

\section{V.4.1. Biblioteca}

En este el análisis de los servicios vamos a incidir en la biblioteca.

La biblioteca de museo es una colección de fondos documentales especializados, organizados para facilitar la adquisición, conservación, comunicación y presentación. Con fines de estudio, educación y deleite de los testimonios materiales que guarda el museo y apoyar las actividades propias del museo.
Falta de una misión para el desarrollo de su trabajo, de acuerdo con un grupo especifico de usuarios al que se intenta servir, adecuación de la biblioteca a unos servicios establecidos.

La misión debería de estar en consonancia con la misión del museo.

Necesidad de establecer unos objetivos, y desarrollo de nuevos servicios, mantener la calidad de un servicio, eliminar los problemas existentes, función especifica determinada,

Las funciones de la biblioteca relacionada con la difusión deberían ser:

-La educación: apoyo aplanes de enseñanza.

-La investigación actividades dirigidas al desarrollo del conocimiento.

-Actividades relacionadas con el ocio. 
Además de las funciones especificas que es el apoyo a las tareas museológicas del museo, asegurar la disponibilidad de la documentación necesaria para los trabajos de investigación que se lleven a cabo dentro del propio museo, ofrecer acceso ala información depositada en la biblioteca a aquellas personas interesadas por tales materiales.

La biblioteca debe fomentar el flujo de la información relativa a los campos que cubre, garantizar el acceso a la documentos en el campo propio del museo, de interés para los usuarios, que se encentaran fuera del ámbito de la biblioteca, además de orientar a los investigadores en la búsqueda y recuperación de la información, en cualquier soporte y a través de cualquier medio.

Respecto a las actividades internas: debe de realizar las tareas de tratamiento técnico de la documentación, circulación e fondos, estudios de usuarios, etc.

Respecto a las actividades institucionales internas: la relativa de las relacionadas con el museo: plan museográfico, organización de actividades, programas de difusión, en cuanto a las externas: las relacionada con otros organismos, otros museo academias etc,

\section{Atención al público:}

Horario: lunes a viernes, de 9.00 a14.00 horas.

Dos ordenanzas se turnan para la atención al publico y al personal del museo. Un espacio de $165 \mathrm{~m}^{2} \sin$ climatización

Los fondos ${ }^{25}$ : Parcialmente los fondos catalogados hasta finales de 2005, el catálogo automatizado lo componen 3750 obras correspondiendo a monografías, artículos de revistas y misceláneas. Hay pues un gran atraso en la catalogación automatizada de la biblioteca

Hasta la entrada de la nueva dirección se encuentra todos los fondos catalogados, continuando solo el registro de las obras.

${ }^{25}$ Más información en el apartado de Análisis y Evaluación de las colecciones. 
El régimen de acceso es libre, pero no se publicita, permaneciendo en un estado de indefinición, fundamentalmente es usada para uso interno y de investigador

El numero de puntos de lectura lo componen cinco mesas a las que se le puede acompañar de 4 sillas por lo que darían 36 puntos de lectura, pero en la actualidad sólo están presenten 6 sillas. Falta de conexión a Internet para ordenadores portátiles, falta de enchufes accesibles también para ordenadores, además las lamparas están desconectadas o fundidas.

El numero de puestos de consulta informática a los fondos con acceso a través Internet consiste en un solo Opac. La biblioteca posee dos licencias de uso del programa del catalogo automatizado (Absys 6.1 express) uno para la consulta de catalogo para los técnico, accesible desde los ordenadores del despacho de técnicos y otro para la gestión e introducción de datos. Mientras que los técnicos están utilizando no se puede consultar el OPAC en el ordenador de la biblioteca.
El catalogo informático es el programa Absys 6.1 expreses. La Interface se compone de una pagina principal con la posibilidad de elegir el idioma: Español, francés, Ingles y euskera. Posibilita Tres opciones de búsqueda: modelo completo de consulta de catalogo, modelo sencillo de consulta de catalogo y modelo intermedio.

Los campos son: cualquier campo, titulo, autor persona, autor corporativo, titulo colección, congreso, editorial, materias, año de publicación,(antes de ,después de)material, lengua.

Hay una falta de personal especializado, pues en la relación de RPT no hay nadie especialmente para la gestión de la biblioteca.

No hay un numero de usurario ni de consultas reales, pues no se suele hacer registro de las mayorías de las consultas internas por lo que no queda constancia de esos fondos. Esto imposibilita algunas veces la localización. Así los datos que se aportan en las memorias o estadísticas son incorrectos. 
No hay servicio de reprografía en algún caso se permite fotocopia de articulo con la maquina q se localiza en el despacho de administración

\section{Fortalezas:}

-Fondo bibliográfico abundante.

-Protección administrativa.

-Instalaciones amplias aprovechables.

-La inversión más importante ya esta hecha.

\section{Puntos débiles:}

-Equipamiento técnico.

-Situación de la automatización de los fondos muy retrasada.

-Nula presencia de Internet para los usuarios excepto catalogo on-line.

-No hay política de usuarios.

-Gestión deficiente.

-Falta de personal y personal técnico.

-Escasez de servicios ofertados.
-Baja tasa de ocupación.

-Instalaciones antiguas.

-Rigidez administrativa.

Oportunidades:

-Internet y tecnología.

-Integración dentro de la administración.

-Incremento de demanda de las bibliotecas: investigación, ocio, difusión, educación, etc.

-relaciones institucionales.

\section{Amenazas:}

-Nula proyección externa.

-Competencia con universidad y sus servicios.

\section{V.4.2. Archivo}

Contiene información documental, escrita y gráfica, relativa a los fondos museográficos y al museo como institución. Posibilita el servicio de consulta a 
investigadores y particulares relacionados con las colecciones

Régimen de acceso libre al igual que la biblioteca, una vez que el investigador ha localizado unas piezas para su estudio debe de solicitar el permiso de la Delegación con por medio y con la aprobación de la dirección, para la consulta de documentación no es necesario.

Los fondos se podrían dividir en archivo de oficina y archivo histórico: Libros de registro, carpeta de ingresos, catalogo sistemático, croquis de salas, fichero mitológico, fichero por materiales,

Fichero de fotografías por sala, fichero fotografías de piezas ordenadas por año(sin acabar), fichero de negativos, documentación de compra, Memorias

Expediente de yacimientos etc.

En la actualidad parte de la información se está volcando en la automatización con el programa Domus.

Los documentos se encuentran repartidos por diferentes muebles, archivadores y muebles enlosl despachos de administración y técnicos. Es Excepcional la reproducción de los fondos.

El procedimiento usual es la búsqueda del numero de registro de la/s pieza/s en un documento en el que aparecen los segmentos de numero de registro ordenados por población(Sevilla, provincia, Cádiz, Huelva, Badajoz, etc.), luego se pasa a la búsqueda de la ficha en el archivo sistemático.

Sobre historia del museo es poca la investigación para algún caso concreto tesis de la historia del museo y tesina del museo.

\section{V.4.3. Sala de investigadores}

Actualmente se ha trasladado la sala de investigadores a la sala contigua a la biblioteca.

El régimen de Acceso para el estudio de la piezas consiste en una petición al director de museo que dado el visto bueno se remite a la Dirección General de Bienes 
Culturales. No es un procedimiento muy optimo contando con varias problemáticas.

No existe ningún punto de consulta informática

El horario esta establecido por la mañanas.

El numero de puestos no está definido. Para investigación de piezas pequeñas el investigador tiene a su disposición las mesas de la biblioteca, las mesas de despacho o la actual sala de investigadores. En el sótano también esta habilitado un espacio para la investigación cuando el material lo exige.

Ningún catalogo está establecido para la localización de la documentación

La principal carencia de la sala de investigación es su indefinición

\section{V.4.4. Salón de actos}

Es un espacio de $\mathrm{m}^{2} 230$ pudiendo tener 200 plazas aproximadamente para sillas retirables. Su función es para usos culturales: conferencias, presentaciones y clases.
Podemos ver una presencia de piezas arqueológicas como son los relieves de los trabajos de Hércules en el frente del salón. La parte central el suelo es de vidrio por lo que la presencia de actividad se percibe en la sala XIX. Además es lugar de paso entre un ala del edificio.

Los medios disponibles: megafonía, proyector de diapositivas, pantalla, cañón de luz (pero no ordenador portátil que se pueda utilizar con el cañón, por lo que de debe de traer de fuera).Cuenta con un sistema de control de la entrada de luz, retirándose algunas veces.

El acceso se efectúa desde el hall de entrada por escalera o ascensor, no tiene acceso independiente.

Es un espacio que su función es de salón de acto pero en ocasiones se utiliza para exposiciones temporales. no se alquila, se ha dado algún caso en el que se ha cedido el espacio. 


\section{V.5. PROGRAMACIÓN DE ACTIVIDADES}

Los museos se deben de configurar como medio de comunicación, siendo su forma más característica la exposición, que se presenta como un método eficaz de difusión cultural.

En el Museo Arqueológico tenemos la exposición básica que es la permanente, aunque nos encontramos también con la programación de exposiciones temporales. Además la actividad difusora como museo se plasma en la programación de actividades y especialmente exposiciones temporales

Para conocer ésta faceta comunicadora del museo comenzaremos con una descripción general de las actividades realizadas en los últimos años:

\section{Exposiciones en 2004}

-"Italica virtual"
-"Palabras de una vida"

\section{Exposiciones en 2005}

-"Artifex"

\section{Actividades en 2004}

-Presentación del Boletín Amigos del Museo

-Apertura de la sala del Ejercito

-Concierto "Ver y sentir el Museo con personas con

Síndrome de Down" Día internacional del museo

- "La música en el Museo Arqueológico de Sevilla"

-Conferencias de Egiptología (tres conferencias)

-Conferencia "Baetica Paleocristiana"

-Conferencia "El Ladrillo estampillado"

-Seminario de introducción a la antropología física.

\section{Actividades en 2005}

-Conferencia "numismática Omeya al-Andalus". 
400

-Conferencia "Las esferas de piedra Precolombina de Costa Rica".

-Visita guiada, día del Museo.

- "Sevilla en la época del Nacimiento", actividad familiar para Navidad

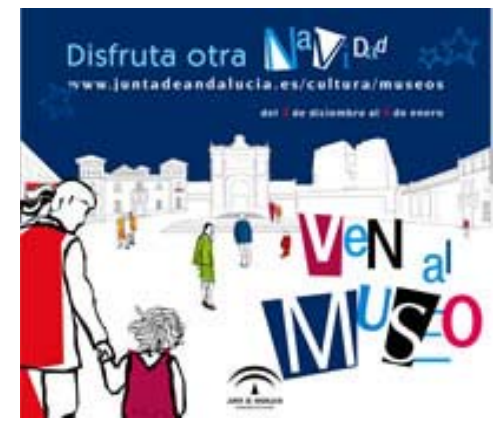

El Calendario de actividades no responde a una planificación, solamente para el día de Andalucía, día internacional de los museos y Navidad se plantea una programación, concentrándose pues en estos días. Las demás actividades, fundamentalmente las conferencias y exposiciones, se distribuyen a lo largo del año dependiendo de diferentes circunstancias.

No existe una oferta de actividades periódica concretas lo que impide crear un publico estable y amplio.

La Tipología de actividades es muy reducida. Aparte de las exposiciones temporales, la mayoría de las posibilidades son actividades pasivas como conferencias y seminarios o conciertos, además de la inauguración de una sala o presentación de publicación, En cuanto a actividades más activas se han plantado algunas visitas familiares en Navidad, visitas especiales y visita guiada temática.

Suelen ser actividades libres aunque las actividades para la Navidad pasada había que reservarla.

La temática presenta la misma problemática que el calendario, la falta de una buena planificación provoca que las temáticas de las actividades sean muy diversas sin 
responder a unos objetivos claros. Responde a circunstancia especificas del momento o a ideas aisladas. A pesar de ello la mayoría de las actividades se ciñen a los contenidos específicos de las colecciones.

El Publico fundamental de conferencias, presentaciones o seminarios son especialistas, asociación amigos del museo personal del museo, iniciados y estudiantes de Historia. Las exposiciones de los últimos años están enfocadas para un publico general. Alguna actividad se han programado para grupos especiales, aunque muy pocas en general.

Podemos apreciar la existencia de actividades aisladas y concretas en el tiempo para publico determinado, así la pasada Navidad se realizo una actividad familiar tipo visita dialogo con el publico, o la visita al museo con personas con Síndrome de Down.

\section{V.5.1. Exposiciones temporales}

Las ultimas exposiciones se han ceñido al mundo romano resultando muy atractivas por el éxito de publico.,A pesar de esto no existen unas líneas para la creación de exposiciones, han sido exposiciones de proyectos exteriores al museo(Colegio san José de Paula, etc),es decir no se ha creado ninguna exposición que se haya exportado a otro museo. Así la participación en exposiciones fuera del museo se ha ceñido al préstamo de piezas.

Como hemos dicho La difusión de las colecciones fuera del museo se ha llevado a cabo con el préstamo de piezas, para poder ver el potencial de este modo de difusión se presentamos continuación el listado de las exposiciones temporales a las que se le ha hecho préstamo de piezas: 
402

\section{Exposiciones en España en el 2003}

-"Suite Vollard" ,7 piezas.

-"Iberoamérica Mestiza”, 21 piezas.

"Teatro romano", 3 piezas.

-“Trajes del saber. Encuadernaciones Mudéjares", 1 pieza.

-"Visión y la vista", 3 piezas.

-“De Finisterre a ...", 1 pieza.

-"Semana del gusto", 10 piezas.

\section{Exposiciones en el extranjero en el 2003}

"Los romanos y su herencia", 1 pieza.

"Rutas marítimas: Desde Sidón hasta Huelva”, 74 piezas.

"Triangulo al-Andalus", 2 piezas.

Total:112 piezas

\section{Exposiciones en España en el 2004}

-"Augusto fundador de Augusta Emerita”, 2 piezas.

-"50 años del Instituto Arqueológico Alemán de Madrid 1954-2004)"

-"El yacimiento arqueológico de la Cueva de la Mora", 97 piezas.

-“Garum y salazones en el Circulo del estrecho”,10 piezas.

-“reyes católicos y la monarquía de España”,1 pieza.

-"Arquelogia del Bajo Guadalquivir; Del Neolítico a la Romanización", 128 piezas.

-“Fortunatae Insulae", 15 piezas.

-“Aqua Romana”, 6 piezas.

-“Una ciudad y un periódico; Sevilla y ABC en 1929”, 2 piezas.

\section{Exposiciones en el extranjero en el extranjero en el} 2004

-“Los judíos de Europa en la Edad Media”. 2 piezas.

-"Hannibal Ad Postas.El poder y la riqueza de Cartago". 


\section{Total:263}

El numero de piezas prestadas nos indica que en las tareas del museos se ocupaba bastante parte del tiempo en las tareas relacionada con las peticiones de préstamo, traslados, etc. quitando tiempo para la realización de otras tareas.

En el museo han participado un heterogéneo grupo de colaboradores y patrocinadores para la realización de exposiciones y actividades. Así se ha contado con las siguientes entidades colaboradoras:

\section{4:}

-Asociación Andaluza de Egiptología.

-Alumnos de la asignatura de museología de la faculta de historia del arte.

-Aspanridown.

-Asociación amigos del Museo.
-Asociación síndrome de Down Sevilla Y Provincia.

-Caja Madrid Obra social.

-Centro dietético Gacela.

-Club UNESCO Sevilla.

-Colegio santa Paula.

-Consejería de Igualdad y Bienestar Social.

-Consejería de Cultura.

-Cultura 2000.

-Delegación provincial de Cultura.

-Dirección General de Instituciones Del Patrimonio Histórico.

-Facultad de Bella Artes.

-Federación Española de síndrome de Down.

-Fundación Once.

-Fundación Academia europea de Yuste.

-Guías voluntarios.

-Ecole française.

-Ministerio de trabajo y asuntos sociales.

-Museo Arqueológico de Sevilla.

- Soprintendenza per i Beni Archeologici di Ostia. 
-Universidad de Sevilla. Departamento de Prehistoria y Arqueología.

\section{5}

-Alumnos de la asignatura de museología de la Facultad de Bellas Artes.

-Arte y Naturaleza.

-Asociación Acoge.

-Asociación Española Amigos de Museos.

-Asociación Amigos del Museo.

-Ayuntamiento de Sevilla.

-Club UNESCO.

-COAS.

-Conservatorio de música Joaquín Turina.

-Consulado de Alemania.

-Colegio de Aparejadores.

-Direccion General de Museos.

-Escuela de Estudios Hispanoamericanos.

-Embajada Costa Rica.

-Fidas.
-Fundación Monte.

-Fundación Juanelo Turrialo.

-Guías voluntarios.

-Itálica, fundación de estudios clásicos.

-Instituto ciencias de la Educación.

-Junta de Andalucía.

-Ministerio de Fomento.

- Ministerio de educación, Cultura y Deporte.

-Museo arqueológico de Sevilla.

-Ploder.

La colaboración depende del tipo de proyecto, dependiendo de entidad y temática de la exposición o actividad. Así para la conferencia "Las esferas de piedra Precolombina de Costa Rica" se contó con la participación de la Embajada de Costa Rica, o para la exposición "Artifex" con la participación de el Ministerio de Fomento y el Ministerio de educación, Cultura y Deporte. Dentro de la actividades del aniversario de Trajano la Consejería de 
Cultura participó para la realización de la exposición "Italica Virtual".

Las colaboraciones más asiduas son instituciones de la Junta de Andalucía, Asociación de amigos del Museo, guías voluntarios y Club UNESCO, estas ultimas centran más su actuación en actividades para el Día de Andalucía o Día internacional de los Museos. Importante, tambien, es la participación de la Asociación Amigos del Museo para la programación de conferencias.

La Universidad tiene una representación en el museo al celebrar clases o actividades relacionadas con la actividad docente como el Seminario de introducción a la antropología física.

En los dos últimos años la presencia de instituciones extrajeras se resume en la participación de la Soprintendenza per i Beni Archeologici di Ostia y la Ecole française.en la exposición de "Paisaje, agua, ciudad" dentro de un proyecto de investigación internacional.

\section{Los criterios de préstamo para exposiciones temporales}

El protocolo a la hora de préstamo es el propio establecido por la legislación estatal y andaluza.

Como hemos podido ver en el listado de piezas, hay mucho prestamos. Casi todo lo que se solicita que cumpla con las condiciones préstamo del museo y la legislación continua con los procedimientos para la salida de la pieza del museo. Algunas veces los compromisos instituciones obligan al préstamo de piezas que no debería del salir del museo.

En una visión amplia la solicitud de piezas se concentra un grupo repetido de piezas, ocurriendo el caso de que en algún momento se ha tenido prestada una pieza y su reproducción. 
El estrés provocado a las piezas que salen del museo puede provocar problemas de conservación por lo que en un futuro se pretende restringir la aceptación de solicitudes de prestamos.

Las exposiciones temporales permiten mostrar piezas que están en los almacenes, propiciar el intercambio con otros museos y agrupar piezas por alguna temática. La exposición temporal es la forma idónea de completar la exposición permanente de este modo las muestras como "Artifex" o "italica virtual" son acciones muy acertadas. Han constituido una forma de renovar la atención al museo. Ya que la exposición permanente ancla y paraliza la imagen, las actividades y las exposiciones temporales sirve de contrapunto contribuyendo a darle vida y animarlo, pero la falta de periodicidad hace que la imagen del museo no se renueve.

En la relación entre exposición permanente y temporal surge una dinámica que no se aprovecha totalmente para crear un espacio de desarrollo cultural y social al servicio de la sociedad. Tampoco en la exposición permanente, los nuevos modos de sensibilización y visualización nos se han aprovechado, a pensar que la celebración de muestras han contado en la mayoría de los casos con abundante visitantes. Así la exposición temporal es una tesis experimental que luego no se ha aplicado a la exposición permanente, no hay rastro de la itálica virtual o de la ingeniería romana.

Posibilidad de arriesgar de las exposiciones temporales no es aprovechada para presentar tesis de los últimos estudios, que refleje la continua investigación y cambio de visión de problemas arqueológicos. Así las investigaciones debidas al auge de las excavaciones arqueológicas en la ciudad no se han plasmado en la programación de exposiciones.

Las muestra temporales son soportes de un trabajo de sensibilización, relación y de animación y constituye un 
medio especifico de comunicación y expresión que une investigación y creación. Pero en la creación de exposiciones del museo no se produce una relación entre investigador y público.

\section{V.6. ACTIVIDADES}

La mayor parte del público no es especialista y necesita más ayuda para conocer el significado y valores de los objetos que se exponen.

Para solucionar esto las vistas guiadas son la solución más habituales, siendo el formato mas extendido el de guías voluntarios(el museo actúa de intermediario entre guías voluntarios y público) o actividades para la vista del museo con personas con síndrome de Down(su realización no tiene periodicidad).La instalación de audioguías permitiría que cada visitante elija un ritmo de visita ajustándose a las necesidades del publico general.

Los museos cuentan con la posibilidad de desarrollar diferentes tipos de actividades: vista-conferencia, visitadialogo, visita activa, vista especial, taller animaciones, etc. Aun así el Museo Arqueológico cuenta con pocos tipos de actividades en sala, concentrándose las realizadas en días determinados. 
En los tres últimos años estudiados no se ha plantado ninguna visita-conferencia, a pesar que se nos sugiere como una de la potencialidades que tiene las piezas y contenidos del museo. En cuanto a visita-dialogo se aplicó para las actividades familiares de la pasada Navidad. No se han planteado visitas activas en las que se utilice medios para la demostración, sistemas audiovisuales, etc. para crear una dinámica que posibilite el descubrimiento del sentido de las colecciones.

La visita especial solo se ha desarrollado en momentos muy concretos, como en al visita para personas con Síndrome de Down.

La introducción de actividades en salas en el museo plantea ciertos problemas que limitan, aunque hay muchas posibilidades de actividades. Por cuestiones de capacidad, características de las salas de exposición, necesidades técnicas(megafonía, diapositiva o que el publico se pueda sentar), requerimientos de no molestar al resto de visitantes entorpeciendo el paso o dificultado la visión de alguna obra y sobre todo conservación de las colecciones, etc algunas actividades no se pueden realizar en salas Para ello el museo cuenta con el salón de actos, usado exclusivamente para presentaciones o conferencia 0 clases. No se utiliza para la proyección de audiovisuales, conciertos, actividades de formación como coloquios, jornadas, etc. Por lo demás el museo no plantea ninguna actividad fuera de las salas que no sea en el salón de actos.

A pesar del libre acceso al salón de actos, sin necesidad de reserva para la asistencia a las actividades en el desarrolladas, cuentan poca afluencia.

Debemos señalar que no se suele organizar conferencias relacionadas con las explosiones como sucede en otros museos y centros culturales. Las conferencias mas bien versan sobre investigaciones de temas concretos(ej:" El Ladrillo estampillado"), temas muy especializados de los contenidos del museo, que a trae aun publico muy determinado. No se programan conferencias para un publico amplio, que se abarquen temas desde diferentes 
perspectivas y tratamientos de la arqueología, historia o patrimonio.

Las excavaciones de la Plaza de la Encarnación o en el Salón de Écija han pasado desapercibidas en las actividades del museo, cuando el interés de la población podía haber traído un amplio publico con la programación de conferencias $o$ actividades relacionadas con el conocimiento de las aportaciones de las últimas excavaciones arqueológicas.

La arqueología tiene un gran juego a la hora de programar talles actividades etc. desde formas mas pasivas a mas activa. Aun así en los dos últimos años no se han programado actividades que requieran de espacios adecuados para juegos, talleres, etc. que favorezcan la experiencia lúdica y sociable $\mathrm{O}$ adquisición de conocimientos mas concretos. Por consecuencia la mayoría actividades recurren a sistemas pasivos. La difusión del museo no debe de olvidar algunas experiencias ya realizadas en el museo y apostar por el diseño de nuevas actividades.
La disposición de los cuadernillos didácticos no se integran aquí ya que son publicaciones dependiendo del profesorado la actividad y uso de él, a pesar que su implementación se lleve a cabo en la visita a salas. Este recurso educativo lo analizaremos cuando veamos las publicaciones en el apartado de comunicación.

Los actuales recursos del museo no permiten el desarrollo de un amplio programa de actividades. No hay que olvidar que todas las actividades que se realizan en le museo son gratuitas, lo que obliga a una búsqueda de aportaciones económicas exteriores al museo. Aunque seria más deseable una programación de actividades, algunas de las cuales contase con una periodicidad.

Desde luego el museo Arqueológico de Sevilla no es un escenario abierto a la sociedad en toda su potencialidad, aunque existen indicios de cambio cuando vemos algunos ejemplos de diversidad de actividades concentrados en determinados días, esperando que en un futuro cuenten con periodicidad y amplitud de tipos. 


\section{Principales carencias}

Falta de relación entre investigación y publico.

Las propuestas innovadoras de la exposiciones temporales no se aplican a la permanente.

Falta de propuestas de actividades continuas, ciclos, etc.

La conservación de las piezas para préstamos.

Falta de creación de exposiciones con fondos que normalmente no están expuestos al publico, o reunirlo tratando temas que no aborda la exposición permanente.

Las actividades se concentran en días muy determinados, como el día de Andalucía o el día de los museos.

No existe oferta de talleres o actividades semanales o mensuales disponible para el público.

\section{Prioridades}

Establecer un criterio de préstamo de colecciones sin menoscabo de la difusión, favoreciéndose la conservación de las piezas y permanencia de obras importantes para la exposición temporal.

Planificación de un programa exposiciones; con objetivos, definición de tipo de publico, líneas temáticas etc.

Planificación de actividades; con objetivos, definición de tipo de publico, líneas temáticas etc.

Diversificación de públicos para atender a las diferentes necesidades de los diversos sectores que conforman la comunidad. Potenciar el museo como servicio público.

Contar con más colaboraciones permanentes para poder favorecer una planificación de actividades 
Planificación de actividades periódicas para publico

determinado a lo largo del año, buscando su

sostenibilidad y continuación. 


\section{V.7. COMUNICACIÓN}

\section{V.7.1. Imagen institucional}

La identidad institucional es el conjunto de atributos, valores o rasgos asumidos como propios por la institución, diferenciándola de otras. Es un fenómeno autoconsciente de los que el museo piensa que es, lo que quiere ser y como le gustaría que lo viesen. La comunicación institucional es el conjunto de recursos de producción y emisión de mensajes que dispone el museo. El museo cuenta con una serie de soportes comunicativos que forman parte de la entidad.

La imagen es la opinión publica, es la idea sintética, resultado de las lecturas parciales que los diferentes sectores sociales tiene del museo, de los atributos y los valores que el público le atribuye. La propia presencia misma del museo en la ciudad comporta una lectura de sus rasgos. Así la imagen se ha conformado espontáneamente a partir de la gestión regular de la institución a lo que hay que añadir los la intervención programada y especializada para enfatizar los valores positivos por parte fundamentalmente desde la consejería (Pagina web, Gabinete de prensa, etc)

La gestión regular del museo y la importante colecciones con piezas incalculables son elementos indispensables ala hora de conformar la imagen de la institución. Así es un lugar de interés para investigadores de ámbito internacional y marco de estudios de la historia del ámbito Mediterráneo, De ahí el nutrido grupo de investigaciones y estudios y solicitud de piezas para diferentes museos y exposiciones. Conocido pero los habitantes de la provincia al poseer alguna pieza de su población además muchas de las poblaciones están interesadas en el retorno de piezas encontradas en su termino. Esto proporciona cierta imagen de museo centralista. 
Dentro de lo que "Que dice de sí misma" podemos decir que no se percibe como centro dinámico. Contando con exposiciones muy puntuales, al igual que el resto de actividades.

De "Que se piensa de ella" los habitantes de la ciudad se percibe como un elemento relacionado con la educación en el colegio y paseos por el parque.

Además se le añade problemática de los demás museos andaluces: falta de seguridad, de mantenimiento, de actualización de contenidos y recursos, y poco rentables, Dentro de ellos El retraso en la modernización del museo se ve mas patente al compararlos con otros museos(Bellas Artes de Sevilla, Museo de Cádiz, etc.

La configuración espontánea de la imagen, desde el museo es muy grande, pero se demuestra ineficaz y se presenta ante la sociedad como un reflejo de una identidad desestructurada, poco definida, no modernizada, etc. Para corregirlo la Consejería de Cultura se ha diseñado una serie de soportes de comunicación para canalizar rasgos de identidad de los museos gestionados por la Junta de Andalucía.

Programar la imagen del museo debe significar un proceso de racionalización interna del museo que contribuya definir explícitamente la imagen institucional y asumirla internamente, aprovechado posteriormente los recursos disponibles para hacer llegar a la opinión publica los atributos de la institución. La función de la programación de la imagen no debe encubrir la realidad, ocultarla o adornarla, sino enfatizar los valores de identidad asumidos por le museo, para que sean percibidos por el publico y en función del proyecto de nueva identidad, hacer avanzar la institución hacia una mejor calidad de servicio.

En resumen la imagen pública que ahora mismo tiene el museo es obsoleta. 


\section{V.7.2. Creación de una imagen corporativa}

"Hay indicios que nos negarnos a reconocer. Son signos minúsculos que percibimos aunque no queremos prestarles atención. No nos conviene o no nos interesa fijarnos. Activamos un mecanismo de defensa que nos ayuda a sobrevivir. Consiste en actuar obviando una parte de la realidad. Nos quedamos con la cara amable de las cosas". Janer, María de la Pau. Pasiones romanas, página 183. Editorial Planeta. ISBN84-08-06311-1

No hay que cambiar la imagen corporativa de la Junta de Andalucía. Esta tiene su imagen como institución que es, para todas sus consejerías y los museos están dentro de la consejería de cultura. Muy bien, es mucho más fundamental que esto.

Ningún museo tiene una imagen que se impongan a través de los nuevos valores de calidad de servicio que ya están aplicando otros museos como por ejemplo el MAQ, Museo
Arqueológico Provincial de Alicante, que lo gestiona la Diputación Provincial de Alicante. Da igual quién lo gestione. Juegan con ventaja para atraer al público. Tienen creado un logo que lo identifica todo el mundo con el museo. Una imagen más moderna y aspiracional. Un diseño que logra optimizar la percepción de los mensajes de la institución. $Y$ ayuda a crear un renovado estilo de comunicación dentro de los museos.

En el caso de los museos estatales también tienen su propia imagen, un Simbolo-Logotipo que identifica que los veintitantos museos reciben ayudas del Estado. Luego cada museo tiene su propio logotipo con la misión de implantar un nuevo estilo corporativo de comunicación puesto al servicio de una demanda cultural individual. Cada uno tiene su potente identidad comunicativa creando nuevos niveles de relevancia y diferenciación dentro del grupo que son: Museos estatales. 
El énfasis en la experiencia refleja la actitud de cara al público en su aprendizaje y entretenimiento.

Ahora reina el caos en el Museo Arqueológico de Sevilla: En los carteles de sala que indican el número de la sala y la tipología existe un símbolo de la institución que ejerce como anagrama. Luego en la página web que es más actual el logotipo "MAR" actúa como imagen de la institución, pero solo nos la encontramos en la página web.

La prioridades consistirían en que crear un diseño con una imagen que esté en consonancia con la misión y los objetivos de la institución, así como que refleje la filosofía y el carácter de la misma.

La imagen tiene que ser coherente al apoyo genérico y financiero y es responsabilidad de todos, desde la dirección del museo hasta el personal de taquilla. Un ejemplo muy ilustrativo de esta necesidad es el ocurrido durante la preparación del presente trabajo. Un día por la mañana entando al museo, se le preguntó al conserje por el resto compañeros del master y éste contestó: - En la salas no están, pero la jefa está arriba. Suponemos que igual que me contestó lo hará con todas las personas ¿Qué imagen está dando el museo a los visitantes?

Objetivos de la imagen corporativa del museo Arqueológico de Sevilla:

La imagen es fundamental y debe reflejarse en el logo.

Está debe respetar las normas de una comunicación visual sencilla y directa, que permita la identificación cognoscitiva de la institución y de sus contenidos.

Se debe proponer el estudio de la existencia de un lema o slogan que sea identificado con la misión del museo.

Se debería estudiar la aplicación de la imagen en los soportes de merchandaising. 


\section{V.7.3. Política de difusión en los medios de comunicación y el Gabinete de prensa}

Las tareas de difusión del museo en los medios de comunicación está compartida entre el encargado de difusión dentro del propio Museo y el Gabinete de prensa.

El gabinete de prensa es el intermediario entre el museo e instituciones de la Junta de Andalucía y los medios de comunicación.

El principal trabajo del gabinete de prensa es llevar a cavo la información acerca de la celebración de exposiciones del museo. Ocupándose entre otras cosas a informar a secretaría del delegado de la inauguración y la fecha, para confirmar la fecha a la dirección del museo posteriormente.

Se intenta evitar que coincida en la agenda de un mismo día la asistencia del Consejero del cultura y el Delegado.
Se redacta un informe que se envía al delegado y al director, recogiendo: tema, objetivo, día, hora, lugar, asistente, duración, contenido de la exposición; lo que da la posibilidad de utilización de la información para el discurso del delegado.

Se continua con las tareas mas relacionada con los medios, redactándose la convocatoria a los medios, indicando: Titulo, texto corto, día, hora, lugar. Un día antes de la inauguración se manda la convocatoria, para recordar.

A los periodistas asistentes se le da la nota de prensa, fotografías de la exposición en CD y el catalogo. La nota de prensa junto a fotografías también se manda el mismo día, al listado de medios vía e-mail.

Además de a los medios de comunicación a la delegación de Gobierno las convocatorias y nota de prensa además de 1 o 2 fotos para el portal de la Junta de Andalucía. 
Por e-mail se manda nota de prensa informe y fotos de personajes asistentes.

Durante el desarrollo de la exposición se manda a los medios recordatorios para las agendas culturales.

La ultimas tareas relacionadas con el Gabinete es la recopilación de noticias en un dossier de prensa de la exposición. Además una nota de prensa al final de la exposición con los visitantes pasa por Consejería y finalizando con la creación un dossier de prensa.

Como hemos podemos ver la comunicación de la dirección del Museo esta gestionada por la delegación de Cultura, así la petición de una entrevista ante los medios debe pasar por gabinete de prensa.

Destacaremos algunas tareas realizadas Conservador dedicado a difusión:
La comunicación de las actividades realizadas desde el museo consiste en el vuelco de la información en la Agenda Cultural de la Consejería de Cultural. Se gestiona a partir de un gestor web en el que se van rellenado campos. Esta agenda cultural tiene el problema que dificultad de centrar algunas actividades según se hayan indizado en los campos.

Si la actividad esta cerrada se gestiona para que se publique en el Boletín de actividades culturales(BAC), lo que obliga a que se mande antes del día 15 del mes anterior.

El vuelco de la información acerca de actividades en la pagina web del museo también se realiza desde el museo aunque el manejo del gestor es mas complicada(normas, tamaños de imagines, etc) 


\section{V.7.4. Claves para un Plan de comunicación:}

Las ventajas de tener el Plan es evidente, nos permite en primer lugar planificar el conjunto de las acciones de manera coordinada.

En segundo lugar, nos facilita tomar decisiones razonadas sobre la clarificación, determinación y secuenciación de los objetivos.

En tercer lugar nos proporciona un mapa global en el que encajar cada una de las diferentes acciones, con la consiguiente posibilidad de ir compaginando las ventajas $y$ los inconvenientes de cada una de las acciones y los impactos en cada una de las acciones y los impactos en cada una de las audiencias objetivas.
Claves en torno a los mensajes:

Diversificación y adecuación de los mensajes a los medios y las audiencias.

Evolución progresiva de los mensajes (combinando el rebote con mensajes nuevos pero evitando mensajes estereotipados).

Claves en torno a las acciones:

Plan continuado en el tiempo (no acciones aisladas)

Personalización de las acciones manipulando la cercanía al objetivo.

Objetivo del Plan de Comunicación:

Institucionales: Administraciones Públicas.

Instituciones del Sector Cultural y Arqueológico

Lideres de opinión: sector arqueológico, cultural. 
Medios de Comunicación: Agencias, Prensa, Radio, TV, Internet, Medios especializados.

Visitantes y Usuarios: Turistas, Agencias, Usuario final, Público nacional, local educativo, Grupo específicos y especiales.

\section{V.7.5. El Gabinete de prensa}

El Gabinete de prensa funciona de forma compartida para gabinete de todos los museos y conjuntos arqueológicos de la provincia de Sevilla, dentro funcionamiento de la delegación de Cultura. Su sede se localiza en la calle Castellar. Su consignas son "Transparencia y cordialidad", actualmente coordinado por Maria Ángeles Guerrero.

La clave del buen programa de medios es un cambio de actitud respecto a la concepción tradicional sobre los que es una noticia y cómo es recogida en los medios. La mayor parte de los museos viven aún en una concepción tradicional donde ellos mismos no son generadores de noticia sino que están instalados en una mentalidad recolectora donde son los medios los que deberían interesarse por los medios los que deberían interesarse por las "importantísimas acciones socio-culturales" que desarrollan.

- Dossier de prensa.

La existencia de un gabinete de prensa virtual y permanente por ejemplo a través de la propia web de una gran facilidad a los medios.

- Radio, TV:

El museo debería diseñar programas exclusivos dedicados a los medios y a los mediadores.

Algunos museos han establecido relaciones permanentes con los medios. 
- La existencia de un gabinete de prensa virtual y permanente. Ej.: Propia en la página web de una gran facilidad a los medios.

En la actualidad existe una proliferación de noticias en los medios de comunicación relacionadas con el patrimonio histórico-artístico, difundido por una enorme cantidad de Medios de Comunicación.

Pero cabe preguntarse ¿Cómo enfocan estas empresas periodísticas el problema de la difusión, denuncia y formación del patrimonio para concienciar a una sociedad capitalista definida como una sociedad de masas y que se supone que demanda este tipo de noticias? En este análisis investigáremos todos los agentes que intervienen en la difusión del patrimonio a través de los medios de comunicación sociales, estudiaremos pues el papel de las empresas periodísticas, la función del periodista, la función del especialista, así como la función de la administración, para concluir que todos estos agentes que intervienen a menudo están enfrentados entre sí por intereses particulares y a veces enfrentados que hace que se cree un estado de confusión y de desinformación en la mal llamada "Cultura de la información y de la Globalización".

\section{V.7.6. La gran proliferación de los medios de comunicación social}

En la sociedad de consumo existe una gran variedad de medios de comunicación que nos informa y nos entretiene de aquellos temas en los que estamos interesados y que demandamos a diario.

Si somos del tipo de personas que nos interesa la cuestión del patrimonio y queremos estar informados puntualmente, disponemos de una gran cantidad de medios de comunicación a nuestro alcance, pero hay que ser conscientes de que cada medio tiene su propia limitación y hay que elegir el medio apropiado: 
En la prensa escrita: destaca los periódicos de carácter nacional, donde se tratan temas o acontecimientos importantes (exposiciones, grandes museos, etc.), es un tipo de publicación más exigente a la hora de tratar un tema relacionado con el patrimonio y mucho más selectiva.

Por el contrario, la prensa local es más receptiva a lo que pasa día a día y es mucho más próxima. Como contrapunto es un tipo de prensa más sensacionalista, ya que se utiliza el patrimonio para enmascarar asuntos netamente políticos. Las noticias patrimoniales no tienen una sección fija ( pueden encontrarse tanto en cultura como en política o incluso en sucesos) y suelen tratarse como elemento de relleno sobre todo en época estival.

Existen en la actualidad numerosas revistas especializadas que tratan casi exclusivamente estos temas y que se suelen adquirir en kioscos y librerías (Bellas Artes, Arqueología, Restauración, Arquitectura ... ) caracterizadas por ser demandadas por un grupo reducido de población de clase media-alta y con cierta formación intelectual.

Entre los medios audiovisuales la carencia que más se aprecia de temas relacionados con el patrimonio es sin ningún lugar a dudas la televisión. Salvo programas especiales y documentales (no se hacen demasiados porque resulta ser un formato caro) en donde se enfoca el patrimonio desde una postura 'esteticista" y que refleja la cara amable y complaciente de la historia (seguramente alentado por el poder político), priman por desgracia los intereses económicos y las audiencias sobre la función social y de formación y concienciación que tienen los medios de comunicación.

Por último destacamos el medio de la radio que en líneas generales sigue las mismas tendencias que impone los criterios televisivos. La radio tiene el inconveniente de tener unos oyentes más heterogéneos que la televisión y también se deben a los patrocinadores. 
Los contenidos patrimoniales se reducen pues a la noticia-patrimonio y a escasos programas culturales.

Desde el Gabinete de Prensa se trabaja con un Listado de Medios de Comunicación que recoge los siguientes medios:

Prensa escrita:

$-A B C$

-DIARIO DE SEVILLA

- EL CORREO DE ANDALUCIA,

- EL MUNDO

- EL PAÍS,

-LA RAZÓN

-LA VANGUARDIA

-METRO DIRECTO

-PUBLICACIONES DEL SUR

-20 MINUTOS

-QUÉ! SEVILLA,

-PUBLICACIÓN LA CRÓNICA DE SEVILLA
Agencia de noticias:

-EFE

-EUROPA PRESS

Radios:

-ANDALUCIA INFORMACIÓN

-CADENA COPE SEVILLA

-CANAL SUR RADIO

-PUNTO RADIO

-RADIO NACIONAL DE ESPAÑA

-RADIO SEVILLA (CADENA SER)

Televisiones:

-ANTENA 3 TELEVISIÓN

-CANAL SUR TELEVISIÓN

-CANAL 2 ANDALUCÍA

-TELECINCO (ATLAS ANDALUCÍA)

-TELEVISIÓN ESPAÑOLA (CENTRO TERRITORIAL EN ANDALUCÍA)

$-\mathrm{CNN}+$ 
-GIRALDA TELEVISIÓN

-SEVILLA TELEVISIÓN

-POPULAR TELEVISIÓN

-CANAL 47

-LOCALIA TELEVISIÓN

Publicaciones de información general:

-CAMBIO 16

-LA COMARCA DEL NUEVO SIGLO

-TIEMPO

Publicaciones de información especializada:

-EL GIRALDILLO

-GACETA UNIVERSITARIA DE ANDALUCÍA

-LA ÚTIL

-MERCURIO

Medios de comunicación digitales:

-ANDALUCIACOMUNICACION.COM

-ANDALUCIA24HORAS.COM,
-ANDALUCIATURISMODIGITAL.COM, -SEVILLACLICK.COM

El gabinete de prensa se encarga, en su relación con los medios de comunicación anteriormente citados, de la creación de:

-Convocatorias de medios de comunicación.

-Notas de prensa

-Notas de prensa recordatoria

-Notas de prensa con los números de visitantes de las exposiciones

-Dossier de presa.

La inserción de anuncios en las agendas culturales de los diferentes medios son gratuitas, lo que desde el gabinete de prensa no se realiza gastos en la comunicación en los medios. 
Respecto a la Publicidad, no existe partida para publicidad dentro de la delegación de Cultura, por lo que la utilización de ésta se enmarcan dentro de una campaña publicitaria de programas de terminados.

\section{Relaciones publicas}

La dirección es la principal encargada de realizar las tareas de relaciones publicas.

En la antigua dirección existían muchos vínculos afectivos y profesionales lo que definía de cierta forma alguna de las actividades de las relaciones publicas de Museo.

La relaciones institucionales son la base de las subvenciones y convenios de colaboración que pueden llegar a convertirse en un capítulo central en la diversificación de la financiación del museo.

A muchos de los representantes institucionales no se les puede llegar por otras vías que por una buena campaña comunicativa.
Debería crearse un plan específico y diferenciado de contactos con los distintos administraciones: Local, Ayuntamiento, Regional, Gobierno regional, consejerías nacional, ministerios. Internacional, Fundaciones, etc.

El Gabinete de presa también realiza papel de relaciones publica, pues es la que comunica la fecha de inauguración de la exposición al Delegado de Cultura y manda el informe acerca del contenido de la exposición. En la convocatoria de prensa y demás trato con periodistas el gabinete de presa establece la relación entre museo, Delegación de Cultura y medios de comunicación.

\section{V.7.7. Publicaciones para la comunicación}

Atendemos en este apartado las publicaciones dispuestas para la difusión y comunicación del museo: 
-Folleto:

En la actualidad sólo existe un folleto que se da la entrada del museo, de seis cuerpos a dos caras y a todo color, donde se nos informa brevemente de los orígenes del museo, quién construyó el edificio y como llegó a ubicar el museo. Nos indica las tres plantas que consta con un plano de la planta baja donde se exponen al público los materiales procedentes de yacimientos prehistóricos de la provincia, siguiendo un orden estrictamente cronológico y cultural. La planta principal recoge todo el Período Romano, la Antigüedad tardía y la Edad Media hasta llegar a la Edad Moderna identificando los periodos a través del color en el plano de situación. Y la planta primera se ubican las áreas de trabajo interno, la Biblioteca, las Salas de Exposiciones Temporales y el Salón de Actos. Junto con los horarios, el precio, las visitas en grupo, los visitantes discapacitados, la biblioteca, la atención a los investigadores y la asociación de amigos del museo.
La fotografías de la piezas no destacan por su tratamiento estético, además no aparece imágenes del interior de las salas.

El plano diferencia los periodos culturales con colores, pero no es aclaratoria en cuanto al sentido de la exposición. Además no presenta referencia de piezazo o elementos que ayuden a la orientación, aunque no supone un gran problema en cuanto que la visita es lineal. Tampoco localiza el acceso y ubicación de la biblioteca, archivo, dirección, sala de exposiciones, en cuanto a los servicios no se indica con iconos fácilmente reconocible al igual que sucede con los accesos para personas con problemas de movilidad.

Participa de la concepción de folleto recuerdo. Finalmente nos planteamos ¿Para que sirven los folletos diseñados para los museos y conjuntos gestionados por la Junta de Andalucía? 
-Hoja informativa:

Consiste en una hoja tamaño folio, impresa a un color a ambas caras.

Esta encabezada por un recuadro con la dirección teléfono fax y dirección de correo electrónico del museo.

Continua con un plano muy poco claro de la localización del Museo. Aparece la representación de alguna vías(sin indicar nombre) y ubicación de algunos puntos de referencia(Oficina de Turismo, Universidad, etc.)

El plano de la planta baja presenta con el números de salas y su leyenda (ej:sala IV: Bronce Final)

En el adverso se presenta el plano de la planta principal, con el recorrido, numero de sala y leyenda.

La aportación fundamental de esta hoja en comparación con el folleto es la presentación de la indicación del sentido del recorrido, y la fácil localización de los contenidos por salas, además de fácil manejo .
Este recurso comunicativo está financiando por la Fundación El Monte

-La Guía oficial:

Se ha editado una guía muy completa que se encuentra dentro de la colección de Museos de Andalucía y es la Guía oficial $n^{\circ} 9$.

Es una guía muy completa y detallada. Con un diseño muy claro diferenciándose la historia, las salas de prehistoria, las salas de arqueología romana y las salas de arqueología medieval junto con el glosario y la bibliografía a través del color. Constando de 256 páginas a todo color y ubicándonos siempre en nuestra lectura a través de la paginación con la época a la que se refiere, junto con un rectángulo del mismo color en el ángulo inferior izquierdo. La maquinación es muy límpida con rectángulo abiertos en un extremo para señalar la sala en la que nos encontramos y el título de esta. Luego empieza con una letra capitular en 
negativo que ocupa dos líneas. La justificación del texto esta en los dos extremos con una tipología simple sin serif.

La calidad de las fotografías es óptima, tienen una buena resolución y están recortada con un fondo blanco aunque hay excepciones donde las piezas tienen una sombra degradada para crear profundidad.

Un problema es la guía es que solo está en castellano. Y el diseño gráfico de las dos publicaciones es diferente, dando un aspecto de descoordinación y una mala imagen.

Respecto al contenido supone mas una exposición de lo que el museo desea que hay en las salas mas que un reflejo fiel de la exposición y su montaje. La guía podría haber suplido algunas carencias de las salas pero no se ha perseguido esa intención. Por ejemplo no abunda en recursos interpretativos:

Es una guía de las piezas pero no de su contexto. -existe un boletín de amigos del museo que ha contado con la publicación de un solo numero.

Principales carencias:

-La imagen pública que ahora mismo tiene el museo es obsoleta.

-Falta de programación de la imagen institucional.

- Realidad institucional desequilibrada. Las diferentes carencias del museo dan una imagen pobre del museo que no corresponde con la importancia de las colecciones y su potencialidad.

-Falta de una diversidad de publicaciones relacionada con la vista al museo: guías temáticas, recursos infantiles, etc

-Falta partida de publicidad ordinaria unida a un plan de marketing en sentido extenso. 
Prioridades

-programar la imagen del museo, definiendo explícitamente la identidad institucional y asumiéndola.

-Diseño de programa de publicaciones y su puesta ala venta en futura tienda.

-Diseño de un plan Comunicación: recogiendo un conjunto de acciones de comunicación que responden los objetivos y las claves realizado entre el propio Museo y la Delegación.

\section{V.7.8. El papel de los medios de comunicación}

Es evidente que los medios de comunicación tienen como objetivo fundamental el informar de aquello que tenga que ver con el patrimonio histórico, pero aquí cabe hacerse una pregunta ¿ese es el único papel de los medios de comunicación? 0 planteado de otro modo ¿Hasta dónde llega el papel de estos agentes en la difusión, denuncia, sensibilización e incluso de la formación?

En primer lugar el papel habitual que le corresponde a estos medios es el informar de lo que resulta o no resulta noticia (noticia entendida como novedad): las agresiones al patrimonio derivadas de acciones de vandalismo o expolios arqueológicos, la degradación de los edificios y derrumbes como consecuencia del paso del tiempo, las restauraciones polémicas como resultado de atacar al rival político. Si realizasemos un seguimiento periodístico de todas las noticias que tratan el tema del patrimonio, veriamos cómo casi el noventa por ciento de las noticias que se publican tratan de esta forma el tema.

El segundo gran objetivo de los medios de comunicación es (o debería ser) el crear estados de opinión para que sus clientes tomaran una conciencia activa para intervenir en los temas de los que se les informan. La sensibilización se 
realiza mediante el impacto de las imágenes consigue la toma de conciencia de los problemas reales del patrimonio con el objetivo de movilizar a la sociedad para conseguir un objetivo final; mostrar el patrimonio como beneficio social y no como fuente constante de problemas. Este patrimonio tiene que ser tan importante y urgente como la política y la educación. Mientras que se continúe con la noticia polémica no se conseguirá este fin.

El objetivo que tienen que perseguir los medios de comunicación es ampliar el interés por el patrimonio histórico a la mayoría de la población y romper con el mito que la cultura pertenece a una elite privilegiada o que la única responsabilidad de salvaguarda del patrimonio histórico pertenece a los poderes públicos.

\section{EL PAPEL DEL PERIODISTA COMO "DIFUSOR Y CONCIENCIADOR.}

Un periodista tiene que ser la correa de transmisión e interpretar la información que interesa al público y la información que quiere transmitir el especialista; por lo que debe valorar la oportunidad de dar una noticia y cómo transformarla para llegar a un público mayoritario.

Por otro lado, el periodista no tiene que abusar del escándalo ni de los titulares excesivamente llamativos o catastrofistas, pese a que entre los especialistas existen conflictos y polémica (prestigio profesional, afinidades políticas, concesiones de rehabilitaciones y restauraciones ... ); pese a que entre la Administración y los especialistas también existan polémicas e incluso entre la Administración y la ciudadanía ( partidos políticos, asociaciones de vecinos, colectivos cívicos, asociaciones culturales etc.). 
Otro peligro que corre el periodista y que en la medida de lo posible tiene que evitar es la manipulación de la noticia. A menudo observamos que en el tratamiento de una noticia solamente se dan por válidas la versión de la Administración, ayuntamientos, gobiernos, etc. o por el contrario (aunque en menos ocasiones) la manipulación de los especialistas que también existen por motivos como el prestigio, la carrera profesional o la carrera política para realizar trabajos de restauración.

\section{EL PAPEL DEL ESPECIALISTA EN PATRIMONIO (RESPECTO AL INFORMADOR).}

La relación entre el especialista y el periodista en este país nunca ha sido lo suficientemente fluida y más bien ha sido tensa e incluso conflictiva; la opinión generalizada en los ambientes académicos es que los periodistas "se inventan" o "manipulan" las cosas que el especialista intenta transmitir, pero ¿ En qué falla la función del especialista en su relación con el periodista?.
La figura del especialista que informa al informador tiene una serie de responsabilidades que en muchas ocasiones no cumple:

El especialista debe responsabilizarse en el proceso de información: evitando los malentendidos, siendo rigurosos e imparciales y siendo conscientes que el periodista tiene que adoptar sus conocimientos al público en general (discurso más asequible, evitando los tecnicismos y evitando los aspectos poco claros y complejos).

El especialista es el primero que debe estar preocupado en transmitir el respeto por el patrimonio histórico (porque tanto él, como el periodista pertenecen a la misma sociedad y que ambos son beneficiarios y usufructuarios del patrimonio histórico), teniendo en cuenta que no a todo el mundo le interesa el patrimonio histórico. Esta transmisión es preferible que se realice por escrito para remitirlo al periodista, para evitar las manipulaciones y las distorsiones. Un ejemplo de solución a este respecto es la 
creación de Gabinetes de Prensa propios que disponen ya casi todos los museos importantes.

En muchas ocasiones el especialista siente recelo y desconfianza, a veces resistencia a informar al periodista ya que en muchas ocasiones el discurso del especialista es complejo y con gran riqueza conceptual y rico en detalles y matices se traduce en la publicación de las noticias como "sensacionalista" o "escandaloso".

\section{A MODO DE CONCLUSIÓN: LAS DEFICIENCIAS DE LOS MEDIOS DE COMUNICACIÓN.}

El proceso de recuperación del patrimonio histórico es lento y laborioso (restauraciones, mantenimiento de edificios, excavaciones arqueológicas...) y no resultan "noticiables". A ésta circunstancia se le une que en este país no hay políticas constantes de protección del patrimonio, como sí ocurre por ejemplo en los países anglosajones. Esta circunstancia se ha hecho palpable en la propaganda política de las últimas elecciones municipales y autonómicas del 2003.

Los medios de comunicación deben ir por delante de la sociedad, pero en realidad éstos sólo responden a lo que les pide la sociedad de consumo. Ignoran que cada día más gente se apunta a asociaciones culturales como la de los amigos del museo, sin embargo esta realidad no se refleja en los medios de comunión. Pero si se trata el patrimonio como una oferta más de "consumo", destinado al sector turístico más que entender el patrimonio como riqueza cultural.

El tratamiento de la noticia tratado como acontecimiento puntual no cala en la sociedad ni como elemento didáctico ni educativo (no olvidemos que tanto la escuela primaria y los medios de comunicación son los únicos agentes que pueden llegar a la generalidad de la población), no se manifiesta en un interés constante y formativo. 
Otro problema importante que cabe resaltar es la poca importancia en general que se le concede a la cultura frente a la preponderancia de los temas políticos o económicos, resumiendo las pocas noticias que salen a elementos como: grandes exposiciones temporales o expolios arqueológicos, cosa que por cierto es más contraproducente que ejemplarizante porque se da a entender que es más fácil robar (por lo que se provoca un aumento de los robos) y se informa que existen redes internacionales de compra-venta de objetos arqueológicos y artísticos.

Por lo tanto el objetivo principal es darle a entender a la sociedad que el museo es un presente vivo y no es memoria del pasado. Es educación y distracción. 


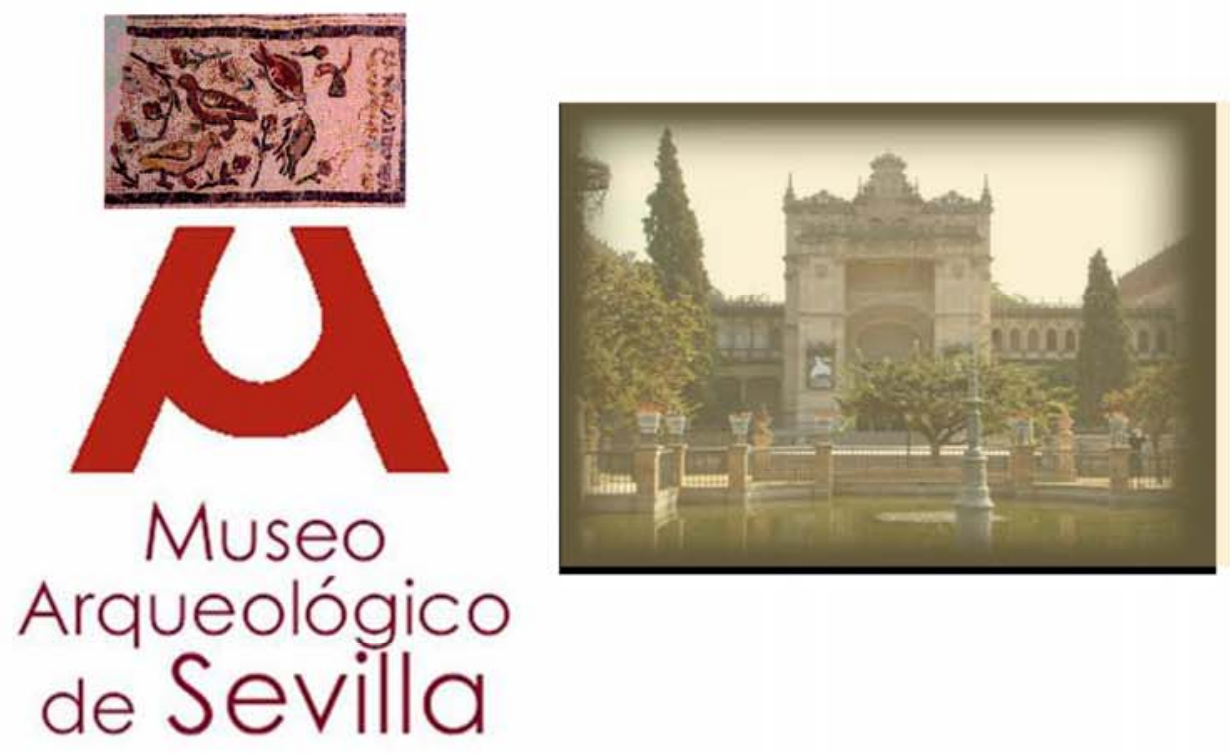

\section{SEGURIDAD}

\section{Patricia Monzo Losada}


El museo cuenta con un sistema muy básico de seguridad que podríamos resumir en los siguientes puntos que trataremos a continuación con más detalle:

\section{VI.1. SISTEMAS DE SEGURIDAD}

\section{a. Seguridad ante robos 0 actos vandálicos: sistemas activos de control.}

b. Seguridad pasiva para prevención de hurtos y actos vandálicos.

\section{c. Seguridad ante incendios.}

Como ya hemos subrayado, el centro cuenta con un sistema de seguridad muy básico que dificulta la buena preservación y salvaguarda de las piezas expuestas.

\section{a. Seguridad ante robos 0 actos vandálicos: sistemas activos de control.}

El museo cuenta con un sistema de alarma que consta de detectores volumétricos colocados en las puertas de acceso de la primera planta, centralizados en un cuadro de control general. Estas alarmas son revisadas periódicamente por SECURITAS, la empresa encargada del mantenimiento de las mismas. En el momento de activarse salta la alarma en la comisaría de la policía de la zona, desde donde se realiza una llamada de comprobación por si se tratara de una falsa alarma.

El sistema de turnos y el número de vigilantes es el suficiente para prever la vigilancia de la zona de "Prehistoria" (salas 1-10) con dos efectivos y en la primera 
planta, "Arqueología", se repartirían según el cuadrante de la siguiente forma: (un vigilante por cada grupo de salas)

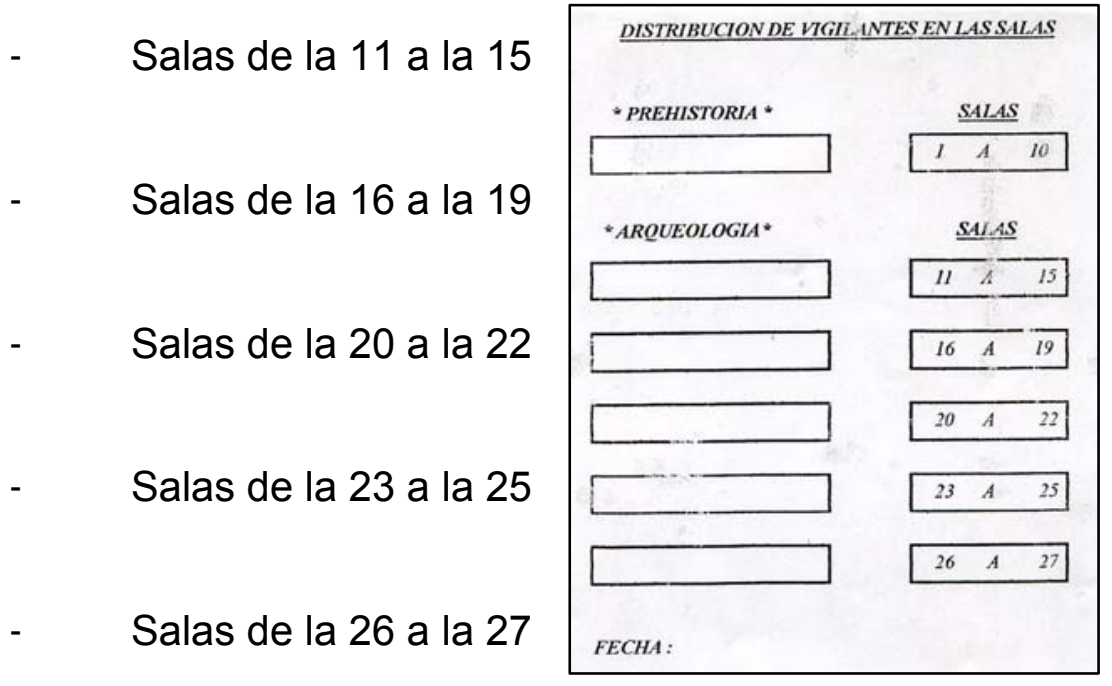

Aunque teóricamente este sistema puede resultar válido, en la práctica da muchos problemas:
Hay que tener en cuenta que en muchas ocasiones el número de vigilantes no siempre está completo por lo que habría zonas desatendidas o más descubiertas de personal.

- Muchas salas, aunque conectadas entre sí, son difíciles de vigilar y se han intentado salvar los muros de separación entre ellas con espejos que ayudan a la visualización de cualquier anomalía que ocurran en las salas anejas, sin embargo, esta solución es bastante

precaria y resulta insuficientemente efectiva para las labores de vigilancia.

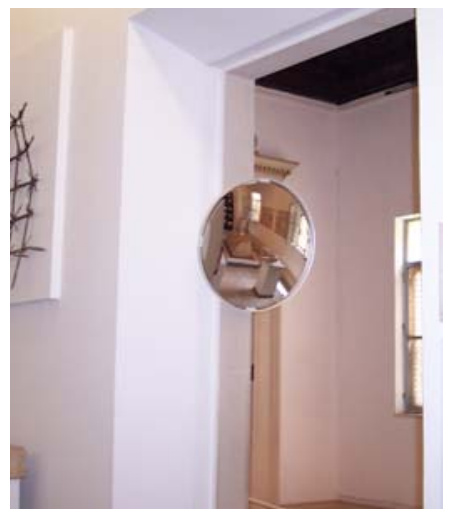




\section{b. Seguridad pasiva para prevención de hurtos y} actos vandálicos.

El centro no cuenta con sistemas pasivos controlados de seguridad perimetral del edificio como vallas o rejas de protección especial.

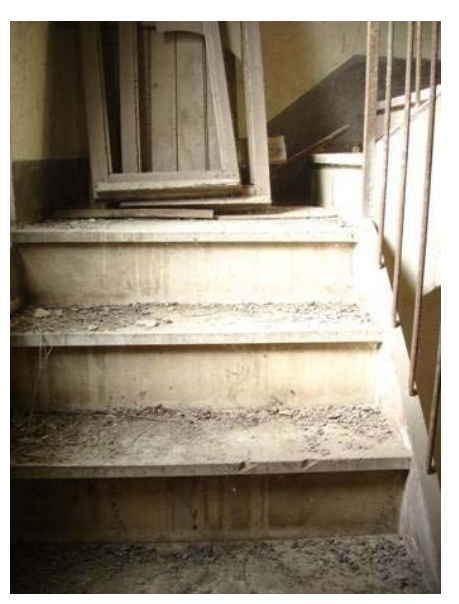

Incluso, el mal estado en que se encuentra el edificio especialmente por algunas zonas, como hemos podido comprobar en el análisis arquitectónico posteriormente analizado, lo hacen muy vulnerable a posibles intrusos tanto en las plantas superiores como inferiores, aunque sobre todo desde las plantas superiores donde hay zonas completamente en desuso y sin sistemas de seguridad que las proteja.

\section{c. Seguridad ante incendios.}

Los detectores de humo están instalados en todo el museo $y$, al igual que las alarmas de seguridad, éstos también son revisados periódicamente.

El detalle más importante que podemos destacar del sistema de seguridad contra incendios y en el que más hincapié hay que hacer es en el sistema de evacuación. Aunque podemos ver en algunas salas las luces de emergencia pertinentes y obligatorias así como la instalación a lo largo del recorrido

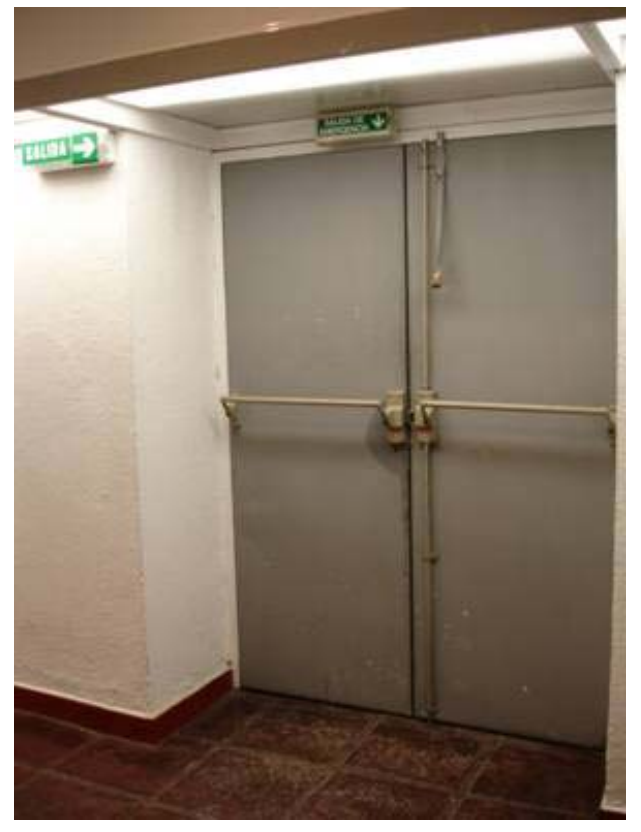


expositivo de algún extintor, sí que se debe destacar que la única salida de emergencia con la que cuenta la planta sótano (Salas dedicadas a la Prehistoria), se encuentre dentro del almacén y no está bien acondicionada ni señalada la ruta hasta llegar a la puerta que da finalmente al exterior del museo.

\section{VI.2. PERSONAL DE SEGURIDAD}

\section{Coordinación y sistema de turnos.}

El personal de seguridad es coordinado por el conserje, encargado de organizar el cuadrante del sistema de turnos y de resolver las cuestiones que vayan surgiendo entre los trabajadores a lo largo del año.

El personal es contratado directamente para el centro desde la Consejería de Cultura, no se trata de una empresa subcontratada como cabría esperar por el ahorro de peso administrativo que supondría para el centro. Además, la empresa sería la encargada de gestionar los despidos o de las contrataciones de los efectivos que en cada momento necesitara el centro así como posibles sustituciones en caso de baja temporal de algún trabajador o de posibles contratos temporales de duración breve para ocasiones especiales. La falta de flexibilidad de la contratación directa se refleja por ejemplo en la carencia de sustituciones en caso de bajas o de días imprevistos como asuntos propios. ${ }^{26}$ Tanto por obligación sindical como por razones de seguridad del museo, éste debería de contar siempre con dos vigilantes al menos en el turno de noche, como podremos comprobar en el Programa de Seguridad previsto más adelante.

El cuadrante del año debe estar cerrado antes de Diciembre y se divide en tres turnos de trabajo: mañana (de 8:00 a 15:00 de la tarde), tarde (de 14:30 a 21:00 de la noche) y noche (de 10:00 a 8:00 de la mañana). Turno especial es de 15:30 a 22:00h. Las compensaciones Fiestas/noches no están incluidas en el cuadrante como

\footnotetext{
${ }^{26}$ Hay que tener en cuenta que el centro se ha podido quedar sin vigilancia nocturna porque durante el turno de noche sólo hay un vigilante y alguna vez por asuntos propios se ha visto obligado a no acudir al museo.
} 
descanso sino que son compensadas con días de trabajo más las bajas, asuntos propios y días de formación. Por esta razón, muy frecuentemente faltan efectivos que son difíciles de cubrir o que no se cubren. Al haber sólo dos taquilleros, cuando falta uno, el vigilante de la sala I ocupa su puesto repartiendo sus tareas.

El turno de mañana se solapa en 30 minutos con el turno de la tarde. La respuesta a este fenómeno es porque durante ese momento se dan las novedades del día. Este solapamiento es necesario aunque suponga un coste extra, resulta muy útil el conocimiento y puesta en común con el siguiente turno de las cuestiones importantes que han ocurrido durante el día.

Como ya hemos señalado, el conserje es el encargado de hacer los turnos y autorizar los días compensados y los días de asuntos propios.
Diariamente se elaboran unos partes que son remitidos al conserje con todas las anomalías que se han producido en el centro y, si fuera necesario, llamar al servicio técnico si se tratara de algún problema de ámbito tecnológico. 


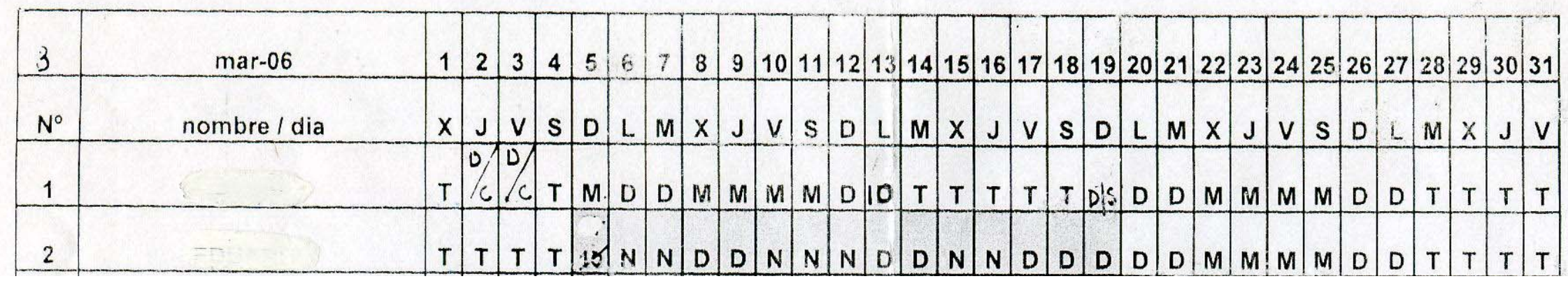

Detalle del cuadrante de turnos diario

\section{VI.3. CONCLUSIÓN}

Tras el análisis realizado, consideramos de importancia que el Programa de Seguridad desarrollado por el proyecto debe contemplar:

- La opción de mejorar los sistemas de seguridad tanto activos como pasivos.
- Ampliar los efectivos de seguridad con los que cuenta el Museo, barajando la posibilidad de externalizar la seguridad a una empresa especializada.

- Un primer acercamiento a la zonificación del museo relacionado con los demás Programas intentando puntualizar las principales zonas de riesgo, tanto de hurto y vandalismo como de incendios. 

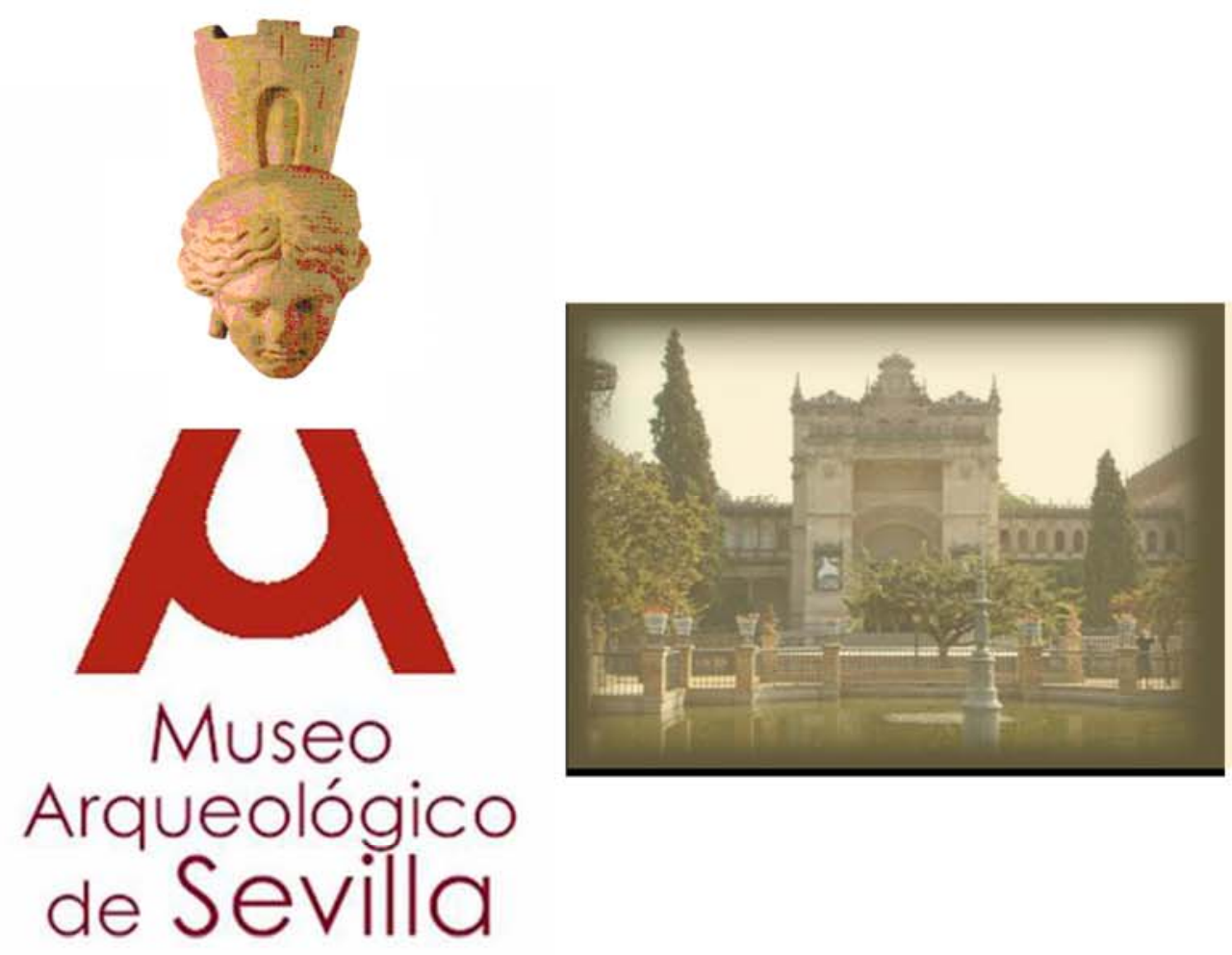

\title{
RECURSOS HUMANOS
}

Patricia Monzo Losada

\begin{abstract}
Sevilla
\end{abstract}




\section{VII.1. ANÁLISIS $Y$ EVALUACIÓN: VII.1.1. Análisis de la estructura técnico- RECURSOS HUMANOS administrativa:}

Nos centraremos ahora en el análisis y posterior evaluación del conjunto de medios humanos con los que cuenta el centro y nos centraremos en especial en:

1. Estructura técnico-administrativa del centro. El objetivo será analizar el organigrama con el que actualmente cuenta el museo.

2. Descripción de los efectivos reales y comprensión la elaboración de la Relación de Puestos de Trabajo de la Junta de Andalucía.

El museo no se encuentra agrupado en su estructura técnico-administrativa por departamentos, sino que se trata de un organigrama funcional de estructura plana. La inexistencia de puestos intermedios coordinadores de áreas de trabajo dificulta en gran medida las labores de organizar objetivos planificados.

La estructura funcional actual permite un desarrollo básico y correcto de las actividades de cada puesto de trabajo o de cada área pero no diferencia entre sectores tan importantes para la organización de un museo como es el de difusión o comunicación, separadamente de investigación de colecciones y de conservación de las mismas.

Aunque sí haya personal encargado de organización de exposiciones o de la difusión dentro del centro, sería 
conveniente la reorganización de la estructura técnicoadministrativa dependiendo no de la nominación de los puestos de trabajo sino desde el punto de vista funcional o departamental, aunque en ocasiones el departamento sea unipersonal.

\section{Organigrama funcional actual del centro}

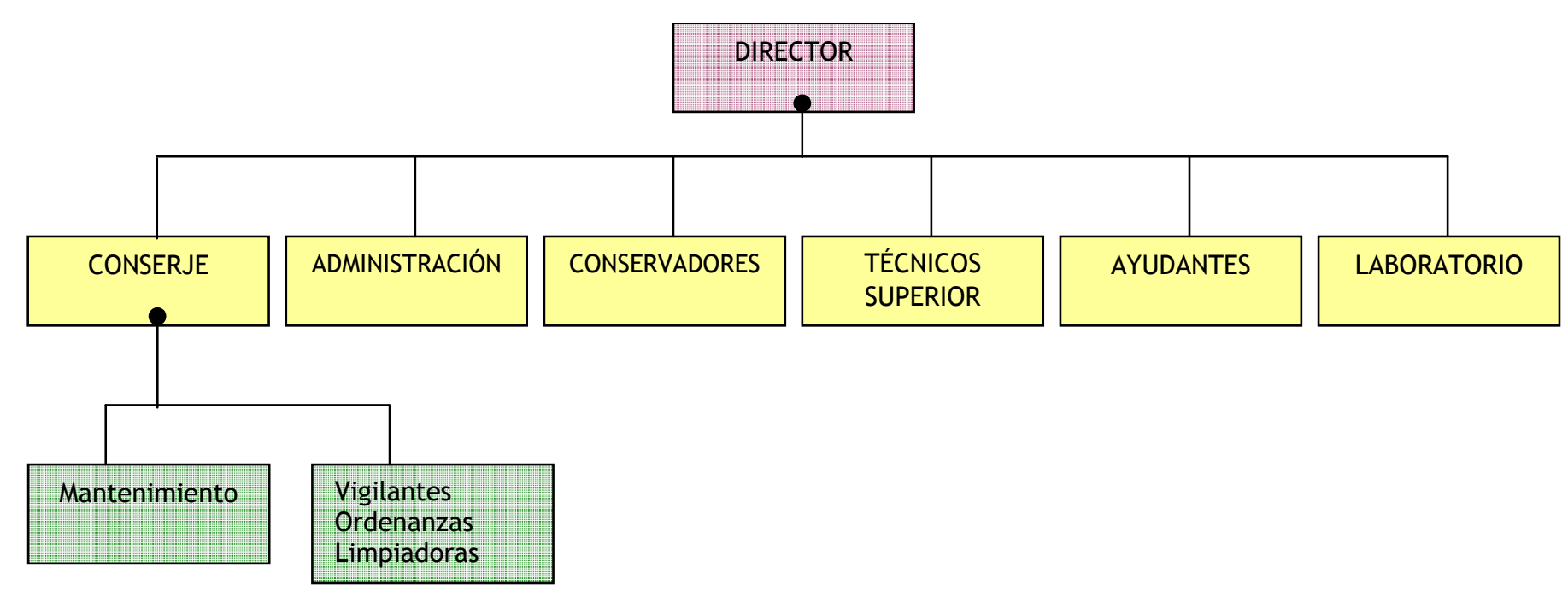


Organigrama determinado por la Auditoría realizada al Museo en 1999

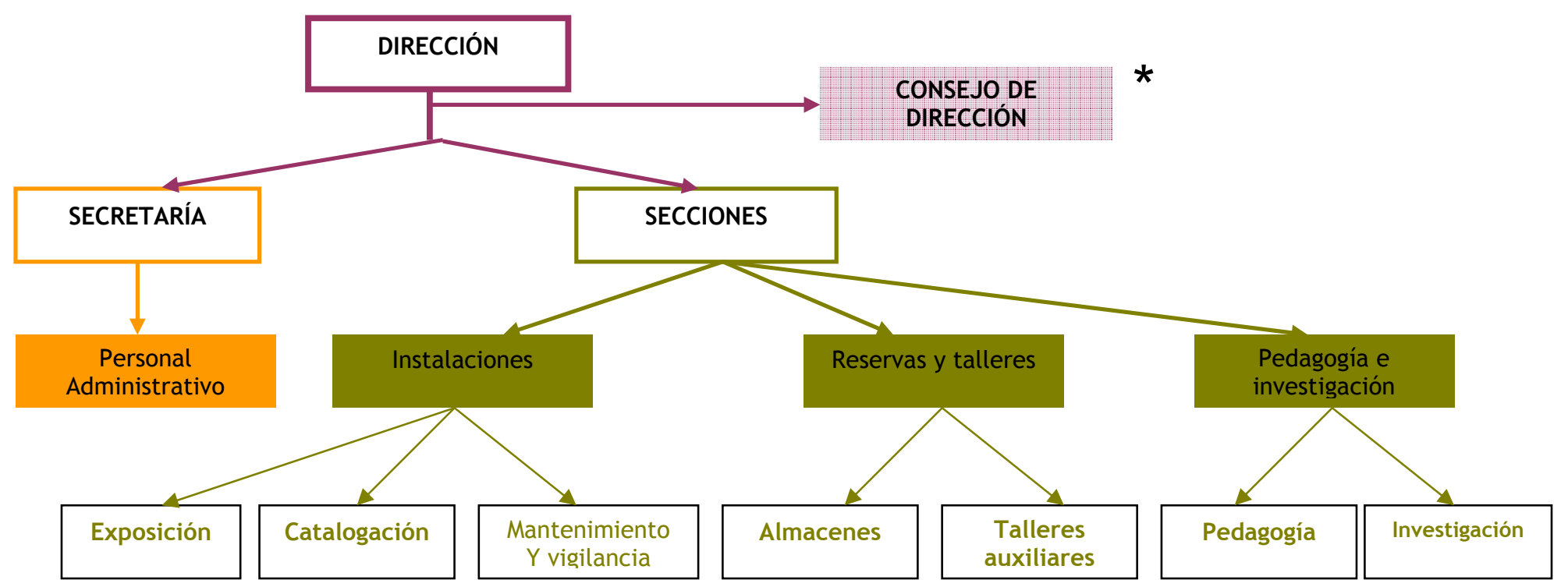

CONSEJO DE DIRECCIÓN: Sería un órgano de decisión colegiado (formado por los técnicos responsables de las área) y cuyas funciones establecen un Plan Anual de Actuación en el que se defina los objetivos, calendarios y medidas para el logro de dichos objetivos del centro. 
En el desarrollo de la auditoría operativa para el Museo Arqueológico de Sevilla de 31 de Diciembre de 1999 hasta 25 de Octubre de 2000, al estudiar las debilidades de este sistema plano de organización del trabajo se determinó la posibilidad de aplicar en el centro el organigrama anteriormente mostrado. Este organigrama si bien presenta una estructura más jerarquizada y administrativamente más efectiva, si la analizamos detenidamente podemos observar incongruencias: no está dividida en áreas departamentales, sino que mezcla lugares de trabajo (ejemplo: "almacenes") con funciones singulares y especializadas (ejemplo: "pedagogía"), también deberíamos destacar el hecho que la secretaría y el personal administrativo siga dependiendo directamente del Director sin ningún tipo de flujo de comunicación intermedio con las Secciones propuestas.

En la creación de los programas habría que determinar la conveniencia de esta nueva organización técnicoadministrativa según el número de efectivos reales que se determinen en la nueva RPT elaborada para el Centro en la segunda fase del proyecto.

\section{VII.1.2. Análisis, descripción de los efectivos reales y comprensión de la elaboración de la Relación de Puestos de Trabajo de la Junta de Andalucía:}

En la Ley 6/85 de 28 de noviembre, de Ordenación de la Función Pública de la Junta de Andalucía "pertenece a la categoría que un Lenguaje político usual denomina leyes institucionales, concepto que intenta evocar una función vertebradora y configuradota de los medios básicos para el ejercicio del poder político".

A través de ella podremos conocer y comprender, entre otras cosas, los términos que se establecen para la elaboración de los puestos de trabajo de la Junta de Andalucía. 
En su artículo 3, Capítulo I Disposiciones Generales, establece que:

1. La Función Pública de la Junta de Andalucía está constituida por las personas integradas en la Administración de la misma y de sus Organismos Autónomos, por una relación de servicios de profesionales y retribuidos, en los términos que en esta Ley se señalan, con independencia de la Administración Pública de donde, en su caso, procedan.

2. No forman parte de ella los titulares de cargos que sean nombrados por Decreto.

La relación de los puestos de trabajo (RPT) son descritos a partir del artículo 11 donde se especifica que:

La Junta de Andalucía, a través de la relación de puestos de trabajo, racionaliza y ordena su Función Pública; determina sus efectivos reales de personal de acuerdo con las necesidades de la organización y de los servicios, trazando previsiones para su evolución futura; precisa los requisitos exigidos para su desempeño, y clasifica y valora cada uno de ellos.

En el artículo 12 podemos leer:

1. Los puestos de trabajo figurarán en una relación, en la que individualmente aparezca cada unos de ellos con las siguientes circunstancias mínimas:

a. Denominación

b. Características esenciales

c. Ente, departamento y centro directivo en que orgánicamente está integrado.

d. Adscripción a funcionarios o laborales en atención a la naturaleza de su contenido

e. Requisitos exigidos para su desempeño, $y$, además, tratándose de funcionarios 
f. Indicación de si el puesto de trabajo es de libre designación

g. Nivel en que ha sido clasificado

h. Complemento específico, con indicación de los factores que se retribuyen con el mismo y su valoración resultante.

En el Decreto 390/1986, de 10 de Abril, por el que se regula la elaboración y aplicación de la relación de puestos de trabajo de la Junta de Andalucía, establece en el artículo 3 que la RPT tiene que comprender exclusivamente los PT de la Administración de la Junta de Andalucía y de sus Organismos Autónomos, que deban ser desempeñados por personal funcionario o personal laboral fijo. Así pues, en la RPT sólo aparecen los puestos de carácter permanente, no así los eventuales, contratos específicos $u$ otras modalidades de contratación. La RPT del museo es creada ajustada a sus necesidades, siendo aprobadas por el Consejo de Gobierno y publicadas en el Boletín Oficial de la Junta de Andalucía (BOJA)
Atendiendo a los datos definitorios del puesto de trabajo, el Decreto 390/1986 de 10 de Abril, en su artículo 4 fija los datos que deben figurar en cada puesto de trabajo, que son los siguientes:

1. Ubicación del puesto: organismo, centro directivo y centro de destino en que se encuentra el puesto de trabajo.

2. Código numérico que identifica al puesto de trabajo e indica el organismo al que pertenece.

3. Denominación: nombre del puesto de trabajo

\section{Adscripción funcionario/laboral:}

En el artículo 12.2 la Ley 6/85 se especifica que:

A los efectos de previstos en la letra d) del apartado anterior (12.1d: adscripción a funcionarios o laborales en atención a la naturaleza de su 
contenido), con carácter general, los puestos de trabajo de la Administración de la Junta de Andalucía y de sus Organismos Autónomos serán desempeñados por funcionarios públicos.

Podrán exceptuarse de la regla anterior y adscribirse a personal laboral en la correspondiente relación de puestos de trabajo:

- Los puestos de naturaleza no permanente y aquellos cuyas actividades se dirijan a satisfacer necesidades de carácter periódico y discontinuo.

- Los puestos cuyas actividades sean propias de oficios, así como los de vigilancia, custodia, porteo y otros análogos.

- Los puestos de trabajo de carácter instrumental correspondientes a las áreas de mantenimiento $y$ conservación de edificios, equipos e instalaciones, artes gráficas, encuestas, protección civil y comunicación social, así como los puestos de las áreas de expresión artística y los vinculados directamente a su desarrollo, servicios sociales y protección de menores.

- Los puestos correspondientes a áreas de actividades que requieran conocimientos técnicos especializados cuando no existan Cuerpos de funcionarios cuyos miembros tengan la preparación específica para su desempeño.

\section{Modo de acceso:}

El sistema normal de acceso para el personal funcionario es el concurso-oposición, también para el personal tanto funcionario como laboral se puede acceder por el concurso de méritos (trabajo realizado, formación, titulaciones y antigüedad).

\section{Tipo de Administración}

\section{Características esenciales:}


Se trata de una serie de requisitos imprescindibles exigidos al funcionario para ocupar cada uno de los puestos de trabajo.

- Grupo de clasificación profesional: se determina a partir de la titulación académica exigida para poder desempeñar el puesto dentro de la Función Pública. Son denominados con una letra los funcionarios y con un número los laborales:

- Grupo A/1: Titulados superiores.

- Grupo B/2: Titulados medios (Diplomaturas, Formación Profesional de tercer grado y equivalentes).

- Grupo C/3: Bachiller, Formación Profesional de segundo grado.

- Grupo D/4: Graduado escolar.

- Grupo E/5: Certificado escolar.

\section{- Cuerpo:}

- Determina la carrera administrativa y la promoción interna, aunque para acceder a ellos se exigen pruebas comunes de acceso.

- El texto Articulado de la Ley de Funcionarios Civiles del Estado establece los siguientes Cuerpos Generales: Técnico, Administrativo, Auxiliar y subalterno (art.23) y Cuerpos especiales: ejercen actividades que constituyen el objeto de un peculiar carrera o profesión (art.24): ejercen actividades que constituyen el objeto de una peculiar carrera o profesión, que en Andalucía se clasifican de la siguiente forma:

\section{- Grupo A:}

- A1 Cuerpo Superior de Administradores.

Especialidades:

○ A1.1 Administradores generales 
- A1.2 Administradores de Gestión Financiera

\section{- A2 Cuerpo Superior} Facultativo. Especialidades.

- Grupo B:

- B1 Cuerpo Gestión Administrativa.

Especialidades.

- B1.1 Administración General

- B1.2 Gestión Financiera

- B2 Cuerpo de técnicos de Grado Medio

- Grupo C:

- C1 Cuerpo General de Administrativos
- C2 Cuerpo de Ayudantes Técnicos

- Grupo D:

- D1 Cuerpo de Auxiliares Administrativos

- D2 Cuerpo de Auxiliares Técnicos

- Grupo E:

- E1 Cuerpos de Subalternos Cuerpo de Oficios varios.

\section{- $\quad$ Área Funcional}

Se entiende por área funcional el conjunto de actividades y tareas homogéneas con características comunes respecto de los conocimientos y formación necesarios, así como de 
los procedimientos de trabajo utilizados. Todos los Puestos de trabajo se deben adscribir a un Área funcional.

\section{- Área relacional}

Es un área fundacional distinta a la que se encuentra adscrito el puesto de trabajo, con la que se relaciona en función de los cometidos, características y procedimientos de trabajo análogos que desarrolla. Algunos puestos de trabajo podrán adscribirse a un área relacional e incluso, excepcionalmente a dos.

\section{- $\quad$ Complemento de destino}

Es un elemento retributivo cuyo valor en euros está en función del nivel de puesto de trabajo desempeñado. Los niveles, del 1-30, se asignan por tramos a cada unos de los grupos: Grupo A:13-30; Grupo B: 11-26; Grupo C: 10-22; Grupo D: 8-18; Grupo E: 7-14.

\section{- $\quad$ Complemento específico}

Destinado a retribuir condiciones especiales de algunos puestos de trabajo, por su especial dificultad técnica, dedicación, responsabilidad, incompatibilidad, peligrosidad/penosidad... En la RPT se indican marcando con una $\mathrm{X}$ los complementos específicos asignados al puesto de trabajo, de entre cinco existentes:

Responsabilidad, Formación, Incompatibilidad, Dedicación, Peligrosidad.

\section{Requisitos para el desempeño:}

Para algunos puestos de trabajo se indican determinados requisitos, que debe reunir el candidato para ocupar dicho puesto de trabajo. 
Experiencia exigida para ocupar el puesto de trabajo, independientemente de aquella que fue necesaria para participar en las pruebas de acceso a la Función Pública.

Titulación específica requerida para ocupar un puesto de trabajo, independientemente de aquella que fue necesaria para participar en las pruebas de acceso a la Función Pública.

Formación especializada requerida para ocupar un puesto de trabajo.

\section{Localidad en que se encuentra el puesto de} trabajo

\section{Otras características:}

Especifica determinadas condiciones que debe reunir el funcionario para ocupar un puesto de trabajo, no recogidas en el resto de los epígrafes de la RPT.
Las nominaciones de los puestos de trabajo son las siguientes:

- Director

- Conservador

- Asesor técnico-conservación e investigación

- Asesor técnico-difusión

- Titulado superior

- Ayudante museo

- Administrativo

- Auxiliar administrativo

- Restaurador

- Oficial primera oficios

- Oficial segunda oficios

- Expendedor

- Ordenanza

- Peón

- Conserje

- Limpiador/a 
- Vigilante

- Si consideramos 40 el número total de puestos de trabajo $(100 \%)^{27}$ obtendremos los siguientes resultados:

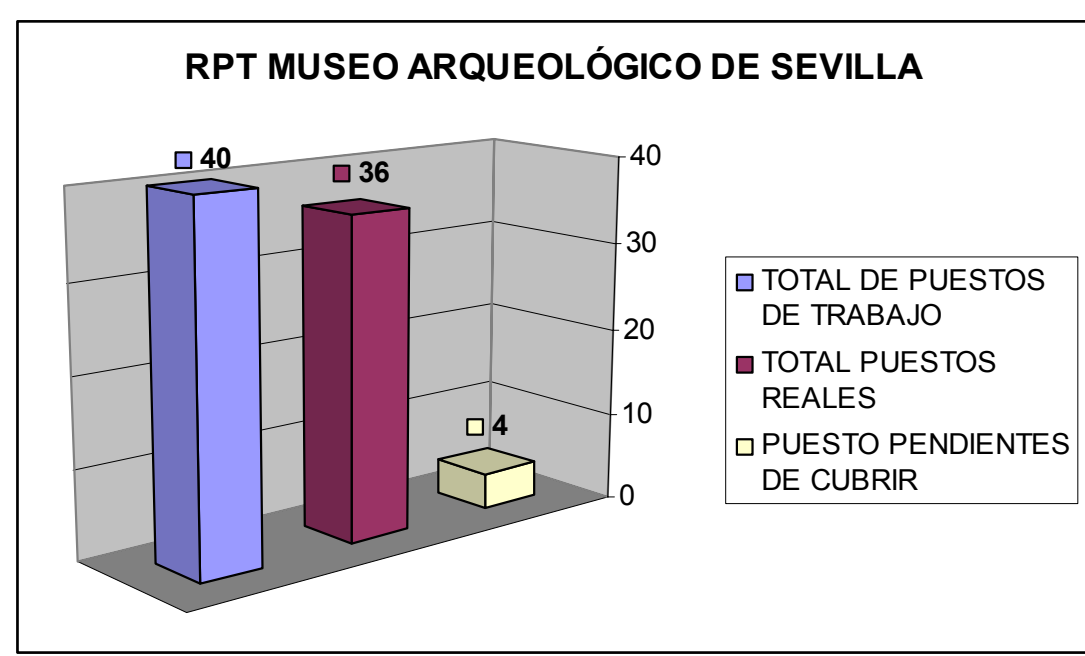

Gráfica 1

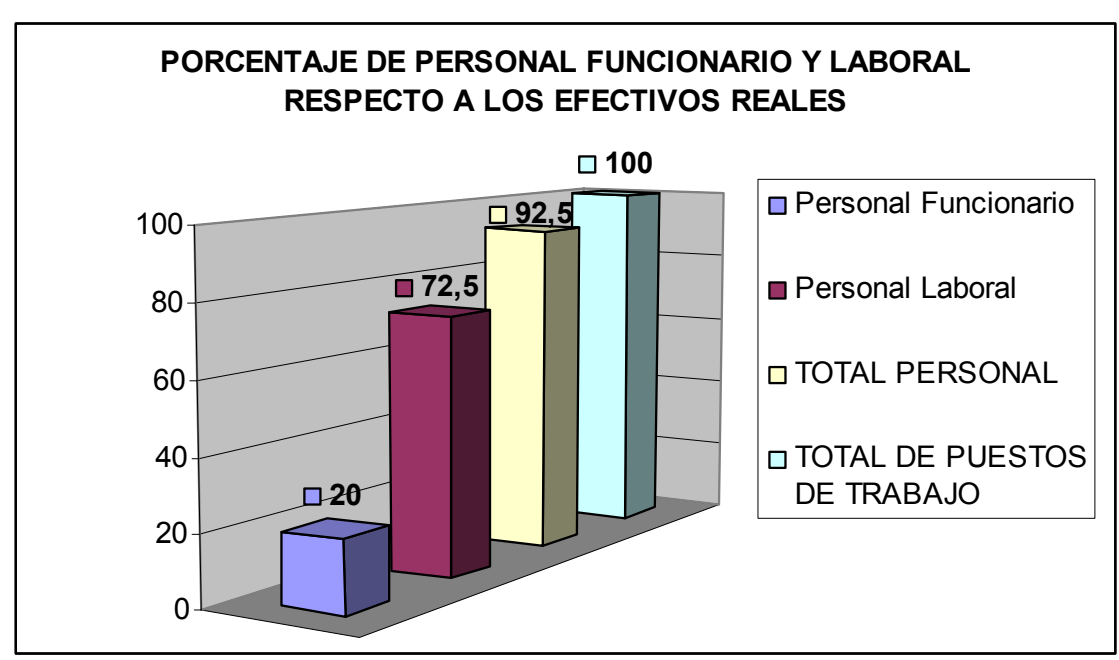

Gráfica 2

${ }^{27} 40$ era el número previsto de puestos de trabajo que debían haberse cubierto según la RPT de 21/06/2005 
Desde la elaboración de la auditoría operativa del museo del 31 de Diciembre de 1999 hasta 25 de Octubre de 2000, observamos que se han creado otras nominaciones de puestos de trabajo de los que carecía el centro, como son: un Asesor técnico-conservación e investigación, asesor técnico-difusión, restaurador.

Sin embargo, el centro carece de un puesto dedicado a la atención al público, tanto del que llega al centro como alguien que pueda resolver cuestiones y recoger sugerencias a través de la Web del museo así como actualizarla periódicamente. A esto habría que añadir de nuevo la importancia de un cambio en la estructura técnicoadministrativa, pues gracias a una buena red interna se podrán de coordinar las áreas funcionales y planificar con facilidad los objetivos de cada una de ellas.

Podemos apreciar en la Gráfica 1 que el centro cuenta casi con la totalidad de todos los efectivos propuestos en la elaboración de la RPT, sin embargo, en la segunda fase de nuestro proyecto debemos evaluar no sólo los puestos vacantes sino los puestos que no existan y que se crea necesaria su creación.

El personal funcionario, como bien podemos apreciar en la gráfica 2, es un porcentaje muy reducido si lo comparamos con el total de efectivos laborales con los que cuenta el centro. El horario de la mayoría de ellos es de turno de mañana, de lunes a viernes. Sin embargo, debemos subrayar y explicar con mayor detenimiento el sistema de turnos del personal de vigilancia ${ }^{28}$.

\footnotetext{
${ }^{28}$ Para no resultar reiterativos y al contar con un apartado importante y específico, el sistema de turnos es detallado en la parte de análisis de la seguridad con la que cuenta el centro.
} 


\section{VII.2. CONCLUSIÓN}

En suma, podemos destacar los siguientes datos como puntos importantes a desarrollar en la siguiente fase de nuestro proyecto:

- Cambiar el organigrama funcional en el que se estructura la base técnico-administrativa del centro.

- Planificando las distintas áreas según la elaboración y consecución de objetivos a corto, medio y largo plazo, en parte, relacionados con la gestión económica del centro.

- Adecuación de la estructura técnico-administrativa a las necesidades del museo. Podríamos vaticinar la importancia de la elaboración de puesto intermedios, así como la creación de relaciones por áreas departamentales y no por nombres del puesto de trabajo.

- Debemos evaluar económicamente para hacerlo viable en el presupuesto, no sólo los puestos vacantes sino los puestos que no existan y que se crea necesaria su creación.

- Elaboración de un plan de riesgos laborales específico para el ámbito del museo, donde se recojan los distintos puestos y sus peculiaridades en torno al tema de la prevención de riesgos en el trabajo. 

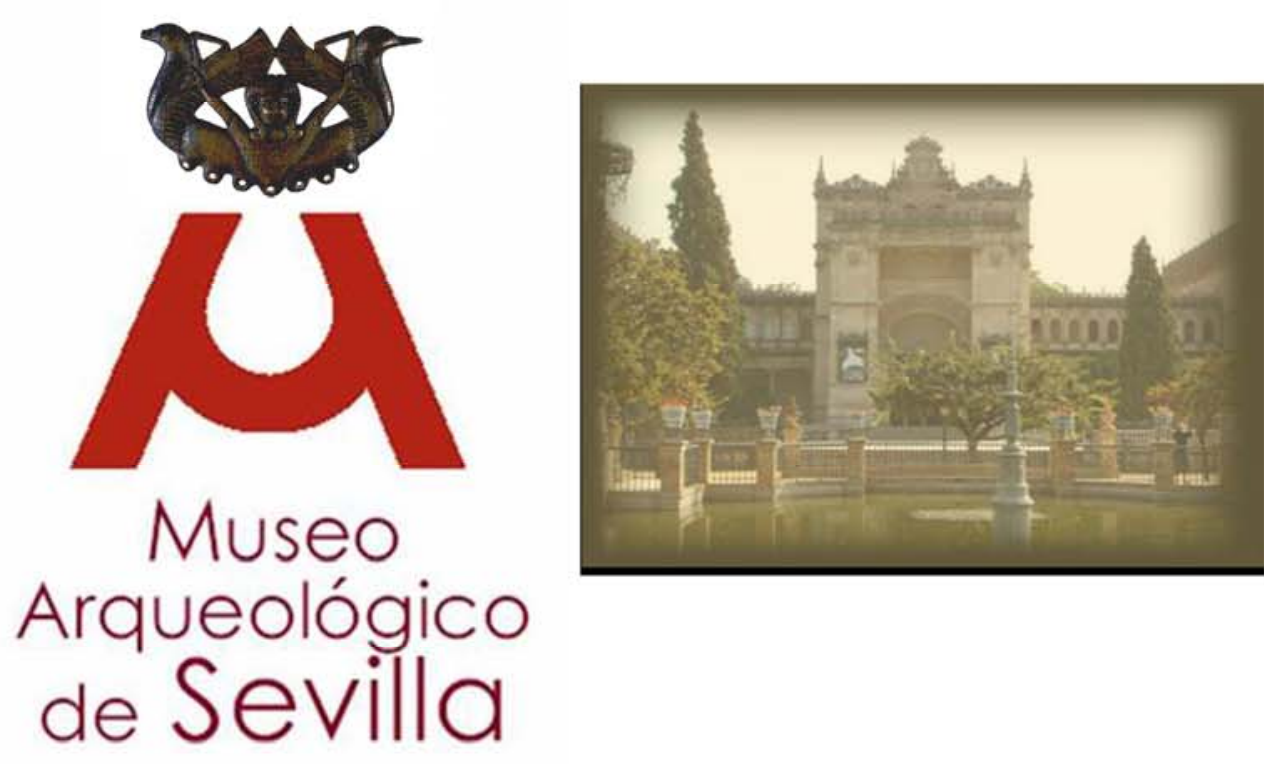

\section{RECURSOS ECONÓMICOS}

Patricia Monzo Losada de Sevilla 
VIII.1. ANÁLISIS Y EVALUACIÓN: RECURSOS ECONÓMICOS

Para la realización del análisis de los recursos económicos del Museo Arqueológico de Sevilla hemos obtenido la información desde diferentes fuentes, entre ellas:

- Auditoria operativa del Museo Arqueológico de Sevilla, 31 de Diciembre de 1999 hasta 25 de Octubre de 2000. Según normas de auditoria establecidas para el sector público.

- Fuentes económicas determinadas por las partidas presupuestarias anuales facilitadas por el personal del museo, años desde el 2003 al 2005.
En el análisis financiero tendremos en cuenta tanto la evaluación de Gestión Eficiente como la Gestión Económica ${ }^{29}$.

Analizaremos sobre todo el capítulo 2 de la Orden de 7 de Junio de $2002^{30}$, referente a los gastos corrientes en bienes y servicios.

El Museo Arqueológico de Sevilla es un Centro de titularidad estatal, gestionado por la Junta de Andalucía en los términos descritos en el convenio sobre gestión de los Archivos y de Museos de Titularidad Estatal de fecha de 8 de Junio de 1984. Dicha gestión es ejercida mediante la Consejería de Cultura de acuerdo con lo dispuesto en el

\footnotetext{
${ }^{29}$ Gestión Eficiente: Aquella que permite transformar los recursos disponibles en productos o servicios de la forma más productiva o al menos coste.

Gestión económica: Aquella en la que la adquisición de recursos debe hacerse en el tiempo oportuno, a un coste lo más bajo posible, en cantidad apropiada y calidad aceptable.

Información adquirida de la Auditoría operativa del Museo Arqueológico de Sevilla, del 31 de Diciembre 1999.

${ }^{30}$ BOJA n. ${ }^{\circ} 71$, Sevilla 18 de Junio de 2002. Orden de 7 de Junio de 2002, por la que se dictan las normas para la elaboración de Presupuesto de la Comunidad Autónoma de Andalucía.
} 
artículo 41.4 de la Ley Orgánica 6/1981 de 30 de Diciembre de Estatuto de Autonomía de Andalucía. Mediante el Decreto 864/1984 de 29 de Febrero la gestión es transferida por el Ministerio de Cultura a la Junta de Andalucía, aunque la titularidad del edificio y del fondo sigue siendo estatal

Atendiendo a la alta estructura administrativa el Centro, gestionado por la Junta de Andalucía, tendría actualmente el siguiente organigrama:

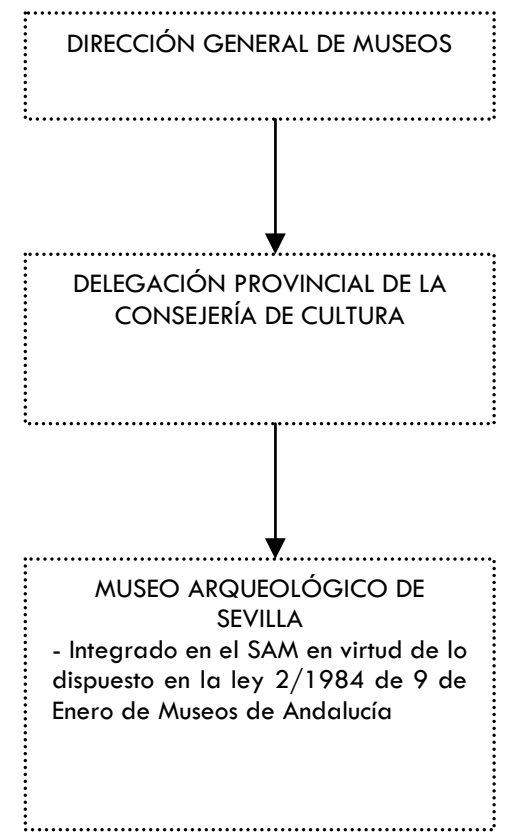

\section{VIII.1.1. Análisis de la evolución presupuestaria}

Para el análisis de la evolución presupuestaria, hemos realizado un estudio de las diferentes partidas desde el año 2003 al 2005. Podemos determinar una doble problemática: si bien debemos hablar de una débil gestión del presupuesto en estos años analizados, también hay que subrayar la dificultad que supone cubrir plenamente las necesidades del centro debido al bajo nivel presupuestario con el que cuenta el Centro en comparación con los otros Museos sevillanos que gozan de la misma titularidad y gestión, como son el Museo de Bellas Artes y el Museo de Artes y Costumbres Populares

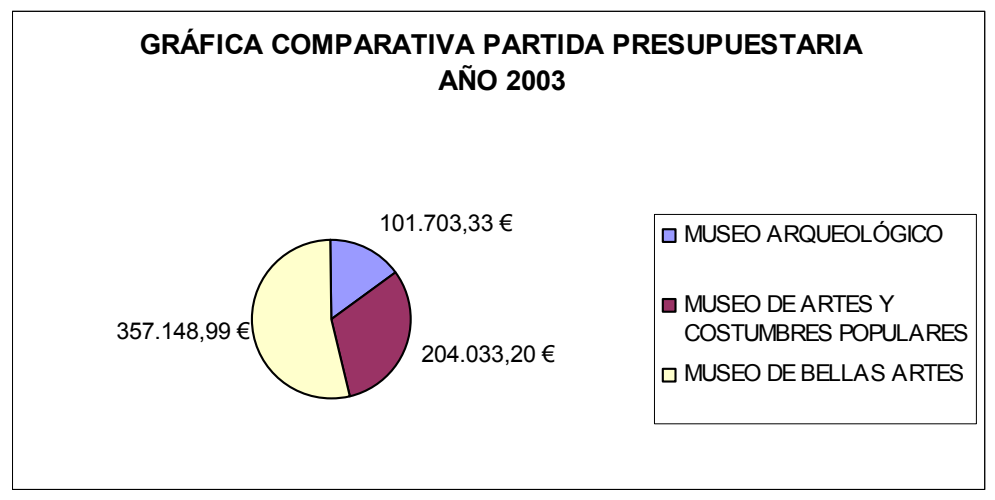



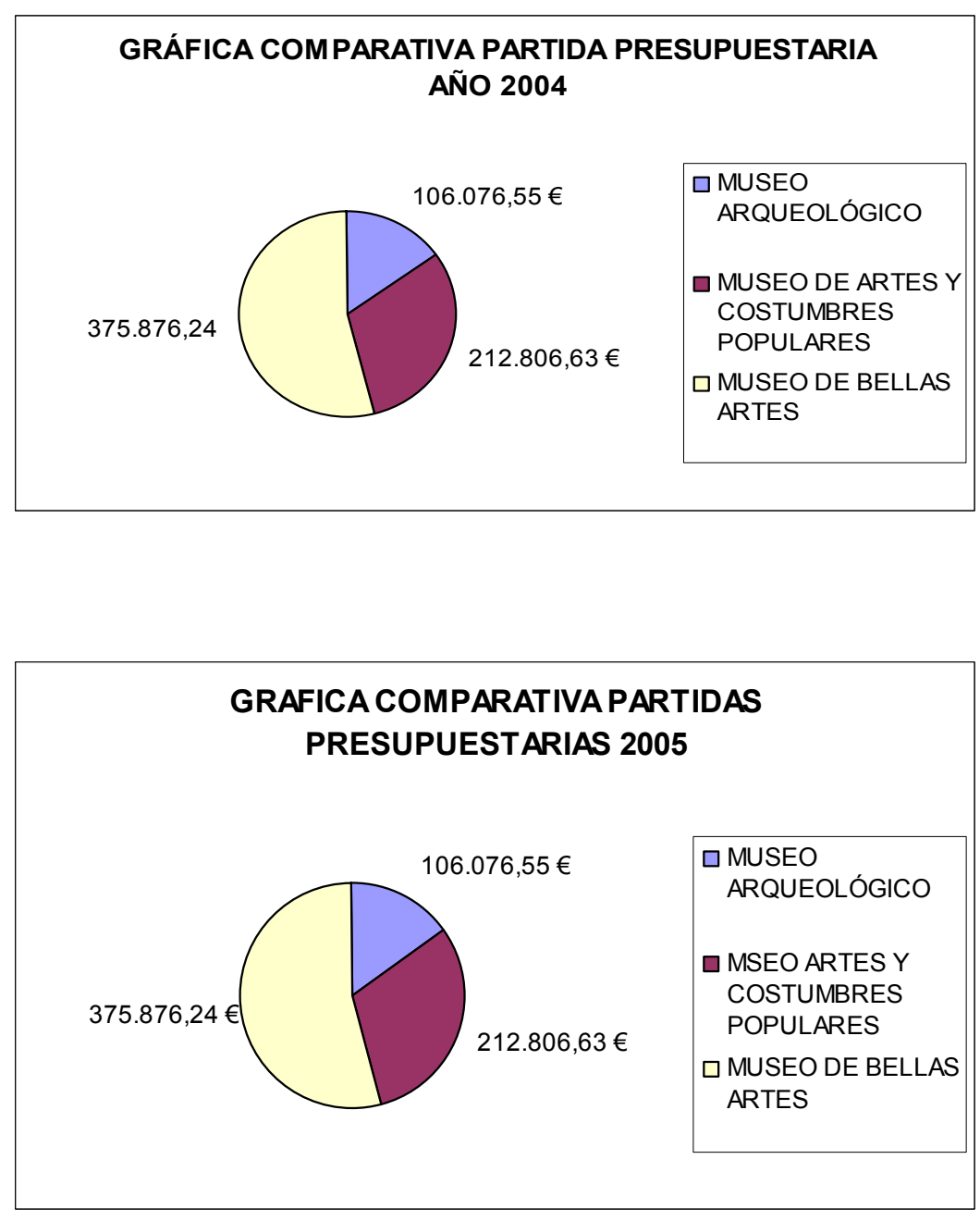

Como podemos observar en las gráficas, el Museo de Arqueología es el menos favorecido en cuanto al reparto presupuestario del capítulo 2 de los Presupuestos Generales en Gastos Corrientes en Bienes y Servicios.

Una de las causas de esta diferencia presupuestaria podría deberse a la carencia de climatización del centro, lo cual reduce la necesidad de un amplio gasto en electricidad. Sin embargo, no hay que olvidar una cuestión importante a tener en cuenta en la gestión de este tipo de museos de arqueología, esto es, la imposibilidad de gestionar su propio crecimiento, que en la mayoría de los casos desborda la capacidad del propio museo, tanto de almacenaje de los fondos como de su mantenimiento. Este punto importante hace que deba ser incrementado no sólo el número de personal pendiente de inventariar los nuevos fondos y el mantenimiento de éstos como veremos más adelante, sino de tener en perfectas condiciones las zonas 
de reserva y almacenaje así como la actualización de los equipos informáticos para su inventario y catalogación.

En la siguiente gráfica podemos apreciar el aumento presupuestario que el museo ha tenido en los últimos tres años. El presupuesto se ha mantenido prácticamente al mismo nivel, sólo ha recibido un pequeño aumento del $4 \%$ en el año 2004 que se ha mantenido durante el año 2005. Este aumento también se ha hecho en el museo vecino de Artes y Costumbres Populares, y de un $5 \%$ en el Museo Bellas de Bellas Artes.

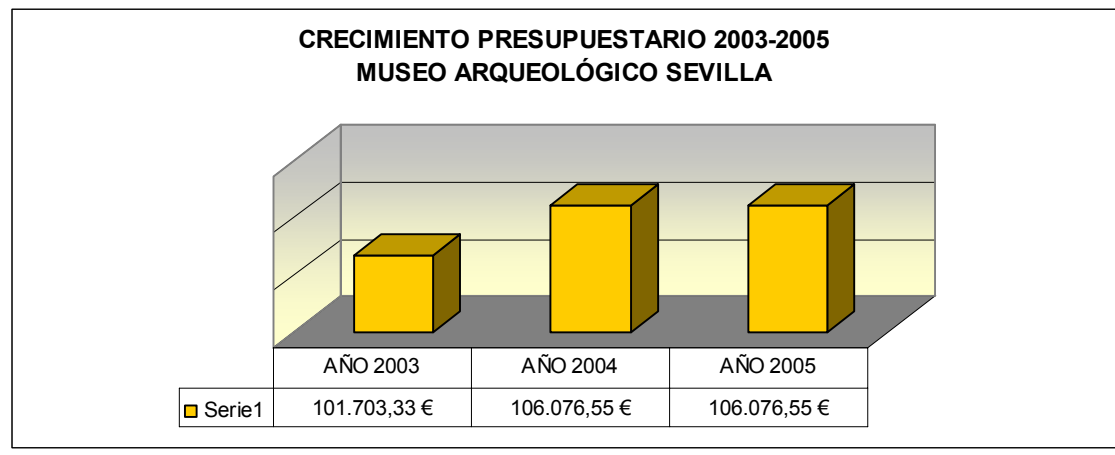

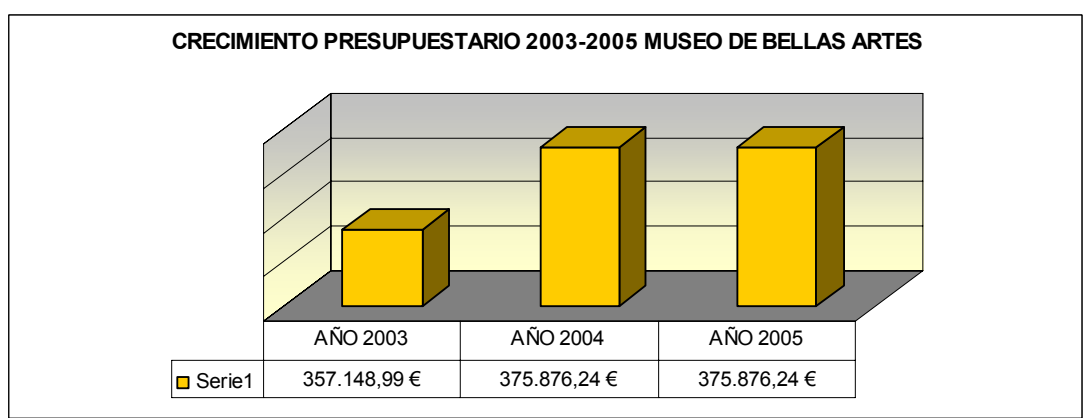

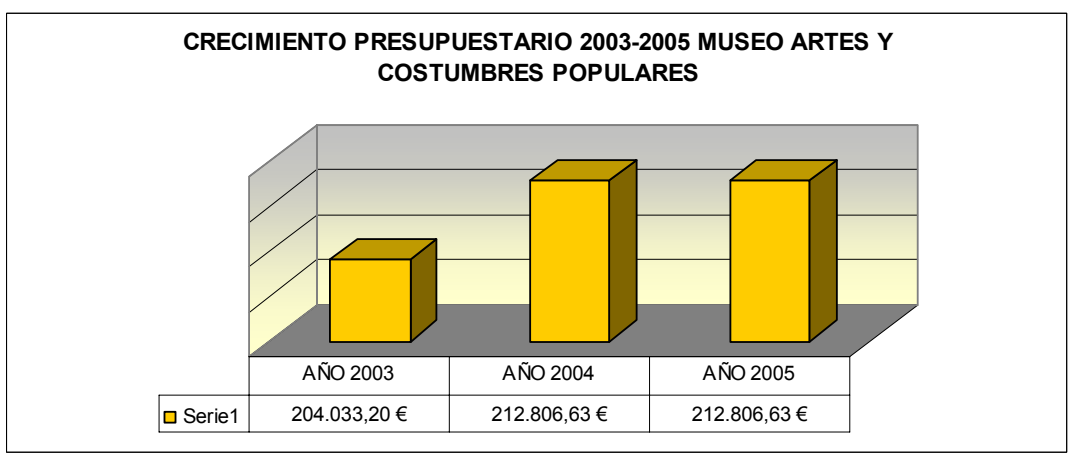

Los datos presentados nos muestran que el aumento del presupuesto en gastos corrientes en bienes y servicios se ha llevado a cabo de forma prácticamente homogénea y no porque se haya realizado un estudio previo a la concesión presupuestaria por parte de la administración gestora de las necesidades de cada uno de los centros. 


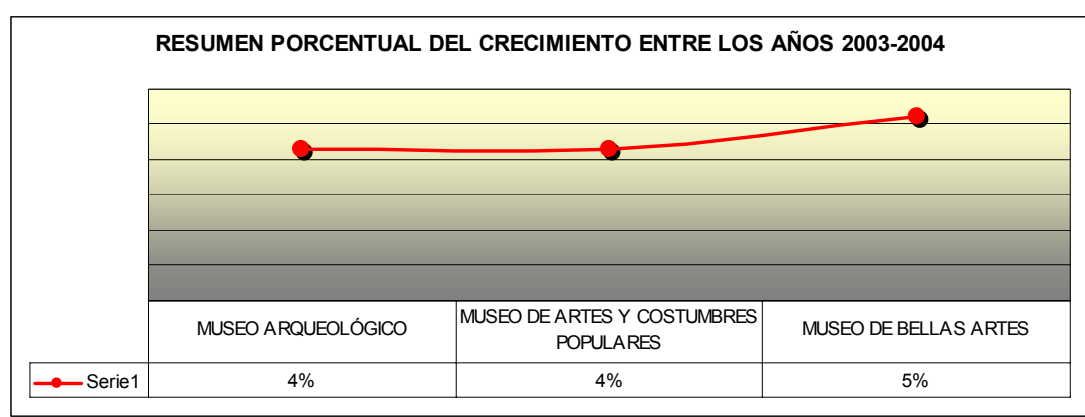

Si observamos la gráfica siguiente, nos damos cuenta de la debilidad del Centro en su capacidad de planificación de la gestión del presupuesto.

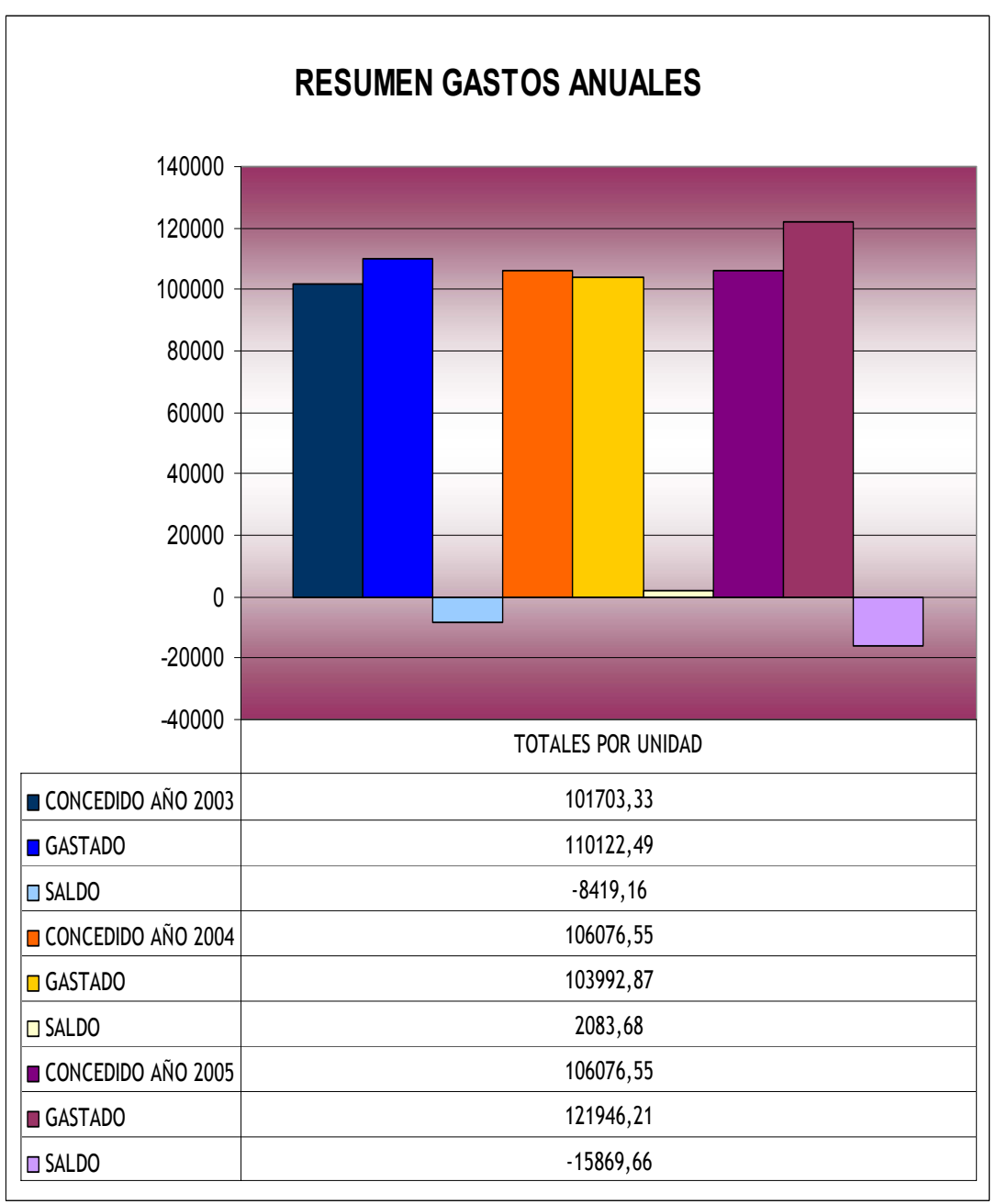


El desfase presupuestario del 2003 es prácticamente duplicado en el 2005, sin embargo, el 2004 contó con presupuesto positivo, lo cual no quiere decir que fuera el resultado de una gestión eficiente y económica del presupuesto sino que debemos leerlo como una falta de planificación a largo plazo de las necesidades del centro. El resultado es un desfase presupuestario en el 2005, como hemos señalado anteriormente, de -15869'66€ que serán prácticamente en su totalidad recortados del presupuesto otorgado para el 2006.

El presupuesto anual, repartido en diferentes conceptos, es gestionado a lo largo del año. Así pues, el presupuesto otorgado sufre modificaciones, pues la clasificación económica del gasto ${ }^{31}$ está dividido en una serie de artículos, conceptos y de subconceptos. Estos últimos son intercambiables entre ellos, pero el presupuesto está vinculado a nivel de artículo lo que supone que las

\footnotetext{
${ }^{31}$ BOJA 113, del 16 de junio de 2003, anexo IV. Clasificación económica del gasto
} público. Operaciones corrientes. modificaciones presupuestarias tengan que ser aprobadas según el volumen de gasto por la Consejería de Cultura, la Consejería de Economía y Hacienda o el Consejo de Gobierno. $^{32}$

La dependencia presupuestaria resta flexibilidad a las acciones para captar ingresos, para gestionar un presupuesto propio y hace, si cabe, más necesaria la planificación a largo plazo del gasto. Estos estudios deberían ser presentados con una anterioridad de al menos 3 ó 4 años a fin completar los objetivos y los programas que cada departamento considerase oportuno.

Tampoco contamos en el centro con un análisis de las inversiones que se han ido realizando, inversiones que deberían estar detalladas no como gastos sino como gestión eficiente de los presupuestos y por tanto incluidas en los estudios anuales que se deben presentar a la

\footnotetext{
${ }^{32}$ El artículo 21, concepto 221.04 (Suministro. Vestuario) cuya cantidad es global para todos los centros, responde a una deuda común. Por sus características no se puede hacer una previsión del gasto de este capítulo.
} 
Delegación Provincial a fin de que anualmente tengan conocimiento detallado de las necesidades y objetivos del centro para los próximos años. Las inversiones en obras y servicios, equipamientos... son necesarias para la amortización de los presupuestos otorgados que no deben ser siempre consumibles a corto plazo sino rentables a la totalidad del centro. ${ }^{33}$

El Centro no percibe ningún ingreso derivado de cafetería, librería o tienda al no disponer de este tipo de servicios. Según lo dispuesto en el Real Decreto 496/1994, de 17 de Marzo, por el que se modifica el artículo 22 del Reglamento de Museos de Titularidad Estatal y del Sistema Español de Museos ${ }^{34}$ :

\footnotetext{
${ }^{33}$ En este tipo de inversiones podemos incluir por ejemplo la obra de actualización del tendido eléctrico en el Museo durante este año 2006, que permitirá la mejora de otras instalaciones que necesitaban una red eléctrica moderna y actualizada como la instalación de la climatización. Además, la antigua red suponía un peligro no sólo para la estructura arquitectónica del edificio en algunas zonas sino que suponía, en ocasiones, un peligro para los propios trabajadores.

${ }^{34}$ Reglamento de Museos de Titularidad Estatal y del Sistema Español de Museos, aprobado por Real Decreto 620/1987, de 10 de Abril.
}

Artículo único (...)

"1. En la visita a cualquier museo de titularidad estatal se respetará la igualdad de trato entre los españoles y los nacionales de los restantes Estados miembros de la Unión Europea, previa acreditación de su nacionalidad.

2. Por Orden se aprobarán los precios de entrada a los museos de titularidad estatal.

3. Se accederá en condiciones de gratuidad a los museos de titularidad estatal, al menos cuatro días a la semana, previamente señalados por los órganos a que se refiere el apartado $1 \mathrm{del}$ artículo anterior y que figurarán a la entrada de los museos.

4. Por Orden ministerial se podrán establecer regímenes especiales de acceso gratuito o de precios reducidos para períodos o para colectivos determinados en atención a las circunstancias culturales o sociales que concurran en los mismos. 
Las Comunidades Autónomas que gestionen museos de titularidad estatal podrán establecer los regímenes complementarios que consideren pertinentes."

Por orden de la Consejería de Cultura, se ha fijado la gratuidad de la entrada en los museos de titularidad estatal y gestionada por la Junta de Andalucía. De los datos obtenidos gracias a la Auditoría operativa realizada en el Museo del 31 de Diciembre de 1999, podemos observar que durante el 98 y 99, los ingresos en el Museo provenían de las visitas que se les cobraba a los usuarios extranjeros así como las tasas por reprografía.

El museo sólo se encargaba de gestionar los cobros, sin poder modificar por tanto las tarifas aplicadas y la tipología de los usuarios a quienes se cobra, pues ésta se regula legalmente.

Habría que establecer un estudio de cuánto supondrían los ingresos no sólo de una nueva tasa del precio de la entrada, sino también y como veremos en la siguiente fase del proyecto, de los ingresos originados por el servicio de cafetería, de librería, tienda, así como los ingresos que se derivarían del cobro de los precios establecidos para la utilización de espacios museísticos para la organización de exposiciones temporales y el alquiler de espacios para fines no meramente museísticos: conferencias, seminarios... 


\section{VIII.2. CONCLUSIÓN}

Del análisis realizado podemos subrayar los siguientes puntos:

- La necesidad de una gestión planificada de los gastos a largo, medio y corto plazo donde se vieran reflejados las previsiones de gasto en cuanto a personal, gastos corrientes en bienes y servicios, inversiones...

- Estudio y control de las inversiones anuales.

- Estudio del aumento del presupuesto derivado por la captación de ingresos provenientes generados por los servicios del propio museo:

- Nueva tarifa de entrada
- Otras aportaciones: tienda, derechos de reproducción, alquiler de espacios...)

- Aportaciones de las subvenciones, tanto de la Asociación de Amigos como de la captación de otras. 

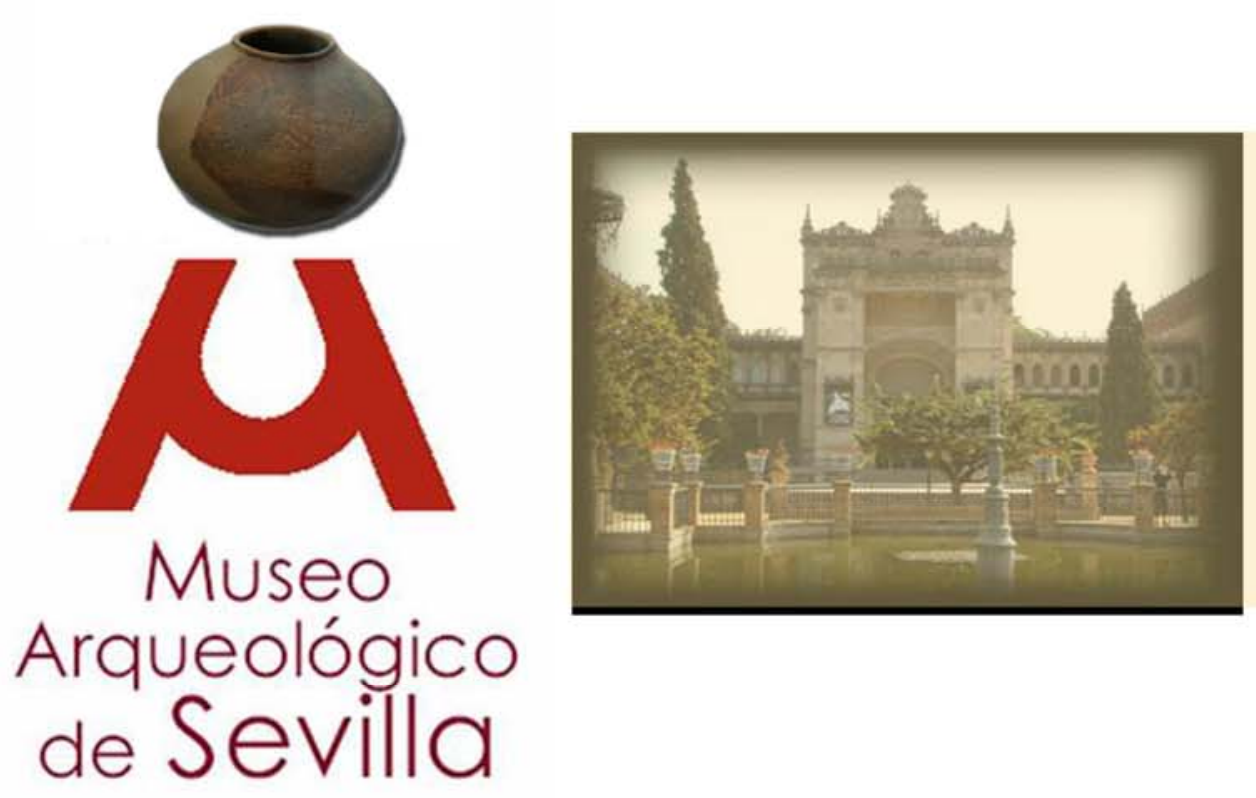

CONCLUSIÓN GENERAL ANÁLISIS Y EVALUACIÓN 


\section{IX.1. CONCLUSIONES DE LA PRIMERA}

\section{FASE. LÍNEAS DE ACTUACIÓN DE LOS}

PROGRAMAS

Tras el análisis y evaluación realizados podemos derivar las siguientes conclusiones generales que serán pilar fundamental en el que basaremos nuestros estudios de los Programas correspondientes.

En general podemos destacar la necesidad de abordar en profundidad las siguientes cuestiones:

- Gestión óptima del museo con una remodelación integral tanto del organigrama funcional como de la planificación económica para poder llevar a cabo los Programas en las fases que definitivamente se propongan.
- La definición de las necesidades que el museo debe de cubrir en sus diferentes servicios, tanto a la sociedad como a su propio personal con la realización de potentes Programas de Difusión y Recursos Humanos.

- El análisis del museo inserto dentro de un espacio mayor vinculado desde su entorno inmediato hasta un ámbito más internacional, una institución de conservación patrimonial que relacione territorio y colección.

- Establecimiento de unos objetivos generales, línea a seguir en la programación y gestión del Museo a fin de conseguir lo previamente definido en la Misión. 
- Debemos subrayar la importancia de insertar todas las reformas que se han establecido en el análisis dentro de un fuerte Programa Arquitectónico que resuelva todas las necesidades del funcionamiento y remodelación del edificio, así como la posibilidad de proyectar un nuevo espacio.

- Tras el análisis realizado hemos podido observar la importancia de estudiar el museo como una institución de conservación del Patrimonio en la que confluye la seguridad tanto de personal, de visitantes como de las colecciones.
- La propia naturaleza del Museo nos ha llevado a la necesidad de realizar un importante Programa de Colecciones que contemple la gestión del incremento y documentación de las piezas de una forma ordenada, clara y efectiva que facilite la conservación, el acceso adecuado a las áreas de reserva del museo y la investigación.

- Finalmente, es interesante destacar la necesidad de establecer un modelo adecuado de comunicación entre la Institución y sus usuarios: exposiciones, actividades, utilización de medios de comunicación... 


\section{IX.2. LA MISIÓN}

La Misión definida para el Museo es la siguiente teniendo en cuenta los análisis realizados en nuestra primera fase. Constituyen objetivos directores que guían la realización de los Programas propuestos para la siguiente fase de actuación de nuestro Plan Museológico. La Misión del Museo Arqueológico de Sevilla servirá de tronco vertebral por el cual se guía los pasos dados por el Museo. Así pues:

\section{El Museo Arqueológico de Sevilla es una institución} cultural integrada en su territorio, ocupada en promover la puesta en valor del Patrimonio arqueológico a partir de sus colecciones. Asumiendo, para ello, las tareas de conservación, investigación, comunicación, difusión y cuantas tareas sean necesarias. Proporcionando, así, el acceso, los servicios y las experiencias más adecuadas para el contribuir en el desarrollo social, buscando siempre la mayor eficacia y calidad.

\section{IX.3. OBJETIVOS GENERALES}

Si bien las líneas de actuación principales que llevaremos a cabo en los Programas son las definidas anteriormente, los objetivos que justifican la realización de dichos Programas son los siguientes:

Mostrar las cuestiones más relevantes de la Arqueología Sevillana de una forma didáctica y educativa.

Transmitir la importancia del Patrimonio Arqueológico andaluz, de forma que se potencie el respeto hacia el patrimonio y los estudios realizados por la Arqueología, creando una imagen global de la importancia de esta ciencia y de sus hallazgos. 
Conservar los bienes de forma adecuada y siempre abiertos a la investigación de aquellas personas interesadas e investigadores.

Modernizar la imagen del legado arqueológico, presentando un centro contenedor de piezas de prestigio internacional y que sea igualmente reconocido por la calidad de sus instalaciones y por la amplia oferta cultural que proponga, así como por las ofertas culturales complementarias que desarrolle. 



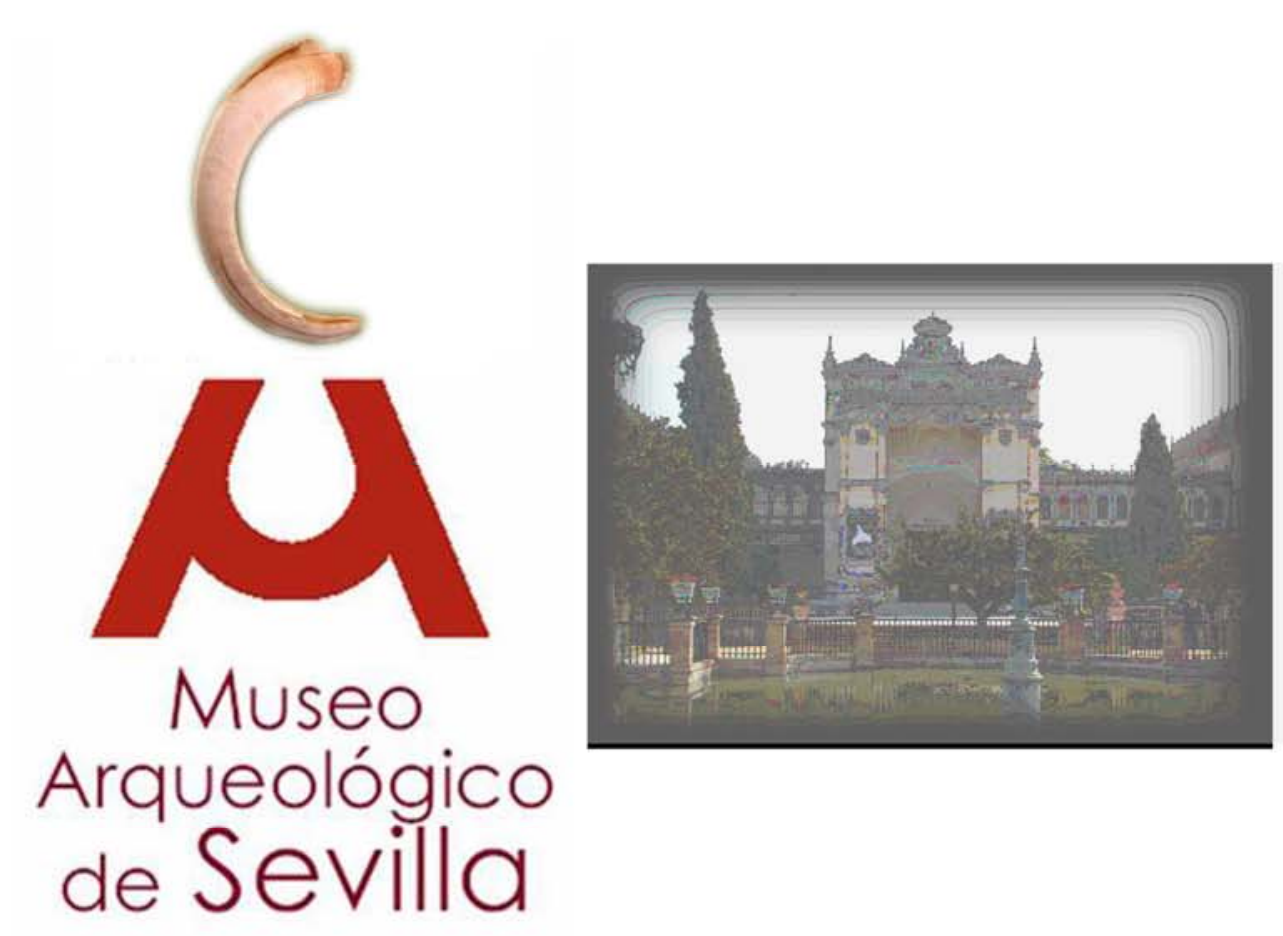

\section{PROGRAMA INSTITUCIONAL}

Yolanda Torrubia Fernández 
El programa institucional debe revisar la vigencia de la institución y precisar la definición del museo en el futuro, desde la triple vertiente de gestión, organización general y relaciones nacionales e internacionales. Es decir, debe precisar si el resto de los programas se han pensado para modificar el museo partiendo de cambios desde el punto de vista institucional, o si la institución permanecerá con la misma organización mientras se revisan los diferentes aspectos que la componen: colecciones, arquitectura, discurso museológico, etc.

\section{I.1. EL MUSEO Y SU LOCALIZACIÓN.}

\section{I.1.1 Emplazamiento y contexto urbano}

Consideramos que la ubicación del museo es adecuada, pues forma parte de un conjunto de gran importancia artística y cultural tanto para los ciudadanos de Sevilla, como desde el punto de vista turístico, pues aunque no se encuentre en la zona de atracción turística fundamental, suele informarse de la existencia del Parque de Maria Luisa (Jardín Histórico) y de la Plaza de América en concreto con los tres pabellones de la Exposición Universal. No obstante, las visitas turísticas no siempre repercuten en el incremento de público en el museo. Es no obstante una zona de esparcimiento y paseo para los habitantes de la ciudad, lo que sí influye positivamente en el museo.

Además el edificio del museo, contemplando la restauración integral del mismo y la reordenación de los espacios que incluye una ampliación, posteriormente detallada en el programa arquitectónico, es adecuado para el cumplimiento de las funciones que el museo debe desempeñar. 


\section{I.2. TEMÁTICA Y OBJETIVOS DEL MUSEO}

Como institución, el museo puede presentar una diversidad notable en su forma, en su contenido, e incluso en su función, pero todos tienen una meta común: preservar, interpretar y exhibir aspectos materiales de la cultura de una sociedad.

Nuestro museo alberga la base de unos contenidos que nos transmiten un mensaje codificado para aquel visitante no experto en la disciplina de la Arqueología. Hoy en día los museos se han transformado en centros productores de la denominada cultura del ocio y cultura de masas. $Y$ para poder responder a esta demanda de la sociedad, hay que mostrar una imagen de institución bien estructurada para cubrir los diversos intereses que le corresponden como institución.
Básicamente, la organización en diversas áreas o servicios especializados nos sirven de medio conductor para transmitir un mensaje claro y conciso de la temática de nuestro museo y del contenido del mismo a través de un discurso expositivo. Para ello, la interpretación y la exhibición de sus piezas organizadas en grandes áreas que a su vez están fragmentadas en unidades temáticas y subtemas, nos pueden orientar a establecer unos parámetros más definidos con el fin de ordenar la divulgación de su colección. Por otro lado, el recorrido de este discurso expositivo se reorganizará con la alternativa de visitar las distintas áreas con independencia una de las otras con el fin de ofrecer al visitante una experiencia agradable y gratificante.

El contenido de este discurso se define con la intención de transmitir un aprendizaje y profundizar en el conocimiento de la disciplina arqueológica, mostrar a la sociedad la riqueza que hemos heredado de nuestros antepasados en el Valle del Guadalquivir y que hemos ido investigando 
sobre ellos hasta nuestros días, gracias al legado que nos han dejado. La colección del museo aporta unos criterios culturales muy significativos para el Patrimonio Histórico tanto nacional como internacional, y por ello, debe revalorizarse el museo como una institución indispensable para la divulgación de los conocimientos culturales de nuestra provincia y su entorno.

En definitiva, un museo sin público no es un museo, pierde su razón de ser. La gestión museística debe prever el contacto de las colecciones con el público, es decir, asegurar la función social del museo, su proyección a la sociedad. Todos los ciudadanos deben beneficiarse del carácter educativo, formador y lúdico de los museos.

\section{I.3. TITULARIDAD. RÉGIMEN JURÍDICO.}

\section{I.3.1. Modelo de gestión}

Es importante tener en cuenta antes de abordar la elaboración de los programas la titularidad, gestión y régimen jurídico del museo, pues la permanencia o el cambio de estos aspectos condicionará el modo de ejecutar los proyectos, con lo que deben contemplarse al dar las directrices que guiarán esos proyectos: los programas.

Como ya se ha planteado en el análisis, en origen el edificio del Pabellón de Bellas Artes era de propiedad municipal, pero fue cedido por el Ayuntamiento al entonces Ministerio de Educación Nacional en 1941. Actualmente, aunque sigue siendo propiedad del Ayuntamiento, el Ministerio de Cultura ejerce como titular a través de esta cesión indefinida condicionada al uso museístico del mismo. En 1994, por Resolución de 27 de mayo de 1994, 
de la Dirección General de Bienes Culturales, por la que se da publicidad a los Convenios entre el Ministerio de Cultura y la Consejería de Cultura y Medio Ambiente, sobre Gestión de Archivos y Museos de titularidad estatal y sobre Gestión de Bibliotecas de titularidad estatal (BOJA 90 de 16 de junio de 1994), dicho Ministerio cedió la gestión de éste y otros museos a la Consejería de Cultura de la Junta de Andalucía. En este convenio se especifica que el Estado mantendrá la titularidad que le corresponde sobre los edificios y colecciones y detalla todos los procesos de autorizaciones a los que el museo queda sometido por parte del Estado (salida de fondos, restauraciones -tanto de edificio como de colecciones-, etc.). Así, las intervenciones que pretendan hacerse en el edificio deberán ejecutarse por parte del Ministerio o con su consentimiento, así como las restauraciones de las piezas adscritas al museo. Además, especifica que los ingresos de fondos que no sean de titularidad estatal se efectuarán en concepto de depósito, lo que actualmente es gran parte de la colección, pues aunque el Estado es titular de una parte, desde la asunción plena de competencias por parte de la Junta de Andalucía en materia arqueológica desde el Real Decreto 864/1984, de 29 de febrero, sobre el traspaso de funciones y servicios del Estado a la Comunidad Autónoma de Andalucía en materia de Cultura, las piezas arqueológicas que se descubran en Andalucía, ya sea por hallazgo fortuito o por consecuencia actividad arqueológica son de titularidad autonómica.

En resumen, el museo es de titularidad estatal pero gestionado por la Comunidad Autónoma, con lo que cualquier intervención que se haga en el edificio deberá ser acometida o autorizada por el Ministerio de Cultura, excepto las de mantenimiento que son obligación de la administración gestora. Esta división del edificio en dos administraciones a veces dificulta las tareas de gestión, mantenimiento o restauración, pues aunque parece claro el cometido de cada una no siempre es así. Además, el hecho de que una intervención en el edificio deba ser ejecutada por el Ministerio hace que la Consejería de 
Cultura no la lleve a cabo, aunque el titular tampoco la haga. Por otra parte, toda intervención debe ser autorizada por el titular, lo que ralentiza el procedimiento en el caso de que la Junta decida llevarla a cabo por ella misma (condicionantes en materia de propiedad, cargas, cesiones de uso...). Lo mismo ocurre con la gestión de las colecciones, pues no siempre es la misma administración la que debe autorizar una restauración, una salida de fondos o una reproducción, lo que dificulta las tareas diarias de gestión.

Por tanto, teniendo en cuenta estas peculiaridades de titularidad y gestión del museo, que afectan negativamente tanto a su funcionamiento diario como a cualquier intervención en el mismo, proponemos la cesión indefinida de la titularidad del museo por parte del Ministerio a la Junta de Andalucía. En realidad sería la cesión del edificio por parte del Ayuntamiento, anulando la que actualmente favorece al Ministerio de Cultura y la de la colección que no pertenece a la Comunidad Autónoma, quedando también las obras cuya titularidad ostenta la Junta de Andalucía adscritas al museo, y no en depósito. Por supuesto se necesitará el consentimiento de las tres administraciones implicadas (municipal, autonómica y estatal). La titularidad la ejercería así la Consejería de Cultura de la Comunidad, actual administración gestora. Creemos que esta administración es más consciente de las necesidades del museo y de las respuestas que éste debe dar a la comunidad a la que sirve dada la mayor cercanía y el hecho de ser la gestora del museo. Con esta cesión, la titularidad y gestión quedarían concentradas en la misma administración, facilitando la gestión del museo y los procedimientos burocráticos. 


\section{I.4. COLECCIONES.}

\section{I.4.1. Temática, incremento y gestión}

Teniendo en cuenta la historia de la institución y las colecciones existentes, como ya se detallará en el Programa de Colecciones, el Museo deberá asumir su condición de monográfico de arqueología sevillana, con especial interés a la sociedad orientalizante (especialmente al mundo de Tartessos) y al rico legado de Itálica, por ser las colecciones más significativas de la institución. A partir de esta definición temática, definirá su política de actividades, sobre todo la línea de exposiciones temporales celebradas en el centro, así como la investigación de sus fondos y la política de adquisiciones. Por tanto, su política de incremento deberá ir orientada al estudio de sus colecciones, a ir perfeccionando las mismas y a completar y reforzar el argumento de las salas de la exposición permanente. Se plantea un incremento controlado, es decir, se adquirirán nuevas piezas conforme a su capacidad de custodia, se realizará un control racional de los ingresos anuales, diferenciando materiales museables y no museables, dando un tratamiento documental y de almacenamiento en diferentes para evitar que se repita el colapso actual.

Esta organización va acompañada en el Programa de Colecciones de una nueva organización del almacén, además de ampliación del mismo y externalización de los objetos no museables, que tendrá capacidad para asumir los ingresos de los próximos 30 años aproximadamente.

La aplicación informática DOMUS, ya implantada para la catalogación, será asignada a las distintas áreas del Museo, lo permitirá una gestión integrada y unificará información. Esta medida facilitará la actividad diaria de la institución mediante la documentación de las colecciones, la gestión de las mismas y la gestión administrativa del Museo como institución. Se establecerán unas prioridades 
de documentación, se implantarán campañas de inventario y catalogación de las colecciones (fondos museográficos y documentales) y se reorganizarán los diferentes archivos del Museo.

Con respecto al fondo bibliográfico, es necesaria la catalogación de todos sus fondos en el actual programa ABSYS para poder poner en marcha una política de préstamos. Además se propone, dentro de la actual política de adquisición, iniciar la colección de textos divulgativos de temática infantil y docente.

\section{I.5. RELACIONES INTERNACIONALES}

El Museo Arqueológico de Sevilla podrá integrarse en redes de información europeas como RACE, para la investigación y desarrollo de las comunicaciones avanzadas, o RAMA, para el acceso remoto a las bases de datos.

\section{I.6. GESTIÓN ECONÓMICA Y RECURSOS HUMANOS}

En todo momento se ha considerado la gestión actual del museo como la base sobre la que elaborar el Programa económico. En éste se plantea la optimización de los recursos y de la gestión con la que cuenta el museo, además de una reorganización de la forma de planificar los gastos o la conversión de recursos no monetarios en inversiones. Estas son algunas de las propuestas destacadas que veremos en el Programa Económico.

Con respecto a los Recursos Humanos de que dispone el museo, en el Programa referente a este apartado se ha realizado una tabla en la que se definen los cometidos de cada uno de los puestos y sus funciones, así como un organigrama de personal que facilitará la gestión diaria del museo. Se han propuesto nuevas formas de contratación en el museo, aunque se siguen contemplando las ya existentes (funcionarios y laborales). 


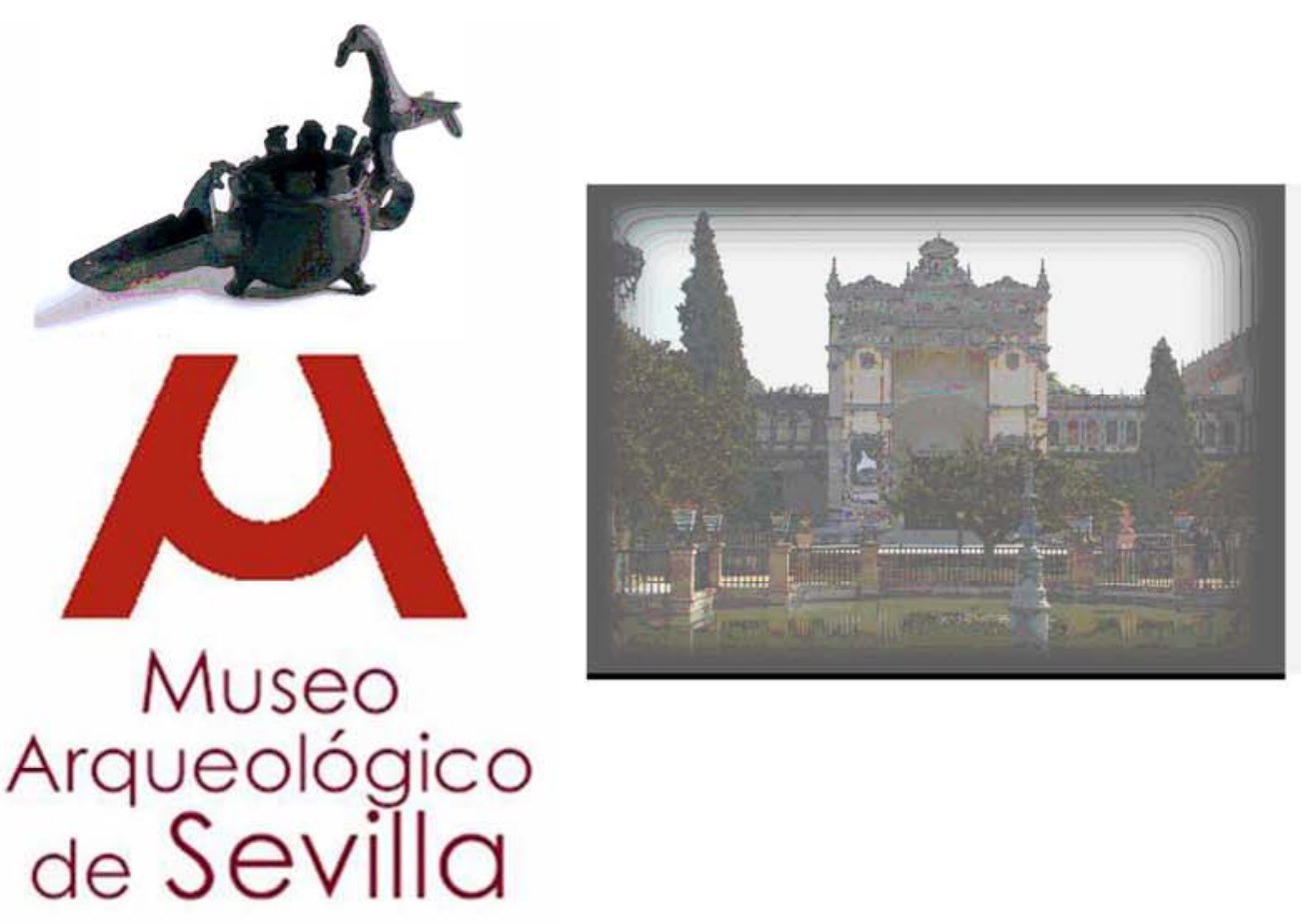

\section{COLECCIONES}

Ismael Andrés Torralba

David Ruiz García 


\section{II.1. PROGRAMA DE INCREMENTO}

\section{II.1.1. Prioridades de incremento de colecciones:}

En la actualidad, el Museo Arqueológico de Sevilla, como institución museística de carácter público, se ha convertido en un lugar indispensable para la salvaguardia de la memoria histórica de Sevilla y su provincia. No obstante, el Museo, por su carácter público, ha de estar vinculado al presente, apostando por la consolidación, mejora y profundización en cada una de sus funciones, entre las que se encuentra la adquisición de bienes culturales muebles.

Coleccionar conlleva una selección, y por ello implica ejercer un juicio de valor que supone a su vez un ejercicio de responsabilidad por parte del personal técnico de la institución.
Las prioridades de incremento necesitarán, no sólo del actual Programa de Incremento, sino del establecimiento de planes periódicos de revisión de las colecciones que desarrolle el Área de Conservación e Investigación, que seleccionará aquellas piezas que contribuyan a dar mayor coherencia al discurso expositivo.

Hay que tener en cuenta que, el incremento de los fondos del Museo deberá estar muy relacionado con el estudio de las colecciones y por la preocupación por ir perfeccionando las mismas, aunque la naturaleza de las colecciones del Museo Arqueológico de Sevilla, dependerán en mayor medida del ritmo de las excavaciones que se realicen en el subsuelo de la provincia, por tanto, la capacidad de maniobra del mismo para dirigir el sentido de su colección será realmente limitado.

En el siguiente apartado de este programa, se especifican y argumentan algunos de los hitos necesarios para 
enriquecer la colección permanente de la institución museística, muy relacionados con el ámbito cultural de la misma. Es el caso del conjunto de piezas romanas procedentes de Itálica, y junto a ellas, las de origen tartésico u orientalizante. Ambas sociedades, permitirán la especialización temática dentro de la disciplina arqueológica que hoy día está desarrollando la Consejería de Cultura en otros museos andaluces de Titularidad Estatal y de Gestión Autonómica, como en el caso del recién inaugurado Museo de Almería, especializado en las culturas neolíticas de Argar y los Millares.

Las futuras adquisiciones responderán a un nuevo criterio, consecuencia de un nuevo discurso museográfico establecido en el Programa de Exposición del presente Plan Museológico.
A la vista de las colecciones existentes y de la propia historia de la institución, el Museo Arqueológico de Sevilla deberá asumir su condición de monográfico de arqueología sevillana, con especial atención al mundo orientalizante y al rico legado de Itálica.

De esta definición temática derivará la política de actividades, las líneas de los temas de las exposiciones temporales, la investigación relativa a sus fondos $\mathrm{y}$, por tanto, lo que será la política de adquisiciones de los años venideros.

Las prioridades de incremento estarán condicionadas a completar y reforzar el argumento de las nuevas salas de exposición permanente. Las piezas que el Museo planteará como las más convenientes para su adquisición son, por tanto, aquellas procedentes de las excavaciones realizadas en Sevilla y provincia, las procedentes de la Colonia Aelia Augusta Italica, y el conjunto de objetos y "tesorillos" orientalizantes y tartésicos que se encuentran en otras 
instituciones museísticas o no museísticas, tales como la Hispanic Society of America de New York, La Previsión Española S.A. de Sevilla, o la Colección G. Cores Uria de Madrid.

II.1.2. Secciones de la colección que necesitan ampliarse o completarse para hacer más coherente el discurso expositivo del museo y, en relación con estas necesidades, la tipología de bienes culturales muebles que deben adquirirse preferentemente

Las salas de exposición permanente deberán contener piezas procedentes de las distintas intervenciones arqueológicas realizadas en Sevilla y su provincia. Por ello, se deberán tenerse en cuenta dos cuestiones: en primer lugar que desde la asunción plena de competencias por parte de la Junta de Andalucía en materia arqueológica operada por el Real Decreto 864/1.984, de 29 de febrero, las piezas arqueológicas que se descubran en Andalucía, sea consecuencia de un hallazgo fortuito o a consecuencia de una actividad arqueológica son de titularidad autonómica y en segundo lugar, que el vigente Reglamento de Actividades Arqueológicas (aprobado por el Decreto 168/2003 de 17 de junio) establece que con carácter previo a la determinación por parte del Director General de Bienes Culturales sobre el museo donde deben depositarse las piezas arqueológicas que aparezcan como consecuencia de una actividad arqueológica, lo que debe hacer al resolver sobre la autorización de dicha actividad, debe pedir informe a la Actual Dirección General de Museos.

El Museo Arqueológico de Sevilla contiene la más completa colección de piezas procedentes de la colonia romana de Itálica. Se puede considerar que esta colección es la más relevante de la institución, por lo que sería necesario adquirir piezas halladas en dicho yacimiento para hacer más coherente el discurso expositivo. 
Se puede solicitar el depósito de la "Estatuilla del dios Pan" que se encuentra asignada por el Estado en el Museo Arqueológico Nacional. Datada a principios del siglo I d.C. y hallada en Itálica. Es de mármol de muy buena calidad, lo que hace pensar que, junto a su delicada talla, pertenezca a un taller itálico o helenístico. Perteneció a una fuente, motivo muy utilizado en los ambientes domésticos de la Bética.

El propio Museo Arqueológico Nacional, también contiene entre sus fondos una colección de bronces jurídicos romanos procedentes de la provincia de Sevilla. De la propia Itálica alberga la "Tabula gladiatoria", documento público escrito en bronce que recoge el discurso de un senador romano con la recomendación de los emperadores Marco Aurelio y Cómodo para que se limitase el número de espectáculos públicos en los que participaban gladiadores. Dicha pieza, completaría el discurso expositivo de la sala dedicada a la Epigrafía Jurídica en bronce.
Otra de las piezas halladas en Itálica es la "Cabeza de Dea Roma", propiedad de la empresa La Previsión Española S.A. de Sevilla. Fue hallada durante las excavaciones del Foro en 1.839 por Ivo de la Cortina. Representa a Dea Roma, relacionada con el culto oficial romano. Se encuentra fechada en época adrianea, como la mayoría de las grandes esculturas halladas en Itálica.

La casa de D. ${ }^{a}$ Regla Manjón en la calle Cuna, conserva una vasta colección de piezas procedentes de Itálica con numerosos utensilios, cerámicas, camafeos, vidrios,... así como varias esculturas. Del conjunto de la colección, el Museo podría solicitar el depósito de las siguientes piezas:

El "Torso femenino con chitón", documentado en un informe de la Comisión de Monumentos Históricos y Artísticos de la Provincia de Sevilla durante las excavaciones realizadas en 1.895. Pertenece al siglo II d.C. y está realizado en mármol blanco. Es una de las pocas esculturas procedentes de un taller local, y como la 
mayoría de las obras romanas, es una adaptación de un original, concretamente de la Venus Genetrix.

El "Torso colosal con piel de macho cabrío", hallado en una casa de la vecina Santiponce, está realizado en mármol blanco. Posiblemente es una versión policlética del dios Pan o de un personaje del thyasos dionisiaco. Se encuentra fechado en época adrianea.

La Hispanic Society of America, conserva en su Museo de Nueva York, dos esculturas que Archer Milton Huntington adquirió a finales del siglo XIX:

El "Busto de un joven desconocido", considerado como una de las piezas más sublime de las aparecidas en suelo italicense, tanto por su buen estado de conservación como por su alta calidad artística. Esta realizada en mármol blanco y ha sido fechada a finales de época adrianea o comienzos de la época antoniana.
El "Torso de Artemisa del tipo Versalles", fue hallada en fecha anterior a 1.873 y está realizada en mármol blanco. Ha sido comparada como una de las grandes obras italicenses de época adrianea.

Ambas piezas, completarían el discurso expositivo dedicado a las grandes esculturas de época adrianea.

Una de las grandes colecciones del Museo, es el conjunto de mosaicos procedentes de Itálica. La tendencia actual de conservarlos in situ tanto en la propia colonia romana como en la Casa de la Condesa de Lebrija, catalogada como Bien de Interés Cultural, hace necesario la alusión de dichos mosaicos en el discurso expositivo del Museo. Entre ellos, se pueden destacar los siguientes:

En Itálica se conserva el "Mosaico de los Pájaros" que da el nombre a la casa que lo alberga. Dicho mosaico posee una serie de recuadros en los que se representan hasta treinta y tres aves de diferentes. 
La Casa de los Pájaros conserva otros mosaicos como el parcialmente conservado en el cubiculum, que representaba a la diosa Tellus, la tierra cultivable; o el de la Gorgona, todos ellos con el predominio general de las teselas blancas y negras que se alternan con figuras de color, al igual que los mosaicos conservados en el Museo.

En la Casa de Neptuno, con el mosaico que da nombre a la edificación. Por la temática que representa, posiblemente decoraría el fondo de una piscina rectangular. Posee las características estilísticas usadas en la Bética, con el uso del blanco y negro. Es una magnífica representación del dios de los mares junto a su cortejo marino.

Esta casa, también conserva otros dos magníficos mosaicos: el "Mosaico del Laberinto", con unas cenefas que representan una muralla de torres almenadas; y el "Mosaico del Cortejo de Baco", con recuadros que representan leones, tigres, ménades sátiros, centauros y bustos de divinidades.
Otro de los grandes mosaicos conservados en Itálica y que podría hacer alusión el propio discurso expositivo del Museo es el "Mosaico del Planetario", conservado en la casa que presta su nombre, representa siete bustos de planetas, es decir, los siete días de la semana.

De los conservados en la casa de D. ${ }^{a}$ Regla Manjón, se pueden hacer mención a "Los Amores de Zeus", al "Mosaico de Medusa", al "Mosaico de las Estaciones" o al "Mosaico de los círculos con esvásticas"; tanto para hacer referencia al coleccionismo sevillano de finales del siglo XIX y principios del XX, como para completar el discurso expositivo sobre los mosaicos descubiertos en Itálica, de esta forma, el usuario del Museo tendrá una completa información sobre esta lujosa técnica utilitaria.

Con respecto a otros periodos, podrían recuperarse piezas de antiguas excavaciones que, por diversos motivos, nunca llegaron a depositarse en las instalaciones del Museo Arqueológico de Sevilla. Es el caso del conjunto de piezas 
pertenecientes al periodo Neolítico procedentes de diversas cuevas de la Sierra Norte de Sevilla que, el profesor Manuel Pellicer descubrió durantes sus intervenciones arqueológicas en la Andalucía Occidental.

Hay que tener en cuenta que, piezas como la cerámica, se consideran como un signo claro del comienzo de la "revolución" neolítica (junto con la agricultura y la ganadería), por tanto, ayudarán a completar el discurso expositivo de las distintas salas de Prehistoria. Es necesario resaltar que, en las últimas excavaciones de Pellicer y Pilar Acosta, se hallaron un tipo de cerámica anterior a la cardial, adornada con gruesos cordones e impresiones digitales pertenecientes a comienzos del VI milenio.

Este paradigma de cerámica, permitirá explicar las técnicas neolíticas del modelado a mano y la posterior cocción en hornos individuales o de pequeño formato. Una cerámica que imitaba a las primeras vasijas hechas con fibras vegetales trenzadas.

En lo referente al periodo orientalizante, se podría solicitar el depósito de parte de la colección L.V.C. de Barcelona compuesta por las siguientes piezas:

"Dos pares de arracadas con decoración geométrica" (Número de Registro: 27) procedentes de la localidad de Marchena y realizadas en oro, poseen un peso de 2,30 gr.. Están constituidas por finas láminas de oro envueltas en sí misma y reforzadas con bandas transversales decoradas con hilos a modo de meandros, motivo típico de la orfebrería etrusca del siglo VII a.C.. Posiblemente estarían enriquecidas con motivos de pasta vítrea.

"Par de arracadas con decoración figurada" (Número de Registro: 1) pertenecientes a la misma población sevillana, poseen un peso de 5,2 gr.. Este par, es de mayor tamaño que los anteriores y de superior calidad artística. Poseen, 
en la parte superior de su cuello, una cabeza de animal que parece representar un león con las fauces abiertas, y con una campanilla colgándole de las fosas nasales. Junto a las cabezas de león, adornos en forma de "T" con caras mirando en sentidos opuestos, y con ellas crecientes, esferas y colgantes a modo de campanillas, que servían de elemento sonoro a la joya.

Junto a estas piezas, la colección L.V.C. contiene otras vestigios de origen orientalizante, como es el caso del "anillo con grifo rampante" (Número de Registro: 31) procedente de Sevilla, el "colgante con representación del árbol de la vida" (Número de Registro: 38) y la "plaquita granulada con palmeta de Lira" (Número de Registro: 37) procedentes de Utrera, o la "plaquita granulada con figura humana" (Número de Registro: 20) procedente de Sevilla.

La colección G. Cores Uria de Madrid, contiene una interesante colección de piezas de origen turdetano que, junto a la magnífica colección orientalizante que Jorge
Bonsor descubrió durante sus excavaciones en los Alcores de Carmona (hoy en la Hispanic Society of America), permiten conocer el fenómeno protohistórico en el Bajo Guadalquivir.

De la primera colección, resulta atrayente el denominado "Tesoro de la Puebla de los Infantes", un interesante conjunto de piezas compuesto por varios anillos de plata así como varios torques, una diadema, fíbulas, cuentas de collar y un anillo, todos ellos realizados en oro.

En lo referente a la segunda colección, es auténticamente significativo el conjunto de cerámicas pintadas, marfiles con diversos motivos figurativos y estatuillas propias de la cultura fenicia que, además de ser una magnífica colección protohistórica, pueden considerarse como parte de una nueva etapa dela Historia de la Arqueología en España, pues para su hallazgo, Jorge Bonsor introdujo los nuevos métodos arqueológicos, cambiando por completo el concepto y el criterio de llevar a cabo las excavaciones, 
primando el método y el orden en las distintas intervenciones.

Para completar el conjunto de "tesorillos" que conserva el Museo, se podría solicitar el depósito del llamado "Tesoro de Lebrija" conservado en el Museo Arqueológico Nacional. Está compuesto por varios candelabros atribuidos a la cultura o sociedad tartésica,. Funcionalmente, pueden considerarse como quemadores de perfumes utilizados en los distintos rituales en honor a una determinada divinidad sagrada.

El propio Museo Arqueológico Nacional, también conserva un interesante "bronce egiptizante" identificado con Osiris o con Reshef, procedente de las cercanías de Sevilla. Una figura que camina con la pierna izquierda adelantada y los brazos extendidos, vestida con el típico faldellín cruzado de los egipcios y tocada con un gorro alto. Este tipo de piezas, podría completar la colección de "esculturillas" de origen orientalizante halladas en la provincia de Sevilla.
Se deberá tener en cuenta que, en aquellos casos en los que sea imposible solicitar el depósito de la pieza original, sería conveniente gestionar su correspondiente reproducción para poder completar el discurso expositivo del Museo Arqueológico de Sevilla.

\section{II.1.3. Plazos de tiempo de aplicación de los criterios expresados}

Se podrá adquirir nuevas piezas una vez finalizados y ejecutados los distintos proyectos de reforma del Museo, conforme a los diferentes programas arquitectónicos y de exposición. Preferentemente se adquirirán cuando la institución pueda exhibirlos en las distintas salas de exposición permanente, principalmente en las salas dedicadas a la cultura o sociedad romana e Itálica.

La prioridad de adquisición de una pieza concreta estará en función de las necesidades del discurso expositivo, por 
ejemplo, la necesidad de adquirir, mediante asignación o depósito, la "Estatuilla del dios Pan", conservado en el Museo Arqueológico Nacional, para explicar el ambiente refinado en el interior de las domus.

El Museo contiene una rica y variada colección de piezas arqueológicas procedentes de Sevilla y su provincia, por lo que las piezas que han sido seleccionadas para ser expuestas en las distintas salas, en función del programa expositivo, podrán ir sustituyéndose a medida que se vayan adquiriendo los nuevos fondos.

Además, el Museo Arqueológico de Sevilla podrá admitir dichas fondos conforme a su capacidad de custodia, según que establecido en el artículo 9 del Reglamento de Museos, por lo que será necesario las distintas reformas establecidas en los diferentes programas, imprescindibles para que la institución pueda hacer un buen servicio con dichos bienes culturales. Para ello, será necesario que se acelere el ritmo de catalogación de los fondos museográficos y se mejore el estado de conservación de las piezas que se encuentran depositadas en el almacén.

\section{II.1.4. Preferentes de incremento de colecciones}

Las principales fuentes para incrementar las colecciones del Museo serán los depósitos que realice la propia Junta de Andalucía. Especialmente los que se producen casi a diario procedentes de las intervenciones arqueológicas realizadas en Sevilla y su provincia.

Para ello, se deberá tener en cuenta la asunción plena de competencias por parte de la Consejería de Cultura de la Junta de Andalucía en materia arqueológica según que establecido en el Real Decreto 864/1.984, de 29 de febrero.

Por otro lado, el Reglamento de Actividades Arqueológicas, aprobado por el Decreto 168/2.003 de 17 de junio, por el que se establece la determinación, con carácter previo por 
parte del Director General de Bienes Culturales, sobre el museo donde deben depositarse las piezas que aparezcan ante cualquier actividad arqueológica.

Es conocido que las numerosas actividades arqueológicas que se realizan en la provincia de Sevilla están generando un enorme volumen de restos arqueológicos, según queda reflejado en el Análisis y Evaluación de las Colecciones.

Otras fuentes para incrementar las colecciones serán mediante los depósitos pertenecientes a terceros, ya sea de carácter voluntario o depósitos forzosos.

De carácter voluntario, según queda establecido en el artículo 94 de la Ley de Patrimonio Histórico de Andalucía, por lo que la propia Consejería de Cultura podrá aceptar el depósito voluntario de bienes culturales muebles integrantes del Patrimonio Histórico Andaluz en las condiciones que convenga con sus titulares.
El Director General de Museos aceptará los depósitos voluntarios según el artículo 5.28 del ROA y en relación con el artículo 2.2 del Decreto 333/96.

Los depósitos forzosos se realizarán ante el incumplimiento de las obligaciones que impone la Ley a los titulares de derechos sobre bienes culturales inscritos en el Catálogo hasta que no se garantice la conservación de los bienes afectados según queda reflejado en el artículo 45.4 de la Ley de Patrimonio Histórico de Andalucía.

La competencia será del Director General de Bienes Culturales según queda reflejado en el artículo 5.29 del ROA, al igual que el artículo 45.4 de la Ley de Patrimonio Histórico de Andalucía y el artículo 36.3 de la Ley de Patrimonio Histórico Español con respecto a los bienes culturales muebles declarados Bien de Interés Cultural o Inventariados. 
Los bienes culturales muebles que han sido declarados Bien de Interés Cultural se podrá acordar, ante la obligación sustitutoria al deber de la visita pública, el depósito del bien en el Museo Arqueológico de Sevilla durante un periodo máximo de cinco meses cada dos años, según queda establecido en el artículo 13.2 de la Ley de Patrimonio Histórico Español.

El órgano competente será el Director General de Bienes Culturales según queda establecido en el artículo 5.29 del ROA.

La Consejería de Cultura también podrá ordenar el depósito de bienes culturales muebles de extraordinario interés existente en otro museo, cuando existan motivos de urgencia, conservación, seguridad o accesibilidad y hasta que desaparezcan las causas que originaron el traslado, según queda establecido en el artículo 11 de la Ley de Museos.
Según el artículo 12 de la Ley de Museos, la Consejería de Cultura igualmente podrá disponer el depósito de los fondos de un museo en el Museo Arqueológico de Sevilla, ante las deficiencias de la instalación o el incumplimiento de la normativa existente por parte de los responsables que pongan en peligro la conservación, seguridad o accesibilidad de los fondos.

En caso de disolución o clausura de un museo, todos su fondos podrán ser depositados en el Museo Arqueológico de Sevilla, siempre que pertenezcan a la disciplina arqueológica y en plena relación con el discurso expositivo, aunque pueden reintegrarse al museo de origen en caso de nueva creación o reapertura del mismo, según queda reflejado en el artículo 13 de la Ley de Museos.

Por último, el artículo 17 de dicha ley, establece que aquellas piezas de interés museográfico para Andalucía cuya importancia sea notoria y que estuvieren por cualquier circunstancia en peligro de destrucción, pérdida o 
deterioro, podrán ser depositados en el Museo Arqueológico de Sevilla. Una vez solventadas dichas circunstancias, podrán volver a su lugar de origen.

Pero no se trata sólo de incrementar; es necesario que el Museo, por su categoría de monográfico de arqueología sevillana, realice un control racional en su política de incremento mediante una selección minuciosa de lo que ingresa cada año en sus instalaciones, principalmente de los materiales procedentes de las distintas intervenciones y prospecciones arqueológicas que se realizan en Sevilla y su provincia; por lo cual, el Área de Conservación e Investigación deberá ejercer, entre sus labores, la diferenciación de los materiales museables y no museables, dando un tratamiento documental y de almacenamiento diferente, pues no se trata tanto de incrementar, sino de racionalizar y controlar en el futuro, el constante incremento para evitar la situación de colapso que actualmente padece la institución.
Será necesario que, el control racionalizado comience in situ, es decir, desde la propia intervención arqueológica, desde la cual, los distintos arqueólogos realizarán una previa selección controlada de los materiales procedentes de las excavaciones, como se contempla en el vigente Reglamento de Actividades Arqueológicas, pero no de forma voluntaria, sino que deberá ser con carácter obligatorio.

Además, muchos de los materiales procedentes de las distintas intervenciones arqueológicas producidas en la provincia de Sevilla, podrán ingresar en los distintos museos locales especializados en arqueología, ya sean de carácter mixto o monográfico, que se encuentren inscritos en el Registro de Museos de Andalucía, como es el caso de los museos históricos de Carmona o Écija.

Esta medida no sólo evitará el colapso de los futuros almacenes, sino que asegurarán una mejor conservación y estudio de las colecciones existentes en el Museo, y permitirá el estudio, la conservación y la exhibición de los 
materiales hallados en el lugar de origen en el cual fueron descubiertos.

\section{II.1.5. Criterios deontológicos}

Según queda recogido en el Código de Deontología Profesional establecido por el Comité del ICOM, el Museo Arqueológico de Sevilla, al igual que el resto de museos, deberá seguir los siguientes criterios en materia de adquisiciones:

\section{El Museo deberá adoptar y publicar una definición de} su política de colecciones:

Abordar cuestiones relativas a la protección y utilización de las colecciones públicas.

Determinar los ámbitos de colección y comprender instrucciones relativas a la conservación perdurable de las colecciones.
Instrucciones que estipulen condiciones o límites.

Restricción relativa a los objetos que se puedan catalogar o exponer adecuadamente.

La política de colecciones debe revisarse cada cinco años.

Los objetos adquiridos deben ajustarse a los objetivos definidos en la política de colecciones y debe escogerse con la perspectiva de conservarlos permanentemente y no con miras a una cesión eventual.

Tener en cuenta los dictámenes profesionales disponibles, el interés de las piezas y los intereses específicos de otros museos.

No deben adquirirse objetos que carezcan de título válido.

Las nuevas adquisiciones deben hacerse públicas, periódica y constantemente. 


\section{Adquisiciones de objetos en situación ilícita:}

El comercio ilícito de los objetos fomenta la destrucción de sitios históricos, así como el robo a nivel local, nacional e internacional.

Los profesionales del Museo deben prestar suma atención al hecho de que apoyar el tráfico ilícito, directa o indirectamente, es contrario a la deontología de un museo.

Se deben desplegar todos los esfuerzos necesarios para asegurarse de que dicho objeto no ha sido adquirido o exportado ilegalmente de su país de origen.

El Museo no debe compra piezas si el órgano rector o la directora tiene razones para pensar que su descubrimiento ha podido causar un daño o destrucción ilegal, intencionada y no científica a monumentos antiguos, o sitios arqueológicos, o que no se ha comunicado el descubrimiento de los objetos a los propietarios $u$ ocupantes del terreno 0 a autoridades jurídicas gubernamentales competentes.

- Cooperación entre museos para una política de colecciones:

El Museo deberá reconocer y refrendar que es necesario cooperar con los museos cuyos intereses y políticas de acopio sean similares o coincidentes y deberán consultar a estas instituciones cuando se puedan crear conflictos de intereses respecto de adquisiciones o de la definición de los campos de especialización. El Museo deberá respetar los campos de acopio de otros museos. 


\section{II.1.6. Medios de captación de colecciones que puedan ingresar en el museo (captación y contraprestaciones para donantes, trabajos de campo, subastas, ofertas puntuales del museo...)}

Entre los medios de captación de bienes culturales muebles, el Museo Arqueológico de Sevilla, podrá realizar la compra, dentro de sus múltiples variantes, mediante la adquisición directa de bienes muebles del Patrimonio Histórico en el mercado libre, o ejerciendo el derecho de tanteo, retracto o de adquisición en las exportaciones y expropiaciones.

De esta forma, podrán adquirirse por compras directas y mediante el ejercicio de tanteo en las subastas públicas, fondos pertenecientes al Patrimonio Histórico Andaluz que permitan eliminar todas aquellas lagunas que se presenten en el discurso expositivo, como en el caso de las colecciones museísticas o particulares instaladas en el extranjero, en las que se deberá estudiar si dichos fondos pueden venderse o donarse; en caso contrario, se solicitará el depósito temporal o la reproducción de dichos fondos, tales como la colección de piezas romanas procedentes de Itálica o la colección orientalizante que se encuentran en la Hispanic Society of América en New York.

El Museo también podrá ejercer ingresos mediante la dación, el ingreso de piezas arqueológicas que han sido producto de distintas intervenciones y prospecciones científicas en Sevilla y provincia (transcurrido un año desde dicha actividad), hallazgos casuales, donación, herencia, legado, ordenación, permuta, premios, usucapión, alta por reintegración, cambio por adscripción o recolección, entre otras.

De este modo, mediante la colaboración con los distintos departamentos de la Universidad de Sevilla, se podrán realizar investigaciones que justifiquen futuras campañas arqueológicas que permitirán eliminar aquellas lagunas que 
se presenten, tanto en la exposición permanente, como en la investigación de los fondos del Museo. Por ejemplo, se podrían incrementar el número de actividades sistemáticas en el triángulo establecido en las localidades de Osuna, El Rubio y El Saucejo, zona en el que se han localizado el mayor número de bronces jurídicos romanos del territorio español.

También, el Departamento de Prehistoria y Arqueología de la Universidad de Sevilla, podría intervenir en las distintas cuevas de la Sierra Norte de la provincia para incrementar el número de piezas correspondientes al periodo Neolítico, una de las mayores lagunas que presentan las distintas salas de Prehistoria, ya que el conjunto de cerámicas anteriores a la cardial halladas por el profesor Manuel Pellicer, sólo podrían recuperarse por imperativo legal.

Para la captación de donaciones o depósitos, los responsables del Museo Arqueológico de Sevilla, deberán iniciar negociaciones con las distintas instituciones museísticas y particulares. Entre ellas, se deberá solicitar al Museo Arqueológico Nacional, el depósito de la "Estatuilla del dios Pan", la "Tabula gladiatoria", el "Tesoro de Lebrija" y el "Bronce egiptizante" que representa al dios Osiris o Reshef.

En cuanto a las colecciones particulares presentes en la capital hispalense, se deberá solicitar el depósito o la donación de la "Cabeza de Dea Roma" perteneciente a la empresa La Previsión Española S.A., así como el "Torso femenino con chitón" y el "Torso colosal con piel de macho cabrío" que alberga la Casa de D. ${ }^{a}$ Regla Manjón en la calle Cuna.

Por último, otras colecciones con las que se deberán iniciar los convenios correspondientes, serán las siguientes:

La Colección L.V.C. de Barcelona, que contiene los "Dos pares de arracadas con decoración geométrica", el "Par de arracadas con decoración figurada", el "Anillo con grifo 
rampante", el "Colgante con representación de árbol de la vida", la "Plaquita granulada con palmeta de Lira", y la "Plaquita granulada con figura humana".

La Colección G. Cores Uria de Madrid que contiene el "Tesoro turdetano de la Puebla de los Infantes".

A ambas colecciones se le solicitarán el depósito o la donación de dichas piezas. En caso de que se produzca cualquier tipo de inconveniente, se procederá a la reproducción de las mismas.

\section{II.1.7. Criterios técnicos que deben regir la aceptación de donaciones y depósitos}

Ante todo incremento de colecciones, teniendo en cuenta que se trata de una de las funciones claves entre las propias a esta institución cultural, se deberá tener en cuenta que dicho acrecentamiento de fondos deberá favorecer a la institución y estará en consonancia con las obligaciones que se encuentran marcadas en el Código de Deontología Profesional del ICOM, aprobado en Buenos Aires en 1.986 y modificado en Barcelona en el 2.001.

También, deberá estar en concordancia con lo establecido en el II Plan General de Bienes Culturales establecido por la Consejería de Cultura de la Junta de Andalucía, el cual, establece los criterios que han de regir la adquisición de Bienes del Patrimonio Histórico dentro del programa de Protección del Sistema de los Bienes Culturales en el Territorio.

Por tanto, se adquirirán bienes del Patrimonio Histórico pertenecientes a la disciplina arqueológica procedentes de Sevilla y su provincia, bienes muebles de gran relevancia pertenecientes al Patrimonio Histórico Andaluz, bienes culturales muebles que faciliten la investigación y el estudio de la colección permanente y bienes culturales muebles que completen las lagunas existentes en las distintas salas de exposición permanente. 
Además, el Museo no deberá, salvo en circunstancias excepcionales, adquirir piezas arqueológicas si tiene pocas posibilidades de catalogarlas, conservarlas, almacenarlas o exponerlas de forma conveniente; no deberá adquirir ninguna pieza arqueológica por compra, donación, legado o intercambio sin que la Consejería de Cultura o la Dirección General del Museo estén seguros de que el Museo Arqueológico de Sevilla pueda obtener un título de propiedad en regla para esa pieza; no deberá comprar nunca piezas si la Consejería de Cultura o la Dirección General del Museo tienen razones para pensar que su descubrimiento ha podido causar un daño o destrucción reciente, intencionada y no científica a monumentos antiguos o yacimientos arqueológicos, o que no se ha comunicado el descubrimiento de los objetos a los propietarios u ocupantes del terreno o a la Consejería de Cultura de la Junta de Andalucía.

Igualmente, el Museo Arqueológico de Sevilla deberá cooperar con otros museos cuyos intereses y políticas de acopio sean similares o coincidentes y deberá procurar consultar a estas instituciones en caso de adquisiciones específicas que puedan crear conflictos de intereses y para definir los campos de especialización. El Museo deberá respetar los límites de los campos de acopio reconocidos a otros museos y evitar adquirir piezas relacionadas con el lugar o que tengan un interés local especial y pertenezcan al ámbito de otro museo sin advertirle debidamente de esta intención.

Por último, para la aceptación de nuevos fondos para la institución, será necesario contar con el asesoramiento técnico de un determinado órgano consultivo, la Comisión Andaluza de Bienes Muebles, que estará formada por representantes de los distintos departamentos de la Universidad de Sevilla que guarden relación con la disciplina arqueológica, como es el caso de los departamentos de Prehistoria y Arqueología, Historia Antigua o Historia del Arte; por el cuerpo de conservadores de la propia institución o de otras instituciones museísticas 
gestionadas por la Consejería de Cultura de la Junta de Andalucía; así como, por el cuerpo de conservadores del Patrimonio Histórico.

\section{II.1.8. Proceso interno a seguir en caso de propuestas concretas de incremento de colecciones (informes técnicos, tramitación administrativa)}

Para las adquisiciones por subastas, el Museo Arqueológico de Sevilla deberá realizar un Informe sobre Propuesta de Adquisición de un determinado bien cultural mueble para la institución.

El informe se redactará a fin de que se estudie la posibilidad de adquisición de una pieza procedente de una subasta pública. Se especificarán los datos de la subasta con el título, la sala, su dirección, teléfonos de contactos, fax y correo electrónico, así como la fecha de celebración.
Se han de indicar las características técnicas de la pieza propuesta para su adquisición cuyas referencias han de estar tomadas del Catálogo de la exposición. La carátula y páginas referidas a los datos, junto a las fotografías han de adjuntarse en un anexo o anexos.

Posteriormente se reflejará el interés de la pieza para las colecciones del Museo Arqueológico de Sevilla y el precio de salida de la subasta.

Se ha de tener en cuenta que sobre el tema del precio de las ofertas, se debe obtener la opinión de la Comisión Andaluza de Bienes Muebles, ya que entre sus competencias está la relativa a las propuestas de adquisición de bienes culturales para la Junta de Andalucía y los museos gestionados por la Comunidad Autónoma.

La propuesta será realizada por la Dirección General de Instituciones del Patrimonio Histórico, aplicando el artículo 38.4 de la Ley 16/1.985, de 25 de junio, del Patrimonio 
Histórico Español, artículo 40.4 del Real Decreto 111/86, de 10 de enero, por el que se desarrolla parcialmente la Ley 16/1.985, modificado por el Real Decreto 64/94, de 21 de enero, artículo 18 de la Ley 1/91, de 3 de julio, de Patrimonio Histórico de Andalucía, artículo 29 del Decreto 19/95, de 7 de febrero, por el que se aprueba el Reglamento de Protección y Fomento del Patrimonio Histórico de Andalucía.

En el caso de ser aceptada la propuesta, la Consejería de Cultura publicará en el B.O.J.A. la Orden por la que se ejerce el derecho de tanteo sobre un determinado bien mueble del Patrimonio Histórico.

Para otros tipos de adquisiciones, se necesitará de un Informe sobre Propuesta de Adquisición de un determinado bien cultural mueble para el Museo Arqueológico de Sevilla.
El Museo redactará un informe para que se estudie la posibilidad de adquirir una determinada pieza en el que deben aparecer los datos del propietario, las características técnicas de la piezas y el estado de conservación.

Las referencias tomadas de la oferta del propietario y las fotografías del bien cultural deberán ir acompañadas en anexos.

Es preferible un análisis directo del bien cultural por los técnicos del Museo y será necesario adjuntarlo al informe.

Posteriormente, se reflejará el interés del bien cultural para las colecciones del Museo Arqueológico de Sevilla, y finalmente se mostrará el precio de la oferta.

Será imprescindible la opinión de la Comisión Andaluza de Bienes Muebles, ya que entre sus competencias está la relativa a las propuestas de adquisición de bienes culturales para la Junta de Andalucía y los museos gestionados por la Comunidad Autónoma. 
La Propuesta será remitida para que pueda ser evaluada por la Consejería de Cultura de la Junta de Andalucía o bien, si procediera, por el Ministerio de Cultura.

Las Ofertas de Venta de bienes muebles del Patrimonio Histórico a la Comunidad Autónoma de Andalucía deberá remitirse a la Dirección General de Instituciones del Patrimonio Histórico de la Consejería de Cultura. Se especificará todos los datos del titular y la acreditación de la propiedad del bien cultural, una declaración de responsabilidad y la oferta de venta en cifras y letras con todos los gastos e impuestos vigentes. En el caso de ser aceptada la oferta, se deberán indicar los datos bancarios para el pago.

Por último, las Ofertas de Venta deberán ir acompañadas de la Relación de bienes muebles del Patrimonio Histórico que se ofertan en venta a la Comunidad Autónoma de Andalucía con los datos de identificación del bien, el autor, título, cronología, dimensiones, técnica, materiales y otros datos identificativos. Será necesario aportar fotografía en color de cada uno de los bienes culturales muebles.

\section{II.1.9. Propuesta de almacenamiento para las nuevas salas de reserva del museo}

Ante la necesidad de crear unos nuevos almacenes o salas de reserva en la zona posterior al Museo, debido al gran volumen de piezas que alberga las actuales salas, así como la dificultad para la manipulación y de conservación de las mismas, se ha optado por la siguiente propuesta de programa de almacenamiento:

Una vez calculados el volumen máximo de piezas en metros cúbicos, obteniéndose un total de 352, el arquitecto procederá a diseñar, primero en un anteproyecto y posteriormente un proyecto de ejecución, un nuevo edificio que contenga tal cantidad de material y que permita albergar el volumen de piezas que ingresan cada año, por 
lo que se ha calculado el volumen total durante los años 2.004 y 2.005 obteniéndose 228 metros cúbicos.

Se ha de tener en cuenta que el gran volumen de piezas ingresadas se debe a dos motivos: por un lado, las excavaciones arqueológicas de grandes superficies realizadas en la ciudad, es el caso del barrio de San Juan de Acre, la plaza de la Encarnación o las propias obras del Metro (calle San Fernando-Puerta de Jeréz); y por otro, las efectuadas por las distintas prospecciones realizadas en las distintas obras del AVE (tramo Sevilla-Bobadilla y tramo Córdoba-Bobadilla) y en el Gaseoducto Écija-Carmona. A todo ello, habría que sumar la gran cantidad de materiales aparecidos en la Plaza de España de Écija, que ha derivado el depósito de una gran variedad y cantidad de material arqueológico.

Las cifras de 2.004 y 2.005 permitirán diseñar un anteproyecto arquitectónico que prevea un elevado incremento de las colecciones depositadas en el nuevo almacén. También se debe tener en cuenta que posiblemente se realicen unos nuevos almacenes en San José de la Rinconada que alberguen todos estos materiales, por lo que el anteproyecto arquitectónico de estos nuevos almacenes necesitarán tales cifras.

Se contabilizaron 11 tipos de cajas, obteniendo un total de 11.920, de las cuales, 9.995 están fabricadas en cartón (83,8 \% del total), 1.920 están elaboradas en plástico $(16,1$ $\%$ del total) y 5 en madera $(0,1 \%$ del total). Las cajas de menor tamaño suelen contener un máximo de 4 bolsas de plástico, mientras que las cajas de mayor tamaño suelen contener 8 bolsas. Algunos de los contenedores poseen piezas que ocupan, en mayor o menor medida, el total del volumen de la caja, normalmente suelen ser piezas completas o fragmentadas.

También existe una gran acumulación de fragmentos arquitectónicos, epigrafías, esculturas, urnas, sarcófagos,..., depositados en el suelo. Suelen ser de 
mediano y gran formato y sus pesos suelen ser bastante elevados.

Para la distribución de la colección contenida en las actuales salas de reserva en los almacenes de nueva planta, será necesaria la siguiente propuesta:

Empleando el modelo estándar de estantería del Museo, de 2,10 m. de altura, todas ellas de seis baldas de $1 \mathrm{~m}$. de ancho y $0,4 \mathrm{~m}$. de profundidad, la distribución será la siguiente:

Para las 6.345 cajas de cartón de $26 \times 14 \times 40 \mathrm{~cm}$., se necesitarán 176 módulos de estantería de 210×100×40 $\mathrm{cm}$., con 6 baldas distanciadas $35 \mathrm{~cm}$. en altura.

Para las 290 cajas de plástico de $41 \times 61 \times 26 \mathrm{~cm}$., se necesitarán 33 módulos de estantería de 210×100×40 cm., con 3 baldas distanciadas $70 \mathrm{~cm}$. en altura.
Para las 3.456 cajas de cartón de $11 \times 8 \times 18 \mathrm{~cm}$., se necesitarán 20 módulos de estantería de 210×100×40cm., con 20 baldas distanciadas $10,5 \mathrm{~cm}$. en altura.

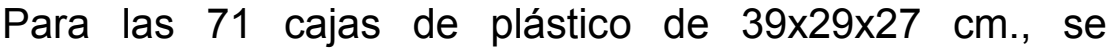
necesitarán 4 módulos de estantería de 210×100×40cm., con 6 baldas distanciadas $35 \mathrm{~cm}$. en altura.

Para las 112 cajas de plástico de $47 \times 27 \times 36 \mathrm{~cm}$., se necesitarán 10 módulos de estantería de 210×100×40 cm., con 6 baldas distanciadas $35 \mathrm{~cm}$. en altura.

Para las 13 cajas de cartón de $35 \times 37 \times 50 \mathrm{~cm}$., se

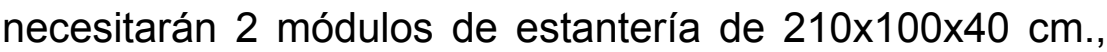
con 5 baldas distanciadas $42 \mathrm{~cm}$. en altura.

Para las 16 cajas de plástico de $60 \times 40 \times 27 \mathrm{~cm}$., se

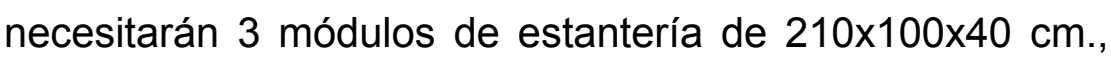
con 6 baldas distanciadas $35 \mathrm{~cm}$. en altura. 
Para las 349 cajas de plástico de $39 \times 30 \times 17 \mathrm{~cm}$., se necesitarán 20 módulos de estantería de 210×100×40 cm., con 6 baldas distanciadas $35 \mathrm{~cm}$. en altura.

Para las 1.082 cajas de plástico de $38 \times 50 \times 27 \mathrm{~cm}$., se necesitarán 91 módulos de estantería de 210x100x40cm., con 6 baldas distanciadas $35 \mathrm{~cm}$. en altura.

Para las 181 cajas de cartón de $40 \times 40 \times 50 \mathrm{~cm}$., se necesitarán 19 módulos de estantería de 210×100×40 cm., con 4 baldas distanciadas $52,5 \mathrm{~cm}$. en altura.

Las 5 cajas de madera de $52 \times 52 \times 124 \mathrm{~cm}$. quedarían depositadas en el suelo o colocadas sobre 5 paletas de 100x140 (modelo europeo).

Para las piezas depositadas en el suelo, se necesitarán 753 paletas, de los cuales, 411 serán de $80 \times 80 \mathrm{~cm}$., 277 de $100 \times 100 \mathrm{~cm}$. y 65 de $100 \times 140 \mathrm{~cm}$.
En los Anexos I, II, III, IV, V y VI se adjuntan la distribución de las distintas cajas en el modelo estándar de estantería utilizado por el Museo Arqueológico de Sevilla.

Las estanterías ocuparían 151,2 metros cuadrados de superficie, mientras que las paletas ocuparían 631,04 metros cuadrados. Por tanto, la superficie total ocupada por las piezas almacenadas es de 782,24 metros cuadrados.

El espacio ocupado por el total de las piezas, permitirá al arquitecto partir de una cantidad, los 782,24 metros cuadrados para diseñar el nuevo edificio. Deberá tener en cuenta los espacios necesarios para los pasillos, imprescindibles para la libre circulación de piezas, por lo que será necesario que tengan el suficiente espacio para el personal (tanto de mantenimiento como conservadores), así como para las carretillas para transportar las piezas.

Para solucionar el gran espacio ocupado por las distintas paletas, 631,04 metros cuadrados, será necesario un 
proyecto para almacenarlas en distintas estanterías. Es preciso tener en cuenta que este tipo de piezas poseen un elevado peso, por lo que será preciso el uso de carretillas elevadoras eléctricas, que deberán poseer un sistema de neumáticos para evitar las vibraciones procedentes del rodamiento sobre el suelo (descartar el uso de carretillas de transporte de ruedas macizas, éstas no reducen vibraciones).

Como propuesta en el ahorro de espacio para almacenar las distintas paletas, la propuesta será la siguiente:

Se realizará un sistema de paletización móvil que permitirá la reducción de la superficie ocupada y una reducción del volumen ocupado. Dicho sistema deberá ser de gran robustez en su construcción y fiabilidad, debido a que deberá soportar piezas de mediano y gran tamaño y de pesos variables. Además, deberá adaptarse a las instalaciones del nuevo edificio.
Mediante el sistema de paletización móvil, se conseguirá que el volumen de paletas se reduzca a la mitad y facilitará el acceso a las piezas que se encuentran almacenadas. Este sistema permite el almacenamiento de cualquier tipo de pieza arqueológica (epígrafes, brocales de pozo, ánforas Dressel, lápidas, esculturas, fragmentos arquitectónicos,...), independientemente de la irregularidad que puedan poseer, adaptando los materiales a las nuevas instalaciones.

Además, permite la utilización reservada de zonas de almacenaje, inventarios rápidos y continuos, distintos pasillos de utilización según las necesidades y un sistema de iluminación de consumo reducido.

Para la accesibilidad de las carretillas eléctricas se podrá realizar pulsando los botones que se situarán en cada base, obteniéndose el pasillo deseado, o a través de un mando a distancia en el interior de la carretilla. 
El diseño del sistema de paletización móvil, dependerá del número de entradas y salidas del almacén, de su grado de utilización o de su grado de gestión.

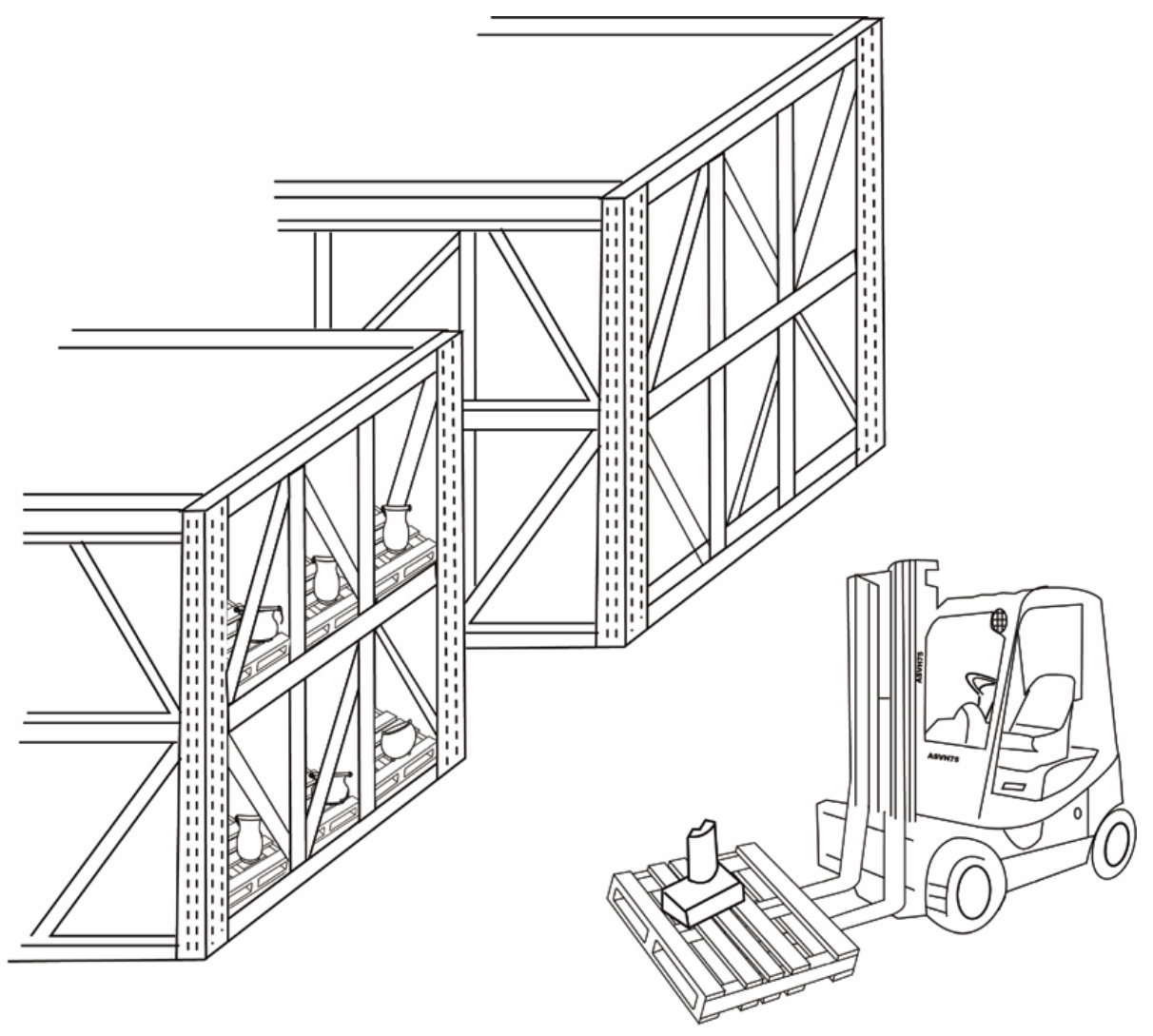

Sistema de paletización móvil y carretilla eléctrica para las nuevas salas de reserva del almacén (M.A.S.)
Otro sistema para almacenar las cajas sería mediante el uso de compactos, es decir, mediante armarios-estanterías móviles que evitarán el número de pasillos, ahorrando espacio y aumentando la capacidad del almacén.

Mediante la estructura móvil de los armarios-estanterías, se conseguirá como mínimo el doble de capacidad en el mismo espacio.

Los actuales almacenes del Museo, se compone de estanterías fijas separadas entre sí por distintos pasillos. Mediante el sistema móvil de los compactos, que se deslizarán sobre raíles empotrados en el pavimento o en plataformas de madera, permitirá que el número de pasillos se reduzca a uno sólo y mantendrá la capacidad del antiguo almacén, pero ahorrando la superficie ocupada en un $50 \%$.

El sistema de armarios-estanterías móviles, se podrá accionar de distintas formas dependiendo del material a 
contener y de la carga del mismo: de forma manual, mecánico a volante o automático a pulsadores.

El sistema manual será apto para pequeñas cargas con poco movimiento. Se basará en el esfuerzo manual del usuario.

El sistema mecánico a volante, compuesto por volantes incorporados en la parte exterior del armario, permitirá deslizar cargas medianas de poco peso, cargas pesadas de frecuente movimiento y elevadas cargas con vagones de grandes dimensiones.

El sistema automático a pulsadores será idóneo para cualquier tipo de carga y tamaño gracias a un pequeño motor reductor que estará incorporado en cada vagón.

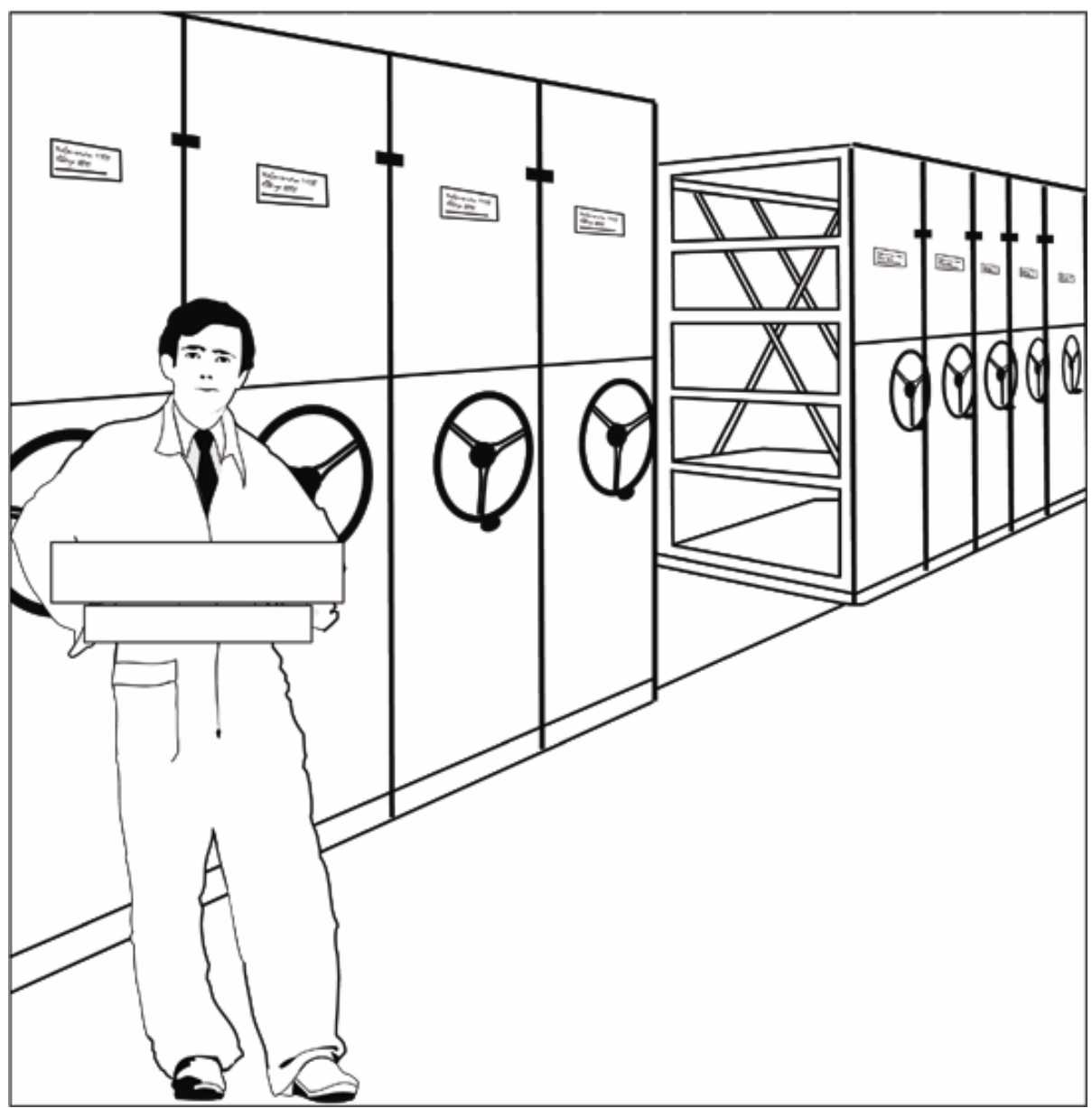

Sistemas de compactos para las nuevas salas de reserva del almacén (M.A.S.) 
Algunas piezas arqueológicas, resultan extremadamente frágiles debido a que están fabricadas en materiales débiles y dotadas de un mínimo punto de apoyo, es el caso de las ánforas de gran tamaño, de las botijas o de los grandes recipientes árabes.

Para las piezas de estas características, será conveniente utilizar cajas individualizadas y personalizadas, realizadas en madera, metal, caucho o resina. En el caso de utilizar cajas de madera, los paneles deberán ser de contrachapado y de pino macizo las esquineras, riostras y patas. El grosor de los paneles y demás elementos de las cajas, estarán en función de las dimensiones de las mismas.

Tanto las esquineras, riostras y patas deberán estar encolados y atornillados, y las tapas y cajas en las zonas de cierre deberán disponer de juntas que garanticen la estanqueidad.
Los materiales utilizados en el revestimiento interno estarán fabricados en poliestileno o poliestireno para garantizar el vibroaislamiento y el termoaislamiento en el interior.

Si las cajas fueran de gran tamaño y peso, deberán disponer de patas para poder ser manipuladas por la carretilla eléctrica.

Para almacenar los distintos fragmentos de mosaicos, se utilizarán paletas de diferentes medidas que serán colocadas sobre los sistemas de paletización móvil.

En aquellas piezas que requieran unas condiciones climáticas especiales, se utilizarán cajas climatizadas que permitirán crear un microclima protector para la obra.

El futuro proyecto arquitectónico también deberá prever el volumen de piezas que tendrá que albergar el almacén ante el continuo crecimiento de la colección del Museo. 
Para ello, con los datos tomados en 2.004 y 2.005 , sería necesario sustituir las 987 cajas de $48 \times 80 \times 60 \mathrm{~cm}$., por cajas de $24 \times 40 \times 30 \mathrm{~cm}$., obteniéndose un total de 1.974 cajas, a las que habría que sumar las 20 cajas de $24 \times 40 \times 30 \mathrm{~cm}$. . El total de cajas de plástico sería de 1.994, que necesitarían 84 módulos de estantería de 210×100×40 $\mathrm{cm}$. (modelo estándar del almacén actual), con 6 baldas distanciadas $35 \mathrm{~cm}$. en altura.

El espacio que ocuparía sería de 33,6 metros cuadrados, cantidad que permitirá conocer, al arquitecto, el espacio que ocupan las piezas que se ingresan cada dos años.

A todo ello habría que sumar las piezas de mediano y gran tamaño, las cuales se depositarán en paletas de $80 \times 80$ cm., de $100 \times 100 \mathrm{~cm}$. y de $100 \times 140 \mathrm{~cm}$..

El proyecto del almacén de colecciones, además de cumplir con los requisitos establecidos en el Programa de Conservación de Colecciones de este Plan Museológico, deberá prever el crecimiento de los fondos en los próximos 30 años, extrapolando el incremento que se ha calculado (33,6 metros cuadrados) para 2 años (2.004-2.005) y planificando una periódica evacuación, a un almacén externo, de fondos no museables o aquellos museables que se considere conveniente.

\section{II.2. PROGRAMA DE DOCUMENTACIÓN}

\section{II.2.1. Directrices generales del sistema de documentación}

Para una correcta gestión de la colección arqueológica del Museo, será necesario realizar una documentación sistemática de cada pieza.

Dicha documentación sistemática será necesaria para la propia actividad de la institución, es decir, para que pueda desarrollar sus labores de conservación, difusión y 
exposición de los distintos fondos. Además, permitirá que el Museo se convierta en un verdadero centro de investigación tanto para el propio personal de la institución como para los investigadores externos y demostrar la propiedad legal de la colección.

Hay que tener en cuenta, que la documentación justifica la conservación de una pieza en el Museo, porque de lo contrario, éste sólo sería un almacén de objetos. La documentación memoriza las condiciones en que fue hallada en un determinado contexto arqueológico, por lo que nos habla de su propia historia.

Dentro de las Áreas Básicas del Museo Arqueológico de Sevilla, como queda establecido en el Artículo 17 del Reglamento de Museos de Titularidad Estatal y del Sistema Español de Museos, el Área de Conservación e Investigación será la encargada de mantener los sistemas de documentación adecuados para la gestión de las distintas colecciones, encargándose del ingreso, control, gestión y baja de las mismas.

Los ingresos de fondos, tras las ofertas puntuales o de las distintas solicitudes, podrán llegar al Museo para formar parte de la colección permanente, en concepto de depósito o de forma temporal, como pueden ser los préstamos o las órdenes judiciales.

El control de fondos, que se producirá en los fondos inscritos en cada uno de los Libros de Registro, permitirá el control de la colección con la asignación de los números de inventario, descripción, clasificación, catalogación, análisis clínicos, siglado, y la ubicación en el almacén o áreas de reserva. La gestión de fondos, se producirá con los movimientos de las piezas. Los movimientos podrán ser externo o interno, y tendrán unos tratamientos legales y documentales distintos.

El Museo Arqueológico de Sevilla, como institución museística de titularidad Estatal y gestionado por la 
Consejería de Cultura de la Junta de Andalucía, deberá realizar los distintos tratamientos administrativos (con el Registro General) y técnicos científicos (con el Inventario y el Catálogo) según queda establecido en las distintas normativas vigentes.

Con la incorporación de la informática DOMUS, como sistema de documentación y gestión de las colecciones, y su uso por parte de las distintas áreas de la institución, permitirá la posibilidad de una gestión integrada del Museo, en la que se unificará la información y a la que podrán acceder las distintas áreas de la institución.

El Sistema Integrado de Documentación y Gestión Museográfica DOMUS versión 3.0, facilitará la actividad diaria del Museo mediante la documentación de las colecciones, según un modelo normalizado de estructuras de información; gestión de colecciones; y gestión administrativa propia del Museo como institución.

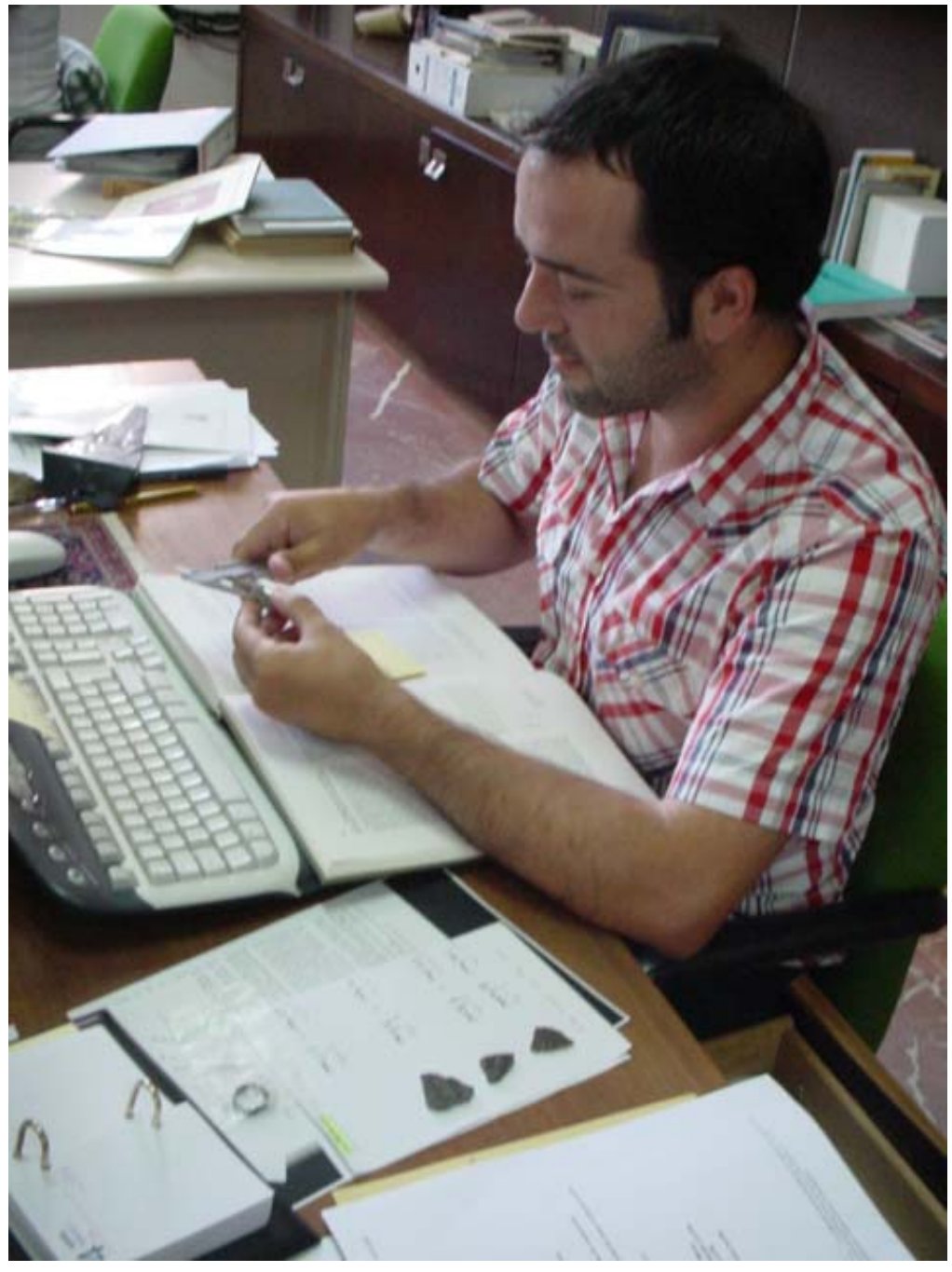




\section{II.2.2. Prioridades de documentación}

Entre las prioridades de documentación que debe realizar el Área de Conservación e Investigación del Museo se encuentran las siguientes:

Se deberá incrementar el grado de inventario y catalogación de los fondos museográficos del Museo en el actual Sistema Integrado de Documentación y Gestión Museográfica DOMUS versión 3.0.

Será necesario incrementar el número de digitalizaciones de los fondos museográficos custodiados en el Museo en la aplicación DOMUS versión 3.0..

Se iniciará el inventario y catalogación de los fondos documentales del Museo en el Sistema Integrado de Documentación y Gestión Museográfica DOMUS versión 3.0.
Acompañando al inicio y catalogación de los fondos documentales en DOMUS versión 3.0, se realizará la digitalización de dichos fondos.

Tanto para la catalogación de los fondos museográficos como los documentales en la aplicación informática DOMUS versión 3.0, se utilizarán todos los módulos que sean necesarios (actualmente sólo se utilizan los módulos: Fondos Museográficos, Documentación Gráfica, Consultas y Conservación).

Es necesario que las distintas áreas del Museo comiencen a utilizar los módulos de la aplicación DOMUS 3.0 que les sean asignados.

En cuanto a la Biblioteca, es preciso que se aumente el grado de catalogación de los Fondos Bibliográficos en el programa ABSYS y posteriormente trasladarla a la aplicación DOMUS versión 3.0 para facilitar el trabajo a los catalogadores. 


\section{II.2.3.Reorganización de los archivos del museo:} archivos de control y gestión de fondos museográficos, archivos históricos, archivos fotográficos, bibliográficos, archivos administrativos

La propuesta para la reorganización de los distintos archivos del Museo es la siguiente:

\section{Archivos de control y gestión de fondos museográficos}

Los archivos de control y gestión de fondos museográficos estarán en continuo crecimiento debido a la acumulación de una gran variedad de documentos, muchos de ellos normalizados, necesarios para el control y gestión de las colecciones:
- Libros de Registro de la colección estable del Museo, en el que se encuentran inscritos, por orden de entrada, los fondos que integran la colección estable del mismo.

- Libros de Registro de depósitos pertenecientes a la Administración del Estado y a sus Organismos Autónomos, en el que se encuentran inscritos por orden de entrada, los de esa titularidad por dicho concepto en el Museo.

- Libros de Registro de otros depósitos, en el que se encuentran inscritos, por orden de entrada, los fondos de cualquier otra titularidad que ingresan en el Museo.

- Fichas de adquisición de piezas, compras y donaciones, compuesto por permisos de excavación, actas de depósito, actas de entrega, diligencias por expolio o exportación ilícita, actas de dación, actas de donación, así como facturas, recibos y certificados de autenticidad que acreditan la pertenencia del bien cultural mueble al Museo. 


\section{Archivos histórico}

El archivo histórico estará compuesto por todos aquellos documentos que han dejado de crecer, al ser sustituidos por el Sistema Integrado de Documentación y Gestión Museográfica DOMUS versión 3.0. o por formar parte de la historia de la institución y de las colecciones:

Fichas Navascués: estará compuesto por las distintas fichas del Inventario General, del Catálogo Sistemático y Monográfico.

- Antiguos Libros de Registro de entrada de objetos en propiedad, según el modelo establecido por las Instrucciones para la redacción de fichas de inventario y de catálogo sistemático en 1.947.

- Antiguos Libros de Registro de entrada de objetos en depósito, según el modelo establecido por las Instrucciones para la redacción de fichas de inventario y de catálogo sistemático en 1.947.

\section{ODISEUS.}

- Actas de correspondencia de antiguos directores/as del Museo.

- Antiguos catálogos del Convento de la Merced.

- Archivo monetario.

- Seudo-archivo antropológico.

\section{Archivo fotográfico}

El archivo fotográfico crecerá, en cierta medida, con la introducción de las distintas reproducciones de imágenes. También albergará las copias de seguridad de las distintas imágenes realizadas en formato JPEG:

- Fotografías de $35 \mathrm{~mm}$. en blanco/negro y color. 
- Contactos.

- Negativos.

- Diapositivas.

- Videos.

\section{$\underline{\text { Ficheros bibliográficos }}$}

Especializado en Arqueología, Museología, Historia Antigua y Arte, y al que se añadirán los textos divulgativos de temática infantil y docente, acorde con la especialidad del Museo. Estará en continuo crecimiento:

\section{- Monografías.}

- Publicaciones periódicas.

- Documentos sonoros.

- Documentos audiovisuales.

Documentos electrónicos.

\section{Archivo Administrativo}

El archivo administrativo crecerá dependiendo del número de memorias, informes, certificados, documentos normalizados... que ingresen en el Área Administrativa del Museo. Gran parte de su información estará almacenada en la base de datos del programa Excell y de la aplicación informática DOMUS versión 3.0.:

- Gestión Administrativa.

- Gestión de Personal.

- Gestión de Presupuesto.

- Gestión del Edificio.

- Gestión de los Visitantes.

- Gestión de Reproducciones.

- Gestión de Actividades y Exposiciones.

- Gestión de Investigaciones.

- Gestión de Movimientos Externos de Fondos.

- Gestión de Colaboraciones Institucionales.

- Correspondencias. 


\section{II.2.4. Cuadro de clasificación de series} documentales

Fondos Museográficos y Documentales

\section{Ingresos:}

$\begin{array}{lc}\text { en colección } & \text { Ingresos } \\ \text { en depósito } & / \\ \text { entradas temporales } & \text { Entradas temporales }\end{array}$

\begin{tabular}{ll}
\hline Registro y Catalogación & $\begin{array}{l}\text { Libros de Registro } \\
\text { Inventario } \\
\text { Catálogo }\end{array}$ \\
\hline Conservación y restauración & $\begin{array}{c}\text { Informes de restauración } \\
\text { Informes previos de conservación } \\
\text { Fichas de conservación } \\
\text { Fichas de conservación abreviada }\end{array}$ \\
\hline Movimientos internos & Informes de entrada bienes culturales \\
laboratorio/taller de restauración \\
Documentos topográficos
\end{tabular}

almacén

exposición

permanente
Movimientos externos:

depósito de fondos

Préstamos para exposiciones préstamo
Informe de constitución del depósito

Documento de autorización

Registro Movimiento de fondo

Informe de constitución o no de

\section{Registro de exposiciones y registro de}

obras y autores

\section{II.2.5. Adopción de vocabularios normalizados (tesauros)}

Se adoptarán la lista de vocabularios normalizados que se encuentran incluidos en el Sistema Integrado de Documentación y Gestión Museográfica DOMUS versión 
3.0. Dicha aplicación informática tiene establecida una normalización terminológica. Con la utilización de los módulos Tesauros, Listas Abiertas y Listas Cerradas se permitirá normalizar la terminología que deba ser empleada en DOMUS.

El uso de los tesauros permitirá gestionar los términos, sus relaciones jerárquicas o referenciales así como consultar los registros de otros módulos que utilizan esa terminología.

\section{II.2.6. Normativas documentales}

Según queda recogido en el vigente Reglamento de Museos de Titularidad Estatal y del Sistema Español de Museos, aprobado por el Real Decreto 620/1.987, de 14 de abril, el Museo Arqueológico de Sevilla deber llevar a cabo un tratamiento administrativo y un tratamiento técnicocientífico de sus fondos a través del Registro, el Inventario y la Catalogación.
El Registro General de las colecciones del Museo tendrá como objetivo la inscripción de los datos relativos a la identificación básica de los bienes culturales que las integran, y constituirá el principal instrumento jurídicoadministrativo que acredita y protege los bienes del Patrimonio Histórico Español y Andaluz custodiado en la institución.

No sólo suministrarán información y serán de ayuda indispensable para el conocimiento de la historia de las colecciones del Museo. Además, en caso de robo y reclamaciones será un auténtico documento probatorio con valor legal. Por este valor documental, se encuentra sujeto a los requisitos que, para estos instrumentos marca la normativa de procedimiento administrativo.

Según queda establecido en el artículo 10.1 del Reglamento de Museos, será obligatorio llevar de forma independiente tres Libros de Registro de Fondos Museográficos relativos a: 
De la colección estable, en el que se inscribirán los fondos que la integran.

De depósitos pertenecientes a la Administración del Estado y a sus Organismos Autónomos, en el que se inscribirán los de esta titularidad que ingresen por dicho concepto en el Museo.

De otros depósitos, en el que se inscribirán los fondos de cualquier otra titularidad que se ingresen en el Museo.

Según queda reflejado en el artículo 11 del Reglamento de Museos, todos los fondos que por cualquier concepto ingresen en el Museo Arqueológico de Sevilla deberán:

Ser inscritos en el Registro correspondiente conforme a lo dispuesto en el artículo anterior, por orden cronológico de su ingreso, haciendo constar los datos que permitan su perfecta identificación $y$, en su caso, el número del expediente relativo al depósito. En este registro se anotarán las incidencias administrativas de los bienes culturales.

Ser marcados con su número de inscripción de dichos Registros mediante la impresión de aquél por el procedimiento más adecuado a la naturaleza de los fondos.

La Disposición Transitoria Segunda del Reglamento establece el plazo de un año a partir de la entrada en vigor del Reglamento para proceder a la adaptación de las inscripciones de los fondos a lo anteriormente indicado, debiéndose respetar en el orden de inscripción el que tuviesen en los Registros o en los Inventarios procedentes del Museo. Además, se indica que todo depósito de bienes propiedad estatal que no esté acreditado documentalmente, pasará a formar parte de la colección estable del Museo como asignado.

El artículo 10.2 establece que no se inscribirán en los Libros de Registro de depósitos los bienes culturales 
muebles que ingresen el Museo para la celebración de exposiciones temporales, sin perjuicio del debido control administrativo de la recepción y de la salida de los mismos.

Tampoco deberán registrarse los depósitos temporales por ofertas de venta o donación, pendientes de resolución.

En cuanto al Inventario y la Catalogación, el actual Reglamento de Museos, en su artículo 12.1 establece que deberán elaborarse separadamente.

El Inventario, tendrá como finalidad identificar pormenorizadamente los fondos asignados al Museo Arqueológico de Sevilla, y los depositados en éste, con referencia a la significación científica o artística de los mismos, y conocer su ubicación topográfica. Este Inventario se llevará por orden cronológico de entrada de los bienes culturales en el Museo.
El Catálogo, tendrá como finalidad documentar y estudiar los fondos asignados al Museo Arqueológico de Sevilla y los depositados en el mismo en relación con su marco artístico, histórico, arqueológico, científico o técnico. Deberá contener los datos sobre el estado de conservación, tratamientos, biografía, bibliografía y demás incidencias análogas relativas a la pieza.

Según queda reflejado en el artículo 13 del Reglamento de Museos, el Ministerio de Cultura dictará normas para la elaboración del Inventario y del Catálogo enunciados anteriormente y las estadísticas de prestación de servicios. Dichas normas técnicas regularán el contenido, la recogida, tratamiento y remisión por el Museo de estas informaciones para su integración por el Ministerio de Cultura en la base de datos correspondiente a Museos de titularidad estatal.

Además, el Ministerio de Cultura prestará colaboración y asistencia técnica a la Consejería de Cultura para el 
cumplimiento de los dispuesto en el artículo 13 del

Reglamento.

\section{II.2.7. Implantación de sistemas informatizados de documentación y gestión de colecciones}

Se continuará con el actual Sistema Integrado de Documentación y Gestión Museográfica DOMUS versión 3.0 desarrollado por el Ministerio de Cultura mediante la Subdirección General de Museos Estatales y Subdirección General de Tratamiento de la Información.

Se trata de una aplicación informática para la documentación y gestión de los fondos museográficos y documentales de los museos, que nace a partir del informe de Normalización Documental de Museos publicado por el Ministerio de Cultura en 1.996, en el que se recogían el análisis funcional y los requerimientos necesarios para la construcción de un sistema informatizado de documentación y gestión museística.
DOMUS integra en una única herramienta los procesos de gestión de información necesarios en la actividad diaria del Museo, referidos a: documentación de colecciones, según un modelo normalizado de estructuras de información; gestión de colecciones, y gestión administrativa propia del Museo como institución. La aplicación informática DOMUS se implantó en el Museo Arqueológico de Sevilla en junio de 2.003, remplazando la anterior aplicación ODISEUS. En junio de 2.006 se sustituyó la anterior versión 2.6 por la actual 3.0, por lo que el Museo irán incluyendo las nuevas versiones de forma progresiva.

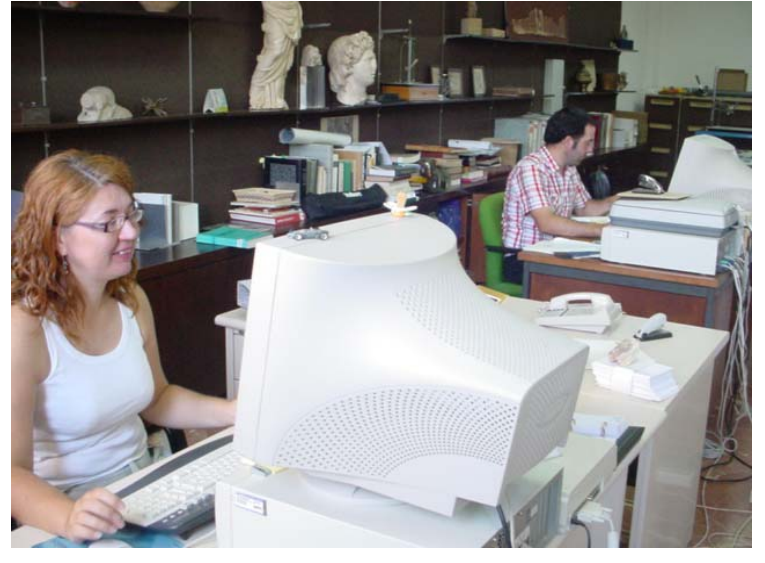

Catalogación de los

Fondos Museográficos en la aplicación informática DOMUS

versión 3.0. Área de Conservación e

Investigación (M.A.S.) 


\section{II.2.8. Campañas de inventario y catalogación de colecciones (fondos museográficos y documentales)}

Para el inventario y la catalogación de los fondos

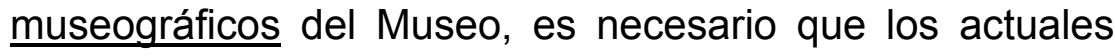
catalogadores continúen con el actual Sistema Integrado de Documentación y Gestión Museográfica DOMUS versión 3.0..

Las campañas de catalogación de los fondos museográficos en la aplicación informática DOMUS comenzaron en junio de 2.003 y actualmente se encuentran catalogados el $10 \%$ de los fondos custodiados en el Museo (junio de 2.006).

Teniendo en cuenta que los fondos de la institución están constituidos por unas 400.000 piezas (tanto piezas individualizadas, como lotes de piezas o fragmentos), se finalizaría el inventario y catalogación de los fondos museográficos en 27 años con el actual sistema de trabajo. Además, hay que tener en cuenta que el incremento de las colecciones en dos años ha sido de 60.000 piezas, que necesitarían 4 años y 6 meses para ser catalogados en la aplicación informática DOMUS.

Los resultados obtenidos reflejan la dificultad de catalogación que posee toda institución museística que alberga colecciones arqueológicas.

Actualmente, se encuentran catalogados casi todos los fondos de la colección permanente y un escaso número de la colección almacenada en las salas de reserva. El incremento del grado de catalogación de los fondos museográficos del Museo va a depender del aumento del personal de catalogación. Sería necesario aumentar la plantilla de catalogadores, ya sea con personal funcionario, laboral o becado; por lo que el grado de catalogación de dichos fondos museográficos dependerá del incremento del 
personal por parte de Junta de Andalucía o por los convenios que realice con las distintas universidades andaluzas.

Como propuesta de campaña de catalogación de los fondos museográficos del Museo, se aumentaría el número de catalogadores a cuatro, de tal forma que se incrementaría la catalogación durante tres años en un 20 $\%$, y ocasionalmente podría aumentar su número por personal becado, especialmente en periodos con campañas arqueológicas intensivas.

Para el inventario y catalogación, la aplicación DOMUS versión 3.0, dispone del módulo de Catalogación de Fondos Museográficos, que se utilizará para introducir toda la información necesaria de los fondos custodiados en el Museo.

Dicha aplicación, permitirá realizar la tradicional documentación en dos niveles, inventario y catálogo, resuelta en campos de obligada cumplimentación, como ficha mínima común para todos los fondos.

Para el inventario y la catalogación de los fondos documentales del Museo, será necesario que dos catalogadores comiencen la catalogación de dichos fondos en la aplicación informática DOMUS versión 3.0.

Hasta ahora, el grado de catalogación de los fondos documentales en el nuevo Sistema de Integrado de Documentación y Catalogación Museográfica ha sido del 0 $\%$, desde su implantación en junio del 2.003. Además, el Área de Conservación e Investigación desconoce el grado de catalogación de forma manual de los fondos documentales del Museo.

Teniendo en cuenta que el grado de catalogación de los fondos museográficos en la aplicación DOMUS versión 3.0 es del $10 \%$ del total de los fondos en un periodo de 3 años, es probable que el grado de catalogación de los 
fondos documentales en dicha aplicación informática sea bastante similar. Por tanto, la propuesta será la siguiente:

Aparecerá una nueva figura dentro del organigrama del personal de la institución, el archivero-documentalista. Se encargará de la reorganización de los archivos del Museo, así como de la investigación y la documentación de dichos archivos.

Servirá de apoyo a los dos nuevos catalogadores, que se encargarán del volcado de la información documental, realizada hasta ahora de forma manual, a la nueva aplicación informática.

Es preferible que el archivero-documentalista pertenezca al cuerpo de funcionarios para que pueda realizar su labor de forma continua, mientras que los catalogadores pueden estar formados por personal laboral o becado, dependiendo del grado de catalogación de dichos fondos documentales.
Para el inventario y la catalogación, la aplicación informática DOMUS versión 3.0, dispone del módulo Catalogación de Fondos Documentales que se utilizará para introducir información acerca de los fondos documentales custodiados en el Museo.

La aplicación DOMUS, permitirá realizar la tradicional documentación en dos niveles, inventario y catálogo, resuelta en diferentes campos de obligada cumplimentación, como ficha mínima común para todos los fondos.

\section{II.2.9. Revisión y control documental de los depósitos de bienes culturales en el museo y fuera del mismo}

Para el control documental de los depósitos de bienes culturales en el Museo se deberán redactar tres Libros de Registros de sus fondos museográficos. Hay que tener en 
cuenta que son, el principal instrumento jurídicoadministrativo que acredita y protege los bienes culturales muebles del Patrimonio Histórico Español y Andaluz custodiado en la institución.

Por su valor legal, estarán sujetos a los requisitos que para estos instrumentos marca la normativa de procedimiento administrativo, por lo que el Museo Arqueológico de Sevilla, continuará con el actual sistema de registro de los fondos museográficos:

De la colección estable del Museo, en el que se deberán inscribir todos los fondos que ingresen en la institución por asignación.

De depósitos pertenecientes a la Administración del Estado y a sus Organismos Autónomos, en el que se inscribirán los de esa titularidad que ingresen por dicho concepto en el Museo.
De otros depósitos, en el que se inscribirán los fondos de cualquier otra titularidad que se ingresen en el Museo.

Según los datos obtenidos durante la consulta de los Libros de Registro, desde el 10 de marzo de 1.943 al 8 de noviembre del 2.005, la colección en depósito, tanto de instituciones publicas como privadas, además de los depósitos de particulares, es de 9.623 piezas, en las que se han considerado los lotes como piezas individualizadas.

La colección estable resulta algo más extensa, 39.105 piezas, formada tanto por piezas individualizadas como por lotes, según el recuento realizado desde el 12 de marzo de 1.880 hasta el 8 de noviembre de 2.005 .

Como se puede apreciar, los distintos Libros de Registro no especifican el número exacto de piezas que se encuentran depositados en el Museo. Se alternan las piezas individuales con los lotes, como en el caso de los lotes de monedas o lotes de glandes, por lo que será 
necesario especificar el número exacto de piezas que forman parte de los distintos lotes, para poder conocer con exactitud el número real de piezas que ingresan en concepto de depósito.

Por ello, el cuerpo de conservadores del Museo deberá iniciar una revisión en los distintos Libros de Registro, Inventarios y Catálogos, tanto de forma manual como informatizada, así como de las distintas actas de depósitos de las excavaciones realizadas en Sevilla y provincia. De esta forma se podrá conocer el número exacto de depósitos existentes en la institución.

En cuanto a los depósitos que el Museo Arqueológico de Sevilla podrá recibir, se encuentran los siguientes:

Los depósitos de bienes pertenecientes a la Administración General del Estado y a sus Organismos Autónomos, que se establecerán por Orden Ministerial, según queda establecido en el artículo 8.1 del Reglamento de los
Museos de Titularidad Estatal y del Sistema Español de Museos (aprobado por el Real Decreto 620/1.987 de 14 de abril), y la entrega deberá acreditarse con la correspondiente acta de transmisión (artículo 8.3 del Reglamento). Los ingresos de fondos que no sean de titularidad Estatal, se realizarán siempre en concepto de depósito, previa autorización de la Consejería de Cultura.

Los depósitos pertenecientes a la Comunidad Autónoma de Andalucía, entre los que destacan la gran cantidad de piezas procedentes de las distintas intervenciones arqueológicas desarrolladas en Sevilla y su provincia. Deberá tenerse en cuenta el actual Reglamento de Actividades Arqueológicas (aprobado por el Decreto 168/2.003 de 17 de junio) que establece que con carácter previo a la determinación por parte del Director General de Bienes Culturales sobre el museo donde deben depositarse las piezas que aparezcan como consecuencia de una actividad arqueológica, lo que debe hacer al 
resolver sobre la autorización de dicha actividad, debe pedir informe a la Dirección General de Museos.

Los depósitos pertenecientes a terceros, ya sean de carácter voluntario o depósitos forzosos:

- De carácter voluntario, previsto en el artículo 94 de la Ley de Patrimonio Histórico Andaluz según el cual la Consejería de Cultura podrá aceptar el depósito voluntario de bienes integrantes del Patrimonio Histórico Andaluz en las condiciones que convenga con sus titulares. El correspondiente contrato quedará formalizado en un documento normalizado y dependerá del Director General de Museos la aceptación de dichos fondos.

- Depósitos forzosos, que podrán producirse ante los siguientes supuestos:

Según queda establecido en el artículo 45.4 de la Ley de Patrimonio Histórico Español, el incumplimiento de las obligaciones de la Ley a los titulares de derechos sobre bienes inscritos en el Catálogo podrá llevar aparejada la designación forzoso del bien cultural en un centro de carácter público hasta tanto no se garantice la conservación de los bienes afectados.

Según queda establecido en el artículo 13 de la Ley de Patrimonio Histórico Español, los bienes declarados de Interés Cultural se podrá acordar con obligación sustitutoria al deber de visita pública, el depósito del bien cultural mueble en un lugar que reúna las condiciones de seguridad y exhibición durante un periodo máximo de cinco meses cada dos años.

Según queda establecido en el artículo 11 de la Ley de Museos, la Consejería de Cultura podrá ordenar el depósito de los bienes culturales de extraordinario interés existentes en un museo, en el que determine, cuando existan excepcionales motivos de urgencia, conservación, 
seguridad o accesibilidad y hasta que desaparezcan las causas que originaron dicho traslado.

Según queda establecido en el artículo 12 de la Ley de Museos, la Consejería podrá disponer el depósito de los fondos de un museo a otro, motivado en las deficiencias de la instalación o el incumplimiento de la normativa existente por parte de los responsables que pongan en peligro la conservación, seguridad o accesibilidad de los fondos.

Según queda establecido en el artículo 13 de la Ley de Museos, en caso de desilusión o clausura de un museo, todos sus fondos serán depositados en otro museo acorde con la naturaleza de los bienes expuestos y conforme al principio de proximidad territorial reintegrándose completamente al museo de origen en caso de nueva creación o reapertura del mismo.

Según queda establecido en el artículo 17 de la Ley de Museos, aquellos objetos de interés museográfico para
Andalucía cuya importancia sea notoria y que estuvieren por cualquier circunstancia en peligro de destrucción, pérdida o deterioro, podrán ser constituidos en depósito en el museo correspondiente. Al cesar dichas circunstancias, se procederá a la devolución de los depositados.

Con respecto al control documental de los depósitos de bienes culturales fuera del Museo, se deberá tener en cuenta que aunque se encuentren depositados en otras instalaciones museísticas o no museísticas para el cumplimiento de otros fines culturales 0 de alta representación del Estado, siguen adscritos al Museo Arqueológico de Sevilla.

También se deberá tener en cuenta la autorización de depósitos en museos inscritos en el Registro de Museos de Andalucía (artículo 13 del Reglamento de Creación de Museos y de Gestión de Fondos Museográficos), que comenzará con la solicitud del representante del museo al Director General de Instituciones del Patrimonio Histórico, 
en el que se especificará la identificación, datos del depósito y el compromiso que contrae con el depositante.

Posteriormente, se requerirá un informe de la directora del Museo Arqueológico de Sevilla y de la Delegación Provincial de Cultura.

Finalmente el Director General de Instituciones del Patrimonio Histórico propondrá a la Consejera de Cultura quien autorizará o denegará el depósito. En caso de autorización, se realizará por Orden de la Consejera de Cultura.

El actual número de piezas en depósito en otras instituciones es de 356, muchas de ellas en museos inscritos en la Red Andaluza de Museos. Al ser un número no muy elevado, el Área de Conservación e Investigación tiene perfectamente constancia del lugar en el que se ubican al estar anotados en el Libro de Registro. Es aquí donde los distintos Libros de Registros jugarán un papel fundamental a la hora de reconocer la propiedad legal de dichos fondos.

\section{II.2.10. Documentación de los procesos de conservación y restauración de colecciones}

Las intervenciones realizadas sobre los materiales arqueológicos se suelen ejecutar en el mismo yacimiento o en las proximidades, en este caso, en el Laboratorio/Taller de Restauración del Museo.

Durante la excavación arqueológica, se realiza la primera fase de documentación de la pieza que, tras ser extraída de su soporte, se deposita directamente en el Museo. Es aquí donde esta institución museística juega un papel fundamental al convertirse en un responsable directo de la conservación y mantenimiento de la propia pieza.

Muchas de las piezas procedentes de las intervenciones arqueológicas, necesitan la intervención del restaurador del 
Museo que realizará una acción activa sobre éstas. Con ello, se pretende mantener la consistencia física, restablecer la unidad potencial y conservar la doble historicidad del nuevo fondo ingresado en el centro.

El restaurador intenta recuperar la funcionalidad del nuevo fondo mediante el rescate de su valor estético, histórico, documental o de uso, dependiendo del tipo de pieza y del momento.

Entre las funciones del restaurador, se encuentran el estudio y diagnóstico de la colección, establecer unas prioridades de actuación, desarrollar las acciones directas necesarias, registrar la información en la respectiva ficha de conservación, estudiar y controlar las condiciones ambientales de las salas que albergan fondos, y finalmente, elaborar un programa de mantenimiento.

Por ello, en toda acción activa en las piezas del Museo, se deberán realizar los correspondientes informes de restauración del Laboratorio/Taller de Restauración en el que se especificarán datos como la identificación del objeto, con su correspondiente número de registro, número de inventario, la fecha de entrada en dicha área, fecha de salida, fecha de comienzo de la intervención, fecha final, departamento, procedencia y datos relativos a las características formales de la pieza, como sus medidas, peso, objeto, materia, técnica de fabricación y una breve descripción de la misma.

Dicho informe, también deberá contener un apartado dedicado a la documentación y analítica, en el que se reflejará el número de negativos, negativos de restauración, diapositivas, análisis y radiografías y la bibliografía.

Finalmente se reflejará el estado de conservación actual y las restauraciones realizadas con anterioridad, el motivo de la intervención, especificando la urgencia, si es una revisión rutinaria o si ha sido solicitada para una exposición 
temporal. Todo ello acompañado del tratamiento realizado, las observaciones, condiciones de conservación que necesita y la persona que ha intervenido en el proceso de restauración.

Para los procesos de desalación se podrán realizar informes que especifiquen los datos de la pieza, fechas de inicio y final de la desalación, y por último las observaciones.

Para una correcta conservación de las colecciones, es necesario que el estado de conservación, tratamientos, biografía, bibliografía y demás incidencias análogas a la pieza se encuentren documentadas en el correspondiente catálogo.

Los informes de conservación serán necesario para la solicitud del préstamo temporal de las colecciones del Museo. Se realizarán tres tipos de documentos:
El informe previo de conservación, en el figuran los datos de la exposición tales como la sede, las fechas de inauguración y clausura, el prestatario y los datos relativos a la pieza como su número de inventario, estado de conservación, informe previo al embalaje, los responsables que han examinado la pieza y la documentación gráfica.

La ficha de conservación, en la que junto a los datos de la exposición figurarán las referencias del prestatario, la pieza solicitada con su número de inventario, los datos previos del estado de conservación, el transporte, contexto expositivo, documentación gráfica, y las referencias necesarias para su montaje.

La ficha de conservación abreviada, que reflejará el título de la exposición, sede, fechas de inauguración y clausura, el prestatario, el informe de conservación, el número interno de la pieza, su número de caja, fecha de llegada y salida con los correspondientes responsables. Dicha ficha 
irá acompañada del la correspondiente documentación gráfica.

En las actas de entrega y de devolución, también figuran el estado de conservación de las piezas que han sido prestadas para las exposiciones temporales. Todo ello irá acompañado de un pliego de observaciones y condiciones sobre el transporte, embalaje y manipulación de los bienes culturales muebles que participan en las exposiciones.

\section{II.2.11. Control de movimientos internos y externos de las colecciones}

El control de movimientos será competencia del Área de Conservación e Investigación del Museo y requerirán de un tratamiento documental para localización física de la pieza en cualquier momento o circunstancia. Además se ha de justificar por qué ha cambiado de sitio.
En el Museo Arqueológico de Sevilla se deberán controlar tres tipos de movimientos: internos, externos y bajas.

- Movimientos internos: se producirán en el interior del Museo, en sus ubicaciones acostumbradas, como pueden ser las salas de exposición permanente, almacenes, restauración, estudio o documentación. No requerirán de ningún tipo de tramitación administrativa por lo que el control lo establecerá el propio Museo.

Además, podrán producirse movimientos internos a corto plazo, para los que no se necesitará cambiar la signatura topográfica; y movimientos internos a largo plazo, que necesitarán un cambio en la signatura topográfica dentro del catálogo.

A pesar de no necesitar ningún tipo de tramitación administrativa, el Museo deberá elaborar los siguientes instrumentos para localizar los fondos: 
Informes de entrada de bienes culturales muebles en el Laboratorio/Taller de Restauración, para localizar las piezas que entran en dicha área.

\section{Documentos topográficos del almacén o salas de reservas,} que se utilizarán para la localización de las piezas situadas en las nuevas salas de reserva del Museo.

En los documentos topográficos del almacén, se reflejarán el número de sala, el número de estantería, el número de balda, la cantidad de cajas que contiene la balda, y por último, la procedencia.

Documentos topográficos de la exposición permanente que serán utilizados para la localización de las piezas situadas en las salas de exposición permanente.

Movimientos externos: se producirán con la salida de los fondos del Museo y podrán tener una duración variable:
Podrán producirse movimientos externos a corto plazo, es decir, durante un corto espacio de tiempo. Se producirán ante las exposiciones temporales fuera del Museo, tratamientos de restauración en el Instituto Andaluz de Patrimonio Histórico (IAPH) o en el Instituto Español de Patrimonio Histórico (IPHE), estudio de piezas fuera de la institución, y en la salida de bienes culturales para las reproducciones.

La solicitud de préstamos de bienes culturales de titularidad estatal para una exposición temporal será autorizada por Orden Ministerial, mientras que, para los préstamos de exposiciones temporales fuera del territorio español se necesitará el debido permiso de exportación temporal, según queda establecido en la Ley de Patrimonio Histórico Español. También se necesitará la autorización de la Junta de Calificación, Valoración y Exportación del Estado, previa solicitud ante la Subdirección General de Museos. 
Para el movimiento de fondos propiedad de la Junta de Andalucía, el Reglamento de Creación de Museos y de Gestión de Fondos Museísticos (Decreto 284/1.995, de 28 de noviembre de 1.995) establece que para la salida de fondos para exposiciones temporales deberá presentarse la correspondiente solicitud en el Museo Arqueológico de Sevilla.

Los depósitos de bienes culturales fuera del Museo durante un largo periodo de tiempo supondrán movimientos externos a largo plazo, ya sean depósitos en otros museos, organismos 0 instituciones, motivados por razones culturales o de alta representación del Estado.

Según queda establecido en el artículo 13 del Reglamento de Creación de Museos y de la Gestión de los Fondos Museísticos, podrán solicitarse el depósito de fondos propiedad de la Junta de Andalucía en museos inscritos en el Registro de Museos de Andalucía.

\section{II.2.12. Documentación de baja de colecciones}

Corresponde al tercer tipo de movimientos que se producirán en el Museo. Tendrán carácter documental, por lo que tendrá su reflejo en el registro de ingreso, inventario y catálogo del Museo Arqueológico de Sevilla.

La baja será justificada por la destrucción, desaparición, reintegración (producen baja los fragmentos de una pieza arqueológica ya inventariados si éstos permiten posteriormente la reconstrucción del bien cultural mueble), ordenación de fondos o permuta.

\section{II.2.13. Conservación de los documentos (escritos, sonoros, audiovisuales, fotográficos, dibujos,...)}

Para los depósitos de libros, y especialmente para la colección anterior a 1.901, la temperatura deberá oscilar los $20^{\circ} \mathrm{C}$ y la humedad relativa deberá ser del $45 \pm 2 \%$. 
Tanto la desecación como las heladas rápidas podrían aportar un pérdida de la flexibilidad, además el papel es extremadamente sensible a los mohos, por lo que se tendrá especial cuidado con la humedad.

El papel es extremadamente sensible a la luz, por lo que no se sobrepasará los 50 lux. Es preferible que la sala que albergue los depósitos de libros, utilice tubos fluorescentes de doble capa, con una temperatura de color del orden de $2.900^{\circ} \mathrm{K}$, o tubos fluorescentes de capa simple, y de la misma temperatura de color, con la condición de suprimir totalmente su radiación ultravioleta por medio de filtros N.B.. La luz diurna deberá ser evitada en la medida de lo posible.

Preferiblemente, dichos libros se depositarán en estanterías que no estén en contacto con los muros del edificio, especialmente los que se encuentran en contacto con el exterior. Para ello, la mejor opción es el uso de un sistema de estantería modular.
El sistema modular podrá adaptarse a las características de las distintas salas y preferiblemente han de ser metálicas, para que sean los suficiente sólidas y resistentes.

Los componentes metálicos deberán estar sometidos a un proceso de fosfatización y cubiertos con una capa de pintura en polvo Epoxi Poliéster aplicada electrostáticamente para garantizar una mayor durabilidad y conservación.

Las antiguas fichas para el Inventario y el Catálogo del modelo Navascués, el archivo monetario, el archivo de metales y el seudo-archivo antropológico deberán estar a una temperatura de $20^{\circ} \mathrm{C}$ y a una humedad relativa del 45 $\pm 2 \%$.

Todas estos documentos son consultados reiteradamente por los conservadores del Museo, especialmente por los 
catalogadores, por lo que sería preferible el uso de tubos fluorescentes con un índice de resolución cromática de 90 sobre 100 , lo que permitirá una imagen nítida en la lectura.

Dichos documentos serán trasladados a cajasarchivadores que permitan una fácil accesibilidad a los distintos investigadores. Además, las unidades en altura deberán soportar hasta $200 \mathrm{~kg}$. de documentos resguardados del polvo.

Es preferible que dichas cajas-archivadores se apilen con toda estabilidad y sin ningún tipo de fijación especial. Para ello será un sistema modular que permitirá su crecimiento en función de cada tipo de archivo.

Las cajas deberán llevar en su frontal una casilla que permita la codificación de su contenido de forma ordenada.

Es conveniente que las fotografías y los films se conserven a una temperatura inferior a los $12^{\circ} \mathrm{C}$, y la humedad oscilará entre el $60 \%$ y el $45 \%$. Al igual que el papel, este tipo de soportes de imágenes son extremadamente sensible a los mohos. Una humedad relativa excesiva ablandaría las gelatinas, y una humedad relativa demasiado seca podría romper el papel y la gelatina.

Tanto las fotografías como los films, son extremadamente sensibles a la luz, por lo que se recomienda que no se sobrepasen los 50 lux y si es posible menos. La luz diurna deberá ser totalmente evitada, por lo que sus contenedores deberán evitar el contacto con la luz solar.

Para los documentos sonoros y audiovisuales se deberá evitar especialmente las partículas de polvo, la temperatura oscilará los $12{ }^{\circ} \mathrm{C}$ y la humedad entre el $60 \%$ y el $45 \%$. Los distintos soportes que contienen este tipo de documentos hacen que la luz no les afecte de forma directa, por lo que se controlarán los lux dependiendo del estado de conservación del mismo. Es preferible que se conserve en un sistema de cajoneras estancas. 
La distintos dibujos que conserva el Museo están realizados sobre soporte de papel, por lo que la humedad relativa y la temperatura será la misma que en los libros y las fichas de Inventario y del Catálogo. Se evitará en todo momento la luz diurna y la luz artificial no superará los 50 lux.

Para acondicionar la colección de dibujos se utilizarán formatos de cartón o passepartout de 40×50cm., 50x60 cm., $60 \times 80 \mathrm{~cm}$. y $70 \times 80 \mathrm{~cm}$. que deberán estar contenidos en camisas de más de $14 \mathrm{~cm}$.. Dichas camisas deberán estar contenidas en cajas que tendrán un $1 \mathrm{~cm}$. más que las mismas para que exista una cierta holgura.

Los dibujos estarán colocados sobre los passpartouts, con una distancia entre los bordes del soporte y el dibujo de no menos de $7 \mathrm{~cm}$.
Cajas, passpartouts y camisas deberán estar fabricadas en papel cartón de $\mathrm{PH}$ neutro, y todo el conjunto se colocarán en cajoneras metálicas.

Aunque toda conservación preventiva ayude a rebajar el grado de envejecimiento de los documentos contenidos en el Museo, es aconsejable que los conservadores dupliquen los originales como medida de seguridad ante cualquier robo o catástrofe, ya que en este tipo de colecciones, es más importante el contenido que el propio soporte.

\section{II.2.14. Digitalización de colecciones y documentos (escritos, sonoros, audiovisuales, fotográficos, dibujos,...)}

Para la digitalización de los fondos museográficos del Museo, se seguirá utilizando el actual sistema de fotografía digital en formato JPEG, que permite una óptima resolución y ayuda al traslado de la documentación gráfica en los 
distintos sistemas informáticos, incluido el Sistema Integrado de Documentación y Gestión Museográfica DOMUS.

Hasta el mes de diciembre de 2.005, se contabilizaron un total de 5.482 imágenes digitalizadas, que corresponden a todos los fondos que se encuentran expuestos en las salas de exposición permanente, y a un escaso número de bienes culturales muebles almacenados en las salas de reserva del almacén. Sería necesario acelerar el grado de digitalización de los fondos museográficos, así como el inicio de la digitalización de los fondos documentales del Museo.

Los documentos escritos, fotografías y dibujos, que por su estado de conservación o por su antigüedad, no permitan el escáner, se utilizará la fotografía digital sobre trípode para transformarlos en formatos JPEG, es decir, en archivo de imagen.
Una vez transformados en formatos JPEG, se procederá a introducirlos en el módulo de Documentación Gráfica de la aplicación DOMUS versión 3.0.

Los documentos sonoros podrán pasar a formato MP3 y los audiovisuales en formatos CD-ROM, lo que permitirá tener varias copias duplicadas del original en el menor espacio posible.

\section{II.2.15. Política de seguridad de datos informatizados}

Con la informatización de las colecciones, se unifica la información, todos los departamentos beben de las mismas fuentes, por lo que será necesario una adecuada política de seguridad de datos informatizados. Para ello, es necesario controlar el acceso de los usuarios y proteger el acceso de la información confidencial o no relevante para otros departamentos; controlar la integridad de la información; controlar la gestión de los derechos de autor, 
los copyrights, sobre todo de las imágenes; establecer protocolos para archivar la documentación en soporte de papel; controlar la seguridad de la información mediante la confidencialidad y seguridad física de los archivos; y proteger el sistema de posibles hackers o virus, por los que se necesita un duplicado off-side.

Por ello es importante la figura del especialista en documentación que, junto al personal de mantenimiento de los equipos informáticos, asegurarán los datos contenidos en dichos equipos.

La aplicación informática DOMUS versión 3.0 instalada en el Museo dispone de un sistema de control de los usuarios, para ello, el Administrador dispondrá de dos opciones de menú para la gestión de los Usuarios que pueden trabajar en DOMUS. Además, también será necesario tener definidos los distintos perfiles a los que se asignará cada usuario, en función de los módulos de aplicación a los que deba acceder.
La pantalla de Usuarios se utilizará para registrar los usuarios con permiso de acceso al sistema. Los campos de pantalla son los siguientes:

Identificador: se usará para identificar el usuario. Posee un campo de escritura libre que sólo será usado internamente por el sistema.

Nombre: para escribir el nombre del usuario. Posee un campo de escritura libre y se utilizará en la pantalla que da acceso al sistema.

Clave: indicará el grupo al que pertenece el usuario. Los permisos de acceso al usuario vendrán determinados por el grupo al que pertenece. En este campo debe seleccionar la información en la lista desplegable. Estarán disponibles todos aquellos grupos añadidos en la Ventana Grupos. 
Fecha inicial: indicará la fecha desde la cual el usuario puede acceder al sistema con los permisos asignados a su grupo.

Fecha final: indicará la fecha hasta la cual el usuario puede acceder al sistema con los permisos asignados a su grupo. Si este campo está vacío, el usuario tendrá acceso, sin caducidad en el tiempo, mientras no sea borrado.

QBE inicial: indicará si al acceder a una ventana con opción QBE esta funcionalidad se activa por defecto. Con la funcionalidad QBE la aplicación permite restringir la información de cada módulo realizando la selección por cualquier campo de pantalla, aportando una mayor agilidad a los procesos de gestión.

Con la instalación de las sucesivas versiones de DOMUS, y con el mantenimiento adecuado, se conseguirá controlar el acceso a toda la información contenida en la aplicación.

\section{II.2.16. Accesibilidad de la documentación a investigadores y público}

El Museo Arqueológico de Sevilla deberá facilitar a los investigadores la contemplación y estudio de los fondos que no estén expuestos al público, así como la consulta de todos los catálogos sin menoscabo del normal funcionamiento de los servicios, según queda establecido en el artículo 23 del Reglamento de los Museos de Titularidad Estatal y del Sistema Español de Museos, aprobado por el Real Decreto 620/1.987, de 14 de abril.

Esta facilidad de acceso será compatible con la previa necesidad de contar con el permiso de investigación cuando sea necesario, como es el estudio y documentación gráfica de los materiales depositados en el Museo, previsto en el artículo 52 de la Ley de Patrimonio Histórico Andaluz y desarrollado en el Reglamento de Actividades Arqueológicas cuya competencia es del Director General de Bienes Culturales, que tiene con 
carácter general la competencia sobre el régimen de autorizaciones en materia de investigación sobre el Patrimonio Histórico, según el artículo 1.1 del Decreto 333/1.996, de 9 de julio.

También será compatible con el cobro a los investigadores de los precios públicos sobre las reproducciones fotográficas que se prevén en la Orden de Precios Públicos de la Consejería de Cultura de 5 de junio de 1.989, y en el Reglamento de Actividades Arqueológicas.

De todas formas, estos precios públicos no afectarán a los estudios de materiales que autoriza la Dirección General de Bienes Culturales, en cumplimiento del Reglamento de Actividades Arqueológicas, en el curso de los cuales el investigador podrá realizar las fotos necesarias sin pagar dicha tasa, y sólo tendrá que hacerlo respecto de las piezas que desee publicar en un futuro inmedianto.
Además, el Museo facilitará el acceso a los Fondos Museográficos y Documentales catalogados en el Sistema Integrado de Documentación y Gestión Museográfica DOMUS versión 3.0 , a través de su publicación en la página web de la institución. De esta forma, los usuarios remotos podrán conocer los fondos que contiene el Museo Arqueológico de Sevilla, siempre que su uso sea con fines de estudio e investigación. Cualquier otro uso deberá ser comunicado al Museo. De esta forma, se permitirá el acceso a la documentación a los usuarios remotos.

\section{II.2.17. Propuesta de sistemas de trabajo en el museo que redunden en una mejor documentación de las colecciones y la gestión de éstas}

En el Capítulo VI del Reglamento de los Museos de Titularidad Estatal y del Sistema Español de Museos, se encuentra reflejado la Dirección y Áreas Básicas que debe poseer el Museo. A la Dirección se le asigna toda la labor 
de dirección y coordinación de los trabajos de tratamiento administrativo y técnico de los fondos; la organización y gestión de los servicios del Museo; adopción de medidas necesarias de seguridad; elaborar un Plan Anual de actividades y presentar una Memoria Anual de actividades que deberá presentar ante la Consejería de Cultura de la Junta de Andalucía.

Dentro de las Áreas Básicas dependientes de la Dirección del Museo, se pueden distinguir las siguientes:

Área de Conservación e Investigación.

Área de Difusión.

Área de Administración.

Para el Área de Conservación e Investigación se ha establecido la siguiente propuesta:

Son necesarios dos conservadores de museos y un Jefe de Departamento, encargado de coordinar las labores propias de dicha área. Para ello, el actual asesor técnico de conservación e investigación deberá realizar las labores propias del actual conservador de la institución. Tendrán la obligación de tener completamente documentadas las colecciones de la institución, y serán los responsables ante la directora de la gestión y documentación de las colecciones.

Además de realizar tareas de estudio e investigación, catalogando los fondos, y como responsables del registro, tendrán la función de crear y mantener los sistemas de documentación adecuados para la gestión de las colecciones; supervisar, numerar, catalogar y almacenar las colecciones del Museo y coordinar los aspectos relativos al préstamo de obras.

Serán responsables de archivar toda la documentación importante, como por ejemplo el registro y la documentación adecuada de las nuevas adquisiciones y de las colecciones existentes de acuerdo con las normas 
apropiadas y los reglamentos y convenios internos del Museo.

Es muy importante que en esta documentación consten todos los detalles sobre la procedencia de cada objeto y las condiciones de aceptación por parte del Museo.

Los originales de todos los datos deberán conservarlo en un lugar seguro y deberá contar con los sistemas apropiados que permitan al personal y a otros usuarios, como en el caso de los investigadores, encontrarlos fácilmente.

Es aconsejable que los conservadores dupliquen los originales como medida de seguridad ante cualquier robo o catástrofe.

Deben procurar que se consulte la documentación manteniendo la confidencialidad de ciertos datos concernientes a la seguridad de sus propias colecciones o de las que custodie por préstamo o depósito, es el caso de la procedencia, forma, cuantía de su adquisición o anteriores propietarios.

Los conservadores intervendrán en todos los momentos relacionados con los movimientos de las piezas. Por ello, serán los responsables del seguimiento de las cuatro fases que contempla la secuencia vital de toda pieza arqueológica: ingreso, control, gestión y baja.

Es necesario contar con dos ayudantes de museos, que serán responsables ante el Jefe de Departamento, y realizarán labores de apoyo al Área de Documentación e Investigación del Museo.

Se encargarán del almacenaje seguro y el cuidado continuo de las colecciones, llevando al día la entrada y catalogación de materiales arqueológicos y elaborando informes del estado de conservación de los mismos. 
Deberán encargarse de la gestión de consultas y solicitudes de información por parte de los conservadores, así como preparar las piezas para su exposición.

Se ampliarán a seis el número de catalogadores y serán responsables ante la Dirección y del cuerpo de conservadores del Museo. Realizarán labores de documentación en la aplicación DOMUS versión 3.0, tanto de los fondos documentales como los museográficos. Ayudarán en la definición de procedimientos de descripción e indexación, y en la elaboración de las terminologías adecuadas (tesauros).

Servirán de apoyo en la gestión de solicitudes de información, tanto internas como externas, incluyendo las relacionadas con el propio conservador.

La ampliación del número de catalogadores a seis, es necesario para iniciar la catalogación de los fondos documentales del Museo y aumentar el grado de catalogación de los fondos museográficos. Al triplicar este personal, se reducirá el tiempo estimado para poner al día las catalogaciones de 27 a 9 años. Estará formado por personal laboral o becado hasta la puesta en día de los fondos documentales y museográficos de la institución.

Aparecerá una nueva figura dentro del organigrama personal del centro, el archivero-documentalista. Será responsable ante la directora de la institución de la reorganización de los archivos del Museo y se encargará de la investigación y la documentación de dichos archivos.

También, se encargará del cuidado de la colección los archivos en todos los soportes, se encargará de la gestión de solicitudes por parte del público y preparará los catálogos $u$ otras publicaciones resultantes de la investigación archivística, sobre cualquier soporte.

Además, se le encomendará la adquisición y baja de material de archivo sobre cualquier soporte y la 
interrelación de los archivos del Museo con redes o bases de datos nacionales o internacionales.

Por último, servirá de apoyo a los catalogadores para iniciar la catalogación de los fondos documentales del Museo.

Para el Área de Administración, encargada del tratamiento administrativo de los fondos del Museo, de la seguridad de éstos y las derivadas de la gestión económicoadministrativa y del régimen interior de la institución, la propuesta es la siguiente:

Serán necesarios las actuales técnico administrativo y auxiliar administrativo, que se encargarán de la gestión financiera, incluyendo presupuesto, contabilidad, compras, recursos humanos, salarios, seguros, impuestos, contratos, libro de sugerencias y reclamaciones y correspondencias.
Además, se encargarán de la documentación económica sobre la Asociación Amigos del Museo, el control de las inversiones y los intereses financieros.

En la biblioteca será preciso contar con un bibliotecario, que se encargará de desarrollar y gestionar la biblioteca del Museo.

Proporcionará servicios a todo el personal y llevará a cabo otros tipos de asistencias como la selección, compra o adquisición de distintas publicaciones relacionadas con Arqueología, Museología, Historia Antigua y Arte; la catalogación y clasificación de la colección; y la circulación y mantenimiento de los materiales impresos o sobre cualquier otro soporte.

Deberá llevar la coordinación tanto el acceso del público a la instalación y como a los usuarios de las bases de datos del Museo, que se encontrarán conectados a redes remotas. 
Será imprescindible que establezca relación con instituciones similares, así como prestar servicios de información.

\section{II.2.18. Establecimiento de redes para intercambiar documentación con otros museos e instituciones} afines

El Sistema Integrado de Documentación y Gestión Museográfica DOMUS versión 3.0 permitirá intercambiar documentación con otros museos que se encuentren en el territorio español. Para ello, deberá existir un control en el acceso a dicha documentación para controlar a los distintos usuarios remotos.

La aplicación DOMUS supone un avance ante la posibilidad de almacenar gran cantidad de datos y por la posibilidad de realizar operaciones racionales de selección de datos en un mínimo tiempo posible. Además, brinda la oportunidad de acceder a otros bancos de datos contenidos en otros museos mediante los sistemas de comunicación en red.

Además, el Museo Arqueológico de Sevilla puede incluirse en redes de información europeas como RACE, para la investigación y desarrollo de las comunicaciones avanzadas, o RAMA, para el acceso remoto a las bases de datos, como ya han hecho algunos museos nacionales, es el caso del Museo Arqueológico Nacional o el Museo del Prado.

\section{II.2.19. Participación en catálogos colectivos de bienes culturales}

Según queda establecido en el artículo 13 del Reglamento de Museos de Titularidad Estatal en cuanto a sistematización de datos, el Ministerio de Cultura dicta normas técnicas para la elaboración del Inventario y del Catálogo así como las estadísticas sobre presentados de 
servicios. Dichas normas técnicas regulan el contenido, la recogida, el tratamiento y la remisión por los museos de estas informaciones para su integración por el Ministerio de Cultura en la base de datos correspondientes a Museos de titularidad Estatal.

Gracias a la aplicación DOMUS implantada en el Museo desde junio de 2.003, todos los fondos museográficos, documentales, bibliográficos y administrativos podrán ser enviados a la base de datos del Ministerio de Cultura. Además, permitirá la consulta de los distintos catálogos incluidos en el Sistema Integrado de Documentación y Gestión Museográfica por los distintos museos de la Comunidad Autónoma de Andalucía o por el resto de instituciones, sean museísticas o no, del territorio español.

Para compatibilizar los distintos gestores de datos, en la Comunidad Autónoma de Andalucía se están implantado la aplicación DOMUS, primero en los museos de titularidad estatal y gestionados por la Junta de Andalucía, y posteriormente, en museos locales, como en es el caso del Museo Histórico Arqueológico de Almedinilla (Córdoba).

Dicha normalización documental permitirá integrar todo el sistema de Información del Patrimonio Histórico de Andalucía junto a otras bases de datos del patrimonio autonómico.

Además, con la nueva web del Museo, se podrá consultar el catálogo de fondos documentales y museográficos de la institución junto a otros catálogos del Sistema Andaluz de Museos.

\section{II.3. BIBLIOTECA}

La biblioteca del Museo Arqueológico de Sevilla posee una colección de fondos documentales especializados en Arqueología, Museología, Historia Antigua y Arte que se encuentran organizados para facilitar la adquisición, 
conservación, comunicación y presentación con fines de estudio, educación y deleite de los testimonios materiales que guarda el Museo y para apoyar las actividades propias del mismo.

Para cumplir estos objetivos, será necesario la catalogación de todos sus fondos en el actual programa informático ABSYS, ya que actualmente se encuentran catalogados el 6,3 \% en dicha aplicación, es decir, 3.400 volúmenes según los datos obtenidos en el mes de noviembre del 2.005 .

El ritmo de informatización es de 20 a 25 documentos al día, por lo que el nuevo bibliotecario finalizará la catalogación de los 21.588 volúmenes, compuestos por monografías y publicaciones periódicas, en 790 días. Además, hay que tener en cuenta el ritmo de crecimiento de las monografías y de las publicaciones periódicas que, en dos años, han aumentado a 586 volúmenes (según los datos obtenidos en 2.004 y 2.005), lo que supondrá que podrá realizarse la catalogación de dichos volúmenes prácticamente al día (como simple hipótesis, si se ingresaran tal cantidad de volúmenes en un solo día, estaría catalogados en el programa ABSYS, en tan sólo 26 días), obteniéndose el tiempo suficiente para desarrollar otros tipos de tareas como la selección, compra o adquisición de las distintas publicaciones, la circulación y mantenimiento de los materiales impresos o sobre cualquier otro soporte.

Será necesario que el bibliotecario ejerza algunas tareas de la aplicación informática DOMUS versión 3.0, debiendo utilizar la opción de Fondos Bibliográficos, pantalla que deberá ser utilizada para introducir y consultar cualquier tipo de información sobre los Fondos Bibliográficos del Museo estén asociados o no a un fondo.

Esta media ayudará enormemente la labor de los catalogadores para el inventario y catalogación de los fondos museográficos y documentales del Museo. Para 
ello, deberá volcar toda la información contenida en el programa ABSYS a la aplicación DOMUS.

La finalización de la catalogación informatizada de los fondos de la biblioteca, permitirá el desarrollo en las redes, y la posibilidad de crear un museo-biblioteca virtual.

Para mejorar la calidad de los servicios ya existentes, sería imprescindible la publicación de sus fondos en la web del Museo. La disponibilidad del catálogo en la red permitiría la consulta de numerosos usuarios remotos como otros museos, docentes, estudiantes, investigadores o público en general. Además, sería una buena medida para captar usuarios potenciales, es decir, los no usuarios, pero que pueden llegar a serlo.

En cuanto a las adquisiciones, se deberá continuar con el incremento de volúmenes especializados en Arqueología, Museología, Historia Antigua y Arte, tanto documentos textuales como sonoros, audiovisuales o electrónicos; para que permitan alcanzar los objetivos y desempeñar las funciones que tiene asignadas tanto la biblioteca como el propio Museo.

La adquisición de fondos especializados servirán de apoyo a las tareas museográficas de la institución, asegurando la disponibilidad de la documentación necesaria para los trabajos de investigación que se lleven a cabo dentro del propio Museo.

Además, se debe iniciar la adquisición de textos divulgativos de temática infantil y docente para incrementar el número de usuarios jóvenes, ya que la mayoría de los beneficiarios son investigadores y público adulto.

Es necesario iniciar una política de préstamos de fondos, lo que facilitará el acceso a la información depositada en la biblioteca a aquellas personas interesadas ajenas al centro, lo que ayudará a fomentar la difusión y flujo de la información relativa a los campos que cubre. Los fondos 
que por su antigüedad o por su estado de conservación, como las anteriores ediciones de 1.901 , se podrán consultar únicamente en las salas de lectura.

El conjunto de monografías y de publicaciones periódicas deberán estar depositadas en las distintas estanterías por orden temático y con su correspondiente signatura topográfica.

Es preferible el uso de un sistema de estantería modular para el depósito de los distintos volúmenes. Dicho sistema podrá adaptarse a las características de la sala y preferiblemente han de ser metálicas, para que sean lo suficiente sólidas y resistentes.

Es aconsejable que los componentes metálicos que forman parte de laS estanterías estén sometidos a un proceso de fosfatización y cubiertos con una capa de pintura en polvo Epoxi Poliéster aplicada electrostáticamente para garantizar una mayor durabilidad y conservación de las mismas.

Las nuevas adquisiciones serán presentadas en estanterías con las mismas particularidades que anteriores, pero expuestas a modo de expositores sobre estantes inclinados y protegidos por vitrinas de puertas correderas.

Será necesario adquirir diferentes aparatos de reproducción, como lectores/reproductores de microformas, imagen y sonido para consultar los distintos documentos audiovisuales, electrónicos y sonoros que contiene la biblioteca. Este tipo de adquisiciones permitirá aumentar el desarrollo tecnológico de la misma y aumentará sus servicios.

Por último, se podrá solicitar el préstamo, para las distintas exposiciones temporales, de bibliografía histórica, manuscritos inéditos (tesis, informes, manuscritos de publicaciones,...), y de documentación antigua (planos, fotografías, dibujos, antiguas correspondencias,...), ya que 
suponen un medio extremadamente eficaz para promover la conciencia social del valor de los fondos conservados en la biblioteca. Un conjunto bienes culturales y testimonios fundamentales para el conocimiento de las distintas disciplinas arqueológicas, museológicas, históricas y artísticas.

\section{II.4. PROGRAMA DE INVESTIGACIÓN.}

En este momento, el museo cuenta con los siguientes especialistas del cuerpo de conservadores de museos de la Junta de Andalucía, además de la directora:

\section{Un jefe de departamento de conservación.}

Se dedica a la investigación, a la documentación dirigiendo el trabajo de los catalogadores, y también a la conservación de las colecciones, en coordinación con los restauradores.

\section{Un asesor técnico en conservación e investigación.}

Se ocupa de la exposición permanente y las colecciones expuestas, de las salidas temporales de piezas y de asesorar en cuestiones museográficas.

\section{Una asesora técnica en difusión.}

Trabaja en el desarrollo de actividades de difusión: exposiciones, publicaciones además de otras actividades, y de los aspectos técnicos relacionados con la atención al público y la comunicación.

\section{Una Titulada Superior.}

Se ocupa de cuestiones técnicas de organización y gestión y apoya en tareas de atención al público y comunicación.

Por tanto, todos estos programas necesitarán de entrada un aumento de personal, ya sea eventual o funcionario. Todos los programas van a tener puntos de encuentro con los demás, pero pensamos que la fase de transversalidad podría llegar con posterioridad, una vez que las líneas aquí esbozadas hubiesen cumplido sus objetivos iniciales. En el caso contrario se podría producir una dispersión de los 
escasos medios y confusión en la toma de decisiones terminando en el abandono de los proyectos.

Las metas hacia las que se dirigen estos programas poseen direcciones muy diversas, pero así se plantean debido al conocimiento del hecho de que la coyuntura política es, en gran medida determinante del desarrollo de las líneas de acción.

El plan de calidad de los museos andaluces, promovido desde la Junta de Andalucía como método de análisis de las necesidades conjuntas de estas instituciones, ha servido como marco conceptual para la elaboración de estos programas, encaminado a dar respuestas progresivas a los problemas específicos del Museo Arqueológico de Sevilla.

\section{II.4.1. Conexión a una red de museos arqueológicos.}

Aún siendo conscientes de la sobrecarga de trabajo a la que se encuentran sometidos los técnicos del museo, debida en parte a la falta de personal, proponemos la creación de una red de colaboración de los museos arqueológicos en el ámbito autonómico. Conocemos el procedimiento por el cual la Junta de Andalucía gestiona a todos los museos públicos del territorio andaluz que así decidan agruparse. Es decir, se está tendiendo desde el gobierno autonómico a dar facilidades a este tipo de iniciativas de descentralización de las diversas instituciones.

A través de la Dirección General de museos, en lo que a este trabajo se refiere, se está a favor de estas agrupaciones. Así aparece recogido en el Plan de calidad de los museos andaluces como una de las funciones básicas asignadas: "Los museos de la red se asocian libremente para realizar actividades diversas", para "abrir los museos a las nuevas tecnologías de la comunicación 
como un instrumento que complementa, perfecciona y transforma sus dispositivos de conocimiento, información, investigación, transferencia, exposición de contenidos etc., creando nuevas formas de relación con el público, los especialistas y los agentes culturales."

Dentro de esta línea de pensamiento, creemos que este modelo descentralizado aquí propuesto, puede constituirse como una unión de rango inferior al actual Sistema Andaluz de Museos. Pero de mejor operatividad, pues se acercaría más a las necesidades propias de este tipo de instituciones, las arqueológicas, frente a una visión más globalizadora, por tanto más esquemática, del enfoque actual.

Se definirán los objetivos comunes, estudiando cuál de cada una de las instituciones implicadas en el proyecto, puede afrontar con mayor competencia la función en cuestión. Unificación de recursos y potencialidades para evitar la dispersión de esfuerzos localizados.
Tras una primera fase de interconexión de recursos de los museos andaluces, el paso a continuación será un acercamiento a museos de otros países interesados en la experiencia. Permitirá entre otras ventajas, la realización de estancias del personal implicado, en museos de otros lugares, con fines de investigación y aprendizaje de toda clase de experiencias.

Esta clase de propuestas cuenta asimismo con el respaldo de organismos internacionales. En Europa se ha creado un grupo de especialistas, denominado DigiCuLT, a los que se ha encargado la preparación de un informe sobre el futuro de las tecnologías digitales en relación con el mundo del Patrimonio Cultural. En dicho informe se afirma que los pequeños museos, como los andaluces, como la mayoría de los europeos en realidad, encuentran un enorme potencial de desarrollo en la "revolución digital" 35 .

\footnotetext{
${ }^{35}$ CARRERAS MONFORT, C., " Museografía en internet: análisis de la situación en
} nuestro país". Versión electrónica de descarga gratuita en la dirección www.ouc.edu. 


\section{II.4.2. Museo - Universidad.}

La finalidad de este programa se sitúa en el fomento del acercamiento de estudiantes e investigadores, con el museo como punto de encuentro. Contactos que no se produjesen de modo aislado, por iniciativa individual, sino con el apoyo institucional. Por ejemplo, se pueden establecer acuerdos entre ambos organismos, por los cuales estudiantes de primeros niveles de las materias relacionadas puedan participar en campos de trabajo, dirigidos por los profesionales del museo. Un punto de aplicación de estos campos de trabajo podría ir dirigido a la organización de los almacenes.

La puesta en valor del museo como institución investigadora, conllevaría la dinamización de la biblioteca ${ }^{36}$. Los estudiantes universitarios apenas hacen uso de estas dependencias. Se lograría potenciar su utilización mediante

\footnotetext{
${ }^{36}$ Tercera línea estratégica del Plan de calidad: El soporte físico de los museos.
}

la habilitación del préstamo de fondos a este personal en vías de especialización. Junto a su función de apoyo a la actividad interna del museo, prestará otros servicios tales como:

Orientación en la búsqueda y recuperación de información especializada en arqueología, prehistoria e historia antigua y medieval de Andalucía..

Facilitar el acceso a documentación de difícil localización por no encontrarse disponible entre sus fondos, a través de las solicitudes de préstamo interbibliotecario.

O desarrollar, en conjunción con las escuelas técnicas, con la posible subvención por parte del ministerio correspondiente de programas de Investigación + Desarrollo, herramientas informáticas de comunicación, específicas para museos, a través de las que se oferten una mayor variedad de servicios a una población 
potencialmente mundial y no solamente una abundante cantidad de información.

Si el programa alcanzase el éxito, otras instituciones como el Consejo Superior de Investigaciones Científicas podrían entrar a formar parte de nuevas líneas de trabajo en este programa dentro del Estado.

Las becas Picasso, de prácticas profesionales en empresas para jóvenes menores de 35 años, o los programas de movilidad de estudiantes de educación secundaria y universitaria, Sócrates y Erasmus, abren las posibilidades de formación y desarrollo profesional, al espacio de la Comunidad europea, y se presenta como una gran oportunidad de intercambio de conocimientos, experiencias y recursos para el sector de los museos.
Así, en colaboración con los departamentos de la Universidad de Sevilla (no sólo de las carreras del sector de las humanidades, sino también de las científicas o de ciencias sociales orientadas al estudio patrimonial), como de la Pablo de Olavide, se podrían abrir plazas, becas o estancias a estudiantes o investigadores extranjeros. Siempre desde unos objetivos bien marcados y con la supervisión constante y directa, tanto de la institución de recepción del investigador como de la de su lugar de origen.

\section{II.5. PROGRAMA DE CONSERVACIÓN}

\section{II.5.1. Criterios generales de conservación de las colecciones.}

La puesta en marcha de un programa de conservación preventiva se ha ideado con un doble fin: 
Por un lado la mejora de las condiciones de "vida" de las piezas en su entorno.

Por otro, se pretende que el departamento de conservación en colaboración con el de difusión den a conocer esta labor del museo a los diferentes grupos de edades. Hemos pensado llamar a esta propuesta C. T. P., "Conserva tu Patrimonio". Comenzando por los alumnos de primaria, y abarcando hasta personas de la tercera edad, se explicarán, según sus posibilidades de comprensión, las pautas de recogida de datos, su interpretación y se animará a los participantes en estos programas a elaborar sus propias propuestas de conservación o restauración, siempre sin ánimo de sustituir el trabajo de los profesionales. Bien al contrario, se trata de involucrar de una manera más directa al visitante en la vida diaria de la institución de fomentar una mayor sensibilización hacia su pasado.
A posteriori, resultará imprescindible la realización de programas de evaluación y corrección de las pautas para recolección y análisis de datos. Igualmente se pondrán en cuestión las medidas que se hayan ido desarrollando, corrigiéndolas en caso necesario.

Para la realización de la evaluación proponemos el seguimiento del esquema circular presentado por Benoit de Tapol que contiene los siguientes apartados:

Misión del museo.

Personal.

Presupuestos.

Sensibilización del público.

Fuego.

Inundaciones.

Robo y vandalismo.

Acondicionamiento de las colecciones.

Inventarios.

Préstamos para exposiciones. 
Manipulación y consultas.

Clima.

Luz

Salubridad de riesgos biológicos.

Limpieza y mantenimiento.

Gestión del espacio del mobiliario.

Funcionalidad del local para la circulación.

Esta serie de conceptos se sitúan en una rueda. Cada uno de ellos se divide en una serie de cuadros. Se contesta a un cuestionario, eligiendo sí o no, y en función de las respuestas se colorea un mayor o menor número de los cuadros. Aunque no se tiene en cuenta en este sistema el estado de conservación, sí que se atiende al acondicionamiento en exposición o en las reservas.

Presenta una forma sencilla de visualizar los puntos fuertes del museo y sus debilidades ${ }^{37}$.

\footnotetext{
${ }^{37}$ De TAPOL, B., "La aplicación de programas norteamericanos asistidos por ordenador para la gestión de la conservación preventiva de museos de Europa", VI coloquio Galego de Museos. A conservación preventiva, A Coruña 27 a 28 xaneiro, 2000, pp. 231-250.
}

Zonas de reserva.

Como se observó en el capítulo dedicado a análisis y evaluación, las condiciones de control de humedad y temperatura deberán ser modificadas si se pretende integrarlas dentro del recorrido expositivo.

El nivel de temperatura de esta zona viene siendo el adecuado, pero la cosa cambia al admitir a público. Se trata de un espacio carente de ventilación pues, como se advierte en el capítulo de análisis arquitectónico, no fue concebido para el uso recibido posteriormente. En consecuencia el flujo de visitantes debería regularse.

En una de las visitas efectuadas a dichas salas de almacenaje, comprobamos personalmente el aumento de temperatura con respecto a las plantas superiores. Una medida a tomar, para el control de temperatura y humedad será la colocación de un par de termohigrógrafos en el interior de estos recintos. Durante un año al menos, se tomarán datos de manera regular. Si fuera posible se 
preferirá el empleo de datalogger, medidores con almacenamiento de datos incluidos, los cuales podrían conectarse a un ordenador en el que se registrarían las tomas progresivas desde todas las fuentes de datos, para la toma de decisiones de cada una de las áreas: salas de exposición, de tratamiento de las piezas, o de almacenaje. Tras este periodo de tiempo, los aparatos de medición y recogida de datos deberán ser comprobados para verificar que no han sufrido un desajuste.

En caso contrario, volverán a ser debidamente calibrados. De este mismo modo se procederá en el conjunto de áreas del museo destinadas a albergar piezas: zona de exposición, laboratorios o talleres.

Junto al control de la temperatura y de la humedad es importante la renovación periódica del aire.

Se conseguirá a través de la instalación de un sistema de climatización. Pensamos este tipo de procedimiento de control para el nuevo edificio pues durante la obra puede planificarse todo aquello considerado oportuno, mientras en el edificio actual las complicaciones serían mucho mayores.

Una de las ventajas de este método es la creación de diversas zonas en cada una de las cuales se pueden adoptar las condiciones que se necesiten.

Auque existen diversas clases de climatizadores, en general estos son sus componentes:

Cámara de mezcla del aire. Introduce el aire exterior y el aire de recirculación para obtener la mezcla buscada.

Zona de filtrado. Se busca aquí la retención de partículas sólidas y de los olores.

A continuación se lleva el aire a las zonas de precalentamiento, humectación, batería de frío y 
postcalentamiento. De aquí sale el aire con las condiciones de humedad y temperatura deseadas. Un ventilador lo impulsa hasta los conductos de salida.

También cuenta con un silenciador que evita la propagación del ruido por las instalaciones.

Pasamos ahora a explicar los diversos materiales recogidos en esta tipología de museo los cuales pueden agruparse de muy diversas formas, todas ellas útiles para el fin de la conservación:

\section{II.5.1.1. Por cronologías.}

Conociendo la edad del vestigio, y procediendo por comparación con otras piezas estudiadas, datadas con seguridad, y quizás tratadas, podremos conocer de una forma más exacta el comportamiento de la pieza ante el proceso de conservación que podamos considerar más adecuado, aplicándolo a las condiciones específicas de este lugar.

\section{II.5.1.2. Por composición.}

Como es lógico, cada una de estas clasificaciones debe ayudarse de las otras, pues en algunos casos resultarán complementarias y en otros indispensables. Este tipo de estudio se encaminará a la determinación de la naturaleza del problema en cuestión que afecta al fragmento.

Y según su ubicación.

Pues los diversos materiales van a reaccionar de modos diversos si están sumergidos, o si son enterrados, es decir según sus condiciones previas.

Estas clasificaciones se pueden aumentar en detalle, pues cada una de ellas es susceptible de alcanzar un mayor número de subdivisiones. Para lo que aquí nos interesa, 
nos centraremos en la división por composición de los materiales, separándolos a su vez, en dos grupos:

Materiales orgánicos: Hueso, marfil, madera y otros. Materiales inorgánicos: Piedra, cerámica, vidrio y metales.

En la clasificación anterior no se escapa el hecho de que un mismo material procedente de situaciones bien diversas debería tener un tratamiento ajustado a sus necesidades, únicas $^{38}$

Aun así, vamos a tratar de ofrecer una caracterización de los problemas que suelen presentar los diferentes materiales enunciados. De estos, obtendremos unas pautas generales que sirvan de guía para la comprensión de la especificidad de casa proceso.

${ }^{38}$ Para la elaboración de este apartado se ha consultado la bibliografía reunida a través de las clases del máster, así como otras fuentes, pero por dar una visión pensamos que global y a la vez bastante pormenorizada del asunto, signamos el siguiente trabajo a modo de obra de referencia: BERDUCOU, M, (coord.), La Conservation en archéologie, Ed. Masson, 1990.

\section{Hueso y marfil.}

Materiales muy similares. Del mismo modo que los demás componentes orgánicos presenta tres tipos de degradación:

\section{De orden físico.}

De muy diversa casuística. Ya sea debida a la presión ejercida por el material, por la congelación del agua, debida al descenso de la temperatura. O bien por la evaporación con la consiguiente pérdida de elasticidad de las fibras de los materiales.

\section{De tipo químico.}

Sobre todo, el proceso de oxidación que conlleva la destrucción de cadenas moleculares, a su vez causa de la 
separación de algunas capas de los materiales. Por tanto pérdida de la consistencia física y química.

\section{Biológica.}

La falta de control de humedad, el aumento de la concentración de agua, puede facilitar la aparición de hongos y bacterias que tomen los materiales como fuente de alimentación para su desarrollo, con la consiguiente destrucción del mismo.

\section{Madera.}

Material muy higroscópico. Como cualquier sustancia orgánica, el agua se encuentra entre sus componentes. $Y$ la capacidad de intercambiarla con su medio ambiente, absorbiéndola o perdiéndola, se conoce como la propiedad de la higroscopicidad. La llamada agua de constitución es aquella que forma enlace químico con alguna otra de las sustancias constitutivas. La que no puede ser enlazada, queda suelta. Si ésta llega a un nivel en torno al $75 \%$ de Humedad Relativa, se debe estar alerta ante el riesgo de hongos. Si por el contrario baja en exceso, algo menos de un $40 \%$, se debe controlar para evitar la aparición de grietas. También se deberá reparar en que es la fuente de alimento de insectos como la polilla.

\section{Piedra}

Puede parecer que es el más duro de todos ellos, pero en las condiciones medioambientales actuales ha dejado de ser así. Las calizas y el mármol son compuestos de carbonato cálcico. El dióxido de azufre, muy presente en la atmósfera de nuestras ciudades, surge como resultado del 
humo de vehículos o industrias. Al combinarse con el oxígeno del aire resulta ácido sulfúrico de gran poder de disolución para los compuestos antes citados.

\section{Cerámica y vidrio}

La cerámica es muy porosa y por ello susceptible de absorber agua. En este medio se encuentran disueltas varias clases de sales las cuales en caso de evaporación pasarían a estado sólido, cristalizando. Producirían entonces una considerable fuerza en la pasta cerámica, con el riesgo de agrietado, o incluso de no poner remedio, de fractura.

El vidrio también puede interactuar con el agua. Absorberla o perderla por evaporación. En el primero de los casos es reconocible por la pérdida de transparencia del cristal. Este fenómeno es conocido como irisación por la adquisición del material de semejantes al contacto con la luz a los del arco iris. Si nos encontramos ante un proceso de evaporación se podrá reconocer por la formación de pequeñas gotas en la superficie. En ambos casos la falta de tratamiento finalizará con la inutilidad del objeto. Algunas recomendaciones para su mejor conservación:

El área de almacenamiento debe estar siempre seca y bien ventilada. Esto no quiere decir que se deberá permitir la entrada de corrientes de aire, del exterior del museo o de cualquier otra zona, con condiciones climáticas muy diferentes. Por el contrario, se pretende explicar que la circulación del aire y su renovación deben realizarse bajo un absoluto control, mediante sistemas de climatización que posean la posibilidad de extracción y regeneración por filtrado del aire.

Durante los días fríos, se debe mantener el almacén cerrado, evitando el enfriamiento de las láminas de vidrio por debajo del punto de rocío del ambiente, y su posterior condensación. 
Su tiempo de permanencia en el almacén debe ser minimizado, a través de utilización de almacenamientos pequeños y bien equilibrados.

\section{Metales}

Todos los metales tienen algún grado de sensibilidad al ambiente. Los que en menor grado la presentan son denominados Metales Nobles, el Oro, la Plata o el Platino. Y el problema más frecuente con el que nos vamos a encontrar en este tipo de piezas, derivado de esta sensibilidad, es el de la corrosión.

Hay que determinar cuál es el nivel que alcanza el deterioro. Si se trata de un daño superficial o de capas más profundas. La corrosión suele tener su comienzo en la humedad ambiental. Para evitarla sería bueno conseguir una estabilización en las zonas de exposición o almacenaje de estas piezas no superior al $45 \%$. Todo esto con la finalidad de decidir cuál será la capa original que mostraremos, ya en las mejores condiciones. La mayor parte de los metales se degrada de una forma lenta, pero hasta la menor distorsión de la superficie por culpa de este proceso de degradación cambia su apariencia, la cual en muchos casos es importante desde el punto de vista de exhibición, produciendo la necesidad de continuas limpiezas que al final significan una degradación acelerada.

\section{II.5.2. Edificio nuevo}

Dentro del programa arquitectónico se ha señalado la necesidad de construir un nuevo edificio destinado, entre otros fines, a albergar como almacén futuras piezas resultado de nuevas excavaciones. Este edificio, al ser de nueva planta, debería dotarse de los necesarios adelantos tecnológicos en materia de conservación, como un buen sistema de aire acondicionado o sistemas integrados por toda la construcción de recogida y almacenaje de datos, de la temperatura o humedad relativa. 


\section{Laboratorio de restauración.}

Los restauradores han expresado como la mayor de sus necesidades un aumento del espacio para disponer de salas de aclimatación de piezas de reciente entrada en el museo o para trabajar con grandes formatos. En estas nuevas salas las condiciones de temperatura y humedad deberán ser las ya expresadas. Sin embargo, en el espacio actual dedicado a restauración, también se han de instalar los imprescindibles aparatos de registro de datos climáticos.

\section{Sala de exposiciones temporales.}

Si en las diversas áreas ya enumeradas y estudiadas del museo, resulta importante el control del clima en sus diversos registros, en ésta todavía en mayor medida. Es muy frecuente que en una exposición temporal entren a formar parte del discurso piezas de muy diversa procedencia. Y es imprescindible minimizar el castigo que esta actividad supone para los materiales. Después de haber dado un tiempo a la pieza entrante para aclimatarse a su nuevo ambiente, al menos mínimamente, se debe realizar controles periódicos con gran frecuencia durante la duración de la muestra, siendo la situación ideal, la agrupación de piezas por materiales. Si los componentes son similares, sus necesidades también. Si esta situación no fuera posible se deberá prestar especial atención a los materiales más sensibles, llegando a plantear una presentación aislada, en vitrinas individuales incluso, de otros de mayor resistencia.

\section{II.5.3. Humedad relativa y temperatura}

Ofrecemos ahora diferentes datos referidos a las condiciones óptimas de control de temperatura y humedad relativa según diversas fuentes de solvencia contrastada, para zonas de exposición. Hemos optado por la inclusión de varias fuentes de estos datos, debido a que no existe 
un acuerdo unánime entre la literatura especializada en cuanto a su determinación. Por eso se trata de orientar, de formar un punto de partida sobre el que decidir o modificar los controles de temperatura y humedad en función de la evolución del conocimiento a cerca del comportamiento de las colecciones y su medio ambiente.

El ICCROM en 1990 se decantaba por los siguientes parámetros.

\section{II.5.3.1. Humedad relativa}

Para objetos inorgánicos como metales, piedra o cerámica en torno a un $0-45 \%$. Si se trata de vidrio entre un 42 y un $45 \%$. Y si fueran fósiles entre un 42 y un $55 \%$. En caso de que sean materiales orgánicos como madera, marfil, cuero o papel, podrían mantenerse con una oscilación entre un 45 un $65 \%$.

Para el mantenimiento de objetos salidos de una excavación antes del tratamiento, tales como piedra, mosaicos o incluso cerámicas o madera, un 100\%

\section{II.5.3.2. Temperatura y humedad}

En general en torno a los 20 grados centígrados o por debajo si fuera posible.

En la bibliografía consultada aparecen diferentes valores provenientes incluso desde este mismo organismo. Atendiendo a una clasificación por materiales indica estas cifras:

Para materiales inorgánicos como metales, una temperatura de 18 grados centígrados, con una máxima de unos 25 grados y una mínima de unos diez. En nuestra 
opinión 10 grados es una cifra excesivamente baja inclusive para los metales. La humedad relativa puede oscilar en este caso entre un 35 y un $50 \%$.

Los materiales orgánicos deben mantener una humedad en torno al $50 \%$ y una temperatura de unos 18 grados que disminuiría hasta diez si fueran materiales de alta humedad.

Garry Thompson uno de los autores de referencia en este campo durante bastante tiempo, opinaba:

La conservación óptima se da en su opinión en torno a los 20 grados con una oscilación de más menos 1,5 grados. Los límites habría que fijarlos entre 16 y 25 grados con una oscilación de más 1,5 grados diarios.

La humedad se debe situar entre un 40 y un $55 \%$ con una posibilidad de oscilación de un $3 \%$.

\section{II.5.4. Contaminación.}

\section{II.5.4.1. Sistemas de medición de la contaminación.}

Un contaminante se define como "cualquier sustancia extraña (sea cual sea su estado físico) que altera la composición normal de la atmósfera"39. Según los autores citados, deberían diferenciarse en la selección de sistemas de recogida de datos de la contaminación entre su naturaleza gaseosa o de partículas.

\section{Procedimientos de medición para gases inorgánicos}

Se dispone de multitud de procedimientos de medición para la gran variedad de gases inorgánicos que existen. Pueden clasificarse en manuales y automáticos.

Procedimientos manuales

${ }^{39}$ MATEINI, M., et MOLES, A., Ciencia y restauración, ed. Nerea y Junta de Andalucía, Guipúzcoa, 2001, p. 273. 
La sustancia objeto de la medición es normalmente absorbida durante el muestreo en una solución o en un material sólido.

En la mayoría de casos se realiza una determinación fotométrica después de una reacción de coloración. Un método especial de muestreo que se utiliza principalmente en los procedimientos manuales de medición es el tubo de separación por difusión. En esta técnica la separación de las fases de gas y de partículas se consigue por las diferentes velocidades de difusión.

En la técnica clásica de separación, el aire que debe analizarse se succiona a través de un tubo de vidrio con un recubrimiento especial, que varía según el material que se pretende recoger.

\section{Procedimientos automatizados}

En el mercado existen numerosos monitores que realizan mediciones continuas del dióxido de azufre, los óxidos de nitrógeno, el monóxido de carbono y el ozono. Todos los procedimientos automáticos de medición que se basan en principios fisicoquímicos deben ser calibrados utilizando procedimientos de referencia manuales.

\section{Procedimientos de medición para contaminantes en forma de polvo y su composición.}

Entre los contaminantes atmosféricos particulados, se puede diferenciar entre la fracción susceptible de sedimentación y la de partículas en suspensión. La primera está formada por partículas más grande, se depositan en el suelo por su tamaño y grosor. La segunda corresponde a las partículas que se dispersan en la atmósfera de una forma homogénea $y$, por lo tanto, permanecen en suspensión durante un cierto tiempo.

\section{El procedimiento del humo negro.}


Este método, desarrollado en Gran Bretaña, ha sido incorporado a las directrices de la Unión Europea para el SO2 y el polvo en suspensión. En este procedimiento, después del muestreo, el ennegrecimiento del filtro se mide con un fotómetro réflex. Los valores de negro de humo obtenidos se convierten con la ayuda de una curva de calibrado en unidades gravimétricas, $\mathrm{g} / \mathrm{m} 3$.

Los métodos más utilizados son la espectroscopia de absorción atómica y la espectroscopia con excitación por plasma. Otros métodos son: el análisis de fluorescencia de rayos $\mathrm{X}$, la polarografía y el análisis de activación de neutrones.

Otro problema es que en el análisis de los compuestos metálicos presentes en el polvo en suspensión, los procedimientos de medición convencionales no permiten distinguir entre diferentes formas de un mismo compuesto o compuestos individuales de los elementos respectivos.

\section{Medición del polvo sedimentable y sus compuestos metálicos}

Para recoger el polvo sedimentable se utilizan dos métodos diferentes:

- Realizar un muestreo en los colectores y,

- Realizar otro muestreo en superficies adhesivas. Un procedimiento habitual consiste en recoger durante unos 30 días toda la precipitación atmosférica, precipitación seca y húmeda, en colectores situados a 1,5 - 2,0 metros por encima del nivel del suelo, precipitación aparente. A continuación, los colectores se envían al laboratorio y se preparan mediante filtrado, evaporación del agua, secado y pesado. El resultado se calcula en función de la superficie del colector y el tiempo de exposición, expresándolo en la unidad g/m2/día. 
Otro procedimiento para la recogida del polvo sedimentable se realiza por la recogida del polvo depositado sobre láminas adhesivas. Las mediciones dependen del aparato utilizado. Las diferencias pueden llegar a ser hasta del 50 $\%$. También influye la composición del polvo depositado. Los métodos analíticos utilizados en este caso son prácticamente iguales a los utilizados para el polvo en suspensión.

\section{Medición de materiales especiales en forma de polvo}

Entre los materiales especiales en forma de polvo se encuentran el amianto y el hollín.

Los métodos utilizados para medir materiales fibrosos se basan en el recuento al microscopio del volumen de fibras adheridas a los filtros. Las fibras se separan en filtros porosos recubiertos de oro. Antes de realizar el análisis en el microscopio electrónico se eliminan de la muestra las sustancias orgánicas mediante incineración por plasma en el mismo filtro. El recuento de fibras se realiza en una parte de la superficie del filtro elegida aleatoriamente y las fibras se clasifican según su forma y tipo. Mediante análisis de dispersión de energía por rayos $X$ (procedimiento denominado EDXA), se diferencian las fibras según su composición elemental. Para determinar el contenido de hollín se utilizan asimismo el etalómetro y el sensor fotoeléctrico de aerosoles.

La contaminación atmosférica, procedente del exterior, no ha producido unos efectos de gravedad en este museo. Al estar situado en un parque, la vegetación circundante realiza una función de importante parapeto. Aún así, en el caso de entrada de nuevas piezas, el estudio de conservación preventiva debe poner buen cuidado en el análisis de este tipo de degradación pues, por estar las piezas del interior a salvo de esta degradación, el contacto con otras posiblemente afectadas podría causar un mayor daño. $Y$ abundando en la necesidad de conocer la evolución del estado de conservación de las piezas. 
En opinión de García Fernández, mientras en los museos de nueva construcción los sistemas de aire acondicionado funcionan como filtro para aislar a las piezas de la contaminación exterior, en los edificios históricos las vitrinas, por la ausencia de sistemas de ventilación, son los principales agentes aislantes para las piezas.

\section{II.5.4.2. Recomendaciones:}

Indicadas por Gaël de Guichen para conseguir vitrinas "adecuadas".

Debemos asegurarnos que las vitrinas se bamboleen. Así cuando los visitantes se acerquen todos los objetos se moverán.

La cerradura se colocará en un lugar bien visible.

Entre las puertas corredizas de la vitrina habrá suficiente espacio para facilitar al visitante acercarse a los objetos.
Nunca se cerrarán herméticamente las vitrinas, ya que los objetos lucen más si están cubiertos de una capa de polvo.

llumine al máximo la zona que rodea a la vitrina.

Insertar reflectores en el interior de la vitrina.

Las dos observaciones anteriores ayudarán a convertir las vitrinas en un buen espejo.

Obstaculice todo lo posible el cambio de as lámparas del interior de la vitrina.

En la construcción de las vitrinas daremos prioridad a la estética frente a la funcionalidad.

Estas recomendaciones se hacen con carácter general, pero en lo referido a los contaminantes, las vitrinas deberán estar construidas con materiales no emisores de sustancias dañinas. 
Los cristales. Son generalmente muy utilizados junto con el metacrilato y el policarbonato.

Los cristales corrientes poseen una buena óptica pero tienen el inconveniente de su fragilidad frente a roturas. Se viene prefiriendo los cristales laminados más resistentes aunque también de un costo más elevado.

El metacrilato resulta fácil de trabajar, es resistente a impactos y a sustancias químicas, poseen buena claridad y su peso es ligero. Como inconvenientes presenta la curvatura de la superficie si se usan planchas grandes pero no proporcionalmente gruesas. Existen diversas tipologías: resistentes a las abrasiones, a los impactos y con filtro contra los rayos UVA.

El policarbonato es el más resistente de los tres, aunque menos transparente no resulta fácil de trabajar ni de moldear por su gran contenido en agua y las juntas son difíciles de esconder ya que es necesario asegurarlo con pegamentos.

Pegamentos y adhesivos. Su gran problemas es la emisión de vapores dañinos para las piezas durante su secado. En caso de tener que unir grandes superficies se preferirán medios mecánicos al empleo de estas sustancias.

Los que se preferirán son los adhesivos al calor por no estar compuestos por disolventes. Igualmente algunos epoxis, pero sólo aquellos formados por dos componentes, el poliuretano, la melamina, el fenol formaldehído o los pegamentos formados a partir de sustancias animales.

Tendremos en cuenta ahora las sustancias utilizadas para la colocación de barreras de impermeabilización en la construcción de las vitrinas, como ayuda para la mejor protección de los objetos. También se tomará en consideración que los materiales elegidos sean de una alta estabilidad. 
Los más efectivos son los laminados plásticos. Se aplican por presión o pegándolos de modo habitual. Sobre todo pertenecen a dos clases: Las láminas metálicas o las películas de polietileno metalizadas, cuidando de no atravesarlos, que no tengan perforaciones.

Usaremos los epoxis o uretanos de dos componentes, el vinilo acrílico o el acrílico modificado, la pintura en polvo, solo para metales, el uretanos acrílico o las emulsiones acrílicas, tanto para interior como en el exterior. Evitaremos las pinturas con base de aceite, los epoxis y uretanos de un componente los barnices de látex las pinturas anticorrosión o las pinturas alquídicas.

\section{II.5.4.3. La contaminación biológica}

En diversas salas, entre ellas la número uno, las vitrinas deben cambiarse por otras estancas, para evitar la entrada de pequeños insectos, o la posibilidad de introducción de objetos.
A pesar de no estar resuelto el control de la entrada de insectos en las vitrinas, pensamos que en este caso no se trata de plagas activas, pues no hemos encontrado restos de materiales como aserrín en las maderas.

El polvo contenido en algunas vitrinas debe ser eliminado para hacer desaparecer esporas de hongos allí contenidas. Un buen método puede ser la utilización de aspiradoras.

En las zonas de nueva planta habrá que mantener una buena ventilación como previsión para la formación de humedades.

En caso de detección de zonas muy húmedas, eliminarlas utilizando productos aislantes. A menor humedad menos posibilidad de desarrollo de agentes biológicos. 
El uso de fungicidas ${ }^{40}$ para eliminar estos agentes debe ser prudente debido a que se desconocen sus efectos a largo plazo sobre las colecciones. Por ello, es preferible la utilización de otros métodos de creación de atmósferas sin oxígeno. Son numerosos los métodos que se están ensayando en este sentido. Entre ellos citaremos:

\section{- Bolsas de polímeros.}

Los polímeros son moléculas tamaño gigante. Se producen por la unión de cientos de miles de moléculas pequeñas denominadas monómeros que forman enormes cadenas de las formas más diversas.

El polietileno de baja densidad, el PVC o el etileno, los cuales presentan baja permeabilidad al oxígeno y una buena resistencia para su manipulación por su elevada elasticidad. No suelen tener un precio muy elevado.

\footnotetext{
${ }^{40}$ Como base para este apartado, se ha escogido el siguiente trabajo: Maekawa, S., et Selwitz, C., Inert Gases in the Control of Museum Insect Pest, en su versión electrónica. Se puede descargar gratuitamente en la siguiente url: www.getty.edu.
}

\section{- Empleo de gases inertes como el argón, el nitrógeno o el dióxido de carbono.}

Se suelen introducir los objetos en atmósferas aisladas a las que se va extrayendo el oxígeno intercambiándolo por alguno de estos gases.

Se mantiene la exposición de objeto o lugar infectado durante un determinado periodo de tiempo, variable en función del gas y de la especie a eliminar.

Se debe poner cuidado en no utilizar los gases en contacto con materiales reactivos a ellos.

Y por supuesto los encargados de la aplicación de esta clase de productos, durante todo el tiempo en que se encuentren en las cercanías de estas atmósferas podrán cuidado en protegerse la vías respiratorias. Una vez finalizada la operación se deberá renovar el aire de la zona 
o habitación en la que se haya estado trabajando para eliminar cualquier posibilidad de peligro para las personas.

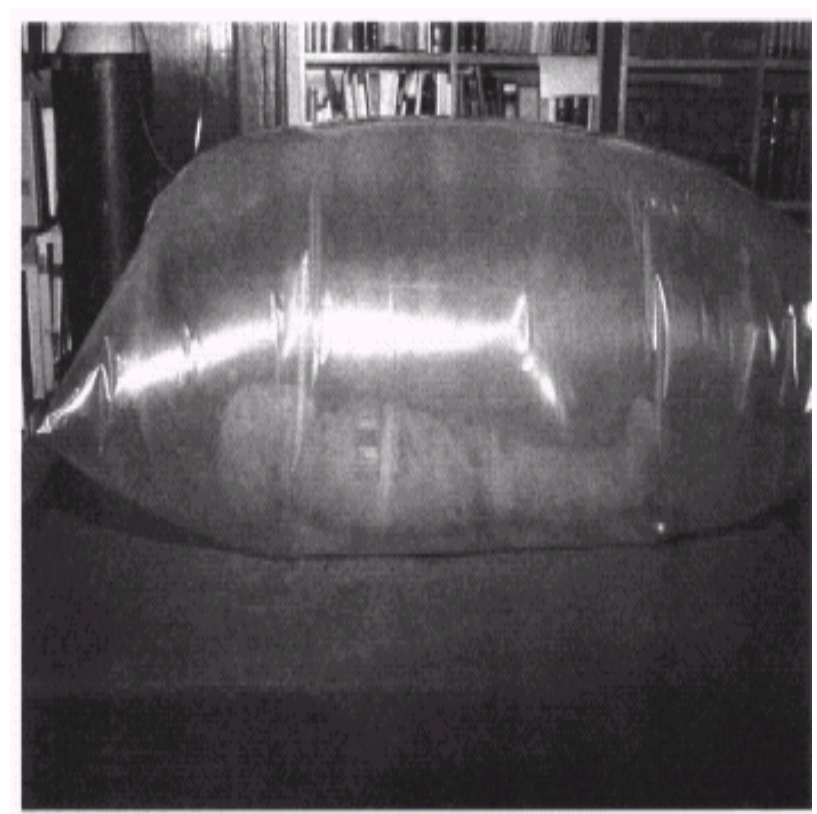

\section{II.5.4.4. Contaminación acústica}

No tiene repercusiones en el estado de conservación de las piezas, pero nos parece interesante reseñarla conjuntamente, pues no deja de ser un problema durante la visita. Debería tenerse en cuenta, sobre todo en la construcción del nuevo edificio, para la instalación de paneles aislantes preferentemente en sus plantas superiores.

\section{Il.5.5. Iluminación.}

Como criterio para el establecimiento de parámetros generales, útil no sólo en museos, se puede seguir la norma europea UNE 12464 de iluminación de lugares de trabajo, junto a las recomendaciones expresadas en las publicaciones del Instituto canadiense de Conservación por Stefan Michalsky. Las que aquí nos van a interesar son las referidas a entornos en los que se ha controlado completamente las condiciones lumínicas y el objetivo a perseguir ese la prolongación al máximo posible de la vida de los objetos. Establecen las siguientes cifras:

Material orgánico y o inorgánico éste sensible a la luz y a la radiación UV: 
- Luz: 50 lux, sólo en presencia de usuarios.

- Ultravioleta: menos de $10 \mathrm{u} \mathrm{W} / \mathrm{lm}$.

\section{Para todo material inorgánico insensible a la luz o a la radiación UV:}

Nivel de iluminación ilimitado, pero no debe elevar la temperatura de la superficie del objeto más de 5 grados centígrados por encima de la temperatura ambiental. Como regla básica, el haz luminoso no debe sentirse caliente sobre la mano.

Si las condiciones de luz no se han controlado completamente, como en el caso de las salas que tienen estatuaria romana:

- Aquellos materiales orgánicos y los inorgánicos que sean sensibles a la luz y a la radiación ultravioleta:
Luz: evite el rango de más de 150 lux.

Ultravioleta: menos de $75 \mathrm{u}$ W/Im.

En el caso de los materiales inorgánicos no sensibles a la luz o a la radiación, tendremos que evitar la incidencia directa del haz de rayos, especialmente si el objeto está compuesto de elementos frágiles, como las tintan antes mencionadas.

Garry Thompson estableció en los años 70 un rango entre 50 y 300 luxes como máximas y mínimas con una media para materiales no muy sensibles de 150 luxes. $Y$ fue aceptado sin excesiva crítica posterior.

Como esquema para calcular las cifras adecuadas en cada museo se puede utilizar el aportado por García Fernández:

“... se prefiere el sistema de exposición total, número de 
horas de exposición al año multiplicado por el nivel de iluminación en luxes ${ }^{41 "}$.

Esto en lo referido a los parámetros calculados con un fin de conservación para las piezas. Pero el investigador también especifica otros factores sobre los cuales reparar como la capacidad visual del espectador, menor cuanto mayor sea su edad, o ante condiciones luminosas de grandes diferencias, el tiempo de exposición del objeto a la luz, no debemos olvidar que el efecto de la luz es acumulativo: la luz recibida durante un periodo de tiempo determinado, por ejemplo un año, se suma a la del siguiente, etc, o las condiciones de contraste entre objeto y entorno.

Sobre este último aspecto aportamos la siguiente tabla de contrastes.

\begin{tabular}{|l|l|}
\hline COLOR DEL OBJETO & COLOR DEL FONDO \\
\hline Negro & Amarillo \\
\hline Verde & Blanco \\
\hline Rojo & Blanco \\
\hline Azul & Blanco \\
\hline Blanco & Azul \\
\hline Negro & Blanco \\
\hline Amarillo & Negro \\
\hline Blanco & Rojo \\
\hline Blanco & Verde \\
\hline Blanco & Negro \\
\hline
\end{tabular}

Para conocer la cantidad de luz que incide sobre los objetos o que rebota desde una pared o superficie, deberemos usar el instrumento denominado luxómetro. Los hay: 
- Digitales o analógicos. Estos últimos deben ser manipulados con gran cuidado evitando los golpes pues pierden la calibración con facilidad.

- De células de medición de diversos materiales. Los más exactos pero también los más caros son los de silicio.

Otros instrumentos útiles en el museo para la medición de la luz serán: los medidores de infrarrojos y ultravioleta o los colorímetros encargados de calibrar la temperatura de color de los objetos.

Vamos a pasar ahora a estudiar la normativa estatal y europea en cuanto a condiciones de iluminación en lugares de trabajo se refiere.

El acondicionamiento de la iluminación conlleva la necesidad de proporcionar un nivel de luz adecuado al tipo de actividad realizada, pero es necesario considerar también otros aspectos importantes, entre los que se encuentran el control del deslumbramiento, la uniformidad de la iluminación, el equilibrio de luminancias en el campo visual y la integración de la luz natural.

Ahora bien, las exigencias visuales de la tarea no constituyen el único factor a considerar en el acondicionamiento de la iluminación, también es necesario tener en cuenta la existencia observadores con una capacidad visual menor de la normal y las consecuencias negativas para la seguridad de las personas que se pueden derivar de los errores debidos a una mala visibilidad. Esto puede requerir el aumento de los niveles de luz y la adecuación de otros aspectos de la iluminación.

El empleo de la luz natural tiene varias ventajas; al ahorro energético que pueda suponer se une la calidad de la luz natural: capacidad de reproducción cromática, estabilidad del flujo luminoso, tonalidad de la luz, etc. Por otra parte, el aporte de luz natural mediante la utilización de ventanas 
puede satisfacer la necesidad psicológica de contacto visual con el mundo exterior.

El acondicionamiento de la iluminación natural lleva consigo la colocación correcta de los puestos de trabajo respecto a las ventanas o claraboyas, de manera que los trabajadores no sufran deslumbramiento y la luz solar no se proyecte directamente sobre la superficie de trabajo. Estas medidas se pueden complementar con la utilización de persianas, estores, cortinas y toldos, destinados a controlar tanto la radiación solar directa como el posible deslumbramiento.

Ahora bien, en la mayoría de los lugares de trabajo la luz solar no será suficiente para iluminar las zonas más alejadas de las ventanas ni para satisfacer las necesidades a cualquier hora del día, por lo que será necesario contar con un sistema de iluminación artificial complementario.

Este sistema estará diseñado para proporcionar una iluminación general suficiente en las condiciones más desfavorables de luz natural.

En los lugares de trabajo donde sea necesario combinar la luz natural y la artificial se recomienda el empleo de lámparas con una "temperatura de color" comprendida entre 4.000 y 5.000 grados Kelvin. Esta tonalidad, compatible con la de la luz natural, se puede lograr fácilmente utilizando lámparas fluorescentes 0 de descarga. Sin embargo, las lámparas incandescentes estándar tienen una temperatura de color demasiado baja para esta finalidad.

En muchos casos, el nivel de la iluminación general puede ser suficiente para todas las tareas realizadas en un local, pero en otras ocasiones las necesidades particulares de algún puesto o tarea visual pueden hacer aconsejable el empleo de sistemas de iluminación localizada que complementen el nivel de la iluminación general. 
Cuando se utilice iluminación localizada en algún puesto o zona de trabajo, es necesario proporcionar también una iluminación general, destinada a evitar desequilibrios de luminancia en el entorno visual. Esta iluminación general deberá ser tanto mayor cuanto más grande sea el nivel de la iluminación localizada.

Por "zona donde se ejecuten tareas" se debe entender cualquier zona donde los trabajadores tengan que realizar una función visual en el transcurso de su actividad.

Por "vía de circulación" se debe entender cualquier lugar de trabajo destinado a la circulación de personas o vehículos, ya sea en interiores o en exteriores.

Por "área o local", de uso habitual u ocasional, se debe entender cualquier otra área, edificada o no, en la que los trabajadores deban permanecer o a la que puedan acceder en razón de su trabajo. Se consideran incluidos en esta definición los servicios higiénicos y locales de descanso, los locales de primeros auxilios y los comedores.

Con el fin de facilitar la interpretación de los niveles mínimos de iluminación establecidos en el presente Real Decreto se puede hacer la siguiente comparación con los niveles mínimos recomendados por las normas UNE 72 163 - 84 y UNE 72 - 112 - 85: 


\begin{tabular}{|c|c|c|c|}
\hline R. DECRETO & $\begin{array}{l}\text { NORMAS } \\
\text { UNE }\end{array}$ & & \\
\hline $\begin{array}{l}\text { Exigencias de } \\
\text { la tarea }\end{array}$ & $\begin{array}{l}\text { Nivel mínimo } \\
\text { requerido } \\
\text { (Lux) }\end{array}$ & $\begin{array}{l}\text { Categoría de } \\
\text { la tarea }\end{array}$ & $\begin{array}{l}\text { Nivel mínimo } \\
\text { recomendado. } \\
\text { (Lux) }\end{array}$ \\
\hline Bajas & 100 & D (fácil) & 200 \\
\hline Moderadas & 200 & $E$ (normal) & 500 \\
\hline Altas & 500 & F (difícil) & 1.000 \\
\hline \multirow[t]{2}{*}{ Muy altas } & 1.000 & G (muy difícil) & 2.000 \\
\hline & & $\begin{array}{l}\mathrm{H} \\
\text { (complicada) }\end{array}$ & 5.000 \\
\hline
\end{tabular}

Categoría D

Categoría E

Categoría F

Categoría G

Categoría H
Manejo de máquinas herramienta pesadas, lavado de automóviles, etc.

Trabajos comerciales, reparación de automóviles, planchado y corte en trabajos de confección, etc.

Escritura y dibujo con tinta, ajuste en mecánica, selección industrial de alimentos, etc.

Escritura y dibujo con lápiz, costura en Actividades de confección, etc.

Montaje sobre circuitos impresos, trabajos de relojería, igualación de colores, etc.

En la tabla se indica también el rendimiento en color de las lámparas, $\mathrm{Ra}$, necesario para cada una de dichas actividades y tareas.

En las áreas de uso general los niveles de iluminación han de obtenerse a una altura de $85 \mathrm{~cm}$ del suelo, en tanto que

\section{EJEMPLOS DE TAREAS VISUALES SEGÚN LA NORMA} UNE 72 - 112 - 85 
en las vías de circulación dichos niveles se deben medir al nivel del suelo, con el fin de asegurar la visualización de posibles obstáculos o discontinuidades en el mismo.

\section{Cuándo se deben incrementar los niveles de iluminación.}

El Real Decreto establece que los niveles mínimos de iluminación se deben duplicar en los siguientes casos:

En las áreas o locales de uso general y en las vías de circulación, cuando, por sus características, estado u ocupación, existan riesgos apreciables de accidente.

La aplicación de este criterio requiere una evaluación previa de los riesgos de accidente existentes en las citadas áreas o vías de circulación. Así, por ejemplo, podría ser necesario duplicar los niveles de iluminación en las áreas o zonas de paso usadas por los trabajadores, en las que se utilicen carretillas automotoras, etc.
En las zonas donde se efectúen tareas, cuando un error de apreciación visual durante la realización de las mismas pueda suponer un peligro para el trabajador que las ejecuta o para terceros.

Como en el caso anterior, la decisión de duplicar el nivel de iluminación, en una determinada zona de trabajo, se debería tomar sobre la base de la evaluación previa del riesgo de accidente.

Finalmente, los niveles mínimos de iluminación también deben ser duplicados cuando el contraste de luminancias o de color entre el objeto a visualizar y el fondo sobre el que se encuentra sea muy débil.

En todo caso, los requisitos señalados para el nivel de iluminación están supeditados a que lo permita la propia naturaleza de la tarea realizada. Por ejemplo, en los 
procesos de revelado fotográfico, realizados en cuarto oscuro, no serían aplicables los citados requerimientos.

\section{II.5.5.1. Puestos de trabajo con pantallas de visualización}

El nivel de iluminación para los puestos de trabajo con pantallas de visualización debe ser apropiado para todas las tareas realizadas en el puesto (por ejemplo, la lectura de la pantalla y de los impresos, la escritura sobre papel, el trabajo con el teclado, etc.), pero sin alcanzar niveles que puedan reducir excesivamente el contraste en la pantalla.

Uniformidad de la iluminación.

La tarea deber ser iluminada de la forma más uniforme posible. Se recomienda que la relación entre los valores mínimo y máximo de los niveles de iluminación existentes en el área del puesto donde se realiza la tarea no sea inferior a 0,8 .
Por otro lado, con el fin de evitar las molestias debidas a los cambios bruscos de luminancia, el nivel de iluminación en los alrededores debe estar en relación con el nivel existente en el área de trabajo. Se recomienda que dichos niveles no difieran en un factor mayor de cinco; por ejemplo, el acceso y los alrededores de una zona de trabajo cuyo nivel de iluminaciónsea de 500 lux, deberán tener una iluminación de, al menos, 100 lux.

\section{II.5.5.2. Equilibrio de luminancias}

La distribución de luminancias en el campo visual puede afectar a la visibilidad de la tarea e influir en la fatiga del trabajador.

La agudeza visual es máxima cuando la luminosidad de la tarea es similar a la existente en el campo visual del trabajador. Sin embargo, cuando la luminosidad de la tarea es muy diferente a la del entorno se puede producir una reducción de la eficiencia visual y la aparición de fatiga, como consecuencia de la repetida adaptación de los ojos. 
Las relaciones de luminancia que deberían ser consideradas en el acondicionamiento de la iluminación son las siguientes:

Entre la tarea y su entorno inmediato.

- Se recomienda que la luminancia del entorno inmediato sea menor que la de la tarea pero no inferior a $1 / 3$.

Entre la tarea y el entorno alejado.

- En este caso se recomienda que la relación de luminancias no sea superior a 10 ni inferior a 1/10.

El equilibrio de luminancias se puede lograr controlando la reflectancia de las superficies del entorno y los niveles de iluminación; es decir, eligiendo colores más o menos claros para las paredes y otras superficies del entorno y empleando una iluminación general adecuada, de manera que la luminosidad del entorno no sea muy diferente a la existente en el puesto de trabajo.

\section{II.5.5.3. Control del deslumbramiento}

El deslumbramiento se puede producir cuando existen fuentes de luz cuya luminancia es excesiva en relación con la luminancia general existente en el interior del local (deslumbramiento directo), o bien, cuando las fuentes de luz rebotan sobre superficies pulidas, deslumbramiento por reflejos.

El deslumbramiento puede adoptar dos formas: Deslumbramiento perturbador, cuyo principal efecto es reducir la visibilidad de la tarea, y deslumbramiento molesto, el cual no reduce la visibilidad pero produce fatiga visual.

Para evitar el deslumbramiento perturbador, los puestos y áreas de trabajo se deben diseñar de manera que no 
existan fuentes luminosas o ventanas situadas frente a los ojos del trabajador. Esto se puede lograr orientando adecuadamente los puestos o bien apantallando las fuentes de luz brillantes.

Para evitar el deslumbramiento molesto es necesario controlar todas las fuentes luminosas existentes dentro del campo visual.

Esto conlleva la utilización de persianas o cortinas en las ventanas, así como el empleo de luminarias con difusores o pantallas.

El apantallamiento debería efectuarse en todas aquellas lámparas que puedan ser vistas, desde cualquier zona de trabajo, bajo un ángulo menor de $45^{\circ}$ respecto a la línea de visión horizontal.

El grado de deslumbramiento puede ser expresado mediante el método "Unified Glare Rating" (UGR) de la
Comisión Internacional de la lluminación (CIE), en el cual se tiene en cuenta la contribución de cada una de las luminarias que forman parte de un determinado sistema de iluminación (Publicación CIE 117.)

\section{II.5.5.4. Control de los reflejos.}

En lo que concierne al control del deslumbramiento provocado por los reflejos, se pueden utilizar los siguientes procedimientos:

Emplear acabados de aspecto mate en las superficies de trabajo y del entorno.

Situar luminarias respecto al puesto de trabajo de manera que la luz llegue al trabajador lateralmente. En general, es recomendable que la iluminación le llegue al trabajador por ambos lados con el fin de evitar también las sombras molestas cuando se trabaja con ambas manos. 
Emplear luminarias con difusores, así como techos y paredes de tonos claros, especialmente cuando la tarea requiera la visualización de objetos pulidos.

\section{II.5.5.5. Dirección de la luz}

Para percibir la forma, el relieve y la textura de los objetos es importante que exista un equilibrio de luz difusa y direccional. Una iluminación demasiado difusa reduce los contrastes, empeorando la percepción de los objetos en sus tres dimensiones, mientras que la iluminación excesivamente direccional produce sombras duras que dificultan la percepción.

Algunos efectos de la luz dirigida también pueden facilitar la percepción de los detalles de una tarea; por ejemplo,

una luz dirigida sobre una superficie bajo un ángulo adecuado puede poner de manifiesto su textura. Esto puede ser importante en algunas tareas de control visual de defectos.

\section{II.5.5.6. Parpadeos.}

El flujo de luz emitido por todas las lámparas alimentadas con corriente alterna presenta una fluctuación periódica; esta fluctuación es más acusada en las lámparas fluorescentes y de descarga que en las lámparas incandescentes, debido a la inercia térmica que presenta el filamento de estas últimas.

El flujo de luz de todas las lámparas alimentadas con corriente alterna de 50 herzios presenta una fluctuación de 100 herzios; esta fluctuación es demasiado rápida para ser detectada por el ojo. No obstante, en las lámparas fluorescentes deterioradas se pueden producir parpadeos muy acusados, lo que exige su rápida sustitución.

La iluminación de emergencia, de evacuación y de seguridad debe estar disponible en todos los lugares de trabajo en los que un fallo del sistema de iluminación 
normal pueda suponer riesgos importantes para la seguridad de los trabajadores que se encuentren realizando su actividad. Esto puede incluir el contacto con máquinas peligrosas, la pérdida de control de procesos críticos, la caída desde lugares elevados, el tropiezo con obstáculos, etc.

También es preciso disponer de un sistema de iluminación que permita la evacuación del personal en caso de incendio $u$ otra emergencia.

Estos tipos de iluminación deberían estar alimentados por una fuente de energía independiente de la que proporciona la iluminación normal. El sistema debería entrar en funcionamiento de forma automática e inmediatamente después de producirse el fallo en el sistema de iluminación habitual. El nivel de iluminación y el tiempo durante el cual debe mantenerse operativo el mencionado sistema deben ser suficientes para permitir la adopción de todas las acciones necesarias para proteger la salud y seguridad de las personas afectadas.

En el Reglamento Electrotécnico de Baja Tensión (M.I.B.T. 025) y en la Norma Básica de la Edificación NBE-CPI 96 (artículo 21), se establecen los requerimientos de estos tipos de iluminación para diversos establecimientos.

Con el fin de evitar los riesgos eléctricos, los sistemas de iluminación deberán cumplir las disposiciones contenidas en el Reglamento Electrotécnico de Baja Tensión.

En relación con los riesgos de incendio y explosión deberán cumplir, específicamente, la Instrucción Complementaria M.I.B.T. 026 del citado Reglamento.

Ofrecemos en este momento unos cuadros que recogen las cifras que se consideran recomendables desde la normativa aplicable. Sólo hemos recogido aquellos datos 
que se puedan relacionar específicamente con las zonas de los museos.

Los datos para su confección han sido tomados del proyecto de norma europea prEN 12464.

\begin{tabular}{|c|c|c|}
\hline \multicolumn{3}{|c|}{$\begin{array}{c}\text { A: ZONAS DE CIRCULACIÓN Y ÁREAS GENERALES } \\
\text { INTERIORES }\end{array}$} \\
\hline $\begin{array}{l}\text { LUGAR } \\
\text { ACTIVIDAD }\end{array}$ & $\mathrm{UGR}^{(2)} \mid \mathrm{Ra}^{(3)}$ & Observaciones $^{(4)}$ \\
\hline nas de circulación & & \\
\hline Pasillos y vías de 100 & 28 & A nivel del suelo. Si hay \\
\hline
\end{tabular}

\begin{tabular}{|l|l|l|l|l|}
\hline circulación & & & & $\begin{array}{l}\text { circulación de vehículos, } \\
\text { aumentar a 150 lux }\end{array}$ \\
\hline $\begin{array}{l}\text { Escaleras y } \\
\text { normales } \\
\text { escaleras } \\
\text { mecánicas }\end{array}$ & 150 & 25 & 40 & \\
\hline $\begin{array}{l}\text { Muelles de } \\
\text { carga/descarga }\end{array}$ & 150 & 25 & 40 & \\
\hline $\begin{array}{l}\text { Comedores de } \\
\text { Salas } \\
\text { descanso }\end{array}$ & 100 & 22 & 80 & \\
\hline
\end{tabular}

\begin{tabular}{|l|l|l|l|l|}
\hline $\begin{array}{l}\text { Vestuarios, servicios } \\
\text { y aseos }\end{array}$ & 100 & 25 & 80 & \\
\hline Enfermería & 500 & 19 & 80 & \\
\hline Salas de fax & 500 & 19 & 80 & \\
\hline $\begin{array}{l}\text { Salas de almacén y } \\
\text { cámaras refrigeradas }\end{array}$ & & & & \\
\hline
\end{tabular}




\begin{tabular}{|c|c|c|c|c|}
\hline Almacenes & \begin{tabular}{|l|l|}
100 & 25
\end{tabular} & 60 & $\begin{array}{l}200 \\
\text { ocup } \\
\text { conti }\end{array}$ & $\begin{array}{l}\text { lux si están } \\
\text { ados } \\
\text { nuamente }\end{array}$ \\
\hline Áreas de embalado & \begin{tabular}{|l|l|}
300 & 25
\end{tabular} & 60 & & \\
\hline $\begin{array}{|ll|}\text { Áreas } & \text { de } \\
\text { almacenamiento } & \text { en } \\
\text { estanterías } & \end{array}$ & & & & \\
\hline $\begin{array}{l}\text { Pasillos } \\
\text { trabajadores }\end{array}$ & 20 & 40 & & \\
\hline $\begin{array}{l}\text { Pasillos } \\
\text { trabajadores }\end{array}$ & 20022 & 60 & & \\
\hline Puestos de control & \begin{tabular}{|l|l|}
200 & 22 \\
\end{tabular} & 60 & & \\
\hline B: ACTIVIDADES IND & DUSTRI & IALES & $Y A R$ & TESANALES \\
\hline LUGAR O ACTIVIDAI & \begin{tabular}{l|l|}
$\mathrm{D}$ & $\mathrm{Em}^{(1)}$ \\
\end{tabular} & $\mathbf{U G R}^{(2)}$ & $\mathrm{Ra}^{(3)}$ & Observaciones $^{(4)}$ \\
\hline $\begin{array}{l}\text { Industria cerámica } \\
\text { del vidrio }\end{array}$ & $\mathrm{y}$ & & & \\
\hline Secado & 50 & 28 & 20 & \\
\hline Esmaltado, grabad & 70,750 & 19 & 80 & \\
\hline
\end{tabular}

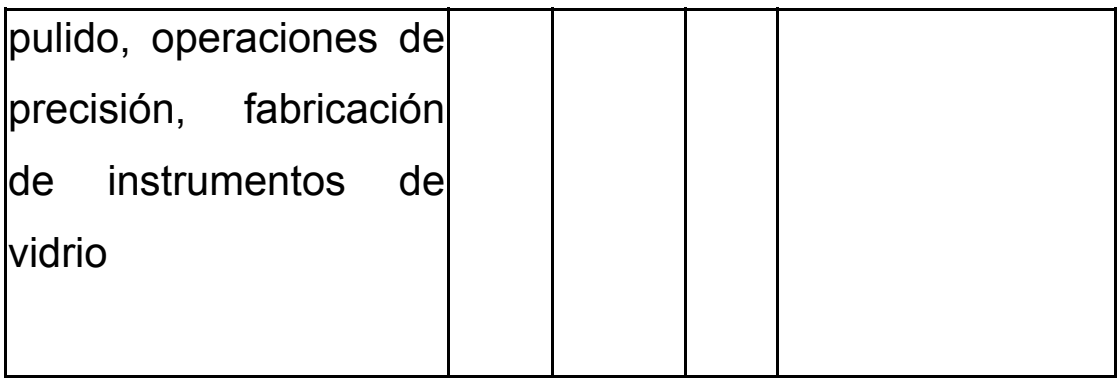

\begin{tabular}{|l|l|l|l|l|}
\hline $\begin{array}{l}\text { Dibujos a mano y } \\
\text { trabajos de precisión: } \\
\text { grabado decorativo, } 1000 \\
\text { etc. }\end{array}$ & 16 & 90 & & \\
\hline $\begin{array}{l}\text { Fabricación de piedras } \\
\text { preciosas artificiales }\end{array}$ & 1500 & 16 & 90 & Tc $4000^{\circ} \mathrm{K}$ \\
\hline $\begin{array}{l}\text { Instalaciones de } \\
\text { procesos con } \\
\text { intervención manual } \\
\text { limitada }\end{array}$ & 100 & 28 & 40 & \\
\hline $\begin{array}{l}\text { Lugares de trabajo con } \\
\text { intervención manual } \\
\text { continua. }\end{array}$ & 25 & 80 & & \\
\hline
\end{tabular}




\begin{tabular}{|l|l|l|l|l|}
\hline $\begin{array}{l}\text { Laboratorios y salas de } \\
\text { medidas de precisión }\end{array}$ & 19 & 80 & \\
\hline LUGAR O ACTIVIDAD & $\mathbf{E m}^{(1)}$ & $\mathbf{U G R}^{(\mathbf{2})}$ & $\mathbf{R a}^{(3)}$ & Observaciones $^{(4)}$ \\
\hline Laboratorios & 500 & 19 & 80 & \\
\hline Inspección de colores & 1000 & 16 & 90 & ${\mathrm{r} \mathrm{Tc} \geq 4000^{\circ} \mathrm{K}}$ \\
\hline Andenes y plataformas & 100 & 25 & 40 & \\
\hline Preparación de arena & 200 & 25 & 80 & \\
\hline $\begin{array}{l}\text { Desmoldeo con } \\
\text { vibrador }\end{array}$ & 25 & 80 & \\
\hline Moldeo manual & 300 & 25 & 80 & \\
\hline Fabricación de moldes & 500 & 22 & 80 & \\
\hline
\end{tabular}

\begin{tabular}{|l|l|l|l|l|}
\hline $\begin{array}{l}\text { LUGAR O } \\
\text { ACTIVIDAD }\end{array}$ & Em $^{(1)}$ & $\mathbf{U G R}^{(2)}$ & $\mathbf{R a}^{(3)}$ & Observaciones $^{(4)}$ \\
\hline $\begin{array}{l}\text { Trabajo con piedras } \\
\text { preciosas }\end{array}$ & 1500 & 16 & 90 & $\begin{array}{l}\text { Temperatura de } \\
\text { color Tc } \geq 4000^{\circ} \mathrm{K}\end{array}$ \\
\hline $\begin{array}{l}\text { Industria del cuero } \\
\text { Descarnado, raspado }\end{array}$ & 300 & 25 & 80 & \\
\hline
\end{tabular}

\begin{tabular}{|c|c|c|c|c|}
\hline y frotado de pieles & & & & \\
\hline $\begin{array}{l}\text { Guarnicionado y: } \\
\text { corte, punzonado, } \\
\text { conformado, cosido, } \\
\text { abrillantado }\end{array}$ & 500 & 22 & 80 & \\
\hline $\begin{array}{l}\text { Clasificación de } \\
\text { pieles }\end{array}$ & e 500 & 22 & 90 & $\mathrm{Tc} \geq 4000^{\circ} \mathrm{K}$ \\
\hline \begin{tabular}{|lll} 
Trabajo de los \\
metales
\end{tabular} & & & & \\
\hline Soldadura & 300 & 25 & 60 & \\
\hline $\begin{array}{l}\text { Trabajos en chapa } \\
\text { (grosor }<5 \mathrm{~mm} \text { ) }\end{array}$ & 300 & 22 & 60 & \\
\hline $\begin{array}{l}\text { Tratamientos } \\
\text { superficiales }\end{array}$ & 500 & 25 & 80 & \\
\hline $\begin{array}{l}\text { Fabricación } \\
\text { procesado de papel, } \\
\text { cartón }\end{array}$ & $\mathrm{y} 300$ & 25 & 80 & \\
\hline Encuadernación & 500 & 22 & 80 & \\
\hline
\end{tabular}




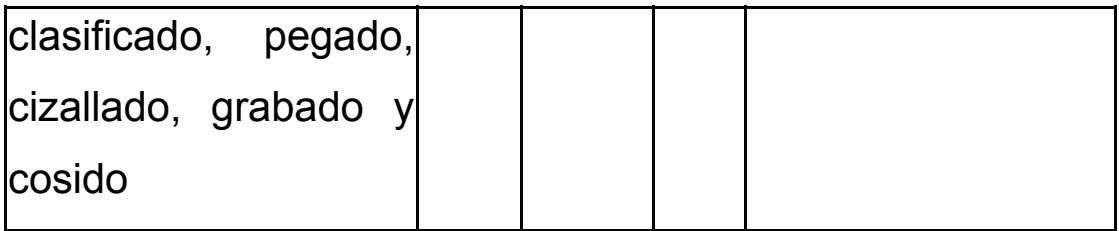

\begin{tabular}{|l|l|l|l|l|}
\hline $\begin{array}{l}\text { LUGAR O } \\
\text { ACTIVIDAD }\end{array}$ & Em $^{(1)}$ & $\mathbf{U G R}^{(2)}$ & $\mathbf{R a}^{(3)}$ & Observaciones $^{(4)}$ \\
\hline $\begin{array}{l}\text { Imprentas } \\
\begin{array}{l}\text { Corte, recubrimiento } \\
\text { electroquímico, } \\
\text { trabajo en planchas, } \\
\text { máquinas de imprimir }\end{array}\end{array}$ & 19 & 80 & \\
\hline $\begin{array}{l}\text { Clasificación de } \\
\text { papel e impresión } \\
\text { manual }\end{array}$ & 19 & 80 & \\
\hline $\begin{array}{l}\text { Composición de } 1000 \\
\text { tipos, retocado, } \\
\text { litografía }\end{array}$ & 19 & 80 & \\
\hline \begin{tabular}{l} 
Inspección de 1500 \\
\hline
\end{tabular} & 16 & 90 & Temperatura de \\
\hline
\end{tabular}

\begin{tabular}{|l|l|l|l|l|}
\hline $\begin{array}{l}\text { color en impresión } \\
\text { Grabado en cobre }\end{array}$ & 2000 & 16 & 80 & color $=5000^{\circ} \mathrm{K}$ \\
\hline $\begin{array}{l}\text { LUGAR } \\
\text { ACTIVIDAD }\end{array}$ & $\mathbf{E m}^{(1)}$ & $\mathbf{U G R}^{(2)}$ & $\mathbf{R a}^{\left(\frac{(3)}{2}\right.}$ & Observaciones $^{(4)}$ \\
\hline $\begin{array}{l}\text { Almacenamiento } \\
\text { de planchas }\end{array}$ & 50 & - & 20 & $\begin{array}{c}\text { reconocibles los } \\
\text { colores de las } \\
\text { señales de } \\
\text { seguridad }\end{array}$ \\
\hline Hornos & 200 & 25 & 60 & \\
\hline Industria textil & & & & \\
\hline
\end{tabular}

\begin{tabular}{|l|l|l|l|l|}
\hline $\begin{array}{l}\text { Zona de apertura de } \\
\text { fardos y balas }\end{array}$ & 200 & 25 & 60 & \\
\hline $\begin{array}{l}\text { Lavado, peinado, } \\
\text { prehilado, etc. }\end{array}$ & 300 & 22 & 80 & \\
\hline Hilado y devanado & 500 & 22 & 80 & $\begin{array}{l}\text { Prevenir } \\
\text { los efectos } \\
\text { estroboscó }\end{array}$ \\
\hline
\end{tabular}




\begin{tabular}{|c|c|c|c|c|}
\hline & & & & picos \\
\hline $\begin{array}{l}\text { Urdimbre, tejido, trenzado, } \\
\text { tricotado }\end{array}$ & 750 & 22 & 80 & \\
\hline Acabado, teñido & 500 & 22 & 80 & \\
\hline Sala de secado & 100 & 28 & 60 & \\
\hline $\begin{array}{l}\text { Arreglos que no pueden } \\
\text { percibirse a simple vista }\end{array}$ & 1500 & 19 & 90 & $\begin{array}{l}\text { Temperatur } \\
\text { a } \text { de } \text { color } \\
4000^{\circ} \mathrm{K}\end{array}$ \\
\hline \multicolumn{5}{|l|}{ Industria de la madera } \\
\hline Tratamientos con vapor & 150 & 28 & 40 & \\
\hline Sierra de cinta & 300 & 25 & 60 & \begin{tabular}{|l|} 
Prevenir \\
los efectos \\
estroboscó \\
picos
\end{tabular} \\
\hline $\begin{array}{l}\text { Trabajos en banco de } \\
\text { taller, ensamblado } \\
\text { encolado }\end{array}$ & 300 & 25 & 80 & \\
\hline $\begin{array}{l}\text { Barnizado, } \\
\text { adornos }\end{array}$ & 500 & 22 & 80 & \\
\hline
\end{tabular}

\begin{tabular}{|l|l|l|l|l|}
\hline $\begin{array}{l}\text { Trabajo de la madera a 500 } \\
\text { máquina: torneado, } \\
\text { cepillado, corte, lijado, } \\
\text { fresado, etc. }\end{array}$ & 19 & 80 & $\begin{array}{l}\text { Prevenir } \\
\text { los efectos } \\
\text { estroboscó } \\
\text { picos }\end{array}$ \\
\hline $\begin{array}{l}\text { Selección de maderas } \\
\text { para chapado }\end{array}$ & 22 & 90 & $\begin{array}{l}\text { Temperatur } \\
\text { a de color } \geq \\
4000^{\circ} \mathrm{K}\end{array}$ \\
\hline $\begin{array}{l}\text { Marquetería y labores de } \\
\text { incrustación en madera }\end{array}$ & 22 & 90 & $\begin{array}{l}\text { Temper } \\
\text { atura de } \\
\text { color } \geq \\
4000^{\circ} \mathrm{K}\end{array}$ \\
\hline
\end{tabular}

\begin{tabular}{|c|c|c|}
\hline C: OFICINAS & & \\
\hline LUGAR & $\mathrm{O}\left|\mathrm{Em}^{(1)} \mathrm{UGR}^{(2)}\right| \mathrm{Ra}^{(3)} \mid$ & Observaciones ${ }^{(4)}$ \\
\hline ACTIVIDAD & & \\
\hline
\end{tabular}




\begin{tabular}{|c|c|c|c|c|}
\hline $\begin{array}{l}\text { Archivos, } \\
\text { copiadoras, áreas } \\
\text { de circulación }\end{array}$ & s 300 & 19 & 80 & \\
\hline $\begin{array}{l}\text { Lectura, escritura, } \\
\text { mecanografía, } \\
\text { proceso de datos }\end{array}$ & 1,500 & 19 & 80 & $\begin{array}{ll}\text { Acondicionar } & \text { las } \\
\text { pantallas } & \text { de } \\
\text { visualización } & \end{array}$ \\
\hline Dibujo técnico & 750 & 16 & 80 & \\
\hline $\begin{array}{ll}\text { Diseño } & \text { asistido } \\
\text { (CAD) } & \end{array}$ & 500 & 19 & 80 & $\begin{array}{l}\text { Acondicionar pantallas } \\
\text { de visualización }\end{array}$ \\
\hline Salas de reunión & 500 & 19 & 80 & \\
\hline $\begin{array}{l}\text { Puestos de } \\
\text { recepción }\end{array}$ & 300 & 22 & 80 & \\
\hline Almacenes & 200 & 25 & 80 & \\
\hline \multicolumn{5}{|l|}{ D: TIENDAS } \\
\hline $\begin{array}{l}\text { LUGAR } \\
\text { ACTIVIDAD }\end{array}$ & $\mathrm{Em}^{11}$ & 1) $\mathrm{UGR}^{(2)}$ & $\mathbf{R a}^{(3)}$ & Observaciones \\
\hline $\begin{array}{l}\text { Áreas de venta al } \\
\text { público }\end{array}$ & 300 & 22 & 80 & 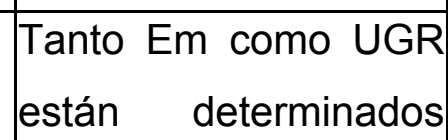 \\
\hline
\end{tabular}

\begin{tabular}{|l|l|l|l|l|}
\hline & & & & por el tipo de tienda \\
\hline $\begin{array}{l}\text { Puesto de } \\
\text { cajero/a }\end{array}$ & 500 & 19 & 80 & \\
\hline
\end{tabular}

Em.-Nivel medio de iluminación mantenido sobre el área de trabajo, en lux.

UGR.-Índice unificado de deslumbramiento ("Unified Glare Rating") obtenido con arreglo al procedimiento dado por CIE en su publicación número 117.

Ra.-Índice de rendimiento en color de las fuentes de luz, suministrado por el fabricante. El valor máximo de Ra es de 100.

Observaciones.-Entre otros requisitos de un sistema de iluminación, se encuentra el de la temperatura de color de las fuentes de luz, expresada en grados Kelvin. Este parámetro hace referencia a la tonalidad de la luz. 
Por último apuntamos las cantidades que Alonso

Fernánde $z^{42}$ opina como adecuadas en cuanto a los límites

máximos de exposición total de los objetos a la luz:

OBJETOS

LUZ-HORA-POR AÑO

Materiales en exhibición

$120.000^{43}$

altamente sensibles (sedas, papel,

tintes delicados).

Materiales exhibidos

180.000

moderadamente sensibles (ciertas

maderas, tintas estables, textiles)

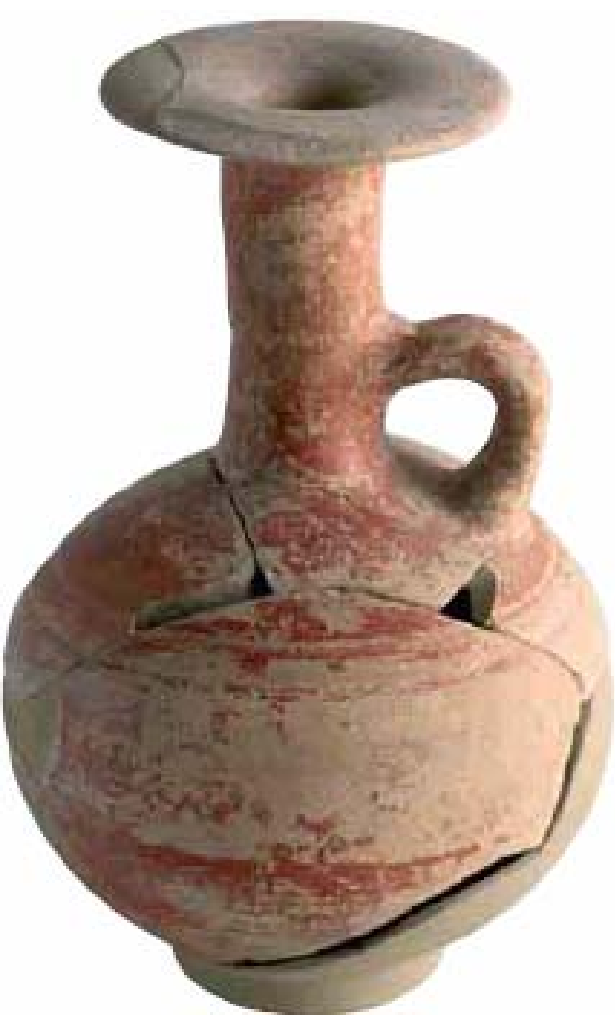

Figura 4: sala V. Las colonizaciones, vaso de barniz rojo con boca de seta.

II.5. 6. Manipulación, almacenaje y trasporte. 42 ALONSO FERNÁNDEZ, L. A., Museología y museografía, ed. del Serbal, Barcelona,
1999, p.224..
43 Id. Unos 50 lux iluminando unas 8 horas diarias y unos trescientos días al año. El
siguiente caso es válido para unos 75 luxes iluminando 8 horas diarias, también unos
trescientos días al año. 
Antes de comenzar con las recomendaciones generales de este apartado, vamos a relacionar otros protocolos a seguir, de acuerdo con la normativa nacional e internacional vigente aplicable.

Para el caso de una situación de incendio, la normativa a seguir será:

La normativa específica de aplicación comprende:

Los requisitos establecidos en el capítulo 5 "Instalaciones de Protección contra Incendios", de la norma básica de edificación NBE-CPI 96, sobre dotaciones mínimas en las instalaciones de protección contra incendios con que deben contar los edificios en función de los usos, superficie o la ocupación de los mismos.

- Los requisitos establecidos en las Ordenanzas Municipales de protección contra incendios.
- I Capítulo VII del Título II de la Ordenanza General de seguridad e higiene en el trabajo que, de acuerdo con la Disposición Derogatoria Única del presente Real Decreto, seguirá vigente para aquellos locales a los que no se les aplique la NBE-CPI 96, y para aquellos que estén excluidos del ámbito de aplicación de este Real Decreto.

- El Reglamento de instalaciones de Protección contra incendios, aprobado por Real Decreto 1942/1993, de 5 de noviembre (B.O.E. 14-12-93), donde se establecen las condiciones que deben cumplir los instaladores y mantenedores de las instalaciones de protección contra incendios, las características de las mismas, los requisitos para su instalación, puesta en servicio y mantenimiento, así como los programas de mantenimiento mínimos a realizar. Otra normativa específica, según el caso.

Los dispositivos de detección, alarma y extinción estarán de acuerdo con la normativa de aplicación. 
Los dispositivos no automáticos de lucha contra incendios serán fácilmente localizables en la zona que se desea proteger.

Las señales deberán ser visibles en todo momento, por lo que, ante un fallo del alumbrado normal, dispondrán de fuentes luminosas incorporadas externa o internamente, o serán autoluminiscentes.

Para el traslado de obras, bien sea de una zona a otra del museo o de éste al exterior, para formar parte de una exposición, se seguirán una serie de criterios. En primer lugar estas operaciones deben ser llevadas a cabo por trabajadores especializados. Nunca se destinará a un único miembro del personal a este fin. Las personas que deban realizar esta operación deberán comenzar por asegurarse de cuál va a ser el recorrido. Incluso en caso de tratarse de un desplazamiento interno, para fotografía o restauración, se comprobará que el camino se encuentra libre de obstáculos: suelos mojados o encerados, útiles de otros miembros del museo o hasta una puerta que no abre correctamente. Determinar con seguridad la adecuación del lugar en el que se va a colocar. Todo con el fin de desplazar la obra u obras sólo lo estrictamente necesario. Para volver a colocarla en la misma situación anterior al desplazamiento será bueno tomar unas fotos que nos faciliten una descripción lo menos arbitraria posible de cuáles eran las condiciones citadas,

Entonces se protegerán con guantes, los de látex o mejor de algodón, son adecuados. Los materiales como el metal, mármol o piedra pueden verse afectados si entran en contacto con las sustancias de las manos como sudor o suciedad. Resulta imprescindible para el museo una buena provisión de éstos de variados tamaños. No se debería fumar por el peligro de quemadura para la obra o para el que la transporta. Tampoco es aconsejable hacerlo en la zona donde se ha de depositar la obra. Nunca se intentará desplazar más de una obra a la vez por la misma persona. 
Si la obra está formada por asas o partes sobresalientes, frágiles o quebradizas (Vaso jonio, sala VII) se evitará la manipulación por estas zonas. Para asirlas, con una de las manos, nos aseguraremos de la estabilidad de la franja elegida. La otra mano protegerá el cuerpo de la obra. Esto, siempre que nos encontremos con obra de tamaño reducido. Además deberán ir protegidas con paños gruesos. Si se puede la postura del transporte será la misma de la que tuviese durante la exposición.

Si vamos a transportar obras muy pesadas o de gran formato, lo cual está desaconsejado por los expertos ${ }^{44}$, bien por el interior del museo o hasta los muelles de carga y descarga, se utilizarán carretillas elevadoras planteando

como requisito previo en el momento de su adquisición la potencia suficiente como para levantar el volumen de las piezas más grandes del museo, evitando el desplazamiento mediante el arrastre.

Además, este tipo de piezas se colocará en las zonas bajas del almacén, evitando así la posibilidad de caída sobre otras. Veremos ahora algunos ejemplos de las posibilidades ofrecidas por el mercado en carretillas elevadoras $^{45}$

\section{De conductor acompañante}

Estos apiladores, dotados de motores de tracción de Tecnología de corriente Alterna, ofrecen una excelente maniobrabilidad hasta en espacios reducidos. Preparados para trabajo en rampas y suelos irregulares o con patas articuladas para la manipulación de palets cerrados. Adaptados para uso en camiones, apilado en bloques y en áreas congestionadas. Adecuados a distancias de unos cincuenta metros, pudiendo llegar a alturas de hasta unos 5 metros y medio.

\section{Carga -Elevación}

\section{SBP10N $1000 \mathrm{Kg}-3300 \mathrm{~mm}$}

${ }^{45}$ www. ulmacarretillas.com 


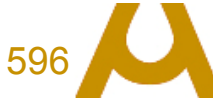

\section{SBP12N/12NI \\ $1200 \mathrm{~kg}-4300 \mathrm{~mm}$ \\ SBP16N/16NI \\ $1600 \mathrm{Kg}-5400 \mathrm{~mm}$}

\section{Con plataforma.}

Estos apiladores llevan incorporada una plataforma y protectores laterales, pudiéndose plegar ambos complementos en zonas reducidas o maniobras muy ajustadas. Ideales para su uso en los espacios más reducidos como camiones, apilado en bloques o en áreas congestionadas. Para usar en transporte de distancias medias.

Carga - Elevación
SBV 12K/12KI
$200 \mathrm{Kg}-4300 \mathrm{~mm}$
SBV $16 K / 16 K I$
1600 Kg. -4300 mm

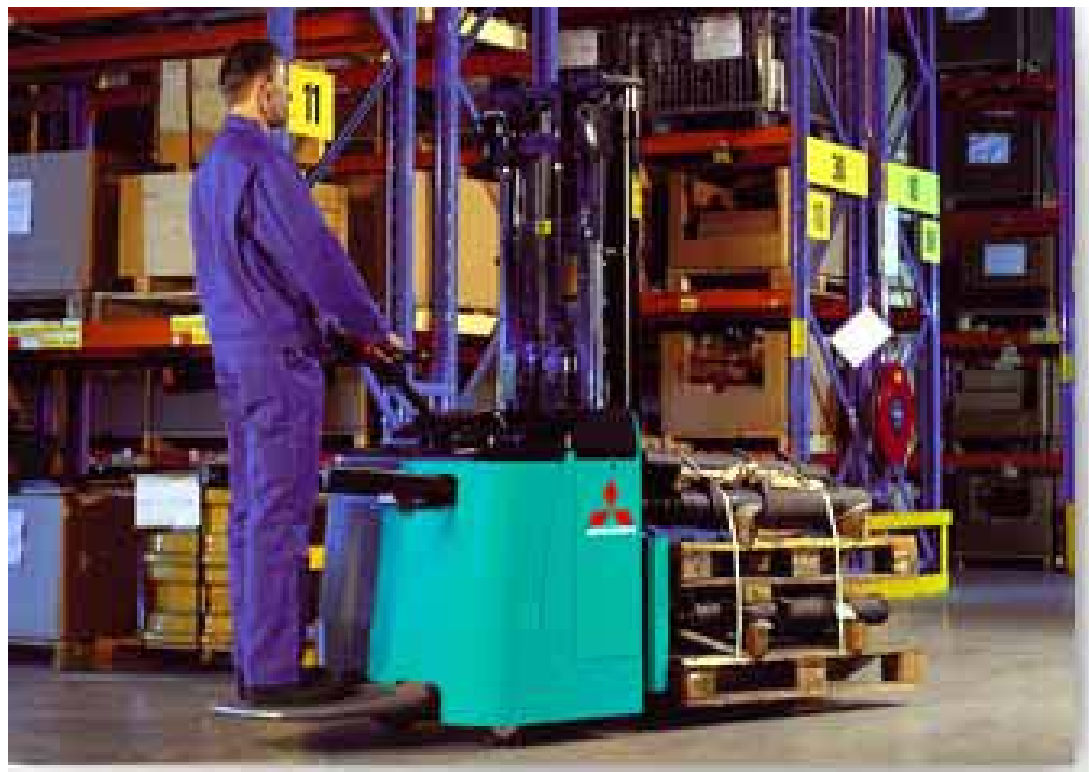

Gracias a sus dimensiones compactas, pueden trabajar en pasillos más estrechos que una retráctil. Tienen una capacidad de elevación de hasta $6.500 \mathrm{~mm}$, aumentando esta gracias a los estabilizadores laterales que incrementan la capacidad residual. Ofrecen una gran ergonomía al conductor junto con una gran visibilidad y una 
precisa dirección electrónica. Para trabajos de apilado que impliquen desplazamiento horizontal en grandes distancias.

Carga - Elevación

SBR12K

SBR15K

SBR20K
$1200 \mathrm{Kg}-6500 \mathrm{~mm}$

1500 Kg. -6500 mm

2000 Kg. -6200 mm

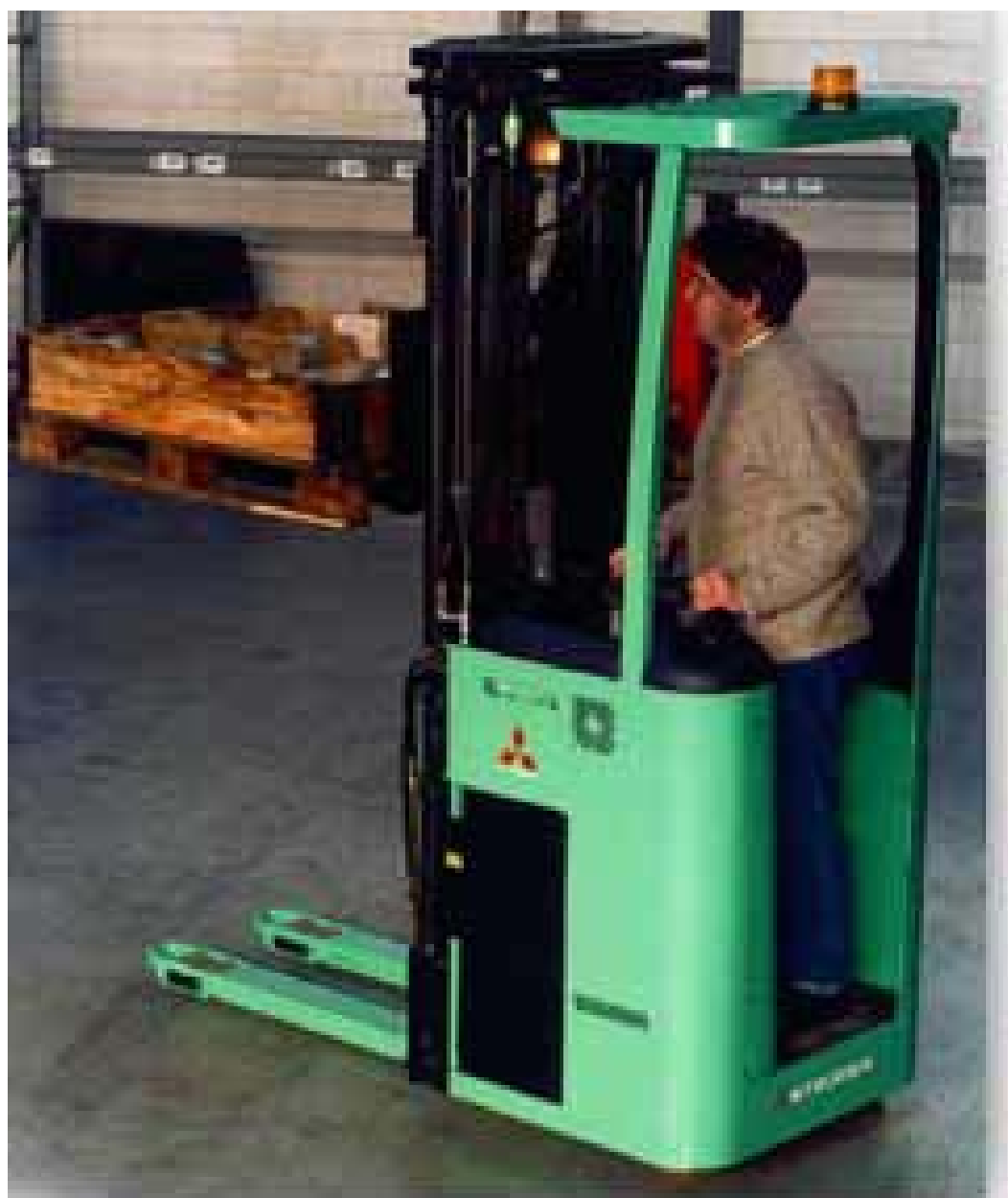




\section{II.5. 7. Almacenaje y exposición}

Sería deseable que el programa destinado al montaje de la exposición permanente del museo, tuviese en cuenta la necesidad de una renovación del discurso en un periodo no más allá de 4 ó 5 años. El enorme tamaño de algunas de las piezas de este museo (ver trajano) dificulta la consecución de este objetivo, por lo que quizás, una posible solución sería el cambio de la museografía y no el traslado de piezas. Los criterios deben diferenciar si hablamos de piezas situadas en los almacenes con carácter definitivo en cuyo caso se podrán mostrar como parte del discurso, si entran o salen de la exposición, deberían tener una zona exclusiva para este uso.

En caso de transportar las piezas al exterior del museo para el préstamo a otras instituciones se hará imprescindible la construcción de un embalaje adecuado a las necesidades específicas. Pero en el interior la obra se puede proteger con materiales envolventes.
Los materiales que toquen las obras deben tener un $\mathrm{PH}$ neutro. El resto de materiales es aconsejable que respondan a este mismo criterio aunque no imprescindible. No deben producir rozamiento o abrasión sobre las piezas. Deben tener una cierta resistencia a la rotura y si no es así los bordes producidos en caso de ésta, no deben producir rasgar o arañar las obras. $\mathrm{Y}$ al igual que en el resto de situaciones del museo como los almacenes o las zonas de exposición, los componentes seleccionados no deben emitir sustancias nocivas para las piezas. Igualmente se escogerán envoltorios que no se carguen de electricidad estática.

Una vez envueltas se colocarán en el interior de embalajes los cuales deberán ser resistentes a las vibraciones, a los choques y crear un microclima que evite las grandes oscilaciones de temperatura y humedad relativa. 
Vibroaislamiento. Los materiales destinados a este tipo de protección se colocarán en las zonas internas del embalaje. Como es lógico la elección de unos u otro materiales se confiará a la evaluación de multitud de factores, como la fragilidad de la obra, el grosor del protector o su densidad. Además tenderán a atenuar las vibraciones y su frecuencia de vibración será diferente a la de la obra.

Aislamiento térmico. En primer lugar dentro del embalaje se deberá colocar un sistema de registro de datos de temperatura y humedad, si es posible con un pequeño sistema de almacenamiento de esos datos para seguir la evolución de las condiciones por las cuales ha pasado la obra.

Estos aislantes deben cubrir todas las caras internas del embalaje y ser autoextinguibles, es decir que en caso de fuego se consuman para que no produzcan combustión. Su sistema de cierre debe sujetarse en las zonas menos alterables de la caja y con la estabilidad suficiente para no coger holgura si tuviesen varios usos.

Solidez. Es buena idea la selección de contrachapados al estar formados por láminas, se trabajan fácilmente y no pesan en exceso. Exteriormente al igual que en las esquinas deben llevar un refuerzo adicional. El embalaje será resistente a curvaturas.

Estas últimas indicaciones son de especial relevancia en el caso de piezas de gran formato, como el caso de la estatua de Trajano.

En cuanto a las condiciones generales adecuadas para el maridaje de conservación preventiva y exposición hay que tener en cuenta: 
Las radiaciones tanto ultravioleta como infrarrojas deben minimizarse al máximo mediante filtros en los puntos de emisión de luz y el empleo de cristales adecuados.

Los materiales, sobre todo aquellos en contacto directo con las piezas, deben ser lo más neutros posibles. Por ejemplo, se prefiere para las vitrinas, el poliuretano al neopreno por ser el primero inerte. Además de favorecer la conservación, posee una buena transparencia.

La base de la vitrina debe asegurar una buena estabilidad, con una iluminación suficiente para una contemplación confortable de la pieza pero sin excesos, para no convertirla en un espejo a los ojos del espectador. 
En el diseño de las cajas empleadas para transporte, lo principal, es el empleo de forros interiores de modo que la pieza quede bloqueada impidiendo toda clase de movimientos. Para estas ocasiones los materiales necesarios pueden ser maderas para los exteriores y espuma que recubra la pieza en el interior.

Tras estas recomendaciones generales para la mayoría de los materiales, vamos a exponer algunas más específicas para materiales de mayor fragilidad.

-Vidrio.

Caballetes

Existen diversos tipos y modelos de caballetes. En todos ellos, siempre respete el ángulo de almacenamiento del vidrio, que debe estar entre 4 y 6 grados. Ángulos menores a 4 grados pueden ocasionar la caída de la pila de vidrio hacia delante, mientras ángulos mayores que 6 grados facilitan la rotura del vidrio por compresión excesiva. Todas las partes del caballete que estén en contacto con el vidrio deben estar protegidas con goma. En las bases, use goma con dos lonas, espesor mínimo de $10 \mathrm{~mm}$ y dureza de 70 Shore. En los apoyos verticales, use goma expandida, de un espesor mínimo de $10 \mathrm{~mm}$ y una dureza de 40 Shore.

La fijación de las gomas protectoras debe hacerse con adhesivo adecuado, evitando el uso de clavos. En caso de que sean inevitables, se ha de asegurar que los clavos estén ubicados bien abajo de la línea de apoyo del vidrio en la goma. El mantenimiento de las gomas debe realizarse periódicamente. Para aumentar la vida útil de la goma podremos pegar sobre ella una capa de fieltro o moqueta.

\section{Espaciadores}

Las pilas de vidrio deben estar separadas por espaciadores de espuma de poliestireno de densidad de 30 a $45 \mathrm{Kg} / \mathrm{m} 3$, largo de $150 \mathrm{~mm}$ y espesor mínimo de 150mm. El largo del 
espaciador debe ser un poco mayor que la altura del vidrio almacenado.

Cuñas

También se pueden usar planchas de madera revestidas con fieltro o moqueta, con la condición de que no presenten deformación permanente, ya que en caso contrario podrán causar concentración de esfuerzo y posterior rotura al vidrio. En almacenes de mayor profundidad, se recomienda el uso de correctores de ángulo (cuñas de espuma de poliestireno) para asegurar la inclinación definida en la zona superior.

De igual modo que los espaciadores, se debe utilizar tres correctores. El espacio entre los correctores de ángulo varía en función del espesor del vidrio. En el caso de vidrios finos, el intervalo más eficaz recomendado por los profesionales, es de hasta cinco pilas.
Palilleros

El almacenamiento de pilas de vidrio en palilleros es más eficiente que en caballetes, pues cada pila de vidrio se apoya individualmente en dos astas metálicas, disminuyendo la carga. Igualmente, toda el área de la base y astas se debe proteger con goma. Se puede incrementar también la protección con fieltro o moqueta. Otra ventaja es la movilidad del palillero, que puede ser fácilmente armado y desarmado, liberando el área rápidamente. Por otro lado, la densidad de almacenamiento disminuye, pues el espacio entre las grandes piezas de vidrio se aumenta.

\section{Colares.}

Aunque el colar ha sido desarrollado para el transporte de vidrio, también puede usarse para su almacenamiento. Es fundamental poner un especial cuidado especial con el piso del almacén, que debe ser plano y proyectado con la 
suficiente capacidad como para resistir a la carga generada por el peso del conjunto paquete y colar.

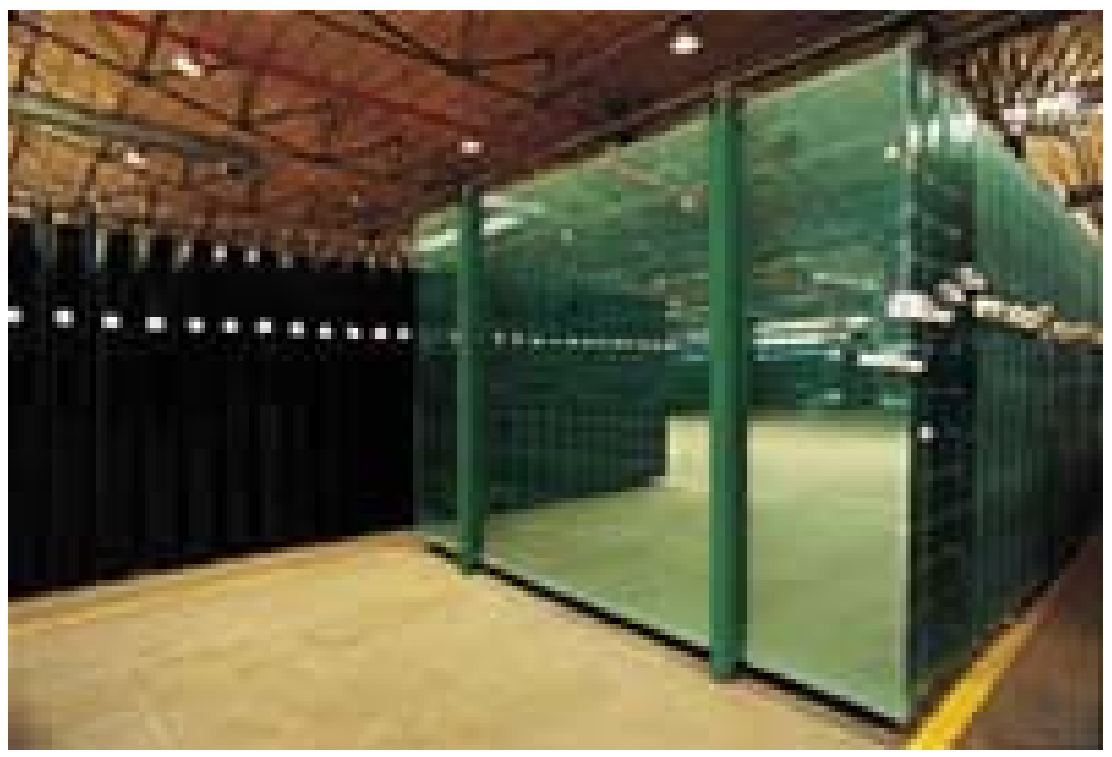

El piso del área de almacenamiento debe mantenerse libre de basuras o suciedad, ya que pueden causar alteración de la inclinación y el derrumbe de la carga. En el primer colar del total se usarán apoyos bien firmes y tanto los primeros como los últimos colares se deberán mantener fijos con la brida metálica. Este tipo de almacenamiento está sujeto a la cantidad de colares disponibles, como en la fotografía.

Cajas

Las cajas también pueden ser almacenadas en palillero, asegurándose de que los calzos de la zona inferior estén apoyados por la base metálica del palillero. Cajas del tipo moldura pueden ser almacenadas en posición vertical, pero deben estar adecuadamente apoyadas, evitando, de este modo, los riesgos de derrumbe.

En caso de retirada de una de las cajas se debe apoyar la caja subsiguiente. Otra forma segura de almacenamiento de cajas tipo moldura verticalmente es a través de la utilización de cintas de nylon y estructura metálica. 


\section{II.6. RESTAURACIÓN.}

Actualmente existe una gran variedad de criterios a la hora de abordar un plan de restauración pero un autor muy seguido es el defensor de la restauración crítica, Cesare BRANDI. Aportó su definición del concepto de restauración: " la restauración constituye el momento metodológico del reconocimiento de la obra de arte en su consistencia física y en su doble polaridad estética e histórica en orden a su transmisión al futuro". Junto a este concepto plasmó sus planteamientos en torno a la restauración en un documento bien conocido, la Carta del Restauro publicada en 1972. Sus bases fundamentales son:

- Se restaura la materialidad de la obra, su consistencia física. La base sustancial de otros valores como el histórico. Y se asegura su pervivencia. Intenta diferenciar entre materia / imagen, transmisora de los valores de la obra y materia estructura, asimilable al soporte. Es consciente de que no en todos los casos es fácil diferenciar entre una y otra.

- Sin embargo, no se deberá caer en la creación de un falso histórico. Es decir, no se debe tratar de imitar con materiales modernos el aspecto antiguo de la obra pues a este nuevo material le faltaría la vida del original. Por tanto, se respetará el rastro que el tiempo ha dejado en la obra. Así, patinas o cualquier otra señal que no representen un peligro para la supervivencia del objeto deberá mantenerse.

- Las reintegraciones se harán con materiales fácilmente diferenciables de los originales, desde un estudio cercano, pero asimilables, desde una visión más alejada, para potenciar la unidad antes mencionada.

Las actuaciones deben tener un carácter reversible, para facilitar posibles nuevas intervenciones en el futuro. Los 
materiales usado deben estar suficientemente comprobados con el fin de evitar reacciones adversas con el original y también para asegurar la posibilidad de que sea eliminado en caso de necesidad sin gran perjuicio para el objeto.

Estos principios se han venido actualizando desde poco tiempo después a su creación. En el año 1987 surge el documento "Carta de la conservación y del restauro de los objetos de arte y de cultura". Sus principales innovaciones con respecto al escrito anterior son:

- Se extiende la protección no sólo a los objetos artísticos sino a los bienes culturales. Refiere esta definición a cualquier clase de objeto que tenga un particular interés para una determinada sociedad.
Las operaciones de intervención sobre los objetos son ampliadas: conservación, preservación, salvaguardia, restauración y mantenimiento.

Conservación preventiva. Una de las principales aportaciones. Se muestra interés hacia los factores ambientales que influyen en el deterioro del bien cultural.

Instancia histórica. Pretenden los redactores de esta carta que el resultado de la restauración con los añadidos incluidos forme un todo armónico visualmente.

A partir de estos documentos de ámbito geográfico más restringido, y motivado por las destrucciones de patrimonio ocasionadas durante la Segunda Guerra Mundial, comienzan a gestionarse la creación de organismos internacionales de los cuales el más destacado ha sido la UNESCO. 
El concepto de patrimonio, gracias al trabajo de dicha organización, se ha ampliado dejando de abarcar únicamente a objetos para incluir costumbres, o zonas geográficas o jardines de interés histórico. Pero aquí vamos a recoger específicamente aquellos textos que hacen referencia a material arqueológico. Sus pautas servirán junto con la normativa aplicable para la creación de protocolos propios para el área de restauración. Veámoslos:

Carta para la protección y gestión del patrimonio arqueológico, ICOMOS, 1990.

Posee como base la carta de Venecia y se articula en nueve puntos. El primero aporta la definición de patrimonio arqueológico. Se refiere a toda clase de restos pero englobándolos por el método utilizado para su recuperación. En el segundo y el tercero se explica la necesidad de integrar la protección del patrimonio arqueológico con todos aquellos sectores con los que pueda relacionarse: agricultura, cultura, legislación y economía. A continuación en el cuarto se habla la creación de inventarios, imprescindibles. En el quinto se hace hincapié en la utilización de métodos de intervención lo menos destructivos posibles. En el sexto se recoge la importancia de la conservación in situ del material recogido pero realizando una selección de lo más representativo para poder presentarlo de modo adecuado al público. El octavo plantea la necesidad de una formación de calidad para los profesionales del patrimonio para lo cual es necesaria la colaboración internacional, artículo noveno.

Convención sobre la protección del patrimonio mundial cultural en caso de conflicto armado o convención de La Haya de 1954.

Se redactó con la intención de atribuirle un carácter vinculante, aunque recientemente la destrucción de los budas de Afganistán sin ninguna clase de contrapartida para los perpetradores demuestra su ineficacia real. 
Recomendaciones sobre principios internacionales para las excavaciones arqueológicas de 1956.

Recomendaciones sobre las medidas de prohibición y prevención de las importaciones y exportaciones ilícitas de los bienes culturales, 1964.

Uno de los primeros intentos de abordar el enorme problema de la importación y exportación ilegal originado tras la Segunda Guerra Mundial. Por su falta de resultados surge por iniciativa privada el convenio Unidroit.

Convención para la protección del patrimonio arqueológico, histórico y artístico de las naciones americanas, Convención de San Salvador, 1976.

Convención europea para la protección del patrimonio arqueológico de Europa, 1992.
Unidroit Convención sobre el robo o exportación ilegal de objetos culturales, 1995.

En este caso nos encontramos ante un documento de tipo jurídico, por lo tanto vinculante. Sin embargo muchas naciones optan por la negativa a firmar este pacto con lo cual la validez sigue siendo reducida.

En el marco estatal la legislación vigente en materia de patrimonio es la ley 16/ 1985 de25 de junio o Ley del Patrimonio Histórico Español. Incluye dentro de un apartado denominado Patrimonio arqueológico los sitios de interés arqueológico y los inmuebles de interés arqueológico, bajo la tutela de las instituciones, además del patrimonio mueble.

La máxima categoría de protección para cualquier clase de patrimonio es el Bien de Interés Cultural (BIC). A nuestro juicio uno de los aspectos más destacados es la posibilidad para cualquier ciudadano de solicitar de la administración 
la inclusión de lo que consideré de interés dentro de esta categoría.

En cuanto a restauración sigue las recomendaciones consideradas internacionalmente, basadas en la revisión de la Carta del restauro.

Toda esta documentación internacional y nacional que aquí apenas ha quedado simplemente esbozada sin entrar en un análisis más detallado, debe servir de base al personal del museo encargado de estas cuestiones para la elaboración de un protocolo de actuaciones que recogiera unos principios aplicables a las necesidades concretas de este museo.

Aunque estas instrucciones sean de obligado cumplimiento para el personal de restauración, dentro de la propia planificación de deberá incluir la revisión y actualización de los comportamientos para la constante mejora del estado de las piezas. 


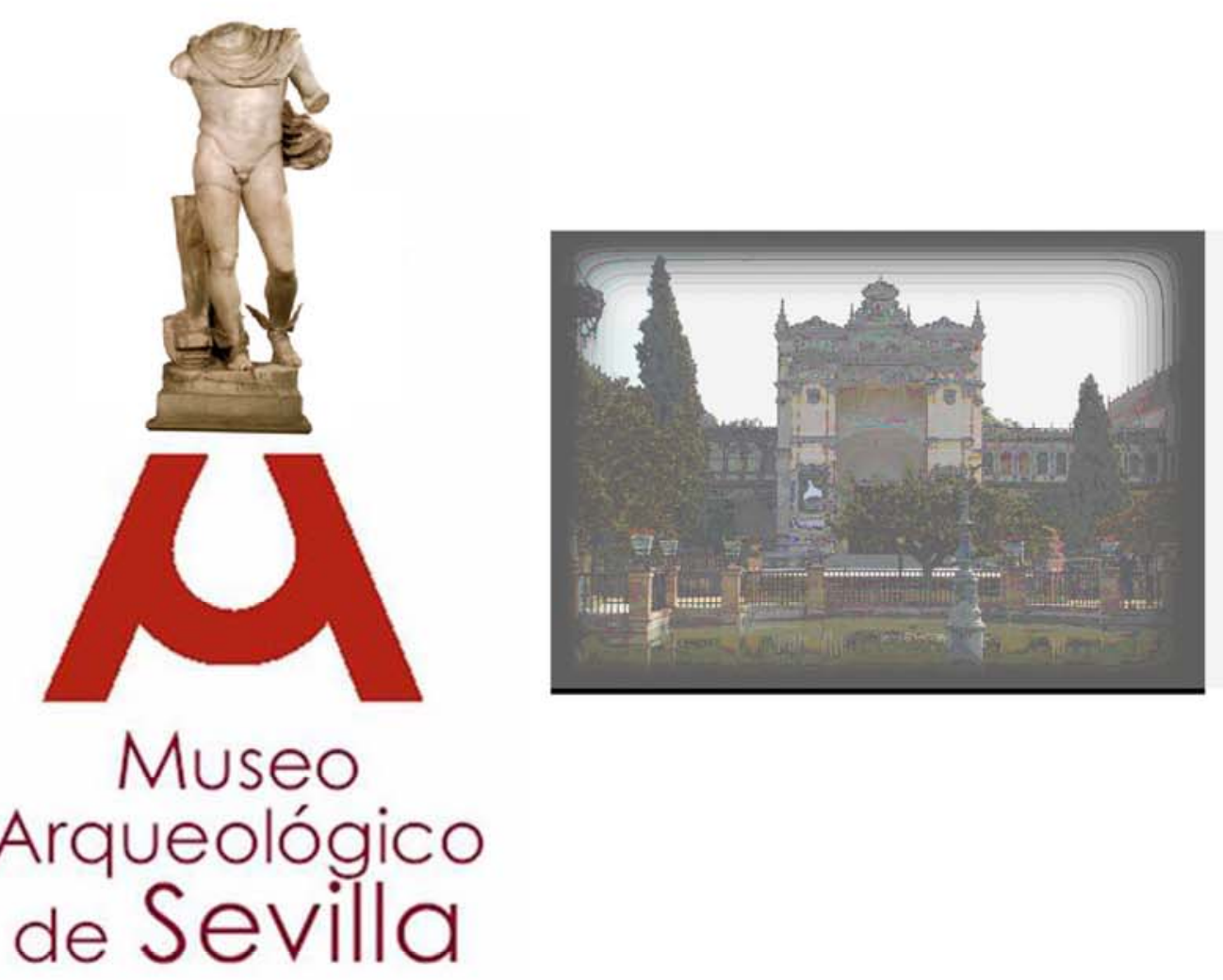

\section{ARQUITECTURA}

Yolanda Torrubia Fernández Arqueológico
de Sevilla 


\section{III.1. CONSIDERACIONES PREVIAS}

A través del análisis que se ha realizado se dan una serie de datos sobre las deficiencias que el museo tiene desde el punto de vista arquitectónico, ya sea desde la visión propiamente estructural, como desde la funcional.

El resultado final del análisis de edificio, espacios, accesos, circulaciones e instalaciones, hace pensar en la necesidad de abordar la reorganización, remodelación y modernización del museo desde un punto de vista integral. Es decir, para conseguir solventar todas las patologías y necesidades que se han analizado será necesaria una intervención en la que se incluyan todos los aspectos del museo. Ésta, que se planteará en los programas, será necesaria ejecutarla por fases bien estructuradas tanto en el tiempo como económicamente o bien mediante una gran inversión y con el cierre temporal del museo.

Así, se podrá plantear un museo moderno y adecuado a las nuevas tendencias de la museología, con mayor atención al público, a su bienestar y a mejorar su comprensión de las piezas, así como en general, su experiencia en el museo. No obstante, esto debe conseguirse sin que suponga un detrimento en el cuidado de las colecciones, cuya conservación y mantenimiento son labores fundamentales del museo, ya que sin un adecuado tratamiento de las piezas es imposible su difusión.

Se plantean como actuaciones preferentes:

- Estudio arquitectónico del edificio. Es necesario un estudio detallado que determine la gravedad de las patologías que se han observado.

- Reordenación de los espacios del museo, así como creación de espacios de los que el museo carece y son necesarios para el cumplimiento de sus funciones de conservación y difusión. La reorganización deberá seguir la 
premisa de separación por sectores de las cuatro zonas fundamentales del mismo:

- Área pública sin colecciones

- Área pública con colecciones

- Área interna con colecciones

- Área interna sin colecciones

- Reestructuración y separación de los accesos y las vías de circulación verticales y horizontales de bienes culturales, visitantes y personal del museo:

- Facilitar la entrada, el transporte y la manipulación de las piezas dentro del museo, de manera que se minimicen los riesgos (evitar tener que salvar escaleras habilitando un montacargas que salve la circulación vertical y pasillos adecuados para la horizontal).

- Aumentar el número de accesos y mejorar la circulación de los visitantes dentro del museo.
- Independizar las zonas de trabajo del personal del museo de las zonas de exposición, tanto temporal como permanente, uniendo a todos los trabajadores en una misma zona del museo. Cuidar que la circulación de los trabajadores no pase por zonas visitables y viceversa.

- Elaborar un Plan de Emergencia y Evacuación con un protocolo de actuación definido, así como determinar la ubicación y señalización de las salidas de emergencia de manera que cumplan la normativa vigente.

- Revisión de las instalaciones de electricidad, fontanería y saneamiento, así como todo lo relativo a instalaciones de este tipo para determinar la idoneidad $o$ no de su funcionamiento y así determinar los daños de las mismas. Asimismo, 
definir las nuevas instalaciones necesarias en el edificio.

- Instalación de un sistema de climatización en todo el edificio que facilite la conservación de las piezas y el bienestar de los visitantes y los trabajadores del museo.
Existen algunos aspectos que pueden condicionar el proyecto arquitectónico:

\section{RÉGIMEN URBANÍSTICO.}

Las ordenanzas municipales y la normativa urbanística que pudiera afectar al edificio o su entorno inmediato no prohíben la construcción en los alrededores del edificio.

Lo que sí es un condicionante fundamental a tener en cuenta en las intervenciones que se realicen en él es el nivel de protección que tiene el edificio, pues esta protección impone una serie de prohibiciones a la hora de actuar sobre el edificio que en ocasiones dificulta el poder efectuar una intervención integral, la cual tendrá que intentar consensuar las necesidades actuales impuestas por su uso museístico y las necesidades de protección y conservación de un edificio histórico. Al ser un museo de titularidad estatal, queda sometido al Real Decreto 620/1987, de 10 de abril, por el que se aprueba el Reglamento de los Museos de Titularidad Estatal y del Sistema Español de Museos, el cual establece en su 
artículo 5 que todos los inmuebles ocupados por museos de titularidad estatal quedan declarados Bien de Interés Cultural. Por tanto, el edificio queda sometido al régimen y las condiciones que la Ley 16/1985, de 25 de junio, del Patrimonio Histórico Español establece para los edificios con tal protección. Tales condiciones quedan recogidas en el Título II. De los Bienes Inmuebles, en los artículos 18, 19,23 y 24 , de la Ley:

\section{Artículo 18.}

Un inmueble declarado bien de interés cultural es inseparable de su entorno. No se podrá proceder a su desplazamiento o remoción, salvo que resulte imprescindible por causa de fuerza mayor o de interés social $y$, en todo caso, conforme al procedimiento previsto en el artículo 9, párrafo 2 de esta Ley.

\section{Artículo 19.}

1. En los monumentos declarados bienes de interés cultural no podrá realizarse obra interior o exterior que afecte directamente al inmueble o a cualquiera de sus partes integrantes o pertenencias sin autorización expresa de los organismos competentes para la ejecución de esta Ley. Será preceptiva la misma autorización para colocar en fachadas o en cubiertas cualquier clase de rótulo, señal o símbolo, así como para realizar obras en el entorno afectado por la declaración.

2. Las obras que afecten a los jardines históricos declarados de interés cultural y a su entorno, así como la colocación en ellos de cualquier clase de rótulo, señal o símbolo, necesitarán autorización expresa de los organismos competentes para la ejecución de esta Ley.

3. Queda prohibida la colocación de publicidad comercial y de cualquier clase de cables, antenas y conducciones aparentes en los jardines históricos y en las fachadas y cubiertas de los monumentos declarados de interés cultural. Se prohíbe también toda construcción que altere el carácter de los inmuebles a que hace referencia este artículo o perturbe su contemplación.

\section{Artículo 23.}

1. No podrán otorgarse licencias para la realización de obras que, conforme a lo previsto en la presente Ley, requieran 
cualquier autorización administrativa hasta que esta haya sido concedida.

2. Las obras realizadas sin cumplir lo establecido en el apartado anterior serán ilegales y los Ayuntamientos o, en su caso, la Administración competente en materia de protección del Patrimonio Histórico Español podrán ordenar su reconstrucción o demolición con cargo al responsable de la infracción en los términos previstos por la legislación urbanística.

\section{Artículo 24.}

1. Si a pesar de lo dispuesto en el artículo 36, llegara a incoarse expediente de ruina de algún inmueble afectado por expediente de declaración de bien de interés cultural, la Administración competente para la ejecución de esta Ley estará legitimada para intervenir como interesado en dicho expediente, debiéndole ser notificada la apertura y las resoluciones que en el mismo se adopten.

2. En ningún caso podrá procederse a la demolición de un inmueble, sin previa firmeza de la declaración de ruina y autorización de la Administración competente, que no la concederá sin informe favorable de al menos dos de las Instituciones consultivas a las que se refiere el artículo 3 .

3. Si existiera urgencia y peligro inminente, la entidad que hubiera incoado expediente de ruina deberá ordenar las medidas necesarias para evitar daños a las personas. Las obras que por razón de fuerza mayor hubieran de realizarse no darán lugar a actos de demolición que no sean estrictamente necesarios para la conservación del inmueble y requerirán en todo caso, la autorización prevista en el artículo 16.1, debiéndose prever además en su caso la reposición de los elementos retirados.

Tales condiciones se resumen en:

- El inmueble es inseparable de su entorno, salvo causa de fuerza mayor.

- No se pueden hacer obras de ningún tipo en el edificio ni en su entorno sin autorización del titular (en este caso el Ministerio de Cultura).

- No se pueden colocar rótulos, señales o símbolos en fachadas y cubiertas sin expresa autorización. 
- Está prohibida la colocación de cables, antenas y conducciones en fachadas y cubiertas.

- Está prohibida cualquier construcción que altere su carácter o perturbe su contemplación.

- Toda obra ejecutada sin la autorización de la administración competente (Ministerio de Cultura) será considerada ilegal y podrá ordenarse su reconstrucción o demolición.

- En ningún caso podrá procederse a su demolición sin que haya sido declarado en ruina previamente y autorizada expresamente la demolición (por el Ministerio de Cultura avalado por dos instituciones consultivas).

En conclusión, toda actuación que programemos en el edificio o su entorno deberá ser autorizada por el Ministerio de Cultura.

No obstante, el solar que el museo tiene detrás es propiedad del Ayuntamiento, por lo que esta administración tendrá que intervenir si se plantea una intervención que le afecte.

\section{CONDICIONANTES HISTÓRICOS.}

Puede considerarse como tal el hecho de que el edificio fuera concebido como pabellón para una exposición universal, es decir, como un edificio de uso efímero como pabellón, si definirse un uso posterior, con lo que no es un inmueble pensado para albergar un museo y ha tenido que adaptarse a este uso y las necesidades que éste ha ido imponiendo a través de intervenciones parciales en el mismo. Además, los sistemas de construcción de principios del siglo XX han impuesto el uso de unos materiales de construcción que no son de primera calidad ni lo suficientemente resistentes para asegurar una larga vida al edificio sin intervenciones importantes. Prueba de ello son las obras de mantenimiento y restauración de algunas zonas que ya han tenido que efectuarse en el edificio a pesar de su relativamente corta vida aunque sea un edificio histórico, ya comentadas en la fase de análisis. 


\section{RÉGIMEN JURÍDICO.}

Otro de los condicionantes a tener en cuenta al planificar una intervención en el edificio es su titularidad y gestión, además del nivel de protección del mismo. En origen, el Pabellón de Bellas Artes era de propiedad municipal, pero fue cedido por el Ayuntamiento al entonces Ministerio de Educación Nacional en 1941. Actualmente, aunque sigue siendo propiedad del Ayuntamiento, el Ministerio de Cultura ejerce como titular a través de esta cesión indefinida condicionada al uso museístico del mismo. En 1994, dicho Ministerio cedió la gestión del museo mediante convenio a la Consejería de Cultura de la Junta de Andalucía. Por tanto, el edificio es de titularidad estatal pero gestionado por la Comunidad Autónoma, con lo que cualquier intervención que se haga en el edificio deberá ser acometida o autorizada por el Ministerio de Cultura, excepto las de mantenimiento que son obligación de la administración gestora. Esta división del edificio en dos administraciones a veces dificulta las tareas de gestión, mantenimiento o restauración, pues aunque parece claro el cometido de cada una no siempre es así. Además, el hecho de que una intervención en el edificio deba ser ejecutada por el Ministerio hace que la Consejería de Cultura no la lleve a cabo, aunque el titular tampoco la haga. Por otra parte, toda intervención debe ser autorizada por el titular, lo que ralentiza el procedimiento en el caso de que la Junta decida llevarla a cabo por ella misma.(condicionantes en materia de propiedad, cargas, cesiones de uso...).

Por tanto, teniendo en cuenta estas peculiaridades de titularidad y gestión del museo, que afectan negativamente tanto a su funcionamiento diario como a cualquier intervención en el mismo, proponemos la cesión indefinida de la titularidad del museo por parte del Ministerio a la Junta de Andalucía. En realidad sería la cesión por parte del Ayuntamiento, anulando la que actualmente favorece al Ministerio de Cultura. Por supuesto se necesitará el consentimiento de las tres administraciones implicadas (municipal, autonómica y estatal). 
La titularidad la ejercería así la Consejería de Cultura de la Comunidad, actual administración gestora. Creemos que esta administración es más consciente de las necesidades del museo y de las respuestas que éste debe dar a la comunidad a la que sirve dada la mayor cercanía y el hecho de ser la gestora del museo. Con esta cesión, la titularidad y gestión quedarían concentradas en la misma administración, facilitando la gestión del museo y los procedimientos burocráticos.

\section{CONDICIONANTES TÉCNICOS.}

Habrá que hacer un estudio para determinar si existen y cuales son, pues la calidad del terreno o la resistencia de los cimientos y muros de carga, así como el conocimiento de los elementos estructurales que soportan el peso del edificio son datos primordiales a tener en cuenta para trazar una nueva configuración de los espacios del mismo.

\section{III.2. TIPO DE ACTUACIÓN PROPUESTA}

A la vista del análisis realizado en el edificio desde el punto de vista arquitectónico y de los espacios, y de estudiar la superficie y la funcionalidad de los mismos, planteamos una intervención integral en el edificio del Museo Arqueológico, que debe partir de la consolidación y restauración del edificio en todos sus aspectos (estructura, conducciones, instalaciones, fachadas, cerrajería, carpintería -incluidos artesonados- , cubiertas...) para posteriormente proceder a la reorganización funcional de los espacios del museo, reorganización que se tendrá en cuenta en el proyecto arquitectónico.

Además de solventar los problemas del edificio actual, a la hora de reorganizar los espacios contaremos con la superficie de un nuevo edificio, que será construido en la parte trasera del museo, sobre la actual pista de patinaje, es decir, entre el museo, el cuartel de la Guardia Civil y el pabellón de Brasil. 
Tras el análisis, concluimos que la superficie total útil del edificio del Pabellón del Renacimiento es de $6718 \mathrm{~m}^{2}$ aproximadamente, incluyendo las terrazas de la fachada principal, pero no las laterales porque no tienen uso actualmente, aunque podrían tenerlo en el nuevo proyecto. De esta superficie, los espacios del museo ocupan 5633 $\mathrm{m}^{2}$; los accesos y circulaciones $475 \mathrm{~m}^{2}$; hay $351 \mathrm{~m}^{2}$ sin uso y $258 \mathrm{~m}^{2}$ actualmente ocupados por otras instituciones ajenas al museo. En nuestro proyecto intentaremos aprovechar al máximo los metros útiles del edificio.

No podemos plantear de manera exacta la superficie que ocupará el nuevo edificio, ya que el será el proyecto arquitectónico el que estimará los metros que son necesarios para los espacios que determinaremos a continuación, además de adaptar el edificio al solar de que disponemos de la manera mas adecuada posible, respetando el entorno del parque (declarado Bien de Interés Cultural en la categoría de Jardín Histórico como ya se ha dicho), el espacio de seguridad que necesita el cuartel de la Guardia Civil y por supuesto, el edificio del museo y su entorno (también Bien de Interés Cultural). No obstante, según los metros cuadrados que tras el análisis se consideran necesarios para el buen funcionamiento del museo, como es por ejemplo, la superficie necesaria para el almacén, ubicado en el nuevo edificio, se podrá dar una estimación aproximada de la superficie del mismo, así como las plantas en las que se distribuirá. También se detallarán las conexiones entre los diferentes espacios, así como la conexión con el edificio antiguo y se planteará una distribución de espacios orientativa, que podría ser modificada en función del proyecto arquitectónico. No obstante, partiendo del espacio en el que podemos construir, que está muy determinado por construcciones alrededor ya citadas y por la gran cantidad de árboles que rodean al edificio actual del museo y que no pueden ser cortados, la superficie estimada que en planta podrá ocupar el museo es de unos $1500 \mathrm{~m}^{2}$. Por supuesto, estos metros se multiplicarán según las plantas que tenga el edificio y que serán determinadas en el proyecto 
arquitectónico siguiendo las necesidades que en este programa se plantean.

Este nuevo edificio estará conectado al existente por un pasillo subterráneo con claraboyas para la entrada de luz, que será trazado respetando los árboles de la fachada sur (trasera) del museo y será lo bastante ancho como para poder ser dividido para el uso del personal del museo, que podrá mover obras por él, y para la circulación de visitantes, que cruzarán del edificio antiguo al nuevo para visitar las exposiciones temporales. Desde el edificio existente, este pasillo partirá de la fachada sur en su parte central, donde hoy se sitúa la zona de recepción de colecciones en el sótano, pero deberá excavarse más abajo el espacio de conexión, pues este sótano sale casi a la superficie y el pasillo será subterráneo. Por tanto, para las colecciones y el personal, el paso llegará directamente al montacargas del edificio, que también será ascensor, y que tendrá que bajar hasta más profundidad del nivel del suelo actual.
Las escaleras y el ascensor del público también deberán construirse de manera que lleguen hasta el nivel del paso subterráneo, antes del cual se ubicará un pequeño vestíbulo al que lleguen estas vías de circulación vertical y que de paso al pasillo para pasar al nuevo edificio. Tras la visita del edificio nuevo, el público podrá salir directamente al exterior, al parque, en cuya salida se ubicará una plaza pública que podrá ser utilizada como lugar de encuentro y realización de actividades al aire libre. Muy cercana a la plaza, en la terraza occidental del museo, se encontrará la cafetería. Esta plaza, por encontrarse entre el edificio nuevo, el antiguo y el pabellón de Brasil tendrá que tener forma triangular y podrá ocupar una superficie de unos 400 $\mathrm{m}^{2}$. No obstante, como ya se ha señalado, estas estimaciones de superficie tendrán que ser confirmadas o modificadas en el proyecto arquitectónico.

Con esta gran intervención arquitectónica y urbanística regeneraremos y revitalizaremos esta zona degradada del parque. 
620
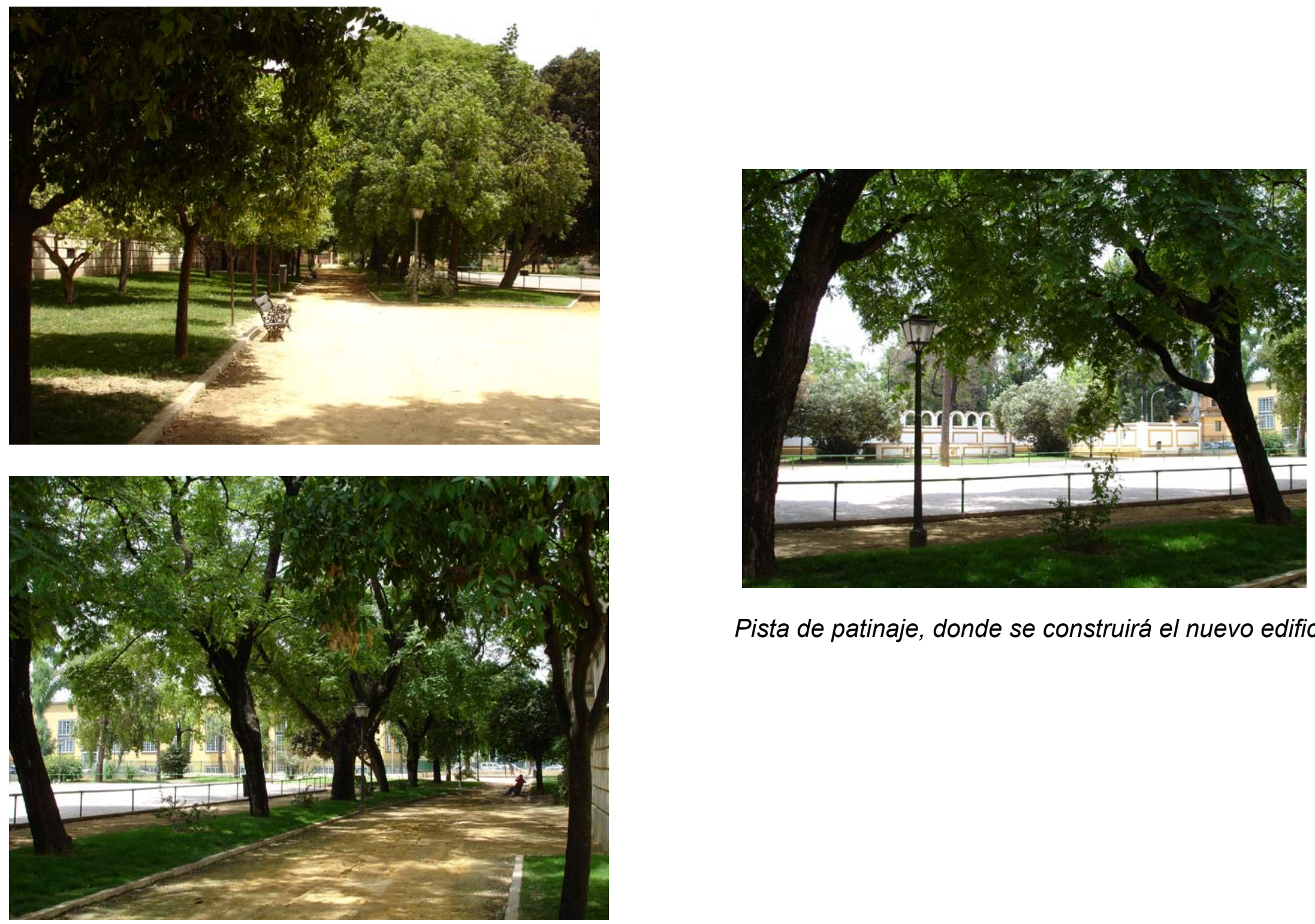

Pista de patinaje, donde se construirá el nuevo edificio

Parte trasera (sur) del museo y espacio 
VISTA AÉREA DEL CONJUNTO DE EDIFICIOS QUE COMPONEN EL SOLAR DONDE SE UBICARÁ EL NUEVO INMUEBLE
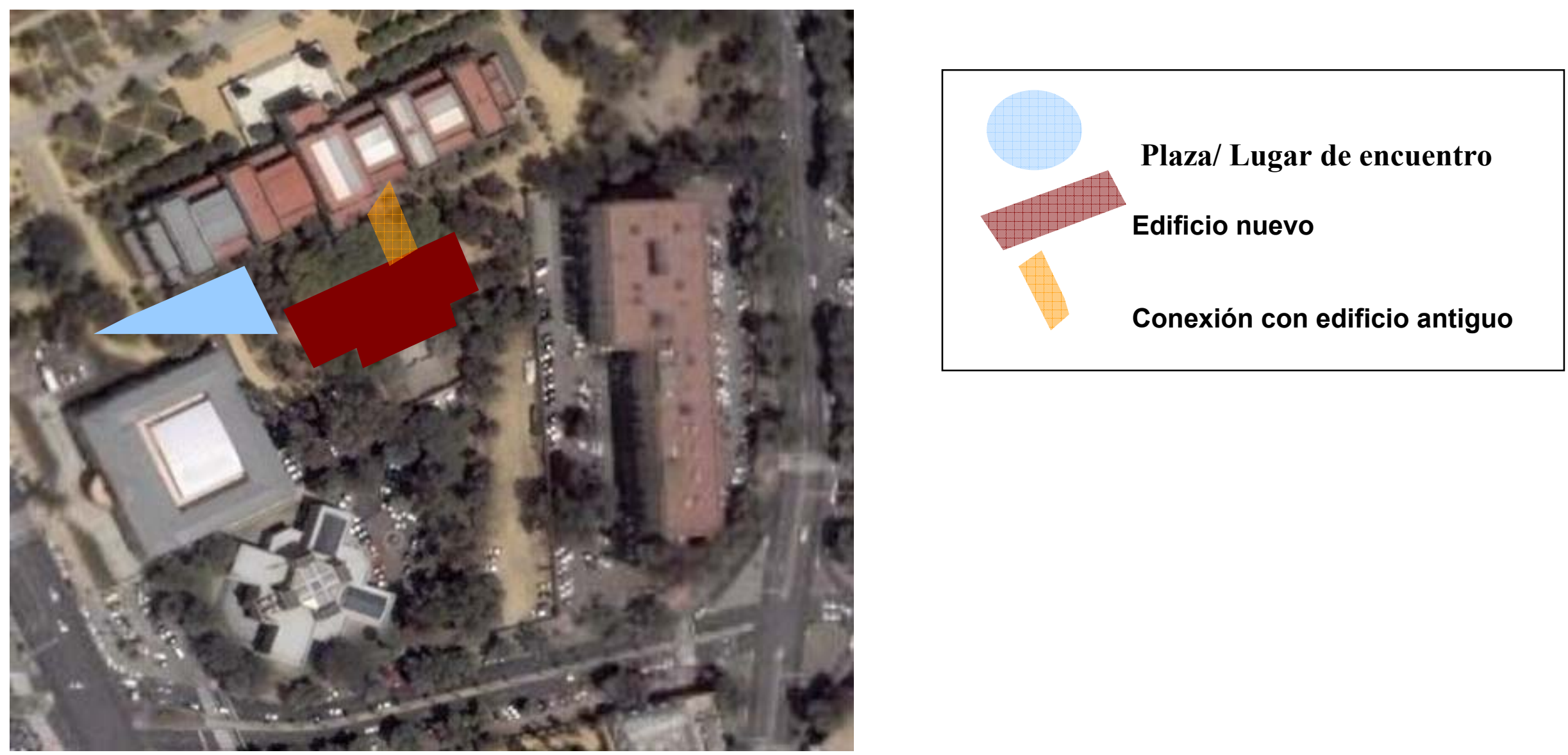
VISTA DEL CONJUNTO DE EDIFICIOS QUE COMPONEN EL SOLAR DONDE SE UBICARÁ EL NUEVO INMUEBLE

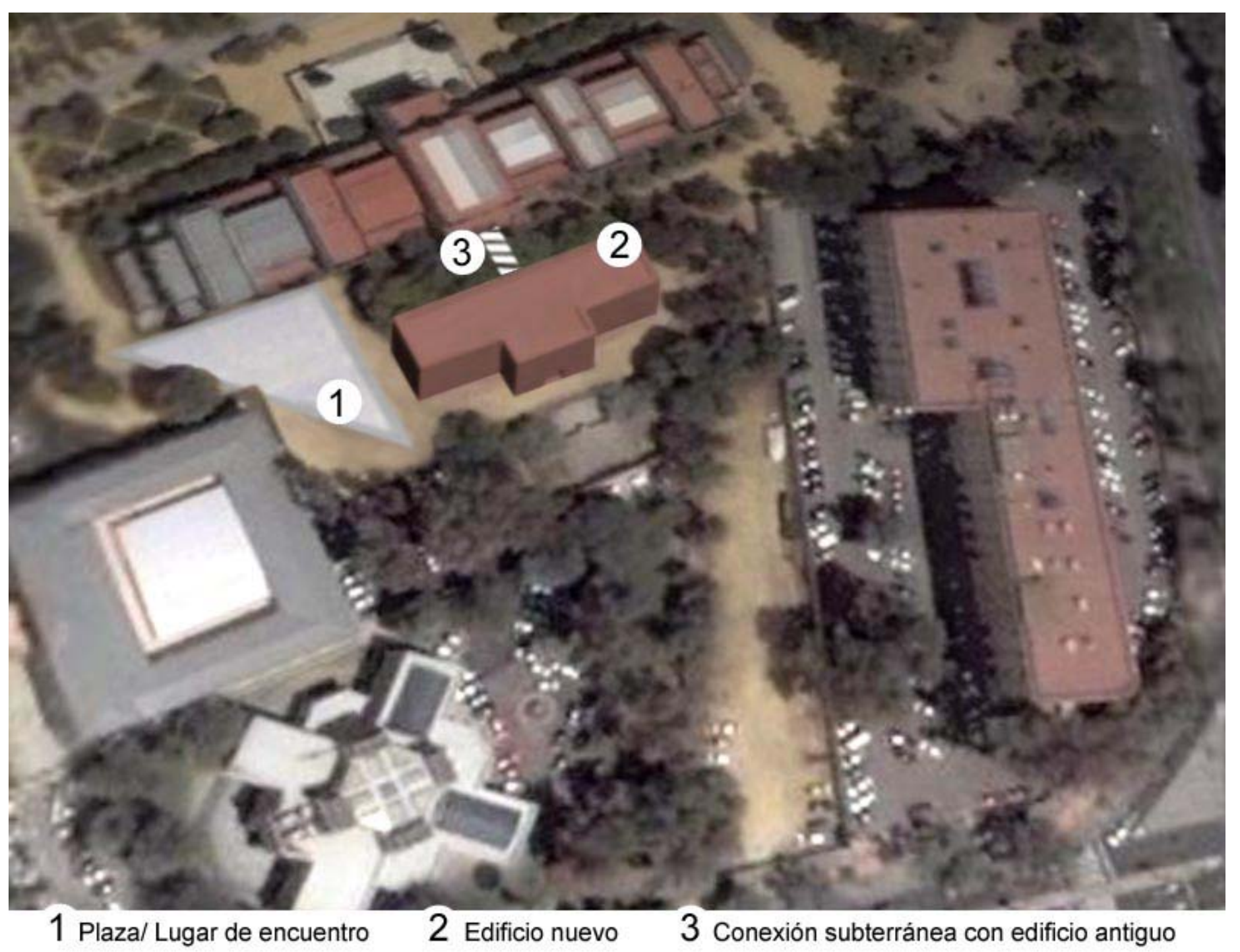


III.3. NECESIDADES DE INTERVENCIÓN

\section{EN EL EDIFICIO DEL PABELLÓN} RENACENTISTA ${ }^{46}$

Las carencias en mantenimiento que el edificio ha tenido desde su construcción, a pesar de su corta vida, han producido daños que actualmente claman una intervención inmediata en el mismo. Los diversos daños y patologías que el inmueble sufre ya han sido detalladas en la fase de análisis y por supuesto deberán ser solventadas, algunas de manera urgente y otras a medio plazo.

46 Las soluciones que aquí se plantean están directamente relacionadas con las observaciones anotadas en la fase de análisis, por lo que seguiremos prácticamente el mismo esquema.

\section{III.3.1. INTERVENCIONES GENERALES ${ }^{47}$}

\section{a) Cimentación}

Debido a las deficiencias en la cimentación han aparecido grietas y fisuras en diferente lugares del edificio.

\section{Algunas posibles soluciones:}

Por un lado, habrá que reparar los daños que ya se han producido y por otro, atajar el problema desde la causa, revisando la cimentación y utilizando técnicas que la hagan más compacta y con menos humedad.

Es importante controlar las fugas que se puedan producir de las conducciones de agua, pues la humectación y desecación hacen mucho daño a la cimentación. Además,

\footnotetext{
${ }^{47}$ Las propuestas de soluciones a las patologías del edificio han sido facilitadas en gran parte por el proyecto de fin de carrera realizado en marzo de 2001 en la Escuela Universitaria de Arquitectura técnica de Sevilla, coordinado por D. José Antonio Solís Burgos, El museo arqueológico de Sevilla. Estudio de Rehabilitación y Plan de Evacuación. Agradecemos su colaboración.
} 
puede mejorarse el terreno con inyecciones de cemento para hacerlo más compacto.

\section{b) Estructura}

En el análisis se determinaron las causas más importantes de los daños de la estructura, como la filtración en las cubiertas y los fallos de cimentación, cuya corrección detendría en gran parte el avance de las patologías. Se destacó la diferencia de los asientos, que podría provocar roturas en los cimientos, los desplomes en pináculos y balaustradas y las fisuras tanto en los muros como en las claves de algunos arcos.

\section{Propuestas de actuación en la estructura:}

Creemos que lo más acertado será corregir en primer lugar los orígenes de las patologías de la cimentación y las cubiertas y posteriormente las de los muros, mediante:

Relleno de fisuras: una vez estabilizado el muro dañado, es decir, eliminado el riesgo de nuevas fracturas ni de que progresen las grietas, rellenar éstas y después sellarlas.

Sujeción: en el caso de que un paño extenso de muro padezca fallos (desplomes, desniveles), los movimientos deben ser detenidos mediante la transmisión de los esfuerzos actuales a otros elementos constructivos que posean robustez y estabilidad, ya sean presentes en el edificio o nuevos. Esta transmisión se suele hacer con elementos auxiliares que trabajan a tracción (tirantes o anclajes) o que trabajan a compresión (codales y tornapuntas).

\section{c) La acción del agua: humedades}

Ya se habló en el análisis del agente más destructor de un edificio, sobre todo en su estado líquido, en el que puede penetrar por diferentes vías ya comentadas. En el edificio que nos ocupa se han encontrado diferentes tipos de humedades (de origen subterráneo, por rotura de la red de abastecimiento o redes sanitarias, por eflorescencias, por 
capilaridad, por lluvia, por condensación en el interior, etc.) que afectan a cubiertas, fachadas, sótanos, soleras, muros, etc. produciendo la disgregación y la pérdida de materiales, la disminución de su capacidad mecánica, la reducción del aislamiento térmico y el favorecimiento de microorganismos y hongos.

Algunas posibles soluciones (según el tipo de humedad):

- Capilaridad:

- Colocar una membrana impermeabilizante (eficaz y caro).

- Aplicar en el muro tuberías de arcilla cocida con mortero poroso que faciliten la evaporación del agua retenida (poca eficacia, problemas estéticos).

- Introducir en los poros del muro un producto sellador que cree una zona impermeable que se oponga a la subida del agua. Se aplica por inyección, difusión o transfusión.
- Sabiendo que la ascensión capilar del agua implica una diferencia de potencial eléctrico, la electro-osmosis se basa en que cuando se anula esta diferencia de potencial o se aplica una tensión inversa, el agua es retenida o rechazada (tiene una eficacia variable).

- Condensación: se ataja haciendo estudios del aislamiento térmico del edificio para resolver los puentes térmicos, lo cual suele hacerse fundamentalmente poniendo un aislamiento en el exterior del edificio, calentando las estancias desde dentro o ventilando las estancias y evitando sitios ocultos.

- Infiltraciones: pueden darse por cubiertas, fachadas o carpintería y por una mala solución constructiva o mala ejecución. La solución será estudiar la causa y atajarla.

- Eflorescencias: habrá que limpiar la mancha y si el muro no está saturado de humedad impregnarlo de 
ácido clorhídrico que reacciona con la cal formando cloruro cálcico, que evita la nueva aparición de eflorescencias.

- Humedad de obra o construcción: algunas soluciones pueden ser ventilar el edificio o aumentar la temperatura de las estancias.

\section{III.3.2. INTERVENCIONES EN EL INTERIOR}

\section{a) Instalación eléctrica}

Ya se señalaba en la fase de análisis que esta instalación había quedado obsoleta tras el Decreto 2413/1973, de 20 de septiembre, por el que se aprueba el Reglamento electrotécnico para baja tensión (REBT), y del posterior Real Decreto 842/2002, de 2 de agosto, que derogaba y modificaba el anterior.

Tras esto concluíamos que era necesaria la renovación total de la instalación eléctrica, ya que las instalaciones anteriores a 1973 son imposibles de aprovechar; las posteriores a 1973 pero que tengan una antigüedad de más de 10-15 años también deben ser renovadas en su totalidad aunque sean reglamentarias, ya que el envejecimiento y obsolescencia de materiales y equipos las incapacita para desarrollar sus funciones; sólo podrán 
aprovecharse las que tengan menos de 10-15 años pero dependiendo de su estado, con lo que al final se ha visto más conveniente instalar nuevamente el sistema eléctrico al realizar la intervención integral que se está planteando en el edificio.

\section{b) Instalaciones de fontanería y saneamiento}

Como todas las instalaciones, pero aún más, ésta requiere un mantenimiento continuado que sea capaz de prevenir y detectar posibles fugas que provoquen humedades en el edificio. Pero más que mantenimiento, se han llevado a cabo diferentes intervenciones que han hecho que actualmente los materiales que componen la instalación sean de diferentes momentos, lo que hace más difícil su reparación.

Habrá que revisar todo el recorrido de los bajantes y sustituir los que estén en mal estado, así como controlar la salida y la entrada de agua desde el exterior.
Asimismo, es importante solucionar los problemas de la red de saneamiento del Parque de Maria Luisa, que afectan al edificio.

\section{III.3.3. INTERVENCIONES EN EL EXTERIOR}

\section{a) Fachadas}

- Cerrajerías: la oxidación de la cerrajería de las fachadas es evidente y es un problema imprescindible de solucionar. Para solucionar los problemas habrá que actuar sobre la causa que ha originado el proceso de corrosión y reparar el efecto. Por tanto, se hará una limpieza a fondo del metal afectado (por cepillado, chorreado, decapados químicos, etc.) y se le aplicará una protección. No obstante, habrá casos en los que el metal no pueda recuperarse y sea más conveniente sustituirlo por uno nuevo, porque hay algunos tipos de oxidación y sobre todo en estados avanzados de corrosión que no permiten el arreglo. 
- Carpintería: la carpintería de madera del exterior está en su mayoría expuesta a riesgos de humedad que puede llevar al ataque de xilófagos, hongos, termitas y a pudriciones. Además, los cambios de temperatura provocan la dilatación y contracción de la madera, lo que origina fendas en la misma, que además de lo que supone de rotura del material, también facilita el ataque de hongos e insectos.

Tras el estudio exhaustivo de las patologías se determinarán las intervenciones más oportunas, con lo que aquí detallaremos algunas recomendaciones:

Ante el ataque de xilófagos habrá que usar productos adecuados, ya sean insecticidas inyectados o pulverizados u otros métodos. Ante las pudriciones habrá que utilizar protectores según el contenido de humedad que tenga la madera, que en este caso es semiseca, para la que se suelen usar protectores hidrosolubles y orgánicos naturales. Si contiene insectos de ciclo larvario se limpiarán con una azuela las zonas superficiales degradadas y después se pulverizará un insecticida en la superficie y se aplicarán inyecciones del producto en el interior de la madera. Ante las termitas, lo primero será eliminar las fuentes de humedad, sanear y desechar la madera afectada; después podrá aplicarse un tratamiento químico por pulverización o inyección, así como colocar barreras químicas en las zonas del muro en contacto con la madera.

Una vez eliminadas las causas directas del deterioro se intentará recuperar las ventanas de madera. Para ello habrá que eliminar los restos de pinturas y barnices antiguos, lijar la superficie hasta llegar a la madera fresca para ver el estado en el que se encuentra, comprobar el estado de los ensambles, etc. La madera expuesta al exterior, es decir, a las causas principales de envejecimiento de la misma que son los rayos ultravioletas y las variaciones de humedad, deberá ser protegida, bien con pinturas $\mathrm{o}$ bien con barnices, que tienen un comportamiento parecido y ralentizan el envejecimiento, siendo las pinturas más efectivas porque los pigmentos aíslan a la madera de la acción de los rayos ultravioleta. 
Además de la reparación es siempre imprescindible prever un mantenimiento continuado de la madera, lavando las ventanas con agua, observando y reparando las juntas de los cristales, las bisagras, etc. Las ventanas metálicas deben ser repintadas cada cinco años mas o menos y ser lavadas regularmente. Para ello habrá que tener muy en cuenta el acceso a las mismas para su conservación.

- Artesonados: La carpintería de armar del porche de acceso al museo y el resto de techos decorativos de madera son de madera de pino. Tras su estudio se determinó en el análisis la presencia de hongos en diferentes manifestaciones y algunos daños físicos como pérdida de materia, alabeos o desprendimientos.

Antes de pasar a la eliminación de estos agentes, la primera medida y la más importante es la corrección de los defectos destructivos que han favorecido su proliferación.

Posteriormente se saneará la madera y se aplicará el tratamiento adecuado. Por lo tanto, algunas actuaciones a seguir serán:

- Contra los ataques de hongos, eliminar las fuentes de humedad y tratar el elemento para que no supere el 18$20 \%$ de humedad. Se limpiarán y eliminarán los restos de madera afectada 0 se sustituirán o consolidarán. Posteriormente se aplicarán inyecciones y/o pulverización de productos químicos funguicidas e insecticidas.

- Contra los ataques de insectos de ciclo larvario, limpiar las zonas superficiales degradadas y aplicar el tratamiento, bien con inyecciones de producto al interior de la madera, bien con un tratamiento superficial aplicándolo todos los años.

- Contra los ataques de termitas, eliminar las fuentes de humedad, sanear la madera afectada, aplicar el tratamiento químico y proteger la madera. 
Si los daños producidos en las piezas de madera son muy graves puede ser necesaria la consolidación o sustitución de algunas partes.

\section{Propuesta de actuación:}

La metodología de trabajo propuesta para intervenir en los artesonados es la siguiente:

1) Estudio en profundidad del estado de cada artesonado, de las condiciones a las que están expuestos, etc.

2) Levantamiento de planos detallados de cada artesonado en los que se indiquen el estado de conservación, los incidentes acontecidos, las intervenciones que ha sufrido, etc. Esta información será completada con un reportaje fotográfico que deberá comprender todos los pasos desde el inicio hasta el final de la intervención y que tendrá un valor técnico y documental.
3) Siglado de las piezas para facilitar la labor de montaje y evitar la variación de la composición original.

4) Limpieza preliminar con brocha y aspirador para eliminar el polvo y las adherencias con el fin de facilitar una correcta adhesión de la posterior protección.

5) En caso de poder conservar la policromía de los artesonados deberá protegerse cubriéndola con papel japonés adherido con cera-resina. Se mantendrá cubierta en la fase de desmontaje y almacenamiento y mientras se procede al sentado y fijación de la película pictórica.

6) Desmontaje con especial cuidado en los elementos en mal estado y toma de pequeñas catas si fuese necesario.

7) Limpieza en profundidad, consolidación mediante la impregnación de resina termoplástica disuelta en medio orgánico para dar consistencia mecánica y desinsectación mediante un agente antiparásitos. Aquellas piezas que 
hayan perdido la forma se rellenarán y remodelarán con resinas epoxídicas y si la destrucción es de gran volumen, se podrán injertar trozos de madera.

8) Sentado de la película pictórica mediante la impregnación de cera-resina sobre el papel japonés, planchas calientes y espátulas eléctricas de sentado. Al terminar esta tarea retiraremos el papel así como los excesos de cera-resina mediante esencia de trementina. Posteriormente se procederá a la limpieza de la película policroma, que tratará de recuperar la policromía original del artesonado. Se realizaría con productos químicos, algodón, escalpelos, espátulas y bisturís. Cumplidos los tiempos de secado, se consolidará con una película de resina termoplástica en medio orgánico para la eliminación de pasmados y evaporaciones inadecuadas.

9) Montaje del artesonado respetando las deformaciones y aplicación de una película de protección.
- Hormigón arquitectónico: utilizado en este edificio no sólo para la unión de la fábrica sino también como revestimiento (de placas de $97 \times 57 \mathrm{~cm}$ ) y ornamentación (con diversos motivos decorativos y crestería de remate), está muy dañado, tanto por el inadecuado armado en su construcción como por la acción directa de los agentes atmosféricos. Ya se han analizado los fenómenos físicos, químicos y biológicos que han contribuido al deterioro, con lo que aquí propondremos algunas soluciones que podrían tomarse, las cuales podrán confirmarse o modificarse según el proyecto de restauración que se plantee.

\section{Algunas posibles actuaciones:}

- Limpieza de los paramentos para eliminar suciedad, polvo, guano, manchas de oxidación, pintadas, etc.

- Existen diferentes tratamientos de limpieza, como el cepillado con cepillo blando, la proyección de agua a presión, la proyección de vapor de agua, la proyección de 
arena seca o húmeda, limpieza mecánica, etc. de los cuales se elegirá el más adecuado a cada zona o tipo de suciedad después de hacer un estudio detallado de las fachadas.

- Reparación de las humedades. Se pueden utilizar diferentes tratamientos de sellado.

- Reconstruir las piezas desprendidas de la crestería con mortero de mayor calidad, después de eliminar y sustituir la armadura dañada.

- Utilizar materiales más resistentes en las juntas para evitar las fisuras.

- Estudio biológico: ya se especificó en el análisis los diferentes agentes que podían atacar al edificio desde el punto de vista biológico y se añadió que el 26 de enero de
2001 se recogieron muestras para su análisis ${ }^{48}$ y dieron como resultado la existencia de cianobacterias, líquenes, musgo y plantas. Sería conveniente realizar un nuevo estudio detallado para determinar en qué medida los elementos anteriormente analizados están afectando a las fachadas del edificio con el fin de encontrar los métodos más adecuados de limpieza y prevención.

\section{b) Cubiertas}

Ya en el análisis se describieron las diferentes estructuras de cubiertas existentes en el edificio, así como las patologías más relevantes que les afectan y sus causas. Además, se destacaron los condicionantes que la normativa vigente impone en cuanto a cubiertas y que por tanto deben cuidarse. Partiendo de este análisis se pueden hacer las siguientes recomendaciones para que el posterior proyecto arquitectónico o de restauración o rehabilitación

${ }^{48}$ Muestras tomadas con motivo de la elaboración del proyecto de fin de carrera ya citado. 
del edificio aplique la normativa y resuelva los problemas de las cubiertas.

Posible actuación para la reparación de las cubiertas:

1) Inspección ocular. Por un lado, comprobar el estado de la viguería metálica y su corrosión y por otro, realizar catas en las techumbres para determinar sus componentes exactos y su estado de conservación. De los resultados de esta inspección depende el tipo de intervención.

2) Saneado de la base estructural. Deberán sustituirse aquellos perfiles metálicos gravemente afectados por la corrosión y aplicarle al resto de la viguería una imprimación para protección de humedades.

3) Intervención del soporte de cobertura. Los tableros tradicionales de doble rosca de ladrillo que nos encontramos poseen una rigidez que hace que ante variaciones de temperatura se produzcan roturas. Se podrían paliar los efectos de la temperatura con protecciones aislantes.

4) Intervención en la cobertura. La penetración de agua se puede corregir con membranas impermeables flotantes. Esta intervención debe ir acompañada por la sustitución de los bajantes y la implantación de cazoletas.

Resaltar que lo más importante para la mejora del estado de conservación de las cubiertas y la ralentización de su deterioro es un buen mantenimiento, que deberá comprender, entre otras medidas, aspectos como la eliminación de la vegetación parásita o la comprobación del funcionamiento de desagües y bajantes. 
En definitiva, es necesaria una intervención integral en el edificio que garantice su buen estado de conservación y el cumplimiento de sus funciones como museo. Para ello, aunque aquí se hayan establecido recomendaciones y propuestas de posibles actuaciones, habrá que llevar a cabo un estudio sistemático del estado de conservación de la arquitectura, a través de análisis oculares, físicos, químicos, etc. para después establecer las actuaciones que serán prioritarias o de urgencia y un proyecto de restauración y rehabilitación que abarque todos los aspectos de la arquitectura del edificio.

\section{III.4. RELACIÓN DE ESPACIOS ${ }^{49}$}

Al plantear la relación de espacios que han de ser solucionados en el proyecto arquitectónico del museo, dividiremos los mismos agrupados en las grandes áreas que ya se han empleado el la fase de análisis:

1. Área pública sin colecciones

2. Área pública con colecciones

3. Área interna con colecciones

4. Área interna sin colecciones

Esta clasificación parte de la idea de que estas grandes áreas suelen tener las mismas necesidades en cuanto a seguridad, conservación, climatización, etc. pero además plantearemos si es posible la unión física de los espacios que conforman estas áreas, pues creemos que para el

${ }^{49}$ La distribución de estos espacios en planta pueden verse en los planos del museo, lo que facilitará su comprensión. 
mejor funcionamiento del museo, ya sea interno y del personal, o de los visitantes e investigadores, estos espacios deben estar físicamente unidos y funcionalmente conectados. Esto se planteará en la medida de lo posible y teniendo en cuenta los condicionantes espaciales del edificio, con lo que quizá algunos espacios de un mismo área estén separados de los demás.

A continuación se detallarán las características, las necesidades, la superficie estimada ${ }^{50}$ y la situación en los

\footnotetext{
${ }^{50}$ Las superficies de los espacios que se especifican a continuación se han hallado teniendo en cuenta las mediciones del edificio existente que se realizaron en la fase de análisis y la superficie del espacio que podrá ocupar el nuevo edificio, medida con el programa Google Earth No obstante, nuestro cometido principal es plantear las necesidades y características de cada espacio para que el proyecto arquitectónico las tenga en cuenta, puesto que a la hora de realizar este proyecto, el arquitecto planteará la superficie de cada espacio, teniendo en cuenta también la normativa de incendios, evacuación, riesgos laborales, etc. y la anchura reglamentaria de las vías de circulación, lo que puede hacer variar la magnitud de estos espacios. Probablemente sean más acordes a lo que en realidad se proyectará, los espacios del edificio existente, pues es más fácil medir cuando el edificio ya está construido. De hecho, en el nuevo edificio, hay que tener en cuenta que todos los espacios verán algo reducidos sus metros al introducir paredes, pilares, etc. que nosotros no tenemos la capacidad de calcular.
}

edificios de cada espacio, siguiendo la clasificación en estas cuatro áreas ya citadas y dentro de éstas el orden que se siguió en el análisis para así facilitar las comparaciones entre lo que existe actualmente y lo que se plantea para el futuro. Esta distribución podrá ser modificada si es imprescindible en el momento de la ejecución del proyecto arquitectónico, si la preservación de los valores históricos del edificio o la adaptación a la normativa (de accesibilidad, seguridad, riesgos laborales, etc.) lo requieren. Aunque se han marcado en plano todos los espacios, los del edificio existente y los del nuevo, en el caso del nuevo resulta solamente una propuesta, pues consideramos las áreas que deben estar conectadas y las que preferiblemente se situarán en la misma planta; estas indicaciones se darían al arquitecto en el momento de proyectar el edificio, pero cabe la posibilidad de realizar cambios en las superficies y en la ubicación según se vaya desarrollando este proyecto. 
A continuación se presenta la distribución de espacios sobre planos, para facilitar la comprensión de las descripciones de este apartado. 
PLANOS DEL EDIFICIO DEL PABELLÓN RENACENTISTA CON LA NUEVA DISTRIBUCIÓN DE ESPACIOS 


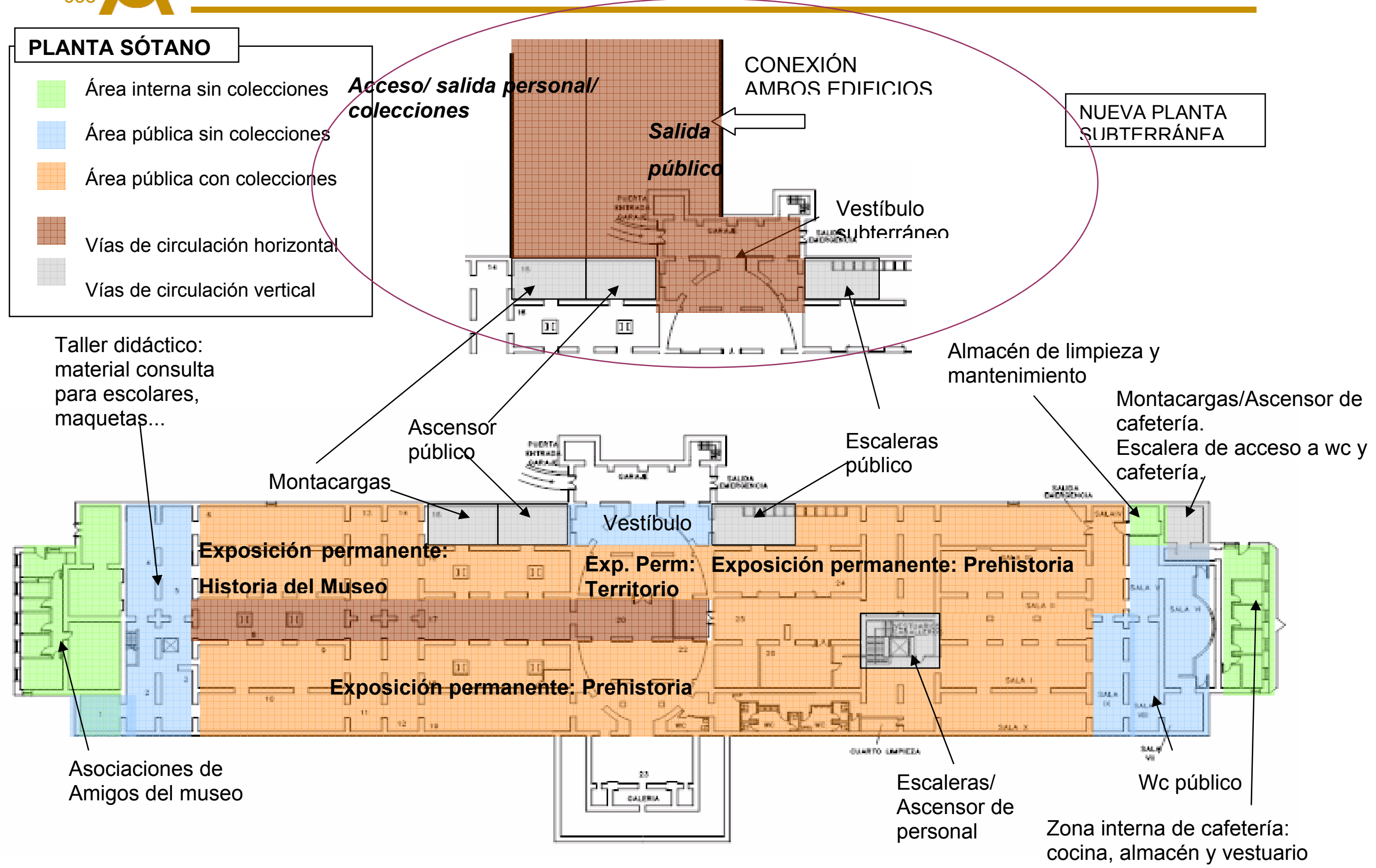




\section{PLANTA BAJA}

uardarropa/

Consigna

Escalera hacia wc público del

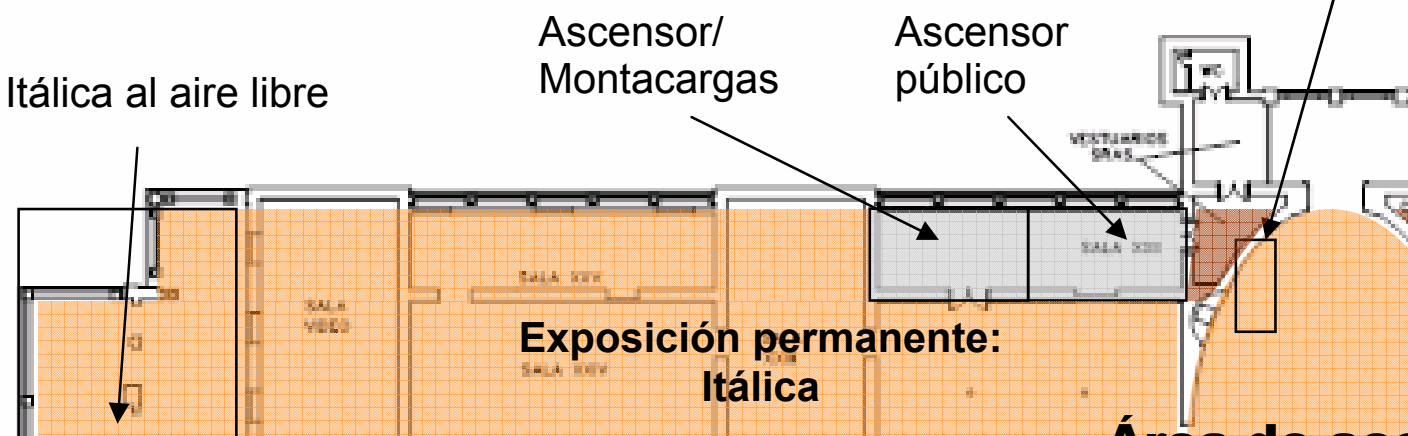

Ascensor/

\section{Ascensor}

Itálica al aire libre

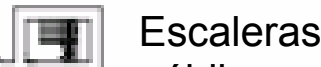

sótano

\section{Área Pública sin colecciones}

Área pública con colecciones 


\section{PLANTA PRIMERA}

Escaleras y ascensor acceso torre

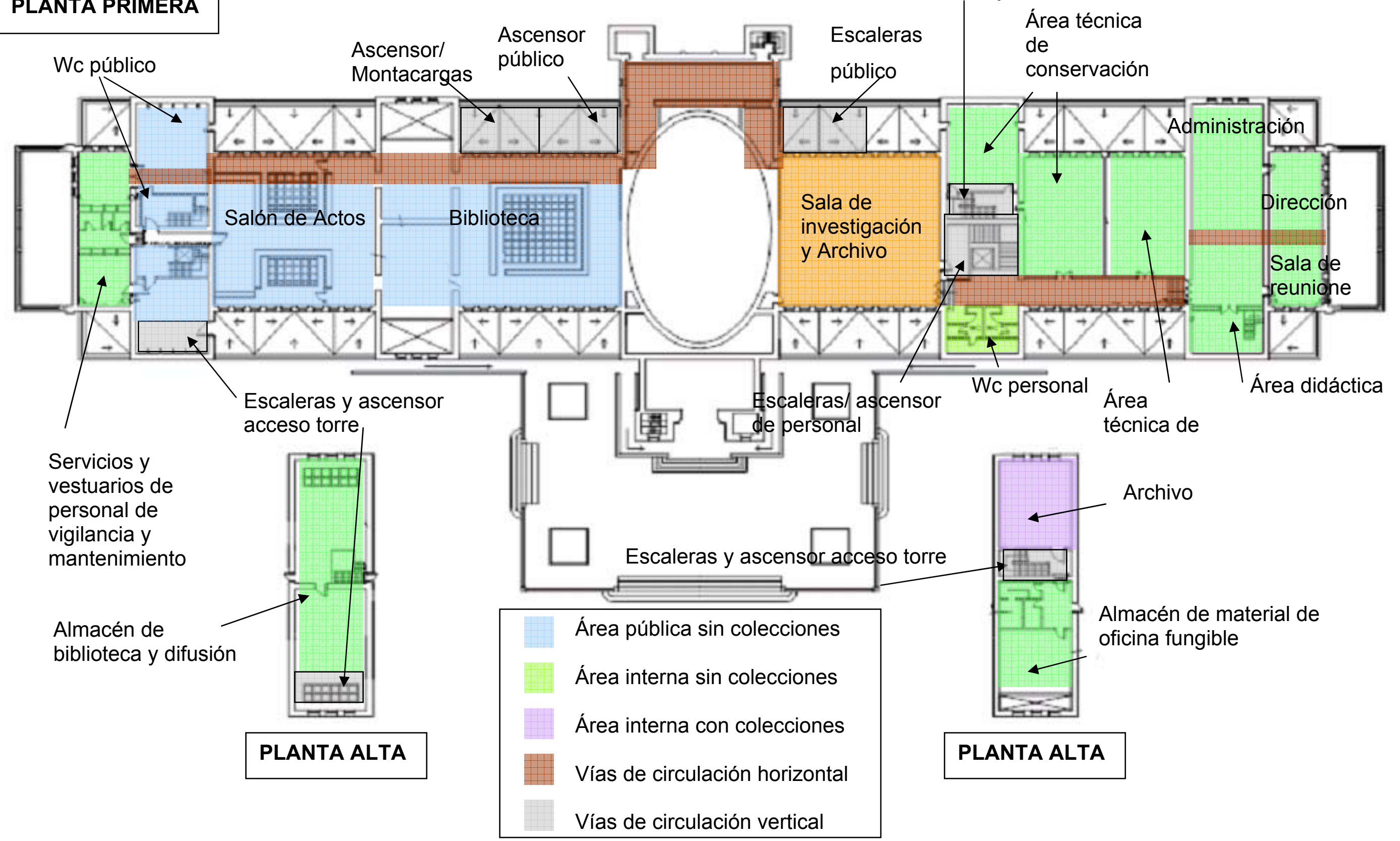


PLANOS DEL NUEVO EDIFICIO CON LA PROPUESTA DE DISTRIBUCIÓN DE ESPACIOS 


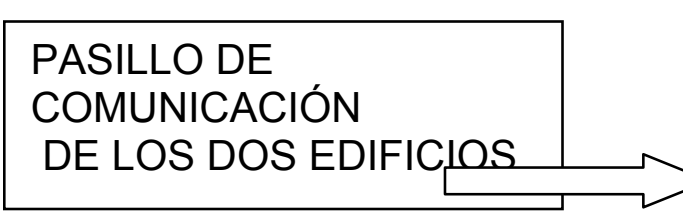

\section{Público / Personal y}

\section{SÓTANO 1}

COMUNICACIÓN

colecciones

Ascensor y escaleras públicos

Entrada de colecciones

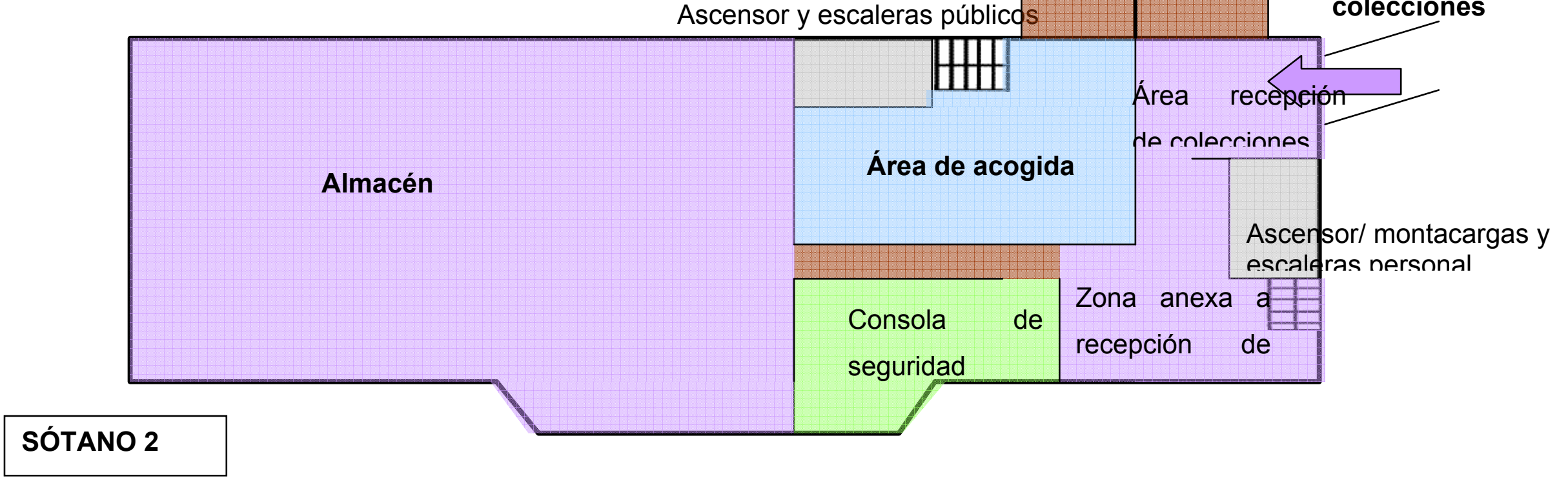

Área interna sin colecciones

Área pública sin colecciones

Área interna con colecciones

Almacén

Ascer/sor/ montacargas y

escale ras nersonal

Vías de circulación horizontal

Vías de circulación vertical 


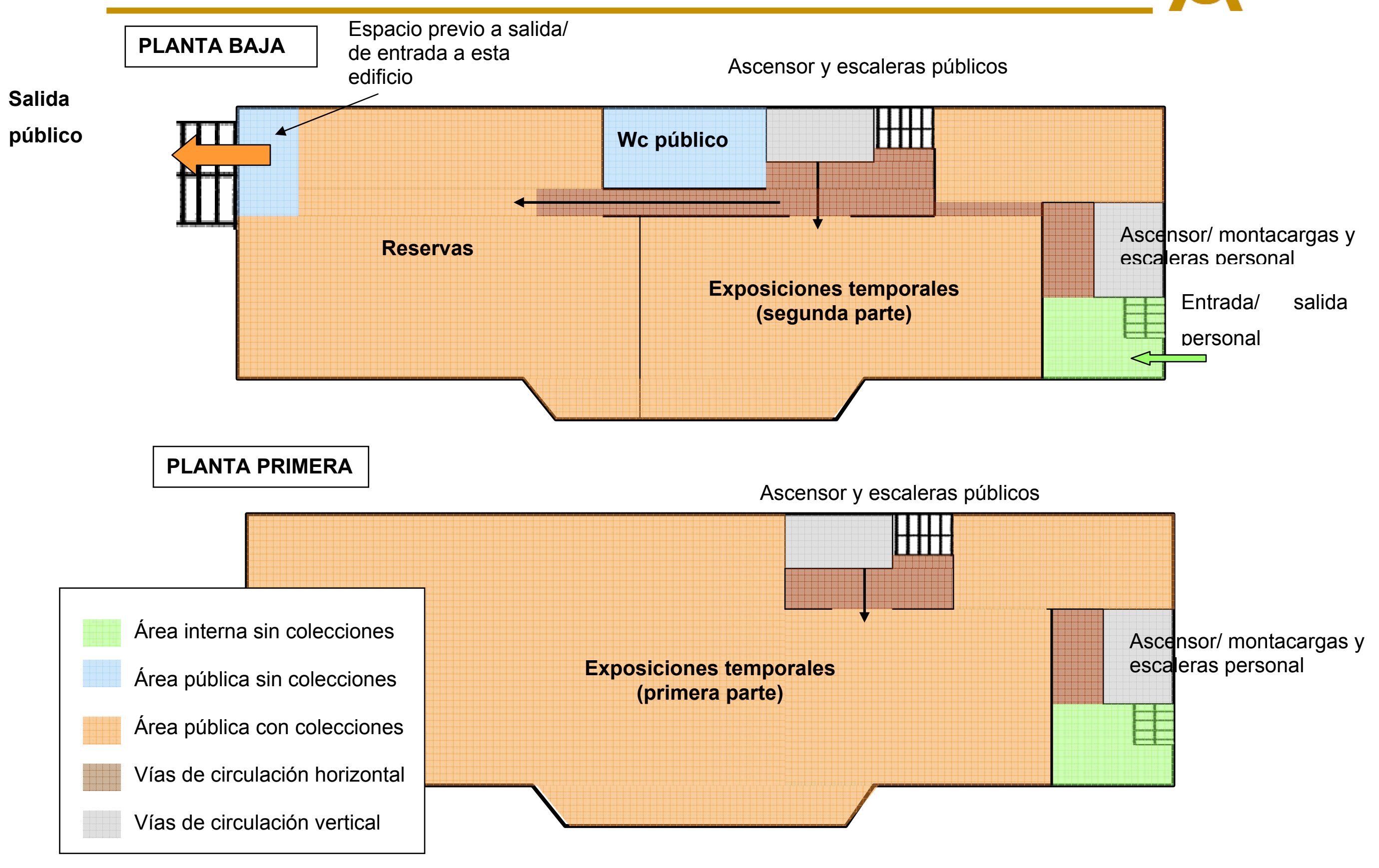




\section{PLANTA SEGUNDA}

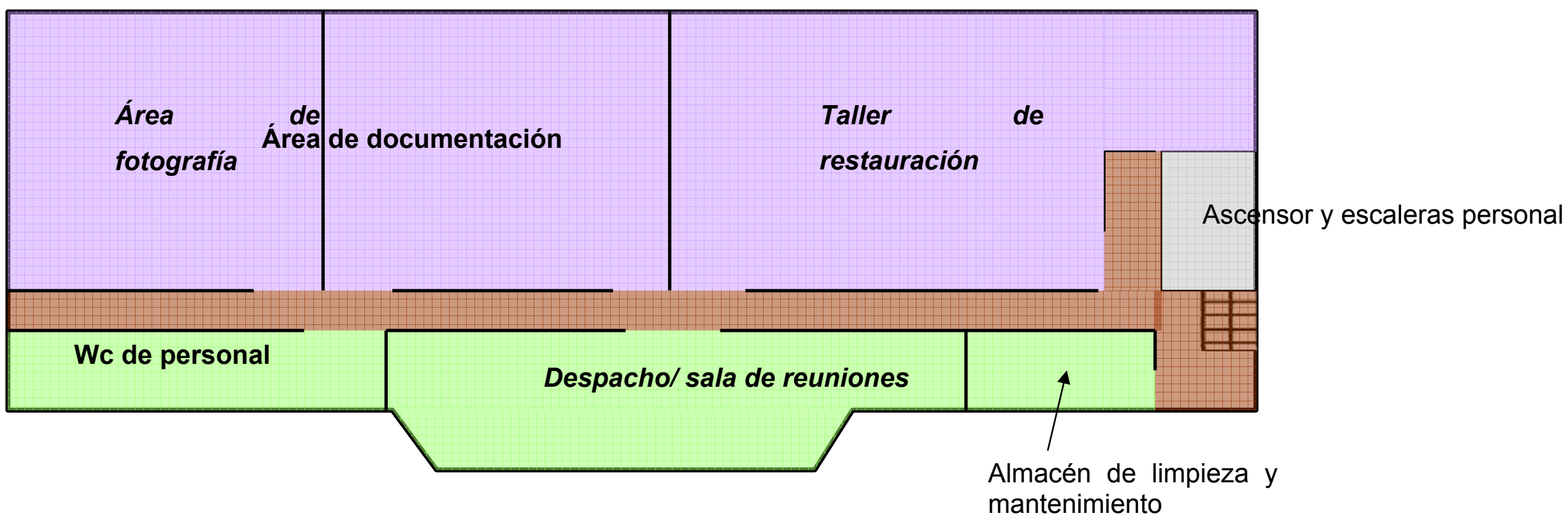

Área interna sin colecciones

Área interna con colecciones

Vías de circulación horizontal

Vías de circulación vertical 


\section{III.4.1 ÁREA PÚBLICA SIN COLECCIONES}

\section{a) Servicios}

Los grandes museos del mundo cada vez dan más importancia a los servicios que se ofrecen al público para hacer que su visita sea más agradable y satisfactoria. Ya en la fase de análisis se destacó la falta de éstos, lo que hace que la imagen que el museo ofrece al visitante sea la de un museo antiguo, no adaptado a la demanda del público actual. Es por eso que en la nueva distribución se ha intentado resolver este problema, ofreciendo al público diferentes servicios, situando además las áreas de descanso y esparcimiento en zonas privilegiadas del museo.
La tienda (de que carecía el museo) se sitúa en la planta baja del edificio ${ }^{51}$, a la izquierda de la puerta de acceso al museo y del vestíbulo de acogida, en la terraza de la fachada que será acristalada para tal fin por detrás de las columnas. El cerramiento a través de cristales está justificado por la intención de mantener tanto desde el exterior como desde el interior, el aspecto primitivo de terraza al aire libre, y por la imposibilidad de aprovechar este espacio si no es con un cerramiento que proteja de la intemperie y las condiciones medioambientales. A ella podrán acceder los visitantes cuando entren al museo y también cuando terminen de visitar el área de exposición permanente dedicada a Itálica, pues desde la última sala de esta área (Sala de usos múltiples) también puede accederse a la tienda. Ésta tendrá una superficie de 63,70 $\mathrm{m}^{2}$.

\footnotetext{
${ }^{51}$ Cuando nos referimos a "edificio" se entiende que se trata del edificio existente, es decir, del Pabellón renacentista. Si se trata de un espacio del edificio nuevo, se especificará como tal.
} 
646

También en planta baja se sitúa la cafetería (que el museo no tenía), en la terraza lateral occidental. Contará con una zona cubierta, la que hoy es un porche techado, que será acristalada por detrás de las arcadas, y otra al aire libre. Así, se mantendrá el aspecto originario de terraza abierta pero se contará con un espacio cerrado climatizado para los momentos en los que el clima no permita disfrutar de la terraza. La cafetería ocupa por tanto toda la terraza occidental, son una superficie total de $188,21 \mathrm{~m}^{2}$, de los cuales 112,93 corresponden a la zona techada y acristalada y 75,28 a la zona al aire libre. El acceso a la cafetería puede efectuarse desde el exterior del museo, para lo que se habilitarán unas escaleras que suban a la misma desde el nivel del suelo del parque y también desde el wc para el público situado en el sótano se habilitará otra escalera y se señalizará la subida a la cafetería. Asimismo, en la cafetería se señalizará la bajada al wc del público, pues en la planta baja no se situarán servicios.

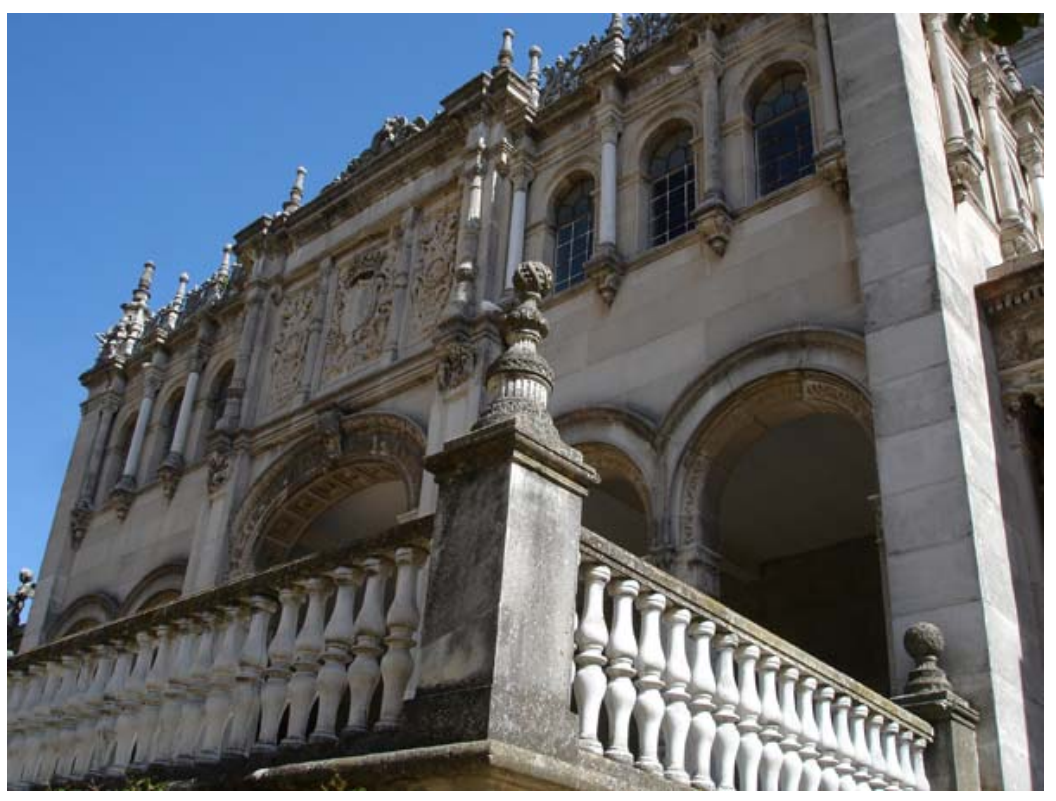

Terraza occidental, 
Se contemplan dos aseos para el público en el edificio existente, uno en la planta sótano y otro en la primera. El más utilizado y por tanto el más grande será el del sótano, situado en el extremo occidental, inmediatamente después de la zona bajo la terraza, que pertenece a cafetería. A éste se puede acceder desde el mismo sótano o desde la planta baja, donde no hay aseos del público. Desde el sótano se llega a través de la zona de exposición permanente dedicada a Tartessos; para lo que se habilitará una zona de tránsito que separe la exposición de los aseos y desde esta zona se accede a un pasillo distribuidor en el que se sitúan las puertas de aseos de hombres, mujeres y minusválidos. Desde la planta primera, tanto desde la cafetería, como desde la zona de exposición permanente dedicada la Economía y el Comercio en Roma se accede a una escalera que baja al sótano y llega a ese pasillo distribuidor en el que se sitúan los wc. Todo este espacio de servicios tiene una superficie total de $193 \mathrm{~m}^{2}$, de los cuales 39,38 ocupa la zona de tránsito que separa la exposición de los aseos; el pasillo distribuidor tiene una superficie de 70,65 y los wc propiamente dichos ocuparán entre los dos unos $83,44 \mathrm{~m}^{2}$. Para poder ubicar en este espacio estos grandes aseos, habrá que reformar en profundidad toda esta zona del edificio, pues habrá que cerrar muros y abrir puertas como se indica en el plano y habrá que habilitar estos espacios para las conducciones de agua y las instalaciones necesarias. Así se cubrirá la necesidad imperiosa que tenía el museo de unos servicios decentes y adecuados para el público.

El otro aseo, más pequeño, se sitúa en la planta primera, en el ala oriental del edificio, junto al salón de actos. Este aseo sólo será utilizado por las personas que accedan la planta primera, que no será todo el público visitante, sino solo el que haga uso de la biblioteca, la sala de investigación, el archivo, el salón de actos, etc. Es por tanto más reducido, contando con aproximadamente $70 \mathrm{~m}^{2}$. También tendrá un baño para mujeres, otro para hombres y otro para minusválidos. Este espacio ya cuenta con conducciones de agua por tratarse actualmente del taller de restauración, con lo que las obras de adaptación a 
servicio serán más sencillas. A este wc se accede desde el salón de actos por el pasillo distribuidor de este ala del edificio.

Ambos aseos son accesibles para minusválidos, pues la llegada a los dos puede realizarse a través de ascensor, ya que todo el museo, como se detallará en el apartado de las vías de circulación, será accesible para todos.

En el edificio nuevo se ubicará otro aseo para el público, en la planta baja, cercano a las exposiciones temporales y con una superficie de unos $100 \mathrm{~m}^{2}$.

Como parte de los servicios al público, se ubicará en la zona de cafetería un teléfono público y un cajero automático, dada la lejanía del museo de estos servicios, en la calle Felipe II o la Avenida de la Borbolla.

\section{b) Salas para actividades}

El salón de actos está situado en la planta primera, en el ala oriental del edificio. Cuenta con $280,95 \mathrm{~m}^{2}$, lo que nos parece espacio suficiente para el aforo de los actos que se suelen hacer en el museo, del cual además podrá separarse si es necesario el pequeño espacio anexo a las escaleras y ascensor de subida a la torre para almacenar enseres de megafonía y audiovisuales. El acceso al mismo tiene la ventaja de no tener que atravesar ninguna zona expositiva, llegándose a él por las escaleras y el ascensor situados detrás del óvalo y tomando el pasillo de comunicación que conecta los espacios de este ala del edificio $^{52}$. Para la ubicación del mismo habrá que habilitar como suelo el espacio que ocupan los lucernarios, con lo que para no perder del todo la configuración original del edificio, se evocarán en el techo de la planta baja mediante cajas de iluminación artificial. Se eliminarán los muros que se ven en el plano para hacer un espacio lo más diáfano posible, lo que es posible porque no son muros sustentantes en su mayoría.

\footnotetext{
${ }^{52}$ Se establecerá un puesto de control para toda la planta primera, ya sea para acceder al salón de actos, biblioteca o sala de investigación y archivo, como para llegar a la zona de administración y trabajo.
} 
No hemos contemplado una sala de audiovisuales como tal, pues nos parecía más interesante ubicarlos a lo largo de la exposición, como se detallará en el apartado del discurso expositivo. En el caso de que se quisieran proyectar audiovisuales al margen de la exposición permanente, podrán hacerse en el salón de actos o en las salas de exposiciones temporales, según convenga, pues el museo dispondrá de aparatos para tal fin.

Los talleres didácticos del museo ocupan el extremo oriental del sótano, con un total de $161,76 \mathrm{~m}^{2}$. Así, se habilita un amplio espacio para el desarrollo de toda clase de actividades, incluso para grupos, que será detallado en el apartado de difusión. Destacar aquí que el acceso a esta zona es bastante directo, pues desde el óvalo se baja al sótano y por un pasillo que se abre a la derecha del visitante se accede directamente a los talleres sin tener que atravesar ninguna zona expositiva. Para la habilitación de esta área como didáctica se intentará reducir al máximo la anchura de los muros que la dividen para conseguir un espacio lo más diáfano posible, aunque algo compartimentado por si se quieren desarrollar varias actividades al mismo tiempo.

Las Asociaciones de Amigos del Museo ocuparán la zona más oriental del edificio, a la que actualmente se accede solamente desde fuera del mismo y tiene una superficie de 165,48 $\mathrm{m}^{2}$. En el sótano, se habilitará este espacio, que contiene varias estancias, para que de cabida a las dos asociaciones de amigos que tiene el museo, con la ventaja de que a él puede accederse directamente desde el exterior, con lo que se independiza el trabajo de las asociaciones y sus horarios de los del museo. No obstante, se abrirán puertas de acceso desde esta área hacia el interior del edificio, pues la comunicación entre el museo y las asociaciones es imprescindible. Esta puerta de conexión llegará además desde el área ocupada por las asociaciones hasta los talleres didácticos, lo que resulta bastante oportuno, pues muchos talleres serán promovidos desde las asociaciones de amigos. 


\section{c) Biblioteca}

Una gran biblioteca, especializada en arqueología y museología, ocupará unos $302,49 \mathrm{~m}^{2}$ de la planta primera del edificio. Situada entre el espacio oval (no aprovechable en planta primera) y el salón de actos, la biblioteca servirá a estudiantes e investigadores con unas instalaciones cómodas y modernas y puestos de conexión al catálogo y a Internet. Es importante tener en cuenta la calidad del mobiliario, las conexiones eléctricas para la utilización de ordenadores portátiles, la climatización para el confort de los usuarios y una buena iluminación; en este caso, además de iluminación artificial añadida, este espacio cuenta con una excelente luz natural, la idónea para un espacio de estudio. Para la habilitación de este espacio para biblioteca habrá que eliminar el lucernario, que será parte del suelo de la biblioteca, pero que para no sea olvidado como parte de la configuración del edificio primitivo, será evocado, como en la zona del salón de actos, en el techo de la planta baja mediante una caja de iluminación artificial. Además se disminuirá hasta el mínimo posible la anchura y el grosor de los muros que parten la biblioteca, para conseguir un espacio diáfano y luminoso. El acceso a la biblioteca se efectúa por las escaleras y el ascensor que parten del óvalo, con lo que se llega directamente sin atravesar ninguna zona expositiva ni de trabajo.

\section{d) Archivos documentales}

Los archivos del museo, ordenados para su posible consulta, es decir, el lugar donde se almacenan los documentos del museo, está situado en la torre encima de la zona de trabajo del personal del museo. Éstos serán especificados más adelante, pues pertenecen más bien al área interna con colecciones, ya que el público no tendrá acceso directamente a estos documentos salvo permiso especial. Sí podrán pedirse documentos concretos para la consulta en la sala de investigación, que será detallada en 
el área pública con colecciones por ser posible en este espacio la presencia de colecciones que se estén investigando.

\section{e) Otros espacios}

Dentro de esta área pública sin colecciones existen otros espacios que no se han descrito hasta ahora y son:

\section{Un área de descanso en la exposición permanente,}

ubicada en la zona dedicada a Itálica en la planta baja, entre las salas de Venus, Mercurio y Diana, más concretamente en la terraza más oriental de la fachada del edificio. Este espacio será acristalado de la misma manera que las otras terrazas de esta fachada y ocupa una superficie de $63,70 \mathrm{~m}^{2}$. Sus características serán detalladas en los apartados del discurso expositivo y difusión.
Una sala de usos múltiples de $115 \mathrm{~m}^{2}$, situada tras la última sala de le exposición permanente de Itálica en la planta baja, desde la que ya se accede a la tienda o de nuevo al óvalo para continuar el recorrido expositivo.

Una sala dedicada a puestos de consulta, situada entre las últimas salas dedicadas a la exposición permanente de Tartessos en el sótano. Este espacio cuenta con unos $40 \mathrm{~m}^{2}$ y será también detallado en el discurso.

Estos tres espacios, aunque se han incluido en este apartado por no tener en principio colecciones y haberse detallado aquí la superficie y el lugar que ocupan, serán incluidos en el área pública con colecciones, en las salas de exposición permanente, y detallados en el apartado del discurso expositivo, pues en ocasiones podrán instalarse en ellas obras concretas y además forman parte coherente del discurso. 


\section{III.4.2. ÁREA PÚBLICA CON COLECCIONES}

\section{a) Área de acogida}

El área de recepción de visitantes al museo se sitúa en el óvalo, que es por donde se efectuará la entrada al edificio. Además de resultar adecuado en tamaño para recibir no sólo a visitantes individuales sino también a grupos, este espacio es acogedor, con entrada de luz natural, y ofrece la primera imagen que el público tendrá del museo, la de un museo importante y bien estructurado. Este espacio tiene una superficie de $272,11 \mathrm{~m}^{2}$. Para habilitar este espacio para este fin no se necesitan obras importantes, ya que se dejará el mosaico que actualmente tiene en el suelo (mosaico de Baco, procedente de Itálica), alrededor del cual se distribuirán sillas y pequeñas mesas con folletos del museo. Aquí se situará en el centro el mostrador que servirá como taquilla e información, con lo que podrá ser atendido por una sola persona y en un lateral el guardarropa-consigna. La entrada a este espacio de acogida se hace directamente en línea recta desde el porche de entrada al edificio en la fachada principal y al fondo del óvalo, a derecha e izquierda se accede al escaleras y ascensor respectivamente, que llevarán al visitante a la planta sótano, que es donde se inicia el recorrido por la exposición permanente.

Esta área de acogida albergará algunas piezas como el mosaico ya citado y otras elegidas para dar la bienvenida al visitante al museo.

Ya en el sótano, puede considerarse también área de acogida el espacio al que se accede desde el ascensor y las escaleras, que actúa de distribuidor antes de acceder a las salas de exposición y tiene una superficie de aproximadamente $26 \mathrm{~m}^{2}$. Para el acceso a la primera sala del sótano, dedicada al territorio, se cerrarán los espacios entre muros que existen ahora para dejar solo una puerta de acceso y salida, para la comunicación ascensor/ 
escaleras- vestíbulo distribuidor- salas de exposición y viceversa.

Se encuadra también en este área de acogida la del edificio nuevo, al que llegará el visitante tras cruzar el paso que une ambos inmuebles y que será la primera impresión que el visitante tendrá del nuevo edificio. Este espacio de recepción de público podrá contar con unos $200 \mathrm{~m}^{2}$ y deberá ser un espacio diáfano en el que entre la luz natural, para lo cual, teniendo en cuenta que viene de un pasillo subterráneo, podrá elevarse a modo de semisótano para abrir ventanas.

Aunque el espacio previo a la salida de este nuevo edificio en planta baja servirá sobre todo como espacio de tránsito previo a dicha salida, tendrá que habilitarse también como espacio de acogida del público que sólo esté interesado en visitar las exposiciones temporales o las reservas visitables y no quiera pasar por el antiguo edificio. Este espacio tendrá una superficie de unos $100 \mathrm{~m}^{2}$.

\section{b) Salas de Exposición Permanente}

Se localizan en la planta baja y el sótano del edificio existente. El acceso del público se realiza, como ya se ha dicho, en planta baja por el óvalo. Desde éste se toman las escaleras o el ascensor que conducen al sótano, donde comienza el recorrido por la exposición permanente. Desde el vestíbulo distribuidor se accede a una sala introductoria en relación al territorio en el que se sitúan las piezas que se exponen en el museo, y el recorrido comienza a mano derecha. Así se accede a un pasillo desde el que el visitante se encontrará una puerta a mano derecha para entrar en las salas dedicadas a la HISTORIA DEL MUSEO. Tras recorrer éstas, saldrá de nuevo al pasillo para encontrarse de frente el acceso a las salas de exposición dedicadas a PREHISTORIA. En esta gran área el visitante irá recorriendo las salas de Primeros poblados, III Milenio, Valencina de la Concepción (Poblado y Necrópolis), Tartessos (en medio de estos se encuentra una sala de puestos de consulta), Ibero-turdetano y Romanización. 
Es un recorrido pensado de forma cronológica y en el que no cabe la posibilidad de que el visitante se desconcierte al encontrar varias salas en las que puede entrar sin saber cual es el orden que debe seguir, pues éste está perfectamente marcado. Tras éste llegará de nuevo a la sala introductoria del territorio para acceder al ascensor o las escaleras que le lleven a la primera planta para continuar el recorrido expositivo. Así, saldrá de nuevo al óvalo, donde se indicará que el recorrido continúa a mano derecha del visitante, es decir, por el ala oriental del edificio, en la que se ubican las salas dedicadas a ITÁLICA. También en un recorrido marcado pero esta vez monográfico sobre la ciudad, no cronológico, el visitante recorrerá las salas denominadas Los Italicenses, Itálica, Nova Urbs, Teatro, Itálica al aire libre, (situada en la terraza, se dedicará a obras pensadas para se contempladas al aire libre en la ciudad), Venus, Mercurio y Diana (entre Mercurio y Diana se marca una zona de descanso y después de Diana, antes de salir al óvalo - o a la tienda- una sala multiusos).
Así, el visitante se encuentra dirigido a salir de nuevo al óvalo, donde se le indicará que el recorrido por la exposición permanente continúa al otro lado del vestíbulo oval, en el ala occidental del edificio, donde se encuentran las salas dedicadas a la BÉTICA Y EL BAJO GUADALQUIVIR, en las que se analiza la vida en Andalucía en las épocas romana y medieval. El visitante recorrerá las salas denominadas Aculturación, Urbanismo y Obras Públicas, Economía, Poder, Vida Cotidiana, Extramuros, Necrópolis, Antigüedad tardía y Legado Andalusí. Tras terminar el recorrido por la exposición permanente, el visitante se encuentra de nuevo en el óvalo, desde el que podrá salir del museo, visitar la tienda, acceder a la zona de talleres, a la biblioteca, al salón de actos, etc.

Toda esta gran área de exposición permanente ocupa $3688,75 \mathrm{~m}^{2}$, repartidos en $1613,56 \mathrm{~m}^{2}$ en el sótano $(265,52$ $\mathrm{m}^{2}$ para Historia del Museo y 1348,04 $\mathrm{m}^{2}$ para Prehistoria) 
y $2075,19 \mathrm{~m}^{2}$ en la planta baja $\left(1112,54 \mathrm{~m}^{2}\right.$ para Itálica y $962,65 \mathrm{~m}^{2}$ para la Bética y el Bajo Guadalquivir).

En el plano de circulaciones pueden observarse los muros que se han ido cerrando y abriendo para configurar la zona de exposición permanente de manera que el visitante sea dirigido por las salas en el orden establecido por el discurso expositivo. Estas obras en el edificio son de poca envergadura, pero en el momento de acometerse el proyecto arquitectónico tendrá que investigarse la viabilidad absoluta de las mismas, o si son necesarios pequeños cambios. Por otra parte, señalar que las cuatro terrazas de la fachada principal se acristalarán para su mejor aprovechamiento, siendo una de ellas la tienda y las otras tres parte de la exposición permanente. La cristalera se situará por detrás de las columnas, con lo que se podrá conjugar su funcionalidad con el aspecto de terraza abierta primitiva, además de dar la impresión de que el museo sale de sus muros y el parque entra en él, llamándose también la atención de los visitantes del parque e instalándoles a visitar el museo. Por supuesto, habrá que tratar los cristales para que dejen pasar el menor número de radiaciones posible y además cuidar que estas áreas se coloquen obras poco sensibles a la luz. Las terrazas de la fachada trasera, ya cegadas en el pasado para aprovecharse como exposición, seguirán cegadas, si bien se diseñará un cerramiento más moderno y acorde con el nuevo edificio que tendrá el actual a su espalda.

En la planta baja, hoy también dedicada a exposición permanente, hay varias salas con mosaicos en paredes y suelos, que habría que mover para conseguir el desarrollo lógico del discurso. En algunos la intervención es bastante complicada pero puede hacerse sin problemas. El único mosaico que permanecerá en su ubicación actual es el de la sala oval, el Mosaico de Baco de Itálica, que dará la bienvenida al público en su espacio de acogida como ejemplo de la excelente colección que el museo ofrece al visitante. 
La circulación del público, la instalación de la colección permanente, la iluminación, climatización y requisitos de esta área serán detallados en el apartado de museografia.

Señalar aquí, que la entrada y salida de piezas de la colección permanente se realizará por el pasillo subterráneo que conecta este edificio con el nuevo y a través del montacargas.

\section{c) Salas de Exposiciones Temporales}

Se situarán en el nuevo edificio, en las plantas primera y baja. El espacio debe ser amplio, diáfano, con entrada de luz natural pero que pueda ser controlada y con iluminación artificial que pueda ser regulada. Además debe ser un espacio modulable, que pueda ser modificado según las necesidades de cada exposición y tiene que estar climatizado, tanto con objeto de preservar las colecciones expuestas, como para favorecer el confort de las personas. Como en todo el museo, esta climatización se instalará teniendo en cuenta la sectorización de los espacios, pues es posible que no se utilicen a la vez todos los metros para exposiciones temporales disponibles.

Teniendo en cuenta que el espacio en planta de que disponemos para nuevo edificio es de unos $1500 \mathrm{~m}^{2}$ y las exposiciones temporales ocuparán parte de la planta baja y parte de la planta primera del nuevo edificio, éstas dispondrán de un total aproximado de $2000 \mathrm{~m}^{2}, 1400$ en la planta primera, que está ocupada en su totalidad por el área de exposiciones temporales (dejando espacio para las vías de circulación horizontales y verticales) y 600 en la planta baja, en la que esta zona comparte su espacio con las reservas visitables y los servicios para el público.

El público accederá desde el edificio antiguo al nuevo, desde esa área de paso subterránea que ya se ha señalado, por el pasillo que llega al sótano 1. Aquí se dispondrá un vestíbulo de recepción también citado, con indicaciones para el ascensor o la escalera, que subirán al 
visitante a la planta primera, donde se comienza el recorrido por las exposiciones temporales. Tras visitar toda esta planta, el público bajará a la planta baja para terminar de visitar el área de exposiciones temporales y también la reserva visitable, que se comentará a continuación. Concluida la visita, la salida se efectuará directamente al exterior, a la plaza pública triangular. No obstante, aunque éste sería el recorrido recomendado por el museo, si el visitante quiere visitar tan sólo las exposiciones temporales, también puede acceder a ellas por esa salida a la plaza, que también será por tanto entrada.

En cuanto a las piezas, para llegar a las salas de exposiciones temporales podrán hacerlo por dos vías, según vengan del edificio antiguo o del exterior. Si vienen del edificio antiguo lo harán por el paso subterráneo, por el sector del mismo separado para personal y piezas, llegando al sótano 1 del nuevo edificio, en que podrán llevarse hasta el montacargas y subir hasta la planta correspondiente. Si vienen desde fuera del museo entrarán por el área de recepción de colecciones, ubicada en el sótano 1, donde también se dispondrá una zona de almacenamiento temporal. Desde esta zona puede llevarse también al montacargas y subir hasta la planta en la que vaya a ser expuesta la pieza.

\section{d) Reservas visitables}

También en el edificio nuevo se habilitará, en la planta baja, una zona dedicada a reservas visitables, donde el público podrá observar piezas importantes del museo que no hayan sido incluidas en la exposición permanente, organizadas a modo de almacén. Esta zona deberá estar climatizada y tendrá una superficie aproximada de $600 \mathrm{~m}^{2}$. Siguiendo el orden lógico de la visita, el público visitará primero la exposición permanente para pasar después al edificio nuevo para ver las temporales. Tras éstas accederá a esta área de reserva visitable, donde concluirá su visita al museo, para salir por un espacio de tránsito (también 
espacio de acogida a este edificio desde el exterior) directamente al exterior, a la plaza pública.

\section{e) Sala de Investigación y Archivo}

El museo no cuenta actualmente con un espacio habilitado para los investigadores, como ya se anotó en el análisis. En la nueva configuración de espacios del edificio existente, la sala de investigadores se situará en la planta primera, a continuación del espacio oval (no aprovechable en esta planta), en el ala occidental del edificio. Es decir, se accederá a ella directamente al salir de la escalera o el ascensor que parten de detrás de óvalo en planta baja. Este espacio ocupa $237,44 \mathrm{~m}^{2}$ y además de servir para la atención a los investigadores, la consulta de datos del museo y el examen de piezas (tras pedir el permiso pertinente), se utilizará también para el examen de las piezas documentales del museo, es decir, los documentos del archivo, que aunque no sean piezas museables sí forman parte de la colección del museo.
No son necesarias obras en este espacio para su adaptación a sala de investigación, que hoy es el salón de actos del museo, pero sí será necesaria la colocación de sillas, mesas, conexiones eléctricas, material necesario para la manipulación de piezas, etc. Además es importante que esta sala esté climatizada, no sólo por el confort de los investigadores que trabajen en ella, sino también por la presencia de piezas en este espacio.

Las piezas que se examinen en esta sala vendrán casi con toda seguridad del almacén situado en el edificio nuevo, con lo que serán traídas por el pasillo de conexión entre los dos edificio y subidas a la planta alta por el montacargas situado en la fachada sur para después llegar a este área. 


\section{III.4.3 ÁREA INTERNA CON COLECCIONES}

\section{a) Área de recepción de colecciones}

Situada en el nuevo edificio, en el extremo más oriental del mismo, que es el que tiene salida más directa a la Avenida de la Borbolla, lo que facilitará el acceso de los medios de transporte de piezas. Desde la calle, el acceso se efectuará con un descenso para desembocar en el interior del museo en el sótano 1 , donde se habilitará una zona de carga y descarga de unos $80 \mathrm{~m}^{2}$, lo que significa un espacio de casi 9 metros de lado, que facilitará el acceso de camiones. Anexa a esta zona de recepción de colecciones se dispondrá de un espacio de unos $300 \mathrm{~m}^{2}$ que podrá ser compartimentado para servir de: almacén de tránsito para piezas que van a ser expuestas inmediatamente o van a salir en los próximos días, almacén de embalajes, zona para el registro de las piezas de forma inmediata a su llegada, aunque después pasen a documentación y un pequeño espacio para poner objetos en cuarentena o aplicar tratamientos sencillos de desinsectación.

Toda esta gran área de casi $400 \mathrm{~m}^{2}$ será climatizada, como todo el museo, y estará contigua al montacargas, por el que las piezas podrán ser fácilmente llevadas a las salas de exposiciones temporales, al taller de restauración, al almacén, etc. $^{53}$

\section{b) Taller de restauración}

Ubicados en el edificio nuevo, se sitúan en la segunda planta del mismo junto con el resto de áreas de trabajo del

\footnotetext{
${ }^{53}$ Este planteamiento del área de recepción de colecciones es el que hemos visto más sencillo, pero también podría plantearse el acceso de las mismas al museo desde la Avenida de Eritaña, desde la esquina entre las parcelas de la Universidad y el cuartel, construyendo un túnel que llegue directamente al nuevo edificio. No obstante, la altura del mismo debe ser la suficiente para el acceso de camiones, con lo que se plantean estas dos posibilidades para que el futuro proyecto arquitectónico las estudie y proyecte la que sea más viable. En función de esto podrían cambiar de lugar el muelle de carga y descarga y el área de recepción de colecciones.
} 
personal de este edificio. A diferencia de los talleres actuales, separados en taller de restauración de piedra y de metales y cerámica, planteamos un único gran taller, aunque dentro de éste se separen físicamente estas especialidades en función de la especialidad de cada restaurador del museo, ya que en la práctica muchos aparatos son utilizados por todos los restauradores. En función de la superficie de esta planta y del resto de espacios que se encuentran en ella, puede estimarse la del taller en unos $500 \mathrm{~m}^{2}$, lo que solventa el problema de los talleres actuales, en los que los restauradores encuentran grandes dificultades para mover piezas de mediano-gran tamaño dentro de los mismos. Habrá que tener en cuanta también, como en todas las zonas por las que tengan que pasar piezas en el museo, que la anchura de pasillos y puertas sea la adecuada, pues actualmente a los talleres no pueden ni siquiera acceder un gran número de piezas del museo dado su mediano-gran tamaño.
Es imprescindible en un taller de restauración una buena ventilación e iluminación natural (complementada con artificial), requisitos fácilmente salvables al estar ubicado en la planta más alta del edificio. También es importante la climatización de estos espacios, tanto por la presencia de piezas como por la de trabajadores.

En cuanto al equipamiento del taller, sería interesante renovar gran parte del que ya se dispone actualmente e introducir nuevos aparatos. Los restauradores consideran necesario contar con campanas de vacío, un microscopio, placas de calentamiento, hornos de secado, baños térmicos, balanzas para pesos pequeños y grandes, un agitador mecánico para mover las mezclas, un baño térmico de arena para volver a dar forma a las planchas deformadas, una instalación de desmineralización de agua, grandes bañeras para la desalinización de grandes piezas y otros tratamientos por inmersión y lámparas de luz día. De estos, hay equipos de los que ya disponen los talleres, aunque algunos podrían ser modernizados, y otros no 
existen actualmente en los mismos. Además, el taller debe contar con una instalación eléctrica que soporte el funcionamiento de todos estos aparatos y un número de enchufes razonable. Asimismo, el taller necesita mobiliario de administración (mesas, sillas) y almacenaje de productos, como un armario específico guardar los productos químicos abiertos que cumpla la normativa de seguridad. Es importante la instalación en el taller de una grúa fija desplazable sobre viga para el levantamiento y desplazamiento de grandes piezas, ya resulta más cómodo a la hora de mover una obra que tener que llevar hasta el taller la grúa móvil utilizada para los traslados internos de piezas en el museo.

El acceso de los restauradores al taller se efectuará por las escaleras o el ascensor/ montacargas habilitado para ello y el pasillo de esta planta, tras acceder al edificio por el acceso para los trabajadores de planta baja, en el ala oriental.
Las piezas también llegarán al taller de restauración por el montacargas y el pasillo, bien provenientes del almacén, del área de recepción de colecciones o del paso subterráneo desde el edificio antiguo.

\section{c) Área de documentación}

Ubicada en el edificio nuevo, en la segunda planta, cerca del taller de restauración, esta área podrá tener una superficie de unos $250 \mathrm{~m}^{2}$. Dispondrá de un sistema de climatización adecuado a la presencia de piezas y trabajadores del museo, así como del equipamiento necesario para la documentación (ordenadores, manipulación y medición de piezas, etc.).

Los catalogadores accederán a esta zona por el acceso del personal en planta baja y subirán por el ascensor/ montacargas o las escaleras internas, mientras que las piezas llegarán aquí, al igual que al taller de restauración, por la misma vía del montacargas y el pasillo de comunicación. 


\section{d) Área de fotografía}

Situada junto al taller de restauración y el área de documentación, puede llegar a contar con una superficie de $200 \mathrm{~m}^{2}$ y deberá contar con el equipamiento necesario para llevar a cabo una buena documentación fotográfica de las piezas del museo (ordenadores, cámaras digitales, escáner, etc.).

\section{e) Almacén}

Será ubicado en el nuevo edificio, ocupando parte del sótano 1 y la totalidad del espacio disponible en el sótano 2 , teniendo en cuenta las vías de circulación vertical y horizontal. Señalar que, a diferencia de la situación actual del los almacenes del museo, con alto grado de disgregación (pues son varios los almacenes en los que actualmente se reparten las piezas) y de desorganización de los mismos, las piezas del museo serán almacenadas en un solo espacio (aunque esté dividido en dos plantas) y serán convenientemente catalogadas y organizadas.

Teniendo en cuenta la superficie de estas dos plantas, en el sótano 1 podrán dedicarse a almacén unos $750 \mathrm{~m}^{2}$, mientras en el sótano 2 disponemos de $1450 \mathrm{~m}^{2}$, lo que hace un total de $2200 \mathrm{~m}^{2}$ de almacén.

En el apartado de colecciones se ha estimado el volumen de las piezas que actualmente se encuentran en los almacenes del museo en metros cúbicos y la superficie que ocuparían, una vez distribuidas por estanterías, en metros cuadrados. Asimismo, se ha hecho una predicción de crecimiento de la colección del museo que se basa en los ingresos de los años 2004 y 2005. Siguiendo estos cálculos se puede concluir que el volumen de las piezas del almacén actual es de unos $352 \mathrm{~m}^{3}$, repartidas en 31 salas en estanterías y pallets. Las estanterías son metálicas, de modelo único, de 6 baldas rectangulares de 1 metro de largo por 0,4 metros de ancho y con una altura total de 2,10 metros. Al repartir las piezas por estas 
estanterías, que son las que se usarán en el nuevo almacén, éstas ocuparían (sin separación entre las mismas) un total de $151 \mathrm{~m}^{2}$. Las piezas de mayor volumen y peso se encuentran en el suelo repartidas en pallets, que son de varios tamaños: 411 son de 0,80x0,80 metros, 277 son de $1 \times 1$ metro y 65 miden $1 \times 1,40$ metros. Al repartir las piezas por los pallets correspondientes, estos ocupan (sin separación entre los mismos) una superficie de aproximadamente $151 \mathrm{~m}^{2}$. Así, sumando las estanterías y los pallets obtenemos que las piezas que actualmente se encuentran en el almacén del museo, ocupan una superficie de $782 \mathrm{~m}^{2}$. No obstante, esta cifra no incluye pasillos de circulación de personas, piezas y maquinaria para la manipulación de las mismas.

Según el incremento de las colecciones del museo durante los años 2004 y 2005, se puede calcular aproximadamente la media de crecimiento anual o bianual del almacén para así proyectar un almacén que no quede colapsado en poco tiempo. Estimaremos un almacén que soporte unos 50 años de crecimiento de las colecciones, si bien después haremos algunas puntualizaciones. En estos dos años citados, las piezas que han ingresado en el museo procedente de excavaciones de Sevilla y provincia ocupan un total de $228 \mathrm{~m}^{3}$ o, una vez repartidas por estanterías, $33,6 \mathrm{~m}^{2}$. El gran volumen de ingreso en estos años está justificado tanto por la gran cantidad de excavaciones que se han acometido en toda la provincia, por ejemplo, en el antiguo barrio de San Juan de Acre de Sevilla, en la Plaza de la Encarnación de Sevilla o en la Plaza de España de Écija, como por las piezas que han aparecido por la construcción de obras públicas como la del Metro de Sevilla o la del AVE en los trayectos Sevilla-Bobadilla y Córdoba-Bobadilla, que han ido a parar a nuestro museo. Por tanto, calcularemos la previsión para 50 años en función de los datos de 2004 y 2005, pero hay que tener en cuenta que probablemente el almacén no se llene en este período porque estos años han sido excepcionales para la arqueología. Así, tendremos en cuenta que en 50 años el volumen de piezas aumentará en $5700 \mathrm{~m}^{3}$, ocupando 840 
$\mathrm{m}^{2}$ (estimación teniendo en cuenta el reparto por estanterías), con lo que si sumamos estas cantidades a la colección actual necesitaremos un almacén para guardar $6052 \mathrm{~m}^{3}$ de piezas o $1622 \mathrm{~m}^{2}$ de estanterías.

Además de tener en cuenta que probablemente el ingreso de piezas no sea tan grande en los próximos años como éstos, debemos matizar sobre las piezas que se guardarán en este nuevo almacén del museo. No todas las que actualmente están en el almacén serán trasladadas al del edificio nuevo, pues sólo se conservarán en el museo las piezas museables, es decir, las susceptibles de ser utilizadas en las funciones de exposición y educación, esto es, de ser expuestas en la exposición permanente o en las temporales del museo, de ser prestadas para otras exposiciones y de ser frecuentemente solicitadas para su estudio por investigadores. Serán en general, las piezas completas o casi completas y selecciones significativas de aquellas fragmentarias que ilustren diversas tipologías (de fabricación, decoración, uso, etc.) o que contengan información singular (inscripción, iconografía, etc.). Hay una ingente cantidad de piezas que con toda seguridad nunca serán expuestas y probablemente tampoco solicitadas para su estudio, como son aquellas piezas que sólo tienen un uso muy restringido por los investigadores arqueólogos, siendo muy poco frecuente su consulta o estudio, una vez depositados en el Museo; nos referimos a objetos completos 0 fragmentarios muy reiterativos, no singulares, restos antropológicos, faunísticos, vegetales, muestras edafológicas, minerales, metalúrgicas, polínicas, carpológicas, etc. Estas piezas no museables serán guardadas en un almacén externo al museo, donde los investigadores interesados podrán acudir para estudiarlas.

Así, teniendo en cuenta que según el espacio del que disponemos para el nuevo edificio y la distribución que estamos planteando, contamos con $2200 \mathrm{~m}^{2}$ de almacén y contando con la externalización de muchas piezas y con que el incremento no sea tan grande como se ha estimado 
en los próximos 50 años, creemos que el almacén podrá ser perfectamente encajado en este espacio del que disponemos. Partimos de esa previsión de $1622 \mathrm{~m}^{2}$ de estanterías, a la que hay añadirle pasillos de unos 0,80 metros de anchura en general y algunos de 1,20 metros de anchura para los lugares en los que se almacenen piezas de gran volumen y peso para poder introducir la maquinaria que haga posible su manipulación. Esa distribución es ya tarea del proyecto arquitectónico.

Señalar que, teniendo en cuenta todo lo que se ha expuesto, el almacén debería poder ubicarse en estas dos plantas del edificio nuevo, pero que no obstante, si al trazar pasillos y vías de circulación dentro del almacén y aplicar la normativa de incendios, seguridad, etc. el proyecto de arquitectura estimase la necesidad de plantear un almacén más grande, podría aumentarse el museo en una planta más abajo, un sótano 3.
El acceso al almacén de piezas se realizará, bien directamente desde el área de recepción de colecciones o por el montacargas, dependiendo de donde venga la pieza y a qué planta del almacén vaya.

El personal podrá acceder al almacén a través del ascensor y las escaleras de personal desde cualquier planta del edificio.

El almacén deberá contar con un sistema de climatización que permita la sectorización y un sistema de iluminación que procure que las piezas no reciban radiaciones negativas para su conservación.

\section{f) Archivos documentales}

Se ubicarán en el edificio actual del museo, en la planta alta, en una de las dos salas de la torre oeste del edificio con una superficie de $59,95 \mathrm{~m}^{2}$. No harán falta intervenciones importantes porque el espacio ya está 
delimitado. Aquí se organizará adecuadamente toda la documentación del museo (archivo histórico, archivo administrativo, archivo fotográfico, etc.) teniendo especial cuidado en su almacenaje para facilitar su mejor conservación. Se accederá por la escalera por la que se sube actualmente, pues está en buen estado, o por el pequeño ascensor que se habilitará en esta zona, desde la los despachos del personal técnico.

En caso de solicitarse la consulta de material del archivo, éste será facilitado por el personal del museo para su examen por parte del solicitante en la sala de investigadores.

\section{III.4.4. ÁREA INTERNA SIN COLECCIONES}

\section{a) Dirección}

El despacho de dirección se sitúa en el edificio actual de museo, en la planta primera, que será donde se encuentren todos los despachos de personal, salvo los que se ubicarán en el nuevo edificio. Se encuentra en el extremo occidental del edificio, junto a la sala de reuniones, con una superficie de unos $32 \mathrm{~m}^{2}$. Para configurar este despacho, la sala que actualmente es anexa a la biblioteca y es utilizada por la Asociación de Amigos del Museo y para algunos cursos del museo o como sala de reuniones, será dividida en dos con un pasillo de circulación en medio, abriéndose a un lado de éste es despacho de dirección y al otro la sala de reuniones. El director accederá a su puesto de trabajo por la escalera o el ascensor de personal, que parte de la planta baja, del área de exposición permanente dedicada a La Bética y el Bajo Guadalquivir. Dada la complejidad de la configuración del edificio, no se ha 
podido establecer una entrada/ salida de personal que no atravesara la zona expositiva, pues esta ocupa toda la planta baja. Por tanto, los trabajadores deberán entrar por el óvalo y dirigirse hacia su izquierda, adentrándose en la zona expositiva ya citada para llegar al ascensor y escaleras de personal, que son las que actualmente utiliza el público en el museo, donde se encuentra el vestíbulo de entrada, que serán arregladas para este acceso se taparán para que no sean visibles por el público ${ }^{54}$. No obstante, el acceso a estas zonas estará precedida por un puesto de control $^{55}$.

\section{b) Administración}

El despacho de administración se sitúa anexo al de dirección, en la planta primera del edificio, en el ala oeste. Tiene una superficie de $78,15 \mathrm{~m}^{2}$ y para configurar su

\footnotetext{
${ }^{54}$ El proyecto arquitectónico deberá estudiar la posibilidad de separar los accesos de personal y de público.

${ }^{55}$ Se establecerá un control de acceso a toda la planta primera, como
} ya se ha dicho. espacio se partirá en dos la sala que hoy es la biblioteca del museo, creando un pasillo de circulación a los lados del cual se abrirán el despacho de administración y el área didáctica. Para acceder al mismo, los trabajadores seguirán el mismo camino que para el despacho de dirección.

\section{c) Departamentos técnicos}

\section{- Área técnica de conservación}

La zona de trabajo de los conservadores del museo se sitúa de nuevo en la primera planta, en el ala oeste del edificio. Son dos los despachos, anexos y comunicados, de que dispondrán los conservadores, ocupando lo que actualmente son el despacho de dirección y de administración, por lo que son dos espacios ya existentes en el museo, que sólo habrá que arreglar. Los despachos tienen 59,95 y $92,65 \mathrm{~m}^{2}$, espacio bastante adecuado al desarrollo de sus funciones. Para acceder a ellos, los 
conservadores seguirán el mismo camino que a los despachos anteriores, por las escaleras o ascensor de personal desde la planta baja y por el pasillo de circulación de la primera.

Resaltar que, aunque se englobe dentro del área interna sin colecciones, en ocasiones puede haberlas por el desarrollo del trabajo de los conservadores.

\section{- Área técnica de difusión}

Los conservadores del museo dedicados a la difusión, así como el resto de personal de difusión que pueda haber en el mismo, tendrán su despacho en la misma planta primera del edificio, en el ala occidental, en el espacio que queda entre el despacho de conservadores y la zona administrativa, que hoy es el despacho de conservadores. Esta área de difusión tiene 92,65 m, lo que la hace adecuada para todas las labores de planificación de actividades del museo encaminadas a difundir la colección del mismo. Para acceder a esta área se tomara el mismo camino que a las anteriormente descritas.

\section{d) Área didáctica}

Situada en esta misma planta primera y ala oeste del edificio, ocupa el otro sector de la división de la biblioteca, frente a lo que será administración, de 49,50 $\mathrm{m}^{2}$. El acceso a ésta es por tanto el mismo que a los despachos anteriores y sus características serán detalladas en el apartado de difusión.

\section{e) Salas de reuniones}

En el edificio antiguo, la sala de reuniones es contigua al despacho de dirección, en el extremo occidental de la primera planta, por lo que se accede por el mismo camino y tiene una superficie de $32 \mathrm{~m}^{2}$, adecuada para disponer mesas y sillas para las reuniones internas del personal del museo o con personas ajenas a la institución. 
En el edificio nuevo se dispondrá de una sala de reuniones a modo de despacho de los trabajadores de este edificio, que sirva para establecer contactos entre ellos, ubicada junto a su zona de trabajo, en la planta segunda y de unos $150 \mathrm{~m}^{2}$ de superficie. Puede ser utilizada también para reuniones de todo el personal del museo o con personas ajenas a él. A ésta se accede por el ascensor o escaleras de personal.

\section{f) Servicios de personal}

Se plantean dos aseos para el uso por parte del personal, uno en el edificio existente y otro en el nuevo. En el edificio actual, se ubican en la primera planta en el ala occidental, que es la ocupada por los despachos de personal, y exactamente estarán donde hoy se encuentran también los servicios de personal, en frente de la salida de las escaleras y el ascensor de uso actualmente y que será el acceso para los trabajadores. Por tanto cuentan ya con las instalaciones necesarias para un wc y ocuparán la misma superficie que ocupan hoy, unos $31 \mathrm{~m}^{2}$.

En el edificio nuevo se ubicarán lógicamente en la zona de trabajo del personal, en la planta segunda, para acceder a él por el ascensor o escaleras de los trabajadores del museo y con una superficie de unos $100 \mathrm{~m}^{2}$. Es de mayor tamaño que el otro porque el edificio nuevo lo permite, pero por supuesto ambos aseos podrán ser utilizados por todo el personal del museo, independientemente del edificio en el que trabaje.

\section{g) Vigilancia y Seguridad}

\section{- Servicios y vestuarios de personal de vigilancia y mantenimiento}

Este tipo de personal del museo necesita tener un espacio amplio como servicios y vestuarios. Éste se situará en la planta primera del edificio, en el extremo más oriental. 
Ocupará todo este extremo, para el que no harán falta instalaciones importantes, tan sólo la construcción, ya que al situarse aquí actualmente unos servicios de personal, existen tomas de agua y de desagüe de sanitarios. Todo el espacio tendrá una superficie de $77,15 \mathrm{~m}^{2}$ y para acceder a él habrá que subir por las escaleras o el ascensor de personal ya citados y tomar el pasillo de comunicación de este ala del edificio hasta el final.

\section{- Consola de seguridad}

La consola de seguridad que controle ambos edificios, se situará en el sótano 1 del edificio nuevo. Desde ahí se vigilarán todos los accesos a los dos edificios, así como la conexión entre ambos y todos los sistemas que tengan que ver con la seguridad del museo. Pensamos que una superficie de $100 \mathrm{~m}^{2}$ sería idónea para este espacio, al que sus trabajadores podrán acceder por la entrada de personal situada en planta baja y bajar una planta por las escaleras o ascensor de personal.

\section{h) Almacén de biblioteca y difusión}

Se situará en la planta alta del edificio existente, en la torre oriental del mismo, es decir, sobre lo que será la biblioteca del museo. Ésta contiene actualmente dos estancias de 83,43 m cada una, que podrían unirse o compartimentarse más según las necesidades que surjan al organizar todos los fondos que se guardarán en este almacén, compuestos por material o libros de la biblioteca que no se tengan en sala y material de difusión que necesite ser guardado. Por tanto, la superficie aproximada de esta área será de unos $166,86 \mathrm{~m}^{2}$. El acceso a esta torre se efectuará desde el salón de actos, por una escalera o ascensor construidos en uno de los extremos del mismo, pues las escaleras que existen hoy son poco seguras y además quedarían en medio del salón de actos, dificultando su funcionamiento. 


\section{i) Almacenes de limpieza y mantenimiento}

Se plantearán dos espacios para el almacenamiento de enseres de limpieza y mantenimiento, uno más pequeño en el edificio existente y otro más amplio en el nuevo.

El del edificio antiguo se situará en el sótano, y se corresponde con una pequeña sala existente actualmente en el extremo occidental del edificio, contigua a lo que será el montacargas de la cafetería y los servicios del público, y con tan sólo unos $10 \mathrm{~m}^{2}$. Actualmente, el acceso a esta sala se realiza desde la zona expositiva, pero será más conveniente cerrar esta puerta y abrir una desde los servicios de público que se encuentran anexos.

En el edificio nuevo, en la planta segunda, se preverá un espacio para el mismo fin de unos $50 \mathrm{~m}^{2}$, fundamentalmente para el mantenimiento y limpieza de este edificio, pero también, si es necesario, del otro, y al que podrá accederse por las vías de circulación vertical del personal, ya sea desde el exterior por el acceso de los trabajadores o desde el edificio antiguo por el paso subterráneo.

\section{j) Almacén de material de oficina fungible}

Para este fin se utilizará, en el edificio existente, una de las salas de la torre occidental del museo de la planta alta, es decir, la que está situada sobre todo el área de trabajo y concretamente sobre la nueva área técnica de conservación. En este espacio de $88,62 \mathrm{~m}^{2}$ se encuentra actualmente compartimentado en varias salas, pero podría unificarse o partirse según las necesidades de almacenaje y a él se accede por las escaleras o el ascensor desde el área técnica.

\section{k) Zona interna de cafetería}

Bajo la cafetería, en el extremo occidental del edificio en el sótano, se contemplará un espacio que sirva al personal de este servicio como almacén, cocina, vestuario, etc. Este 
espacio de $63,70 \mathrm{~m}^{2}$ se encuentra actualmente compartimentado, pero podrá unificarse o separarse en más estancias, según las necesidades. Desde planta baja, es decir, desde la cafetería, se tomará el ascensor/ montacargas o las escaleras que se ubican en esta zona para bajar al almacén, pero preferiblemente el ascensor, que sólo será utilizado por el público que no pueda bajar escaleras, pues éstas sí son de circulación de visitantes para acceder al wc del sótano desde la cafetería.

\section{I) Asociaciones de Amigos del Museo}

Aunque el espacio ocupado por éstas ya ha sido explicado en el área pública sin colecciones porque a él podrán acceder personas ajenas al museo, señalar que también podría incluirse aquí, puesto que no se trata de un espacio público como puede ser el vestíbulo de acogida o la biblioteca, sino que tendrá un acceso restringido a los

horarios en que las personas de la asociación se encuentren en él. 


\section{TABLA DE SUPERFICIES}

\begin{tabular}{|c|c|c|c|}
\hline \multirow{9}{*}{$\begin{array}{l}0 \\
0 \\
0 \\
0 \\
0 \\
0\end{array}$} & \multirow{5}{*}{ 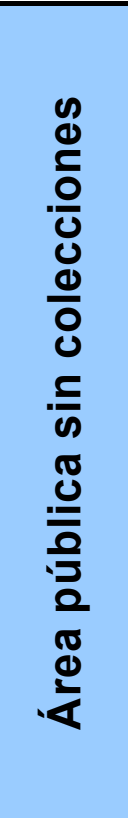 } & $\begin{array}{l}\text { a) Área de acogida } \\
\text { Área de acogida Pabellón renacentista-Vestíbulo oval- } \\
\text { Dsitribuidor/ vestíbulo sótano } \\
\text { Área de acogida edificio nuevo } \\
\text { Acceso al edificio nuevo desde el exterior }\end{array}$ & $\begin{array}{c}598,11 \\
272,11 \\
26 \\
200 \\
100\end{array}$ \\
\hline & & $\begin{array}{l}\text { b) Servicios } \\
\text { Tienda } \\
\text { Cafetería } \\
\text { Aseos de público en Pabellón renacentista planta sótano } \\
\text { Aseos de público en Pabellón renacentista planta primera } \\
\text { Aseos de público edificio nuevo }\end{array}$ & $\begin{array}{c}615,38 \\
63,7 \\
188,21 \\
193,47 \\
70 \\
100\end{array}$ \\
\hline & & $\begin{array}{l}\text { c) Salas para actividades } \\
\text { Salón de Actos } \\
\text { Talleres didácticos } \\
\text { Asociaciones de Amigos del Museo }\end{array}$ & $\begin{array}{l}608,19 \\
280,95 \\
161,76 \\
165,48\end{array}$ \\
\hline & & d) Biblioteca & 302,49 \\
\hline & & Total & 2124,17 \\
\hline & 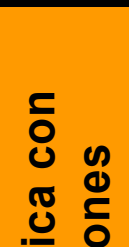 & $\begin{array}{l}\text { a) Salas de exposición permanente } \\
\text { Planta sótano -Historia del Museo- } \\
\text { Planta sótano -Prehistoria- } \\
\text { Planta baja -Itálica- } \\
\text { Planta baja -Bética y Bajo Guadalquivir- }\end{array}$ & $\begin{array}{c}3688,75 \\
265,52 \\
1348,04 \\
1112,54 \\
962,65\end{array}$ \\
\hline & $\begin{array}{ll}\overline{0} & 0 \\
\frac{3}{2} & 0 \\
0 & 0 \\
0 & 0 \\
0 & 0\end{array}$ & $\begin{array}{l}\text { b) Salas de Exposiciones Temporales } \\
\text { Planta primera } \\
\text { Planta baja } \\
\text { c) Reservas visitables } \\
\end{array}$ & $\begin{array}{l}2000 \\
1400 \\
600 \\
600\end{array}$ \\
\hline & $<$ & d) Sala de investigación y consulta del archivo & 237,44 \\
\hline & & Total & 6526,19 \\
\hline
\end{tabular}




\begin{tabular}{|c|c|c|c|}
\hline \multirow{8}{*}{\multicolumn{2}{|c|}{ 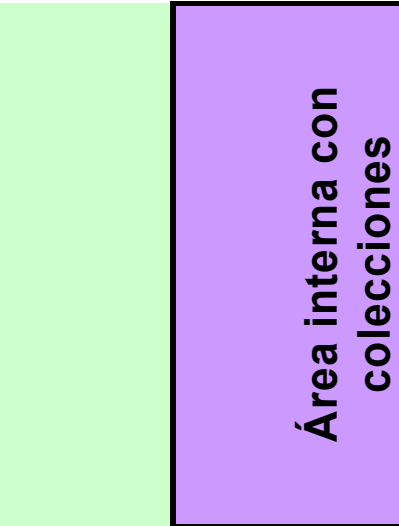 }} & $\begin{array}{l}\text { a) Área de recepción de colecciones } \\
\text { Zona de carga y descarga } \\
\text { Zona anexa a recepción de colecciones }\end{array}$ & $\begin{array}{c}380 \\
80 \\
300 \\
\end{array}$ \\
\hline & & b) Taller de Restauración & 500 \\
\hline & & c) Área de documentación & 250 \\
\hline & & d) Área de fotografía & 200 \\
\hline & & c) Almacén & 2200 \\
\hline & & Sótano 2 & 1450 \\
\hline & & f) Archivos documentales & 59,95 \\
\hline & & Total & 3080 \\
\hline \multirow{21}{*}{ 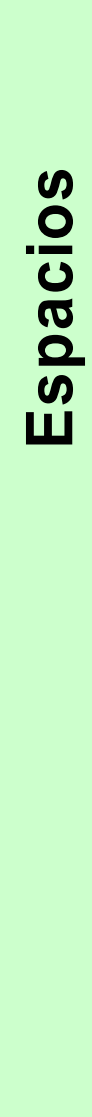 } & \multirow{20}{*}{ 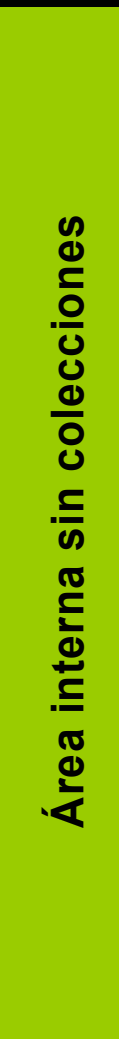 } & a) Dirección & 32 \\
\hline & & b) Administración & 78,15 \\
\hline & & c) Departamentos técnicos & 245,25 \\
\hline & & Área técnica de conservación & 152,6 \\
\hline & & Área técnica de difusión & 92,65 \\
\hline & & e) Salas de reuniones & 182 \\
\hline & & Pabellón renacentista & 32 \\
\hline & & Edificio nuevo & 150 \\
\hline & & f) Servicios de personal & 131 \\
\hline & & Pabellón renacentista & 31 \\
\hline & & Edificio nuevo & 100 \\
\hline & & g) Vigilancia y Seguridad & 177,15 \\
\hline & & Servicios/ vestuarios del personal de seguridad & 77,15 \\
\hline & & Consola de seguridad & 100 \\
\hline & & h) Almacén de biblioteca y difusión & 166,86 \\
\hline & & i) Mantenimiento y Limpieza & 60 \\
\hline & & Almacén de mantenimiento y limpieza Pabellón renacentista & 10 \\
\hline & & Almacén de mantenimiento y limpieza Edificio nuevo & 50 \\
\hline & & j) Almacén de material de oficina fungible & 88,62 \\
\hline & & k) Zona interna de cafetería & 63,7 \\
\hline & & Total & 13004,59 \\
\hline
\end{tabular}




\begin{tabular}{|c|c|c|c|}
\hline \multirow{4}{*}{ 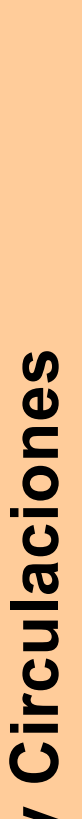 } & \multirow{5}{*}{ 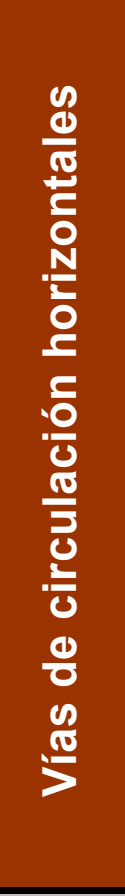 } & $\begin{array}{l}\text { PABELLÓN RENACENTISTA } \\
\text { Espacio de tránsito subterráneo } \\
\text { Planta sótano -pasillo- } \\
\text { Planta baja -espacios de tránsito para el acceso a escaleras y ascensor de público- } \\
\text { Planta primera -pasillo de conexión de las dos alas del edificio- } \\
\text { Planta primera -pasillo despachos trabajadores- } \\
\text { Planta primera -pasillo administración, dirección, área didáctica, sala de reuniones- }\end{array}$ & $\begin{array}{c}268,52 \\
80 \\
171 \\
17,52 \\
95,84 \\
60,42 \\
19,51 \\
\end{array}$ \\
\hline & & Planta primera -pasillo de conexión biblioteca, salón de actos, wc, vestuarios seguridad & 110 \\
\hline & & $\begin{array}{l}\text { EDIFICIO NUEVO } \\
\text { Sótano } 2 \text {-espacio de tránsito previo al almacén- } \\
\text { Sótano } 1 \text {-pasillo- } \\
\text { Planta baja -espacio de tránsito personal- } \\
\text { Planta baja -pasillo público- } \\
\text { Planta primera -espacio de tránsito público- } \\
\text { Planta primera -espacio de tránsito personal- } \\
\text { Planta segunda -espacio de tránsito y pasillo de personal- }\end{array}$ & $\begin{array}{c}420 \\
30 \\
50 \\
30 \\
50 \\
30 \\
30 \\
200 \\
\end{array}$ \\
\hline & & CONEXIÓN AMBOS EDIFICIOS: PASILLO SUBTERRÁNEO & 130 \\
\hline \multirow{5}{*}{$\begin{array}{l}\infty \\
0 \\
0 \\
0 \\
0 \\
0\end{array}$} & & Total & 818,52 \\
\hline & \multirow{3}{*}{ 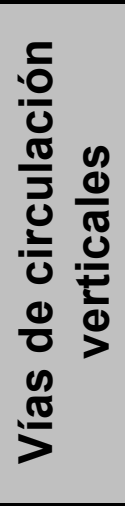 } & $\begin{array}{l}\text { PABELLÓN RENACENTISTA } \\
\text { Ascensor de público } \\
\text { Escaleras de público } \\
\text { Escaleras y ascensor de personal } \\
\text { Escaleras y ascensores de acceso a torres } \\
\text { Montacargas } \\
\end{array}$ & $\begin{array}{c}177,87 \\
30 \\
33 \\
36,87 \\
48 \\
30 \\
\end{array}$ \\
\hline & & $\begin{array}{l}\text { EDIFICIO NUEVO } \\
\text { Ascensor y escaleras de público } \\
\text { Ascensor/ Montacargas y escaleras de personal }\end{array}$ & $\begin{array}{l}\mathbf{3 0} \\
15 \\
15 \\
\end{array}$ \\
\hline & & Total & 385,74 \\
\hline & & Total & 1204,26 \\
\hline
\end{tabular}


$676 \bigcirc$

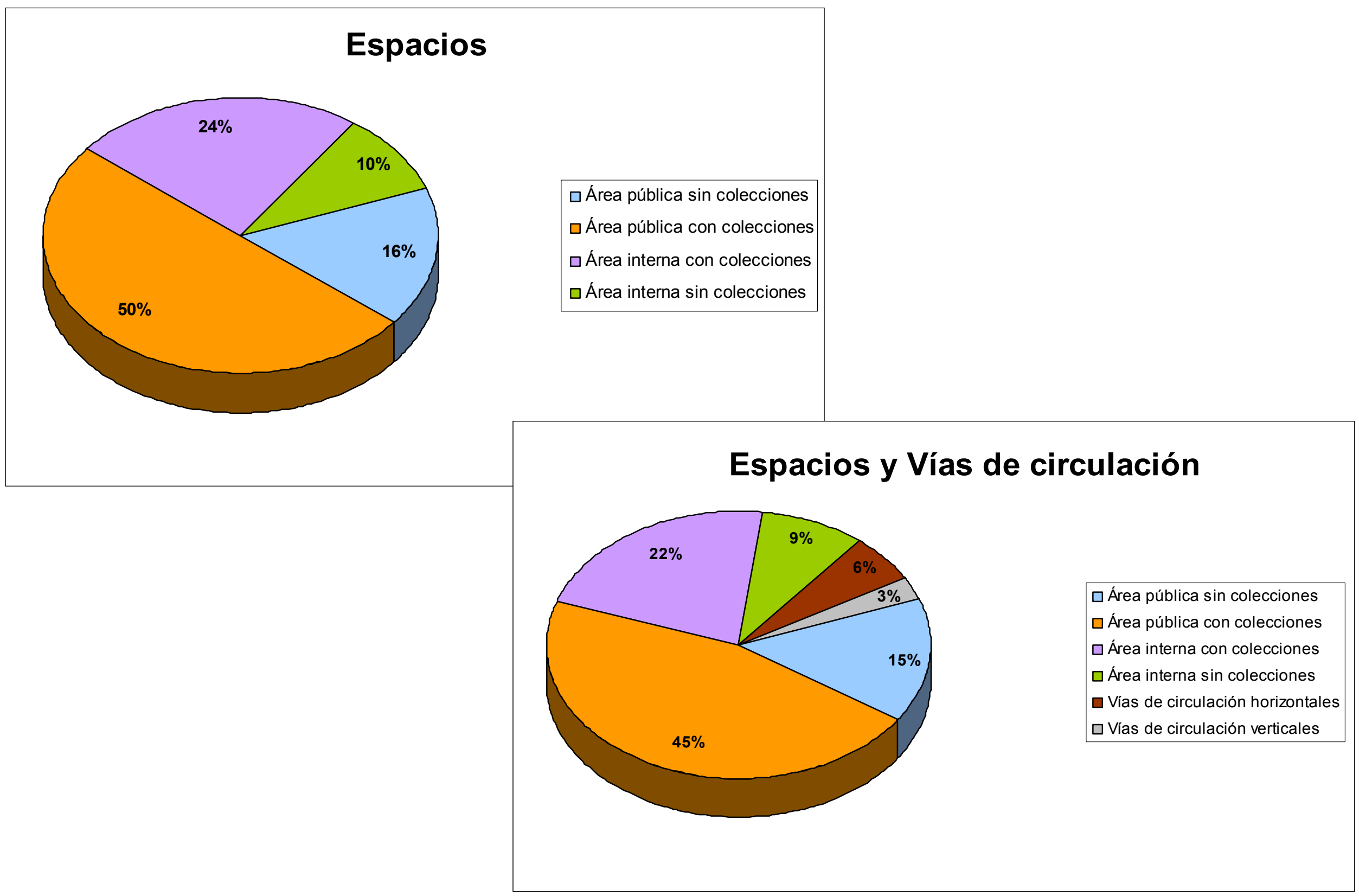




\section{III.5. ACCESOS Y CIRCULACIONES}

\section{III.5.1 SUPERFICIES Y CARACTERÍSTICAS DE LOS ACCESOS Y LAS VÍAS DE CIRCULACIÓN}

Analizaremos en este apartado, aunque ya se han ido citando algunos en la relación de espacios, todos los accesos al museo, tanto por el edificio nuevo como por el existente, así como las vías de circulación horizontales y verticales de ambos edificios.

\section{a) Accesos}

\section{Pabellón renacentista:}

Existe un acceso al museo para las personas, un acceso directo desde el exterior a la cafetería y un acceso para las obras.
Los visitantes entrarán en el museo por la puerta principal, en la fachada norte del museo, llegando en línea recta al área de acogida, desde el que podrán tomar diferentes direcciones, aconsejándoseles el tomar las escaleras o ascensor de público para llegar al sótano y comenzar el recorrido cronológico por la exposición permanente.

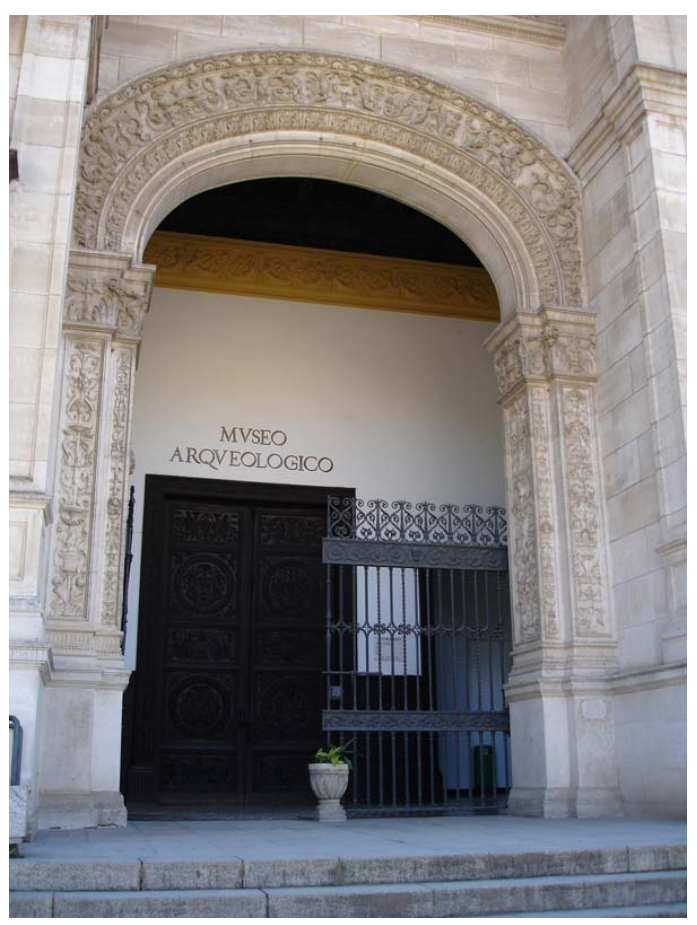

Puerta de acceso 
El personal del museo deberá acceder por la misma puerta ya que, aunque se ha intentado, no ha podido separarse el acceso del personal del de los visitantes, porque el no poder abrir huecos en la fachada del edificio condiciona el tener que utilizar los accesos de que ya dispone el mismo ${ }^{56}$. Desde el óvalo, atravesando en parte la zona de exposición permanente, llegará al ascensor y la escalera de personal.

Las obras llegan a este edificio desde el nuevo, que es donde se encuentra el área de recepción de colecciones, el almacén, etc. Por el paso subterráneo que conecta los dos edificios se llegará directamente al montacargas del edificio actual, situado en la fachada sur, en la salida de la conexión. Desde el montacargas podrán llegar ya a cualquier planta del museo.

56 Como ya se ha dicho anteriormente, el proyecto arquitectónico deberá intentar solucionar este problema e independizar los accesos de personal y de público.

\section{Edificio nuevo:}

Existen en total en este edificio tres accesos para las personas y dos para las obras.

Los visitantes accederán a este edificio normalmente desde el otro, por el paso de comunicación, llegando al área de acogida de éste, situada en el sótano 1, desde la que podrán subir por las escaleras o el ascensor de público. No obstante, aquellos visitantes que sólo quieran visitar la exposición temporal, podrán acceder desde el exterior del edificio por su extremo occidental a la planta baja, por donde normalmente se efectuará la salida del museo, pero donde se dispondrá un espacio de acogida donde poder dar información de las exposiciones temporales que se estén desarrollando.

El otro acceso para personas será utilizado por el personal que trabaje en este edificio y estará situado en el extremo oriental del mismo en planta baja. Desde este acceso 
podrán llegar a sus puestos de trabajo a través de las escaleras o el ascensor de personal.

Las piezas podrán llegar a este edificio por dos accesos, dependiendo de si vienen de la calle o del otro inmueble. Desde el exterior, las piezas ingresarán en el museo por la entrada de colecciones, situada en el extremo oriental del edificio y que efectuará una bajada para desembocar en el sótano 1 , donde se sitúa el área de recepción de colecciones y desde donde por el montacargas pueden llevarse a cualquier lugar del museo.

\section{b) Vías de circulación}

\section{Pabellón renacentista:}

- Vías de circulación verticales:

Ascensor de público: situado en el lado sur del edificio, al este del saliente central del mismo. Recorrerá en vertical todo el edificio, desde la salida del paso subterráneo de comunicación con el edificio nuevo, hasta la planta primera. Según el espacio en el que se ubica, tendrá una superficie de unos $30 \mathrm{~m}^{2}$, con $7,5 \times 4$ metros de lado. Será tomado por el público desde el área de acogida oval para llegar a cualquier planta del museo. En su llegada a la planta sótano saldrá al espacio de acogida de esta planta; en planta baja al espacio oval y en planta primera al pasillo de conexión de las dos alas, este y oeste, del edificio. En esta primera planta quedará sobre lo que actualmente es una terraza, con lo que se verá desde el exterior.

Escaleras de público: estarán situadas también en el lado sur del edificio, pero al oeste del saliente central del mismo, es decir, al otro lado del área de acogida que el ascensor. Recorrerán también el edificio en todas sus plantas y se ubicarán en un espacio de unos $33 \mathrm{~m}^{2}$. Para acceder a estas escaleras, el público atravesará el espacio oval para encontrarlas a mano derecha. Al llegar al sótano, las escaleras darán al espacio de acogida de esta planta; en 
planta baja al espacio oval y en planta primera al pasillo de conexión de las alas este y oeste del edificio. En esta primera planta, al igual que el ascensor, quedarán en la que hoy es otra de las terrazas del museo, con lo que serán vistas desde el exterior.

Ascensor y escaleras de personal: ubicados uno al lado del otro, se sitúan donde actualmente están estas vías de circulación, es decir, en el centro del ala occidental del edificio. Ocuparán en total ambos una superficie de unos $36,87 \mathrm{~m}^{2}$, que serán distribuidos en escaleras y ascensor por el futuro proyecto arquitectónico. Para llegar a ellos, el personal accederá por la misma entrada que el público, pues aunque, como ya se ha dicho, se han tratado de separar los accesos, las características del edificio lo hacen inviable. Así, atravesando en parte la exposición permanente de este ala occidental llegarán a estas vías de circulación que recorrerán todo el edificio desde la planta sótano hasta la planta primera. En el sótano llega a la zona de exposición permanente de Prehistoria y en planta baja a la de la Bética y el Bajo Guadalquivir, pero en ambos casos estas vías serán ocultadas al público. Al llegar a la planta primera se accede al pasillo de comunicación del que salen todos los despachos.

Para bajar al pasillo de conexión de ambos edificios, el personal tendrá que bajar por el montacargas, que también será ascensor, situado en el flanco sur del edificio.

Hay otras dos escaleras y ascensores en el edificio que también serán solamente utilizadas por el personal, y son las que suben a la planta alta, es decir, a las dos torres del mismo. A la torre situada en el ala occidental, que estará ocupada por el archivo y el almacén de material de oficina fungible se llegará por las escaleras que actualmente se utilizan, junto a las que se albergará un pequeño ascensor, y que parten de un pequeño espacio contiguo al área técnica de conservación. A la torre situada en el ala oriental, ocupada por el almacén de biblioteca y difusión, se accederá por unas nuevas escaleras y ascensor, eliminando las actuales escaleras poco seguras, que 
partirán de un extremo del salón de actos. Cada una de estas escaleras y ascensores ocupara un espacio de unos $12 \mathrm{~m}^{2}$ con lo que habría que sumar a la superficie de las vías de circulación vertical unos $48 \mathrm{~m}^{2}$.

Montacargas: estará situado en el lado sur del edificio, contiguo al ascensor de público, con lo que podrán compartir alguna instalación o al menos la conexión eléctrica. Recorrerá verticalmente todo el edificio, desde la salida del paso de conexión hasta la planta primera. En el sótano, el montacargas desembocará en la zona de exposición permanente de Historia del museo y en la planta baja en la de Itálica, lo que no es un problema porque de todos modos cualquier movimiento de piezas de la exposición permanente será realizado en horas en que no sea visitable por el público. En la planta primera llegará a la biblioteca y aquí, al igual que el ascensor y las escaleras de público, quedará sobre lo que actualmente es una terraza del museo. Con lo que se verá desde el exterior. Es muy importante que el nuevo montacargas que se instale en el museo no de los mismos problemas que el que tiene actualmente, que no soporta más de $400 \mathrm{Kg}$. de peso y es demasiado pequeño. Del estudio elaborado en el apartado de colecciones habrá que determinar el peso que el montacargas debe poder soportar, pero no obstante será el máximo, es decir, deberá instalarse el modelo que más peso permita transportar, pues las piezas arqueológicas pueden llegar a ser muy pesadas. Se prevé una superficie aproximada, según el espacio en el que se ubicará, de 30 $\mathrm{m}^{2}$, es decir, de unos $7,5 \times 4$ metros de lado. 
- Vías de circulación horizontales:

Serán descritas por plantas de abajo a arriba.

Bajo el sótano actual: habrá que construir un espacio de tránsito desde las escaleras y ascensor de público hasta el pasillo de conexión entre ambos edificios ${ }^{57}$. Este espacio de tránsito tendrá una superficie de unos $80 \mathrm{~m}^{2}$.

En el sótano del edificio, un pasillo distribuidor que sale de la sala introductoria dedicada al territorio, dará la posibilidad al visitante de acceder a la exposición permanente sobre la Historia del Museo, a la de Prehistoria - a los Talleres didácticos. Este pasillo ocupa una superficie de $171 \mathrm{~m}^{2}$, siendo de 38 metros de largo y 4,5 metros de ancho. El resto de circulación en esta planta se realiza a través de las salas expositivas.

\footnotetext{
${ }^{57}$ Por ser una vía de circulación horizontal que sirve a ambos edificios pero realmente no pertenece a ninguno de los dos, será analizado posteriormente de forma individualizada.
}

En la planta baja, pueden considerarse espacios de circulación los que quedan entre el espacio de acogida oval y las escaleras y ascensor del público, teniendo cada uno de ellos una superficie de $8,76 \mathrm{~m}^{2}$, con lo que habría que sumar a estas vías de circulación horizontal $17,52 \mathrm{~m}^{2}$. El resto del tránsito se realiza a través de las salas de exposición y el espacio de acogida, que sirve de distribuidor del público.

En la planta primera, el pasillo de circulación que actualmente conecta por el centro del edificio, rodeando el óvalo (no accesible en esta planta), ambas alas del edificio, seguirá teniendo la misma utilidad con sus 95,84 $\mathrm{m}^{2}$. Además de éste, se seguirá utilizando el pasillo que actualmente llega a la biblioteca para el acceso del personal a sus despachos, situados en esta área , con una superficie de $60,42 \mathrm{~m}^{2}$, con 22,80 metros de largo y 2,65 metros de ancho. Los desniveles que hay en los extremos del pasillo, es decir, entre éste y los espacios que serán la 
sala de investigación y archivo y el área didáctica se salvarán con escaleras y una plataforma elevadora para personas con movilidad reducida. Un nuevo pasillo se abrirá en el extremo occidental del edificio, abriéndose a un lado del mismo administración y dirección, y al otro el área didáctica y la sala de reuniones. Este pasillo tiene 10,27 metros de largo y 1,90 de ancho, con lo que su superficie es de 19,51 $\mathrm{m}^{2}$. En el ala oriental del edificio se habilitará otro pasillo de unos $110 \mathrm{~m}^{2}$ que conectará desde las vías de circulación verticales la biblioteca, el salón de actos, los servicios del público de esta planta y los servicios y vestuarios del personal de vigilancia y mantenimiento, para no tener que atravesar zonas con uso específico para llegar a éstas. Este pasillo dispondrá de ventanas para permitir el paso de la luz desde el exterior a los espacios que conecta, pues en ellos es idónea la entrada de luz natural.
Edificio nuevo $^{58}$ :

- Vías de circulación verticales:

Ascensor y escaleras de público: se sitúan en flanco norte del edificio, a la salida del pasillo de conexión con el otro inmueble del museo. Recorren verticalmente desde el sótano 1 hasta la planta primera, ya que en el sótano 2 y en la planta segunda sólo hay espacios de uso por el personal del museo y por tanto no accesibles al público. Desde el sótano 1 estas vías parten del área de acogida de visitantes y en las plantas baja y primera llegan a pasillos de circulación y conexión entre los diferentes espacios. El espacio reservado para estas vías de circulación es de unos $15 \mathrm{~m}^{2}$, que podrían repartirse en $9 \mathrm{~m}^{2}$ para el

\footnotetext{
58 Las superficies de las vías de circulación del edificio nuevo, al igua que las de los espacios anteriormente detallados) son estimativas, es decir, se han calculado en función de la superficie del solar que ocupará el nuevo edificio y la del resto de los espacios que se distribuyen en él. No obstante, el proyecto arquitectónico será el que trace la superficie definitiva de los espacios y de las vías de circulación en función de la viabilidad y aplicando las normas de seguridad contra incendios, de evacuación, etc.
} 
ascensor ( $3 \times 3$ metros de lado) y $6 \mathrm{~m}^{2}$ para las escaleras, pero ese reparto se definirá en el proyecto arquitectónico.

\section{Ascensorl montacargas y escaleras de personal: se} ubicarán en el extremo oriental del edificio, también cercanos al pasillo de conexión con el otro inmueble del museo. Recorren en vertical todas las plantas del edificio, es decir, desde el sótano 2 , en que dan a una zona de tránsito previa al almacén; pasando por sótano 1, en que desembocan en la zona anexa al área de recepción de colecciones; la planta baja, por donde se entra directamente desde la entrada/ salida de personal; la planta primera, en la que llegan a un espacio interno anexo a las salas de exposiciones temporales; hasta la planta segunda, donde desembocan en el pasillo distribuidor de todas las zonas de trabajo de este edificio. Así, el personal y las colecciones del museo podrán moverse por todo el edificio, en el que se establecerá un protocolo de acceso a las áreas que contengan piezas para el mejor control y seguridad de las mismas. Para estas vías verticales de circulación se estiman unos $15 \mathrm{~m}^{2}$, que podrían ser repartidos en $9 \mathrm{~m}^{2}$ para el ascensor, que también será el montacargas de este edificio ( $3 \times 3$ metros de lado) y 6 para las escaleras; no obstante este reparto y distribución definitiva de superficies tendrá que ser solventada por el futuro proyecto arquitectónico. Este montacargas deberá soportar el mayor peso posible, como ya se ha indicado en el del otro edificio, pues debe solventar el problema del actual montacargas, por el que no pueden moverse todas las piezas del museo, pues además de ser muy pequeño soporta muy poca cantidad de peso.

- Vías de circulación horizontales:

Se describirán de abajo a arriba del edificio.

En el sótano 2, al salir del ascensor/ montacargas o las escaleras de personal se accede a un espacio de tránsito previo al almacén de unos $30 \mathrm{~m}^{2}$. 
En el sótano 1 existirá un pasillo que conecte el área de recepción de colecciones con la consola de seguridad y el almacén para poder acceder a estos espacios desde las vías verticales del personal. Se prevén unos $50 \mathrm{~m}^{2}$ de pasillo, aunque tendrá que ser especificada esta superficie por el proyecto arquitectónico.

En la planta baja serán necesarios varios espacios de tránsito. Uno de ellos para el personal, reducido (unos 30 $\mathrm{m}^{2}$ ), a continuación de la entrada de personal por el extremo oriental del edificio; y dos para visitantes, un pasillo que los conduzca desde el ascensor o escaleras de público hasta las exposiciones temporales de esta planta y las reservas visitables (unos $50 \mathrm{~m}^{2}$ ), y un espacio previo a la salida del edificio por el que también se pueda acceder al mismo (unos $100 \mathrm{~m}^{2}$-esta superficie será computada como área de acogida, por ser el acceso al edificio desde el exterior-).
En la planta primera habrá que tener en cuenta un pequeño espacio de tránsito (unos $30 \mathrm{~m}^{2}$ ) del ascensor y escaleras de público hasta las exposiciones temporales y otro para el personal (unos $30 \mathrm{~m}^{2}$ ) desde sus vías de circulación verticales hasta estas exposiciones.

En la planta segunda se han previsto unos $200 \mathrm{~m}^{2}$ para ubicar un pasillo que atraviese a lo largo toda la planta y desde el que se abrirán todas las estancias de la misma, y para un espacio de tránsito a la salida de las escaleras y el ascensor de personal.

\section{VÍA DE CIRCULACIÓN HORIZONTAL DE AMBOS EDIFICIOS: El paso subterráneo}

Es imprescindible que ambos edificios estén conectados, y al encontrarse el solar oportuno para el nuevo edificio en la trasera del existente, es decir, frente a su fachada sur, la conexión debe hacerse por este lado. La dificultad está que en esta fachada del museo actual existen gran cantidad de árboles que debemos respetar en la intervención. Así, la 
única solución posible es hacer un paso subterráneo que conecte los dos edificios, que no es una solución novedosa, pues muchos museos se han conectado por un subterráneo a su ampliación, como la prestigiosa National Gallery de Washington. Desde el edificio actual, este paso partirá de un nivel inferior al del sótano para desembocar en el sótano 1 del nuevo edificio y para su iluminación natural podrían abrirse claraboyas en el suelo actual del parque. Contando con que el edificio nuevo se prevé construir sobre la actual pista de patinaje y que ocupará la mayor superficie posible que respete la vegetación alrededor (unos $1500 \mathrm{~m}^{2}$ ), entre los muros de ambos edificios quedará una distancia aproximada de 12 metros. Hay que tener en cuenta que en el lugar de esta conexión el edificio actual tiene un saliente, que hace que el pasillo tenga que tener unos 12 metros en un lado y 17 en el otro. La anchura razonable para este paso consideramos que es de unos 9 o 10 metros, ya que será dividido realmente en dos pasillos, uno para la circulación del público y otro para la de personal y colecciones. Haciendo un cálculo aproximado, el pasillo tendrá unos $130 \mathrm{~m}^{2}$ de superficie. Como ya se ha dicho anteriormente, el sector del pasillo utilizado por el público unirá el edificio antiguo por una zona de tránsito bajo el sótano al nuevo por al área de cogida. El sector de personal y colecciones llegará del montacargas del edificio existente al área de recepción de colecciones del nuevo. 


\section{III.5.2. DESCRIPCIÓN Y ANÁLISIS DE LOS ACCESOS Y CIRCULACIONES VERTICALES Y HORIZONTALES DE:}

\section{a) Bienes Culturales (obras)}

Como ya se ha dicho, el área de recepción de colecciones se sitúa en el sótano 1 del edificio que ampliará el museo. Desde aquí, las colecciones pueden realizar cualquier movimiento por los dos edificios del museo sin encontrar impedimentos que las hagan correr riesgos, ni siquiera escaleras, gracias a los montacargas de ambos edificios y al pasillo de conexión entra éstos.

Algunos de los movimientos más frecuentes de las piezas del museo son los siguientes:
- Área de recepción de colecciones $\rightarrow$ desembalaje $\rightarrow$ registro inmediato $\rightarrow$ montacargas $\rightarrow$ sala de exposiciones temporales.

Es el movimiento de las piezas que entran en el museo para participar en exposiciones temporales. Desde su entrada por el área de recepción en el sótano 1 del nuevo edificio, son desembaladas y registradas en la zona anexa a ésta (aunque si se hará una documentación más detallada se llevará a cabo en el área de documentación de la segunda planta) y por el montacargas llevadas a las plantas baja o primera, donde se desarrollan las exposiciones.

- Área de recepción de colecciones $\rightarrow$ desembalaje $\rightarrow$ registro inmediato $\rightarrow$ talleres de restauración.

Es el recorrido que suelen hacer las piezas procedentes de excavaciones, donaciones, etc. si van a exponerse o es necesaria su intervención, aunque vayan a ser 
almacenadas. Desde el área de recepción subirán por el montacargas hasta la planta segunda del nuevo edificio para proceder a su restauración.

\section{- Área de recepción de colecciones $\rightarrow$ desembalaje $\rightarrow$ almacén.}

Es el recorrido más habitual en las piezas que ingresan en el museo, procedentes de excavaciones, donaciones, etc. que van a permanecer en el almacén sin restaurarse ni exponerse inmediatamente. Desde el área de recepción pueden pasar directamente al almacén del sótano 1 o bajar por el montacargas hasta el almacén del sótano 2 del nuevo edificio.

\section{- Exposición permanente $\rightarrow$ almacenes (y viceversa).}

Es el recorrido de las obras que se van cambiando de la exposición permanente, aunque es más frecuente este movimiento de la exposición permanente al almacén, porque si va del almacén a la exposición suelen antes restaurarse. Desde la exposición permanente, en el edificio existente, las piezas serán montadas en el montacargas para llegar al pasillo de conexión subterráneo y de éste al sótano 1 del nuevo edificio, donde se encuentran parte de los almacenes, o podrá bajarse en el montacargas de este edificio hasta el sótano 2 , donde se almacena el resto de la colección. El recorrido a la inversa es exactamente igual.

\section{- Almacenes $\rightarrow$ taller de restauración $\rightarrow$ exposición permanente.}

Cuando una obra va a exponerse suele restaurarse antes, con lo que irá de los almacenes de los sótanos 1 o 2 a la planta segunda del edificio nuevo por el montacargas y una vez restaurada será otra vez por el mismo montacargas por el que llegue al pasillo de conexión de los dos edificios para desembocar en el montacargas del edificio antiguo y desde aquí a las salas de exposición permanente del sótano o de la planta baja. 
- Exposición permanente $\rightarrow$ taller de restauración $\rightarrow$ exposición permanente.

Se trata de obras que suelen estar expuestas pero necesitan ser restauradas. De las salas de exposición permanente situadas en el edificio actual, la pieza en cuestión será llevada por el montacargas hasta el pasillo de comunicación de ambos edificios para llegar al área de recepción de colecciones del nuevo edificio y desde ésta por el montacargas a la planta segunda al taller de restauración. Una vez restaurada, la pieza seguirá el mismo recorrido para volver a su lugar en la exposición permanente.

- Almacén $\rightarrow$ taller de restauración $\rightarrow$ almacén.

Es el recorrido de las obras que son restauradas pero no expuestas al menos inmediatamente y vuelven al almacén. Para este movimiento sólo habrá que llevar la obra por el montacargas del almacén de los sótanos 1 o 2 del edificio nuevo hasta la planta segunda del mismo edificio y viceversa.

- Almacén $\rightarrow$ sala de investigación

Cuando un investigador solicite ver una obra del almacén, habrá que llevar ésta desde el almacén del nuevo edificio por el pasillo de conexión hasta el montacargas del edificio actual, subir hasta la primera planta y llevar por ésta la pieza por el pasillo de conexión de las dos alas del edificio que desemboca directamente en la sala de investigación.

- Almacenes/ Exposición permanente $\rightarrow$ taller de restauración $\rightarrow$ salida.

Es el movimiento habitual cuando una obra va a ser prestada a una exposición temporal externa.

Del almacén al taller de restauración ya ha sido comentado el recorrido, y una vez restaurada, la obra será llevada por 
el montacargas desde el taller, en la segunda planta, hasta el área de recepción de colecciones del sótano 1 para su embalaje y salida.

También ha sido comentado el recorrido desde las salas de exposición hasta el taller, y una vez restaurada seguirá el recorrido desde éste hasta la salida.

Destacar que, a diferencia de la descripción de movimiento de piezas que se realizó en la fase de análisis, los nuevos recorridos que se plantean son mucho más sencillos y más seguros, garantizando que la pieza no sufra ningún daño por problemas en la manipulación y el transporte dentro del museo.

Además, se ha tenido en cuenta al trazar la configuración de las grandes áreas y los espacios concretos del museo, es decir, de ambos edificios, que las zonas en las que es frecuente o continua la presencia de colecciones se pueda sectorizar y separar del resto estableciendo un protocolo de acceso a estas áreas, a las que sólo accederá el personal autorizado. Asimismo, esta sectorización facilitará la aplicación de las medidas de conservación preventiva, como son el control de la climatización, la iluminación, etc.

\section{b) Público visitante}

El recorrido habitual del público ya ha sido anteriormente comentado, pero detallaremos los diferentes movimientos que pueden hacer dentro del museo.

La mayor parte del público llegará al museo con la intención de visitar las exposiciones, la permanente y la temporal. Para ello, accederá por la puerta principal situada en el centro de la fachada norte llegando en línea recta al área de acogida. A mano izquierda, antes de entrar en el área de acogida podrá acceder a la tienda si lo desea. En el espacio oval se situará los servicios de atención al visitante, donde podrá recibir información sobre todas las exposiciones y actividades del museo, y se le recomendará el itinerario marcado por el museo que, de forma 
cronológica, comienza en el sótano. Por las escaleras o el ascensor situados al fondo del vestíbulo llegará al espacio distribuidor del sótano desde el que pasará a la sala introductoria dedicada al territorio. Después de ésta se le indicará el sentido de la visita a mano derecha, recorriendo las áreas de exposición permanente del sótano de manera dirigida para llegar de nuevo al vestíbulo distribuidor y subir a la planta baja. En ésta se le instará de nuevo a seguir el sentido de la visita continuando en el ala oriental con las salas dedicadas a Itálica. Al final de estas salas podrá acceder de nuevo a la tienda si lo desea y saldrá de nuevo al espacio de acogida oval para recorrer el otro ala del edificio. Tras concluir en el óvalo la visita a la exposición permanente saldrá de nuevo al óvalo desde el que podrá salir al exterior o visitar las exposiciones permanentes. Para esta segunda opción tomará de nuevo el ascensor o escaleras para bajar al espacio de tránsito previo al pasillo de comunicación de los dos edificio. Por él accederá al área de acogida del nuevo edificio, donde se le dará información sobre la exposición o exposiciones temporales que va a visitar, que comenzarán normalmente por la planta primera, para después tomar el ascensor o las escaleras hasta la planta baja para terminar de visitar la exposición y recorrer las reservas visitables. Concluida la visita, el público saldrá de este edificio por el extremo occidental del mismo a una plaza pública que se planteará en el exterior como lugar de encuentro y de desarrollo de actividades al aire libre. Muy cerca se encuentra la cafetería del museo, a la que se accede desde el exterior del edificio por unas escaleras. No obstante, el visitante que lo desee puede acceder a la cafetería desde unas escaleras situadas en el sótano justo debajo de ésta.

Los visitantes que quieran ver sólo las exposiciones temporales o la reserva visitable podrán acceder directamente al nuevo edificio por el acceso situado en el extremo occidental del mismo desde la plaza pública antes citada y salir por esta misma puerta, de entrada y salida, ya que se prevén pasillos que hagan sencilla la circulación dentro del edificio. 
El público puede también puede acceder directamente, sin pasar por zonas expositivas, al taller de realización de actividades. Para ello entrará al área de acogida oval, tomará el ascensor o escaleras y bajará al sótano, donde un pasillo distribuidor lo llevará directamente al extremo oriental del edificio donde se sitúa el taller.

Para llegar a la biblioteca, el usuario entrará al museo de nuevo por el área de acogida oval y tomará el ascensor o la escalera para subir a la primera planta, desembocando el primero en el pasillo que ya da acceso a la biblioteca y la segunda al pasillo de conexión de las dos alas el edificio, que tomará para llegar al pasillo del ala oriental. El mismo recorrido tendrá que efectuar para llegar al salón de actos, tomando el pasillo que conecta todo el ala oriental para acceder al mismo. Para la sala de investigación y consulta del archivo subirá por los mismos ascensor o escaleras de público y llagará por el pasillo de comunicación de ambas alas hasta el ala occidental del edificio.
En cualquier momento de su estancia en el museo el visitante puede acceder a la tienda, desde el espacio oval, a la cafetería, por una escalera o ascensor/ montacargas de cafetería que parte del sótano o cualquiera de los servicios del público. Al del sótano del edificio actual desde las salas de exposición permanente o desde la planta baja por las escaleras contiguas; al de la primera planta desde el salón de actos; y al del nuevo edificio desde la zona de tránsito de la planta baja.

\section{c) Personal del museo}

Nos referimos en este apartado en general a todas las personas que trabajan en los edificios del museo, sean o no personal fijo o laboral de éste.

Los trabajadores que tengan su puesto en el edificio actual accederán al museo por el mismo acceso que los visitantes y llegarán a mano izquierda al ascensor y escaleras de 
personal. El personal técnico, el de dirección y administración tomarán el pasillo que sale a la derecha de estas vías verticales de circulación, que desembocan en el pasillo al que se abren el servicio del personal, el área técnica de conservación y el área técnica de difusión, desde la que parte otro pasillo a los lados del cual se sitúan la administración, el área didáctica, la dirección y la sala de reuniones. El personal de la sala de investigación y archivo y de la biblioteca tomarán la dirección opuesta al salir del ascensor o escaleras para llegar a sus puestos de trabajo. El personal de vigilancia y seguridad tiene su vestuario en esta misma planta primera en el extremos oriental, con lo que atravesarán todo este ala para llegar a él antes de incorporarse a su puesto de trabajo en sala o en la consola de seguridad del edificio nuevo, a la que accederá por el pasillo de comunicación.

El personal de atención al público se quedará en el espacio oval y el de la tienda accederá a ésta desde este mismo espacio. El personal de cafetería llegará a la cafetería directamente por las escaleras que serán habilitadas en el exterior del museo ${ }^{59}$

Los trabajadores del edificio nuevo accederán por la entrada/ salida del personal, situada en el extremo occidental del edificio en planta baja. Desde aquí, los restauradores, documentalistas y los trabajadores del área de fotografía, subirán a la planta segunda por el ascensor o las escaleras de personal.

El personal de la consola de seguridad podrá acceder directamente al edificio nuevo por el mismo acceso y bajar hasta el sótano 1.

El personal de mantenimiento y limpieza podrá acceder a ambos edificios por los accesos del personal para desarrollar sus tareas.

\footnotetext{
${ }^{59}$ Ya se ha apuntado la necesidad de intentar conjugar las imposiciones que derivan de la configuración del edificio y la idoneidad de separar los accesos de público y de personal, que serán estudiados por el proyecto arquitectónico.
} 
Es importante destacar que todo el museo es accesible a personas con movilidad reducida, lo que resuelve uno de los defectos más importantes del museo actual.

Por otra parte se ha intentado, en la medida de lo posible, independizar físicamente las grandes áreas funcionales en las que se divide el museo para poder independizarse también en horarios. Cuando no se ha conseguido ha sido por los condicionantes que impone un edificio ya construido de estas características.

\section{III.6. PLANES DE EMERGENCIA Y EVACUACIÓN}

Tras el análisis de los sistemas de emergencia y evacuación actuales y ante la construcción de un nuevo edificio, se puede concluir la necesidad de elaborar un plan de emergencia que siga la normativa vigente en cuanto a la evacuación de personas en ocasiones excepcionales y establezca un protocolo de actuación que clarifique el papel a seguir por cada miembro del personal del museo en caso de emergencia. Éste será diseñado por el proyecto arquitectónico, una vez determinados los espacios y las vías de circulación horizontales y verticales definitivas, pues habrá que aplicar toda normativa existente sobre esta materia. 


\section{III.7. INSTALACIONES}

\section{III.7.1. CONDICIONES AMBIENTALES}

\section{- Sistemas de ventilación del museo}

Actualmente no existen sistemas de ventilación forzados, pero además hay zonas del museo que deberían estar más ventiladas aunque sea con una ventilación natural, como los actuales almacenes del sótano y algunas zonas de la exposición permanente. No obstante, sería preferible que donde hubiera piezas, la ventilación se realizara a través de sistemas que filtraran las partículas dañinas para éstas y controlara la calidad del aire dentro del museo. En el edificio nuevo, todas las estancias dispondrán de una instalación de estas características, siendo fundamental la ventilación en las zonas con colecciones, como los almacenes, y aún más en el taller de restauración, donde la normativa referente al uso de productos tóxicos impone una ventilación adecuada. En el edificio antiguo también se intentará instalar un sistema de ventilación forzado más moderno que el que actualmente tiene. No obstante, los detalles sobre este sistema y el modo de instalarla, tanto en el edificio nuevo, en el que se presupone será más fácil, como en el edificio antiguo, donde será más complicado, serán estudiados por el arquitecto y especialistas en el tema y plasmadas en el futuro proyecto arquitectónico.

\section{- Sistemas de climatización}

El museo no cuenta actualmente con sistemas de climatización, con lo que el trabajo del personal en los meses de más frío y calor, así como la visita y es uso de áreas como la biblioteca, se hace bastante difícil, casi desagradable. Además, como ya se destacó en el análisis, no existe tampoco cuidado en la temperatura y humedad a la que están las piezas, ni las almacenadas ni las expuestas. En la intervención integral prevista para todo el museo, incluyendo la construcción del nuevo edificio, se 
climatizará toda la superficie del mismo para la mejor conservación de las piezas y el confort del público y el personal del museo. Resulta difícil instalar un sistema de climatización moderno en el edificio preexistente, declarado Bien de Interés Cultural, por lo que la gran mayoría de la maquinaria para climatizar ambos inmuebles se ubicará en el nuevo edificio, en el techo del mismo. No obstante, el proyecto arquitectónico junto con los especialistas en el tema, decidirán si es oportuno instalar alguna maquinaria más pequeña en el edificio existente para la climatización de algunas zonas como los despachos, aunque el grueso de la misma ocupe todo el "techo técnico" del edificio nuevo.

\section{- Sistemas de medición de la polución ambiental}

Junto con el sistema de ventilación se instalará otro que revise la calidad del aire en el interior del museo, que será especificado en el proyecto arquitectónico.

\section{- Control ambiental en contenedores expositivos (vitrinas)}

Se controlarán por supuesto humedad y temperatura, así como polución, en el interior de las vitrinas con sistemas que será analizados en el programa de conservación.

\section{III.7.2. ELECTRICIDAD}

Como ya se dijo en las conclusiones del análisis será necesaria la revisión y renovación de la instalación eléctrica del edificio existente, que posee unas instalaciones tan anticuadas que no son reglamentarias y además no soportan los aparatos que funcionan normalmente en un museo, como la maquinaria de restauración. Por supuesto en el nuevo edificio se realizará una instalación eléctrica moderna. 


\section{III.7.3. FONTANERÍA}

También es obsoleta la instalación de fontanería y saneamiento en el edificio actual, con lo que habrá que revisarla para adaptarla a la normativa y para resolver los problemas que actualmente tiene relacionados con atascos en las vías y con la red de saneamiento del parque. En el edificio nuevo no habrá problema para que la instalación sea moderna y reglamentaria.

\section{III.7.4. VOZ Y DATOS}

La red telefónica y de ordenadores será interna y cubrirá todo el museo, ambos edificios, además de disponer de acceso a Internet en todos los ordenadores. Es importante solucionar los cables visibles por el edificio actual y prever lo mismo cuando se instale en el nuevo.

\section{III.8. CONCLUSIONES}

Este programa arquitectónico intenta solventar las carencias y deficiencias que se observaron en el análisis. Son requisitos básicos que, a la vista de lo analizado, el futuro proyecto arquitectónico deberá cumplir.

En definitiva, la intervención integral que se plantea sobre el museo pasa por la rehabilitación o restauración de la arquitectura del Pabellón renacentista, la construcción de un nuevo edificio que amplíe el espacio disponible para el uso museístico y la redistribución de los espacios necesarios para el funcionamiento de la institución.

Tras esta actuación habremos configurado un museo moderno, adaptado al siglo XXI, es decir, preocupado por llegar al público en las labores de exposición y difusión, además de mejorar en la conservación e investigación de sus colecciones. 


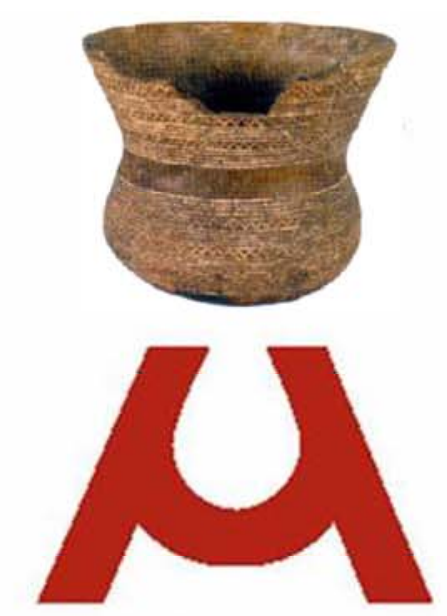

Museo

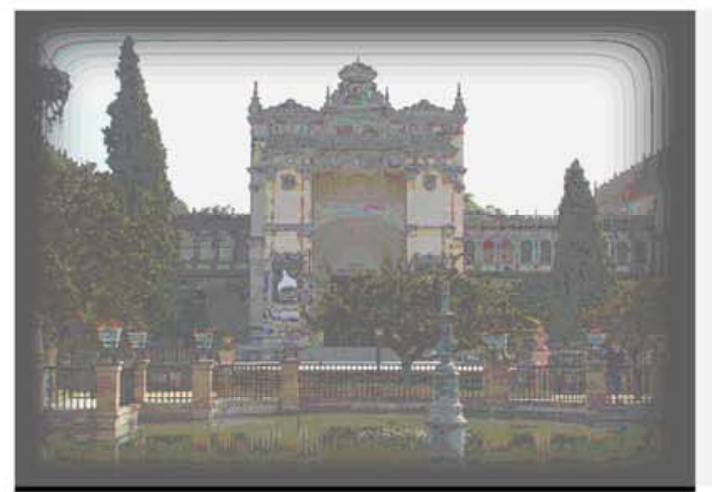

Arqueológico de Sevilla

\section{EXPOSICIÓN}

María Dolores García Pérez Sebastián Podadera Fernández 


\section{IV.1. INTRODUCCIÓN TEÓRICA}

Para la proposición de un nuevo discurso museológico se requiere un diagnóstico previo de las colecciones que alberga el museo para así redistribuir las piezas de una manera más coherente, con la finalidad de transmitir el mensaje que se quiere dar en función de la misión que hemos otorgado al museo.

Por ello, tras el análisis efectuado, el discurso museológico se plantearía en grandes áreas, que a su vez estarían fraccionadas en distintas unidades temáticas con varios subtemas expositivos. De esta forma, la línea de trabajo estaría enfocada a transmitir la riqueza de las tierras del Valle del Guadalquivir y hacer comprender al público el legado de las distintas culturas que han dejado su impronta como prueba de su existencia; todo esto con un fin de espíritu vigente que no sería mas que hacer ver al espectador porque es tan importante la revalorización de la cultura andaluza. Señalar que a pesar de la propuesta que realizamos a continuación, los diferentes espacios arqueológicos serán revisados y estudiados por equipos de trabajo interdisciplinares y especializados en cada temática, los cuales realizarán su labor en la fase de proyectos.

Para concretar, proponemos las siguientes grandes áreas temáticas:

- ¿¿ARQUEOLOGIA??

- Historia del M.A.S.

- Tesoros del Bajo Guadalquivir.

- Itálica.

- El corazón de la bética.

- La antigüedad tardía.

- El legado andalusí.

Esta clasificación nos ayuda a ofrecer al visitante un itinerario alternativo, con la posibilidad de acceder a cada 
una de las salas por separado, o realizar todo el recorrido, que será siempre lo aconsejado por todas las personas responsables de la guía por las diferentes áreas temáticas. Esta posibilidad nos la ofrece, como ya comentábamos en el documento de análisis, la presencia del gran salón oval, vestíbulo de entrada y el nexo de unión de todas las grandes áreas que hemos planteado.

Antes de comenzar el paseo museológico que planteamos para el discurso hemos de hacer una pequeña introducción en la que dar una serie de pautas que condicionarán el planteamiento, tanto técnico como conceptual, de los recursos museográficos. La importancia del M.A.S nos debe llevar a fijarnos en una de las exposiciones modelos de arqueología inauguradas hace muy poco y que hoy es un nuevo referente más cercano aún al Museo Arqueológico Provincial de Alicante, nos referimos al novísimo Museo de Almería, en el que se ha querido dar un punto de inflexión al hecho de que el público entienda la Arqueología como una ciencia profesional y, como tal, exigente de una preparación y un tratamiento profesional, lejos de los expolios de hace unos años y de la idea de 'hobby' de mucha gente, en algunos casos eruditos que deberían dar ejemplo.

La eficacia de este planteamiento está directamente relacionado con la garantización de la transmisión de un discurso apoyado en la tecnología y en la rigurosidad científica, una mezcla entre ambos planteamientos es lo que ha llevado al éxito al MARQ y que va a llevar al Museo de Almería, y esperemos que también al M.A.S.

Es importante señalar que el M.A.S posee una colección amplísima de piezas $\mathrm{y}$, por tanto, hemos de ser conscientes que un planteamiento de discurso demasiado cargado podría hacer que el espectador no captara el discurso tal y como queremos plantearlo, así, habrá que ser conscientes de que no es necesario que se observen todas las piezas sino que será mejor una disposición en conjuntos y eludir las repeticiones salvo cuando sean 
necesarias para dar importancia a una determinada pieza.

Después será nuestra habilidad narrativa y los puntos de inflexión los que mantengan el interés del visitante.

\section{IV.2. CARACTERÍSTICAS TÉCNICAS}

Una serie de características técnicas expositivas también a tener en cuenta son las siguientes:

- Necesidad de dar la posibilidad al personal 'no especializado' del museo de desarrollar de forma autónoma las labores más simples de adaptación de la estructura expositiva, así como de limpieza y mantenimiento de luces, cristales, piezas descolocadas, etc...

- Esto desembocaría en una ayuda necesaria a la administración del museo que no tendrá que acudir continuamente a ayuda especializada, aunque puede ser efectivo el planteamiento de una serie de cursos de formación anteriores a la apertura del museo para garantizar el uso apropiado de materiales y tecnologías.

- Las luces jugarán también un papel muy importante en nuestro museo puesto que al diferenciarse tanto el planteamiento de las salas de planta sótano y planta primera, se plantea también la distinción de sistemas iluminativos que van desde la fibra óptica y led's que se usarán en la primera y los raíles para grupos eléctricos que serán más flexibles para la segunda.

- La distinción anteriormente señalada de sistemas artificiales de iluminación viene dada por un deseo de diferenciación entre piezas arqueológicas que deben ser mostradas contextualizadas enormemente por su falta de sentido estético que contrasta con las esculturas o mosaicos romanos. 
- Otro elemento que nos lleva a jugar con la iluminación es la presencia de unos techos muy bajos en la planta sótano, mientras en la planta suelo son techos muy altos que necesitarán de elementos de iluminación más potentes y flexibles. Además la planta dedicada a Itálica y el Bajo Guadalquivir está afectada por ventanales de luz natural que habrán de ser tenidos en consideración en la fase de proyectos mediante diferentes pruebas de luz por si fuese necesario orientar las piezas hacia otros lugares o mitigar las fuentes naturales de luz.

- $\quad$ Con respecto a las vitrinas serán diseñadas teniendo muy en cuenta que van a albergar objetos de tamaño reducido, por lo que una disposición en talud, de visibilidad alta (a nivel del eje del ojo humano, $155 \mathrm{~cm}$ ) y con juego de prismas de metacrilato con iluminación de fibra óptica direccionable, sería lo mas apropiado. Siempre serán herméticas y lo más estancas posibles, con un sistema de apertura y cierre telescópico que permita esas características.
- Los materiales serán la madera tratada e ignifugada, el cristal y el acero, siempre usados con uniformidad de estilo.

- La durabilidad de la instalación no será más de 10 o 15 años, teniendo siempre en cuanta que la instalación que conserva actualmente el Museo lleva más de 30 años ahí.

- Lecturas a diversos niveles y a libre elección del visitante, desde audiovisuales que serán un recurso en el que los visitantes se apoyarán muchísimo hasta un punto de consulta en ordenador o una hoja de sala a la que los visitante suelen acudir para llevársela a casa como recuerdo de la visita.

- Tenderemos a una mejora de la visualización de las piezas mediante ampliaciones relacionadas con las piezas de forma directa, espejos en zonas de difícil acceso al visitante o mecanismo giratorios opcionales. 
- Es muy importante tener en cuenta los fondos sobre los que irán las piezas y se tenderá a un "rojo roma" que contratará muy bien con la iluminación teatral de la planta sótano y la disposición de las esculturas en mármol que también hacen buen juego con ese color. Como hemos señalado en casos anteriores este punto también estará ligado a un estudio en la fase de proyectos.

- El discurso deberá responder a una contextualización que se convierta en estrategia fundamental para que la arqueología pueda transmitir al visitante conceptos complejos que no se desprendan de las propias piezas, para conducir la mirada y dar una auténtica visión adaptada al ojo del visitante.

- La colocación de paneles retroiluminados en la planta sótano podría responder a una instalación de falsas paredes (donde colocar los sistemas de climatización) de madera tratada e ignifugada que faciliten el juego de luces y sombras.

- La colocación de los sistemas de iluminación será la siguiente:

Para la fibra óptica se usará una de tipo direccionable que permita acercarnos a las pequeñas piezas e iluminar rincones que serían imposibles con otros sistemas y dar, además, una visión de 'tesoro' de la pieza iluminada. Ésta iluminación podrá estar apoyada por otros puntos de iluminación general que se colocarían en el techo de la vitrina como señalamos en un dibujo que hemos colocado en este documento.

La recreación teatral del laberinto de vitrinas que supondrá la planta sótano estará apoyada mediante led's que se colocarán a ras de suelo o en el filo superior de las vitrinas, teniendo en cuenta la necesidad de visibilidad y haciendo la función de camino guía para el espectador. 
Los raíles de la zona de la planta superior, y como hemos señalado ya, tendrán una facilidad de instalación y flexibilidad adecuadas a la altura de los techos, por tanto podrán ir mas arriba o más abajo dependiendo de las piezas a iluminar y del tema de la sala, además no tendrán por qué tener en cuenta la cantidad de luxes al exponer a la pieza puesto que son materiales los que se iluminan que no se deterioran por esta causa, en la mayoría de los casos, pero a pesar de ello serán 150 luxes los que se proyectarán como máximo, salvo que una escultura en particular necesite de una mayor intensidad. En cuanto a la temperatura de color irá tendiendo más bien a lo cálido pero sin excedernos (en torno a 3000 grados Kelvin). Todas estas especificaciones técnicas deberán ser estudiadas detenidamente por un proyecto de iluminación que será encargado una de las empresas especializada en este ámbito.

En cualquier caso y como conclusión hay que decir que el diseño de la exposición deberá ir encaminado a garantizar la identificación emotiva apoyándose si es necesario en recursos humorísticos y en comparaciones directas de la vida del pasado con la actual.

\section{IV.3. PASEO ARQUEOLÓGICO}

Nuestro paseo comenzará en la planta sótano, donde se le planteará al espectador toda una serie de elementos explicativos en los que pudiese entender la ¿¿Arqueología?? como una ciencia totalmente sorprendente por el hecho de que es capaz de darnos toda la información sobre los modos de vida de nuestros antepasados, todo ello apoyándose en otras ciencias auxiliares como la palinología, la geofísica, etc...

A pesar de que esta área va a tener una función meramente introductoria, los medios expositivos deberán ser la piedra angular del despertar de la expectación del espectador. Por ello, el discurso estará apoyado en 
pequeñas reproducciones de maquetas que expliquen los diferentes métodos de excavación, los diferentes territorios en los que se puede excavar o investigar arqueológicamente (tierra, mar, lagos, ríos, montañas, hielo, etc...) y sin olvidarnos de la presencia de toda herramienta necesaria para realizar una excavación, dándoles la posibilidad a los visitantes de poder usarlas en pequeños escenarios recreados para que puedan ser manipuladas dichas herramientas. Interesante también, será la presencia de una serie de paneles, donde se le explique al espectador en qué situaciones se puede encontrar el arqueólogo, la vestimenta que debe usar y el porqué, dando a entender que no es un trabajo fácil y que en muchas ocasiones supone una auténtica aventura en el sentido de peligrosidad y de riesgo en su investigación por descubrir las huellas de nuestros antepasados para darnos a conocer la interpretación científica de su trabajo. Quizás no estaría de más el poder colocar todas las herramientas en un Jeep (contando con que el espacio sea suficiente) y que el visitante conozca a fondo la vida del arqueólogo.
Una vez realizada esta introducción, profundizaríamos en las explicaciones centrándonos ya en la arqueología usada para conocer las piezas que se nos van a presentar en el museo, todo ello dividido mediante dos métodos:

1. Análisis de la situación geográfica e histórica en la que se encuentra nuestra comarca.

2. Las distintas ciencias científicas que aportan a la investigación arqueológica de nuestros antepasados.

La primera unidad detallará la situación geográfica desde el golfo marino a la formación de las marismas del bajo Guadalquivir, y la provincia de Sevilla en la parte suroeste de la Península Ibérica como localización de la ocupación humana y la evolución histórica que han protagonizado la estirpe humana en nuestra comarca. Esta introducción contextualizaría al visitante para situar nuestro entorno, 
una contextualización que se realizaría mediante mapas retroiluminados apoyados por textos, que sitúen el río Guadalquivir y su función en los asentamientos humanos, los diferentes accidentes geográficos que condicionan el espacio habitable, el posible clima que se daba en esas latitudes y sus semejanzas al actual, en definitiva toda una introducción geofísica e histórica capaz de hacer comprender al espectador la vida hace millones de años.

Por otro lado, se dará otro nivel expositivo en esta estancia, el análisis de los distintos métodos de investigación de la arqueología aplicada sobre la realidad de un hecho tal como los estudios antropológicos de una población, el estudio estratigráfico de la arqueología ilustrada o la funcionalidad de técnicas científicas como la palinología, la antracología, la carpología o los estudios faunísticos. Estos temas nos ayudarían a comprender que la disciplina de la arqueología no está limitada a la excavación de un yacimiento, sino que hoy día el avance científico también nos documenta sobre hechos relacionados con la evolución del hombre y su entorno.

Para que todo esto sea posible necesitaremos todo un despliegue de urnas que permitan el desarrollo de la imaginación en el espectador, así, se podrán proponer en cada una de esas urnas un método diferente de análisis (simplificado por supuesto) en el que el espectador sea partícipe del mismo, y para ello se deberá consultar a expertos en las diferentes materias que nos den claves para que el espectador pueda hacer pequeños y aproximados análisis polinológicos, geofísicos, etc... Incluso sería interesante, por la gran colección de cerámicas que alberga el museo, que se colocasen una serie de amorfos y que se le explicase al espectador cómo se unen los mismos para formar las vasijas que luego podrá visitar en el recorrido.

Ya hemos situado al espectador tanto geográfica como históricamente. Sin embargo, y a pesar del buen análisis temático, se crea la necesidad de exhibir al visitante la 
envergadura del lugar donde se encuentra. Por ello, proponemos la creación del área titulada Historia del

M.A.S. En ella se exhibirán a modo de resumen el legado de los anticuarios y coleccionistas sevillanos del siglo XIX, en conexión con la documentación bibliográfica más significativa de la época y destacando a los más importantes como el Duque de Medinaceli, Francisco de Bruna, Demetrio de los Ríos, Jorge Bonsor, los avatares de sus orígenes, su construcción y la evolución arquitectónica del edificio, situando al museo como una importante institución tanto por su titularidad como por el contenido de sus colecciones y lo que ello repercute en el patrimonio histórico artístico de nuestro país actualmente.

Museográficamente esta sería un área de propuestas simples pero muy llamativas $y$, sobre todo, fáciles de entender, para el espectador. Así lo que vemos más correcto será colocar una serie de vitrinas donde se destacará cronológicamente los diferentes avatares por los que ha ido pasando el museo, desde el descubrimiento de una pieza por un determinado estudioso, hasta por donde ha ido pasando arquitectónicamente la colección y el edificio actual. Proponemos, por tanto, vitrinas dispuestas diagonalmente en las salas, con un sistema de retroiluminación y cristalería que le permita al visitante ir avanzando en saltos mediante hitos en la historia del museo.

A modo de ejemplo, todo esto, se traduciría en destacar, por ejemplo, la época de Jorge Bonsor poniendo una foto suya retroiluminada, una de las piezas más importantes de su descubrimiento y fotos sobre la fase en que se encontraba el museo tanto arquitectónicamente como logísticamente, igual ocurriría con los demás estudiosos o las diferentes reformas del edificio.

La vitrina nos permitiría un juego de luces que teatralizarían muy bien la evolución y las piezas que se colocarán en los espacios dedicados al uso. 
ESQUEMA DE PRESENTACION DE VITRINA

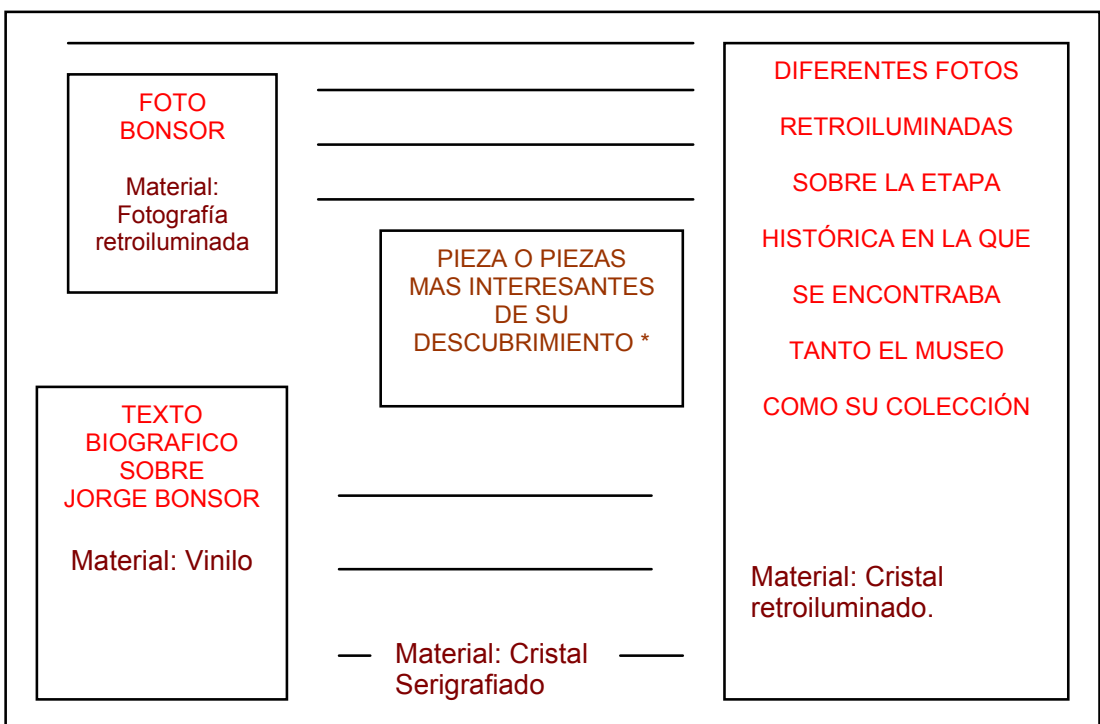

* La pieza se colocaría sobre una peana realizada en DM tratado y acoplado para que la pieza pueda ser iluminada desde la zona superior a través de fibra óptica. Aquí se podrían incluir material de archivo como dibujos, bibliografía de la época, inventarios, etc...

Tras esta gran introducción al museo y a lo que vamos a poder encontrar en él, comenzaremos el recorrido con colecciones, a través de una primera gran área de prehistoria que titularemos Tesoros del Bajo Guadalquivir y en la cual, nos encontraremos toda una serie de subtemas representativos de los pobladores del Bajo Guadalquivir hasta Roma. Esta área reunirá una gran parte de la cultura prehistórica de dicha zona, así como desde las primeras ocupaciones de los homínidos en nuestra tierra, pasando por la necrópolis de Valencina de la Concepción, la Cultura Tartésica y el tránsito de la Cultura Ibero-Turdetana hasta llegar a la influencia romana.

En primer lugar, nos encontraríamos una sala titulada 'Los Primeros Pobladores'. La idea del surgimiento de la vida en el valle del Guadalquivir y del estrecho de Gibraltar después de haber estado sumergida en aguas marinas, es lo primero que el visitante debería retener en su mente, para así continuar con la evolución del ser humano en esta zona. Para ello, la exposición permanente que hay actualmente nos puede aportar algunas piezas como pequeños fósiles de moluscos, conchas de ostras y peces, lo cual podría estar apoyado por un audiovisual colocado 
en una pantalla medianamente grande, donde se pudiesen observar los mapas a un tamaño correcto para que el espectador se hiciese una idea de cómo la zona pasa de ser habitada por criaturas marinas a ser una de las cuencas hidrográficas más ricas de la península. Será interesante colocar delante de esta pantalla una serie de asientos en los que el espectador, tras una zona bastante interactiva, pueda parar a descansar, relajarse $e$ ir adecuando la vista a las siguientes salas, donde la luz baja en intensidad y la teatralización de la misma van a adquirir gran relevancia en el discurso museográfico.

En la misma pantalla podrán incorporarse otros audiovisuales que pueden ser pasados aleatoriamente e incluso poder ser elegidos por el espectador a través de algún sistema de votación interactiva, haciendo así partícipe al espectador del Museo. Para ello, serán interesantes exponer algunos videos sobre la evolución humana, las formas de economías de subsistencia, útiles, etc... Este hecho debe representarse de una manera práctica y divertida que seduzca al visitante y se lleve una sensación gratificante.

Al mismo tiempo y enfrentada a esta pantalla, se completaría la contextualización de esta unidad con la exhibición de otros subtemas como la funcionalidad de sus útiles comparándola con útiles actuales y el recurso que le aportaban las terrazas del occidente para poder fabricar sus contenedores de alimentos. Es muy interesante museográficamente esta propuesta, puesto que nos da la posibilidad de hacer ver al espectador que los útiles que comienzan a usar nuestros antepasados no distan mucho ni en sus formas, ni en uso de nuestros útiles actuales, por ello propondremos la colocación de una vitrina-panel en el que poder observar como un simple cuchillo actual tiene la misma forma y se comporta de la misma manera hoy y hace millones de años.

Muy interesantes para esta vitrina serían las piezas encontradas en la Cueva Chica de Santiago en Cazalla de la Sierra, son hachas, hoces, instrumentos líticos, etc... De 
esta forma nos adentramos poco a poco en el período neolítico que se consolidaría con las cerámicas neolíticas de las simas de la Veredilla de Cádiz, o la de Algamitas del sureste sevillano, las cuales podrían exponerse en los laterales de la sala siempre haciendo una discriminación de piezas bastante científica y reducida, que permita que la sala no resulte demasiado densa en su contenido.

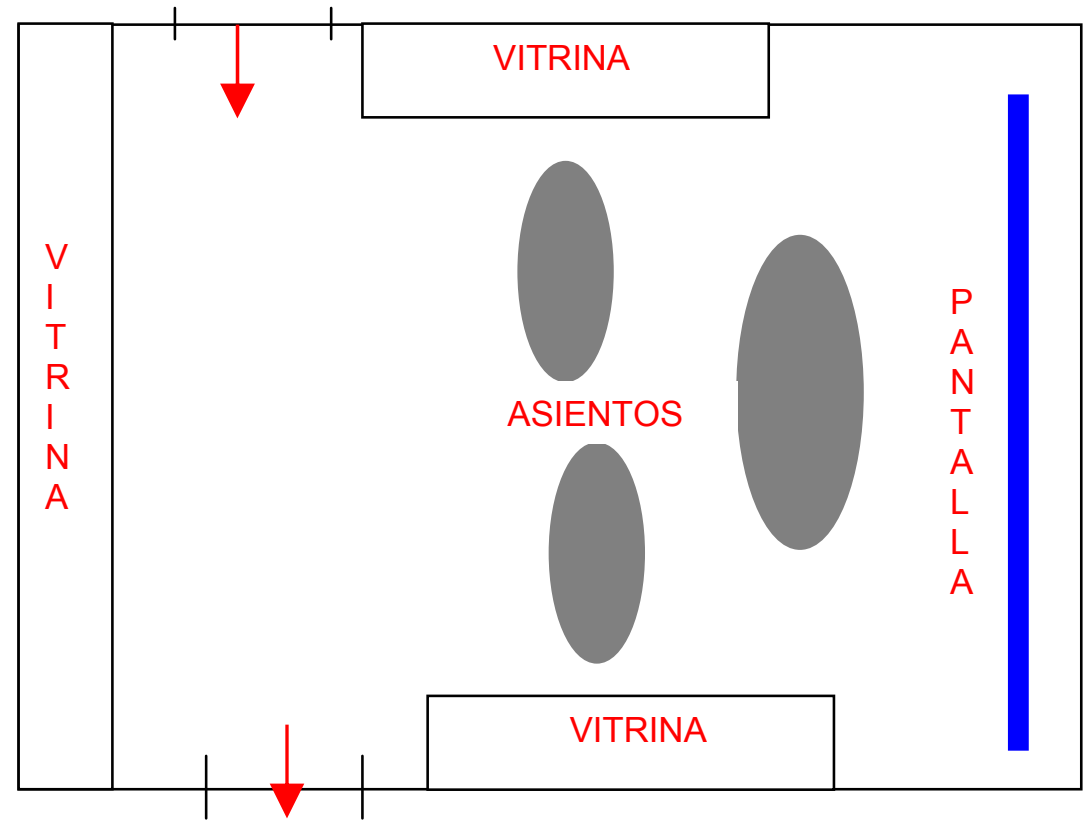

La próxima unidad temática que planteamos dentro de este gran área es la sala titulada el 'III Milenio', donde la consolidación de la economía productora ayuda a la construcción de poblados creando las distintas tipologías constructivas de la época. De ello tenemos la representación de los dólmenes y los tholoi del Gandul.

El recurso visual de la localización en mapas de los poblados de la Edad del Cobre en los alcores, el Valle del Corbones y la Campiña, entre otras, facilitarán la comprensión de la unidad. En esta sala los principales elementos museográficos en los que nos apoyaremos será en mapas retroiluminados que nos hagan entender los patrones de asentamiento y como éstos estarán condicionados también por los rituales espirituales reflejados en construcciones tan interesantes como los tholoi o los dólmenes, de los cuales, será muy interesante explicar los métodos arquitectónicos para conseguir estas magnificas y pesadas construcciones, acompañando el discurso con maquetas, no demasiado pequeñas, tanto de 
los métodos de construcción como de los acabados de los monumentos más interesantes como los localizados en El Gandul o en Constantina.

A estas alturas de visita llegamos a una de las salas que más importancia en el discurso museológico del Museo puesto que nos encontramos uno de los poblados mejor excavados e investigados de los que se poseen en el Museo Arqueológico de Sevilla y punto de referencia para el estudio de la Edad del Cobre en Andalucía, hablamos de Valencina de la Concepción, una localidad que ha aportado toda una serie de piezas que permiten estudiar este tipo de poblados en todas sus facetas: cerámicas, símbolos, fauna, ajuares funerarios, arquitectura funeraria, arquitectura de almacenaje, etc...

Hemos creído conveniente otorgarle un cierto protagonismo, tanto por su poblado como por sus monumentos funerarios. Esta unidad la titularemos tal cual su nombre indica, 'Valencina de la Concepción' y nos va a servir para aportar todos aquellos aspectos de transición y de transformaciones sociales del III al II Milenio. Las piezas que servirán de referente para su exposición será el conjunto de cerámicas, destacando la cerámica campaniforme, instrumentos y objetos simbólicos como los ídolos. De alguna manera, estará diferenciada esta estancia de la necrópolis, a la que se le dedicará la maqueta del dolmen de La Pastora, Matarrubilla y Ontiveros. Dicha estancia enfatizará lo misterioso de estos monumentos fúnebres y su megalitismo, ya que su forma y el juego de su distribución resultará muy beneficioso para el propio discurso museológico.

Gracias al gran aporte de piezas, que como ya hemos señalado, nos permiten ver prácticamente todos los aspectos de la vida en un poblado de estas características, la recreación de esta gran sala puede apoyarse en grandes dioramas en los que se nos explique el uso de las cerámicas colocando las mismas en grandes vitrinas con maniquíes de homo-sapiens en las que se deje claro las funciones de las cerámicas y los útiles diarios. También 
será interesante dedicar una zona de la sala al mundo simbólico y funerario colocando teatralmente toda una serie de ídolos, pinturas rupestres, que significaba la fauna existente en este poblado, donde los estudios faunísticos nos permiten este tipo de recreaciones. Otra zona podría ir ocupada por arquitectura tanto de almacenaje como de maquetas de los sepulcros encontrados en el poblado, incluso incluyendo aquí una zona donde poder hacer prácticas de excavación interactivas de uno de los sepulcros. Por la amplitud que deberá tener esta sala se podrán hacer muchos juegos de distribución de espacios, lo que quedaría reservado a un estudio mucho más pormenorizado que correspondería al proyecto museográfico de distribución de espacios necesario no solo aquí sino también en el resto del museo.

Mención a parte también merecería el tratamiento específico de la cerámica campaniforme del foco de Carmona, donde explicaríamos de donde proviene esa denominación, cómo se realizaban las piezas, los materiales que se empleaban y su uso.
Enlazando con la sala anterior y siendo el final de un etapa histórica y el comienzo de las grandes civilizaciones en Andalucía (Tartesos) nos encontramos una sala dedicada principalmente a las 'Necrópolis', destacando los enterramientos "en cista" como una particularidad de esta cultura del Bronce Pleno y Final. Existen gran cantidad de piezas, algunas de ellas será necesario reclamarlas para completar esta parte de la colección del museo.

Museográficamente esta sala estará representada con la misma teatralidad en la que se desarrollan las anteriores aunque quizás con un énfasis mayor por tratarse de un tema muy particular, se colocarán focos puntuales destacando los enterramientos de Chichina y se colocará toda una serie de vitrinas exentas donde presentar los ajuares encontrados procurando no ser reiterativos con las piezas presentadas e iluminando muy puntualmente, incluso con fibra óptica que nos permita el acercamiento exacto a zonas de las piezas que queramos destacar. Todo 
ello planteado en vitrinas que den la impresión de estar guardando tesoros únicos y poniendo en valor hasta la pieza que pueda parecer al espectador menos interesante. A continuación, proponemos entrar en un mundo muy poco conocido hasta por los propios investigadores. Se trata del área de la Cultura Tartésica y sus entramados históricos en estas tierras andaluzas. Se le dedicarán cinco estancias, de las cuales, la primera será a modo introductorio de sus antecedentes para situar al visitante. Se tomará como referente la sociedad Tartésica y las relaciones mediterráneas del momento. Es por ello, que se explicará la existencia de este poblado poco localizado, insinuándose a través de la ausencia de suficiente rigor científico, su situación entre Sevilla y Cádiz, muy cerca de la rivera del Guadalquivir.

Así museográficamente, la primera sala dedicada a esta cultura será eminentemente documental presentando textos griegos relativos a la cultura tartésica, mapas en los que se ubiquen los posibles poblados existentes, además de su relación con las colonias fenicias, apoyado finalmente por todo un despliegue audiovisual que nos explique el origen de esta civilización, las leyendas que se cuentan sobre ella y todo un estudio pormenorizado de las costumbres de la misma. Para poder conseguir esto habrá que plantear o encargar un estudio pormenorizado a un departamento de alguna universidad que nos permita conocer mucho mejor de lo que se conoce en la actualidad a Tartesos y, en concreto, a la gran colección que conserva este museo. La exposición de esta importante colección documental se hará mediante vitrinas adosadas al muro que planteen disposiciones en talud para permitir una máxima visualización del documento al espectador y una iluminación mediante led's situados en los filos superiores de la vitrina que incidan directamente en los documentos con una intensidad no mayor a los 50 luxes y dando una temperatura de color cálida que permita al ojo humano poder observar nítidamente esta exposición. 
El siguiente tema que se dará a conocer es el proceso de conformación de la cultura tartésica y su evolución como poblado indígena. Se han recogido varias leyendas poco fundamentadas, que nos pueden orientar a descifrar la mitología de este pueblo. Los Tartesos principalmente se dedicaban a la minería y a la actividad agro-ganadera. Para ello, se rescataría el conjunto de estelas funerarias del Bronce final, junto a los conjuntos de objetos metalúrgicos de espadas, puntas de lanza, hachas, cinceles y brazaletes.

El modo museográfico de estas primeras salas introductorias deberá plantear al espectador que la cultura tartessa fue propia de la Península lbérica en estos años y dejar clara la diferencia con las colonizaciones fenicias que posteriormente se mezclarán con la población indígena existente ya en Andalucía. Para ello se colocara en la primera sala toda una serie de estelas funerarias como nexo de unión, a través de los ritos funerarios, con las salas anteriores de la Edad del Bronce. Estas estelas podrían plantearse ambientadas en un suelo de arena simulando su colocación en los parajes funerarios y colocando un camino en medio de ellas para que el espectador pueda visitarlas, con una luz general muy tenue. Mediante led's que guíen el camino y focos iluminado las estelas puntualmente. Estas piezas nos aportarán la documentación del cambio social hacia una sociedad jerarquizada y elitista.

Gracias a que gran cantidad de esta planta se va a dedicar a esta primera gran civilización del Bajo Guadalquivir podemos recrearnos en las explicaciones que sean necesarios, por tanto a esta sala podría acompañarle otro espacio en el que se de a conocer cómo estos pobladores dominaban ya la fundición del bronce y todas sus herramientas, tanto de guerra como cotidianas, colocándose así, toda una serie de piezas en vitrinas que muestren las colecciones de hachas, espadas, puntas de flecha, brazaletes, etc... 
Todos estos recursos museográficos deberán estar acompañados y apoyados por sus correspondientes textos en vinilo que den las precisas explicaciones al espectador de lo que está viendo. Como apoyo serviría también, paneles que hicieran fondo de la vitrina con escenas de caza, preparación del alimento, fundición, etc...

A continuación, la siguiente sala nos servirá para mostrar la convivencia de la cultura tartésica junto con la colonización de la influencia fenicia. Las piezas que nos contextualizarían en este estado serían el Bronce de Carriazo, y las pequeñas esculturillas de Hércules-Melkart, junto con otras piezas de cerámicas orientalizantes relacionadas con la colonización fenicia, los ajuares de El Acebuchal, restos faunísticos y exóticos como los huevos de avestruz, etc...

La presentación de estas piezas se realizará mediante vitrinas exentas de un diseño unificado que recorra el espacio en forma de serpiente que haga el transcurrir por la exposición muy ameno para el visitante. Todo el recorrido estará planteado de forma teatralizada, con luz baja, dibujos y luces en el suelo que nos indiquen el camino correcto y toda una disposición de paneles de apoyo donde se coloquen textos, fotografías retroiluminadas e incluso piezas embutidas en los muros de las paredes que separan las salas para dar un poco de dinamismo al recorrido y que el espectador deba estar mirando hacia todos lados por encontrarse piezas en cualquier lugar, así mantendremos siempre despierto su interés, sin dar tiempo al aburrimiento. El interior de las vitrinas respondería a las características de conservación propicia para cada tipo de piezas, dependiendo de qué material sean y la luz que se utilizaría sería fibra óptica que permitiera una iluminación puntual, cenital y muy liberada en sus movimientos por toda la superficie de exposición interna.

Para conformar una idea general de dicha cultura tartésica, se esbozará en la siguiente sala la necrópolis de Setefilla, 
con una maqueta que nos ayudará a contextualizar la idea del mundo funerario de esta etapa histórica, todo ello apoyado por los ajuares encontrados en las excavaciones que se colocarán en vitrinas con forma de un cuarto de círculo rodeando la gran maqueta anteriormente comentada de uno de los túmulos. Todo ello, apoyado por textos explicativos, decoración de dibujos acorde con la etapa histórica y el tema a tratar y con el sistema teatralizado de luz anteriormente comentado.

Del poblado de los Tartesos sabemos a través de algunas citas bibliográficas que poseían un alto nivel de cultura y con un gran desarrollo de la agricultura, ganadería y minería. De aquí, que podamos utilizar esta herramienta para poder mostrar al público visitante la destreza de este poblado con la fundición, documentándolo con el conjunto de objetos del Cerro Salomón.

Se mostrará en los paños de pared toda una serie de planimetrías arqueológicas que pueden ser colocadas retroiluminadas y en las que se explique la grandiosidad de este poblado y la importancia científica del mismo.

\section{ESQUEMA TIPO DE VITRINA*.}

*No tendrán porque guardar una forma fija rectangular sino que se podrá adecuar las formas a las necesidades teniendo en cuenta que hay maderas de grosores mínimos y por tanto flexibles para conseguir formad curvas. 


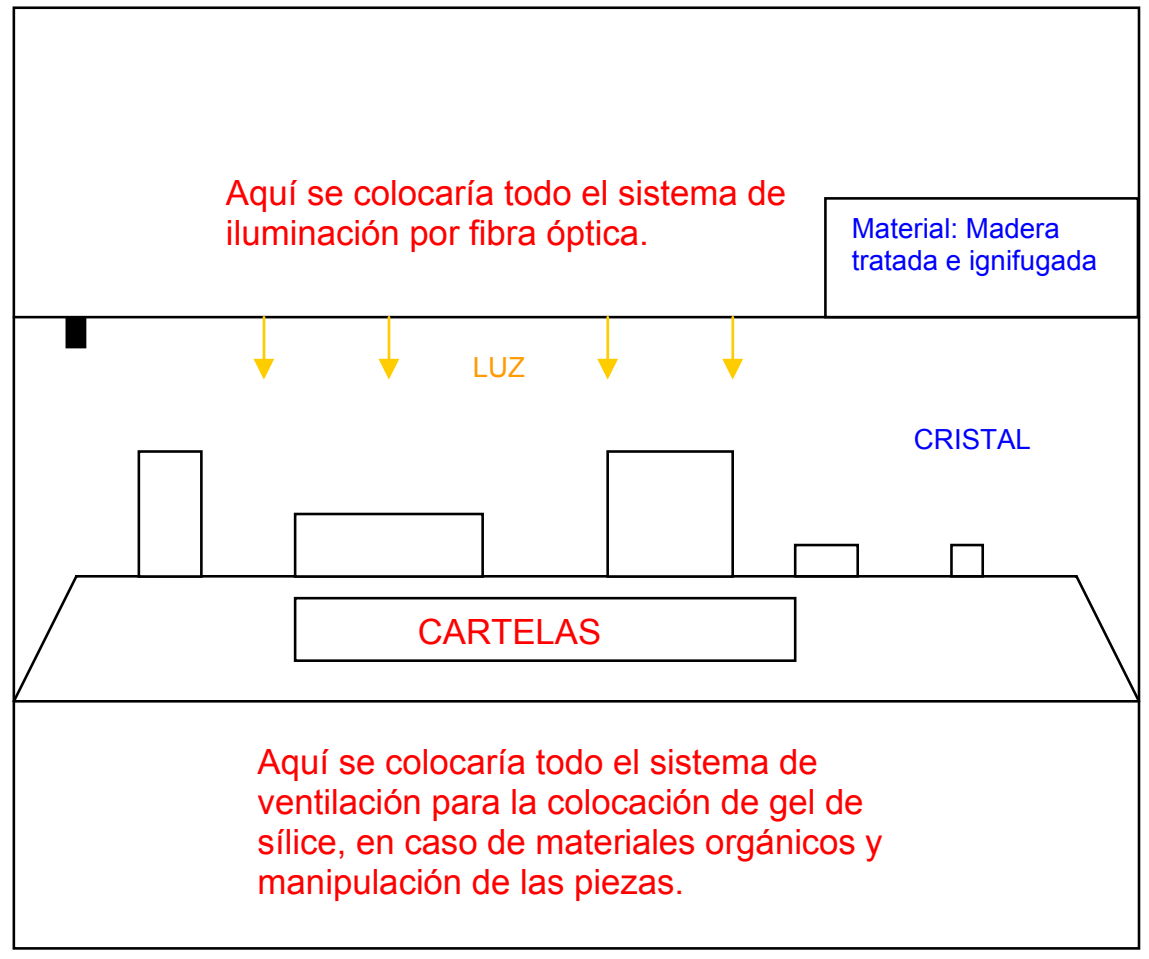

Para finalizar con la Cultura Tartésica, la quinta sala, la más grande dedicada a esta cultura, albergará el gran Tesoro del Carambolo. Estas piezas contienen un significado especial, ya no sólo por su valía sino por su historia y su descubrimiento. Este inédito descubrimiento otorga al discurso museológico la fusión de la Historia de nuestros antepasados con la Historia más reciente. De esta forma, el visitante se encontraría con una conexión más cercana al discurso apoyado en posibles citas bibliográficas fantásticas y legendarias.

Quizás sean las piezas que menos problemas planteen a la hora de ser puestas en valor museográficamente hablando, puesto que son unas de las que más conocen los visitantes y de las más bellas de la colección del museo debido a que están realizadas en materiales nobles. Así, lo que proponemos es colocarlas en vitrinas cuadradas, muy parecidas a las actuales, pero con sistemas de conservación preventiva, seguridad e iluminación más actuales, usando de nuevo la fibra óptica para acercarnos a las piezas sin calor e iluminarlas de forma más precisa. $A$ la presentación en vitrinas podríamos añadir, a modo de espectacularidad, teatralidad y atracción hacia el espectador un audiovisual contando cómo fueron estas 
joyas descubiertas y cómo han llegado hasta nuestras manos, todo un recorrido histórico que a la gente le gusta ver en imágenes. Al mismo tiempo, mostrar las distintas interpretaciones a las que los investigadores han llegado para su uso, deduciendo que podría ser usado tanto por un personaje ilustre del poblado o por algún animal simbólico de esta cultura. Para poder llevar a cabo esto, habrá que hacer un estudio pormenorizado y encargar el proyecto de realización de la pequeña película a una productora especializada en este tipo de documentales.

Respecto a este tesoro, podemos destacar la presencia de una piececita muy pequeña, pero que a la vez es muy representativa del museo por haber constituido siempre base fotográfica para las diferentes fuentes bibliográficas del museo, por lo que resulta una pieza bastante conocida para el público. Se trata de la Astarté sedente que en la actualidad está ubicada en una hornacina en la pared. Así, teniendo en cuenta que es una pieza que podría seguir siendo símbolo del museo proponemos su colocación del mismo modo, en un espacio aparte, aunque no aislado del resto del Tesoro, dándole una puesta en valor particular, incluso usando la museografía anterior en hornacina pero con una preparación más actualizada.

Comentar también que la sala del Tesoro, para hacer también un guiño a la museografía antigua podría estar ambientada al estilo que está en la actualidad con esa disposición en altar y la colocación de piedras a modo de un pequeño "sancta santurum" de esta planta sótano.

Para hacer una pequeña parada en el discurso, y puesto que nos queda una pequeña sala muy adecuada al relax y también, al resumen interactivo y atractivo al espectador, planteamos la opción de colocar en ella toda una serie de ordenadores en los que el espectador jugara e interactuara a través de la red con recursos didácticos que permitieran a la vez descansar de lo denso del discurso y además repasar lo que ya ha visitado. Habría una zona para adultos con información técnica de las excavaciones y los 
métodos llevados a cabo y otra zona infantil con recursos pedagógicos más acorde con esas edades.

La herencia de los Tartesos y la Cultura ibero-turdetana representan un buen conjunto de piezas a las que dedicarle una estancia. Así rescataremos los conjuntos de objetos procedentes de los poblados de Cerro Macareno y Alhonoz junto con el Tesoro de Mairena del Alcor y otras piezas de orfebrería y metalistería de la época. En este mismo lugar, se expondrán las ánforas púnicas de Ceuta junto con la escultura ibérica: leones, cabezas de caballos, relieve de la cierva. Todo ello, nos transmite la idea de los factores que condicionan a que la influencia romana vaya poco a poco ocupando su sitio en estas culturas indígenas. Éstas van absorbiendo el modo de vida social y su cultura hasta llegar a la culminación de la romanización intensificando las rutas comerciales de los oficios de la alfarería, que se demostrará con el Horno Ibérico del Pajar, junto con la aculturación del mundo funerario apoyado en la necrópolis del Olivar Alto. Esta sala nos da la información para observar el proceso de romanización que progresivamente va a experimentar Andalucía y, por tanto, deberá tener en cuenta esa situación acompañando a las piezas por mapas en los que se observe la evolución en la ocupación del Imperio Romano, a través del ejército, comercio, la red viaria y el asentamiento de sus ciudades mostrándolo a través de mapas que se podrán ir esparciendo por las salas llamadas de la Romanización y que serían hitos explicativos de la ocupación latina en España.

La primera parte de la sala podría contener vitrinas que nos presentan piezas de orfebrería de otros tesoros encontrados en la comarca, no rompiendo así el discurso que veníamos dando con el Carambolo, a continuación otra serie de vitrinas con cerámicas de los poblados íberos, incluyendo las mencionadas ánforas púnicas de Ceuta, las cuales podrían apoyarse en paneles explicativos en los que se diera a conocer al espectador las diferencias de realización, de formas o de cocción de las piezas con 
respecto a las cerámicas ya visitadas y finalmente un espacio dedicado a las primeras piezas de esculturas que presenta la colección del museo, es decir, la colección de pequeños leones y caballos que en la actualidad encontramos en un rincón de la sala XI y una selección del resto de grandes piezas prerromanas que colocaremos en peanas coloreadas en "rojo roma" para ir dando pinceladas a lo que va a poder ver el espectador en las siguientes salas, de museografía y criterios diferentes a los ya planteados.

Esta romanización se situará en dos unidades temáticas. La primera la planteamos con la conquista de la zona del Valle del Guadalquivir con una población autóctona y la emigración de la civilización romana. Como tradición ibérica utilizaremos los relieves de Estepa, las inscripciones latinas con mención de nombres ibéricos y los retratos romanos. Para la segunda estancia se recurrirá a la explotación agraria y la exportación del aceite en la Bética recreando una ciudad romana ideal de una villa rústica señorial y una casa urbana, contraponiendo estos dos modos de vida bajo la imposición de la romanización.

Si analizamos el discurso museológico de esta área podríamos decir que mantiene un orden cronológico y temático. La exhibición de esta museología está condicionada a la línea evolutiva de la propia colección. Los recursos de presentación de estas zonas serán a través de grandes dioramas que hagan comprender al espectador la arquitectura ibérica, sus costumbres y la evolución en las formas de vida con respecto a los poblados más arcaicos, haciendo ver que está calando el modo de vida romano no solo por la invasión del territorio sino también porque sus métodos y tecnología hacen que los pobladores vivan mejor y aprovechen mejor sus recursos. Para hacer ver esto sería interesante colocar una serie de maquetas de infraestructuras romanas para que el espectador viese la tecnología que comenzaba a nacer con Roma. Las paredes y las zonas anexas a estas estarían cubiertas de relieves sujetos por pinzas metálicas a la 
pared y toda una serie de retratos romanos colocados sobre plintos a la manera de las casas romanas que hagan ver las diferencias sociales que también se iban haciendo presentes en la Península Ibérica.

Pasando ya a la Planta Baja, el área de Itálica plantea otra línea diferente en su discurso, pues al centrarse sólo y exclusivamente en la civilización romana, éste se plantea temáticamente en distintas unidades en torno a su fundación y el proceso evolutivo mientras que perduró su asentamiento. Este discurso museológico evoca a lo estético, a la exhibición de la obra de arte propiamente dicha. La validez artística de sus piezas como objetos de admiración y ostentación, que, por otra parte, son el espíritu que acompañaba a las esculturas romanas, además de su simbología espiritual y religiosa, que normalmente terminaban siendo ofrendas a los diferentes dioses, al Imperio o al señor de la casa.
El contenido museográfico de este tema lo distribuiremos en ocho unidades, que determinarán dicho discurso. En primer lugar, presentaremos esta civilización bajo el lema 'Los Italicenses'. Este poblado fue fundado por Publio Cornelio Escipión en el año 206 a. C. para establecer permanentemente a sus tropas en la llamada Itálica, haciendo homenaje a su patria de origen. Surgió así, un proceso de mezcla de la población compuesta por romanos e indígenas a lo largo de la República, convirtiéndose en un municipio propiamente romano en la segunda mitad del siglo I a. C.

Este proceso de reconversión lo utilizaríamos para presentar en esta primera sala, quienes son los Italicenses, su composición social y los ciudadanos más destacados. Los epígrafes funerarios junto con los bustos de personajes ilustres acompañarían al mosaico de M. Trahius como prueba del aprendizaje en planeamientos urbanos de opus signinum. La disposición de los mosaicos probablemente sea siempre sobre la pared, aunque habrá salas de Itálica 
donde se colocará el mosaico en el suelo para que el público pueda observar la auténtica razón de ser del mismo como decoración del pavimento de la casa romana, excusa de sobra para colocar paneles al lado de cada mosaico que se exponga ubicando su colocación en la casa que se halló, donde se sitúa la casa dentro de su correspondiente excavación y si es en Itálica dentro de la planimetría de Itálica, todo ello jugando con la retroiluminación y los paneleados de madera.

La colocación de los mosaicos en el suelo que permitan una buena visualización y para que a la vez no sean arrollados por el espectador, hemos encontrado una buena solución visitando algunos de los museos andaluces (fuente de una de las salas del Museo de la Alhambra), así será alzado sobre una tarima fabricada en estructura de acero que sustente el mosaico y una disposición de losas de piedra que separen al espectador del mosaico por si da el paso de montarse en dicha estructura, momento en el cual, deberá haber un vigilante de sala que advierta de la imposibilidad de realizar ese movimiento al visitante.

Museográficamente estas salas ya propiamente de la colección de Itálica van a tener un tratamiento diferente, ya que consideramos que no son obras que necesiten de la teatralización expuesta en la planta sótano sino que requieren una puesta en escena mucho más real, en tono de dignificación de los objetos más que en escenificación. Así, salvo en los casos que sea requerido específicamente las esculturas, que es la mayor parte de la colección que encontramos, irán sobre peanas hechas específicamente para la pieza, con sujeciones interiores y exterior en madera tratada para que no desprenda vapores y produzca posibles deterioros en las piezas e ignifugada, que pueda ser pintada en un tono "rojo roma" o "amarillo albero". Destacar que estás estructuras metálicas que soporten los pesos tanto de mosaicos como de las grandes esculturas deberán ser estudiadas por especialistas en la fase de proyectos para conseguir una instalación manejable, 
incluso se podría hablar de la colocación de un sistema de enganche que permita a las grúas una facilidad de transporte mayor por si alguna pieza sale a una exposición temporal.

Una vez aclarada esta situación comenzamos a proponer por la llamada sala de los italescenses, en donde se podrá introducir los cambios sociales que va a suponer la adaptación de la cultura romana socialmente, así, comenzaremos por colocar los retratos que conservamos en orden de importancia jerárquica en una sociedad donde existirá el hombre libre y la esclavitud, y donde esos rasgos podrán verse simplemente observando el retrato de la persona, por tanto, sería muy interesante la interactuación del espectador explicándole, mediante paneles, sonidos y documentos que conservamos con nombres y puesto que ocupó cada personaje, la diferenciación de clases sociales. Un recurso interesante para colocar toda una serie de disfraces para que la gente pueda verse en espejos vestidos como iban las diferentes clases sociales que se muestran en la exposición.

En la siguiente sala, trataremos el tema de su fundación y las adquisición del Estatuto jurídico del municipio romano distinguiendo dos zonas: la vetus urbs (ciudad vieja), núcleo fundado por Escisión, y la nova urbs (ciudad nueva), de época adrianea. Las piezas que demostrarían la monumentalidad de 'Itálica' serían el torso masculino colosal y la cabeza colosal con corona cívica. Todo ello apoyado con planos y recreación ideal del foro, a través de maquetas en soporte digital, para que el visitante pueda manejar y ver los nombres de cada zona de la ciudad, explicar cómo se traza esa ciudad y como se va formando poco a poco a través de las principales construcciones, colocando a la casa romana como unidad principal y familiar de la ciudad y explicando su estructura y diferentes estructuras domésticas definiendo aquellos edificios de Itálica que tenían carácter privado en oposición a los edificios públicos que veremos más adelante. 
El nuevo proyecto urbano promovido por Adriano y el cual dedicó a Trajano con el Traianeum presentan al espectador la gran escultura de Trajano como emperador divinizado. La grandeza y el poder de este conjunto arqueológico adquieren un mayor protagonismo en esta unidad temática apoyado en su programa iconográfico. El mosaico de Hylas, junto con los restos arquitectónicos del Traianeum, permite distinguir la conformación de los nuevos edificios que caracterizarán la nova urbs. Entre las esculturas que pueden contextualizar esta sala destacaremos la presencia de Trajano.

Cabe la posibilidad de exhibir el orden urbanístico de Itálica, la formación de las calles, su enlosado, el trazado ortogonal de sus manzanas rectangulares de diversos tamaños, destacan la correspondiente edificación de unos espacios públicos que requieren distintas unidades temáticas para su exposición.
Esta sala deberá ser presidida museográficamente por la colosal y bellísima escultura de Trajano, la cual será colocada en el paño del fondo derecho de la sala para que la mirada del espectador se dirija a él y que entienda a que etapa histórica de la presencia de Roma en Andalucía pertenece la sala. Alrededor de la escultura iluminada puntualmente por todos sus ángulos, se colocarán el torso que se presume de Adriano, el mosaico de Hylas colocado en el suelo en el centro de la sala, sobreelevado como hemos señalado antes y los restos arquitectónicos colocados en pared recreando su posición tal y como estarían en el edificio, para ello recurriremos a los sistemas de sujeción mediante pinzas metálicas al estilo que usó Rodríguez Frade en el Museo de la Alhambra.

A continuación detallaremos el Anfiteatro y el 'Teatro' en las siguientes unidad temática como reflejo de los edificios públicos de mayor renovación urbana de épocas augustea y adrianea. Para ello será fácil hacer entender lo que significaban estos edificios en la cultura romana puesto que 
en la actualidad siguen teniendo vigencia como centro de cultura para la población en pleno siglo XXI. Se detallarán sus ubicaciones en la ciudad, las funciones que tenían, las tipologías arquitectónicas, sus diferentes estructuras respondiendo a lo habitual en los teatros romanos (graderío, orquesta y escenario) todo ello mediante panelado, apoyo digital mediante un audiovisual $y$ maquetas que se refieran a teatros cercanos a Itálica, incluyendo el de la misma, junto con inscripciones de importantes testimonios epigráficos referentes a su construcción y las aras cilíndricas de la orquesta que aparecieron en las excavaciones.

En cuanto al anfiteatro, al igual que el teatro, también se recurrirá a su proyecto de edificación y sus distintas partes constando de arena, donde se desarrollaban los juegos y el graderío para los espectadores. En definitiva lugares de ocio dedicadas a espectáculos para la población de Itálica que nos ha dejado huella hasta en la actualidad.
La visita se ensalzará a continuación con la sala llamada 'Itálica al aire libre', una visión de la ciudad en una zona del museo donde se nos permitirá la colocación de las piezas casi como si las estuviésemos viendo en la propia Itálica, así, se exhibirán algunas esculturas colosales y mosaicos, en la terraza oeste del edificio, recreando al aire libre la visión idílica de lo que sería Itálica in situ.

Entre los mosaicos se podrán exponer en el centro el pavimento marino que sirvió de fondo a una fuente de una casa romana con la técnica de opus signinum. $Y$ entre las esculturas el torso femenino de una divinidad fluvial. Todo ello, con muy poco tratamiento museográfico aunque con una disposición muy cuidada que haga que el espectador pueda imaginarse la grandiosidad que alcanzó la ciudad y la manera en que se decoraba con esas grandes esculturas y esos cuidados mosaicos. Esta sala es una gran apuesta de este proyecto y por tanto, se le quiere dar bastante importancia, así requerirá un estudio 
pormenorizado en su montaje y un proyecto concienzudo de estudios de espacios.

A continuación, nos centraríamos en dedicarle una sala a las esculturas de las divinidades mitológicas más bellas encontradas en la ciudad de Itálica, comenzando con la figura femenina de 'Venus'. Su exposición se enaltecerá de forma que captará la mirada del espectador. Alrededor de ella, se colocarán esculturas de menor tamaño junto con las piezas pequeñas que estuvieran relacionadas con la Diosa. Para cerrar esta sala se colocarán paneles explicativos e incluso sonido en el que se explicaran los ritos que se realizaban a esta divinidad, que significado tenía en Roma explicando que era la diosa del amor y uniendo a estas explicaciones fotografías en tamaño real de otras imágenes parecidas encontradas a lo largo y ancho de la geografía española. En cuanto a los sistemas de sujeción de las obras irán como en la escultura de Trajano, estructura interna de metal que sujete la escultura y permita su desmonte y cubierta en DM pintado.
Otra de las esculturas que concentrará mucha atención será 'Mercurio', el cual, se expondrá de la misma manera que la pieza anterior, con vitrinas que contengan piezas que llamen la atención, entre otras, la mano de Júpiter.

Entre estas dos bellas piezas, se ubicaría una sala de descanso que albergaría recursos expositivos que darían juego a la interactividad. Pero este punto, será más detallado en el Programa de Difusión.

Por último, la escultura de 'Diana Cazadora'. En nuestro discurso museológico hemos creído conveniente valorar la importancia artística tanto de esta pieza, como las dos anteriores, haciendo hincapié en su destreza artística y su valía histórica. En este caso, también la contextualizaremos con el torso de Diana, para comparar un caso y otro.

Al finalizar esta área, se dedicará el tema báquico junto con otros temas con la intencionalidad de perfilar el discurso 
dedicado a la ciudad de Itálica y a sus principales deidades. Se decorará con el mosaico de Baco, esculturas femeninas de menor tamaño como la Diosa Fortuna y fragmentos de mosaicos con representaciones de la primavera y el otoño.

Para dejar clara la técnica de colocación de los mosaicos en la pared, hay que decir que serán extraídos por piezas, unidas mediante grapas de acero en su parte posterior para permitir su desmontaje en caso de que deban salir a alguna exposición temporal y sujetos a la pared en su exposición permanente mediante presas de acero que lo suspenderían en el aire con una mínima inclinación para que pudiese ser apoyado sobre una estructura metálica adosada a la pared y sufriera los mínimos movimientos posibles. Esto requerirá, como es natural, un estudio pormenorizado de los mosaicos a exponer (peso, medidas, material, estado de conservación, etc...) del que se sacarán las conclusiones suficientes para hacer efectivo este sistema de sujeción que permite que la pieza no sea esclava del museo y pueda contribuir a su difusión en exposiciones externas. En el caso de que algún mosaico saliese del museo y para paliar ese gran hueco que dejaría en la pared se estudiaría o bien exponer alguno que se encuentre en almacén o realizar una lona serigrafiada con la misma imagen que muestra el mosaico.

El área dedicada al Corazón de la Bética se planteará con un discurso básicamente temático, complementando todo aquello que no se ha tratado en el área anterior. Nuestra intención es mostrar al espectador que existieron otras civilizaciones contemporáneas a la ciudad de Itálica y que siguieron la misma conformación de Itálica, tanto social como culturalmente. No obstante, nuestro discurso museológico seguirá una línea algo más disciplinada frente al planteamiento idílico y estético del discurso museológico desarrollado en Itálica. Encontraremos una museología científica basada en la documentación arqueológica de los distintos yacimientos de la Bética. Es aquí donde cada unidad temática detallará todas y cada una de las 
características más destacadas de la época romana con otras civilizaciones contemporáneas, cómo se conquistaron los territorios, su modo de vida, su subsistencia económica, su religión...

Para comenzar, debemos presentar a estas sociedades coetáneas a Itálica, su localización geográfica y la influencia de otras civilizaciones colonizadoras. La sala se llamará 'Aculturización', haciendo referencia a esa extensión e influencia que alcanzará el Imperio Romano que tenía como centro en Andalucía la ciudad de Itálica. Se tomará otro modelo de ciudad, como es el caso del yacimiento de Munigua. Este caso presenta un modo de vida diferente, una sociedad que está condicionada a la explotación minero-metalúrgica. Todo ello, estará relacionado con la presentación de textos epigráficos jurídicos y retratos de aquellas personas ilustres que tuvieron su significado protagonismo en éstas civilizaciones. La museografía aquí, jugará un papel intermedio entre la exposición planteada en la zona de prehistoria y la dedicada a la colección de Itálica, así volveremos al diseño de vitrinas comentadas anteriormente, con formas adecuadas a las piezas que albergará, y al transcurrir del circuito que queramos que realice el espectador, aunque aquí no habrá una iluminación tenue sino que se procurará una iluminación cenital natural atenuada por persianas de polietileno apoyada por la fibra óptica que se localizará dentro de la vitrina. Hemos querido hacerlo así, porque este sala del museo presenta una iluminación natural aprovechable si se trata con cuidado.

Rescatando el mismo modelo anterior de la ciudad de Munigua, podemos enlazar la siguiente unidad para tratar el tema urbanístico y la conformación de otras ciudades. Se contextualizará con una sección epigráfica y elementos arquitectónicos que nos transmitan la idea de las construcciones de sus edificaciones como obra pública de estas sociedades. Le acompañarán como hitos los Miliarios. 
Se atenderá a la visión de la 'Económica y la actividad comercial' de estas sociedades en el Valle del Guadalquivir. Ello permite afirmar que la actividad comercial tiene unas grandes coincidencias históricas con la evolución de la Humanidad. Ciertamente, las primeras necesidades no eran ni numerosas ni sofisticadas, a la manera que hoy las contemplamos en la actualidad, pero no obstante, nos llevan a reflexionar sobre las capacidades de gestionar los transportes de sus productos, las medidas y pesas utilizadas para las cantidades, la acuñación de algunas monedas sustituyendo al intercambio o al trueque y en definitiva, la exposición de textos epigráficos que lo documenten. La colección de monedas que conserva el museo nos permiten hacer un tratamiento del comercio muy detallado, colocando incluso una especie de mercado real con sonidos aproximados a lo que se podría escuchar en la Roma mercantil, una actividad que resultó importantísima para el desarrollo del mundo que conocemos actualmente por las rutas del comercio que se generaron, el conocimiento de nuevos productos, etc...

Otra unidad recurrente es la imagen del 'poder' con las esculturas y retratos de emperadores como propaganda política, las monedas, las colecciones menores relacionadas con el ejército y la actividad bélica descrita en los textos epigráficos, como el Concursos Honorum, nos aportarían la idea de la magnitud de las ciudades gobernadas y dirigidas por sus representantes.

La 'vida cotidiana' de estas civilizaciones la vemos reflejada en piezas menores de bronce o cerámica junto con pequeños lares y penates domésticos que plasman la destreza decorativa y las distintas funciones de los utensilios, como menajes de cocina, la higiene, la relación familiar, el ocio, los juegos... Al mismo tiempo, se puede ambientar la diferencia de género y el protagonismo que cada miembro familiar puede aportar a la población con respecto a la diferencia de clases sociales. 
A continuación, debemos conocer los distintos 'oficios y talleres' de fábrica imbricados con la subsistencia que el terreno y el clima puede facilitarles. Tales como la minería, la metalurgia, los alfares, el vidrio apoyados en unos recursos expositivos que sean atractivos para el espectador. Será muy interesante incluir aquí maquetas de maquinaria que permita ser manipulada por el espectador $y$ hacer ver cómo muchos de los métodos usados en estos trabajos han sido repetidos hasta no hace muchos años.

Por último, se le dedicará una estancia para el 'tema religioso', la vida del más allá de estas civilizaciones y como eran sus rituales para los enterramientos pueden presentarse a través de la documentación epigráfica con aspectos funerarios, sarcófagos encontrados y sus ajuares poniendo en consonancia los distintos modelos de necrópolis de la zona incluyendo el de Itálica, Dos Hermanas y Carmona. Muy interesante aquí las piezas que se conservan de pequeños enterramientos que deberán ser apoyadas por paneles de textos e imágenes explicativas sobre la función de estos enterramientos y el porqué de su uso de esa manera y no de otra, diferenciándolos con otros tipos de enterramientos de otras civilizaciones anteriores, posteriores(catacumbas) y de diferentes lugares geográficos.

Para finalizar, atenderemos a las dos últimas áreas temáticas dedicadas a la Antigüedad tardía y al Legado

Andalusí. Se planteará el cambio trascendental de la Historia con la aparición del cristianismo y sus primeras manifestaciones artísticas. Entre los distintos subtemas que se pueden tratar, podemos desarrollar sus orígenes en las catacumbas romanas y su impronta en la civilización de la Hispania del siglo II. Añadir la diferencia de esas clases sociales entre las más acomodadas y las menos pudientes para atesorar en su poder ajuares funerarios que plasman la creencia cristiana. Los sarcófagos, los mosaicos sepulcrales, la colección de elementos arquitectónicos decorados con citas bíblicas, la epigrafía paleocristiana, las 
lucernas para alumbrar mientras oraban la liturgia, nos evocan la majestuosidad de su legado que hay en el museo junto con la transmisión de su pensamiento a través de este hecho.

La caída del Imperio Romano dio lugar a la invasión de otras civilizaciones que ocuparon la Bética. Entre otras, aparece la influencia de las corrientes llegadas del Mediterráneo Oriental, sobre todo la sociedad islámica. Los temas a tratar podrían plasmarse a través de la sociedad y la cultura andalusí, con epitafios, inscripciones originales y objetos de época califal, como la pila de abluciones nos pueden ambientar en la contextualización histórica de Sevilla durante el califato a través de la recreación.

Para la ambientación museográfica de estos temas sería muy interesante ligarse al modo presentado por Rodríguez Frade en el Museo de la Alhambra, ya que las piezas que conserva el museo son principalmente artes decorativas y algo de arquitectura interior, así el juego de colocaciones en alturas de al arquitectura semejando su colocación real, el ambiente de luz artificial, maderas y colores cálidos seria lo más acertado, y llevaríamos al espectador a identificar estas formas con el mundo árabe que no solo estuvo presente en el reino de Granada sino que fue la civilización más importante, junto a Roma, que pasó por tierras del Valle del Guadalquivir. Aprovechando esto se podrían ir colocando paneles explicativos sobre la evolución de la cultural islámica en la ocupación de la Península Ibérica y su posterior abandono a la fuerza por parte de los Reyes Católicos, así también estaríamos dando la importancia que se merece e invitaríamos al espectador a seguir conociendo la historia de los acontecimientos y culturas que conforman la cultura andaluza en la actualidad

Como anécdota podemos exponer la romántica leyenda de Al-Mutamid y Rumaykiyya, recogido en el epígrafe de la erección de un alminar en la mezquita de la princesa. Colocando aquí la inscripción traducida y una explicación 
sobre la forma tan particular de escritura de una cultura tan cercana a la nuestra.

Por otro lado, no debemos dejar pasar todas y cada una de las aportaciones de esta civilización que hoy día perdura en la ciudad de Sevilla, y su extensión en el sur de la Península Ibérica. Entre estas aportaciones citaremos la facultad artística de la decoración mural con azulejos, sus vasijas,...los fragmentos de artesonados, celosías y otras piezas mudéjares como legado de sus manifestaciones artísticas. 


\section{IV.4. CUADRO DEL DISCURSO}

\begin{tabular}{|c|c|c|c|}
\hline \multirow{20}{*}{ 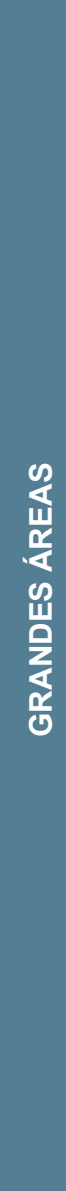 } & \multicolumn{2}{|c|}{ UNIDADES TEMÁTICAS } & SUBTEMAS \\
\hline & \multirow{2}{*}{\multicolumn{2}{|c|}{ ¿¿¿ARQUEOLOGÍA??? }} & Situación geográfica e histórica \\
\hline & & & Ciencias científicas de investigación \\
\hline & \multirow{4}{*}{\multicolumn{2}{|c|}{ HISTORIA DEL M.A.S }} & Legado de anticuarios y coleccionistas sevillanos \\
\hline & & & Documentación Bibliográfica \\
\hline & & & Personajes ilustres y destacados \\
\hline & & & Evolución arquitectónica del edificio y su colección \\
\hline & \multirow{6}{*}{ 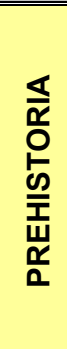 } & \multirow{6}{*}{$\begin{array}{c}\text { TESOROS DEL BAJO } \\
\text { GUADALQUIVIR }\end{array}$} & Primeros pobladores \\
\hline & & & IIII Milenio \\
\hline & & & Valencina de la Concepción \\
\hline & & & Cultura Tartésica \\
\hline & & & Cultura Ibero- turdetana \\
\hline & & & Romanización \\
\hline & \multirow{7}{*}{$\frac{\mathbb{U}}{\frac{U}{1}}$} & \multirow{7}{*}{ ITÁLICA } & Los italicenses \\
\hline & & & Itálica \\
\hline & & & Edificios Públicos \\
\hline & & & Itálica al aire libre \\
\hline & & & Venus \\
\hline & & & Mercurio \\
\hline & & & Diana Cazadora \\
\hline
\end{tabular}




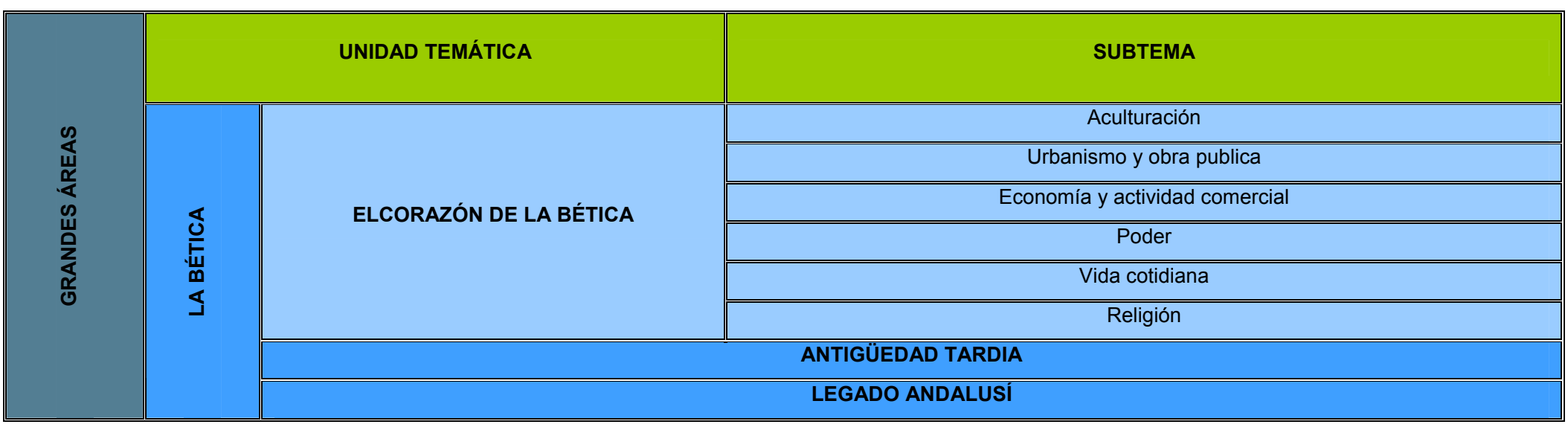




\section{IV.5. PLANOS DEL DISCURSO}

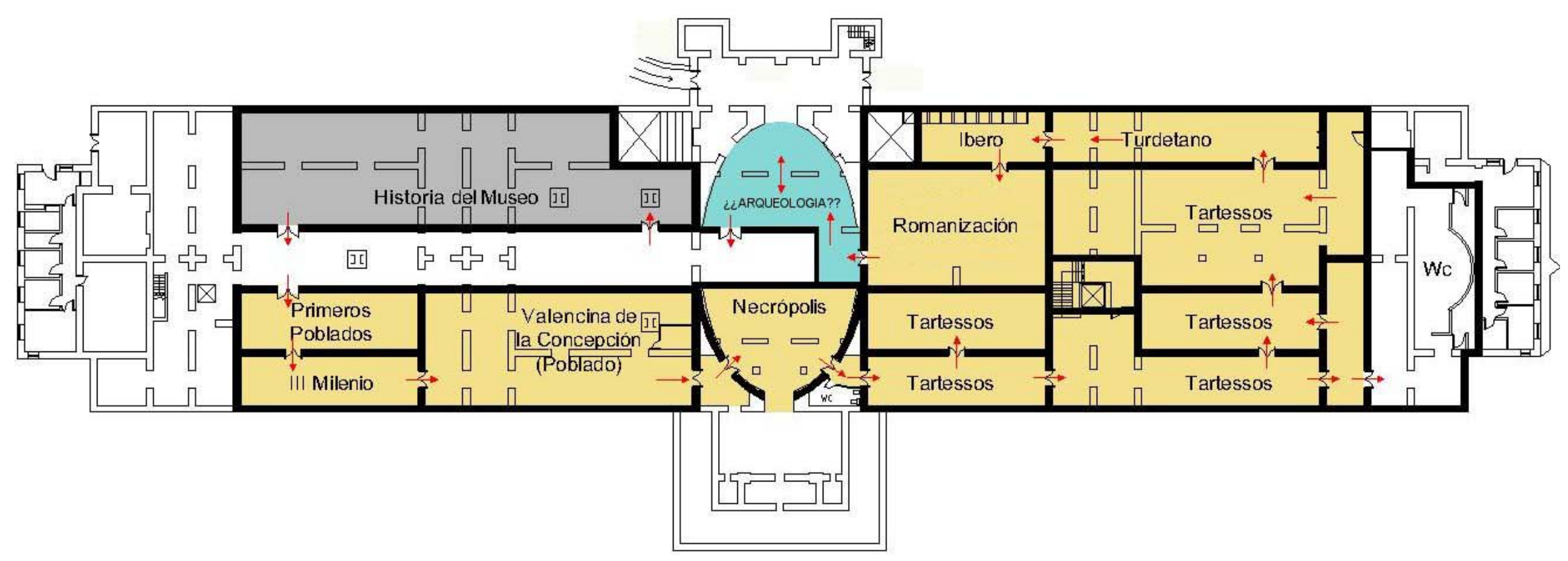

¿¿ARQUEOLOGIA??

Historia del M.A.S.

Tesoros del Bajo Guadalquivir 


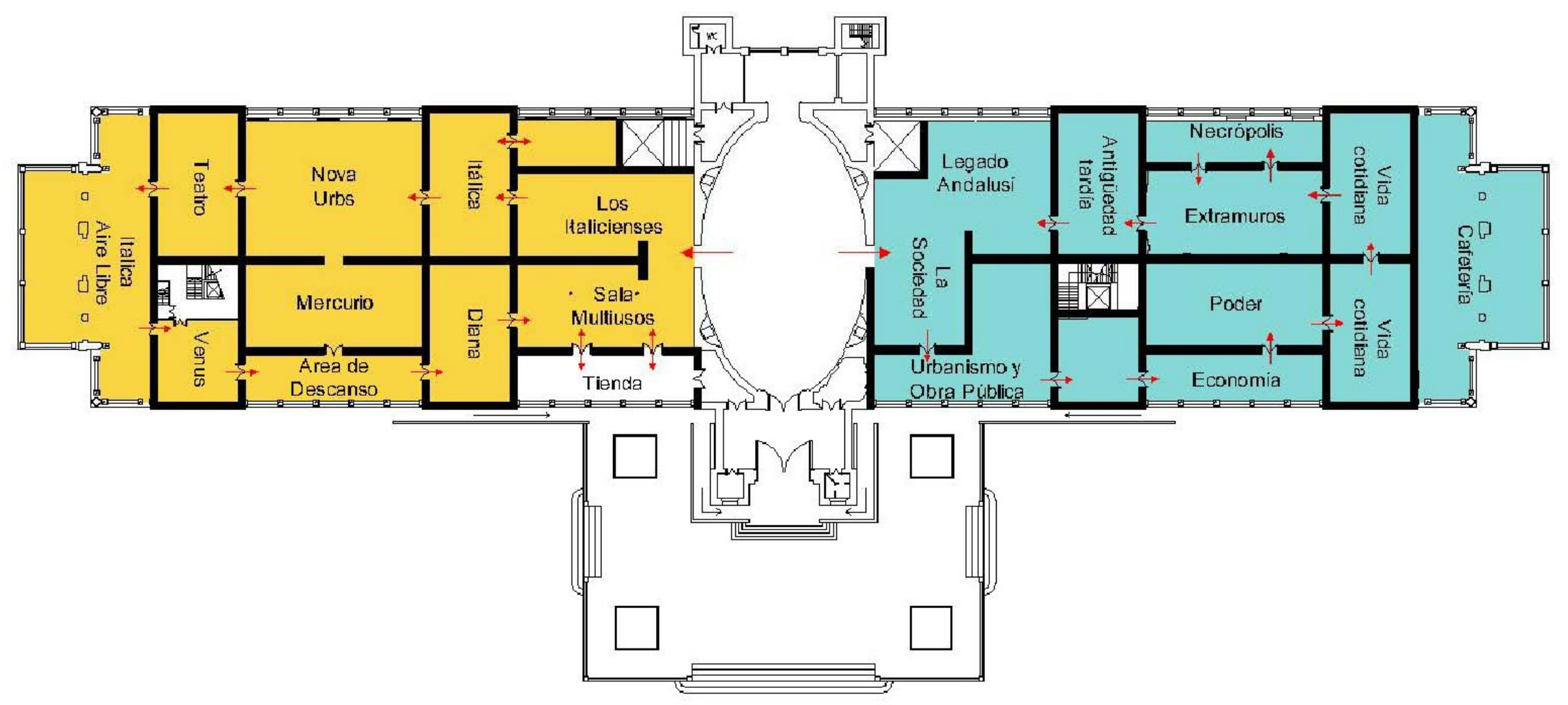

Itálica

El Corazón de la Bética $\mid \begin{aligned} & \text { Antigüedad Tardía } \\ & \text { Legado Andalusí }\end{aligned}$ 


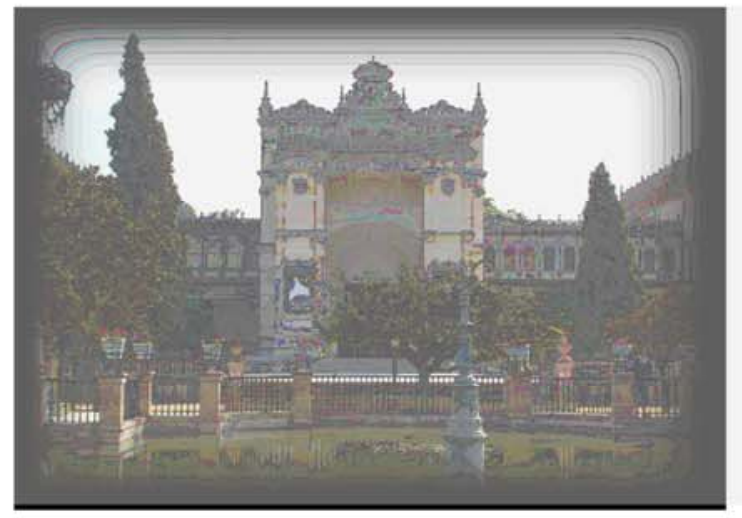

\section{DIFUSIÓN}

\section{Rafael Díaz Alonso}

Museo

Arqueológico de Sevilla 


\section{V.1. LA DIFUSIÓN EN UN MUSEO ARQUEOLÓGICO}
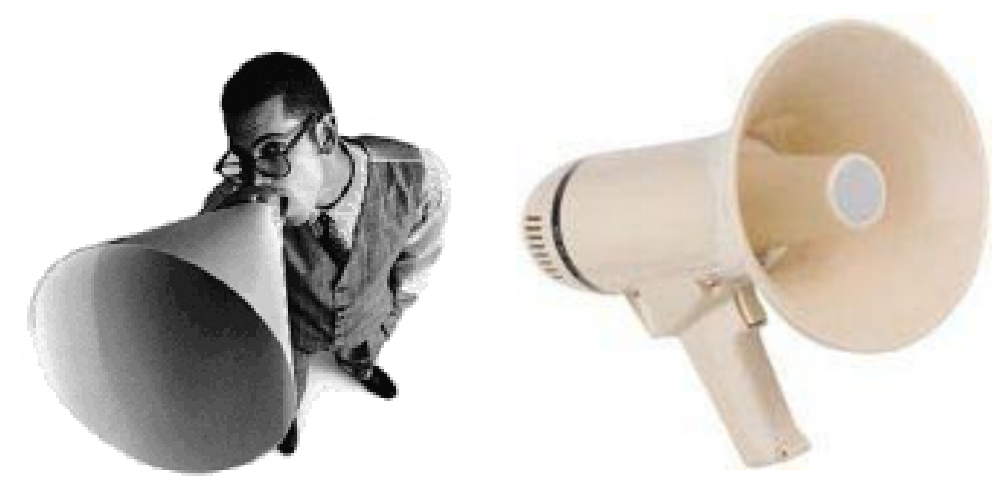

Los museos arqueológicos suelen atraer a un público reducido. Por lo que considera necesaria una "profunda reflexión" para resultar más atractivos. No hay que olvidar en relación a esto que "un museo es cada vez menos lo que tiene y cada vez mas lo que hace". Lo que obliga a diseñar un adecuando conjunto de programas públicos y educativos, que sirvan para complementar los mensajes hacia expectativas y objetivos determinados, en reacción con las tareas del museo.

Debiéndose desarrollar, así, el papel mediador entre el museo y el público poniendo énfasis en la función comunicadora del museo, ya que es lo que le permite a la institución integrarse en la sociedad que le ha dado origen y mantenerse activa.

Para que el museo pueda estar "al servicio de la sociedad y desarrollo, abierto al publico, que adquiera, conserve, investigue, comunique y exhiba para fines de estudio ,de educación y deleite testimonios materiales del hombre y su entorno" 60 hay que consolidar los equipos y el trabajo de los profesionales del museo dedicado a la difusión y educación en el Museo.

La programación de las visitas escolares o la oferta de guías o diseño de algunas actividades con colectivos concretos son importantes pero no suficientes. Sólo es una

\footnotetext{
${ }^{60}$ Estatutos del ICOM
} 
parte de los servicios para la difusión que se debe de ofrecer al publico.

Por ello, se establecerá los elementos genéricos y criterios básicos para desenvolver unos proyectos adecuados de difusión, que posteriormente se presentarán como propuestas.

El museo arqueológico es una institución cultural, un almacén de conocimientos y no de meros objetos, lo cual se debe de reflejar en la difusión. Divulgando no solo los objetos sino también de los conocimientos. Por tanto el museo debe de realizar una acción cultural basándose preferentemente en colecciones que posee. Además la acción cultural del museo se organizará teniendo en cuenta que no es un centro cultural independiente y único, sino que se debe de diseñar teniendo en cuenta buscando la complementariedad con los demás centros. No debiendo, de este modo, organizar actividades completamente ajenas a la institución.
La dimensión social del museo obliga a trabajar para poner en disposición de la sociedad todos los conocimientos extraídos de sus colecciones, contribuyendo en el desarrollo de la comunidad: para el estudio, deleite, investigación, transmitiendo a ésta todo aquello que la pueda enriquecer desde un nivel intelectual a emocional. Así el museo permitiría el desenvolvimiento de la dimensión cultural como aspecto global del ser humano, y permitir además desarrollarse como colectivo. De aquí el desarrollo progresivo al que se debe llevar la institución en la conciencia de servicio al ciudadano; $Y$ por tanto que favorezca una total y amplia comunicación con la sociedad. Una sociedad que se acercará en su tiempo libre o laboral; para ver sus exposiciones, para estudiar las colecciones, para asistir a actividades culturales, para aprender, para consultar en la biblioteca, para obtener placer, etc.

EI MAS debe de trabajar en su implicación con el territorio, cada museo es diferente, presentando unos testimonios históricos únicos y relacionados con un territorio preciso, 
dentro de una red y una configuración irrepetible. Además la función de sus actividades de un modo u otro colabora en el desarrollo de su propio ámbito, en nuestro caso el Polígono sur, Sevilla, Andalucía, etc.

El éxito del acto comunicativo del museo se valorará en cuanto a la calidad e implicación de los servicios establecidos. Así, El éxito de la difusión no se medirá exclusivamente en la cantidad de público y variedad sino también en el papel científico que la institución debe jugar en su territorio.

El Museo Arqueológico de Sevilla como comunicador debe de hacer llegar las investigaciones realizadas en el museo o relacionadas con los fondos del museo, por ello la comunicación debe ser actual: Nuevos materiales encontrados, ultimas y nuevas interpretaciones, nuevas formas de investigación, etc; Ofreciendo un mensaje contemporáneo y no obsoleto. Debe de diseñarse, para ello, diferentes medios adaptándolos a cada tipo de receptores. Dotándose de metodologías comunicativas atractivas, teniendo en cuenta aprovechar las oportunidades del momento para rentabilizar los esfuerzo de comunicación. La exposición se nos presenta como el recurso más propio del museo para la difusión, pero no el único. Ésta permitirá presentar los contenidos de forma adecuada, pudiendo presentarla en contextos mas generales, aprovechando conceptos y temas muy atractivos para el publico: anécdotas, juegos, sorpresas, tesoros, etc.

La difusión en el Museo Arqueológico se centraría en el ámbito de sus colecciones y la disciplina científica de la arqueología en la Provincia de Sevilla. Difundiendo a las generaciones actuales y futuras los conocimientos que de las colecciones se extrae a través de la documentación e investigación. Además promovería el interés de la disciplina arqueológica como método de investigación y de la aportación de la interpretación de la historia a través de 
la arqueología para el conocimiento de nuestro patrimonio e historia.

La arqueología y el método arqueológico estudian el pasado principalmente a través de materiales conservados. El descubrimiento de información del pasado por medio de restos materiales mediante un análisis científico y el ejercicio de la imaginación creativa aportan una esmerada interpretación del pasado que nos permite entender al ser humano. Es decir interpretando la cultural material en términos humanos. Los objetos arqueológicos no dicen mucho directamente, su registro arqueológico ofrece la oportunidad de recoger datos, permitiendo realizar experimentos y formular hipótesis, por lo tanto, ciencia y disciplina humanística.

EI MAS como museo arqueológico nos puede ofrecer diferentes oportunidades:

-Cuestiones profesionales de la arqueología: métodos, formas de entender de trabajar problemáticas etc.
-Interpretaciones del pasado basado en las disciplinas arqueológicas.

\section{-Hacer uso de la historia como disfrute, enseñanza y} desarrollo.

Son tres grandes niveles que el museo debe de trabajar y ofrecer a los diferentes tipos de usuarios. Debiéndose tener cuidando los niveles que se facilitan. Muchas veces dar más importancia en las exposiciones o actividades al primer nivel y es el origen del poco éxito de estos servicios. Cada servicio del Museo Arqueológico se centrará en el nivel más adecuado: biblioteca, archivos, exposición actividades; Atendiendo, además, al tipo de usuario según características, necesidades, etc.

En relación a La educación patrimonial el museo debe ser consciente de su valor educativo cultural. El descubrimiento de nuestro patrimonio estimula la conciencia critica, respecto a nuestras creencias y nuestra 
identidad, así como el respeto a hacia los demás, a la vez que constatamos la existencia de valores humanos compartidos (en le tiempo y en el espacio) que unen a las diferentes culturas. El Patrimonio Cultural nos permite entender mejor el papel de la humanidad en el mundo a través del tiempo, colaborando en apreciar con más intensidad la dimensión ética y moral de la vida humana. Así vemos que Valor indiscutible del Patrimonio en el desarrollo de la humanidad

Así para las generaciones siguientes es necesario la conservación del patrimonio. Por lo que el museo tiene una función de Tutela con el patrimonio de sus colecciones y su territorio. Debiendo asumir un papel en la recuperación y análisis del patrimonio arqueológico del territorio del que forma parte geográficamente y culturalmente.

\section{El museo tiene a la historia como uno de elementos}

centrales, "si el conocimiento de la historia tiene una importancia práctica es porque por ella aprendemos a conocer hombres, que en circunstancias diferentes, con medios diferentes, en la mayoría de los casos inaplicables a nuestra época, que han luchado por valores e ideales análogos a los que tenemos en la actualidad, y esto nos da conciencia de formar parte de un todo que nos trasciende, que continuamos presente y de los que vendrán por el porvenir" ${ }^{61}$. A falta de museo de Historia hace que los museos provinciales deban de subsanar esta carencia convirtiéndose en un museo historia y arqueología. De este modo el MAS muestra los testimonios históricos a través de una metodología concreta. Este uso compartido impide en algunos casos una difusión centrada en el método e investigaciones centradas propiamente en la arqueología.

El Museo Arqueológico de Sevilla se erige como lugar propio para la difusión de la historia por medio de patrimonio. El tratamiento por yacimientos se sacrificaría en parte por la presentación de una narrativa histórica. Presentado una narrativa de la historia basado en la

${ }^{61}$ Goldmann Lucien. 
arqueología. Introduciendo aspectos de la antropología histórica, historia de las mentalidades, sociología historia, sicología, historia del pensamiento, etc. a la hora interpretar el patrimonio arqueológico. Dando, además, una complementación de la información de los materiales arqueológico analizados desde múltiples disciplinas.

Se intentará mostrar una visión más global de los diferentes aspectos que conforman las culturas que nos llegaron a través de testimonios materiales. De este modo, el museo es un lugar de recuperación de la memoria histórica en un amplio sentido. Permitiéndonos una visión general de la memoria histórica y la recuperación de algunos aspectos olvidados. Es hora que conozcer toda nuestra Historia, para que algunos dejen de ubicarse en la actualidad como si estuvieran en el pasado y también dejen de templar miedos que frenen a una sociedad que desea avanzar socialmente. Recuperando la memoria histórica de diferentes grupos, personas y sociedades que lucharon, sufrieron (esclavos, niños, mujeres, grupos religiosos, artistas, etc) que ya hemos olvidado y en muchos casos no aparecen el los discursos de nuestros museos historicos.

La institución puede servir para mantener la memoria histórica del pasado, ya que " sin la historia no se entiende el presente, la historia es la maestra de la vida", como decía Cicerón; ayudándonos a evitar los errores que se han cometido.. Así el MAS trataría del pasado, presente y futuro, lo cual se debe de reflejar en la planificación y contenidos de la difusión del museo.

Toda esta base teórica nos permite establecer el objetivo principal de la difusión del Museo arqueológico de Sevilla.

Objetivo: Poner a disposición de la sociedad todos los conocimientos extraídos a partir de las colecciones arqueológicas, para desarrollo de la persona por medio de deleite, la educación, etc.,así como enriquecer a la comunidad. 


\section{V.2. ÁREA DE DIFUSIÓN}

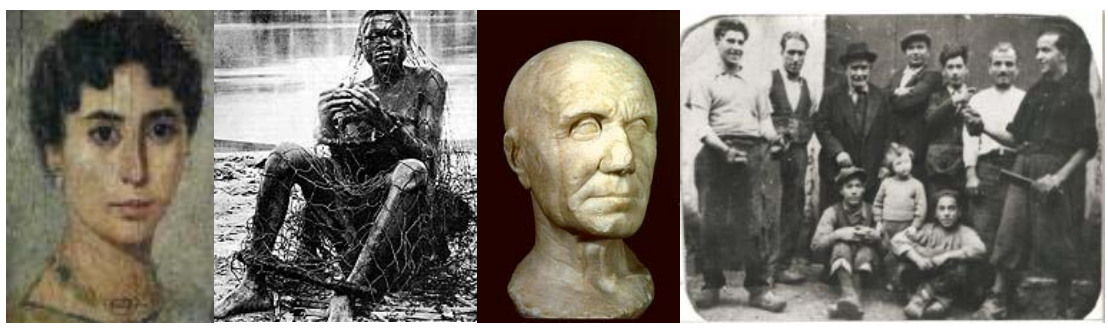

Presentamos los criterios básicos para el desarrollo del área de difusión en el museo. Basada en la difusión entendida en un sentido amplio.

Partiría de la visión socializante del patrimonio que adquiere su valor mediante la contemplación y compresión y uso por parte de los integrantes de la sociedad. Y se ocuparía de las actividades pedagógicas para escolares, para demás grupos de educación formal, visitas individuales, grupos especiales, actividades de difusión general etc. Es decir para todo tipo de público del museo.
El primer trabajo debe de ser la definición de los departamentos que trabajaran la relación del museo y el público:

\section{V.2.1. Sus objetivos ${ }^{62}$ :}

Consistirán en participar íntegramente en los objetivos generales del museo, responder de manera especifica a la finalidad comunicadora del museo por su propia definición, además de dinamizar el museo, según la oferta y demanda de la comunidad.

Las funciones del departamento: Relacionadas con la actuación sobre los siguientes campos: el museo, el público, la relación museo-público.

${ }^{62}$ Basados en las IV jornadas de DEAC de Museos(1985) 


\section{V.2.1.1. Campo de trabajo del departamento}

Respecto al museo:

-Estudiar las posibilidades comunicativas del museo, de las colecciones (sus contexto social y natural, como testimonio de la evolución) y de la disciplina del museo.

-Análisis y selección de los niveles de información que desprende el objeto y su carácter interdisciplinario.

-difusión de la imagen institucional del museo en las facetas de investigación, de estudio, de educación y lúdico.

Respecto al público:

-Investigación sobre tipologías, características sociológicas del público, según factores diferentes del mismo. Utilizando recursos externos y creados por el propio museo.
-Programación de montajes, servicios y actividades dirigidos a diferentes tipos de público. Organizados dentro del él o fuera.

-Establecer programas de actuación que recojan las demandas culturales del público.

-Ampliar el campo de acción del museo hacia el público potencial. Además de insistir en la formación de educadores, animadores culturales y guías, voluntarios etc.

Respecto a la comunicación museo-publico

-Cooperación en el planteamiento comunicativo del montaje museográfico, desde el inicio hasta su realización, formando parte del equipo técnico del museo, en el que se aporte la visión de las distintas especialidades, propias de cada función del museo. 
-Planteamiento y actuación sobre las ediciones escritas, audiovisuales, etc., destinados al público general, tanto en su diseño como en su contenido.

-Planteamiento y realización de ediciones.

\section{Metodología}

-Trabajo en equipo

-Control de la calidad de servicios

-Rigor científico

-Documentación sobre la actuación del departamento

-Evaluación de resultados.

\section{Dependencias}

Se contará con: Dependencias de uso interno: departamento, almacén de material diverso y de uso público: salón de actos biblioteca, sala de usos múltiples, áreas de descanso, aula didáctica, etc.

\section{Recursos-infraestructura}

Las diversas tareas serán llevada a cabo por :El personal técnico del museo, becarios de formación, personal contratado para servicios y voluntarios.

\section{Presupuesto}

Para la consecución del objetivo establecido anteriormente se definen las siguientes líneas estratégicas:

-Difusión de las colecciones y el conocimiento relacionado.

-Gestión optima de la difusión.

-Diseño de una programación más contínua. 
-Llegar a todos los públicos a través de los programas de difusión. Aplicando los conocimientos de las características y necesidades del usuario en la programación.

-Aprovechamiento de recursos variados(web, contenidos, instalación, voluntarios, etc.).

-Aprovechar la potencialidad del museo, el cual pueda encantarse entre los primeros de España, creando un "profundo proceso de transformaciones para mejorar su servicio".

-Gestión de la comunicación: el museo como comunicador.

-Integración del diseño de exposición permanente con el resto de programación de actividades de difusión.

La programación de actividades se basará en un presupuesto real.

\section{V.2.2. Proyectos}

A partir de las líneas estratégicas establecidas se desarrollaran las diferentes propuestas de difusión con envergadura y entidad diversa, las cuales deberán ser totalmente definidas tras la planificación temporal concreta.

\section{V.2.2.1. Proyecto de gestión de actividades de difusión.}

\section{Gestión de contenidos.}

Se deberá de definir contenidos prioritarios para el diseño de los programas educativos y de difusión.

- Por contenidos:

-Conocer aspectos históricos: Historia de Sevilla y Provincia, el corazón de la Bética, Itálica, el coleccionismo en Sevilla. etc. 
- Por actitudes:

-Sensibilización sobre el patrimonio.

-Conocer el museo como lugar de conservación.

-Conocer las colecciones que el Museo conserva.

-Acercarse a la metodología arqueológica como método para el conocimiento.

- Por valores:

-Respeto a la dignidad humana y los derechos.

-Respeto a las diferentes culturas.

-Vivir en valores positivos.

-Equilibrio social y con el entorno.
-Apostar por el desarrollo continuo del individuo y comunidad a partir del Patrimonio.

\section{V.2.2.2. Gestión actividades y La programación de} actividades.

Se establecerán los mecanismos adecuados para la gestión de la difusión. La gestión seguirá las cuatro funciones para alcanzar sus objetivos: Planificación, organización, motivación y control; teniendo en cuenta dentro de la gestión de recursos.

La programación de las actividades será un aspecto fundamental para la consecución de objetivos propuestos en los programas de difusión en concreto.

En primer lugar se partirá de la concepción de los programas de difusión como parte fundamental de los 
servicios del museo. Por lo que la permanecía de la programación permitirá que se perciba como servicio(ver apartados servicios),favoreciendo , a la vez, la fidelización del público.

La programación de actividades no son un complemento a la exposición permanente o temporal sino un elemento más del museo.

La planificación deberá ser estudiada, no premeditada, con una lógica a largo tiempo, que permita abarcar a los públicos objetivos establecidos previamente. Debe ser, además, una programación que no se diseñe independientemente sino relacionado: las exposiciones temporales, la programación pedagógicas y demás actividades. Permitiendo aprovechar y apoyarse unas actividades con otras, optimización de recursos, ideas, potencialidad.
El personal técnico del Museo llevará a cabo las tareas de que planificar, marcar objetivos, supervisar el desarrollo, controlar y evaluar, externalizando en algunos casos la producción y ejecución. Además este servicio se sustentará, en parte, gracias al grupo de Voluntarios del Museo, que de manera totalmente desinteresada y sin contraprestación económica alguna, dedicarán su tiempo y sus conocimientos a la difusión del Museo y su Colección a públicos especiales.

\section{La programación}

Un plan de actuación como el plan de difusión del museo deberá tener un horizonte temporal de al menos tres años, aunque se haga un especial hincapié en el primer años y dar una visión general de los dos siguientes. El plan de actividades deberá ser dinámico, es decir que una vez realizado algunos acontecimientos internos o externos pueden requerir modificaciones al mismo, y en cualquier caso una vez puestos en marcha conviene volver a 
estudiarlo actualizándolo al menos de forma anual, incorporando la experiencia adquiridas y añadiendo un año mas en el horizonte de planificación, de manera que siempre contemple 3 años. El desarrollo completo anual se ajustará a las diferentes necesidades y tendencias de usuarios, el cual estará diferenciado en periodos Cuatrimestrales:

-Septiembre-Diciembre: inicio del curso escolar.

-Enero-abril.

-Mayo -Agosto: caracterizado por el día de los Museo, el buen tiempo para la realización actividades en el exterior y la ampliación del tiempo de ocio del público general.

Además, el plan de difusión-actividades debe de contemplarse de forma conjunta con los demás planes establecidos por el museo(de comunicación, etc.) ya que unos se condicionan a otros.
Se apostará por la colaboración con entidades, asociaciones, etc. interesadas en las actividades programadas, la planificación permitirá evaluar la viabilidad de los proyectos para emprender y posibilitar la búsqueda de recursos financieros o recursos materiales con antelación.

Cada diseño de actividad del plan de difusión contará en un concepto básico de:

- Objetivos generales.

- Objetivos específicos.

- Actividad.

- Destinatario.

- Lugar.

- Metodología.

-Temporalización.

- Recurso personal.

- Evaluación para la planificación.

- Archivo.

- Mejoras. 
La elección de temáticas y su programación en fechas determinadas podrá ser tenida en cuenta. Como en el caso actividades de temática relacionada con la navidad, días internacionales, etc. Además se intentará aprovechar modas o noticias para crear actividades: Así el impacto Código da Vinci permitiría la programación de exposiciones o visita de los códigos ocultos del museo; o la presentación del diseño Metrosol parasol hubieran sido motivo de actividades en el museo, excusas para presentar contenidos rigurosos para reflexionar sobre las noticias.

Este proyecto de difusión propone una amplia gama posibilidades de actividades las cuales se pueden desarrollar dependiendo de los recursos y objetivos de la planificación a largo tiempo. No se proponen como actividades que funcionen todas a la vez, sino como propuestas a elegir.
De este modo, en la implantación de la planificación para la difusión tendremos en cuenta dos niveles:

-La planificación a corto y medio plazo.

-y la planificación a largo plazo.

En el siguiente cuadro diferenciaremos los proyectos que son imprescindible desarrollar en un corto y medio plazo y los que pueden ir desarrollándose posteriormente, a media que los medios económicos lo permitan y las necesidades lo requiera. La evaluación de los planes de difusión realizados permitirá establecer los programas que deben de seguir realizándose o qué actividades han de ser sustituidas en los siguientes planes (para lo cual presentamos diversas opciones en cada propuesta). 


\section{Programación a corto y medio plazo.}

-Programas educativos para diferentes niveles.

- Actividades para Navidad.

-Dos Exposiciones temporales al año, y un numero de microexposiciones variables según la coyuntura.

-Inicio de la política de colaboración institucional para proyectos concretos.

-Puesta en marcha de la primera fase de la programación de publicaciones.

-Acceso virtual al catálogo.

-Definición y primeras actuaciones para la Plaza de los Museos, fundamentalmente centrados en el día internacional del Museo y Noches con las Musas.

\section{A medio plazo:}

-Pieza del mes.

\section{-Domingos en familia.}

-Proyecto arqueología abierta

-Modulo de arqueología virtual: La historia Viva

-Inicio en promover la celebración de Días conmemorativos.

-Atención a necesidades (educativas) especiales

-Desarrollo de primeras iniciativas del Proyecto CNP.

-Ampliación de publicaciones monográficas, colección Harris, etc.

-Una vez que esté remodelada la biblioteca se implantarán diversas actividades para dinamizar su uso.

\section{Programación a largo plazo}

-Diversificación de los programas educativos dentro de cada nivel.

- Incrementar las actividades relacionadas con la Plaza de los museos(pabellón Real y Noches con las Musas).

-Formación de profesorado. 
-Atención a otros sectores sociales.

-Espacio para actividades de verano.

-Actividades para personas mayores.

-Implantación de mejoras en los servicios a través de la web.

-Desarrollo del programa de Museo abierto.

- Creado un nuevo almacén se desarrollará el programa de Acceso a éste.

Dentro de cada apartado de propuestas de difusión se presentara diversas opciones, lo no que significa que todas se implanten, sino que pueden establecerse como opciones a elegir para desarrollo a la hora de la planificación.

\section{Diseño de personajes para dinamización}

Para el desempeño a lo largo del tiempo de diferentes actividades será necesario el diseño de unos personajes atractivos para el publico infantil.
Se ha optado por la definición de unos personajes basados en personajes reales Baalyaton y su hermano Abdbaal, hermanos que dedicaron la escultura de Astarté. Sus nombres en diminutivos serian: Bal y Adba. Para su diseño definitivo se proponen los siguientes rasgos para caracterizarlos:

-Son hijos de un comerciante del Mediterráneo.

-Ha acompañado a su padre en muchos viajes y han tenido muchas aventuras conociendo diferentes culturas.

-Tienen la posibilidad de imaginarse viajando a través del tiempo.

\section{Espacios para la comunicación}

Para la remodelación de espacios se precisa trabajar conjuntamente aportando necesidades e ideas a los 
proyectos arquitectónicos. Permitiendo establecer exigencias para cada espacio.

Los espacios donde se pueden realizarían actividades son:

-Aula didáctica: para talleres y recepción,

-Salas de exposición permanente: donde se realizarían actividades en salas, visitas guiadas, visitas dramatizadas, etc.

-Sala de exposición temporal: donde se desarrollarían, igualmente, actividades en salas, visitas guiadas, visitas dramatizadas, etc.

-Hall: Para la recepción de visitas dramatizadas.

-Salón Multiuso.

-Espacios de descanso.

-Salón de actos: Que permitiese la realización de talleres con exigencia de escenario, conferencias, proyecciones, etc.
-Plaza de América: donde se desarrollen diversas actividades. Teniendo en cuenta la seguridad y la limpieza.

\section{V.2.2.3. Proyecto de programas educativos}

A continuación presentamos un amplio avance de actividades necesarias propuestas a potenciar por el museo. Propuestas que sirvan de ideas base para la diseño y ejecución de los proyectos. Para cada publico y nivel se establecerá diversas opciones a elegir.

Para su definición se ha partido del concepto del museo como un instrumento de aprendizaje para el ser humano en constante desarrollo.

En primer lugar trataremos los Programas Educativos que se realizarían de forma presencial en el Museo. Se presentan actividades educativas de diversa índole y se 
han estructurado en función de los públicos y sus necesidades.

Las propuestas educativas del museo se dirigirán a todos los niveles y colectivos, tanto de la educación formal como la del ocio.

El programa de actividades de educación formal abarcarán Educación Infantil, Primaria y Secundaria Obligatoria y Postobligatoria, ajustando los contenidos y los procedimientos a los objetivos y contenidos curriculares de los diferentes ciclos de cada etapa.

También, las propuestas van dirigidas a la Educación de Adultos y a las personas con Necesidades Educativas Especiales, diseñadas para atender a las necesidades de ambos colectivos y creadas expresamente.

Las actividades de Difusión General, se conciben como educación no formal dentro de un sentido amplio de la educación, presentaremos diversas oportunidades adaptadas a los diversos colectivos y circunstancias. Se intentará abarcar una diversidad de público usuario tratados en grupos homogéneos.

Se propondrán, además, actividades dirigidas a las familias durante los domingos, que ofrecerían entretenimiento a pequeños y mayores.

Las actividades del programa estarían diseñadas por el área de difusión y serían llevadas por educadores especializados y voluntarios.

Las propuestas para cada nivel se presentan con diferentes opciones de actividades. No quiere decir que todas ellas se pongan a disposición del publico sino que en el diseño concreto para cada nivel se podrá optar por una u otra propuesta. En algunos casos se podrá diseñar totalmente varias actividades para un nivel, para que el personal de difusión pueda elegir una u otra según el momento, además de evitar los aspectos nocivos de la repetición de las mismas taras. 


\section{V.2.3. Programación para la educación formal}

Un amplio grupo objetivo en la atención en la visita al museo es el público escolar de educación obligatoria. Se ha plantado el diseño de actividades en salas dependiendo de las posibilidades del espacio, las cuales centrará su motivo en los objetos expuestos en salas.

Dos tipos de actividades propuestas:

- La autónoma: en la que el profesor prepara la visita con su cuenta o ayuda de material, o bien siguen actividades diseñada para la vista autónoma.

- Con monitor: vistas diseñadas por área de difusión. Podrán ser visitas guiadas concertadas o actividad Programa de Visitas Dinamizadas, taller, cuento animado, etc
El Programa de Visita Dinamizada que consiste en la realización de un recorrido temático por el Museo acompañados de un educador que anima a la participación y al análisis, descubriendo aspectos de la historia de nuestros antepasados y métodos para el conocimiento de la cultura material por parte de los alumnos. Las visita guiada llevaría a conocer diferentes piezas del museo dentro de su contexto cultural y arqueológico.

Recogen Actividades para exposición permanente, para exposición temporal, que complementan el aula didáctica.

Los contenidos se especificarán en el diseño de cada programa de acuerdo con los objetivos de difusión.

Además, el departamento redactará una serie de normas para las visitas concertadas que será de obligado cumplimiento para todos los grupos que quieran participar en estos programas. Con objeto del buen funcionamiento de las actividades se establecerá: 
- El numero máximo de reserva por Centros.

- La gratuicidad de actividad.

- El número máximo de alumnos.

- Agrupo máximo de profesores.

- Forma de admitir las solicitudes de la actividad.

- La duración de la actividad.

- Puntualidad del grupo.

- Responsabilidad de loso profesores ante el grupo.

- La función del profesor en la actividad.

- Documentación para acceder a la actividad.

La actividad se solicitaría por las diferentes vías con suficiente antelación según ya funciona en el propio museo, Siendo la solicitud por la web la manera más propia.

Los grupos educativos que se atendería se han establecido a partir de:

\section{La edad, y, el contexto.}

En la edad se trataría a los cursos escolares y el contexto la adaptación de la actividades a necesidades concretas de los alumnos (Barrio marginal, intereses determinados, lugar de origen, discapacidad determinada).

En la educación infantil se trataría con niños de 3 a 5 años. En la educación primaria contaríamos con alumnos de primer ciclo, segundo ciclo y tercer ciclo. $Y$ finalmente en la educación secundaria estaría dividido en primer y segundo ciclo.

El desarrollo de un programa de educación formal debería de ir acompañado de una ampliación de ayuda al profesor:

En colaboración con la ya emprendida con el Gabinete Pedagógico, se intentaría potenciar cursos de formación de profesorado para la vista del museo arqueológico. Seria 
muy útil el diseño de una carta de servicios disponibles al profesor y su difusión. Establecimiento claramente de los recursos disponibles para el profesorado (espacios para actividades en el museo, material didáctico, publicaciones,...)

Se proponen las siguientes opciones de recorridos a elegir para el Programa de Visita Dinamizada a la colección permanente. Éstos tendrán diferente desarrollo según la edad y nivel educativo:

- La historia del "Taper"

- Historias misteriosas

- Nosotros y nuestra ciudad.

- Tu, yo, el y nosotros Conociendo lugares y gentes

Cualquiera de las actividades pretendería:

-Acercar al niño al entendimiento de la cultura material, obtener información del patrimonio.
-Desarrollar el pensamiento crítico y educativo, estableciendo interrogantes al niño.

-Fomentar el diálogo entre los participantes y el respeto a la opinión del otro.

-Que la arqueología es una forma de reconstruir el pasado.

-Aprender a respetar cualquier forma de patrimonio, entendiéndolo como algo propio

-Establecer vías de colaboración y diálogo entre el Museo y las instituciones educativas

\section{- Infantil}

Las actividades diseñadas para los más pequeños consistirán en las Visitas Dinamizadas ya propuestas , o en: 
-Un Taller: En el cual la actividad que plantea como un descubrimiento del paisaje —urbano, rural y natural- a partir de maquetas y de elementos táctiles, sonoros, visuales y olfativos presentes es la exposición.

-Una fantástica narración-dinamización con los personajes Bal y Adba.

\section{- Primaria:}

Presentamos como alternativa ala visita dinamizada propuestas opciones pensadas para desarrollar la curiosidad, el deseo de observar, de comparar, de expresar sentimientos y emociones, y así avanzar en el proceso de descubrimiento y conocimiento.

-Visitas Dinamizada: Un fantástico cuento -dinamización con los personajes Bal y Adba, en la que conocen a Argantonio, Iberos, fenicios, romanos y visigodos, y viven, así, muchas y aventuras; permitiendo un itinerario con recorridos temáticos y cronológicos.

-Itinerario:¿Que es un museo?,El consejo de los sabios

-Donde vivían nuestros abuelos

\section{- Secundaria}

Para los alumnos de secundaria de proponen dos tipos de actividades a parte del Programa de Visita Dinamizada:

-El taller del arqueólogo. Actividad adaptada al nivel escolar, por la que se introduce en la investigación llevada por un educador. Los participantes se convierten en un ambiente lúdico en aprendices de historiadores, utilizando los principales procedimientos de las ciencias sociales: la manipulación de objetos, la observación y la comparación de fuentes primarias y secundarias, la clasificación de los 
datos obtenidos, la elaboración de hipótesis, el contraste de datos y el establecimiento de tesis. Con la finalidad de poder construir conceptos históricos claros y estructurados. Mediante el trabajo con las piezas de la exposición y textos, etc se podrían conocer las principales características de las formas de vida y de cultura romana, así como sus aportaciones a la cultura occidental en los ámbitos tecnológico, científico e intelectual.

El otro tipo de actividades son las Visitas Comentadas a

la Colección Permanente no en su totalidad, si no por temas, para poder facilitar la profundización. Se querrá acercar al público juvenil al Museo y a la Historia y ofrecerles unas herramientas básicas para entender el patrimonio histórico. La metodología aplicada en la actividad sería dirigida por un educador y se basa en el diálogo frente a la pieza y en la participación activa de los asistentes. Para el acercamiento a la Colección se ha pensado en los siguiente recorridos preparados, los cuales si se desarrollaria en totalidad ya que sería el profesorado el que elegiría el tema de mas interés.

-El ser humano curioso y científico.

-Tartesos.

-Roma.

-Iberos y la actualidad.

-Exposición temporal.

Este programa pretendería, entre otras cosas:

- Acercar al entendimiento de la cultura material, atreverse a preguntar a las colecciones.

- Desarrollar el pensamiento crítico y deductivo del niño.

- Fomentar el diálogo entre los participantes y el respeto a la opinión del otro. 
- Que la arqueología es una forma de reconstruir el pasado.

- Aprender a respetar cualquier forma de patrimonio entendiéndolo como algo propio.

- Establecer vías de colaboración y diálogo entre el Museo y las instituciones educativas.

\section{- Segundaría post-obligatoria}

La atención del publico escolar no se finalizará en la educación obligatoria. Se atenderán a adolescentes y jóvenes a los que usualmente se les oferta poco o nulos actividades de difusión especiales.

Para los alumnos de educación post-obligatoria, el Museo ofrecerá dos itinerarios cronológicos que repasan los hechos más significativos del valle del Guadalquivir. Todas las actividades de Bachillerato tienen en cuenta las necesidades educativas del nivel, tanto en lo que respecta a los contenidos como en lo que respecta a los procedimientos, valores y actitudes. Una tercera opción seria la de un taller practico.

-Itinerario A

-Itinerario B

-Clase dinámica de arte en el museo, Especialmente dedicado a Bachillerato de Arte. Donde se podrá dibujar con modelos originales etc.

\section{V.2.4. Proyecto necesidades (educativas) especiales}

Se atenderá a grupos que necesiten un apoyo especial para la comprensión de la exposición permanente motivado por físicos o psíquicos. El método elegido es el reforzamiento de sentidos alternativos o adaptación de contenidos. 
Aquellas actividades preparadas para grupos que requieran de una atención especial se realizan a través de dos itinerarios por las salas del Museo y cada actividad responde a unos objetivos y unas metodologías diferentes, que permiten la adaptación a las características de cada uno de los grupos. Ambos itinerarios se dirigen a alumnos con discapacidades leves o moderadas

Para el desenvolvimiento de estas actividades se buscará la colaboración con entidades y asociaciones relacionadas o interesadas con las actividades programadas.

\section{Visitas Especiales con problemas psíquicos:}

Itinerario "Los abuelos de nuestros abuelos y mucho más". Acompañados por un educador, el grupo se iniciará en el conocimiento de las nociones básicas de temporalidad y en el concepto de historia. También trabajarán aspectos referidos a las habilidades sociales.
Itinerario y taller en los que, a partir de la observación y del sentido del gusto, se evidencian las formas utilizadas a lo largo del tiempo para endulzar los alimentos y la evolución de las formas de vida de los últimos dos mil años. Propuesta para trabajar sería a partir de un centro de interés -el dulce-, sus peculiaridades y características

\section{Visitas Especiales con problemas sensoriales}

Se proponen dos opciones:

-“Tocar con manos blancas”:

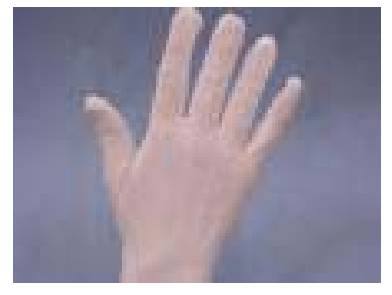

El grupo estará equipado con guantes de algodón para poder apreciar las formas, tamaños, texturas, etc. de las esculturas. Se necesitaría una selección de las piezas más adecuadas, para que no suponga un estrés excesivo el desarrollo de esta actividad. 
-Acompañados por un educador el grupo se iniciará en el conocimiento de las nociones básicas de temporalidad y en el concepto de historia. También trabajarán aspectos referidos a las habilidades sociales.

\section{Programa educación en el Ocio}

En este apartado podemos centrarnos en un amplio grupo de personas con ampliado tiempo libre como las personas mayores. o la atención a los jóvenes cuya visita no es usual a los centro museísticos; pero también a grupos familiares deseosos de encontrar actividades lúdicoculturales, teniendo en cuenta la cercanía del Parque.

Su programación tendría en cuanta las fechas mas adecuadas, especiales donde el tiempo de ocio se amplia (vacaciones, fines de semanas, fiestas, etc.)

-Actividades para jóvenes (De 13 a 17 años, o más)

-Actividades para personas mayores.
-Visitas-taller para familias (Para familias con niños entre los 6 y 12 años)

-Espacio para actividades de verano (De los 4 a los 12 años)

-Actividades de Navidad (Para familias con niños entre los 6 y 12 años)

-la piezas del mes (Para público adulto)

Únicamente concretaremos algunas de estas actividades.

- Niños y adolescentes y jóvenes en la educación de ocio

Pensado en actividades para los chicos y los jóvenes que participen de la educación en el ocio se ha ideado la actividad: CNI, Caso No Investigado. Aprovechando el impacto de series como CSI y otras serie de éxito de la televisión en la que se descubren enigmas a partir de datos fundamentalmente jóvenes, se pretende acercar la 
arqueología a jóvenes. La Colección se convierte en un espacio abierto a este público en el que desarrollar, desde su propio punto de vista una reconstrucción de la Historia.

\section{- Personas mayores}

Las actividades que se proponen para enseñanza primaria y para enseñanza secundarían están disponibles (adaptadas) para los programas de formación de adultos. Sin embargo, en este apartado ofrecemos una actividad más adecuadas a los objetivos y a las características de la formación de adultos.

Constaría en una visita guiada estableciendo una relación entre los recuerdos del pasado de la vida de los miembros del grupo y los testimonios que nos aportan las colecciones de la exposición permanente. Además se contaría con la colaboración de centro de educación para mayores, etc.

\section{- Actividades para Navidad}

Durante las navidades se desarrollaría una actividad para familias con niños entre los 6 y los 12 años acompañados de algún adulto. Siendo el número de participantes de 20 personas por grupo aproximadamente.

Cada año se trataría la navidad desde un punto de vista distinto. El formato de la actividad sería el de visita-taller, relacionándose las colecciones con elementos que están presentes en la vida de los niños durante estos días.

Habría que tener en cuenta la posible fidelización de los usuarios, por lo que no se debe hacer actividades muy abarcadoras en relación con el tema navideño, al agotarse pronto las colecciones relacionadas. Se propone, por ello, una alternancia de actividades de temas relacionados con la navidad con otros. 
Un ejemplo de actividad seria:

- Bal y Adba en Judea. Dinamización con los personajes Bal y Adba a modo de cuento activo y participativo para conocer en el ambiente del mediterráneo antiguo.

\section{- Pieza del mes.}

Mes a mes el Museo, a través de la mirada de especialistas, se presentaría una mirada de una obra significativa de la Colección a través de una conferenciavisita junto a la obra. Pudiéndose establecer comparaciones y dialogo con otras obras. Iría dirigido a todo el público en general y el calendario propuesto seria de noviembre a junio.

\section{- Domingos en familia.}

Cada vez son más las familias que dedican parte de su tiempo de ocio del Domingo el visitar museo por encontrase el edificio dentro del Parque de Maria Luisa. Así se propone que estos usuarios puedan encontrar actividades educativas y lúdicas adecuadas a sus intereses y circunstancias, que ofrezcan entretenimiento y conocimientos al mismo tiempo.

Se creará un programa por temporadas que permita una gran interrelación con los niños y visita autónoma de los adultos. La actividad practicaría sobre algún aspecto lúdico para la presentación de mensajes en relación con la exposición. Es fundamental asegurar la relación de la actividad con la exposición para propicia una visita posterior y no causar sensación de haber perdido la visita, Haciendo descubrir a los adultos otras visitas al museo.

Un elemento que no hay que olvidar es la difusión al máximo de estas actividades en el entorno del Parque.

Se podría contar en algunos momentos con la colaboración de alguna empresa de alimentación para que ofreciese 
muestras de helados, bebidas, frutos secos, dulces, etc a los participantes. Cada visita tendría una duración aproximada de unas horas y media. Realizándose varias veces en toda la mañana para la mayor afluencia de público si fuera necesario.

Los grupos de participante serian de unos 20 participantes. $Y$ el calendario propuesto seria de Septiembre a Junio. Domingos de 11 a 13 horas, sin necesidad reservas hasta formar grupos.

Constaría un itinerario, algunas propuestas son:

- Los amigos de Hércules: introducción para la familia de los habitantes del Olimpo anécdotas adaptadas a los grupos familiares. A través del cuento y la dramatización acercaremos a los más pequeños al mágico mundo de la mitología romana.

-“Los animales del museo": un recorrido por salas en busca de las señales de diversos animales.
-Juegos familiares: actividad de fundamental contenido lúdico en el que se invita a las familias a aprender los juegos en la antigua Roma.

\section{- Verano en el Museo.}

En una programación a largo plazo proponemos el programa: Verano con las Musas. El Museo ofrecerá a sus pequeños amigos la oportunidad de disfrutar, durante el periodo estival de vivir experiencias en el museo. A través de los personajes ya definidos, conocerán y vivenciarán nuevos aspectos de la vida cotidiana de los romanos y otras culturas antiguas.

En colaboración con escuelas de Verano y campamentos urbanos, se ofrecería el espacio del museo para el desarrollo de días o varias jornadas. Además de ofrecer material lúdico-didáctico para que los monitores puedan programar sus jornadas en el museo. 


\section{- Vistas comentadas:}

Con guías voluntarios del Museo recorridos por las salas (a continuación de la dinámica actual)

\section{V.2.5. Proyecto museo abierto}

\section{- Museo abierto.}

La utilización del museo como espacio cultural y dinamizador permitirá una amplia difusión de la institución. Favoreciendo la presencia en el panorama cultural, así como la obtención de beneficios materiales y publicitarios de las actividades.

\section{Creando proyectos en común.}

Dentro de los objetivos del Museo estaría el poder llegar a todos los públicos a través de sus programas didácticos en colaboración con instituciones o asociaciones que permita crear materiales, realización de visitas guiadas, etc. Además la colaboración con institutos, centros de formación y educación permitiría establecer practicas, clases y posibilidad de diseñar proyectos relacionaos con el campo del centro(Arte, educación social, comunicación, construcción, etc)

\section{Museo y universidad.}

La finalidad de este apartado es la de establecer lazos de colaboración con estas instituciones y difundir su actividad, coleccion y exposiciones temporales entre el público universitario. Por medio del establecimiento de acuerdos el Museo con las universidades para crear proyectos en común: con Departamentos de universidades, Facultad de Arquitectura, facultad de Bellas artes, facultad de historia antigua y arqueología, Facultades de Historia, facultad de antropología, etc. 
Posibilitando prestar instalaciones, espacios y recursos para:

-Cursos para estudiantes universitarios.

-Cursos de verano (UNED, universidad de Sevilla,

Universidad -internacional, etc.)

-Simposia.

-Universidad de mayores.

-Talleres de Artista.

Además de fomentar la relación con las instituciones. universitarias para: aprendizaje en vivo con las colecciones, investigaciones, prácticas, etc.

\section{Colaboración institucional:}

El museo debe de apostar y aprovechar la oportunidad de colaboración con otras instituciones patrimoniales. Para ello se incrementará una política de relaciones entre instituciones, para la conservación, difusión, investigación, etc. apostando por fortalecer una comunidad de intereses comunes.

Pudiendo integrase dentro de iniciativas propias o de otras instituciones o ámbitos, para:

-Colaborar en proyectos comunes (exposiciones, etc.)

-Compartir experiencias para las mejoras de servicios del museo.

-Crear espacios de dialogo.

-Ofrecer una visión más universal del patrimonio.

-Difusión de la institución y sus colecciones.

Dentro de un ámbito local se podría establecer relaciones entre instituciones de la provincia, o de la comunidad autónoma o nacional, etc. En un ámbito más ambicioso como el europeo, la colaboración podría ir encaminada por el fortalecimiento y difusión e investigación del pasado común de Europa en diversas épocas. 
Así se propone la posibilidad de ingresar en diversas iniciativas como la "Roman Europe. Roman Museums in Europe". Proyecto liderado por el Museo Nacional de Arte Romano de Mérida, en el marco de la convocatoria del Programa Cultura 2000 de la CEE.
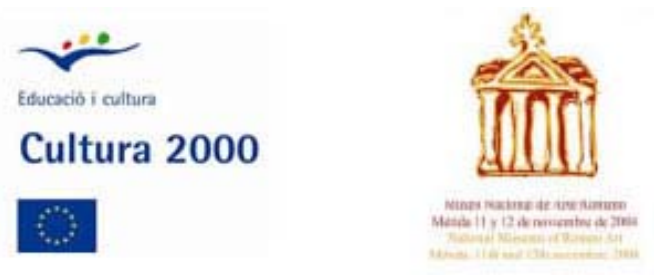

Donde también colabora el Museo Arqueológico y Etnológico de Córdoba, el Museo de los Foros Imperiales de Roma (Italia), el Museo Romano-Germánico de Colonia (Alemania), el Museo Romano de Bath (Inglaterra), el Museo Saint-Raymond de Toulouse, el Museo de Arles (Francia), el Museo Nacional de Historia y Arqueología de Constança (Rumania) i el Museo Monográfico de Conímbriga (Portugal).
El Proyecto de arqueología abierta que más adelante se presentará necesitaría de esta colaboración entre instituciones.

\section{- Seminarios, jornadas, Congresos convenciones,} conferencias, etc.

El museo estaría abierto a diferentes entidades culturales y educativas. Para ello ampliaría su oferta a aquellos visitantes que, además de disfrutar de la riqueza de sus colecciones y exposiciones, quieran hacerlo de sus instalaciones. Particulares, empresas culturales, asociaciones, organismos e instituciones. Ofreciendo instalaciones para conferencias, cursos, cursos de expertos, presentación de resultados arqueológicos, presentación de libros, mesas redondas, clases magistrales, presentación de servicios, productos relacionados con la historia y arqueología, congresos, convenciones, seminarios, viajes de incentivos, reuniones de negocios y encuentros profesionales, 
ruedas de prensa, presentaciones, workshops, actos sociales, etc.

\section{- Celebración de días conmemorativos.}

Estas actividades tendrán como objetivo fomentar el compromiso social del museo y dar conocer el museo como institución cultural. Se Aprovecharía los días conmemorativos europeos e internacionales para la programación de actividades conjuntas con instituciones, organismos $\mathrm{u}$ organizaciones relacionadas. El museo programaría o ofrecería el espacio museístico como lugar para conmemorar.

A parte de la celebración del Día Internacional del Museo se proponen:

-El día Mundial del Libro y de los Derechos de Autor.
-El día Mundial de Lucha contra la Desertificación y la Sequía.

-El día Internacional de la solidaridad.

-El día internacional del Orgullo Gay.

-El día Internacional de la mujer trabajadora, etc.

\section{- Formación profesorado}

En un desarrollo a largo plazo se propone en colaboración con el Gabinete Pedagógico crear programas y cursos pensados para satisfacer la demanda de los educadores de los distintos niveles educativos y ofrecer apoyo a los educadores que quieren utilizar las colecciones del museo como recurso educativo. Además sería acompañado en la mejora y ampliación de material del material didáctico del Gabinete pedagógico, Creando nuevas formas y con nuevas temáticas para los profesores que quieran enseñar el museo por su cuenta a sus alumnos. 


\section{V.2.6. Proyecto: el MAS en extensión.}

Este proyecto se ocupa de la programación de actividades de contenidos más lúdicos para la difusión del museo, apoyándose en perspectivas de la arqueología más amplia. Son Programadas para la atracción de un amplio público al museo y hacer más atractiva la visita.

Es fundamental la importancia de elección de las tácticas de comunicación de las actividades, debiendo de favorecer la llegada a una amplia gama de destinatarios.

Este programa permitiría poner en marchas diferentes iniciativas:

\section{- Representaciones}

Consistirian en representación espectáculos teatrales basados en obras clásicas, épocas o personajes históricos, así como la representación de Ballet Clásico y contemporáneo, o la puesta en escena de mitos, proyecciones cinematográficas, etc. Estos se realizarían en diferentes espacios disponibles en el museo(salón de actos, sala de recepción sala multiusos, salas de exposición amplias)o en el entorno del Museo.

Se podría establecer, para ello, colaboración con la disponibilidad de recursos a ICAS (Instituto de la Cultura y Artes de Sevilla). Además de establecer colaboraciones con jóvenes compañías de Sevilla para la producciones de espectáculos diseñados a medida.

\section{- Jóvenes expresiones.}

Esta iniciativa se propone como un acercamiento menos global de los jóvenes buscando centros de interés para cada grupo. Pudiendo dedicar diferentes actividades para grupos concretos relacionado con intereses comunes. 
Un ejemplo de este tipo de actividad podría ser realizar una sesión nocturna de música electrónica el espacio oval del hall, acompañado de efectos de luz. El horario del museo se ampliaría hasta la noche, permaneciendo abierta solamente la planta Baja.

\section{- La plaza de los museos.}

Para el futuro del Museo Arqueológico seria un elemento potencialísimo la creación de una plaza cultural o de museos en la plaza de América, en la cual se ubica el Museo Arqueológico y el Museo de Artes y Costumbres populares.

Las diferentes instituciones culturales instaladas podrían aunar y promocionar proyectos en común para atraer al público a la plaza de América como espacio cultural.

Supondría un elemento cultural y museístico particular en la ciudad y en la Comunidad Autónoma. Potenciando una imagen atractiva para este publico local y turistas.
Este espacio se presentaría como lugar idóneo para el desarrollo de actividades del programa MAS en extensión

En reilación con esta idea se propone promover la instalación de una tercera institución cultural en el Pabellón Real, aunque transciende del propio proyecto museológico del Museo Arqueológico, pero habría que tenerlo en cuanta en una programación-gestión conjunta para la Plaza de América.

A continuación se presentan diversas alternativas para el contenido del edificio:

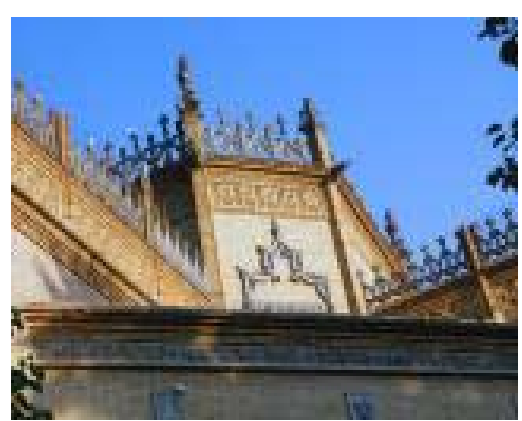


-Centro de interpretación del Parque Maria Luisa. Consistente en una exposición permanente sobre la historia del Parque, sus elementos, etc. Sería de Gestión municipal. Además también podría ubicarse una sede para una asociación o fundación del Parque Maria Luisa.

-Museo de las exposiciones: Muestra de la Exposición Ibero -Americana de 1929 donde el Parque de Maria luisa fue un elemento fundamental en su configuración y de la Exposición de 1992.

-Centro de la arquitectura del valle del Guadalquivir. Pudiendo entablarse colaboración entre la Fundación Fidas, Ayuntamiento de Sevilla, Conserjería de Cultura, Consejería de Obras publicas, Universidad, etc.

-Centro de interpretación de los Jardines Andaluces. Mostrando el Parque de Maria luisa como Jardín Publico, además de los jardines de tradición islámica, los patios andaluces, etc.
-Centro de interpretación de los espacios lúdicos. Como complemento del museo de Artes y Costumbres Populares

En otra poción el Pabellón Real podría ser cedido como espacio de usos compartidos para el museo Arqueológico y el de Artes y Costumbres Populares: Sala de exposición, etc. 


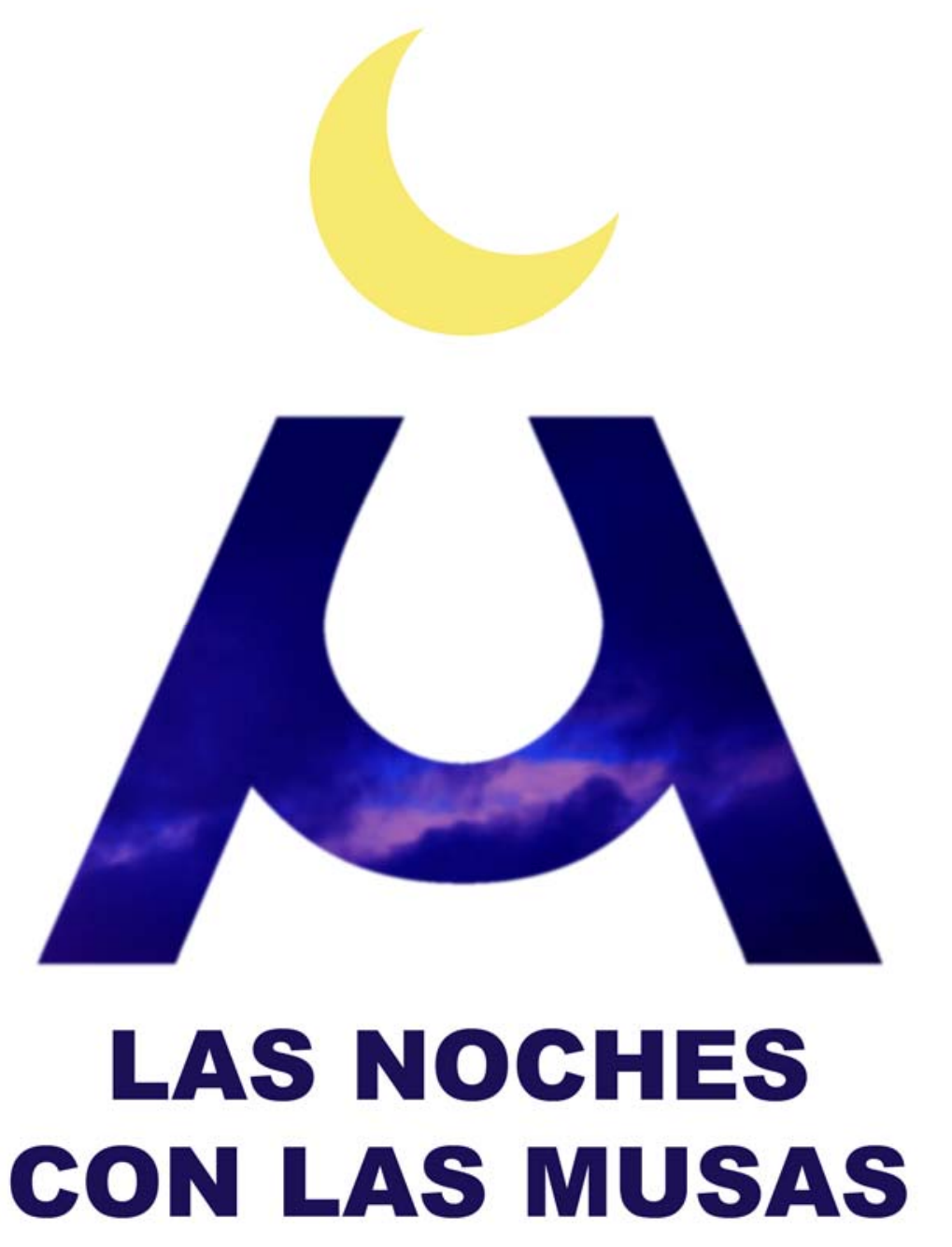

\section{Noches con las Musas}

En el proyecto de la Plaza de los Museos un elemento fundamental es la programación de actividades nocturnas bajo una imagen común: "Noches con las Musas":

Bajo esta imagen se desarrollaría las diferentes actividades ya propuestas en este documento las cuales se desarrollas en horario fuera del usual de apertura del Museo.

Aun así el Museo podría ofertar abrir sus puertas en horario especial de 21.00 a 00.00 horas durante los días de representaciones prestando una atención al público, mediante visitas guiadas a la exposición permanente y temporal.

Habría que estudiar económicamente si se podría tener abierta la cafetería y tienda. 


\section{V.2.7. Proyecto arqueología abierta}

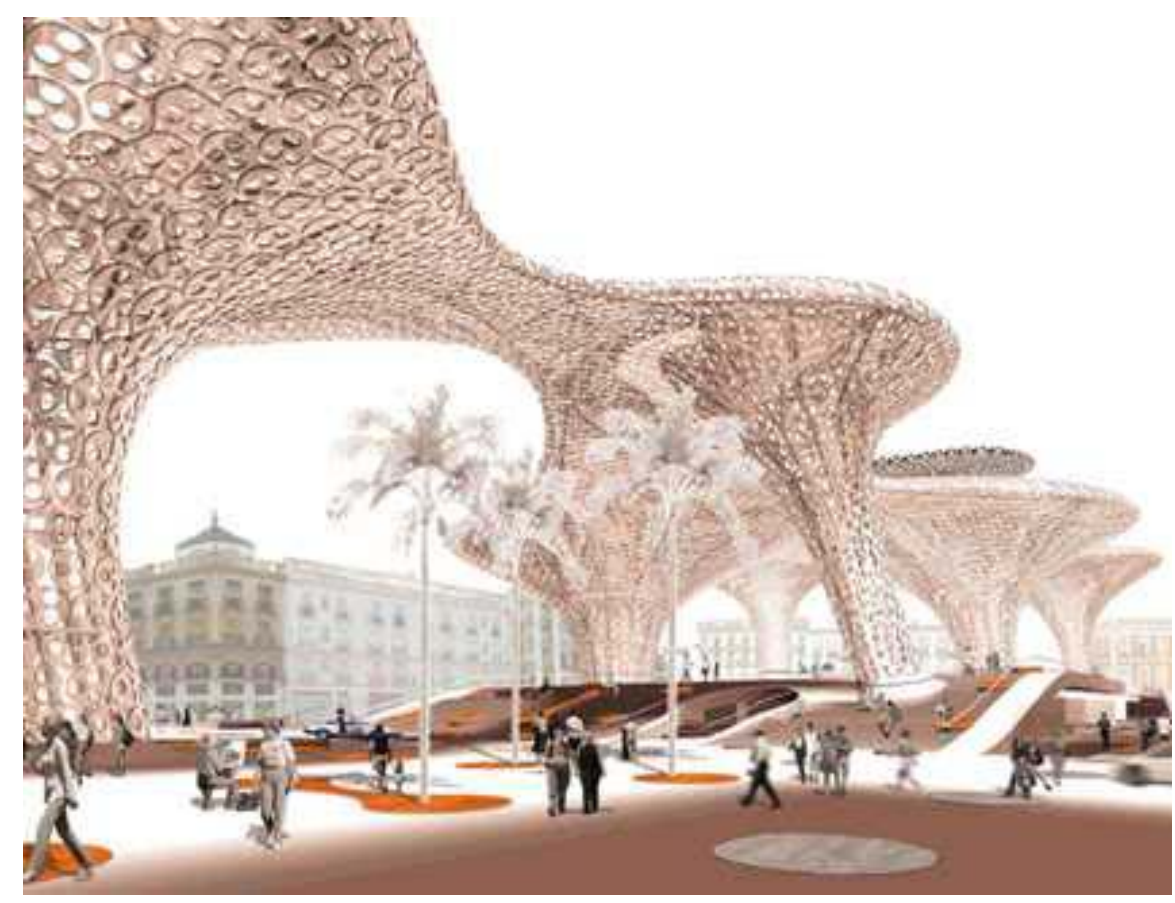

EI MAS puede servir de lanzadera para que el público visite una futura musealizacion del Yacimiento Arqueológico de la Encarnación.

El museo tiene la oportunidad o deber de presentar un panorama de la arqueología en la actualidad, tanto como trabajos actuales, como testimonios arqueológicos que pervivan en el territorio.

Se desarrollará el acercamiento a yacimientos arqueológicos que por diferentes motivos no establecen actividades de difusión in situ. Así como dar conocer ese patrimonio arqueológico desconocidos para el público. Por un lado la actividad contemporánea de excavaciones arqueológicas debería estar presente en la exposición del museo, y por otra, el museo debe de establecer una relación mas comprometida con conjuntos arqueológicos, bienes culturales, ... diseminados en el territorio.

Así se debe de establecer medios para la comunicación de trabajos que se estén realizando en Sevilla y provincia. Presentado a la sociedad yacimientos como los de la Encarnación, San Laureano, Écija, etc. 
Es una musealización de lo externo de un modo temporal y se desarrollaría en diversos lugares y modos, pudiéndose definir dos dimensiones:

-Dentro del museo.

-Otra fuera, estableciendo en casos lazos de interrelación.

El proyecto Arqueología abierta se compone de diferentes elementos.

\section{- Dinamizar la arqueología}

Dentro de la "arqueología abierta" se intentaría dar a conocer la arqueología fuera de as paredes del museo, sirviendo a modo de trampolín o centro de visitantes. Dando a conocer museo locales, yacimientos, restos Arqueológicos, Red Andaluza de Yacimientos Arqueológicos, etc.
Así se darían propuesta de rutas o yacimientos arqueológicos en activo o visitables dentro del discurso expositivo de la exposición temporal asociado a una pieza o contenido. Debiéndose presentar datos prácticos para su visita.

Además, en cualquier momento comunicativo del museo se podría dar a conocer yacimiento visitables o restos determinado, facilitado datos para su visita:

-En la exposición temporal, -en la exposición permanente, -en actividades de contenido lúdico, -por medio de cartelería,

- folletos, tarjetas, flyers,

- y módulo cam.

Más participación de las instituciones interesadas en este recurso-trampolín posibilitará la creación proyectos conjuntos que sirviesen de plataformas de lanzamiento de 
una institución a otra: exposiciones en dos sedes, exposiciones del Museo de Carmona en el MAS, o inversamente, etc.

- Modulo de arqueología virtual: La historia Viva.
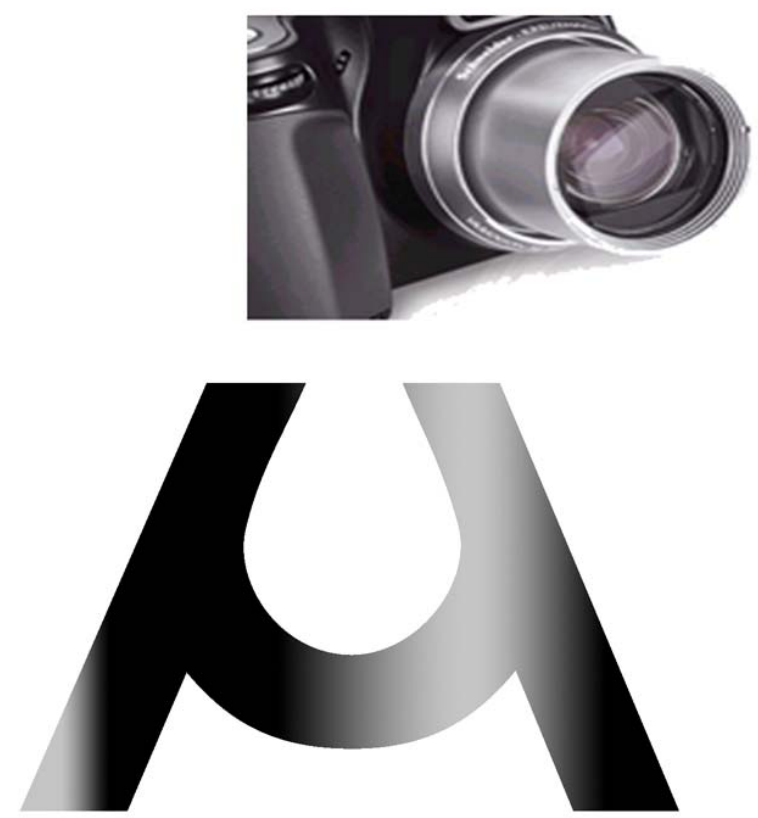

LA HISTORIA EN VIVO
Este elemento tiene como objetivo dar a conocer la existencia de excavaciones arqueológica diariamente y presentar algunos de los datos que se están aportando. Consiste en la conexión a tiempo real a yacimientos arqueológicos, presentadas en dos líneas:

-El acceso por medio de la página web del museo.

-El acceso por un módulo ubicado en la exposición permanente.

Que presentaría una pantalla de visualización e información concisa sobre el yacimiento. Este módulo debería de estar diseñado para poder ser cambiado de ubicación con absoluta facilidad. Permitiendo establecer un dialogo entre el contenido de la sala y el material encontrado en la excavación.

Necesaria la colaboración de arqueólogos, diversas Consejerías, vecinos, etc. para el cuidado, mantenimiento 
de la cámara y conexión. Podremos tener en cuenta la posibilidad de contar con colaboraciones de empresas relacionas con nuevas tecnologías.

\section{- Colaboración con instituciones:}

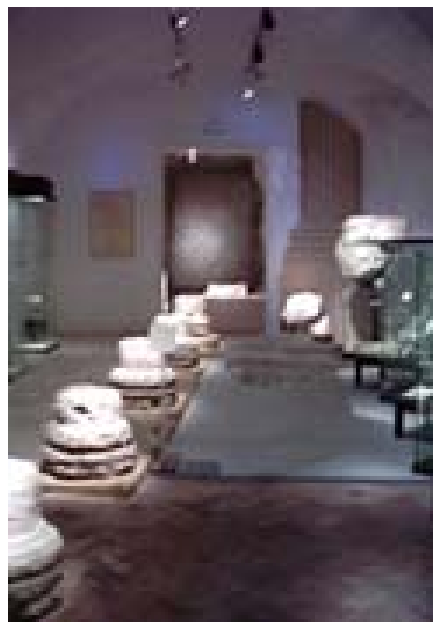

El museo establecerá contactos con Museos Locales, Conjuntos Arqueológicos, Yacimientos arqueológicos, Empresas de construcción para poder conseguir los objetivos de este proyecto y gestionar: Exposiciones, visitas especiales, visitas virtuales, etc.

\section{- Museo en comunicación directa:}

Se establecerá la posibilidad de la recopilación de e-mail y direcciones que faciliten la comunicación de actividades del museo a sus usuarios. Además de la presencia de un buzón de sugerencias y la posibilidad de participación por medio de la pagina web.

\section{V.2.8. Proyecto de acceso a almacenes}

Pensado para el publico general, se contaría con un escueto material interpretativo-identificativo (topología, temática, material numero de inventario, etc.) de las piezas almacenadas en el almacén visitable. Además facilitaría el estudio por parte de los investigadores y el contacto directo de estos con el público general.

Para su desarrollo el diseño del proyecto arquitectónico deberá de tener en cuenta la visita publica de los almacenes de las piezas museables del museo. Su diseño debe asegurar una compatibilidad por la conservación y acceso. 
La organización asemejara a un anticuario histórico, y se organizará por la materialidad de las colecciones: Lápidas, esculturas, metales, monedas, vidrios, cerámicas.

No hay que olvidar la disponibilidad de un espacio para investigación.

\section{V.2.9. Proyecto de publicaciones}

Las propuestas descritas se presentan como idea para la ejecución de un proyecto de publicaciones. Así el departamento de difusión, junto con los demás departamentos diseñará un plan de publicaciones a largo plazo. Estableciendo que tipos de divulgación es necesaria y quecolaboraciones se podrían establecer (investigadores, etc).

Las publicaciones relacionadas con los fondos será fundamentalmente el objetivo de esta planificación, a lo que se une una diversidad de temas relacionados con la arqueología.

Se propone los siguientes elementos para el programa de publicaciones:

- Guías: actualizaciones de la guía del museo.

- Catálogos de exposiciones.

- Monografías de investigaciones realizadas en el seno de las colecciones del propio museo. Ediciones en colaboración con la universidad, institutos científicos, fundaciones, etc. Consistentes en tesis e investigaciones.

- Material didáctico: resultado de la actividad divulgativa del museo. 
- Colección Harris: La denominación viene dada por la metodología más utilizada en las excavaciones actualmente. Extra colección consiste en una serie de publicaciones divulgativas de los trabajos realizados en excavaciones arqueológicas de la provincia. Son publicaciones relacionadas con el proyecto "arqueología Abierta" y su implicación con el territorio.

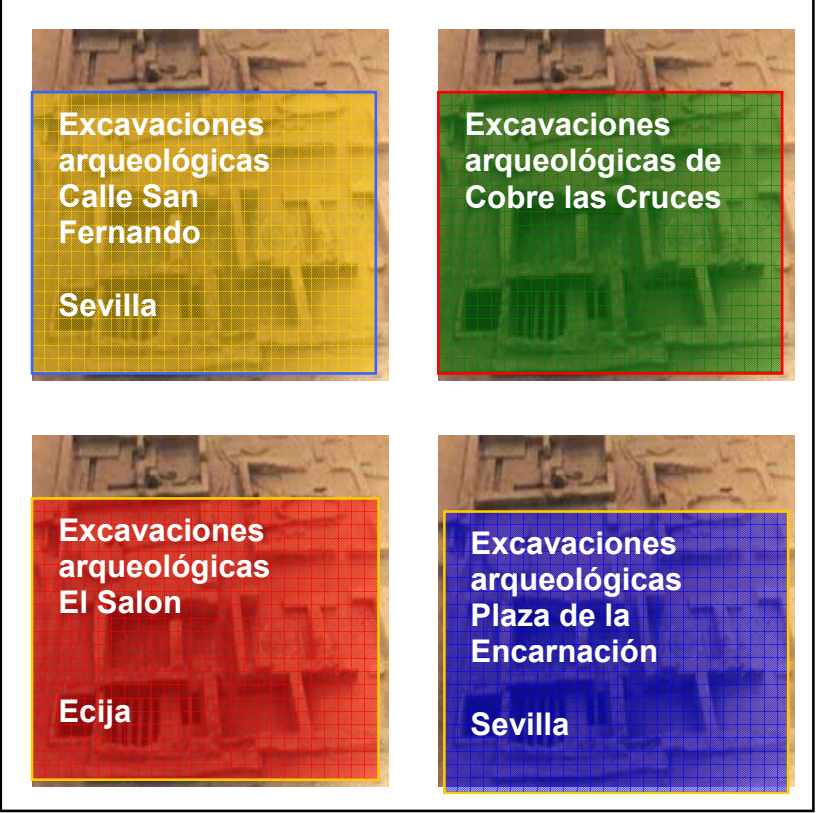

\section{V.2.10. Proyecto CP.}

En este proyecto donde la divulgación y la conservación unen sus objetivos:

-Difundir sobre la fragilidad de los objetos patrimoniales.

-Concienciar en la tarea de todos en la conservación del patrimonio.

-Conocer las tareas que realiza el museo para la conservación de las colecciones.

Este proyecto que se materializaría de diferentes modos:

-Presentación de obras restauradas.

-Visita a departamento de conservación(universitarios, colegios, etc. 
-Participación en la formación continua de profesionales.

-Jornada técnica con estudiantes de restauración de la facultad de Bellas Artes para ver analizar y ver una restauración.

-Promover publicación acerca de casos prácticos de restauración.

-Crear material interpretativo in situ de los recursos utilizados en la restauración y conservación preventiva.

\section{V.2.11. Programa de exposiciones}

Las propuestas descritas a continuación servirán de llave para el diseño y ejecución del proyecto de exposiciones temporales.
Para completar la colección permanente el museo ofrecerá una programación de exposiciones relacionadas con el discurso, colecciones o campo científico de la arqueología.

Estas exposiciones serán ya de producción propia o bien realizadas en colaboración con otras organizaciones.

\section{Objetivos:}

-Como medio de completar y enriquecer la exposición permanente.

-Integración de las colecciones dentro de un ámbito más general de patrimonio, de la historia y la arqueología.

-Difundir colecciones de un modo adecuado al público.

\section{Líneas estratégicas:}

-Temas transversales y interdisciplinarios 
-Apostar por nuevos conceptos museológicos y museográficos.

- establecer convenios de colaboración con otras instituciones. Permitiendo así una producción ajena, propia y compartida.

\section{Gestión de exposiciones}

La política general de las Exposiciones temporales en el museo se debe de basar en una planificación organizada y con antelación. Favoreciendo, además, la creación de marcos de colaboración propicios con otras instituciones y estableciendo un clima adecuado para colaboración de arqueólogos e investigadores.

Se contará con auto-recursos para producción de exposiciones que permita la creación de algunas exposiciones rápidamente, Así como la posibilidad del almacenamiento para estos recursos museográficos

\section{Espacios para exposiciones temporales:}

El nuevo espacio para exposiciones temporales debe cumplir las siguientes características:

-Que facilite un rápido y fácil cambio de imagen (minimalista con luz natural; oscura con iluminación dramática, etc.)

-Que permita diversos tipos de museografía.

-Que facilite el diseño de una sala de exposiciones modulable que se adapte a las necesidades del tamaño de las diversas

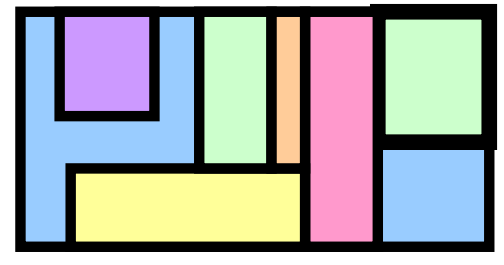
exposición o exposiciones. 
-Que tenga previsto la celebración de varias exposiciones a la vez, lo exigiría varios accesos posibles.

-Existencia de un pequeño almacén de material cercano

-Suelo cómodo para la visita.

-Además, de conexión a Internet.

\section{Política Exposiciones temporales concretas}

La exposición temporal será el medio divulgativo por excelencia para el gran publico, aunque sin olvidar que la oportunidad de la exposición también aporte interese a expertos. Aunando, así, exposiciones y contenidos científicos y divulgativos. Aun así hay que tener en cuenta que para la divulgación de contenidos mas técnicos hay otros medios publicaciones etc.

Desde un corto plazo se proveen dos grandes exposiciones al año, usualmente para Otoño-Invierno y otra para primavera -Verano. A la que se añadirá una serie variable de pequeñas exposiciones.

Se propone, para ello, dos líneas

- Micro-exposiciones. De temas concretos y adaptables a diversos espacios y formas.

- Exposiciones Globales o extensas, donde el préstamo de piezas será más importante.

\section{- Globales:}

La presentación de tesis dará la oportunidad de Analizara temáticas en las que se integre piezas del propio museo con las provenientes de otros lugares.

Propuestas:

-La diosa madre en el mediterráneo desde Laussel a la Macarena 
-Tras la caída de Roma. Exposición entorno a la época tardo-romana hasta la llegada de la cultura islámica.

-Deporte en el Mediterráneo Antiguo

-El hundimiento de barcos.

-La historia material del lenguaje en Andalucía.

\section{- Micro-exposiciones:}

Estas exposiciones se adaptarán diferentes formas, y se podrán ubicar en diferentes espacios dependiendo de su intencionalidad, etc.

Trataran temas más concretos y será el modo de presentar las colecciones del museo desde otras perspectivas 0 relaciones.
Las temáticas de las exposiciones podemos ver en las agrupaciones:

\section{- Contextos:}

El Objetivo de estas exposiciones es establecer las problemáticas en torno a determinados yacimientos clásicos.

\section{-Arqueología viva:}

Responden a la necesidad de divulgar los datos de las investigaciones científicas al público general y de un modo continuo y accesible. Acercan la actualidad de actuaciones arqueológicas en el momento de debates ciudadanos o desde su desconocimiento para el publico general. Presentarán materiales, interpretaciones, resultados, contextualización y proyectos de futuro relacionados con el yacimiento. Estas exposiciones se enmarcan dentro del proyecto Arqueología Abierta. 
Para su gestación en algunos casos se aprovecharía la presencia en los periódicos de debates o noticias acerca de un yacimiento. Serían de un estilo sencillo, exigiendo un rápido montaje acorde con lo inmediato de algunas noticias.

Propuestas de temas para estas exposiciones son:

-Metrosol parasol.

-Las las murallas e la ciudad o la excavación en la calle san Fernando.

-San Laureano.

-La restauración de la Iglesia del Salvado de Sevilla.

-Obras en la Plaza Nueva: exposición del convento de san Francisco.

-El Salón: los recientes descubrimientos producidos en Ecija.

\section{Exposiciones entorno a...}

Su objetivo seria crear exposiciones de temas relacionados con el museo pero que atraigan a públicos que usualmente no acuden. Atrayendo a públicos interesados en otros temas diferentes a la arqueología (tauromaquia, arte contemporáneo, arquitectura, música popular, etc).

Propuestas para este tipo de exposiciones:

-Aprovechar el aniversario de la muerte del torero Joselito el Gallo para hablar de la historia del pabellón renacentista etc.

-Los juegos de azar. Alrededor de las planchas de naipes.

-La memoria histórica reciente y lejana.

-Resultado de excavaciones sobre la guerra civil o periodos que nos se integran en el discurso museográfico museo. 


\section{-La arqueóloga como ciencia:}

Estas exposiciones tienen como objetivo dar a conocer aspectos concretos de arqueología. La divulgación de contenidos referentes a la disciplina del museo, no ya solo de resultados sino como disciplina científica, es decir la divulgación científica sobre metodologías y cuestiones de la arqueología como ciencia. Ejemplos de estas exposiciones serian:

-La arqueología subacuatica en colaboración con el IAPH de arqueología Subacuatica.

- La fotografía aérea en arqueología.

-La arqueología en humedad.

-Otras momias esquimales.

-La arqueología experimental como método para estudiar los procesos.

-Las tipologías: Cerámicas, hachas y coches.

¿¿Que aspecto tenían?

-¿Que comían?
-La ciencia y arqueología:el carbono 14.

-La arqueomagnética.

-La arqueología forense.

-La palinología.

\section{-Espacios de reflexión:}

Son exposiciones que proponen un espacio de dialogo y reflexión acerca de cuestiones relacionadas con el patrimonio y arqueología:

-¿de quien es el pasado?

-La evidencia. ¿Existieron los que nos los dejaron testimonios?

-La arqueología, una ciencia que arranca paginas del pasado.

-¿Que dirán de nosotros cuando hayamos muerto?

\section{-Protagonistas de la historia}


Consistirían en dar un contenido social al museo aprovechando el recurso expositivo. Consistirían en exposiciones ocupadas de la recuperación de la memoria histórica de personas y grupos que se han olvidado o no hay espacio para su presencia en la exposición permanente e historia general. Así:

-Esclavo, construyendo un imperio.

-Las familias en torno en roma y la muerte.

-La mujer tras la celosía.

-El servicio domestico.

-Los enfermos y enfermedades.

\section{-El Corazón de la Bética:}

Bajo este titulo se abarca exposiciones para la interacción con el ciudadano y también como lugar de expresión artística. Así el museo como lugar de desarrollo personal y comunitario en la sociedad actual. Desarrollando temas actuales con la perspectiva los testimonios del pasado:

\section{-La emigración}

-La lucha de derechos

-El papel de la mujer

-La evasión de la vida: drogas y otros

-Imperialismo e invasiones

-Arqueología en pintura.

-Creaciones musicales en el museo.

-Instalaciones de artistas contemporáneos

\section{- Exposición personalizada}

Estas exposiciones permiten el acceso controlado a las piezas, a determinados grupos que requieran una fundamentada necesidad.

Resolviendo, de un modo controlado y personalizado, las necesidades de acceso a la colección para grupos de estudiantes, grupos de investigadores, colectivos interesados en determinadas piezas, grupos de localidades de la provincia, etc. 
Consistiría en un espacio con una o dos vitrinas y mesa de trabajo. Permitiendo la contemplación de las piezas seleccionadas con antelación por parte del grupo.

\section{Prestamos de piezas a exposiciones fuera del museo}

El museo deberá de establecer que piezas no están sujetas a préstamo para exposiciones temporales, considerándose que por motivos de conservación o de del montaje museográfico no pueden salir del museo.

\section{V.2.12. Proyecto de mejora de la página web del museo:}

Los diferentes elementos de mejora se aplicarán tanto a corto como a largo plazo. La página web se afianzara, así, como un servicio más al público. La apuesta por las nuevas tecnologías permite un acercamiento a la democratización, lo que supone un espacio de comunicación del público y el museo sin tener que acudir al edificio.
La diversificación y ampliación de contenidos de la página web consistirán en:

Crear una mayor dialogo con el público como espacio mas democrático, independientemente de los lazos del tiempo y el espacio.

En Museo Abierto se ofrecerá una serie de entornos de colaboración, interactividad y aprendizaje en línea, en los que la comunicación entre los usuarios y el Museo será básico para la creación de un espacio educativo y de debate en torno a la historia y el patrimonio arqueológico.

Arqueología abierta. Desde la pagina web del museo se podría tener acceso a las imágenes tomadas por la cámara del proyecto "la historia en vivo"

Se posibilitara la Visita virtual del museo.

Acceso virtual a colecciones mediante la disposición del catálogo de los fondos en Domus. Consistirá un elemento 
indispensable para una difusión extensa independiente de horarios y espacio.

Exposición virtual, se creará exposiciones virtuales, aprovechando la oportunidad que ofrece unos recursos como hipertextos, Internet, etc. que solo se pueden crear a través de la red:

Itinerarios temáticos, temporales etc.

Material didáctico, a través de la pagina web se podrá acceder a determinados materiales recomendados para la organización de una visita.

La publicidad de la página web. Es imprescindible hacer publicidad y divulgar la página web del museo, como requisito necesario para que la página web cumpla con su función comunicadora, por mucho y atractivo contenido que se le dé si no se conoce se habrá fracasado en su fin.

\section{V.2.13. La difusión en la exposición permanente:}

Desde la difusión se presentan unas propuestas que sirvan de llave para la diseño y ejecución del proyecto de Exposición permanente. La exposición del Museo Arqueológico de Sevilla permitirá descubrir el pasado de una forma contemplativa, interactiva, lúdica $y$ comprensible.

La exposición permanente mostrará la evolución de las formas de vida que se han dado principalmente en nuestro territorio, el valle del Guadalquivir, a partir de materiales arqueológicos, acompañados de diversas reproducciones de objetos, documentos y reconstrucciones basadas en la información histórica. Con el apoyo de innumerables elementos interactivos manuales, informáticos y audiovisuales. Itálica y Roma surgirán como los elementos 
más impresionantes y característicos. Además se podrá conocer el interés del hombre por coleccionar y aprender.

Presentamos a continuación la serie de necesidades y requisitos que por parte del programa de difusión debería de tener en cuenta en la definición del proyecto museográfico:

Que permita múltiples niveles y tipos de visita. Entre ello que permita la contemplación para publico general e investigadores

Que sea Didáctica.

Adaptada a las principales discapacidades dentro de la gama de discapacidades relacionadas con la vista: Maquetas tridimensionales, esculturas, a escala y en bronces. Para que videntes e invidentes puedan hacerse una idea de edificios o ciudades de la que solo quedan restos arqueológicos. Además debiéndose atender la visibilidad de vitrinas y piezas.
Disponibilidad de espacios amplios para accesibilidad de silla de ruedas y grupos.

Contar con espacios para actividades en sala.

Disponer de espacios de descanso repartidos por las salas.

Facilidad de retirada de piezas para investigación o préstamo.

Que el préstamo de piezas no desvirtúe el sentido de la exposición.

Existencia de seguridad para los usuarios que aun no están familiarizado con las normas de uso de la sala de exposiciones.

Ubicar en una cronología y contexto mas amplio para los contenidos generales. 
Diversidad de recursos. Una diversidad de recursos no repetitivos que ayuden a crear un ritmo y mejorar la experiencia museográfica. Accesos multisensoriales (visual, sonidos, táctil, manipulativo, temperaturas, etc) Presentando entre otros, los sonidos del pasado: relacionados con los contenidos(talla de piedra, ruido de carro, fundición, jaleo de calle, animales, olas, etc.)

Presentación de recursos apoyados en documentos no arqueológicos.

Además el modulo "La historia en Vivo" estará presente en las salas de una forma itinerante.

Respecto al audio-guía, el nuevo diseño museográfico debe perseguir la innecesidad de incorporar audio-guías para el entendimiento y disfrute de la exposición permanente
V.2.14. Proyecto: A.M.A.R, nueva asociación de jóvenes amigos del museo arqueológico de Sevilla

A.M.A.R. es un proyecto real, que consiste en una asociación de jóvenes que se está formando para colaborar con el Museo Arqueológico de Sevilla en las tareas de conservación y difusión de su Patrimonio.

Las asociaciones de jóvenes Amigos son esenciales, ya que en algún momento los museos serán administrados por éstos. Permitirán transmitir un mensaje a un nuevo publico, aportar vitalidad a las actividades, activad y eclecticismo, además de aprovechar oportunidades de beneficios de experiencia y promoción. Así se creará un nuevo nexo entre el museo y la sociedad.

La asociación es un medio para poder poner en marcha y colaborar en algunos de los proyectos propuestos 
anteriormente. La nueva asociación está abierta a aficionados a la Arqueología, profesionales, etc. a todos que estén preocupados y les guste la conservación de nuestro patrimonio y su difusión. La asociación contribuirá a la organización de exposiciones, excursiones y talleres no solo para jóvenes, sino también para que las familias puedan encontrar en el museo un lugar de ocio, disfrute y conocimiento.

Trabajaría la comunicación entre las distintas Asociaciones de Amigos y organizaciones que se dediquen a la Arqueología y a su divulgación, para la mayor difusión de las actividades que se realicen.

Impulsará la realización de nuevos estudios y análisis de piezas del museo, así como realización de foros de debates y discusión. Además serviría de plataforma de información y contacto de curso, seminarios relacionados con la arqueología y el museo.
Para el momento presente se ha redactado los estatutos que regularán el funcionamiento del grupo.

(Los estatutos de la asociación podemos verlos en el anexo de documentación)

\section{V.2.15. Programa de difusión institucional}

Fundamentalmente es un proyecto que se pondrá en marcha dentro del desarrollo de los programas de Difusión, Servicios y Comunicación. Consistente en:

-Dar a conocer la existencia de la institución.

-Dar a conocer la institución como servicio a la sociedad.

-Dar a conocer las funciones del museo.

-Dar a conocer los servicios del museo.

Creando en determinados momentos visitas a departamentos del museo, para conocer las actividades y 
tareas del museo, dirigida a diferentes grupos:

Profesionales, gran público, especialistas, instituciones ...

En la cuestión de dar a conocer los servicios del museo es fundamental la difusión de la biblioteca con programas concretos para la animación a usar el servicio de la biblioteca. Es una biblioteca especializada abierta a investigadores, estudiantes de arqueología, historia, generales; aficionados; estudiantes de enseñanza obligatoria, etc. Además, para su reactivación se deberá de disponer de folletos en otras bibliotecas y tener informados a bibliotecarios de las otras bibliotecas de sus servicios: en especial la biblioteca del departamento de Historia Antigua y Arqueología, y demás facultades de historia de la Universidad de Sevilla, así como en la facultad de Humanidades de la Universidad Pablo de Olavide. 


\section{V.3. SERVICIOS}

A continuación trataremos los elementos genéricos para el estableciendo de necesidades y requisitos que permitan desenvolver los proyectos concretos relacionados con los servicios, con el fin de la puesta al día del Museo Arqueológico de Sevilla.

El primer elemento consistirá en apostar por un acercamiento al concepto más adecuado de usuario, alejándonos del concepto de "visitante". Aquel se define a partir del uso de los servicios del museo. La definición de usuario, parte así, de la relación entre el museo y público, es decir de la dimensión publica. La relación del público con el museo se establecerá como usuario de diversos servicios: Biblioteca, investigación, actividades, exposición..
Hay que tener en cuenta:

- La definición de los servicios, teniendo en cuenta la faceta cultural y de servicio público de la Institución.

- El sentido de servicio público se desarrollará en toda la naturaleza de la institución. Estableciéndose, además, objetivos claros para ampliar y mejorar la dimensión publica del museo.

- La definición de segmentos de comunidad a los que el museo le gustaría servir mas profundamente, para una implicación sustantiva. Desarrollando servicios a partir de identificar usuarios con necesidades especiales.

- Diferenciar entre los departamentos del museo y los servicios que puede prestar éste. 
Además se deberá de definir una política de atención al usuario que servirá para establecer la calidad a la que se debe de llegar en cada uno de los servicios del museo. Abarcando todos los espacios donde se establece contacto con el usuario: gestión de colecciones, acceso ,marketing, muestras, educación, atención directa, seguridad, evaluación, etc.

Una vez establecidos los servicios su divulgación será fundamental para dar a conocerlos por usuarios y profesionales.

Llegados a este punto es necesario redactar los objetivos específicos con relación a los servicios. En otros apartados se han recogido objetivos relacionados con la difusión o las colecciones, así que a continuación se establecerán los objetivos para el resto de servicios no abarcados, sirviendo a la vez para la totalidad de servicios del museo. Los objetivos específicos y normas de funcionamiento de los servicios del museo, de la cara pública, deberá tener origen en los objetivos generales del museo.

\section{Objetivo:}

Establecer la forma adecuada de atención al público.

Líneas estratégicas:

-Concebir las tareas del museo como diferentes tipos de servicios que ofrece el museo en el desarrollo de sus objetivos.

-Conseguir la calidad en los servicios.

-Definir la de accesibilidad: de acogida y acceso.

-Estructurar la información y señalética. 


\section{V.4. PROYECTOS PARA LOS SERVICIOS}

Vistas las bases teóricas se dan unas propuestas de definición de los proyectos que sirvan de llave para el diseño y ejecución de los proyectos finales:

\section{V.4.1. Proyecto de definición de los servicios del museo:}

Éste proyecto se ocupa de la definición de los principales servicios, Instalaciones y equipamientos adecuados, etc, puestos a disposición para los distintos usuarios.

\section{Servicios de atención al publico-usuario.}

Espacio de acogida.

El programa arquitectónico posibilitará la presencia de un espacio adecuado para la acogida, el cual recuperará el sentido original del edificio: la sala oval como entrada al edificio. Supondrá contar con un gran espacio de acogida, representativo y atractivo.

Nos encontraremos en este espacio con el primer nivel de señalética, que nos indicarán las grandes áreas del museo, la sala de exposición temporal, los ascensores, las escaleras, los aseos, la tienda, la cafetería y demás servicios para usuarios.

Además estará presente el inicio de señalización interna hacia espacios para otros usuarios: archivo, biblioteca, departamentos, dirección, área administrativa, etc.

En este espacio se dispondrá de la recepción de usuarios.

El visitante ya tendrá alguna información desde fuera del museo(pagina web guías, señalética externa, etc), pero aquí será donde se ponga a disposición la atención al usuario que acceda al museo, así como la disposición centralizada de información. 
Se atenderá desde un mostrador de información, donde se ubicará un personal formado en el concepto de acogida y atención al publico. La imagen de atención al público es fundamental a la hora de la experiencia museológica del usuario, por lo que se establecerá un ambiente cálido, donde el nuevo usuario se sienta atendido e invitado.
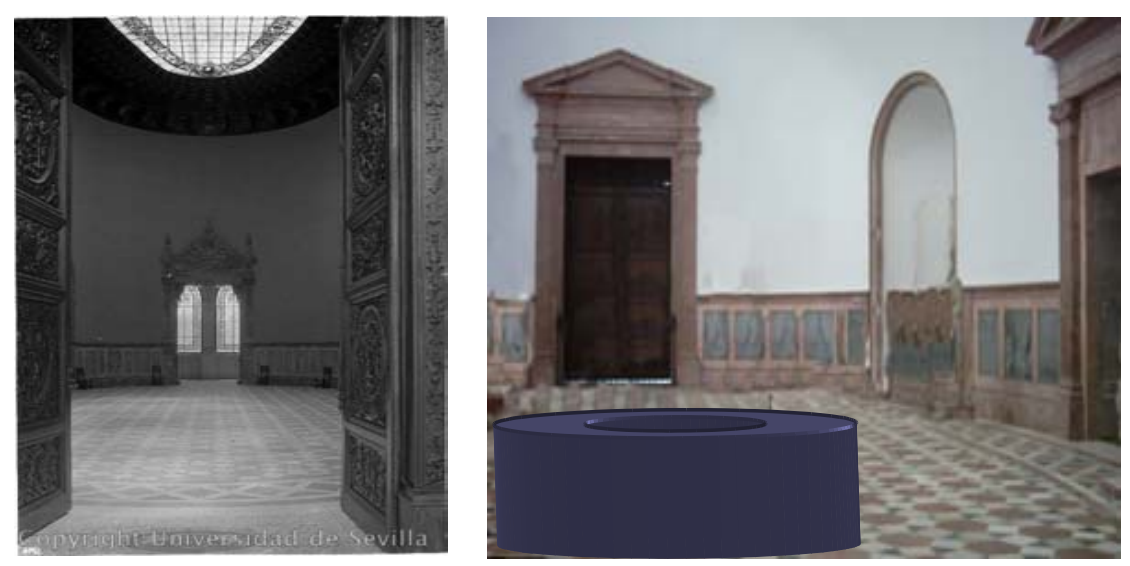

La restitución de la Sala Oval como espacio de recepción es un elemento característico del nuevo plan museológico.

\section{-Taquilla.}

-Información de la exposición y actividades.
-Control de entrada al museo.

-Recepción de usuarios tanto para la exposición permanente, como para la exposición temporal, la tienda; pero también para investigadores, usuarios de biblioteca...

-Se atenderá a la información básica de los servicios solicitados: exposición, biblioteca, departamento del propio museo, archivo, etc.

-Administrará e invitará a la realización de cuestionarios.

-Atenderá de llegada de grupos.

-Facilitará los folletos, carta de servicios, etc.

-Así como la atención telefónica. 


\section{Otros elementos del espacio de acogida:}

-Pantallas: estos elementos de comunicación visual mostrarán una presentación dinámica de las áreas y servicios del museo, que permita con conocimiento previo de los que se puede encontrar. Además, permitirá crear unas expectativas, amenizar el tiempo de espera en la formación de grupos organizados, encuentros, inicio de actividades, etc.

-Guardarropa/ taquillas.

-Módulos de espera y descanso.

\section{Servicio de exposición temporal y permanente.}

Consiste en el servicio más característico del museo.

(Ver programa de exposición permanente)

\section{Servicio de actividades.}

(Ver programa de difusión)
Aseos.

Se repartirán por todo el edificio y se adaptarán a las normativas de accesibilidad. Además de disponer de servicio de cambiador de bebés( Ver proyecto arquitectónico)

\section{Servicios para el descanso y relajación.}

El programa arquitectónico prevé la creación de espacios de descanso, para el confort del público. Para ello se propone un espacio principal de descanso dispuesto cerca de la exposición permanente, consistente en el acristalamiento de una de las loggias, permitiendo un agradable espacio de relajación con vistas a la Plaza América. En éste se dispondrá de mobiliario para el descanso, así como el acceso a información complementaria. 


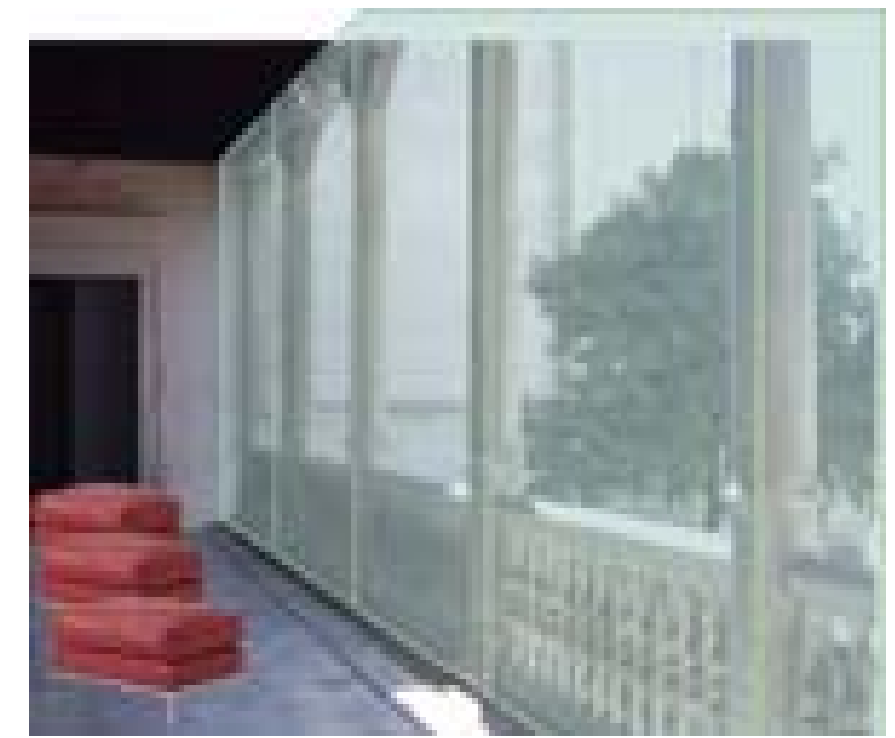

Recreación de los nuevos espacios de descanso creados en las loggias

\section{Servicio de cafetería-restauración.}

En la apuesta por atender a las comodidades y disfrute de la vista, así como de aportar servicios para el propio personal del Museo, se creará una cafetería localizada en uno de los extremos del museo(Ver proyecto de cafetería)
Servicio de venta de publicaciones, objetos culturales y de regalo.

EI MAS contará con una tienda como servicio al usuario para satisfacer sus necesidades y comodidades (Ver proyecto de tienda más adelante)

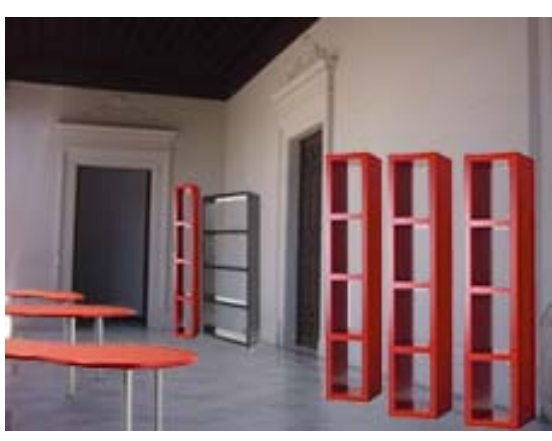

El acristalamiento

de una de las

loqaias permitirá

\section{Servicio de biblioteca.}

La Biblioteca, llevada por personal especializado, satisfacerá las necesidades de información de distintos usuarios. 
El régimen de acceso será libre, tanto para investigadores, como estudiantes, etc. Aunque se creará mecanismos para que la consulta por parte de investigadores tenga preferencia al ser una biblioteca con fondos especializados.

El horario tenderá a ser lo más amplio posible con la posibilidad de abrir al menos una tarde de la semana.

Aunque la consulta de fondos será libre para los usuarios dentro de las salas, y progresivamente se procederá a la posibilidad de préstamo.

Ofrecerá servicios de información y referencia y se ofrecerá la disposición del catalogo informatizado actualizado para la consulta de usuarios. Además de la posibilidad de consulta de Internet, para la consulta de bases de datos remotas, uso de correo y transferencias de ficheros. No se olvidará facilitar las comodidades de reprografía para los usuarios.
Las instalaciones deberán facilitar la comodidad de usuarios por lo que la disponibilidad de los puestos de consulta debe ser suficiente. Valorando que unos 30-40 serán suficientes para atender el Incremento de los diferentes tipos de usuarios gracias a la puesta en marcha de actividades de dinamización, divulgación y difusión de la biblioteca como servicio a disposición de la sociedad.

Éstas actividades de dinamización tendrán diversos objetivos: dar a conocer los fondos de la biblioteca, animar al uso de los fondos por diferentes colectivos, etc. La biblioteca también gestionaría la selección de las publicaciones disponibles en los pequeños apartados bibliográficos disponibles en los espacios de descanso de la loggia y otros espacios habilitados.

Por ultimo, no hay que olvidar la existencia de una señalética adecuada para la localización de fondos y servicios interiores, así como de los recorridos para llegar desde la recepción del Museo. 


\section{Servicio de investigación.}

El régimen acceso continuara siendo el actual, debiéndose de facilitar una información clara para la tramitación del permiso de estudio fondos(exigencias y modo). Además se intentará la posibilidad de definición de unos horarios extensos.

Respecto a los puestos de trabajo, deben de permitir el trabajo de los investigadores, pudiéndose realizar cerca de almacén y en un espacio dispuesto para investigaciones. El museo deberá de disponer mecanismos para la seguridad las piezas estudiadas. Además debe de existir en estos espacios de investigación el acceso a consulta informática del catalogo.

Y por ultimo, se ofrecerá el servicio de reprografía/ reproducciones según la normativa al respecto en instrucciones públicas.

\section{Servicio de reproducciones y fotografías.}

Para la disponibilidad de reproducciones y fotografías se organizará un servicio que facilite fotografías de calidad de la colección a quien las requieran. Que permita un trabajo más cómodo que el mandar fotógrafos por parte de las instituciones y particulares. Evitando, a la vez, el sacar repetidas veces las piezas de las vitrinas.

El usuario tendrá disposición de éste servicio mediante el pago de un precio estipulado previamente. Siguiendo siempre lo dispuesto por la Consejería de Cultura y utilizando en lo posible las instalaciones disponibles por el Museo.

\section{Servicio de publicaciones.}

(Ver Programa de Difusión) 
El departamento de difusión tendría la tarea de la gestión del diseño, publicación, así como de su disponibilidad en biblioteca y en la pagina web. Se contaría con un plan de publicaciones a largo plazo, que recogería las siguientes modalidades:

\section{-Catálogos}

-Material didácticos, en coordinación con el Gabinete Pedagógico.

-Monografías.

-Colección Harris

\section{Servicios on-line.}

A través de la Pagina Web del Museo se tendría acceso a:

-Información útil.

-Información del Museo.

-Visita virtual.
-Acceso a determinados programas de difusión: arqueología abierta, etc.)

-Carta de servicio del propio museo.

-Catálogo On-line ,en formato Domus y sólo para consulta.

-Reserva de determinadas actividades.

-Consulta de la Programación de actividades

-Descarga de material de difusión-didáctico

-Comunicación y participación del público con el Museo

\section{Servicios departamentales}

(ver programa de Recursos Humanos)

\section{Servicios para personal interno}

El museo también tendrá establecido una serie de servicios para el funcionamiento interno de su personal. 
Consistentes entre otras cosas en:

-Aseos y duchas.

-Taquillas.

-Espacios de trabajos por departamentos(ver programa arquitectónico).

-Espacios de reunión(ver programa arquitectónico).

-Espacios para realización de tareas(ver programa arquitectónico.)

-Espacio de descanso.

-Medios comunicativos.

-Archivos.

(Ver Programa de Recursos Humanos)

\section{Servicios de personal en sala.}

El personal de vigilancia y atención de público en las salas. Es en parte la cara hacia el publico por lo que habría que tener especial atención hacia estos trabajadores. Se debe de crear un clima de bienestar en el desenvolvimiento de su tarea. Así como la definición y formación especializada para el desempeño de su función.

\section{Servicio de atención personalizada.}

Consistente en acompañamiento y/o atención de las necesidades de visitantes que requieran de una atención concreta y personalizada. Nos referimos a visitas de diversa índole: visita institucional, inspección, rodaje en sala, técnicos, etc.

En este servicio se facilitará la disposición de equipos, espacios visitables, etc., que el museo pueda disponer para el mejor desarrollo de la visita. Además, se deberá de tener en cuenta la definición de los diferentes niveles de acceso según los tipos de visitantes. La dirección establecerá qué personal atenderá en cada momento. Finalmente siempre actuará en acuerdo con la imagen institucional establecida y siguiendo el protocolo si la situación lo exigiese. 


\section{Servicios de disponibilidad espacios:}

El museo estaría abierto a diferentes entidades, por lo que ampliaría su oferta a quienes quieran disfrutar de sus instalaciones. Dirigido a particulares, instituciones y empresas culturales, asociaciones, centros de enseñanza, organismos, etc. Ofreciendo sus instalaciones para conferencias, cursos, cursos de expertos, presentación de resultados arqueológicos, presentación de libros, mesas redondas, clases magistrales, presentación de servicios, productos relacionados con la historia y arqueología, congresos, convenciones, seminarios, viajes de incentivos, reuniones de negocios y encuentros profesionales, ruedas de prensa, presentaciones, workshops, actos sociales, etc.

El Museo ofrecería una serie de espacios, que sin perjuicio de la actividad del museo, permita una rápida organización, limpieza, monje de stand, etc.
Serían cedidos gratuitamente o a cambio de prestar algún servicio al museo (patrocinio de alguna actividad, publicación, etc.)

\section{Servicio de comunicación institucional}

Este servicio estará llevado por el personal definido en los Recursos Humanos para dicha tarea, el cual deberá estar siempre coordinado con el Gabinete de prensa de la delegación de la Conserjería de Cultura.(Ver Proyectos de Comunicación y Recursos Humanos)

\section{V.4.2. Proyecto para la calidad de servicios ${ }^{63}$.}

\footnotetext{
${ }^{63}$ Decreto 317/2003, de 18 de noviembre, por el que se regulan las Cartas de Servicios, el sistema de evaluación de la calidad de los servicios y se establecen los Premios a la Calidad de los servicios públicos. Y Decreto 177/2005, de 19 de julio, por el que se modifica el Decreto anterior, de 18 de noviembre por el que se regulan las Cartas de Servicios, el sistema de evaluación de la calidad de los servicios y se establecen los Premios a la Calidad de los servicios públicos (BOJA número 154 de 9 de agosto de 2005)
} 
El museo debe de responder a los proyectos de calidad de la administración. Las líneas de expansión de los servicios públicos que presta la Administración de la Junta de Andalucía, exige de generar una mejora en la calidad de los usuarios del Museo.

El Museo debe garantizar el derecho de los ciudadanos y ciudadanas a recibir unos servicios públicos con niveles óptimos de calidad y satisfacción, basados en estándares medibles y asumidos como compromisos por la propia administración. Para ello el Consejo de Gobierno creó la Estrategia para la Modernización de los Servicios Públicos de la Junta de Andalucía para avanzar en la modernización de sus servicios y responder a las nuevas demandas y necesidades sociales. Un nuevo Plan estará vigente de 2006 a 2010, y desarrollará las acciones necesarias para continuar mejorando la atención al ciudadano, ampliar el uso de las nuevas tecnologías y simplificar y agilizar los trámites en la Administración autonómica.
En el marco del anterior Plan Director de Organización para la Calidad de los Servicios (2001-2005), la Junta realiza la evaluación de la excelencia en la gestión en las organizaciones, organismos y entidades dependientes de la Junta de Andalucía prestadoras de servicios públicos tomando como base un instrumento, el Modelo Europeo de Excelencia en la Gestión adaptado al Sector Público (Modelo EFQM Sector Público), que permite la autoevaluación y la evaluación externa, así como la evaluación global e integrada en el conjunto de la gestión pública.

Siguiendo dicho modelo, que ayuda a las organizaciones a establecer un sistema de gestión apropiado para alcanzar el éxito. La Consejería de Justicia y Administración Pública desarrolla Programas de Auto-evaluaciones para que las organizaciones, organismos y entidades, mediante el uso de esta herramienta, midan en qué lugar se encuentran en el camino hacia la excelencia, ayudándoles a identificar posibles carencias y a implantar soluciones. El Museo, pues, se debe integrarse en estos programas. 


\section{Redacción y aplicación de carta de servicios}

La primera tarea del Museo para integrarse en la organización de los Calidad de los Servicios será la redacción de su Carta de Servicios.

Las Cartas de Servicio suponen un compromiso concreto y perceptible con la ciudadanía para la mejora de la Calidad en los servicios prestados.

El museo en su interés por mejorar los servicios trabajará en su propia carta de Servicios. Para ello seguirá el Decreto $177 / 2005$, de 19 de julio, por el que se modifica el Decreto $37 / 2003$, de 18 de noviembre por el que se regulan las Cartas de Servicios, el sistema de evaluación de la calidad de los servicios y se establecen los Premios a la Calidad de los servicios públicos

El museo afecta en el ámbito de aplicación del decreto, al aplicarse a todos los órganos y unidades de la Administración de la Junta de Andalucía.
Corresponde a la Dirección General de Organización, Inspección y Calidad de los Servicios la coordinación, impulso y apoyo de las distintas medidas dispuestas para la implantación de las Cartas de Servicios, evaluación de la calidad y Premios a la Calidad de los servicios públicos.

La redacción de la Carta de Servicio tiene por objeto informar al ciudadano sobre los servicios públicos del Museo, las condiciones en que se prestan, los derechos de los ciudadanos en relación con estos servicios y los compromisos de calidad que se ofrecen en relación con su prestación.

Se redactará de forma breve y clara, conteniendo los siguientes apartados:

De carácter General:

-Datos identificativos y fines del museo.

-Responsable de la elaboración, gestión y seguimiento.

-Servicios del museo. 
-Consistentes en la conservación, catalogación y la exposición de sus colecciones en relación con sus fondos y especialidad científica.

-la Investigación de sus colecciones y ámbito.

-Establecer medios de comunicación con el publico.

-Actividades de difusión contenido y temática.

-Elaboración y publicación de catálogo y monografías referentes al museo.

-Cooperación con instituciones, organismos red ámbito local nacional o intencional.

-Derechos del usuario Derechos concretos de los ciudadanos y usuarios en relación con los servicios prestados:

-Constitucionales, genéricos y específicos.
Se especificará los medios por los cuales el público puede participar en la mejora de los servicios del museo (asociación amigos del museo, por escritos a la dirección y por sugerencias. Especificando la disponibilidad y acceso al Libro de Sugerencias y Reclamaciones.

- Las direcciones postales, telefónicas y telemáticas de todas las oficinas donde se prestan cada uno de los servicios, indicando claramente la forma de acceso y, en su caso, los medios de transporte.

- Relación actualizada de las normas reguladoras de cada una de las prestaciones y servicios.

-Sistema de aseguramiento de la calidad.

-Compromisos de calidad.

-Participación de los usuarios. 
Determinación estándares de calidad ofrecida: plazos previstos de tramitación de los procedimientos y servicios.

Así nos informará sobre la forma de responder a la solicitación de Información, el compromiso de respuestas, sobre reservas, la atención de peticiones de investigadores para acceder fondos, etc. Además la posibilidad de la tramitación electrónica de los servicios prestados.

El compromiso sobre la realización de estudios y de satisfacción de publico de servicios, periódicamente.

-Indicadores de nivel de calidad.

-Indicaciones que faciliten el acceso al servicio y mejoren las condiciones de la prestación.

-Sistemas de gestión de calidad, de gestión ambiental y de gestión de riesgos laborales.

- Referencia para las distintas modalidades de evaluación

- Otros datos de interés sobre los servicios prestados particularmente por el Museo Arqueológico de Sevilla
-Normativa reguladora.

-Información general.

La Carta de Servicio será aprobada por resolución del titular o máximo responsable de la unidad, previo informe de la Dirección General de Organización, Inspección y Calidad de los Servicios. Tendrá efecto en el momento de la resolución aprobatoria de se publicará en el BOJA.

Cuando la Carta de Servicios esté aprobada, la unidad responsable de su gestión y seguimiento deberá remitirla a la Dirección General de Organización, Inspección y Calidad de los Servicios, en formato papel y soporte informático.

La carta de Servicios deberá de ser actualizada siempre que haya modificaciones sustanciales.

En el primer trimestre de cada año el Museo debe elaborar "un informe detallado sobre la observancia de la misma durante el año anterior, analizando resultados e indicadores y explicando las medidas correctoras o planes 
de mejora que se propongan aplicar, que serán tenidos en cuenta para la actualización de los compromisos previstos en las Cartas de Servicios". El informe de seguimiento de las Cartas de Servicios se remitirá por el titular o máximo responsable del órgano a la Dirección General de Organización, Inspección y Calidad de los Servicios y se incluirá en la Memoria anual de cada Consejería.

\section{Difusión de la carta de servicio}

El Museo garantizará en todo momento que pueda ser conocida por los usuarios a través de la publicación de un folleto informativo de las carta de servicio, el cual estará a disposición del público en los diferentes servicios y en el mostrados de recepción. Así como en la pagina web del Museo y de la propia administración de La Consejería de Cultura.

Además deberán ser facilitadas por las unidades responsables de su gestión, con carácter general y en número suficiente, a las Oficinas de Información al Ciudadano de la Administración de la Junta de Andalucía. Se tendrá en cuenda que el Dirección General de Organización, Inspección y Calidad de los Servicios para que la divulgación responda a criterios uniformes.

En el diseño se tendrá encuarta la imagen unitaria para la identificación genérica de las Cartas de Servicios en la Administración de la Junta de Andalucía.

\section{Evaluación de la Calidad de los Servicios}

La evaluación de la calidad constituye un proceso que engloba el diagnóstico sobre los niveles efectivos de prestación de los servicios y su relación con las expectativas de los ciudadanos, así como la medición del grado de cumplimiento de los compromisos declarados.

"La evaluación de la calidad tiene como finalidad proporcionar a los órganos directivos de la Administración 
General de la Junta de Andalucía y sus Organismos Autónomos la información agregada necesaria para ordenar y dirigir los servicios públicos y planificar y adoptar las medidas de mejora que les sean precisas. Asimismo permitirá informar a los ciudadanos sobre el nivel de calidad de los servicios públicos prestados para el mejor ejercicio de sus derechos"

La evaluación de la calidad de los servicios se articulará mediante las modalidades de auto-evaluación y evaluación externa sobre la base del Modelo Europeo de Excelencia en la Gestión adaptado al Sector Público. Ambos tipos de evaluación precisan de la medición previa y periódica de los niveles efectivos de prestación de los servicios.

La auto-evaluación consistirá en un examen interno que permitirá conocer a los empleados públicos que intervienen en la prestación del servicio, los puntos fuertes y áreas de mejora, y a los responsables del servicio actuar sobre el nivel de calidad del servicio prestado adoptando medidas correctoras y planes de mejora.

La evaluación externa proporciona la información agregada necesaria para la adecuada ordenación de los servicios y para la adopción de iniciativas generales de mejora, así como para informar a los ciudadanos sobre los niveles de calidad ofrecidos y facilitarles el ejercicio de sus derechos.

La Medición de los niveles de prestación de los servicios se hará basándose en el diagnóstico del nivel de calidad con que se vienen prestando los servicios sobre la base del Modelo EFQM Sector Público, los órganos, organismos y unidades implantarán sistemas de medición de acuerdo con los siguientes criterios:

Selección de indicadores de calidad fiables y representativos de los parámetros o dimensiones de la prestación del servicio más relevante para los usuarios. 


\section{Cuantificar la evolución de los indicadores.}

La evaluación de los niveles de calidad con que se dan los servicios incluirá datos sobre la satisfacción de los usuarios, así como sobre la eficacia y la eficiencia de los servicios, que se obtendrán directamente a través de métodos de encuesta, estudio de público, y formularios de actividades, Para lo que los estudio de público continuo aportarían estos datos necesarios.

Anualmente se elaborará un informe sobre la evolución de los indicadores de calidad, que será remitido a la Dirección General de Organización, Inspección y Calidad de los Servicios

La auto-evaluación se dirigirá a comprobar el nivel, asesorados por las unidades de calidad de las respectivas Consejerías y Organismos Autónomos, coordinados con la Dirección General de Organización, Inspección y Calidad de los Servicios..Permitirá la establecerán en planes de mejora anuales los nuevos objetivos y compromisos, cuyo grado de cumplimiento se comprobará en la siguiente autoevaluación.

Se tendrá en cuanta la evaluación externa será realizada con autonomía y objetividad de forma que se pueda comprobar e informar a los responsables de la Administración Pública sobre el nivel de excelencia y calidad de la prestación de los servicios públicos. Además del nivel de excelencia alcanzado, se determinarán las áreas de mejora que permitan poner en marcha planes de mejora de la calidad.

Los responsables de los órganos, organismos y unidades, a partir de los informes de evolución de los indicadores de calidad y de seguimiento de las Cartas de Servicios, así como especialmente de las auto-evaluaciones y evaluaciones externas, establecerán planes de mejora de la calidad de los servicios que prestan con la participación del personal público. 


\section{Conseguir un reconocimiento.}

El Museo Programará y trabajará para la obtención de un reconocimiento de la calidad del museo como signo del esfuerzo emprendido con la remodelación.

Los Premios a la Calidad de los servicios públicos ${ }^{64}$ de la Junta de Andalucía tienen el fin de distinguir el trabajo de mejora. Anualmente se convocarán dichos Premios mediante Orden de la Consejería de Justicia y Administración Pública

Se optaría por alguna de las siguientes modalidades de Premios:

"El Premio a la excelencia de los servicios públicos en la Junta de Andalucía tiene organismos y unidades que mediante su actividad de mejora hayan incrementado la calidad de los servicios que prestan a los ciudadanos, y

\footnotetext{
${ }^{64}$ Por el capitulo IV del Decreto 177/2005
}

tengan aprobadas y publicadas las correspondientes Cartas de Servicios".

Premios a las mejores prácticas de calidad en la Junta de Andalucía. "Los Premios a las mejores prácticas tienen como fin el reconocimiento a los órganos, organismos y unidades que más se hayan distinguido en la implantación de técnicas o instrumentos de mejora que hayan contribuido a incrementar la calidad con la que se prestan los servicios públicos".

\section{V.4.3. Proyecto de accesibilidad}

Se definirá en el proyecto arquitectónico.

\section{V.4.3.1. Proyecto de señalética}

Presentada la necesidad de una mejora señalética en el apartado de evaluación se propone a continuación las principales líneas para el diseño del proyecto de senalética 
para el Museo. Además, El proyecto señalético trataría de intervenir sobre el contenido para que se convierta en un elemento clave de la identidad visual.

\section{A Señalización externa:}

Se dispondrá de una señalización externa que facilite la localización y el acceso, además que publicite de antemano el museo, favoreciendo la creación de su identidad visual, imagen publica. La señalización se utilizará ,así mismo, para indicar la dirección en que se encuentra el museo, indicar la zona de aparcamientos, orientar sobre las paradas(bus) y ocasionalmente orientar sobre las exposiciones, actividades, cursos conferencias...

Esta señalética podemos agruparla en:

-Las señales de dirección y localización
Las principales y de mayor tamaño indicarían el acceso al edificio desde calles y avenidas adyacentes, áreas de estacionamiento y paradas de transportes públicos. Las señales de segundo nivel direccionales indicarán los accesos concretos al edificio o el tránsito alrededor del mismo. Así indicarán:

\section{-Entrando a la ciudad \\ -Dentro de la ciudad \\ -En el entorno del Parque}

Las señales externas de localización (aparcamientos minusválidos, de bicicleta etc.) deberán estar en lugares visibles y alrededores del museo, excepto los carteles de direccionamiento hacia ella que estarán colocados en puntos estratégicos de la población y como mínimo en un radio de 2 Kilómetro del edificio.

Deberá utilizarse soportes estándar en algunos casos (para las vías de comunicación, etc.) 
- Las señales de identificación:

Se ocuparian de significar la existencia del edificio del Museo en el entorno en el que se ubica, acompañadas de un rótulo del símbolo del museo. A nivel general, bastaría con una señal que indicara el nombre de la institución, pero puede incluirse un indicativo con la fecha de construcción o algún otro dato significativo (B.I.C. arquitecto).

A este tipo de señales, le acompañarían también unas informaciones complementarias sobre la identificación de accesos, entradas o parte principal del edificio, con menores dimensiones y de carácter secundario. Podría consistir en una mejora en la señalización del ayuntamiento existente frente al Museo.

Las señales externas de contenidos comprenden las relativas a la denominación del museo y pero estas no hacen falta puesto que existen varios indicadores(fachada del museo, indicadores del Parque)
Habría que tener en cuenta el diálogo entre el patrimonio y la señalética externa al encontrarnos en un BIC.

- Señales exteriores de instrucción:

Se referirán a aspectos que regulen el tráfico, entrada, estacionamiento, horarios de apertura y condiciones especiales de acceso restringido.

-Señales exteriores de carácter informativo.

Consistiría en el diseño de panel informativo de actividades sobre información de carácter general como horario de apertura, etc. accesible sin necesidad de acceder al museo, y una vez que las puertas del museo estén cerradas. Debe de permitir actualizar la información, para exposiciones, encuentros ,día Internacional del Museo, actividades nocturnas ,etc. Presentará una 
iluminación nocturna y tendrá que ser resistente a actos vandálicos.

El proyecto de señalética debe perseguir, por tanto, orientar e informar al ciudadano de un sitio complejo en el que se alternan edificio y espacios verdes, y todo ello con la obligación de proporcionar un fuerte carácter artístico aportando contemporaneidad al conjunto.

Tener en cuenta: contenido informativo, ubicación en el entorno, la forma exterior de la señal, su fijación (suspendida, adosada, exenta...)

Se deberá tomar como punto de partida una clasificación clara en cuanto a las señales, facilitaría en gran medida el proceso de diseño ya que se pasaría a localizar aquellos puntos de mayor interés en un plano, con la finalidad de determinar la cantidad y la ubicación de las señales y poder comenzar con una estimación aproximada sobre tamaños, tipos, materiales, iluminación, tc.
La ubicación de las señales requerirán un estudio minucioso, ya que un número mayor de ellas puede provocar el efecto contrario al deseado de orientar y una ausencia de las mismas puede no llegar a ser suficiente en el proceso comunicativo. Es común el comentario en esta línea que es preferible un defecto a un exceso de señales que llevará a un caos informativo o como mínimo a una contaminación visual.

Concibiendo soporte señaléticos que se integren en este paisaje urbano de excepción. Reflexionando detenidamente acerca de todos los elementos: los materiales, el tamaño, los volúmenes, los colores y el número en los que se compondrían.

\section{B. Señalización interna:}

Antes de realizar un diseño de señalización interna hay que homologar el diseño aprobado como norma básica de aplicación universal. 
Nos encontraríamos con tres espacios fundamentales para la ubicación de señalética:

-En el Ovalo, como lugar de recepción.

-En el recorrido, exigiendo una fácil ubicación del visitante en el edificio.

-En las distintas instalaciones (salón de actos sala de exposición permanente, etc.)

\section{Los directorios generales:}

Se ubicaran en los puntos más visibles en el acceso al edificio, en la hall de entrada de modo que sean la primera información que reciba el usuario, y así pueda conducir su visita. Como el edificio consta de varias plantas conviene situar un directorio de planta única(con plano) en los accesos a cada nivel bien junto al ascensor o bien junto a las escaleras.
Se deberá de tener en cuenta la accesibilidad de usuarios por los dos edificios por lo que habrá que duplicar los directorios generales.

En el Hall se ubicará primera jerarquía de señalética para la de ubicación de espacios y servicios. Debe Facilitar de identificar en un espacio tan grandioso, dejar claro las grandes áreas del museo.

\section{Las señales de dirección:}

Se presentarán a lo largo de toda la planta del edificio, su finalidad principal es indicar y confirmar el recorrido a seguir por el usuario. Podemos encontrar estas señales a lo largo de corredores y puntos en los que se puedan tomar distintas alternativas. No hay olvidar en el diseño que el museo tendrá entrada por dos edificios diferentes. Así mismo, se debe de facilitar la Identificación de espacios, para todo tipo de usuarios, área publica o área interna. 


\section{Las señales de identificación:}

Su finalidad de ubica fácilmente al usuario confirmando que finalmente ha localizado el motivo de búsqueda. Todos los destinos finales deberán ser señalizados. Desde los principales a los secundarios. Las señales más importantes nombrarán el número de sala y el contenido. Las de segundo nivel de identificación se refieren a los llamados destinos particulares dentro del museo, así como algunos elementos añadidos de interés como pueden ser los aseos, extintores Las instalación: cafetería, sala de exposición temporal, tienda, dirección, aula didáctica etc. La identificación también llegaría a la personalización, identificando los miembros del museo.
En el espacio de acogida

aparecerán los indicadores de las grandes áreas del museo.

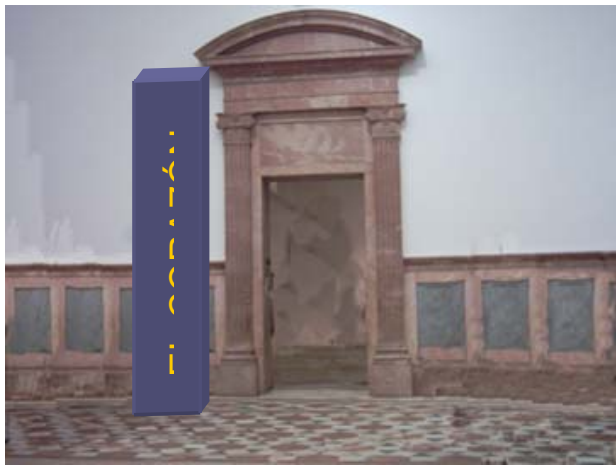

También entra en este apartado la definición de las señales de identificación de las áreas temáticas principales de la exposición permanente:

\section{Las señales de instrucción:}

Se referirán a horarios y referencias a aquellas prohibiciones o condiciones especiales que hay que respetar dentro del edificio (no fumar, no comer, guardar silencio, acceso restringido a ciertas áreas...) 
Las señales de instrucción, irán situadas junto a equipos de seguridad, apertura de puertas, etc Las imperativas, según la normativa, se ubicarán en itinerarios de salida de emergencia y donde estipulen las normas ya que es un Bien de Interés Cultural.

La colocación de las señales debe situarse de modo que pueda verse y ser leída a la distancia suficiente para tomar cualquier decisión que sea necesaria. Esto significa que deben colocarse, a ser posible, para ser visualizadas de frente por el usuario y su altura debe ser tal que se encuentre dentro del ángulo visual de un observador de altura media.

Al tratarse de un sistema, es lógico que señales del mismo tipo se encuentren expuestas del mismo modo, con la misma forma, en situación y altura similares. La finalidad es doble:

Por una parte se evita una competencia entre señales y por otra el usuario busca la señal siguiente del recorrido en una situación similar a la que ya conoce y le ayuda a seguir el sistema señalético con mayor facilidad.

La señalética de la exposición no entraría en las competencias del programa de señalética del museo (Ver programa museográfico)

\section{Señalización democrática:}

Las señales deben ser accesibles para todos los usuarios:

-Accesible a todo tipo de alturas.

-Visibles con facilidad.

-Fáciles de identificar.

Hay que tener en cuenta la variedad y gama de problemas físicos de accesibilidad a la información (visual, motores, etc.). 
Encontramos en este punto una especie de vacío, ya que aún no existe suficiente atención a este porcentaje de la población que presenta cualquier minusvalía, no sólo hablamos de la ceguera, sino de defectos más leves en la visión, falta de movilidad, pérdidas auditivas,etc.

Solucionándolo de un modo imaginativo.

El sistema braille aplicado a los señaléticos en España aún está bastante descuidado, encontrando mayores referencias sobre todo en Estados Unidos. Los mapas táctiles, la numeración braille en ascensores, los sonidos que identifican si el ascensor sube o baja, son pequeñas mejoras que pueden eliminar las barreras para discapacitados con un bajo coste de producción.

Prevención y Atención a Minusvalías implantación de la señalética en la arquitectura debe de tenerse en cuanta desde la fase de planificación arquitectónica.
No se olvidará, ademas, la señalización de rutas alternativas sillas de ruedas, personas mayores etc.

\section{Elementos del sistema de señalización}

El diseño de Los elementos constitutivos del sistema de señalización deberá recoger las siguientes elementos:

Los caracteres tipográficos valorarán el diseño de una buena legibilidad, para lo que habrá que decidir el tipo de letra claro, con letras mayúsculas y minúsculas combinadas para diferenciar los niveles del mensaje. El tamaño de los caracteres determina la distancia a la que pueden ser leídos, así como la separación entre caracteres.

-Estilo: el diseño atenderá al carácter histórico del edificio pero con una estética moderna e imagen de calidad.

-Diseño unificado. 
-Símbolos: Los símbolos diseñados en el sistema de señalización serán fundamentalmente de los siguientes tipos:

Información:aseos,taquillas,escaleras,ascensores,aparcami ento,cafeteria tienda sala de exposición temporal, secciones de exposición permanente, salón de actos ,sala multiuso, espacios de descanso, etc. Además de contra incendios extintores y mangueras, salidas de emergencia.

Dirección: Hacia las secciones del museo.

Prohibición: En relación con la seguridad, zonas de uso interno, seguridad para las colecciones, etc. Debe emplearse un uso medido que no de la impresión de prohibirlo todo. Se intentará ,no obstante que el diseño de mobiliario y arquitectónico expresen las prohibiciones.

-Colores: Los colores deberán tener en cuenta su valor estético acorde con el diseño general de las instalaciones

del museo y también valor comunicativo, asociándose fácilmente con los conceptos. Además debe de garantizar la máxima legibilidad del mensaje, armonizando a la vez con el ambiente del museo.

-Materiales: La señalética externa de dirección deberá atenerse a la señalética estándar en los casos que así estuviesen establecidos(direcciones de trafico, señalética municipal para jardines, etc)

\section{V.4.3.2. Proyecto para la cafetería}

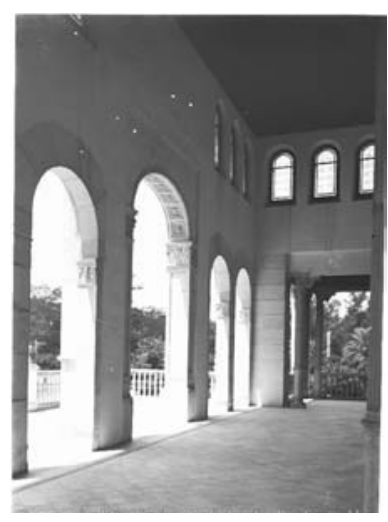

La rehabilitación de las terrazas y loggias de los extremos del museo permitirá crear espacios para el descanso y servicio de cafetería
El Museo dispondrá de un espacio de restauración para mejorar la experiencia y satisfacción de usuario.

La Empresa Pública de Gestión de Programas Culturales gestionaría las 
propuestas de los concursos públicos para llevar acabo el funcionamiento de este servicio. Definiéndose la cuantía, los suministro necesarios, los plazos, etc. para ello se seguirá lo establecido en el Real Decreto Legislativo $2 / 2000$, de 16 de junio, por el que se aprueba el Texto Refundido de la Ley de Contratos de las Administraciones Públicas.

Por medio de concurso publico se establecerá , además, la empresa para la gestión y administración del servicio de la cafetería.

Como ya hemos visto en los proyectos arquitectónicos se instalará en el extremo Oeste del museo, ocupando la logia, la cual se acristalará para alojar las instalaciones, y además se podrá acceder a la terraza a modo de velador.

\section{V.4.4. Proyecto para la tienda}

El museo se dotaría de un servicio al público para la adquisición de productos relacionados con el Museo. A modo del resto de tiendas de museos y conjuntos Arqueológicos dependientes de la Consejería de Cultura.

La Empresa Pública de Gestión de Programas Culturales gestionaría las propuestas de los concursos públicos para llevar acabo el funcionamiento de este servicio. Definiéndose la cuantía, los suministros y plazos. Siguiendo, como ya se señaló para la cafetería, lo establecido en la Orden de 17 de marzo de $1994^{65}$ y en el Real Decreto Legislativo 2/2000, de 16 de junio, por el que se aprueba el Texto Refundido de la Ley de Contratos de las Administraciones Públicas. Permitiendo el suministro de los diferentes productos propuestos (fotomecánica,

65 Orden de 17 de marzo de 1994, por la que se encomienda la gestión de las instalaciones para servicio de venta de publicaciones y otros artículos en los Museos y Conjuntos Monumentales y Arqueológicos de la Comunidad Autónoma de Andalucía a la Empresa Pública de Gestión de Programas y Actividades Culturales y Deportivas. (BOJA 91 de 17 de junio de 1994) 
impresión y suministro de artículos de papelería, reproducciones y textiles) y de la gestión de la tienda.

A continuación se proponen los productos comerciales a la venta en la tienda:

- Papelería:

-Carteles.

-Postales.

-Grabados itálica.

-Separadores de libro.

-Lápices: lápiz grafito, lápiz flexible, etc.

-Alfombrilla.

-juegos cartas y sobres.

-Gomas: flexible, etc.

-Bolígrafos.

-Portaminas.

-Sacapuntas.
-Libreta.

- Textil:

-Pañuelo.

-Camiseta con la imagen corporativa $y / u$ otros diseños exclusivos. Tallas: 2 , 2/4, 5/6, 7, 8, 9 , S, M, L, XL, etc.

-Gorra.

-Corbata.

- Librería:

-Guía del Museo Arqueológico y otros.

-Catalogo de exposiciones del museo y otros.

-Publicaciones de arqueología y metodología arqueológica.

-Cartas de riesgo.

- Publicaciones de Yacimientos Arqueológicos.

- Publicaciones de Patrimonio.

- Publicaciones de Museología. 
- Publicaciones divulgativas de otros museos, Conjuntos Arqueológicos e Instituciones del patrimonio Histórico.

-Publicación juveniles e infantiles de historia, arqueología y museos.

-Material didáctico del Museo y otros.

- Publicaciones de cultura Prehistórica, Ibérica, romana, Islámica, cultura Medieval, moderna.

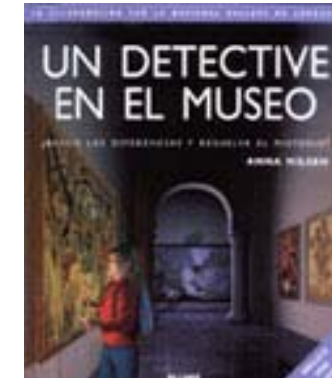

En la Tienda se adquirir productos para diferentes tipos usuarios

-CD/ documentos sonoros: selección de música de diferentes épocas y culturas relacionada con la exposición, e himno de Andalucía.

- Juegos:

-Disfraces: De romano, emperatriz, faraón, momia, princesa, rey, etc.

-Videojuegos. Selección de juegos relacionados con la historia y arqueología: Age of Empire, Tomb Raider, Legend, etc.
- Productos de gran calidad:

- Reproducción de piezas del Museo: Mano de Zeus, motivos de mosaicos enmarcados, jarras de cristal, platos y cuencos romanos, busto de Adriano, juego de monedas de diferentes épocas, Astarté, bandeja de El Gandul, etc. -Joyería: pendientes, colgantes, piercing, pins, etc.

-Zapatos: Selección de una marca reconocida con modelos que pervivan formas antiguas $o$ inspirados en formas tradicionales esparto, sandalias etc.

-Artesanía exclusiva inspirada en la colección del museo: caja de mosaico, fibula-alfiler, anillos, juego de complementos inspirados en el Tesoro del carambolo, lapicero inspirado en las aras bálquicas o ídolos calcolíticos, etc. 


\section{V.4.5. Proyecto para los espacios para el descanso}

Para mejorar la experiencia de los usuarios se definirán espacios para:

-descanso y contemplación.

-Acceso a información complementaria y miniludoteca Los cuales se ubicaran a lo largo de la exposición permanente y anexa a ella.

Este proyecto se definiría conjuntamente con el proyecto arquitectónico y museográfico.

\section{V.4.6. La oferta de recursos para la difusión y educación}

Se ofrecería al público herramientas para la programación de una visita de antemano, posibilitando acercarse de manera comprensible al mundo de la historia, patrimonio y arqueología, así como conocer las Colecciones que alberga el Museo y sus exposiciones temporales.

El primer recurso disponible sería La Guía del Museo, que permite tener un documento básico para seguir la visita al museo y una lectura posteriori a ésta.

La Guía del Profesor ofrece un punto de partida para que pueda acercar a sus alumnos a la Colección y preparar un recorrido con las piezas mas destacadas. Con estas guías se dota al Museo de herramientas de interpretación fundamental para la visita.

Las Guías de Actividades para el Alumno son un instrumento de ayuda para reforzar la visita y trabajar posteriormente los contenidos en el aula.

Las guías didácticas estarían pensadas como un material de apoyo para profesores, estudiantes y público general para la visita a las exposiciones temporales. 


\section{Guías de Actividades:}

Se trata de un banco de recursos educativos, consistentes en una serie de ideas y sugerencias para que niños y adultos puedan tener una experiencia gratificante en la estancia en el Museo. Este material estaría disponible para monitores, acompañantes animadores, etc. Pudiendo ser utilizada en diferentes contextos: vistas familiares, campamento urbano, escuelas de Verano, etc,

En ellas encontraremos desde juegos y actividades de contenido diverso, basados en el aspecto lúdico; hasta herramientas que ayudarán a observar, a generar interrogantes y a potenciar la capacidad perceptiva y reflexiva. Permitiendo, al mismo tiempo, un recorrido por las obras más significativas de la Colección, aspectos históricos y modos de investigación arqueológica.

Estas herramientas estarían disponibles en:
-Consultables en la Biblioteca del Museo.

-Adquirible en la tienda del Museo.

- La pagina web del museo. 


\section{V.5. EL USUARIO DEL MUSEO}

Antes de comenzar con los programas de Difusión y Comunicación se procederá al establecimiento previo de cuestiones relacionadas con la definición del público del Museo. Permitiendo, posteriormente, las propuestas para desenvolver los proyectos concretos de difusión, comunicación y servicios.

\section{V.5.1. Museo democrático, redefinición del concepto del público del museo.}

El museo tiene la misión de transmitir a la comunidad todo aquello que la pueda enriquecer, desde un nivel intelectual a otro emocional. De aquí el desarrollo progresivo al que se debe llevar la institución en la concienciación del servicio al ciudadano. El Museo se debe de establecerse, así, como un museo para todos; una orientación de dirigirse a todos los públicos, en la medida de sus posibilidades. Tratando

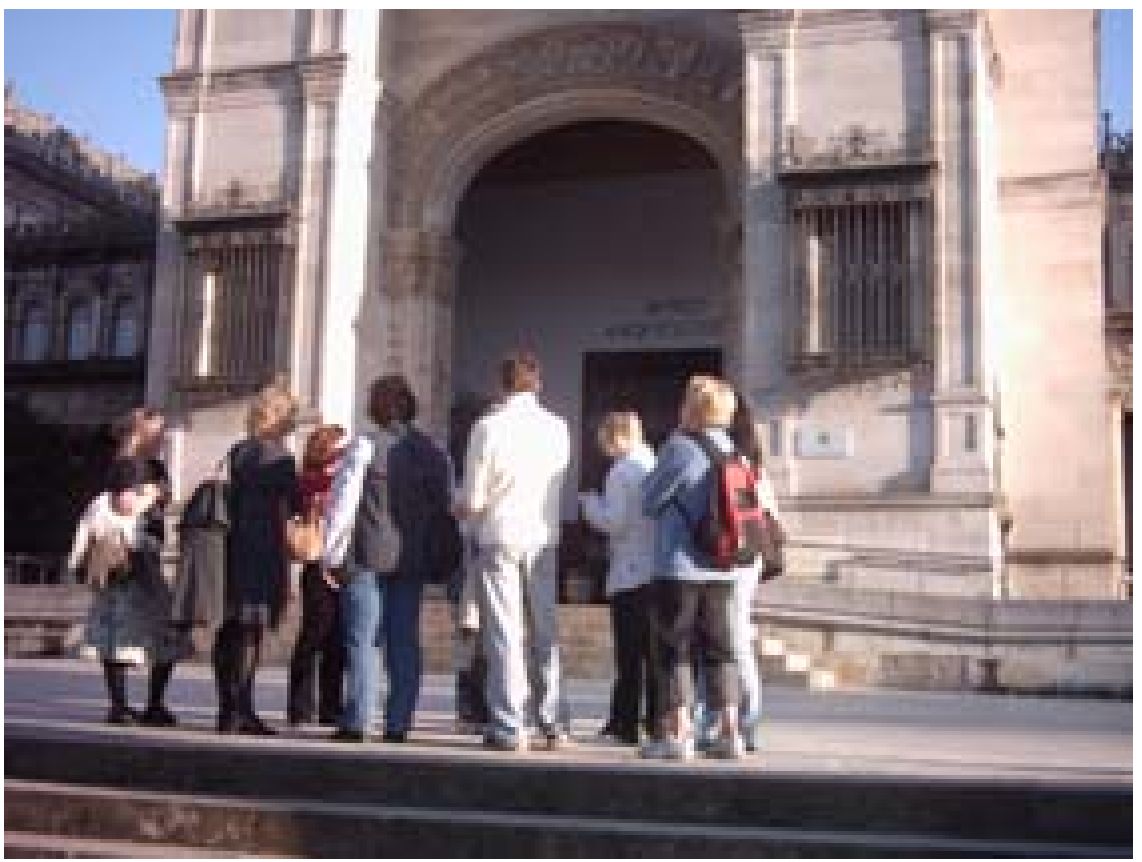

de hacer una oferta suficientemente variada y estructurada, de manera que pueda ser atractiva, así como necesaria a personas con diferentes niveles de formación e intereses específicos.

Se partirá del concepto de que todo el que se acerque al museo a utilizar un servicio debe de ser tratado como usuario, desterrando conceptos como "visitante", etc. 
La institución debe trabajar por los usuarios de los diferentes servicios que ofrezca: exposiciones, biblioteca, tienda, etc. Aun así no debemos de perder la perspectiva de que la exposición será el servicio del museo el recurso más usado de las institución, en la que se atenderá a un mayor tipo de usuarios.( En el apartado de servicios se establecerá más detenidamente la redefinición del usuario/visitante del museo.)

Para responder a las necesidades de cada uno de los tipos de usuarios surge la necesidad del control o conocimiento de los visitantes de la exposición pero también investigadores, empresas, etc. Para lo que se establecería un estudio de públicos y demás herramientas necesarias.

Definición de públicos funcionales. De esta definición dependerá sustantivamente la complejidad expositiva, los programas de actividades y la comunicación que el centro pondrá en marcha.
La delimitación de los públicos permite la adaptación a las necesidades y requerimientos de los usuarios del museo en faceta de éste como servicio publico.

Objetivo en relación al público: Establecimiento del concepto usuario de museo. Diferenciando los usuarios según los servicios que requieran y sus características intrínsecas.

\section{V.5.1.1. Líneas estratégicas:}

Diversificación de los públicos: visitantes locales, minorías.. Búsqueda de la calidad.

Satisfacción de las necesidades concretas del público.

Establecimiento de servicios enfocados tanto hacia las necesidades de visitantes actuales, como potenciales.

Definición de la relación del usuario con el museo.

Gestión del usuario. 
Estudio de marketing: de productos y público.

Evaluación de exposiciones permanentes.

Implementación del conocimiento del público en la gestión y funcionamiento del museo.

Atracción y aumento de público.

\section{V.5.1.2. Tipo de usuario por servicios.}

Partiendo del estudio de público se establecerá con claridad un primer mapa de usuarios que se atenderá desde el museo.

Hay una serie de servicios que resuelven necesidades generales: facilitar la localización y existencia de servicios específicos, así como la presencia de accesos en red, aseos, lugares de descanso, seguridad, etc. Estos no establecerán ningún tipo especial de usuarios, sino que será el uso de determinados servicios específicos los que nos ayudará a establecer una primera categorización de usuarios.

El primer grupo de usuarios es el referido al uso de servicios por parte del llamado gran público:

\section{Usuarios de actividades difusión/comunicación.}

Los cuales necesitaran el conocimiento del horario, información general de las actividades, lugar donde se desarrollaran éstas, formas de contacto, etc.

\section{Usuario de exposición permanente.}

Se tendrá en cuenta la oportunidad de elegir el recorrido, la claridad del sentido de éste, la necesidad de adaptación de los contenidos, que sea atractiva para todos los visitantes, así como la presencia de espacios para el descanso, aseos, etc. 


\section{Usuario de exposición temporal.}

Deben ser atendidas las necesidades generales del público que acude al museo para ver las exposiciones temporales.

\section{Usuario del programa educativo.}

Se cubrirán las necesidades del acompañante o monitor y las propias de cada grupo, así como se facilitará el movimiento de éste y la presencia de espacios para desarrollar actividades, etc.

A continuación los usuarios relacionados con las demás funciones del museo:

\section{Usuario de investigación.}

Se proporcionará la facilidad de tramitación del permiso para consultar los fondos (exigencias y modo), existencia de espacio para trabajo, seguridad para las piezas estudiadas, además de facilitar un conociendo general de los fondos, acceso a catálogo informatizado, facilitar la accesibilidad a la reproducción de fondos.

\section{Usuario de biblioteca.}

Necesitará: un lugar de consulta de fondos, acceso a Internet, catalogo informatizado de la colección, conexión a electricidad, iluminación adecuada, sin olvidar facilitar conocimientos sobre los fondos bibliográficos, comodidad, reprografía, etc.

Usuarios establecidos en el desarrollo de la actividad interna del propio museo:

\section{Usuario interno.}

Acceso a Internet e intranet, espacios de reunión, comunicación, espacios de almacenamiento, acceso a información, aseos, espacios de descanso, etc. 


\section{Usuarios interno-temporal.}

Se debe de facilitar la accesibilidad y comodidad para el desarrollo de proyectos, montajes de exposiciones, espacio para colocación de material, preparación de actividades, etc.

Otros: usuarios necesidades referentes a agentes de comunicación, etc.

Otros:

\section{Usuario de institución}

Atender las necesidades que afecte a relaciones institucionales, etc.

\section{Usuario de espacios}

La utilización del museo como espacio cultural-dinamizador necesitará resolver y facilitar la llegada de servicios exteriores, permitiéndose rapidez de organización, limpieza, montaje de stand, etc.

\section{V.5.1.3. Mapa de usuarios: Usuarios por características}

Continuaremos con la definición de los usuarios para establecer las necesidades y requisitos que resolverán los proyectos de difusión, comunicación y servicios.

Su correcta definición garantiza que los proyectos respondan a las necesidades reales de los usuarios: Según niveles educativos (genéricos y temáticos), interés(ocio, investigación, etc.), características físicas, intereses, usuarios de servicios, etc. Aun así, nos 
centraremos más en las características en relación con los usuarios de las exposiciones (temporal y permanente) al ser estos los de mayor afluencia.

En el análisis de los servicios y funciones del museo podemos encontrar los siguientes tipos de usuarios:

\section{Investigadores.}

Los cuales necesitarán de la accesibilidad a las piezas de exposición y almacenes, acceso a información complementaria (archivos catalogo informatizado, etc), biblioteca, facilidad para trabajar o conseguir reproducciones, etc.

\section{Expertos.}

Requiriendo la atención a un alto nivel de exigencia de información.

\section{Profesionales en formación relacionados con el museo.}

Atención dentro de un ámbito académico y de formación: Profesores de universidad, estudiantes de Arqueología, estudiantes Historia del Arte, etc.

\section{Personas con problemas físicos e intelectuales.}

Todo el mundo de un modo en grado diferente tiene alguna discapacidad. Para algunos casos se precisarán la atención a necesidades especiales.

La atención a estas características nos obliga a apostar por la exposición multisensorial. Además, de definir un museo sin barreras, no solo en la arquitectura, sino también en el diseño de exposiciones, actividades y resto de servicios. 
En concreto se tendrá en cuenta:

El acceso para minusválidos, facilitando la accesibilidad con silla de ruedas:

La atención a personas con deficiencias auditivas.

La atención de personas con problemas de visión. A la hora del diseño de textos, contenidos y demás recursos expositivos, se tendrá en cuenta la facilidad de visión. La iluminación evitará reflejos o visión directa de las fuentes de luz desde los ángulos de accesibilidad del visitante. Además se ofrecerá una visión cómoda para el visitante de todas las alturas.

La atención a personas con discapacidad intelectual. Programando actividades adecuadas según sus requerimientos.

\section{Por procedencia.}

Los servicios pueden ser utilizados por personas de diversos orígenes, lo cual habrá que tenerlo en cuenta en los idiomas empleados en los diferentes sistemas señaléticos. Así como en los contenidos presentados. Los conceptos sobre historia sabidos por los usuarios son diferentes dependiendo de su lugar de procedencia y educación.

La procedencia afecta principalmente al usuario de la exposición permanente y temporal.

Turistas. Interesado en conocer aspectos culturales de la ciudad, especialmente de su patrimonio. El museo Contribuirá como recurso en la satisfacción en la experiencia turística. La exposición permitirá un mayor disfrute del visitante, aumentado el interés y estimulando la exploración más amplia de territorio. 
Los fragmentos a tener en cuenta son:

-visitantes de la provincia.

-visitante de la Comunidad.

- visitantes nacionales.

-visitantes de la UE.

-visitantes no UE.

Local. Son pocos los residentes en la ciudad que acuden asiduamente al museo. Hay una parte de público local, que visitan exposiciones $y$ otros museos, que tienen abandonado el Museo Arqueológico debido, entre otros motivos, a la imagen de poca puesta al día y dejadez.

El museo puede establecerse para este público como un nuevo lugar de encuentro de la población, el centro donde hacerse conscientes de su entorno y las necesidades de conservación de su patrimonio, además de comprenderlo.

Este público es el que por sus comentarios favorables pueden motivar a otros a visitar el museo.

\section{Participantes en programas específicos}

El museo puede contar con la presencia de público debido a la organización de cursos, congresos, programas de asociaciones, etc.

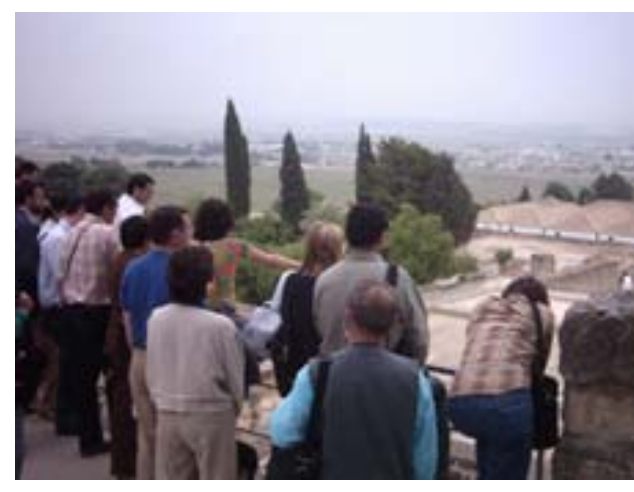

\section{Minorías}

Al museo pueden acudir personas con diferentes orígenes étnico-culturales, tanto europeos, como de países en vías de desarrollo; de distintas creencias religiosas, personas venidas del mundo rural, grupos de jóvenes (pertenecientes a subculturas urbanas),etc. Por ello El museo se deberá de esforzar por servir como medio de 
integración de su cultura, así como tener en cuenta sus perspectivas del mundo.

En relación con la actividad interna del museo:

Trabajadores del Museo.

Relacionado con Agencias de comunicación, actos Prensa y medios de comunicación.

\section{Personal Externo}

Montadores, Profesionales del mundo de la cultura y las artes (cine, teatro, etc.), suministros, etc.

\section{Empresas y Patrocinadores}

Además de entidades que organizan actos, fundaciones e instituciones culturales.

\section{Amigos voluntarios}

A los que hay que prestar atención en agradecer su colaboración, haciéndoles sentirse integrados e importantes. Además de facilitar la organización de sus actividades, la formación, conocimiento del Museo y movilidad dentro de la institución.

\section{Instituciones, organizaciones.}

Teniendo que tener presente cuestiones referentes a la representación, imagen, protocolo, etc.

\section{Forma de visita.}

-Visita individual.

-Visita en pareja.

-Visita en familia. 
Hay que Tener en cuenta los distintos tipos de familias y grupos familiares existentes, formados por: Padres, tutores, abuelos, niños, etc. Es un tipo de visitante que necesitará una atención concreta.

\section{-Vista en grupo reducido.}

\section{-Visita grupo organizado.}

Las instalaciones y servicios deben de permitir la visita de estos grupos.

\section{-Visita concertada.}

La posibilidad de solicitar la una visita programada para que el grupo pueda organizar su agenda.

\section{-Visita rápida.}

Supone crear una exposición que permita el paseo y se incite a una visita mas profunda por medio de lo atractivo del montaje, de las piezas y la comodidad.

\section{-Visita en profundidad}

Para la visita íntegra, habrá que tener en cuenta el agotamiento que puede sufrir la visita. Debiendo de estudiar la diversidad y selección de contenidos atractivos, así como de la posibilidad de disponer servicios para comodidad.

\section{-Visita repetitiva}

Se debe de encontrar alicientes para la repetición de la visita, encontrando en cada visita contenidos nuevos. 


\section{-Visita con guía voluntario}

Se debe de contar con disponer de forma ágil de un guía voluntario del museo.

\section{-Visita con guía propio}

Disponer de información y servicios para el propio guía y el grupo.

-Vista por la mañana

-Vista por la tarde

-Visita a exposición permanente

-Visita permanente y temporal

-Visita permanente y actividad

\section{-Grupos educativos}

El museo establecerá medios para que la visita a la exposición y la institución merezca la pena para el grupo y los formadores dentro del entorno educativo.

Por formación (ver difusión sobre aspectos educativos)

La experiencia satisfactoria dentro de la formación debe de ser motivo para volver en una visita posterior.

Se debe facilitar la planificación de la visita con antelación, además de contar con espacios para almorzar, espacios para guardar objetos personales, etc.

El profesor necesita información detallada y especifica sobre el tipo de ayuda que puede obtener por parte del Museo y Gabinete Pedagógico. Así como de la ayuda 
material y equipos disponibles, lo que deben traer y cuales son las instalaciones (ver apartado de difusión)

Los grupos escolares van a ser el grupo educativo más numeroso y constante en el museo, por lo que se debe de realizar un esfuerzo por aumentar los demás grupos.

En general se atenderá de un modo u otro a grupos de:

-Infantil, ajustándose a los planes de estudios generales. -Primaria, ajustándose a los planes de estudios generales. -Secundaria, ajustándose a los planes de estudios generales.

-Formación profesional, adecuando la visita a sus expectativas y facilitando la realización de prácticas.

-Universitarios, adecuando el servicio a su interés académico.

-Postgrado.

-Formación continua.

\section{Edad:}

Podemos establecer diferencias de contenidos $u$ orientación para las diferentes edades, así como de los servicios que requieran.

\section{-Infantil.}

Hay que tener en cuenta nos dice respecto a las características la psicología del desarrollo, además de cuestionarse qué es lo que se quiere que el museo dé al niño y qué es lo que les gusta.

\section{- Adolescentes y jóvenes.}

En un sentido amplio podemos incluir a personas entre 14 y 30, aunque la definición administrativa sea mas restringida. Atendiéndose a estos grupos de un modo individualizado respecto a niños y adultos. 
-Adultos.

\section{-Personas Mayores.}

Se debe de atender especialmente a este sector el cual tiene un amplio tiempo libre, estableciendo comodidades para su presencia en el museo: posibilidad de un ritmo mas relajado, teniendo en cuenta la capacidad auditiva o visión,la capacidad de movilidad, etc.

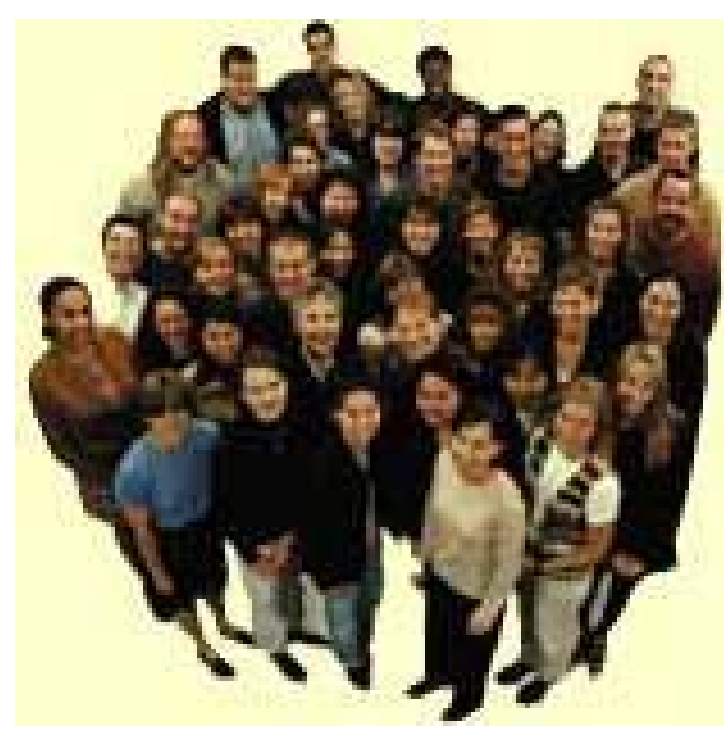

V.5.2. Definición de públicos objetivos para el museo:

Para continuar será necesario establecer una serie de grupos objetivos dentro de este programa museológico. La definición más concreta de los estos grupos permitirá establecer los aspectos que deberán de tenerse en cuenta en los proyectos de difusión, comunicación y servicios.

Esta definición responderá a dos dimensiones:

-Atender más adecuadamente a los públicos actuales, y

-Programar servicios adecuados para atraer a un público potencial, que no se siente atraído por el Museo.

Se puede planificar las necesidades de cada grupo durante un periodo de tres años, en los cuales cada uno de estos 
colectivos encuentren algo que sea especial relevante para sus necesidades e intereses. Permitiendo anticiparse a las necesidades, decidiendo donde realizar un mayor esfuerzo para incrementará el grado de afluencia.

En el presente plan museológico nos regiremos en base a los siguientes grupos objetivos:

- Turistas

- Escolares de educación formal.

- Emigrantes: latinoamericanos, de Europa del Este, magrebíes, subsaharianos, y de China.

- Jóvenes.

- Tercera Edad: como usuarios con mucho tiempo libre.

- Familias: grupo con gran potencial a encontrase el museo en un lugar de ocio familiar como es el Parque Maria Luisa.

- Niños y familias en época de vacaciones.
- Publico local que ha dejado de encontrar el museo atractivo.

- Personas con algún grado de discapacidad física o psíquica. Además de personas con necesidades educativas especiales (Como Síndrome de Down, etc.)

\section{V.5.3. Proyectos}

A continuación se exponen tres proyectos que se desarrollarán conjuntamente con los programas de difusión, comunicación, etc. No hay que olvidar que las actividades de difusión irán encaminadas a la atención de los públicos establecidos anteriormente (Ver proyectos de Difusión) 


\section{V.5.3.1. Proyecto: estudios de públicos.}

Es el proyecto fundamental para conocer a los usuarios del museo. Implica el conocimiento de los diferentes usuarios, tanto sus características psicológicas y demográficas, como sus expectativas, intereses, concepciones espontáneas, concepciones erróneas, sus posibilidades de compresión de mensajes complejos, etc. Implica, además, la delimitación de las bolsas o segmentos de no público, publico actual, público potencial y público cautivo, así como la delimitación de las necesidades especiales de determinados públicos específicos.

La recopilación de información se realizara a partir de los formularios de participación de actividades, de los datos de la venta de entradas, además de métodos propios de investigación:
-Reunión de focus grupos.

-Entrevistas y encuestas.

-Entrevistas en profundidad.

-Mening maps.

-Estudios sobre referentes curriculares.

-Evaluación de exposiciones permanentes

Así como Estudios de audiencias potenciales y estudio de público potencial por segmentos.

Los objetivos de los estudios de públicos serían:

-Definición de las actividades y las exposiciones futuras.

-Conocer el impacto del museo.

-Establecer grupos homogéneos de intereses -Implementar los resultados en la gestión del museo.

-Mejorar los servicios. 


\section{V.5.3.2. Gestión de estudios de públicos:}

Los datos y resultados se deben de integrar en bases de datos adecuados que permitan un almacenaje y su uso para tratamiento, comparación, análisis, etc.

Se planificará los días en los que se recolectará datos para que sean lo más representativos posibles. Además, Se realizará a todos los tipos de usuarios de los diferentes servicios y trabajadores del museo: exposición permanente temporal biblioteca, investigadores, conservadores, cafetería, etc.

En la obtención de datos se contará con la colaboración diverso personal del museo, según los métodos: personal temporal de actividades, personal de taquilla, becarios, personal de sala, bibliotecario/a, personal de estudios de público, etc.

\section{V.5.3.3. Proyecto de gestión del usuario}

Se plantea la instalación de un ordenador para informatizar diferentes tareas en el mostrador de recepción.

Entre otras, permitirá optimizar la recogida de los datos relativos a las ventas de entradas, permitiéndose la consulta por la intranet del museo por parte de los conservadores. Así como de una gestión más cómoda de las reservas de escolares, grupos 0 asistentes de actividades.

Además facilitará conocer avisos de llegada de personas determinadas, agenda de tareas del día, etc.

En definitiva facilitar el funcionamiento del mostrador, y la comunicación entre éste y las demás tareas del Museo. 


\section{V.5.3.4. Proyecto conocimiento al público}

Consistirá en todas las tareas establecidas en los proyectos de comunicación. Tanto la gestión para establecer los medios más adecuados como, por ejemplo, la recopilación de e-mail para comunicarse de forma rápida con los usuarios el museo. (Ver Programa de Comunicación a continuación). 


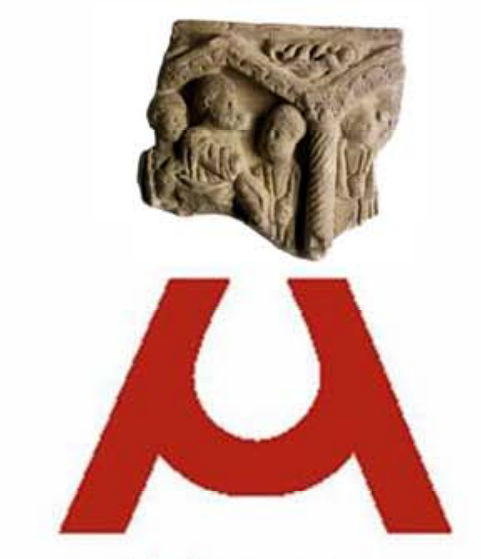

Museo

Arqueológico

de Sevilla

\section{COMUNICACIÓN}

\section{Josefa Cano García}

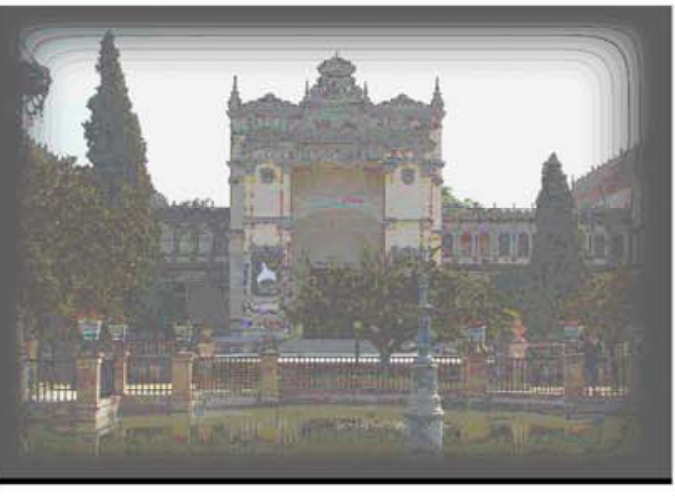


Definiremos, a continuación, los criterios genéricos básicos de la comunicación del Museo Arqueológico de Sevilla, estableciendo las necesidades y requisitos que se desenvolverán en los proyectos concretos de comunicación. De este modo las bases teóricas irán acompañadas de propuestas para la materialización de la teoría museológica.

\section{VI.1. BREVE INTRODUCCIÓN AL} CONCEPTO DE CORPORATE

El concepto de corporate surge a principios de los años noventa a raíz de una crisis estructural en el sector publicitario. Se hace necesaria una gestión estratégica de todos los factores que influyen en la imagen de una institución. La imagen pasa a ser una variable más del management ${ }^{66}$. Se entiende que esta no es fruto solo de la comunicación, sino también de la gestión de la empresa.

Así pues, el corporate es la gestión de los intangibles, valores que hoy por hoy son, prácticamente, los más importantes.

En España, actualmente, el corporate se ha asentado en las grandes instituciones y corporaciones. Éste cuenta con varias herramientas para la gestión de la imagen de las organizaciones. Una de las más importantes es el Manual de gestión de la comunicación.

Management, Voz inglesa, usada con cierta frecuencia en el lenguaje empresarial. Se trata de un anglicismo evitable, ya que equivale a los términos españoles dirección gestión o administración. También significa 'cuerpo directivo de una empresa', caso en el que debe sustituirse por dirección, gerencia o directiva. Diccionario panhispánico de dudas @2005. Real Academia Española @ Todos los derechos reservados.

El Management se define como un proceso, con aspectos interpersonales como técnicos, a través del cual los objetivos de la institución se definen y se cumplen, mediante la utilización de recursos humanos, físicos y tecnóógicos. El proceso de medlant la utilzación de recursos humanos, fisicos y tecnológicos. El proceso de inpuls ( rent puede ser visto como una sinple relación de input - output en la cual los inputs ( recursos humanos, fisicos y tecnológicos) son transformados, bajo la influencia del Management, en los objetivos deseados ( cumplimiento de los objetivos de la organización respecto de los servicios, productos y demás parámetros del desempeño de dicha organización) Por definición, los Managers enfocan su tarea hacia el establecimiento de los objetivos de la organización y hacia su realización. 


\section{VI.1.1 Qué es y para qué sirve un Manual de Gestión de la Comunicación}

El Manual de gestión de la comunicación es una de las herramientas más importantes para la gestión de la comunicación de empresas y organizaciones. A menudo confundido con el Plan de comunicación, al que engloba y determina, y con el MAGICO (Manual de gestión de la imagen corporativa), con el que comparte los mismos principios, se trata de un instrumento relativamente novedoso sobre todo en España, donde aún hay mucho camino por recorrer en cuestiones de corporate.

\section{VI.1.2. Funciones}

Al ser un instrumento globalizador de la gestión de la Comunicación, cumple muchas y diversas funciones, de las que podemos destacar:
El manual de gestión de la comunicación tiene como primera e imprescindible función el determinar la estrategia de comunicación e imagen de la empresa u organización, para un período de tres a cinco años. Esta estrategia se concretará y matizará anualmente por medio del Plan de comunicación.

Consolidar un estilo de comunicación, que es hoy por hoy algo básico si queremos que nuestra organización se identifique y diferencie dentro del panorama de sobre información de la sociedad actual.

En él trazará, igualmente, el diseño orgánico del departamento de comunicación de nuestra organización.

Por último, el Manual deberá prescribir normas concretas para la práctica de cualquier persona de la organización, para su consulta y que se deberá revisar cada cierto tiempo, puesto que nuestra organización es un ente vivo y desarrolla su actividad en un entorno cambiante. 
Como ya se ha apuntado, se trata de un instrumento de un gran nivel profesional para la gestión de la comunicación. Es prácticamente imprescindible para las instituciones y corporaciones con un alto nivel de actividad comunicativa. Este es el caso del Museo, puesto que una de las principales funciones de la organización es la de difundir su patrimonio cultural y científico.

\section{VI.1. 3. Conclusión}

El Museo es un ente vivo y desarrolla sus actividades dentro de un entorno también vivo y, por tanto, cambiante, es por esto que las normas, prescripciones y demás indicaciones que plantee nuestro Manual no podrán ser leyes férreas e inamovibles, sino que deberán permitir su revisión y actualización constante.

\section{VI.2.EL CORPORATE EN INSTITUCIONES CULTURALES. PARTICULARIDADES $Y$ SITUACIÓN ACTUAL}

Como ya se ha apuntado, en España aún queda un largo camino por recorrer en materia de Comunicación. Cuando hablamos de entidades cuyo principal objetivo es la difusión y conservación de la cultura y no la búsqueda del beneficio empresarial, podemos suponer que, en un país con deficiencias en materia de Comunicación de empresa, en estos casos tales insuficiencias se verán acentuadas. Esto se pone de manifiesto especialmente en aquellas entidades que dependen del Estado o de la Junta de Andalucía, como es la red de Museos Andaluces, a la que pertenece este Museo Arqueológico de Sevilla, ya que la supervivencia de este depende directamente de la Junta de Andalucía dentro de la Consejería de Cultura. 
Síntoma de este escaso nivel en el desarrollo profesional de la Comunicación dentro en nuestros museos es el hecho de encontrar las tareas de comunicación ubicadas a menudo dentro del mismo departamento de difusión o no encontrarlas en ningún departamento, o incluso gestionada desde fuera del propio museo. Las tareas que tienen que ver con la Comunicación son múltiples y necesitan de un departamento (aunque sea unipersonal) que se dedique exclusivamente a ellas.

La nueva museología pretende que el museo sea un ente vivo, atractivo y activo un centro que, sin descuidar sus otras labores, se dedique al visitante. Invertir en nuevas técnicas museográficas, sistemas de accesibilidad, talleres, conferencias... puede no servirnos de nada si nuestro museo no dispone de un aparato comunicativo de calidad. Es por ello que estudiantes y profesionales debemos seguir trabajando para tener una mayor competitividad en materia de Comunicación. Sin duda, ayudará al desarrollo de nuestros museos y organizaciones culturales y estamos convencidos de que este es un fin que merece la pena.

\section{Objetivo del programa de comunicación:}

-Como institución pública y cultural, establecer una adecuada comunicación entre museo, sociedad y usuarios.

\section{Líneas estratégicas:}

-Creación de una imagen corporativa institucional e interna.

-Crear una imagen atractiva, identificarla como único, acompañándolo de un sentido lógico y de modernidad.

-Diversificación y adecuación de la comunicación del museo. Seleccionando los medios de comunicación más adecuados para los usuarios objetivos. 
832

-Establecer los protocolos y códigos de actuación.

\section{VI.3. PROYECTOS}

En este apartado se presenta la materialización de las líneas estratégicas en diferentes proyectos. Las propuestas descritas servirán de llave para la diseño final y ejecución de los proyectos.

\section{VI.3.1. Proyecto para el plan estratégico de la imagen corporativa:}

\section{La imagen actual del museo}

Resulta muy complicado valorar la imagen actual de una institución. Esta se constituye a partir de múltiples variables. Nosotros intentaremos hacernos una idea de cuál es el perfil de la imagen actual del Museo Arqueológico de Sevilla analizando los siguiente aspectos: visitantes, talleres, actividades para adultos, prensa y medios de comunicación, gestión económica, comunicación interna, área de comunicación y prensa del departamento de difusión y un problema de identidad que, a raíz de estos estudios, hemos detectado.

Visitantes:

Ver el estudio general y específico entre los años 1990 y 2005 realizado en la parte de difusión.

Visitas guiadas:

Las interpretación de las salas por un guía son muy valoradas por la sociedad actual y el Museo Arqueológico de Sevilla debería poner mucha atención a ellas.

Actividades, conferencias, cursos: 
Las actividades más demandados son conferencias, cursos, certámenes de fotografía... En general los participantes prefieren las actividades por las tardes, consideran que entre los mates y los jueves son los días más adecuados y en marzo-mayo, junto con octubre y noviembre los mejores meses.

Los participantes realizaron las siguientes observaciones, muy interesantes como datos cualitativos:

- Felicitaciones en cuanto a las actividades y el hecho de que sean gratuitas.

- El museo está mal comunicado y el acceso mal señalizado.

- Las cartelas difíciles de consultar.

- El espacio para los cursos no es el adecuado, ya que no facilita la comunicación entre los ponentes y asistentes.

- Piden que el absceso a la biblioteca no sea tan restringido.

\section{Prensa y medios de comunicación}

A pesar de no contar con una presencia masiva en los medios, sí se ha producido un número de noticias con la incorporación de la nueva dirección al Museo.

Hay que trabajar duro para que las apariciones en los medios vayan siempre en aumento.

Parece que la mayoría de las noticias se publicaron en medios de prensa e internet, aunque no se puede afirmar este hecho definitivamente, puesto que el Departamento de Difusión del Museo tiene deficiencias en cuanto a la recogida de noticias de prensa impresa. Todavía hay muchísimo medios que no han dedicado ningún artículo al museo y podrían hacerlo: hay que trabajar para conseguirlo, contactar nuevos medios y ampliar la base de datos. 
Resumiendo: Hay una imagen obsoleta entre los medios, pero habría que pararse a analizar si esa imagen es exactamente la que se quiere dar.

\section{Problema de identidad corporativa}

Cuando hemos analizado la imagen corporativa hemos visto que cada medio utiliza una imagen diferente para identificarlo.

Si esas acciones de comunicación no se apoyan en una situación real, si no encuentran sustento en unas acciones museísticas, los visitantes y los medios seguirán percibiendo ese problema de identificación del museo.

\section{Cuentas}

El Museo Arqueológico de Sevilla tiene unas cuentas impecables, reflejadas en sus memorias y en el apartado de Gestión de este proyecto.

\section{Comunicación interna}

No se realizan ninguna acción dentro del museo en orden a mejorar la comunicación entre departamentos. El Museo cuenta con un obstáculo de tipo arquitectónico a la hora de desarrollar este tipo de comunicación: la distribución de sus oficinas y departamentos en distintas ubicaciones dentro del museo.

Se podrían llevar acabo la incorporación de carteles informativos en los lugares de paso para informar de lo que museo tiene previsto de actividades y acontecimientos aunque esta acción solo es informativa, no comunicadora.

\section{Departamento de difusión: área de comunicación}

Para finalizar, dedicaremos unas líneas a valorar el estado del área de comunicación y prensa del Departamento de difusión. 
En el departamento de difusión el gran problema son los pocos recursos personales que desempeña este trabajo y se debería de contratar a personal eventual que se encargue de poner en marcha estas funciones y de crear una base de datos de medios y periodistas, que se revise periódicamente. Junto con el seguimiento de medios y la elaboración de los clipping de prensa (archivos de noticias en las que aparece el Museo Arqueológico), puesto que no se recibe prensa diaria en el departamento.

Aunque estas herramientas no son de uso exclusivo para la persona que lleva las relaciones con los medios. Deberían estar al alcance de todo el personal del Museo y se debería, incluso incitar a los trabajadores su consulta.

Cualquier persona que trabaja en una institución es un agente comunicador de la misma.

\section{Visión estratégica:}

Trabajar por y para nuestros visitantes y ser reconocidos por estos y por los especialistas como un museo de calidad excepcional, que muestra los resultados de la recuperación de material arqueológico y patrimonial.

\section{Misión del museo.}

Establecida en el represente proyecto museológico del Museo.

\section{Síntesis del proyecto:}

La nueva institución, en atención a la procedencia de una buena parte de sus colecciones tiene, entre otros, los siguientes objetivos científicos:

Conservar, proteger y promover el conocimiento del Patrimonio Arqueológico, integrado por todos aquellos 
testimonios que son, o han sido, expresión relevante de los diferentes estadios culturales.

Exponer de manera destacada la evolución histórica a partir de los materiales arqueológicos, analizando sus implicaciones técnicas, sociales, ideológicas y creativas a través de la diversidad y el continuo cambio. Se reúnen para ello las muestras materiales y elementos informativos necesarios.

Potenciar la investigación en el ámbito del patrimonio arqueológico del Valle del Guadalquivir principalmente, convirtiéndose en un centro de referencia nacional e internacional.

Para finalizar, señalar la reflexión de que, en este museo se hace más cierta que nunca la idea de la Ley del Patrimonio Histórico Español de que el valor de los bienes culturales lo proporciona el aprecio con que la sensibilidad de los ciudadanos los ha ido revalorizando.

\section{VI.3.2. Posicionamiento estratégico:}

El posicionamiento estratégico del museo nos ayuda a desarrollar "argumentos de comunicación", es decir, contenidos que destacan los puntos fuertes y diferenciales de nuestra organización, que deben se usados a la hora de elaborar cualquier texto de la institución y, de hecho, ha de procurarse repetirlos en continuación, para reforzarlos y que verdaderamente identifiquen al Museo Arqueológico de Sevilla. Para desarrollarlos se toman como punto de partida los objetivos científicos, que se traducen a objetivos de imagen, de los que se infieren atributos de imagen, que a su vez dan lugar a argumentos de comunicación.

\section{Ser un museo de calidad excepcional:}

Mostrar unas colecciones de gran calidad.

El Museo es una institución única porque sus colecciones están formadas por unas piezas testimoniales únicas que 
abarcan diversos periodos históricos y de un territorio, en concreto, con gran diversidad histórica.

Los especialistas trabajan, para conservar, estudiar y difundir sus colecciones.

El Museo es un lugar seguro para sus colecciones porque apostaría por adecuados talleres de restauración y conservación. Las salas mantienen las mejores condiciones para la conservación de las piezas.

\section{Contar con unos servicios inmejorables.}

Especialmente contará con los servicios necesarios para ofrecer una visita cómoda ala exposición permanente.

Garantizará la seguridad de sus instalaciones inclusive el acceso a personas en sillas de ruedas y de la tercera edad.

\section{Museo democrático}

El museo trabaja para ofrecer unos servicios especializados atendiendo a cada unos de los grupos de usuarios que requieran necesidades concretas: Servicios para uso interno de personal, para diferentes exigencias de usuarios externos, etc.

\section{Contar con una museografía moderna, didáctica y excelente.}

Debe se un museo innovador y poner al servicio del visitante las técnicas expositivas más novedosas.

La museografía debe ser única en su campo y ofrecer una información relativa a las piezas a través de hojas de sala y paneles informativos, que sustituyan a las tradicionales cartelas. 
El museo debe de ser Didáctico y no limitarse a mostrar las piezas arqueológicas, sino que además explicar la historia, su evolución, sus razones sociológicas, etc.

Debe contar con un Área Didáctica que explique, de un modo ameno y de fácil compresión porqué las piezas expuestas son importantes.

\section{Trabajar para la mejora constante.}

El Museo Arqueológico debe de ser transparente en el uso de sus fondos para destinarlos a actividades para el visitante.

Que éste cuente con toda la información relativa al Museo en su página Web y pueda consultar al personal aquello que en ésta no figure.

El museo Arqueológico debe de ser un confiable; cumpliendo con sus horarios establecidos cumpliendo con sus programas de actividades y siguiendo unos criterios justos y razonables a la hora de seleccionar los asistentes para las actividades con limite de plazas teniendo en cuenta las reclamaciones de sus visitantes y darles respuesta. Manteniendo sus exposiciones en estado optimo para su visita

\section{Ser un museo que funciona para sus visitantes:}

Con el usuario-visitante es con el que se debe de establecer más mecanismos de comunicación.

\section{Ofrecer actividades culturales de gran calidad, para todos.}

El Museo tiene que se beneficioso para la sociedad detectando necesidades presentes en nuestra sociedad y ofrecer actividades culturales con el objetivo de solucionarlas. 
Tener en cuenta a aquellos colectivos de nuestra sociedad que, por sus propias característica, necesitan de una atención especial (tercera edad, público infantil, discapacitados...)

Desempeñando una labor de educación para los niños por medio de aprendizajes informales, a través de sus talleres y sus vistas escolares.

El Museo es asequible, es un museo gratuito.

Es un Museo Didáctico todas las actividades tienen un fin didáctico. $Y$ debería de contar con un departamento dedicado a desarrollar programas didácticos de actividades, auto evaluaciones, ...

\section{Estar siempre a disposición del visitante, para ayudarle} en lo que este necesite.
El Museo debe de ser servicial; el personal de sala estará siempre a disposición del visitante para solventar sus necesidades, responder a sus dudas...

Se deben de posibilitar cauces a la comunicación entre el personal que no se dedica a la atención al visitante y el propio visitante.

El Museo debe de se un lugar cercano y ofrecer a sus visitantes un trato "de tú a tú". El visitante se debe sentir como parte de éste.

\section{Hacer que nuestro visitante se sienta participe de nuestra actividad.}

El Museo debe de ser receptivo; tiene que trabajar siempre teniendo en cuenta la opinión del visitante. Trabajando para establecer nuevos mecanismos de participación del visitante con cabina de votación y sugerencias. 
Alimentar cauces de comunicación con nuestros visitantes

El Museo tiene que ser comunicativo y tener establecidos los cauces con sus visitantes a través de correo. El museo debe desarrollar una comunicación con feedback, que reduce al mínimo la unidireccionalidad. Y facilitar al máximo al visitante la posibilidad de dar su opinión y solicitar información acerca del Museo.

\section{Recoger la evolución cultural mediante los testimonios materiales arqueológicos}

Ofreciendo un recorrido histórico, por medio de piezas originales acompañado de recursos interpretativos adecuados. Además ofreciendo otros aspectos relacionados con la arqueología en el Valle del Guadalquivir
Ofreciendo una exposición permanente que no se limite a mostrar, sino que pretenda que sus visitantes disfruten aprendiendo la historia de la indumentaria.

Poniendo los medios necesarios, en diversos soportes, para comprender el recorrido histórico que muestra.

Contando con los mejores arqueólogos especialistas.

Mostrando un Museo de referencia para aquellos que en le desarrollo de su profesión necesiten ampliar su información acerca de algún periodo.

Elaborando sus mensajes de forma clara y sencilla, sin descuidar el contenido. 


\section{Completando con los medios necesarios la} información relativa a aquellos periodos de la historia que no se tienen piezas.

Dando la posibilidad a nuestros visitantes de ampliar la información, a través de diferentes actividades: Mesas de lectura, actividades culturales, visitas guiadas... Su personal está la servicio de sus visitantes para darles la información que precisan.

\section{Mirar hacia el futuro}

Incluir en nuestra programación actividades que tengan relación con nuestros fondos Arqueológicos.

El museo es amplio en su oferta cultural y sus actividades tienen que ir más allá de la exposición permanente, aprovechando los extensos fondos que tiene el museo.

Realizar actividades cuyos temas sean tan variados como sus colecciones, pero siempre con un criterio de calidad y excelencia.

\section{Estudiar el Patrimonio y explicarlo a sus visitantes}

El museo debería contar con publicaciones de las investigaciones desarrolladas. Ya que, los especialistas estudian sus fondos de manera rigurosa y deberían publicar los resultados de sus investigaciones.

Trabajando conjuntamente en la catalogación, restauración y conservación de las piezas.

Dando a conocer los fondos del museo que no forman parte de la exposición permanente, a los visitantes. El museo, al no contar integramente todos sus fondos en la exposición permanente, debe de renovar constantemente las fórmulas de presentación de este patrimonio a modo de exposiciones temporales. 


\section{VI.4. LA DIRECCIÓN DE LA COMUNICACIÓN}

Esta parte del manual describe el organigrama, las funciones y las herramientas de que se sirve la dirección o departamento de comunicación.

En el Museo Arqueológico de Sevilla nos encontramos con un caso particular, aunque frecuente dentro de los museos:

no existe un departamento que se dedique exclusivamente a la comunicación, sino que estas funciones se desarrollan principalmente dentro del Departamento de Difusión, que también se encarga, asimismo, de los programas de didáctica que ofrece.
Este sería el organigrama del departamento de difusión:

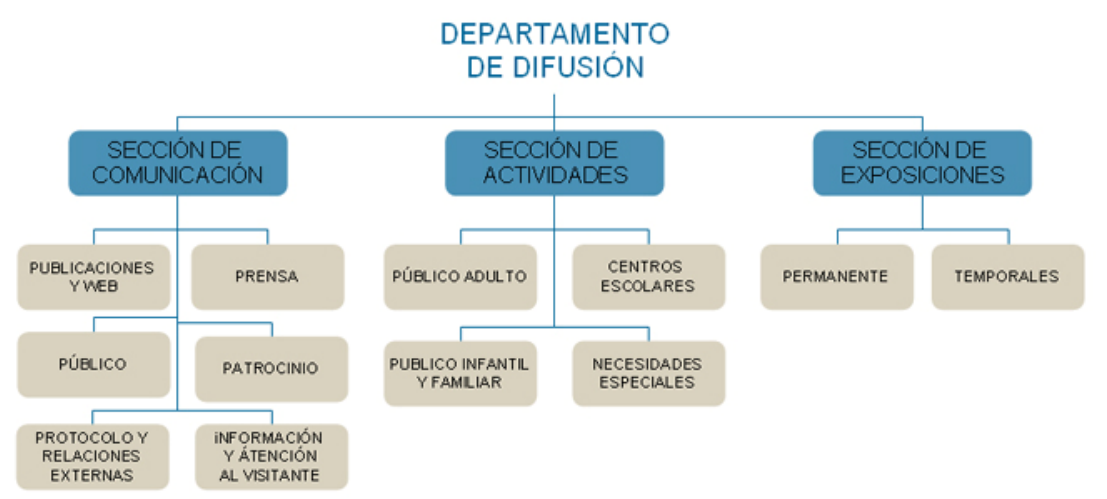

Las personas que se dedican a llevar la comunicación y las relaciones con el Gabinete de Prensa, realizan además otras funciones y no han desarrollado mecanismos de puesta en común para trabajar juntas. Nos encontramos con una disgregación de las funciones principales e intransferibles de la Dirección de Comunicación, a saber: la elaboración del Manual de Gestión de la Comunicación, el ejercicio de portavoz del Museo y la organización de la agenda comunicativa de la Directora del Museo. Además, debería una única persona, 
conservadora, ayudante de museos o contratada, de encargarse exclusivamente de las relaciones con la prensa y las labores específicas de Corporate.

No obstante en este apartado procuraremos buscar mecanismos que faciliten la puesta en común entre las diversas personas que se encargan de las variables de comunicación del Museo, para ayudar a llevar una praxis constante y rigurosa de su Comunicación estratégica y que permita no perder nunca la visión de conjunto del ejercicio de la comunicación del Museo Arqueológico de Sevilla

\section{VI.5. FUNCIONES DE LA COMUNICACIÓN:}

Para empezar describiremos las funciones de

Comunicación que deberán desempeñarse dentro del Departamento de Difusión, por las personas encargadas del área de Comunicación y prensa.
La primera de las funciones es la de elaborar el Manual de Gestión de la Comunicación. Teniendo en cuenta que este manual se diseña para un periodo plurianual, no obstante deberá ser revisado periódicamente para introducir los cambios oportunos y elaborar, cada año, el Plan Anual de Comunicación. Además, deberían desarrollarse otras herramientas de gestión profesional de la comunicación, como el Plan de comunicación interna.

Por otro lado, el área de comunicación debería conseguir tener más peso en el Museo y cumplir una función normatíva que, dictando una serie de normas a través, principalmente, del diseño de la cultura corporativa (carta de identidad, identidad visual, manual de gestión de la comunicación), logre la coordinación, cooperación y coherencia de todos los aspectos que conforman la imagen de nuestro Museo. 
Otra función importantísima de esta área de Comunicación y prensa es la de asesorar al resto de departamentos en materia de comunicación, ya que, como sabemos, prácticamente cualquier actividad del Museo comunica y cualquier trabajador puede convertirse en agente comunicador. En relación con esto, esta área debería, asimismo, crear un programa de formación o un compendio de normas para el personal del Museo que está continuamente en contacto con el visitante, como el personal de sala. No tengo, noticia de que se haya desarrollado algo así hasta el momento y consideramos que sería muy positivo, ya que hay carencias encontradas.

Además, es factible y muy aconsejable que esta área establezca un modesto OPIC (Observatorio Permanente de la Imagen Corporativa). Después del estudio realizado para desarrollar el PEIC de este manual, hemos elaborado una propuesta en este sentido, que se incluye en este Manual (punto 7). Con esta herramienta podremos desarrollar en cualquier momento y fácilmente un diagnóstico de la Imagen corporativa del Museo Arqueológico de Sevilla

Por otra parte, estas son las funciones que ya se realizan día a día en el área de Comunicación y Prensa:

Nos encargamos de las relaciones con la prensa y medios de comunicación, enviándoles las notas de prensa y convocatorias correspondientes a los acontecimientos que suceden en el Museo, atendiendo sus e-mails, llamadas y enviándoles la información que solicitan, recibiéndoles y acompañándoles en sus visitas a nuestro Museo, etc.

Para perfeccionar el funcionamiento en cuanto a este particular, debemos mejorar nuestra base de datos de medios, actualizándola, ampliándola e incluyendo más información, que nos permita funcionar de una manera más óptima (por ejemplo, necesitamos incluir con qué antelación cierran los números, para poderles enviar la 
información con tiempo suficiente para ser incluidos en sus ediciones).

Gestión del mailing: a través de este servicio enviamos información sobre nuestros actos y actividades a los visitantes que lo solicitan, facultades, profesores interesados por las materias de cada evento, etc.

\section{Controlamos que la información de nuestra web está} actualizada.

Elaboramos el Dossier o clippínq de prensa, en el que recogemos todas las noticias del Museo que aparecen en medios impresos, televisión y radio.

Procuramos informar de las actividades que tienen lugar en el Museo al resto de departamentos, para lo que colocamos carteles en el ascensor, en el tablón de anuncios y las zonas de la entrada.
Enviamos en PDIF el cuaderno de actividades, a modo de boletín informativo.

\section{Controlamos que taquilla está siempre bien provista de} los folletos pertinentes del Museo (general, exposición permanente, actividades...).

Para la correcta gestión de la comunicación necesitamos una serie de instrumentos. El primero de ellos es el presente Manual.

El segundo es el Comité de imagen, aún no constituido. Este se encargará de tomar las decisiones más importantes y globales en materia de comunicación, coordinando todas las funciones del Museo desde el punto de vista de la Comunicación y aprobando las herramientas que se creen para la gestión de la Comunicación y las revisiones de las mismas. 
Los miembros que constituyan este Comité deberán ser: la Directora del Museo, el Subdirector, un conservador de Difusión y las personas encargadas de comunicación (prensa, diseño de imagen corporativa, gestión de la web, comunicación. . .).

Para un correcto desarrollo de la actividad de este Comité se considera necesario que se reúna de forma anual, para hacer balance de las actividades del año en materia de comunicación, revisar las herramientas y documentos existentes, realizar propuestas y estudiar y aprobar el Plan Anual de Comunicación del año siguiente. Para ello, el área de comunicación y prensa se encargará, previamente, de realizar un informe con la ayuda del OPIC y de la memoria del museo, en el que evalúe la Imagen del Museo en ese momento y la actividad comunicativa del Museo a lo largo del año. Además, deberá desarrollar el Plan Anual de Comunicación.
El tercer y último instrumento es el OPIC (Observatorio Permanente de la Imagen Corporativa), del que ya hemos hablado previamente y que constituye el séptimo y último punto de este Manual.

Control de usuarios: el diseño de la comunicación debe de terene muy presente el tipo de publico ql que se quiere llegar para permitir el establecimiento de los medios mas adecuados:

-Televisión y radio ( inauguraciones, presentaciones,

-Prensa local(inauguraciones, presentaciones

-Publicaciones especializadas para congresos, cursos, seminarios, etc.

-e-mail para personalizar la información(mailing de inauguraciones y actividades, comunicación de la institución.

-Fax y telefono:uso interno de departamento

-Comunicación directa: pasacalles, reparto de Fliyer.

-Interna (circular, reunión de departamentos, entre otros. 


\section{VI.6. NORMAS GENERALES DE COMUNICACIÓN}

\section{VI.6.1. Dimensión conceptual:}

La dimensión conceptual de las Normas generales de comunicación de una institución, se compone, básicamente, de la Carta de identidad y de la definición de su Posicionamiento estratégico. No los incluimos en este apartado, por hallarse ya contenidos dentro del PEIC.

\section{6.2. Dimensión formal:}

Normas sobre la redacción de textos:

Se debe elaborar el Libro de estilo para el Museo Arqueológico de Sevilla. Dicho libro, podría seguir el siguiente esquema, sacado del libro La gestión profesional de la imagen corporativa, de Justo Villafañe ${ }^{67}$ :

1. Principios generales para la eficacia de la comunicación.

a. Sencillez y fácil comprensión.

b. Calidad de la información.

c. Corrección de la comunicación.

2. Normas generales.
a. Uso del idioma.
b. La construcción de textos y frases.
c. Concordancias de género y número.
d. Primera persona y pronombres posesivos.

3. Nombres.
a. Nombres catalanes, gallegos y vascos.
b. Nombres en latín.
c. Nombres de cargos públicos. 
4. Abreviaciones.
a. Abreviaturas.
b. Símbolos.
c. Siglas.

5. Signos ortográficos.
a. Coma.
b. Punto.
c. Punto y coma.
d. Dos puntos.
e. Comillas.

6. Normas gramaticales.
a. Adverbios.
b. Adjetivos.
C. Preposiciones.

7. Errores frecuentes.

a. Lenguaje pretencioso e Incorrecto,

b. Otros errores diversos.
Actualmente en el museo no se cuenta con ningún documento y es una herramienta muy útil para la confección de cualquier texto de comunicación externa, tendría que consultarse dicha normativa de estilo.

\section{VI.6.3. Normas sobre la redacción de textos}

1. Instituciones.

Poner con mayúsculas los nombres que integran el nombre de la institución. P. e., Museo Arqueológico de Sevilla.

2. Fechas.

Las horas, separadas con coma; después la letra h, con punto $(17,30$ h. $)$

Los días y los meses con minúscula.

Los días deben ir siempre con nombre y número- Jueves 10, o 10 Jueves. 
3. Temas.

El título es lo fundamental. La connotación de fechas es secundaria (en una guía): Programa de actividades de educación formal 2004-2005.Tu, yo y nosotros. Lo que está en negrita es lo fundamental.

\section{Puntuación.}

Deben ponerse siempre, salvo que por motivos de diseño y tamaño de la frase (menos de una línea) no sea conveniente.

En la enumeración de cargos/títulos, lugares de trabajo, etc., separar por puntos.

\section{Espacios y cargos.}

Mayúscula la primera: Primera planta. Sala de exposiciones. Área didáctica.
Tener en cuenta el título y el cargo de la persona, en todas las ocasiones.

6. Actividades.

Hay que especificar siempre: lugar, fecha, hora, quien puede asistir (requisitos) y cómo puede hacerlo (forma de inscripción). $Y$ ponerlo siempre de la misma manera.

Hay que especificar el contenido de forma clara: Visitas comentadas en lugar de Visitas.

7. Casos concretos.

1) Domingos en familia: incluir la forma de solicitarlos.

2) Verano en el Museo: incluir la forma de solicitarlos.

3) Vistas comentadas: incluir la duración aproximada, cuándo comienzan (o si se puede elegir hora).

4) Organización: debe sustituirse por organizador/es, si se citan las instituciones que lo hacen posible. 
5) Respetar el mismo título siempre que aparezca en varios lugares.

\section{VI.7. MANUAL DE LA GESTIÓN DE LA} IMAGEN CORPORATIVA

El Museo Arqueológico de Sevilla no cuenta con ningún Manual de Imagen Corporativa para poder ser consultado por cualquier empleado. Aquí se realiza un manual citando las normas, mostrando el logo, las fuentes corporativas...

-Símbolo, que juega con la "M" del museo y la "a" de arqueológico.

- Nombre

- Logo completo
- Colores corporativos, tenemos que procurar que sean los colores que usemos a la hora de elaborar cualquier informe, etc.

- Fuentes corportativas.

- Hojas de cartas y sobres.

- Carpetas corporativas.

- Folletos, trípticos, etc. Deben seguir una línea muy precisa y sencilla para la identificación.

- Notas de prensa. Las notas de prensa ocuparán siempre sólo una cara de un A4. Procuraremos acompañarlas de una fotografía en baja resolución, que figurará dentro del mismo documento, pero en la siguiente página con el evento en cuestión. 
1. Encabezado: Siempre con el logotipo de la Junta de Andalucía, consejería de cultura.

2. La fecha siempre tras el encabezado, alineada a la derecha, en HelveticaNeue 45.

3. Título genérico (Nota de prensa), siempre centrado, subrayado, en negrita y con la fuente corporativa Bauer Bodoni, cuerpo 18.

Título de la noticia, centrado o justificado, en negrita sin subrayar, fuente Bauer Bodoni, cuerpo 18.

4. Cuerpo de la noticia en HelvéticaNeue 45, cuerpo 11 o 12, justificado. Si lleva un subtítulo, también en HelvéticaNeue 45, cuerpo 14 y en cursiva.

5. No tenemos la negrita de Helvética comprada, pero podemos obtener el mismo efecto usando la HelvéticaNeue 65.

6. En el pie siempre figurará este texto, centrado y en gris.

Para los dossieres de prensa o para entregar cualquier documento a periodistas, visitantes o a quien proceda, usaremos siempre las carpetas corporativas.
Para cualquier duda acerca del uso de la imagen corporativa, se consultará el Manual (MAGICO) o se solicitará ayuda a nuestros expertos en diseño gráfico.

\section{VI.7.1 El símbolo}

Del Museo Arqueológico de Sevilla es la unión de una "M" mayúscula y una "a" minúscula, siendo la expresión de una parte de nuestra Historia. Letras iniciales de su nombre. Con evocaciones a los sellos y los lacres de los artesanos de hace más de 2.500 años, los tatuajes tribales y los modernos, los escudos nobiliarios y los monárquicos, la firma personal de cada uno o las rúbricas de los artistas del Renacimiento. Una evocación no casual.

El símbolo es hoy algo más: un instrumento decisivo para personalizar, identificar y distinguir al Museo de la competencia, sin confusiones ni distorsiones para el visitante. 


\section{VI.8. DIMENSIÓN FUNCIONAL}

La dimensión funcional de la comunicación es uno de los apartados más complicados de este manual. Regula muchas y diversas acciones comunicativas.

En el caso del Museo Arqueológico de Sevilla, estas acciones se pueden dividir en los siguientes apartados:

- comunicación interna,

- atención al visitante,

- protocolo de actos y eventos, y

- relaciones con la prensa.

Además del mantenimiento de la pagina web y publicaciones (ver las relativo a las mejoras de estos elementos en los apartados de difusión y servicios)
Todos los planes requieren de una elaboración de reglamentos que los regulen y dichos reglamentos deberán ser elaborados por el departamento de difusión y comunicación dentro del plan anual de comunicación.

Detallaremos a continuación las normas que regulan las relaciones con la prensa.

\section{VI.9. PROTOCOLO DE RELACIONES CON}

\section{LA PRENSA}

Las actividades de prensa estará llevado fundamentalmente por la centralización en el Gabinete de Prensa de Conserjería de Cultura para todos los museo de la provincia de Sevilla 


\section{VI.9.1. Dossier de prensa}

Debemos tener siempre preparados varios (al menos 10 en castellano y 5 en inglés) para poder entregarlos cuando recibamos a la prensa. El dossier completo incluye:

- Nota de prensa acerca del Museo Arqueológico de Sevilla.

- Hoja de autorización de uso de imágenes.

- Tríptico general del museo.

- Lista de créditos de las imágenes.

- CD con la versión digital del Dossier, que incluye todas las imágenes, nota en inglés y castellano, mapa, hoja de autorización del uso de imágenes, créditos de imágenes.

- Guía abreviada.
- Folleto de la exposición del momento.

\section{VI.9.2. Normas generales a la hora de atender a los} Medios.

- Amabilidad y cercanía ante todo.

- Mantenerles informados, a través del mailing:

- Actividades: enviarles el PDF trimestral de actividades, nada más que esté hecho.

- Notas de prensa: elaborar notas de prensa acerca de nuestros eventos (exposiciones, inauguraciones, actos, actividades...) y enviarlas con la suficiente antelación (depende del medio). Acompañarlas de una foto en baja resolución y tener preparadas más imágenes para enviarlas a los medios que las soliciten.

- Convocatorias: sólo en ocasiones especiales. Pueden enviarse con dos o tres días de antelación.

- Disponibilidad y predisposición: aunque tenemos algunos problemas a la hora de ofrecer nuestras salas para 
reportajes (imposibilidad de uso de focos, etc), tenemos que intentar darle a la prensa todas las facilidades posibles, ya que sus artículos, etc. nos son muy valiosos. Un artículo que aparece en un medio tiene mucho más impacto entre el público y los lectores, que un anuncio publicitario. Además, en el Museo Arqueológico de Sevilla no se cuenta con presupuesto para publicidad, puesto que esto se gestiona desde la Junta de Andalucía a través de la Consejería de Cultura.

- Tendencia a establecer lazos, a crear una comunicación fluida, continua y efectiva con aquellos periodistas y medios que nos dedican espacios. También procurar ir más allá y ofrecer un trato especial a aquellos periodistas más sensibles hacia nuestro Museo (incluirlos en el mailing para invitaciones a inauguraciones, enviarles e-mails de agradecimiento...).

\section{VI.9.3. Gestión de solicitud de visita para reportajes, artículos, etc. por teléfono o e-mail.}

Amabilidad, cercanía, predisposición, disponibilidad e inmediatez.

Buscar el mejor día de la semana y la mejor hora para recibirlos (los lunes son siempre los días más convenientes, al permanecer el Museo cerrado de cara al público).

Buscar la persona entre nuestro personal más adecuada para contestar a sus preguntas, otorgarles información, acompañarles en su visita al Museo.

Acreditaciones: solicitar los nombres, apellidos y números de DNI de las personas que acudirán al Museo. Con esta información, se envía un e-mail, con la fecha y hora de la visita, a los siguientes contactos: 
- Seguridad.

- Seguridad consola.

- Portero mayor.

- Portería.

Advertirles de las condiciones especiales del Museo: prohibición de realizar alguna fotografía, la iluminación en el Tesoro del Carambolo...

\section{VI.9.4. Visitas de periodistas.}

- Deberán ser siempre acompañados por el especialista pertinente $\mathrm{Y}$ por una persona de prensa y comunicación.

- Se tiene que estar disponibles a la hora de la cita. NO HACER ESPERAR A LA PRENSA.

- Entregarles un dossier de prensa y las Imágenes que soliciten.

\section{VI.9.5. Entrevistas telefónicas}

- Concertar la entrevista con uno de nuestros especialistas (el más pertinente), a la hora que indique el medio.

- Facilitar al medio el número de teléfono más adecuado.

- En el caso de entrevistas en directo, preguntar al medio cuáles van a ser las preguntas.

VI.9.6. Solicitud de información, imágenes... por e-mail o teléfono.

- Amabilidad, cercanía, predisposición, disponibilidad e inmediatez.

- En el caso de que el artículo que vayan a realizar sea sobre un tema ajeno al Museo, solicitaremos que en el artículo indiquen nuestra colaboración, pongan los créditos de las imágenes, etc. 
856

- NINGÚN E-MAIL DEBE ESTAR SIN CONTESTAR. Aunque no podamos ayudarles, siempre debemos contestarles y disculparnos por no series de utilidad.

\section{VI.10. MAPA DE PÚBLICOS}

\section{Vl.10.1. Introducción}

Se trata de una herramienta muy útil, ya que pretende señalar los diferentes públicos a los que debe de dirigirse la entidad y da pistas, a nivel cualitativo y a nivel cuantitativo, acerca de la información y comunicación que debe recibir cada uno. Nos ayuda a establecer unos canales de información más personalizados, más dirigidos a cada tipo de público.

Ya definido anteriormente en el apartado de público, desarrollamos un primer mapa de públicos básico. Deberá ser ampliado y mejorado en el futuro, segmentando mucho más estos públicos, con los datos que sigamos obteniendo de nuestros estudios de visitantes.

Estableceremos el repertorio de esos públicos a los que nos dirigimos. Seguidamente, estableceremos las variables de configuración, es decir, las variables en función de las cuales valoraremos ese público. Estas variables nos servirán tanto para saber qué tipo de información, qué canales de comunicación y qué trato requiere cada público, como para otorgarles unos valores numéricos que nos ayuden a determinar si necesitan nivel de atención en la comunicación normal o especial.

\section{VI.10.2. Repertorio de públicos}

(ver Programas de Usuarios) 


\section{Vl.10.3. Variables de configuración:}

A partir de ellas determinaremos la atención que debemos concederle a cada tipología del repertorio de públicos.

\section{Dimensión estratégica}

Se valora la importancia que tiene ese público para el desarrollo del proyecto

1: Coyunturales - importancia de carácter episódico.

2: Tácticos - importancia continua pero que afecta sólo a algunos aspectos del museo.

3: Estratégicos - son públicos fundamentales para el desarrollo de nuestra actividad.

\section{VI.10.4. Intereses económicos}

Se valora la importancia de ese público desde el punto de vista económico: si ayuda económicamente a nuestro
Museo, si comparte intereses económicos o de otro tipo con nosotros...

1: Potencialmente aliados - públicos susceptibles de convertirse en colaboradores $\mathrm{y}$, por tanto, compartir intereses con el Museo.

2: Aliados - colaboradores (comparten intereses con nosotros).

3: Providencia - se trata de un público muy beneficioso para nuestro Museo.

\section{VI.10.5. Capacidad de influencia en la opinión pública.}

1: difusores - aquí entra sobre todo el "boca a boca".

2: mediadores.

3: prescriptores - son puntos de referencia y, por tanto, tienen una capacidad muy alta de influencia en la opinión pública. 


\section{VI.10.6. Transmisión directa de la imagen.}

1: esporádico: sólo se relaciona con el Museo para un acto de comunicación circunstancialmente.

2: asociado: público que ejerce como intermediario.

3: interno: forma parte del Museo y realiza actos de comunicación.

\section{VI.10.7. Necesidades de información funcional.}

1: Superficial.

2: Funcional.

3: Estructural.

\section{VI.10.8. Coeficiente}

A:

- Grupos que precisan unos niveles de información y comunicación normal.

- Grupos con total menor que 7.
- Son:

Tercera edad.

Niños.

Familias.

Amas de casa.

Parados.

Turistas.

Estudiantes de Historia del Arte.

Estudiantes de Diseño de moda.

Visitantes en general.

Investigadores.

Personal de Museos Estatales.

Usuarios de actividades.

B:

- Grupos que precisan unos niveles de información y comunicación especial.

- Grupos con total igual o mayor que 7.

- Son: 
Museos estatales.

Otras instituciones culturales.

Agencias de comunicación que llevan actos del Museo (internos y externos). Profesionales del mundo de la cultura y las artes (cine, teatro, etc.).

Fundaciones que organizan actos externos en el Museo.

Entidades que organizan actos externos en el Museo.

\section{VI.11. PLAN ANUAL DE COMUNICACIÓN $2007^{68}$}

En este apartado acompañamos a las bases teóricas, además, de propuestas para un plan de comunicación del año 200X, año de la puesta en marcha de las reformas del museo.

\footnotetext{
${ }^{68}$ La elección de este año es a modo demostrativo.
}

La puesta en marcha del programa de comunicación comenzaría con el establecimiento del plan anual de comunicación para el año elegido 2007

El presente Plan Anual de Comunicación (PAC), organiza las principales acciones de comunicación que habrán de efectuarse durante el año 2007.

No se tratará esta vez de un PAC al uso, ya que algunos apartados no figurarán, por incluirse en la primera parte del Manual.

Partiremos pues de lo ya señalado en el punto 2 del Manual, para determinar los objetivos generales y las acciones concretas a realizar por el área de comunicación y prensa del Departamento de difusión durante este periodo. Después estableceremos el calendario y por último, preveremos la realización del PAC 2007-2008 y señalaremos los pasos a seguir para su elaboración. 


\section{VI.11.1. Objetivos generales.}

Mejora del funcionamiento.

\section{A. Estructuración del área:}

A raíz de la llegada de una persona que será la responsable del área de comunicación, esta tendrá que ser reestructurada y se deberán determinar las funciones que desempeñará cada uno de los miembros del equipo. Para efectuar esta labor, mirar el punto 3 del presente Manual (La dirección de comunicación), donde se ha enumerado las funciones de esta área. Por el momento no planearemos esta acción en el calendario, puesto que aún no se sabe se incorporará una persona.

1.B. Puesta en funcionamiento el Instrumento Permanente de Evaluación y Control de la Imagen del Museo (IPECIM):
El instrumento permanente de evaluación y control de la imagen del Museo se incluye en los anexos de este Manual, y puede ser puesto en marcha inmediatamente. Sólo falta revisar, corregir y poner en marcha la Encuesta de evaluación de servicios y elaborar una tabla para el análisis de las noticias del Museo en radio y televisión.

\section{C. Actualización de base de datos de prensa}

Esta tarea debe ser puesta en marcha inmediatamente, puesto que la base de datos de contactos de prensa y medios se halla en un estado lamentable. Para actualizarla tendremos que, en primer lugar, comprobar telefónicamente los errores que hemos listado al realizar mailing. Seguidamente, comprobaremos el resto de contactos $\mathrm{y}$, por último, procuraremos añadir nuevos contactos, para lo que nos serviremos de Internet y de la Agenda de comunicación de 2006. 


\section{D. Revisión y mejora del mapa del públicos:}

En realidad se trata de una labor constante del departamento muy unida a los estudios de visitantes de visitantes, dentro del (IPECIM)

\section{VI.11.2. Elaboración de herramientas necesarias.}

\section{A. Plan de comunicación de crisis:}

Urge la elaboración de un plan que establezca unas pautas de comunicación a la hora de enfrentarnos a una crisis. Las crisis no son solo catástrofes, sino que pueden ser de morfología muy diversa. Se trata de un trabajo difícil y serio, sobre todo teniendo en cuenta que no contamos en el departamento con ninguna herramienta similar. Se requerirá de al menos un mes para su elaboración.

\section{B. Plan de comunicación interna:}

Como ya hemos dicho, el Museo Arqueológico de Sevilla no consta de ninguna Comunicación Interna. Debemos pues elaborar un Plan que establezca cauces para mejorar nuestra labor en ese sentido. La elaboración del Plan de comunicación interna debe tomarse en serio y no puede limitarse al establecimiento de un boletín interno. Estimamos que será necesario al menos dos meses para llevar a cabo esta tarea.

\section{C. Protocolo de actos y eventos:}

La persona responsable de RRPP del Museo, elaborará un documento en el que se establecerán unas reglas básicas de protocolo para nuestros actos y eventos._Dicho compendio de normas estará a disposición de todo el departamento para su consulta y uso. 


\section{D. Normas de atención al visitante:}

Tendremos que elaborar un documento que comprenda una serie de normas básicas y directrices para nuestro personal de atención al visitante (personal de sala, reservas, mostrador... ) y para el resto del equipo en sus funciones de atención de llamadas, e-mails, etc. No se trata de elaborar un manual muy extenso, por lo que pienso un solo mes bastarán para la elaboración de dicho documento.

\section{E. Elaboración de un Libro de Estilo:}

Este libro será incluido en el punto 4 de este Manual. Se encargarán de su elaboración la persona responsable de corregir los textos que se vayan a publicar.

\section{VI.11.3. Acciones concretas de comunicación.}

\section{A. Estreno del programa para educación formal}

Inicio de las nuevas actividades para los diferentes alumnos de la educación formal. Acompañado de nota de prensa y e-mail a instituciones educativas. Además de anuncio especial en pagina web del museo y en la Agenda cultural de actividades de la conserjería de Cultura.

3.B Estreno Actividades para inmigrantes (mes de abril)-.

En el mes de abril estrenamos de las Actividades para inmigrantes. Desde el departamento de difusión, se tienen que llevar a cabo diversas acciones para tratar de darles una buena difusión a dichas actividades. No obstante, es una ocasión muy buena para generar una noticia con un carácter muy humano y atractivo. 
Es recomendable elaborar una nota de prensa en la que se relate el desarrollo y éxito de la actividad, y enviarla el día después de la inauguración a todos nuestros contactos de prensa. Sería igualmente recomendable acompañarla de fotos del mismo taller.

\section{C. Presentación del Proyecto Arqueología viva y} Encuentro con Arqueólogos que se encuentren excavando (mes de mayo):

Se trata de un acto que puede atraer mucho público, por lo que debemos prestar mucha atención a su difusión.

A finales del mes de abril deberíamos enviar una pequeña nota de prensa a nuestros contactos (salvo a aquellas revistas que cierran sus números con mucha antelación, puesto que ya habrán sido advertidas), en la que se informe de la celebración del acto.
Una semana antes del encuentro enviaremos la convocatoria de prensa a todos nuestros contactos.

Por último, el día posterior al encuentro se enviará a todos nuestros contactos la nota de prensa en la que describamos la celebración.

En el transcurso de este encuentro tendrá lugar la presentación de los componentes que conforman el proyecto arqueología viva, así como la puesta en marcha de uno o varios de los componentes

\section{D. Día Internacional de los Museos:}

Actividades en relación con el tema del año y concurso de fotografía (18 de mayo)

El día 19 enviaremos una nota de prensa en la que relatemos la celebración del Día Internacional de los Museos en el Museo Arqueológico de Sevilla y la entrega de premios del Primer Concurso de Fotografía 


\section{E. Noche de los Museos e inauguración Noches con} las musas

Rueda de prensa para la presentación del Proyecto de actividades nocturnas en la Plaza América

Concierto de música medieval (en relación con las ultimas salas de la actual montaje museográfico) y visita nocturna (20 de mayo):

Se trata de una propuesta muy atractiva, para una noche de sábado, por lo que tenemos que intentar darle una gran difusión.

El viernes 11 enviaremos una nota de prensa que anuncie la celebración de este evento.

El Lunes 22 enviaremos una nota de prensa en la que relatemos el éxito del concierto. Debemos intentar sacar atractivas fotos, para enviarlas junto a esta nota, ya que, se trata de un evento muy sugerente.

\section{F. Noches con las musas(junio y julio)}

Segundo día del proyecto "Noches con las musas". Previamente en la programación se habrá establecido cauces para la cooperación y diseño conjunto con el museo de Artes y Costumbres Populares.

En nuestra base de datos intentaremos establecer algún contacto especializado en teatro. Para ello, tendremos que comenzar a trabajar en abril.

Enviaremos a estos contactos y a los que consideremos oportunos (especialmente a agendas, guías de ocio, etc) una nota de prensa previa y otra a posteriori con el resultado de la celebración. 


\section{J. Exposiciones:}

-Inauguración de exposición en Marzo: La cultura dolménica.

-Inauguración de exposición en Noviembre: El agua en Roma

-Apertura Micro-Exposición. La Encarnación

-Apertura Micro-Exposición: El Salón de Ecija.

\section{K. Actividades de Navidad}

3.I. Inauguración programa visitas Domingos en Familia.

3.M. A finales de Junio de 2007, comprobaremos el calendario de actividades de verano y actualizaremos el Plan Anual de Comunicación 2007 planeando las acciones de comunicación pertinentes.

\section{VI.12. DIRECTRICES PARA LA}

\section{ELABORACIÓN DEL PAC 2007}

A partir del 1 de febrero de 2008, tendremos que comenzar la elaboración del Plan Anual de Comunicación 2008. Su puesta en marcha será a partir del 1 de abril de 2008. Proponemos el siguiente esquema:

Análisis previo de la situación del Museo Arqueológico de Sevilla, a través de los informes que elaboremos con nuestro instrumento permanente de evaluación y control de la imagen del Museo:

- Análisis de resultados del Plan Anual de Comunicación 2007.

- Enumeración de oportunidades y problemas.

- Revisión y renovación de la estrategia de imagen del Manual. 
- Determinación de objetivos generales.

- Determinación de objetivos operativos por públicos (usar el mapa de públicos).

- Programación de acciones concretas de comunicación.

- Calendario.

\section{VI.12.1. Proyecto de relanzamiento de las mejoras del museo}

Abierto por reformas. Siguiendo iniciativas llevadas a cabo en otro tipo de bienes culturales (Catedral de Vitoria, Iglesia del Salvador, etc) se apostaría por una iniciativa innovadora y original dentro del panorama de museístico. Este proyecto, concebido como proyecto integral, tendría como objetivo reubicar la institución en el panorama cultural local y general, aprovechando las circunstancias de remodelación de las instalaciones.

Consistiría en una serie de iniciativas culturales dentro de la filosofía de proyecto integral que rodea a toda la forma parte de las actividades culturales vinculadas a la recuperación de una institución singular.

Acercar el proyecto al público. El museo debe de acometer una serie de obras de mejoras pero no debe de abandonar la oferta de sus servicios. Pero existirán periodos en los que ciertas salas, servicios o piezas estarán inaccesible por lo que se ofertaría otras alternativas. Estas alternativas vendrían de la oportunidad única de ver el museo en un trasiego de construcción, redefiniciones, cambio de ubicación de piezas, restauraciones etc.

Las diferentes actividades permitirán el aumento y permanente presencia del museo en los medios de comunicación.

Actividades a emprender: 
-Visitas de las terrazas del museo, para poder acceder a una perspectiva del museo poco conocida.

-Las colecciones se trasladan, conoce las piezas íntimamente. Una propuesta de conocimiento de algunas obras de arte de primera fila de las colecciones del Museo. -Exposición de diferentes momentos históricos del edificio. Selección de fotografías de la Universidad de Sevilla, fondo documental del Museo, Archivo fotográfico Municipal, etc -Inauguración de salas

-Etc.

Así este concepto de proyecto integral permitirían, la integración de la sociedad en la propia reforma.

\section{VI.12.2. Proyecto permanente de evaluación y} control de la imagen del Museo Arqueológico de Sevilla.

Dentro del proyecto de la calidad de servicios propuesto en el apartado de servicios, se establecerá este instrumento. Se optaría por uno sencillo con el objeto de que resulte factible.

Las variables a estudiar serán:

\section{VI.12.2.1. Prensa y medios de comunicación}

Para analizar la prensa escrita se contará con la ayuda de la Tabla EXCEL para el análisis del dossier de prensa. En ella se incluirán los gráficos que nos servirán para la redacción de un informe que nos aclare: 
- que periódico ha publicado más noticias en relación al Museo Arqueológico de Sevilla.

- En que revistas se han publicado noticias referentes al Museo.

- Los tipos de medios.

- Las noticias por meses.

- El tratamiento de la información si es: informativa, negativa, positiva, secundaria, $\mathrm{o}$ no se sabe relativa al Museo.

- La extensión de la noticia.

- El tema de la noticia.

- La secciones donde aparece la noticia.

- El número de fotografías que aparecen.

- Si la imagen de identidad corporativa del Museo es el correcto.

\section{VI.12.2.2. Visitantes}

El diseño de un estudio de publico continuo facilitara el control de la calidad de la dimensión comunicadora del museo (ver apartado de usuarios)

Para poder llevar un seguimiento de los visitantes del Museo se creará una encuesta de evaluación de servicios. Que es una herramienta básica para conocer el grado de satisfacción de los visitantes del Museo en general. Aunque no se realizarán muchas y aunque sólo se ponga en marcha en determinados períodos del año, nos proporcionará una información utilísima. Se podrán dejar en taquilla para que las conteste quién lo desee y también dar la posibilidad de realizarla a través de la página web del Museo. Inclusive proponiendo organizar un sorteo anual entre los participantes con un premio factible, como por ejemplo realizar una visita guiada a la exposición por un conservador del Museo, para el ganador y tres personas más. 
Después se elaborará un documento en Excell con una serie de tablas y gráficos asociados a la encuesta, para facilitar la recogida de datos, su análisis y la elaboración del informe.

\section{El ejemplo de encuesta podría ser:}

1. ¿Cómo valora el Museo en su conjunto?

a. Malo

b. Regular

c. Bueno

\section{d. Excelente}

\section{Perfil del visitante}

Sexo:

$$
\text { Hombre Mujer }
$$

a. Edad.

b. Situación laboral:

Ocupado/a

Jubilado/a

Estudiante

Parado/a
Tareas del hogar

Otros

c. Nivel máximo de estudios:

Sin estudios

Primarios

Secundarios

Universitarios

d. nacionalidad

e. españoles/provincia

3. ¿Es la primera vez que viene a este Museo?

Sí

No

3.1. Si lia venido anteriormente, considera que el Museo ...
a.
Ha mejorado.
b.
Ha empeorado.
c. Se mantienen igual.

4. ¿Porqué visita hoy el Museo?

Tenía curlosidad por conocerlo

Por casualidad/pasaba por aquí

Para asistir a una actividad prograrnada

Para visitar la exposición teniporal 
Para coinpletary profundizar su conocinuento del Museo

Para enseñar el Museo a fanilliares y amigos

Por estudios

Por inotivos profesionales

Por otros motivos.

5. ¿,Qué tipo de entrada ha utilizado hoy?

a. Reducida

b. Gratuita

c. De precio normal

6. Valoración de servicios (aseos. casilleros, audiovisuales...)
a. Malo
b. Regular
c. Bueno
d. Excelente

e. Comentarios/quejas/sugerencias...

7. Valoración del personal (taquillas. visitas guiadas, guardarropía..)

a. Malo

b. Regular

\section{c. Bueno}

d. Excelente

e. Corrientarios/quejas, sugerencias....

8. ¿Considera adecuado el horario del Museo?

a. Sí

b. No

9. Otros cornentarlos. sugerencias. quejas...

\section{VI.12.2.3. Actividades}

Desde que se realizan actividades se tendrían que realizar unos cuestionarios de evaluación sobre éstas para los adultos.

En este apartado se propone un modelo básico de encuesta para comprender el grado de satisfacción del visitante con respecto a cualquiera de las actividades culturales del Museo. 
Es posible que cada actividad requiera preguntas específicas, como la valoración de los ponentes de un curso, la duración del mismo... en este caso no habría más que añadirlas.

$Y$ con tablas de Excel y con diversos cuadros y gráficos analizar los datos proporcionados por los mismos para la elaboración del informe.

\section{VI.12.2.4. Talleres infantiles y de tercera edad.}

Cuando se realicen se incorporarán unas fichas de inscripción con una información muy detallada que será una gran fuente de datos para analizar y conocer a nuestro público tanto infantil como los mayores de 65.

A partir de estas se elaborarán unas tablas y gráficos en documentos Excel para el análisis de cada taller en particular y ayudarles a elaborar informes periódicos sobre los talleres en conjunto.
Ejemplo de la ficha de inscripción:

1. NOMBRE DE LA PERSONA QUE RELLENA LA FICHA

FECHA/HORA:

2. DATOS DEL ADULTO

NOMBRE Y APELLIDOS:

DIRECCIÓN

3. LOCALIDAD:

4. CÓDIGO POSTAL:

E-MAIL:

TELEFONO/S

5. RELACIóN CON LOS NIÑOS QUE INSCRIBE

Hijos Sobrinos

Nietos Amigos

Otros 


\section{DATOS DE LOS NIÑOS}

6. NOMBRE, APELLIDOS y año de naciemiento

7. TALLER EN QUE SE INSCRIBEN:

BREVE CUESTIONARIO

10. ¿Conocen los niños el Museo?

11. ¿Conocen los adultos el Museo?

12. ¿Han participado en otros talleres? ¿Cuándo?

13. ¿Cómo se ha enterado de la actividad? Prensa:

Radio:

Televisión:

En el Museo

Amigos/Familiares

Web del Museo

Otras webs:
14. OBSERVACIONES

Ejemplo del cuestionario sobre actividades culturales:

1. Sexo:
A. Mujer
B. Hombre

2. Edad:
A. - de 20
E. $36-40$
B. $21-25$
F. 41-45
C. $26-30$
G. $46-50$
D. 31-35
H. 51-55

\section{Ocupación:}
A. Ocupado/a
D. Parado/a 

B. Jubilado/a
E. Tareas del hogar
C. Estudiante
F. Otros

4. Nivel máximo de estudios:
A. Sin estudios
B. Primarios
C. Secundarios
D. Universitarios

Con la intención de adecuar nuestra programación de actividades a sus preferencias, rogamos conteste el siguiente cuestionario:

\section{SOBRE LA ACTIVIDAD:}

S. ¿Cómo se enteró de la actividad?

A. Me llegó la información por correo electrónico B. Me llegó la información por correo postal

i. Por el folleto de actividades del museo

ii. Por la revista/web del Colegio de Licenciados

C. Visitando el Museo

D. Por Internet

i. En la Web del Museo ii. En otra Web (Especificar)
E. Por la prensa
F. Por un amigo/a
G. Otros (Especificar):

6. ¿Por qué le interesó participar en esta actividad?

A. Para ampliar mis conocimientos sobre el tema

B. Porque tiene relación con mi actividad profesional

C. Por curiosidad

D. Otros (Especificar).,

7. Si esta actividad está relacionada con su vida profesional, ¿Cree que los conocimientos adquiridos le ayudarán a mejorarla?
A. POCO
C. Bastante

B. Regular

D. Mucho

8. ¿Ha respondido la actividad a sus expectativas?
A. POCO
C. Bastante
B. Regular
D.Mucho 
9. ¿Le ha parecido adecuado el horario?

Bien

No, hubiera preferido por la mañana

10. ¿Le han parecido adecuadas las instalaciones donde se ha celebrado esta actividad?

A. POCO

C. Bastante

B. Regular

D. Mucho

11. ¿Le han parecido adecuados los medios (técnicos, audiovisuales, humanos....) utilizados?

A. POCO

C. Bastante

\section{B. Regular}

\section{Mucho}

12. ¿Cree que la actividad ha estado bien organizada?

A. POCO

C. Bastante

B. Regular

D. Mucho

13. Valore el trato recibido por parte del personal del Museo.

A. Malo

B. Regular

C. Bueno

D. Excelente

14. Señale los aspectos del curso que más le han gustado: 
15. Señale los aspectos del curso que menos le han gustado:

\section{SOBRE ACTIVIDADES FUTURAS DEL MUSEO:}

16. ¿Qué tipo de actividades le resultan más interesantes?

\author{
A. Cursos \\ B. Conferencias \\ c. Encuentros con diseñadores \\ D. Ciclos de cine \\ E. Conciertos \\ F. Otros (Especificar).
}

17. ¿Qué días le resultaría más fácil acudir a las actividades?
A. Lunes
D. Jueves
G. Domingo
B. Martes
E. Viernes
C. Miércoles
F. Sábado

18. ¿Qué meses del año le resultaría más cómoda la asistencia a nuestras actividades?
A. Enero
E. Mayo
i. Septiembre
B. Febrero
F. Junio
j. Octubre
C. Marzo
G. Julio
K. Noviembre
D. Abril
H. Agosto
L. Diciembre

19. Proponga temas de su interés para los próximos cursos, conferencias, etc.

20. Proponga actividades que le gustaría que realizasemos:

\section{Vl.12.2.5. Programa de actividades de educación formal y otras.}

Cuando se realicen se incorporarán unas fichas de inscripción con una información muy detallada que será una gran fuente de datos para analizar y conocer a nuestro público. 
A partir de estas se elaborarán unas tablas y gráficos en documentos Excel para el análisis de cada taller en

particular y ayudarles a elaborar informes periódicos sobre los talleres en conjunto.

Ejemplo de la ficha de inscripción:

1. NOMBRE DE LA PERSONA QUE RELLENA LA FICHA FECHA/HORA:

\section{DATOS DEL ADULTO}

NOMBRE Y APELLIDOS:

DIRECCIÓN:

3. LOCALIDAD:

4. CÓDIGO POSTAL:

E-MAIL:

TELEFONO/S

\author{
5. RELACIóN CON LOS NIÑOS QUE INSCRIBE \\ Hijos Sobrinos \\ Nietos Amigos \\ Otros
}

\section{DATOS DE LOS NIÑOS}

6. NOMBRE, APELLIDOS y año de naciemiento

7. TALLER EN QUE SE INSCRIBEN:

\section{BREVE CUESTIONARIO}

10. ¿Conocen los niños el Museo?

11. ¿Conocen los adultos el Museo?

12. ¿Han participado en otros talleres?

¿Cuándo?

13. ¿Cómo se ha enterado de la actividad? Prensa:

Radio: 
Televisión:

En el Museo

Amigos/Familiares

Web del Museo

Otras webs:

He recibido folleto en casa.

14. OBSERVACIONES

\section{VI.12.2.6. El presupuesto}

Al tratarse de un museo de la Junta de Andalucía no autónomo, dependiente de la Consejería de Cultura, su partida presupuestaria es muy distinta a la de un museo autónomo o una empresa privada y por tanto, actualmente, no contarnos con una partida solo para el Departamento de difusión.

Además, todas las acciones de comunicación planeadas en este Manual y en el Plan Anual de Comunicación 2007, no suponen a penas coste adicional para el departamento.
Se trata, principalmente, de distribuir el mismo dinero y los esfuerzos de una manera diversa, más ordenada.

No se incluye por tanto ningún presupuesto.

\section{VI.13. PROBLEMAS DE IDENTIDAD CORPORATIVA}

Con los datos que el análisis del dossier de prensa nos de a este respecto y los que asimismo extraigamos de la encuesta de visitantes, podremos sacar algunas conclusiones de ¿Qué aparece en los medios?, ¿Cómo conocen nuestros visitantes nuestra imagen corporativa?. Más adelante sería conveniente desarrollar un método de análisis más metódico, sobre todo de cara a la inauguración de la nueva museografía del museo. 


\section{VI.13.1. Comunicación interna}

Cómo ya se ha dicho, el Museo Arqueológico de Sevilla, no cuenta con un programa de comunicación interna. Será necesario desarrollarlo y establecer métodos para analizar el mismo y también el personal que trabaja en el museo (sus opiniones sobre el Museo, su satisfacción con respecto a su trabajo, etc.)

\section{VI.13.2. Funcionamiento del área de comunicación del departamento de difusión.}

Se trata de un apartado complejo de la metodología ya que no se cuenta con ningún dato cuantitativo que analizar. Se considera que la mejor forma de analizar este análisis es elaborar una memoria anual, en la que se analice de forma empírica puesto que no hay elección los siguientes puntos:
- Las herramientas de comunicación corporativa: Si se han desarrollado nuevas, si las ya existentes están actualizadas, si se hace uso de las mismas, si el personal comprende su funcionamiento...

- El Personal y distribución de tareas.

- Las Tareas: si se cumplen, cuales están más atrasadas, si se pueden organizar mejor, si conviene añadir nuevas...

- Revisión del Plan Anual de Comunicación: Si se han cumplido los planes en los tiempos previstos y si lo llevamos a cabo. 


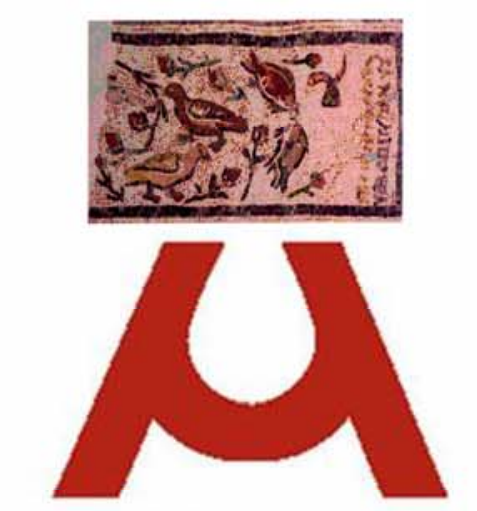

Museo

Arqueológico de Sevilla

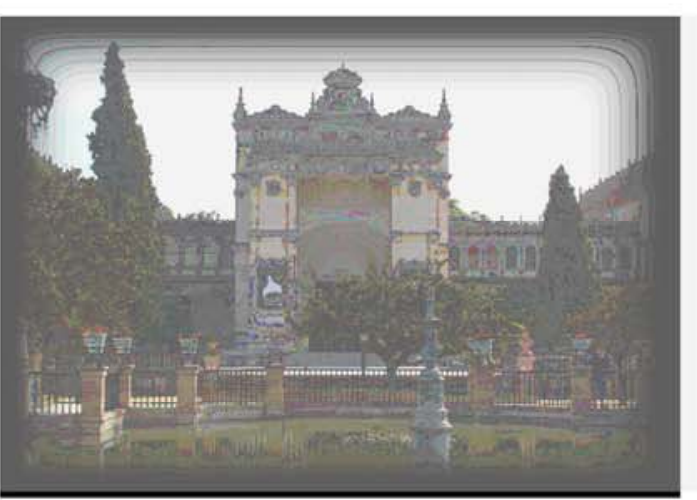

\section{SEGURIDAD}

Yolanda Torrubia Fernández Patricia Monzo Losada 
En el programa de seguridad definiremos el nivel de seguridad necesario para asegurar la protección de las colecciones, el edificio, el personal y el público.

Deben considerase diferentes aspectos:

- Protección contra incendios.

- Protección contra actos antisociales.

- Protección contra accidentes, tanto laborales como de los visitantes.

\section{VII.1. PROTECCIÓN CONTRA}

\section{INCENDIOS}

El Real Decreto 2177/1996, del 4 de octubre, establece las Normas Básicas de la Edificación: Condiciones de protección contra incendios en los edificios (NBE-CPI/96). En ésta, se establece la normativa sobre compartimentación, evacuación y señalización (capítulo 2), sobre los materiales reglamentarios para la construcción (capítulo 3), sobre instalaciones generales y locales y zonas de riesgo especial (capítulo 4) y sobre las instalaciones de protección contra incendios (capítulo 5).

Toda la normativa incluida en este Real Decreto deberá ser aplicada en el museo. No obstante, los condicionantes que impone el edificio existente deberán ser salvados por el proyecto arquitectónico, que deberá encontrar la forma de conjugar la protección por parte de la Ley del Patrimonio Histórico Español con la normativa de seguridad. Así, se instalará un sistema de protección contra incendios que contenga los sistemas reglamentarios de detección y extinción de incendios, la señalización obligatoria, la sectorización de espacios, sistemas de megafonía o alarma para la evacuación, etc. además de preverse el mantenimiento de todo este sistema. 
Algunas de las normas de este Real Decreto que afectan a nuestro edificio son:

- Estará compartimentado en sectores de incendios de forma que cada uno de esos sectores tenga una superficie construida menor que $2500 \mathrm{~m}^{2}$ (Artículo 4.1).

- El nivel de ocupación no debe ser mayor de una persona por cada $2 \mathrm{~m}^{2}$ en zonas de uso público en museos, galerías de arte... (artículo 6.1.e).

- La anchura libre en puertas, pasos y huecos previstos como salida de evacuación debe ser mayor o igual a 0,80 metros. La anchura de la hoja será igual o menor que 1,20 metros, y en puertas de dos hojas, igual o mayor que 0,60 metros (artículo 7.4.3).

- La anchura libre de las escaleras y de los pasillos previstos como recorridos de evacuación será igual o mayor que 1 metro (artículo 7.4.3).
El recorrido real en cada planta desde cualquier origen de evacuación hasta un extintor no superará los 15 metros. Cada extintor tendrá una eficacia como mínimo 21A-113B (artículo 20.1).

- Estará protegido con bocas de incendio equipadas por ser su superficie total construida mayor que $2000 \mathrm{~m}^{2}$ (artículo 20.3).

- Contará con una instalación de detección y alarma de incendio, pues su superficie total construida es mayor que $2000 \mathrm{~m}^{2}$ (artículo 20.4.c).

- Se dispondrán detectores de incendios y pulsadores manuales en todo el edificio. Los detectores serán térmicos o de humo, según la clase de fuego previsible (artículo A.20.4.c).

- Estará dotado con rociadores automáticos de agua o con una instalación de extinción automática mediante 
agentes gaseosos, por tener una superficie construida mayor que $5000 \mathrm{~m}^{2}$ (artículos A.20.6 y A.20.7).

- Contará con una instalación de alumbrado de emergencia, puesto que la ocupación puede ser mayor que 100 personas (artículo 21.1).

Así, siguiendo la normativa existente, el proyecto arquitectónico deberá diseñar la instalación de protección contra incendios que considere más adecuada a las necesidades de un edificio donde se produce la convivencia de colecciones, trabajadores, público, etc.

\section{VII.2. PROTECCIÓN CONTRA ACTOS}

\section{ANTISOCIALES}

Habrá que establecer sistemas de seguridad contra la intrusión y el hurto cuando el museo esté cerrado, así como seguridad en salas a museo abierto. Además, se establecerá un protocolo de acceso para el personal del museo a las áreas en las que haya colecciones.

Tanto el personal de vigilancia como la instalación y el mantenimiento de los sistemas de seguridad serán externalizados.

En el apartado de Recursos Humanos se detalla el número de personas que trabajarán en el museo en relación con la seguridad y las funciones que cada una de ellas desempeña en relación con la seguridad del museo. En resumen, estarán trabajando en el museo al mismo tiempo, es decir, en cada turno:
- 1 conserje
- 1 ordenanza
- 20 vigilantes de sala
- 2 vigilantes en la consola de seguridad

Recomendamos la instalación en el museo de los siguientes sistemas: 
- Un circuito cerrado de televisión (CCTV) que controle, tanto a museo abierto como cerrado, los alrededores del edificio y el interior del mismo. A museo abierto controlará los visitantes de las salas y su comportamiento respecto a las colecciones del museo y las instalaciones del mismo, así como que el acceso del público al museo se realice por los accesos y de la forma reglamentaria. A museo cerrado vigilará el exterior y el interior del mismo para evitar intrusismo y hurtos.

Desde la consola de seguridad, ubicada en el sótano 1 del nuevo edificio, se controlarán todas las cámaras instaladas en los dos inmuebles del museo. Estas televisiones serán controladas por dos personas en cada turno.

El proyecto arquitectónico estudiará, teniendo en cuenta la superficie de cada área y su ocupación, el número de cámaras y su distribución en ambos edificios del museo.
- Una alarma que detecte la intrusión en el museo cuando éste está cerrado. Tendrá que contar con los siguientes requisitos:

- Conexión a la central receptora de alarmas.

- Llamada de comprobación en caso de disparo de la alarma (directamente a la consola de seguridad).

- Clave y contraclave.

- Aviso de corte telefónico.

- Servicio de acuda.

\section{- Barreras físicas y puertas de seguridad tanto en el} exterior como en determinados pasos o zonas del interior, por ejemplo, en los vanos al exterior del edificio actual instalar rejas, puertas de seguridad y cristales blindados; en el interior, instalar puertas de seguridad en los vanos de comunicación museo-cafetería y museo-asociación de amigos. 


\section{- Vitrinas de seguridad para las piezas de gran valor} económico (tesoros del Carambolo, de Ébora, de Mairena del Alcor...). No obstante, la zona tartéssica, que contiene piezas de gran valor, deberá quedar acorazada al cierre del museo. Estas medidas servirán, además de para garantizar la seguridad de las piezas expuestas, para posibilitar la exposición de otras que actualmente no se exponen por no poder garantizarse su seguridad, como es el tesoro del Carambolo, del que se muestra una reproducción, permaneciendo el original en la caja fuerte de un banco.

\section{- Caja fuerte para las piezas que gran valor no} expuestas, cuya ubicación será determinada por el proyecto arquitectónico tras estudiar el lugar más adecuado para la misma.
- Además de estos sistemas deberán tenerse en cuenta medidas como:

- Monitorización de las comunicaciones diarias del museo.

- Reevaluación anual del riesgo.

- Mantenimiento anual de los sistemas de seguridad, desde el punto de vista preventivo y correctivo.

- Asesoría personal de seguridad.

- Custodia y gestión de llaves, unido al protocolo de acceso a áreas restringidas.

- Red corporativa de comunicación fija y móvil. 


\section{VII.3. PROTECCIÓN CONTRA} ACCIDENTES

Será detallada en el apartado de Recursos Humanos en el Plan previsto de Riesgos Laborales.

A continuación se han detallado en los planos de los dos edificios las zonas de mayor riesgo de incendios y de intrusión, robo o vandalismo

\section{LEYENDA PARA LOS PLANOS}

\section{Zona de máximo riesgo de incendios}

Zona de riesgo medio de incendios

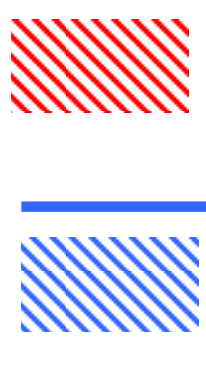

Ascensores, escaleras, accesos y salidas

Zona de máximo riego de intrusión, robo o vandalismo

Zona de riesgo medio de intrusión, robo o vandalismo 


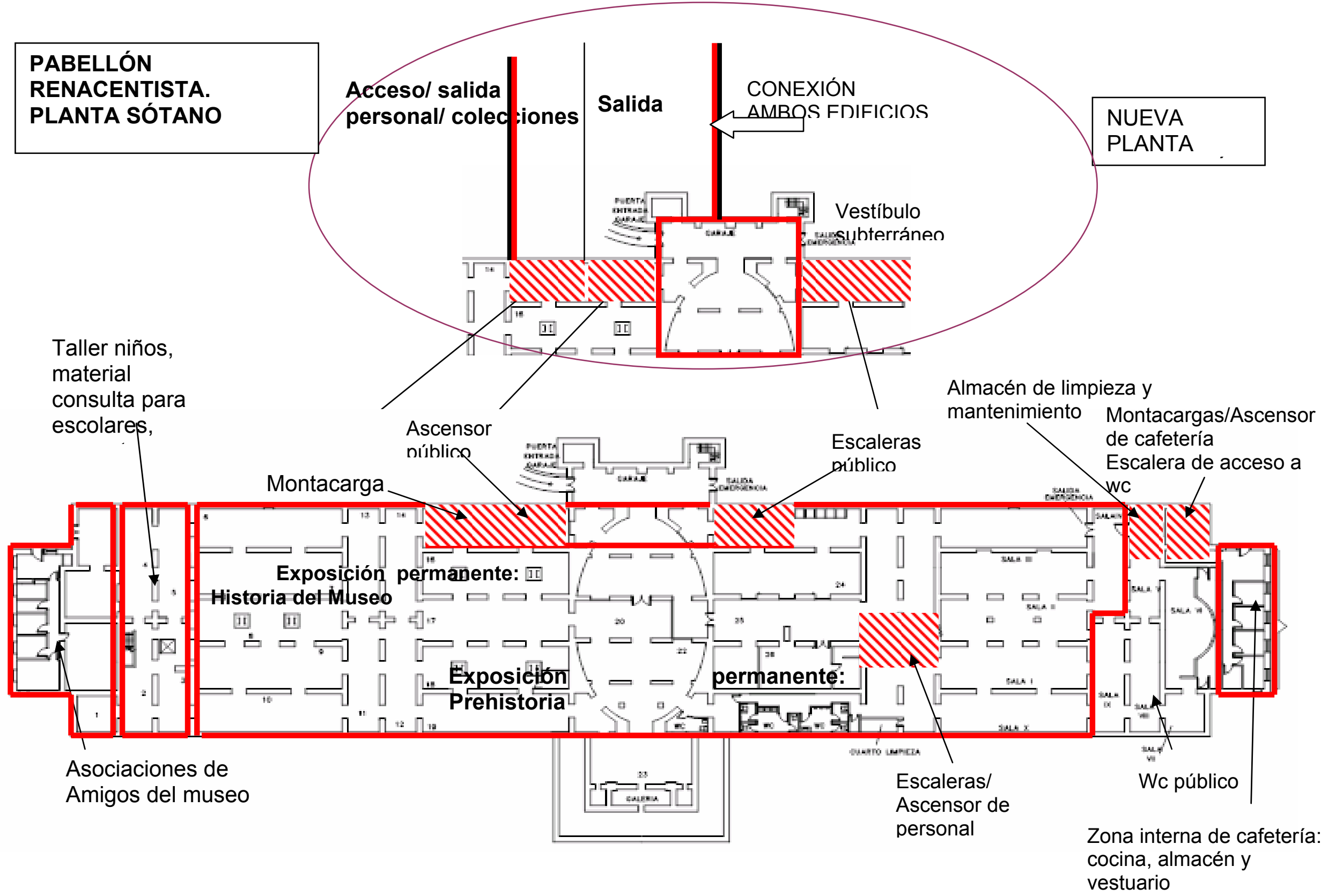




\section{PABELLÓN RENACENTISTA. \\ PLANTA BAJA}

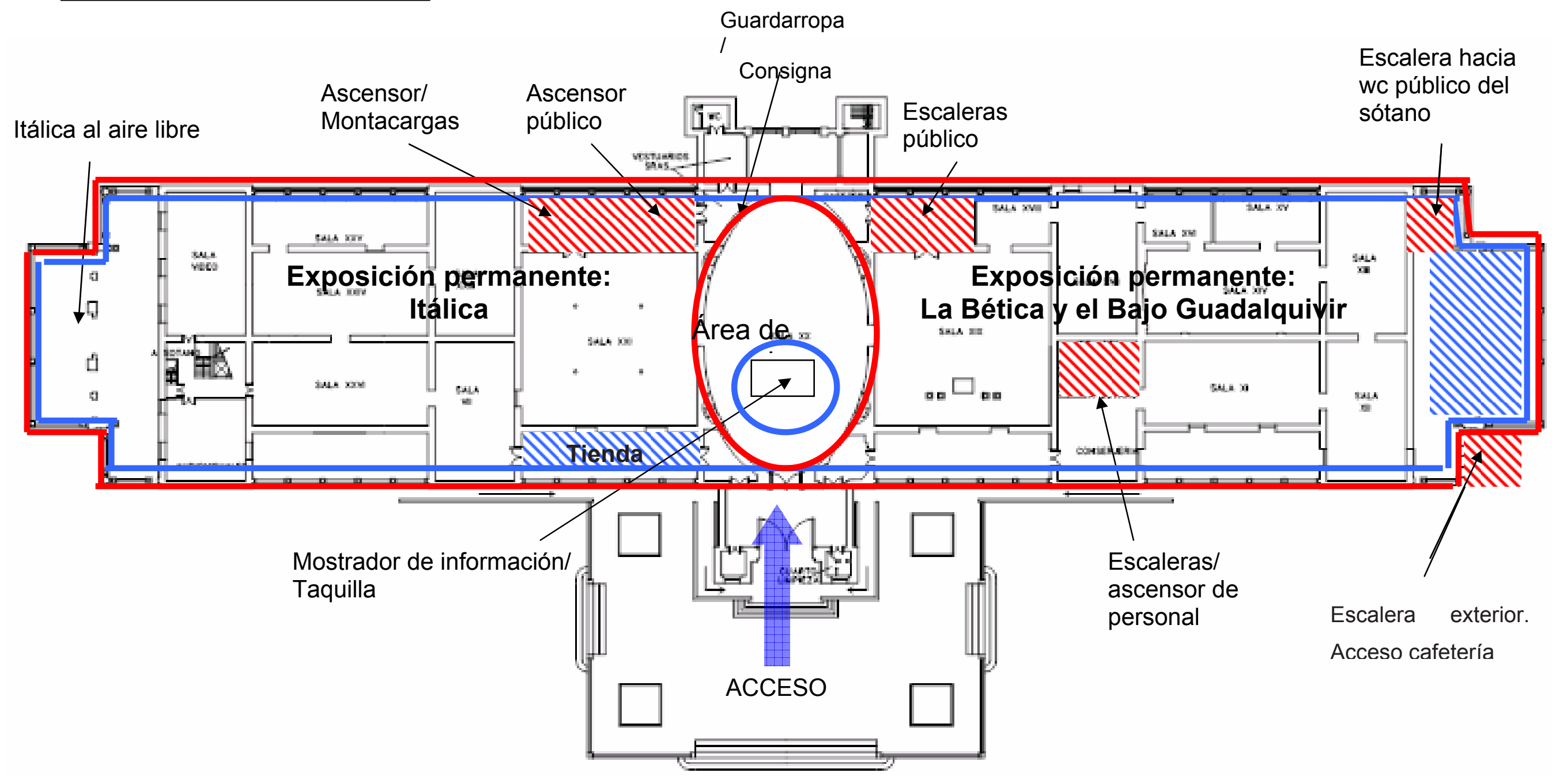


PABELLÓN RENACENTISTA.

\section{PLANTA PRIMERA}

Wc público

\section{Escaleras acceso torre}

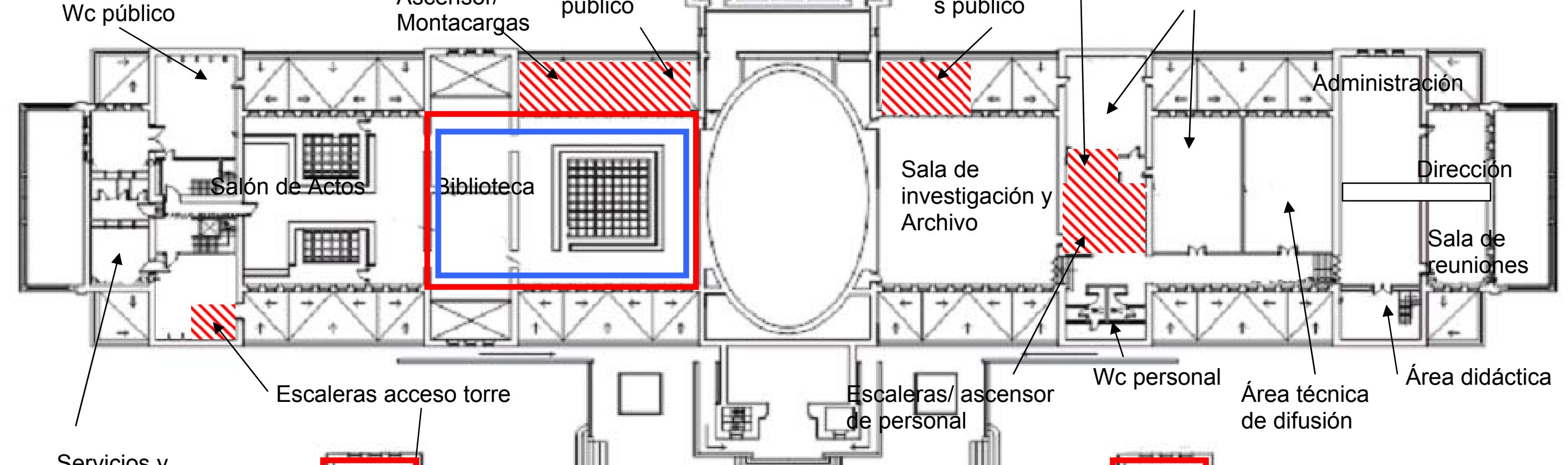

Servicios y vestuarios de personal de vigilancia y seguridad

Almacén de biblioteca y difusión
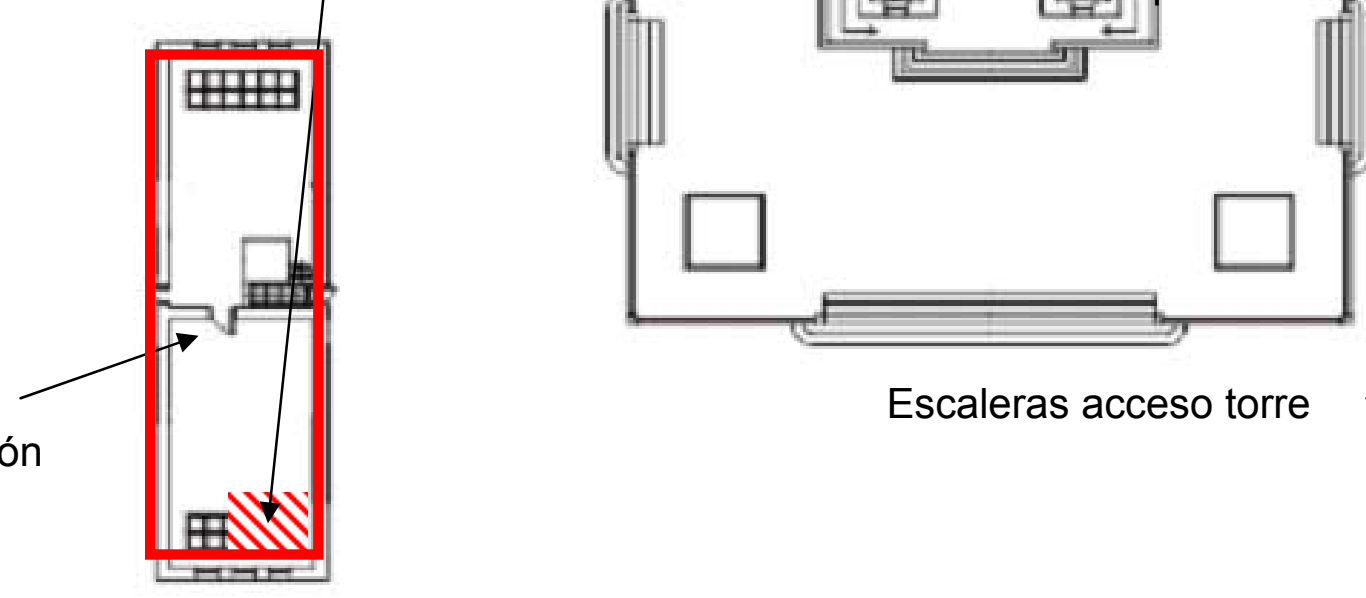

Escaleras acceso torre

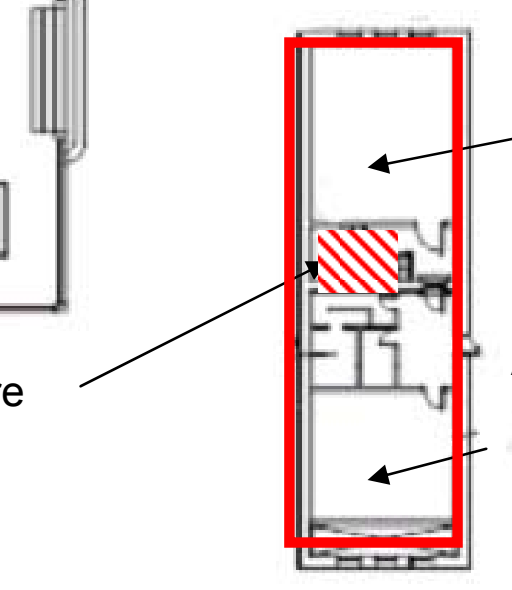

Archivo

Almacén de material de oficina fungible 


\section{EDIFICIO NUEVO}

SÓTANO

\section{PASILLO DE}

COMUNICACIÓN

Ascensor y escaleras

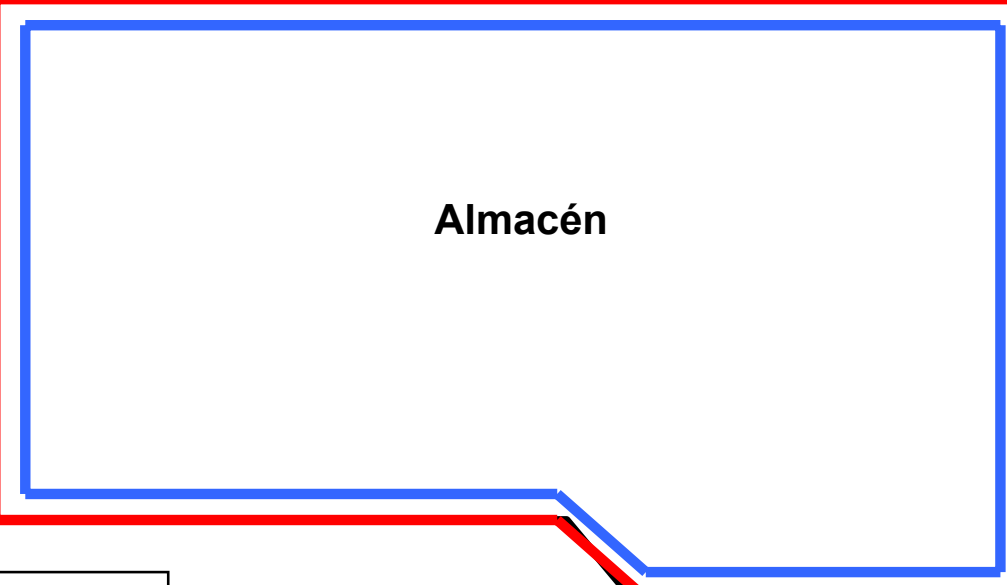

SÓTANO

Almacén
Público Personal y colecciones

Entrada de colecciones

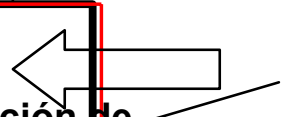

Area recepción colecciones

de

Área

.

Zona anexa

Consola

de recepción

Ascensor/ montacargas y

assateras personal

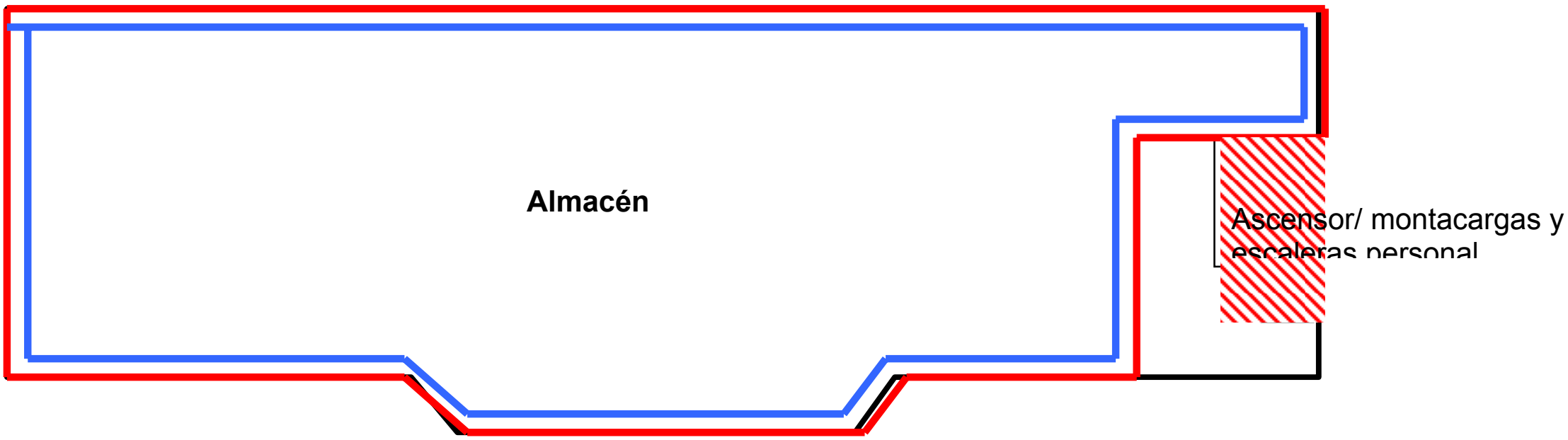




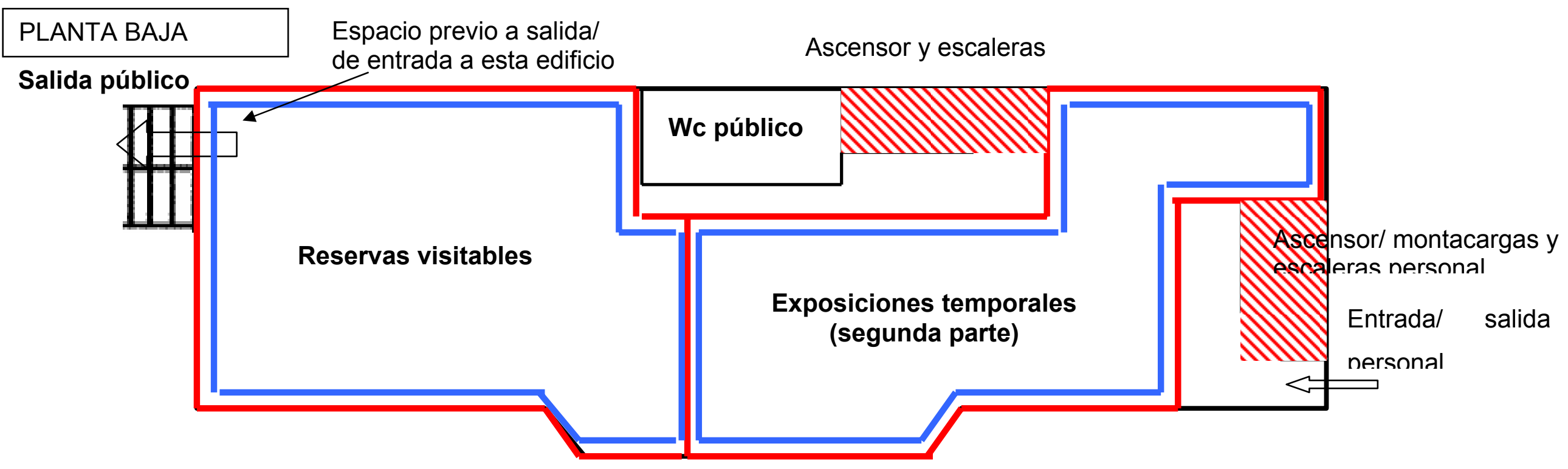

PLANTA PRIMERA

Ascensor y escaleras

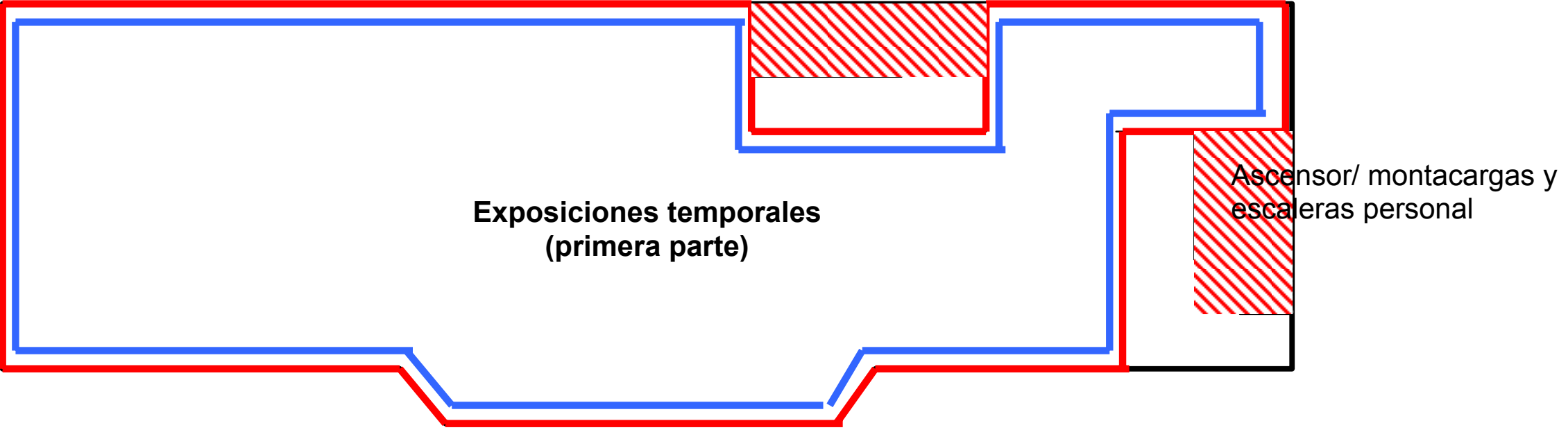




\section{PLANTA SEGUNDA}

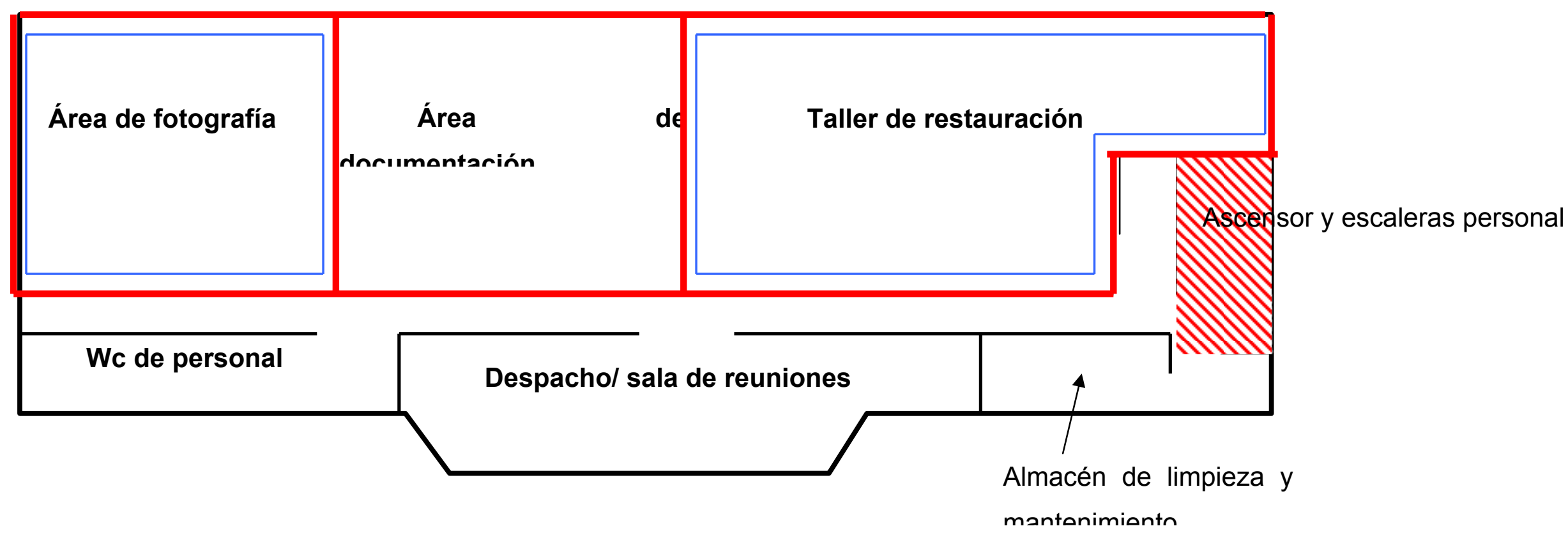




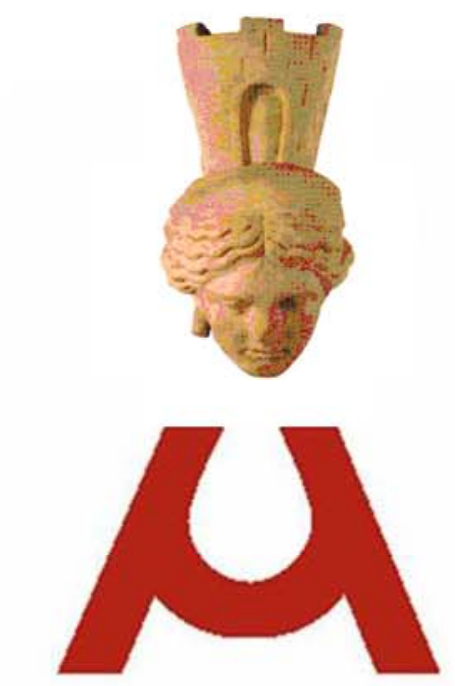

Museo

Arqueológico de Sevilla

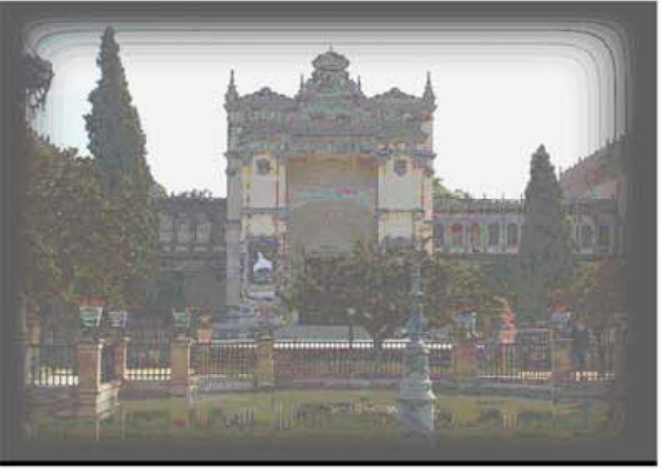

RECURSOS HUMANOS

Patricia Monzo Losada 


\section{VIII.1. CONSIDERACIONES GENERALES}

Ya hemos señalado en la Fase I de Análisis y Evaluación de los recursos humanos el peso específico de personal funcionario dentro del Museo.

Los trabajadores son los activos reales del Museo. La ampliación, los avances técnicos y las mejoras de servicios ofrecidos, conllevan la obligación de una organización y un personal cualificado para atender a un público más exigente.

A continuación elaboraremos una serie de puntos que deberían destacarse como necesidades de cambio en la RPT y en el organigrama funcional. La creación de un Plan de Prevención de Riesgos Laborales será otro de los puntos destacados en el programa de Recursos Humanos.

\section{VIII.2. RELACIÓN DE PUESTOS DE}

\section{TRABAJO}

\section{Propuesta de RPT, principales características y funciones de los puestos de trabajo. La externalización como solución de conflictos actuales}

En la propuesta de RPT que mostramos a continuación, se han contemplado varias modificaciones que hemos considerado necesarias con respecto a la relación de puestos de trabajo que tenía el museo anteriormente.

- La denominación de puestos de trabajo se han realizado en función del nombre del puesto y no de la formación requerida. Específicamente, en la RPT prevista por la Consejería de Cultura para el Museo Arqueológico de Sevilla que está pendiente de ser 
aprobada por la Dirección General de la Función

Pública, se denominan puestos nuevos como

Titulado Grado Superior o Titulado Grado Medio.

Tales denominaciones no hacen referencia a puestos de trabajo sino a requerimiento formativos con lo que se volvería a incurrir en un error de base a la hora de realizar la nueva RPT.

- Hemos considerado la opción de externalización de puestos como: limpieza y seguridad. La finalidad es la minimización de conflictos y problemas que causaban al museo.

- En las Funciones especificamos las posibles relaciones que se pueden dar entre los departamentos y las unidades, que serán representadas gráficamente en el apartado siguiente al representar el organigrama funcional.
- Es necesario aclarar que el puesto asignado como Responsable de Atención al visitante y al Investigador, ha sido creado no sólo para recepción del público sino también como primer acercamiento del investigador al museo, donde podrá conocer en todo momento las solicitudes y trámites que debe rellenar para poder acceder a la manipulación de las piezas solicitadas, el acceso a las áreas de reserva... De esta forma se consigue principalmente que:

- El investigador pueda conocer en todo momento los trámites que necesite y poder tener acceso a ellos.

- A través de un primer registro, la Unidad de Investigación y Documentación pueda tener un conocimiento previo de las necesidades $\mathrm{y}$ requerimientos del investigador. 


\begin{tabular}{|c|c|c|c|c|c|c|c|}
\hline \multicolumn{8}{|c|}{ NUEVA RELACIÓN DE PUESTOS DE TRABAJO (RPT) PARA EL M.A.S. } \\
\hline DIRECTOR & 1 & $\mathrm{~N}$ & A & DIRECCIÓN & $\begin{array}{l}\text { LICENCIATURA } \\
\text { HISTORIA Y } \\
\text { ARQUEOLOGÍA } \\
\text { FORMACIÓN EN } \\
\text { MUSEOLOGÍA }\end{array}$ & $\begin{array}{l}\text {-Amplia experiencia en } \\
\text { gestión y administración en } \\
\text { el sector cultural. } \\
\text {-Conocimiento en gestión } \\
\text { financiera y fiscal } \\
\text {-Conocimiento sobre } \\
\text { legislación }\end{array}$ & $\begin{array}{l}\text {-Responsable de llevar a cabo la misión del } \\
\text { museo } \\
\text {-Ejercer liderazgo } \\
\text {-Relaciones institucionales } \\
\text {-Garantizar la toma de decisiones y aprobar las } \\
\text { líneas de actuación determinadas en las } \\
\text { reuniones departamentales. } \\
\text {-Supervisión de las actuaciones del gestor. } \\
\text {-Elaborar propuestas de programación del Museo } \\
\text { apoyado por los responsables de cada área. } \\
\text {-Orden de tramitar la solicitud de concurso } \\
\text { público a la Empresa Pública de Programas } \\
\text { Culturales en el caso de necesitar una empresa } \\
\text { externa para la realización de alguna actividad } \\
\text { que lo necesitara. }\end{array}$ \\
\hline GERENTE & 1 & $\mathrm{~F}$ & A & $\begin{array}{l}\text { DIRECCIÓN } \\
\text { (GERENCIA) }\end{array}$ & $\begin{array}{l}\text { LICENCIATURA } \\
\text { GESTIÓN Y } \\
\text { ADMINISTRACIÓN } \\
\text { DE EMPRESAS }\end{array}$ & $\begin{array}{l}\text {-Museología y Gestión de } \\
\text { Museos } \\
\text {-Negociado }\end{array}$ & $\begin{array}{l}\text {-Recomendar políticas y planes de actuación a } \\
\text { los grupos departamentales } \\
\text {-Asesorar al director en cuestiones económico- } \\
\text { financieras } \\
\text {-Asegurar la coordinación entre los jefes de los } \\
\text { distintos departamentos. } \\
\text {-Coordinador directo de las tareas llevadas a } \\
\text { cabo por el Negociado de Gestión Económica y } \\
\text { Administrativa y por el Negociado de Recursos } \\
\text { Humanos. }\end{array}$ \\
\hline
\end{tabular}




\begin{tabular}{|c|c|c|c|c|c|c|c|}
\hline $\begin{array}{l}\text { JEFE DE } \\
\text { COLECCIONES } \\
\text { (Conservador de } \\
\text { museos) }\end{array}$ & 1 & $F$ & $A$ & $\begin{array}{l}\text { COORDINADOR } \\
\text { DEL } \\
\text { DEPARTAMENTO } \\
\text { DE COLECCIONES } \\
\text { (UNIDAD DE } \\
\text { CONSERVACIÓN Y } \\
\text { RESTAURACIÓN) }\end{array}$ & $\begin{array}{l}\text { LINCENCIATURA } \\
\text { HISTORIA Y } \\
\text { ARQUEOLOGÍA } \\
\text { FORMACIÓN EN } \\
\text { MUSEOLOGÍA }\end{array}$ & $\begin{array}{l}\text {-especialista en } \\
\text { conservación preventiva y } \\
\text { restauración }\end{array}$ & $\begin{array}{l}\text {-Coordinador y responsable del cumplimiento de } \\
\text { los objetivos fijados en el Departamento de } \\
\text { Colecciones. } \\
\text {-Supervisión de las tareas de conservación de la } \\
\text { colección. } \\
\text {-Examen junto con el restaurador y el Asesor } \\
\text { técnico de conservación de todas las } \\
\text { adquisiciones y préstamos. } \\
\text {-Evaluación de posibles daños en la recepción de } \\
\text { piezas y su transporte. } \\
\text {-Elaborar los informes de conservación para el } \\
\text { envío de piezas para exposiciones temporales, } \\
\text { apoyados por los informes de restauración en } \\
\text { caso de que la pieza los haya necesitado. Envío a } \\
\text { registro y desde allí al archivo del museo. }\end{array}$ \\
\hline $\begin{array}{l}\text { ASESOR TÉCNICO } \\
\text { DE } \\
\text { CONSERVACIÓN E } \\
\text { INVESTIGACIÓN }\end{array}$ & 1 & $F$ & $A$ & $\begin{array}{l}\text { DEPARTAMENTO } \\
\text { DE COLECCIONES } \\
\text { (UNIDAD DE } \\
\text { CONSERVACIÓN Y } \\
\text { RESTAURACIÓN) }\end{array}$ & $\begin{array}{l}\text { LICENCIATURA } \\
\text { HISTORIA Y } \\
\text { ARQUEOLOGÍA } \\
\text { FORMACIÓN EN } \\
\text { MUSEOLOGÍA }\end{array}$ & $\begin{array}{l}\text {-CONSERVACIÓN } \\
\text {-MUSEOLOGÍAY } \\
\text { MONTAJE DE } \\
\text { EXPOSICIONES }\end{array}$ & $\begin{array}{l}\text {-Examen junto con el restaurador y el jefe de } \\
\text { colecciones (conservador de museo) de la } \\
\text { conservación de todas las adquisiciones y } \\
\text { préstamos. } \\
\text {-Trabajo junto con el Encargado de almacén y el } \\
\text { restaurador en la recepción y envío de piezas. }\end{array}$ \\
\hline
\end{tabular}




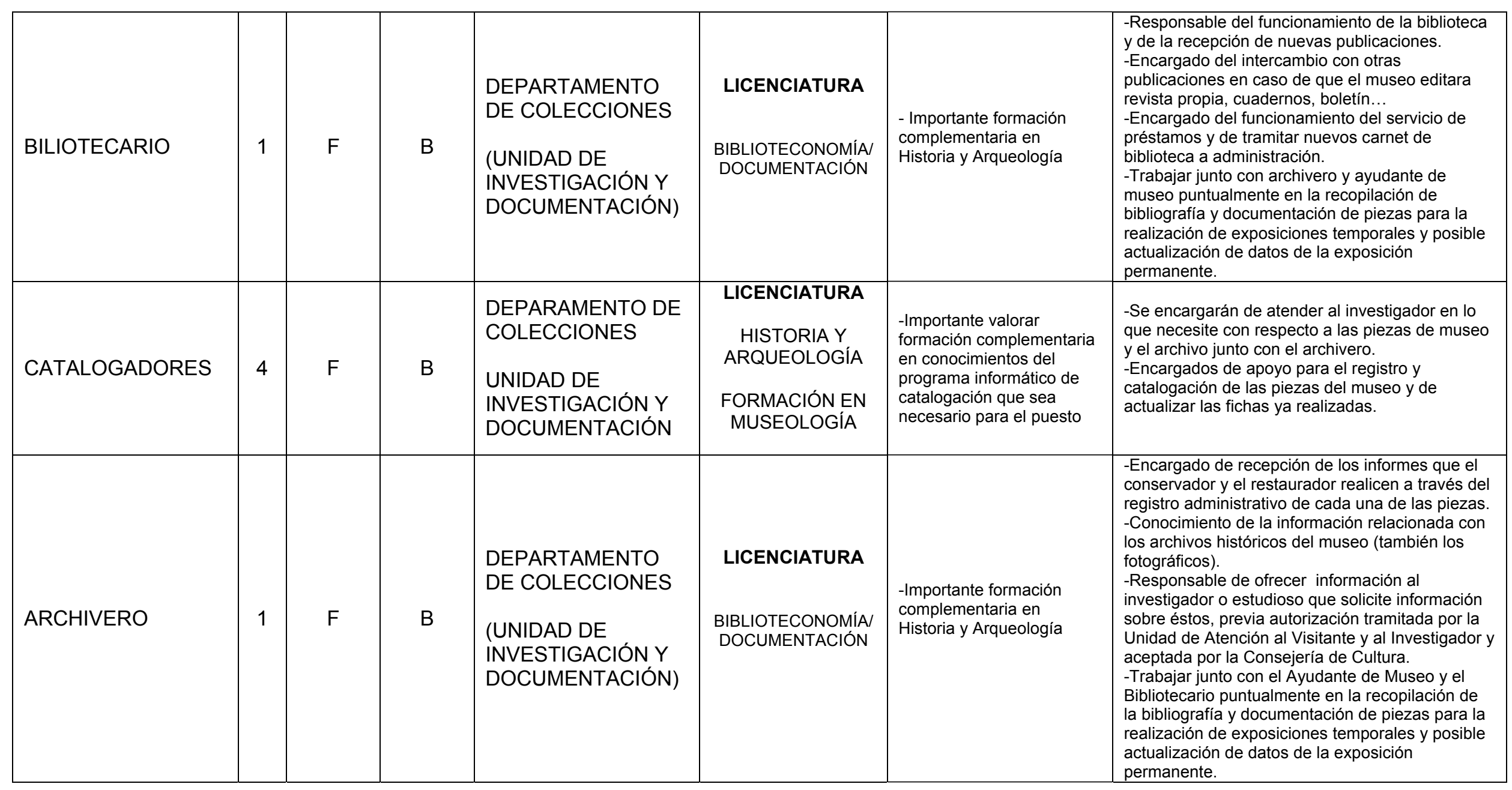




\begin{tabular}{|c|c|c|c|c|c|c|c|}
\hline $\begin{array}{l}\text { AYUDANTE DE } \\
\text { MUSEO }\end{array}$ & 2 & $\mathrm{~F}$ & B & $\begin{array}{l}\text { DEPARTAMENTO } \\
\text { DE COLECCIONES } \\
\text { (UNIDAD DE } \\
\text { INVESTIGACIÓN Y } \\
\text { DOCUMENTACIÓN) }\end{array}$ & $\begin{array}{l}\text { LICENCIATURA } \\
\text { HISTORIA Y } \\
\text { ARQUEOLOGÍA } \\
\text { FORMACIÓN EN } \\
\text { MUSEOLOGÍA }\end{array}$ & $\begin{array}{l}\text {-Importante formación en } \\
\text { documentación e iniciación } \\
\text { a la investigación }\end{array}$ & $\begin{array}{l}\text {-Responsable de investigación y documentación } \\
\text { para la catalogación de piezas en DOMUS } \\
\text {-Supervisores de los trabajos del personal } \\
\text { contratado de DOMUS a través de la Empresa } \\
\text { Pública de Programas Culturales. } \\
\text {-Responsables de documentar y trabajar junto } \\
\text { con archivero y bibliotecario cuando sea preciso } \\
\text { para recopilar bibliografía y documentación de } \\
\text { piezas para la realización de exposiciones } \\
\text { temporales y posible actualización de datos de la } \\
\text { exposición permanente. }\end{array}$ \\
\hline $\begin{array}{l}\text { OFICIAL } 1^{\circ} \mathrm{DE} \\
\text { FOTOGRAFÍA }\end{array}$ & 1 & $\mathrm{~L}$ & III & $\begin{array}{l}\text { DEPARTAMENTO } \\
\text { DE COLECCIONES } \\
\text { (UNIDAD DE } \\
\text { INVESTIGACIÓN Y } \\
\text { DOCUMENTACIÓN) }\end{array}$ & $\begin{array}{l}\text { DIPLOMATURA/ } \\
\text { FORMACIÓN } \\
\text { GRADO } \\
\text { SUPERIOR } \\
\text { FOTOGRAFÍA }\end{array}$ & $\begin{array}{l}\text {-FOTOGRAFÍA Y } \\
\text { DOCUMENTACIÓN }\end{array}$ & $\begin{array}{l}\text { - Responsable de fotografiar las piezas para el } \\
\text { informe de restauradores y conservadores. } \\
\text {-Fotografía artística para la edición de paneles y/o } \\
\text { publicaciones. } \\
\text {-Todas las fotografías realizadas serán pasadas } \\
\text { por registro y desde allí a formar parte del archivo } \\
\text { fotográfico. } \\
\text {-Debe controlar la base de datos fotográfica con } \\
\text { el índice topográfico de cada una de las } \\
\text { fotografías realizadas. }\end{array}$ \\
\hline $\begin{array}{l}\text { JEFE DE DIFUSIÓN } \\
\text { (Asesor Técnico de } \\
\text { difusión) }\end{array}$ & 1 & $F$ & A & $\begin{array}{l}\text { COORDINADOR } \\
\text { DEL } \\
\text { DEPARTAMENTO } \\
\text { DE DIFUSIÓN }\end{array}$ & $\begin{array}{l}\text { LICENCIATURA } \\
\text { HISTORIA Y } \\
\text { ARQUEOLOGÍA } \\
\text { FORMACIÓN EN } \\
\text { MUSEOLOGÍA }\end{array}$ & $\begin{array}{l}\text {-COMUNICACIÓN } \\
\text { AUDIOVISUAL } \\
\text {-PEDAGOGÍA } \\
\text {-MUSEOLOGÍA }\end{array}$ & $\begin{array}{l}\text {-Responsable de coordinar las unidades del } \\
\text { Departamento de difusión. } \\
\text {-Encargado junto con el Departamento de } \\
\text { Comunicación y el de Educación de la propuesta } \\
\text { anual de actividades y exposiciones temporales. } \\
\text {-Responsable del museo de atender a las } \\
\text { propuestas realizadas por la Asociación Amigos } \\
\text { del Museo y colaborar con ellos en la creación de } \\
\text { exposiciones, publicaciones... } \\
\text {-Relacionado con el Oficial } 1^{\circ} \text { de Fotografía para } \\
\text { la publicación de noticias, y la creación de } \\
\text { exposiciones. } \\
\text {-Importante relación con el encargado de } \\
\text { exposiciones de la Unidad de Exposiciones para } \\
\text { la realización de Exposiciones Temporales y } \\
\text { posibles actualizaciones de la exposiciones } \\
\text { permanente así como la coordinación de las } \\
\text { publicaciones y sus costes. }\end{array}$ \\
\hline
\end{tabular}




\begin{tabular}{|c|c|c|c|c|c|c|c|}
\hline $\begin{array}{l}\text { ENCARGADO DE } \\
\text { CONTROL Y } \\
\text { ATENCIÓN AL } \\
\text { PÚBLICO }\end{array}$ & 4 & $\mathrm{~L}$ & III & $\begin{array}{l}\text { DEPARTAMENTO } \\
\text { DE DIFUSIÓN } \\
\\
\text { (UNIDAD DE } \\
\text { ATENCIÓN AL } \\
\text { PÚBLICO Y AL } \\
\text { INVESTIGADOR) }\end{array}$ & $\begin{array}{l}\text { DIPLOMATURA/ } \\
\text { FORMACIÓN GRADO } \\
\text { SUPERIOR } \\
\\
\text { ADMINISTRACIÓN/ } \\
\text { SECRETARIIDO/ } \\
\text { RECEPCIÓN }\end{array}$ & $\begin{array}{l}\text {-RECEPCIÓN } \\
\text {-INFORMÁTICA }\end{array}$ & $\begin{array}{l}\text {-Encargados de informar al visitante de lo } \\
\text { que el museo puede ofrecerles } \\
\text {-Explicación de audio-guías, en caso de que } \\
\text { alguna exposición lo necesitara } \\
\text {-Recepción de sugerencias, quejas y } \\
\text { evaluación mensual de las mismas para } \\
\text { realizar informe anual. El informe se pasará } \\
\text { por registro y formará parte del archivo } \\
\text { administrativo. } \\
\text {-Recepción de investigadores para facilitar } \\
\text { una primera explicación de la tramitación de } \\
\text { las diferentes solicitudes antes de pasar a la } \\
\text { Unidad de Investigación y Documentación, } \\
\text { donde podrán tener acceso a las piezas o } \\
\text { archivos solicitados y aceptados } \\
\text {-Registro de nombres de investigadores y } \\
\text { ámbito de estudio, piezas y archivos } \\
\text { consultados para llevar un registro de las } \\
\text { investigaciones que se llevan a cabo en el } \\
\text { Museo y que la Unidad de Investigación y } \\
\text { Documentación tenga conocimiento } \\
\text { periódico de ello. }\end{array}$ \\
\hline EXPENDEDORES & 4 & $L$ & V & $\begin{array}{l}\text { DEPARTAMENTO } \\
\text { DE DIFUSIÓN } \\
\\
\text { (UNIDAD DE } \\
\text { ATENCIÓN AL } \\
\text { PÚBLICO Y AL } \\
\text { INVESTIGADOR) }\end{array}$ & $\begin{array}{l}\text { FORMACIÓN GRADO } \\
\text { MEDIO/SUPERIOR } \\
\text { ADMINISTRACIÓN/ } \\
\text { RECEPCIÓN }\end{array}$ & $\begin{array}{l}\text {-RECEPCIÓN } \\
\text {-NOCIONES } \\
\text { INFORMÁTICAS }\end{array}$ & $\begin{array}{l}\text {-Expendedor de entradas } \\
\text {-Recaudación del precio de las entradas. } \\
\text {-Balance diario de la recaudación. Informe } \\
\text { de la recaudación mensual. Pasando al } \\
\text { archivo administrativo desde su previo } \\
\text { registro. } \\
\text {-Informe mensual del balance de visitas al } \\
\text { museo. Primero pasadas por registro y } \\
\text { desde allí a formar parte del archivo } \\
\text { administrativo. }\end{array}$ \\
\hline $\begin{array}{l}\text { ENCARGADO DE } \\
\text { EDUCACIÓN Y } \\
\text { ACTIVIDADES } \\
\text { DIDÁCTICAS }\end{array}$ & 2 & $\mathrm{~F}$ & $A / B$ & $\begin{array}{l}\text { DEPARTAMENTO } \\
\text { DE DIFUSIÓN } \\
\text { (UNIDAD DE } \\
\text { EDUCACIÓN) }\end{array}$ & $\begin{array}{l}\text { LICENCIATURA/ } \\
\text { DIPLOMATURA } \\
\\
\text { PEDAGOGÍA } \\
\text { CIENCIAS DE LA } \\
\text { EDUCACIÓN/ } \\
\text { EDUCACIÓN SOCIAL }\end{array}$ & $\begin{array}{l}\text {-PEDAGOGÍA } \\
\text {-ORGANIZACIÓN DE } \\
\text { ACTIVIDADES } \\
\text { DIDÁCTICAS }\end{array}$ & $\begin{array}{l}\text {-Educador del aula didáctica } \\
\text {-Responsable de proponer actividades } \\
\text { didácticas y culturales trabajando en } \\
\text { colaboración con el asesor técnico de } \\
\text { difusión y el resto del equipo del } \\
\text { Departamento de Difusión. } \\
\text {-Trabajo conjunto con el Departamento de } \\
\text { Investigación y Documentación para la } \\
\text { realización de textos para paneles, folletos y } \\
\text { cuadernos didácticos. }\end{array}$ \\
\hline
\end{tabular}




\begin{tabular}{|c|c|c|c|c|c|c|c|}
\hline $\begin{array}{l}\text { RESPONSABLE DE } \\
\text { EXPOSICIONES }\end{array}$ & 1 & $F$ & $A / B$ & $\begin{array}{l}\text { DEPARTAMENTO } \\
\text { DE DIFUSIÓN } \\
\text { (UNIDAD DE } \\
\text { EXPOSICIONES) }\end{array}$ & $\begin{array}{l}\text { LICENCIATURA } \\
\text { HISTORIA/ } \\
\text { ARQUEOLOGÍA } \\
\text { MUSEOLOGÍA/ } \\
\text { MUSEOGRAFÍA }\end{array}$ & -COMUNICACIÓN & $\begin{array}{l}\text { - Trabajar junto con el Jefe de Difusión en la } \\
\text { coordinación y realización de proyectos de } \\
\text { exposición y actividades para la realización } \\
\text { de presupuestos que serán elevados a la } \\
\text { administración para una valoración de los } \\
\text { costes. El informe del proyecto será enviado } \\
\text { a registro durante el primer semestre del año } \\
\text { para corregir posibles errores de } \\
\text { presupuesto. } \\
\text {-Prever proyectos menores (exposiciones de } \\
\text { menor alcance o actividades para aula de } \\
\text { educación) para posibles remanentes } \\
\text { presupuestarios. } \\
\text {-Encargado de coordinar los trabajos de } \\
\text { publicaciones realizadas por el museo como } \\
\text { catálogos o guías, así como junto con el } \\
\text { encargado de educación y actividades } \\
\text { didácticas en la publicación de guías } \\
\text { docentes. }\end{array}$ \\
\hline $\begin{array}{l}\text { OPERADOR DE } \\
\text { CONSOLA }\end{array}$ & 1 & $\mathrm{~F}$ & $A-B$ & $\begin{array}{c}\text { DEPARTAMENTO } \\
\text { DE DIFUSIÓN } \\
\text { (UNIDAD } \\
\text { COMUNICACIÓN Y } \\
\text { RELACIONES } \\
\text { EXTERNAS) }\end{array}$ & $\begin{array}{l}\text { LICENCIATURA } \\
\text { DIPLOMATURA } \\
\text { TELECOMINICACIONES } \\
\text { INFORMÁTICA }\end{array}$ & $\begin{array}{l}\text {-TÉCNICO } \\
\text { INFORMÁTICA } \\
\text { Y } \\
\text { TELECOMUNICACIONE } \\
S\end{array}$ & $\begin{array}{l}\text {-Encargado de actualizar la página web del } \\
\text { museo } \\
\text {-Configuración de la INTRANET para la } \\
\text { comunicación entre los diferentes espacios y } \\
\text { áreas. } \\
\text {-Solución de problemas informáticos y de } \\
\text { comunicación (Telefonía, Internet, Intranet, } \\
\text { fax,...) } \\
\text {-Instalación y solución de problemas de } \\
\text { software y hardware cuando fueran } \\
\text { necesarios. }\end{array}$ \\
\hline
\end{tabular}




\begin{tabular}{|c|c|c|c|c|c|c|c|}
\hline $\begin{array}{l}\text { JEFE DE OBRAS Y } \\
\text { SERVICIOS }\end{array}$ & 1 & $\mathrm{~F}$ & C-D & $\begin{array}{l}\text { COORDINADOR } \\
\text { DEL } \\
\text { DEPARTAMENTO } \\
\text { DE OBRAS Y } \\
\text { SERVICIOS } \\
\text { AUXILIARES } \\
\text { (UNIDAD DE } \\
\text { COORDINACIÓN DE } \\
\text { ACTIVIDADES } \\
\text { AUXILIARES) }\end{array}$ & $\begin{array}{l}\text { LICENCIATURA/ } \\
\text { DIPLOMATURA } \\
\text { ADMINISTRACIÓN Y } \\
\text { DIRECCIÓN DE } \\
\text { EMPRESAS }\end{array}$ & - Liderazgo empresarial & $\begin{array}{l}\text {-Responsable de la coordinación de los } \\
\text { Recursos Humanos del Departamento de } \\
\text { Obras y Servicios Auxiliares. } \\
\text {-Principal responsable de la organización de } \\
\text { los turnos de los trabajadores de la Unidad } \\
\text { de Coordinación de Actividades Auxiliares, la } \\
\text { Unidad de Almacén y Obras y de la Unidad } \\
\text { de Personal Auxiliar. } \\
\text { - Responsable de que se cumplan las tareas } \\
\text { asignadas para cada puesto en el } \\
\text { Departamento de Obras y Servicios } \\
\text { Auxiliares. } \\
\text {-Principal responsable de solucionar } \\
\text { problemas relacionados con la Unidad de } \\
\text { Coordinación de Actividades Auxiliares y si } \\
\text { no fuera posible, elevar el problema al } \\
\text { Director, quien dará las instrucciones } \\
\text { oportunas para su solución. }\end{array}$ \\
\hline SEGURIDAD & 30 & $\mathrm{~L}$ & \multirow{4}{*}{\multicolumn{5}{|c|}{$\begin{array}{c}\text { DEPARTAMENTO DE OBRAS Y SERVICIOS AUXILIARES } \\
\text { (UNIDAD DE COORDINACIÓN DE ACTIVIDADES AUXILIARES) } \\
\text { EXTERNALIZACIÓN DE RECURSOS }\end{array}$}} \\
\hline LIMPIEZA & 6 & $\mathrm{~L}$ & & & & & \\
\hline TIENDA & 4 & $L$ & & & & & \\
\hline CAFETERÍA & 10 & $\mathrm{~L}$ & & & & & \\
\hline $\begin{array}{l}\text { ENCARGADO DE } \\
\text { ALMACÉN }\end{array}$ & 1 & $\mathrm{~L}$ & III & $\begin{array}{l}\text { DEPARTAMENTO } \\
\text { DE OBRAS Y } \\
\text { SERVICIOS } \\
\text { AUXILIARES } \\
\text { (UNIDAD DE } \\
\text { ALMACÉN Y } \\
\text { MANTENIMIENTO) }\end{array}$ & $\begin{array}{c}\text { FORMACIÓN GRADO } \\
\text { SUPERIOR }\end{array}$ & $\begin{array}{l}\text {-ARQUEOLOGÍA } \\
\text {-ETIQUETAR MATERIAL } \\
\text { ARQUEOLÓGICO } \\
\text {-INVENTARIAR } \\
\text { MATERIAL } \\
\text { ARQUEOLÓGICO }\end{array}$ & $\begin{array}{l}\text {-Informe de la recepción de material para su } \\
\text { posterior catalogación e inventario por los } \\
\text { encargados del Departamento de } \\
\text { Investigación y Documentación. } \\
\text {-Adecuar topográficamente el material } \\
\text { recibido en el almacén. } \\
\text {-Limpieza de material arqueológico que no } \\
\text { esté adecuadamente limpio así como utilizar } \\
\text { cajas y bolsas normalizadas por el museo. } \\
\text {-Coordinación de las tareas para las que sea } \\
\text { necesaria voluntarios y personal en prácticas } \\
\text { tal y como se especifica en el Programa } \\
\text { Económico: Colaboración con Empresas y } \\
\text { formación Universitaria. }\end{array}$ \\
\hline
\end{tabular}




\begin{tabular}{|c|c|c|c|c|c|c|c|}
\hline PEONES & 3 & $\mathrm{~L}$ & V & $\begin{array}{c}\text { DEPARTAMENTO } \\
\text { DE OBRAS Y } \\
\text { SERVICIOS } \\
\text { AUXILIARES } \\
\text { (UNIDAD DE } \\
\text { ALMACÉN Y } \\
\text { MANTENIMIENTO) }\end{array}$ & $\begin{array}{c}\text { FORMACIÓN } \\
\text { BÁSICA/ESO/ESA }\end{array}$ & -FORMACIÓN OFICIO & $\begin{array}{l}\text {-Realización de obras menores de } \\
\text { mantenimiento. } \\
\text {-Colaboración con el Encargado de Almacén } \\
\text { en la recepción de las piezas. }\end{array}$ \\
\hline $\begin{array}{l}\text { PEÓN DE } \\
\text { MANTENIMIENTO }\end{array}$ & 1 & $\mathrm{~L}$ & $\mathrm{~V}$ & $\begin{array}{c}\text { DEPARTAMENTO } \\
\text { DE OBRAS Y } \\
\text { SERVICIOS } \\
\text { AUXILIARES } \\
\\
\text { (UNIDAD DE } \\
\text { ALMACÉN Y } \\
\text { MANTENIMIENTO) }\end{array}$ & $\begin{array}{c}\text { FORMACIÓN } \\
\text { BÁSICA/ ESO/ESA }\end{array}$ & -FORMACIÓN OFICIO & $\begin{array}{l}\text {-Reposición de alumbrado } \\
\text {-Colaboración en las tareas de limpieza más } \\
\text { especificas } \\
\text {-Pequeñas reparaciones } \\
\text {-Pintura... }\end{array}$ \\
\hline $\begin{array}{l}\text { AUXILIARES DE } \\
\text { INSTITUCIONES } \\
\text { CULTURALES }\end{array}$ & 6 & $\mathrm{~L}$ & IV & $\begin{array}{c}\text { DEPARTAMENTO } \\
\text { DE OBRAS Y } \\
\text { SERVICIOS } \\
\text { AUXILIARES } \\
\text { (UNIDAD DE } \\
\text { PERSONAL } \\
\text { AUXILIAR) } \\
\end{array}$ & $\begin{array}{l}\text { FORMACIÓN DE } \\
\text { GRADO MEDIO }\end{array}$ & $\begin{array}{l}\text {-ARQUEOLOGÍA } \\
\text {-ETIQUETADO DE } \\
\text { MATERIAL }\end{array}$ & $\begin{array}{l}\text {-Apoyo al Encargado de Almacén para el } \\
\text { etiquetado de material } \\
\text {-Colaboración en guía de grupos del museo } \\
\text { para grupos numerosos o de escolares } \\
\text {-Apoyo para la unidad de Educación en la } \\
\text { organización de grupos escolares }\end{array}$ \\
\hline
\end{tabular}




\begin{tabular}{|c|c|c|c|c|c|c|c|}
\hline ORDENANZAS & 3 & $\mathrm{~L}$ & V & $\begin{array}{l}\text { DEPARTAMENTO } \\
\text { DE OBRAS Y } \\
\text { SERVICIOS } \\
\text { AUXILIARES } \\
\\
\text { (UNIDAD DE } \\
\text { PERSONAL } \\
\text { AUXILIAR) } \\
\end{array}$ & $\begin{array}{c}\text { FORMACIÓN } \\
\text { BÁSICA/ ESO/ESA }\end{array}$ & -FORMACIÓN OFICIO & $\begin{array}{l}\text {-Recoger y enviar correo. } \\
\text {-Repartir el correo entre los distintos } \\
\text { departamentos y personal. } \\
\text {-Apoyo a los conserjes en sus tareas } \\
\text {-Realización de tareas en el exterior del } \\
\text { museo: compra de material para } \\
\text { reparaciones menores, compra de material } \\
\text { fungible de oficina... }\end{array}$ \\
\hline ADMINISTRATIVO & 1 & $\mathrm{~F}$ & C & $\begin{array}{l}\text { NEGOCIADO DE } \\
\text { GESTIÓN } \\
\text { ADMINISTRATIVA }\end{array}$ & $\begin{array}{l}\text { FORMACIÓN DE } \\
\text { GRADO SUPERIOR }\end{array}$ & $\begin{array}{l}\text {-ADMINISTRACIÓN Y } \\
\text { REGISTRO }\end{array}$ & $\begin{array}{l}\text {-Encargado de registrar informes para } \\
\text { tramitarlos al director. Una copia queda en } \\
\text { registro y el original sellado por el director } \\
\text { pasa, bien al archivo de documentación y } \\
\text { fotografía (caso de informes de } \\
\text { conservación, restauración, fotografías...), } \\
\text { bien al archivo administrativo del museo } \\
\text { (informes, expedientes, trámites, } \\
\text { solicitudes...) }\end{array}$ \\
\hline $\begin{array}{l}\text { AUXILIARES } \\
\text { ADMINISTRATIVOS }\end{array}$ & 3 & $\mathrm{~F}$ & D & $\begin{array}{c}\text { NEGOCIADO DE } \\
\text { GESTIÓN } \\
\text { ADMINISTRATIVA }\end{array}$ & $\begin{array}{l}\text { FORMACIÓN DE } \\
\text { GRADO MEDIO }\end{array}$ & $\begin{array}{l}\text {-ADMINISTRACIÓN Y } \\
\text { REGISTRO }\end{array}$ & $\begin{array}{l}\text {-Responsables de la organización del } \\
\text { archivo administrativo. } \\
\text {-Resolución de trámites que pueda realizarlo } \\
\text { el gestor. } \\
\text {-Asignación de un administrativo como } \\
\text { apoyo al responsable de personal para el } \\
\text { mejor desempeño de sus actividades }\end{array}$ \\
\hline
\end{tabular}


VIII.3. ORGANIGRAMA FUNCIONAL

\section{Paso de una organización por designación de puestos a una organización departamental}

Como vimos en la Fase de Análisis, el modelo de organización actual se fundamenta en una estructura plana en la que se establece una conexión directa entre la dirección, el único departamento existente (Departamento de Conservación) y cada uno de los trabajadores, a excepción de ordenanzas, mantenimiento y limpieza, que cuenta con la figura intermedia del Conserje.

En el nuevo organigrama que proponemos, como hemos comentado, la división departamental se ha realizado según la denominación de los puestos de trabajo.
En relación a los puestos de trabajo, encontramos profesionales cuya actividad requiere una altísima cualificación (conservadores, restauradores..), así como otros puestos donde no se requiere tal nivel de especialización (conserjes, peones, auxiliares..).

Esta diferenciación determina de manera clara las características fundamentales de unos puestos y otros, lo que a su vez nos servirá para determinar los modelos de coordinación aplicables.

Así pues, los puestos cualificados se caracterizan por una gran especificidad de su tarea, así como una gran autonomía en el desarrollo de su actividad, mientras los puestos menos cualificados tienen un menor poder de disposición en cuanto al desarrollo de sus actividades.

Un modelo de coordinación adecuado para este segundo grupo de trabajadores sería la denominada supervisión 
directa, es decir, el control de sus actividades se va a conseguir responsabilizando a una persona del trabajo de los demás, dándoles instrucciones y controlando sus acciones.

Respecto a los puestos más especializados la coordinación y el control se va a efectuar desde dos perspectivas, la primera, denominada normalización de habilidades, viene determinada por la misma administración desde el momento que determina cuál es la capacitación requerida para ocupar un puesto en concreto. Por otra parte, se hace necesario otro mecanismo que nos sirva para coordinar sus actuaciones en el desempeño de su actividad a lo largo del tiempo. Esta otra fórmula se refiere a la normalización de los procesos de trabajo, es decir a la programación del trabajo a desarrollar y posterior evaluación de los resultados obtenidos en reuniones cada cierto tiempo.
A partir de esta exposición podemos empezar a analizar determinadas cuestiones con el objeto de mejorar aspectos relativos a la organización de los puestos de trabajo.

Como decíamos al principio, el modelo de la estructura de dicha organización es plano, frente a los modelos piramidales, de manera que se consigue una mayor agilidad de actuación dado los pocos niveles jerárquicos que en ella se dan, fundamentado esencialmente en una mejor y más rápida fluidez de la información que encuentra menores obstáculos que si de una estructura piramidal estuviéramos hablando.

Si bien ello es claramente beneficioso no se ha de conseguir una mejor agilidad en las comunicaciones a costa del empeoramiento de la coordinación pues ello nos llevaría a compensar la mejor fluidez de la información con una mayor dificultad en la coordinación de manera que no se habría avanzado ni aprovechado las ventajas de nuestro tipo de estructura. Si no existen esos puestos 
coordinadores lo que conseguiremos es recargar a puestos jerárquicamente superiores de tareas no propias de estos, tales como el control de las actuaciones de los trabajadores menos cualificados mediante la supervisión directa o la programación de actuaciones en relación a los puestos más especializados, con el consiguiente perjuicio en tanto en cuanto no se van a poder dedicar o al menos no en la media que sería deseable a sus propias tareas.

Si establecemos, como ocurre actualmente, una conexión entre el director, el departamento actual y los trabajadores directamente, vamos a responsabilizar a éste de la supervisión de tareas como mantenimiento, limpieza o del control de actividades por parte de restauradores, archiveros...., de manera que las tareas de mantener $y$ reactivar relaciones institucionales o elaborar propuestas de programación podrían quedar en un segundo plano.
Notas al Organigrama Funcional

-Las unidades no están subordinadas entre sí dentro del Departamento al que pertenezcan.

-Dentro de cada Unidad sí que puede haber subordinaciones de puestos de trabajo.

-Las funciones aclaradas en el cuadro de la RPT nos indica las relaciones entre los distintos puestos de trabajo.

-Cada una de las unidades del Departamento de Obras y Servicios Auxiliares debe de contar con un supervisor que esté en contacto con el jefe de departamento, para que no sea necesario que éste coordine directamente las actividades cotidianas.

-En el Negociado de Gestión Económica y Administrativa se encuentra el Registro Administrativo del Museo. Tanto este negociado como el Negociado de Recursos Humanos están directamente relacionados y coordinados directamente por el Gerente del Museo.

-El Organigrama funcional no es una estructura meramente teórica sino que será puesta en conocimiento de cada uno de los trabajadores al principio de su incorporación como trabajadores del museo. Anualmente se deberá hacer un Training, organizado por los responsables del Negociado de Recursos Humanos. Estos breves cursos de organización y de conocimiento de la estructura funcional, son favorables no sólo para que los trabajadores conozcan perfectamente su puesto de trabajo y las relaciones que se dan con las demás unidades sino que une experiencias entre puestos y entre trabajadores, siendo cada uno consciente de la importante labor que realizan en el buen funcionamiento del Museo. 


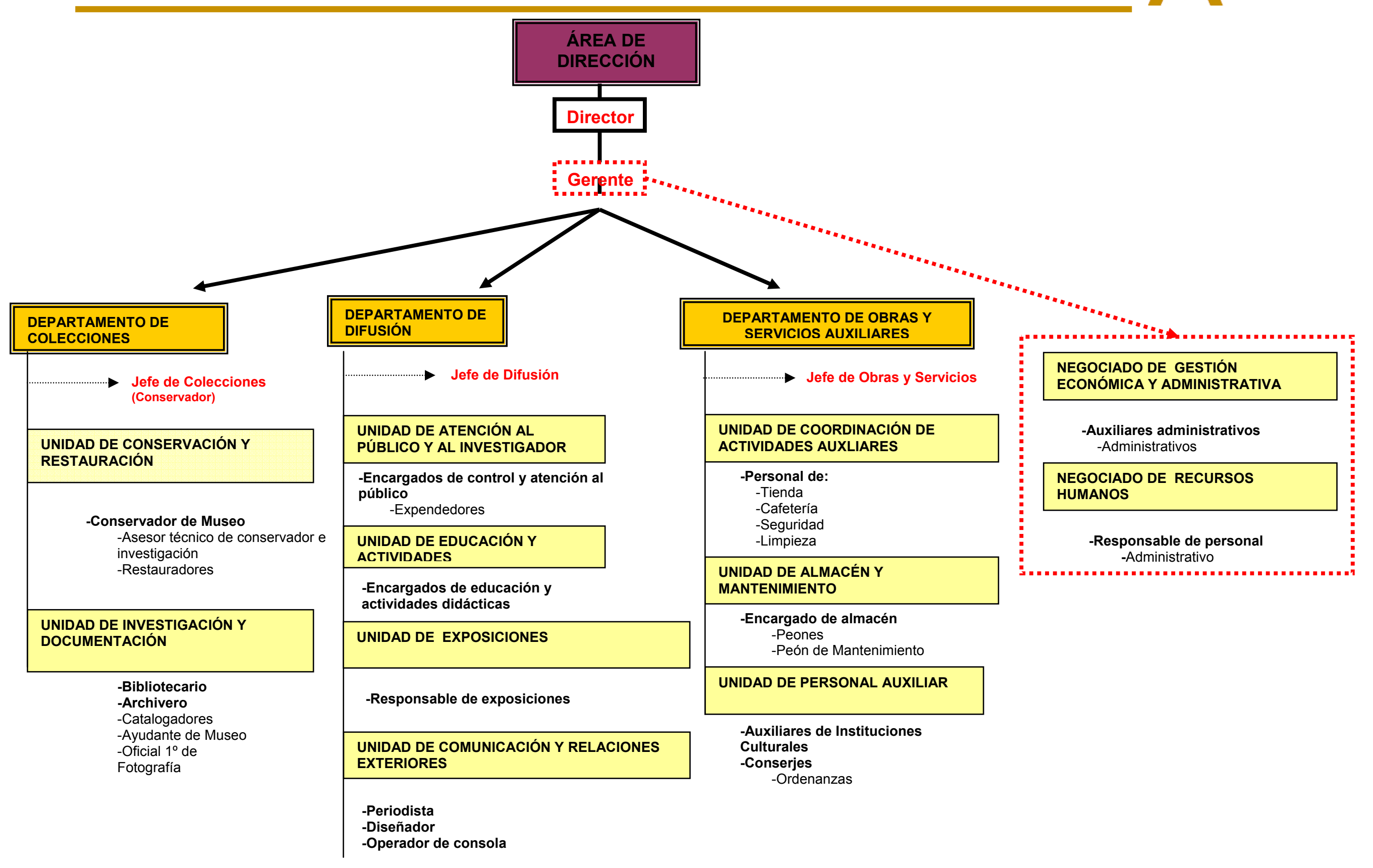


908

\section{VIII.4. PREVISIÓN DE UN PLAN DE PREVENCIÓN DE RIESGOS LABORALES}

El desempeño de cualquier actividad profesional va a suponer la exposición en mayor o menor medida a una serie de riesgos laborales que van a afectar a la salud de los trabajadores.

El desgaste al que cualquier trabajador se va a ver sometido a lo largo de su vida laboral nos lleva a tratar de eliminar dichos riesgos 0 al menos, minimizar las consecuencias de aquellos que, por la naturaleza de las funciones de dicho trabajador, no puedan ser excluidos en su influencia de manera absoluta.

El desarrollo de un sistema de prevención en el seno de un organismo como el que nos ocupa nos lleva a plantearnos una serie de cuestiones previas, que vamos a intentar clarificar, derivadas de las peculiaridades que dicha entidad presenta.

Por un lado nos encontramos ante la necesidad de plantear un sistema de prevención y seguridad de cara a las personas que trabajan en el Museo, pero no podemos obviar la igualmente necesaria seguridad que requieren los visitantes que acudan a nuestras instalaciones. Visitantes que bien podríamos comparar, por la importancia de los mismos, con los propios clientes de cualquier empresa privada.

Por tanto dentro de un primer análisis vamos a diferenciar entre prevención y seguridad laboral, aspecto que trataremos a continuación, y la propia seguridad en relación al visitante así como la seguridad de la propia materia prima de la que un museo se "alimenta", las obras de arte. Aspecto este último que es tratado en el correspondiente Programa de Seguridad del Museo. 
Centrándonos en la prevención de riesgos laborales y atendiendo a las peculiaridades que anunciábamos el principio, nos encontramos ante la dificultad de concretar cuales van a ser los preceptos legislativos que se han de aplicar y por los cuales nos debemos regir a la hora de implantar nuestro plan de prevención. Encontramos la convivencia en un mismo centro de trabajo, que es cómo entendemos el museo desde el punto de vista de la prevención, de dos tipos de trabajadores que como sabemos suelen tener legislaciones reguladoras bastante diferenciadas en algunos casos, por un lado personal funcionario mientras por el otro encontramos personal laboral al servicio de la administración, sin olvidar las relaciones que se establezcan mediante contratos con otras empresas al externalizar determinadas actividades ya comentadas.

La Ley de Prevención de Riesgos Laborales, nos resuelve en gran medida dicha incertidumbre pues desde su entrada en vigor ha intentado ser norma con una clara vocación generalista que regulara dicho campo de la prevención independientemente del sector o características de las actividades profesionales. Si bien hemos de concretar que las claras diferencias en cuanto a las características de la actividad funcionarial y la puramente laboral, han determinado una adaptación para los primeros, respecto a algunas cuestiones, en pro de esa generalidad de aplicación. Adaptaciones que habremos de tener en cuenta y que desarrollaremos más adelante.

La prevención de riesgos laborales ha de ser una actividad continua dentro del museo de manera que en ningún caso podemos creer que la prevención está realizada si nos conformamos con poseer un plan de prevención de quinientas páginas, como un mero documento teórico que guardar para las inspecciones de trabajo. 
910

El plan de prevención sólo es una parte, que es de gran importancia y que supone el inicio de tal sistema de prevención, pero que no puede ser la última o único eslabón de una cadena que resulta mucho más larga.

De esta forma empezaremos hablando de las distintas fases de dicho plan para pasar a ver posteriormente los mecanismos internos de control que se han de establecer para comprobar una adecuada aplicación del sistema, así como la manera en que se ajusta el plan a las necesidades del museo mediante consulta a sus propios protagonistas, los trabajadores, para terminar con la necesaria actualización que de este sistema se ha de dar.

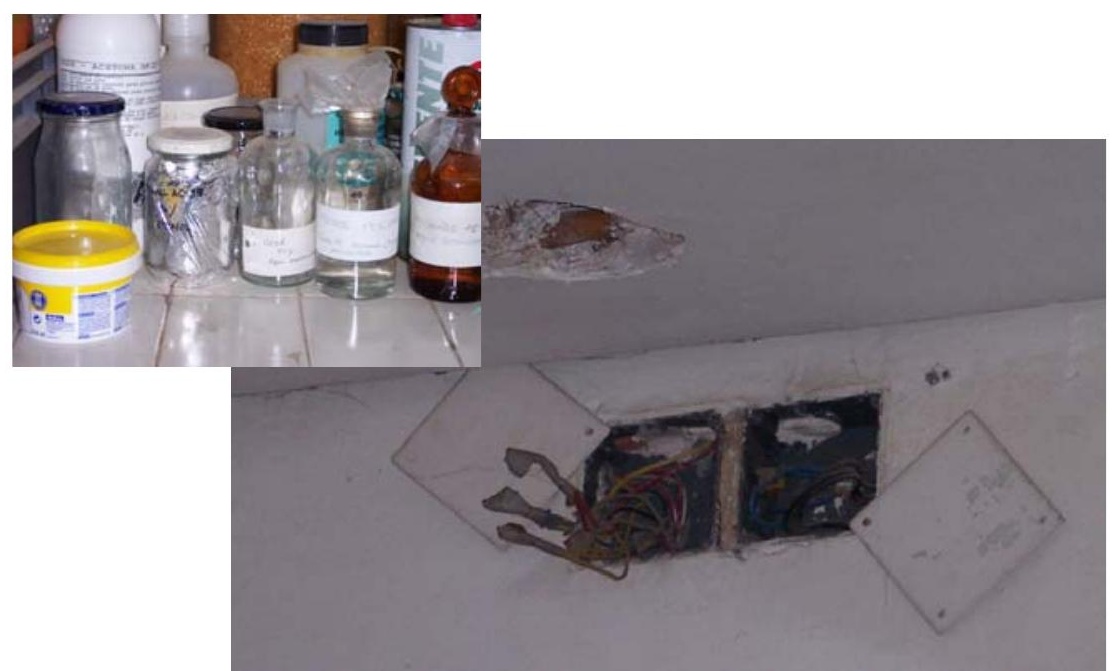

Con la Propuesta de realización de un Plan de Prevención de Riesgos específico para el Museo intentamos, como se ha especificado anteriormente, eliminar los riesgos a los que los trabajadores están expuestos, y respecto a los que sean imposibles de ser eliminados tratar de limitar al máximo su influencia, así pues, nuestro plan habrá de comenzar haciéndose una evaluación de los riesgos presentes en cada puesto de trabajo. Será el momento de concretar aspectos tales como:

- El riesgo para la salud que supone la manipulación de piezas pesadas

- La peligrosidad derivada del uso de productos químicos como ocurre con la restauración,

- El manejo de determinada maquinaria

- Los riesgos a los que se ven expuestos los trabajadores cuya actividad consiste en estar sentados la mayor parte del día ( problemas 
columna vertebral, cervicales, en la vista debido a la visualización de pantallas de ordenadores etc..).

- Principales estresores psicosociales en el trabajo.

(..)

Una vez determinados los peligros existentes se pasará a comprobar si las medidas existentes son las adecuadas, por ejemplo: ver si se utilizan mascarillas de protección cuando se hace uso de dichos productos químicos, comprobar si los empleados que se han de dedicar a la manipulación de piezas pesadas cuentan con la maquinaria necesaria o si los lugares de trabajos cumplen con los requisitos ergonómicos para la mejor adaptación posible hombre-entorno.

Haciéndonos eco de lo que denominamos una actuación continuada respecto a la prevención hemos de especificar que dicha evaluación habrá de ser repetida siempre y cuando cambien las condiciones de trabajo, cuando se produzca algún daño para la salud, cuando se adquieran nuevos equipos de trabajo o por el transcurso del tiempo y con independencia de que se hayan producido daños o deficiencias.

Esta evaluación se va realizar en todo caso con el necesario asesoramiento del servicio de prevención propio o ajeno, y consultando previamente a los trabajadores, aspectos ambos que abordaremos a continuación.

El servicio de prevención va a actuar como asesor además de velar por una adecuada implantación del posterior plan de prevención y es aquí cuando podemos comprobar como se hace palpable las diferencias legislativas a las que hacíamos referencia, de forma que por el hecho de tratarse de la administración pública, la manera en que se constituya dicho servicio va a estar limitada. Si bien en la empresa privada podría ser el propio 
empresario el que asumiera dichas capacidades, por tratarse de la administración pública, su homólogo, el director del museo no va a poder asumir dichas tareas pudiendo acogerse a cualquiera de las otras modalidades. Por tratarse de una entidad con un número no muy elevado de trabajadores, parece más lógico recurrir a la designación de trabajadores para tal fin, no obstante se requerirá una formación necesaria en tales materias para poder realizar sus cometidos así como el consentimiento por parte de los mismos, sin el cual no sería posible imputarles tales tareas. Otra opción sería recurrir a un servicio de prevención ajeno que actuará como una empresa contratada externamente y especialista en esta materia, como si del servicio de seguridad y vigilancia se tratara. Si pasamos a ver el aspecto de la consulta a los trabajadores sobre dicha evaluación de riesgos entramos de nuevo en la necesidad de diferenciar a personal funcionario y laboral. Dicha consulta se va a efectuar a los representantes de los trabajadores que como sabemos, y en principio se van a diferenciar en delegados de personal para los laborales y Juntas de Personal para los funcionarios, no obstante y en materia de prevención la propia ley establece la necesidad de establecer un comité único con representación proporcionada de unos y otros, en función del número que supongan en el total de trabajadores en el Museo.

Se ha realizado un análisis de la situación actual en el museo y ahora vamos a proceder a establecer una planificación preventiva en la que se va a determinar de manera priorizada cuales van a ser las medidas a adoptar para combatir la existencia de dichos riesgos presentes, la programación temporal para su puesta en vigor y la asignación de recursos económicos para poder llevarlos a cabo.

Finalmente, tras la evaluación, consulta, planificación y establecimiento de nuestro servicio de prevención, una actividad fundamental que nunca debemos olvidar será la continua formación en prevención que nuestros 
trabajadores han de recibir cuando se produzcan cambios por la introducción de nuevos equipos de trabajo, nuevas tecnologías o de manera periódica si no se produce ninguna circunstancia objetiva que la provoque. 

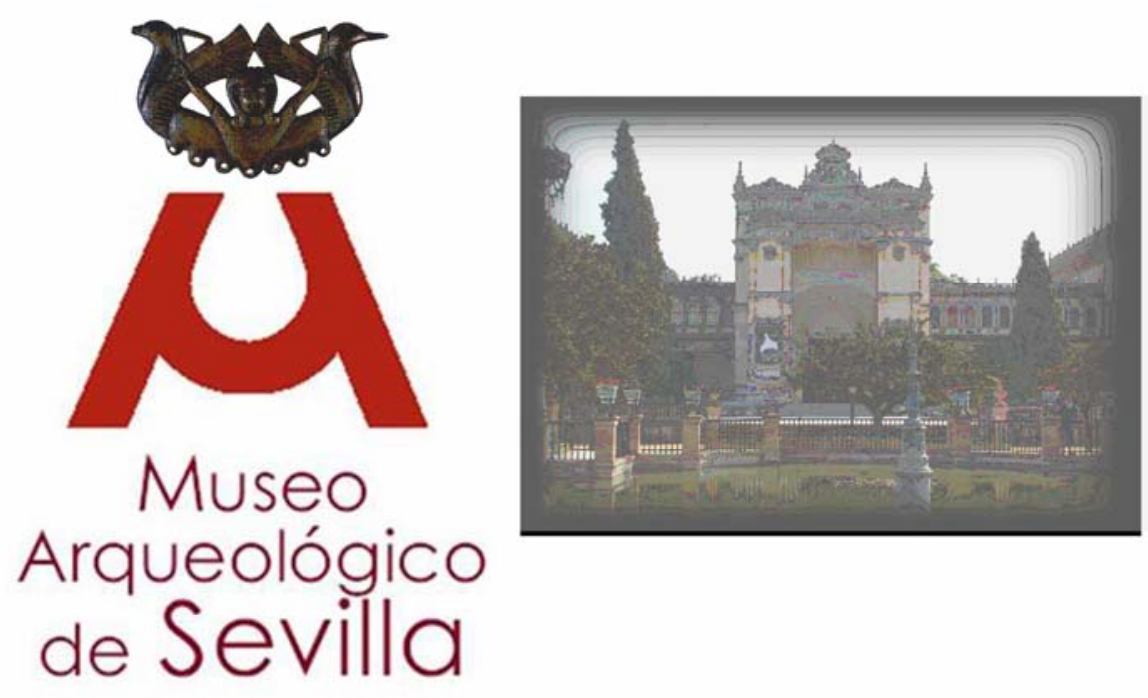

RECURSOS ECONÓMICOS

Patricia Monzo Losada 


\section{IX.1. CONSIDERACIONES GENERALES}

El tipo de planificación económica que se lleve a cabo en el museo se encuentra supeditada al régimen jurídico de éste. En nuestro caso es bastante limitado a la hora de establecer los presupuestos pues no tiene libertad en este sentido. Teniendo en cuenta esta cuestión, realizaremos un programa de Gestión económica que se ajuste y se pueda llevar a cabo, para poder analizar la viabilidad económicofinanciera de la rehabilitación integral del Museo Arqueológico que estamos proponiendo.

Antes de comenzar a desglosar los puntos que hemos considerado de interés para realizar un programa económico-financiero adecuado y que se ajuste a las leyes vigentes, teniendo en consideración la titularidad y gestión públicas del edificio, debemos subrayar los principales objetivos del Museo Arqueológico de Sevilla. Con éstos, como metas principales se plantearán los principales elementos de la estrategia que mostrarán tanto un coste aproximado de nuestro proyecto, la necesidad de emprenderlo, como la viabilidad económica del mismo.

Algunas cuestiones ya comentadas nos ayudarán a establecer una base sólida que justifique la necesidad de llevar a cabo la rehabilitación integral del centro y del presupuesto previsto.

Así pues, según las conclusiones derivadas de la Fase de Análisis y Evaluación de la Difusión, podemos definir las siguientes premisas para crear una hipótesis preliminar sobre la investigación de mercado:

- El ambiente externo favorecedor que presenta el museo por encontrarse en el Parque de María Luisa, en sí mismo captador de turismo y la cercanía del museo a otros centros culturales, el más cercano, el Museo de Artes y Costumbres y más alejado pero que tendríamos que tener 
en cuenta, el Teatro Lope de Vega, la Biblioteca Pública Infanta Helena y la Universidad Hispalense, además de edificios relevantes que atraen al turismo.

- El tipo de oferta cultural del museo es más relevante para los visitantes residentes en la zona.

Sería también interesante destacar, como hemos visto en la Fase de Análisis y Evaluación de las Colecciones no sólo la magnitud de estas y su calidad sino la relación del museo con la provincia completa. De ello se deriva:

- La importancia de acondicionar un almacén adecuado para colecciones arqueológicas y con capacidad suficiente para admitir el gran volumen de piezas que el museo recibe diariamente.

- El propio origen diverso de las colecciones hace necesaria la relación entre los yacimientos de la provincia como Itálica o la Necrópolis de Carmona, como la comunicación entre el museo con los diferentes museos locales, representantes de centros neurálgicos de la
Arqueología actual en Sevilla como pueden ser el Museo Arqueológico de Carmona o el Museo Histórico Municipal de Écija.

Del Análisis y Evaluación de la RPT del centro, podemos destacar que el incremento de ésta supondría una mayor necesidad de aumento del presupuesto anual pues en las tablas hemos podido comprobar que el porcentaje anual de costes de un museo en este sentido supera el $27 \%$ de sus ingresos.

La gestión de los recursos como la tienda y la cafetería, que en otros museos no gestionados por organismos públicos, resultan una fuente importante de ingresos, en el caso del Museo Arqueológico de Sevilla, gestionado la Junta de Andalucía, no es posible reinvertir en él los ingresos que genere. Consideraremos la posibilidad de la concesión de la gestión de estos recursos, bien creados a través de la Empresa Pública de Programas Culturales, bien a través de la Asociación de Amigos del Museo. 
Principalmente, la creación de estos recursos se debe a la necesidad de ofrecer al público un mejor servicio, creando un museo moderno que cubra las necesidades del público y sea ejemplo de una Andalucía moderna capaz de ofrecer servicios de calidad al turismo ya sea nacional como internacional, así como a los propios habitantes de la ciudad.

Teniendo en cuenta la inversión que supone la rehabilitación integral del Museo Arqueológico de Sevilla, proponemos a continuación una serie de puntos principales en los que se tiene que basar la reestructuración y la planificación económica.

- Planificación estratégica como principal medio para la rehabilitación integral y acondicionamiento del nuevo espacio previsto.
- Estimación del presupuesto general para la rehabilitación integral del Museo Arqueológico de Sevilla 
PLAN ESTRATÉGICO DE GESTIÓN

ANÁLISIS DEL MICROENTORNO

El análisis del microentorno permitirá:

\section{INGRESOS DIRECTOS}

-Estudio del aumento del presupuesto derivado de la

captación de ingresos generados por

los servicios del propio museo:

- Nueva tarifa de entrada

- Otras aportaciones: tienda, derechos de reproducción, alquiler de espacios..

\section{INGRESOS INDIRECTOS}

-Aportaciones y subvenciones de la Asociación de Amigos y de otros

organismos.

-análisis prospectivo de los gastos a corto, medio y largo plazo, para

prever las inversiones necesarias y

los gastos posibles.

conocer: económico:

provincia.

de la zona.

\section{IX.2. PLANIFICACIÓN ESTRATÉGICA}

\section{Como principal medio para la rehabilitación integral del museo y acondicionamiento del nuevo espacio previsto.}

El análisis del macroentorno

nos dará la posibilidad de

-Estimación del impacto

-Generación del incremento del PIB debido a la mejora

del museo, recursos y servicios al público.

-Incrementación de

impuestos recaudados -empleos generados

-Entorno (variables externas no controlables, pero previsibles)

- Situación con respecto a los

demás museos de Sevilla y

- Capacidad de relación con los demás elementos patrimoniales
La planificación estratégica nace como respuesta a una situación singular de partida como es la rehabilitación integral y la reorganización de la estructura funcionaladministrativa del Museo Arqueológico de Sevilla. Para la consecución de los objetivos propuestos debemos de tener en cuenta una serie de factores y de premisas que no podemos dejar de lado a la hora de establecer las pautas para llevar a cabo el proyecto.

La planificación se estructura en actividades y actuaciones a corto, medio y largo plazo. Con ella se intentará que el impacto económico esté lo más regulado posible y 
teniendo la precaución de prever todos los aspectos necesarios para llevar a cabo la rehabilitación integral.

\section{ANÁLISIS DEL MICROENTORNO}

Justificación de las propuestas de los cambios económicos y de la rehabilitación integral del Museo Arqueológico de Sevilla.

\section{INGRESOS DIRECTOS}

Los principales flujos monetarios están relacionados principalmente por los ingresos directos relacionados, como hemos especificado anteriormente y debido a la titularidad y gestión del edificio, con los presupuestos anuales públicos que ya analizamos en la primera fase de análisis y evaluación de la gestión realizada. Esto genera la imposibilidad para captar otros ingresos directos que en otros museos resulta de gran importancia, como financiaciones privadas, cesión de espacios, recaudación de los ingresos de tiendas y cafetería...

La reinversión de los ingresos en el propio museo permitiría la gestión de estos recursos por éste, lo que constituiría la mejora de los planes de gestión al conocer de antemano parte de los ingresos con los que cuenta y poder preverlos.

Según los datos recogidos de los museos correspondientes podemos obtener las siguientes gráficas durante el año 2000 de dos de los principales museos españoles. 


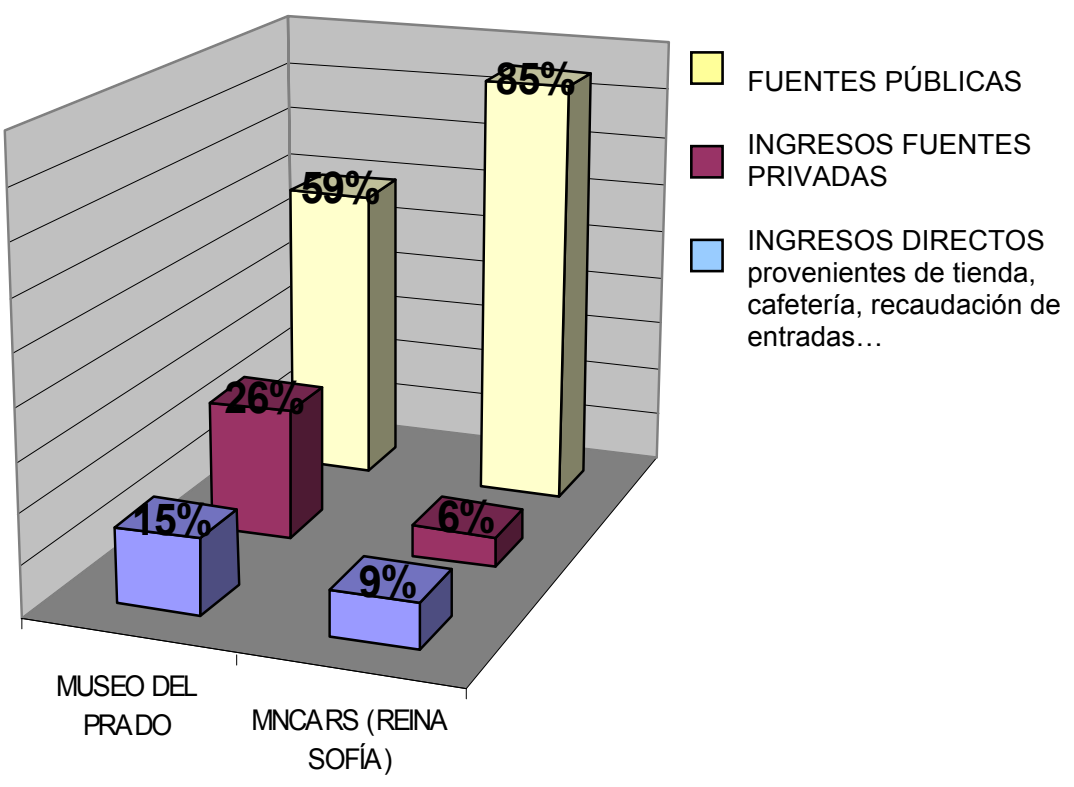

Detalle de desglose de los ingresos directos del Museo del Prado y del MNCARS.

Como podemos observar en la gráfica anterior, aunque las aportaciones con respecto al presupuesto total del Museo del Prado y del MNCARS se componen principalmente de los ingresos directos de los presupuestos de las fuentes públicas, las aportaciones de los ingresos generados por los recursos que se obtienen a través de la tienda, la concesión de la gestión de la cafetería, la recaudación de las entradas y los ingresos de fuentes privadas suponen en suma una aportación de:

- Museo del Prado: $41 \%$ de su presupuesto total

- MNCARS: $15 \%$ de su presupuesto total

La comparación de los ingresos y de las fuentes financiación con otros museos nos permite comprobar cómo la concesión en la gestión de la tienda, la cafetería, la capacidad de recaudación de las entradas, previo precio estipulado por la Consejería de Cultura, al igual que la gestión de la cesión de espacios, constituyen si no la mayoría de su presupuesto, sí una parte significativa de éste. La ampliación del Museo en un total de $1500 \mathrm{~m}^{2}$ aproximadamente y la remodelación integral en todos los aspectos supondrá una ampliación del volumen de visitantes. Por ello consideramos de importancia la concesión de algunos recursos o de un tanto por ciento de éstos y convertirlo en ingresos directos. 
Mediante cálculos por analogía ${ }^{69}$ con otros museos remodelados recientemente, podríamos considerar las tarifas de entradas siguientes:

\section{TARIFA ORDINARIA: ${ }^{70}$}

VISITA COLECCIÓN PERMANENTE: 3,00€

VISITA EXPOSICIÓN TEMPORAL: $2 €$

VISITA EXPOSICIÓN TEMPORAL Y COLECCIÓN PERMANENTE (VÁLIDO PARA UN MES): $4 €$

\section{TARIFA REDUCIDA:}

- Familias: niño menor de 12 años y un adulto que pague su entrada. Primera bebida y aperitivo a mitad de precio en cafetería mostrando la entrada.

\footnotetext{
${ }^{69}$ Hemos tenido en cuenta las tarifas del Museo Arqueológico de Alicante, Museo Nacional de Arte Contemporáneo Reina Sofía. También de museos locales con importancia en Arqueología como el Museo Histórico Municipal de Écija y el Museo de la ciudad de Carmona, que si bien tienen un volumen inferior de visitantes al año sí que hay que tener en cuenta que están dentro de la red turística "Las Rutas de la Bética" lo que hace de estos pueblos sevillanos importantes núcleos turísticos de la provincia.

${ }^{0}$ Según estipula la Ley
}

- Jóvenes menores de 25 con carnet joven: potenciación de la relación entre museo e Instituto de la Juventud. Posibilidad de participar gratuitamente en una de las actividades que se llevara a cabo por la Asociación de Jóvenes Amigos.

- Jóvenes menores de 25 años con carnet de estudiante.

VISITA COLECCIÓN PERMANENTE: 1,50€

VISITA EXPOSICIÓN TEMPORAL: 1,00€

VISITA CONJUNTA EXPOSICIÓN TEMPORAL Y COLECCIÓN PERMANENTE (VÁLIDO PARA UN MES):

$2 €$

\section{GRATUITA:}

- Mayores de 65 años

- Grupos escolares

- Personas cuyo motivo de visita sea el estudio o la investigación.

- Miembros del ICOM, estudiantes de Museología acreditados y miembros de la Asociación de Amigos 
del Museo y de la Asociación de Jóvenes Amigos

A.M.Ar luvenis.

Teniendo presente, como pudimos comprobar en la Fase de Análisis de Difusión, que el volumen de visitas anual oscila entre los 50000 y 60000 visitantes, siendo los grupos escolares los más numerosos con un régimen de visitas alrededor de los 16000 visitantes, llegamos a la conclusión que si bien la recaudación de estas tarifas o un tanto por ciento de éstas, previa estipulación por la Junta de Andalucía, no será una cantidad especialmente significativa, con ella podremos tener la oportunidad de afianzar y crear nuevos vínculos que pueden ser de importancia para el Museo y que favorecerán a la mejora de los servicios que éste pueda ofrecer al público:

- Vinculación Museo/Instituto de la Juventud

- Potenciación del Museo como un lugar de comunicación favoreciendo la visita a familias y jóvenes.
- Integración de los jóvenes dentro del museo con la posibilidad de participar en alguna actividad de la nueva Asociación de Jóvenes Amigos que se está gestando en el Museo.

- Potenciar la Investigación arqueológica y al estudio Museológico, facilitando la entrada las veces que sea necesaria. $^{71}$

- Gratuidad a los grupos escolares, que constituyen una parte importante del volumen de visitas.

Igualmente, siguiendo la recaudación de ingresos directos que obtienen otros museos de ámbito estatal, la financiación privada también es importante en la captación de presupuesto. La imposibilidad del Museo Arqueológico de Sevilla de llegar a este ámbito de actuación debido a su titularidad y gestión exclusiva de la Junta de Andalucía no permite estimar esta posibilidad como vía de financiación adicional. Sin embargo, en el Programa de Difusión se ha

\footnotetext{
${ }^{71}$ Según determina el art. 18 del Decreto 284/1995 de 28 de Noviembre, por el que se aprueba el Reglamento de Creación de Museos y de Gestión de Fondos museísticos de la Comunidad Autónoma de Andalucía. (BOJA 16 de Enero de 1996).
} 
especificado la creación de red de comunicaciones entre distintos centros e instituciones que pueden transformar ingresos directos en recursos indirectos para el museo con la atracción de público debido a la difusión y publicidad del museo fuera de sus propios muros.

Aunque no consideremos la posibilidad de aceptar financiación privada para incrementar los presupuestos del museo, sí que nos gustaría proponer lo que supondría el alquiler de espacios.

En nuestro caso podemos contar con: ${ }^{72}$

- salas de exposiciones temporales, ÁreA DE ACOGIDA (GRAN SALA OVAL) Y ESPACIOS CUBIERTOS NO MUSEABLES: Museo cerrado.

Según la aplicación del artículo 3, tarifa I, grupo III. $2 € / m^{2} \times\left(n^{\circ}\right.$ de $\left.m^{2}\right) \times\left(n^{\circ}\right.$ de horas de utilización)

${ }^{72}$ Estimación realizada a partir de las tasas dadas en la ORDEN DE 18 DE ENERO DE 2000 por la que se establecen las tarifas de los servicios o actividades sujetos a la tasa por utilización de espacios en museos y otras instituciones culturales del ministerio de educación y cultural (BOE 26/01/2000). Estimando las tasas como GRUPO III.
- SALÓN DE ACTOS: para reuniones, congresos, cursos de formación... Cesión del espacio para cursos de formación continua a empresas externas cuyo ámbito de actuación esté relacionado con el museo. (Empresa de transporte, manipulación de piezas arqueológicas, empresas de técnicas de restauración arqueológica...) y a cursos escolares de educación primaria, secundaria y universitarios.

Hasta dos horas de utilización $600 €$. Por cada hora adicional $120 €$.

\section{- EQUIPOS DE FILMACIÓN Y MATERIAL TÉCNICO} DEL MUSEO: Se computará adicionalmente y constará de equipos informáticos para charlas, conferencias, cursos. Cesión de los materiales para cursos de formación continua como especificamos en el punto anterior.

$240 €$ por cada hora de filmación o utilización en caso del material informático. 
Podríamos hacer hipotéticamente, aplicando estas tasas, cuánto nos reportaría económicamente el alquiler de estos espacios:

Alquiler de la Sala de Acogida dos veces al año para recepción o cóctel durante tres horas supondría un incremento de los ingresos directos:

$2 € / \mathrm{m}^{2} \times 39,55 \mathrm{~m}^{2} \times(3$ horas $)=237,3 € \times 2$ veces al año $=474,6 €$

El alquiler del Salón de Actos tres veces al año para conferencias con duración variable:

- $\quad$ un ciclo de conferencias de tres días (4 horas/día)

$600 €+(120 € \times 2)=840 \times 3$ días $=2520 €$

- $\quad$ una reunión de tres horas

$600 €+120 €=720 €$

- $\quad$ un curso de formación de dos días (8h/día)

$600 €+(120 € \times 6)=1320 € \times 2=2640 €$
Este caso hipotético, supondría anualmente un total de $6356,6 €$ de los ingresos directos recaudados.

Además de la aportación económica, el alquiler y cesión de espacios son positivos para:

- Promover la vinculación y comunicación entre diferentes instituciones, y la promoción del museo.

- La cesión de espacios del museo para la organización de ciclos de conferencias, cursos, seminarios... destinados a la formación y especialización de personal vinculado con el campo de los museos supone el apoyo del museo a la formación y a la mejora de la disciplina museológica.

La reinversión de los ingresos aportados en la tienda y/o librería también supondría un apoyo importante a los presupuestos concedidos por la Consejería de Cultural.

Actualmente, las tiendas de los museos públicos gestionados por la Junta de Andalucía son tramitadas a través de la Empresa Pública de Programas Culturales de 
la Junta de Andalucía. Los ingresos generados no se reinvierten en el propio museo.

\section{IX.2.1. Transformación de los ingresos indirectos en un proyecto anual de captación de bienes y servicios.}

Desde el punto de vista económico los ingresos indirectos son otra fuente de aumento del presupuesto para museos tanto privados como autónomos que acepten donaciones privadas. Volvemos a subrayar la naturaleza del museo y la imposibilidad de éste de aceptar ingresos derivados de donaciones económicas, aportaciones de patrocinadores para eventos concretos (como organización de exposiciones o cursos), los ingresos derivados de la realización de cursos de formación o actividades pedagógica... Sin embargo estos ingresos materiales concretos podemos transformarlos en ingresos no monetarios, aportaciones en servicios con empresas privadas, con la aportación de personal en práctica en los diferentes campos que precise el museo, la colaboración de voluntarios y las aportaciones de la Asociación de Amigos del Museo y de la nueva Asociación de Jóvenes Amigos.

La transformación de los ingresos indirectos en la aportación directa de bienes y servicios, debe gestionarse anualmente, con una cartera de posibles empresas que puedan estar dispuestas a ello.

Entre los beneficios que pueden ofrecerse desde el museo a las empresas privadas son:

- En colaboración con la Consejería de Cultura, pueden gestionarse a través de la Empresa Pública de Programas Culturales, programas de prácticas y voluntarios con las empresas privadas que los soliciten y según plazas previamente establecidas por el museo. Esta colaboración privada con empresas de Gestión Cultural, 
Arqueología o de Programas Didácticos y Educativos... tendrán la oportunidad de formar durante un tiempo determinado a personal cualificado en el museo. A cambio estas empresas aportarán al museo aquello que precise de su campo de actuación previamente establecido.

A modo de ejemplo podríamos aplicar un caso con una empresa de Arqueología:

Una empresa privada sevillana de arqueología está vinculada a la Universidad Pablo de Olavide de Sevilla para los programas de prácticas externas que la Facultad de Humanidades tiene en colaboración con la Fundación Universidad Sociedad. El museo puede proponer a esta empresa la formación de los alumnos becados en la formación de éstos durante un periodo de la duración de su práctica total para formarlos en tareas como catalogación, limpieza y sistematización en la forma de etiquetar material arqueológico. Durante una semana, por ejemplo, podrían tener esta formación, que por una parte se verá agilizada en la excavación de campo aportando una ayuda a la empresa y por otro lado, durante ese periodo los alumnos podrán ayudar al encargado de almacén en tales tareas.

- La aportación de material para la realización de exposiciones o talleres educativos por parte de empresas privadas a cambio de publicidad de su marca también puede ser una ayuda a la realización de tales actividades por parte del museo.

- La vinculación del Museo con la Universidad, más que una ayuda es una necesidad. Como se ha tratado en el Programa de Difusión, la formación de la Universidad debe completarse con la posibilidad de hacer prácticas reales. Aunque la realización de un programa de prácticas en el museo es cuantificable económicamente como un coste si tenemos en cuenta el desgaste de tiempo de personal dedicado a la formación de los alumnos en prácticas, esta estimación, a medio/largo plazo es insignificante por cuanto un programa de prácticas continuado y constante supone: 
- Agilización de procesos como inventariar, catalogar... que en el caso del Museo Arqueológico de Sevilla es necesario por el volumen de piezas que tiene y que genera en su crecimiento ilimitado.

- Formación de nuevos profesionales, lo que reportará mejoras a largo plazo en el campo de los museos en general.

Una vez comentadas tales observaciones, podríamos realizar un cuadro que ilustrara las aportaciones de los distintos tipos de ingresos tanto económicos como en bienes y servicios. Para su realización se ha tenido en cuenta la concesión de sólo de tanto por ciento variable, previo convenio con la Consejería de Cultura, de la recaudación de los ingresos de las entradas, de la tienda y de la cafetería. Aunque somos conscientes del principio de solidaridad por el que la recaudación de los ingresos no puede ser gestionada ni reinvertida por el propio museo directamente por lo que probablemente esta recaudación Libproapureda ser posible.
gestion

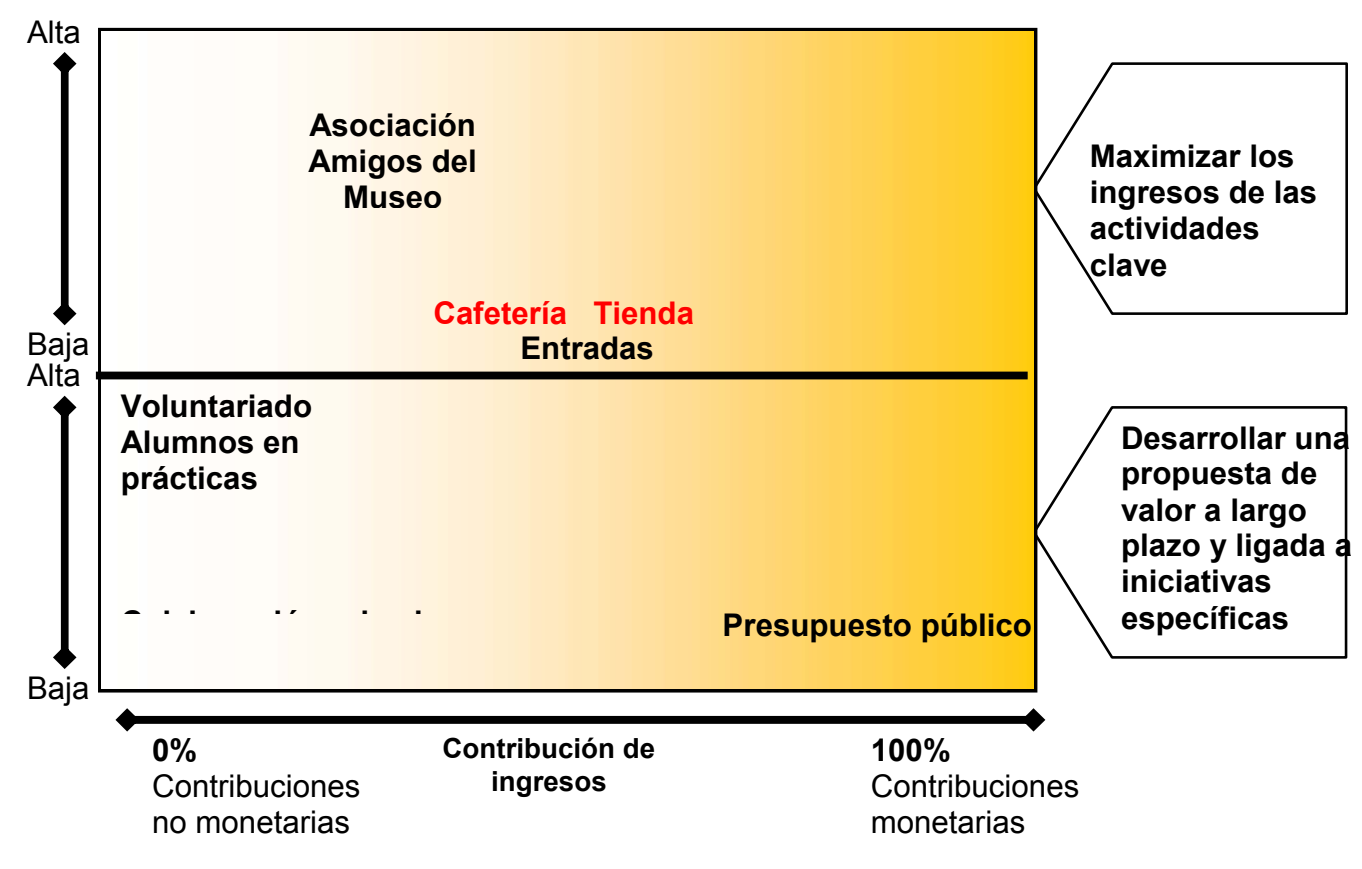

Contratación externa

Notas al cuadro anterior:

En el cuadro anterior podemos observar en un mismo conjunto dividido en dos grandes bloques, aquellas actividades en las que son necesarias la maximización de los ingresos ya sea por aportaciones económicas como por aportaciones no económicas pero positivas para el museo.

En el bloque inferior mostramos aquellas actividades en las que es más importante desarrollar una propuesta de valor a largo plazo y ligada a iniciativas especificas, también graduados por la contribución de ingresos que generan, no sólo económicos sino también por aportaciones favorables al museo no monetarias.

sino también por aportaciones favorables al museo no monetarias. En ambos bloques se ha anadido una graduación de la posible libertad de gestión y actuación que los responsables del museo podrán tener de las actividades señaladas. El gráfico puede ser explicativo esquemáticamente y servir de primer acercamiento a un nosible incremento o decremento de unas actividades con resnecto a otras 


\section{IX.3. ANÁLISIS DE COSTES}

El programa económico debe recoger anualmente cuáles han sido, según el total de su presupuesto, los costes tanto del Capítulo I dedicado a Personal como el recogido en el Capítulo II sobre Gastos corrientes en Bienes y Servicios.

Podemos estimar según los costes por naturaleza de otros museos cuáles serán los costes que se generarán tras la rehabilitación y que se deben de prever.

PORCENTAJE DE COSTES

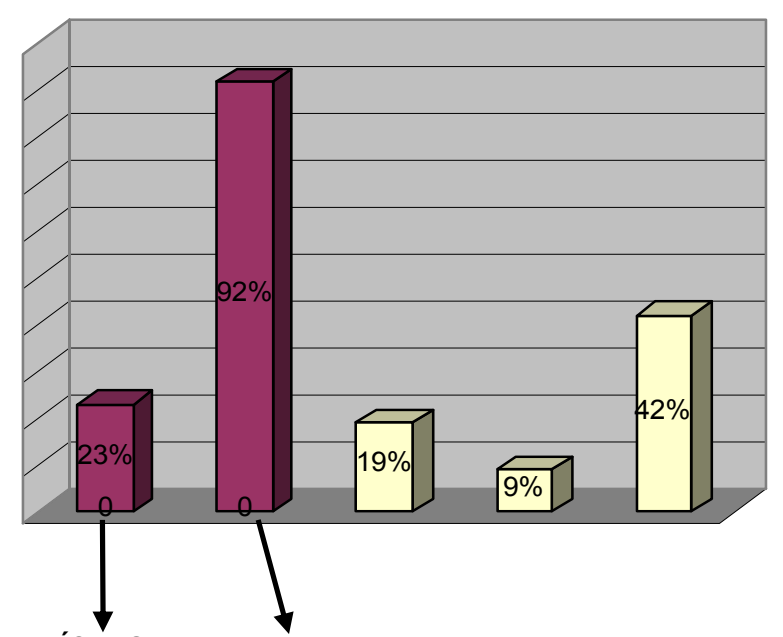

Dentro de los costes que el museo presenta vemos en el presupuesto del año 2005 cómo el Artículo 21 sobre Reparaciones y Conservación constituyó un tanto por ciento elevado del presupuesto total, sin embargo debemos destacar el alto porcentaje que supone el artículo 22 del Capítulo II del Presupuesto. Entre los diferentes subconceptos debemos subrayar el gasto concerniente al 227.00, donde se especifica: Trabajos otras empresas: limpieza y aseo.

Datos aportados por el Museo Picasso de Málaga del 2004 nos indican que, en lo referente a Mantenimiento, el coste anual es de un $5 \%$ de su presupuesto total, el personal un $23 \%$ y en Seguridad un $32 \%$. Con respecto a estos datos hay que tener en cuenta la superioridad presupuestaria del Museo Picasso con más de 7 millones de $€$ anuales mientras que el presupuesto del Museo Arqueológico de 
Sevilla no llega a un millón de $€$, teniendo un edificio de similares dimensiones.

La propuesta de externalización de la seguridad y la limpieza y las nuevas instalaciones que reportará la rehabilitación integral del museo puede acercarnos a los porcentajes citados al Museo Picasso. Por lo que debemos prever la minimización de los costes de mantenimiento y reparaciones y aportar nuevos porcentajes al trabajo realizado por otras empresas. Si seguimos un esquema general de costes podremos obtener los siguientes datos: 


\begin{tabular}{|c|c|c|}
\hline $\begin{array}{l}\text { PRESUPUESTO DE COSTES OPERATIVOS } \\
\text { DEL MUSEO (Excluye el coste de personal } \\
\text { funcionario y laboral) Miles de Euros }\end{array}$ & DETALLE & $\begin{array}{l}\text { HIPÓTESIS APLICADA } \\
\text { AL MUSEO } \\
\text { ARQUEOLÓGICO DE } \\
\text { SEVILLA }^{73} \\
\end{array}$ \\
\hline Atención al visitante & Material (incluye folletos informativos, entradas...) & $20 \%$ del coste personal \\
\hline \multirow{6}{*}{ Operación mantenimiento } & Mantenimiento (material) & $10 € / \mathrm{m}^{2}$ \\
\hline & Limpieza & $15 € / \mathrm{m}^{2}$ \\
\hline & Suministros & $20 € / \mathrm{m}^{2}$ \\
\hline & Seguridad & $12 € / h$ \\
\hline & Vigilantes de sala & 30 personas $10 \mathrm{~h} / \mathrm{día}$ \\
\hline & Sala de control & $\begin{array}{l}3 \text { personas } 365 \text { días } \\
24 \text { h/día }\end{array}$ \\
\hline \multirow[t]{2}{*}{ Marketing y comunicación } & Material & $20 \%$ del coste personal \\
\hline & Presupuesto destinados a marketing & \\
\hline \multirow[t]{2}{*}{ Tienda } & Material de tienda & $60 \%$ Facturación anual \\
\hline & Mantenimiento & $10 \%$ Facturación anual \\
\hline \multirow[t]{2}{*}{ Salón de Actos } & Mantenimiento & $20 \%$ del coste personal \\
\hline & Programación & \\
\hline \multirow[t]{2}{*}{ Biblioteca } & Mantenimiento & $20 \%$ del coste personal \\
\hline & Material para biblioteca & $20 \%$ del coste personal \\
\hline Educación & Coste del curso de educación & \\
\hline \multirow[t]{2}{*}{ Dirección y Administración } & Material de oficina & $10 \%$ del coste personal \\
\hline & Otros gastos de Oficina (teléfono, correo...) & $20 \%$ del coste personal \\
\hline
\end{tabular}

${ }^{73}$ Hay que tener en cuenta que al externalizar la limpieza y la seguridad el coste por hora es variable según la empresa, incrementándose el gasto debido a las comisiones que la empresa incluye en el precio. 


\section{IX.3.1. Análisis del macroentorno}

Justificación de la rehabilitación integral del Museo Arqueológico de Sevilla desde el punto de vista del lugar donde se encuentra y las posibles variables de su entorno.

El análisis del Macroentorno, permitirá:

- Analizar el impacto económico que supondrá la rehabilitación integral del centro.

- Prever las variables externas al museo que puedan influir en el desarrollo de éste.

\section{IX.3.2. Análisis del impacto económico}

El Museo se inserta en un parque público, dentro de una zona con un alto valor inmobiliario. Sin embargo, la rehabilitación integral del Museo incrementará el número de visitas, al mostrar un museo moderno y atractivo que reactivará y será propulsor de las mejoras del propio Parque de María Luisa.

La creación de un nuevo edificio en la parte trasera del actual impulsará la remodelación de esta parte un tanto degradada del Parque que, como hemos visto en el Programa de Arquitectura, contará con la construcción de una plaza.

A esto se puede añadir a que contribuiría a una mejora más en la ciudad que se inserta dentro del plan de remodelación urbana que está sufriendo actualmente el casco antiguo de Sevilla. La construcción del metro-centro, del metro, peatonalización del centro, construcción de $77 \mathrm{Km}$ de carriles bici...obras que se verían culminadas con la construcción de un centro cultural de referencia con una de las más importantes colecciones arqueológicas del país. 
La generación del PIB se traduce en la zona por un mayor flujo monetario que se reinvierte directamente en otras actividades de la zona como restaurantes, transporte, alojamiento... efectos directos que producen un efecto inducido pues los gastos de los propios salarios son una fuente de reinversión en esos mismos recursos.

El siguiente cuadro puede ilustrar los flujos monetarios generados en la zona:

PREVISIÓN DE LOS PRINCIPALES FLUJOS MONETARIOS GENERADOS POR EL MUSEO

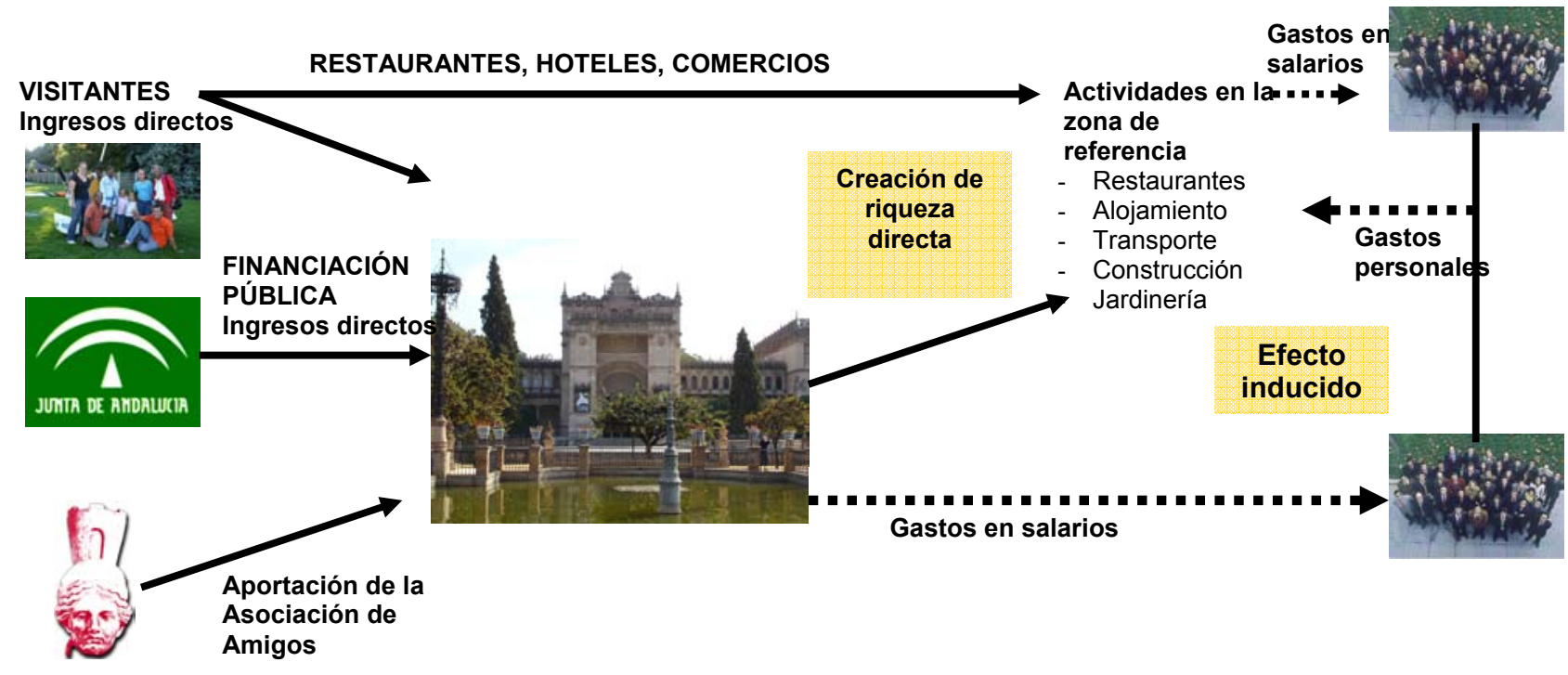




\section{IX.3.3. Previsión de las variables externas:}

A través del análisis de las variables externas podrá hacerse una previsión:

Fases en la construcción del proyecto de rehabilitación.

Análisis sistemático de museos y elementos patrimoniales del entorno para, estudiar posibles vías de comunicación y relación entre ellos. Disminución así de la posible amenaza de apertura de elementos análogos o relacionados que puedan favorecer la disminución del flujo de público.

De los puntos expuestos trataremos para terminar una posible planificación de la gestión en las fases constructivas del proyecto que puede reducir al mínimo los gastos generados por el cierre total del museo. Estas fases se podrían planificar a través de partidas presupuestarias que servirán para programar y acotar los gastos que se realicen con el fin prever fácilmente posibles problemas en la planificación.

$1^{\circ}$ Fase de construcción del nuevo edificio y remodelación de la zona trasera del antiguo edificio.

Supondrá la adecuación en las nuevas instalaciones y el acomodamiento provisional del área de administración y dirección. Desde esta primera fase incipiente se deberá aplicar el nuevo Plan de Riesgos Laborales, así como será importante que comiencen a funcionar los nuevos mecanismos de comunicación y relación ya mencionados en el nuevo organigrama funcional.

Una parte de la zona de exposiciones temporales contendrá una exposición del proceso de rehabilitación y otra zona una pequeña muestra de las piezas más importantes de la exposición permanente, con el fin de no cerrar el museo al público en ningún momento. 
El hecho de equipar el edificio nuevo hará que se pueda ir trabajando en el área de fotografía y documentación, así como la instalación definitiva de las nuevas instalaciones del Taller de Restauración.

Una parte de lo que será la reserva visitable podría, en esta primera fase, adecuarse con material didáctico para que los numerosos grupos escolares que el museo alberga durante el año siguieran disfrutando de las instalaciones y conociendo los nuevos recursos que éste va a ofrecerles.

\section{$2^{\mathrm{a}}$ Fase de rehabilitación del antiguo edificio}

Al igual que la construcción del nuevo edificio, la rehabilitación del antiguo edificio, se hará por partidas presupuestarias en dos fases anuales por la complejidad que supone la obra arquitectónica.

Primera fase anual: Rehabilitación arquitectónica
Segunda fase anual: Equipamiento técnico del edificio e instalaciones definitivas.

\section{$3^{\text {a }}$ Fase: Readecuación de los puestos}

En la tercera fase de apertura y puesta en marcha, cada espacio será ocupado con los puestos de trabajos y departamentos para los que se ha diseñado y pensado. 


\section{IX.3.4. Estimación del presupuesto general para la rehabilitación integral del Museo Arqueológico de Sevilla}

La estimación total del coste de la rehabilitación integral y la construcción del nuevo edificio es una cantidad difícil de barajar teniendo en cuenta la magnitud del proyecto.

- Estimación de los costes de rehabilitación del edificio del 29 con todos los problemas derivados de su arquitectura, como estuvimos comprobando en el análisis y evaluación de la Arquitectura del edificio.

- Movilidad del gran volumen de piezas para su recolocación en el nuevo espacio proyectado como almacén.

- $\quad$ Construcción de un nuevo edificio.
- Gastos provenientes de la necesidad de transplantar numerosos árboles para evitar su tala en la construcción del nuevo edificio.

Para hacer la estimación del presupuesto final hemos tomado como referencia los cálculos previstos en el Plan de Calidad de Museos Andaluces y la inversión realizada en la construcción final del Museo de Almería. ${ }^{74}$

${ }^{74}$ Paredes Pedrosa, El Proyecto arquitectónico del museo de Almería, en mus-A, nº4, p.60 
PREPUESTOS PREVISTOS EN EL PLAN DE CALIDAD DE MUSEOS ANDALUCES

\begin{tabular}{|c|c|c|}
\hline \multirow[t]{3}{*}{ ESTUDIO ECONÓMICO DEL MUSEO DE ALMERÍA } & COSTE TOTAL PREVISTO DE LA ACTUACIÓN & 10500000 \\
\hline & \multirow{2}{*}{$\begin{array}{l}\text { INVERSIÓN REALIZADA ANTES DE } 2003 \\
\text { INVERSIÓN PREVISTA }\end{array}$} & 5806960 \\
\hline & & $258026 c$ \\
\hline $\begin{array}{l}\text { ESTUDIO ECONÓMICO DEL MUSEO ARQUEOLÓGICO Y ETNOLÓGICO DE } \\
\text { CÓRDOBA }\end{array}$ & COSTE TOTAL PREVISTO DE LA ACTUACIÓN & 597065 \\
\hline & INVERSIÓN REALIZADA ANTES DE 2003 & $172424 C$ \\
\hline & INVERSIÓN PREVISTA & 182205 \\
\hline
\end{tabular}

\begin{tabular}{|c|c|c|}
\hline MUSEO DE BELLAS ARTES DE CÓRDOBA & COSTE TOTAL PREVISTO DE LA ACTUACIÓN & 944000 \\
\hline & INVERSIÓN REALIZADA ANTES DE 2003 & 51740 \\
\hline & INVERSIÓN PREVISTA & 334200 \\
\hline COSTE TOTAL PREVISTO $2^{a}$ FASE DE LA CONSTRUCIÓN DE LA NUEVA SEDE & & 697000 \\
\hline MUSEO ARQUEOLÓGICO Y ETNOLÓGICO DE GRANADA & COSTE TOTAL PREVISTO DE LA ACTUACIÓN & 609000 \\
\hline & $\begin{array}{l}\text { INVERSIÓN REALIZADA ANTES DE } 2003 \\
\text { INVERSIÓN PREVISTA }\end{array}$ & \\
\hline
\end{tabular}

\begin{tabular}{|l|l|r|}
\hline MUSEO DE BELLAS ARTES DE CÓRDOBA & & \\
\hline $1^{\text {a } F A S E: ~ R E N O V A C I O ́ N ~ D E ~ I N S T A L A C I O N E S ~ E N ~ L A ~ S E D E ~ A C T U A L ~}$ & COSTE TOTAL PREVISTO DE LA ACTUACIÓN & 944000 \\
\hline & INVERSIÓN REALIZADA ANTES DE 2003 & \\
\hline & INVERSIÓN PREVISTA & 31740 \\
\hline COSTE TOTAL PREVISTO 2a FASE: CONSTRUCCIÓN DE NUEVA SEDE & & \\
\hline
\end{tabular}

MUSEO ARQUEOLÓGICO Y ETNOLÓGICO DE GRANADA: REHABILITACIÓNY

RENOVACIÓN MUSEOGRÁFICA

\begin{tabular}{|l|r|} 
& \\
\hline & 6090000 \\
\hline INVERSIÓN REALIZADA ANTES DE 2003 & 0 \\
\hline INVERSIÓN PREVISTA & 90000 \\
\hline
\end{tabular}

\begin{tabular}{|l|l}
\hline MUSEO ARQUEOLÓGICO DE SEVILLA: REHABILITACIÓN INTEGRAL DEL MUSEO & COSTE TOTAL ESTIMADO \\
\hline
\end{tabular}

\begin{tabular}{|l|r|}
\hline INVERSIÓN PREVISTA 2003 & 10010000 \\
\hline
\end{tabular}


La inversión prevista en el mismo Plan de Calidad para el Museo Arqueológico de Sevilla es de un coste total aproximado de 10.010.000 $€$ con una inversión inicial prevista desde el 2003 de $120.000 €$. A los puntos anteriormente comentados en la estimación del presupuesto, tenemos que añadir que los $\mathrm{m}^{2}$ se incrementan con respecto al Museo de Almería en $1459 \mathrm{~m}^{2}$ aproximadamente. Subrayamos el hecho de que gran parte de la rehabilitación integral consta de la remodelación y restauración de un edificio antiguo con lo que habría que aumentar el presupuesto.
Si bien debería estimarse el incremento necesario del presupuesto inicialmente estipulado en el Plan de Calidad de Museos Andaluces, la previsión de las fases de actuación de las obras antes comentadas, permitirán que el museo no esté cerrado en ningún momento completamente y pueda seguir ofreciendo servicio al público. La remodelación ya en su primera fase de la RPT y del nuevo organigrama funcional, pondrán en funcionamiento los nuevos mecanismos de comunicación entre el personal en un espacio más reducido de trabajo lo que favorecerá a la detección de problemas en el organigrama de forma incipiente reduciendo así los gastos de posibles correcciones tanto en el Organigrama como en la nueva RPT. 


\section{BIBLIOGRAFÍA}

\section{Bibliografía Colecciones}

- ALONSO FERNÁNDEZ, L. A., Museología y museografía, ed. del Serbal, Barcelona, 1999, p.224..

- ARCE, J. y BURKHALTER, F. (1993).- Congreso Internacional de Bronces Antiguos (1.990 Madrid): Bronces y religión romana: actas del XI Congreso Internacional de Bronces Antiguos, Madrid, Consejo Superior de Investigaciones Científicas.

- BERDUCOU, M, (coord.), La Conservation en archéologie, Ed. Masson, 1990.

- BLANCO FREJEIRO, Antonio (1.978).- Mosaicos romanos de Itálica: mosaicos conservados en colecciones públicas y particulares de la ciudad de Sevilla, Madrid, Instituto Español de Arqueología "Rodrigo Caro".

- BUCES AGUADO, J., A., "El Guernica de Picasso: criterios de prestación".

- CABALLOS RUFINO, Antonio; MARÍN FATUARTE, Jesús y RODRÍGUEZ HIDALGO, José M. (1.999).Itálica Arqueológica, Sevilla, Secretaría de Publicaciones de la Universidad de Sevilla, Fundación El Monte, Consejería de Cultura de la Junta de Andalucía.

- CARRERAS MONFORT, C., " Museografía en internet: análisis de la situación en nuestro país". Versión electrónica de descarga gratuita en la dirección www.ouc.edu.

- CASTELLANO HERNÁNDEZ, Ángeles y GRANADOS ORTEGA, María Ángeles (2.002).- 
Museo Arqueológico Nacional, Madrid, Ministerio de Educación, Cultura y Deporte, Secretaría de Estado de Cultura, Electa.

- De TAPOL, B., "La aplicación de programas norteamericanos asistidos por ordenador para la gestión de la conservación preventiva de museos de Europa", VI coloquio Galego de Museos. A conservación preventiva, A Coruña 27 a 28 xaneiro, 2000.

- FERNÁNDEZ-CHICARRO, Concepción y FERNÁNDEZ GÓMEZ, Fernando (1.980).- Catálogo del Museo Arqueológico de Sevilla (II). Salas de Arqueología romana y medieval, Madrid, Ministerio de Cultura.
- FERNÁNDEZ-CHICARRO, Concepción (1.969).Catálogo del Museo Arqueológico de Sevilla, Madrid, Ministerio de Educación y Ciencia, Dirección General de Bellas Artes, $2^{a}$ ed. corregida y aumentada.

a FERNÁNDEZ GÓMEZ, F., "Una sala para el ejército romano en el museo arqueológico de Sevilla", en MUSA, Sevilla, 2006, pp. 147-156.

- GARCÍA BLANCO, Ángela; ELVIRA BARBA, Miguel Ángel y FERNÁNDEZ TAPIA, Teodora.- Museo Arqueológico Nacional: un paseo por la historia, Barcelona, Ámbit Servicios Editoriales, Universidad Camilo José Cela, Ministerio de Educación, Cultura y Deporte, Secretaría de Estado de Cultura. 
- GARCÍA FERNÁNDEZ. I., La conservación preventiva y la exposición de objetos y obras de arte, ed. KR, Murcia, 1999.

a GUICHEN de, GAËL, "La conservación preventiva: un cambio profundo de mentalidad", Master de Museología III ed. Granada, 2005.

- GONZÁLEZ VARAS, I., Conservación de Bienes Culturales, Teoría. Historia, principios y normas, Manuales de arte Cátedra, Madrid, 1999.

- LEÓN, Pilar (1.995).- Esculturas de Itálica, Sevilla, Empresa Pública de Gestión de Programas Culturales, Junta de Andalucía, Consejería de Cultura.

- LÓPEZ RODRÍGUEZ, J. R., ."El desarrollo de los museos arqueológicos en Andalucía durante el siglo XIX", en: María Belén Deamos y José Beltrán Fortes (ed.) Arqueología fin de siglo. La arqueología española de la segunda mitad del siglo XIX (I Reunión Andaluza de Historiografía Arqueológica), Spal Monografías III, Sevilla, 2002, pp. 158-178.

- LORD, Barry y DEXTER LORD, Gail (1.998).Manual de gestión de museos, Barcelona, Ariel Patrimonio Histórico, $1^{\mathrm{a}}$ ed.

- MAEKAWA, S., (ed.), Oxygen - Free Museum Cases, The Getty Conservation Institute, 1998.

a MAEKAWA, S., ET SELWITZ, C., Inert Gases in the Control of Museum Insect Pest. En su versión electrónica, se puede descargar gratuitamente en la siguiente url: www.getty.edu. 
- MAIER, Jorge (2.001).- Carmona Romana, Carmona, Editor Antonio Caballos Rufino, Delegación de Cultura, Excmo. Ayuntamiento de Carmona, Universidad de Sevilla.

- MATEINI, M., et MOLES, A., Ciencia y restauración, ed. Nerea y Junta de Andalucía, Guipúzcoa, 2001.

- MARTÍNEZ JUSTICIA, Historia y teoría de la conservación y restauración artística, tecnos, Madrid, 2000.

- PUENTE, R., "Clasificación de las fuentes luminosas", Master de Museología III ed. Granada, 2005.

- STOLOW, N., Conservation \& Exhibition. Packing, Transport, Storage and Enviromental Considerations, Butterworths, London, 1987.
- AA.VV. (1.995).- Itálica en el Museo Arqueológico de Sevilla, Sevilla, Consejería de Cultura de la Junta de Andalucía, Fundación El Monte.

- AA.VV. (1.997).- Tesoros de la antigüedad en el Valle del Guadalquivir (catálogo de la exposición), Córdoba; del 4 al 23 de marzo de 1.997, Sevilla, del 1 al 20 de abril de 1.997, Sevilla, Junta de Andalucía, Consejería de Cultura.

- AA. VV., Criterios para la elaboración del plan museológico, Ministerio de Cultura, Secretaría general técnica, Madrid, 2005.

- AA. VV., Guión del Plan museológico, Master de museología III ed., Granada, 2005. 
- REVISTA MUS-A (2.003).- Revista de las Instituciones del Patrimonio Histórico de Andalucía N. ${ }^{\circ}$ 2, Sevilla, Dirección General de Patrimonio Histórico, Consejería de Cultura.

\section{Bibliografía Arquitectura}

- El museo arqueológico de Sevilla. Estudio de Rehabilitación y Plan de Evacuación. Proyecto fin de carrera. Coordinador D. José Antonio Solís Burgos. E.U. Arquitectura Técnica de Sevilla. Marzo de 2001.

- FERNÁNDEZ CHICARRO, C. Catálogo del Museo Arqueológico de Sevilla. Madrid, 1969.

- MORRILLA, J.L. Museo arqueológico de Sevilla. Tesina inédita. Sevilla, 1993.
- PÉREZ ESCOLANO, V. Aníbal González, arquitecto (1876-1929). Sevilla, 1973.

- VILLAR MOVELLÁN, A. Arquitectura del Regionalismo en Sevilla (1900-1935). Sevilla, 1979.

- VILLAR MOVELLÁN, A. Introducción a la arquitectura regionalista: el modelo sevillano. Córdoba, 1978.

\section{Bibliografía Exposición}

- "Itálica arqueológica”. Antonio Caballos Rufino, Jesús Marín Tatuarte y José Manuel Rodríguez Hidalgo. 1999. Editada por el Secretariado de Publicaciones de la Universidad de Sevilla, Fundación El Monte y Consejería de Cultura de la Junta de Andalucía. 
- Catálogo del Museo Arqueológico de Sevilla (II). Salas de arqueologia romana y medieval. Concepción Fernández-Chicarro y de Dios y Fernando Fernánde Gómez. Ministerio de Cultura. 1980. Tercera edición.

- Itálica. Guía ofical del conjunto arqueológico. AA.VV. Junta de Andalucía. Consejería de Cultura. 2005.

- Museo Arqueológico de Sevilla. Guía Oficial. AA.VV. Junta de Andalucía. Consejería de Cultura. 2005.

- Itálica en el Museo Arqueológico de Sevilla. José Ramón López, Fernando Fernández Gómez, José Beltrán Fortes y Fernando de Amores Carredano. Junta de Andalucía. Consejería de Cultura. 1995.

- Curso de Museología. Francisco Javier Zubiaur Carreño. Ediciones Trea, S.L. 2004.
- Manual de Gestión de Museos. Barry Lord y Gail Dexter Lord. Editorial Ariel. 1998.

- Manual de Museología. Francisca Hernández Hernández. Editorial Sintesis. 2001.

- Mus-A. Incrementando las colecciones de los museos andaluces. $\mathrm{n}^{\circ}$ 02. Julio 2003. Artículo: La Conservación como modelo interpretativo en el Conjunto Arqueológico de Itálica. $\mathrm{M}^{\mathrm{a}}$ Soledad Gil de los Reyes, Francisco Reina Fernández-Trujillo y Antonio Pérez Paz. Pág 120.

- Catálogo Erco. Programa. Espacio Interior, Espacio Exterior y Controles de luz. Edición 2004/05.

- Catálogo Erco. 75 años iluminando sus ideas. Edición 2004/05. 


\section{Bibliografía Difusión}

- PASTOR HOMS, M. INMACULADA. Pedagogía museística ,Ed. Ariel Barcelona 2004.

- KOTLER N. Y KOTLER P. estrategias y marketing de museos. Ed Ariel. Barcelona 2001.

a PEREZ SANTOS E. Estudio de visitantes en museos.

- SANTACANA MESTRE, J y SERRAT ANTOLI N. Museografía didáctica

a V.V.A.A. Consejería de cultura 2006 Musa , $n^{\circ} 6$

- VALDES SAGUES, M DEL C. La difusión cultural en el museo: servicios destinados al gran publico. 1999 Gijón Ed Trea.
- HOOPER-GREENHILL ,E. Los museos y sus visitantes Ed. Trea 1998 Gijón

- ASENSION M., POL E., GOMS. MARINA Planificación en Museologia : el caso del Museo Maritim de Barcelona 2001

a CALAF MASACHS, R. Arte para todos: Miradas para enseñar y aprender el patrimonio Ed Trea 2003 Gijón.

- HERNADEZ HERNADEZ F. El patrimnio cultural :la memoria recuperada Ed. Trea Gijón 2002

- Plan de calidad de los museos andaluces Junta de Andalucia. Consejería de cultura. 


\section{Bibliografía Comunicación}

- Burgelin, Olivier. "La comunicación de masas". Barcelona A.T.E. 1974.

a De Fleur, Melvin L. "Teorías de la comunicación de masas. Melvin L. De Fleur. Barcelona; Buenos Aires, México: Paidós comunicación, D.L. 2000

- Escobar de la Serna, Luís. "Comunicación de masas y cultura: los modernos medios técnicos de comunicación social como vehículo de espresión cultural". Luis Escobar de la Serna. Madrid: Instituto Nacional de Publicidad, 1978

- Escobar de la Serna, Luís. "Comunicación, información y cultura de masas". Luís Escobar de la Serna. Madrid: Ministerio de Cultura, Secretaría General Técnica, 1980
- Guber, Román. "Comunicación y cultura de masas". Román Gubern. Barcelona: Península, 1977.

\ Hernández Hernández, Francisca. "El museo como espacio de comunicación". Gijón, Trea, 1998

a Hund, Wulf D. "Comunicación y sociedad". Barcelona: Comunicación; Madrid: Alberto Corazón, 1972.

- Jornadas sobre Patrimonio y Medios de comunicación. Valencia: Generalitat, Conselleria de Cultura, Educació i Ciéncia, 1998

- Leach, Edmund. Cultura y comunicación, la lógica de la conexión de los símbolos. Edmund Leach. Madrid: Siglo XXI, 1989 
- Maturana, León A. "Comunicación, sistema y cultura". León A. Maturana. Buenos Aires, Almagesto 1991

- Munari, Bruno. "Diseño y comunicación visual: contribución a una metodología didáctica". Barcelona: Gustavo Gili, 1985.

- Nuño, Ma Rosa. "Cultura y comunicación: una aportación interdisciplinar para el conocimiento de los pequeños grupos". Ma Rosa Nuño. Madrid.

- Ricci, Pio E. "Comportamiento no verbal y comunicación", Barcelona: Gustavo Gili, 1980

\ Stevenson, Nick. "Culturas mediáticas: teoría social y comunicación masiva". Buenos Aires: Amorrortu, 1998
- VVAA. Cibersociedad 2.0: Una visita a la comunidad y la comunicación mediada por ordenador" Steven G. Jones. Editor. Barcelona: UOC, 2003

\section{Bibliografía seguridad, recursos humanos y económicos}

\ V.AA. (1999): Principio de Organización y Sistemas. Estrategia Empresarial. Modelo Dinámico del Proceso Estratégico. Asociación Española de Contabilidad y Administración de Empresas.

DOCUMENTOS, Madrid.

- VV.AA. (2003): Estrategias de distribución comercial en el mercado del arte.

- Font, J. y Elvira, O. (2003): Presupuestos, Planes Financieros y Estudios de Viabilidad, Barcelona. 
- Godet, M. (1993): De la Anticipación a la Acción. Manual de Prospectiva y estrategia, Barcelona

- Ruiz Rodríguez, I (coord.) (2004): Nuevas Perspectivas sobre la Ley 31/95, sus Reformas y el Real Decreto 39/97, Madrid.

- López Gandía, J. y Blasco Lahor, J. F. (2002): Curso de prevención de riesgos laborales, Valencia.

- Mintzberg, H. (1993): La estructuración de las organizaciones. La teoría Política de la Gestión, Barcelona.

口 Dolan, S; Schuler, S. R.; Valle, R. (1999): La Gestión de los Recursos Humanos, Madrid. 